\title{
La vida musical en Murcia durante la segunda mitad del siglo XIX
}

\author{
María Esperanza Clares Clares
}

\begin{abstract}
ADVERTIMENT. La consulta d'aquesta tesi queda condicionada a l'acceptació de les següents condicions d'ús: La difusió d'aquesta tesi per mitjà del servei TDX (www.tdx.cat) ha estat autoritzada pels titulars dels drets de propietat intel-lectual únicament per a usos privats emmarcats en activitats d'investigació i docència. No s'autoritza la seva reproducció amb finalitats de lucre ni la seva difusió i posada a disposició des d'un lloc aliè al servei TDX. No s'autoritza la presentació del seu contingut en una finestra o marc aliè a TDX (framing). Aquesta reserva de drets afecta tant al resum de presentació de la tesi com als seus continguts. En la utilització o cita de parts de la tesi és obligat indicar el nom de la persona autora.
\end{abstract}

ADVERTENCIA. La consulta de esta tesis queda condicionada a la aceptación de las siguientes condiciones de uso: La difusión de esta tesis por medio del servicio TDR (www.tdx.cat) ha sido autorizada por los titulares de los derechos de propiedad intelectual únicamente para usos privados enmarcados en actividades de investigación y docencia. No se autoriza su reproducción con finalidades de lucro ni su difusión y puesta a disposición desde un sitio ajeno al servicio TDR. No se autoriza la presentación de su contenido en una ventana o marco ajeno a TDR (framing). Esta reserva de derechos afecta tanto al resumen de presentación de la tesis como a sus contenidos. En la utilización o cita de partes de la tesis es obligado indicar el nombre de la persona autora.

WARNING. On having consulted this thesis you're accepting the following use conditions: Spreading this thesis by the TDX (www.tdx.cat) service has been authorized by the titular of the intellectual property rights only for private uses placed in investigation and teaching activities. Reproduction with lucrative aims is not authorized neither its spreading and availability from a site foreign to the TDX service. Introducing its content in a window or frame foreign to the TDX service is not authorized (framing). This rights affect to the presentation summary of the thesis as well as to its contents. In the using or citation of parts of the thesis it's obliged to indicate the name of the author. 
Tesis Doctoral dirigida por:

Dra ${ }^{\mathrm{a}}$ D. ${ }^{\mathrm{a}}$ María Gembero Ustárroz 

Departament de Història de l'Arte.

Programa de Doctorat Música a l'Espanya Contemporània

\title{
LA VIDA MUSICAL EN MURCIA
}

\section{DURANTE LA SEGUNDA MITAD DEL SIGLO XIX}

Tesis Doctoral para optar al Título de Doctora por la Universidad de Barcelona, realizada por

\section{MARíA ESPERANZA CLARES CLARES}

\author{
Directora: \\ Dra ${ }^{\mathrm{a}}$. D. ${ }^{\mathrm{a}}$ María Gembero Ustárroz \\ Consejo Superior de Investigaciones Científicas \\ Institución "Milà i Fontanals", Barcelona \\ Tutora: \\ Dr ${ }^{\mathrm{a}}$. D. ${ }^{\mathrm{a}}$ María Magdalena Polo Pujadas \\ Departamento de Història de l'Art, Universitat de Barcelona
}



A Miguel Ángel Clares 



\section{ÍNDICE GENERAL}

\section{VOLUMEN 1}

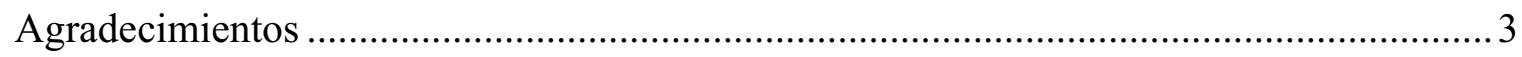

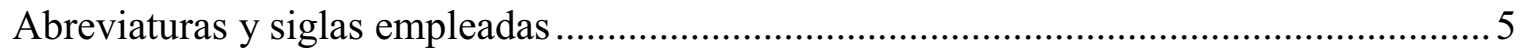

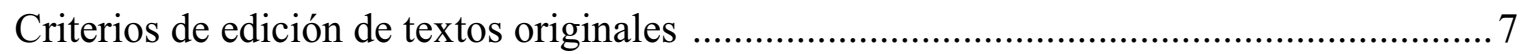

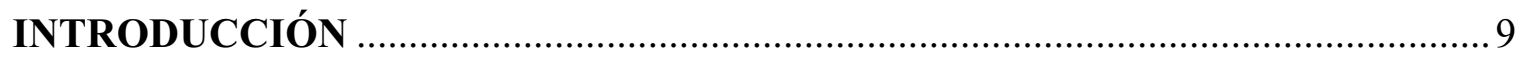

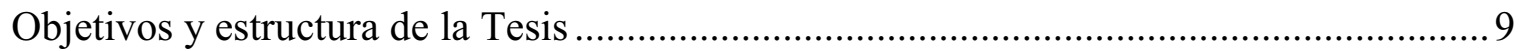

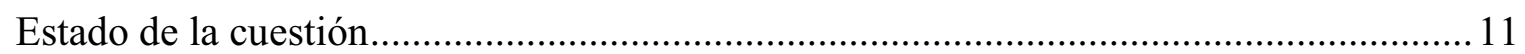

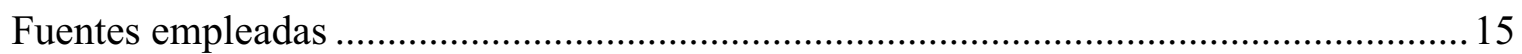

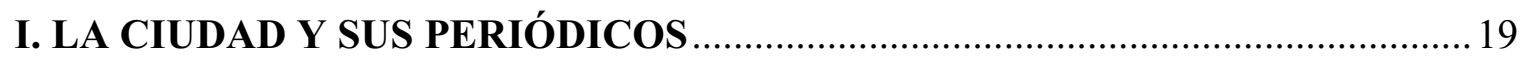

Capítulo 1. La música en la prensa murciana del siglo XIX ....................................2

1. El marco urbano: Murcia capital durante la segunda mitad del siglo XIX..................21

2. Panorámica de la prensa murciana durante la segunda mitad del siglo XIX ...............29

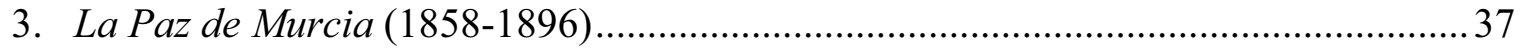

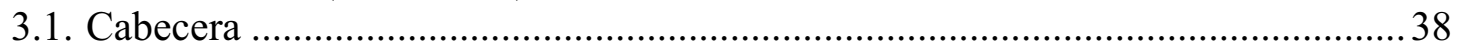

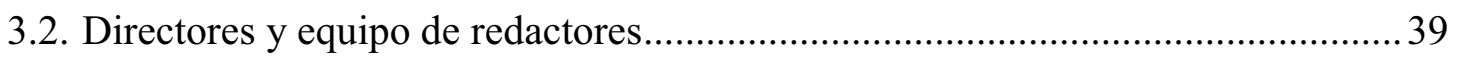

3.3. Oficinas de redacción, administración y talleres de impresión ............................ 41

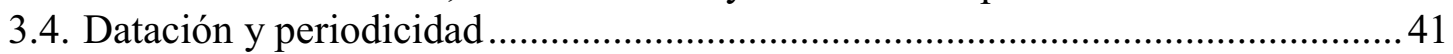

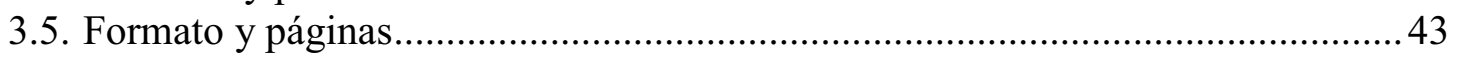

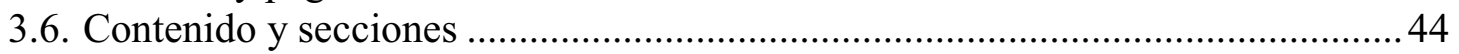

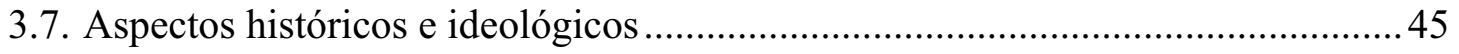

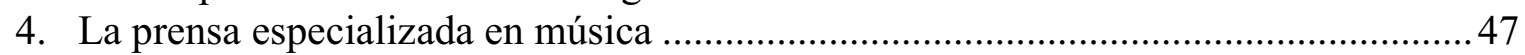

5. La música en las publicaciones periódicas murcianas del siglo XIX ..........................49

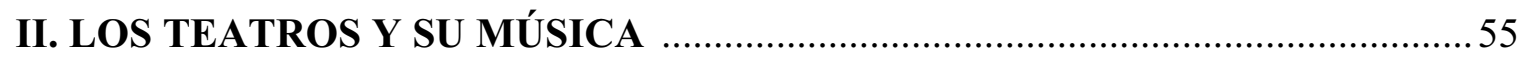

Capítulo 2. Teatros y locales teatrales de Murcia durante la segunda mitad

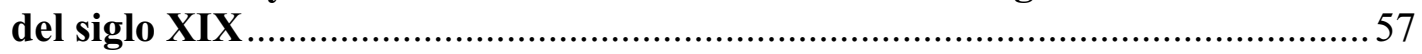

1. Del Teatro de la Puerta del Toro al Teatro Romea (1858-1895) .................................57

1.1. El derribo del Teatro del Toro y la construcción del Teatro de los Infantes

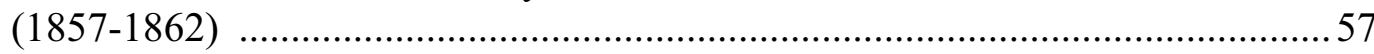

1.2. Evolución y cambios de denominación del teatro principal de Murcia: Teatro de los Infantes (1862-1872), Teatro de la Soberanía Nacional (1868-1872)

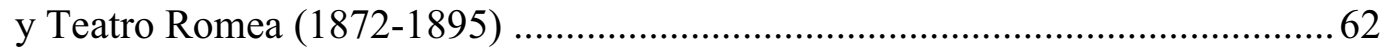

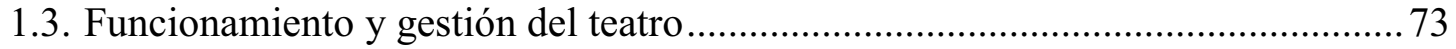

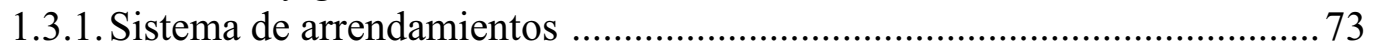

1.3.2. Las temporadas teatrales, los abonos y las funciones .............................. 91

1.3.3. Las normas de comportamiento en el teatro: el Bando de Buen

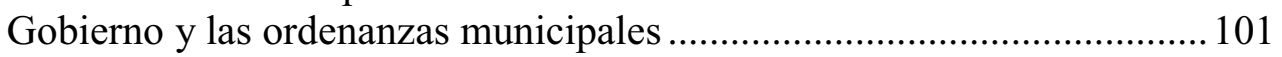




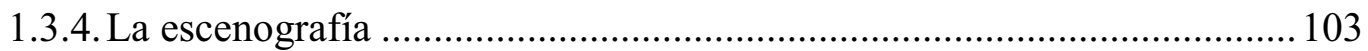

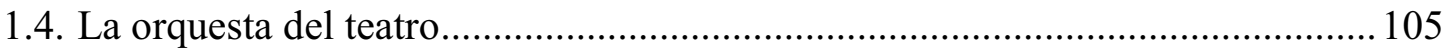

1.4.1. Directores de orquesta (1858-1881) ........................................................ 105

1.4.2. La polémica en torno a la creación de la orquesta del Teatro Romea

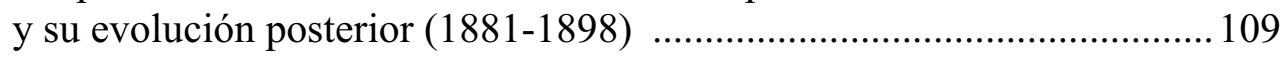

1.4.3. Estructura y composición ........................................................................ 133

1.4.4. Afinación y ubicación en el interior del teatro ......................................... 136

2. Otros teatros y locales de uso teatral................................................................... 138

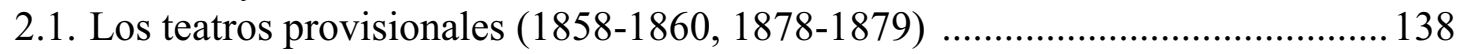

2.2. El Teatro Circo de la Rambla (1880-1885) ...................................................... 141

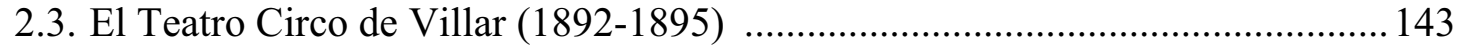

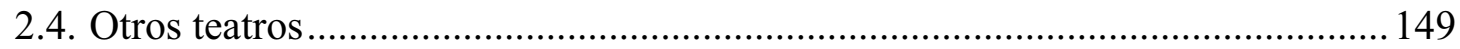

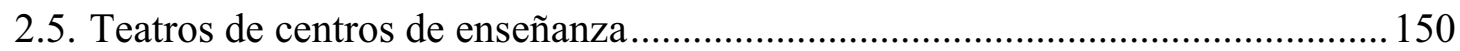

\section{Capítulo 3. Zarzuela y opereta en Murcia durante la segunda mitad}

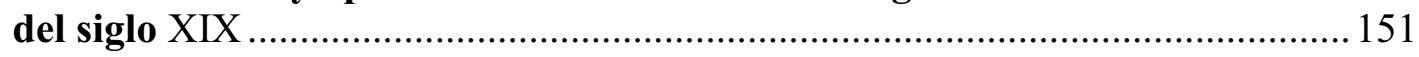

1. La zarzuela hasta la apertura del Teatro de los Infantes de Murcia (1849-1862) .... 151

1.1. Las primeras representaciones documentadas de zarzuela en el Teatro del Toro (1849-1855)

1.2. La zarzuela en el Teatro Provisional de Murcia (1858-1860) ........................... 152

2. La zarzuela en el Teatro de los Infantes-Romea (1862-1895) ................................. 155

2.1. La zarzuela hasta la introducción del género bufo (1862-1871) …………….... 155

2.2. Del género bufo al teatro por horas (1871-1888) ………………………........ 160

2.2.1. La polémica consolidación del género bufo (1871): zarzuela bufa

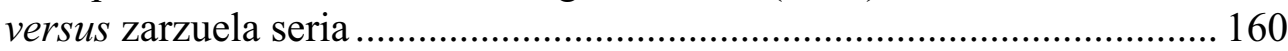

2.2.2. Problemática de las compañías de zarzuela del Teatro Romea hasta el primer incendio (1872-1877) ........................................................ 166

2.2.3. Compañías de zarzuela del Teatro Romea después del

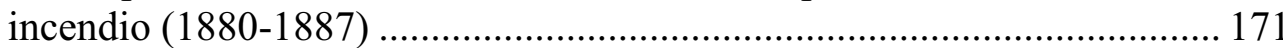

2.3. La zarzuela y el teatro por horas desde 1888 hasta 1895 ................................. 183

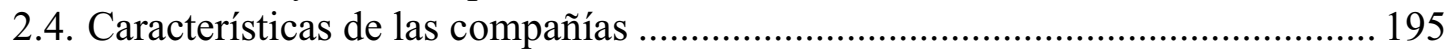

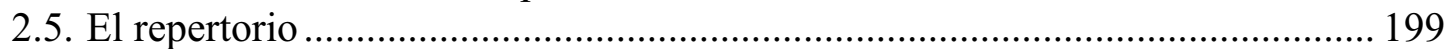

3. La zarzuela en otros teatros de Murcia ………………………………………... 208

3.1 El Teatro Circo de la Rambla (1880-1885) ……………………………..... 208

3.2 El Teatro Circo Villar (1893-1895)_....................................................... 215

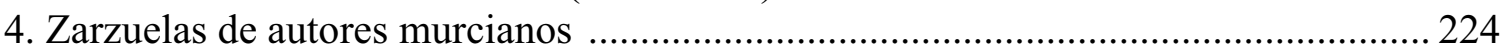

5. La Compañia Romana de Opereta y Baile de Gaetano Tani (1894) ........................... 239

\section{Capítulo 4. Ópera y crítica teatral en Murcia durante la segunda mitad}

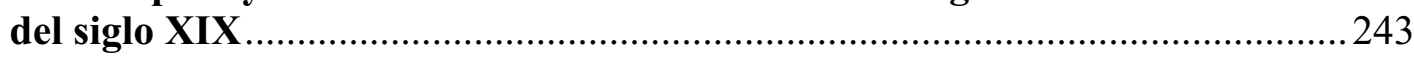

1. La ópera en Murcia durante la primera mitad del siglo XIX ..................................... 243

2. La ópera en Murcia desde mitad de siglo hasta la apertura del Teatro de los Infantes (1851-1862)

3. La ópera en el Teatro de los Infantes-Romea (1862-1899) ...................................... 248

3.1. La compañía de Peruzzi (1864) ………………………………………....... 248

3.2. Paréntesis sin compañías profesionales de ópera $(1865-1880)$.......................... 248 
3.3. Compañías de ópera desde 1881 hasta 1899

3.4. El repertorio de ópera en el Teatro de los Infantes-Romea desde 1862 hasta 1899

4. Ópera en otros teatros murcianos: la compañía de Arturo Baratta en

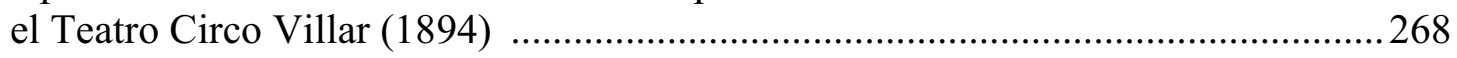

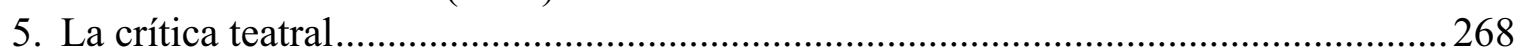

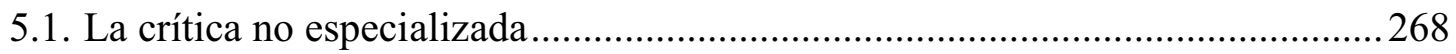

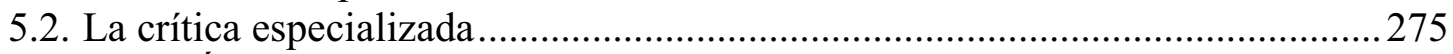

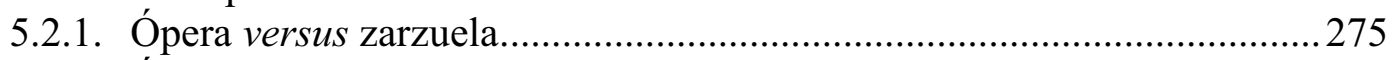

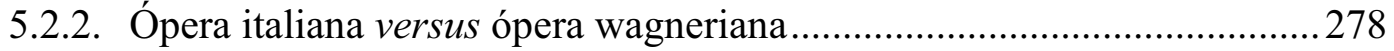

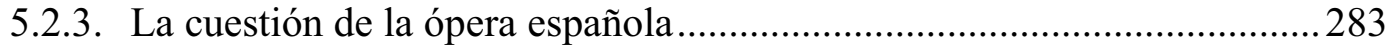

5.2.4. La calidad de las representaciones operísticas ....................................... 287

5.3. Polémicas periodísticas relacionadas con la crítica ...........................................291

Capítulo 5. Repertorio orquestal y conciertos de solistas en los teatros murcianos de la segunda mitad del siglo XIX ...............................2297

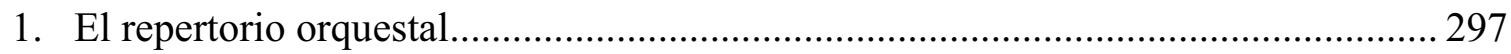

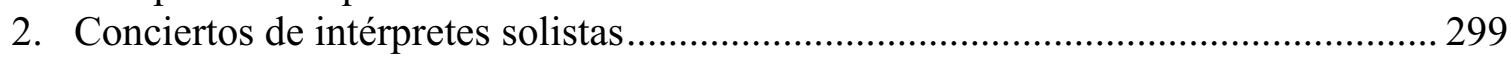

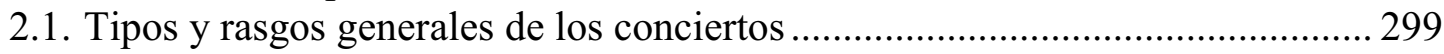

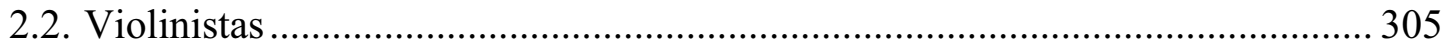

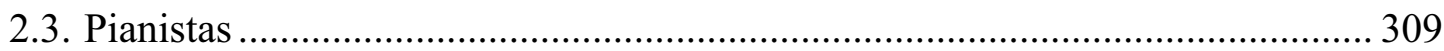

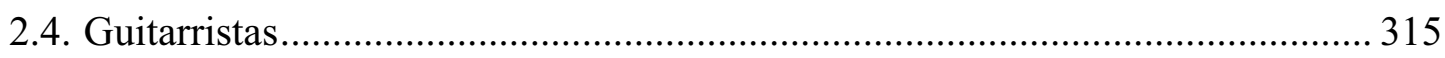

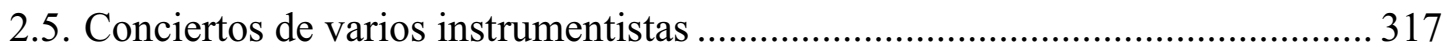

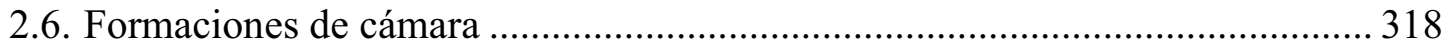

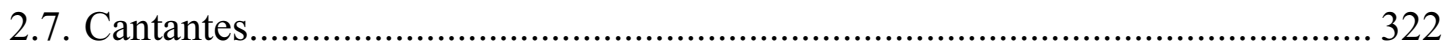

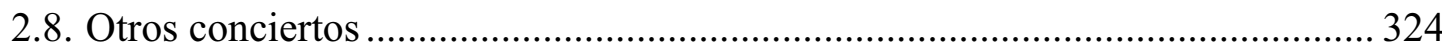

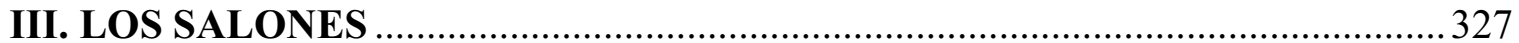

Capítulo 6. Sociedades, escuelas y academias de música en Murcia durante

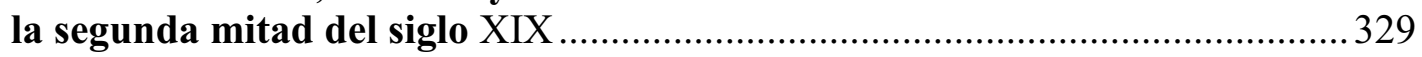

1. La música en las sociedades murcianas de la segunda mitad del siglo XIX ..............329

2. El Liceo Artístico y Literario de Murcia (1839) y otros liceos posteriores $(1859,1867)$

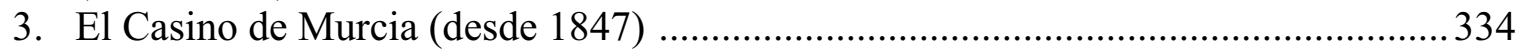

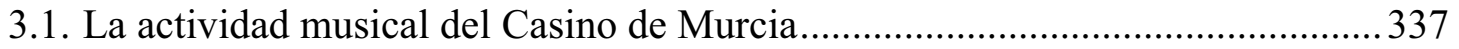

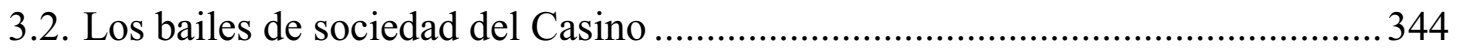

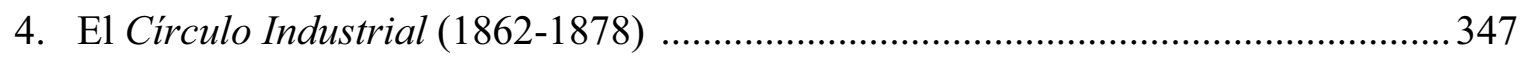

4.1. Primeras noticias sobre la fundación de la sociedad del

Círculo Industrial (1862-1866)

4.2. La construcción del teatro del Círculo Industrial y la creación de la sección lírico-dramática (1867-1869)

4.3. La actividad concertística y teatral del Círculo Industrial desde 1870 a 1872

4.4. La "Escuela de Canto y Declamación Padilla" y los ejercicios prácticos lírico-dramáticos (1873) 
4.5. La actividad teatral y concertística del Círculo Industrial desde 1873 hasta 1877

4.6. Los bailes de sociedad en el Círculo Industrial (1865-1878)............................ 359

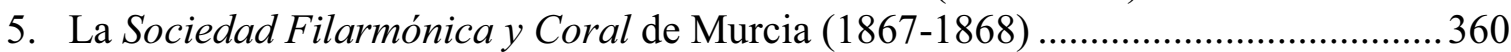

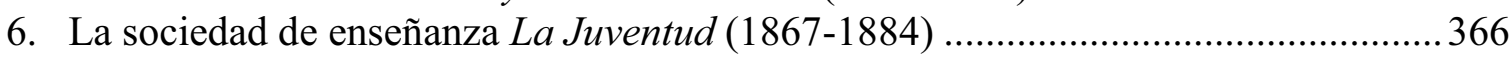

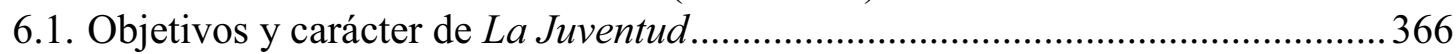

6.2. La anexión de la Filarmónica y la actividad musical de La Juventud

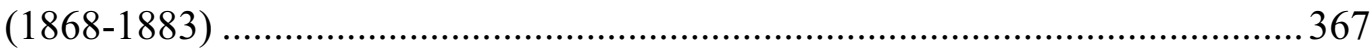

6.3. La unión de La Juventud y El Progreso: la Unión Literaria (1884-1885)......... 371

7. La Ilustración. Sociedad científico-literaria y artística (1869-1871) ...........................372

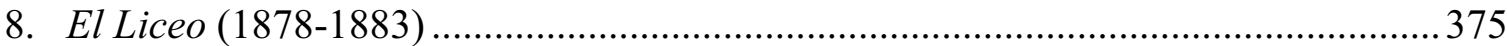

8.1. La unión del Círculo Industrial y la sociedad Ateneo: El Liceo (1878-1883)....375

8.2. El fin de El Liceo y el nacimiento del Círculo Taurino (1880-1883) ................. 380

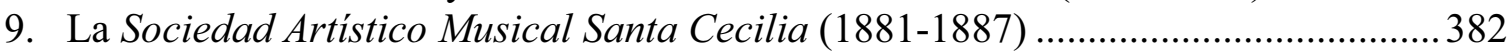

9.1. El proyecto de creación de un conservatorio de música murciano (1881) .......... 382

9.2. Fundación y actividad musical de la Sociedad Santa Cecilia hasta 1884 ...........384

9.3. La Sociedad Santa Cecilia, arrendataria del teatro Romea (1884-1887) ............ 390

9.4. La sociedad y la festividad de Santa Cecilia ........................................................ 392

10. Escuela de Canto y Declamación para la carrera artística teatral

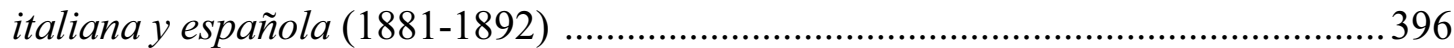

10.1. Fundación y primer año de existencia de la Escuela de Canto (1881) ...........396

10.2. De Escuela de Canto y Declamación a Real Escuela de Canto y

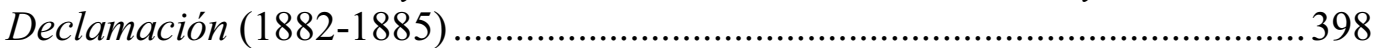

10.3. El traslado de la Real Escuela de Canto de Murcia a Madrid (1885-1892).... 400

11. La Sociedad Filarmónica Amigos de Antonio Raya (1883-1884) ..............................402

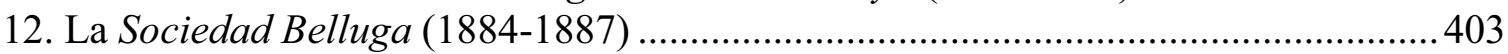

13. La Sociedad lírico-dramática Julián Romea (1888) ..................................................406

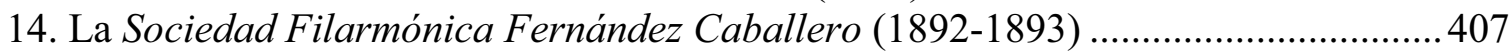

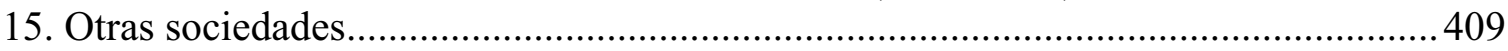

15.1. Veladas con música de la Juventud Católica (1870-1872) .............................409

15.2. Las veladas musicales de la Real Sociedad Económica de Amigos del País (1881)................................................................................... 410

15.3. La música en las sociedades dramáticas Romea, Apolo, Amigos de Talía

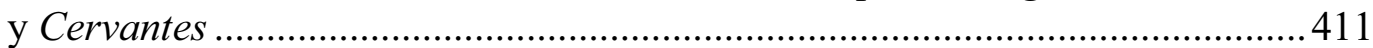

15.4. La música en las sociedades del barrio del Carmen Amigos del Progreso (1886-1888) y Amigos del Porvenir (1886-1889) ............................. 414

15.5. El Círculo Católico Obrero (1891-1900) ........................................................ 420

16. La Academia de Música de Mariano García López y Fernando Verdú

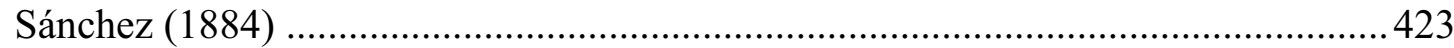

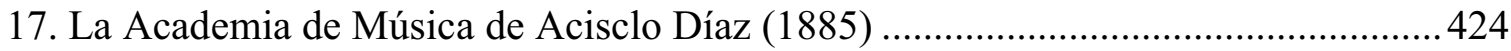

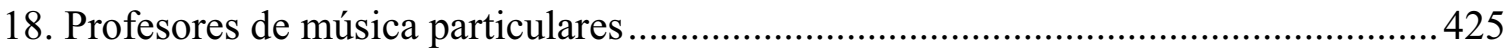

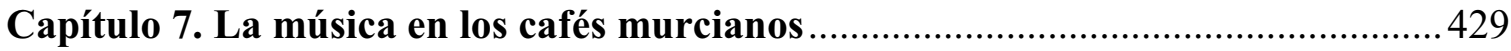

1. Los cafés de Murcia durante la segunda mitad del siglo XIX .................................429

1.1. El Café del Comercio (1866-1893) ................................................................... 435

1.2. Café de la Puerta del Sol (1869-1935) ............................................................438

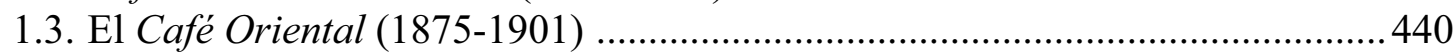

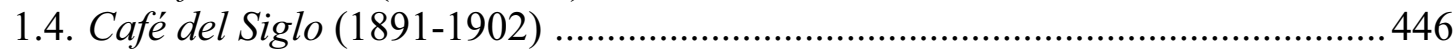




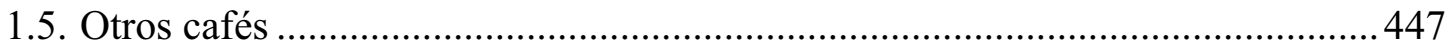

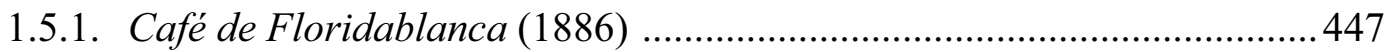

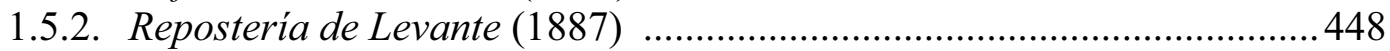

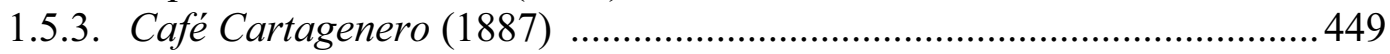

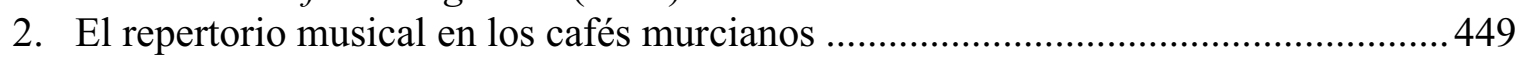

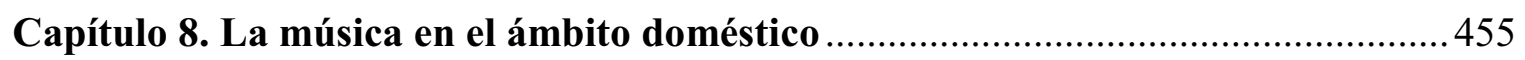

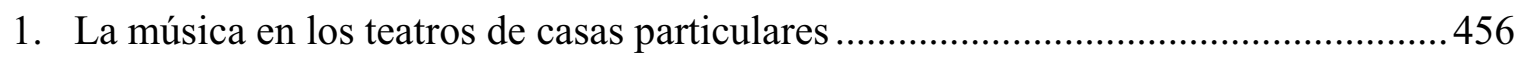

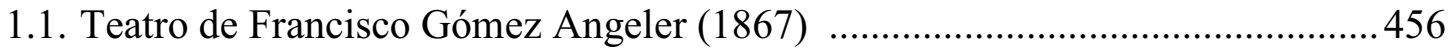

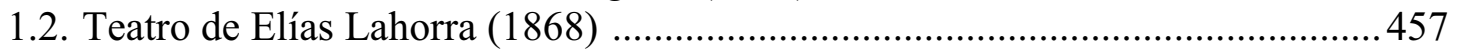

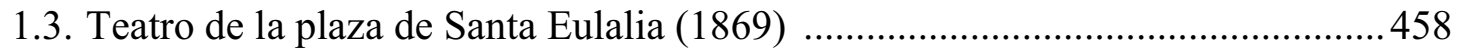

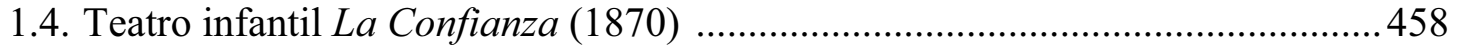

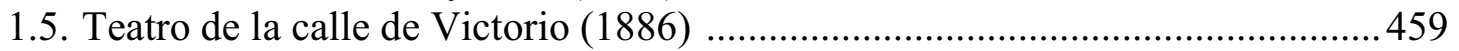

1.6. Teatro de la calle del Val de San Juan (1887) ...................................................459

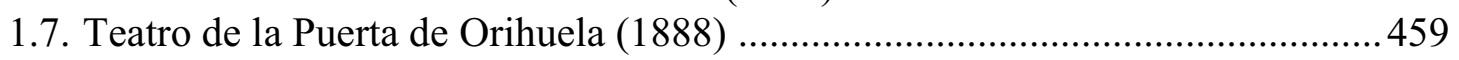

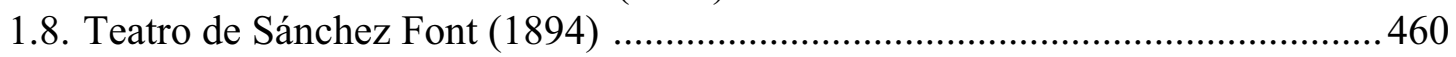

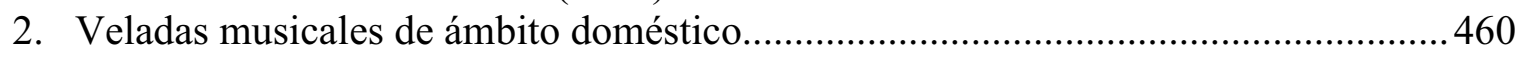

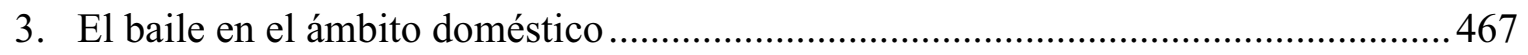

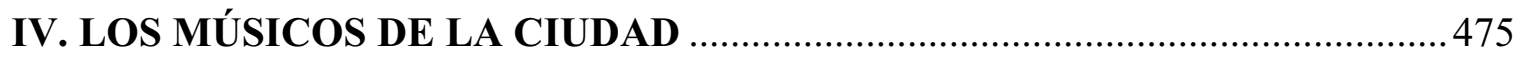

Capítulo 9. Generaciones de músicos murcianos .................................................... 477

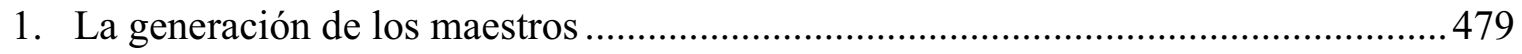

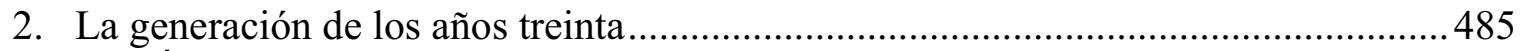

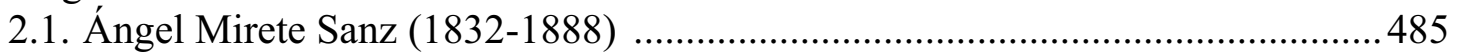

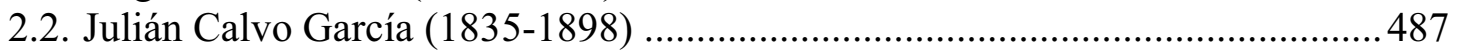

2.3. El maestro de capilla Mariano García López (1836-1906) …............................ 499

2.4. Acisclo Díaz Rocher (1837-1887) ......................................................................502

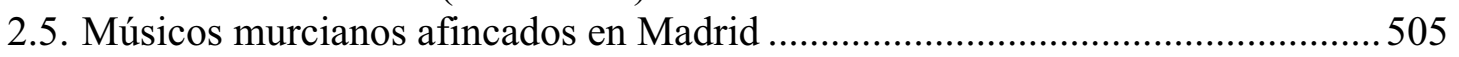

2.5.1. Gaspar Espinosa de los Monteros (1836-1898) .....................................505

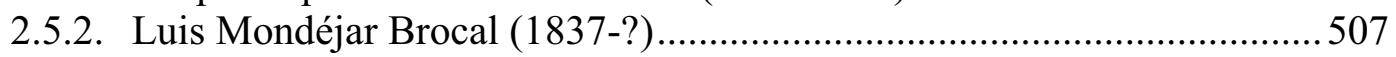

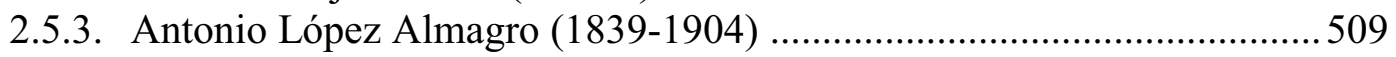

3. Músicos murcianos nacidos en los años cuarenta y cincuenta..................................525

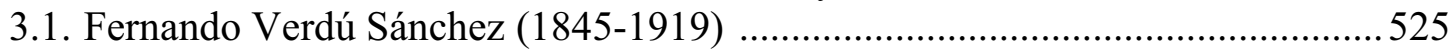

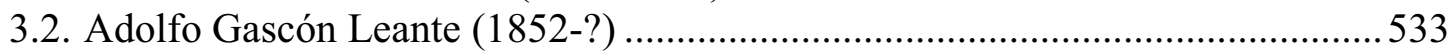

Capítulo 10. Mariano Padilla (1843-1906): un barítono murciano de proyección internacional

1. Infancia y juventud: la formación musical de Mariano Padilla en España (1843-1855)

2. Etapa italiana: conclusión de sus estudios musicales y despegue

profesional (1856-1861)

3. La carrera profesional de Padilla (1861-1906) .......................................................541

3.1. Actuaciones de Padilla en el Teatro Real de Madrid (1861-62 y 1862-63)

y en Río de Janeiro (1864) 
3.2. La gira mexicana: Actuaciones de Mariano Padilla en teatro Principal de México (1865)

3.3. Las temporadas invernales de 1867 y 1868: de Berlín a Rusia ..........................545

3.4. Matrimonio con Desirèe Artôt y traslado a Berlín (1869-1883) .......................547

3.5. La plenitud de su carrera artística: décadas ochenta y noventa ..........................556

3.6. Sus últimos años: los escritos periodísticos de Mariano Padilla en la prensa murciana

4. La personalidad de Mariano Padilla y sus características como cantante a través de la prensa

\section{Capítulo 11. Creación e investigación musical en Murcia durante la segunda} mitad del siglo XIX

1. Los Juegos Florales de Murcia y el fomento de la creación musical (1873-1883) ....577

2. Orígenes de la historiografía musical murciana: los "Apuntes para la historia de la música en Murcia” de El Semanario Murciano (1878-1879) 590

2.1. Andrés Blanco García, posible autor de los "Apuntes para la historia de la música en Murcia"

2.2. Estructura y fuentes de los "Apuntes"

2.3. Historia del piano en Murcia

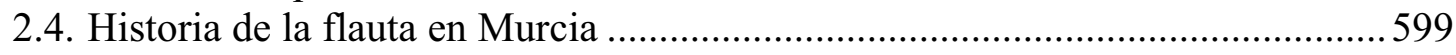

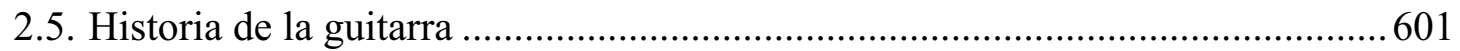

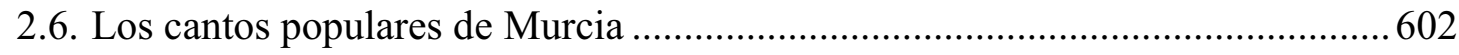

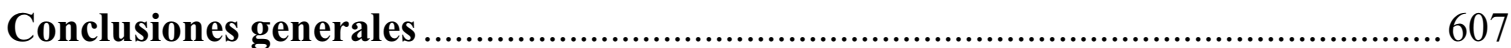

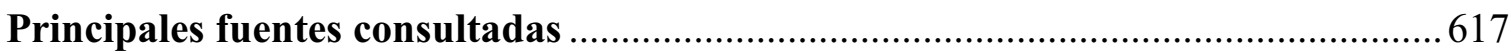

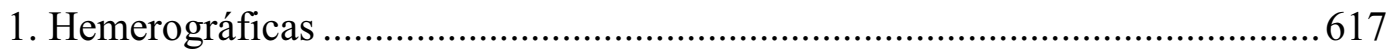

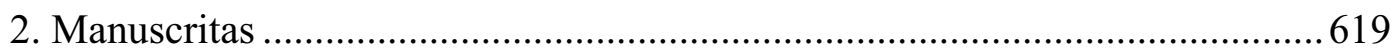

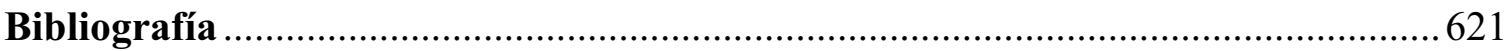

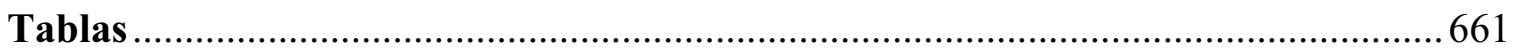

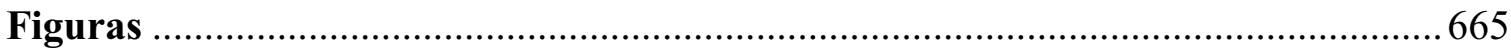

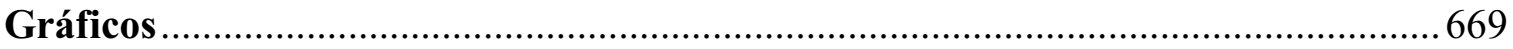

\section{VOLUMEN 2 \\ (en CD-ROM)}

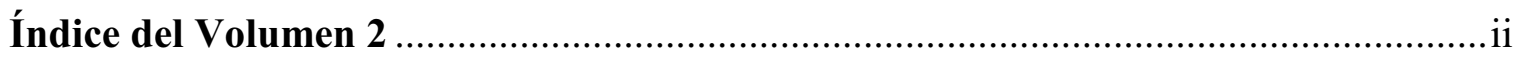

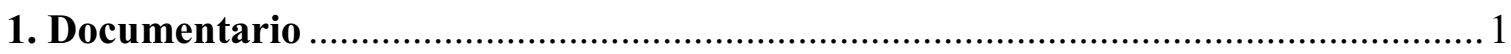

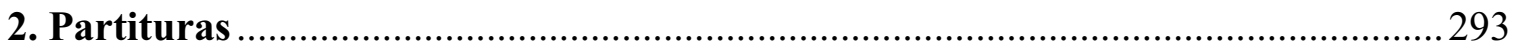

Coro final de Una broma de estudiantes, zarzuela en dos actos (Julián Calvo)...............2 294

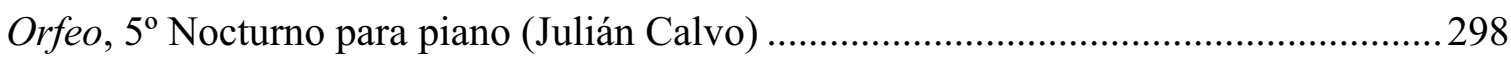

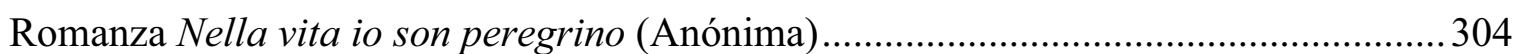

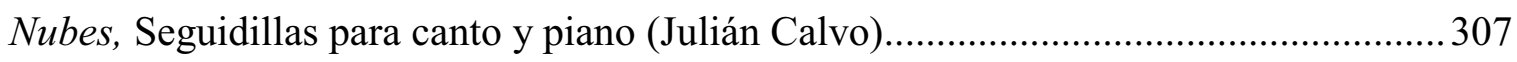


1.1 Mapa de la provincia de Murcia hacia 1864

1.2 Plano de la ciudad de Murcia con los edificios públicos de los siglos XVIII y XIX

1.3 Características de la prensa murciana conservada de la segunda mitad del siglo XIX.

1.4 La Paz de Murcia (1858-1896): evolución externa....

2.1 Teatros activos en la ciudad de Murcia durante la segunda mitad del siglo XIX......327

2.2 Compañías y espectáculos teatrales en los teatros de Murcia capital (1858-1895) ..328

2.3 Listado de arrendatarios del Teatro de los Infantes (1862-1868), posteriormente denominado Teatro de la Soberanía Nacional (1868-1872) y Teatro Romea (1872-1896)

2.4 Principales diferencias entre los arrendamientos del Teatro de la Soberanía Nacional y Romea de Murcia de los años 1871, 1881, 1884 y 1887.

2.5 Disposiciones sobre teatro en el Bando General de Buen Gobierno (1884)

2.6 Directores de orquesta de las compañías teatrales en los teatros de Murcia (1862-1884)

2.7 Artículos publicados en la prensa murciana sobre la orquesta del Teatro Romea (1881-1898)

2.8 Instrumentistas y directores opositores a las plazas de orquesta del

Teatro Romea y repertorio interpretado (1884)

2.9 Sueldos en la orquesta del Teatro Romea en funciones de zarzuela en los años 1884 y 1889 .380

2.10 Ubicación de los teatros de centros educativos de Murcia durante la segunda mitad del siglo XIX.

3.1 Anuncios en prensa que indican composición, repertorio y precios de abono de las compañías de zarzuela que actuaron en los teatros de Murcia (1858-1895) .......382

3.2 Estructura de las compañías profesionales de zarzuela que actuaron en los teatros murcianos (1858-1895)

3.3 Representaciones de zarzuela en el Teatro Provisional (1858-1860) de Murcia.......436

3.4 Representaciones de zarzuela en el Teatro de los Infantes de Murcia, posterior Soberanía Nacional y Romea (1862-1895)

3.5 Funciones benéficas en el Teatro Infantes-Romea (1873-1895): selección

3.6 Compositores y obras representadas por las compañías de zarzuela en el Teatro Infantes-Romea, por etapas (1862-1895)

3.7 Compositores y obras representadas por las compañías de zarzuela en los teatros murcianos Provisional (1858-1860), Infantes- Romea (1862-1895), Circo de la Rambla (1880-1885) y Circo Villar (1893-1895)

3.8 Representaciones de zarzuela en otros teatros de Murcia: Teatro Circo de la Rambla (1880-1885) y Teatro Circo Villar (1893-1895)

3.9 Mari Cruz Verde, zarzuela de costumbres murcianas en tres actos de Esteban Capdepón (música) y Javier Fuentes y Ponte (libreto): estructura musical y principales rasgos. 
3.10 Anuncio en prensa de la Compañía Romana de Opereta y Baile de Gaetano Tani (1894)

3.11 Representaciones de la Compañía Romana de Opereta y Baile de Gaetano Tani en el Teatro Romea de Murcia (1894) ................................................................906

4.1 Óperas representadas en el Teatro del Toro de Murcia (1821-1849) .......................914

4.2 Anuncios en prensa que indican composición, repertorio y precios de abono de las compañías de ópera que actuaron en los teatros de Murcia (1851-1899) .....917

4.3 Estructura de las compañías de ópera que actuaron en los teatros murcianos (1851-1899)

4.4 Óperas representadas en los teatros de Murcia (1851-1899)

5.1 Conciertos de solistas en los teatros de Murcia durante la segunda mitad del siglo XIX (selección)

6.1 Sociedades musicales (o relacionadas con la música) de Murcia durante la segunda mitad del siglo XIX y principales características

6.2 Selección de conciertos ofrecidos en el Casino de Murcia (1867-1883)

6.3 Conciertos ofrecidos por la sociedad Círculo Industrial (1867-1877) 996

6.4 Representaciones teatrales con música a cargo de la Sección Lírico-Dramática del Círculo Industrial en el teatro del Círculo Industrial de Murcia (1870-1872) 1000

6.5 Ejercicios prácticos lírico-dramáticos de la sociedad Círculo Industrial (1872-1873) y de su Escuela de Canto y Declamación "Padilla" de Murcia (1873) 1009

6.6 Conciertos de la Sociedad Filarmónica y Coral de Murcia (1867-1868) ...............1018

6.7 Conciertos organizados por la sociedad murciana La Juventud (1868-1869) ........1023

6.8 Certámenes artístico-literarios de la sociedad La Ilustración (1870-1871) .............1024

6.9 Conciertos ofrecidos por la sociedad El Liceo (1878-1883) ...................................1027

6.10 Representaciones teatrales en el Teatro El Liceo de Murcia (1878-1879) ............1031

6.11 Conciertos de la Sociedad Santa Cecilia de Murcia (1882-1883) ........................1037

6.12 Repertorio, intérpretes y oradores de las funciones religiosas por la festividad de Santa Cecilia en el convento de Madres Agustinas de Murcia $(1880-1884,1886,1889$ y 1891$)$ 1044

6.13 Programa del certamen literario y musical de la sociedad Belluga en homenaje al Cardenal Belluga (1884) 1046

6.14 Anuncios en prensa que indican la composición de las compañías que actuaron en el Teatro Porvenir de Murcia 1048

6.15 Representaciones de zarzuela de la compañía de de Gaspar Galinier y

Federico Montañés en el Teatro Porvenir de Murcia (1887-1888)

7.1 Veladas musicales del Café del Comercio (1878)

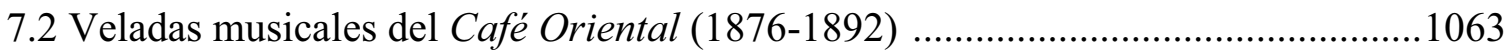

7.3 Veladas musicales del Café del Siglo (1891-1895) ................................................1104

8.1 Veladas musicales en casas particulares de Murcia durante la segunda mitad del siglo XIX

9.1 Composiciones localizadas de Julián Calvo (Murcia, 1835-Murcia, 1898)

9.2 Obras profanas de Julián Calvo mencionadas en la prensa murciana (1859-1891) 1134

9.3 Obras de Antonio López Almagro citadas en la prensa murciana (1866-1874) .....1138

9.4 Obras de Fernando Verdú mencionadas por la prensa murciana (1866-1894) ........1140 
10.1 Partida de Bautismo de Mariano Marco Padilla Ramos

10.2 Árbol genealógico de Mariano Marco Padilla Ramos (1843-1906)

10.3 Carta de Mariano Padilla al Vice-protector del Conservatorio de Música y Declamación de Madrid, exponiendo las razones de su entrevista con el cantante Beneventano

10.4 Actuaciones de Mariano Padilla en el Teatro Real de Madrid (1861-1862, $1862-1863,1877-1878)$

10.5 Gira inglesa de la compañía Mapleson (octubre 1886-enero 1887)

11.1 Premios los Juegos Florales de Murcia (1873-1881)

11.2 Premios y composiciones exigidas en las bases de los Juegos Florales de Murcia en la modalidad "Música" (1874-1881, 1883)

11.3 Ganadores de la sección de Música de los Juegos Florales de Murcia (1874-1881) 1160

11.4 Estructura y contenido de los artículos "Apuntes para la historia de la música en Murcia" de "Un aficionado" (1878-1879)

11.5 Catálogo de pianos de cola, verticales y de mesa de la ciudad de Murcia durante el siglo XIX 

LA VIDA MUSICAL EN MURCIA

DURANTE LA SEGUNDA MITAD DEL SIGLO XIX

\author{
VOLUMEN 1
}

María Esperanza Clares Clares 



\section{Agradecimientos}

Durante los años de preparación de esta Tesis Doctoral, han sido muchas las personas que me han facilitado el camino para concluir esta investigación. En primer lugar, debo agradecer de manera especial y sincera a la Dra. María Gembero, Científica Titular del CSIC en la Institució Milá i Fontanals de Barcelona y directora de esta Tesis Doctoral, por prestarme incondicionalmente su apoyo, su capacidad y su experiencia científica. Sus comentarios siempre precisos y rigurosos han despejado mis múltiples dudas.

Mi agradecimiento al Dr. Xosé Aviñoa, coordinador del Programa de Doctorado Música a l'Espanya contemporánia de la Universitat de Barcelona, por acoger esta Tesis Doctoral y a la Dra. Magda Polo. Ambos me han ayudado a resolver las interminables cuestiones administrativas con gran diligencia y paciencia.

Agradezco también de forma especial la ayuda que recibí del Dr. Franco Piperno, profesor de la Universidad "La Sapienza" de Roma, que fue mi Tutor durante mi estancia de investigación en esa institución entre junio y septiembre de 2007. Él me abrió generosamente las puertas de su despacho y me orientó en los laberínticos archivos romanos. Durante mi estancia en Roma tuve la suerte de contar además con la generosa acogida y valiosísimos consejos del Dr. Agostino Ziíno, profesor de la Universitá Tor Vergata de Roma, que mostró un gran interés por mi trabajo desde mis primeros contactos con él.

Deseo expresar mi gratitud a los responsables y personal técnico de todos los archivos y bibliotecas que he visitado. Mención especial merecen $\mathrm{M}^{\mathrm{a}}$ Ángeles Jover, directora del Archivo Municipal de Murcia, y todo el personal de este archivo, en el que mis constantes y numerosas consultas fueron atendidas con particular profesionalidad, amabilidad y buena disposición. Debo también un especial agradecimiento a la familia Martínez Calvo, en especial a Pilar Martínez Calvo, y a Mabel Breis que me permitieron investigar en sus archivos familiares y me prestaron durante meses valiosas partituras del compositor murciano Julián Calvo conservadas en ellos.

Agradezco a mis amigos, especialmente a Mary Joe y a Gorka, que han sufrido mis ausencias y falta de tiempo, su paciencia y su comprensión. Giulio Cargnello me prestó generosamente su casa y sus conocimientos en mi etapa de investigación en Italia, Diego Sanz me cedió parte de su tiempo en la revisión de algunos textos y Cándido Gutiérrez me ayudó a configurar la presentación de los datos numéricos presentes en algunas Tablas y Gráficos de esta Tesis.

Quiero expresar también mi más sentido agradecimiento a mi familia $\mathrm{y}$, en especial, a mis padres. En los últimos años, especialmente duros para ellos por razones ajenas a mi investigación, han sabido transmitirme siempre vitalidad y palabras de ánimo en los momentos tristes. Ellos me han inculcado que la perseverancia, el esfuerzo y la constancia son el camino para lograr objetivos. 



\begin{tabular}{|c|c|}
\hline \multicolumn{2}{|c|}{ Abreviaturas y siglas empleadas } \\
\hline $\mathrm{AC}$ & Acta Capitular \\
\hline arr. & arreglo, arreglista \\
\hline$A U S: C A n l$ & Canberra, National Library of Australia \\
\hline$C: H A B n$ & Archivo Nacional, La Habana, Cuba \\
\hline$c a$. & hacia \\
\hline $\mathrm{cm} . / \mathrm{cms}$ & centímetro, centímetros \\
\hline coord./coords. & coordinador, coordinadores \\
\hline dir., dirs. & director, directores \\
\hline$E: B b c$ & Biblioteca de Cataluña, Barcelona \\
\hline$E: C A R m$ & Archivo Municipal de Cartagena, Murcia \\
\hline$E: M c$ & Archivo del Conservatorio Superior de Música de Madrid \\
\hline$E: M h m$ & Hemeroteca Municipal de Madrid \\
\hline$E: M n$ & Biblioteca Nacional de España (Madrid) \\
\hline$E: M p b$ & Biblioteca Virtual del Patrimonio Bibliográfico \\
\hline$E: M U b r$ & Biblioteca Regional Digital de Murcia \\
\hline$E: M U c$ & Archivo de Música de la Catedral de Murcia \\
\hline E:MUhp & Archivo Histórico Provincial de Murcia \\
\hline$E: M U m$ & Archivo Municipal de Murcia \\
\hline$E: M U p j$ & Archivo Parroquial de San Juan Bautista de Murcia \\
\hline$E: M U s c$ & Archivo del Conservatorio Superior de Música de Murcia \\
\hline ed./eds. & editor, editores \\
\hline et al. & y otros autores \\
\hline $\exp$ & Expediente \\
\hline f. / fols. & folio, folios \\
\hline$F: B n$ & Bibliothèque Nationale, Francia \\
\hline
\end{tabular}


Ibid., Ibidem En el mismo lugar

id. $\quad$ idem

leg. $\quad$ legajo

ms. Manuscrito

N:Bo Bergen Offentlige Bibliotek, Bergen, Noruega

$\mathrm{n}^{\mathrm{o}}, \mathrm{n}^{\mathrm{os}} \quad$ número, números

op. cit. $\quad$ obra citada

p., pp. página, páginas

t. tomo

US: Wc Library of Congress, Washinton DC, Estados Unidos

vol., vols. $\quad$ volumen, volúmenes 


\section{Criterios de edición de textos originales}

En la edición literal de textos extraídos de la prensa del siglo XIX, así como de los documentos de Actas Capitulares y Legajos, he actualizado la ortografía, las abreviaturas, la acentuación, la puntuación y el uso de mayúsculas. He mantenido la ortografía original de los nombres propios de lugares y personas, y las expresiones en cursiva y las mayúsculas cuando afectan a palabras completas. He respetado los títulos de las obras teatrales tal y como aparecen en los documentos consultados. Los saltos de página se indican mediante el signo / y el número de página o folio entre corchetes. 



\section{INTRODUCCIÓN}

\section{Objetivos y estructura de la Tesis}

El objetivo de la presente Tesis Doctoral es analizar la actividad musical que tuvo lugar en la ciudad de Murcia durante la segunda mitad del siglo XIX, principalmente a través de la prensa local de carácter general, aunque empleando también otras fuentes complementarias, tanto españolas como italianas, que describiré después. El corpus más relevante de noticias en el que baso mi estudio procede de los numerosos ejemplares conservados del periódico La Paz de Murcia, publicado entre 1858 y 1896. La rica información proporcionada por esta publicación es completada con datos procedentes de otras fuentes y colecciones periódicas, especialmente en los periodos 1800-1857 y 18961900, en que no hay ejemplares de La Paz de Murcia. Debido a la enorme cantidad de documentación de interés musical localizada, he limitado mi estudio a la ciudad de Murcia, dejando para futuras investigaciones los abundantes datos recogidos sobre la rica actividad musical de pueblos, municipios y pedanías cercanas, en muchos casos, estrechamente vinculada a la capital. Me he centrado en la segunda mitad del siglo XIX para poder tener una visión general de la actividad musical murciana y completar la investigación que previamente había realizado sobre la primera mitad del siglo ${ }^{1}$.

El marco cronológico escogido, que no corresponde a una etapa política unitaria ${ }^{2}$, permite analizar con perspectiva, en una ciudad de la periferia española como Murcia, la evolución e implantación de diversos géneros musicales (zarzuela, ópera, sinfonismo, conciertos de solistas, música de salón), los gustos del público, la recepción de determinados autores y obras, la situación social de los músicos murcianos y sus conexiones con el exterior, entre otros aspectos. El estudio realizado aporta información particularmente relevante sobre la música profana en muy diversas facetas, y especialmente en lo referente a música teatral, sociedades y salones musicales ${ }^{3}$. La Tesis aporta también mucha información nueva sobre música religiosa, especialmente al tratar la producción de varios compositores murcianos, aunque la música religiosa de Murcia en el siglo XIX requiere un estudio sistemático más amplio que no ha sido posible abordar aquí, entre otras razones por la imposibilidad de acceso desde hace varios años a los fondos musicales de la Catedral de Murcia y la ausencia de documentación sobre el siglo

\footnotetext{
${ }^{1}$ Clares, La vida musical. La subdivisión del siglo en dos mitades fue también la opción elegida en una importante obra de referencia: The Cambridge History of Nineteenth-Century Music, editada por Jim Samson (Cambridge: Cambrigde University Press, 2002); se trata de una colección de ensayos divididos en dos partes (1800-1850 y 1850-1900) en los que se abordan temas como la profesión del músico antes y después de 1800 (Rink, "The profession of music"), la industria de la ópera (Parker, "The opera industry"), el consumo de la música (Carew, The consumption of music"), la estructuras de la vida musical (Ellis, "The structures of musical life") y música y clases sociales (Scott, "Music and social"), entre otros.

2 Este estudio comienza en los últimos años de la "década moderada" (1843-1854), en pleno reinado de Isabel II (1843-1868) y abarca, sucesivamente, el Sexenio revolucionario (1868-1874), la Restauración borbónica de Alfonso XII (1875-1885) y, en parte, la Regencia de María Cristina de Habsburgo-Lorena (1885-1902). Para una visión de conjunto sobre la historia de España durante el marco cronológico estudiado véase, entre otras obras: Bahamonde y Martínez. Historia de España. Siglo XIX; Espadas Burgos y De Urquijo. Guerra de la Independencia y época constitucional (1808-1898) y Álvarez Junco, Mater dolorosa. La idea de España en el siglo XIX.

${ }^{3}$ La actividad musical al aire libre y las bandas de música fueron objeto de estudio en otras publicaciones mías, y aquí sólo serán mencionadas tangencialmente. Véase, Clares, "Bandas y música" y "Murcia y su música".
} 
XIX en otros centros importantes, como por ejemplo el Convento de Madres Agustinas de Murcia.

El planteamiento de esta Tesis es fundamentalmente urbano, y se orienta sobre todo a analizar la presencia de la música en la sociedad de Murcia. Este trabajo conecta, por tanto, con una sólida tradición de estudios sobre "la vida musical en" diferentes ciudades, particularmente rica en la musicología europea ${ }^{4}$, que está teniendo también cada vez mayor presencia en la musicología hispánica ${ }^{5}$. Incluyo también en la Tesis comentarios sobre algunas composiciones musicales relacionadas con Murcia en el periodo estudiado, que eran inéditas o desconocidas hasta ahora. Mi aproximación no intenta ofrecer un análisis evolutivo ni exhaustivo del estilo musical, sino situar las obras en el contexto social y cultural en el que fueron creadas y/o escuchadas.

La Tesis consta de dos volúmenes, el primero en papel y el segundo en CD-ROM. El Volumen 1 contiene el estudio propiamente dicho, dividido en cuatro partes y once capítulos. La primera parte, "La ciudad y sus periódicos", incluye un único capítulo en el que analizo la presencia de la música en las publicaciones periódicas murcianas de carácter general durante el siglo XIX.

La segunda parte, "Los teatros y su música", comprende los capítulos 2 al 5. El Capítulo 2 describe los teatros de Murcia durante la segunda mitad del siglo XIX, dando por primera vez una visión global de todos ellos (que hasta el momento habían sido tratados sólo de forma independiente y fragmentaria) y aborda el estudio detallado del coliseo más importante de la ciudad, el Teatro Romea. El Capítulo 3 está dedicado a la zarzuela y opereta, el Capítulo 4 a la ópera y la crítica teatral y el Capítulo 5 al repertorio orquestal y los conciertos de solistas en los teatros murcianos.

\footnotetext{
${ }^{4}$ Véanse, por ejemplo, los resultados del programa "Musical life in Europe 1600-1900. Circulation, institutions, representation", editados por Christoph Hellmut Mahling, Christian Meyer y Eugene K. Lobo, 12 vols., Berlín, Berliner Wissenschafts-Verlag, 2003-2008, que incluyen volúmenes específicos sobre las sociedades musicales (Les sociétés de musique en Europe. 1700-1920. Structures, pratiques musicales, sociabilités, 2007), los conciertos (Organisateurs et formes d'organisation du concert y Espaces et lieux de concert en Europe, ambos del 2008) y las orquestas (The Opera Orchestra in the 18th-and 19th-Century Europe, 2 vols., 2008). Otros importantes estudios que me han servido de referencia son: Cooper, The rise of instrumental music and concert series in Paris, 1828-1871, pp. 135-167; Cowgil y Holman (eds.), Music in the British provinces, 1690-1914 y, especialmente, Drage, "The Larks of Dean", pp. 195-221 y Dale, "The Provincial Musical”, pp. 325-347; Gauthier y Traversier (dir.), Mélodies urbaines. La musique dans les villes d'Europe (XVI $-X I X^{e}$ siécles); De Angelis, La musica del Granduca. Vita musicale e corrente critiche a Firenze 1800-1855; De Brito y Cranmer, Crónicas da Vida Musical Portuguesa na Primeira Metade do Século XIX; Fonseca, A vida musical no Porto na segunda metade do século XIX; Weber, Music and the Middle Class. The Social Structure of Concert Life in London, Patis and vienna y la colección de artículos publicados en La música en Hispanoamérica en el siglo XIX, cuyo volumen ha sido editado por Consuelo Carredano y Victoria Eli.

5 Para una reflexión historiográfica sobre los estudios de musicología urbana en España, véase Carreras, "Música y ciudad". Entre las publicaciones sobre la vida musical de ciudades españolas en el siglo XIX están las de Pilar Alén y María García Caballero sobre La Coruña y Santiago de Compostela; María Antonia Virgili y Victoria Cavia sobre Valladolid; Adelaida Muñoz y Antonio Cabeza sobre Palencia; Olga Sánchez Huedo sobre Albacete; María Nagore sobre Bilbao y Pamplona; José Ignacio Palacios sobre Soria; María Ester-Sala y Josep Maria Vilar, Xosé Aviñoa, Roger Alier y Monserrat Comellas i Barri sobre Barcelona; Manuel Sancho García sobre Valencia; Juan de Dios Aguilar y Vicente Ramos, sobre Alicante; Antonio Álvarez Cañibano y Andrés Moreno Mengíbar sobre Sevilla; Gonzalo Martín Tenllado sobre Málaga, José Miguel Barberá sobre Granada y Rosa Martínez Anguita sobre Jaén. Véanse las referencias completas de estos trabajos en la bibliografía final.
} 
La tercera parte de la Tesis, titulada "Los salones", comprende los capítulos 6 al 8. El Capítulo 6 presenta un análisis detallado de la actividad musical en las sociedades, escuelas y academias musicales de Murcia durante la segunda mitad del siglo XIX. En él se estudian veintiocho sociedades recreativas que influyeron poderosamente en la actividad cultural murciana, así como otras escuelas y academias musicales. En el Capítulo 7 se analiza la música en los cafés murcianos y el Capítulo 8 se centra en la actividad musical y baile en el ámbito doméstico.

La cuarta parte de esta Tesis Doctoral (capítulos 9 al 11) estudia los músicos de Murcia. En el Capítulo 9 abordo las generaciones de músicos murcianos nacidos desde los años finales del siglo XVIII hasta los cincuenta del siglo XIX y presento las biografías y obras de los más destacados, como Julián Calvo, el maestro de capilla Mariano García López y Antonio López Almagro, entre otros, cuyas trayectorias habían sido escasamente estudiadas hasta la fecha. El Capítulo 10 está dedicado al barítono Mariano Padilla (18431906), músico murciano que alcanzó una particular proyección internacional, cuya exitosa carrera se analiza por primera vez en esta Tesis. El Capítulo 11 se refiere a la creación musical de autores murcianos a través de los "Juegos Florales" (certámenes artístico-literarios que estimularon la composición musical local) y a los orígenes de la historiografía musical murciana.

El Volumen 1 finaliza con las Conclusiones Generales, relación de las principales fuentes empleadas, Bibliografía e índices de Tablas, Figuras y Gráficos. En el Volumen 2 incluyo un Documentario con ciento setenta documentos procedentes de prensa y otras fuentes; una selección de cuatro partituras comentadas a lo largo de la Tesis y sesenta y tres apéndices, entre los que incluyo la reconstrucción de los programas de teatro musical de todos los teatros murcianos (públicos y privados) en 1858-1895 y la programación musical de los distintos salones murcianos (sociedades, cafés y casas particulares).

\section{Estado de la cuestión}

La Historia de la Música en Murcia ha sido, hasta el momento, una temática escasamente investigada ${ }^{6}$ y en ocasiones ha sido abordada desde perspectivas meramente divulgativas $^{7}$. A las contribuciones sobre folklore musical ${ }^{8}$, órganos y organeros ${ }^{9}$ y

\footnotetext{
${ }^{6}$ A ello ha contribuido la inaccesibilidad de algunos archivos con ricos fondos musicales, como por ejemplo, el de la Catedral de Murcia, y la falta de catálogos musicales de archivos murcianos. En 2008 se creó el Centro de Documentación Musical de Murcia con fondos provenientes sobre todo de donaciones particulares, aunque este centro desapareció lamentablemente en 2010 y sus fondos pasaron al Archivo General de la Región de Murcia, actualmente en proceso de catalogación.

${ }^{7}$ Véanse, por ejemplo, aportaciones divulgativas como Soler, Manuel Fernández; Oliver, Medio siglo y Cano, Murcianos.

${ }^{8}$ De los estudios sobre folclore murciano, destacan por su relación con esta Tesis: Martínez y Narejos, Pasionaria; Ortega, "Cantos"; Encabo, "Las primeras"; Rocamora, Los auroros; Gris (ed.), Los Auroros; y, Flores, "Los auroros".

9 Latcham, "The instrument"; Pina, "Órganos y organeros"; Artigas, "El presupuesto"; Candel, "Contrato para la construcción"; Melendreras, "Órganos"; Máximo, "Tadeo"; Máximo, El órgano; y Melendreras, "El órgano".
} 
fondos archivísticos ${ }^{10}$ hay que añadir dos estudios relevantes en los últimos años: las Tesis Doctorales de Cristina Pina y Consuelo Prats, centradas en aspectos musicales de Murcia en la Edad Moderna ${ }^{11}$.

La música del siglo XIX en Murcia comenzó a ser estudiada sistemáticamente en mi trabajo La vida musical murciana en la primera mitad del siglo XIX a través de la prensa: estudio y documentario ${ }^{12}$ y en varios artículos posteriores ${ }^{13}$, de los que la presente Tesis Doctoral es continuación. José Gelardo Navarro ha investigado sobre el flamenco en la prensa murciana del siglo $\mathrm{XIX}^{14} \mathrm{y}$ otros autores han estudiado diversos aspectos de la actividad musical murciana de esa centuria ${ }^{15}$.

El teatro ha sido una de las temáticas murcianas más estudiadas y los trabajos sobre esta materia contienen valiosa información de interés musical ${ }^{16}$. Destaca la recopilación de datos sobre el teatro en Murcia realizada por Antonio Crespo ${ }^{17}$.

${ }^{10}$ Ezquerro, "Memoria de actividades", p. 271-301 en el que se informa sobre la catalogación de los fondos musicales de la Catedral de Murcia según las normas del RISM y los estudios de López García, Los fondos y López García, "Obras".

${ }^{11}$ Pina, La música civil, se centra en la música de los reinados de Felipe V a Carlos III (1700 a 1789); y la de Prats, Música y músicos analiza la actividad musical de la Catedral de Murcia entre los años 1600 a 1750. Las Tesis de Pina y Prats se complementan con otros estudios de las mismas autoras: Pina, "La Capilla" explora la trayectoria de la Capilla de Música de Santa Cecilia como un ejemplo temprano de asociacionismo en la Murcia del siglo XVIII; y el de Prats, Educación Musical indaga sobre la educación musical de los infantes de coro en el Colegio de San Leandro de Murcia (dependiente de la Catedral) durante los años 1600-1760. Posterior al siglo XIX es la Tesis Doctoral de Juan Lanzón, La música, que analiza la música en Murcia a partir de la Guerra Civil Española (1939-1975), y el estudio inédito de Valero, La música centrado en la actividad musical de los cafés concierto y cines de Murcia a principios del siglo XX. Todos ellos son imprescindibles para conocer la música murciana durante las etapas precedentes y posteriores al marco cronológico de esta Tesis.

${ }^{12}$ Este trabajo, requisito imprescindible para la obtención del D.E.A., fue dirigido por la Dra. María Gembero Ustárroz y defendido en la Universidad de Granada en 2003. Para esa investigación consulté más de mil ejemplares de periódicos murcianos pertenecientes a treinta y dos publicaciones diferentes de contenidos e información generales. Ese trabajo puso de manifiesto el enorme interés de las fuentes hemerográficas para estudiar, desde distintos ámbitos, la actividad musical de Murcia.

${ }^{13}$ Además de los citados en notas anteriores, véase Clares, "La música teatral".

${ }^{14}$ De Gelardo, entre otros títulos, destacan: Las claras del día; El Flamenco; El flamenco en Lorca y Con el flamenco.

${ }^{15}$ García Seco y González Cutillas han publicado varias entradas sobre compositores murcianos del siglo XIX en la Gran Enciclopedia de la Región de Murcia (véase Bibliografía). También sobre música murciana en el siglo XIX son los trabajos de García Seco, "Prensa musical", p. 164; Crespo, "Apuntes", pp. 107-117 y Crespo, "Algunos autores", pp. 69-88. Aunque relativo a músicos murcianos de Cartagena, el trabajo de García Segura, Músicos también es una valiosa fuente de información sobre artistas murcianos del siglo XIX.

${ }^{16}$ En 1958, Barceló publicó la primera edición de la Historia del Teatro en Murcia, obra que abarcaba hasta el siglo XVII y posteriormente fue ampliada con nuevos capítulos (siglos XVIII, XIX y XX) en una segunda edición publicada en 1980 . No obstante, no hay todavía un buen estudio que analice la actividad teatral murciana de la segunda mitad del siglo, quizás por la visión negativa que se ha tenido de sus primeras décadas (Guerra de la Independencia, desastres naturales y epidemias). En el prólogo a la segunda edición de su Historia del teatro en Murcia (p. 5), Barceló afirmaba "la historia del teatro en Murcia a partir del siglo XVIII no ofrece el interés de los siglos anteriores". Véase también Barceló: "El Teatro Romea", pp. 5-58.

17 Los trabajos de Crespo, sin embargo, carecen de un análisis profundo que presente las particularidades de la vida teatral murciana en relación al contexto nacional. Son, fundamentalmente, estudios diacrónicos en los que se enumeran las obras representadas. Véanse Crespo: Historia del teatro, El 
La presencia de los músicos murcianos del siglo XIX en obras generales sobre música española se reduce a varias entradas en el Diccionario de la Música Española e Hispanoamericana y en el Diccionario de la Zarzuela ${ }^{18}$; e información muy diseminada en trabajos como el Diccionario de efemérides de Saldoni ${ }^{19}$ y el estudio de Celsa Alonso sobre la canción lírica ${ }^{20}$. No hay todavía estudios sistemáticos sobre importantes músicos murcianos del siglo XIX, como Manuel Fernández Caballero y Antonio López Almagro, que sólo han sido objeto hasta ahora de trabajos puntuales ${ }^{21}$.

Para contextualizar los aspectos históricos, económicos y sociales de Murcia en el siglo XIX, han sido de gran utilidad diversos estudios no específicamente musicales. Sobre historia de Murcia durante el siglo XIX las obras de síntesis más destacadas son la de Merino Álvarez ${ }^{22}$; el volumen correspondiente al siglo XIX de la Historia de la Región Murcia $^{23}$; El proceso de modernización, de Pérez Picazo y Guy Lemeunier ${ }^{24}$; y las recientes aportaciones de Rodríguez Llopis y Martínez Carrión ${ }^{25}$.

La prensa es una fuente informativa de capital importancia para los estudios de historia en general y especialmente de historia cultural y social. Las publicaciones periódicas dan cuenta de los hechos históricos desde la propia premura de su acontecer y, en muchos casos, la función comunicativa se solapa con fines propagandísticos e ideológicos interesantes de analizar ${ }^{26}$. El interés de los investigadores por la prensa como fuente de investigación musical se ha incrementado en las últimas décadas, paralelamente al desarrollo de programas de actuación nacional e internacional que tratan de localizar,

Teatro Romea, Antiguos teatros, "El Teatro de los Crímenes". Otros estudios sobre el teatro en Murcia en el siglo XIX son: Rubio García, "Documentos"; Sanz Romero, "Escenografía” y Montalbán, "Análisis teatral".

${ }^{18}$ Por ejemplo, Prats, "Murcia"; Casares, "Muñoz Pedrera"; Casares, "Soriano"; Climent, "Gil Yuncar [sic], José”; Climent, “Giménez, Agustín”; González Cutillas, “Gil Yuncas, Julián”; Ruiz Tarazona, "Puig, Antonio"; Sobrino, "Calvo García”; Sobrino, "Espinosa de los Monteros"; Vázquez Tur y Garbayo, "López Almagro".

${ }^{19}$ Saldoni, Diccionario.

${ }^{20}$ Por ejemplo, sobre las canciones de Antonio López Almagro. Véase Alonso, La Canción, pp. 475476.

${ }^{21}$ Una excepción es el trabajo inédito de José López Rico y Víctor Pliego de Andrés (biografía y estudio musical, respectivamente) sobre Antonio López Almagro, titulado Antonio López. González Cutillas, en "Manuel Fernández", presenta un trabajo preliminar sobre la figura de este célebre compositor murciano y me consta que en la actualidad continúa trabajando sobre él. Es reciente la Tesis Doctoral de Juan Bautista Boïls Ibiza, titulada La Historia de la Música Española de Mariano Soriano Fuertes (18171880). Edición crítica de una fuente esencial en la historiografía de la música española del siglo XIX (Universidad de Valladolid, 2010).

${ }^{22}$ Aunque se publicó en 1915, el bien documentado estudio de Merino, Geografía sigue siendo válido y no superado en algunos aspectos.

${ }^{23}$ Alonso Navarro (dir.) et al. Gran Enciclopedia, vol. 8 aporta enfoques de materias como historia, arquitectura y urbanismo, literatura, escultura, pintura, cerámica y vidrio.

${ }^{24}$ Pérez Picazo y Lemeunier, El proceso.

${ }^{25}$ Rodríguez Llopis, Historia de la Región y Martínez Carrión, Historia económica. Véase también, Rodríguez Llopis (dir.) y Martínez Carrión (coord.), Atlas. Sobre el asociacinismo en la región murciana, véase Crespo, "Un sindicato", pp. 105-109 y De los Reyes, "El asociacionismo", pp. 85-91.

${ }^{26}$ Véase, por ejemplo, el estudio sobre las constantes ideológicas adheridas al wagnerismo en la crítica musical del periódico L’Avenç (1881-1884 y 1889-1893) que propone Aviñoa, "Les constans". 
preservar, catalogar y facilitar el acceso a las colecciones existentes ${ }^{27}$. En España, Jacinto Torres fue pionero en los estudios sobre música y prensa $^{28}$, y en los últimos años se han incrementado las investigaciones en esta línea ${ }^{29}$, que también es cada vez más importante en el ámbito hispanoamericano ${ }^{30}$.

Las colecciones periódicas (públicas y privadas) conservadas en Murcia han sido objeto de concienzudas investigaciones en los últimos años ${ }^{31}$. Sobresale la aportación de Ibáñez, Serie cronológica de la prensa periódica en Murcia, primer estudio sistemático sobre la prensa murciana desde sus orígenes hasta principios del siglo XX, y el de Crespo, Historia de la prensa periódica en la ciudad de Murcia $^{32}$. A estas obras de referencia se une la aportación de Pío Tejera que, sin ser de temática estrictamente periodística, contiene numerosos datos sobre prensa ${ }^{33}$; la de García Soriano, meritorio estudio dedicado a la imprenta en la Región de Murcia; las Fuentes del periodismo murciano, de

${ }^{27}$ El proyecto internacional más destacado es el RIPM (Retrospective Index to Music Periodicals), promovido por la International Musicological Society, que está catalogando e indexando publicaciones periódicas musicales de más de una veintena de países entre 1800 y 1950 .

${ }^{28}$ La Tesis Doctoral de Jacinto Torres, Las publicaciones periódicas musicales en España (18121990): estudio crítico-bibliográfico y repertorio general, abrió un campo de estudio que aún sigue explorándose; véanse otros trabajos del mismo autor en la Bibliografía final. Sobre historia de la prensa española en el siglo XIX, véase Albert, Sánchez Aranda y Guash, Historia, de pp. 189-209; Barrère, et al, Metodología; Botrel, Libros, prensa; Chivelet, Historia; Pizarroso, Historia; Seoane, Historia; Tuñón de Lara (dir.), La prensa; y Tuñón de Lara, Elorza y Pérez (eds.) Prensa y sociedad.

${ }^{29}$ Entre los trabajos sobre prensa y música en la España del siglo XIX, pueden señalarse (además de mis propias publicaciones sobre Murcia): Gimeno Arlanzón, Las publicaciones, sobre periódicos musicales de Zaragoza durante la Restauración (1883-1924); Crespí, "Publicaciones periódicas" sobre periódicos de Cataluña; Pidal, "Breve reflexión", que analiza la crítica musical en la Gaceta Musical de Madrid; Alonso Fernández, "El órgano en la prensa"; Vargas, "La música en la prensa femenina"; Vargas, "La música en el Álbum Granadino". En la Universidad de Oviedo se inició (bajo la dirección de Ramón Sobrino) el Vaciado científico e índices informáticos de la prensa musical española del siglo XIX y principio del XX, (véase Sobrino, "Un estudio", pp. 52-60), aunque según Gimeno, Las publicaciones, p. 13, este proyecto no ha continuado por la complejidad del tema. Recientemente se han incorporado al RIPM ocho publicaciones periódicas musicales españolas del siglo XIX (La Iberia Musical, El Anfión Matritense, La Zarzuela, La España Artística, La Gaceta Musical Barcelona, Revista y Gaceta Musical, La Música Ilustrada HispanoAmericana y La Música Ilustrada), con participación de los investigadores Belén Vargas, Juan de Dios Rodríguez Bailón y Esperanza Berrocal. Véanse más detalles en: http://www.ripm.org/titles_indexed.php5\#SPANISH\%20ES (acceso el 10-07-2011).

${ }^{30}$ Véase, entre otros, Duque, La música, sobre las publicaciones periódicas colombianas; Vargas, "La música en la prensa femenina" sobre el periódico La Semana de la Señoritas Mexicanas; Rodríguez, "Los compositores venezolanos", que analiza la vinculación de los compositores venezolanos y la música de salón en dos publicaciones de este país; Quintana, "La música", que aporta una interesante visión comparativa de la música de salón en Colombia y Venezuela a través de publicaciones periódicas de los siglos XIX y XX; y Quintana, "El movimiento" sobre la música en Caracas desde la perspectiva de la revista El cojo ilustrado. Muy recientemente Meierovich, "Enseñanza" ha ofrecido una panorámica sobre la música en periódicos, revistas y gacetas de Hispanoamérica.

31 Alonso Navarro, "La Hemeroteca", pp. 35-62: 57-58, facilita una lista de temas investigados a partir de la prensa murciana. Véase también, García Hourcade, "Panorama de la prensa murciana", pp. 373383.

${ }^{32}$ Ibáñez, Serie cronológica; aunque el autor omite el análisis de los periódicos más importantes del siglo XX (El Liberal, La Verdad y El Tiempo) sí abordados por Crespo, Historia de la prensa. Sobre este último, véase también la reseña de Díez de Revenga, "La prensa murciana”, pp. 169-172.

${ }^{33}$ Tejera, Biblioteca del murciano, es una especie de catálogo de datos sobre autores murcianos desde la Antigüedad hasta el siglo XVIII. 
Francisco Martínez Martínez ${ }^{34}$; Amanecer de la prensa periódica en Murcia de José Ballester $^{35}$; la imprescindible colección de artículos Actas de las Jornadas sobre prensa y sociedad en la Murcia contemporánea ${ }^{36}$ así como los de La prensa local en la Región de Murcia $(1706-1939)^{37}$.

\section{Fuentes empleadas}

Para realizar esta investigación he consultado una ingente cantidad de ejemplares de publicaciones periódicas conservadas en diferentes archivos y bibliotecas españolas e italianas y otras fuentes archivísticas (ver listado de "Principales fuentes consultadas" al final del Volumen 1 de esta Tesis). A continuación, describiré brevemente los principales archivos y fuentes en los que he basado mi trabajo.

\section{Archivo Municipal de Murcia (E: MUm)}

Está ubicado en el céntrico Palacio del Almudí de la capital murciana y se divide en tres grandes secciones: Archivo propiamente dicho, Biblioteca y Hemeroteca ${ }^{38}$. En la sección Archivo consulté diversas actas capitulares y legajos referentes al teatro, músicos, orquestas y bandas de música de Murcia.

La Biblioteca del Archivo Municipal de Murcia conserva una interesante colección de libros publicados en Murcia durante el siglo XIX, en algunos casos ejemplares hoy únicos en la región y en el país. En este fondo pude localizar información muy detallada sobre reglamentos y estatutos de algunas sociedades, traducciones de óperas italianas al castellano, bandos de buen gobierno y guías de Murcia en el siglo XIX, entre otros.

La Hemeroteca del Archivo Municipal de Murcia fue de capital importancia para la realización de esta Tesis, ya que conserva los fondos hemerográficos más ricos de la provincia, entre ellos un importante conjunto de títulos periodísticos desde el siglo XVIII hasta la actualidad, publicados en Murcia capital y en otros municipios de la región. En esta Hemeroteca consulté más de 12.000 ejemplares de periódicos murcianos

${ }^{34}$ García Soriano, Anales de la imprenta. Martínez Martínez, Fuentes del periodismo presenta una detallada enumeración de artículos periodísticos publicados sobre prensa murciana.

${ }^{35}$ Ballester, Amanecer. Según las palabras del autor, se trata de un "ensayo de evasión” que aporta noticias de la última década del siglo XVIII en Murcia a partir de la entonces recién aparecida prensa periódica.

${ }^{36}$ Entre ellos, destacan: De los Reyes, "La prensa murciana", que analiza la influencia de las leyes reguladoras sobre prensa y la censura sobre el periodismo murciano del siglo XIX y el de Pérez Crespo, "La censura”, pp. 417-434. Las Actas de las Jornadas sobre el Sexenio Revolucionario y el Cantón murciano también incluyeron algunos artículos sobre prensa murciana, entre ellos el de Arroyo, "La prensa murciana". Véase también, Martínez Martínez, Fuentes del periodismo.

${ }^{37}$ González Castaño (coord.). La prensa local.

38 Desde finales de marzo de 2010, parte de los fondos periodísticos de este Archivo han sido digitalizados (entre ellos, La Paz de Murcia y El Diario de Murcia), y pueden consultarse en http://www.archivodemurcia.es/ (acceso el 11-07-2011). Sobre los fondos hemerográficos del E: MUm, véase: Jover, "Fondos" y Jover, “Archivos". 
pertenecientes a treinta y nueve publicaciones diferentes, que han aportado un total aproximado de 11.000 noticias de interés en diversos campos de la actividad musical profana y religiosa y otras de índole histórica, económica, social y cultural, idóneas para contextualizar la actividad musical.

El núcleo central de la documentación manejada para la realización de este trabajo procede de La Paz de Murcia, uno de los periódicos más relevantes e influyentes de la segunda mitad del siglo XIX en Murcia, editado ininterrumpidamente desde febrero de 1858 hasta enero de 1896 y del que consulté 9.270 ejemplares, cuyas características analizo en el Capítulo $1^{39}$. Además, exploré y extraje noticias de interés musical en otras colecciones y periódicos del mismo archivo, como El Diario de Murcia ${ }^{40}$, La Vega (1853), El Segura (publicado desde enero hasta abril de 1863), el semanal El Sacamuelas (editado desde octubre de 1863 a enero del año siguiente), El Semanario Murciano (18781882), El Eco de Murcia (1881-1882), periódicos considerados republicanos como El Obrero (1870-1873) y El Aguijón (1871-1872), literarios como La Ilustración Murciana (1871), El Aura Murciana (1871) y El Chocolate (1872), El Noticiero de Murcia (18721898), La Correspondencia de Murcia (1873), Las Provincias de Levante (1885-1902) y el Boletín Oficial de la Provincia de Murcia (1884, 1887, 1891). Otros periódicos examinados aportaron información musical escasa o coincidente con la conocida por diversas fuentes ${ }^{41}$.

\section{Otros archivos de Murcia}

He consultado los archivos particulares de la familia Martínez Calvo y de Mabel Breis, así como el Archivo del Conservatorio Superior de Música de Murcia, que guardan valiosas partituras manuscritas e impresas del compositor murciano Julián Calvo, cuyo catálogo provisional de obras presento en el Capítulo $9^{42}$. También consulté el Archivo

39 En E:MUm se conserva una colección casi íntegra de 38 volúmenes de La Paz de Murcia que abarcan desde el 2 de marzo de 1858 al 31 de marzo de 1895. Faltan, sin embargo, los ejemplares correspondientes a los años 1861 a 1864 (ambos inclusive), 1880, 1893, los doce primeros ejemplares de la publicación y diversos números de 1860 y 1878, entre otras ausencias más puntuales. Según Ibáñez, Serie, pp. 84-85:84, el Ayuntamiento de Murcia compró esta colección a la viuda de Rafael Almazán, director del periódico.

${ }^{40}$ El importante periódico El Diario de Murcia fue especialmente útil para reconstruir la actividad musical en 1851, 1880 y 1893, años en los que no se conservan ejemplares de La Paz de Murcia. En E:MUm, se conserva una colección completa de veintiocho volúmenes de El Diario de Murcia publicados entre 1879-1903. Este periódico (sobre el que trataré en el Capítulo 1) contiene documentación de interés musical suficiente como para abordar un estudio específico.

${ }^{41} \mathrm{Al}$ grupo de periódicos con escasa información musical pertenecen El Industrial de Murcia (1854), El Liberal Murciano (1855), El Murciano (1867), El Avisador (1869) y su continuador El Avisador Murciano (1872), Perico el de los Palotes (1868), El Buen Deseo (1869), El Zorongo (1871), El Ideal Político (1873), La Violeta (1872), Las Noticias (1875), El Comercio (1878-1879), El Clamor Murciano (1879), La Provincia (1882), El Criterio Murciano (1886, 1888-1890), La Revista Murciana (1886), El Correo Murciano (1889) y El Anunciador Mercantil (1890).

${ }^{42}$ Agradezco profundamente a la familia Martínez Calvo, bisnietos de Julián Calvo, y en especial a Pilar Martínez Calvo, por la facilidad que me dieron para trabajar durante meses con materiales de su archivo particular y para tener acceso a diversos objetos personales del compositor y organista. Mi gratitud, también, a Mabel Breiss, fundadora y directora de la actual Academia de Música "Santa Cecilia" de Murcia y directora del Coro de Cámara "Santa Cecilia" adscrito a la Academia, por brindarme acceso a su archivo personal y cederme valiosas partituras fotocopiadas de Julián Calvo, procedentes del Archivo de la Catedral de Murcia y que custodia para su difusión en sus conciertos. 
Parroquial de la Iglesia de San Juan Bautista de Murcia (donde localicé partidas de bautismo de diversos músicos murcianos) y el Archivo Histórico Provincial de Murcia (donde consulté Protocolos Notariales de 1878 relacionados con los Juegos Florales de Murcia durante ese año).

\section{Biblioteca Nacional de España en Madrid (E: Mn)}

Conserva colecciones de periódicos murcianos sobre todo de la primera mitad del siglo XIX. De fecha posterior a 1850 consulté varios periódicos murcianos de carácter literario, como El Álbum (1876-1877), así como los diarios nacionales La Correspondencia de España (1865, 1869, 1871, 1887), La Correspondencia Musical (1881), El Correo Universal (1855), El Liberal (1887) La Iberia (1855, 1862-1863, septiembre de 1869), Gaceta Musical de Madrid (1855-1856), La Correspondencia Musical (1881) y La Ópera Española (1875-1876) ${ }^{43}$.

\section{Hemeroteca Municipal de Madrid (E:Mhm)}

Custodia valiosos ejemplares de la prensa murciana del siglo XVIII, como Las Tardes de Roque Pío y Don Rufo de Alfarache y los siete ejemplares del Correo Murciano de 1808. De la segunda mitad del siglo XIX consulté allí tres ejemplares del Boletín Oficial de la Junta Provincial Revolucionaria de Murcia de octubre de 1868. También en este archivo han sido consultados los periódicos nacionales El Artista (18661868), Crónica de la Música (1878-1882) y La Escena (1865-1867).

\section{Archivo del Conservatorio Superior de Música de Madrid $(E: M c)$}

En este Archivo examiné los Legajos 9 y 10 y las Actas de exámenes de los años 1856-1857, que me permitieron conocer datos inéditos sobre la formación de algunos músicos murcianos que estudiaron en el conservatorio madrileño, como fue el caso de Mariano Padilla.

\section{Archivos consultados en Italia}

Durante una estancia de investigación que realicé en Roma entre junio y septiembre de 2007, pude consultar diversas colecciones de periódicos italianos en las siguientes bibliotecas: Biblioteca Nazionale e Centrale "Vittorio Emanuele II"44 y

${ }^{43}$ Los periódicos nacionales fueron examinados tanto en papel como en versión digital. Véase catálogo y fondos de la Hemeroteca Digital de la Biblioteca Nacional de España en http://www.bne.es/es/Catalogos/HemerotecaDigital/ (acceso 24-06-2011); y el de la Biblioteca Virtual de

Prensa Histórica, promovida por el Ministerio de Cultura de España, en http://prensahistorica.mcu.es/es/estaticos/contenido.cmd?pagina=estaticos/presentacion (acceso en 24-062011).

${ }^{44}$ En ella, consulté periódicos especializados en música y teatro como: Euterpe (1868-1871), Gazzetta Musicale di Napoli (1852-1857), Il teatro illustrato: ritratti di maestri ed artisti celebri, vedute e bozzetti di scene, disegni di teatri monumentali, costumi teatrali, ornamentazioni (1881 a 1886), Il teatro illustrato e la musica popolare: ritratti di maestri ed artisti celebri, vedute e bozzetti di scene, disegni di teatri monumentali, costumi teatrali ornamentazioni (1887-1892), Il mondo artistico: giornale di musica dei 
Biblioteca Universitaria Alessandrina ${ }^{45}$, entre otras. Los datos obtenidos me permitieron documentar la proyección internacional del importante barítono murciano Mariano Padilla, que estudio en el Capítulo 10 de esta Tesis.

Para el trabajo de documentación bibliográfica, he empleado principalmente fondos de la Biblioteca Nacional de España, Biblioteca de la Universidad de Murcia, Biblioteca de la Facultad de Filosofía y Letras de la Universidad de Granada, Centro de Documentación Musical de Granada, bibliotecas de la Universidad Complutense de Madrid y de la Universidad de Barcelona, "Biblioteca "Tomás Navarro Tomás" (Madrid) y Biblioteca de la Institución Milá y Fontanals (Barcelona), estas dos últimas pertenecientes al Consejo Superior de Investigaciones Científicas. De los fondos bibliográficos y hemerográficos accesibles en Internet, no citados anteriormente, me han sido particularmente útiles los localizados en la Biblioteca Virtual "Miguel de Cervantes" (http://www.cervantesvirtual.com/), Biblioteca Virtual del CSIC (http://bibliotecas.csic.es/), "Colección Histórica Virtual” de la Universidad de Murcia (http://www.um.es/biblioteca/), Biblioteca Digital de la Región de Murcia (http://bibliotecadigital.carm.es/inicio/index.php), y Archivo Municipal de Cartagena, Murcia (http://archivo.cartagena.es/pandora/index.html).

teatri e delle belle arti; La lente. Giornale umoristico. Lettere, sicenze, arti, commercio, industria, teatri (1856-1858); L'Arte. Gionale letterario, artistico, teatrale (1857-1858); L'Eptacordo: giornale poligrafico di teatri, belle arti e varietà (1860-1867); L'Italia Musicale: giornale dei teatri, di letteratura, belle arti e varietà (1850); L'Italia Teatrale. Artsitica, musicale e illustrata (1890 y 1892); Lo scaramuccia (18531854, 1867-1857) у Musica e musicisti: rivista illustrata bimestrale (1902-1905), entre otros.

${ }^{45}$ Las colecciones más relevantes que consulté en la Biblioteca Alessandrina son: Il Corriere artisticoteatrale-letterario (1888); Carro di Tespi. Periodico di critica teatrale delle principati delle principati città italiane, con ritratti di artisti (1889-1891); La grancassa: Revista artistica dei caffé-concerto, circhi e compagnie d'operette (1894-1895); La Tribuna: supplemento illustrato della domenica (1893-1896); La vita artistica. Rivista letteraria, teatrale, artistica, mondana (1898-1906). 

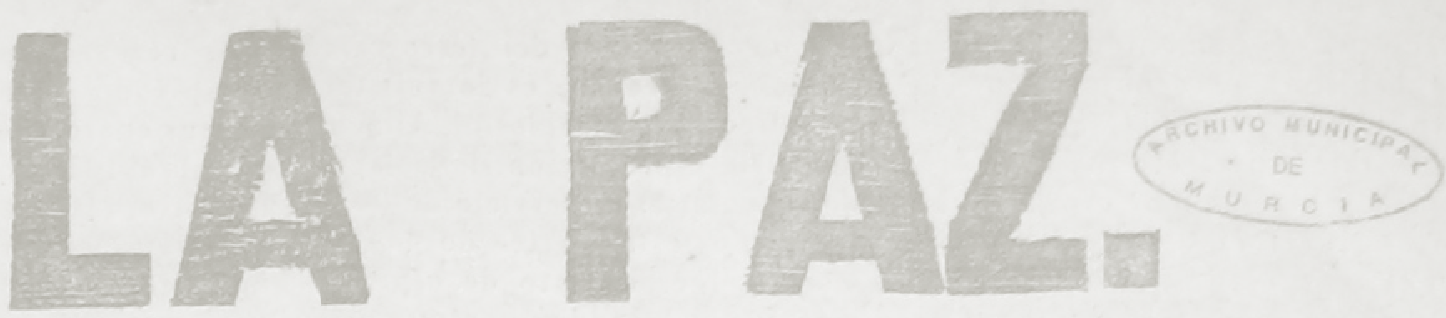

PERIÓDICO DE NOTICAAS, AVISOS Y DE FOMRNTO DE LA PROVINCIA DE VIURCA

Precin de suscricion.

En Murcia 7 rs, un mes y 19 tres

Fuera 8 rs. un mes y 22 tres.
Sale los martes, jueves y domingos,

Comunicados y anuncios, 12 mrs. line?
En la redaccion, plaza del Dsparto, y et

1

MURCIA 28 DE FEBRERO

Altrataren el n. ${ }^{\circ} .^{\circ}$ de los calicatas y cechos ane de ellas nacen, liemos cita. narte de la real órden de $10^{\circ}$ de se-

\section{LA CIUDAD Y SUS PERIÓDICOS}

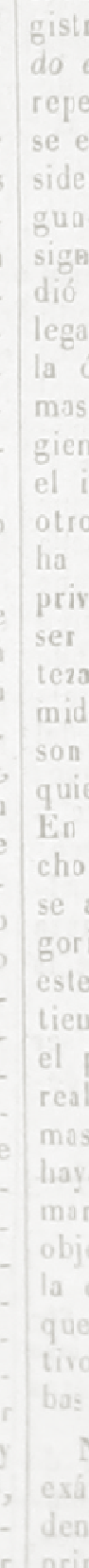




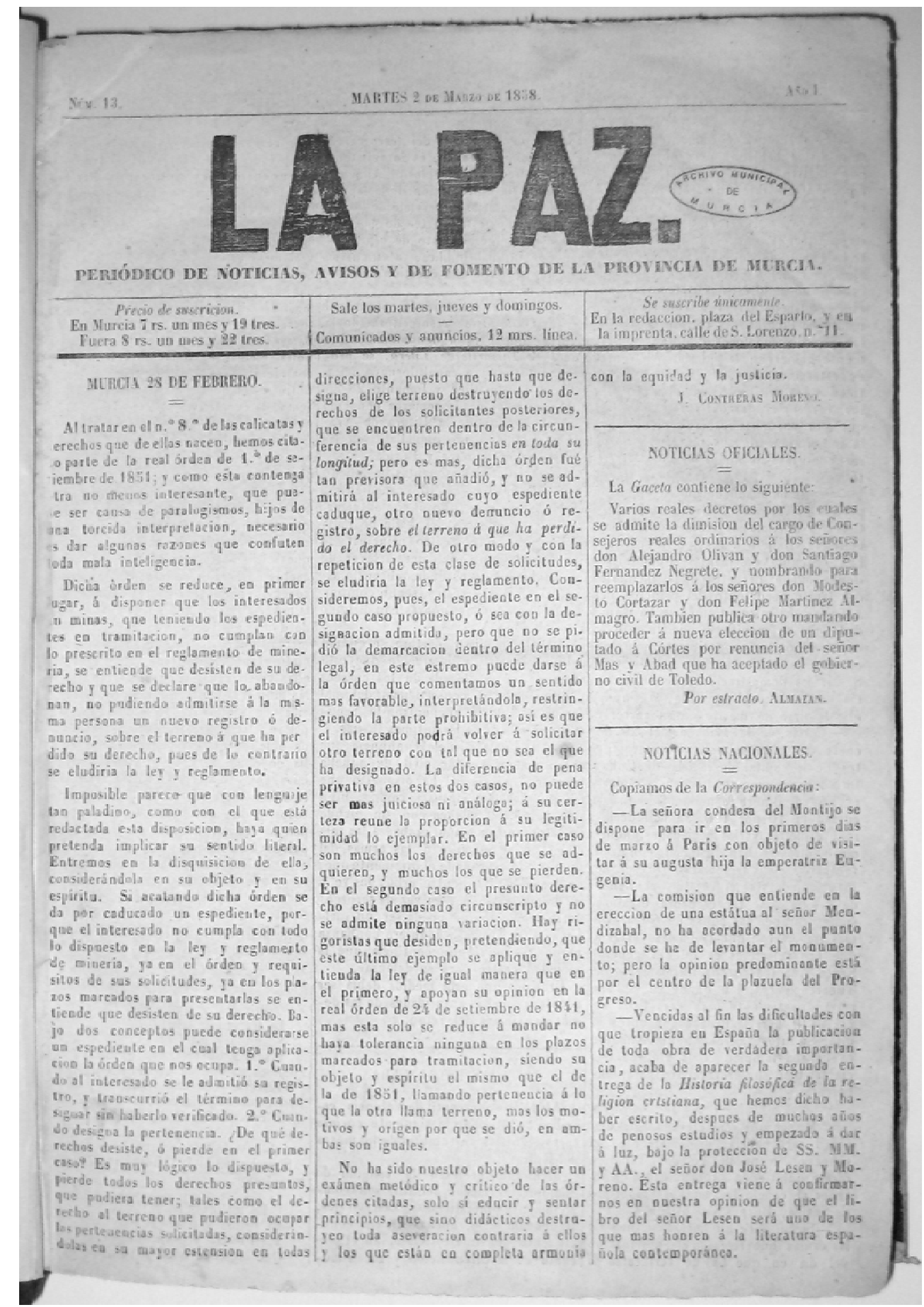

I. La Paz de Murcia, I (1858), n 13, 2 marzo, p. 1, E:MUm. 


\section{Capítulo 1. La música en la prensa murciana del siglo XIX}

\section{El marco urbano: Murcia capital durante la segunda mitad del siglo XIX}

La región de Murcia es actualmente una comunidad autónoma uniprovincial situada al Sudeste de la Península Ibérica. Limita al Este y Noroeste con la Comunidad Valenciana; al Norte y Noroeste con Castilla La Mancha; al Oeste y Suroeste con Andalucía; y al Sur y Sureste con el Mar Mediterráneo ${ }^{1}$. Las tierras murcianas se articulan en torno a dos ejes principales: el que desde el Mediterráneo llega a Andalucía tierra adentro-, por una parte; y el que conecta Cartagena con el camino de Castilla, siguiendo la falla del río Segura, por otro. En el punto de intersección de ambos ejes se encuentra la capital, Murcia, situada en la parte centro-oriental de la región (ver Figura 1.1). La variedad de espacios terrestres, marítimos e insulares de la región, dan lugar a una gran diversidad de paisajes, climas y modos de vida.

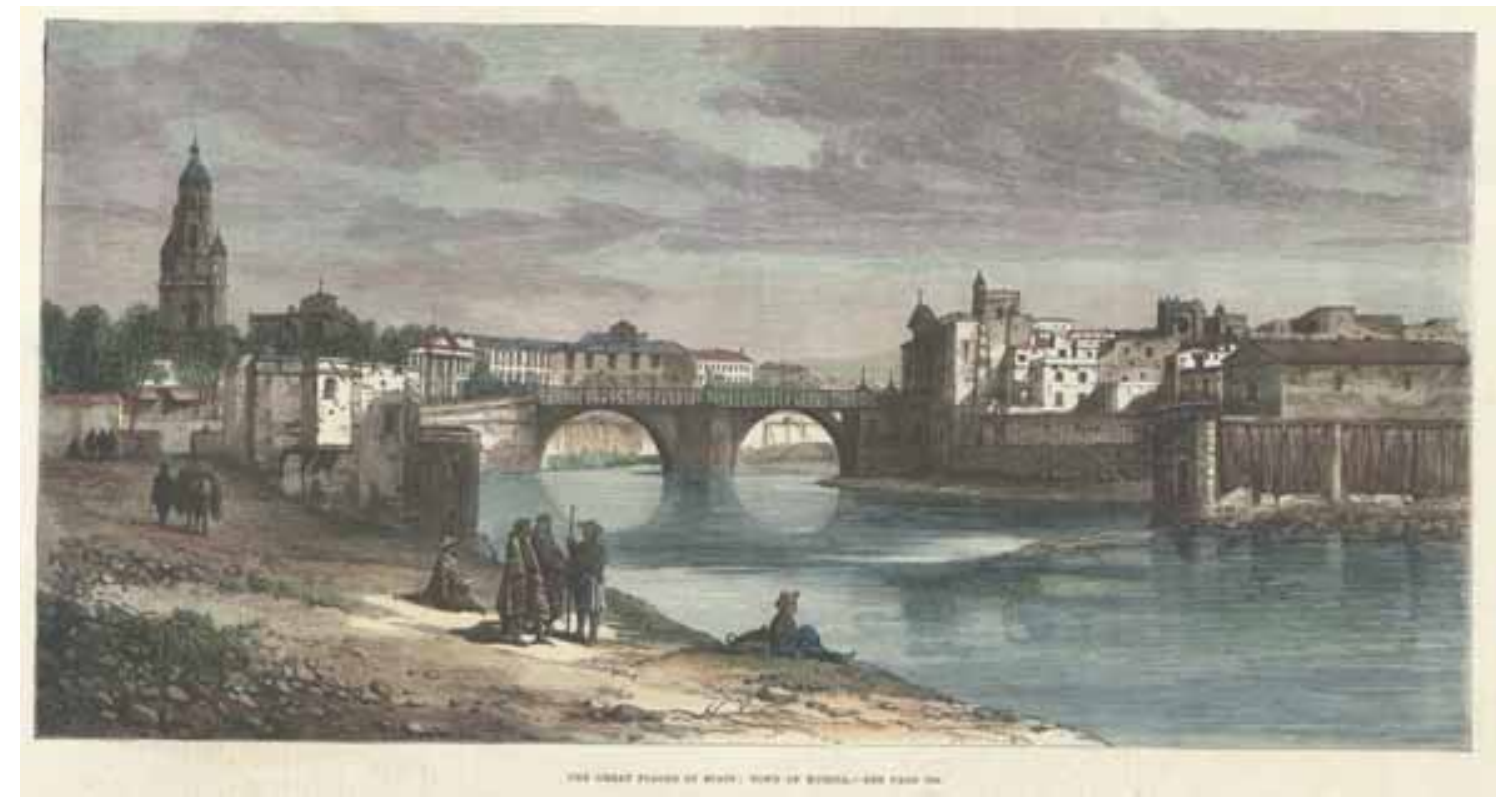

Figura 1. 1. Vista de la ciudad de Murcia (1879).

The great floods in Spain: Town of Murcia. Londres: The Illustrated News, 1879.

E:MUbr. Accesible en: http://bibliotecadigital.carm.es (acceso el 15-07-2011).

La distribución, extensión y perímetro actuales de la región murciana se remontan a 1833 (diseño de división provincial de Javier de Burgos), a excepción de la segregación del municipio de Sax que se incorporó en 1836 al partido de Villena, provincia de Alicante (véase Apéndice 1.1).

\footnotetext{
${ }^{1}$ Martínez Carrión, Historia, p. 38.

${ }^{2}$ Hasta 1833 hubo numerosas reformas bajo los mandatos de Jefes Superiores de Provincia y Jefes Políticos, que dividieron el territorio en departamentos y prefecturas, siguiendo las orientaciones administrativas españolas. Algunas de estas reformas no pasaron de ser simples proyectos. La división del espacio actual fue decretada por Real Decreto de 21 de abril de 1834 y ordenó el espacio en siete partidos judiciales: Caravaca, Cartagena, Cieza, Lorca, Mula, Murcia, Totana y Yecla. Para una información más detallada sobre los centros de población, villas y pueblos de cada partido, véase la tercera y cuarta parte de
} 
Las reformas liberales implantadas durante la primera mitad del siglo XIX y, de forma paralela, la desmembración de las estructuras del Antiguo Régimen sentaron las bases para el desarrollo económico y propiciaron los mecanismos para la conquista de la capitalización y la modernización de la Región ${ }^{3}$.

En las siguientes líneas esbozaré a grandes rasgos las particularidades de Murcia durante el marco cronológico estudiado.

En el siglo XVIII, Murcia pasó de ser una población demográficamente primitiva a ser una población moderna, gracias a su progreso económico (aumento de regadíos, mejora de los cultivos, estímulos de la industria y de la minería). Las densidades de población llegaron, y en algunos casos superaron, los 20 habitantes $/ \mathrm{km}^{2}$. A finales de ese mismo siglo la tendencia se invirtió, estancándose el crecimiento de la población y provocando el desequilibrio desfavorable entre la producción agrícola y el número de habitantes. Hasta la década de los treinta del siglo XIX no llegó la recuperación, aunque desigualmente repartida entre las distintas comarcas de la región. El porcentaje de habitantes del medio rural $(70 \%)$ creció más rápidamente que los residentes en los medios urbanos $(30 \%)$. Además, la población murciana estuvo sometida a altas tasas de mortalidad y a frecuentes crisis epidémicas o de subsistencia por baja producción de las cosechas, sequías, inundaciones, aparición de brotes como el cólera, el tifus, el paludismo y la fiebre amarilla, las catástrofes y la expansión del hambre. La Tabla 1.1 muestra la evolución de la población regional murciana desde finales del siglo XVIII hasta la primera década del siglo XX.

Tabla 1.1. Evolución demográfica de Murcia en el contexto español (1787-1910)

Fuente: Martínez Carrión, Historia, p. 62.

TCAM: Tasa de crecimiento neto anual intercensal.

\begin{tabular}{|l|c|c|c|c|c|c|}
\hline Año & \multirow{2}{*}{ Habitantes } & \multirow{2}{*}{$\begin{array}{l}\text { \%) en } \\
\text { España }\end{array}$} & \multicolumn{2}{|c|}{ TCAM } & \multicolumn{2}{c|}{ Densidad } \\
\cline { 4 - 7 } & & & España & Murcia & España & Murcia \\
\hline 1787 & 256.641 & 2,47 & - & - & 20,5 & 22,6 \\
\hline 1797 & 291.252 & 2,76 & 1,42 & 12,73 & 20,8 & 25,7 \\
\hline 1857 & 380.969 & 2,47 & 6,40 & 4,49 & 30,5 & 33,7 \\
\hline 1860 & 382.812 & 2,45 & 4,09 & 1,61 & 30,9 & 33,8 \\
\hline 1877 & 451.611 & 2,72 & 3,57 & 9,77 & 32,8 & 39,9 \\
\hline 1887 & 491.436 & 2,80 & 5,44 & 8,49 & 34,7 & 43,4 \\
\hline 1900 & 577.987 & 3,11 & 4,46 & 12,56 & 36,7 & 51,1 \\
\hline 1910 & 615.105 & 3,09 & 6,95 & 6,24 & 39,4 & 54,4 \\
\hline
\end{tabular}

Merino, Geografía, pp. 381 y ss. Más recientemente, Vilar García, Territorio ha estudiado el proceso de configuración de la región de Murcia.

${ }^{3}$ Pérez Picazo, "Historia", p. 4. A grandes rasgos, las reformas liberales hacia la mitad de la centuria habían conseguido la ya apuntada demarcación definitiva de la Provincia de Murcia y sus municipios, así como la reorganización institucional y administrativa, la reconversión de las funciones de los ayuntamientos y la incorporación de la propiedad privada, y la transformación de la oligarquía regional en la clase burguesa dirigente. Los procesos de desvinculación y desamortización de la región de Murcia pueden seguirse en: Rodríguez Llopis, Historia, pp. 368-377 y en Martínez Carrión, Historia, pp. 232-247. 
Durante la primera mitad del siglo XIX la tasa de crecimiento de la región fue menor que la media nacional ${ }^{4}$. Sin embargo, tal y como apunta Martínez Carrión, entre 1860 y 1900, Murcia "registra la mayor tasa de crecimiento anual medio de España (junto al País Vasco y Canarias)" ". Es más, entre 1887 y 1900, Murcia se situó entre las regiones europeas más dinámicas desde el punto de vista demográfico. Su población aumentó durante estos años en casi 80.000 habitantes, lo que constituyó una verdadera "explosión demográfica" ". La ocupación del territorio y la distribución de la población indican, sin embargo, un marcado carácter rural que estuvo íntimamente vinculado al peso de las actividades agrícolas (Véase Figura 1.2) ${ }^{7}$.

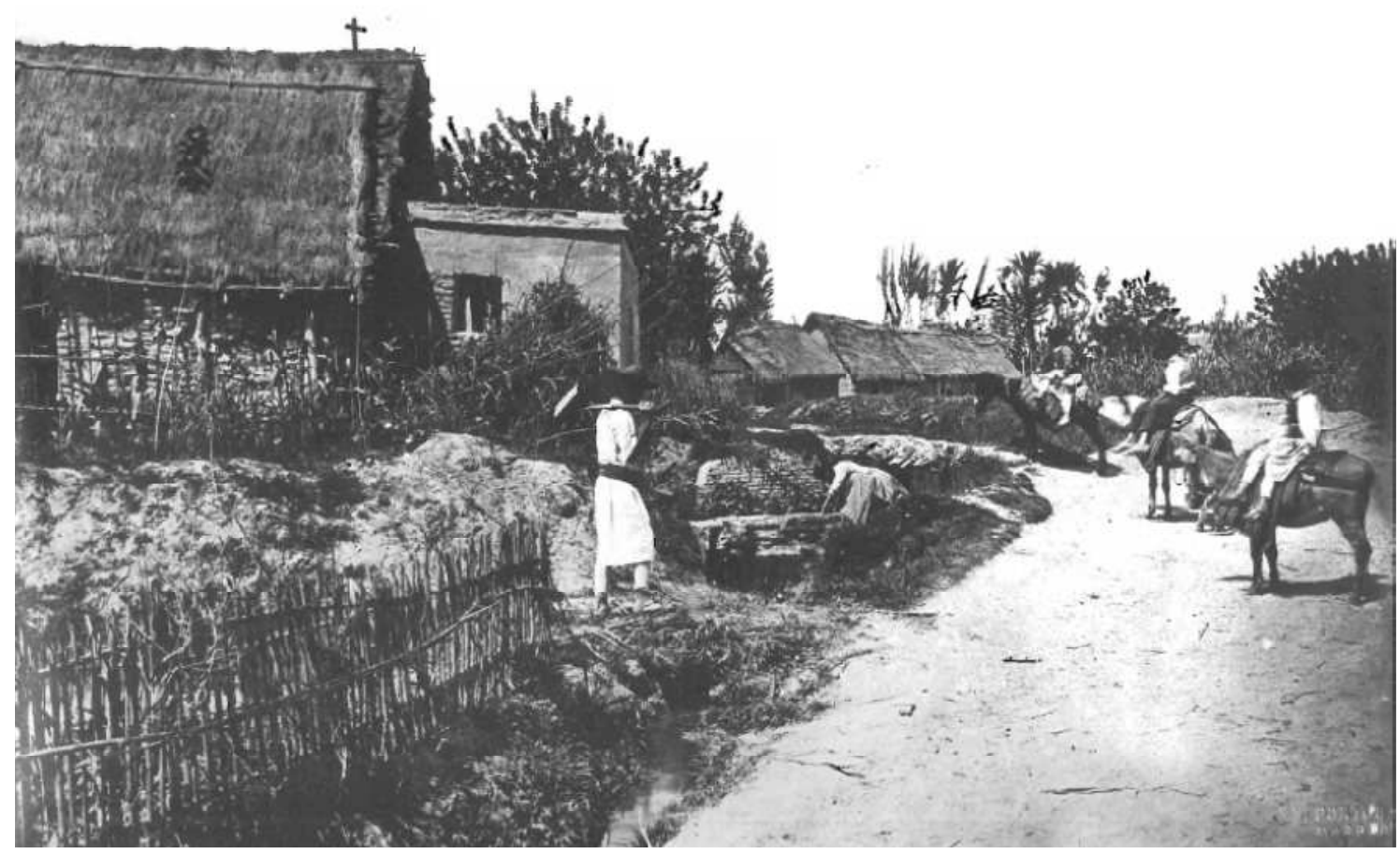

Figura 1.2. Paisaje de la huerta murciana. Primera mitad del siglo XX. E:MUm. Accesible en: http://www.archivodemurcia.es (acceso el 11-08-2011).

${ }^{4}$ Sin embargo, el conjunto de la provincia presentó una tasa de crecimiento del $27 \%$ si comparamos las cifras de finales del siglo XVIII y 1857: Rodríguez Llopis, Historia, p. 385. Sobre el éxodo rural del campo a los centros urbanos (fenómeno general en la época) y sobre las migraciones de murcianos durante la segunda mitad del siglo XIX con destino a la Argelia francesa (Orán y su región principalmente) y después de 1900 a Cataluña y Francia, véase Vilar Ramírez, Murcia.

${ }^{5}$ Martínez Carrión, Historia, p. 62.

${ }^{6}$ Entre 1858 y 1900 la región murciana fue la que más creció junto con Canarias. En esas cuatro últimas décadas del siglo XIX la población murciana aumentó de tamaño un 52\%. Véase, Martínez Carrión, Historia, p. 278, 280-281.

${ }^{7}$ En 1877 aproximadamente el 71\% se dedicaba al sector agricultura, el 17\% a la industria y apenas el 12\% a la construcción: Martínez Carrión, Historia, p. 73. Para conocer más detalles sobre la agricultura y la ganadería murciana véase: Rodríguez Llopis, Historia, pp. 387-390. 
Casi dos tercios de los efectivos del núcleo urbano de Murcia capital residían en las pedanías de huerta y campo, como se aprecia en las siguientes Tablas 1.2 y 1.3:

Tabla 1.2. Evolución de la población del municipio de Murcia (1860-1901) Pérez Picazo, Oligarquía, p. $72^{8}$.

\begin{tabular}{|c|c|c|c|c|c|c|}
\hline \multicolumn{4}{|c|}{ CENSOS } & \multicolumn{3}{c|}{ PADRONES } \\
\hline Años & Ciudad & Huerta & Total & Ciudad & Huerta & Total \\
\hline 1860 & 21.628 & 62.295 & 87.923 & - & - & - \\
\hline 1875 & - & - & 82.620 & - & - & - \\
\hline 1879 & 26.735 & 64.774 & 91.509 & 24.384 & 50.981 & 75.815 \\
\hline 1889 & 30.793 & 60.233 & 96.028 & 27.078 & 56.078 & 82.512 \\
\hline 1899 & 31.672 & 75.143 & 108.476 & 22.018 & 62.573 & 84.581 \\
\hline 1901 & - & - & - & 25.371 & 66.827 & 92.198 \\
\hline
\end{tabular}

Tabla 1.3. Población rural y urbana del municipio de Murcia (1860-1899) Pérez Picazo, Oligarquía, p. 73.

\begin{tabular}{|c|c|c|c|c|}
\hline & $\mathbf{1 8 6 0}$ & $\mathbf{1 8 7 9}$ & $\mathbf{1 8 8 9}$ & $\mathbf{1 8 9 9}$ \\
\hline Población rural & $70.8 \%$ & $67.2 \%$ & $68.3 \%$ & $72.4 \%$ \\
\hline Población urbana & $24.5 \%$ & $32.8 \%$ & $32.7 \%$ & $27.6 \%$ \\
\hline
\end{tabular}

La estructura del empleo por sectores productivos así lo confirma: en 1877 aproximadamente el $71 \%$ se dedicaba al sector agricultura, el $17 \%$ a la industria y apenas el $12 \%$ a la construcción ${ }^{9}$.

En 1862 llegó el ferrocarril a Murcia y en los años posteriores las redes ferroviarias pusieron en contacto la ciudad portuaria de Cartagena con Madrid, favoreciendo la inserción de Murcia en la economía nacional y en el comercio internacional, por un lado, y abriendo nuevas vías de renovación desde el punto de vista sociológico, por otro ${ }^{10}$. La prensa local se hacía eco de la importancia del recién estrenado ferrocarril, tanto para la economía como para las artes y la música:

[...] El ferrocarril nos ha puesto en comunicación activa y fácil con Europa. Los ricos productos de nuestra hermosa vega tienen hoy sus mercados principales en Madrid y París. No son raros los murcianos que viajan por el extranjero y visitan los grandes certámenes de la industria y alguno hay, como el eminente barítono Padilla, que arranca entusiastas aplausos en San Petersburgo. Si antes los hijos de Murcia sólo

\footnotetext{
${ }^{8}$ Véanse las apreciaciones de Pérez Picaso, Oligarquía, p. 71 sobre las discrepancias numéricas entre censos y padrones.

${ }^{9}$ Martínez Carrión, Historia, p. 73. La evolución del empleo hacia sectores industriales tuvo lugar a partir de la década $1930 \mathrm{y}$, desde 1960, al sector servicios.

${ }^{10}$ En 1862, Isabel II inauguró el primer ferrocarril de Murcia, que unió la capital murciana con Cartagena. La línea de Madrid se concluyó tres años más tarde, después de finalizarse la conexión con Chinchilla. Durante la década de los 1880 se amplió la red ferroviaria hacia otras comarcas: en 1884 Murcia capital quedó conectada con Alicante y en 1885, esta misma línea continuó hasta Lorca y sucesivamente hasta Baza (1888) y Águilas (1890): Rodríguez Llopis, Historia, p. 395.
} 
sabían vivir a la sombra de su torre, ahora saben abrirse camino y conquistarse nombres y posición, en la administración, las ciencias, las armas y las artes $[\ldots]^{11}$.

La minería protagonizó una etapa de verdadero esplendor que ayudó a la región a integrarse en los mercados capitalistas. La extracción de plomo (posteriormente, también hierro y zinc) de las sierras de La Unión-Cartagena desde 1840, y las de Mazarrón y Águilas a partir de 1870 atrajo a inversores de la región de casi todos los sectores sociales (comerciantes, profesiones liberales y propietarios) y, más tarde, a inversores extranjeros (multinacionales). Paralelamente a la dinamización de la agricultura, la industria y el comercio se impulsaron las primeras entidades financieras y bancas privadas.

El despegue económico introdujo cambios sociales muy significativos. Comerciantes, propietarios agrícolas, pequeña burguesía urbana y profesionales liberales pudieron ampliar sus negocios invirtiendo en nuevos cultivos, minas e industrias, acumular patrimonio (especialmente, agrícola), e incluso especular con él ${ }^{12}$.

La supremacía de la actividad agrícola imprimió a Murcia capital un marcado carácter de "agrociudad", término acuñado por los historiadores, que condicionó y determinó aspectos tan importantes como el bajo nivel de alfabetización y la propia estructura urbana de la ciudad ${ }^{13}$. Murcia, hasta 1940, se encontraba entre las autonomías más analfabetas de España, junto con Andalucía, Canarias, Castilla- La Mancha y Extremadura. En 1887, casi el 80\% de la población murciana de diez o más años no sabía leer ni escribir ${ }^{14}$. La evolución de la alfabetización regional por sexos se muestra en la siguiente Tabla 1.4:

Tabla 1.4. Evolución porcentual de la alfabetización en la Región de Murcia, por sexos (1860-1910)

Fuente: Martínez Carrión, Historia, p. 125.

\begin{tabular}{|c|c|c|c|c|c|c|}
\hline \multirow{2}{*}{ Año } & \multicolumn{2}{|c|}{ Masculina } & \multicolumn{2}{c|}{ Femenina } & \multicolumn{2}{c|}{ Total } \\
\cline { 2 - 7 } & Murcia & España & Murcia & España & Murcia & España \\
\hline 1860 & 25 & 40 & 9 & 12 & 17 & 26 \\
\hline 1877 & 28 & 45 & 13 & 19 & 20 & 31 \\
\hline 1887 & 31 & 50 & 15 & 24 & 23 & 37 \\
\hline 1900 & 37 & 55 & 22 & 32 & 29 & 43 \\
\hline 1910 & 41 & 61 & 24 & 41 & 32 & 50 \\
\hline
\end{tabular}

${ }^{11}$ [Anónimo], "Murcia y los murcianos a principios del siglo", El Semanario Murciano, III (1880), nº 148, 12 diciembre, p. 399.

${ }^{12}$ Martínez Carrión, Historia, p. 272. Como describe Pérez Picazo, "Historia”, p. 130 las diferencias sociales se acentuaron. Sobre la estructura social de Murcia en el periodo analizado puede consultarse: $\mathrm{M}^{\mathrm{a}}$ Pérez Picazo, Oligarquía.

${ }^{13}$ El elevado porcentaje de analfabetismo, crucial en algunas zonas españolas, fue consecuencia de una deficiente escolarización. La sociedad no demandó el "uso" de la lectura y escritura. Viñao, "Historia", pp. 45-50 señala que durante la segunda mitad del siglo XIX cambió la actitud hacia lo impreso (hasta el momento, oral y visual antes que escrita), reflejándose en el aumento del número de publicaciones de periódicos, revistas, folletos y literatura de recreo. Sobre la evolución de la alfabetización en el municipio de Murcia, véase también: Viñao, Historia y Viñao, "El proceso”, pp. 235-250.

${ }^{14}$ Cifra tomada de Vilanova y Moreno, Atlas, pp. 173 y 177. Todavía a principios del siglo XX sólo un tercio de la población sabía leer y escribir: Martínez Carrión, Historia, p. 124. 
El acceso a los recursos educativos fue desigual, tanto a nivel social y geográfico como en función del sexo ${ }^{15}$. El analfabetismo afectó principalmente a las mujeres de la huerta o campo, mientras que los hombres residentes en la ciudad tuvieron una alfabetización superior. La escasa escolarización, como se muestra en la Tabla 1.5, explica estos datos:

Tabla 1.5. Niños escolarizados en la ciudad de Murcia (1830-1855) Fuente: Vicente Jara, Política, pp. 180, 187.

\begin{tabular}{|c|c|c|c|c|c|c|c|c|}
\hline Año & Vecinos & Almas & Escuelas & Alumnos & Alumnas & $\begin{array}{c}\text { Total } \\
\text { alumnos y } \\
\text { alumnas }\end{array}$ & $\begin{array}{c}\text { Relación } \\
\text { alumnos/ } \\
\text { almas }\end{array}$ & $\begin{array}{c}\text { Relación } \\
\text { Escuelas/vecinos }\end{array}$ \\
\hline 1830 & 4.573 & 18.292 & 31 & 597 & 453 & 1050 & $1 / 17$ & $\begin{array}{c}1 \text { por cada } 148 \\
\text { vecinos }\end{array}$ \\
\hline 1845 & 5.337 & 22.285 & 44 & 972 & 612 & 1584 & $1 / 14$ & $\begin{array}{c}1 \text { por cada } 121 \\
\text { vecinos }\end{array}$ \\
\hline 1850 & 6.080 & 24.320 & 33 & 1.025 & 521 & 1.546 & $1 / 30$ & $\begin{array}{c}1 \text { por cada } 367 \\
\text { vecinos }\end{array}$ \\
\hline 1855 & 5764 & 23054 & 25 & 976 & 584 & 976 & $1 / 15$ & $\begin{array}{c}1 \text { por cada } 266 \\
\text { vecinos }\end{array}$ \\
\hline
\end{tabular}

Del elevado analfabetismo y la escasa escolarización infantil se deduce que, en realidad, fueron pocos los murcianos que podían leer directamente la prensa. Sin embargo, Botrel advierte que "no hay que dejarse llevar por la confusión entre alfabetización y lectura, entre alfabetizados y lectores" ", ya que fueron habituales los gabinetes de lectura u otro tipo de locales empleados al efecto (por ejemplo, cafés) los que sirvieron de marco para las lecturas en grupo, contribuyendo enormemente a la formación de la opinión pública ${ }^{17}$.

Desde la estructuración provincial española de 1833, Murcia capital fue sede de edificios públicos (Administración de Hacienda, Fomento, Gobierno Político). Aumentó el contingente militar de la ciudad (Cuarteles de la Trinidad, Caballería en la Posada del Puente, Guardia Civil), aunque la división en doce parroquias siguió siendo la base de la organización ciudadana ${ }^{18}$.

\footnotetext{
${ }^{15}$ Véanse más detalles sobre el número escuelas para niños y para niñas por municipios murcianos en Martínez Carrión, Historia, p. 126-135. La situación de las escuelas, por otra parte, era lamentable. La Paz de Murcia, XII (1869), no 3514, 9 marzo, p. 1 describía: "El primer obstáculo que salta a la vista al penetrar en cualquiera de las escuelas, si se exceptúan las de párvulos y la elemental de Santa Catalina, es la estrechez y malas condiciones higiénicas y, al mismo tiempo, la excesiva aglomeración de niños concurrentes". La prensa publicó numerosos artículos denunciando la escasa política educativa española, en general, y murciana en particular. Véanse: [Anónimo], "De la ignorancia en España", La Paz de Murcia, XI (1868), $\mathrm{n}^{\mathrm{o}}$ 3241, 20 mayo, p. 2, reproducción del periódico madrileño La Nación y Francisco Tarín, "Necesidades de esta época", La Paz de Murcia, XXV (1882), nº 7358, 13 junio, p. 1.

${ }^{16}$ Botrel, Libros, p. 303.

${ }^{17}$ Valls, Prensa y burguesía, pp. 36-38.

${ }^{18}$ La división municipal de parroquias y partidos de Murcia en 1867 puede consultarse en La Paz de Murcia, X (1867), no 2777, 22 enero, pp. 1-2; la misma información para 1891 la aporta Botella, Guía. Esta guía, junto a las de Martínez Tornel, Guía y Belando y Perelló, Guía, resultan muy eficaces para conocer múltiples aspectos de la ciudad, como la administración municipal (con listados de funcionarios y otros cargos públicos), el comercio (mercados públicos, catálogos de establecimientos con su localización y
} 
La desamortización de 1836 alteró el paisaje urbano, modificándolo sustancialmente: los espacios ocupados por conventos y zonas adyacentes (huertos y jardines) desaparecieron y en su lugar se construyeron nuevos edificios públicos, como el Casino, el Teatro Romea y la Plaza de Toros (ver Figura 1.3) ${ }^{19}$.

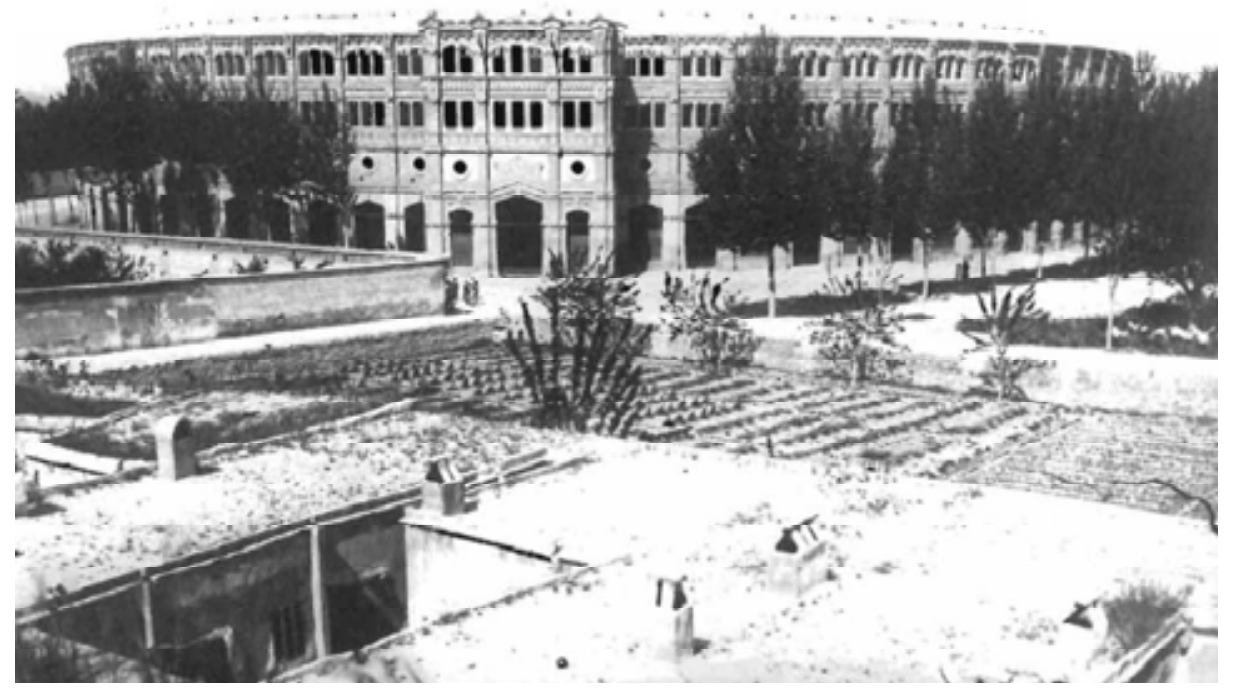

Figura 1.3. Plaza de toros de Murcia. Primera mitad del siglo XX.

E:MUm. Accesible en: http://www.archivodemurcia.es (acceso el 11-08-2011).

Sin embargo, la urbanización de la ciudad fue deficiente y sólo en épocas de holgura económica se invirtió en la mejora de las calles, alumbrado y edificios públicos (véase Apéndice 1.2), como denunciaba en 1868 un periódico local:

aquí no existe policía de ornato. El capricho impera en todas partes y el caciquismo presenta su asquerosa y deforme huella en las construcciones y en los edificios.

El interés privado viene de tiempo inmemorialmente antepuesto a la conveniencia pública y lo que en el terreno de la legalidad y la justicia no podía tener explicación posible, la recibe y muy completa por la irritante presión de influencias particulares. [...]

En el año 1868 la sexta población de España no tiene un plano aprobado. Los cortes de casas, las alineaciones de las calles y el sistema de edificar es todo pura voluntad de las municipalidades que se suceden. Lo que hoy hace un alcalde puede otro mañana impunemente deshacerlo. Donde abrimos una plaza, es posible que un plano verdadero y perfecto retrotraiga aquel sitio a ser calle, en tanto que la calle ya alineada, venga a ser plaza. Se forman a costa de grandes sacrificios pavimentos de adoquines y dejamos descomunales canalones para que los destruyan. Cada propietario espera para hacer en sus casas ciertas reformas que como hechos consumados después se respetan. La insubordinación, la disciplina y la desobediencia

dueños, por ejemplo) o la urbanización (nomenclatura de calles y plazas y descripción de jardines, entre otros). Sobre las guías como fuentes de investigación, véase: Crespo, "Las guías", pp. 139-150.

${ }^{19}$ Sobre las modificaciones del paisaje urbano murciano y monumentos de la ciudad durante el siglo XIX, véanse: Roselló, Evolución; Montes, "Las murallas”, pp. 95-101 y Melendreras, "Monumentos", pp. 1697-1712. 
de los habitantes se traduce en el aspecto de la ciudad. La opinión de ingobernables la tenemos bien merecida.

Hay además en la capital otras señales que demuestran el estado de cultura y civilización que alcanzamos.

El trabajo y la instrucción son las dos cosas que más acreditan el bienestar y la felicidad de los pueblos. El trabajo moraliza, la instrucción enaltece. Aquí se trabaja lo menos que se puede y la enseñanza está muy atrasada. El pueblo en su inmensa mayoría no sabe leer ni escribir. $[\ldots]^{20}$.

Un importante foco cultural de la ciudad fue el Seminario Conciliar de San Fulgencio $^{21}$. El Instituto Provincial de Segunda Enseñanza fue creado en 1837 y en él se estudiaba Latín, Matemáticas, Teología Moral y Religión, Historia Natural, Física, Historia y Geografía, Química y Mecánica, así como Agricultura ${ }^{22}$. En 1840, el Instituto funcionó como Universidad Literaria, aunque en julio de 1841 volvió a ser sólo Instituto $^{23}$.

La Sociedad Económica de Amigos del País de Murcia, fundada en 1777, prestó especial atención a la educación primaria y profesional de los ciudadanos. Durante el siglo XIX, se crearon varias cátedras en la sociedad con este fin ${ }^{24}$.

Otros centros murcianos de interés cultural serán comentaros más adelante por sus actividades musicales. Cabe subrayar el enorme dinamismo de las sociedades recreativas murcianas creadas durante la segunda mitad del siglo XIX. Muchas de ellas tuvieron un

${ }^{20}$ [Anónimo], "Revista de Murcia. Impresiones de viaje. Contestación a 'El Abuelo"”, La Paz de Murcia, XI (1868), $\mathrm{n}^{\mathrm{o}} 3218,26$ abril, p. 1. Sobre aspectos concretos como la iluminación y la red de tranvías murcianos durante el siglo XIX, consúltense los estudios de Montes, "La iluminación”, pp. 173190 y Montes, “Los tranvías”, pp. 191-213.

${ }^{21}$ El Seminario Conciliar de San Fulgencio fue creado en 1592, siendo obispo de Cartagena Sancho Dávila y Toledo (1546-1625). Desde sus inicios, desempeñó un papel esencial como centro de estudios de carácter no sólo eclesiástico, sino también jurídico y filosófico. En 1705, tras el nombramiento de Luis Belluga y Moncada como obispo de la diócesis de Cartagena-Murcia, la institución adquirió mayor esplendor. Belluga prestó especial atención a la educación de los seminaristas y dispuso la fundación de varios colegios. En el Colegio de San Leandro (1749) se estudiaba música, mientras que en el de San Isidoro, teología. Sobre el primero véase, el trabajo inédito de Prats, Educación. Agradezco a la autora que me permitiera su consulta.

${ }^{22}$ Véase, Hernández Pina, "La enseñanza", p. 29. El Instituto estaba suscrito en 1883-1884 a quine publicaciones periódicas nacionales y murcianas. Rodríguez Llopis, Historia, 408 señala que este centro fue dotado con un rico patrimonio proveniente de los bienes desamortizados, convirtiéndose en el cuarto instituto español más rico, lo que le permitió afianzarse como "la principal institución docente de la provincia y constituirse en un centro generador de interesantes proyectos culturales". Según Martínez Tornel, Guía, p. 11, solían concurrir anualmente al Instituto unos doscientos alumnos oficiales. El número ascendía hasta las 2000 matrículas con los alumnos "de enseñanza privada y los de doméstica".

23 En la Universidad Literaria se impartieron las siguientes materias: Gramática, Filosofía, Matemáticas, Botánica, Agricultura, Leyes y Medicina: Hernández Pina, "La enseñanza", p. 17. Tal y como apunta Rodríguez Llopis, pp. 408-409, la burguesía murciana prefirió educar a sus hijos fuera de Murcia y, en especial, en Madrid. En 1869 surgió la Universidad Libre de Murcia con estudios de bachillerato y una licenciatura en Derecho, que siguió activa hasta la llegada de la monarquía de Alfonso XII y la nueva ley de enseñanza de 1874.

${ }^{24}$ Entre 1816 y 1836 se incorporaron las siguientes cátedras: Economía Política, Historia Natural, Geografía, Estudio de la Constitución Española, Geometría, Mecánica aplicada a las artes, Química, Delineación, Agricultura, Dibujo, Veterinaria y Lengua Francesa, según Vicente Jara, Politica, p. 235. 
doble carácter lúdico e instructivo, convirtiéndose en importantes focos de irradiación de cultura y educación.

\section{Panorámica de la prensa murciana durante la segunda mitad del siglo $\mathrm{XIX}^{25}$}

A finales del siglo XVIII, Murcia fue la sexta ciudad española con mayor número de periódicos, por detrás de Madrid, Granada, Sevilla, Barcelona y Cádiz ${ }^{26}$. Durante la primera mitad del siglo siguiente se publicaron en Murcia medio centenar de periódicos de diversa naturaleza. Sólo en el Trienio Constitucional (1820-1823) vieron la luz una veintena de periódicos, entre los que destacan El paradislero, Periódico de la Sociedad Patrótica, El Católico instruido en su religión, El Liberto, El Censor Político y Literario, Diario Popular de Murcia, Periódico Constitucional de la Provincia de Murcia, El Chismoso, Correo Murciano y El Argos ${ }^{27}$. La libertad de imprenta favoreció en gran parte esta proliferación periodística, que dio lugar a publicaciones de corta vida, escasa tirada, alto contenido político (e introductores, muchos de ellos, de las ideas liberales) y, salvo en breves periodos de tiempo, sometidas a censura ${ }^{28}$.

Los ejemplares de periódicos murcianos de la primera mitad del siglo XIX que se conservan muestran una tipografía y contenidos muy limitados ${ }^{29}$. Además, no se conservan ejemplares de un buen número de periódicos cuya existencia se conoce sólo por referencias de diversas fuentes ${ }^{30}$. Sin embargo, de la segunda mitad del siglo XIX

${ }^{25}$ Esta visión panorámica se basa principalmente en estudios previos, como el de Crespo, Historia de la prensa y otros, con aportaciones puntuales fruto de mi propia consulta de las fuentes.

${ }^{26}$ Frente a los ciento cuarenta periódicos de Madrid, había dieciséis en Granada, catorce en Sevilla, diez en Barcelona, diez en Cádiz y siete en Murcia, según Yanes, Metodología, p. 155. La primera publicación periódica de Murcia fue la Gazeta de Murcia (1706). Hasta mediados del siglo XVIII no se publicó ningún otro periódico en Murcia, ya que una prohibición de 1757 impedía editarlos sin privilegio del Rey. Un año después, el Corregidor autorizó la aparición de Semanero de Murcia, del que no se conserva ningún ejemplar. En 1792 vio la luz el Diario de Murcia, primer hebdomadario murciano que, con estilo de crónica de campaña, daba noticias referidas a la Guerra de Sucesión. En la década de los noventa del siglo XVIII aparecieron otros periódicos más: El Censor del Diario de Murcia, el Correo de Murcia (subtitulado Correo Literario de Murcia), Las Tardes de Roque Pío y Don Rufo de Alafarache, y Obras Periódicas o Anécdotas (de este último no existen ejemplares). Sobre prensa murciana del siglo XVIII, véanse, además de los estudios citados en el estado de la cuestión, otros como: Alonso Navarro, Prensa; Botías, El Correo y Vilar García, "Entre la Ilustración”, pp. 353-375.

${ }^{27}$ Crespo, Historia de la prensa, p. 48 opina que el periodismo de la tríada liberal fue "muy crítico, muy batallador, y a veces también, muy violento y desmedido".

${ }^{28}$ Las características de algunos de estos periódicos pueden consultarse en Clares, La vida musical, Apéndice 4.

${ }^{29}$ Crespo, Historia de la prensa, pp. 11-12 denomina el siglo XIX como la "Edad Antigua" de la prensa local, delimitando su marco cronológico hasta 1858, año de aparición de La Paz de Murcia.

${ }^{30}$ Las colecciones más completas de periódicos para el periodo 1800-1850 son las de la Gazeta de Murcia, El Censor Político y Literario, Periódico Constitucional de la Provincia de Murcia, El Chismoso, Correo Murciano, Diario de Órdenes y Avisos, Boletín Oficial de la Provincia de Murcia, El Indicador Murciano, El Segura, La Lira del Tader y La Palma. En el transcurso de mi investigación, he localizado una interesante colección de El Dispertador, Gazeta Patriótica de Murcia (1810-1811) cuya existencia se conocía sólo por vagas referencias. Este periódico, centrado en la Guerra de la Independencia y las Cortes de Cádiz, ha de añadirse a los escasísimos ejemplares periodísticos que hoy día se conservan de los primeros años del siglo XIX: Clares, "La colección". Sobre la prensa murciana de finales del siglo XVIII y principios del XIX, véase el resumen que propone García Hourcade, "Panorama", pp. 373-383. 
quedan bastantes colecciones de periódicos completas y en buenas condiciones de conservación ${ }^{31}$.

Los historiadores coinciden en afirmar que fue en el Reinado de Isabel II (18331868) cuando la prensa adquirió carácter industrial y empresarial, a pesar de los vaivenes políticos que, según los casos, reprimieron o favorecieron la libertad de imprenta o impusieron la censura ${ }^{32}$. Como apunta Chivelet, el avance de las técnicas de impresión introdujo el concepto de "velocidad", modificando el planteamiento de los periódicos e incorporando el factor "actualidad". Los sistemas de comunicación, difusión y distribución de la información se agilizaron gracias a la sustitución del proceso manual de edición por mecanismos industriales y al empleo del ferrocarril, el telégrafo y el teléfono ${ }^{33}$. Además, la elevación del nivel cultural de las clases acomodadas y de las masas populares incrementó el número de lectores y diversificó los gustos del público. Los periódicos murcianos de la segunda mitad del siglo XIX permiten seguir la evolución descrita. De La Paz de Murcia (1858-1896), uno de los más importantes, trataré específicamente en el apartado siguiente. A continuación comentaré otros periódicos murcianos aparecidos desde los años cincuenta del siglo XIX, cuyas características presento resumidamente en el Apéndice 1.3. De la mitad de la centuria se conservan ejemplares del Diario de Murcia $(1851)^{34}$ y La Vega (1853) (de información general) ${ }^{35}$, El Industrial de Murcia (1854) y El Liberal Murciano $(1855)^{36}$. Los dos primeros fueron periódicos de información general y, los dos últimos, se especializaron en temas políticos, industriales y mercantiles. Durante el Reinado de Isabel II también destacan otras colecciones como El Segura (desde enero de 1863) y El Sacamuelas ${ }^{37}$, ambos son de

${ }^{31}$ Véase el balance de Jover, “Archivos”, pp. 113-131.

${ }^{32}$ Véase el interesante análisis sobre la prensa española del periodo 1833-1868 en Pizarroso, Historia, pp. 275- 280. Sobre la libertad de imprenta puede consultarse el estudio de Blanco, “Opinión”, pp. $27-51$. Sobre legislación de la imprenta véase: De Eguizábal, Apuntes.

${ }^{33}$ Chivelet, Historia, p. 30.

${ }^{34}$ El Diario de Murcia, subtitulado Periódico de todo, menos de política y religión, comenzó a publicarse diariamente el 1 de enero de 1851, excepto los lunes. Se conservan ejemplares desde el $n^{\circ} 28$ hasta el 256 (este último con fecha de 31-10-1851). En él se publicaron artículos de muy diversos temas (minería, agricultura, medicina y ferrocarril, entre otros) además de breves informaciones sobre la bolsa, los cultos religiosos y el teatro. Dio informaciones sobre el extranjero y sobre otras provincias españolas (muchas de ellas con textos de otros periódicos nacionales). Véase, Crespo, Historia de la prensa, pp. 103104.

35 Subtitulado Periódico científico, artístico y literario y dirigido por Juan López Somalo. Según Crespo, Historia de la prensa, p. 104, este periódico comenzó a publicarse en febrero de 1853 con periodicidad quincenal y, posteriormente, semanal. Se desconoce hasta cuándo se publicó. En La Vega se insertaron artículos de Diego Espinosa, Vicente Cuenta Lucherini y poesías de Miguel Rubio Arróniz, Navarro, Angustias Fernández y Antonio Arnao, entre otros. El periódico abordó una gran variedad de temas literarios, poéticos, económicos, históricos y científicos y repartió litografías con retratos de murcianos ilustres y vistas de Murcia (hoy no localizadas).

${ }^{36}$ Otros periódicos de la segunda mitad del siglo XIX de los que se tiene noticia (aunque no se han localizado ejemplares) son: El Avisador, El Correo de Murcia, La Abeja, El Telégrafo y El Vulcano.

${ }^{37}$ Otros periódicos de este periodo fueron: Revista Murciana, Boletín Eclesiástico del Obispado de Cartagena, El Murciano y El Faro Murciano. La Revista Murciana, subtitulada Periódico quincenal, de intereses materiales, ciencias, artes y literatura, estuvo dirigida por Antonio Hernández Amores. Se publicó desde marzo hasta septiembre de 1860. En el $E: M U m$ se conservan dos ejemplares incompletos. El Boletín Eclesiástico nació en febrero de 1865 y se editó hasta diciembre de 1872. Divulgó documentos pontificios y episcopales e informaciones de ámbito religioso (nombramientos, ordenaciones y visitas pastorales). El Murciano, periódico de literatura y recreo dirigido por Andrés Blanco García, salía cuatro 
información general, aunque el segundo de carácter satírico. El Segura se subtitulaba Diario de intereses materiales, científico, literario, artístico y de noticias. Según Ibáñez, su director fue el ex-teólogo del Seminario murciano Manuel Illán Albaladejo y su editor responsable, el impresor Antonio Molina. En esta publicación colaboraron José Selgas, García Clemencín, Mariano Ruiz Jara, Felipe Blanco de Ibáñez y el citado Illán. Tenía cuatro páginas y publicó, entre otras, la cartelera teatral diaria, reseñas, artículos y editoriales de opinión, y poesías de autores murcianos ${ }^{38}$. El Sacamuelas, subtitulado Periódico joco-serio, de todo, menos política y religión, vio la luz en octubre de 1863 . Se publicó en tres etapas ${ }^{39}$ y difundió un tipo de periodismo satírico-político, en ocasiones agresivo y radical. Por este motivo, algunos números fueron censurados y se publicaron con espacios en blanco ${ }^{40}$.

El Sexenio Revolucionario (1868-1873) fue el periodo de mayor libertad de prensa del siglo XIX, tanto en España como en Murcia ${ }^{41}$. Entre 1868 y 1872 llegaron a ver la luz más de treintena de publicaciones en la capital murciana de una amplia variedad ideológica. Sin embargo, eran todavía publicaciones de corta vida. De los problemas que había para mantener un periódico en Murcia dio El Zorongo en mayo de 1871:

[...] El que crea que es un negocio publicar un periódico en Murcia no sabe de la misa la mitad.

Sostener en esta ciudad un periódico, de cualquier clase que sea, es un problema que no ha podido resolver todavía más que el cálculo frío y linfático de Almazán, y esto a fuerza de aceite de bellotas. Así se comprende que, habiendo entre nosotros tantos jóvenes que manejen con aplauso la péñola, sea tan raquítica la vida de los periódicos. [...]/ [p. 10]

No hay en Murcia un periodista que haya tomado café una sola vez con las ganancias de la profesión. Las personas ilustradas respetan a los periodistas pero, en cambio, los jóvenes disipados, que por desgracia son muchos, y los hombres de orden y de buche, nos miran con prevención $[\ldots]^{42}$.

Una excepción por su larga duración fue El Noticiero de Murcia (1872-1917) ${ }^{43}$. Otros periódicos de estos años fueron El Avisador (1868-1872) ${ }^{44}$, Perico el de los Palotes

veces al mes; en sus páginas había artículos de costumbres, literarios y científicos, "todo menos de política y religión". El Faro Murciano, de temática literaria, apareció en enero de 1868 y fue dirigido por Rafael del Castillo. Véanse más detalles en: Crespo, Historia de la prensa, pp. 117-123.

${ }^{38}$ Crespo, Historia de la prensa, p. 118

${ }^{39}$ De octubre de 1863 a enero del año siguiente la primera etapa; a partir del mes mayo de 1864 la segunda; y de septiembre de 1871 a noviembre del mismo año, la tercera.

${ }^{40}$ El E:MUm conserva una colección prácticamente completa de El Sacamuelas. Véanse más detalles en: Crespo, Historia de la prensa, pp. 118-121.

${ }^{41}$ Sobre la prensa murciana del Sexenio Revolucionario, véase: Arroyo, "La prensa en el Sexenio", pp. 69-79.

42 [Anónimo], "Los periódicos y los periodistas de Murcia”, El Zorongo, (1871), no 2, 30 mayo, pp. 510: 6 y10. Véase también, [Anónimo], "La prensa de provincias", La Paz de Murcia, X (1867), n 2771, 15 enero, p. 1.

${ }^{43}$ El Noticiero de Murcia, dirigido por Felipe Blanco de Ibáñez, fue un periódico de información general, que nació el 15 de abril de 1872 y se publicó hasta 1917. Véase Crespo, Historia de la prensa, pp. 142-143. Lamentablemente se conservan pocos ejemplares si tenemos en cuenta el largo periodo en el que apareció. 
$(1868)^{45}$, El Buen Deseo $(1869)^{46}$; los republicanos El Zorongo $(1871)^{47}$ y El Obrero $(1870-1873)^{48}$, el periódico político El Aguijón $(1871-1872)^{49}$ y el periódico monárquico El Ideal Político $(1873)^{50}$. Todos ellos se ocuparon en mayor o medida de los acontecimientos políticos e insertaron en sus páginas información local muy variada.

De carácter literario fueron otros periódicos como La Ilustración Murciana
$(1871)^{51}$, El Aura Murciana $(1871)^{52}$, El Chocolate $(1872)^{53}$ y La Violeta (1872), éste

44 Subtitulado Semanario de anuncios, literatura, ciencias y artes, comercio, etcétera y posteriormente, Hoja volante de anuncios y otros artículos que se quieran insertar. Comenzó a publicarse a principios de octubre de 1868 y fue dirigido por Riera. Se desconoce cuándo dejó de publicarse ya que de esta época se conserva un único ejemplar con fecha de 22 de enero de 1869. Reapareció en noviembre de 1872 con el título de El Avisador Murciano. En esta nueva etapa, que duró tres meses, fue dirigido por Antonio Ibáñez González; se subtituló Periódico de intereses materiales; agricultura, industria y comercio y se conserva un único ejemplar de noviembre de 1872. Véanse más detalles en Crespo, Historia de la prensa, pp. 125-126.

${ }^{45}$ Dirigido por el sacerdote José $\mathrm{M}^{\mathrm{a}}$ Martínez López. Formaron parte de sus redactores los periodistas Martínez Tornel y Rodolfo Carles. Según Crespo, Historia de la prensa, p. 126, sus páginas ofrecían una "inusual mezcla de firme catolicismo y liberalismo a ultranza".

46 Subtitulado Diario Independiente. Según Crespo, Historia de la prensa, p. 127, defendió el conservadurismo tradicional y las doctrinas de la Iglesia. En el E:MUm se conservan dos ejemplares de mayo y septiembre de 1871 .

${ }^{47}$ Se desconoce cuándo comenzó a publicarse aunque Ibáñez, Serie, p. 117 lo sitúa en torno a 1870. Se conservan dos ejemplares de mayo y septiembre de 1871. Publicó artículos de costumbre, política, modas y literatura, entre otros. Según Crespo, Historia de la prensa, p. 129 es de "ideología republicana y con aire desenfadado están redactados sus comentarios críticos".

48 Subtitulado Semanario republicano federal, nació en julio de 1870 y fue fundado por Saturnino Tortosa y dirigido por José $\mathrm{M}^{\mathrm{a}}$ Martínez. Se publicó en tres etapas. El E:MUm conserva una colección de 83 ejemplares entre julio de 1870 y 1873. Para Crespo, Historia de la prensa, pp. 131-132: "Imperaba [en el periódico] un aire mitinesco en la mayoría de los textos, con durísimas diatribas contra los adversarios ideológicos".

49 Subtitulado Periódico político-literario. Según Crespo, Historia de la prensa, p. 132, era de ideología conservadora y partidaria de la monarquía alfonsina. Se publicó en dos etapas: la primera diciembre de 1870 a marzo de 1871 y la segunda desde octubre de 1871 hasta finales de septiembre de 1872. El E:MUm conserva una colección de 28 ejemplares de fechas comprendidas ente octubre de 1871 y septiembre de 1872 .

${ }^{50}$ Según Crespo, Historia de la prensa, p. 133, este periódico fue defensor de la dinastía borbónica y partícipe del príncipe Alfonso como rey.

${ }^{51}$ Este periódico nació en el seno de La Ilustración. Sociedad científico-literaria creada en 1869 por varios estudiantes de la recién fundada Universidad Libre de Murcia (Véase el Capítulo 6). Era dirigido por Andrés Baquero, secretario de la mencionada sociedad y sus redactores fueron mayoritariamente estudiantes universitarios ajenos al periodismo. La Ilustración Murciana publicaba leyendas, cuentos y poesías, entre otros. En su larga lista de colaboradores hubo destacados escritores y periodistas, como Ricardo Gil, Andrés Baquero, Andrés Blanco, López Somalo, Martínez Tornel y Javier Fuentes. El periódico aparecía los días 4, 12, 20 y 27 de cada mes. Se publicaron 24 números entre el 20 de enero de 1871 y el 27 de julio del mismo año (19 de los cuales aportan noticias de interés musical).

${ }^{52}$ Subtitulado Periódico científico-literario, aparecía cuatro veces al mes. Se publicaron 24 números ( 1 de febrero de 1871 a 14 de julio del mismo año, todos conservados en E:MUm). Según Ibáñez, Serie, 127, lo dirigió Ildefonso Rodríguez García, un ex-seminarista de San Fulgencio. El periódico prestó especial interés a la ciencia, aunque también publicó artículos de historia, economía y literatura, entre otros.

${ }^{53}$ Subtitulado Periódico dominguero y madrugador y, posteriormente, Revista de literatura, modas y pasatiempos. De este periódico aparecieron 29 números entre el 20 de octubre de 1872 y el 29 de septiembre de 1873 (con una interrupción de dos meses entre diciembre de 1872 y febrero de 1873), todos ellos conservados en el E:MUm. El Chocolate se editaba en los talleres de La Paz de Murcia y publicó 
último primer periódico murciano dedicado a la mujer ${ }^{54}$. En ellos colaboraron los escritores y periodistas murcianos más relevantes del periodo, como Díaz Cassou, Ricardo Gil, Andrés Blanco, Andrés Baquero, López Somalo, Martínez Tornel y Javier Fuentes. En líneas generales, el contenido de estas publicaciones era muy variado: poesías, narración corta (cuentos y leyendas) y artículos (teatrales, de moda, científicos, de divulgación, de costumbres y curiosidades murcianas), entre otros muchos temas.

Con la Primera República (1873) nacieron en la ciudad al menos ocho periódicos de diversa índole. El más importante fue La Correspondencia de Murcia (1873), un periódico de noticias y avisos, ajeno a la política, que fue dirigido por Martínez Candela ${ }^{55}$.

La prensa española se desarrolló y estabilización entre 1874 y $1930^{56}$. A ello contribuyó la relativa calma política y social y la aprobación de la Ley de Policía de Imprenta de 1883 que dio mayor libertad de expresión y simplificó las exigencias para publicar periódicos nuevos ${ }^{57}$. La función que la prensa debía tener se definía así en esos años en Murcia:

[...] Ilustrar la opinión pública en todos los asuntos de importancia; hacer resplandecer la justicia y la verdad, sin petulancias pero con tesón; censurar sin pasión / [p. 2] ni odio; reprender prudentemente las imperfecciones en general, para que cada cual saque la enseñanza que se desea, sin ofensa directa a nadie; no penetrar jamás en el interior de la vida privada para ridiculizar a las leyes; contribuir al mejoramiento social con el consejo, la sensatez y el patriotismo; tener, en fin, un mismo criterio para juzgar con imparcialidad todos los hombres. He aquí cual es la verdadera, la excelsa, la sublime misión de la prensa ${ }^{58}$.

A pesar de la disminución del número de nuevos periódicos al inicio de la Restauración (1875), a partir de la mencionada Ley de Policía de Imprenta (1883) se multiplicaron llegando a máximas cotas en $1886^{59}$. Esta tendencia del periodismo español

artículos de costumbres, modas, crónicas sociales, poesías y pasatiempos con un estilo ameno y cercano a sus lectores. Contó con importantes colaboradores, algunos vinculados a otros periódicos, como Javier Fuentes, Martínez Tornel, Pedro Díaz Cassou, Ricardo Gil, Rodolfo Carles, José Selgas, Sánchez Madrigal y Andrés Blanco, entre otros.

${ }^{54}$ Subtitulado Revista Bimensual de literatura y bellas artes, dedicada al bello sexo. Comenzó a publicarse el 20 de abril de 1872.

${ }^{55}$ La Correspondencia de Murcia se subtituló Periódico de anuncios y noticias de la noche y empezó a salir el 16 de enero de 1873 y el último número se publicó el 20 de febrero del mismo año. El diario publicó información local y provincial y noticias relacionadas "con el ideario republicano federal": Crespo, Historia de la prensa, p. 147. Los otros siete periódicos de 1873 eran: La Lucerna, La Fin del mundo (ambos de carácter humorístico), El Táder, La Fraternidad, El Correo Murciano, La Provincia y el semanario republicano titulado la Libertad. Véanse más detalles en Crespo, Historia de la prensa, pp. 148149.

${ }^{56}$ Albert, Historia, p. 199 habla de etapa de oro de la prensa española en ese periodo.

${ }^{57}$ La Ley de Imprenta de 1883 no exigía licencia previa para la edición de impresos periódicos, sino sólo "la puesta en conocimiento de la primera autoridad gubernativa de la localidad". Véase Soria, "La ley", p. 25.

${ }^{58}$ El Diario de Murcia, V (1883), nº 1333, 25 julio, pp. 1-2.

${ }^{59}$ Pizarroso, Historia, p. 283. 
también se constata en Murcia capital, donde entre enero de 1875 y 1882 aparecieron trece nuevas cabeceras y, sólo en el año 1883, siete.

Tras la Proclamación de Alfonso XII como rey (29-12-1874) nació en Murcia el periódico liberal Las Noticias $(1875-¿ 1882 \text { ? })^{60}$ y, ya en el marco de la promulgada Constitución de 1876, se publicaron en la ciudad tres periódicos más: El Álbum, El Comercio $^{61}$ y El Semanario Murciano. El Álbum fue una de las más notables revistas literarias de la segunda mitad del siglo XIX en Murcia y en ella colaboraron importantes escritores murcianos de la época ${ }^{62}$. También de carácter literario fue El Semanario Murciano (1878-1882), dirigido por Hernández Amores ${ }^{63}$.

El 15 de febrero de 1879 comenzó a publicarse El Diario de Murcia, uno de los más importantes e influyentes de la ciudad durante la segunda mitad del siglo XIX, junto a La Paz de Murcia ${ }^{64}$. Su fundador fue José Martínez Tornel (ver Figura 1.4), un experimentado periodista que también había dirigido El Comercio y colaborado en diversas publicaciones como La Paz de Murcia, El Álbum y El Semanario Murciano. Según Crespo, El Diario de Murcia fue un "diario ameno y popular, abierto y dialogante, defensor de los intereses locales y ajeno a los partidismos políticos" ${ }^{\text {"65 }}$.

${ }^{60}$ Subtitulado Periódico de intereses morales y materiales, inició su andadura el 3 de enero de 1875. Entre sus directores estuvieron José Baleriola (1877), José Ma Ibáñez Maceres (desde 1879 hasta octubre de 1880) y Ezequiel Díez y Sanz de Revenga hasta 1882, probable fecha de desaparición. Según Crespo, Historia de la prensa, p. 150, Las Noticias fue un periódico claramente político y defensor "tenaz de una postura anticanovista, atacó duramente a los conservadores que estaban en el poder".

61 El Comercio, subtitulado Semanario mercantil, agrícola e industrial, nació a principios de septiembre de 1876 y según Crespo, Historia de la prensa, p. 154 alcanzó prestigio y suficientes suscriptores como para publicarse durante cinco años.

${ }^{62}$ El Álbum se subtituló Semanario de literatura y ciencias y se publicó entre el 27 de septiembre de 1876 y el 2 de noviembre de 1877. Para Crespo, Historia de la prensa, p. 151, la publicación se promovió en las tertulias de escritores que el matrimonio Pagán-Guerra organizaba semanalmente en los salones de su casa (el desaparecido palacio de los Vélez). El periódico dejó de publicarse tras la prematura muerte de Leonor Guerra, brillante escritora, poetisa y considerada la verdadera artífice de estas reuniones. En las páginas de El Álbum colaboraron numerosos literatos murcianos, como José Selgas, Ricardo Gil, Andrés Baquero, Sánchez Madrigal, Pío Tejera, Martínez Tornel, Andrés Blanco y García Alix. En la E:Mn se conservan 47 ejemplares de El Álbum correspondientes a diversas fechas entre octubre de 1876 y noviembre del año siguiente.

${ }^{63}$ El Semanario Murciano. Revista científica, literaria y artística se inició el 17 de febrero de 1878 y terminó, con el número 199, el 31 de enero de 1882. El E:MUm conserva una colección completa de 199 ejemplares, más un suplemento de agosto de 1881. Durante sus casi cuatro años de vida, esta publicación contó con un elevado número de redactores y colaboradores, como Rodolfo Carles, Olayo Díaz, Andrés Baquero, Antonio Arnao, Juan García Aldeguer, José Amador de los Ríos, Andrés Blanco, el músico Julián Calvo, entre otros. Publicó artículos sobre literatura, música, ciencias, artes, agricultura, industria y comercio. A pesar de que en su primer número se afirmó: "no trataremos de política" terminó convirtiéndose en "un periódico político, defensor y seguidor incondicional del general Martínez Campos". Véase Jover, “Archivos”, p. 125 y Crespo, Historia de la prensa, pp. 154-155.

${ }^{64}$ Cuando surgió El Diario de Murcia se editaban en la ciudad cinco periódicos: La Paz de Murcia, El Noticiero, Las Noticias, El Comercio y El Semanario Murciano.

${ }^{65}$ Crespo, Historia de la prensa, p. 156. 


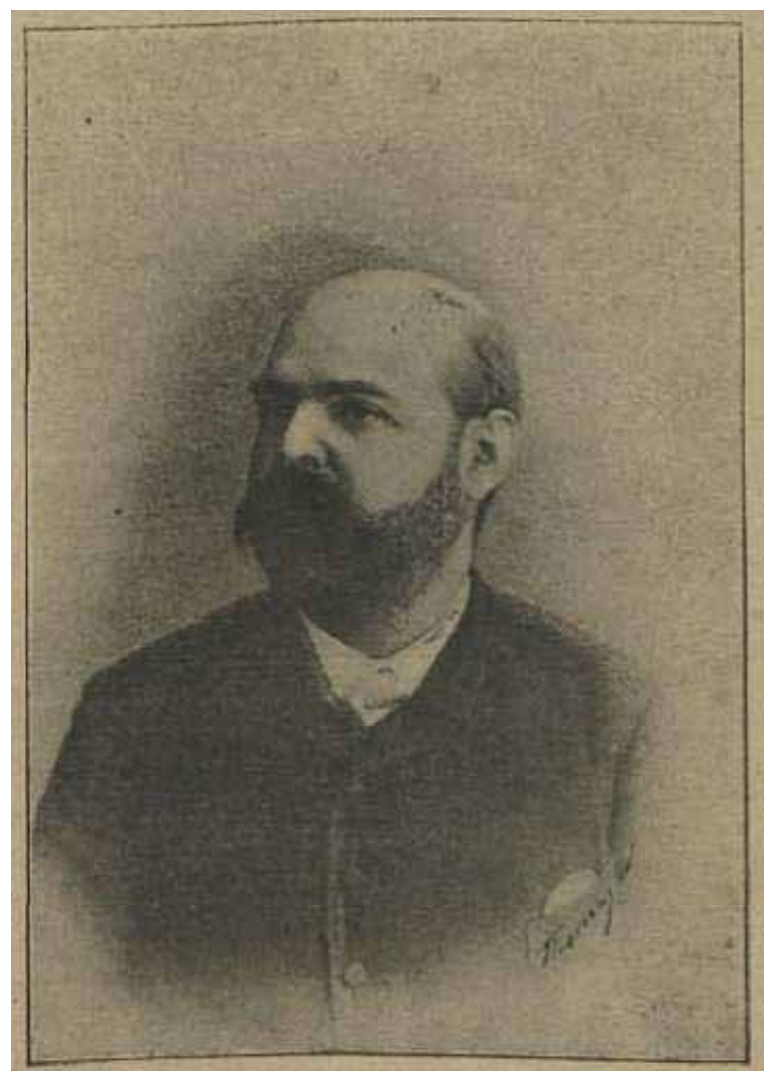

Figura 1.4. Retrato de José Martínez Tornel, director de El Diario de Murcia E:CARm. Cartagena Artística, I (1890), nº 6, 1 junio, p. 1. Accesible en: http://archivo.cartagena.es (acceso el 21-08-2011).

De 1879 a 1893, El Diario de Murcia se subtituló Periódico para todos (Figura 1.5), suprimiéndose a partir de 1894. El Diario de Murcia dejó de publicarse en 1903, ya que no pudo competir con otros periódicos como El Liberal y La Verdad.

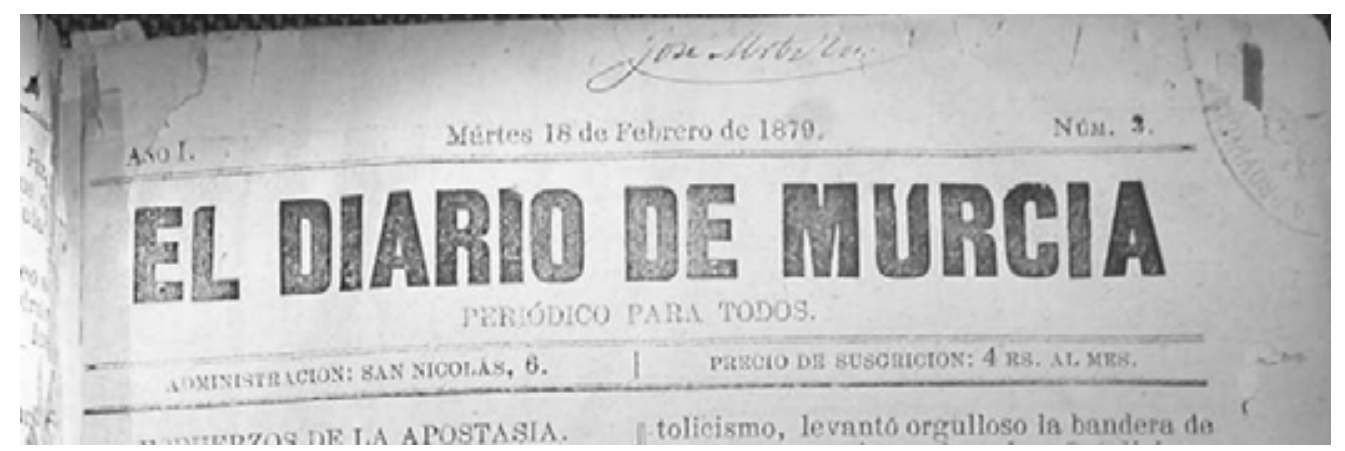

Figura 1.5. Cabecera de El Diario de Murcia, I (1879), nº 3, 18 febrero, p. 1, E:MUm. En la parte superior de la hoja aparece la firma autógrafa de su director, José Martínez Tornel.

A finales de los años setenta del siglo XIX existió también El Clamor Murciano, un periódico bisemanal de carácter político que fue portavoz del partido democrático ${ }^{66}$.

${ }^{66}$ Es posible que El Clamor Murciano (del que sólo se conoce un ejemplar), desapareciera a mediados de octubre de 1880, coincidiendo con el fallecimiento de Bernardino Rossi, su probable director o propietario, según Crespo, Historia de la prensa, pp. 162-163. 
Entre 1880 (año de inicio de la Regencia de María Cristina de Habsburgo) y 1885, aparecieron en Murcia capital veintitrés periódicos ${ }^{67}$, generalmente de vida corta y que, con frecuencia, se fusionaron entre sí. Por su contenido, estos periódicos pueden dividirse en tres grandes grupos ${ }^{68}$ :

1. Periódicos de información general, literarios, taurinos ${ }^{69}$, educativos $\mathrm{y}$ de entretenimiento: La Trompeta (1880) dirigido por Gabriel Baleriola; La Camelia (1880), dirigido por Virgilio Guirao; El Vínculo (1882), por Eugenio Tejero; El Vigía (1883) ${ }^{70}$; el Boletín del Colegio de la Purísima Concepción (1883) dirigido por Antonio Ortíz Bernal; El Chicarro (1883); El Murciano (1884); La Revista (1884), dirigido por José Sellés; La Verdad (1884); El Panocho (1884); El Bouquet (1884); El Artista (1884) y El Progreso Murciano $(1884)^{71}$.

2. Periódicos políticos: La Democracia $(1881)^{72}$; El Eco de Murcia $(1881)^{73}$; La Federación $(1882)^{74}$; La Opinión $(1883)^{75}$ y los republicanos El Pueblo (1883) y La Campaña $(1883)^{76}$.

3. Independientes y satíricos: La Provincia $(1882)^{77}$, El Profeta $(1884)^{78}$ y Las Disciplinas $(1884)^{79}$.

${ }^{67}$ La Trompeta (1880), La Camelia (1880), La Democracia (1881), El Eco de Murcia (1881), La Provincia (1882), La Federación (1882), El Vínculo (1882), El Vigía (1883), Boletín del Colegio de la Purísima Concepción (1883), La Opinión (1883), El Pueblo (1883), La Campaña (1883), El Murciano (1883), La Revista (1883), La Verdad (1884), El Panocho (1884), El Bouquet (1884), El Artista (1884), El Profeta (1884), Las Disciplinas (1884), El Progreso Murciano (1884), El Liberalito (1885) y El Monaguillo (1885).

${ }^{68}$ Los datos sobre estos periódicos son muy escasos, ya que se conservan pocos o ningún ejemplar. La clasificación que presento es orientativa y se basa en Crespo, Historia de la prensa.

${ }^{69}$ La prensa taurina ha sido estudiada por Barceló, "El periodismo”, pp. 579-585.

${ }^{70}$ Subtitulado Periódico de intereses morales y materiales. Según Crespo, Historia de la prensa, p. 169 fue promovido por Hernández Amores. Incluyó información local, literatura y noticias culturales, entre otros.

${ }^{71}$ En un principio, El Progreso Murciano tuvo carácter literario, pero desde marzo de 1885 "tomó el rumbo de los monárquico-demócratas de Segismundo Moret”: Crespo, Historia de la prensa, p. 175. No se conservan ejemplares de esta publicación.

${ }^{72}$ La Democracia fue "órgano del partido demócrata progresista”, según Crespo, Historia de la prensa, pp. 164.

${ }^{73}$ El Eco de Murcia, subtitulado Diario político liberal-conservador, nació en abril de 1881 y cerró a principios de 1882. Estuvo dirigido por Mariano Castillo Jiménez, alcalde de Murcia durante 27 días (1 a 27 de julio de 1885) y, posteriormente, gobernador civil de la Provincia. Véase, Crespo, Historia de la prensa, pp. 166-167 y Cano, Alcaldes, pp. 349-352.

${ }^{74}$ La Federación surgió como órgano de expresión de un grupo político candidato a las elecciones municipales, presidido por el catedrático de Instituto Olayo Díaz Giménez y el cantonalista Antonete Gálvez. Véase, Crespo, Historia de la prensa, p. 168.

${ }^{75}$ La Opinión, dirigido por Antonio Ibáñez, tuvo periodicidad bisemanal y era un "periódico independiente, pero de tendencia liberal en sus editoriales y artículos", según Crespo, Historia de la prensa, p. 170.

${ }^{76}$ Ambos periódicos tuvieron escasa trascendencia y fueron "portavoces de dos sectores federalistas en los años 1883 y 84, añorantes de la brevísima República del 73”, según Crespo, Historia de la prensa, p. 170 . 
En 1885 surgieron en Murcia ocho nuevos periódicos, entre los que destacó Las provincias de Levante ${ }^{80}$, que se publicó entre 1885 y 1902 y fue dirigido por el reputado periodista Gabriel Baleriola. En Las Provincias de Levante se combinaba la información de actualidad con textos literarios de autores murcianos e ilustración a pluma, como la del famoso barítono murciano Mariano Padilla ${ }^{81}$.

Durante la década final del siglo XIX aparecieron nuevas publicaciones tanto en Murcia capital como en la provincia ${ }^{82}$. Las más significativas fueron El Pueblo (1893), primer diario murciano en usar los grandes titulares, y La Tarde (1894), que utilizó por primera vez "ladillos" y sumarios.

El Heraldo (1898) y El Correo de Levante (1899) fueron los últimos diarios aparecidos en el siglo XIX ${ }^{83}$.

\section{La Paz de Murcia (1858-1896)}

La Paz de Murcia es uno de los periódicos murcianos más importantes de la segunda mitad del siglo XIX y del que he extraído numerosos datos de interés musical presentes en esta Tesis. A lo largo de sus treinta y ocho años de historia las características de este periódico fueron variando. El Apéndice 1.4 muestra algunos de los cambios más sustantivos que experimentó en títulos, subtítulos, paginación, periodicidad y formato ${ }^{84}$. Hasta la década de los ochenta del siglo XIX el periódico cambió en aspecto físico (cabecera, tipos de imprenta, papel) y en ideología, métodos de recogida y sistemas de

${ }^{77}$ La Provincia, dirigido por Gabriel Baleriola, se autocalificaba como Diario independiente, según Crespo, Historia de la prensa, p. 167.

${ }^{78}$ El Profeta, de carácter semanal y dirigido por Gabriel Baleriola, surgió en octubre de 1884 y dejó de publicarse en marzo de 1885. Su redactor- jefe fue el sacerdote José Hernández Ardieta y, sin embargo, tuvo una actitud "rabiosamente anticatólica", según Crespo, Historia de la prensa, p. 173.

${ }^{79}$ Las Disciplinas, subtitulado Periódico satírico, era un semanario dirigido por el abogado Julián de la Cierva en el que todos sus redactores eran jóvenes letrados, según Crespo, Historia de la prensa, p. 174.

${ }^{80}$ Los otros siete periódicos surgidos en 1885 eran: El Liberal, El Liberalito, El Monaguillo, La Región de Levante, El Diario de la Noche, El Vigía de Levante y la publicación de carácter religioso titutulada El Criterio Murciano.

${ }^{81}$ El E:MUm conserva una colección de 51 ejemplares de este periódico, de fechas comprendidas entre mayo de 1887 y abril de 1893. Véanse más detalles en Crespo, Historia de la prensa, pp. 177-180.

${ }^{82}$ En el año 1886 aparecieron El Libre Pensamiento (publicado desde enero hasta octubre de $1886 \mathrm{y}$ del que no quedan ejemplares), el Heraldo, El Huertano, La Revista Murciana, Te has colado, El Liberal Dinástico, El Diario Murciano, La Enseñanza Católica y El Eco de las Aulas. En 1888 se publicaron La Enciclopedia, La Miscelánea y La Juventud Literaria, y ya en los años siguientes El Anunciador Mercantil (1888), La Ilustración de Levante (1890), El Independiente (1891), El Bazar Murciano (1892) y las publicaciones literarias El Álbum Murciano (1895), El Mosaico (1896), Quevedo (1897) y El Diablo verde (1898). Véase Crespo, Historia de la prensa, pp. 184-204.

${ }^{83}$ Sobre la prensa murciana de finales del siglo XIX y comienzos del XX, véase, Arroyo, "La prensa murciana en el desastre del 98", pp. 15-25; Crespo, Historia de la prensa, pp. 214-220 y De los Reyes, "La prensa murciana".

${ }^{84}$ Véase el interesante balance que el propio periódico hizo de su trayectoria en La Paz de Murcia, XVI (1873), $n^{\circ} 4701,1$ enero, p. 1. 
distribución de las noticias. Los cambios fueron más acentuados en los dos primeros años de vida de la publicación (1858-1859), y menores a partir de los años ochenta.

\subsection{Cabecera}

El primer título del periódico en 1858 fue La Paz. Periódico de noticias, avisos y de fomento de la Provincia de Murcia. El título definitivo, La Paz de Murcia, se adoptó en agosto de 1859 y permaneció inalterable hasta el fin de la publicación en 1896. Las Figuras 1.6 y 1.7 muestran la cabecera del periódico en 1858 y 1895, años del primer y último ejemplar conservado ${ }^{85}$.

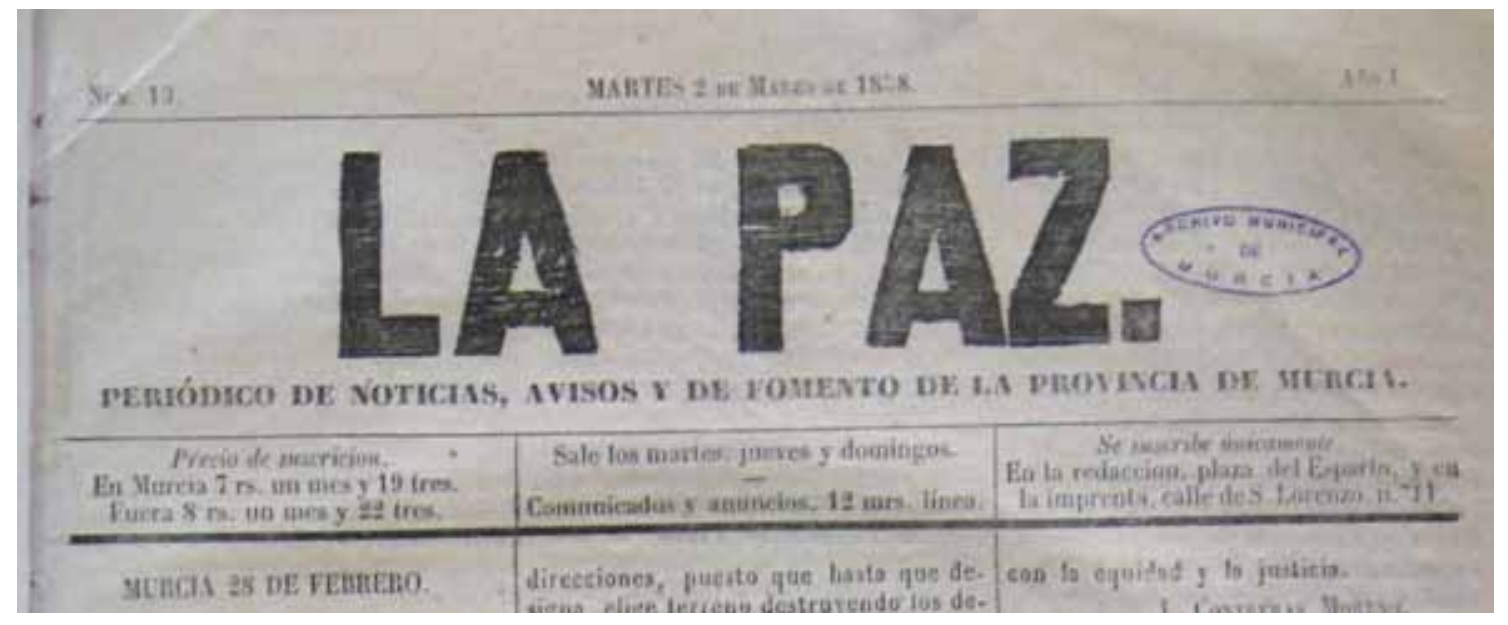

Figura 1. 6. Cabecera del primer ejemplar conservado del periódico La Paz de Murcia, I (1858), nº 13, 2 marzo, p. 1, E:MUm.

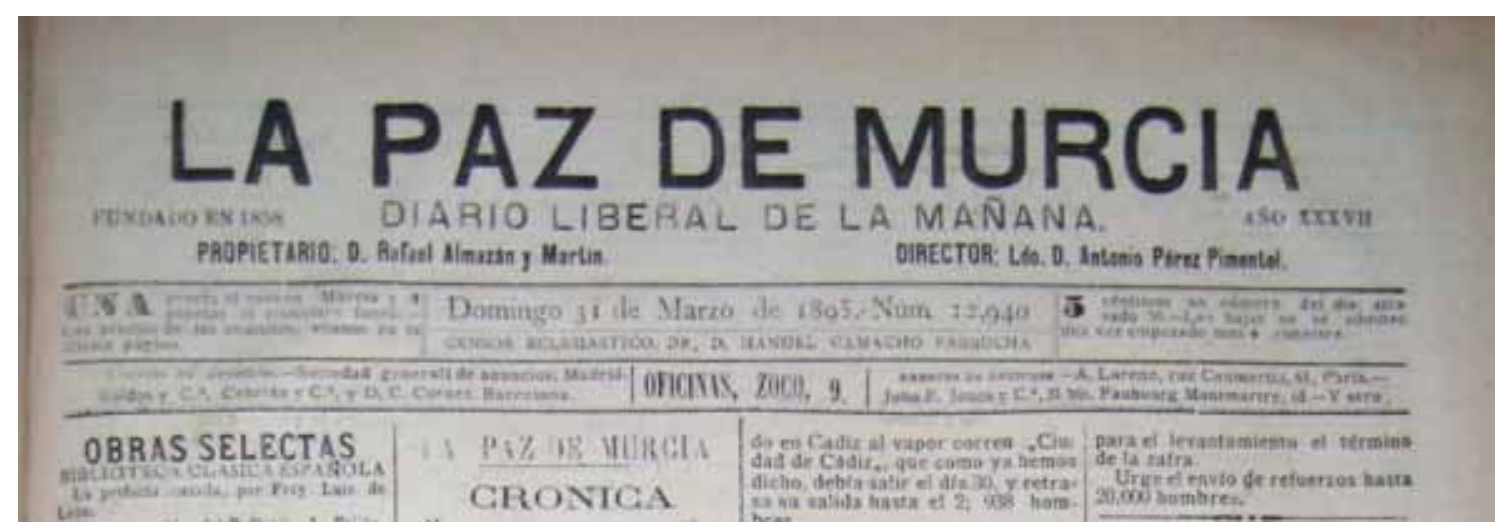

Figura 1.7. Cabecera del último ejemplar conservado de La Paz de Murcia, XXXVII (1895), nº 12940, 31 marzo, p. 1, E:MUm.

Los subtítulos de La Paz de Murcia cambiaron en múltiples ocasiones a lo largo de su existencia, al igual que los tipos de imprenta y formatos. Algunos subtítulos

${ }^{85}$ En esta Tesis he optado por utilizar siempre La Paz de Murcia como título del periódico, a pesar del título original ( $L a P a z)$. 
empleados fueron: "Diario de fomento, ciencias, artes, literatura, noticias y anuncios" (1858), "Diario político de noticias, intereses materiales, ciencias, artes, literatura, modas, noticias y anuncios" (julio de 1865), "Diario monárquico-democrático y de avisos y anuncios" (marzo de 1871), "Periódico científico, literario, de administración y noticias" (julio de 1872) y "Diario liberal y de noticias y anuncios" (enero de 1891). Los subtítulos variables revelan algunos cambios de ideología o tendencia política según el contexto histórico y actúan, en palabras de Antonio de los Reyes, como sumarios ${ }^{86}$.

Los números dedicados a algún acontecimiento extraordinario fueron subrayados con cambios en el aspecto externo de la publicación, especialmente en la primera página. En estas ocasiones especiales se alteraba la cabecera y los márgenes de la portada con guirnaldas y otros motivos ornamentales ${ }^{87}$. A veces, incluso, se utilizaba papel con tintes especiales, como el rosáceo que se muestra en la siguiente Figura 1.8:

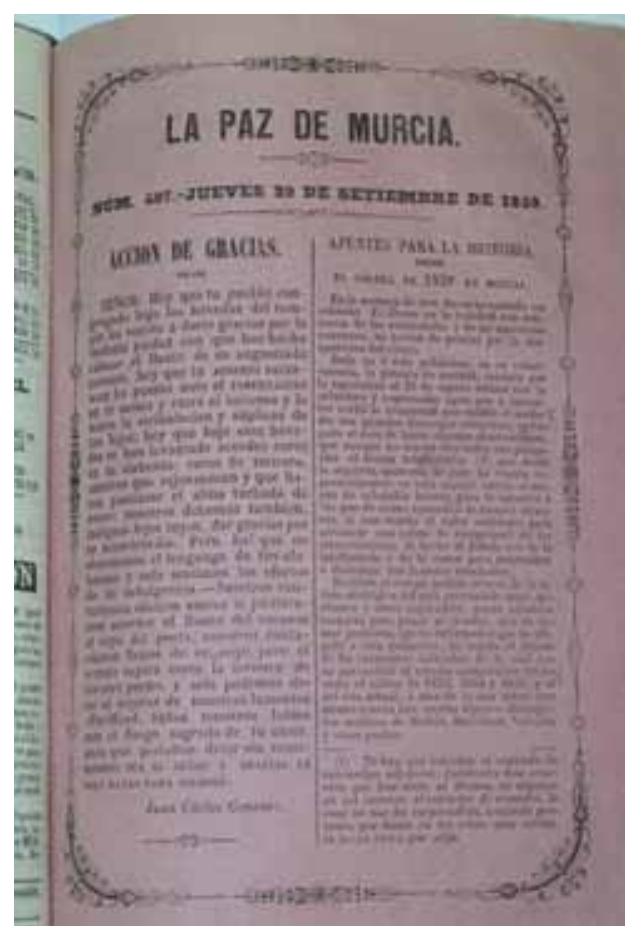

Figura 1.8. Edición especial de La Paz de Murcia, II (1859), nº 497, 29 septiembre, p. 1, E:MUm.

\subsection{Directores y equipo de redactores}

La Paz de Murcia fue fundada por el abogado Juan Contreras y Moreno, aunque diversos investigadores sitúan a su sucesor, Rafael Almazán Martín, como el verdadero

\footnotetext{
${ }^{86}$ De los Reyes, “La prensa murciana”, p. 350. Véase también el punto 3.7 de este capítulo.

${ }^{87}$ Por ejemplo, los márgenes del ejemplar del 9 de octubre de 1885 estaban adornados con una orla en homenaje a las víctimas de una epidémica de cólera que asoló, entre otras provincias españolas, Murcia. Según las cifras del periódico, Murcia tuvo 16046 infectados y 6226 defunciones por la epidemia. Ver, La Paz de Murcia, XXVIII (1885), nº 8339, 9 octubre, p. 1.
} 
impulsor del diario ${ }^{88}$. Almazán, encargado inicialmente de la administración del periódico, asumió su dirección el 20 de abril de 1858, apenas tres meses y medio después de la publicación del primer ejemplar (2-02-1858) y siguió en el puesto (salvo en un breve paréntesis) hasta que, tras sufrir una larga enfermedad, cedió las riendas del periódico a Antonio Pérez Pimentel el 13 de marzo de $1895^{89}$. La propiedad de La Paz de Murcia pasó a ser de Ernesto de Vilches y Mateo de Hoyos, que fueron sus directores desde el 4 de mayo de 1895 hasta el final del periódico en enero de $1896^{90}$.

Los artículos de La Paz de Murcia eran obra de un equipo de redactores propios, de colaboradores externos y de una agencia de información exterior. Ente otros redactores y colaboradores estuvieron López Somalo, Hermenegildo Lumeras, Juan López Parra, Ricardo Guirao, Adolfo Balboa y Luis Marco Ramírez, Antonio Ibáñez González, Eduardo Tirado Ayala y Manuel Ramos Pinar ${ }^{91}$. Sobre temas musicales colaboraron Antonio Ramírez, Diego Espinosa y Julián Calvo, entre otros. La Paz de Murcia tuvo corresponsales en Madrid prácticamente desde el inicio de su publicación ${ }^{92}$.

${ }^{88}$ Véase Ibáñez, Serie, p. 83; Crespo, pp. 116-117 y Jover, “Archivos”, p. 124. Los testimonios sobre la constancia y el empeño de Almazán para sacar el periódico adelante son muy numerosos. En La Paz de

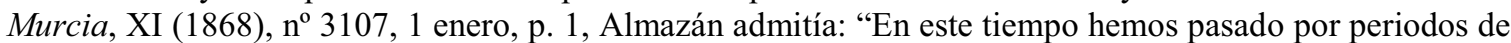
prueba necesitando de toda nuestra inalterable perseverancia para no desmayar y retroceder en nuestra empresa. Nuestra virtud principal ha sido la constancia y a ella debemos el haber atravesado terribles crisis. [...]. Que el lucro no ha sido el móvil de nuestra conducta es evidente, pues en diferentes ocasiones hemos demostrado de una manera matemática que nos es gravoso el sostenimiento del periódico". El granadino y empleado de imprenta Rafael Almazán Martín se trasladó a Murcia entre los años 1854-1855, donde emprendió la publicación de diversos periódicos, tales como El Avisador, El Correo de Murcia, El Telégrafo y El Vulcano. Los dos últimos se integraron en La Paz de Murcia en marzo de 1858, ya que la ley vigente en ese momento impedía que una misma persona fuese el editor de más de un periódico a la vez. Véase, La Paz de Murcia, I (1858), n ${ }^{\text {os }}$ 16, 9 marzo, p. 1 y 37, 23 abril, p. 1. No se han localizado ejemplares de estas colecciones, según Crespo, Historia de la prensa, pp. 110-111.

${ }^{89}$ El paréntesis en que Almazán dejó de dirigir el periódico fue el periodo entre julio de 1865 y agosto de 1866, aunque el editor responsable fue Antonio Hérnandez Amores. Véase, Crespo, Historia de la prensa, pp. 109-110 y García Soriano, Anales, p. 77. Amores estuvo también implicado en otros periódicos murcianos, como la Revista Murciana, de la que fue propietario y editor responsable, La Ilustración Murciana, editada por la sociedad del mismo nombre que él presidía, y El Semanario Murciano, también de su propiedad, entre otros.

${ }^{90}$ Ibáñez, Serie, p. 82 y Crespo, Historia de la prensa, p. 117. De los Reyes, "La prensa murciana", pp. 350-351 afirma que tras la muerte de Almazán (20-04-1895) su viuda vendió el periódico por dos veces, y que se llegaron a publicar dos periódicos con la misma cabecera, uno propiedad de Ernesto Vilches y dirigido por Mateo de Hoyos Masegosa y otro dirigido por Herminio Aguilar, del que no se han localizado ejemplares.

${ }^{91}$ Crespo, Historia de la prensa, p. 115. Ibáñez, Serie, p. 83 señaló que La Paz de Murcia "fue campo neutral en que se libraron rudas campanas por escritores de opuestos criterios" reafirmando la idea de independencia defendida por su director.

${ }^{92}$ En junio de 1858 La Paz de Murcia anunció que se había asociado a un red de periódicos de diversas ciudades españolas: "De este modo, cada uno de los periódicos tiene en la corte un corresponsal propio, imparcial y desinteresado que no solo le ponga al corriente de los altos misterios de la política, financieros y bursátiles, sino que le facilite informes seguros de toda clase de sociedades y empresas [...], evitándose de este modo hacer el secundario papel de copistas y reflejo de noticieros interesados": [Anónimo], "Centralización. La publicidad es la garantía de los pueblos civilizados", La Paz de Murcia, I (1858), n 92, 28 junio, p. 1. En 1859, por ejemplo, el corresponsal fue Montano, "el cual saben nuestros lectores nos remite una correspondencia y partes telegráficos propios diariamente": La Paz de Murcia, II (1859), n 372, 16 mayo, p. 1. En 1872, también contó con un buen servicio de noticias que le procuraban las agencias Fabra y Caries: Arroyo, "La prensa murciana en el Sexenio", p. 74. 


\subsection{Oficinas de redacción, administración y talleres de impresión}

La primera redacción de La Paz de Murcia estuvo en la plaza del Esparto (actualmente, de Romea) y la imprenta era común a la de El Telégrafo (periódico que también dirigió Almazán), en la calle de San Lorenzo, 11. Desde 1863, el taller de impresión de La Paz de Murcia estuvo ubicado en la calle Zoco, 5, mientras que las oficinas de administración y redacción fueron cambiando de ubicación ${ }^{93}$.

\subsection{Datación y periodicidad}

Inicialmente, La Paz de Murcia se publicó en días alternos (martes, jueves y domingos). En abril de 1858, su recién nombrado nuevo director, Rafael Almazán, comenzó a publicarlo todos los días salvo los lunes y con esta periodicidad se mantuvo la mayor parte de su existencia, excepto en algunos periodos puntuales (ver Apéndice 1.4).

Los cambios en periodicidad, formato y tipografía del periódico se debieron, en gran parte, a las continuas crisis financieras que le afectaron desde el comienzo, debidas sobre todo a cuatro causas: 1) la escasa tirada del periódico por el número insuficiente de suscriptores; 2) la baja rentabilidad de los anuncios publicados; 3) la fuerte competencia entre los diversos periódicos murcianos ${ }^{94}$ y 4) el alto grado de analfabetismo en la ciudad $^{95}$.

En 1859 el periódico contaba con 93 suscriptores, que pasaron a ser 205 en 1867 (167 de la ciudad y 38 de fuera de ella) ${ }^{96}$. La Tabla 1.4 muestra las cantidades percibidas por suscripción en 1867 :

93 Según García Soriano, Anales, pp. 112-118, el establecimiento tipográfico de La Paz de Murcia estuvo situado en la calle Zoco, número 5 desde 1863 hasta 1890; en la calle San Cristóbal, número 7 (1891-1894) y en la calle Zoco, número 9 en 1895. En los ejemplares consultados consta que las oficinas del periódico estuvieron situadas en calle San Cristóbal, número 7 y Pinares, número 2 (noviembre de 1888 a enero de 1889); en San Cristóbal, 7 y Zoco, 5 (1889-1891); San Cristóbal, 7 y Montijo, 13 (1891-1894); San Cristóbal, 7 y Zoco 9 (desde mediados del mes de noviembre de 1894); y, finalmente, en Zoco, 9 desde 1895.

${ }^{94}$ Con la aparición de El Diario de Murcia, en 1879, se inició una dura competencia entre éste y La Paz de Murcia. El Diario de Murcia "atrajo rápidamente al sector urbano más tradicional. Los partidos políticos a los que $\mathrm{La} P a z$ sirvió de portavoz le proporcionaron algunas suscripciones, pero no el socorro económico que precisaba". En 1892, El Diario de Murcia tenía una tirada de 1300 ejemplares, mientras que La Paz de Murcia sacaba una quinta parte (300 ejemplares). Ver Crespo, Historia de la prensa, p. 116.

${ }^{95}$ La Paz de Murcia, IX (1866), n’ 2780, 13 octubre, p. 1 publicó un interesante artículo titulado "La prensa de España", tomado de El Guadalquivir, según el cual, sólo una tercera parte de españoles alfabetizados se interesaba por algún tipo de prensa. Sobre Murcia, apunta los siguientes datos: de 87.803 habitantes, sólo sabían leer 13785, es decir, poco más de la sexta parte. Según [Anónimo], "El periódico", La Paz de Murcia, XXXI (1888), n 9400, 11 enero, p. 1 de 93.892 habitantes sólo 14.000 sabían leer en 1888. En ese año se publicaban en Murcia capital nueve periódicos y once más en Cartagena.

${ }^{96}$ La Paz de Murcia, II (1859), no 372, 16 mayo, p. 1 y La Paz de Murcia, X (1867), nº 3015, 29 septiembre, pp. 2-3. 
Tabla 1.6. Cuotas de suscripción y cantidades que generaban al periódico La Paz de Murcia en 1867. Fuente: La Paz de Murcia, X (1867), no 3015, 29 septiembre, pp. 2-3.

\begin{tabular}{|l|c|l|}
\cline { 2 - 3 } \multicolumn{1}{c|}{} & $\begin{array}{l}\text { Cuotas trimestrales } \\
\text { por suscriptor, en } \\
\text { reales }\end{array}$ & \multicolumn{1}{c|}{$\begin{array}{c}\text { Cantidad mensual } \\
\text { generada }\end{array}$} \\
\hline Suscriptores de Murcia & 20 & 1113 reales, 33 céntimos \\
\hline Suscriptores foráneos & 23 & 291 reales, 33 céntimos \\
\hline Total & 43 & 1404 reales, 66 céntimos \\
\hline
\end{tabular}

Los gastos mensuales del periódico ascendían a más de 2000 reales mensuales, generándose cada mes un déficit de 364 reales con 9 céntimos $^{97}$. La Paz de Murcia publicó continuas advertencias a sus suscriptores reclamando por adelantado sus pagos, como se muestra en el siguiente párrafo:

La circunstancia de tener que pagar además de las obligaciones de nuestro establecimiento, la impresión de las dos páginas interiores que se nos hacen en Madrid, su porte en ferrocarril y otros gastos creados con la reforma hecha en LA PAZ, cuyas obligaciones tenemos que atender con suma puntualidad, nos obligan a ser más exigentes y a llevar con rigor la condición que de antiguo tenemos establecida, como todos los demás periódicos, de cobrar por adelantado ${ }^{98}$.

Para incentivar las suscripciones, el director del periódico Rafael Almazán, recurrió en varias ocasiones a la edición conjunta con diarios madrileños, como La Correspondencia Autógrafa, La Correspondencia de España, El Popular y la Gaceta Universal (véase Apéndice 1.4) ${ }^{99}$. Además, publicó en la imprenta de La Paz de Murcia todo tipo de escritos y separatas de temática y formatos variados que regalaba o vendía a los suscriptores según la ocasión. Por ejemplo, en 1864, se entregaban semanalmente junto a La Paz de Murcia figurines de modas cuyas explicaciones se aportaban en las columnas del diario y en 1865, se regaló un Boletín Agrícola que, en según Ibáñez, era "muy útil como divulgadora de las teorías y prácticas de la agricultura"100. También gratuitas para los lectores de La Paz de Murcia fueron La Enciclopedia y La Miscelánea, dos revistas de carácter literario, publicadas desde 1888 y 1890 , respectivamente ${ }^{101}$. A

${ }^{97}$ Las cuentas detalladas pueden consultarse en La Paz de Murcia, X (1867), nº 3015, 29 septiembre, pp. 2-3, donde se concluye: "no es negocio el tener un periódico en Murcia".

${ }^{98}$ La Paz de Murcia, XII (1869), no 3490, 9 febrero, p. 1. Las advertencias de este tipo fueron muy numerosas. Véanse por ejemplo, las publicadas durante los meses de mayo y septiembre de 1871. El director Almazán llegó a publicar los nombres de algunos morosos. Por ejemplo, en La Paz de Murcia, XIV (1871), $\mathrm{n}^{\mathrm{o}}$ 4265, 12 septiembre, p. 1 se citaron deudores como los alcaldes de Ceutí y Ulea, José Tomás López y Juan Valero Dardalla, entre otros personajes conocidos.

${ }^{99}$ Este tipo de fórmulas de consorcio con otros periódicos provinciales fueron muy habituales, ya que ayudaban a incrementar las tiradas de la prensa madrileña y abarataban los costes de edición para los periódicos asociados. Véase Albert, Historia, p. 198.

100 Ibáñez, Serie, p. 78. En 1867, a los lectores que pagaban por adelantado el importe de la suscripción de los tres meses iniciales de ese año se les regalaba "un cuadro de tarifas de franqueo propio para pared": La Paz de Murcia, X (1867), n² 2760, 4 enero, p. 1.

${ }^{101}$ La Enciclopedia, de periodicidad semanal, se publicó por primera vez el 8 de agosto de 1888 y cesó el 25 de marzo del año siguiente. Se editó en ocho páginas y en ella colaboraron escritores como Díaz Cassoy y Avilés Martini, entre otros. Le sucedió La Miscelánea, editada entre el 3 de marzo de 1889 y el 29 de septiembre de 1890. Véase, Ibáñez, Serie, pp. 81-82 y Crespo, Historia de la prensa, pp. 191-195. 
ellas hay añadir la publicación de novelas, folletines, calendarios, almanaques, mapas, libros y otros suplementos extraordinarios en la imprenta de La Paz de Murcia ${ }^{102}$. La siguiente Figura 1.9 muestra la cabecera de un suplemento del diario encuadernado junto a un ejemplar normal. Como puede observarse, ambos tipos de entregas tenían tamaños de página diferentes.

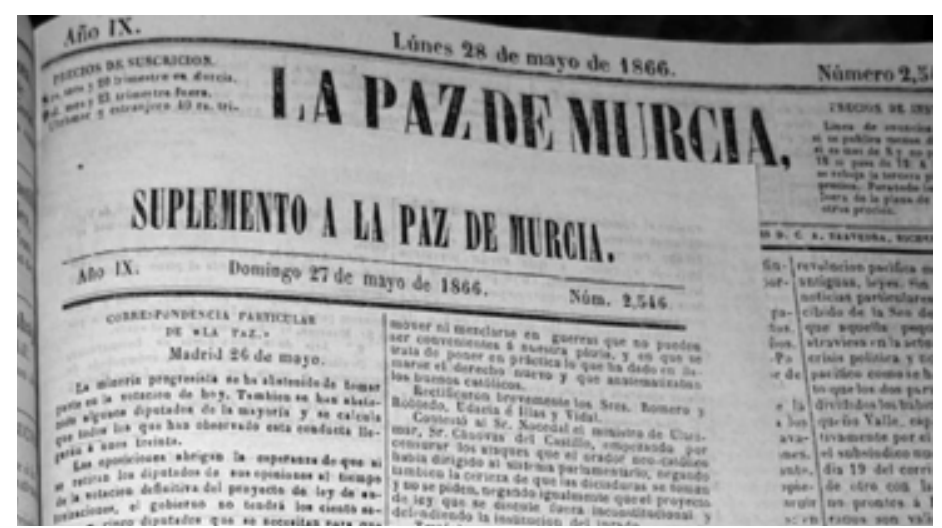

Figura 1.9. En primer plano, cabecera del suplemento a La Paz de Murcia, IX (1866), $\mathrm{n}^{\circ}$ 2546, 27 de mayo, p. 1. Detrás, La Paz de Murcia, IX (1866), nº 2547, 28 mayo, p. 1, E:MUm.

\title{
3.5. Formato y páginas
}

Los cambios en el formato y número de páginas de La Paz de Murcia estuvieron directamente relacionados con la periodicidad del diario y con las etapas de edición conjunta con periódicos nacionales (ver Apéndice 1.4). Por ejemplo, desde junio de 1865, La Paz de Murcia se publicó junto a La Correspondencia de España, en tamaño 49x33.5 cms. y la información propia de Murcia se vio limitada a una sola página. Desde el 23 de marzo de 1866, La Paz de Murcia tuvo dos ediciones: una edición que salía al mediodía en números sueltos para suscriptores de fuera y una edición de la tarde que aparecía como cuarta página de La Correspondencia de España. Desde abril de 1866 hasta enero de 1869, La Paz de Murcia se publicó de nuevo en solitario pero entre 1869 y 1891, se asoció a varios diarios madrileños.

La posibilidad de ofrecer dos periódicos diferentes en el mismo ejemplar fue un recurso eficaz que Rafael Almazán empleó para atraer lectores, junto con el regalo de revistas, folletines y otros escritos. Otra de las tácticas empleadas por Almazán para ganar adeptos a La Paz de Murcia era ofrecer a los suscriptores otras publicaciones a precios ventajosos:

\author{
IMPORTANTE VENTAJA \\ PARA LOS SUSCRIPTORES DE \\ LA PAZ DE MURCIA
}

\begin{abstract}
Deseando la empresa de este periódico facilitar a sus suscriptores la lectura de un periódico político, ínterin llega el día que LA PAZ pueda tomar este carácter, por el cual se puedan enterar de las sesiones de Cortes y de la opinión que la prensa forme de
\end{abstract}

102 Según Ibáñez, en 1866 Almazán proyectó hacer una edición semanal que se repartiría los lunes (único día que no salía La Paz de Murcia). Véase La Paz de Murcia, X (1867), nº 2772, 16 enero, p. 1. 
las cuestiones que a nosotros no nos es dado tratar, se compromete a servir a domicilio desde mediados del mes actual, SOLO a los suscriptores de LA PAZ y por la módica cantidad de 6 reales mensuales, una suscripción de la edición económica de LA IBERIA, si para el día 13 se han reunido más de 25 suscriptores. Según esto por 14 reales mensuales y sin ningún otro gasto, se pueden tener dos periódicos diarios, uno local y otro de Madrid ${ }^{103}$.

Así pues, un lector de $L a P a z$ en enero 1865 podía adquirir por una módica cantidad extra un periódico nacional como La Iberia.

\subsection{Contenido y secciones}

La Paz de Murcia abordó un sinfín de aspectos de la vida económica, política, social y cultural de la ciudad por lo que es una importantísima fuente de información para analizar la vida murciana de la segunda mitad del siglo XIX.

Desde su inicio, La Paz de Murcia tuvo una clara división en secciones que se distribuían entre las páginas disponibles en cada momento. El cuerpo del periódico iba dividido en columnas. En la primera página (y a veces, también en la siguiente) solían aparecer las noticias y artículos más importantes que dependían de la actualidad, buena parte de los cuales se referían a temas murcianos.

A veces, un solo artículo ocupaba toda o gran parte de la primera página ${ }^{104}$. En 1867, por ejemplo, fue habitual publicar la "Revista teatral" en el tercio inferior de la primera y segunda página. Ocasionalmente, también apareció en la página inicial una sección denominada "Correspondencia particular", en la que se daba cabida a los escritos enviados por corresponsales o suscriptores opinando, informando o denunciando algún hecho.

A partir de la segunda página de La Paz de Murcia solían aparecer las "Noticias Oficiales" (también llamadas "Avisos oficiales" o "Sección Oficial"), que eran anuncios de carácter oficial ${ }^{105}$; la "Gacetilla", compuesta por noticias de extensión variable y temática variopinta, generalmente precedidas de una o varias palabras a modo de titular; la ecléctica sección "Variedades", que incluyó biografías de artistas, críticas teatrales y musicales, poemas, pasatiempos y "charadas", entre otros; las "Noticias mercantiles" (o "Sección mercantil"); las "Noticias religiosas" (o "Sección religiosa"), con los santos del día y los horarios de misas y oficios de los centros religiosos de la ciudad; los "Espectáculos" o cartelera teatral y de toros; "Vapores"; "Ferrocarriles"; "Correos"; y, finalmente, "Anuncios"106.

${ }^{103}$ La Paz de Murcia, VIII (1865), no 2072, 4 enero, p. 1.

${ }^{104}$ Así ocurrió, por ejemplo, con la muerte del pintor murciano Ruipérez: La Paz de Murcia, X (1867), $\mathrm{n}^{\mathrm{o}} 3032,16$ octubre, p. 1; o con la visita de grandes personalidades a la ciudad.

105 En 1858, fueron secciones habituales las "Noticias nacionales" y las "Noticias extranjeras". En 1860, le seguía la "Sección noticias", conformada por informaciones breves de ámbito nacional e internacional.

${ }^{106}$ Los anuncios ocupaban los últimos espacios del periódico, salvo en los últimos años, en los que éstos se repartían por toda la superficie del periódico, incluida la primera página. A partir de abril de 1866, se incorporó una sección final denominada "Sección de avisos y anuncios" que ocupó la tercera y cuarta 
Tuvieron carácter ocasional otras secciones, como el "Parte Telegráfico"107, "Baturrillo" y "Charadas" (breves poemas o letrillas humorísticas, pasatiempos y acertijos).

\subsection{Aspectos históricos e ideológicos}

La Paz de Murcia nació en el reinado de Isabel II (1843-1868), bajo el Gobierno de Armero (1858) y se mantuvo activo en etapas muy diferentes: el Sexenio revolucionario (1868-1874) incluyendo un gobierno provisional, el reinado de Amadeo I, 1870-1873 y la Primera República en 1873-1874, la Restauración borbónica de Alfonso XII (1875-1885) y la Regencia de María Cristina de Habsburgo-Lorena (1885-1902). En este periodo hubo varias guerras, pérdidas de territorios coloniales, un golpe de estado (General Pavía, 1874), dos constituciones (1869 y 1876), continuos cambios de gobierno y alternancia de partidos conservadores y liberales. Estos avatares influyeron inevitablemente en la trayectoria ideológica de La Paz de Murcia que, desde su fundación pasó por cuatro etapas ${ }^{108}$ :

1. Hasta la revolución de septiembre del 68, " $L a P a z$ era un periódico independiente, informativo, de ideología afín a la Unión Liberal" ${ }^{109}$. En septiembre de 1868, después de crearse la Junta Revolucionaria de Murcia, el periódico adoptó como subtítulo “¡Viva la libertad! ¡Viva la moralidad!” y, al mes siguiente, “Su lema: libertad con orden y moralidad".

2. Desde diciembre de 1868, La Paz de Murcia se convirtió en un "Diario monárquico-democrático", acatando la monarquía de Amadeo I ${ }^{110}$.

3. Desde noviembre de 1872, tras la crisis de la Unión Liberal y su posterior desaparición, La Paz de Murcia se reubicó ideológicamente en torno al Partido Constitucional que lideraba Sagasta, como constaba en su subtítulo (Véase Apéndice 1.4).

página del periódico. En ella se incluía la cartelera teatral, las secciones religiosa, climatológica (temperaturas del día anterior) y de "Mercados", además de la sección propiamente dicha de anuncios. En [Anónimo], "Los anuncios", La Paz de Murcia, XI (1868), n $\mathrm{n}^{\circ}$ 3261, 10 junio, p. 1 se describieron las ventajas para particulares y empresarios de anunciar sus productos. En esta sección se anunciaron varios catálogos de música, como el publicado en La Paz de Murcia, III (1860), nº 607, 1 febrero, p. 4, que daba noticia de 36 partituras con sus precios. Podían adquirirse en el almacén propiedad de Isidro Lozano, en la calle de Pontejos, número 8 de Madrid.

${ }^{107}$ En la sección de telegramas se daban "con 24 horas de anticipación las noticias de más interés de cada día”: La Paz de Murcia, XVII (1874), n 4975, 16 enero, p. 1.

${ }^{108}$ Las cuatro primeras etapas son descritas por Arroyo, "La prensa murciana en el Sexenio", pp. 6979. Las restantes son una aportación mía a partir de las propias fuentes periodísticas.

${ }^{109}$ Arroyo, "La prensa murciana en el Sexenio", p. 73. Los subtítulos del periódico hasta septiembre de 1868, sufrieron modificaciones no sustanciales: "diario de noticias y anuncios" primero y "de intereses materiales", después. Sin embargo, entre julio de 1865 y agosto de 1866, el subtítulo anunciaba ya su carácter político: Diario político, de noticias, intereses materiales, ciencias, artes, literatura, modas, noticias y anuncios.

${ }^{110}$ La Paz de Murcia defendió la candidatura de Montpensier y nunca aceptó plenamente al "Rey extranjero", según Arroyo, "La prensa murciana en el Sexenio", p. 73. 
4. Con el establecimiento de la Primera República en febrero de 1873, los responsables de La Paz de Murcia se vieron obligados a aceptarla, "pero sin entusiasmo" $\mathrm{y}$, de forma independiente al partido, se adhirieron a la causa alfonsina ${ }^{111}$. Desde el $28 \mathrm{de}$ octubre de 1873, el periódico se subtituló "Diario monárquico constitucional" y con esta designación se mantuvo al menos hasta 1879. La Figura 1.10 muestra los adornos especiales con los que se revistió el diario para anunciar la llegada de la monarquía de Alfonso XII:

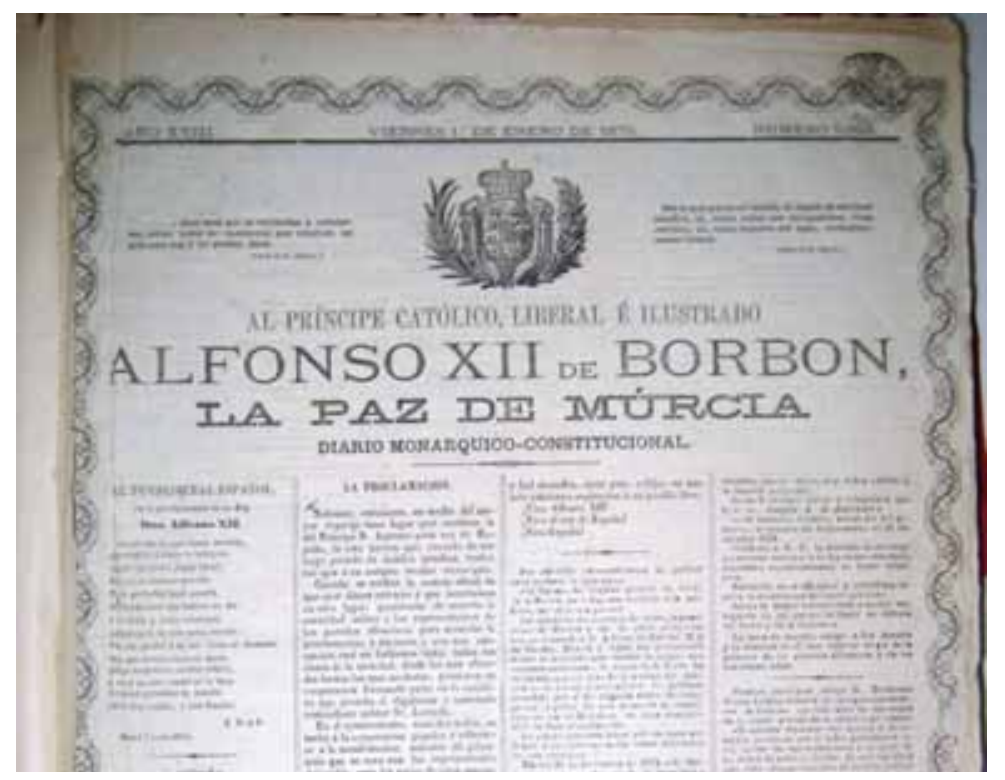

Figura 1.10. Cabecera de La Paz de Murcia, XVIII (1875), $\mathrm{n}^{\circ}$ 5253, 1 enero, p. 1 dedicada a Alfonso XII de Borbón, E:MUm.

5. Entre enero y agosto de 1881, La Paz de Murcia fue un "diario político", que contaba con el favor "de los comités del partido liberal-dinástico""112.

LA PAZ es el único diario de esta capital autorizado para dar las noticias de carácter político y tratar las cuestiones de esa índole, para lo cual tiene llenados todos los requisitos legales y satisface la cuota de contribución correspondiente. Repetimos esto y lo repetiremos más porque nos interesa se penetren bien de ello todos los que nos lean, pues es indudable que el carácter político es una circunstancia que da alguna más importancia a las publicaciones periódicas de la que se guían muchos anunciantes $\mathrm{y}$, el obtenerla, cuesta sacrificios que los demás no hacen ${ }^{113}$.

6. Desde agosto de 1881 el subtítulo de la publicación se limita a decir que era un "Diario de noticias y anuncios" y, desde marzo de 1883, "Diario de noticias, avisos y anuncios". En 1885 admitían: "Somos izquierdistas tan decididos como cristianos fervorosos" $" 114$.

\footnotetext{
${ }^{111}$ Arroyo, "La prensa murciana en el Sexenio", p. 74.

${ }^{112}$ La Paz de Murcia, XXIV (1881), nº 6940, 1 enero, p. 1.

${ }^{113}$ La Paz de Murcia, XXIV (1881), no 6943, 5 enero, p. 1.

${ }^{114}$ La Paz de Murcia, XXVIII (1885), nº 8233, 29 mayo, p. 1.
} 
7. Desde el 1 de enero de 1891 hasta el 31 de marzo de 1895 (último ejemplar conservado), el periódico se autocalificaba como "Diario liberal". Sus metas e ideología en ese momento se resumen en el siguiente párrafo, publicado a comienzos de 1891 en el que se subraya la defensa de la monarquía liberal católica y los intereses de Murcia:

$\mathrm{Su}$ historia ahorra hacer un programa extenso de los fines que se propone que son: en primer lugar, los intereses morales y materiales de Murcia y su provincia, bajo el lema de "Todo por Murcia y para Murcia"; en política, dentro de la monarquía reinante, liberal avanzado, cuya bandera es [sic] los ideales democráticos aceptados por el partido y liberal; en religión, católico apostólico romano $[\ldots]^{115}$.

La evolución ideológica de La Paz de Murcia ha sido considerada por García Ibáñez como "oportunista"116. Esta opinión, sin embargo, ha sido discutida por Arroyo, para quien "no se puede tildar a $L a P a z$ de oportunismo, pues siempre fue fiel a sus ideas. Simplemente se acomodaba a la realidad del momento"117. A lo largo de su trayectoria, el periódico sufrió algunas denuncias y censuras por motivos políticos y militares que provocaron su cierre en momentos puntuales ${ }^{118}$.

\section{La prensa especializada en música}

Entre el conjunto de las numerosas publicaciones periódicas murcianas del siglo XIX que he consultado durante mis años de investigación, no he hallado ninguna conservada que estuviera especializada en música aunque sí he podido constatar que existieron varios periódicos musicales hoy en día no localizados.

García Seco mencionó El Iris, una publicación periódica musical de ocho páginas, impresa en litografía en la Casa Carlos Palacios, de la que no especificó año de edición y que fue dirigida por el organista invidente murciano Juan Diego Manresa y por Narciso Ibáñez ${ }^{119}$.

En marzo de 1851, el Diario de Murcia de 1851 anunció el periódico musical La Lira del Segura, dirigido por el citado organista Manresa. El artículo ensalzaba la influencia de la música sobre los pueblos y la necesidad de emprender esta publicación ante la creciente demanda musical en Murcia:

\footnotetext{
${ }^{115}$ La Paz de Murcia, XXXIV (1891), nº 11220, 1 enero, p. 3.
}

${ }^{116}$ Ibáñez, Serie, p. 80. El autor sugiere que durante los diez primeros años el periódico fue "incoloro". Sin embargo, el número insuficiente de suscriptores y, en general, la falta de apoyo económico hizo sacrificar su "independencia" y ceder "ante el apremio de las circunstancias".

${ }^{117}$ Arroyo, "La prensa murciana en el Sexenio", p. 72. Una opinión similar tiene Crespo, quien afirma que la postura ideológica de La Paz de Murcia fue "cambiante" y acorde con los acontecimientos históricos: Crespo, Historia de la prensa, p. 115.

${ }^{118}$ Según relata Crespo, Historia de la prensa, p. 115 el cierre más importante de La Paz de Murcia tuvo lugar por orden gubernativa de 3 marzo de 1874 y por tres meses, aunque finalmente quedó reducida a dos semanas. Véanse más detalles en: Pérez Crespo, "La censura", pp. 417-434.

${ }^{119}$ Según García Seco, "Prensa musical”, p. 164, “entre las partituras insertas figura el aria de Alcira para piano". No he encontrado ningún dato sobre esta publicación en los archivos y hemerotecas visitadas. 
La Música embellece nuestra existencia en la prosperidad; en el infortunio, mitiga o disipa los pesares, abriendo a nuestros ojos un provenir menos sobrio. La Música es por consiguiente una necesidad social.

Hoy que la afición a este arte encantador ha adquirido en nuestra población notable desarrollo, sentimos más que nunca la falta de un periódico que recoja sus progresos $[\ldots]^{120}$.

Según el mismo anuncio, La Lira del Segura se repartiría los días 1 y 16 de cada mes a partir del 1 de abril de 1851, "constando cada entrega de cuatro páginas en folio" "21. La publicación costaba cuatro reales al mes y se imprimiría en la Imprenta y Litografía de Carlos Palacios. Los interesados podían suscribirse en la casa del músico invidente Juan Diego Manresa (calle de la Quintería, número 4). Desconozco si realmente este periódico llegó a aparecer, ya que ninguno de los estudios que he consultado lo mencionan.

En 1859, el músico murciano Julián Calvo inició la publicación de $E l$ Filarmónico, un periódico subtitulado Álbum Musical del que se llegaron a publicar siete números con carácter trimestral ${ }^{122}$. Repartió pequeñas piezas para piano (como polcas, valses, rigodones, romanzas y piezas a cuatro manos) y otras para canto y piano con letras de poetas contemporáneos, musicalizadas por Calvo ${ }^{123}$.

Otra de las publicaciones especializadas en música fue La Lira Murciana, dirigida por el músico Adolfo Gascón Leante. Según García Seco se imprimía en la Litografía Millán, se repartía en cuadernillos por entregas y de ella aparecieron doce números de los que no menciona fechas de edición ${ }^{124}$.

García Seco mencionó también otra publicación musical que apareció al final de la década de los ochenta, aunque no aportó su título. Fue dirigida por el maestro de capilla Mariano García López y se repartía en cuadernillos tamaño folio ${ }^{125}$. Según el historiador, repartió composiciones originales de diversos músicos ligados a la Catedral de Murcia, como los organistas Julián Calvo y Agustín Jiménez y los maestros de capilla Francisco Miras, Fernando Verdú y Mariano García ${ }^{126}$.

${ }^{120}$ Diario de Murcia, I (1851), nº 65, 16 marzo, pp. 2-3 (ver Documentario).

${ }^{121}$ Diario de Murcia, I (1851), nº 65, 16 marzo, pp. 2- 3.

${ }^{122}$ Según García Seco, "Prensa musical”, p. 164. Según Ibáñez, Serie, p. 86 fue mensual.

${ }^{123}$ Entre los autores de los poemas estuvieron Francisco Villegas, Ramón Guerrero, Juan Cayuela y José Castell, según Ibáñez, Serie, p. 86. García Seco, "Prensa musical”, p. 164 publicó una fotografía de la portada del periódico en la que se aprecia que fue impreso en la Litografía de A[ntonio] Soler (calle Trapería, 26). En cambio en García Soriano, Anales, p. 112 consta que El Filarmónico fue impreso en el establecimiento tipográfico de Leandro y Vicente Riera (calle Lencería, 20).

${ }^{124}$ García Seco, "Prensa musical”, p. 164.

${ }^{125}$ García Seco, "Prensa musical”, p. 164.

${ }^{126}$ Según García Seco, "Prensa musical”, p. 164 de Fernando Verdú apareció un Miserere que fue estrenado en 1883 (sobre esta composición trataré en el Capítulo 9); del maestro de capilla Francisco Miras Muñoz se publicó un Tota Pulchra a cinco voces compuesto en 1773; y, finalmente, de Mariano García el autor menciona que aparecieron varias obras, aunque no especifica sus títulos. 


\section{La música en las publicaciones periódicas murcianas del siglo XIX}

En mi estudio sobre la música en los periódicos de murcianos de la primera mitad del siglo XIX pude constatar que el 30\% de los 1004 ejemplares que consulté para realizar aquella investigación contenían noticias de interés musical, a pesar de que no eran periódicos especializados en música. La siguiente Tabla 1.7 muestra la evolución porcentual de las noticias de interés musical en periódicos de Murcia entre 1800 y1851:

Tabla 1.7. Evolución porcentual de las noticias de interés musical en periódicos de Murcia (1800-1851)

Elaboración propia

\begin{tabular}{|c|c|c|c|}
\hline Década & $\begin{array}{c}\mathbf{N}^{\mathbf{0}} \text { periódicos } \\
\text { consultados }\end{array}$ & $\begin{array}{c}\mathbf{N}^{\mathbf{0}} \text { periódicos } \\
\text { con noticias de } \\
\text { de interés } \\
\text { musical }\end{array}$ & $\%$ \\
\hline $1800-1809$ & 7 & 0 & 0 \\
\hline $1810-1819$ & 85 & 26 & 30.5 \\
\hline $1820-1829$ & 555 & 97 & 17.5 \\
\hline $1830-1839$ & 36 & 16 & 44.5 \\
\hline $1840-1849$ & 93 & 44 & 47.5 \\
\hline $1850-1851$ & 228 & 154 & 67.5 \\
\hline Totales & 1004 & 337 & 33.5 \\
\hline
\end{tabular}

Al trasladar los datos de las dos primeras columnas de la Tabla 1.7 a un gráfico, el resultado es el siguiente:

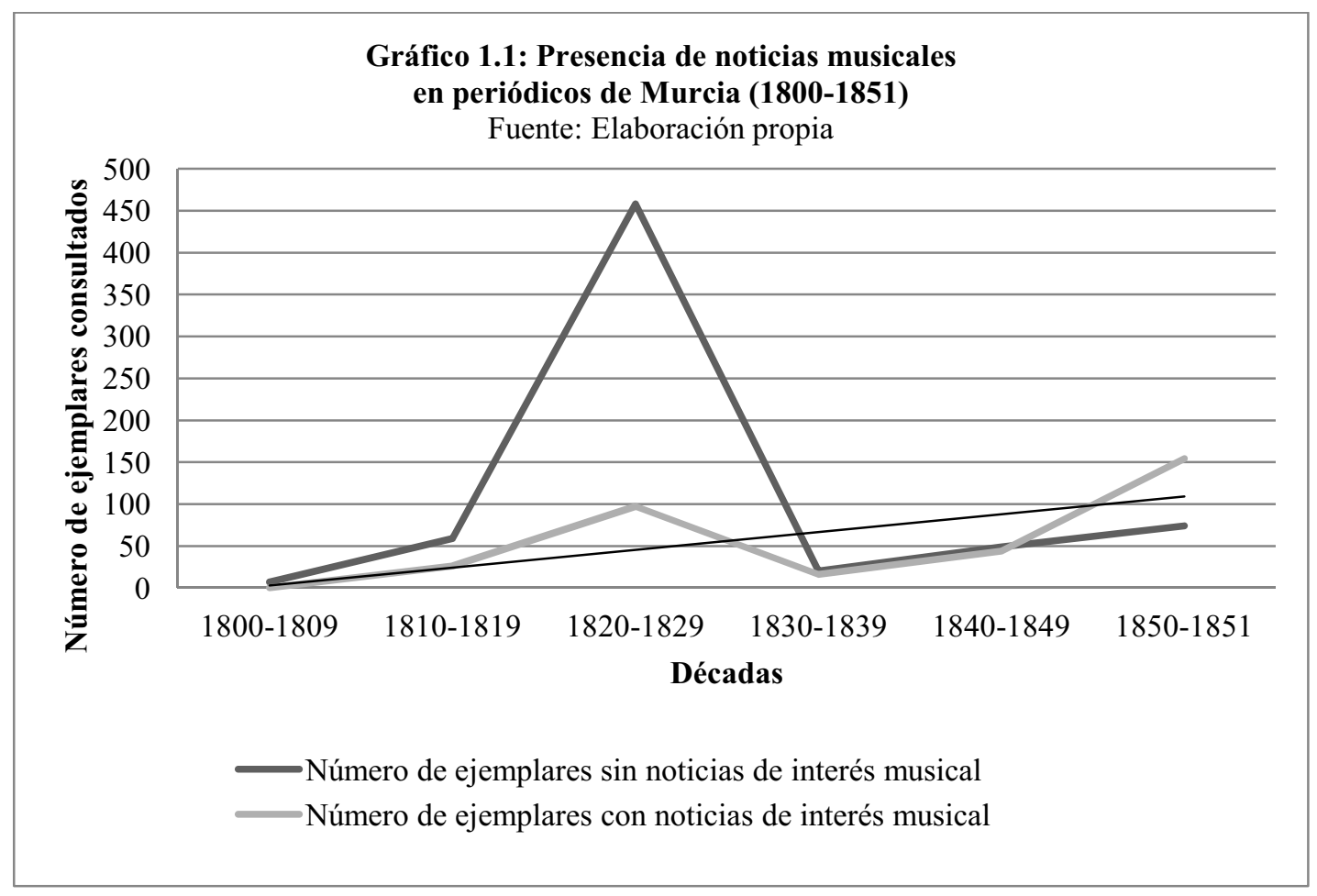


El Gráfico 1.1 muestra una curva máxima de ejemplares conservados en los años 1820-1829, dado que el número de periódicos que se conserva es mucho mayor que en otras décadas. Sin embargo, el volumen de prensa a partir de los años cuarenta, aunque es menor, contiene más noticias de interés musical. Este incremento se aprecia mejor en el Gráfico 1.2, que muestra la evolución porcentual de las noticias con interés musical:

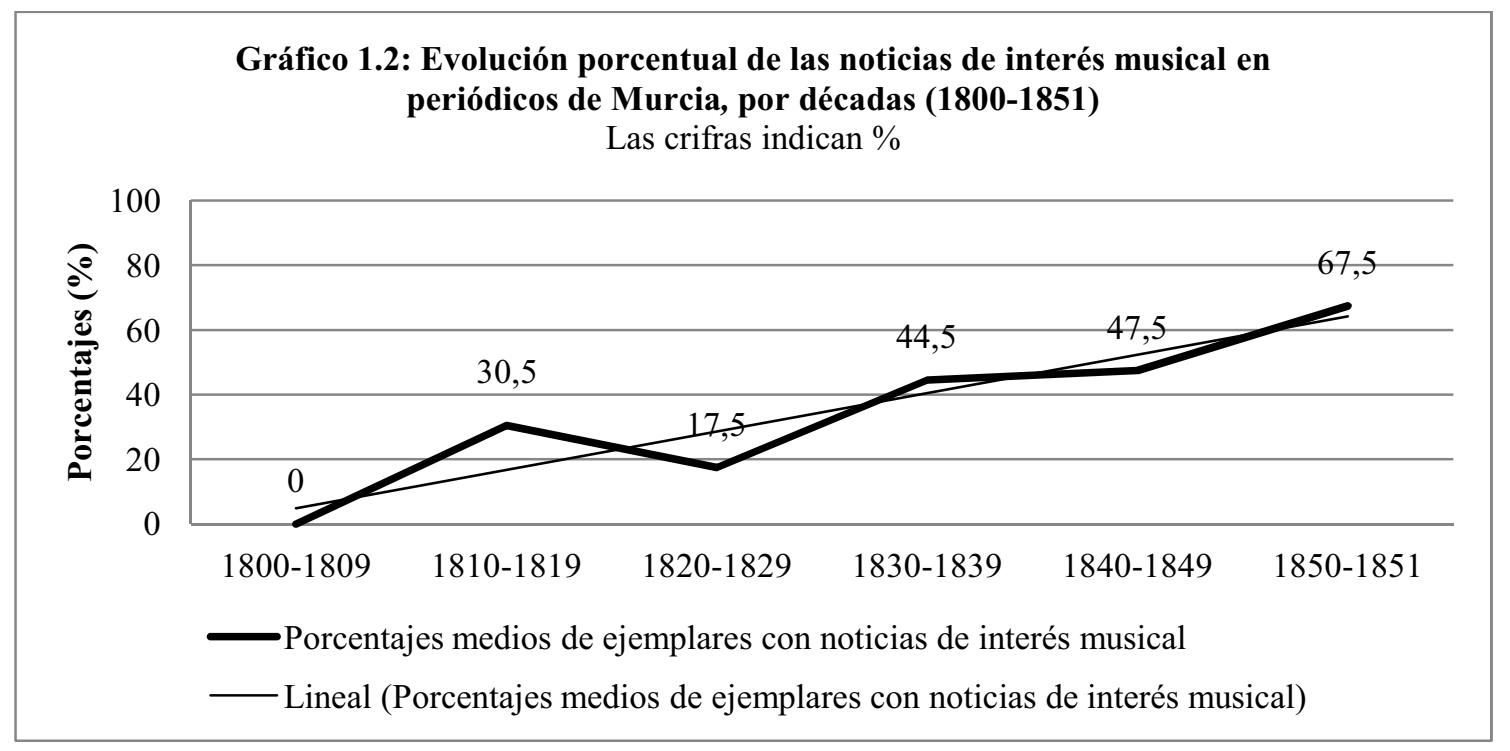

Los dos gráficos anteriores muestran que, hasta mediados del siglo XIX las noticias de interés musical insertas en los diarios de información general experimentaron un claro incremento.

En el Diario de Murcia de 1851 las noticias de temática musical y los referidos al teatro se igualaron en número, lo que se relaciona con la finalidad del periódico: informar "de todo, menos de política y religión", como anunciaba su subtítulo ${ }^{127}$. El Diario de Murcia fue el primer y significativo exponente en Murcia de una prensa interesada en informar sobre música como fenómeno en sí mismo, alejada de asuntos militares y políticos como en épocas anteriores, con el objetivo claro de su divulgación y dedicando para ello secciones concretas. Prueba de ello es la única partitura que he hallado en la prensa murciana del siglo XIX: una Romanza sobre un poema en italiano (Nel la vita io son peregrino) que analizaré más adelante.

En el Diario de Murcia he recopilado más de doscientas cuarenta noticias de interés musical agrupadas en tres temas fundamentales, correspondientes a secciones fijas

${ }^{127}$ Diario de Murcia. Periódico de todo, menos de política y religión. Otros hechos le hacen destacar con respecto a sus precedentes más inmediatos, igualmente dedicados a informar sobre cuestiones no políticas, La Lira del Táder (1845) y La Palma (1849). El primero es la propia vida del periódico: frente a los diez meses del Diario de Murcia (desde enero de 1851 hasta octubre del mismo) se registran sólo cinco meses de La Lira del Táder (de abril a agosto de 1845) y cuatro de La Palma (desde mayo hasta agosto de 1849). El segundo es el hecho de que el Diario de Murcia no tuvo que competir con otros periódicos puesto que La Vega no se publicó hasta 1853. 
del periódico: música religiosa, noticias sobre teatro y artículos de divulgación e historia de la música ${ }^{128}$.

Entre el Diario de Murcia de 1851 y La Paz de Murcia (a partir de 1858) se publicaron varios periódicos, aunque en la actualidad únicamente se conservan treinta y siete ejemplares de La Vega (1853), El Industrial de Murcia (1854) y El Liberal Murciano (1855) y en ninguno de ellos he localizado datos de interés musical.

Durante los años de publicación de La Paz de Murcia con ejemplares conservados (1858-1895), el porcentaje medio de ejemplares con noticias de interés musical asciende al 71\%, una cifra ligeramente superior a la media del Diario de Murcia de 1851 (67.5\%). La evolución porcentual por décadas se muestra en la Tabla 1.8 y en el Gráfico 1.3:

Tabla 1.8. Porcentajes de ejemplares con noticias de interés musical de La Paz de Murcia (1858-1895)

Fuente: Elaboración propia

\begin{tabular}{|r|c|c|c|}
\hline Años & $\begin{array}{c}\mathbf{N}^{\mathbf{0}} \\
\text { periódicos } \\
\text { consultados }\end{array}$ & $\begin{array}{c}\mathbf{N}^{\mathbf{0}} \text { periódicos con } \\
\text { noticias de de } \\
\text { interés musical }\end{array}$ & $\mathbf{\%}$ \\
\hline $1858-1859$ & 565 & 199 & 35 \\
\hline $1860-1869$ & 1710 & 1168 & 68 \\
\hline $1870-1879$ & 2982 & 2083 & 69 \\
\hline $1880-1889$ & 2729 & 2167 & 79 \\
\hline $1890-1895$ & 1284 & 980 & 76 \\
\hline Totales & 9270 & 6597 & 71 \\
\hline
\end{tabular}

${ }^{128}$ Tales como tales como "Rara enfermedad febril curada por la música", Diario de Murcia (1851), $\mathrm{n}^{\circ}$ 51, 28 febrero, pp. 1-3; “Observaciones fisiológicas sobre los órganos de la voz y de la entonación”: Diario de Murcia (1851), no 100, 27 abril, p. 1; "Sobre la sensibilidad": Diario de Murcia (1851), n 104, 2 mayo, p. 1(todos ellos sin que se especifiquen autores) y una interesante serie de siete artículos de "Historia general de la Música desde los tiempos más recientes hasta el presente", en la que su redactor, que firmó con las iniciales M. R., interpola comentarios y citas en castellano de la famosa historia de la música de Charles Burney: Diario de Murcia (1851), $\mathrm{n}^{\text {os }} 85-88,93-94,96-98$, todos correspondientes a abril y en pp. 1-2. 


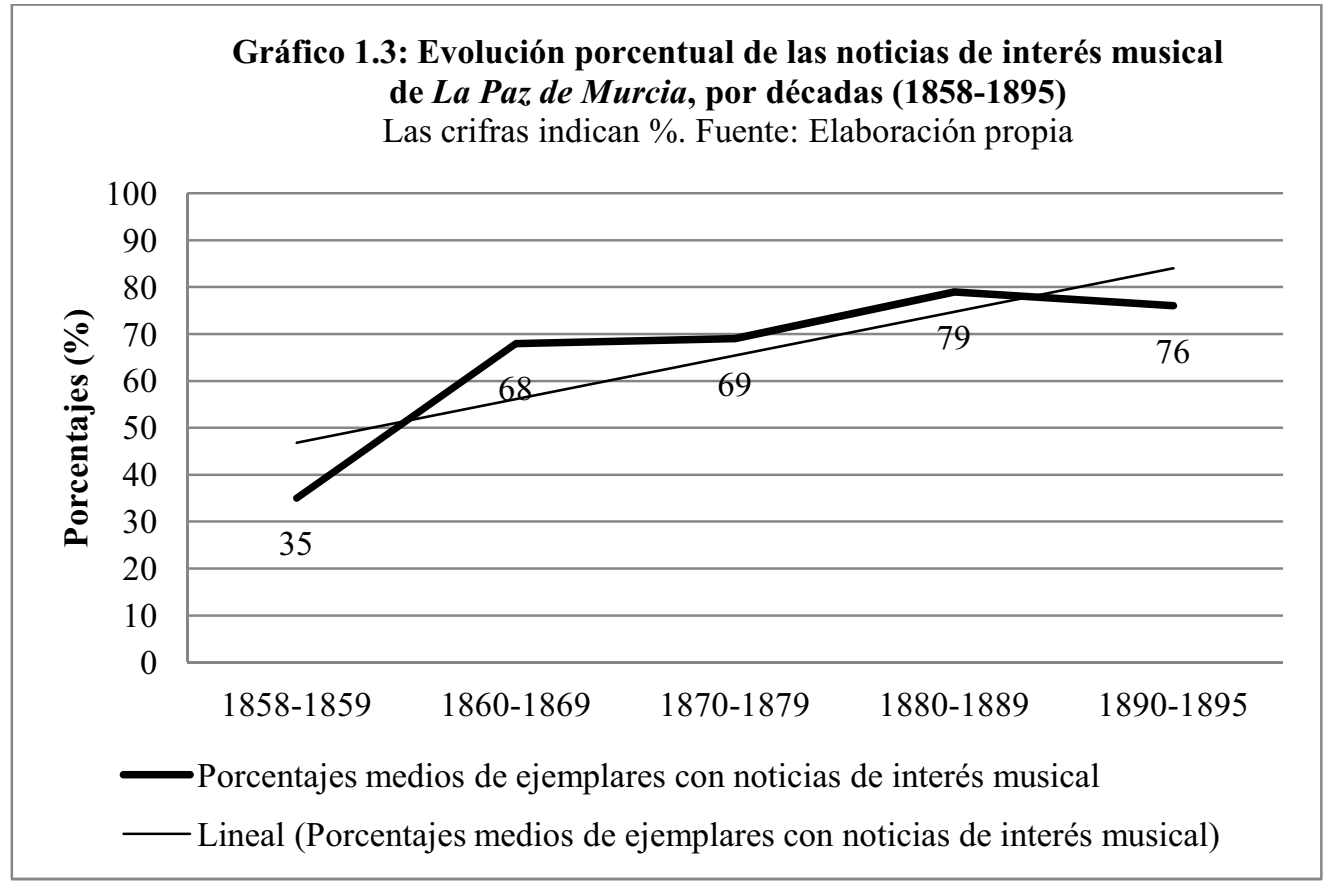

La Paz de Murcia publicó una media de trescientos tres ejemplares por año. Si relacionamos los ejemplares consultados con las noticias de interés musical en ellos se obtiene también un aumento progresivo del número de periódicos que incluyeron noticias sobre música, como muestran los Gráficos 1.4 y 1.5:

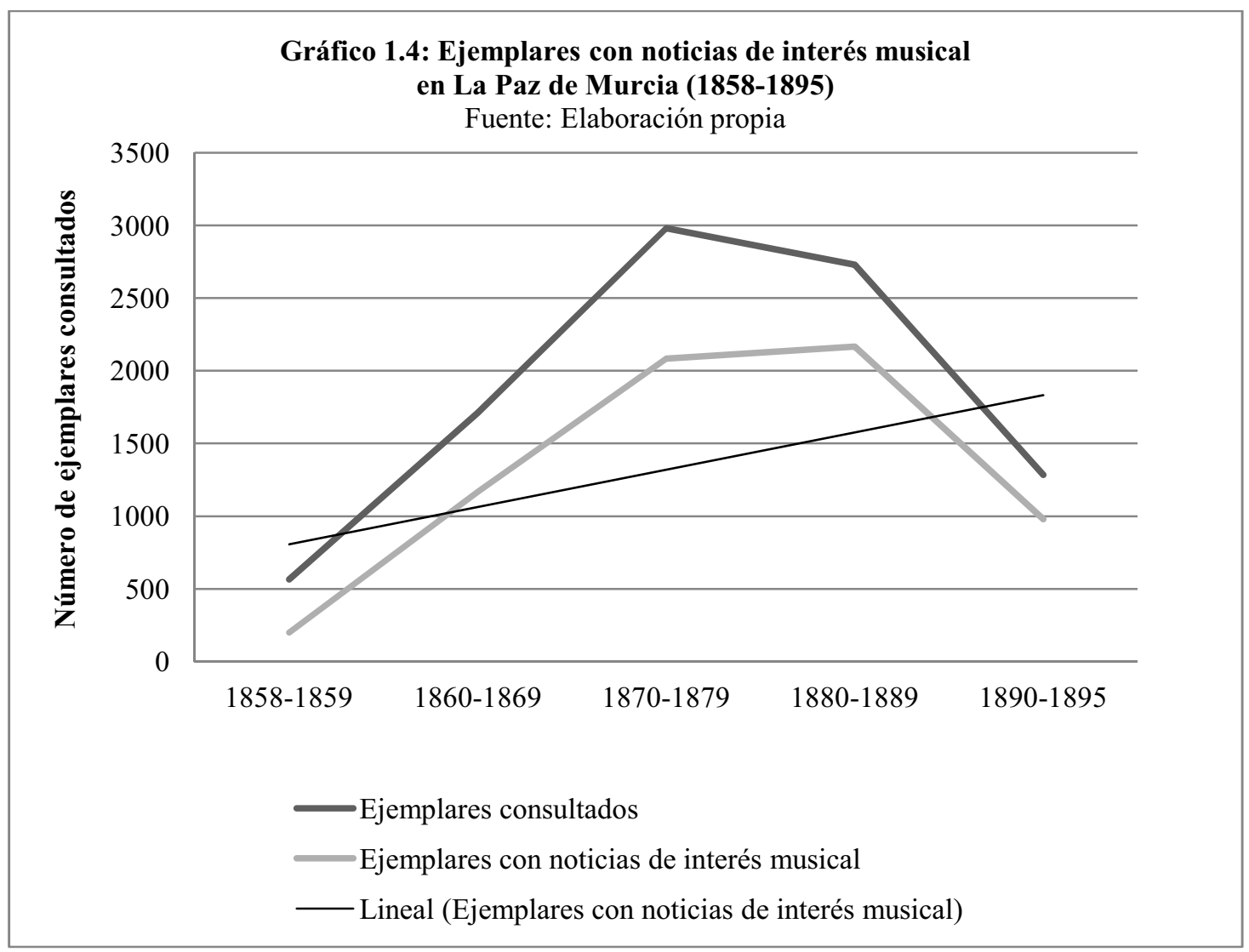




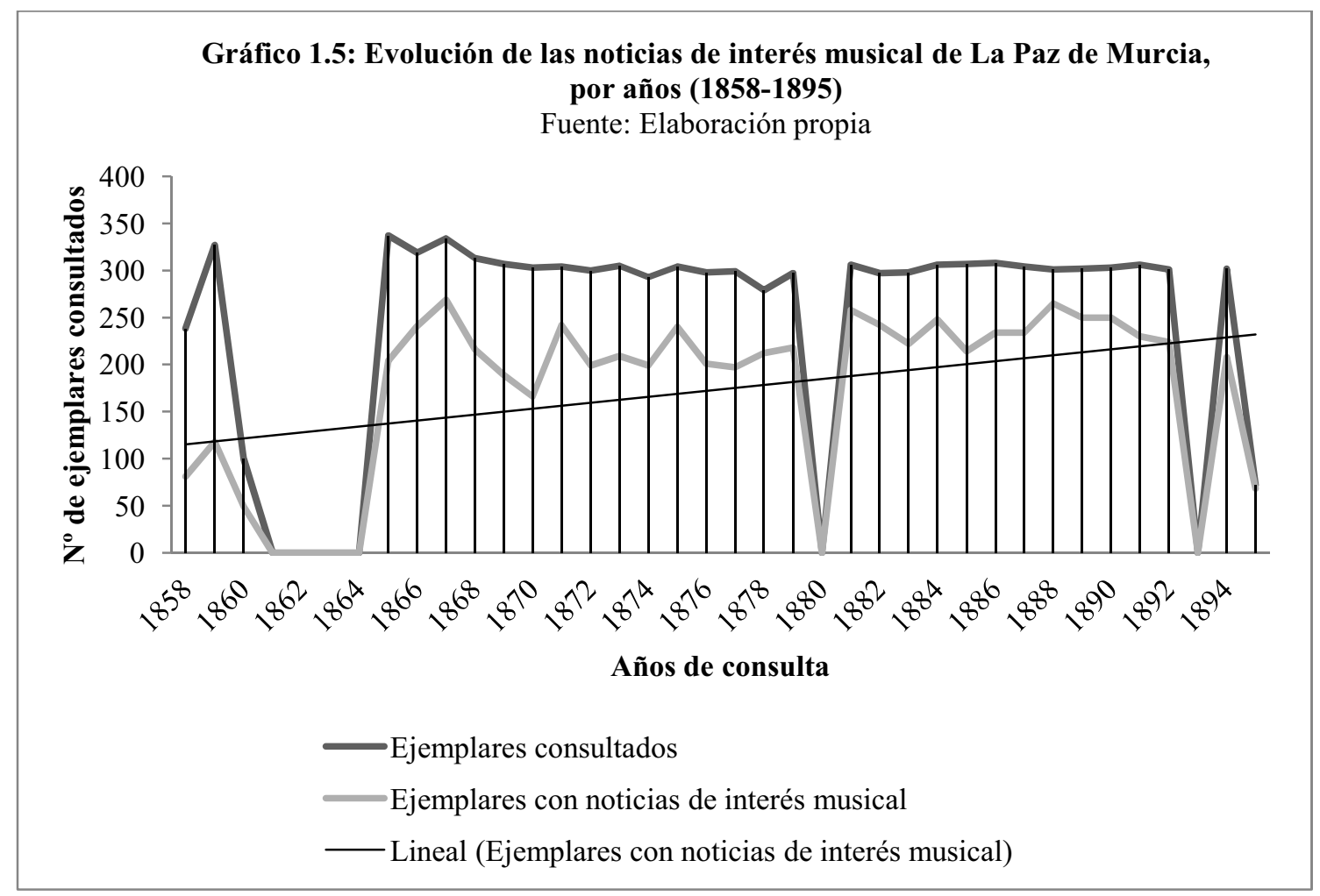

Los descensos de 1860, 1861 a 1864, 1880, 1893 y 1895 se deben a la falta total o parcial de ejemplares del periódico en esas fechas.

Entre marzo de 1858 y diciembre de 1859, el periódico todavía no se ocupaba de forma regular de la actividad musical. Entre 1865 y 1868 las noticias de interés musical se elevan con respecto a los dos primeros años de la publicación. El número de noticias por ejemplar se sitúa en torno a las dos o tres noticias y se mantiene estable hasta 1895. Varios hechos se relacionan con el aumento indicado: el Teatro de los Infantes, inaugurado en 1862, generaba muchas noticias relacionadas con la actividad teatral. Además, La Paz de Murcia también dio cabida a una ingente cantidad de información sobre diversas sociedades recreativas, como la Sociedad Filarmónica (1867) y el Liceo Lírico-Dramático (1867). También en 1867 se construye el Teatro del Círculo Industrial, una sociedad que, por estos años, estaba a pleno rendimiento. Ese coliseo fue, junto al Teatro de los Infantes, uno de los teatros murcianos que más música programó durante la segunda mitad del siglo XIX. Todo eso explica que en el año 1867 se alcanzara el punto más elevado de ejemplares con noticias de interés musical de todo el periodo de años de publicación de La Paz de Murcia. 



\section{LOS TEATROS Y SU MÚSICA}




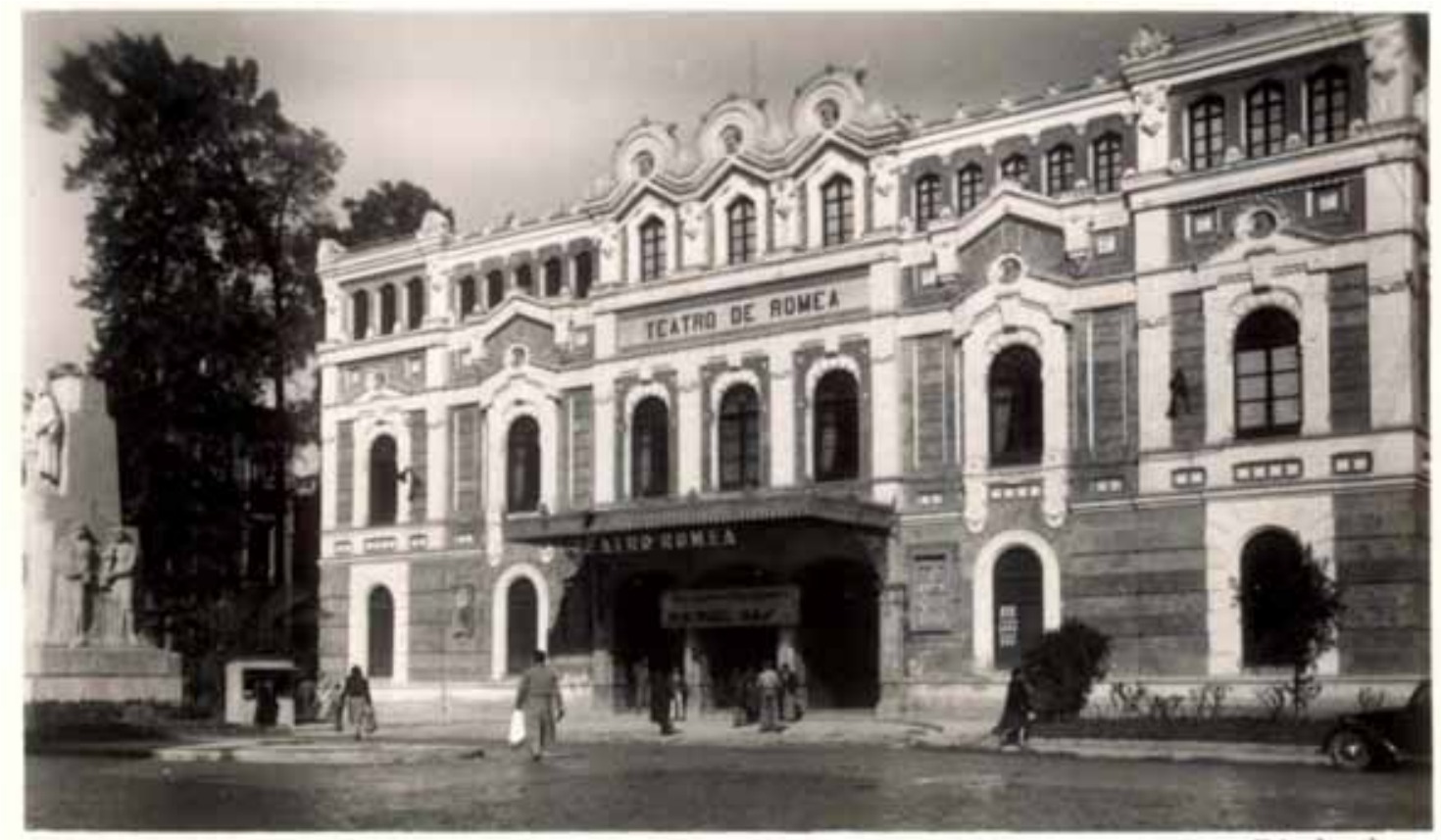

37- Murcia

Teatro Romea

Ed. Arribas

II. Teatro Romea de Murcia. Zaragoza: Ed. Arribas, ca. 194?. E:MUbr. Accesible en: http://bibliotecadigital.carm.es (acceso el 27-09-2011). 


\section{Capítulo 2. Teatros y locales teatrales de la ciudad de Murcia durante la segunda mitad del siglo XIX}

\section{Del Teatro del Toro al Teatro Romea (1858-1895)}

\subsection{El derribo del Teatro del Toro y la construcción del Teatro de los Infantes (1857-1862)}

Durante el siglo XIX la ciudad de Murcia contaba con varios locales en los que se celebraban representaciones teatrales, aunque no estuvieron especializados en un determinado género, como en cambio ocurría en otras provincias españolas ${ }^{1}$. El Apéndice 2.1 muestra los teatros y salones teatrales activos (públicos y privados) de Murcia durante la segunda mitad del siglo XIX y el Apéndice 2.2 la relación de compañías y espectáculos teatrales de teatros no dependientes de sociedades ni de particulares, tratados estos últimos en sus capítulos correspondientes.

El teatro principal de Murcia fue la Casa-Teatro o Corral de las Comedias, también denominado Teatro del Toro y estuvo situado en la antigua puerta del mismo nombre, junto a la muralla de la ciudad ${ }^{2}$. Empezó a construirse en 1610 y sufrió numerosas remodelaciones y reconstrucciones en los años posteriores. Un redactor de $L a$ Paz de Murcia, bajo el pseudónimo de "Un caballero particular", lo recordaba así en 1868:

[...] Aquel postigo que daba entrada angosta y difícil a una sola persona y por el que penetrábamos codeando en las noches de Pascua [...] aquella tertulia, centro de reunión de la gente alegre y divertida, en donde cubierta la cabeza con la popular montera y embozados hasta los ojos escuchábamos la función a toda comodidad y holgura; aquellas lunetas separadas por barras de hierro y forradas de bayeta, cuyos duros e incómodos asientos nos tenían en continuo movimiento y mortificante tortura; aquella galería con sus sillones de madera en donde teníamos que penetrar con el cuerpo encorvado para librar nuestros sombreros o nuestras cabezas de algún golpe y en la cual constantemente encontrábamos alguna de nuestras dignidades de la iglesia; aquella platea con sus pantallas verdes siempre abonada por los magníficos, de donde salía la iniciativa para crear partidos a las actrices, para alimentar las rivalidades de los músicos o para organizar funciones de ópera y verso ejecutadas por aficionados; aquel alumbrado siempre amenazando con su sucio líquido las ropas de los que a él se aproximaban y, con su apestoso olor, los órganos respiratorios de los concurrentes; aquellos eternos, constantes, aunque escasos abonados, que muchas noches se encontraban solos y como en familia; aquellas expansiones patrióticas que allí tuvieron lugar y que algunas de ellas fue sofocada por la energía de una autoridad

1 Por ejemplo, el Teatro Principal de Valencia, inaugurado en 1832, se construyó como local específico para representar ópera italiana $\mathrm{y}$, de hecho, fue un importante foco de difusión del género operístico. Véase, Galbis, "Ópera", p. 176. Sobre la actividad teatral de Murcia durante la primera mitad del siglo XIX, véase Clares, "La música teatral”, pp. 451-478.

${ }^{2}$ El Teatro del Toro (o Teatro de la Puerta del Toro) se construyó cerca de la Plaza de Ceballos (ver Apéndice 1.2). Su puerta principal y dos laterales daban a las calles de San Juan de Dios (antes Santa María de Gracia) y Barandillo (antes Val-Hondillo). El teatro tenía planta trapezoidal y estaba adosado a la antigua muralla de la ciudad por su lado orientado al sur: Nicolás, Arquitectura, p. 239. Fuentes, Murcia, p. 419, sugirió que la puerta de la antigua muralla árabe fue derribada para la construcción del teatro. Véase también: Barceló, Historia, pp. 13 y 39. 
contra los espíritus inquietos y cabezas calientes de entonces y que hoy son hombres de orden porque son viejos; aquel escenario, aquel taquillero, aquellas decoraciones, aquellos trajes y aquellos muebles, vivieron, viven y vivirán en la memoria de la generación que se fue, en la que se va y en la que viene $[\ldots]^{3}$.

Durante la primera mitad del siglo XIX, las autoridades municipales se vieron obligadas a realizar continuas reformas en este teatro, ante la imposibilidad económica de financiar la construcción de otro. Las actas municipales de esos años conservan reiterados testimonios sobre el peligro de incendio y derrumbamiento $\mathrm{y}$, en general, sobre su inutilidad para albergar representaciones, consecuencia de su lamentable estado ${ }^{4}$.

Según Barceló Jiménez, a partir del mes de diciembre de 1842 la Corporación Municipal "de forma real y urgente" comenzó a plantearse edificar un teatro nuevo ${ }^{5}$. Sin embargo, la prensa venía denunciando (y concienciando) desde años antes el estado deplorable del teatro y proponiendo alternativas como la de aprovechar terrenos que habían pertenecido a religiosos y que la desamortización había dejado sin uso. Un claro ejemplo es el artículo publicado por El Indicador Murciano, en 1837 en el que se proponen diversas mejoras urbanísticas, entre ellas la construcción de un nuevo teatro:

La construcción de un teatro, aunque se considere a primera vista como un objeto secundario y de mera diversión en la opinión de aquellos que no miran las cosas sino bajo un aspecto físico y material es, en nuestro juicio, otra de las mejoras

\footnotetext{
${ }^{3}$ La Paz de Murcia, XI (1868), n 3203, 12 abril, p. 1. Otra descripción de esta Casa de Comedias fue publicada como apéndice documental por Pina, "La música civil", pp.1592-1593 así como en su Tesis Doctoral, La música civil, pp. 446-447. El Diario de Murcia, II (1880), nº 305, 13 febrero, pp. 1-2 publicó un interesante artículo titulado "Nuestro antiguo teatro" en el que se transcribe un inventario con los enseres de este teatro en 1779 y el elenco de una compañía de ópera y baile que actuó en él durante el mencionado año, entre otros interesantes datos.

${ }^{4}$ En octubre de 1803, por ejemplo, el Ayuntamiento denegó temporalmente el permiso para hacer representaciones teatrales: Barceló, Historia, p. 46. Véase también, E:MUm, Leg. 3451, "Informe facultativo del Coliseo" (1836), así como E:MUm, Leg. 4159, Expediente 7.

${ }^{5}$ Barceló, "El Teatro Romea”, pp. 5-58: 21-24. Según el autor, las gestiones para construir un nuevo teatro en el solar del Convento de Santo Domingo de Padres Dominicos se iniciaron en 1842 y se prolongaron hasta 1849. Como ocurrió con otras ciudades españolas la desamortización de Mendizábal, iniciada en 1836, dejó a las autoridades municipales solares de antiguos conventos y monasterios suprimidos, donde posteriormente se edificaron teatros. El E:MUm, Leg. 4166 contiene el "Expediente sobre construcción de uno en el edificio Convento de Santo Domingo", firmado por Salvador Marín Baldo en mayo 1846. En él se describe el estado de "deterioro y ruina" del "antiguo y defectuoso" Teatro del Toro, la imposibilidad de seguir reparándolo y la necesidad de "construcción de otro cuya planta, situación y demás circunstancias se hallen en armonía con las necesidades públicas, con la comodidad de los concurrentes, con las buenas reglas del arte y por último, con cuanto a las disposiciones exigen las ordenanzas de Policía y Orden Público para esta clase de establecimiento". Los argumentos de Marín Baldo fueron, entre otros: 1) el viejo teatro, con su forma "irregular, incomoda y desagradable" y su ubicación "en una reducida manzana de edificios particulares, sumamente aislados y pequeños" impedía construir sobre él el nuevo teatro con las dependencias de oficinas y servidumbre que éste necesitaba; 2) la entrada principal del viejo teatro daba a un callejón "estrecho, único y miserable" que no permitía el trasiego de público y carruajes; 3) el grave peligro del vecindario por "lo carcomido de sus maderas, desplomadas sus paredes, abiertos sus ángulos, sin estribos de resistencia, sin arcos ni puntos que sostengan, enlacen y entretengan la cohesión de su fábrica hace temer con fundamento una catástrofe". La ubicación propuesta (el céntrico ex convento de Dominicos) haría desaparecer "el triste e insalubre aspecto que presenta su asqueroso claustro habitado por gente miserable y poco aseada y sentina de vicios y corrupción en el paraje más cómodo, más céntrico y más pintoresco": $E: M U m$, Leg. 4166.
} 
necesarias, y sobre las que ha debido fijarse la consideración de las autoridades locales en obsequio de la civilización y el concepto del país. La cultura de un pueblo, decíamos en nuestros primeros números, se aprecia y aún puede medirse con exactitud por la compostura y decoro con que se le ve conducirse en los espectáculos y muy especialmente en el teatro, y éste [es] un principio tan posible y de una exactitud tan precisa que, cuando un forastero reflexivo e ilustrado asiste por primera vez a una función teatral, sin más que la observación ociosa e imparcial de los espectadores, se cree ya con un derecho razonable para deducir consecuencias respecto a su mayor o menor ilustración. [...] Multitud de conventos, algunos de ellos situados ventajosamente y cuya construcción les hace a propósito para cualquiera de los objetos indicados, están clamando porque se les destine y no se abandonen con una reprensible indiferencia a que la injuria del tiempo y mil otras causas, tal vez más desorganizadoras, reduzcan a una multitud despreciable de escombros sus majestuosas y costosísimas fábricas. Utilícense pues, en beneficio de la población [...]

No nos ponga en el caso de contribuir por nuestra parte con una nueva prueba para calificar de destructor el siglo que, por tantas otras razones, tiene ya respecto a nuestra desventurada patria un título tan fatal, cuanto justamente adquirido ${ }^{6}$.

A pesar de las malas condiciones en que se encontraba el Teatro del Toro, las representaciones se sucedieron en él con encomiable regularidad, de tal forma que con los ingresos obtenidos se sufragaron los gastos ocasionados por las reparaciones ${ }^{7}$.

El problema no se resolvió hasta que el Ayuntamiento derribó el viejo teatro en 1857 y construyó el nuevo Teatro de los Infantes sobre el céntrico solar del convento de Santo Domingo ${ }^{8}$. La nueva ubicación era una zona de huertos y jardines al norte de la

${ }^{6}$ El Indicador Murciano (1837), $\mathrm{n}^{\circ}$ 6, 21 enero, pp. 2-3. En 1851 se insertaron en las páginas de El Diario de Murcia, I (1851), $\mathrm{n}^{\circ}$ 31, 5 febrero, p. 1, nuevas peticiones en este sentido: "El gobierno de Su Majestad concedió al ilustre Ayuntamiento de esta ciudad el local que fue convento de Santo Domingo para la construcción de un teatro, y aún no hemos tenido el gusto de ver empezar los trabajos [...]. Concluimos rogando al señor Gobernador y demás autoridades que contribuyan con sus esfuerzos, a fin de que en breve veamos levantarse el templo de Talía y Melpómene”. En 1842, José Ramón Berenguer presentó a la Sociedad Económica de Amigos del País de Murcia un "Proyecto de Teatro acomodado al terreno que ocupa el extinguido Convento de Santo Domingo de esta ciudad”, cuya planta, sección y fachada principal estaba orientada a Levante: Nicolás, Arquitectura, p. 239.

${ }^{7}$ Véanse más detalles en Barceló, “El Teatro Romea”, pp. 12-16 y Barceló, Historia, pp. 39-47, así como en Crespo, Historia del Teatro, pp. 11-13.

${ }^{8}$ La adquisición formal del antiguo convento por el Ayuntamiento tuvo lugar en septiembre de 1848. El derribo del Teatro del Toro fue debatido en dos sesiones municipales en abril de 1857. En la primera (1504-1857) se informó de la amenaza de derrumbamiento del muro Norte del viejo teatro y del importe para su reparación según informe del arquitecto (77.600 reales). Los concejales acordaron la demolición y nombraron una comisión para estudiar la construcción de un nuevo teatro. En la segunda sesión (17-041857) se señalaron las condiciones de subasta del derribo y venta de enseres del viejo teatro. Se fijó su valor en 86.066 reales, de los cuales 9720 reales correspondían a los gastos de derribo y el resto, al valor de los materiales. La demolición comenzó el 18 de junio de 1857 y, al mismo tiempo, el Ayuntamiento convocó el concurso público para proyectar el nuevo teatro. Sus bases se resumen en: 1) El teatro habría de estar aislado y su fachada principal tendría que tener su frente a la plaza del Esparto (hoy plaza de Romea); 2) Tendría una capacidad de entre 1300 y 1600 localidades; 3) El presupuesto inicial sería de 32000 duros (640.000 reales); 4) El fallo sería decisión de la Real Academia San Fernando; 5) Los proyectos debían presentarse en la Secretaría del Ayuntamiento en un plazo de treinta días, tras su anuncio en la Gaceta y el Boletín Oficial de Murcia; 6) Se premiaría al ganador con 8000 reales. En primera convocatoria el concurso quedó desierto por ausencia de candidatos. El proyecto ganador fue presentado fuera de plazo por Diego Manuel Molina y Carlos Mancha, y aprobado por la Academia de Bellas Artes de San Fernando en octubre de 1857. Posteriormente, el Ayuntamiento emprendió las gestiones de demarcación del solar y elaboración del presupuesto del nuevo teatro. Sobre la asignación de los terrenos del convento para el nuevo teatro, la 
ciudad. Los límites espaciales del viejo Teatro del Toro y la demarcación del nuevo solar aparecen descritos en el siguiente documento de julio de 1859:

[...] Una parte del solar que ocupaba el demolido teatro de esta ciudad, situada en la parroquia de Santa María, procedente del Ayuntamiento de esta capital y comprensiva de 4806 pies cuadrados, equivalente a 373-1262 metros cuadrados, linda por L[evante] con la plaza del Toro, M[ediodía] calle que deberá quedar entre esta parte del solar y la rectificación que se haga de la línea de la fachada del Norte de las casas de don Juan Antonio Saenz de Tejada, P[oniente] calle del Teatro y N[orte] con casas de don Antonio García y don Lope Gisbert, muralla antigua de por medio y cuya mitad de grueso está comprendida en la extensión superficial marcada a la parte del solar que se enajena, pues esta mitad de grueso correspondía al demolido Teatro, como lo manifiesta la servidumbre que en ella tenía para dar cabida a la aguas llovedizas de sus cubiertas, y conforme está trazado todo en el plano mandado levantar por el Excelentísimo Ayuntamiento: tasada por los peritos en venta en 21.360 reales, cuya cantidad servirá de tipo para la subasta.

Una parte sobrante del solar que posee el Ayuntamiento de esta ciudad para la construcción de un teatro, situada en la parroquia de San Miguel y comprensiva de 20518128 pies cuadrados, equivalentes a 1593 metros cuadrados; linda por L[evante] con la plaza de Santo Domingo, M[ediodía] calle que deberá quedar de ocho metros de latitud entre la parte de solar que se enajena y la iglesia de Santo Domingo, P[oniente] otra calle de veinte y cinco metros y setenta y cinco centímetros de latitud, que así mismo deberá quedar entre el Teatro que se proyecta construir y la expresada porción de solar que se enajena, y N[orte] con la calle de Santa Clara, conforme se halla todo trazado en el plano mandado levantar por el Ayuntamiento: tasada por los peritos en venta en 77513 reales, sin corresponder en esta tasación los materiales existentes en esta parte de solar, cuya cantidad servirá de tipo para la subasta. $[\ldots]^{9}$.

A diferencia de otros teatros españoles, erigidos por iniciativa burguesa, fue el Ayuntamiento de Murcia el que auspició las obras del nuevo edificio. No obstante, la burguesía murciana aportó grandes sumas de dinero no sólo en el alzamiento del teatro, sino en reedificaciones posteriores. Las gestiones del Ayuntamiento se centraron en cuatro puntos: la venta del solar del antiguo teatro y sus enseres, la demolición del Teatro del Toro, la asignación del solar del antiguo convento de Santo Domingo y los presupuestos para la construcción del nuevo teatro. La Tabla 2.1 muestra las partidas económicas aplicadas al nuevo edificio:

Tabla 2.1. Financiación del nuevo Teatro de los Infantes de Murcia

Fuente: Elaboración propia a partir de los datos aportados por Barceló, “El Teatro Romea”, p. 26.

\begin{tabular}{|l|l|}
\hline Procedencia de los ingresos & $\begin{array}{l}\text { Importe en } \\
\text { reales }\end{array}$ \\
\hline Venta del solar del antiguo Teatro del Toro & 32.472 \\
\hline Venta de enseres del antiguo teatro del Toro & 20.000 \\
\hline $\begin{array}{l}\text { Venta de terrenos sobrantes del antiguo convento de Dominicos } \\
\text { donde se proyectó construir el teatro nuevo (huerto Soto) }\end{array}$ & 72.216 \\
\hline $\begin{array}{l}\text { Venta de materiales existentes del derribo de Santo Domingo y } \\
\text { huerto Soto }\end{array}$ & 60.000 \\
\hline
\end{tabular}

venta de los enseres del ex-convento y los presupuestos del Ayuntamiento, véase la bibliografía que aporto en la nota anterior.

\footnotetext{
${ }^{9}$ La Paz de Murcia, II (1859), nº 434, 20 julio, p. 2.

${ }^{10}$ Los límites de este solar aparecieron descritos en La Paz de Murcia, II (1859), n 434, 20 julio, p. 2.
} 


\begin{tabular}{|l|l|}
\hline $\begin{array}{l}\text { Financiación prevista del propio Ayuntamiento (60.000 reales por } \\
\text { año) }\end{array}$ & 120.000 \\
\hline Otros medios de financiación & 438 \\
\hline Total financiación propia & 305.126 \\
\hline Total & $1.119 .126,04$ \\
\hline Déficit (financiación ajena) & $814.438,04$ \\
\hline
\end{tabular}

Como se aprecia en la Tabla 2.1, el importe de la financiación ascendía a 1.119.126,04 reales, con un déficit de 814.438,04 reales. Para cubrirlo, la Comisión de Propios del Ayuntamiento de Murcia propuso un préstamo por acciones transferibles mediante "endoso" (o la asunción de tal cantidad por una sola persona, aunque no fue posible). Se emitieron 407 acciones (también denominadas "raciones") de 2000 reales cada una, ofertadas en cuatro series: tres de cien y la última de ciento siete. Cada serie sería lanzada con un intervalo de tres meses y los accionistas percibirían un tipo de interés del 6\%. Como garantía, el Ayuntamiento hipotecó las obras del nuevo teatro y destinó los beneficios de la Casa Rastro a pagar los intereses. El Ayuntamiento contribuiría con 60.000 reales anuales, y con los productos del teatro se amortizarían las acciones que correspondieran, según sorteo anual. De esta manera, el teatro sería en diez años propiedad municipal ${ }^{11}$. Además, los duques de Montpensier contribuyeron económicamente al proyecto con una donación de 6000 reales $^{12}$.

A pesar de esta planificación económica, la edificación del teatro no estuvo exenta de obstáculos: falta de fondos, amenazas de paralización y lentitud en las obras. Paralelamente a la construcción del nuevo teatro, la prensa publicó diversos artículos sobre los mecanismos que otras ciudades empleaban en grandes construcciones. Por ejemplo, en marzo de 1860, La Paz de Murcia publicó un artículo de Carlos Jiménez en el que explicaba que las suscripciones por acciones habían permitido dotar a la ciudad de Málaga de un retablo para la catedral y un puente: "no hay mayor fuerza que la del ejemplo" " En opinión del periodista, en el teatro de los Infantes de Murcia se estaba trabajando "lenta y raquíticamente" a causa de la falta de medios y la pobreza de recursos, por lo que solicitó la ayuda del Gobernador de la ciudad:

[...] Próximos a pararse hasta esos pobres trabajos, según se dice de público, no es posible guardar silencio y preciso es que acudamos a éste para que en defensa de sí propio venga a levantar ese edificio en que las artes reciben su ensanche y su engrandecimiento.

No diríamos nada sobre esta obra, dejándola a su propia ventura, pero el recordar que Cartagena, Lorca, Mula, Caravaca y Cehegín en la provincia, tienen teatros respectivamente mejores de lo que a cada localidad les corresponde, nos mueve a llamar la atención del señor Gobernador para que, estimulando el celo de los que

${ }^{11}$ Este empréstito fue autorizado por Real Orden de 27 de septiembre de 1858: La Paz de Murcia, I (1858), $\mathrm{n}^{\text {os }} 229,2$ diciembre, p. 1; 231, 4 diciembre, p. 1 y 232, 5 diciembre, p. 1.

${ }^{12}$ En agradecimiento, el Ayuntamiento acordó cambiar el nombre de la plaza situada frente al teatro (Plaza del Esparto) por “Plaza de los Duques de Montpensier”: Barceló, “El Teatro Romea”, p. 31.

${ }^{13}$ Carlos Giménez, "Obra de teatro", La Paz de Murcia, III (1860), nº 630, 6 marzo, p. 1. Un ejemplo de esta identificación de lo que estaba ocurriendo en Murcia con otras ciudades es el artículo publicado en La Paz de Murcia, I (1858), n 42, 29 abril, p. 2. En él se informó sobre la construcción del Teatro del Príncipe Imperial en París a través de un préstamo de 12000 acciones que reportarían a los accionistas un beneficio entre el cinco y el seis por ciento. 
valen y pueden, tomen el ejemplo de esos mismos pueblos nuestros en que a costa de sus propios sacrificios han contribuido a prestar su apoyo al bien material del país ${ }^{14}$.

En 1862, después de nueve años desde el inicio del nuevo Teatro de los Infantes, finalizaron las obras y se llevaron a cabo los últimos trámites: la contratación del seguro contra incendios con la compañía La Unión y otros servicios del nuevo teatro: maquinista (José Gómez), taquillero (Juan de Dios Ródenas), alumbrador (Cecilio Martínez) y porteros general (Andrés López) y del vestuario (José Ferrer) ${ }^{15}$.

\title{
1.2. Evolución y cambios de denominación del teatro principal de Murcia: Teatro de los Infantes (1862-1872), Teatro de la Soberanía Nacional (1868- 1872) y Teatro Romea (1872-1895)
}

El nuevo teatro se denominó inicialmente Teatro de los Infantes y fue inaugurado el 26 de octubre de 1862 por la compañía dramática de José Dardalla con el célebre actor murciano Julián Romea, ante la presencia de la Reina Isabel II y su esposo Francisco de Asís de Borbón, duque de Cádiz ${ }^{16}$. Según proyecto de los arquitectos Diego Manuel Molina y Carlos Mancha Escobar, el edificio tenía "una longitud de 64 metros, 37 de ancho y unos 15 de altura" ${ }^{17}$. Su céntrica ubicación (actual plaza Julián Romea) le situó en uno de los puntos estratégicos de la ciudad: muy cercano a la plaza de Santo Domingo y a la calle Trapería, que desemboca en la Catedral (véase Figura 2.1). Según la descripción de Juan Barceló, el teatro tenía:

\begin{abstract}
butacas de terciopelo grana y palcos y plateas de proscenio de carmesí con adornos de oro. Los antepechos, pilastras, recuadros y cornisamentos lucían sencillos bajorrelieves de exquisito gusto. A los costados boca-parte, enlazados con ricas molduras, se veían multitud de lujos, representando los atributos de las Bellas Artes, intercalados por medallones, en cuyo fondo se destacaban los bustos de varios de nuestros más célebres ingenios ${ }^{18}$.
\end{abstract}

Varios candelabros y alrededor de doscientas luces de aceite iluminaban el interior del teatro, que disponía de 246 butacas de patio, 10 plateas, 18 palcos principales, 10

${ }^{14}$ La Paz de Murcia, III (1860), nº 647, 24 marzo, p. 1.

${ }^{15}$ E: $M U m$, AC 21-11-1862, fols. 149v- 150r. El seguro se realizó por un periodo de seis años por valor de 800.000 reales y con una prima de 4.872 reales por año: $E$ : $M U m$, AC 12-12-1862, fols. 166v-167v; E:MUm, AC 19-12-1862, fol. 175v.

${ }^{16}$ Se llevó a escena La cruz del matrimonio, de Luis Eguilaz y Mi secretario y yo, de Manuel Bretón de los Herreros. Sobre la inauguración del Teatro de los Infantes véase, además de los citados, Arróniz, Crónica.

17 Barceló, "El Teatro Romea”, p. 27. Sobre estos arquitectos, véase el estudio de Nicolás, Arquitectura, pp. 145-150.

${ }^{18}$ Barceló, "El Teatro Romea", p. 29. El telón de boca fue obra de Luis Muriel y las pinturas que decoraron el techo eran de José Pascual Valls y Joaquín Rubio. El teatro contó con una sala denominada de los Infantes, también llamada Salón de Oriente, destinada al descanso de personajes reales e ilustres asistentes. Véanse más detalles en Crespo, Historia del Teatro, pp. 65-68. 
palcos segundos, 44 delanteras y 209 asientos de galería baja, 36 delanteras de galería principal (o grada), 600 entradas generales y 300 de paraíso ${ }^{19}$.

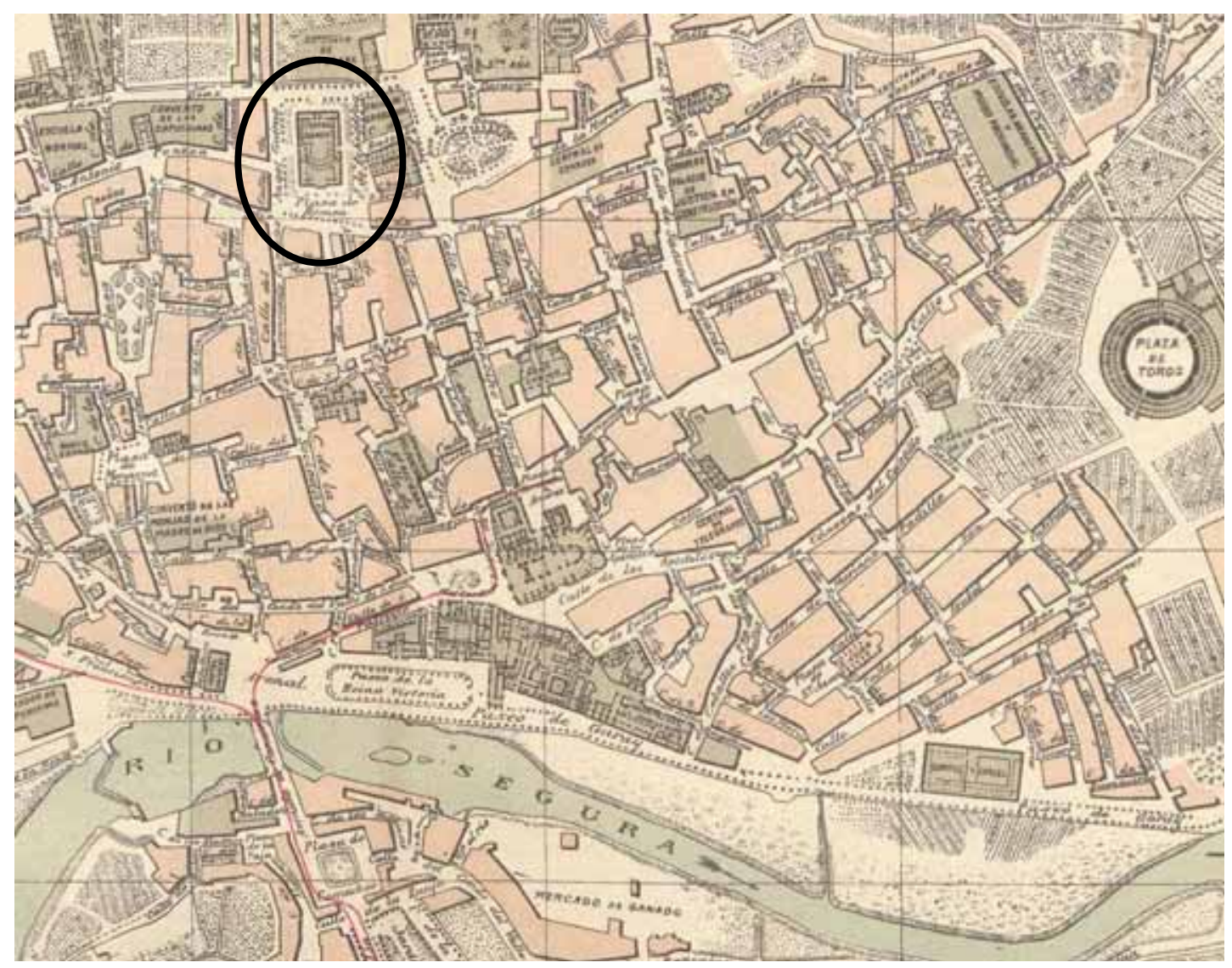

Figura 2. 1 Ubicación del Teatro Romea, originariamente denominado Teatro de los Infantes. Pedro García Faria, Plano de Murcia (Barcelona: Alberto Martín, s.a.). E:Mpb. Accesible en: http://bibliotecadigital.carm.es (acceso el 16-07-2011).

El Teatro de los Infantes siguió los cánones del «teatro a la italiana». Las localidades marcaban la separación de las clases sociales y su poder económico ${ }^{20}$. Cada grupo social ocupaba un lugar diferente dentro del local. Las localidades más bajas (patio de butacas, plateas y palcos) eran para la aristocracia, burguesía y los grupos dirigentes. Las butacas de anfiteatro (sobre los palcos principales) para las capas medias (pequeños burgueses, profesionales, funcionarios, entre otros) y el paraíso (gradas altas o "galerías") para el público más popular.

El Teatro de los Infantes sufrió diversas reformas y dos grandes incendios que modificaron considerablemente su aspecto exterior e interior. Una de las primeras reformas, según los datos hallados, fue la sustitución de la galería baja por palcos ${ }^{21}$. En

\footnotetext{
${ }^{19}$ Crespo, Historia del Teatro, pp. 66-69. El autor aporta este número de localidades a partir de la lista de precios de la compañía dramático-coreográfica de Manuel Méndez (1 ${ }^{\mathrm{a}}$ temporada 1865-1866) y de las cuentas de una función benéfica en 1868 en la que se detalló el aforo.

${ }^{20}$ Sobre arquitectura teatral española y usos sociales en el siglo XIX, véase: Peruarena, "Alrededor", pp. 13-35 y Peruarena, "Imaginario burgués", pp. 97-142.

${ }^{21}$ Esta reforma se hizo antes de abril de 1863. En febrero de ese año se aprobó el presupuesto para habilitar una habitación para el conserje encargado de la guardia y custodia del teatro: E: MUm, AC 20-02-
} 
octubre de 1863, la compañía de zarzuela del empresario Javier de Mendoza tuvo escaso éxito que fue achacado en la prensa a la modificación de las localidades en el teatro murciano, como vimos en el Capítulo $2^{22}$.

En abril de 1865 se solicitó el restablecimiento de los palcos "para dar ensanche y comodidad al público que no le es posible acudir a las localidades de lujo" 23 y en octubre del mismo año se restauró "la antigua galería baja"24.

Junto a estas reformas interiores, el Ayuntamiento acometió las obras de enlucido y decoración de tres de las fachadas exteriores del teatro en junio de $1863^{25}$. Las obras emprendidas en años posteriores se relacionan con la manutención del edificio y dotación de elementos escénicos ${ }^{26}$.

La construcción del Teatro de los Infantes fue vista como un símbolo de adelanto y modernidad para la ciudad. Sin embargo, no todo fueron elogios y hubo también críticas negativas sobre las condiciones del local, como la siguiente:

[...] Hay asientos desde los que no se ve ni se oye, y otros desde los que se oye y no se ve. Hay espectadores que han de ver la función con un solo ojo y otros a quienes solo les toca ver subir y bajar el telón. El decorado es precioso. El techo es la obra de un verdadero artista. Las pocas decoraciones que tiene, magníficas. Sobra sitio en alguna de sus dependencias y falta en otras. Sus proporciones para la colocación del público son muy malas. Parece de gran cabida y la tiene muy escasa. Cuando se considera ocupado por una gran concurrencia, apenas si ha producido para los gastos más necesarios $[\ldots]^{27}$.

La denominación del teatro cambió en octubre de 1868, a causa de las

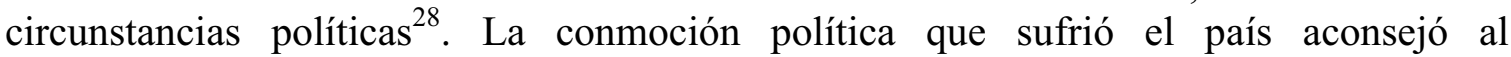

1863, fol. 37v. El 6 de junio de 1864, los arquitectos municipal y provincial informaron que "a causa de la premura con la que se terminaron las obras" y por el asiento del propio edificio en algunos puntos de la cubierta de teja no podía salir libremente el agua de lluvia, lo que había producido filtraciones y goteras. La obra se presupuestó en 27570 reales: E:MUm, Leg. 3194 (I).

${ }^{22}$ El Sacamuelas, I (1863), n ${ }^{\circ}$ 1, 25 octubre, p. 6. Las cursivas son editoriales. Sólo unos días más tarde, el mismo periódico se hizo eco de un rumor en el que se aseguraba la intención de convertir los palcos bajos en galerías: El Sacamuelas, I (1863), nº 3, 8 noviembre, p. 6.

${ }^{23}$ La Paz de Murcia, VIII (1865), no 2156, 20 abril, p. 1. Según Crespo, Historia del Teatro, pp. 78-79 el concejal Clavijo solicitó que las plateas de las galerías bajas fuesen sustituidas por asientos individuales. Se nombró una comisión para estudiar el tema, formada por los ediles Abellán, Turán y el mencionado Clavijo.

${ }^{24}$ La Paz de Murcia, VIII (1865), no 2318, 6 octubre, p. 1. Véase también: La Paz de Murcia, VIII (1865), nº 2368, 25 noviembre, p. 1.

${ }^{25}$ Salvo la fachada principal que, tal y como apunta Antonio Crespo, fue la única terminada antes de la inauguración. Estas obras fueron encargadas a José Antonio Muñoz. Crespo, Historia del Teatro, pp. 73-74.

${ }^{26}$ En febrero de 1867 se acometieron diversas obras de refuerzo de cornisas de las fachadas y colocación de canalones para desagüe de aguas. Véase, Crespo, Historia del Teatro, p. 132.

${ }^{27}$ [Anónimo], "Revista de Murcia. El teatro", en La Paz de Murcia, XI (1868), nº 3203, 12 abril, p. 1.

${ }^{28}$ Con el destronamiento y exilio a Francia de Isabel II en 1868, comenzó el Sexenio Democrático, la instauración de la Primera República Española y un proceso federalista en el que Murcia tomó parte activa. Tras el intento fallido de Prim de coronar a Amadeo de Saboya, Pi y Margall formó un gobierno que generó dentro de la recién creada República Federal una situación de convulsión general en toda España. Fue en 
Gobernador Quiñones de León a declarar el estado de guerra el 22 de septiembre de 1868. Unos días más tarde, se creó la Junta Revolucionaria, que asumió las riendas del poder en Murcia. El 6 de octubre, el Ayuntamiento acordó cambiar el nombre del Teatro de los Infantes por el de Teatro de la Soberanía Nacional. Sin embargo, la nueva denominación no gustó. El 18 de octubre de 1868, el teatro acogió una función "patriótica" presidida por Gerónimo Torres (Vicepresidente de la Junta Revolucionaria) en el que participaron, entre otros, alumnos del Instituto Provincial y el Orfeón de la Sociedad Filarmónica. Entre diversos discursos y poesías, se leyó "una exposición firmada por algunos señores de esta población pidiendo a la Junta Revolucionaria que en lo sucesivo se titulase nuestro teatro de Romea, en justa memoria de nuestro célebre paisano" ${ }^{29}$ (véase Figura 2.2). El nombre de Teatro de Romea se asignó al teatro principal de Murcia el 6 de mayo de 1872, por acuerdo del Ayuntamiento tras aprobar por unanimidad una moción presentada por Rafael Almazán, director de La Paz de Murcia ${ }^{30}$. En las mismas fechas, el Ayuntamiento emprendió obras "de consideración" en el exterior e interior del teatro que obligaron a retrasar el comienzo de la temporada teatral de 1872-1873, como expondré más adelante $^{31}$.

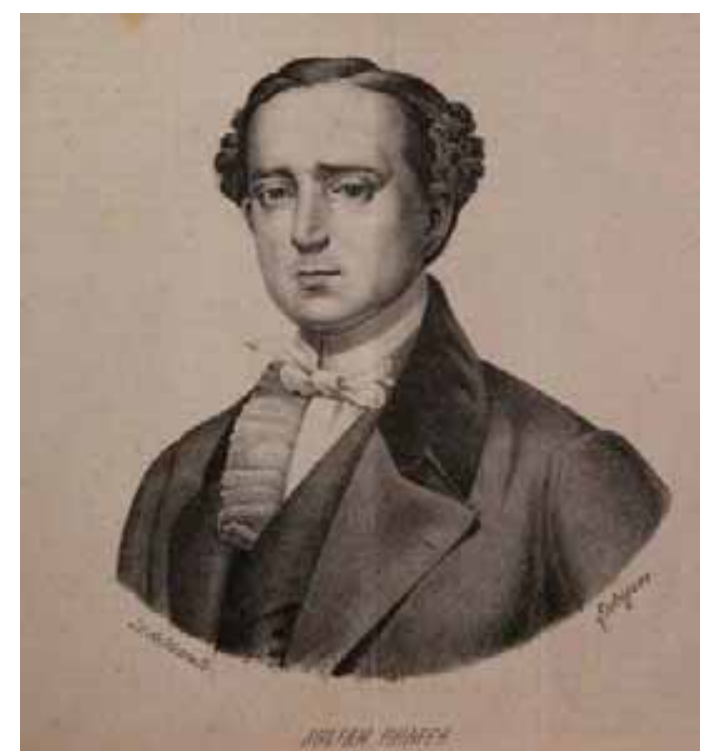

Figura 2. 2. Retrato de Julián Romea (1813-1868).

E:MUm, Cartagena Ilustrada, II (1872), nº 21, agosto, p. 81.

este momento cuando se inició el proceso cantonal cartagenero. Véanse más detalles en Pérez Crespo, $E l$ Cantón.

${ }^{29}$ Las cursivas son editoriales. La proposición fue "aplaudida enérgicamente por los concurrentes": $\mathrm{La}$ Paz de Murcia, XI (1868), $\mathrm{n}^{\circ} 3388,20$ octubre, p. 1. El periódico exhortó a otros medios para que difundieran la moción y se recogieran firmas en la secretaría del Casino: La Paz de Murcia, XI (1868), ${ }^{\circ}$ 3388, 20 octubre, p. 2. En la citada función, el Orfeón cantó un "Himno a la Libertad" con música de Antonio López y letra de Andrés Blanco. Véase el programa en: La Paz de Murcia, XI (1868), n 3386, 17 octubre, p. 3.

${ }^{30}$ Barceló, Historia, pp. 56-57. La Paz de Murcia solicitó en reiteradas ocasiones que se colgara en la fachada el título de Teatro de Romea y pidió al empresario del teatro que anunciara así las representaciones teatrales: La Paz de Murcia, XV (1872), ns ${ }^{\text {os }} 4628,29$ octubre, p. 1; 4632, 3 noviembre, p. 1 y 4634, 6 noviembre, p. 1. Véase la nota de agradecimiento tras el cambio de denominación en La Paz de Murcia, XV (1872), no 4638,10 noviembre, p. 1.

${ }^{31}$ La prensa no especificó en qué consistieron las obras, aunque publicó sus cuentas. Véase: $L a P a z d e$ Murcia, XV (1872), nos 4614, 12 octubre, p. 1; 4628, 29 octubre, p. 1 y 4666, 20 noviembre, p. 1. 
Las remodelaciones más importantes del Teatro Romea se acometieron como consecuencia de dos importantes incendios. El primero de ellos se inició en la madrugada del 7 al 8 de febrero de $1877^{32}$. El día 7 había actuado la compañía dramática de Emilio Corominas representando, entre otras obras, la revista de Ricardo Sánchez Madrigal El año que pasó y el espectáculo concluyó sin incidentes. Sin embargo, "alguna chispa de las bengalas quemadas en la noche del miércoles debió quedar oculta, ya entre los bastidores, ya en el foso del escenario, o bien en cualquiera otra parte de las muchas donde con tanta facilidad podía arder todo el teatro"33. El incendio, declarado después de esta representación, duró varios días y acabó con la parte norte del teatro (escenario, patio de butacas, palcos y cubiertas). Únicamente se salvó lo "que hay desde la puerta principal hasta el muro que daba entrada al patio, palcos y galerías"34.

Además de reedificar el teatro, el incendio de 1877 originó otros problemas colaterales al Ayuntamiento ${ }^{35}$. El primero de ellos fue cobrar el seguro contra incendios de la compañía "La Urbana", ya que la corporación, "por desatender la sacratísima obligación de satisfacer la prima del seguro, se encontró con que había perdido su derecho respecto de la empresa y que ésta, como era natural, se negaba al pago de lo que se le exigía" ${ }^{36}$. Después de intensas gestiones, en octubre de 1877 se cobraron 93.000 pesetas de $L a$ Urbana $^{37}$. Otro problema fue negociar la deuda que el municipio tenía contraída con los accionistas desde la construcción del Teatro de los Infantes. Desde La Paz de Murcia se propuso una posible solución:

[...] Teniendo en cuenta que sobre el municipio pesa una deuda importante a favor de los accionistas, y éstos por hipoteca tienen la renta de la Casa Rastro y consideran además que para el municipio no ha sido nunca un negocio el teatro, sino

${ }^{32}$ Antes del primer gran incendio en 1877 , hubo otro de menor consideración la noche del 9 de febrero de 1875. Se representaba El potosí submarino de Arrieta con libreto de Santisteban, por la compañía de zarzuela de Nicanor Sanmartín y León Carvajal (1 ${ }^{a}$ temporada 1874-1875). En el segundo acto una gasa que imitaba el agua ardió. La rápida intervención del segundo apuntador y del maquinista González impidió que el fuego se propagara a las bambalinas y telones. No hubo que lamentar daños personales ni apenas daños materiales: La Paz de Murcia, XVIII (1875), n 5284, 10 febrero, p. 1.

${ }^{33}$ La Paz de Murcia, XX (1877), no 5970, 2 febrero, p. 1.

${ }^{34}$ Ibídem. En marzo hubo alguna propuesta privada para reconstruir el teatro (no constan nombres de los posible benefactores): La Paz de Murcia, XX (1877), $\mathrm{n}^{\circ}$ 5995, 7 marzo, p. 1; 5999, 11 marzo, p. 1; 6000, 13 marzo, p. 1. La Correspondencia de Murcia citada por La Paz de Murcia, XX (1877), n 6002, 15 marzo, p. 1 dejó clara su postura: "El teatro si se reedifica ha de ser por un esfuerzo del Ayuntamiento". Véanse más detalles en Crespo, "Los dos incendios", pp. 85-96.

${ }^{35}$ La pérdida de uno de los edificios más emblemáticos de la ciudad, unido a las largas obras de reconstrucción (prolongadas durante más de tres años) originó en la prensa intensos debates sobre la eficacia de las gestiones del Ayuntamiento. De un lado se situó El Semanario Murciano, que publicó diversos artículos con una visión crítica y dura hacia las autoridades murcianas. Un buen ejemplo es el artículo "El Teatro Romea", publicado en El Semanario Murciano, I (1878), n 16, 2 junio, p. 1. De otro lado se situó La Paz de Murcia, que defendió al Ayuntamiento: La Paz de Murcia, XXI (1878), n 6232, 4 junio, p. 1; esta postura era lógica, ya que su director, Rafael Almazán, fue miembro de la Junta Mixta de reedificación del Teatro, como veremos más adelante. Véanse: El Semanario Murciano, I (1878), $\mathrm{n}^{\circ}$ 17, 9 junio, p. 3; 31, 15 septiembre, p. 1; 41, 24 noviembre, pp. 6-7 y La Paz de Murcia: XXI (1878), nº 6248, 23 junio, p. 1 y XXII (1879), no 6544, 9 marzo, p. 1.

${ }^{36}$ El Semanario Murciano, I (1878), nº 16, 2 junio, p. 1.

${ }^{37}$ El Ayuntamiento debía dos cuotas anuales a la aseguradora antes del incendio: La Paz de Murcia, XX (1877), $\mathrm{n}^{\text {os }} 6161,25$ septiembre, p. $1 ; 6020,6$ abril, p. 1; 6023, 10 abril, p. 1; 6036, 26 abril, p. 1 y 6175,11 octubre, p. 1 . 
una carga y origen de disgustos y compromisos, oímos proponer convendría tasar la parte existente de Romea y como se calcula que excederá en valor a la deuda que el municipio hace a los accionistas, reunidos acreedores y deudor, podían convenir, por medio de las condiciones que se estipularan, canjear la deuda por lo existente del teatro y levantar la hipoteca, quedado libre el Ayuntamiento de la responsabilidad que tiene por su débito y de que los acreedores, cansados algún día de esperar, dispongan de la hipoteca y hagan más conflictiva la situación de la caja municipal al perder una de sus mejores rentas.

Resuelta esta cuestión, que es la primera que debe solventarse, si tenía este arreglo, los accionistas, dueños entonces de la parte que respetó el fuego y del solar restante, podían elegir una junta para que ésta gestionara la reconstrucción del teatro llamando licitadores y es indudable que encontrarían empresas que la hiciera con beneficio de los accionistas que podían reintegrarse con creces de sus créditos, haciendo el beneficio que el Ayuntamiento quizá no pueda proporcionar en mucho tiempo, de conseguir que Murcia no carezca de un templo del arte digno de su importancia y del renombre que adquirió con el destruido.

Próxima la reunión que con el Ayuntamiento han de celebrar los accionistas, en ella podía proponerse esta solución que tiene mucho de realizable ${ }^{38}$.

Ésta fue la primera vez que se planteó deslindar el Teatro Romea del Ayuntamiento de Murcia, aunque no fue la única, como se verá más adelante. La cuestión se solventó mediante un acuerdo de la corporación municipal con los accionistas a base de pagos demorados y la participación en la empresa reconstructora. Además, se constituyó una "Junta Mixta de reconstrucción del Teatro" para supervisar los planos ${ }^{39}$. Para proyectar y presupuestar las obras de reedificación el Ayuntamiento recurrió, una vez más, a la fórmula de emplear capital particular mediante un préstamo por acciones o “empréstito" (200.000 pesetas) ${ }^{40}$.

El 1 junio de 1879, el Ayuntamiento firmó un contrato con los accionistas del préstamo para apoyar la reconstrucción del teatro y, posteriormente, se formó una "Comisión Mixta de Teatro" con representantes de ambas partes. En adelante, las decisiones en material teatral ya no dependieron en exclusiva del municipio, lo cual repercutió en múltiples aspectos de su actividad, como se verá después ${ }^{41}$.

${ }^{38}$ La Paz de Murcia, XX (1877), nº 6122, 9 agosto, p. 1. Las cursivas son editoriales.

${ }^{39}$ La Paz de Murcia, XXI (1878), $\mathrm{n}^{\mathrm{o}}$ 6232, 4 junio, p. 1. La primera reunión entre accionistas y Ayuntamiento tuvo lugar el 26 de septiembre de 1877: La Paz de Murcia, XX (1877), n 6163, 27 septiembre, p. 1. La Junta Mixta se formó con una comisión de accionistas y la comisión de Teatro del Ayuntamiento de Murcia. Sus integrantes fueron: Antonio Hernández Amores (Alcalde), José Illán González, Pedro Díaz García, Ricardo Guirao, Fulgencio Martínez, Juan Miguel Hernán Sáez, Diego Salmerón, Rafael Almazán y Pedro Mazeres. Para conocer las negociaciones entre accionistas y autoridades, consúltese: La Paz de Murcia: XX (1877), ${ }^{\text {os }} 6170,5$ octubre, p. 1 y 6160, 23 octubre, p. 1; XXI (1878), $\mathrm{n}^{\text {os }}$ 6204, 8 marzo, p. 1; 6207, 12 marzo, p. 1; 6208, 13 marzo, p. 1; 6254, 2 julio, p. 1; 6260, 9 julio, p. 1 y 6366, 4 diciembre, p. 1; XXII (1879), $\mathrm{n}^{\text {os }} 6525,14$ febrero, p. 1; 6605, 25 mayo, p. 1; 6607, 27 mayo, p. 1 y 6670, 10 agosto, p. 1, así como El Semanario Murciano, I (1878), nº 7, 31 marzo, p. 7.

${ }^{40}$ La Paz de Murcia, XXI (1878), nº 6284, 8 agosto, p. 1. El préstamo fue autorizado por Real Orden de 26 de junio de 1878. El reintegro a los accionistas se efectuaría mediante una hipoteca de los rendimientos del Matadero y los productos íntegros del Teatro, sin que el Alcalde "pueda jamás dar distinta inversión a dichos productos [...] que la reedificación indicada del Teatro": E:MUm, AC 18-07-1894, fols. 266v-269v: 267v.

${ }^{41}$ La cláusula doce del mencionado acuerdo lo dejaba claro: "Dicha Comisión Mixta entenderá en todo contrato de arriendo [del teatro] o administración de sus productos y servicios a cuyo dictamen deberá sujetarse el Ayuntamiento mientras no hayan amortizado todas las gestiones de manera que ha de contar siempre la conformidad de los accionistas": E:MUm, AC 18-07-1894, fol. 267v. En 1890, formaban la Comisión Mixta de Teatro los siguientes cargos: un Presidente Nato, un Presidente y seis vocales: Botella, 
El proyecto de reedificación del Teatro Romea fue realizado por el arquitecto municipal Gerónimo Ros y su ayudante Pedro Belando ${ }^{42}$. Con respecto a la distribución anterior, el nuevo proyecto mejoraba la capacidad del teatro, así como sus condiciones acústicas:

[...] El proyecto de los señores Ros y Belando suprime todas las gradas que para entrar en el local hay después del primer vestíbulo, ensancha la platea y da cabida a un ciento más de butacas, aumenta dos plateas y éstas las establece en el piso que ha de haber por bajo de las antiguas. Aquéllas se convierten en palcos de entresuelo en mayor número. Lo que eran palcos bajos antes quedan convertidos en palcos principales y una galería en el centro, estando este orden al piso del salón de descanso y demás laterales. Por último, el paraíso y una doble galería en los lados sustituyen al orden de palcos altos que antes había. La altura que resta queda por encima del cielo raso para un salón de pinturas donde puedan pintarse cuantos telones se necesiten.

La mayor cabida de butacas y el mayor número de plateas y palcos que ha de contener el teatro en su reconstrucción se debe en el proyecto al ensanche que produce una modificación en los antepalcos y la rectificación de las líneas de la herradura para facilitar la vista desde todas las localidades dando, por tanto, más latitud a la embocadura del escenario. Se calcula por las medidas que la cabida será una mitad más que antes tenía el incendiado Romea.

El tablado avanza más que el telón de boca y facilita la salida de los actores para mejorar de este modo las condiciones acústicas que antes no eran las mejores.

La entrada al escenario por la puerta del Norte se verificará por sólo cuatro gradas y los cuartos de los actores estarán al piso de aquél. $[\ldots]^{43}$.

Los planos, enviados a la Academia de Bellas Artes de San Fernando en Madrid, fueron aprobados en enero de $1879^{44}$. Las obras comenzaron a finales de mayo de $1879^{45}$ y tres meses después, el Concejo encargó al arquitecto Justo Millán la dirección de las mismas $^{46}$. Sobre el primitivo proyecto de Ros y Belando, Millán modificó los planos en aras de una mayor comodidad y número de localidades y diseñó una sólida estructura de hierro que acortó y abarató las obras ${ }^{47}$.

Guía, p. 225. En julio de 1894, el concejal Lumeras presentó una moción para derogar este punto, en base al siguiente argumento: "Las atribuciones [...] a los ayuntamientos, corporaciones económico-administrativas [...] no pueden ser transmitidas ni delegadas en nadie, por ninguna razón ni motivo [...] sino que han de ser ejercidas siempre y en todo caso por las corporaciones que la voluntad de los pueblos, manifestada en los comicios, designó para el gobierno, gestión y dirección de sus intereses [...]: Ibid., fol. 267r. Según su razonamiento, la mencionada cláusula era ilegal y, por tanto, revocable.

${ }^{42}$ Véase, Nicolás, Arquitectura, pp. 102-106.

${ }^{43}$ La Paz de Murcia, XXI (1878), nº 6207, 12 marzo, p. 1.

${ }^{44}$ La Academia de San Fernando pidió al Ayuntamiento "los datos que debían acompañarle y juzga y admite lo remitido como anteproyecto": La Paz de Murcia, XXII (1879), nº 6522, 11 febrero, p. 1. Véanse también La Paz de Murcia, XXII (1879), no ${ }^{\text {os }} 6517,5$ febrero, p. 1 y 6521, 9 febrero, p. 1

${ }^{45}$ La Paz de Murcia, XXII (1879), n 6605, 25 mayo, p. 1. En ocasiones, La Paz de Murcia publicó las cuentas detalladas de los gastos empleados en el teatro: La Paz de Murcia, XXII (1879), $\mathrm{n}^{\circ}$ 6664, 3 agosto, p. 1; 6677, 20 agosto, p. 1

46 "El trabajo diario del señor Ros como arquitecto municipal no le permitía atender a las obras con la asiduidad necesaria": El Diario de Murcia II (1880), no 555, 12 diciembre, p. 1. Miguel Sanmiguel fue ayudante de Millán: La Paz de Murcia, XXII (1879), nº 6676, 19 agosto, p. 1.

${ }^{47}$ La Paz de Murcia, XXII (1879), nº 6697, 13 septiembre, p. 1. 
En enero de 1880, el Ayuntamiento sacó a concurso público la pintura del techo, cuyos bocetos también fueron enviados a la Academia de Bellas Artes para su aprobación ${ }^{48}$. El ganador fue Federico Mauricio y su obra en el Teatro Romea fue descrita así en la prensa:

[...] El medallón del centro del cielo raso representa a las cuatro artes de la escena: la Poesía, la Música, la Comedia y el Baile. La primera en el acto de recibir una corona y además dos niños arrojando flores sobre ella. Otro niño representa la Pintura. Todo el medallón está rodeado de una bien pintada balaustrada sobre la cual hay cinco macetones llenos de flores que caen hacia abajo con tanta propiedad y exactitud que merecen elogio unánime de todo el que los mira ${ }^{49}$.

A finales de 1880 la remodelación del teatro estaba casi terminada ${ }^{50}$. La reapertura del teatro tuvo lugar el 11 de diciembre de 1880, aunque desde febrero de 1878 se venían organizando bailes de carnaval en los salones no destruidos por el fuego ${ }^{51}$. El Teatro Romea disponía de las siguientes localidades para un total de 1186 personas: "Plateas, 10. Palcos principales, 20. Ídem segundos, 10. Ídem terceros, 10. Plateas y palcos de bolsa, 6. Butacas de patio, 272. Ídem de anfiteatro, 134. Delanteras de anfiteatros, 91. Ídem de paraíso, 78. Localidades de anfiteatro y paraíso, $800^{\prime, 52}$.

El segundo incendio de grandes proporciones en el Teatro Romea tuvo lugar la tarde del 10 de diciembre de 1899 , a causa de un cortocircuito ${ }^{53}$. La Compañía de Zarzuela y Ópera Española de Ricardo Sendra y Lucio Delgado representaba la zarzuela de Marqués El anillo de hierro, en la sesión de tarde. Los músicos de la orquesta perdieron en el fuego gran parte de sus instrumentos, como relataron al pedir una indemnización (que no obtuvieron):

[...] hallábanse los que recurren en su sitio de la orquesta cuando, con la rapidez del rayo, vieron arder en breves instantes las bambalinas del segundo extremo del escenario. No se nos ocultaba el grave riesgo a que nos exponíamos de continuar en nuestro puestos, toda vez que el lugar destinado para la orquesta había de ver, como efectivamente lo fue, uno de los primeros invadidos por las llamas devastadoras, pero

${ }^{48}$ Crespo, El Teatro Romea, p. 37. Véase también, El Diario de Murcia, II (1880), nº 356, 15 abril, p. 2. El Ayuntamiento envió una circular a los pintores participantes "llamando a las puertas de sus sentimientos patrióticos, para que acceda a pintarlo por una modesta cantidad, en vista de la angustiosa situación del erario municipal": El Semanario Murciano, III (1880), nº 117, 9 mayo, p. 152.

${ }^{49}$ La Paz de Murcia transcrito por El Diario de Murcia, II (1880), nº 556, 14 diciembre, p. 2.

${ }^{50}$ Desde marzo hasta octubre de 1880 se llevaron a cabo las siguientes subastas: colocación de la cubierta de madera del escenario; construcción de las gradas del anfiteatro y del entarimado del piso bajo (concedidas, respectivamente a Vicente Ferrer y Jesús Coll); y, finalmente ajuste de sillas para palcos y plateas, así como su tapizado (concedido a Juan García y Andrés Sánchez): El Diario de Murcia, II (1880), $\mathrm{n}^{\text {os }} 323,3$ marzo, p. 2; 486, 21 septiembre, p. 3 y 504, 12 octubre, p. 2. Poco después, El Diario de Murcia planteó la cuestión de su denominación, proponiendo Teatro Romea o Teatro de Romea: El Diario de Murcia, II (1880), $\mathrm{n}^{\text {os }} 551,8$ diciembre, pp. 1-2 y 561, 19 diciembre, p. 3.

${ }^{51}$ La Paz de Murcia, XXII (1879), $\mathrm{n}^{\mathrm{o}}$ 6515, 2 febrero, p. 1. Hubo otro conato de incendio el 16 de febrero de 1879, aunque afortunadamente se evitó a tiempo: La Paz de Murcia, XXII (1879), n 6528, 18 febrero, p. 1. Véanse más detalles de la inauguración en las monografías antes citadas.

${ }^{52}$ La Paz de Murcia, XXX (1887), nº 8205, 22 mayo, p. 1.

${ }^{53}$ Véase la descripción que hace Crespo, El Teatro Romea, pp. 424-429. 
al mismo tiempo tampoco se nos ocultó a los exponentes en aquellos terribles momentos que una súbita huida en busca de la puerta salvadora habría determinado ciertamente en el numeroso público que asistió a la representación una de esas confusiones terribles que en casos semejantes suelen producir más víctimas que la causa de la cual se huye. Ante tal disyuntiva los recurrentes no vacilaron un momento y / despreciando el peligro cada vez más cercano y más inminente optaron por permanecer en sus respectivos asientos, para que con su actitud al parecer tranquila, aminorase a los ojos de los espectadores la gravedad del peligro y con la serenidad de ánimo y el orden posible, ganasen todos las puertas de salida, sin esas precipitaciones generadoras en casos tales de tantas y tan lamentables desgracias.

Con tan humanitario fin, permanecieron los que suscriben en sus correspondientes sitios, hasta los últimos momentos, aquellos tan supremos que, para librarse de una muerte tan horrible como segura, era llegado el caso de huir precipitadamente abandonando todo, como quedaron en efecto los instrumentos musicales, único patrimonio de la mayor parte de los que firman $[\ldots]^{54}$.

Las llamas destruyeron parcialmente el edificio del teatro aunque se salvaron la mayor parte los materiales de la guardarropía, la sastrería de la compañía, casi todo el vestuario de los artistas, el archivo, la armería y algunos instrumentos de la orquesta ${ }^{55}$. El arquitecto Justo Millán fue de nuevo el encargado de las obras de reconstrucción. Con él trabajaron José Gallego (maestro de obras), José Huertas (decorador) y Martínez Molla, Sanz y Conejero (responsables de las nuevas escenografías).

La tercera inauguración del Teatro Romea tuvo lugar el 16 de febrero de $1901^{56}$. Esta rehabilitación dio al teatro una estructura que, salvo por algunos cambios, permanece básicamente en la actualidad. La sala tiene forma de herradura, como el modelo italiano del que se parte en todo el siglo XIX, con patio de butacas rodeado de plateas, tres niveles de palcos y otros tantos de gradas superiores. El aforo con el que volvió a abrirse el teatro en 1901 fue de 1.792 localidades, que, con el tiempo, se ha reducido hasta el millar escaso actual (1179). El escenario tiene 16 metros de ancho, 19 de fondo, desde la embocadura, y 18 de alto. Tras un profundo proceso de restauración, el teatro tuvo su cuarta inauguración en $1988^{57}$. Véanse Figuras 2.3 y 2.4.

${ }^{54}$ E:MUm, Leg. 1129 (II), "Expediente promovido por el Director e individuos de la Orquesta pidiendo indemnización", fechado en 18 de diciembre de 1899 y presentado en el Negociado de Incendios del Ayuntamiento de Murcia. En él se incluye una relación de los instrumentos perdidos en el incendio: una viola, estuche y arco, de José Juver; un violonchelo y arco, de Joaquín Alarcón; un contrabajo, arca y caja así como un bajo en do' de cilindro, ambos de José Yepes; un flautín en do', de Antonio López; una trompa, de Patricio Martínez; un bombardino de cilindro, de José María Alonso; un bombardino de cilindro, de Conrado López; juego de timbales con pie y baquetas, de Ginés Hurtado; una caja prusiana, de Joaquín Cascales; un bombo de varillas, un par de platillo, unos triángulos, unas postizas y una maza, todos de Antonio Giménez. La Comisión de Hacienda del Ayuntamiento de Murcia denegó la petición de los músicos a ser indemnizados (22-01-1900).

${ }^{55}$ Crespo, El Teatro Romea, p. 427. Por la noche estaba anunciada Jugar con fuego (Ventura de la Vega y Barbieri) y El dúo de la Africana (Miguel Echegaray con música de Fernández Caballero). Murió atrapado en el foso el joven de 17 años, Antonio Garrido, hijo del tramoyista: Crespo, El Teatro Romea, p. 427.

${ }^{56}$ Para una descripción del Teatro Romea en años posteriores, véase: Alonso de Quintanilla, El Teatro Romea; Martínez López, El Romea y Martínez López, “El teatro y las gentes”, pp. 115-128.

${ }^{57}$ La rehabilitación del edificio se produjo en 1985 y fue promovida por los ministerios de Cultura y Obras Públicas y Urbanismo de España. Los arquitectos fueron Oñoro, Ortiz y Ortega y el rehabilitador Alonso de Quintanilla. Las puertas del Teatro Romea se abrieron, por cuarta vez, el 7 de febrero de 1988. 


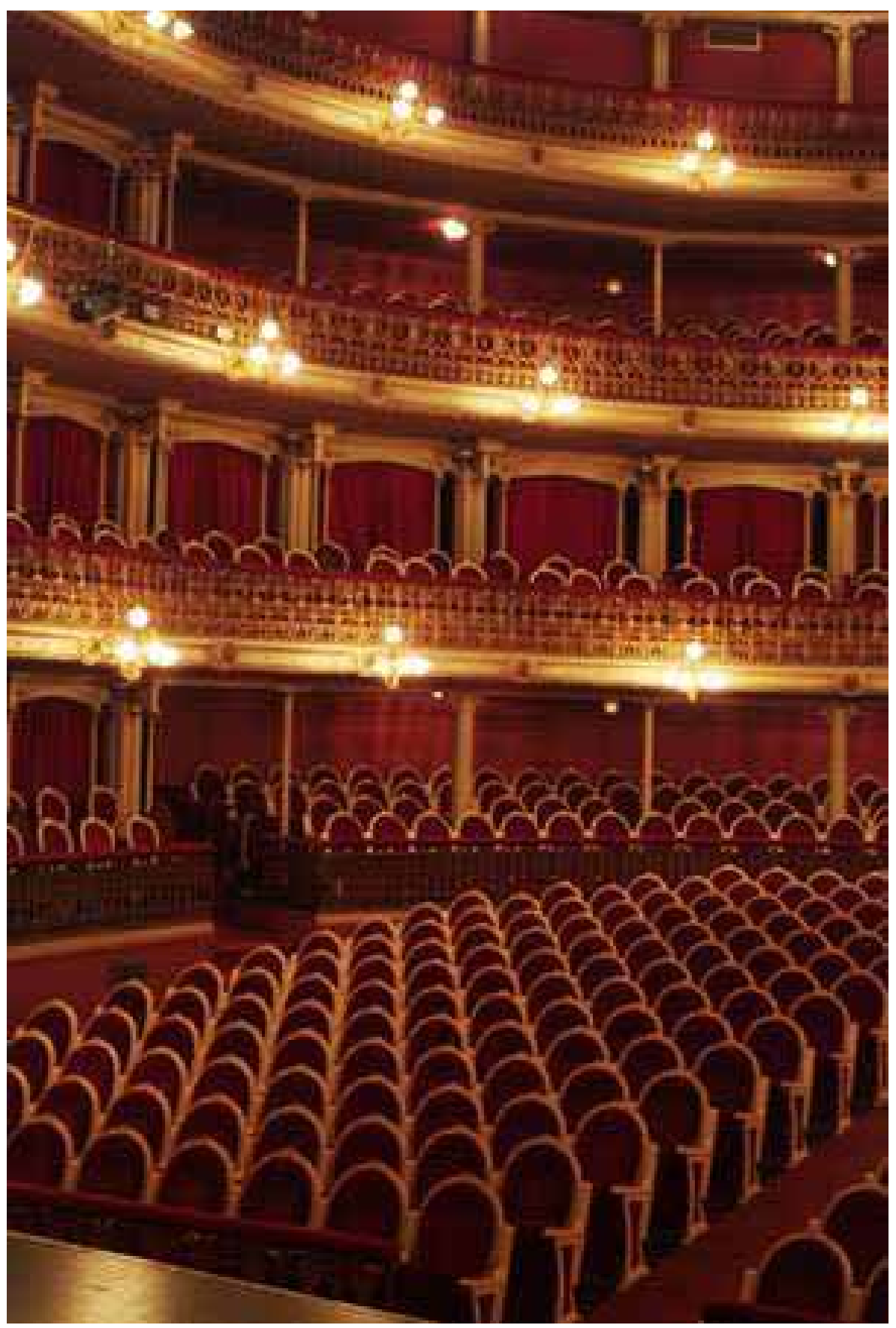

Figura 2.3. Patio de butacas, palcos y plateas del Teatro Romea, antes de su cierre en 2007. Accesible en: Región de Murcia Digital, http://www.regmurcia.com (acceso el 10-07-2011). 


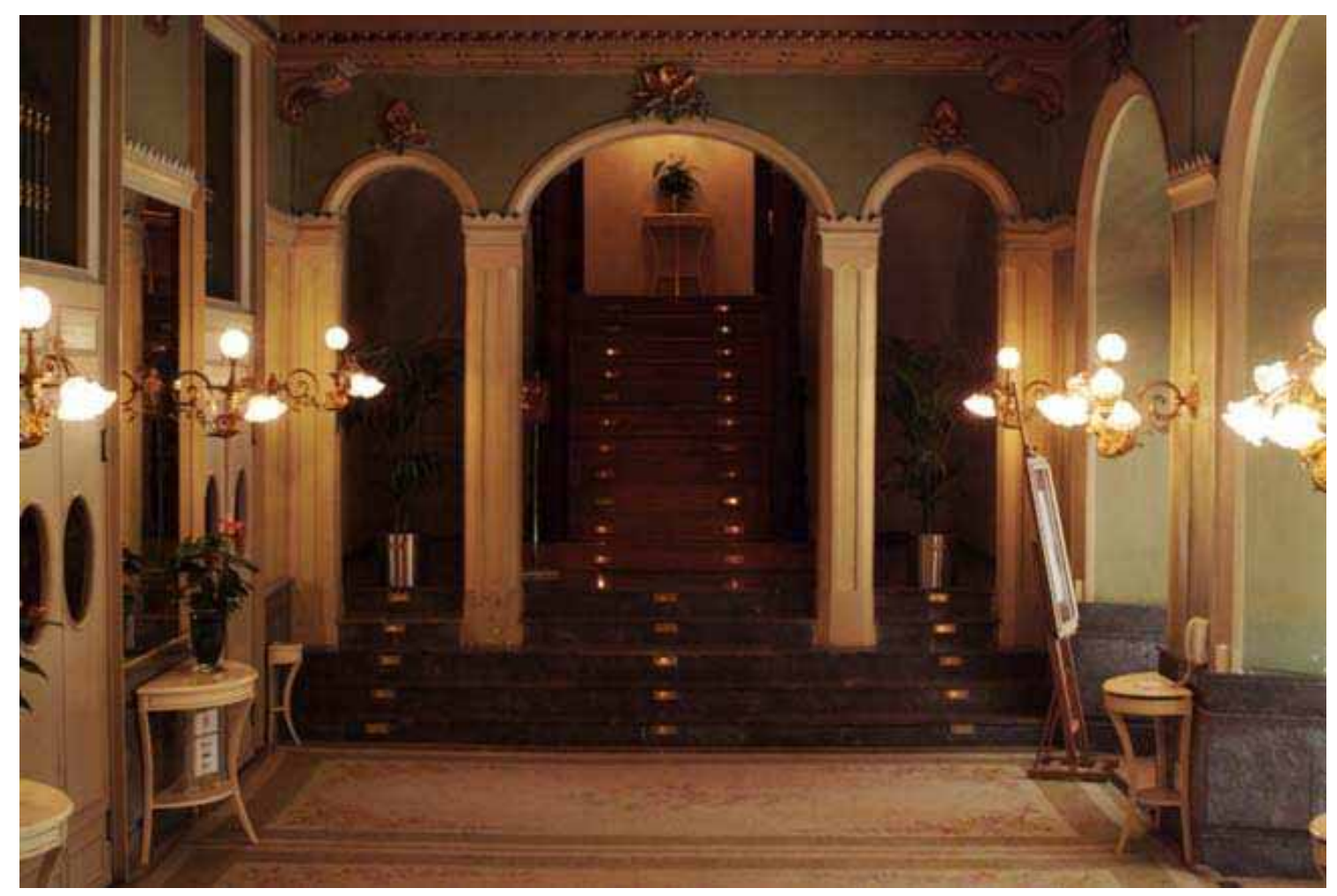

Figura 2.4. Vestíbulo de entrada al Teatro Romea de Murcia, antes de su cierre en 2007. Accesible en: Región de Murcia Digital: http://www.regmurcia.com (acceso el 11-07-2011)

Las pinturas del techo, obra de Antonio de la Torre e Inocencio Medina, fueron pintadas sobre lienzo y posteriormente pegadas al cielo raso. Ocupan unos $100 \mathrm{~m}^{2} \mathrm{y}$ representas la coronación de Julián Romea por musas del Parnaso. En 1910, las pinturas fueron retocadas por Antonio Meseguer, después de un hundimiento del falso techo, que incluyó una alegoría de la huerta murciana. En su moldura, de izquierda a derecha, hay ocho retratos de varios dramaturgos (García Gutiérrez, Bretón de los Herreros, Ventura de la Vega, Tamayo y Baus, López de Ayala, Zorrilla, Hartzenbusch y el duque de Rivas) y diversos medallones con nombres de actores, actrices y autores (Latorre, Matilde Diez, Larra, Bárbara Lamadrid, Ricardo Calvo, Eulogio Florentino Sanz, Narciso Serra, Barbieri, Luis de Eguilaz, Joaquín Gaztambide, Emilio Arrieta, Tomás Rodríguez Rubí y Antonio Gil y Zarate).

La fachada principal del Teatro Romea es de inspiración neoclásica, con detalles modernistas (marquesina y verjas de forja de la entrada) y está organizada en tres cuerpos (véase Figura 2.5). En el cuerpo inferior se abre un gran porche con la puerta principal de acceso y ventanas a ambos lados. El cuerpo intermedio es jalonado con tres ventanas centrales y dos más a cada lado y separadas cada una de ellas por pilastras. El cuerpo superior es una galería de ventanas corridas y sobre él sobresalen tres bustos de Beethoven, Mozart y Listz ${ }^{58}$.

\footnotetext{
${ }^{58}$ Barceló, "El Teatro Romea”, p. 42.
} 


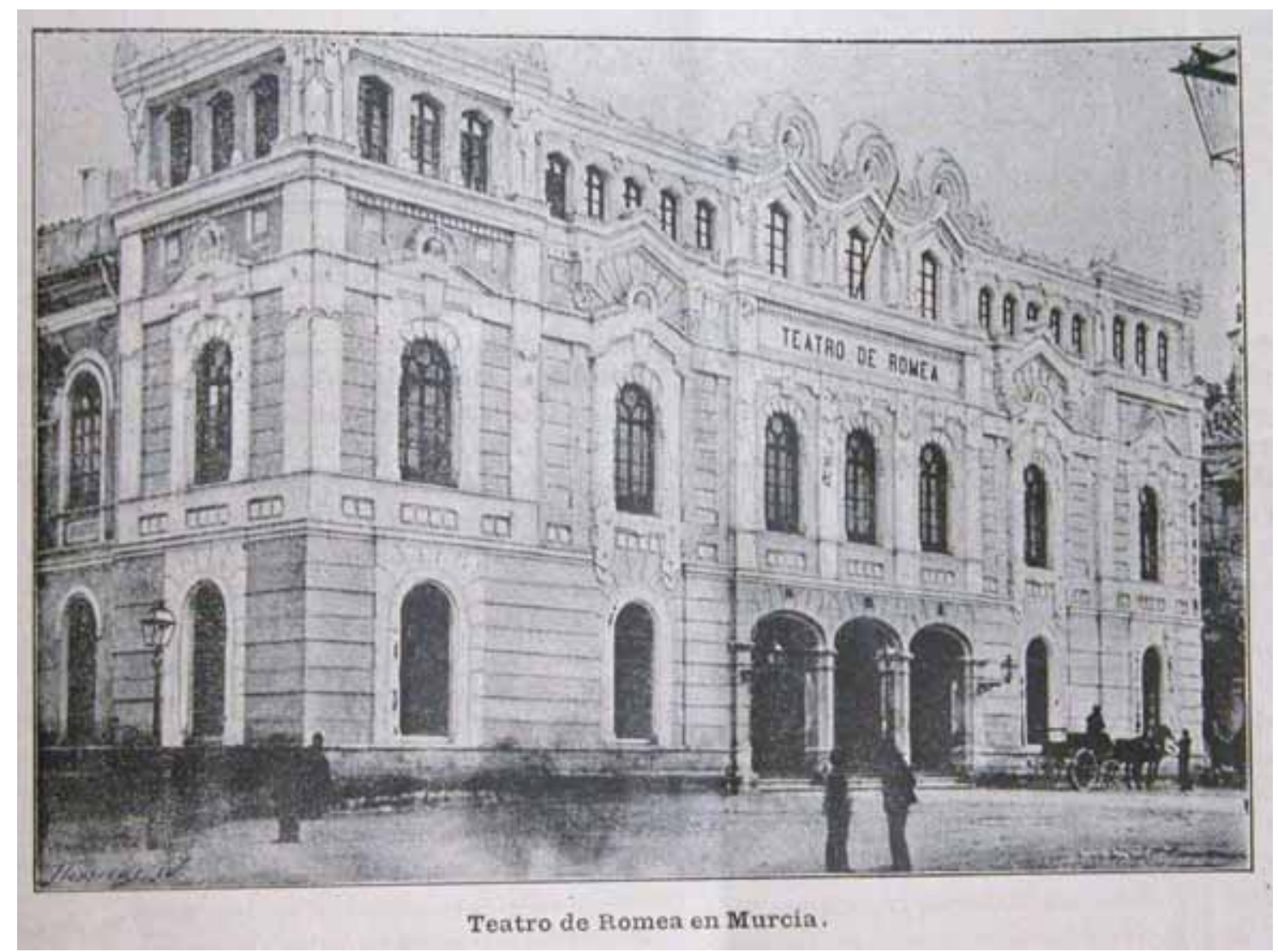

Figura 2.5. Fachada del Teatro Romea de Murcia en 1890 .

E:MUm. Cartagena Artística, I (1890), n 11, 20 julio, p. 47.

En la actualidad, el Teatro Romea se encuentra cerrado al público desde el año 2007, camino de su quinta remodelación.

\subsection{Funcionamiento y gestión del teatro}

\subsubsection{Sistema de arrendamientos}

El Teatro Romea y todos los asuntos relacionados con él dependían del Ayuntamiento de Murcia ${ }^{59}$. El coliseo era arrendado a empresarios por años cómicos o por temporadas y los procedimientos de arrendamiento fueron uno de los puntos más problemáticos de su gestión ${ }^{60}$. Los contratos entre empresarios y autoridades permiten

59 Después de la inauguración del Teatro de los Infantes, el Ayuntamiento nombró una comisión permanente para que atendiera los asuntos del teatro, formado por un presidente y varios vocales. Desde abril de 1866 las competencias sobre teatro se integraron en la Comisión 4a (Beneficencia y Sanidad, Corrección pública, Ferias y Teatro), aunque en enero de 1867 pasó a formar parte del bloque Registro Civil, Policía Urbana, Bomberos y Alumbrado. Véase, Crespo, Historia del Teatro, pp. 101 y 127. Como vimos anteriormente, desde junio de 1879 los asuntos del teatro pasaban por la "Comisión Mixta de Teatro", nombrada por el Alcalde e integrada, además, por concejales y varios representantes de los accionistas del préstamo.

${ }^{60}$ Véase el significado de año cómico y temporadas al inicio del epígrafe "Las temporadas teatrales, los abonos y los funciones" de este Capítulo. 
conocer aspectos muy variados tanto de la actividad escénica como de la rentabilidad económica del Teatro Romea. En el ámbito musical aportan valiosa información sobre la contratación de compañías (exigencia de incluir determinados cantantes y/o repertorio), orquestas y su estructura (plantillas y sueldos) y otros aspectos escenográficos (por ejemplo, contratación de pintores escenógrafos y obligaciones de construir decorados nuevos).

Durante la segunda mitad del siglo XIX, el arrendamiento del Teatro de los Infantes (más tarde Romea) se efectuó mediante dos sistemas: subasta pública o arriendo directo a una empresa teatral. El primer caso es el más abundante y su procedimiento estaba legislado mediante leyes que afectaban a todo el territorio nacional ${ }^{61}$. Consistía en la subasta pública de la gestión del teatro durante un tiempo determinado (una temporada concreta, un año o varios). El proceso se iniciaba con el diseño de las condiciones (o cláusulas) de arriendo por parte de la "Comisión de Teatro". Posteriormente, el Alcalde y los concejales las discutían y, según los casos, se modificaban. Una vez aprobadas, el Ayuntamiento las hacía públicas, fijando un precio mínimo para concurrir a la subasta ${ }^{62}$. El pliego de condiciones formulaba las bases para concursar, los derechos y las obligaciones de los empresarios y del Ayuntamiento. El acto de licitación (o subasta pública) estaba regulado de la siguiente forma:

[... $3^{\circ}$ La subasta se verificará por pliegos cerrados y tendrá efecto en las salas consistoriales bajo la presidencia del señor Alcalde, de once y media a doce de la mañana del día designado por dicha autoridad.

$4^{\circ}$ En la referida media hora podrán presentar sus pliegos en el despacho de la Alcaldía las personas que deseen tomar parte en la subasta. A dichos pliegos que se redactarán con sujeción al modelo puesto al final, deberá acompañarse la cédula personal de los que los suscriban y el recibo que acredite haber consignado en la Depositaría Municipal la cantidad de 2500 pesetas en efectivo o 3750 pesetas en papel de la deuda, al tipo de la última cotización oficial que se conozca por la "Gaceta" en el día de la subasta. A las doce en punto de la mañana se procederá a la apertura de los pliegos que hasta ese momento se hubieran presentado y se adjudicará la subasta a favor del que resulte mejor postor, devolviéndose en el acto los demás depósitos que se hubieran hecho por los licitadores.

$5^{\circ}$ Las proposiciones han de basar necesariamente sobre aumento de la cantidad que se fija como tipo para la subasta. En el caso de resultar iguales dos o más proposiciones se abrirá licitación oral por término de cinco minutos, adjudicando la subasta al que resulte mejor postor $[\ldots]^{63}$.

\footnotetext{
${ }^{61}$ Sobre cuestiones de legislación teatral, véase: Arimón, El código.

${ }^{62}$ Las condiciones de arrendamiento del teatro no se publicaron en la prensa hasta la década de los setenta. Los motivos se expresan en las siguientes líneas: "comprendemos que los que traten de hacer postura no tendrán bastante con que se puedan ver en Secretaría, porque tendrán que estudiarlas detenidamente. También comprendemos que los vecinos de esta ciudad, propietarios de esa finca, deben conocer con qué condiciones la arrienda su administrador": La Paz de Murcia, XIV (1871), n 4221, 18 julio, p. 1. Con anterioridad a los años setenta, la información puede hallarse en las actas capitulares del E:MUm. Dado que un estudio pormenorizado de éstas excede los límites de este estudio, me ceñiré al arriendo efectuado en el Teatro de los Infantes en 1862, coincidiendo con su inauguración y los efectuados en los años 1871, 1881, 1884, 1887 y 1890. Una de las cláusulas de arrendamiento del año 1887 especifica que los gastos de anunciar la subasta en el Boletín Oficial de la Provincia así como en otros periódicos correrían a cargo del contratista: La Paz de Murcia, XXX (1887), nº 8197, 12 mayo, p. 1.
}

\footnotetext{
${ }^{63}$ La Paz de Murcia, XXIV (1881), no 7015, 1 abril, p. 1.
} 
El que presentaba la mejor oferta era proclamado arrendatario provisional del teatro hasta que depositara la cantidad ofertada (o un tanto por ciento de la misma). Una vez recibido el dinero, el Ayuntamiento adjudicaba definitivamente el teatro y entregaba el inmueble al arrendatario. La Comisión era la encargada de hacer efectivos estos trámites. Como es lógico, los cambios de arrendamiento se llevaban a cabo durante el verano, época en la que no había representaciones ${ }^{64}$. La ausencia de candidatos para arrendar, la interrupción de los contratos antes de su finalización, las crisis económicas, los acontecimientos políticos o incluso sociales (por ejemplo, epidemias) alteraron, en muchas ocasiones, el procedimiento descrito y llevaron a aplicar otras fórmulas de cesión directa. A continuación analizaré, siguiendo un orden cronológico, los arrendamientos más relevantes del Teatro de los Infantes (posterior Romea), así como los problemas que se plantearon. El Apéndice 2.3 recoge un listado de los arrendatarios del Teatro de los Infantes, Teatro de la Soberanía Nacional y Teatro Romea (1862-1894).

La función inaugural del Teatro de los Infantes (26-10-1862) estuvo a cargo de la compañía de José María Dardalla. El actor y empresario había solicitado al Ayuntamiento de Murcia el arrendamiento del coliseo para la primera temporada de 1862-1863. Las autoridades municipales solicitaron permiso al Gobernador para contratar directamente a la citada compañía sin convocar una subasta pública, ya que no había tiempo para ello ${ }^{65}$ :

\begin{abstract}
La precipitada inauguración del teatro, habilitado inesperadamente y por causas que nadie ignora, impuso al Municipio la necesidad de arrendarle en una época la menos a propósito para tener concurrencia de empresas que desearan adquirirle y cuando no se podía disponer de tiempo suficiente para estudiar las condiciones que debieran imponerse. El año cómico había empezado, eran pocos los actores que podían encontrarse sin ajuste y no quedaba más medio que admitir los primeros que se presentasen $[\ldots]^{66}$.
\end{abstract}

El Gobernador accedió a la petición, aunque advirtió que el teatro debía seguir el protocolo legislado para las temporadas siguientes. En enero de 1863, el Ayuntamiento encargó a la Comisión de Teatro que estudiara las condiciones de arrendamiento para la temporada teatral 1863-1864 y que realizase las gestiones oportunas para su subasta pública $^{67}$. La licitación del teatro tuvo lugar el 10 de julio de 1863 , aunque no se presentó

${ }^{64}$ En agosto de 1864 el Concejo aprobó que en lo sucesivo las subastas se realizaran en febrero: Crespo, Historia del Teatro, p. 82.

${ }^{65}$ El contrato fue firmado por Antonio Romero Saavedra (socio de Dardalla) y el Ayuntamiento de Murcia. Según Crespo, Historia del Teatro, p. 59 las condiciones fueron: alquiler del teatro hasta el Jueves Santo de 1863, el contratista debía pagar 100 reales por función (incluido el uso de la guardarropía baja) y se comprometía a traer un pintor (Luis Muriel) para que realizase tres decoraciones: salón corto, salón largo y calle corta. El arrendamiento del teatro para la temporada de Pascua de 1863 se concedió a Manuel Fernández: E:MUm, AC 23-03-1863, fol. 59v. El Segura, I (1863), n ${ }^{\text {os }} 54,4$ marzo, p. 3 lo anunció más tarde.

${ }^{66}$ El Segura, I (1863), no 2, 2 enero, pp. 1-2.

${ }^{67}$ La comisión estuvo integrada por el presidente Andrés Brugarolas (presidente) y los vocales Rosendo Carlos, Miguel Mazón, José Melgarejo Flores y Vicente Ochoa. Antonio Crespo, Historia del Teatro, pp. 70-77 especifica también los trámites que se llevaron a cabo antes de la subasta definitiva en julio de 1863 . 
ningún candidato ${ }^{68}$. Una semana más tarde, el Ayuntamiento recibió una instancia de Francisco Usera, apoderado del madrileño Javier de Mendoza Morá, solicitando el teatro. Su propuesta constaba de dieciocho puntos que legislaban los derechos del Ayuntamiento y las obligaciones del arrendatario:

1. Recibir el arrendamiento del Teatro de los Infantes desde el 15 de agosto de 1863 al 15 de junio de 1864 (ampliable por un año más).

2. Notificar a las autoridades municipales la aceptación de la prórroga quince días antes de la finalización del primer año cómico ${ }^{69}$.

3 a 5. El Ayuntamiento podía disponer del salón, dos gabinetes para el servicio público, el "palco de la municipalidad" (o palco presidencial) y el contiguo a éste para personas reales o colocación de retratos reales (punto quinto). Se excluía del arrendamiento la habitación del conserje.

6. Entrada libre a todas las funciones de los miembros de la Guardia Municipal y cuatro bomberos (sin ocupar localidad).

7. El solicitante recibiría bajo inventario los enseres del teatro (tanto fijos como móviles), comprometiéndose a conservarlos en perfecto estado y devolverlos dentro de los quince días de finalización del contrato.

8. Llevar a su cargo (o por subarriendo) el servicio de cafetería.

9. No introducir modificación alguna en el local ni en sus enseres sin consentimiento del Ayuntamiento

10. Utilizar el edificio para representaciones teatrales (dramáticas, líricas o coreográficas, entre otras) y no programar bailes, funciones de circo y "juegos olímpicos".

11. El Ayuntamiento no pediría compensación por el deterioro del uso habitual de los enseres del teatro.

12. Pagar cinco duros y medio (44 ó 110 reales) por función.

13. Iluminar el teatro con petróleo o aceite no inflamable.

14. Ofrecer una función benéfica a elección del Ayuntamiento.

15. Ceder al archivo del teatro un ejemplar de una de las zarzuelas en tres actos que se hubiera representado.

16. Formar una "Compañía de Zarzuela para trabajar en este teatro, sirviendo de base la actriz doña Elisa Zamacois, cuya compañía será, cuando menos como la que acaba de actuar, si no es mejor,"70.

17. Pagar al contratista de la guardarropía cien reales por cada función y ocho reales diarios al conserje.

18. Abonar 20.000 reales en concepto de depósito ${ }^{71}$.

${ }^{68}$ E: $M U m$, AC $22-05-1863$, fol. 104v. Las condiciones de arrendamiento no se publicaron en la prensa (al menos en los ejemplares periodísticos existentes) aunque pueden consultarse en AC 10-07-1863, fol. 138 r. trabajo.

${ }^{69}$ Véase la explicación que aporto sobre el significado de "año cómico" en el punto 1.3.2 de este

${ }^{70} \mathrm{E}: \mathrm{MUm}$, AC 17-07-1863, fol. 143r.

${ }^{71}$ E: $M U m$, AC 17-07-1863, fol. 142r-143r. Mendoza propuso que la cesión del teatro pudiera ser prorrogable otro año más (junio de 1865). Salvo los puntos 12, 15 y 16, estas cláusulas serán muy similares a las de años posteriores. En comparación con los contratos de arriendo del teatro de la primera mitad del siglo XIX, los estudiados en el presente capítulo incorporan paulatinamente mayor número de cláusulas (los efectuados en la década de los noventa, se estructuran en capítulos y apartados). El arriendo de la Casa 
El Ayuntamiento murciano modificó cinco de los puntos propuestos por Mendoza y agregó otros cuatro ${ }^{72}$. Con las condiciones ya establecidas y con un posible candidato, el Ayuntamiento realizó una nueva subasta en agosto de 1863 que concluyó en la cesión del teatro a Javier Mendoza para un año cómico ${ }^{73}$. Sin embargo, a mediados de octubre de ese año, el empresario solicitó hasta en dos ocasiones la rescisión de su contrato por las pérdidas económicas que venía sufriendo ${ }^{74}$. A finales de noviembre de 1863 , Mendoza se marchó inesperadamente de Murcia, dejando a la compañía abandonada. El Ayuntamiento declaró a su empresa en quiebra y, sin previa subasta, aceptó la solicitud de Francisco Miguel Fernández para continuar las representaciones con los actores de la compañía Mendoza que aún permanecían en Murcia ${ }^{75}$. Para El Sacamuelas, la causa del fracaso fue el excesivo lujo y número de componentes:

[...] En cuanto a la empresa, si quiere tomar un consejo leal y desinteresado, si quiere oír la opinión pública unánimemente pronunciada por la inmensa mayoría de todos los hombres sensatos, debe suprimir, economizar, reducir sus gastos y su personal, que le sobra y mucho con que poder continuar dando funciones de importancia. El teatro de Murcia no puede responder de ese exceso de lujo y esplendidez con que la empresa ha querido exornarlo dotándolo de una compañía tan numerosa. El público todo se dará por satisfecho y créanos de buena fe, si no obra así, esté segura de que sus pérdidas crecerán ${ }^{76}$.

El arriendo del teatro para el año cómico 1864-1865 tampoco estuvo exento de problemas. A mediados de junio de 1864 se establecieron las condiciones y se fijó la fecha de la subasta para el 30 de julio ${ }^{77}$. No hubo ofertas en la subasta pero Prudencio Soler (contratista de la guardarropía baja) solicitó el alquiler del teatro ofreciendo 15.000 reales. El Ayuntamiento rechazó esta oferta y fijó una nueva subasta (16-08-1864) que

Coliseo para el año cómico 1837-1838, por ejemplo, fue otorgado a José Segura y constó de 16 cláusulas: E:MUm, Leg. 3449.

${ }^{72}$ Los puntos modificados fueron: 1) el arrendamiento tendría lugar en las fechas 1-09-1863 a 30-061864 ; 2) en caso de prórroga se requeriría acuerdo mutuo y previa propuesta del empresario dos meses antes de finalizar el contrato; 3 ) cualquier modificación del local debía ser autorizada por el Concejo; 4) el pago de cinco duros y medios ascendería a sesenta reales en los días con funciones de tarde y noche; y 5) el depósito de garantía se devolvería tras el cumplimiento de todas las obligaciones. Las condiciones añadidas por el Ayuntamiento fueron: 1) las decoraciones o muebles construidos por la empresa para las funciones pasarían a ser propiedad del teatro; 2) por cada mes sin función el empresario abonaría 2000 reales que se deducirían de la fianza; 3 ) la subasta se realizaría mediante pliegos cerrados junto al recibo justificando el pago de 2000 reales en la Depositaría; y 4) el Ayuntamiento se reservaría el derecho a deliberar durante quince minutos las ofertas presentadas: E:MUm, AC 17-07-1863, fol. 144r-145r. Véase también, Crespo, Historia del Teatro, pp. 72-73.

${ }^{73}$ La entrega no fue inmediata. Javier Mendoza depositó la fianza en la Tesorería Central de Madrid, donde residía. El Ayuntamiento formalizó el inventario y aprobó la cesión del edificio pero la Comisión de Teatro se negó a realizar la entrega porque no se le había consultado. El Ayuntamiento respondió que era su potestad oír o no a la Comisión y que debía entregar el edificio en un plazo de un día, a lo que la Comisión respondió con la dimisión de todos sus miembros: Crespo, Historia del Teatro, p. 74.

${ }^{74}$ E: $M U m$, AC 16-10-1863, fol. 183r; AC 23-10-1863, fols. 185v-186v.

${ }^{75}$ E:MUm, AC 26-11-1863, fol. 201r., AC 27-11-1863, fol. 202r.

${ }^{76}$ El Sacamuelas, I (1863), $\mathrm{n}^{\mathrm{o}}$ 2, 1 noviembre, p. 7. Las cursivas son editoriales.

${ }^{77}$ Las condiciones de este arrendamiento son muy similares a las expuestas anteriormente, salvo por el incremento de la cantidad de la fianza (30.000 reales frente a los 20.000 reales del arrendamiento anterior). Véase E:MUm, AC 17-06-1864, fols. 94v-99v. 
tampoco obtuvo ningún resultado. A finales de agosto, con la temporada a punto de comenzar, el Ayuntamiento se vio obligado a aceptar la oferta de Soler ${ }^{78}$.

La escasez de candidatos y la frecuente rescisión de contratos indican la escasa rentabilidad que tenía el Teatro de los Infantes en esos años. Esta situación llegó a su punto más crítico a finales de la década de los sesenta, como describe un testimonio periodístico de abril de 1868:

[...] Reducido el país a sus solas fuerzas para sostener dos largas temporadas, se retraen de concurrir al teatro las primeras fortunas de la población. Van los que siempre fueron sin que la afición aumente gradualmente el número de asiduos concurrentes. No tenemos movimiento de forasteros, ni numerosa guarnición, ni muchos empleados, que son los que en otras partes forman la concurrencia habitual y ordinaria.

La vida de nuestro teatro ha de ser, por ahora, completamente artificial.

Después de recoger un activo empresario las primicias de la inauguración y después de haberse sepultado como en hondo plazo una fortuna conquistada con el trabajo y la economía, ha de venir precisamente una época turbulenta y de grandes peripecias.

Ya no acudirá el público llamado por la novedad de la inauguración, ni encontraremos otro hombre tan fiel a sus compromisos o tan obcecado que entregue el premio de sus ahorros a la voracidad de los comediantes.

Nuestro teatro irá a manos de herejes, para explotar en vez de ser explotados, para sacrificar en vez de ser sacrificados. Quien cargue con tan pesada cruz será para llevarla con la ayuda del público.

Nuestro teatro, tal y como se encuentra montado, se ha hecho imposible a los empresarios de buena fe.

Hay contratos onerosos, obligaciones permanentes y gastos precisos que consumiendo la parte mejor y más importante de sus productos, embarazan y dificultan la marcha libre e independiente que debe dejarse al que se encuentre al frente de un negocio de esa importancia. Por todas partes surgen dificultades y entorpecimientos y se le hacen al empresario imposiciones que no tienen otra razón de ser que el capricho del que las hizo y la conveniencia de aquellos para quien[es] fueron hechas.

Somos pocos los que concurrimos al teatro pero en cambio, ya no toleramos las medianas compañías, llegando a tener con nuestras exigencias injustificadas pretensiones. Pedimos a voz en cuello artistas de primer orden y no se nos ocurre al hacerlo, volver la cabeza y contar el número de espectadores que a veces no llega al de los actores.

Hablamos de la carestía de esta diversión y no pensamos en ponerla al alcance de todas las fortunas, estableciendo turnos entre distintas familias, fomentándose por este medio la afición al teatro.

Somos díscolos entes, como en todo, y aún no hemos logrado ponernos de acuerdo para saber qué clase de espectáculo es el que más agrada a este público.

Pedimos zarzuela cuando nos dan comedia y echamos de menos el verso cuando destrozan nuestros delicados oídos los cantores de coplas. Una sola vez tuvimos buena compañía de ópera y el teatro estuvo desierto $[\ldots]^{79}$.

Tal y como se sugiere en los párrafos anteriores, el problema residía en las obligaciones económicas que se les imponían a las empresas. Junto a la cantidad preestablecida en el contrato de alquiler y los sueldos de los integrantes de la compañía, el

${ }^{78}$ Aquiles Ronchy solicitó el teatro para representar funciones de ópera italiana desde febrero a marzo de 1864 (E:MUm, AC 5-02-1864, fols. 98v-99r.) y Mariano Ridaura para espectáculos de magia desde marzo a junio. Véase también Crespo, Historia del Teatro, pp. 79-80.

${ }^{79}$ La Paz de Murcia, XI (1868), no 3203, 12 abril, p. 1. Las cursivas son editoriales. 
empresario tenía que asumir otros gastos cada vez que se alzaba el telón (alumbrado, imprenta, conserje y aposentadores y arbitrio de las entradas vendidas, por citar algunos). Para afrontarlos, los empresarios recurrieron a los "abonos condicionales", las funciones por turnos, el encarecimiento de los precios de las localidades, la contratación de actores de segunda o tercera fila (más baratos), la reducción del alquiler y fabricación de los elementos escenográficos o la suspensión inesperada de las representaciones si la afluencia era escasa. La compañía dramática que dirigía José Mata en 1869 llegó a solicitar "del municipio la gracia de que se le dé de balde, en vista del exiguo precio a que ha reducido el abono, precio no conocido en el actual coliseo y de los esfuerzos que se están haciendo para aumentar los abonados" ${ }^{\prime 80}$.

La ausencia de arrendatario durante la temporada 1869-1870 provocó el cierre del Teatro de la Soberanía Nacional ${ }^{81}$. Sin embargo, el Ayuntamiento había recibido dos solicitudes de alquiler: la de Antonio Molina, anterior arrendatario, y la de Prudencio Soler. Molina pedía una ampliación de su contrato por dos años ${ }^{82}$. Prudencio Soler ofrecía alquilar el teatro por dos años, pagar la suma total del arriendo (20.000 reales) en efectivo y por adelantado, y hacer rebajas en los precios de las localidades ${ }^{83}$. El asunto se trató en la sesión del Ayuntamiento del 23 de abril de 1869, cuyo resumen publicó La Paz de Murcia dos días más tarde:

[...] La comisión [de Teatro] opinaba porque se desestimasen ambas peticiones, puesto que no es posible continuar el arrendamiento como hasta hoy se ha hecho y para que, quedando de este modo a cargo exclusivo de la municipalidad, puedan removerse todos los obstáculos que hasta hoy han ocasionado la ruina de cuantos han tratado de funcionar en él, con notable perjuicio del público que se ha visto privado varias veces de funciones y no ha experimentado ventajas en los precios.

El señor Cayuela manifestó que el teatro no era una finca productiva para el municipio, puesto que lo que de él se cobraba apenas bastaba a cubrir los 3000 reales señalados al conserje, los 4000 del seguro de incendios y los gastos de reparación y mantenimiento, por lo cual sostenía lo que en otra ocasión dijo respecto a que debía darse gratis al que mejor compañía y mejores condiciones para el público ofreciese, quedando a cargo de los que lo ocupen el pago del conserje. [...].

${ }^{80}$ La Paz de Murcia, XII (1869), nº 3542, 11 abril, p. 1. El arrendatario había hecho grandes esfuerzos por traer la compañía de José Mata para esa temporada, ampliando el abono y mejorando las condiciones económicas de las entradas. Sin embargo, no fue suficiente y a lo largo del mes de abril se vio obligado a cerrar en diversas ocasiones las puertas del teatro. La Paz de Murcia llegó a sugerir a las autoridades que se favoreciese a las empresas teatrales mediante subvenciones, como en otras ciudades españolas: La Paz de Murcia, XII (1869), no 3522, 18 marzo, p. 1. Véanse también, La Paz de Murcia: XI (1868), n 3360, 22 septiembre, p. 2; XII (1869), $\mathrm{n}^{\text {os }} 3518,13$ marzo, p. 1; 3519, 14 marzo, p. 1; 3539, 8 abril, p. 1; 3541, 10 abril, p. 1; 3549, 20 abril, p. 1 y 3550, 21 abril, p. 1 .

${ }^{81}$ En septiembre de 1869 se pidió el teatro para una compañía de zarzuela con la tiple Cubas, primero, y la compañía dramática de José Mata, a continuación, aunque no llegaron a actuar: La Paz de Murcia, XII (1869), n $\mathrm{n}^{\circ}$ 3678, 19 septiembre, p. 1. El Teatro de la Soberanía Nacional abrió sus puertas esporádicamente para funciones benéficas. El 27-03-1870 y el 3-04-1870 para acoger una a beneficio de los presos republicanos y emigrados, con obras dramáticas: La Paz de Murcia, XIII (1870), n ${ }^{\text {os }} 3836,27$ marzo, p. 1; 3837, 29 marzo, p. 1 y 38415 abril, p. 1. El 22-05-1870, para la redención de quintos: La Paz de Murcia, XIII (1870), $\mathrm{n}^{\text {os }} 3882,21$ mayo, p. 1 y 3884,24 mayo, p. 1.

${ }^{82} \mathrm{El}$ arrendatario contaba con un repertorio preparado para ofrecer al público y esperaba resarcirse de las pérdidas económicas sufridas en la temporada anterior: La Paz de Murcia, XII (1869), n 3554, 25 abril, p. 1.

${ }^{83}$ La Paz de Murcia, XII (1869), n ${ }^{\text {s }} 3518,13$ marzo, p. 1 y 3519, 14 marzo, p. 1. 
El señor Camprubi, conforme en parte con el señor Cayuela, manifestó que la concesión debía ser siempre por todo el tiempo de la temporada cómica.

El señor Alcalde presidente fue de parecer de que no fuera gratuita por completo la cesión del local que nos ocupa, siendo así que sobre él pesaban obligaciones imprescindibles, a lo cual replicó el señor Cayuela manifestando que los de conserje y composiciones de los deterioros que sufriera debían estar a cargo de las empresas que lo ocuparan.

El señor Alcalde dijo que toda la cuestión estriba en evitar se sacrifique a las compañías que a él vengan, imponiéndoles obligaciones imprescindibles de música, alumbrado, imprenta, etcétera, ocasionando así gastos exorbitantes que podrían disminuirse dejando a aquellas en libertad absoluta de tratar con quien más le convenga, y desapareciendo la tutela que hoy se ejerce; que esto es lo principal en que debe fijarse el municipio, puesto que aún cuando se diera gratis el local, haciendo gracia de los 100 reales que por función se cobran, o disminuyendo este tipo, nunca sería bastante a evitar el perjuicio que sufran las compañías, si continuaban las demás condiciones onerosas; que, por tanto, si bien el municipio debe utilizar una cantidad módica por función para cubrir los gastos que tiene sobre sí la casa-teatro, y estos no vengan a pesar sobre los demás capítulos del presupuesto, con perjuicio del servicio, debe reservarse el derecho de concederla a quien más convenga y hacer que allí no se conozca otra persona que el municipio, por medio de la comisión de teatro que lo represente $[\ldots]^{84}$.

No he podido constatar qué motivos llevaron al Ayuntamiento a denegar las peticiones de los empresarios Molina y Soler.

La clausura del coliseo principal de la ciudad dio lugar a la creación de otros teatros promovidos mayoritariamente por aficionados desde el seno de sociedades recreativas, como comentaré más adelante.

El arriendo del teatro para la temporada cómica 1871-1872 revela prácticas poco lícitas por parte de los empresarios. En agosto de 1871, el Ayuntamiento concedió el alquiler del teatro, sin fianza, al empresario Nicolás Rodríguez ${ }^{85}$. Sin embargo, a mediados de septiembre el teatro seguía cerrado ${ }^{86}$. La prensa confirmaba, poco después, que el empresario estaba en realidad programando obras en Sevilla:

AL AYUNTAMIENTO. Si esta corporación hubiese exigido una fianza al tiempo de conceder el teatro a don Nicolás Rodríguez ¿no habría evitado que este señor jugase a dos barajas, es decir, que mientras que hacía como que buscaba actores para nuestro teatro, publicaba en Sevilla la lista de compañía lírico-dramática que bajo su dirección ha de actuar en el teatro de San Fernando? [...]. Los perjuicios de que continúe cerrado nuestro teatro ¿quién los indemnizará? ${ }^{87}$.

${ }^{84}$ La Paz de Murcia, XII (1869), no 3554, 25 abril, p. 1. En reiteradas ocasiones la prensa instó al público para que apoyara a las empresas con su asistencia a las representaciones teatrales e insistió en la necesidad de revisar las cláusulas de los contratos arrendatarios.

${ }^{85}$ Según, La Paz de Murcia, XIV (1871), n 4256, 31 agosto, p. 1 la compañía de Nicolás Rodríguez había actuado en la temporada anterior (1870-1871) en los teatros de Granada y Almería.

${ }^{86}$ Tampoco Rodríguez había presentado al Ayuntamiento posibles compañías para actuar.

${ }^{87}$ La Paz de Murcia, XIV (1871), n 4273, 21 septiembre, p. 1. Véase también, La Paz de Murcia, XIV (1871), n ${ }^{\text {os }} 4269,16$ septiembre, p. 1 y 4260, 17 septiembre, p. 1. 
Esta situación hizo que en la prensa se cuestionaran las ventajas de que el teatro fuese de propiedad pública y se planteara la posibilidad de venderlo:

El Ayuntamiento de Granada subastó el edificio del Teatro Principal de aquella ciudad, y hecho el remate ha quedado a favor de don Joaquín Guindos en 300.112 pesetas (1.200,448 reales). Ya no es sólo el Ayuntamiento de Murcia el que propone la venta de esos edificios y, en parte, para que de todos modos venga a ser negocio para algún empresario, o permanezca cerrado y de una o de otra manera el público no tenga beneficio alguno, creemos que no estaría mal siendo propiedad particular; que cual las fincas de bienes nacionales vendidas, mejoraría el dueño por su propio interés y por su mismo interés haría por buscar medios para que, estando abierto al público el mayor tiempo posible le rindiese mayor renta ${ }^{88}$.

El teatro murciano fue finalmente arrendado al empresario del Teatro Principal de Cartagena, Antonio Molina, aunque con un enorme retraso en el inicio de la temporada teatral $(31-10-1871)^{89}$.

Los problemas continuaron en los años siguientes. El arriendo de 1872-1873 fue concedido a Ramón Ros, del que la prensa murciana desconfiaba: "El señor Ros ha llegado a Murcia, pero solo. Se dice que tiene en Madrid formada la compañía, pero ¿por qué no la ha traído?. Promesas tras de promesas y... coro conjunto" ${ }^{90}$. Ros formó una compañía de zarzuela bajo la dirección escénica de José González Orejuela. Salvo algunos problemas iniciales, que comentaré más adelante, la temporada fue "la más afortunada que hemos conocido [...]. El señor Ros no ha quedado a deber ni un céntimo y todos los que han estado a sus órdenes quedan muy satisfechos de su comportamiento"91.

El arriendo de la temporada 1873-1874 se otorgó a Manuel Soler Roby, tras dos subastas y por un plazo de ocho años (1873-1881) ${ }^{92}$. El incendio del Romea en 1877 interrumpió su contrato en la práctica pero no en teoría. En julio de 1880 el Ayuntamiento arrendó el teatro mediante subasta a Martiano Aguilar para la temporada $1880-1881^{93}$. Dado que el contrato anterior no había expirado, se originó un pleito entre el

${ }^{88}$ La Paz de Murcia, XIV (1871), nº 4279, 28 septiembre, p. 1. Las cursivas son editoriales.

${ }^{89}$ El Aguijón, (1871), no 2, 31 octubre, pp. 10-11. A principios de octubre el Ayuntamiento recibió otra solicitud del empresario de Valencia, Quintana, que ofrecía cuarenta funciones con una compañía dramática y otras tantas con una de zarzuela: La Paz de Murcia, XIV (1871), $\mathrm{n}^{\circ}$ 4282, 1 octubre, p. 1. Sin embargo, el Ayuntamiento concedió el coliseo a Antonio Molina: La Paz de Murcia: XIV (1871), nº 4293, 14 octubre, p. 1 y XV (1872), nº 4488, 9 febrero, p. 1.

${ }^{90}$ La Paz de Murcia, XV (1872), no 4614, 12 octubre, p. 1. Véase el por qué de esta desconfianza en: La Paz de Murcia, XIV (1871), $\mathrm{n}^{\mathrm{os}}$ 4154, 30 abril, p. 1 y 4155, 2 mayo, p. 1, así como en La Ilustración Murciana, I (1871), $\mathrm{n}^{\circ}$ 13, 4 mayo, pp. 6-7.

${ }^{91}$ La Paz de Murcia, XVI (1873), no 4688, 18 febrero, p. 1.

${ }^{92}$ Los anuncios de las subastas fueron publicados en: La Paz de Murcia, XVI (1873), n 4709, 28 febrero, p. 1; 4703, 4 marzo, p. 1. El Leg. 595 del E:MUm contiene un documento en el que consta que, con fecha 11-06-1873, se arrendó el Teatro Romea a Manuel Soler Roby (único postor) por un plazo de ocho años.

${ }^{93}$ El contrato tenía una duración de un año ampliable a dos si el contratista accedía. Debía pagar una cantidad anual de 30000 reales, una fianza de 8000 reales y se comprometía a inaugurar el teatro con una "compañía dramática de primer orden": El Diario de Murcia, II (1880), nº 428, 14 julio, p. 2. Véase también El Diario de Murcia, II (1880), $\mathrm{n}^{\text {os }}$ 445, 3 agosto, p. 2 y 481, 15 septiembre, p. 2, así como La Paz de Murcia, XXIV (1881), nº 6987, 26 febrero, p. 1. 
Ayuntamiento y Soler ${ }^{94}$. A pesar de la situación, se respetaron los derechos que tenían los abonados a las localidades del teatro destruido por el incendio ${ }^{95}$.

A principios de marzo de 1881, Aguilar rescindió su contrato con el Ayuntamiento de Murcia y obligó a éste a convocar una precipitada subasta para que el Teatro Romea no permaneciera cerrado durante la temporada de Pascua. El nuevo arrendatario del teatro fue Gregorio Meseguer, quien se comprometió a dar quince funciones de ópera y otras con una compañía lírica o dramática, como expondré en los capítulos siguientes ${ }^{96}$.

Resueltas las representaciones teatrales hasta junio, el Ayuntamiento subastó el Romea por un periodo de tres años (1-07-1881 a 30-06-1884). El arriendo fue conferido a Mariano Medina ${ }^{97}$, con las siguientes diferencias respecto a casos anteriores:

1. Es el primer arrendamiento convocado para un plazo superior al año cómico. En adelante los arriendos se efectuarían por periodos de tres años, a excepción, como veremos, de las temporadas 1890-1891 y 1891-1893.

2. Las cláusulas del arrendamiento de 1881-1884 son más restrictivas y específicas que las de años anteriores e incluyen, por primera vez, una referencia expresa a la orquesta del teatro:

[...] 18. Igualmente se obliga el contratista a que las compañías dramáticas, lírico-dramáticas, líricas o coreográficas con que ha de funcionar en el teatro, reúnan todas las condiciones debidas para que la importancia artística de las mismas sea la que merece el público de esta capital y, por lo tanto, las primeras partes de aquéllas han debido trabajar con buen éxito y con igual carácter, en los principales teatros de Madrid, Barcelona, Valencia, Sevilla, Cádiz o Granada. Así mismo se obliga a contratar para dichas funciones una orquesta digna en todos conceptos de la compañía que haya de trabajar y del público ${ }^{98}$.

${ }^{94}$ Algunos detalles del pleito pueden verse en El Diario de Murcia, III (1881), no 583, 15 enero, p. 3; La Paz de Murcia, XXIV (1881), n $\mathrm{n}^{\circ}$ 7149, 24 septiembre, p. 1. En mayo de 1884, el Ayuntamiento aprobó indemnizar a Soler con 5000 pesetas y arrendarle la guardarropía del teatro por cinco años. Cada una de las partes debía asumir sus costas: La Paz de Murcia, XXVII (1884), n ${ }^{\text {os }} 7931,29$ mayo, p. 1 y 7890, 9 abril, p. 1.

95 El Diario de Murcia, II (1880), no 534, 16 noviembre, p. 1 publicó un aviso del Ayuntamiento concediendo un plazo de un mes y diez días para que los abonados reservaran sus antiguas localidades $u$ otras similares en el nuevo teatro.

${ }^{96}$ La subasta tuvo lugar el 20 de marzo de 1881. El teatro se alquiló por 1150 pesetas para toda la temporada: La Paz de Murcia, XXIV (1881), nº 7007, 22 marzo, p. 1.

${ }^{97}$ Las condiciones fueron estudiadas durante el mes de marzo de 1881: La Paz de Murcia, XXIV (1881), $\mathrm{n}^{\mathrm{o}}$ 6993, 5 marzo, p. 1 y El Diario de Murcia, III (1881), $\mathrm{n}^{\mathrm{o}}$ 619, 11 marzo, p. 2. Mariano Medina obtuvo el arrendamiento por la cantidad de 6027 pesetas anuales. Otros concurrentes y sus cantidades ofertadas anuales fueron: José Miralles (3755 pesetas), Vicente Arques (3750 pesetas) y José Martínez Illán (5555 pesetas): El Diario de Murcia, III (1881), n 651, 21 abril, p. 2. Las condiciones de arrendamiento se publicaron en La Paz de Murcia, XXIV (1881), $\mathrm{n}^{\text {os }}$ 7015, 1 abril, p. 1; 7016, 2 abril, p. 1; 7018, 5 abril, p. 1; 7021, 8 abril, p. 1 y 7022, 9 abril, p. 1. A mediados de abril, Medina solicitó al Ayuntamiento "que se le exima del arbitrio municipal que pesa sobre las entradas, con motivo de lo gravosos impuestos de toda clase que recientemente pesan sobre dichas empresas": El Diario de Murcia, IV (1882), n 945, 11 abril, p. 2.

${ }^{98}$ La Paz de Murcia, XXIV (1881), n 7022,9 abril, p. 1. Las cursivas son editoriales. 
En la normativa impuesta por el Ayuntamiento murciano en 1881, la calidad de actores y cantantes se volvió, pues, más exigente, comparada, por ejemplo, con la cláusula equivalente impuesta para el arriendo de 1871:

Las compañías que hayan de actuar en el teatro, sean dramáticas o líricas, han de estar reputados sus actores como de segundo orden al menos. Cuando un artista no correspondiera a estas condiciones a juicio de la Comisión del Ayuntamiento, el empresario viene obligado a reemplazarlo con otro de más reputación y mérito artístico, en el plazo que aquélla le designe" 99 .

La cláusula del arriendo de 1881 fue largamente debatida antes de alquilar el Teatro Romea en abril de 1884, por otro periodo de tres años (1-07-1884 a 30-06$1887)^{100}$. Desde el punto de vista musical, el arriendo de 1884 fue particularmente importante por dos motivos:

1. La gestión del teatro durante el periodo de la subasta (1884-1887) recayó en una empresa formada para esta finalidad en el seno de la asociación artístico-musical Santa Cecilia ${ }^{101}$.

2. Se formó una orquesta específica para el Teatro Romea cuyas plazas se asignaban por oposición pública, como detallaré más adelante.

A pesar de que la actividad teatral se estabilizó y de que se regularizó el sistema de arriendos con condiciones más exigentes, las empresas teatrales seguían sufriendo pérdidas económicas, a juzgar por algunos testimonios periodísticos, como éste de 1887:

Tiene razón "El Criterio": temporada teatral tan sosa como la presente, con tantas interrupciones y disgustos fuera y dentro del telón, no la hemos visto; pues si el público ha tenido razón para quejarse más de una vez, la empresa, que no ha visto concurrencia más que en las Pascuas y todos los días unos gastos de hoja que suben a tanto como la compañía, también ha tenido razón para no estar satisfecha. Preciso es que se estudien las condiciones de arriendo de modo que a las empresas les sea más llevadero el negocio y a la vez se les pueda exigir con más rigor el que las compañías

${ }^{99}$ La Paz de Murcia, XIV (1871), nº 4225, 22 julio, p. 1.

${ }^{100}$ Boletín Oficial de la Provincia de Murcia (1884), $\mathrm{n}^{\mathrm{o}}$ 217, 11 marzo, p. 4. Ninguno de los periódicos que he consultado publicaron el pliego de condiciones exigidas a los empresarios, salvo algunas referencias que he indicado en el Apéndice 2.4, en el apartado 1.4 y en el Capítulo 6.

${ }^{101}$ El 13 de abril de 1884 la sociedad Santa Cecilia aprobó formar una sociedad por acciones el Teatro Romea. Asistieron, entre otros, Mariano García, Presidente Honorario de Santa Cecilia, el licitador José María Reverte y los músicos Luis Mondéjar, Verdú, Mirete y el director del periódico La Paz de Murcia, Rafael Almazán. La propuesta fue aceptada y se acordó emitir doscientas cincuenta acciones por valor de 50 pesetas cada una. Quedaron suscritas en esta reunión cien acciones entre los cuarenta y cuatro socios asistentes: La Paz de Murcia, XXVII (1884), n ${ }^{\text {s }} 7894,15$ abril, p. 1; 7899, 20 abril, p. 1 y 7907, 30 abril, p. 1. El Diario de Murcia, VII (1885), n 1763, 1 enero, p. 2 da el día 19 de abril como fecha de acuerdo de la formación de la sociedad empresaria del teatro Romea desde en el seno de la sociedad Santa Cecilia. En junio de 1884, la directiva de la empresa arrendataria contaba con los siguientes cargos: Francisco Medina (Presidente), Rafael González Adalid (Depositario), José María Reverte (Secretario Contador), Segundo Ríos y Rafael García Serna (vocales): El Diario de Murcia, VI (1884), nº 1596, 7 junio, p. 3. En el Archivo Municipal de Murcia, Leg. 1194 (II) se conservan cinco de las acciones mencionadas (números 174 a 178) a favor de José Tortosa Tornel (dos acciones), José Cuartero Clemente, José Lorca Torrijos y Alfonso Cordova [sic] Aznar. 
no desdigan de la categoría de nuestro teatro y que los precios estén al alcance de todas las fortunas para facilitar la concurrencia con lo que aquellas ganarán como ganará el nombre de la población y se apartará a muchos otros de diferentes recreos menos convenientes.

También se hace necesario que no haya lucha en la subasta, tanto que en ella aceptaríamos lo que creemos debe perseguirse en otras que es la inteligencia de los que quieran, no el negocio, sino la intervención en esos recreos ${ }^{102}$.

Probablemente por quejas como la anterior, el Ayuntamiento mejoró las condiciones económicas del arriendo del Romea durante los tres años siguientes (1-071887 a 30-06-1890). La cantidad anual descendió un tercio respecto del arrendamiento anterior, al igual que la cuota por participar en la subasta, lo que repercutió en un incremento del número de candidatos licitadores ${ }^{103}$. El pliego de condiciones es más detallado que los anteriores: sus cláusulas se agrupan por temas y se recogen apartados especiales para la orquesta y las compañías, reguladas por primera vez en puntos distintos (véase Apéndice 2.4). Sobre los actores y cantantes se pide "que hayan actuado como tales partes principales en cualquiera de los tres años últimos en teatros de igual o superior categoría que el de esta capital"104. De la orquesta, se concreta el número de instrumentistas, los precios máximos de la orquesta por tipo de espectáculo y otras exigencias, como la presencia en funciones no sólo líricas (también dramáticas o de otra índole) de un sexteto "que deberá formase con los profesores principales de la misma y con otros dos profesores notables, uno de piano y otro de armonio"

El arriendo de 1887-1890 fue concedido a José María Amorós Vázquez. Sin embargo, los escasos beneficios económicos por la falta de público a los espectáculos no compensaban los gastos de arriendo del Romea. En enero de 1888, Amorós solicitó al Ayuntamiento una rescisión de su contrato sin la pérdida de la fianza. Fue autorizada y el teatro se cedió a Anselmo Arques ${ }^{106}$.

A pesar de la exigencia de contratar compañías con buena reputación se dieron muchas quejas sobre la escasa calidad de actores y cantantes, comportamientos irrespetuosos del público, fluctuación en la asistencia y, en general, irregularidad de la actividad escénica, manifiesta en periodos en los que el teatro permaneció cerrado ${ }^{107}$. La

${ }^{102}$ La Paz de Murcia, XXX (1887), nº 8103, 27 enero, p. 1. Las cursivas son editoriales.

${ }^{103}$ Boletín Oficial de la Región de Murcia (1887), nº 259, 1 mayo, p. 4. La subasta se celebró el 30 de mayo de 1887 en el salón de sesiones del Ayuntamiento. Se presentaron doce candidatos: Juan Hernández Guijarro, Mariano Medina, José María Reverte, José María Fernández Albaladejo, Andrés Gabardo, Anselmo Arques, Rafael García Serna, Mariano Barquero, José Gil López Prieto, Francisco Ríos, Antonio Romero Palarea y el ganador José María Amorós Vázquez: La Paz de Murcia, XXX (1887), nº 8213, 31 mayo, p. 1; 8217,4 junio, p. 1.

${ }^{104}$ Cláusula número 36, "De las condiciones que han de reunir los actores": La Paz de Murcia, XXX (1887), $\mathrm{n}^{\mathrm{o}} 8205,22$ mayo, p. 1.

105 Cláusula número 35, "De la orquesta": La Paz de Murcia, XXX (1887), nº 8204, 21 mayo, p. 1.

${ }^{106}$ El Diario de Murcia, X (1888), n ${ }^{\text {os }} 3220,26$ enero, p. 3 y 3223, 31 enero, p. 1.

107 En la sesión plenaria del Ayuntamiento de Murcia del 12-12-1887 el concejal Ruiz "llamó la atención sobre las compañías que vienen funcionando en el teatro Romea y excitó a la presidencia para que llame al arrendatario [...]. El señor López López hizo notar que no se debe apremiar de tal manera al arrendatario para que cumpla la cláusula que trata de la categoría que han de tener las compañías que en Romea actúen, porque el público no responde": La Paz de Murcia, XXX (1887), n 8307, 14 diciembre, p. 1. 
escasa rentabilidad del Romea fue, de nuevo, subrayada por la prensa en 1887 y achacada a la mala calidad de los espectáculos:

\section{SIN TEATRO}

Tenemos un magnifico teatro propiedad del Ayuntamiento, protegido por el mismo, con su orquesta municipal y todos los demás enseres artísticos para espectáculos de esta índole y, sin embargo, no tenemos nada porque en él no se dan funciones $[\ldots]$.

¿Y esto por qué es? Muy sencillo: porque siguiendo el teatro de propiedad del Ayuntamiento, para regodeo de unos cuantos, vemos pésimas compañías, mientras la municipalidad se ve privada del capital que aquél representa.

Nosotros recordamos que sin la protección del Ayuntamiento se han visto aquí muy buenos artistas y se han sostenido largas temporadas teatrales.

¿Es que hay ahora menos afición al teatro que antes?

Creemos que no. Lo que resulta es que traen cómicos de la legua, y la gente, y en esto hace bien, no quiere hacer el sacrificio de un abono para ver y oír vulgaridades.

Cuando el ayuntamiento no imponía los gravámenes que hoy impone y se traían buenas compañías, entonces estaba siempre el teatro lleno y nosotros recordamos que con Calvo, Vico y Tamberlik nunca ha perdido la empresa.

Quedamos en que el Ayuntamiento tiene amortizado ahí un capital para proteger el arte y resulta que solamente en Pascua vemos una mala compañía de mala muerte que algunas veces se deja hasta los muebles empeñados, pues aquí también se ha aprendido á guillotinar artistas ${ }^{108}$.

La cuestión se hizo más crítica a principios de la temporada 1887-1888, cuando varios periódicos de la ciudad retomaron la idea de vender el teatro a una empresa para que gestionara su explotación ${ }^{109}$. No era la primera vez que se planteaba la medida pero la idea fue apoyada por el Ayuntamiento a partir de una moción presentada por el concejal Ricardo López López ${ }^{110}$. La cuestión se debatió en una sesión municipal con sólo tres concejales presentes (de cuarenta y tres), que aprobaron por unanimidad la moción ${ }^{111}$. En La Paz de Murcia, se criticó esta decisión y se justificó la escasa rentabilidad del teatro por las obras de reedificación posteriores al incendio de 1877:

Romea no es una carga para el Ayuntamiento. Esto lo prueban las condiciones del arrendamiento y los gastos ordinarios a que tiene que atender el municipio. Si hoy gasta más es porque ni el edifico está concluido ni libre de trabas pero, una vez concluidas las obras y pagados los accionistas, cuando sólo haya que atender a la conservación, seguro y demás gastos ordinarios, esos salen con holgura del arrendamiento. ¡Ojalá pudiera ser una carga para el Ayuntamiento porque este en vez de arrendarlo lo diese libre o subvencionado, pero esto no lo permite la ley!

${ }^{108}$ Las Provincias de Levante, II (1887), no 297, 4 octubre, p. 1.

${ }^{109}$ Según La Paz de Murcia, XXX (1887), no 8233, 18 septiembre, p. 1 se posicionaron a favor Las Provincias de Levante y El Noticiero y, en contra de la venta, La Paz de Murcia y El Criterio.

${ }^{110}$ La moción presentada por López estimaba que con el producto de la venta del teatro se pagaría a los accionistas del teatro "y con el sobrante a la construcción de un matadero y una lonja": La Paz de Murcia, XXXI (1888), no 9459, 21 marzo, p. 1.

${ }^{111}$ La sesión dio lugar a un interesante artículo titulado "La venta de Romea", La Paz de Murcia, XXXI (1888), no 9459, 21 marzo, p. 1 que he transcrito en el Documentario. El periodista cuestiona la validez de las decisiones tomadas por el Ayuntamiento de Murcia en sesiones municipales con escaso número de concejales y reflexiona sobre los inconvenientes legales de vender el teatro. 
Las razones en que se apoyan los que piden la venta son infundadas por hoy y es de esperar lo sean lo mismo en lo sucesivo $[\ldots]^{112}$.

En mayo de 1888, el Ayuntamiento de Murcia desestimó finalmente la moción de López y decidió que el Teatro Romea no sería vendido ${ }^{113}$. Sin embargo, los continuos problemas generados con las compañías y con los arriendos hicieron que las autoridades murcianas se plantearan una nueva fórmula de gestión del coliseo en 1890 (coincidiendo con la finalización del contrato de alquiler de Anselmo Arques) ${ }^{114}$. Pretendían "cortar abusos y extirpar todo lo malo que los arriendos había[n] hecho abusivamente" "Se suprimieron las subastas por años cómicos completos y se acordó contratar directamente por parte del Ayuntamiento las compañías teatrales (o a las empresas que las representaban). El Ayuntamiento exigía a las compañías contratadas el pago de 50 pesetas diarias ${ }^{116}$. La prensa desconfió de este sistema y de su correcta gestión por parte de las autoridades murcianas, como muestra este comentario de agosto de 1890 :

Nuestro teatro Romea parece lo pretenden una compañía de zarzuela cómica, otra de zarzuela seria y la señora Nevada para unas cuantas funciones de ópera. Y a todo esto no se reúne la Comisión de Teatro cuando ahora es la época de los ajustes y esos solicitantes, al ver la calma y parsimonia que gastan nuestros ediles, pueden irse a otros puntos donde los atiendan más pronto.

¿Y para éstos se ha querido no arrendar el teatro? ¿No sucederá con esto que a última hora venga aquí lo que no encuentre colocación en otra parte, o lo que sea rechazado de alguna, y haya que admitirlo si no ha de estar cerrado el coliseo? ${ }^{117}$.

También en 1890 el Ayuntamiento decidió suprimir la orquesta del teatro (formada por oposición en 1884) y anular las plazas en propiedad de los músicos de la misma, lo que originó un largo debate periodístico del que hablaré más adelante ${ }^{118}$. La

${ }^{112}$ La Paz de Murcia, XXXI (1888), nº 9460, 22 marzo, p. 1. En marzo de 1888, se incorporaron al debate El Diario de Murcia y El Noticiero (al menos en esta ocasión) contrarios a vender el Romea: El Diario de Murcia, X (1888), n ${ }^{\text {o } 3269, ~} 24$ marzo, p. 1 y El Noticiero citado por La Paz de Murcia, XXXI (1888), n 9466, 29 marzo, p. 1. La cuestión enfrentó a Las Provincias de Levante y La Paz de Murcia. Véase, como ejemplo: La Paz de Murcia, XXXI (1888), nos 9471, 5 abril, p. 1; 9473, 7 abril, p. 1 y 9474, 8 abril, p. 1 .

${ }^{113}$ La Paz de Murcia, XXXI (1888), no 9517, 30 mayo, p. 1. Según Crespo, El Teatro Romea, p. 210, se tuvo en cuenta a la opinión pública representada por la prensa murciana. Véase también el artículo anónimo "La campaña municipal”, Las Provincias de Levante, VII (1892), no 1854, 1 diciembre, p. 1, transcrito en el Documentario, en el que se analizan los beneficios y gastos del Teatro Romea durante un año, las repercusiones de su venta y la influencia de la reciente apertura del teatro privado Circo de Villar en noviembre de 1892 .

${ }^{114}$ El cierre de la temporada 1889-1890 mereció el siguiente balance de la prensa: "concluyen las funciones con un arrendatario que no funciona por su cuenta sino que subarrienda y, además de las condiciones a que viene obligado con el Ayuntamiento, pone otras a que se tienen que subyugar las compañías que quieran actuar en Murcia”: La Paz de Murcia, XXXIII (1890), nº 11051, 12 junio, p. 1.

${ }^{115}$ La Paz de Murcia, XXXIII (1890), no 11117, 31 agosto, p. 1.

${ }^{116}$ La Paz de Murcia, XXXIII (1890), nº 11115, 29 agosto, p. 1.

${ }^{117}$ La Paz de Murcia, XXXIII (1890), no 11110, 23 agosto, p. 1.

${ }^{118}$ La junta de accionistas del teatro, en mayo de 1890 estuvo compuesta por Diego Salmerón, Conde de Roche, Mariano Lanzarote, José Díaz Cassou y José María Ibáñez García: La Paz de Murcia, XXXIII (1890), nº 11027, 13 mayo, p. 4. El acuerdo citado fue tomado en la sesión del Ayuntamiento del día 26 de 
temporada 1890-1891 comenzó el 31 de agosto con la compañía dramática de Antonio Vico y un sexteto musical que suplía a la orquesta. Las actuaciones se prolongaron hasta el 22 de septiembre de 1890 , pero entonces el teatro quedó cerrado ${ }^{119}$, ya que no se aceptó la propuesta del maestro director y empresario Francisco Gueri. Las frustradas negociaciones entre el Ayuntamiento de Murcia y el citado empresario, pusieron de manifiesto algunos problemas del nuevo sistema de gestión del teatro:

[...] La comisión especial ha venido antes tratando con el maestro director y empresario don Francisco Gueri, que pedía el teatro desde octubre hasta la Cuaresma y que ofreció actuar hasta Reyes con una compañía de zarzuela dramática o de zarzuela cómica, cuyas listas presentó estrenando las obras modernas; después de Reyes y hasta carnaval, con una compañía de zarzuela seria buena; y, en Cuaresma, con una de ópera que estrenaría Carmen y Los amantes de Teruel.

No se le admitieron las listas para la primera de estas tres temporadas y se le dijo que contaría con el teatro si presentaba una compañía de zarzuela seria y que cuanto mejor fuera ésta más barato sería el precio.

El señor Gueri hizo entonces la siguiente proposición: traer una buena compañía de zarzuela seria con segundas partes numerosas capaces para la zarzuela cómica; dar tres funciones en semana en días alternados con zarzuela seria [y] en los restantes zarzuela cómica; abrir tres abonos, uno general o diario, otro especial a la zarzuela seria y otro también especial a la zarzuela cómica. De este modo habría espectáculos para todos los gustos y todos los bolsillos, no se cansaba a los abonados con las repeticiones, pues sólo las sufrirían los que por su gusto se abonasen a diario llevando la ventaja de rebaja en el precio de su abono sobre el de los especiales, y habría lugar para los ensayos de la obras.

Esta proposición fue admitida el sábado por la comisión especial, lo cual lo escribió su representante para que viniera y, cuando estaba al venir y formando ya el señor Gueri su compañía, que ofrecía sería del agrado del inteligente público murciano, su representante ha tenido que telegrafiarle que no venga y que suspenda todo por el cambio de acuerdo en la última sesión de la comisión especial celebrada el martes. No ha habido, sin embargo, inconsecuencia. Lo que ha habido es lo que sucede muchas veces en las sesiones supletorias: que algunos de los que acordaron el sábado admitir en principio las últimas proposiciones del señor Gueri, en virtud de cuyo acuerdo su representante le pudo escribir que viniese a contratar y ultimar, no fueron los mismos que en absoluto se reunieron el martes, los cuales además estaban ignorantes del aviso dado al representante del señor Gueri y que éste trasmitió con suma diligencia. $[\ldots]^{120}$.

Para el comienzo de la temporada teatral 1890-1891 se cedió el teatro al empresario José Muñoz y a la compañía de zarzuela de Daniel Banquells ${ }^{121}$, que actuó hasta enero de 1891, aunque con desigual asistencia de público:

mayo de 1890: La Paz de Murcia, XXXIII (1890), nº 11039, 28 mayo, p. 1. Véase también, La Paz de Murcia, XXXIII (1890), nos 11038, 27 mayo, p. 1; 11114, 28 agosto, p. 1 y 11117, 31 agosto, p. 1.

${ }^{119}$ A juzgar por los comentarios de La Paz de Murcia la concurrencia durante la temporada 1890-1891 fue escasa: "De butacas hubo gran venta pero el bono de las personas conocidas y que concurren a diario es poco": La Paz de Murcia, XXXIII (1890), n 11118, 2 septiembre, p. 1.

${ }^{120}$ La Paz de Murcia, XXXIII (1890), no 11137, 25 septiembre, p. 1. Las cursivas son editoriales.

${ }^{121}$ Muñoz encabezaba una sociedad formada por nueve socios murcianos. Ofertó dar entre 25 y 30 representaciones mensuales de zarzuela seria pagando al Ayuntamiento 35 pesetas por función. La nueva empresa abrió un abono de 28 funciones con la compañía de zarzuela de Daniel Banquells con funciones por turnos. En ella tomaron parte varios murcianos, como los tenores Barrera y Barrenas: La Paz de Murcia, XXXIII (1890), no 11137, 25 septiembre, p. 1. Véase también, Crespo, El Teatro Romea, p. 256. El 9 de octubre de 1890 la Comisión de Teatro volvió a reunirse con Gueri y ultimaron un convenio de cesión 
[...] Esto justifica lo que más de una vez hemos dicho y es que una temporada larga con un mismo espectáculo, con repeticiones, no la resiste Romea, pues sea el motivo el que fuere, más o menos justificado, no existe el afán en las clases acomodadas que se notó al inaugurar el teatro, que se disputaban las localidades y resultó chico el local.

Por eso una temporada larga se habría llevado bien como se propuso al Ayuntamiento, con un espectáculo mixto, mitad de funciones de zarzuelas serias y otra mitad de funciones por horas, alternando, y de ese modo se habría facilitado mayor ingreso en taquilla por la concurrencia de personas que ahora no siempre pueden ir. $[\ldots]^{122}$.

El arrendamiento de la segunda temporada 1890-1891 tampoco estuvo exento de problemas. Actuaron una compañía de fantoches de Narvón, la compañía de ópera italiana del empresario Francisco Gueri y la dramática de Ricardo Calvo. La compañía de ópera fracasó, como se pone de relieve en el siguiente testimonio:

La comisión mixta del teatro Romea, en vista del horrible fracaso de la compañía de ópera y celosa del buen hombre de esta ciudad y de su coliseo, se reunió anteayer tarde, acordando dirigir una enérgica comunicación al empresario señor Gueri, en la que le previenen que con suspensión del espectáculo, modifique en el plazo de cinco días el cuadro de compañía presentando los artistas anunciados y otros de su categoría, el que trascurrido sin hacerlo, procederá la comisión a rescindir el contrato de arrendamiento con pérdida por parte del arrendatario de las cantidades que tiene adelantadas. La primera representación de ópera reveló de qué modo el señor Gueri burlaba las legítimas aspiraciones de los abonados y del público, burla que la citada comisión no podía consentir y por ello le enviamos nuestro aplauso ${ }^{123}$.

El Ayuntamiento rescindió el contrato de Gueri y cedió el Romea al empresario José Muñoz Hernández, con la prohibición expresa de hacer funciones por horas ${ }^{124}$.

Dado que el sistema de administración del teatro tampoco fue beneficioso para el Ayuntamiento, en junio de 1891 se volvió al sistema de arrendamiento a un empresario por subasta pública. El teatro se ofertó por un periodo de dos años (1-07-1891 a 30-061893) y una cantidad mínima de 20.000 pesetas (10.000 pesetas por año) ${ }^{125}$. El nuevo arriendo de 1891 suprimió los gastos del seguro contra incendios, la construcción de un decorado y la función a beneficio del Ayuntamiento, ya que encarecían el gasto anual:

del Romea para la temporada de Pascua con una compañía de ópera: La Paz de Murcia, XXXIII (1890), ${ }^{\circ}$ 11150,10 octubre, p. 1.

${ }^{122}$ La Paz de Murcia, XXXIII (1890), nº 11199, 6 diciembre, p. 1. Tal y como se explica en la cita, el Ayuntamiento fue muy reticente a autorizar las funciones por horas, debido a la larga lista de incidentes y escándalos producidos en la sala en temporadas anteriores, como veremos en el capítulo correspondiente.

${ }^{123}$ El Diario de Murcia, XIII (1891), n 4293, 1 abril, p. 3. Véase también, La Paz de Murcia, XXXIV (1891), no 11292, 31 marzo, p. 1.

${ }^{124}$ Actuaron la compañía de zarzuela dirigida por Pablo Gorgé, bajo la dirección escénica de Andrés López, desde mediados de abril a principios de mayo de 1891, y la compañía dramática de Rafael Calvo, durante el resto del mes de mayo.

${ }^{125}$ El arrendamiento fue aprobado en sesión ordinaria de 3-06-1891: El Diario de Murcia, XIII (1891), $\mathrm{n}^{\circ}$ 4346, 4 de junio, p. 1. Los candidatos tenían que ingresar, como cuota fija por participar, el $5 \%$ de las 10.000 pesetas: El Diario de Murcia, XIII (1891), $\mathrm{n}^{\mathrm{o}} 4350,9$ junio, o. 3. 
[...] Respecto al precio del arriendo, ya nosotros demostramos cuando el primer anuncio que, bien examinados, resultaba más barato que el de las dos últimas temporadas en que tuvo este arriendo empeñados competidores; porque entonces, si bien el precio era sólo de seis mil pesetas, tenía el arrendatario que pagar además el seguro de incendios y hacer anualmente una decoración de valor de dos mil pesetas y dar una función de beneficio que importase otras mil, y todos los trastos escénicos que construyese nuevos habían de quedar para el teatro, y podía entrar gratis una porción de gente y se imponía el contratar a la orquesta como una obligación; mientras que ahora, por sus diez mil pesetas anuales, el arrendatario es el dueño de su teatro para explotarlo libremente como un negocio, sin más trabas que las atenciones debidas a la cultura del público. $[\ldots]^{126}$.

La primera subasta de 1891 quedó desierta por falta de postores (27-06-1891) ${ }^{127}$. La segunda subasta (31-07-1891) contó únicamente con un candidato, el impresor Juan Hernández Guijarro, que ofertó 19.167 pesetas (es decir, la cantidad mínima establecida menos la parte correspondiente al mes de julio que ya había transcurrido) ${ }^{128}$. Sin embargo, el Ayuntamiento no aceptó la oferta y convocó una tercera subasta en la que habían de pagarse 18.750 (20.000 pesetas iniciales menos 1250 pesetas correspondientes al mes y medio perdido) ${ }^{129}$. La cuestión siguió sin resolverse y el único licitador, Hernández Guijarro, pidió una reforma de las condiciones del contrato. El Ayuntamiento denegó la petición y la tercera subasta quedó desierta ${ }^{130}$. Ya fuera de subasta, Hernández volvió a solicitar ser el arrendatario del teatro con las siguientes condiciones: pagar 18.750 pesetas por el total del arriendo y efectuar los pagos en el segundo mes de cada trimestre, aceptando todas las demás cláusulas del pliego de condiciones de la subasta ${ }^{131}$. El Ayuntamiento de Murcia lanzó una contraoferta: que Hernández Guijarro pagara 18.750 pesetas con una fianza de 2500 pesetas, manteniendo los restantes detalles de la oferta del empresario. En este punto se llegó a un acuerdo y el Ayuntamiento le entregó el Romea el 29 de agosto de $1891^{132}$. Poco después, el empresario solicitó poder representar funciones por horas, alternándolas con funciones completas:

El contratista del teatro Romea, nuestro amigo don Juan Hernández, en vista de las dificultades que se tocan para obtener una compañía absolutamente de trabajo serio de zarzuela ha presentado un escrito al Ayuntamiento, pidiendo autorización para dar funciones por horas alternadas con otras enteras de trabajo serio con una buena compañía.

${ }^{126}$ El Diario de Murcia, XIII (1891), no 4391, 28 julio, p. 1. Véase también el anuncio que se publicó en el Boletín Oficial de la Provincia de Murcia, (1891), nº 18, 21 julio, p. 4.

${ }^{127}$ El Diario de Murcia, XIII (1891), nº 4367, 28 de junio, p. 3.

${ }^{128}$ El Diario de Murcia, XIII (1891), n ${ }^{\text {os }} 4381,16$ julio, p. 1; 4391, 28 julio, p. 1; $\mathrm{n}^{\circ} 4394,31$ julio, pp. 1 y 3 y 4395,1 agosto, p. 1 .

${ }^{129}$ El Diario de Murcia, XIII (1891), nº 4399, 6 agosto, p. 1.

${ }^{130}$ Boletín Oficial de la Provincia de Murcia (1891), nº 44, 20 agosto, p. 4.

${ }^{131}$ El Diario de Murcia, XIII (1891), n 4409, 18 agosto, p. 1.

${ }^{132}$ El Diario de Murcia, XIII (1891), n 4411, 20 agosto, pp. 1 y 3. Según El Diario de Murcia, XIII (1891), n ${ }^{\circ} 4413,22$ agosto, p. 1, Hernández Guijarro iba a gestionar el teatro junto a los socios José María Godínez (presidente de la empresa-sociedad arrendataria), Fernando Verdú, Germán Andreu, José Antonio Godínez y Mariano Medina Badino. 
No dudamos que el Ayuntamiento comprendiendo la razón que asiste al peticionario y de que no es una novedad lo que ya impera en todas partes, inspirándose en la equidad y conveniencia le autorizará lo que pide ${ }^{133}$.

Parece que, de momento, Hernández Guijarro no obtuvo el permiso solicitado, ya que durante toda la temporada 1891-1892 continuaron las peticiones en la prensa para que el Ayuntamiento autorizase la programación de funciones por horas ${ }^{134}$. En julio de 1892, la Comisión del Teatro emitió un informe favorable a la implantación de dichas funciones aunque con cuatro condiciones: 1) que las compañías fuesen dignas del público; 2) que el arrendatario asumiese las multas impuestas por el alcalde, en caso de infracciones; 3) que aumentara el número de aposentadores en las localidades altas o en los lugares indicados por la Comisión o el alcalde; y 4) que se responsabilizara de las roturas o deterioros producidos violentamente en el local ${ }^{135}$. Las condiciones mencionadas reflejan cuáles fueron precisamente los problemas que tuvo que afrontar el Ayuntamiento murciano desde la implantación de las funciones por horas ${ }^{136}$.

A principios de junio de 1893, el Teatro Romea fue arrendado por un periodo de tres años (1-07-1893 a 30-06-1896) a Mariano Ríos Guillamón ${ }^{137}$. La reinauguración del Teatro Circo de Villar como local de espectáculos teatrales, en octubre de 1893, estimuló la competencia entre los dos teatros murcianos:

[...] Como no lleguen a entenderse las empresas de uno y otro teatro o, si no se entienden, al menos que no se perjudiquen, difícilmente tirarán las compañías que a cualquiera de los dos vengan la temporada de invierno, porque la experiencia ha demostrado que dos teatros funcionando a la vez en esta ciudad se perjudican irremediablemente hasta donde las empresas no pueden resistir $[\ldots]^{138}$.

${ }^{133}$ La Paz de Murcia, XXXIV (1891), nº 11425, 11 septiembre, p. 3. Las cursivas son editoriales.

${ }^{134}$ E:MUm, AC 6-07-1894, fol. 304r-v. La Paz de Murcia defendió en numerosas ocasiones la programación del repertorio en funciones por secciones (u horas): "El teatro debe funcionar a diario ya para que el Ayuntamiento saque el gasto de su conservación, ya para que las empresas puedan abonar el arrendamiento, y está probado que ni los artistas que hay hoy, ni lo que se escribe, ni el público, dan medios para eso más que en las funciones por secciones": La Paz de Murcia, XXXIV (1891), $\mathrm{n}^{\circ}$ 11481, 16 noviembre, p. 1. Véanse otros ejemplos en: La Paz de Murcia, XXXV (1892), n ${ }^{\text {os }} 11552,7$ marzo, p. 1; 11553, 8 marzo, p. 1; 11558, 14 marzo, p. 2 y 11595, 30 de abril, p. 1; El Diario de Murcia, XIV (1892), ${ }^{\text {os }}$ 4549, 30 enero, pp. 1-2 y 5018, 10 junio, p. 3.

${ }^{135}$ E:MUm, AC 27-07-1894, fol. 334r-v.. Véase también Crespo, El Teatro Romea, p. 304.

${ }^{136}$ La segunda y última temporada del arriendo (1892-1893) transcurrió con grandes éxitos para la empresa. Prueba de ello fue la comida organizada en el Hotel Universal por Hernández Guijarro para celebrar, junto a la prensa y amigos el "feliz resultado obtenido por la empresa en su liquidación": El Diario de Murcia, XV (1893), nº 5963, 22 junio, p. 2.

${ }^{137}$ El Diario de Murcia, XV (1893), n $\mathrm{n}^{\mathrm{o}}$ 5947, 3 junio, p. 2. Ríos fue, en realidad, el único candidato que cumplió los requisitos legales (la otra propuesta, de Rafael Camacho, fue desestimada por no cumplirlos). Ríos ofertó 40.060 pesetas (frente a la cantidad mínima fijada por el Ayuntamiento en 30000 pesetas), un $5 \%$ del producto líquido anual y la obligación de costear tres decorados al final de cada año.

${ }^{138}$ El Diario de Murcia, XVI (1894), nº 6346, 28 julio, p. 1. 
El resultado económico del Teatro Romea durante el primer año cómico 18931894 fue negativo ${ }^{139}$. Ríos Guillamón dirigió un escrito al Ayuntamiento solicitando una rebaja del $50 \%$ de lo que había de pagar y autorización para dar funciones por horas, o bien, la rescisión de su contrato ${ }^{140}$. El Ayuntamiento rescindió el contrato y convocó una nueva subasta, a pesar de que algún periódico como La Paz de Murcia pronosticó dificultades para lograr un nuevo arrendatario ${ }^{141}$. No hubo ofertas ${ }^{142}$ y el Ayuntamiento acordó devolver el expediente a la Comisión Mixta para que reformase las condiciones de subasta para una nueva adjudicación. Se convocó una segunda subasta tras la cual, el Teatro Romea fue adjudicado a Ramón Sierra ${ }^{143}$.

\subsubsection{Las temporadas teatrales, los abonos y las funciones}

En Murcia, como en el resto del país, los espectáculos teatrales estaban sujetos a la normativa legal vigente en cada momento ${ }^{144}$. La actividad teatral se organizaba en años

${ }^{139}$ A principios de junio de 1894, el empresario debía al Ayuntamiento 2225,57 pesetas en concepto de pagos correspondientes a abril y mayo: $E$ : $M U m$, AC 4-06-4894, fols. 199v-202r: 201r-202r.

${ }^{140}$ Ibid., fols. 199r-201r. El Ayuntamiento consideró que no era posible rebajar la cantidad estipulada en el contrato de arrendamiento aunque, según acuerdo de 9-04-1894, estaba autorizado a dar funciones por horas. Por votación nominal, se acordó rescindir el contrato a Ríos Guillamón y seguir con el "procedimiento ejecutivo" para cobrar la deuda: La Paz de Murcia, XXXVI (1894), n 12709, 5 junio, p. 3.

${ }^{141}$ E: MUm, AC 27-06-1894, fol. 234v. Véanse las discusiones sobre las cláusulas de arrendamiento en E:MUm, AC 4-07-1894, fols. 243r-245r y en AC 11-07-1894, fols. 255r-256r. Uno de los puntos más debatidos fue el establecimiento del número de funciones que el empresario estaría obligado a dar durante el periodo de arriendo. La Paz de Murcia, XXXVI (1894), n' 12710, 6 junio, p. 1 afirmó rotundamente: "La cuestión teatro se ha echado a perder en Murcia. Las dos empresas han perdido en el año cómico que fina: la de Romea y la del Circo. [...] Tenemos dos teatros y estamos expuestos a estar peor que si no tuviéramos ninguno". La subasta fue convocada para el 20 de junio de 1894, por el tiempo que restaba hasta el 30 de junio de 1896, bajo la cantidad mínima de 20278 pesetas y con sujeción a las demás condiciones que rigieron el contrato rescindido. Las proposiciones, como era habitual, se realizarían en pliegos cerrados, previo depósito del 5\% de la cantidad establecida y una fianza definitiva del $20 \%$ de la subasta: El Diario de Murcia, XVI (1894), nº 6297, 10 de junio, p. 3.

${ }^{142}$ El periódico insistió de nuevo: "El Teatro Romea no tuvo postor en la subasta [...] por haber dado lugar a que suba el tipo con las valentías de los últimos arrendatarios [...]. Por tanto, bueno será que vaya pensando en administrarlo directamente y en elegir persona que se encargue de esa administración con celo e interés": La Paz de Murcia, XXXVI (1894), n 12726, 23 junio, p. 1.

${ }^{143}$ La segunda subasta tuvo lugar el 27 de julio de 1894 por una cantidad mínima de 14.000 pesetas. El acto fue presidido por el concejal Juan Piqueras del Molinero. Los candidatos y sus ofertas fueron: Ramón Sierra, 16251,52 pesetas y acogerse a las condiciones del arriendo; Anselmo Arques, 17070 pesetas, restaurar un decorado y construir otro nuevo, celebrar una función a beneficio de la tienda asilo, otra a beneficio del "Asilo de ancianos, arrepentidas y Siervas de Jesús", dar cada año 170 representaciones aunque la fianza ( $20 \%$ de la cantidad ofertada) sería satisfecha por años separados. Fue desestimada por no sujetarse a las condiciones establecidas; Roque Molera, 16027,20 pesetas; y Juan Hernández Guijarro, 14.000 pesetas y si se declarase desierta 12.000 (declarada inadmisible por no haber realizado el depósito de participación): La Paz de Murcia, XXXVI (1894), $\mathrm{n}^{\circ} 12730,28$ junio, p. 2. En el transcurso de estas licitaciones, el alcalde autorizó a José Muñoz a dar de tres a seis funciones con la compañía lírico dramática de Carlos Servat abonando el 7\% de los ingresos de taquilla y a José Sánchez Palma, con una compañía de "verso, cante y baile". Sobre arriendos posteriores del Teatro Romea, fuera del marco cronológico de esta investigación, véase Crespo, El Teatro Romea, pp. 371 y 375.

${ }^{144}$ Los Decretos Orgánicos de 7-02-1849 y del 28-07-1852 regulaban la actividad teatral, con vigencia durante la época isabelina, en múltiples aspectos: construcción de teatros, funciones de la Junta de Censura de Madrid y de los censores provinciales nombrados por los responsables políticos y gobernadores civiles, 
cómicos que comenzaban, por lo general, en septiembre (u octubre) y se prolongaban hasta junio (las compañías, previa autorización, también podían trabajar en julio y agosto). Cada año cómico constaba de dos temporadas, antes y después de la Cuaresma: la primera temporada (denominada en ocasiones, "temporada de invierno") concluía antes del periodo cuaresmal. Tras éste, comenzaba la segunda que se prolongaba hasta junio o julio $^{145}$. Las dificultades para arrendar el teatro y contratar compañías, así como la frecuente rescisión de contratos, retrasaron y/o acortaron en ocasiones la duración de las temporadas ${ }^{146}$. También influían otros factores, como las crisis económicas, las epidemias y el contexto político. En 1866 se inició en España una crisis económica que afectó a muchas ciudades españolas, entre ellas Murcia, y que tuvo su momento más crítico en los años $1867-1868^{147}$. La fragilidad de la economía afectó enormemente a la actividad teatral. En mayo de 1867, La Paz de Murcia afirmaba: "Las entradas se resienten, con grave perjuicio de la empresa, por la crisis metálica que se viene atravesando, pues no a otra causa podemos atribuir el no ver más llenas las galerías alta y baja y el paraíso, que

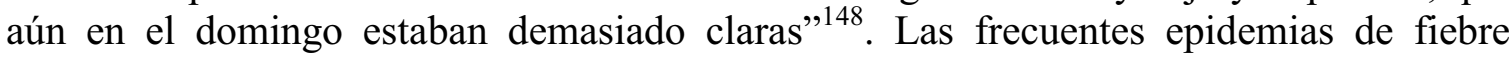
amarilla, cólera y afecciones endémicas obligaron en más de una ocasión a cerrar las puertas del teatro, retrasando el comienzo de las temporadas. Así ocurrió en 1865-1866 y $1870-1871^{149}$.

El contexto político influyó de manera determinante en la actividad teatral de Murcia a finales de los sesenta y principios de los setenta del siglo XIX. La revolución de septiembre de 1868, iniciada por el unionista almirante Topete en Cádiz y que puso fin al reinado de Isabel II, originó sublevaciones populares en muchas ciudades de España. En Murcia, el Gobernador Quiñones de León decretó el estado de guerra. La temporada de

las temporadas teatrales, la supresión de los impuestos a favor de los establecimientos de Beneficencia, las condiciones de arrendamiento de locales, la reserva de localidades para las autoridades civiles y militares, los derechos a percibir por los autores literarios y musicales, la hora de comienzo de los espectáculos y las sanciones a los actores y/o empresarios por inmoralidades, entre otros muchos. Entre 1833 y 1874 había dos niveles de actividad dramática y lírica: el teatro público profesional (cuyo funcionamiento estaba reglamentado por la legislación señalada) y el teatro de aficionados en casas particulares y sociedades recreativas. Sobre el marco legal y el ordenamiento jurídico de los espectáculos teatrales, véase: Mas, $E l$ teatre, pp. 19-44; Sirera, El Teatre, pp. 141-149 y Lloret, El teatre, p. 26.

${ }^{145}$ Salvo alguna excepción, ninguna de las compañías estudiadas actuaron durante el mes de agosto. A partir de los años ochenta, fue habitual que durante los días de feria (primera quincena de septiembre) actuara una compañía, como se verá en los capítulos siguientes.

146 Veamos algunos ejemplos. La compañía de Hermenegildo Manzanedo actuó en el teatro Provisional de Murcia desde finales de octubre de 1859. La compañía llegó a la ciudad en circunstancias difíciles porque una epidemia de cólera había asolado la ciudad durante los meses de agosto y septiembre. Como consecuencia, la temporada teatral comenzó con retraso. El miedo al contagio y los exigentes lutos de la época provocaron, además, un descenso del número de espectadores, al menos en las primeras representaciones de la compañía. En La Paz de Murcia, II (1859), n 524, 30 octubre, pp. 2-3 se llegó a proponer que el Ayuntamiento subvencionara a la empresa con una cantidad reembolsable si los beneficios eran superiores. De esta forma, se evitaba el cierre de teatros y se proporcionaba diversión y evasión entre los murcianos.

${ }^{147}$ Pérez y Lemeunier, El proceso, pp. 339-340.

${ }^{148}$ La Paz de Murcia, X (1867), nº 2887, 17 mayo, p. 2.

149 En esas temporadas, las representaciones comenzaron el 24 de noviembre de 1866 y el 1 de diciembre de 1870, respectivamente. En el primer caso, una epidemia de cólera devastó la ciudad durante el verano. En el segundo, el grave brote de fiebre amarilla en Alicante provocó el miedo al contagio entre la población murciana. Véase, La Paz de Murcia: VIII (1865), $\mathrm{n}^{\mathrm{o}} 2368,25$ noviembre, p. 1; XIII (1870), $\mathrm{n}^{\text {os }}$ 4007, 30 octubre, p. 1 y 4030, 27 noviembre, p. 1. 
actuaciones en el Teatro de la Soberanía Nacional de Murcia en 1868-1869 comenzó con retraso (10-11-1868) y con un público escaso y temeroso por la situación política ${ }^{150}$.

Como comenté anteriormente, la gestión del teatro se iniciaba con el arriendo del teatro a un empresario. Una vez que el edificio estaba adjudicado a un arrendatario, éste contrataba compañías y actores en la misma ciudad o en otras como Madrid, Barcelona o Valencia ${ }^{151 .}$ El arrendatario confeccionaba la programación: elegía el repertorio de cada compañía que actuaba y las obras que debían representarse. Aunque en muchos casos la programación se decidía sobre la marcha, al menos solían determinarse las obras a estrenar, para atraer el mayor número posible de abonados ${ }^{152}$.

El contrato de cada compañía se realizaba para un número determinado de representaciones o "abonos" (de cuatro hasta sesenta representaciones, aunque lo más frecuente eran los abonos de veinte). Si la compañía tenía éxito, se anunciaban nuevas funciones ${ }^{153}$. Esta es una de las diferencias con respecto a los teatros de grandes ciudades, donde los abonos eran por temporadas completas.

La empresa adjudicataria del teatro publicaba en prensa, a través de carteles o bien en algún establecimiento conocido de la ciudad, el elenco de actores, cantantes y personal de cada compañía que actuaba. El anuncio también informaba del repertorio, el día y las obras del debut, los plazos para abonarse, los precios de los abonos y de las entradas libres y las condiciones de pago en el caso de abonarse a una localidad. En algunas ocasiones, se incluyó información adicional como, por ejemplo, la trayectoria de la compañía, la procedencia del aparato escénico o el repertorio de estreno. El empresario teatral enviaba regularmente a los periódicos la cartelera de representaciones diarias del teatro (a veces, con un día de antelación) ${ }^{154}$. En la ciudad se pegaban también carteles con el mismo propósito, en ocasiones sobre las fachadas de las casas, perjudicando a sus dueños:

${ }^{150}$ La Paz de Murcia propuso que "entre los aficionados se formase una sociedad sin idea alguna de lucro, pues de ese modo sería fácil su apertura": La Paz de Murcia, XI (1868), n 3360, 22 septiembre, p. 2.

${ }^{151}$ En La Paz de Murcia, IX (1866), n 2624, 17 agosto, p. 2 se menciona que existió una publicación titulada Indicador de Teatros que publicaba regularmente listados de actores que estaban disponibles. En ocasiones, era el propio empresario de la compañía el que escribía directamente al Ayuntamiento o al arrendatario del teatro para solicitar el teatro por un número concreto de funciones. El Legajo 2 del Archivo Municipal de Murcia conserva correspondencia de empresarios italianos, como Angelo Marcucci, solicitando el teatro a las autoridades para representaciones teatrales durante la primera mitad del siglo XIX.

152 A veces eran los propios abonados quienes, a través de la prensa, pedían la representación o repetición de una obra en concreto.

${ }^{153}$ La compañía de ópera de Emma Nevada y Mariano Padilla dio únicamente cuatro funciones. También fue habitual que las compañías que actuaban en días de feria (primera quincena de septiembre) redujeran sus actuaciones a ocho o diez. Véase, como ejemplo, la compañía de zarzuela de Eduardo Ortiz (Romea, $1^{\mathrm{a}}$ temporada 1889-1890) cuyo anuncio se publicó en La Paz de Murcia, XXXII (1889), nº 9894, 8 agosto, p. 1. Como veremos en los capítulos siguientes, fue relativamente frecuente la interrupción de las representaciones antes de concluir los abonos, casi siempre por causas económicas (quiebras de las compañías ante el insuficiente número de espectadores, por ejemplo).

${ }^{154}$ En ocasiones, los periódicos no recibían a tiempo la información sobre los espectáculos del teatro, por lo que la sección correspondiente aparecía con la frase "No se ha recibido el anuncio". La Paz de Murcia imprimió en reiteradas ocasiones la cartelera teatral y dio motivo a que otros medios de comunicación cuestionaran la objetividad de su información que, desde el periódico se defendía así: "LA PAZ, haciendo o no carteles su imprenta, obrando bien o mal con su dueño, ha tratado siempre los asuntos de Romea con una imparcialidad ejemplar": La Paz de Murcia, XXXIII (1890), n 10081, 15 marzo, p. 1. 
QUE SE ADOPTE. Volvemos a insistir en la necesidad de que cese el vicioso sistema de fijar los anuncios en las fachadas de las casas, perjudicando a los dueños de las fincas. Aconsejamos a la municipalidad que haga construir unas tablas y, colocadas en los sitios públicos a imitación de Cádiz, Sevilla y otros puntos menos importantes, sirvan para fijar aquéllos, prohibiendo bajo un severo castigo que nadie pueda poner anuncios en otro sitio más que en el que dejamos dicho. Esto, a más de ser de gran utilidad, sería considerado como cuestión de ornato público y estando a cargo de los establecimientos de beneficencia los productos podrían servir de beneficios a los mismos.

Y a propósito de esto, leemos en un periódico de Madrid que un artista muy conocido del público ha presentado a la municipalidad por medio de un concejal un proyecto para fabricar tabiques carteleros con el fin de regularizar el modo de fijar carteles. Si el Ayuntamiento les concede lo que en su exposición pide, los fabricará en unión de otro asociado para el caso. La exposición y el proyecto deben estar a estas horas bajo la resolución del cuerpo municipal ${ }^{155}$.

Los retratos de los actores/actrices o cantantes se exponían al público a veces en el lugar donde se adquiría el abono y junto al elenco de la compañía ${ }^{156}$. La compañía de Manuel Rodriguez, por ejemplo, exhibió las fotografías de sus artistas en el Casino ${ }^{157}$.

Los abonados eran una garantía para las empresas, ya que proporcionaban ingresos fijos y seguros y aseguraban una afluencia mínima de espectadores (con un número mínimo de abonados, la temporada podía sostenerse). Las frecuentes crisis por las que atravesó el teatro principal de la ciudad (Teatro de los Infantes de Murcia, después llamado de la Soberanía Nacional y Teatro Romea) y los fracasos empresariales provocaron, en ocasiones, falta de confianza y una actitud recelosa por parte del público.

Una práctica habitual fue el "abono por turnos", consistente en la compra de un abono completo por parte de dos interesados. Dichos compradores llegaban a un acuerdo particular para asistir al teatro en días alternos, obteniendo las localidades a precios de abono. El sistema también tenía desventajas como se indica en el siguiente párrafo:

Con la función anunciada para hoy van cuatro en la temporada actual. En la segunda y en la cuarta se ha puesto Campanone, con lo cual resulta que, mientras los abonados a segundo turno ven dos veces esta zarzuela, los abonados al primero no la han visto ninguna, pero tampoco han tenido repetición en las dos funciones que les ha correspondido. Esperamos que por la empresa se tenga presente esto para las repeticiones $^{158}$.

${ }^{155}$ La Paz de Murcia, IX (1866), n 2786, 19 octubre, p. 2. La cuestión de colocar los carteles en sitios adecuados fue tratada varias veces por la prensa. Véase, como ejemplo, el siguiente párrafo extraído de $L a$ Paz de Murcia, XXXIII (1890), no 11115, 29 agosto, p. 1: "Si el Ayuntamiento no construye biombos, kioscos, tableros o algo en que se fijen los anuncios, con el tiempo no cobrará nada del arbitrio de carteles. Nos fundamos en que los sitios se agotan y los que fijan anuncios no van a poder exponerlos. Hasta ahora uno de los sitios en que podían fijar anuncios era las Cuatro Esquinas de San Cristóbal y ya se ha concluido, ya no es posible utilizar este sitio".

${ }^{156}$ La Paz de Murcia, XIV (1871), no 4175, 25 mayo, p. 1. Pultz, citado por Fornaro, “Género”, pp. 23 afirma que "Los retratos de actores de teatro adquirieron una importancia adicional, pues proporcionaban un conocimiento directo e íntimo del rostro y cuerpo del actor".

${ }^{157}$ La Paz de Murcia, XXXII (1889), nº 9968, 7 noviembre, p. 1.

${ }^{158}$ La Paz de Murcia, IX (1866), n 2497, 5 abril, p. 1. Se refiere a las representaciones de la compañías de zarzuela de Francisco Villegas (2a temporada de 1865-1866). 
La petición de la prensa no obtuvo resultado, ya que estos acuerdos se realizaban de forma privada y sin que interviniera la empresa teatral: "La empresa del teatro nos ha hecho ver que, si bien hay abonados a turno, esto es por convenio particular entre los mismos abonados pero no porque ella haya hechos abonos de esta clase. Por lo tanto, de aquí el que las repeticiones no puedan ser siempre a gusto de todos"159.

La compañía lírico-dramática de Miguel Tormo (segunda temporada de 18671868) inauguró, a juzgar por los datos examinados, un nuevo tipo de "abono condicional": "Siendo públicos los grandes perjuicios sufridos por la empresa en las últimas temporadas, ésta se ve en la precisión de hacer el abono condicional. Si dicho abono no llena siquiera un número regular de localidades, se tendrá éste por no efectuado" $" 160$.

Debido a la variable afluencia de público, las empresas no se arriesgaron a cubrir gastos con las entradas compradas a última hora en la taquilla del teatro. Los verdaderos artífices de que las compañías se sostuvieran en cartel (al menos hasta la llegada del teatro por horas) eran los abonados a las temporadas teatrales. Si el número de abonos no era suficiente, se suspendían las representaciones. Los abonados gozaban de varias ventajas: un precio inferior al de una entrada normal ${ }^{161}$; la garantía de tener localidad durante toda la temporada, el derecho a mantenerla si adquirían abonos en temporadas posteriores $^{162}$; y la posibilidad de asistir a los ensayos. El público abonado asistía a las funciones de la noche y quedaban fuera de abono las de la tarde (programadas en épocas festivas, como la Navidad, y dirigidas a un público más popular) y las funciones extraordinarias, aunque se les reservaban a los abonados localidades si avisaban con antelación ${ }^{163}$. En las funciones por secciones o por horas los abonados "a palcos y plateas, mediante el pago de un sola entrada, tienen derecho a asistir a todo el espectáculo, disfrutando gratis sus localidades en las funciones [...] de la tarde, con sólo el abono de la entrada" 164 .

${ }^{159}$ La Paz de Murcia, IX (1866), nº 2500, 8 abril, p. 1.

${ }^{160}$ La Paz de Murcia, XI (1868), nº 3190, 28 marzo, p. 3.

${ }^{161}$ El anuncio de la compañía de Hermenegildo Manzanedo especificaba que el abono a una localidad costaba un 10\% menos que el precio de una entada libre: La Paz de Murcia II (1859), $\mathrm{n}^{\circ}$ 516, 21 octubre, pp. 3-4. Es el mínimo porcentaje de rebaja con respecto a las entradas en taquilla. Lloret, El teatre, pp. 4445 menciona una diferencia entre un $25 \%$ y $35 \%$ (variable según las localidades y los géneros).

${ }^{162}$ Las sesiones plenarias previas al arriendo de 1884-1887, se llegó al acuerdo de: "Acerca de la 18 , que trata de los abonos, también se discutió mucho, quedando acordado suprimir el requerimiento a que obligaba a las empresas, sujetándolas solo a respetar los abonos hasta 24 horas antes de empezar a funcionar, y a reservar las localidades a los abonados hasta las $12 \mathrm{del}$ día en las funciones que antes de cerrar el abono no hubiese acudido a contaduría y reclamado su derecho, lo perderá": La Paz de Murcia, XXVII (1884), nº 7852, 23 febrero, p. 1.

${ }^{163} \mathrm{Al}$ menos en la temporada 1886-1887, los abonados podían asistir gratis a las funciones de la tarde. En ocasiones, las compañías organizaban las funciones alternando las de abono y las que quedaban fuera de éste, como fue el caso de la compañía de zarzuela de Casimiro Espino (Romea, $1^{a}$ temporada 1884-1885): "La empresa es regular no dé función diaria a los abonados, pues quizá entre en su cálculo y para descanso de aquellos dar una o dos funciones fuera de abono de la semana. No se anuncia repertorio y sí que se elegirán las obras más selectas del antiguo y moderno, lo cual está en el interés de la empresa": La Paz de Murcia, XXVII (1884), nº 8035, 4 octubre, p. 1.

${ }^{164}$ Anuncio de la compañía de zarzuela de Francisco Galván y Félix Berros (1 $1^{\mathrm{a}}$ temporada de 1888 1889): La Paz de Murcia, XXXI (1888), nº 9616, 28 septiembre, p. 4. En cambio, la compañía de zarzuela de Enrique Lloret (Romea, $1^{\text {a }}$ temporada 1889-1890) estableció precios de abonos en las funciones por 
Los abonos se pagaban en la contaduría del teatro o en algún establecimiento conocido de la ciudad ${ }^{165}$. El plazo para comprarlos solía concluir antes de la primera representación ${ }^{166}$. La forma de pago seguía una de estas dos modalidades:

1. Pago íntegro al suscribirse al abono, como en el caso de la compañía de Hermenegildo Manzanedo ( $1^{\text {a }}$ temporada de 1859-1860) o en un día concreto establecido por la empresa, como en el caso de la compañía lírico-dramática de Miguel Tormo ( $2^{\mathrm{a}}$ temporada de 1867-1868).

2. Pago por plazos. La cantidad del abono se cobraba en dos plazos: la mitad al hacer la suscripción y la otra mitad cuando habían transcurrido las funciones de la mitad de las establecidas en el abono. Ésta fue la fórmula de pago más habitual con las compañías de los años setenta en adelante: la de zarzuela de Manuel Iglesias $\left(2^{\mathrm{a}}\right.$ temporada de 1870-1871), la de José González Orejuela (1 ${ }^{\mathrm{a}}$ temporada de 18721873 ) y la de Nicolás Rodríguez ( $2^{\mathrm{a}}$ temporada de $\left.1872-1873\right)^{167}$. Cuando el abono era de precio muy elevado, los plazos para pagarlo podían ser tres. Por ejemplo, la compañía de Eugenio Fernández, que actuó en el Romea durante la primera temporada de 1882-1883, abrió un abono de sesenta representaciones pagaderas en tres plazos (o cada veinte funciones de abono).

A partir de los años setenta del siglo XIX se precisaron más detalles sobre las condiciones para abonarse. Desde 1867, por ejemplo, se indicó: “A los señores militares y empleados que tuvieran que ausentarse por traslado, se les devolverá a prorrata el importe de las funciones que tuvieren anticipadas y no se le hubieren verificado" "168. Las empresas se reservaban el derecho a modificar los precios de las entradas en las funciones de estreno y en las que tenían beneficios, y a devolverlo cuando se suspendían. Las localidades se vendían mediante talonarios, para evitar fraudes y abusos:

[...] A fin de evitar abusos en la expendición de localidades en contaduría, como en los sitios de costumbre, la empresa ha dispuesto: que la localidad sea talonada; que los dependientes en los despachos de billetes exhiban los talonarios a quien lo pretenda para que se cerciore si existe o no la localidad que desea; que una vez cortado el billete y entrada de talón, el adquiriente no tiene derecho a devolverle ni cambiarle por otro, único medio de evitar el abuso $[\ldots]^{169}$.

horas pero, si se quería asistir a las cuatro secciones, debía pagarse aparte 25 céntimos: La Paz de Murcia,

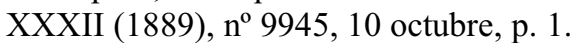

${ }^{165}$ El abono de las representaciones de la compañía de Eugenio Fernández ( $2^{\text {a }}$ temporada de 18661867) y el de la lírico-dramática de Miguel Tormo ( $2^{a}$ temporada de 1867-1868) se fijó "en el establecimiento [tipográfico] de don Antonio Molina, calle del Príncipe Alfonso, número 32, frente al Café del Comercio". Sin embargo, fue más frecuente en años anteriores pagar en la contaduría del teatro. Véanse los anuncios de las compañías La Paz de Murcia: I (1858), nº 193, 22 octubre, p. 2 y II (1859), nº 516, 21 octubre, pp. 3-4.

166 En algunos casos, las empresas dejaban que el plazo de abono se cerrase tras las primeras representaciones, para que los abonados comprobaran la calidad de los intérpretes ante de abonarse definitivamente.

${ }^{167}$ La compañía de zarzuela de Eugenio Fernández, cuando actuó en el teatro de los Infantes en la segunda temporada 1866-1867 utilizó también esta forma de pago.

${ }^{168}$ Anuncio de la compañía de Eugenio Fernández (2ª temporada de 1866-1867): La Paz de Murcia, X (1867), nº 2858, 16 abril, p. 2.

${ }^{169}$ La Paz de Murcia, XVI (1873), no 4736, 13 abril, p. 1. 
Las zarzuelas con gran aparato escénico, después de ejecutadas para el abono, se podían representar fuera del mismo, con reserva de localidades y precios de abono para los abonados, si asistían ${ }^{170}$. Desde la temporada $1875-1876$, los abonados a plateas y palcos podían contratar luz de gas por veinte reales mensuales ${ }^{171}$.

Aunque los abonados garantizaban la actividad teatral de las compañías, los empresarios no olvidaron controlar los precios diarios de las funciones fuera de abono, que servían para incrementar los ingresos ${ }^{172}$. Los precios de las localidades variaban según el tipo de espectáculo y la categoría de la compañía y actores.

Cada entrada general permitía al espectador entrar al teatro pero, para ocupar cualquier localidad, debía abonar además el precio según el asiento ocupado. En determinadas temporadas o funciones especiales había dos entradas generales con precios diferentes (más caro en el piso inferior y más económico en los pisos altos); la entrada general principal servía para el patio de butacas y primer piso, y valía cuatro reales. La entrada general para el segundo y tercer piso tenía un precio de dos reales. En los primeros años de la trayectoria del Teatro de los Infantes hasta el incendio de 1877, la entrada general osciló entre los dos reales en las temporadas más baratas para una función dramática y seis reales para una función de ópera con una compañía de una cierta importancia. Los precios habituales por una entrada eran: dos reales para género dramático, tres reales para la zarzuela y cuatro reales para una función de ópera. Además de estas diferencias por géneros, había otras si se trataba de estrenos (más caros) o de obras ya representadas en la ciudad (más económicas).

Los anuncios de las compañías teatrales publicados por la prensa incluían a veces los precios de las localidades o abonos. La Tabla 2.2 muestra los precios de las localidades en un espectáculo de zarzuela en el Teatro de los Infantes:

Tabla 2.2. Precios de las localidades en el Teatro de los Infantes y posterior Teatro Romea (1858-1887) Fuente: Anuncios de las compañías de zarzuela en la prensa consultada (ver Capítulo 3).

Varias cantidades referidas a una misma cantidad reflejan precios diferentes según las compañías.

\begin{tabular}{|l|l|l|}
\hline Localidades & $\begin{array}{l}\text { Precios } \\
\text { (en reales) }\end{array}$ & $\begin{array}{l}\text { Precios } \\
\text { (en pesetas) }\end{array}$ \\
\hline Plateas & $34,36,38,41,44$ & $8.5,9,9.5,10.25,11$ \\
\hline Palcos & $30,34,36$ & $7.5,8.5,9$ \\
\hline Palcos segundos & $16,24,30$ & $4,6,7.5$ \\
\hline Butacas & 7,8 & $1.75,2$ \\
\hline Delanteras de galería baja & 5,6 & $1.25,1.5$ \\
\hline Asientos interiores de galería & 4 & 1 \\
\hline Delanteras de galería principal & 5,6 & $1.25,1.5$ \\
\hline Delanteras de paraíso & $2,3,4$ & $0.5,0.75,1$ \\
\hline Entrada general & 3 & 0.75 \\
\hline Entrada al paraíso & $2,2.5$ & $0.5,0.62$ \\
\hline $\begin{array}{l}\text { Tres primeras representaciones } \\
\text { de estrenos }\end{array}$ & 4 & 1 \\
\hline
\end{tabular}

${ }^{170}$ Esta última condición aparece en el anuncio de la compañía de zarzuela de Nicolás Rodríguez ( $2^{\mathrm{a}}$ temporada de 1873-1874): La Paz de Murcia, XVII (1874), nº 5045, 16 mayo, p. 1.

${ }^{171}$ La Paz de Murcia, XVIII (1875), no 5464, 7 octubre, p. 1.

${ }^{172}$ Lloret, El teatre, pp. 43-44. 
Como se aprecia en la tabla, las plateas, los palcos y los asientos delanteros de galería principal y paraíso son las localidades que presentaron mayores variaciones de precio. La entrada general se mantuvo estable en tres reales, aunque hubo compañías que cobraron cuatro reales, como la de zarzuela de Tomás Brotons ( $1^{\mathrm{a}}$ temporada de 1873 1874).

Tras el incendio del Teatro Romea y su posterior reedificación, los precios de las localidades se mantuvieron (ver Tabla 2.3):

Tabla 2.3. Precios diarios de las localidades del Teatro Romea de la compañía de zarzuela de Ventura de la Vega (Romea, $2^{\text {a }}$ temporada de 1885-1886)

Fuente: Anuncio de la citada compañía en la prensa consultada (ver Capítulo 3).

\begin{tabular}{|l|c|c|}
\hline Localidades & $\begin{array}{l}\text { Precios } \\
\text { en reales }\end{array}$ & $\begin{array}{l}\text { Precios en } \\
\text { pesetas }\end{array}$ \\
\hline Plateas y palcos principales & 50 & 12.5 \\
\hline Palcos segundos & 30 & 7.5 \\
\hline Palcos terceros & 20 & 5 \\
\hline Plateas de escenario & 30 & 7.5 \\
\hline Palcos segundos de escenario & 24 & 6 \\
\hline Palcos terceros de escenario & 20 & 5 \\
\hline Butacas de patio, sin entrada & 20 & 5 \\
\hline Butacas de anfiteatro primera fila & 20 & 5 \\
\hline $\begin{array}{l}\text { Butacas de anfiteatro segunda, tercera y } \\
\text { cuarta fila }\end{array}$ & 7 & 1.75 \\
\hline $\begin{array}{l}\text { Butacas de patio y primera fila de } \\
\text { anfiteatro, con entrada }\end{array}$ & 5 & 1.25 \\
\hline $\begin{array}{l}\text { Butacas de anfiteatro segunda, tercera y } \\
\text { cuarta fila con entrada }\end{array}$ & 4 & 1 \\
\hline $\begin{array}{l}\text { Delantera de anfiteatro primera y } \\
\text { segunda fila, con entrada }\end{array}$ & 3 & 0.75 \\
\hline Delanteras de paraíso, con ídem & 3 & 0.75 \\
\hline Entrada general & & \\
\hline
\end{tabular}

En el caso de las funciones por horas, cada sección del espectáculo costaba quince céntimos de peseta. Los abonados a palcos y plateas podían asistir a las cuatro secciones por veinticinco céntimos de peseta más (ver Tabla 2.4):

Tabla 2.4. Precios de las localidades del Teatro Romea con la compañía de zarzuela de Enrique Lloret (Romea, $1^{a}$ temporada de 1889-1890) Fuente: Anuncios en prensa de la ciudad compañía (ver Capítulo 3).

\begin{tabular}{|c|c|c|}
\hline Localidades & $\begin{array}{lr}\begin{array}{l}\text { Precios } \\
\text { abono }\end{array} & \begin{array}{r}\text { por } \\
\text { (en } \\
\text { pesetas) }\end{array} \\
\end{array}$ & $\begin{array}{l}\text { Precios por } \\
\text { sección } \\
\text { (en pesetas) }\end{array}$ \\
\hline Plateas y palcos principales por abono & 5 & 1.5 \\
\hline Palcos segundos & 3 & 1.5 \\
\hline Palcos terceros & 1.5 & 1 \\
\hline Palcos primeros de escenario: primeros & 4 & 2.50 \\
\hline Palcos segundos de escenario & 3 & 2 \\
\hline Palcos terceros de escenario & 2 & 1.5 \\
\hline Butacas de patio y primera fila de anfiteatro & 1 & 0.5 \\
\hline Segundas, terceras y cuartas filas de anfiteatro & 0.75 & 0.35 \\
\hline Delanteras de anfiteatro primero y segundo & 0.5 & 0.25 \\
\hline Entrada general & & 15 \\
\hline
\end{tabular}


Los ingresos procedentes de las entradas en muchas ocasiones no daban para pagar los gastos de mantenimiento del local, los de las compañías y la amortización del arrendamiento. En consecuencia, el negocio no dejaba grandes beneficios y muchos empresarios fracasaban.

El teatro acogía todos los días de la semana una función de noche. En épocas festivas, como la Navidad, se daban también funciones de tarde. Dependiendo de la estructura y del repertorio de los espectáculos, los empresarios y directores de las compañías fijaban los horarios ${ }^{173}$. Las funciones se programaban tratando de que hubiera variedad de espectáculos.

Una sesión normal solía incluir una sinfonía inicial interpretada por la orquesta, un drama o una comedia larga y, entre los actos y/o al final, un número bailable y/o musical.

Las últimas representaciones de las compañías solían destinarse a las "funciones a beneficio" de un cantante principal, al director de la orquesta, a algún miembro del personal de servicio del teatro (taquilleros y maquinistas, entre otros) o incluso al público (ver Figura 2.6). El "beneficio" consistía en una función homenaje al artista en cuestión y solían ser la ocasión perfecta para que los admiradores agradecieran el talento artístico del artista con regalos de alto valor. El repertorio en estos casos era escogido por el beneficiado y normalmente se tenía en cuenta el lucimiento del artista, la popularidad de la obra y su poder de convocatoria. En las funciones a beneficio del público las localidades eran más económicas.

También en las últimas representaciones de las compañías se programaba una o dos funciones a beneficio del Ayuntamiento, cuya recaudación se entregaba a alguna institución (casa de huérfanos, hospitales, casa de pobres) ${ }^{174}$. De forma extraordinaria, la empresa del teatro podía organizar funciones benéficas por otros muchos motivos, como catástrofes naturales, acontecimientos bélicos, celebraciones de hechos políticos y religiosos de Murcia o de otras provincias españolas. Estas funciones quedaban fuera de los abonos. Si la iniciativa partía del Ayuntamiento, la empresa tenía que ceder esa noche los beneficios del teatro y, a cambio, no pagaba el alquiler del local correspondiente a ese día ${ }^{175}$.

También fue usual que, al concluir los abonos de las compañías dramáticas, líricas o coreográficas, el teatro acogiera espectáculos variados de magia, equilibrismo, ilusionismo y variedades, entre otros ${ }^{176}$. En otros casos, los empresarios recurrieron a la programación conjunta de espectáculos de verso o música con funciones más informales.

${ }^{173}$ A causa de la extensión de las obras y de los largos intermedios para cambiar los decorados, las funciones podían superar las tres o cuatro horas. Ello dio lugar a reiteradas peticiones desde la prensa a los empresarios y directores para que adelantaran la hora de comienzo: "El director de escena don Juan Cubas, debiera evitar la desmedida prolongación de los intermedios que impacientan justamente al público y dan lugar a demostraciones de desagrado, que empezando con comedimiento concluyen con extralimitación": La Paz de Murcia, XXX (1887), nº 8099, 22 enero, p. 1.

${ }^{174}$ La compañía de Julia Cirera destinó el dinero del beneficio del Ayuntamiento a las obras de la fachada del teatro. Ver Crespo, El Teatro Romea, p. 188.

${ }^{175}$ Por ejemplo, el 14 de febrero de 1863 el Ayuntamiento organizó una función a beneficio de los afectados por la epidemia de fiebre amarilla en Canarias. Actuaba entonces la compañía de zarzuela de Marina Albini que intervino en la función representando El último mono y Tramoya. Véase, El Segura, I (1863), $\mathrm{n}^{\text {os }} 38,13$ febrero, p. 2 y 42, 18 febrero, p. 1.

${ }^{176}$ Por lo general, este tipo de espectáculos se daban en una, dos o tres ocasiones, casi nunca más de una semana. 


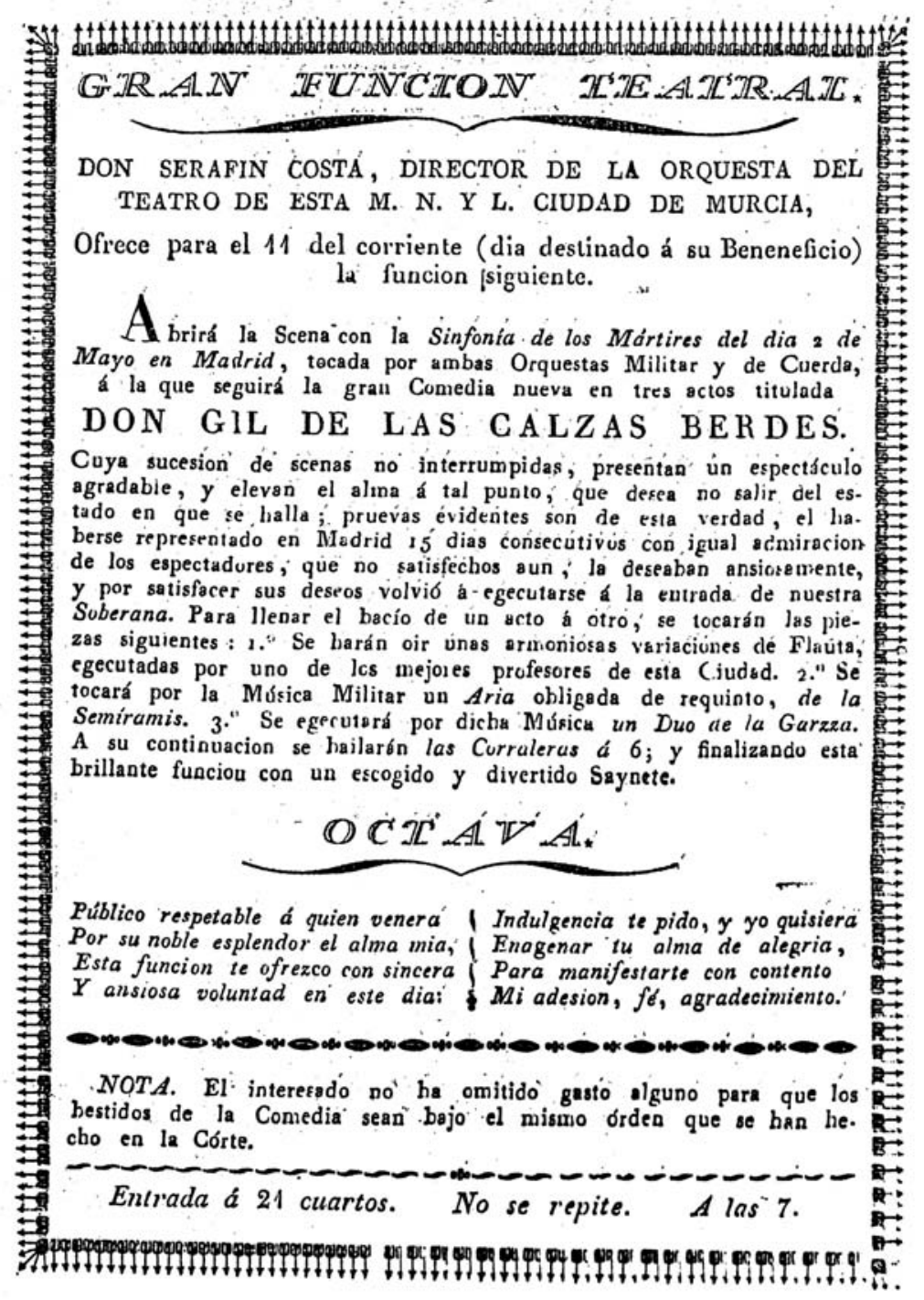

Figura 2.6. Cartelera teatral de la función a beneficio del director de orquesta Serafín Costa en el Teatro del Toro de Murcia, ca. 1830. E:MUm, Leg. 1491 (s.a.).

Cuando el programa de alguna función debía verse alterado por causas inesperadas (como enfermedades de los cantantes y accidentes) la empresa había de pedir permiso a las autoridades. Por ejemplo, los dos últimos actos de la zarzuela Catalina de Gaztambide, llevada a escena en diciembre de 1859 en el Teatro de los Infantes por la compañía de Hermenegildo Manzanedo fueron sustituidos por El amor y el almuerzo y Un caballero particular, debido a la enfermedad del barítono Aguilón ${ }^{177}$.

Dado que la variedad del repertorio obligaba a llevar a escena varias obras en una misma semana, los actores no siempre dispusieron de tiempo suficiente para ensayarlas, por lo que cobraban gran importancia los apuntadores, algo que fue criticado reiteradamente en la prensa murciana.

${ }^{177}$ La Paz de Murcia, II (1859), nº 564, 10 diciembre, p. 1. 
El teatro también se usó con otras finalidades, diferentes a la actividad teatral. Fue escenario de acontecimientos políticos y celebraciones e incluso se utilizó como restaurante. El 19 de noviembre de 1884, por ejemplo, se utilizó el Teatro Romea para un banquete político en honor del general José López Domínguez (1829-1911) ${ }^{178}$. Estos usos no propiamente teatrales del local eran a veces criticados en la prensa ${ }^{179}$.

\subsubsection{Las normas de comportamiento en el teatro: el Bando de Buen Gobierno y las ordenanzas municipales}

El teatro era uno de los lugares de encuentro más significativos de la sociedad murciana del siglo XIX. De él se esperaba que reflejara las buenas costumbres y maneras, y del público, que éste pudiera aprender en el teatro de los personajes y de sus lecciones morales. Una descripción de enero de 1874 nos relata el ambiente de las representaciones teatrales en las funciones de tarde y noche:

[...] Por las tardes se llena de centenares de chiquillos que por invadir y trastearlo todo llegan a ocupar hasta el palco del municipio. Por todas partes corren y algo estropean. Respecto a gritos y escándalo en los intermedios y durante la representación, de más está el hablar.

Por las noches no hay muchachos, pero los grandes de las localidades altas, con sus dichos y silbidos y algunos espectadores de las butacas, con sus peticiones de repetición, hacen que el empleo de las musas se convierta en una plaza de toros.

Conveniente sería que se procurase disminuir estos ademanes y que los concurrentes a las butacas moderasen sus deseos, pues así como es razonable el pedir la repetición de una pieza cuando agrada a la generalidad y en ello tiene satisfacción en acceder el artista, cuando la petición se hace por segunda vez cansa al público y molesta al actor, dándose lugar a que, como el jueves, usando de su derecho, no tuviese a bien la señora Castilla el repetir por tercer vez las coplas del cuarto acto de El sargento Federico ${ }^{180}$.

Tal y como se deduce de estas líneas, el teatro se convirtió a menudo en lugar de algarabía y jaleo. La implantación del sistema por horas en 1888 multiplicó los escándalos, los abusos y las anécdotas sobre comportamientos incorrectos del público. Uno de los abusos consistía en obligar a los artistas a repetir los números musicales que más gustaba al público, como muestra este testimonio:

\section{Los abusos del Romea}

[...] El público tiene derecho a manifestar su aprobación o desagrado cuando sea oportuno por los medios admitidos en esos centros de cultura; pero no por sistema. La exigencia de que todos los números de canto de las zarzuelas se repitan y que esto

${ }^{178}$ Crespo, El Teatro Romea, p. 131. A dicho banquete asistieron doscientos comensales que ocuparon una mesa en forma de herradura en el patio de butacas.

${ }^{179}$ En relación a los bailes celebrados en el teatro, La Paz de Murcia, XV (1872), $\mathrm{n}^{\mathrm{o}}$ 4496, 20 febrero, p. 1 solicitaba: "suplicamos al Ayuntamiento no vuelva a conceder autorización para esa clase de espectáculos, a no ser que tenga evidencia de que nuestro teatro no se ha de prostituir hasta el extremo en que lo ha sido".

${ }^{180}$ La Paz de Murcia, XVII (1874), no 4965, 3 enero, p. 1. 
sea tantas veces, tres, como monedas de perro chico cuesta la entrada es un abuso que molesta a los espectadores a diario y a toda la función y cansa hasta la saciedad a los actores que, por no desagradar, aunque no puedan, tienen que complacer de un modo forzoso a ese insaciable público de las alturas.

Y si esto es censurable, lo es más la exigencia de pedir lo que no está anunciado, lo que quizá no sepa el artista, lo que no venga bien dentro de la obra que se represente, lo que no tenga la orquesta papeles para acompañarlo. Eso no está permitido, el público carece de derecho para pedirlo no sólo tumultuariamente como en la noche del domingo, cortando la representación y molestando al público sensato, del cual parte abandonó el local sino que de ningún modo está autorizado el pedir lo que no está anunciado en los programas. $[\ldots]^{181}$.

Las normas de conducta que debían seguirse en el teatro se recogieron en el "Reglamento de teatros" de 2 de agosto de 1886. Resumidas por La Paz de Murcia, las disposiciones sobre el comportamiento de los espectadores eran:

[...] Queda prohibido fumar en todo espectáculo público que no se verifique al aire libre fuera de las salas destinadas al efecto.

No se permitirá en los teatros estar con el sombrero puesto en ninguna localidad mientras se halle el telón alzado.

El que hiciere manifestaciones o produjere ruidos de cualquier clase durante una función dramática será expulsado del local, sin derecho al reintegro del importe de la localidad que ocupase, pero no se entenderán como interrupciones las manifestaciones de agrado o desagrado hechas por el público, a menos que llegasen a producir tumulto y una verdadera alteración de orden, o constituyeren falta a la cultura, a las conveniencias sociales o a la moral. Tampoco se permitirán las manifestaciones que perturben a la generalidad del público en el tranquilo goce del espectáculo.

La autoridad podrá impedir que se ponga en caricatura en la escena, en cualquier forma que sea, a persona determinada. Bastará la reclamación del interesado o de cualquier individuo de su familia para que la autoridad impida la representación en escena del personaje a que la reclamación se refiera. $[\ldots]^{182}$.

Además, en el "Bando del Buen Gobierno" y en las "Ordenanzas Municipales" de Murcia había disposiciones legales sobre el teatro y los espectáculos públicos ${ }^{183}$. El Bando de Buen Gobierno regula en sus artículos 22 a 28 del apartado "Teatro" el comportamiento del público asistente, con prohibiciones como la de fumar o tener la cabeza cubierta mientras el telón permanecía corrido o revender entradas, entre otras. Del artículo 29 al 49, el Bando establece otras normas dirigidas a empresarios teatrales (por

181 [Anónimo], "Los abusos del Romea”, La Paz de Murcia, XXXI (1888), nº 9643, 30 octubre, p. 1 (ver Documentario). Los ejemplos sobre silbidos y malas conductas en el teatro con muy numerosos. Véase, por ejemplo, [Anónimo], "Desmanes en Romea", La Paz de Murcia, XXX (1887), nº 8096, 19 enero, p. 1 y El Diario de Murcia, III (1881), n 593, 25 enero, p. 3.

182 [Anónimo], "El reglamento de teatros", La Paz de Murcia, XXIX (1886), nº 8989, 8 agosto, p. 1. Véase el artículo completo en el Documentario.

183 "Proyecto de Ordenanzas que somete a la aprobación del Excelentísimo Ayuntamiento el síndico don Juan López Somalo formadas por encargo verbal del señor Alcalde con vista del Bando de Buen Gobierno aprobado en 12 de diciembre de 1865 y publicado en $1^{\circ}$ de enero de 1866 , reformándolo en parte que ha creído conveniente y adicionándole con las disposiciones que rigen en diferentes capitales de España y que han podido ser aplicables a las necesidades de esta Capital", E:MUm, AC 21-05-1889, fols. 264r 268v y Bando General de Buen gobierno (Murcia: Imprenta de los Hijos de P. Nogués, reimpresión de 1884). Véase Documentario y Apéndice 2.5. 
ejemplo, la obligación de representar completamente las obras anunciadas sin variar de repertorio, cuidar la escenografía y el vestuario), a los artistas ("deberán guardar en su traje y acciones el decoro debido"184), al personal de servicios (maquinista, conserje, entre otros) y al público espectador.

\title{
1.3.4. La escenografía
}

La escasez de medios no sólo se tradujo en locales a menudo mal acondicionados sino también en la reutilización, repintado y remendado de decorados y enseres de la escena con el fin de reducir gastos ${ }^{185}$. Fueron usuales las denuncias periodísticas sobre la necesidad de adquirir determinados elementos escénicos, como la que se describe a continuación:

\begin{abstract}
DECORACIONES. Llamamos la atención de nuestro municipio, y especialmente de la comisión segunda del mismo a que corresponde el negociado de teatro, sobre la necesidad que hay de dotar a éste de una decoración de sala de casa pobre para que no nos veamos, como viene sucediendo desde la inauguración del mismo, en la necesidad de admirar las bellezas de una decoración de patio cuando se necesita una de sala que no hay. También se están echando de menos algunas decoraciones de gabinete y otros distintos usos, pues en este ramo está nuestro teatro muy pobre en razón a que hasta ahora solo se le ha provisto de grandes salones y galerías y una decoración de jardín que, si bien son muy buenas y han costado bastante dinero, no son en cambio de las que más se necesitan; las que sin embargo, por tener que acudir a ellas en todas ocasiones (hasta para los bailes) se están estropeando. Las decoraciones que hacen falta son de muy poco coste, pues su mayor valor consiste en el lienzo y madera que gasten, en razón a que con papel de vestir habitaciones se pueden arreglar muy fácilmente, por cuya razón esperamos sean tenidas en cuenta nuestras indicaciones ${ }^{186}$.
\end{abstract}

Excepcionalmente, algunas empresas teatrales alquilaron decorados, sastrería y demás utensilios escenográficos para ocasiones determinadas, casi siempre ligadas al estreno de una obra ${ }^{187}$. Las siguientes líneas, que fueron escritas a propósito de la última función de la compañía de zarzuela del empresario Francisco Miguel Fernández (Teatro de los Infantes, $1^{\text {a }}$ temporada de 1863-1864), son un ejemplo:

${ }^{184}$ Bando General, p. 9.

${ }^{185} \mathrm{La}$ escasa variedad y renovación de decorados y vestuario escénico no fue exclusivo de Murcia. Arias, "La escenografía", pp. 183-188 detectó la misma práctica en los teatros madrileños, donde las decoraciones se reutilizaban en varias obras, o bien, se repintaban hasta su total deterioro. Véase más detalles en el estudio Sanz Romero de Castellón, "Escenografía" que analiza la escenografía del Teatro Romea de Murcia de 1862 a 1877.

${ }^{186}$ La Paz de Murcia, X (1867), nº 3070, 24 noviembre, p. 2. Un ejemplo más de control de la escenografía en la prensa puede verse en: "nos llamó la atención que en el cuarto acto no se estrenase la decoración de jardín que hace tiempo se recibió y que no sabemos para cuándo se guarda": La Paz de Murcia, VIII (1865), no 2133, 21 marzo, p. 2. Según Benito, La vida, p. 73, cualquier teatro debía contar con unas decoraciones genéricas: un salón regio y otro de corte, una calle larga, una casa de clase media, una casa rústica, una plaza, un campo, un bosque y un jardín.

${ }^{187}$ El retraso en los pedidos provocó, incluso, el cierre del teatro: "Por no haber llegado a tiempo la sastrería, no ha podido abrir sus puertas el Teatro Romea": El Diario de Murcia, XVI (1894), n 6470, 30 noviembre, p. 3. 
También nos parece justo tributar la enhorabuena al dueño de la guardarropía de nuestro teatro, señor Soler, quien a costa de innumerables sacrificios y con un desprendimiento que tanto le hora, ha llegado a elevar a aquélla a la altura de las principales de España. La noche cuya función venimos reseñando nos dio una prueba fragante de ello vistiendo la escena con un gusto exquisito y con una elegancia nunca vista en Murcia, estrenando una magnífica sillería del tiempo de Luis XIV que tanto juego hace con la riquísima decoración que aquella noche se estrenó, pintada en Barcelona y que figura un salón regio, época del renacimiento, que si bien recargado de adorno, tiene un cornisamento de mucho mérito artístico y unas puertas figuradas de muy bien gusto. La alfombra que cubría la escena, también nueva y de la propiedad del indicado señor Soler, a quien le cuesta 5000 reales, lo mismo que los trajes que en la indicada función usaron los coristas $[\ldots]^{188}$.

La inversión en la escenografía por parte de las empresas no solo reportaba mayor afluencia de público ${ }^{189}$ sino que, en ocasiones, salvaban una representación poco ensayada o con actores mediocres ${ }^{190}$. La luminotecnia es uno de los aspectos menos comentados por la prensa murciana, y casi siempre se refieren a la iluminación general de la sala teatral ${ }^{191}$. Las siguientes líneas, escritas tras el estreno de El potosí submarino de Arrieta y Santisteban, son un ejemplo:

[...] Para ella ha pintado el entendido escenógrafo señor Sanmiguel una decoración submarina que se presenta en el segundo acto [...]. Sigue a esa en el mismo acto otra que es la alegoría final y teniendo en cuanta los cortos límites en que podía desplegar el señor Sanmiguel su buen gusto, nada puede exigírsele, pues ha presentado las figuras lo mejor que es posible en el reducido pensamiento a que ha tenido que limitarse.

A este cuadro debía dar mejor efecto la luz Drumont [Drummond], pero ésta no lo hizo la noche de estreno, y la segunda y la tercera de un modo incompleto, por

${ }^{188}$ [Anónimo], “Revista de teatro”, El Sacamuelas, I (1864), nº 13, 17 enero, pp. 6-7: 6.

189 En 1859, durante los ensayos de la zarzuela Catalina de Gaztambide, la prensa sugirió a los empresarios de la compañía de Hermenegildo Manzanedo: "aunque el Teatro Provisional no permite mucho aparato, esperamos que, teniendo en cuenta de que esta producción es la que mejor se presentó en el derribado, a lo cual en gran parte debió su fama, hará la empresa cuanto esté a su alcance para que se ponga en escena con la mayor lucidez, lo que aunque le proporcione gastos crecidos puede darle grandes entradas": La Paz de Murcia, II (1859), n 548, 23 noviembre, p. 2. La ambientación de los bailes también fueron objeto de cuidadas escenografías: "En el baile La danza murciana se estrenó la bonita decoración de jardín últimamente recibida, la que se presentó muy bien iluminada y pudo apreciarse su valor. Gustó mucho a todos. La referida danza no tiene de murciana nada más que los zaragüeles y la montera que vistieron los boleros [...]. Los peinados de las boleras [...] no [se] correspondían": La Paz de Murcia, VIII (1865), $\mathrm{n}^{\mathrm{o}}$ 2156, 20 abril, p. 2. Dos ejemplos de críticas a decorados en sí pueden consultarse en La Paz de Murcia: XV (1872), no 4519, 17 marzo, p. 1 y XVIII (1875), nº 5285, 11 febrero, p. 1.

${ }^{190}$ Por ejemplo, en La Paz de Murcia, XVIII (1875), nº 5603, 21 noviembre, p. 1 se criticaron algunos aspectos de la representación, mientras que el vestuario fue alabado: "Anoche se estrenó en Romea la zarzuela bufa El rey Midas y a consecuencia de la falta de ensayos adoleció de algunos defectos que es regular veamos esta noche corregidos; especialmente la maquinaria estuvo entorpecida. El vestuario de las partes principales llamó la atención por lo lujoso.

${ }^{191}$ La luz eléctrica, que sustituyó al gas y a la batería de luces que alumbraban el palco escénico se incorporó en el Teatro Romea en 1895. Véase más detalles en Crespo, Historia del Teatro, pp. 340-341, 357. 
haber tenido que hacer desparecer las gasas que completan el pensamiento, para evitar el mal efecto que haría el marcarse en ellas el disco de la luz $[\ldots]^{192}$.

\subsection{La orquesta del teatro}

\subsubsection{Directores de orquesta (1858-1881)}

La mayor parte de las compañías que actuaron en Murcia durante la etapa estudiada, y especialmente durante las últimas décadas del siglo XIX, actuaron con su propio "maestro director y concertador" de orquesta. El desplazamiento de una orquesta incrementaba enormemente los gastos de las compañías y, por este motivo, era habitual contratar músicos y orquestas que existían en la ciudad ${ }^{193}$. En algunas ocasiones, incluso, la orquesta fue sustituida por formaciones instrumentales menos numerosas, como veremos más adelante. El Apéndice 2.6 recoge los directores de las orquestas de las compañías que actuaron en los teatros de Murcia Provisional y Romea (1858-1884).

En los años del Teatro Provisional, entre 1858 y 1860, Mariano Esbrí fue el director las compañías de Bernardo Llorens ( $2^{\mathrm{a}}$ temporada 1858-1859), Hermenegildo Manzanedo ( $1^{\mathrm{a}}$ temporada $\left.1859-1860\right)$ y María Toral $\left(2^{\mathrm{a}}\right.$ temporada $\left.1859-1860\right)$. Lamentablemente no se conserva prensa de los años 1861-1862, aunque es muy probable que Esbrí continuara vinculado con la actividad teatral de este teatro. Como veremos en el capítulo correspondiente, Esbrí estuvo también al frente de la orquesta del Casino de Murcia, así como de una banda de música ${ }^{194}$.

Un mes antes de la inauguración del Teatro de los Infantes (septiembre de 1862) el director de la Banda Municipal, Ángel Mirete, solicitó al Ayuntamiento dirigir la orquesta del teatro "o que este cargo se confiriera por oposición", aunque no obtuvo su propósito $^{195}$. Las autoridades concedieron la plaza de director orquestal del teatro a Mariano Esbrí para la temporada de invierno de 1862-1863, probablemente influidos por su vinculación con el Teatro Provisional en años anteriores ${ }^{196}$. Durante estos años, las críticas teatrales aluden con frecuencia a una orquesta de escasa afinación y pobre repertorio. En 1860, por ejemplo, decía un crítico:

${ }^{192}$ La Paz de Murcia, XVIII (1875), n n 5285, 11 febrero, p. 1. Manuel Sanmiguel fue el pintor escenógrafo más habitual de los teatros murcianos de la segunda mitad del siglo XIX, especialmente del Teatro Romea. La luz Drummond (limelight) es un tipo de luz de escenario, muy utilizado en los teatros del siglo XIX y que permitía orientar, seleccionar y matizar áreas diversas de la escena, por ejemplo, para poner de relieve a los solistas. Ver, Bobes, Semiótica, p. 534.

${ }^{193}$ Es difícil distinguir a través de la prensa si las compañías actuaban con la orquesta del teatro de Murcia o bien traían la suya propia. La única fuente de información son los anuncios de las compañías que, salvo una excepción, no concretaban este aspecto.

${ }^{194}$ En 1858 Mariano Esbrí dirigía la orquesta del Casino y en junio del año siguiente, formó una banda de música, que debutó en las fiestas de San Juan y del Corpus: La Paz de Murcia, II (1859), n 409, 25 junio, p. 1.

${ }^{195}$ E:MUm, AC 19-12-1862, fol. 118r. Se acordó "aplazar la resolución del caso para cuando aquélla finalizase". Según los datos consultados, es la primera referencia a la creación de una orquesta estable para el teatro aunque, como veremos, no llegó a producirse hasta veinte años más tarde, en 1884 .

${ }^{196}$ E:MUm, AC 19-12-1862, fol. 118r. Véase también, Crespo, Historia del Teatro, pp. 58-59. 
[...] No concluiré esta carta sin ponerte al corriente de cierta guasa de una parte del público que todas las noches compromete al director de orquesta señor Esbrí, a fin de que en los intermedios se toquen por ésta los Alcules [sic]. Ya lo ves, cuán ridícula es semejante exigencia y mucho más por la idea tan miserable y raquítica que de los murcianos podrán formar los forasteros que accidentalmente concurran a las funciones. Bien es verdad que no tienen la culpa los dandys que tal cosa piden, sino el señor Esbrí que en su deseo por complacerlos, olvida sin duda que puede decirse de su orquesta que sólo sirve para ejecutar aires tan oídos, puesto que tan a menudo los toca. $[\ldots]^{197}$.

La escasa calidad de la orquesta repercutía negativamente en las representaciones teatrales y, sobre todo, en los beneficios de las empresas. A comienzos de enero de 1863, El Segura publicó una serie de artículos reflexionando sobre las condiciones idóneas para arrendar el recién inaugurado Teatro de los Infantes para el año cómico 1863-1864. Sobre la orquesta propuso:

[...] No podemos hacer la misma excepción respecto al maestro director de la orquesta porque si siempre es injusto obligar a las compañias acepten, más a las líricas, uno que no merezca su confianza, con más motivo cuando lo que se les impere es esa reunión inarmónica de instrumentos a la que tan impropiamente se nombra orquesta y no por esto tratamos de rebajar el mérito de un profesor al que apenas conocemos pero es indudable que los resultados prácticos ni con mucho han correspondido a los que debiera esperarse después de la polémica que sostuvo en la prensa con uno de sus compañeros y comprofesores ${ }^{198}$.

Consecuencia o no de las reiteradas críticas, el Presidente de la Comisión del Teatro, Andrés Brugarolas, dispuso en marzo de 1863 que la orquesta había de mejorar:

Bien hecho. Según tenemos entendido, el Presidente de la Comisión del Teatro, don Andrés Brugarolas ha dictado oportunas disposiciones para que se mejore la orquesta de nuestro coliseo y efectivamente debe ser así porque hace algunas noches venimos notando que hay más gusto en la elección de piezas y hasta creemos que más afinación. Sigan en tan buen camino los individuos de la citada comisión y se lo agradeceremos profundamente ${ }^{199}$.

La nueva orquesta fue "compuesta de individuos de las tres que hay en esta capital y bajo la acertada dirección del profesor traído expresamente, don Modesto Julián"200.

${ }^{197}$ La Paz de Murcia, III (1860), no 682, 9 mayo, p. 1. Otro ejemplo de crítica hacia la orquesta puede verse en El Segura, I (1863), nº 3, 3 enero, p. 2.

198 El Segura, I (1863), nº 4, 4 enero, p. 2. Las cursivas con editoriales. Sobre la polémica a la que alude el texto, véase el apartado 1.4.2 de este Capítulo 2.

${ }^{199}$ El Segura, I (1863), no 59, 10 marzo, p. 2. Las mejoras fueron rápidamente anunciadas por la compañía de zarzuela de la primera tiple Elisa Zamacois (Infantes, $2^{a}$ temporada 1862-1863): "la empresa no ha omitido medio alguno para reunir una brillante orquesta que, correspondiendo a las exigencias de la compañía lírica que presenta, llene como esta los deseos del público": El Segura, I (1863), n 77, 1 abril, p. 2.

${ }^{200}$ El Segura, I (1863), n 86, 14 abril, p. 1. Desconozco a qué tres orquestas se refiere el texto. En muchas ocasiones, la prensa empleó como sinónimos los términos "orquesta” y "banda". En los años sesenta la ciudad contaba con dos bandas civiles y una militar: la Municipal, dirigida por Ángel Mirete, la 
Juan García dirigió las orquestas de las compañías de zarzuela de Francisco Villegas ( $2^{\mathrm{a}}$ temporada 1865-1866) y Eugenio Fernández ( $2^{\mathrm{a}}$ temporada, 1866-1867) y la orquesta de la compañía lírico-dramática de Miguel Tormo (2a temporada 1867-1868) ${ }^{201}$. Desde 1868 hasta 1875, el murciano Ángel Mirete ejerció el cargo de director con varias compañías. Este músico era compositor, director de la Banda Municipal y de la capilla de música de las Madres Agustinas de Murcia (ver Capítulo 9) ${ }^{202}$. Mirete contaba con un amplio grupo de músicos a su disposición a los que organizaba según la ocasión y a los que prohibía formar nuevas orquestas, ejerciendo un verdadero monopolio orquestal en la ciudad:

Se ha formado una nueva orquesta por los individuos de la banda del señor Raya que dirigirá éste, y lo cual le obliga a perder cien duros que debe entregar al señor Mirete, con quien y bajo esta multa tenía convenido por escritura no formar nueva orquesta ni separarse de la suya. $[\ldots]^{203}$.

La formación orquestal de Mirete también aparece vinculada a varias sociedades recreativas y al Casino de Murcia, como se describe en el siguiente testimonio de febrero de 1868:

BAILES. [...]. Casino. Desde la primera hora en que estaba anunciado, muchas bellas con el rostro cubierto para después hacer resaltar mucho más sus gracias, fueron llenando el salón y, aunque por más incidencia que se va haciendo ya de notar no pudo principiar a la hora establecida, reinó la animación en el ínterin no empezaron los acordes de la orquesta, teniéndose que mandar un recado al teatro al director de ella, señor Mirete, a fin de que no demorase por mucho tiempo su presencia, mediante a que se le estaba esperando.

Nos atreveríamos a suplicar a quien corresponda, procure que en noches como ésta no haya la costumbre de poner en escena dramas de tan larga duración, en las que el baile termina a las doce o más; o cuando no que se mudase éste a uno de los intermedios para que la orquesta se desocupe más pronto. $[\ldots]^{204}$.

Durante estos años, las críticas hacia la orquesta de Mirete fueron variables, aunque predominaron las desfavorables. En julio de 1870, La Paz de Murcia publicó que "la única [orquesta] que hoy reúne condiciones para ocupar dignamente el puesto en nuestro teatro es la del señor Mirete" ${ }^{205}$. Sin embargo, otros comentarios fueron muy negativos, denunciando, por ejemplo, la falta de ensayos: "La orquesta regular. La causa,

de Mariano Esbrí y la Banda de Artillería: Clares, "Bandas", pp. 543-550. La Catedral de Murcia contaba con una capilla de músicos, al igual que el Convento de las Madres Agustinas y el Casino de Murcia contaba con una orquesta propia.

${ }^{201}$ No dispongo de más información sobre Juan García.

${ }^{202}$ Sobre Ángel Mirete, véase el Capítulo 9.

${ }^{203}$ El Diario de Murcia, II (1880), nº 278, 13 enero, p. 2.

${ }^{204}$ La Paz de Murcia, XI (1868), nº 3139, 5 febrero, p. 2. Las cursivas son editoriales. La orquesta del teatro asistió a otros eventos como serenatas a personajes relevantes: La Paz de Murcia: XI (1868), $\mathrm{n}^{\circ} 3182$, 19 marzo, p. 2 y XIII (1870), no 3794, 6 febrero, p. 1 conciertos de sociedades recreativas, como veremos en el capítulo correspondiente. Mirete también dirigió una capilla de música para ceremonias religiosas: $L a$ Paz de Murcia: XI (1868), no 3138, 4 febrero, p. 2; XIII (1870), no 3794, 6 febrero, p. 1 y XIV (1871), $\mathrm{n}^{\circ}$ 4134, 6 abril, p. 1, entre otros. Cabe suponer que contara con los mismos instrumentistas o parte de ellos.

${ }^{205}$ La Paz de Murcia, XIII (1870), no 3919, 19 julio, p. 1. 
falta de ensayos. Aconsejamos a nuestro particular amigo señor Mirete deseche el miedo y sacará doble partido de los buenos profesores que tiene bajo su dirección y podrá ocuparse más en dar las entradas a los artistas y a las obras el claro oscuro que necesitan" ${ }^{\text {206; }}$ otras críticas, en cambio, pusieron en evidencia la ausencia de algunos músicos de sus puestos de trabajo:

En la función celebrada en Romea la noche del miércoles notamos en alguna de las piezas de que se componía la nueva zarzuela la falta de varios músicos y entre ellos una de las primeras partes. Aconsejamos al señor Mirete procure evitar estas faltas puesto que de otro modo nunca se oirá la verdad del autor ${ }^{207}$.

En abril de 1874, la orquesta del Teatro Romea fue reformada "con la del señor [Emilio] Raya y bastantes compañeros de este profesor [Ángel Mirete]"208. Las fuentes indican que se formó una orquesta numerosa, aunque no por ello de calidad:

[...] De la orquesta sola decimos que, cuando está todo el personal, nos deja satisfechos $y$, en cambio, a su director (el señor Mirete) nos parece que sabe demasiado dar entradas y algo más que entradas que quizá ignoren por completo sus detractores y envidiosos.

Diremos en fin para terminar que no comprendemos, musicalmente hablando, cómo los contrabajos van a contratiempo. Comprendemos mejor que fueran retrasados aunque comprendemos todavía mejor que los contrabajos de la orquesta saben su obligación. Y esto lo decimos porque hemos leído, no recordamos dónde, que existen en nuestra orquesta además de esa y otras varias quisicosas un fenómeno asar, raro y extraño. Violines improvisados ¡cielo! ¿Cómo se verifica esto? ¿Será tocar el violín el oficio del aguador? Por nuestra vida que desearíamos saberlo para nuestro contento y regocijo $^{209}$

Desde 1875 hasta 1884, las compañías de zarzuela que pasaron por el Romea actuaron con directores de orquesta contratados por ellas. Los directores de los años posteriores serán tratados en el apartado siguiente.

${ }^{206}$ La Paz de Murcia, XV (1872), nº 4633, 5 noviembre, p. 1.

${ }^{207}$ La Paz de Murcia, XVII (1874), nº 5018, 20 marzo, p. 1.

${ }^{208}$ La Paz de Murcia, XVII (1874), no 5041, 18 abril, p. 1. A juzgar por testimonios periodísticos posteriores, la orquesta era muy numerosa, aunque no se especifica el número de instrumentistas: La Paz de Murcia, XVII (1874), nº 5027, 24 abril, p. 1.

209 La Paz de Murcia, XVII (1874), n ${ }^{\circ}$ 5249, 27 diciembre, p. 1. Las críticas se refieren a las representaciones de la compañía de zarzuela de Nicanor Sanmartín y León Carvajal ( $1^{\text {a }}$ temporada de $1874-$ 1875). En sus primeras actuaciones, las reseñas publicadas por la prensa indican actuaciones muy mediocres, elenco incompleto de cantantes y escasa concurrencia. A principios de diciembre de 1874, Ángel Mirete anunció públicamente su intención de renunciar al cargo de maestro concertador y director de orquesta: La Paz de Murcia, XVII (1874), nº 5234, 5 diciembre, p. 1. 


\subsubsection{La polémica en torno a la creación de la orquesta del Teatro Romea y su evolución posterior (1881-1898)}

La orquesta del teatro suscitó grandes polémicas y recelos entre los músicos de la ciudad, incluso en la primera mitad del siglo XIX. Las diferentes formaciones orquestales de la ciudad compitieron entre sí para trabajar en el teatro, sin duda buscando un sustento económico estable. El periódico nacional El Clamor Público explicaba así la contienda musical entre las orquestas dirigidas por Julián Gil y Mariano Esbrí, en 1849:

[...] La orquesta que dirige don Julián Gil se halla compuesta casi en su totalidad de profesores, es decir, de músicos antiguos acostumbrados mal o bien de mucho tiempo a tocar en público. El director de ella, tan antiguo como ella misma, al entrar en esta reñida competencia sólo tenía que dar la voz de aviso y prepararse a la lucha.

Don Mariano Esbrí, director de la nueva orquesta ha tenido que improvisarla y al entrar en tan peligrosa lid, sólo contaba con un pequeño número de principiantes y algunos jóvenes profesores.

Tan ventajosamente colocado don Julián Gil respecto al personal de las orquestas tocó la primera noche y tocó bien, si atendemos a la precisión, al esmero, al afanoso cuidado con que cada uno de los músicos deseaba desempeñar la parte que le estaba encargada; pero si consultamos el gusto, si tenemos en cuenta los claros y oscuros, la gracia de los aires más o menos vivos, el sentimiento en fin de las notas verdaderamente comprendidas y expresadas, la orquesta de Julián Gil no satisfizo los deseos de los inteligentes. Hizo lo que un cómico que leyera correctamente su papel pero que no lo declamara.

A la noche inmediata se presentó la joven orquesta y llenó admirablemente los deseos de todos porque el gusto, la delicadeza con que toca, la expresión bien concertada y bien dirigida de de cada una de las notas fueron un testimonio vivo de que si el antiguo director alcanza al nuevo en conocimientos músicos y en ejecución en el violín, éste le aventaja considerablemente en gusto, en delicadez y en sentimiento. $[\ldots]^{210}$.

En 1878, un interesante artículo titulado "Los músicos de Murcia" puso de manifiesto la precaria situación social y económica de los músicos de orquesta murcianos y las frecuentes desavenencias que existieron entre ellos ${ }^{211}$. Estas desavenencias impidieron la creación de una orquesta para la sociedad El Liceo (1878-1883) (véase Capítulo 6).

Durante los años siguientes, crecieron las diferencias entre los instrumentistas que dieron lugar en 1881 a una gran polémica bautizada por la prensa como "cuestión orquesta" (o "cuestión musical"). El conflicto se prolongó hasta 1898 y generó más de un centenar de escritos en los diarios de la ciudad. El Apéndice 2.7 muestra un índice de artículos publicados en la prensa murciana en torno a la orquesta del Teatro Romea y sus ideas principales (1881-1898). El conflicto estuvo marcado por tres hechos clave:

${ }^{210}$ El Clamor Público, (1849), $\mathrm{n}^{\circ}$ 1585, 2 enero, p. 4. He incluido el testimonio íntegro en el Documentario.

211 El Semanario Murciano, I (1878), n 12, 5 mayo, pp. 2-3. No consta el nombre del autor. El artículo fue firmado bajo el pseudónimo "Un músico viejo", que quizás era Mariano Esbrí. 
1. Debate sobre la creación de una orquesta estable para el Teatro Romea y sobre el procedimiento para formarla (1881-1884).

2. Creación de una orquesta mediante oposición pública (1884-1890).

3. Constitución de un sexteto en sustitución de la orquesta (septiembre de 1890) y creación de una nueva orquesta para el Teatro Romea (octubre de 1890).

\section{El debate sobre la creación de una orquesta estable en el Teatro Romea}

El origen de la polémica se remonta a mayo de 1881. El Diario de Murcia se hacía eco de un rumor sobre una nueva reorganización de la orquesta del teatro Romea:

Decía "El Diario" el sábado que se iba a reorganizar la orquesta del teatro bajo una nueva base. ¿Se va a reorganizar o se va a desorganizar lo que hay y que todos veíamos con gusto iba en mejoría, debido a la buena unión y armonía que reinaba entre los profesores músicos? ${ }^{212}$.

Seis meses más tarde, El Eco de Murcia publicó un artículo titulado "La orquesta de Murcia", parcialmente reproducido por El Diario de Murcia, en el que se pedía la creación de una orquesta con plazas fijas por oposición ${ }^{213}$ :

[...] La división y la perpetuación introducida en la mayor parte de los profesores y artistas de esta capital ha venido a retrogradar el arte, en vez de proporcionarle una nueva senda de adelantos, como hubiera sucedido en donde las personalidades supieran ahogar rencores y sólo tuvieran por estímulo la gloria del país.

Antes habia en Murcia una orquesta que por falta de estudio y por sobra de monopolio, a pesar de contar en su seno con reputados profesores, no pasaba de ser mediana y solo en algunos casos llegaba a buena. Hoy podemos decir que, teniendo dos orquestas, no hay ninguna, pues reducida al silencio la antigua y llena de principiantes la nueva, para que pueda oírse sin completo desagrado tiene que ser reforzada con ejecutantes forasteros, cada vez que ha de interpretar ante público inteligente papeles de alguna importancia.

Siguiendo de este modo, dentro de poco tiempo, no podremos contar en Murcia con profesores de ninguna clase.

Esto no debe suceder en manera alguna. Como buenos murcianos, como amantes de nuestro país, llamamos sobre este punto la atención de nuestro Ayuntamiento que, sin desembolsos, sin violencia y con solo fijarse un momento puede hacer que en un solo día se levante el arte en Murcia y podamos presentar una orquesta con condiciones y elementos para que llene cumplidamente su misión.

Siendo el Ayuntamiento dueño de uno de los más elegantes teatros de Europa, como es el de Romea, debiera dar la iniciativa en este asunto, formando para dicho teatro una orquesta de plazas fijas, por oposición, sin director determinado, el cual podría serlo cuando no estuviese entre la compañía de actores, uno de los mismos músicos a elección de éstos, concluyendo de este modo la disidencia y el caciquismo.

Creadas las plazas fijas, por oposición, podrían formar una sola orquesta los mejores profesores de las dos que hoy conocemos, y como quedarían libres de

${ }^{212}$ El Diario de Murcia citado por La Paz de Murcia, XXIV (1881), nº 7061, 30 mayo, p. 1. Varias críticas teatrales de La Paz de Murcia parecen confirmar una mejoría en las actuaciones de la orquesta. Véase, por ejemplo: La Paz de Murcia, XXIV (1881), n 7029, 19 abril, p. 1.

${ }^{213}$ El Diario de Murcia, III (1881), n 821, 10 noviembre, p. 1. El artículo original en El Eco de Murcia no se conserva. 
presiones y de compromisos y solo atenderían a la conservación de su puesto, tratarían de estudiar con más asiduidad, y en breve podrían ejecutarse las obras más difíciles, sin que se dieran los casos tan desagradables que desde hace algún tiempo hemos presenciado en más de una ocasión ${ }^{214}$.

El artículo provocó diversas reacciones. La Paz de Murcia apoyó la fórmula de creación de una orquesta por oposición ${ }^{215}$. En un primer momento, El Diario de Murcia también fue favorable a la idea y consideró que, "habiendo profesores en esta ciudad, no está bien que se traigan de fuera" ${ }^{216}$. Sin embargo, a principios de diciembre de $1881 \mathrm{su}$ postura cambió: "la oposición no supone nada y estamos seguros de que ningún músico acudiría a ella" ${ }^{217}$. El Semanario Murciano estuvo de acuerdo con la formación de la orquesta por oposición, pero se opuso a que esta cuestión suscitara entre los músicos ríos de tinta que acapararan las páginas de los diarios de la ciudad:

[...] porque si los músicos se aperciben de la cosa y empiezan a tirar líneas y a decir que sí y que no, y que el arte, y que los artistas, y el teatro, y fulano, etcétera, ya hay cuestión orquesta para rato. Si a eso se añade la publicación de un periódico, órgano de los músicos, que dicen que pronto va a ver la luz en esta capital, sin duda para darnos a conocer la armonía que reina entre ellos, va a ser cosa divertida ${ }^{218}$.

A mediados de noviembre de 1881, la cuestión se debatió en una sesión plenaria del Ayuntamiento a propuesta de Almazán, director del periódico La Paz de Murcia. El Ayuntamiento designó una Comisión integrada por el Alcalde (Joaquín Casalduero Conte), Julián Calvo y el mencionado Almazán para "que estudie si es fácil dotar al Teatro de Romea de una orquesta cual se exigen en las condiciones del contrato, lo cual no se puede crear por la iniciativa particular de los profesores, en virtud de sus desavenencias"219. El problema fundamental estribó en el enfrentamiento personal ente algunos músicos y su incapacidad para llegar a un acuerdo. Para El Diario de Murcia la solución era que Mariano García, maestro de capilla de la Catedral, junto con los músicos Mirete y Raya, decidieran quiénes debían formar parte de la orquesta:

214 [Anónimo], "La orquesta de Murcia”, El Diario de Murcia, III (1881), nº 821, 10 noviembre, p. 1 (ver Documentario). Las cursivas son editoriales.

${ }^{215}$ La Paz de Murcia, XXIV (1881), nº 7186, 9 noviembre, p. 1.

${ }^{216}$ Sin embargo, duda sobre la eficacia en las gestiones de la municipalidad: “[...] dudamos del éxito de este buen pensamiento porque los ayuntamientos tienen mala mano para organizar estas cosas y porque, en último caso, las relaciones entre los profesores y las empresas que puedan venir siempre han de ser de libre y mutuo convenio": El Diario de Murcia, III (1881), no 824, 13 noviembre, p. 3.

217 "Las plazas de profesores de la orquesta del teatro Romea no pueden nunca constituir una propiedad. A las empresas no se les puede imponer una orquesta dada [...]. ¿Hay algún teatro en el mundo donde se forme la orquesta por oposición?”: El Diario de Murcia, III (1881), nº 839, 1 diciembre, p. 3.

${ }^{218}$ El Semanario Murciano, IV (1881), $n^{o}$ 192, 13 noviembre, $p .335$.

${ }^{219}$ La Paz de Murcia, XXIV (1881), nº 7191, 15 noviembre, p. 1. La cuestión se debatió en la sesión del 21 de noviembre de 1881. "Dicha comisión se informará de personas competentes, entre ellas los señores Maestro de Capilla, Icabalceta y otros": La Paz de Murcia, XXIV (1881), n 7162, 23 noviembre, p. 1. Véase también, La Paz de Murcia, XXIV (1881), nº 7171, 3 diciembre, p. 1. 
[...] Lo que nosotros creemos que daría resultado sería el juntar al Maestro de Capilla, al señor Mirete y al señor Raya y decirles: "Pónganse ustedes de acuerdo, convengan ustedes, que conocen el personal, en los profesores que han de formar dicha corporación y lo que ustedes hagan lo daremos todos por lo mejor posible". No habiendo esta buena voluntad "a priori” es inútil cuanto se haga, según nuestro humilde parecer ${ }^{220}$.

Los tres músicos citados eran directores de los grupos musicales más importantes de la ciudad. Ángel Mirete era director de la orquesta del Teatro Romea, la Banda Municipal y la capilla de música del Convento de las Agustinas. Emilio Raya era director de una orquesta y de una banda de música muy populares entre los murcianos.

Desde el mes de diciembre de 1881, la Comisión para la constitución de la orquesta se reunió en varias ocasiones ${ }^{221}$ y a finales de enero del año siguiente, "dieron su misión por terminada, convencidos de que ellos, por sí, no pueden llegar a ningún resultado positivo" 222 . La orquesta recibió duras críticas durante las representaciones de zarzuela de la compañía de Daniel Banquells (1ª temporada de 1881-1882), concluidas en febrero de 1882. Ante la llegada de una compañía de ópera tras la Pascua, se instó al empresario del Romea, Medina, a que reorganizara la orquesta:

[...] Ahora se anuncia la venida de una compañía de ópera, con cuyo motivo hemos oído algunos comentarios que se relacionan con la tan manoseada cuestión de orquesta y que en el fondo encierran, a nuestro juicio, algo de verdad; por lo que nos hemos decidido a escribir este suelto que puede la empresa de Romea tomar como consejo desinteresado de quien es imparcial en el asunto.

Ha sucedido en el teatro durante toda la temporada que, lejos de suscitarse cuestiones más o menos vehementes acerca de la bondad de la orquesta [...] ha imperado, por el contrario [...], la mayor tolerancia por parte del público y especialmente por la de aquellas personas que son las llamadas a depurar en el crisol de la crítica racional y justa, lo que hubiese de bueno o de malo en la ejecución de las obras. Pero esta conducta, que ha podido ser plausible tratándose de música de zarzuela, se tornaría en censurable si al ocupar la escena de nuestro teatro una compañía de ópera italiana, se dejara pasar con indiferencia y sin correctivo, las faltas a que nos ha tenido acostumbrados la orquesta y que entonces vendrían a desvirtuar las bellas partituras de insignes maestros, cosas que en rigor de verdad, no debe nunca convertirse.

Suprimir un solo a un instrumento porque el artista encargado de su ejecución no sea bastante apto para ello, como ha sucedido en Las dos coronas; variar a menudo ciertos pasajes escritos, por ejemplo, para el oboe, y que lo oigamos en el violín; que el clarinete diga un solo de fagot o que se supriman ciertas bellezas como el acompañamiento de flauta en la magnífica fermata de tiple del final de La tela de araña y otras muchas mutilaciones que se han notado, sin protesta ostensible de nadie, debe la empresa a toda costa trata de evitarlo de manera que juzgue más conveniente, respecto de la ópera.

En Murcia hay elementos para formar una buena orquesta y la empresa es la llamada a organizarla sin confiarse en que lo haga cualquier caciquillo que, o ha de guiarle su propio egoísmo o se ha de ver imposibilitado de contratar a muchos

${ }^{220}$ El Diario de Murcia, III (1881), nº 837, 29 noviembre, p. 2. Se insistió en esta solución en El Diario de Murcia, III (1881), $\mathrm{n}^{\circ} 841,3$ diciembre, p. 2.

${ }^{221}$ La Paz de Murcia, XXIV (1881), ñ 7215, 14 diciembre, p. 1 y El Diario de Murcia, III (1881), $\mathrm{n}^{\mathrm{o}}$ 873, 13 enero, p. 2.

${ }^{222}$ El Diario de Murcia, IV (1882), nº 876, 17 enero, p. 3. 
profesores murcianos, los unos por enemistades personales de la localidad, más o menos fundadas, y otros por sentimientos de dignidad $[\ldots]^{223}$.

Para esta fecha, La Paz de Murcia había modificado su postura inicial en la "cuestión orquesta": ya no consideraba al Ayuntamiento responsable de promocionar una buena orquesta para el teatro, sino a las empresas teatrales ${ }^{224}$.

La orquesta del teatro dirigida por Emilio Raya para las representaciones de ópera fue ampliada, aunque no fue la formación de Ángel Mirete, sino la de Emilio Raya ${ }^{225}$. La polémica, entonces, se desplazó hacia otro punto. En líneas generales, El Diario y El Noticiero consideraron apropiada la ampliación de la orquesta de Raya y con ella, zanjada la cuestión. El Eco de Murcia y La Paz de Murcia pensaron, en cambio, que la contratación de músicos foráneos relegaba a los murcianos; por tanto, el problema de la orquesta persistía y debían buscarse los medios necesarios para que el Teatro Romea contara con una buena orquesta formada única y exclusivamente por instrumentistas de la ciudad.

El origen de este nuevo conflicto fue la crítica teatral del pianista Antonio Ramírez a la representación de Aida, publicada en El Diario de Murcia. Ramírez dedicó grandes elogios al director de la orquesta Bavagnoli y escribió sobre Raya: "Este modesto artista, sin exclusivismo de ningún género, sin hacer de su corporación campo cerrado donde sólo a los iniciados fuese lícita la entrada, ha conseguido que la orquesta responda a las exigencias de nuestro teatro" ${ }^{226}$. La crítica teatral de Ramírez obtuvo dos respuestas que, a su vez, desencadenaron otros escritos periodísticos. La primera de ellas, anónima, apareció en El Eco de Murcia. Aunque no se conserva, sus ideas principales aparecen en un segundo artículo anónimo que respondía a El Eco y fue publicado en El Diario de Murcia, en defensa de Ramírez:

${ }^{223}$ La Paz de Murcia, XXV (1882), nº 7273, 25 febrero, p. 1 (ver Documentario). Las cursivas son editoriales. El redactor hizo hincapié en que esta situación, que podía ser plausible tratándose de compañías de verso o de zarzuela, pasaría a calificarse de censurable si la compañía era de ópera italiana pues "vendrían a desvirtuar las bellas partituras de insignes maestros". Unos días más tarde, el periódico rectificaba la información: "no eran del todo exactas las citas que hacíamos, especialmente respecto de Las dos coronas y de que el clarinete desempeñase los pasajes encomendados al fagot, pues solo el violín concertino encargado más que de tocar su papel, de cubrir las faltas de las partes y de los demás instrumentos, ha podido alguna vez tocar alguna nota de aquel": La Paz de Murcia, XXV (1882), nº 7276, 1 marzo, p. 1 (ver Documentario).

${ }^{224} \mathrm{El}$ artículo fue citado por otros medios de comunicación, como El Diario de Murcia, IV (1882), $\mathrm{n}^{\circ}$ 913, 28 febrero, p. 2.

${ }^{225}$ La Paz de Murcia afirmó que, a pesar de que habían sido contratados mayoritariamente instrumentistas murcianos, debían "venir todavía de fuera alguna de las partes principales, por no haber avenencia con los que pudieran desempeñarla": La Paz de Murcia, XXV (1882), $\mathrm{n}^{\circ}$ 7276, 1 marzo, p. 1. El Diario de Murcia aseguró que la orquesta dirigida por Raya había ensayado El Trovador con mayor número de instrumentistas, aunque ninguno de fuera: El Diario de Murcia, IV (1882), nº 932, 24 marzo, p. 2. El Eco, reproducido por La Paz de Murcia, aportaba otros datos como el número específico de instrumentos y la cantidad que percibiría la orquesta por cada función de ópera. Estos datos serán comentados más adelante: La Paz de Murcia, XXV (1882), no 2286, 5 abril, p. 1. Es preciso añadir que la compañía actuó con la orquesta de Raya aunque figuró como maestro director y concertador el italiano Maulio Bavagnoli.

${ }^{226}$ El Diario de Murcia, IV (1882), nº 953, 20 abril, pp. 1-2 (ver Documentario). 
REMITIDO. Vamos a dirigirnos al "Eco" y ante todo queremos aclarar a quién del "Eco" nos dirigimos. No es a su director ni a su redacción. Es a ese ente anónimo, gran maestro de música que lo sabe todo y sobre todo, todo lo que no puede alcanzar un buen pianista. Ese maestro que se ha creído coco de los artistas y profesores, no ha visto con buenos ojos la revista que ha publicado EL DIARIO sobre la primera representación de Aida y la combate por cuatro razones: $1^{\circ}$ Porque el que la ha escrito es pianista y ¡claro está!, un pianista no puede decir una palabra sobre el estreno de Aida. Esto se concluye. $2^{\circ}$ Porque ha dicho que no se calienten ya la cabeza los confeccionadores de los proyectos para mejorar la antigua orquesta del teatro por cuanto que la actual ha resuelto el problema de tocar bien una obra difícil, en lo cual está conforme el maestro pero con una salvedad: la de que estos profesores han tocado bien Aida porque la han ensayado mucho. ¡Bueno! vaya por cuando otros ensayan lo mucho, tocaban bastante mal obras más fáciles y conocidas que Aida. $3^{\circ}$ Porque supone al señor Ramírez entusiasmo por la orquesta del señor Raya en las representaciones de Trovador, Lucia y Rigoletto, cosa que no se lee ni se adivina en su revista, pero que ahora declara que ha podido tenerlo, por cuanto nunca se han ejecutado aquí mejor que ahora las dichas obras. $4^{\circ}$ Porque supone no confiesa el señor Ramírez que la orquesta del teatro de Romea es numerosa y nada más que numerosa, es decir, que solo sirve para la guerra, que es para lo que sirve la mucha gente. No señor, no puede el señor Ramírez confesar eso porque ve, y el público lo ve también, que es numerosa y apta, que cada uno de sus individuos desempeña su papel sin suprimir nada y sin que el concertino en ningún caso tenga que sacar a nadie del atolladero.

Estos son los cuatro puntos fundamentales del sueltista del "Eco", los cuales basta exponerlos, como hemos hecho, para que queden refutados. $[\ldots]^{227}$.

La segunda respuesta a la crítica de Aida publicada por Ramírez fue una carta del violinista y compositor Fernando Verdú, aparecida en La Paz de Murcia. Verdú consideraba que la mejoría de la orquesta no radicaba en la cantidad de instrumentistas contratados o en su calidad como músicos, sino en el aumento del número de ensayos:

[...] La antigua orquesta, como tú sabes, se componía de muchos de los profesores que constituyen hoy lo que aplaudes: aquélla con sus propios elementos, hacía lo que podía y también te consta que siempre desempeñó su cometido sin tener tiempo para ensayar ni aún medianamente las obras. ¿Qué más podía pedirse a una orquesta que ha ejecutado óperas desconocidas con dos ensayos a la ligera, con trasportes sin cuento y con papeles ininteligibles? Hoy sucede, precisamente, lo mismo que ocurría entonces, que se oía bueno y malo porque no es posible otra cosa en provincias donde las empresas, para no perder los ojos, tienen necesidad de presentar función diaria y repetir poco las obras. De este modo las orquestas nunca podrán lucirse $[\ldots]^{228}$.

${ }^{227}$ El Diario de Murcia, IV (1882), n 956, 23 abril, p. 1 (ver Documentario). Este artículo provocó un conflicto personal entre Ramírez y Mariano García, a quien Ramírez creía el autor del artículo de El Eco de Murcia. A pesar de que el maestro de capilla lo desmintió, el pianista Ramírez continuó atribuyéndole su autoría: Antonio Ramírez, "Teatro de Romea. Compañía de ópera. Fausto", El Diario de Murcia, IV (1882), no 958, 26 abril, p. 1; Mariano García, "Remitido", El Diario de Murcia, IV (1882), n 959, 27 abril, p. 2 y Antonio Ramírez, "Remitido", en El Diario de Murcia, IV (1882), nº 960, 28 abril, pp. 1-2. El Eco de Murcia entonces, desveló que los escritores del citado artículo eran Mariano Castillo y Andrés Blanco: El Eco de Murcia reproducido por La Paz de Murcia, XXV (1882), n 7327, 29 abril, p. 1. La reconciliación entre García y Ramírez se produjo a finales de abril de 1882, mediante una reunión privada mediada por Acisclo Díaz, director de la Banda de Misericordia. La disputa puede seguirse en: El Diario de Murcia, IV (1882), nº 962, 30 abril, p. 2 y La Paz de Murcia, XXV (1882), nº 7328, 1 mayo, p. 1.

${ }^{228}$ Fernando Verdú, [Carta remitida], La Paz de Murcia, XXV (1882), nº 3024, 26 abril, p. 1 (ver Documentario). Según Verdú, la "cuestión orquesta" podía correr el peligro de convertirse en una nueva "cuestión fermata", "en la que, como sabes, los dignos profesores que sostuvieron la contienda aguzaron el 
Pese a las reacciones en su contra, Antonio Ramírez publicó una segunda crítica teatral, en esta ocasión, sobre la representación de la ópera Fausto ${ }^{229}$. Sus reflexiones en torno a la orquesta eran favorables:

[...] Aunque el revistero no quiera, aunque le pese, la razón se impone y le obliga a estar conforme conmigo en que la orquesta es buena (relativamente, [se] entiende). Además, solo hay cuatro profesores forasteros y dígame el revistero en conciencia si los ha oído y sabe lo que tocan: ¿no es verdad que son indispensables?, ¿no es verdad que ha hecho bien el señor Raya en contratarlos?, ¿no es verdad que hubiera hecho bien también cualquiera otro director en traerlos para tocar óperas? Pues entonces no hay que tomarlo a mal, sino muy al contrario, el que se sienten en los atriles de nuestro teatro.

Ahora me queda que decir que yo no entro ni salgo en la cuestión de jefaturas de orquesta. Renuncio a ser confeccionador de ningún plan para tales arreglos; y lo renuncio, no como un cargo enojoso, sino como un honor para el cual no me creo apto. Tengo mi opinión de que todo lo que se quiera intentar por personas ajenas a las dos corporaciones será completamente inútil. $[\ldots]^{230}$.

A la muerte de Emilio Raya (11-05-1882), la orquesta fue nuevamente reorganizada y pasó a ser gestionada por una Junta Directiva, presidida por Antonio Ramírez $^{231}$. Aparentemente, la "cuestión orquesta" había concluido. Sin embargo, a finales de julio de 1882, El Diario de Murcia mencionó nuevas desavenencias de los músicos ante los actos de la Exposición Provincial de Murcia, lo que desató un nuevo aluvión de escritos: "Los profesores de esta ciudad no han podido entenderse para ordenar un programa musical y concurrir a la Exposición" 232 .

El periódico La Provincia publicó una carta de Ángel Mirete, Adolfo Gascón, Fernando Verdú, Acisclo Díaz, Julián Calvo, Mariano García y Juan Diego Manresa desmintieron categóricamente la noticia de El Diario de Murcia ${ }^{233}$. Para La Paz de

ingenio para procurar el triunfo de sus opiniones; pero lastimosamente se zahirieron en más de un escrito y rodó por el suelo más de una honra profesional". La polémica en torno al término fermata tuvo lugar entre los músicos Adolfo Gascón Leante, Juan Diego Manresa y Mariano García (véase Capítulo 4). Por este motivo, Verdú desaprobaba que las polémicas entre los músicos fueran aireadas públicamente.

${ }^{229}$ La ópera Fausto, de Gounod, fue interpretada por la compañía de Bavagnoli los días 24 y 25 de abril de 1882 .

${ }^{230}$ El Diario de Murcia, IV (1882), n 958, 26 abril, p. 1.

231 El Diario de Murcia, IV (1882), $\mathrm{n}^{\text {os }}$ 974, 14 mayo, p. 2 y 7343, 15 mayo, p. 1 (véase la transcripción de la primera fuente en el Documentario). El resto de miembros de la Junta fueron: Mariano Esbrí (presidente honorario), Miguel Martínez y Antonio Puche (vicepresidentes), Mariano Esbrí, Jorge Goderch, Antonio Raya y Mariano Monserrate (vocales), Rafael Megías (depositario) y Lorenzo Linares (secretario contador).

${ }^{232}$ El Diario de Murcia, IV (1882), n 1039, 27 julio, p. 3. La Exposición Provincial se celebró en Murcia entre el 1 y el 10 de septiembre de 1882. Contó, entre otras, con una sección agrícola y otra industrial donde se exhibieron productos murcianos y de otras provincias españolas. Véanse, por ejemplo, las descripciones publicadas por El Diario de Murcia, IV (1882), $\mathrm{n}^{\text {os }} 1068,2$ septiembre, p. 1; 1069,3 septiembre, pp. 1-2 y 1070, 5 septiembre, p. 1. Mariano Castillo, Presidente de la comisión encargada de organizar la feria, había concebido la idea de reunir a los músicos murcianos en un gran concierto, como parte de los festejos de la exposición.

${ }^{233}$ No se conservan ejemplares de La Provincia. La carta fue reproducida por La Paz de Murcia, XXV (1882), $\mathrm{n}^{\circ} 7395,28$ julio, p. 1 (ver Documentario). En ella se afirmaba que Ramírez era el único músico que 
Murcia, el problema era que "los profesores que hoy dirige el señor Ramírez, antes de Raya, no quieren tocar en unión de los de Mirete" ${ }^{234}$. A mediados de febrero de 1883, Ramírez dimitió de la dirección de la orquesta del Teatro Romea, sustituyéndole Acisclo Díaz, director de la banda de huérfanos de la Casa de Misericordia ${ }^{235}$.

La polémica se reabrió un año más tarde, a partir del artículo titulado "Una opinión sobre la orquesta del teatro", de Antonio Ramírez. Para el pianista, existían dos bandos "irreconciliables" representados por dos orquestas: la dirigida por Ángel Mirete y la del teatro, regentada por Acisclo Díaz: "el uno está en la oposición; el otro está en el poder. El uno en la oposición se reorganiza, el otro en el poder se gasta. [...] Es evidente que cualquiera de las dos orquestas solas no valdrá tanto como valdría escogiendo lo mejor para llegar de una y otra" ${ }^{236}$. Ramírez observaba que la conciliación entre ambas orquestas no era posible, si no se conseguían sueldos dignos:

[...] Es la cuestión de sueldo. Voy a ser bien claro. Una orquesta completa, una orquesta con timbales, ruido, fagotes de verdad, dos clarinetes, dos oboes, flautas, metal bueno y completo y cuerda en número proporcionado; una orquesta que no puede bajar de cuarenta profesores ¿está bien pagada con trescientos reales o con ciento sesenta cuando es verso? Absolutamente no, eso es completamente imposible. Es decir, imposible no es, puesto que la orquesta actual de Romea tiene próximamente ese número de músicos, o acaso más; pero ¿qué milagros van a exigirle al hombre que está siete horas diarias en el teatro y al final de la jornada se lleva a su casa para mantener a su familia dos [p. 2] pesetas o diez reales cuando más? Y esto solo cuando el teatro está abierto y dejo además de hablar de los que ganan seis reales, o cuatro, o dos, que no son pocos, sino más de la mitad. $[\ldots]^{237}$.

Resuelta la cuestión económica con una subida de la retribución de la orquesta, Ramírez se planteó quién debería hacer la selección de los músicos:

[...] ¿Pero quién puede ser el encargado de hacer tal selección?. Particularmente o exclusivamente ninguno, porque todos tienen compromisos y afecciones particulares. Colectivamente, los profesores más notables de música en

había rehusado la invitación a participar en la Exposición, por tener comprometida su orquesta con la empresa del Teatro Circo desde el 15 de agosto de 1882 y para la temporada 1882-1883.

${ }^{234}$ Y publicaba en el mismo ejemplar una carta de Ramírez que, a su vez, fue contestada por otra de Ángel Mirete: La Paz de Murcia, XXV (1882), nº 7396, 29 julio, p. 1 (ver Documentario) y El Diario de Murcia, IV (1882), $\mathrm{n}^{\mathrm{o}}$ 1042, 30 julio, p. 2. Los puntos más relevantes de esta carta son: afirma ser el inspirador de la noticia publicada por El Diario de Murcia, IV (1882), n ${ }^{\circ}$ 1039, 27 julio, p. 3; reconoce la incapacidad para acordar un programa conjunto entre todos los músicos para el concierto de la Exposición de septiembre; y, finalmente, desmiente que el presidente de la Junta de la Exposición obligara a los músicos de Ramírez y Mirete a tocar juntos. Posteriormente, La Paz de Murcia, XXV (1882), nº 7399, 2 agosto, p. 1 publicó otra carta de Ángel Mirete en la que hace constar que no se opuso ni se oponía a reunir a ambas orquestas.

${ }^{235}$ La Paz de Murcia, XXVI (1883), no 7561, 14 febrero, p. 1 y El Diario de Murcia, V (1883), ${ }^{\circ}$ 1204, 15 febrero, p. 3.

${ }^{236}$ Antonio Ramírez, "Una opinión sobre la orquesta del teatro", El Diario de Murcia, VI (1884), n 1501, 12 febrero, pp. 1-2.

237 Antonio Ramírez, “Una opinión”, pp. 1-2. Más adelante, Ramírez expresa rotundamente: “Es preciso sentar por adelantado que la orquesta está pobremente retribuida". El término "ruido" se refiere a instrumentos de percusión, como por ejemplo el triángulo o las campanas. 
compañía de una comisión del Ayuntamiento, interesado como está en todo lo que redunde en mayor lustre y esplendor del coliseo de que es propietario. [... $]^{238}$.

\section{Mariano García describió las diferencias entre ambas orquesta aunque no aportó ninguna solución:}

[...] Como dice bien el señor Ramírez, Mirete se rehace en la oposición, mientras Díaz se gasta en el poder. Aquél espera que concluya el compromiso de la actual empresa del teatro y éste teme que alguna vez el público muestre más rigor en sus apreciaciones o los cantantes sean más exigentes. Mirete tiene probada la constancia y afecciones de sus individuos. Díaz está al frente de una agrupación que no ha creado, la cual se muestra recelosa cada vez que vaca un puesto y es ocupado por un asilado de la Misericordia. Aquél cuenta con personal suficiente para, en un momento dado, con solo el cambio de algunos instrumentos, presentar una orquesta si no del todo buena, muy aceptable y con gran práctica en sus principales grupos. Éste tiene que recurrir al forastero para cubrir lo que le falta, perjudicando la ganancia individual.

Ahora bien, ¿puede prescindirse de estos dos señores, jefes de las actuales orquestas? No. Cada cual tiene grandes compromisos que sostener y cumplir y puede asegurarse que ninguno cederá. ¿Caben juntos en una misma orquesta? Difícil lo veo. Mirete posee el instrumento más necesario, y sin ofender a nadie, es el primero de su clase entre todos los de Murcia. Díaz tiene grandes conocimientos pero sobre instrumentos secundarios, por lo cual siempre habría disparidad, y por consecuencia surgiría el descontento [...].

Ya están agotados los recursos que se han creído convenientes para llegar a la mejor inteligencia y el resultado ha sido nulo. [...] Yo no veo solución alguna y lo que es peor, presiento que al concluir la actual empresa, la lucha tomará forma más graves y mezquinas y entonces será cuando, con razón, mi amigo podrá quejarse de la mala retribución que tiene el trabajo de un músico ${ }^{239}$.

\section{Un supuesto Ángel Mirete denunció:}

[...] Tantas veces como he procurado arreglar mi orquesta, una mano oculta me la ha descompuesto. Yo no culpo a nadie pero el hecho es ese y aún más: se ha trabajado por arrojarme de las procesiones de Semana Santa, del teatro y de todos los puntos donde se obtiene esa mezquina gratificación que es necesaria" 240 .

Fernando Verdú consideró que se había llegado al "personalismo raquítico" y proponía que la formación de la orquesta recayese en "una corporación o persona neutral”,241.

${ }^{238}$ Antonio Ramírez, "Una opinión”, p. 2. El pianista concluía su escrito invitando a Mariano García, Ángel Mirete, Julián Calvo, Acisclo Díaz y Fernando Verdú a opinar sobre el asunto.

${ }^{239}$ El Diario de Murcia, VI (1884), n 1503, 14 febrero, p. 1.

${ }^{240}$ El Diario de Murcia, VI (1884), $\mathrm{n}^{\circ}$ 1504, 15 febrero, p. 1. La redacción del periódico advirtió al día siguiente que la supuesta carta remitida por Ángel Mirete había llegado por correo interior y que había sido publicada por creerse auténtica, pero el propio Mirete solicitó al periódico su rectificación: El Diario de Murcia, VI (1884), n 1504, 15 febrero, p. 1. Desconozco quién fue el verdadero autor.

${ }^{241}$ El Diario de Murcia, VI (1884), n 1505, 16 febrero, pp. 1-2 y La Paz de Murcia, XXVII (1884), $\mathrm{n}^{\circ}$ 7846, 16 febrero, p. 1. 
El debate periodístico en torno a la creación de una orquesta para el teatro encontró eco en el Ayuntamiento, a raíz del nuevo arrendamiento del Teatro Romea para 1884-1887. La solución de ampliar la orquesta había resuelto parcialmente el problema aunque la calidad de los músicos seguía siendo muy discutida. El nuevo contrato de alquiler del coliseo debía contar con una plantilla de músicos eficaz y estable ${ }^{242}$. El 18 de febrero de 1884, un grupo de diez concejales propusieron que fuese nombrado director de la orquesta Ángel Mirete. Sus argumentos fueron los siguientes:

[...] Los concejales que suscriben, teniendo en cuenta que no obstante lo estipulado en las condiciones de arrendamiento del Teatro Romea con respecto a Orquesta, ésta ha dejado y deja mucho que desear, con notable perjuicio del público y de los profesores de esta localidad y sin ventajas para la empresa arrendataria, teniendo en consideración que la orquesta que actualmente / [fol. 62v] dirige don Ángel Mirete es la mejor organizada, que sus profesores son hijos de esta ciudad y que su director además de ser notable violinista reúne condiciones de aptitud para el cargo que desempeña, proponen a V[uestra] E[xcelencia] se sirva acordar que el expresado señor Mirete sea nombrado director de la orquesta del Teatro $[\ldots]^{243}$.

El también concejal García Alix señaló que debían evitarse "dos escollos" respecto de la orquesta: el monopolio de algunos músicos (sin duda aludiendo veladamente a Ángel Mirete) y que la orquesta no tuviera la calidad que la ciudad y el teatro merecían:

[...] El señor García Alix creyó debía estudiarse para evitar el sancionar un monopolio, no dar al público lo que no es digno de él ni del teatro, como los inteligentes dice que sucede hoy. El señor Piqueras dijo que estaba muy lejos de querer el monopolio, mas como no hay recursos para costear una orquesta, es preciso buscar el medio para que el público perciba otros sonidos más armónicos que hoy. El señor Garcia Alix reconoce que hay que hacer algo. El señor Lumeras que se debe imponer a las empresas la obligación de tener una orquesta digna de Murcia. El señor Lopez (don Ricardo) que podría adoptarse el conceder las plazas por concurso a los que se las ganases. El acuerdo fue nombrar una comisión especial que informe, compuesta de los señores Piqueras, Guillamón, Ballester, Lopez y Garcia Alix. [... $]^{244}$.

Todos querían organizar una nueva orquesta para el teatro, aunque únicamente el concejal Ricardo López sugirió la posibilidad de convocar una oposición pública, opción que finalmente aceptó la Comisión Especial sobre el tema, el 22 de febrero de 1884:

${ }^{242}$ Así lo hizo constar el Regidor, Rafael Almazán (director de La Paz de Murcia) en la sesión ordinaria de 18-02-1884 en la que se abordó la discusión sobre las cláusulas del contrato de arrendamiento: "El señor Almazán observa a las empresas arrendatarias se deben favorecer, por lo que respecto a estas le parecen bien las condiciones pero nota que hay cierta vaguedad en la relativa a la música, lo cual debe ser conforme a las exigencias del público y a la importancia de la Capital": E:MUm, AC 18-02-1884, fol. 61r.

${ }^{243}$ E: $M U m$, AC 18-02-1884, fols. 62r-62v. La proposición fue discutida por los concejales José López Caberuelo, Felipe Guillamón, José María Solís, José Cayuela, Juan Piqueras, Rafael Almazán Martín, Ricardo Cantó, Federico Gómez Cortina, Fulgencio Meseguer y Diego Salmerón. Se aprobó su resolución en la sesión siguiente (22-02-1884). La nueva reunión retomó la discusión sobre el pliego de condiciones de alquiler del Teatro Romea y la dirección de su orquesta.

${ }^{244}$ La Paz de Murcia, XXVII (1884), nº 7850, 21 febrero, p. 1. 
[...] siendo siempre ardua tarea el resolver / [fol. 86r] cuestiones personales y con el fin de evitar resentimientos unánimemente ha convenido esta Comisión y así lo propone a V[uestra] E[excelencia] que tanto la plaza de Director de la Orquesta del Teatro, como los demás individuos que hayan de formarla, se provean por oposición, constituyéndose al efecto un tribunal compuesto de tres profesores de reconocida competencia y dos señores Concejales $[\ldots]^{245}$.

\section{Creación de la orquesta del Teatro Romea por oposición pública (1884)}

Al mismo tiempo que se decidió crear una orquesta fija por oposición para el Teatro Romea, se establecieron su plantilla y otros aspectos de su funcionamiento. La plantilla constaría de treinta y ocho músicos: un violín concertino, cinco violines primeros y seis segundos, dos violas, dos violonchelos, tres contrabajos, dos flautas, dos oboes, dos clarinetes, dos fagots, dos trompas, dos cornetines, tres trombones, un figle. Las plazas de percusión (un timbalero, un bombo y un cajista -este último, sólo cuando se necesitase-) quedaban fuera de la oposición y sus ocupantes serían designados directamente por el director. Todos los aspirantes a plazas de la orquesta debían ser vecinos de la ciudad.

Las pruebas que habían de superar el director y los restantes músicos se establecieron de la siguiente forma:

[...] Las condiciones y pruebas de aptitud a que creemos deben someterse los que aspiren a la plaza de Director son las siguientes:

$1^{\text {a }}$ Suficiencia probada en el manejo de la batuta.

$2^{\text {a }}$ Enmendar una partitura equivocada [fol. 86v] en un momento dado.

$3^{\text {a }}$ Que los aspirantes profesen el instrumento más necesario en la Orquesta, o sea el violín, para poder desempeñar el puesto de concertino en las temporadas en que por las empresas se haya contratado director para espectáculos líricos.

$4^{\mathrm{a}}$ Instrumentar para orquesta una pieza o trozo de música en un tiempo dado.

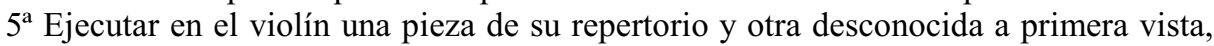
sin más tiempo que cinco minutos para leerla.

$6^{\text {a }}$ Que componga un trozo de música original, en el tiempo que el Jurado designe, instrumentada para orquesta.

$7^{\mathrm{a}}$ Dirigir una pieza desconocida.

$8^{\text {a }}$ Presentar obras originales de cualquier género, publicadas o inéditas, compuestas por el opositor, bien para orquesta o banda militar, a fin de probar sus méritos como armonista y compositor.

$9^{\text {a }}$ Que los opositores serán vecinos de esta Capital.

Los ejercicios de oposición para las demás plazas de la orquesta, consistirán en ejecutar una pieza de su repertorio en el instrumento que el aspirante posea y otra parte que se le presente, trasportándola al tono que el tribunal designe $[\ldots]^{246}$.

${ }^{245}$ E: $M U m$, AC 22-02-1884, fols. 85v-86r. Véase la transcripción completa de los acuerdos de la sesión en el Documentario.

${ }^{246}$ E:MUm, AC 22-02-1884, fol. 86. Ver más detalles en el Documentario. El Concejal García Alix propuso que se suprimiese la condición que obligaba al director ser violinista, "pues con ello parece se limita la oposición a favor de determinada persona [Ángel Mirete]": E: MUm, AC 22-02-1884, fol. 88r. Tras un largo debate, votaron a favor de la opción director-violinista quince ediles (entre ellos el director del periódico La Paz de Murcia, Almazán); en contra, trece. Sin embargo, a principios de marzo de 1884 los músicos Ángel Mirete, Antonio Puche, Jorge Coderch, Fernando Verdú y José Fresneda propusieron al Ayuntamiento que reconsideraran esta votación y, por tanto, que el director no fuera violinista "para evitar todo motivo de disgusto y quitar todo pretexto a los que la han censurado, y sólo se exija la primera, segunda, cuarta, quinta, sexta, séptima, octava y novena, de las aprobadas, con lo que no quedará ese vacío que la maledicencia de contados individuos han creído ver en el justo y competente acuerdo evitado": E:MUm, AC, 3-03-1884, fol. 99r. (ver Documentario). La solicitud hizo reflexionar a los concejales, una 
Los precios máximos que se pagarían a la orquesta por cada función diaria serían: 100 pesetas en las óperas, 75 en las zarzuelas y 40 en las funciones dramáticas.

Quedaron pendientes de estudio el número de ensayos y otros puntos relacionados con la orquesta del teatro ${ }^{247}$.

El 11 de abril de 1884 la prensa hizo público el plazo para inscribirse en las oposiciones de acceso a la orquesta del Teatro Romea ${ }^{248}$. El tribunal estuvo constituido por Juan Piqueras, Segundo Teniente de Alcalde de Murcia; Felipe Guillamón, concejal; Mariano García, maestro de capilla de la Catedral de Murcia; Julián Calvo y Simón Espín, organistas de la misma). Las pruebas serían en el salón principal del Teatro Romea los días 15 a 18 de mayo, de seis a diez de la noche ${ }^{249}$. Se inscribieron treinta y un aspirantes aunque concurrieron únicamente veintiocho ${ }^{250}$. Entre ellos, optaban a la plaza de director Ángel Mirete y Fernando Verdú.

Los exámenes, abiertos al público, fueron un acontecimiento en la ciudad ${ }^{251}$. En primer lugar se examinaron los instrumentistas ${ }^{252}$. Cada uno de ellos realizó dos pruebas. La primera consistió en la ejecución de una obra elegida por el candidato. Los opositores fueron acompañados por los pianistas Mariano García, Julián Calvo, Adolfo Gascón y José Solano. El Apéndice 2.8 recoge los nombres de los aspirantes, instrumentos que tocaban y obras interpretadas. El $50 \%$ del repertorio escogido por los opositores eran fantasías, variaciones o fragmentos de ópera; otro $40 \%$ fueron estudios y ejercicios, entre otras composiciones para instrumentos solos; el $10 \%$ restante estaba constituido por obras diversas, como el concierto de violín de Bériot, sonata de Beethoven y el "Adiós a la Alhambra" de Jesús de Monasterio.

vez más. Guillamón consideraba que "al venir compañías que traen su Director de Orquesta, el Director de la que se crea y no sabe tocar el violín concertino, no ocuparía ningún lugar, cobrando un sueldo en el ínterin y desmereciendo en el concepto de sus subordinados, habiendo de pagarse otro concertino, con lo que se gravarían los demás artistas en su pequeño sueldo": E:MUm, AC, 3-03-1884, fol. 99r. Finalmente se acordó aprobar la propuesta de los músicos y anunciar en la prensa la oposición para la orquesta del Teatro Romea.

${ }^{247}$ Se publicó un resumen de la sesión en La Paz de Murcia, XXVII (1884), nº 7852, 23 febrero, p. 1. Entre otros puntos, también se acordó que "si una compañía de ópera trajese con ella la orquesta le sería admitida; pero cuando sólo vengan algunas partes de la orquesta, éstas no alterarán la que aquí se cree”.

${ }^{248}$ El Diario de Murcia, VI (1884), n 1525, 11 marzo, p. 2.

${ }^{249}$ E:MUm, AC, 28-04-1884, fol. 175v. Durante la primera jornada se examinaron a nueve candidatos.

${ }^{250}$ El Diario de Murcia, VI (1884), nº 1529, 15 marzo, p. 2.

${ }^{251}$ Véase una descripción en La Paz de Murcia, XXVII (1884), nº 7925, 21 mayo, p. 1. Al evento asistió un numeroso público. Se obsequió con dulces y bouquet de flores a las señoras por cortesía de los concejales Piqueras y Guillamón.

${ }^{252}$ El expediente de la oposición se encuentra en E:MUm, Leg. 1194 (II) y contiene los siguientes documentos: Solicitudes de los aspirantes, listado de presentados con indicación de los instrumentos que tocaban, actas de las sesiones en las que se especifican las obras interpretadas, listado de obras aportadas Ángel Mirete, relación de obras presentadas por Fernando Verdú y una partitura para orquesta compuesta de varios fragmentos numerados de la obertura de la ópera Haydèe de Aubert. 
La segunda prueba de los instrumentistas fue una lectura a primera vista de una pieza aportada por el tribunal ${ }^{253}$. El $60 \%$ del repertorio de repentización estuvo constituido por composiciones de los propios miembros del tribunal. De Mariano García se interpretó un "Trío para dos violines y contrabajo" (en dos ocasiones distintas y por seis opositores), una "Improvisación para violonchelo" y un "Capricho improvisado" para trompa; de Simón Espín, hubo una "Improvisación" para contrabajo; de Julián Calvo, las obras "Capricho improvisado" para clarinete, "Improvisación" para el mismo instrumento y "Melodía" para oboe; finalmente, de Felipe Guillamón, su "Capricho" para cornetín 254. ejercicios:

Los candidatos a la plaza de director, Mirete y Verdú, realizaron los siguientes

$1^{\mathrm{o}}$ Corregir una partitura con compases equivocados desde el punto de vista armónico, a partir de varios fragmentos de la obertura de la ópera cómica Haydèe de Aubert.

$2^{\circ}$ Orquestar una pieza (o fragmento) en un tiempo determinado.

$3^{\circ}$ Interpretar una obra de su elección y otra a primera vista. Mirete interpretó al violín una "Fantasía con variaciones" de Bériot y Verdú una "Fantasía para violín sobre motivos de Guillermo Tell". El ejercicio de repentización consistió, para ambos, en la ejecución de un "Rondó en Sol Mayor" de Beethoven.

$4^{\text {o }}$ Componer un fragmento de música original para orquesta. No hay más información.

$5^{\circ}$ Dirigir una partitura desconocida por los candidatos. Ambos dirigieron una "Sinfonía para orquesta" de Julián Calvo.

$6^{\circ}$ Presentar obras originales, publicadas o inéditas y para orquesta o banda de música, compuestas por los candidatos. Ángel Mirete presentó dos sinfonías (Sinfonía ${ }^{\circ}$ 12 y Sinfonía titulada "La Primavera", no 9) y un "Rondó", premiado en unos Juegos Florales (no consta año). Verdú presentó dos sinfonías compuestas en 1866 y 1867, respectivamente, una "Salve Regina a cinco voces, coro y grande orquesta" (1871), la obertura "Tula" (premiada en los Juegos Florales de Murcia de 1876), "Gran Marcha Triunfal para orquesta dedicada a Julián Romea" (1880), "Magníficat para orquesta y tres voces" (premiado en los Juegos Florales de Murcia en 1881), una obertura para orquesta titulada "Un ramillete dedicado a D. Julián Romea" (premiado por la Sociedad Julián Romea de Barcelona, no consta el año) y un "Miserere a cuatro voces y coro con acompañamiento de orquesta dedicado a don Mariano García, Maestro de Capilla" $(1883)^{255}$.

${ }^{253}$ A pesar de que en el Acta de la sesión municipal del 22-02-1884 se había dicho que la segunda prueba consistiría en un ejercicio de transporte, el acta de los exámenes indica claramente que fueron interpretadas a primera vista.

${ }^{254}$ El resto de obras fueron: "Romanza para violín" de Martini, fragmento del "Andante" de una Sonata para viola de Rubinstein, un "Estudio" de Garivoldi para oboe y otras piezas cuyos compositores no se especificaron. Véanse más detalles en el Apéndice 2.8.

${ }^{255}$ E:MUm, Leg. 1194 (II). 
El resultado de las oposiciones apareció publicado en la prensa el 21 de mayo de 1884. Como director resultó elegido Ángel Mirete:

Quedan vacantes las plazas de primer viola, segundo violoncelo, segundo oboe, los fagots, primer trompa, un cornetín, dos trombones y el figle. [...]

El jurado los propone en esta forma: el señor Mirete, director primero por su antigüedad y concertino, para cuando las compañías traigan director. Al señor Verdú, segundo director, para sustituir en ausencias, enfermedad o vacante el primero y para el primer violín.

El señor Alix propuso en la sesión del Ayuntamiento en que se aprobó este informe que estos nombramientos fuesen por seis años, para no cerrar la puerta a nuevos méritos, pero se desechó la proposición, quedando aprobado en definitiva el señor Mirete, Director y el señor Verdú, Vicedirector.

Los demás opositores han sido calificados en la forma y condiciones siguientes: Violines primeros: $1^{\circ}$ don Antonio Puche, $2^{\circ}$ y $3^{\circ}$ con igual categoría, don José Ángel Mirete y doña Trinidad Ballester, $4^{\circ}$ don José [Jorge] Coderch.

Violines segundos: don Vicente Espada, don José López Rubio, don José Puche, don Juan Pérez Sánchez y don Antonio García Pasias, a don Isidro Vela se le aprobaron los ejercicios.

Violas: $2^{\circ}$ don Antonio Canales.

Violoncelos: $1^{\mathrm{o}}$ don Francisco Jover.

Contrabajos: $1^{\circ}$ don Pedro Martínez, don José García Pujol, don Antonio Mendoza.

Clarinetes: $1^{\circ}$ don [José] Calvo, $2^{\circ}$ don Mariano Guerrero.

Flautas: $1^{\circ}$ don José María Carrasco, $2^{\circ}$ don Mariano Guerrero, por mérito relativo.

Oboe: $1^{\circ}$ don Jesús García

Trompa: $2^{\circ}$ don Antonio Leante.

Trombón: $1^{\circ}$ don Bonifacio Ballester.

Cornetines: $1^{\circ}$ provisionalmente don Mariano Infer.

Para completar las plazas que faltan con profesores interinos, ha sido autorizado el director nombrado señor Mirete ${ }^{256}$.

Aunque el Ayuntamiento había aprobado una única plaza de director, el tribunal de las pruebas propuso designar un segundo director, plaza que recayó en el primer violín, Fernando Verdú. Este violinista quedaría nombrado además director titular, si Mirete fallaba:

[...] este tribunal no puede, en absoluto, dar su veredicto a favor de uno solo de los aspirantes sin creer que lastima al otro; $y$, en tal supuesto, solo puede proponer al Excelentísimo Ayuntamiento que modifique su acuerdo nombrando a ambos señores opositores directores de la orquesta, si bien, dando carácter de Primero a don Angel Mirete por su antigüedad y asignándole además el cargo de concertino de la orquesta para cuando ésta haya de estar regida por el director que la empresa traiga de fuera, y nombrar Segundo Director a don Fernando Verdú para sustituir al Primero en ausencias y enfermedades con el cargo, a más de primer violín de la expresada orquesta, quedando desde luego el citado señor Verdú con el carácter de director músico, sin necesidad de nueva oposición desde el momento en que el señor Mirete renunciase o dejase vacante el cargo que se le confiere. ${ }^{257}$.

${ }^{256}$ El Diario de Murcia, VI (1884), no 1583, 21 mayo, p. 1. La fuente menciona como primer clarinete a "Francisco" Calvo aunque el acta de calificación de las oposiciones aprobada en 19-05-1884, el nombre que aparece es José Calvo (véase $E: M U m$, AC 19-05-1884, fols. 193r a 195r, transcrito en el Documentario). En la mencionada acta se detallan las opiniones de los concejales sobre la concesión de las plazas a perpetuidad o por un tiempo limitado de años, como propuso García Alix.

${ }^{257}$ E:MUm, AC 19-05-1884, fol. 194r. 
Posteriormente, Fernando Verdú renunció a su nombramiento de Vicedirector de la orquesta (no al de primer violín), aunque el Ayuntamiento de Murcia no aceptó la renuncia $^{258}$.

Durante los años siguientes, la mayor parte de las críticas teatrales elogiaron a la recién formada orquesta, a pesar de que algunas subrayaron la falta de ensayos. No parece haber habido modificaciones importantes en la plantilla de la orquesta los tres primeros años de su existencia. Sólo hay que reseñar algunas sustituciones de unos músicos por otros y ampliaciones puntuales en temporadas de ópera ${ }^{259}$. La crítica de Antonio Ramírez a Rigoletto, representada durante la segunda temporada 1885-1886 en el Romea por la compañía de ópera de Cecilio Sanmartí, dio una visión positiva de la orquesta:

[...] La orquesta merece capítulo aparte. Es numeroso y completo el personal que se ha aumentado con algunos forasteros. Ha recibido algunas muestras de censura por parte del público, contra las que yo protesto por las razones que voy a exponer para que no se dé a mis palabras más significación que la que tienen. Yo concedo que la orquesta tiene la obligación de tocar bien, pero no tiene la obligación de improvisar óperas ni de repentizar transportes. Ensayar por la tarde y tocar una ópera a la noche, con aquel ensayo, es más de lo que humanamente se puede pedir. En cambio, cuando ha podido ensayar, ha llenado cumplidamente su cometido. Yo sostengo que el "Rigoleto" no se ha tocado nunca en nuestro teatro mejor que ahora. $[\ldots]^{260}$.

Como vimos anteriormente, el pliego de condiciones de arrendamiento del Teatro Romea para el periodo 1887 a 1890 detalló minuciosamente muchos aspectos de la actividad teatral y por primera vez hubo apartados especiales para la orquesta y para las compañías. El capítulo XI del pliego de condiciones, en su apartado "De la orquesta" estableció algunas novedades:

[...] $35^{\circ}$. Queda obligado el contratista a aceptar las funciones, la orquesta formada en virtud de acuerdo del Ayuntamiento, cuyo número de profesores no podrá ser menor de 35 a 40 como mímimun.

En el caso de que las compañías de ópera traigan orquesta podrán actuar con ella.

Será potestativo en el contratista tener orquesta en las funciones dramáticas o amenizar los espectáculos con un sexteto que deberá formarse con los profesores principales de la misma y con otros dos profesores notables, uno de piano y otro de armonio.

El precio que habrá de pagar el contratista a la orquesta no excederá:

De cuarenta pesetas en las funciones dramáticas cuando asista toda la orquesta.

De setenta y cinco pesetas en las lírico dramáticas.

$\mathrm{Y}$ de ciento en las de ópera.

${ }^{258}$ Documento con fecha de entrada 30-05-1884: E:MUm, Leg. 1194 (II).

${ }^{259}$ Así lo confirma La Paz de Murcia, XXX (1887), nº 8308, 15 diciembre, p. 1.

${ }^{260}$ El Diario de Murcia, VII (1885), nº 1865, 24 mayo, p. 3. La misma idea fue transmitida por La Paz de Murcia, XXVIII (1885), n 8230, 26 mayo, p. 1: “cuando se le da tiempo para ensayar y no se la obliga a improvisar, ni ha de hacer trasportes repentinos, [la orquesta] cumple con su cometido a satisfacción del público". Para Julián Calvo, "parte de esta culpa la vemos en que la mayoría del público quiere tener función distinta en las pocas o muchas representaciones que se le ofrecen": La Paz de Murcia, XXVIII (1885), $\mathrm{n}^{\circ} 8232,28$ mayo, p. 1. En otra ocasión, se especifica: "ésta [la orquesta] hizo más que se podía esperar, dada la premura con se ha puesto, por haber recibido los papeles a última hora": La Paz de Murcia, XXVIII (1885), nº 8240, 7 junio, p. 1. 
En cuanto al sexteto indicado anteriormente, lo podrá ajustar el contratista en la forma que le convenga.

Todos los profesores que formen la orquesta tienen la obligación de asistir con la misma puntualidad a los espectáculos. Si por falta en el cumplimiento de sus deberes dejase de concurrir algún individuo de la orquesta, no vendrá obligado el contratista a pagar el sueldo correspondiente al que faltase, sino que quedará a su favor.

Cada principio de temporada se pasará nota a la Alcaldía del personal que forme la orquesta, con expresión de los motivos que ocasionen el cambio o cambios de algunos profesores, todo con objeto de saber si aquélla responde al fin para que se creó. $[\ldots]^{261}$.

El número de instrumentistas y los precios de la orquesta no variaron en comparación con el arriendo anterior. Sin embargo, en las condiciones de 1887 hubo novedades importantes relativas a la orquesta: la posibilidad de sustituirla por un sexteto con piano y armonio en las funciones dramáticas, por un lado, y la indicación de normas de conducta y funcionamiento de la orquesta, por otro. No he hallado datos que confirmen que la primera medida se llevara a cabo ${ }^{262}$. Sin embargo, se fue gestando la idea de que la orquesta no era necesaria en determinadas funciones, como iremos viendo.

Respecto a la conducta de los integrantes de la formación orquestal, las advertencias del Ayuntamiento para evitar las ausencias de músicos ponen de manifiesto que éstas eran frecuentes, como también se puede constatar en otras fuentes documentales ${ }^{263}$. En la sesión ordinaria del Ayuntamiento de 20-01-1888 se trató "Sobre las faltas por los músicos de la Orquesta del Teatro Romea":

[...] El señor Ruiz dice que ya saben los concejales lo que pasa en la cuestión del teatro, que han surgido diferencias en los músicos y el Director, encontrándose éste sin carácter dentro de ellos porque no tiene atribuciones para multarlos, separarlos, etcétera.

El señor Alcalde le interrumpe manifestándole que, habiendo acudido ante él a quejarse de que los había expulsado de la orquesta el Director y enterado de que había sido por faltar a su deber, llamó al señor Mirete diciéndole que lo podía hacer como

${ }^{261}$ La Paz de Murcia, XXX (1887), nº 8204, 21 mayo, p. 1. Véase también el Apéndice 2.4.

262 A finales de mayo de 1887, varios músicos pidieron al Ayuntamiento la modificación de la mencionada cláusula y la regularización de los ensayos: El Diario de Murcia, IX (1887), n 3010, 28 mayo, p. 3.

${ }^{263}$ El Leg. 1194 (II) del E: MUm contiene un documento firmado por Juan Pérez Sánchez (segundo violín de la orquesta), fechado en 27 de abril de 1885 en el que el músico solicita al Ayuntamiento la remisión de su suspensión de sueldo, castigo impuesto por el director (Ángel Mirete) "por haber ido a Villena con la Música de la Misericordia". El músico afirmaba: "Como esta Orquesta no tiene un Reglamento que a sus individuos les marque sus obligaciones, así como sus derechos, creyó el que suscribe que, con permiso del jefe de la misma, podía usar de esta licencia en la forma que tuviese por conveniente". La participación de los músicos de la orquesta en otros eventos era muy frecuente. El mismo Mirete lo afirmaba en un escrito de 24 de abril de 1885 (contenido en el mismo Legajo), en el que daba cuenta al Ayuntamiento de un altercado con Pérez: "Pero habiendo ocurrido durante la presente temporada que profesores de la orquesta de los que han ganado la plaza por oposición, se han marchado a otros puntos ya contratados con compañías líricas y a hacer funciones de pueblos, porque unas y otras les produjese más que el sueldo que en el teatro perciben, ha creído el que suscribe que este hecho constituye un abuso que pudiera dar por resultado el que no hubiese orquesta". 
jefe y que cuando ocurriera algo, lo dijese de oficio al Ayuntamiento, con objeto de que impusiese como puede los correctivos y multas ${ }^{264}$.

Las ausencias (justificadas o no) de algunos instrumentistas provocaron despidos y sustituciones ordenadas por el director Mirete. La ausencia de un Reglamento que velara por los derechos y deberes de sus integrantes hizo que esta situación se prolongara hasta 1889 , como testimonian las actas capitulares ${ }^{265}$.

En marzo de 1888 Ángel Mirete cayó gravemente enfermo y murió el 19 de junio del mismo año ${ }^{266}$. Durante esos meses la dirección de la orquesta fue asumida, provisionalmente y con carácter interino, por su hijo José Mirete ${ }^{267}$. El Ayuntamiento tuvo que abordar la sucesión de la dirección de la orquesta del teatro y de la Banda Municipal $^{268}$ y a mediados de julio nombró director y concertino a Fernando Verdú (a quien correspondía legalmente), mientras que el cargo de segundo director y la dirección de la Banda Municipal recayeron en José Mirete ${ }^{269}$.

Con la sucesión resuelta y para evitar los continuos altercados entre instrumentistas y director, se acordaron los siguientes puntos:

[... $1^{\circ}$ Ninguno de los profesores que ocupan en la orquesta plaza ganada por oposición podrá excusar el cumplimiento de las órdenes que reciba del director de la misma, sin ausentarse sin su consentimiento. $2^{\circ}$ Inmediatamente después de ausentarse alguno sin permiso del expresado director lo participará éste al Ayuntamiento, el cual le autorizará para cubrir provisionalmente la plaza y en definitiva a los diez días posteriores si no se presenta el ausente y justifica en debida forma el motivo de su falta, imponiéndole en el caso de que proceda, el correctivo a que hubiere lugar. El mencionado director formará en el pazo de un mes un pro / [fol. 1054v] yecto de reglamento para el mejor régimen de dicha orquesta y una relación nominal de todos

\footnotetext{
${ }^{264}$ E:MUm, AC 20-01-1888, fol. 13r-v (transcrito en el Documentario).
}

265 Véanse algunos ejemplos en E:MUm, AC 4-11-1888, fol. 1053v-1054v:1053v, AC 25-11-1888, fol. 1081r-v, así como El Diario de Murcia, XI (1889), nº 3869, 5 noviembre, p. 1.

${ }^{266}$ La Paz de Murcia, XXXI (1888), n ${ }^{\text {os }}$ 9450, 10 marzo, p. 1; 9508, 19 mayo, p. 1; 9519, 2 junio, p. 1; 9534, 20 junio, p. 1. La crónica de su entierro se publicó en: La Paz de Murcia, XXXI (1888), nº 9535, 21 junio, p. 1 y El Diario de Murcia, X (1888), nº 3342, 21 junio, p. 1.

${ }^{267}$ El propio Ángel Mirete, poco antes de morir, así lo solicitó al Ayuntamiento: E: MUm, AC 11-061888, fols. 256r-262v. Legalmente, la oposición otorgaba a Verdú la plaza de Primer Director de la Orquesta del Teatro Romea aunque el Ayuntamiento transigió "por motivos de humanidad muy atendibles" otorgándole la plaza con carácter interino al hijo de Mirete. En la misma sesión se acordó conceder a José Mirete la dirección de la Banda Municipal. Véase también, La Paz de Murcia, XXXI (1888), $\mathrm{n}^{\text {os }}$ 9527, 12 junio, p. 1 y 9529, 14 junio, p. 1 y El Diario de Murcia, X (1888), n 3335, 13 junio, p. 1. Este es un ejemplo claro de pervivencia de esa práctica tan usual durante el Antiguo Régimen de heredar de padres a hijos los oficios. Marín, "Familia, colegas y amigos", pp. 115-156: 121 ha estudiado la influencia de los lazos de parentesco para cubrir vacantes de niño de coro en la catedral de Jaca durante el siglo XVIII llegando a la conclusión de que, además de ser un procedimiento habitual, era aceptado por casi todos los cabildos catedralicios.

${ }^{268}$ Durante el mes de junio la orquesta se reunió en varias ocasiones para tratar de su organización interna, aunque no trascendieron los acuerdos adoptados: La Paz de Murcia, XXXI (1888), n 9541, 28 junio, p. 1.

${ }^{269}$ E:MUm, AC 18-06-1888, fol. 288r-v, La Paz de Murcia, XXXI (1888), nº 9553, 13 julio, p. 1. En el acto de posesión de su cargo, Verdú interpretó una "Marcha Triunfal", premiada en Granada y dedicada al poeta Zorrilla: El Diario de Murcia, 1888 (X), n 3409, 6 septiembre, p. 3. 
los profesores que forman la misma, indicando en ella quiénes desempeñan plazas ganadas por oposición y el Ayuntamiento se reserva la facultad de aprobar o reformar dicho proyecto de reglamento. $[\ldots]^{270}$.

El Reglamento para el funcionamiento de la orquesta fue presentado a finales del mes de noviembre de 1889 , aunque no se aprobó hasta principios del mes siguiente ${ }^{271}$. Los concejales Calvo y Solís propusieron incorporar una cláusula que obligaba a los instrumentistas de viento de la orquesta del Romea a pertenecer al mismo tiempo a la Banda Municipal:

“[...] No permitiendo el estado económico del Ayuntamiento sostener por sí ni subvencionar la música Municipal como ocurre en otras poblaciones de importancia [fol. 1090r] [...] proponemos:

Todos los individuos de la Orquesta del Teatro Romea que toquen en ella instrumentos a propósito para banda, o caso de no serlo se sepa posean otro adecuado a ella, tienen obligación de pertenecer a la Banda de Música Municipal que fundó en el año 1858 don Ángel Mirete y que dirige actualmente su hijo don José Ángel Mirete. $[\ldots]$

Cuando una y otra corporación haya de actuar por sí sola, los individuos que la compongan tienen obligación de concurrir al punto a que fueren citados por su respectivo director, sin que se admitan otras faltas que las que éste crea deben tolerarse. Cuando a un mismo tiempo hayan de actuar en puestos distintos, la orquesta y la banda, los directores de ambas corporaciones, puestos / [fol. 1090v] de acuerdo, designarán el personal que perteneciendo a ambas, haya de concurrir a uno y otro punto, procurando siempre queden cubiertas las plazas principales. Cuando la Banda Municipal haya de concurrir a algún puesto citado por el Ayuntamiento en ocasión de que también tenga que actuar la Orquesta, los individuos de ésta que no haya que sustituir en ella para que concurran a la primera, percibirán la asignación que tengan marcada con cargo y como si desempeñaran su puesto en la Orquesta sin derecho a otro sueldo por parte de la Banda. Las faltas que voluntariamente y sin causa justa cometan los individuos de la Banda que a la vez pertenecen a la Orquesta, se considerarán como cometidas en ésta y se aplicará la penalidad marcada por el Reglamento en la misma" $[\ldots]^{272}$.

La propuesta no fue aceptada, probablemente porque su aplicación hubiera desorganizado la orquesta del teatro y hubiera perjudicado a las empresas teatrales.

${ }^{270}$ E:MUm, AC 4-11-1888, fols. 1054r-1054v. (ver transcripción completa en el Documentario).

${ }^{271}$ E: $M U m$, AC 25-11-1889, fols. 1081v-1083v, 1089v-1090v y "Reglamento para el régimen de la Orquesta del Teatro Romea": E:MUm, AC, 2-12-1889, fols. 1095v-1098r. (ambos transcritos en el Documentario). En la última sesión citada se debatió la modificación de dos cláusulas del citado documento $\left(n^{\text {os }} 6\right.$ y 16). En la redacción original del primer artículo, el director de la orquesta estaba autorizado a nombrar un director honorario que le supliera en caso de enfermedad u otras ausencias, en las funciones de verso. Sin embargo, el Ayuntamiento ya tenía nombrado un segundo director, José Mirete y, por tanto, se denegó otra opción. En el segundo artículo se regulaba el pago de las nóminas a los músicos por las funciones y actos públicos dentro o fuera del teatro. Las autoridades consideraron que los actos que tenían lugar fuera del teatro no estaban sujetos a la competencia de la municipalidad y, por tanto, no debían reglamentarse. La memoria original presentada por Verdú (ilocalizable) presentaba el proyecto de reglamento, una plantilla del personal de la orquesta con los sueldos en funciones de verso, zarzuela y ópera y una relación nominal de los músicos que la componían en aquel momento, especificando cuáles habían ganado la plaza por oposición.

${ }^{272}$ E: MUm, AC 25-11-1889, fol.s 1089v-1090v. 
El "Reglamento para el régimen de la Orquesta del Teatro Romea", aprobado en 1889, consta de tres capítulos (véase Documentario). El primero, "Organización de la orquesta", contiene siete artículos que legislan las competencias de la orquesta, plantilla, sueldos y modo de proveer las plazas vacantes. La orquesta del teatro estaba patrocinada y protegida por el Ayuntamiento de Murcia "a fin de evitar que éstos [los músicos] sean víctimas de especulación o monopolio por parte de empresas y de los directores" ${ }^{\prime 273}$. Para proveer las plazas, se establecieron dos vías: los nombramientos en propiedad y los interinos. Los primeros eran competencia del alcalde mientras que los segundos tenían carácter provisional y eran designados por el director. El sexto artículo establecía: "Todos los años, en la primera quincena del mes de julio, se reunirá el tribunal de oposiciones si hubiere vacante y por consecuencia de ésta se presentase algún aspirante solicitando la plaza por oposición" 274 .

El segundo capítulo, "Del director", enumera las obligaciones del mismo (artículos 8 a 19): representar a la orquesta, dirigir los intermedios de las funciones que no fueran líricas "pues sabido es que para éstas, las empresas traen siempre el maestro director y concertador" (artículo 10), establecer días y horas de ensayo, escoger el repertorio, controlar la asistencia y el buen comportamiento de los músicos, pagarles, custodiar los libros de contabilidad y el archivo de música y seleccionar personal para cubrir las plazas vacantes.

El tercer y último capítulo del "Reglamento, "De los profesores" (artículos 20 a 25) establecía las obligaciones y derechos de los músicos y se disponían dos artículos sobre los derechos de los interinos y el sistema de ascenso interno:

[...] Artículo 23. Los profesores que no sean de oposición y hayan probado su aptitud desempeñando plaza interinamente y sin interrupción por más de una temporada cómica de invierno, tendrán derecho a que se les nombre en propiedad, si en este interregno no se hubiere presentado algún aspirante pidiéndola por oposición, en cuyo caso el interino deberá también presentarse a examen, sirviéndole de mérito los servicios prestados para que sea preferido en igualdad de circunstancias.

Artículo $24^{\circ}$. Conforme vayan vacando las plazas, a excepción de la del Director, el profesor que desempeñe un puesto inferior tendrá derecho al ascenso si reúne mérito y aptitud probada a cuyo efecto el Director hará la propuesta al señor Presidente del Excelentísimo Ayuntamiento para que se le expida el nuevo título. $[\ldots]^{275}$.

Con la aprobación del Reglamento la orquesta quedaba legislada en todos los $\operatorname{aspectos}^{276}$. Sin embargo, había que contar además con la aprobación de los

273 "Reglamento para el régimen de la Orquesta del Teatro Romea", AC, 2-12-1889, fol. 1096r.

274 "Reglamento", fol. 1096r. El tribunal estaría constituido por un presidente (Alcalde o el regidor en quien delegase) y cuatro vocales (Director, un miembro de la orquesta y dos músicos ajenos a la agrupación residentes en Murcia.

${ }^{275}$ Ibídem, fol. $1097 \mathrm{v}$.

${ }^{276}$ Aprobaron el Reglamento los siguientes asistentes: Carlos Díaz Hernández, quinto Teniente de Alcalde; Patricio Almela Vila y José Albaladejo Pérez, octavo y décimo tenientes de Alcalde; concejales, Antonio Clemares Martínez, Federico Gómez Cortina, Manuel López Gómez, Enrique Barnuevo Rodrigo de Villamayor, Prudencio Soler, Marín Salazar, Pausa, Callejas e Illán Sánchez. 
accionistas $^{277}$, que en mayo de 1890 manifestaron su oposición a las condiciones con las que se había regulado la orquesta:

[...] "La comisión de Propios asociada del Regidor Síndico señor Lopez Somalo y de la representación de los accionistas del empréstito del Teatro de Romea [...] ha examinado detenidamente los expedientes sobre creación de la orquesta del referido teatro y sobre aprobación del reglamento para el régimen de la misma; y considerando / [fol. 314r] que si bien la creación de aquélla no grava el presupuesto municipal, perjudica a los arrendatarios o a quien administre el teatro por la obligación que se les impone de pagar los sueldos asignados a los profesores en el Reglamento indicado. Considerando: que los acuerdos del Ayuntamiento relativos al segundo [el Reglamento], se tomaron sin la conformidad de los accionistas del empréstito, requerida en la cláusula $12^{a}$ de la escritura de primero de junio de 1879 , la cual dice terminantemente que la Comisión mixta de concejales y accionistas habrá de entender en todo contrato de arriendo o administración de los productos y servicios del Teatro, a cuyo dictamen deberá sujetarse el Ayuntamiento, mientras no se hayan amortizado todas las acciones de tal manera que conste siempre la conformidad de dichos accionistas; y considerando, por último, las dificultades que han de ofrecerse al Ayuntamiento y a esta comisión al tener que dar el Teatro con tal gravamen, cuando es sabido que en algunas ocasiones no es necesaria la orquesta, o se sustituye por un sexteto, según así viene haciéndose en teatros de tanta o más importancia que el de esta capital, ha resuelto por una [fol. 314v] nimidad la comisión y asociados [...] proponerle se digne revocar sus acuerdos relativos a dicha orquesta, toda vez que, habiéndose tomado éstos sin llenar las formalidades prevenidas no debe reconocérseles el valor legal necesario para mantenerlos vigentes" ${ }^{\text {278 }}$.

Los accionistas del Teatro Romea querían suprimir la orquesta basándose en tres argumentos:

$1^{\circ}$ Aunque la orquesta del Teatro Romea no gravaba el presupuesto municipal, sí perjudicaba económicamente a las empresas arrendatarias ya que les obligaba a contratar y pagar los sueldos de los instrumentistas.

$2^{\circ}$ Los acuerdos del Ayuntamiento relativos al Reglamento de la orquesta habían sido tomados sin la conformidad de los accionistas.

$3^{\circ}$ La orquesta, que no siempre era necesaria, creaba numerosas dificultades al Ayuntamiento y a la Comisión del Teatro.

El Ayuntamiento aprobó por mayoría la disolución de la orquesta, con un solo concejal en contra, Cayuela. Esta disposición reavivó la publicación de todo tipo de escritos oponiéndose al acuerdo (véanse Apéndice 2.7 y Documentario) ${ }^{279}$. Desde mayo de 1890, por tanto, las empresas tenían de nuevo libertad para contratar la orquesta de

${ }^{277}$ Recordemos que los accionistas habían prestado su capital para reedificar el Teatro Romea tras el incendio de 1877 y que habían firmado un contrato con el Ayuntamiento de Murcia, fechado en 1-06-1879, mediante el cual participaban de las decisiones en materia teatral conjuntamente con las autoridades municipales.

${ }^{278}$ E: $M U m$, AC 26-05-1890, fols. 313v-314v. Ver transcripción completa en el Documentario.

${ }^{279}$ La noticia saltó rápidamente a la prensa. Véase: "Cuestión orquesta", La Paz de Murcia, XXXIII (1890), $\mathrm{n}^{\mathrm{o}}$ 11039, 28 mayo, pp. 1, 4 (transcrita en el Documentario); El Diario de Murcia, XII (1890), $\mathrm{n}^{\circ}$ 4101, 14 agosto, p. 2; La Paz de Murcia, XXXIII (1890), $\mathrm{n}^{\text {os }} 11104,15$ agosto, p. 1 y 11114, 28 agosto, p. 1 y 11115,29 agosto, p. 1, así como el Apéndice 2.7 . 
Verdú o cualquier otra, lo que acentuó las divisiones y rivalidades entre los músicos murcianos que veían en el teatro un sustento económico importante.

\section{Constitución de un sexteto en sustitución de la orquesta y creación de una nueva orquesta para el Teatro Romea (1890)}

Una vez disuelta la orquesta, y para abaratar los costes de las representaciones, se retomó la idea de emplear un sexteto en las funciones dramáticas:

Se dice que hay quien está buscando músicos para formar un sexteto para las funciones de verso en Romea y que hasta se toma el nombre del Ayuntamiento. Esto pudiera tener muchos inconvenientes, pues tras de resultar deficiente para los que no estamos acostumbrados a un sexteto, podía darse el caso de que en las funciones líricas se desquitase la orquesta exigiendo más honorarios.

El Ayuntamiento, por lo menos, debe evitar se tome su nombre.

Lo cierto es que lo único en que hasta ahora se ha conocido la descentralización que se pretende es en lo que ningún perjuicio sufrían las empresas y el público salía ganancioso ${ }^{280}$.

La creación del sexteto fue negociada por el director de la compañía, Vico, y encargada a José María Carrasco, primer flauta de la orquesta del Teatro Romea, tal y como él mismo explicó:

[...] Las empresas de Romea tienen ya libertad de obrar sin imposiciones forzosas. El señor Vico quería un sexteto y no la orquesta. Me encargó la formación y mis compañeros de siempre se negaron a secundarme, para obligar así a la empresa a toda la orquesta. Yo, en vista de esto, traje dos profesores y el sexteto está funcionando sin contratiempo hasta ahora. $[\ldots]^{281}$.

A la polémica medida sobre la derogación de la orquesta por oposición, se unió su sustitución por un sexteto y una nueva trifulca entre Verdú y Carrasco que mantuvo entretenidos a los lectores de la prensa durante los primeros días de septiembre de

${ }^{280}$ La Paz de Murcia, XXXIII (1890), $\mathrm{n}^{\circ}$ 11100, 10 agosto, p. 1. El sexteto actuó en las funciones dramáticas de la compañía de Antonio Vico (Romea, $1^{\circ}$ temporada 1890-1891). A finales de agosto de 1890, el rumor se confirmó: "el público se verá privado de la buena orquesta que al mismo asistía y será sustituida ésta por seis dignísimos profesores que formarán el sexteto pero que, tocando en los intermedios cuando se habla en palcos, butacas y pasillos, no se percibirán sus notas": La Paz de Murcia, XXXIII (1890), $\mathrm{n}^{\mathrm{o}}$ 11115, 29 agosto, p. 1. Véanse más críticas en: La Paz de Murcia, XXXIII (1890), n ${ }^{\text {os }} 11117,31$ agosto, p. 1 y 11118, 2 septiembre, p. 1. Poco más tarde, la prensa anunció que habían sido contratados dos músicos alicantinos para completar el sexteto "y no porque dichos profesores sean de Alicante, sino porque el hecho patentiza el estado de discordia en que se encuentran nuestros paisanos los profesores músicos de Murcia”: El Diario de Murcia, XII (1890), nº 4115, 31 agosto, p. 2.

281 José María Carrasco, "Remitido", El Diario de Murcia, XII (1890), no 4118, 4 septiembre, p. 2. Carrasco había aprobado la oposición de primer flauta aunque, según escribe él mismo, Verdú lo despidió (no me consta cuándo). Al día siguiente La Paz de Murcia, XXXIII (1890), $\mathrm{n}^{\circ}$ 11121, 5 septiembre, p. 1 varios músicos de la orquesta desmentían el despido a través de la prensa: "su director no ha echado de ella a nadie, a no ser que así se entienda el despedirse un profesor por no poder seguir a causa de prescripción facultativa y, por desempeñar una plaza imprescindible, hubiese necesidad de sustituirle con otro". 
$1890^{282}$. El sexteto actuó hasta mediados de este mes, coincidiendo con las representaciones de la compañía de Vico.

A comienzos de octubre de 1890, la prensa informó de la creación de una nueva orquesta dirigida por José Mirete, autorizada por el Ayuntamiento para actuar con la compañía de zarzuela de Daniel Banquells:

Cuando veníamos elogiando la buena unión que entre los músicos de Murcia existía, el Ayuntamiento la ha roto con un acuerdo poco o nada beneficioso para los profesores músicos, para las empresas y para el público, y esa rotura, que ya produjo algunos disgustos con el sexteto, los ha aumentado ahora la formación de una nueva orquesta con las consecuencias que trae consigo cuando no hay personal sobrante y hay que sacar de un lado para otro y hasta traer forasteros; pero si esto tiene pase, teniendo en cuenta que cada uno es libre para obrar como le convenga, sentimos que todavía llegue a mayores y se oigan amenazas y palabras fuertes, como ayer sucedió en la calle el Príncipe Alfonso, entre un partidario de la nueva y un individuo perteneciente a la antigua orquesta. Esa clase de sinfonías no son muy gratas al oído $^{283}$.

Según el elenco anunciado por la compañía, la orquesta constaba de cuarenta instrumentistas, de los que dieciséis (el 40\%) provenían de la antigua formación orquestal establecida por oposición y dirigida por Verdú ${ }^{284}$. Mirete tuvo que recurrir, además, a la contratación de personal foráneo $^{285}$. Ello reavivó la publicación de todo tipo de artículos de opinión, comunicados y cartas, implicándose un número cada vez mayor de periódicos (El Noticiero, Las Noticias, La Provincia, El Independiente y El Anunciador Mercantil). La Paz de Murcia mantuvo una postura muy crítica hacia las autoridades, no sólo por la supresión de la orquesta por oposición, sino también por la formación del sexteto y por la creación de la nueva orquesta. En sus escritos, este diario exhortó a las autoridades a apoyar sobre todo a los músicos murcianos ${ }^{286}$ :

${ }^{282}$ El ex director de la orquesta del Teatro Romea, Fernando Verdú, difería de la versión sobre la creación del sexteto que Carrasco había difundido en la prensa. Según Verdú, el empresario Vico quería contratar la abolida orquesta para sus representaciones por la misma cantidad que hubiese pagado al sexteto. Verdú no aceptó, aunque le ofreció una rebaja del precio de la orquesta por función. Vico la rechazó y pidió a Verdú crear y dirigir el sexteto, a lo cual Verdú se negó. Fue en ese momento cuando Vico encargó la formación del sexteto al mencionado Carrasco: Fernando Verdú, "Remitido", El Diario de Murcia, XII (1890), $\mathrm{n}^{\mathrm{o}}$ 4120, 6 septiembre, p. 2. Véase el resto de escritos en el Apéndice 2.7. Sólo ha quedado constancia de otro integrante del sexteto, el pianista Antonio Ramírez.

${ }^{283}$ La Paz de Murcia, XXXIII (1890), nº 11148, 8 octubre, p. 1. Las cursivas son editoriales.

${ }^{284}$ Los integrantes de la nueva orquesta se publicaron en La Paz de Murcia, XXXIII (1890), nº 11149 , 9 octubre, p. 1. Las cifras sobre los músicos de Verdú que pasaron a formar parte de la orquesta de José Mirete se encuentran en La Paz de Murcia, XXXIII (1890), nº 11158, 19 octubre, p. 1. Según esta fuente, veintiún músicos permanecieron en la orquesta de Verdú: cinco violines primeros (Fernando Verdú, los hermanos Fresneda, Puche y Coderch), cuatro violines segundos (hermanos Espada, Pérez y J. Verdú), una viola primera y una segunda (Puche y Canales), un violonchelo primero (Jover), dos contrabajos (Mendoza y Gil), un flauta primero (Sánchez Vigueras), un fagot segundo (Mora), un cornetín segundo (Martínez), un figle (Verbo), timbalero (Cascales) y un bombo (Comentes). Véanse también La Paz de Murcia, XXXIII (1890), $\mathrm{n}^{\text {os }} 11153,14$ octubre, p. 1 y 11165,28 octubre, p. 1.

${ }^{285}$ Según La Paz de Murcia, XXXIII (1890), n 11149, 9 octubre, p. 1 “unos seis profesores” de fuera.

${ }^{286}$ Las posturas de otros periódicos son más difíciles de analizar, puesto que muchos de ellos no se conservan, salvo por las referencias que hizo La Paz de Murcia o El Diario de Murcia. De ellas se desprende que El Anunciador Mercantil, por ejemplo, no defendió a la agrupación de Fernando Verdú 
[...] Tenemos anunciada para la Pascua de Resurrección la llegada de una buena compañía de ópera y a la vez se dice por la prensa que, para reforzar la orquesta que ha tocado en Romea durante la temporada del invierno, se traerán músicos forasteros, como si no los hubiera en Murcia, o mejor dicho, como si en Murcia no hubiera una orquesta completa y buena, compuesta casi toda de los ejecutantes que obtuvieron sus plazas en reñida e imparcial oposición.

Si eso fuera verdad, no sabríamos si esa resolución tendría más de escandalosa que de ridícula pero lo que es cierto, si tal cosa sucediera, es que tendría la culpa quien pudo y no quiso evitar los odios que hoy dividen a los músicos murcianos, por más que la prensa lo hizo saber con anticipación, previendo que iba a padecer el arte y el nombre de Murcia.

¿Qué protección es la que se dispensa al hijo del país que sabe y puede desempeñar su cometido, permitiendo que ocupen su lugar forasteros que, sobre utilizarse de lo que le corresponde a un artista murciano, puedan dar lugar a que en otras poblaciones crean y digan que aquí no hay quien valga ni sirva para nada, y que para que nuestra orquesta pueda utilizarse, hay que completarla con instrumentistas de otra parte?

Sobre tales despropósitos llamamos la atención del señor Alcalde, de la Comisión mixta del Teatro y, sobre todo el Ayuntamiento. No se trata de política, no se trata de oposición y defensa sobre el sistema que nos rige: es cuestión puramente murciana y se trata de Murcia. $[\ldots]^{287}$.

Quizás influido por la presión mediática, el arrendatario del teatro se vio obligado a realizar un llamamiento público a los músicos de Murcia para que participaran en la nueva orquesta:

Deseando la empresa de Romea que la orquesta que ha de actuar en la próxima temporada de Resurrección sea de tanta importancia como la notable compañía de ópera que el inteligente señor Gueri presentará al público en la citada época, invita a los artistas murcianos que quieran formar parte de aquella corporación y tengan cabida en ella, a inscribir sus nombres e indicar condiciones al almacén de música de don Adolfo Gascón, desde hoy hasta el domingo ocho del actual, inclusive.

Los que sean admitidos, firmarán sus contratos y recibirán los préstamos tan luego sea aceptada por la comisión del Ayuntamiento la lista del personal artístico que obra en el negociado correspondiente ${ }^{288}$.

Gran parte de los músicos que permanecían fieles a la orquesta creada anteriormente por el Ayuntamiento se negaron a engrosar las filas de la nueva orquesta, como medida de presión a las autoridades:

cuando José Mirete creó la nueva orquesta. En La Paz de Murcia, XXXIII (1890), nº 11165, 28 octubre, p. 1 el diario llegó a afirmar: "Puede inventar cuanto quiera nuestro colega [El Anunciador Mercantil] para torcer la opinión, como hizo al decir que el señor Verdú redactó un reglamento que nadie le había pedido y al olvidar que ocupó la dirección de la orquesta al fallecimiento del señor Mirete por derecho antes adquirido y que solo él tenía, y con estas citas verá que no dio en el clavo ni demostraba estar bien informado en su artículo anterior y que si no le rebatimos todo lo que escribió fue porque nos pareció que, para demostrarlo, bastaba con un botón”.

${ }^{287}$ La Paz de Murcia, XXXIV (1891), n $\mathrm{n}^{\circ} 11270,28$ febrero, p. 1. El documento íntegro aparece transcrito en el Documentario. Véase también el anuncio publicado por El Diario de Murcia, XIII (1891), $\mathrm{n}^{\mathrm{o}}$ 4266, 27 febrero, p. 3. La cuestión de la contratación de músicos no murcianos fue debatida en diversas ocasiones en el Ayuntamiento. Véase E: MUm, AC 4-03-1891, fols. 104v-105r y AC11-03-1891, fols. 109v$111 \mathrm{v}$, documentos transcritos en el Documentario.

\footnotetext{
${ }^{288}$ El Diario de Murcia, XIII (1891), no 4271, 5 marzo, p. 3.
} 
La cuestión música sigue sin arreglo, pues los que ahora son necesarios dicen que no quieren sacar a nadie de apuros para luego volver a quedarse fuera, y no se contratan.

Esa cuestión no la puede arreglar más que el Ayuntamiento que la ha motivado volviendo atrás y éste parece que se empeña en dejar en libertad a todos ${ }^{289}$.

Así pues, en 1891 había dos orquestas teatrales: la formación dirigida por Fernando Verdú que subsistió de forma independiente después de ser abolida por el Ayuntamiento de Murcia y otra agrupación orquestal de nueva creación dirigida por José Mirete; ambas con plazas vacantes (ver Tabla 2.5):

Tabla 2.5. Plazas vacantes en las orquestas dirigidas por Fernando Verdú y José Mirete (1891) La Paz de Murcia, XXXIV (1891), n 11280, 12 marzo, p. 1.

Nota: Los guiones indican plazas cubiertas.

\begin{tabular}{|c|c|c|}
\hline $\begin{array}{l}\text { Plantilla de la orquesta } \\
\text { creada por el } \\
\text { Ayuntamiento mediante } \\
\text { oposición pública } \\
(\mathbf{1 8 8 4 )} \\
\end{array}$ & $\begin{array}{l}\text { Orquesta dirigida por } \\
\text { Fernando Verdú } \\
\text { (antigua orquesta del } \\
\text { Teatro Romea creada por } \\
\text { oposición en 1884) }\end{array}$ & $\begin{array}{l}\text { Orquesta dirigida por José } \\
\text { Mirete (creada en octubre } \\
\text { de 1890) }\end{array}$ \\
\hline Concertino & - & - \\
\hline 5 violines primeros & - & 3 violines primeros \\
\hline 6 violines segundos & - & 2 violines segundos \\
\hline 2 violas & - & 2 violas \\
\hline 2 violonchelos & 1 violonchelo & 1 violonchelo \\
\hline 3 contrabajos & 1 contrabajo & 1 contrabajo \\
\hline 2 flautas & - & 1 flauta \\
\hline 2 oboes & 2 oboes & - \\
\hline 2 clarinetes & 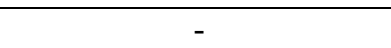 & 1 clarinete \\
\hline 2 fagots & 1 fagot & - \\
\hline 2 trompas & 2 trompas & 2 trompas \\
\hline 2 cornetines & 2 cornetines & - \\
\hline 3 trombones & - & - \\
\hline 1 figle & 2 figles & - \\
\hline Timbal & - & - \\
\hline Bombo & - & - \\
\hline $\begin{array}{l}\text { Caja (sólo en caso de } \\
\text { necesidad) }\end{array}$ & - & - \\
\hline Total instrumentistas: 38 & Total vacantes: 11 & Total vacantes: 13 \\
\hline
\end{tabular}

La mayor parte de los instrumentistas de cuerda permanecieron fieles a la agrupación de Verdú, mientras que parte del viento pasó a la de Mirete. La prensa no menciona cómo se cubrieron las vacantes aunque, probablemente, se contrataron músicos no murcianos.

Durante los años posteriores (1892-1895) la prensa murciana publicó un número mucho menor de noticias relacionadas con la orquesta, la mayor parte de ellas insertas en

${ }^{289}$ La Paz de Murcia, XXXIV (1891), nº 11278, 10 marzo, p. 1. Véase el comunicado que los músicos Antonio Puche, Mariano Sanz, José Puche, Vicente España, Antonio Canales, Fresneda, Juan Pérez y Antonio Mendoza dirigieron a La Paz de Murcia, XXXIV (1891), nº 11279, 11 marzo, p. 1 (transcrito en el Documentario). 
críticas de las representaciones teatrales. Los comentarios periodísticos describen una orquesta "nutrida" y con las expectativas de tener un "éxito excelente" 290.

En el año 1892, se cita en varias ocasiones a Fernando Verdú como director de la orquesta del Romea ${ }^{291}$ :

Anteanoche se representó en el Teatro de Romea, por la compañía del señor Bueno la célebre obra en tres actos "García del Castañar". [...]

Todas las noches, en los intermedios, la orquesta del señor Verdú viene ejecutando con gran acierto y precisión una serie de piezas selectas y completamente nuevas muchas de ellas que agradan extraordinariamente al público, no sólo por el mérito de dichas obras sino también por la perfección y buen gusto con que las ejecuta la orquesta, bajo la competente y acertada dirección de su reputado maestro director don Fernando Verdú.

Anteanoche en uno de los intermedios tocó la referida orquesta una preciosa mazurca que el público aplaudió espontáneamente con gran entusiasmo, haciéndola repetir, cosa poco frecuente en las temporadas de obras dramáticas en las que se ejecuta la música durante los entreactos, cuando generalmente el público no fija en ella toda su atención.

Nos complacemos mucho en consignarlo así, haciendo justicia al señor Verdú y a los distinguidos profesores que componen la numerosa orquesta del teatro Romea ${ }^{292}$.

La misma orquesta de Verdú trabajó en noviembre del año 1894 en el Teatro Circo de Villar con la compañía del primer actor y director Lino Ruiloa ${ }^{293}$; mientras que la formación orquestal de José Mirete, por su parte, actuaba en las mismas fechas con la compañía de zarzuela de Florencio de la Cruz en el Romea.

Cabe suponer que las dos orquestas siguieron funcionando por separado hasta noviembre de 1898, en que se unieron: "A la orquesta que dirigía don José Mirete en el Teatro Romea se había agregado los elementos que formaban la otra orquesta que dirigió antes el señor Verdú,294.

\subsubsection{Estructura y composición}

La orquesta del teatro de Murcia desde la temporada 1866-1867 contaba con un total de unos cuarenta músicos, aunque eventualmente el conjunto podía ser más reducido (ver Tabla 2.6):

\footnotetext{
${ }^{290}$ El Diario de Murcia, XIII (1891), nº 4290, 28 marzo, p. 3.

${ }^{291}$ La Paz de Murcia, XXXV (1892), n ${ }^{\text {os }} 11545,4$ febrero, p. 3 y 11620, 31 mayo, p. 2.

${ }^{292}$ El Diario de Murcia, XIV (1892), n $\mathrm{n}^{\mathrm{0}}$ 4593, 24 marzo, p. 3. En general, las críticas eran muy favorables. Véase también: La Paz de Murcia XXXV (1892), nº 11527, 13 enero, p. 3.

${ }^{293}$ La Paz de Murcia, XXXVI (1894), nº 12839, 21 noviembre, p. 1.

${ }^{294}$ El Diario de Murcia, XX (1898), nº 7852, 18 noviembre, p. 2.
} 
Tabla 2.6. Compañías teatrales que actuaron en Murcia con orquestas de menos de cuarenta componentes

Fuentes: Anuncios de las compañías teatrales publicados en prensa (véanse Capítulo 3 y 4 )

\begin{tabular}{|l|c|l|c|}
\hline Director & $\begin{array}{l}\text { Tipo de } \\
\text { compañía }\end{array}$ & $\begin{array}{l}\text { Teatro, temporada y } \\
\text { año cómico }\end{array}$ & $\begin{array}{c}\text { Componentes } \\
\text { orquesta }\end{array}$ \\
\hline Regino Martínez & Ópera & $\begin{array}{l}\text { Romea, 2 } 2^{\mathrm{a}} \text { temporada, } \\
1882-1883\end{array}$ & 24 \\
\hline $\begin{array}{l}\text { Manuel Taberner y } \\
\text { José María Lorente }\end{array}$ & Zarzuela & $\begin{array}{l}\text { Romea, } 1^{\mathrm{a}} \text { temporada, } \\
1891-1892\end{array}$ & 30 \\
\hline Nicolás Rodríguez & Zarzuela & $\begin{array}{l}\text { Romea, } 2^{\mathrm{a}} \text { temporada, } \\
1873-1874\end{array}$ & 32 \\
\hline Tomás Brotón & Zarzuela & $\begin{array}{l}\text { Romea, } 1^{\mathrm{a}} \text { temporada, } \\
1873-1874\end{array}$ & 32 \\
\hline Juan García Catalá & Zarzuela & $\begin{array}{l}\text { Romea, } 1^{\mathrm{a}} \text { temporada, } \\
1883-1884\end{array}$ & 33 \\
\hline $\begin{array}{l}\text { Juan Cubas y Rafael } \\
\text { Pastor }\end{array}$ & Zarzuela & $\begin{array}{l}\text { Romea, } 1^{\mathrm{a}} \text { temporada, } \\
1887-1888\end{array}$ & 36 \\
\hline
\end{tabular}

La compañía de ópera de Regino Martínez llegó a Murcia con sólo veinticuatro músicos, que eran los integrantes de la orquesta del Teatro Cervantes de Málaga ${ }^{295}$. Sin embargo, no fue lo habitual. La de Benigno Giardini ( $2^{\mathrm{a}}$ temporada de 1881-1882) contó con cincuenta y un miembros: dos concertinos, ocho violines primeros, diez violines segundos, dos violas, tres violonchelos, cinco contrabajos, tres flautas, tres oboes, dos clarinetes, dos saxofones, cuatro trompas, dos cornetines, cuatro trombones, bombo y timbales ${ }^{296}$.

Cuando se constituyó la orquesta del Teatro Romea por oposición (1884) se estableció un número fijo de treinta y ocho integrantes: un concertino, cinco violines primeros, seis violines segundos, dos violas, dos violonchelos, tres contrabajos, dos flautas, dos oboes, dos clarinetes, dos fagotes, dos trompas, dos cornetines, tres

${ }^{295}$ La Paz, XXVI (1883), no 7642, 3 junio, p. 1 y El Diario de Murcia, V (1883), nº 1292, 5 junio, pp. 2-3. La orquesta del Teatro Cervantes de Málaga estaba integrada por "tres primeros violines, tres segundos, dos violas, flauta, oboe, dos clarinetes, fagot, dos cornetines, dos trompas, tres trombones, violon, contrabajo, arpa y bombo": La Paz de Murcia, XXVI (1883), n 7655, 19 junio, p. 1. Es preciso aclarar que los anuncios de las compañías publicados en la prensa no siempre indican el número de componentes o la procedencia de la orquesta.

${ }^{296}$ Según La Paz de Murcia, XXV (1882), no 2286, 5 abril, p. 1, la orquesta cobraba 18 duros (90 pesetas) por cada función de ópera, de forma que cada músico tocaba por 5 ó 6 reales (una peseta y veinticinco céntimos o una peseta y media). Un litro de aceite en febrero de 1882, según la misma fuente, costaba una peseta y cinco céntimos, un quilo de garbanzos, 56 céntimos, uno quilo de arroz, 37 céntimos, un quilo de carne de vaca, dos pesetas. Estos precios indican que los instrumentistas de la orquesta pertenecían más bien a las clases más populares y alejadas de los sustratos más bajos de la clase media. Compárense, por ejemplo, con los presupuestos diarios que aporta Pérez Picazo, Oligarquía, pp. 262-267 y que son: una familia de cuatro miembros perteneciente a la clase popular residente en calles periféricas de Murcia en 1886, 1.49 pesetas, mientras que una familia también de cuatro miembros de la clase media sobre la base de un sueldo anual de 1200 pesetas en 1886 tenía un presupuesto diario de 3.33 pesetas. La compañía de Benigno Giardini dio 26 funciones documentadas entre el 9 de abril de 1882 y el 11 de mayo del mismo año, de forma que cada músico, según la información de la citada fuente, ganó entre 32 pesetas y media y 39 pesetas (en otras palabras, poco más de una peseta para gastar diariamente). Sancho, Romanticismo, p. 26 afirma que el sueldo diario de un músico de orquesta a lo largo de la etapa 1870-1875 se situaba entre 7-8 reales lo que a efectos comparativos, concluye Sancho, eran salarios equiparables a los de albañiles, carpinteros, zapateros y obreros de la industria del papel o tejido, entre otros. 
trombones, figle, timbales, bombo y, cuando se necesitara, caja ${ }^{297}$. El Reglamento de la orquesta (1889) incluía, además, un "avisador". Esta orquesta actuó en zarzuelas, óperas y operetas hasta su disolución en mayo de 1890, y ocasionalmente aumentaba el número de sus efectivos ${ }^{298}$.

Después de 1890 y hasta finales del siglo XIX, el número habitual de miembros de las orquestas que actuaban en el Teatro Romea de Murcia parece haber sido de nuevo de cuarenta. Esas eran las dimensiones, por ejemplo, de la orquesta de José Mirete, creada en 1890 para actuar con la compañía de zarzuela de Daniel Banquells ${ }^{299}$. En el caso de las funciones dramáticas, la orquesta se reducía o, incluso, se sustituía por otras formaciones, como por ejemplo un sexteto con piano y armonio.

En 1884, la orquesta cobraba por cada noche según el género representado: 40 pesetas (dramático), 75 pesetas (zarzuela) y 100 pesetas (ópera) (véase Apéndice 2.4). Con anterioridad a esta fecha, los precios, al menos los de ópera, eran inferiores. El Apéndice 2.9 muestra una comparativa de los sueldos que percibían los músicos de la orquesta del Teatro Romea en los años 1884 y 1889. El concertino y los primeros puestos de cada instrumento percibían una cantidad mayor. El sueldo del director concertino, fue ajustado a la baja por el propio director, Fernando Verdú, para que pudiera aumentarse el de otros instrumentistas:

[...] Del propio modo debe manifestar al Excelentísimo Ayuntamiento esta Comisión que las plantillas que acompañan al mencionado Reglamento están formadas con arreglo a lo que la conciencia y la equidad aconsejan, siendo de notar un rasgo del señor Verdú que demuestra su amor al arte y el afecto que profesa a sus subordinados, cuyo rasgo consiste en haberse rebajado su sueldo voluntariamente para aumentárselo a otros a quienes según él debían aumentársele. $[\ldots]^{300}$.

\footnotetext{
${ }^{297}$ Las condiciones de arriendo del año del Teatro Romea en 1887 establecían una orquesta de 35 a 40 instrumentistas.

${ }^{298}$ Con la orquesta de la compañía de ópera de Giovanni Goula ( $2^{\mathrm{a}}$ temporada de 1884-1885) actuaron cuarenta y cuatro instrumentistas además de una banda militar: La Paz de Murcia, XXVIII (1885), nº 8219, 12 mayo, p. 1.

${ }^{299}$ Esta formación es muy similar a las empleadas en teatros madrileños dedicados a la zarzuela. Por ejemplo, en 1856, el Teatro de la Zarzuela contaba con una plantilla orquestal de 41 instrumentistas (concertino, seis violines primeros, seis violines segundos, dos violas, dos violonchelos, cuatro contrabajos, flautín, flauta, dos oboes, dos clarinetes, dos fagotes, dos trompas, dos cornetines, tres trombones, figle (o dos trombones y figle), timbales y triángulo: Sobrino, "Orquesta", p. 382. Por otra parte, Sancho menciona que las orquestas valencianas oscilaron, según las temporadas teatrales, entre treinta y cinco y sesenta instrumentistas: Sancho, Romanticismo, pp. 24-26; Liberal, Antonio Reparaz, pp. 102-103 afirma que la orquesta del Real Teatro de S. João de Oporto (Portugal) contaba con 34 músicos durante la temporada 1874-1875, mientras que la del Teatro de S. Carlos de Liboa, en los años 1860 poseía una orquesta de sesenta instrumentistas como término medio. Para conocer la evolución del número de efectivos de las orquestas teatrales de ópera en el Madrid de finales del siglo XVIII y XIX, véase: Leza, "Las orquestas", pp. 115-139. En su estudio sobre las orquestas de los teatros de ópera italianos, Piperno y Rostagno, "The Orchestra”, p. 48-49 aportan las dimensiones de las orquestas de varios teatros italianos entre los años 1825 a 1872. Según los autores, la orquesta más pequeña estaba constituida por 48 miembros (Parma, 1829) y la más grande, por 94 (Milán, 1872). Véanse más detalles sobre las dimensiones de las orquestas europeas durante el siglo XIX en Jensen y Piperno (eds.). The Opera Orchestra y en Koury, Orchestral.
}

${ }^{300}$ E:MUm, AC 25-11-1889, fol. 1082v. Ver transcripción completa en el Documentario. 
Durante la primera temporada 1889-1890 actuaron en el Romea cuatro compañías de zarzuela (Eduardo Ortiz, Enrique Lloret, Manuel Rodríguez y Manuel Martínez) lo que hace un total de, al menos, 93 representaciones en función de noche ${ }^{301}$. Según esta cantidad, y teniendo en cuenta la plantilla del Reglamento, un violín primero percibió, como mínimo, 348'75 pesetas entre los meses de septiembre a febrero; un violín segundo, 186 pesetas, un flauta segunda, 139'5 pesetas y un fagot primero, 232'5 pesetas. Estas cantidades no eran muy elevadas. Mensualmente, el violín primero ganaba una media de 58'12 pesetas, es decir, un sueldo muy inferior a lo que percibía, por ejemplo, un funcionario murciano (de 1500 a 2000 pesetas anuales, es decir, 125 a 166 pesetas al mes) ${ }^{302}$. No obstante, el sueldo se incrementaba si el instrumentista participaba, como fue habitual, en otros eventos musicales de la ciudad.

\subsubsection{Afinación y ubicación en el interior del teatro}

Antes del primer incendio del Teatro Romea en 1877, el foso para la orquesta estaba considerablemente más bajo que el escenario, como se deduce del siguiente texto de 1873:

[...] Antes de concluir debemos hacer una observación al digno municipio, dueño del teatro. La caja armónica está muy baja y de aquí que el artista, desde el segundo término de la escena, no perciba la cuerda. Los espectadores escuchan muchas veces discordancia en los sonidos por esta razón. No es del señor Mirete, a quien desde aquí enviamos un aplauso, el que tiene la culpa de que los ecos no sean redondos. Elévese la orquesta una cuarta más y será la manera única de obviar en parte el defecto horrible de que adolece el palco escénico de nuestro teatro $[\ldots]^{303}$.

La Figura 2.7 muestra una imagen del interior del teatro en 1901 en el que se aprecia el foso de la orquesta.

${ }^{301}$ No se puede conocer con exactitud el número de funciones totales ya que la única fuente de información para conocer la cartelera es la prensa. Los lunes no se publicaban diarios y, en otras, ocasiones, no se publicó el anuncio.

302 Pérez Picazo, Oligarquía, pp. 359-364. El armonista y compositor Antonio López Almagro, por poner otro ejemplo, ganaba 3.000 pesetas anuales desde que aprobó la Cátedra de Armonio del Conservatorio de Madrid por oposición en 1888. Véase, Pliego de Andrés y López Rico, Antonio López, p. 85 .

${ }^{303}$ La Paz de Murcia, XVI (1873), nº 4718, 21 marzo, p. 1. 


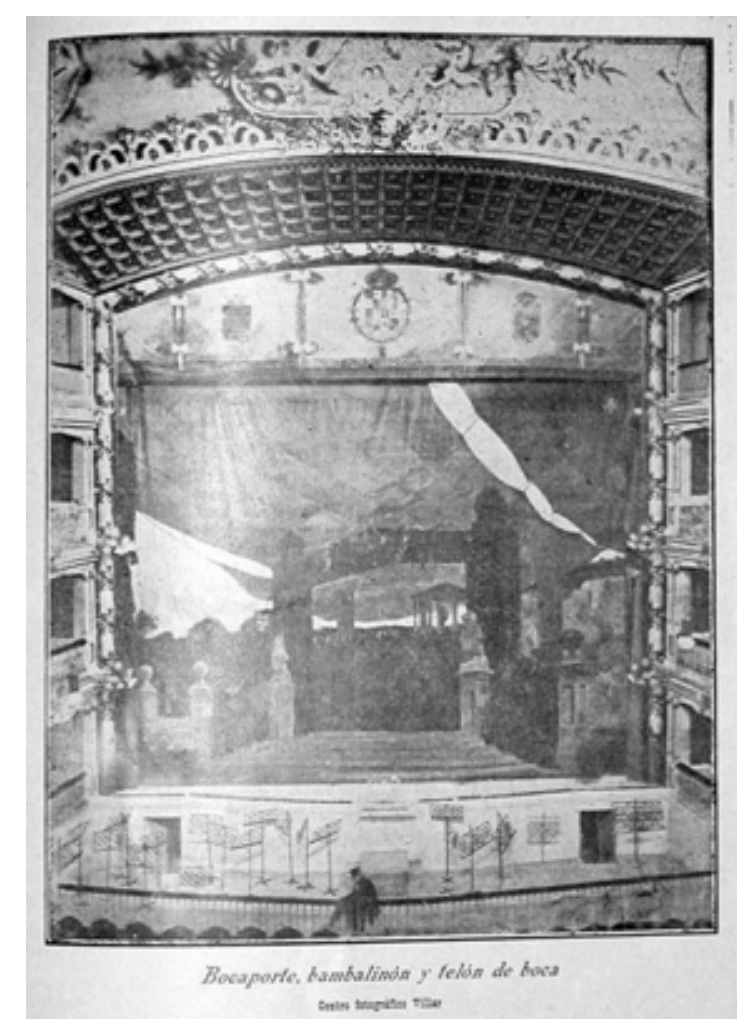

Figura 2. 7. Bocaporte, bambalinón y telón de boca del Teatro Romea (1901). E:MUm, El Correo de Levante (1901), no extraordinario, 16 febrero.

La orquesta del Teatro Romea afinaba, al parecer, medio tono más agudo de lo que era habitual en otros teatros. La tendencia alcista de la afinación, común al ámbito europeo, fue fuertemente combatida por los cantantes, ya que debían forzar sus voces para seguir la afinación de la orquesta ${ }^{304}$. Por ejemplo, el concierto de la Sociedad Filarmónica, celebrado en el Teatro de los Infantes en julio de 1868 con la participación del barítono murciano Mariano Padilla se celebró con esta afinación:

[...] Después de un ligero descanso se abrió de nuevo el palco escénico con el aria de El Trovador desempeñada por el señor Padilla y cuerpo de coros. En esta pieza tenía nuestro querido paisano que luchar con dificultades de mucha importancia, que generalmente pasan desapercibidas para el público. El aria es excesivamente fuerte. Con frecuencia tiene escritos el $f a$ y el sol bemol, puntos peligrosos, si se tiene en cuenta que la orquesta de nuestro teatro, arreglada al corista antiguo, esté medio tono más alto del moderno corista teatro. El señor Padilla venía ya fatigado, a pesar de todo, su ejecución fue brillante y esmerada. El coro se colocó a una altura honrosa en la difícil parte que desempeñó en esta pieza, secundó dignamente al señor Padilla. $[\ldots]^{305}$.

Otro comentario en las mismas fechas corrobora la afinación más aguda de la orquesta murciana:

\footnotetext{
${ }^{304}$ Haynes, "Pitch", pp. 793-802.
}

${ }^{305}$ La Paz de Murcia, XI (1868), no 3293, 15 julio, p. 2. Las cursivas son editoriales. "Corista" es un vocablo italiano que significa diapasón. 
[...] Que "el público no está al alcance de la circunstancia de que la orquesta de nuestro teatro se halla un semitono más alta que el moderno corista teatral" (eso de corista nos huele a rutina). Busque usted el nombre verdadero de este instrumento, señor Otello, ¡diapasón, diapasón, hombre! Pues señor, está usted errado porque no hay más que coger un moderno instrumento de viento y comparar su tonalidad en un órgano antiguo y se verá que no es la diferencia que supone, atendiendo a que la orquesta de París está más alta que los órganos antiguos $[\ldots]^{306}$.

Queda pendiente investigar hasta qué punto esta afinación era una peculiaridad murciana o se daba también otros teatros españoles de la época.

\section{Otros teatros y locales de uso teatral}

En Murcia, además del teatro principal (con sus diferentes denominaciones) existieron otros teatros y locales acondicionados para la representación de espectáculos, algunos de los cuales se utilizaron desde la primera mitad del siglo XIX ${ }^{307}$. En el presente apartado trataré los teatros más relevantes de la segunda mitad de la centuria que no dependieron de sociedades recreativas ni de particulares (ya que éstos serán analizados en los capítulos correspondientes a ellos). Durante la década de los ochenta del siglo XIX hubo una gran proliferación de locales teatrales en Murcia (véase Apéndice 2.1). Si excluimos al Teatro del Circo, las características comunes a todos ellos son:

1. Existencia breve y actividad teatral irregular y no continua.

2. No tenían temporadas teatrales estables ni abonos.

3. Actividad a veces limitada a géneros dramáticos, excluyendo los musicales.

4. La mayor parte de las compañías que actuaban en estos recintos eran de aficionados o de aficionados combinados con profesionales de la escena.

\subsection{Los teatros provisionales (1858-1860, 1878-1879)}

Los teatros provisionales sustituyeron al Teatro Romea en los periodos en los que éste permaneció cerrado a consecuencia de las obras de construcción o reconstrucción. Los años 1858 a 1860, desde el derribo del Teatro de la Puerta del Toro (junio de 1857) hasta la inauguración del Teatro de los Infantes (octubre de 1862), marcan la primera

\footnotetext{
${ }^{306}$ La Paz de Murcia, XI (1868), nº 3300, 22 julio, p. 2.

${ }^{307}$ El periódico El Indicador Murciano menciona "el suprimido convento de Verónicas": El Indicador Murciano (1837), $\mathrm{n}^{\mathrm{o}}$ 15, 21 marzo, p. 1. También hubo representaciones en la Cárcel Vieja del Puente, el Granero del Cabildo o Almudí Viejo (situado en la Rambla del Cuerno, cerca de la Merced): "Ha llegado a esta ciudad una compañía de orquesta [...]. La persona que guste oír sus habilidades acudirá a la posada del Almudí, cuarto número 7": Diario Popular de Murcia (1821), n $\mathrm{n}^{\circ}$ 10, 10 julio, p. 40; "el parador de Santo domingo (calle del Desengaño)": Diario Popular de Murcia, I (1851), n 174, 16 diciembre, p. 678 y la Fábrica de la Seda. En estos dos últimos se celebraron además bailes de máscaras: "Los salones de máscaras: el del Almudí sin concurrencia; el de la Fábrica de la Seda sobradamente repleto": Diario de Murcia, I (1851), n 36, 11 febrero, p. 3. Véase Clares, "La música teatral”, pp. 451-478.
} 
etapa del Teatro Provisional. Las primeras noticias sobre el mismo datan de 1858, aunque es probable que ya se utilizara desde $1857^{308}$. Su entrada principal daba a la calle del Cura (hoy Selgas), cercano al templo de La Merced y la Rambla del Cuerno (actualmente calle de Saavedra Fajardo) ${ }^{309}$ (véase Figura 2.8).

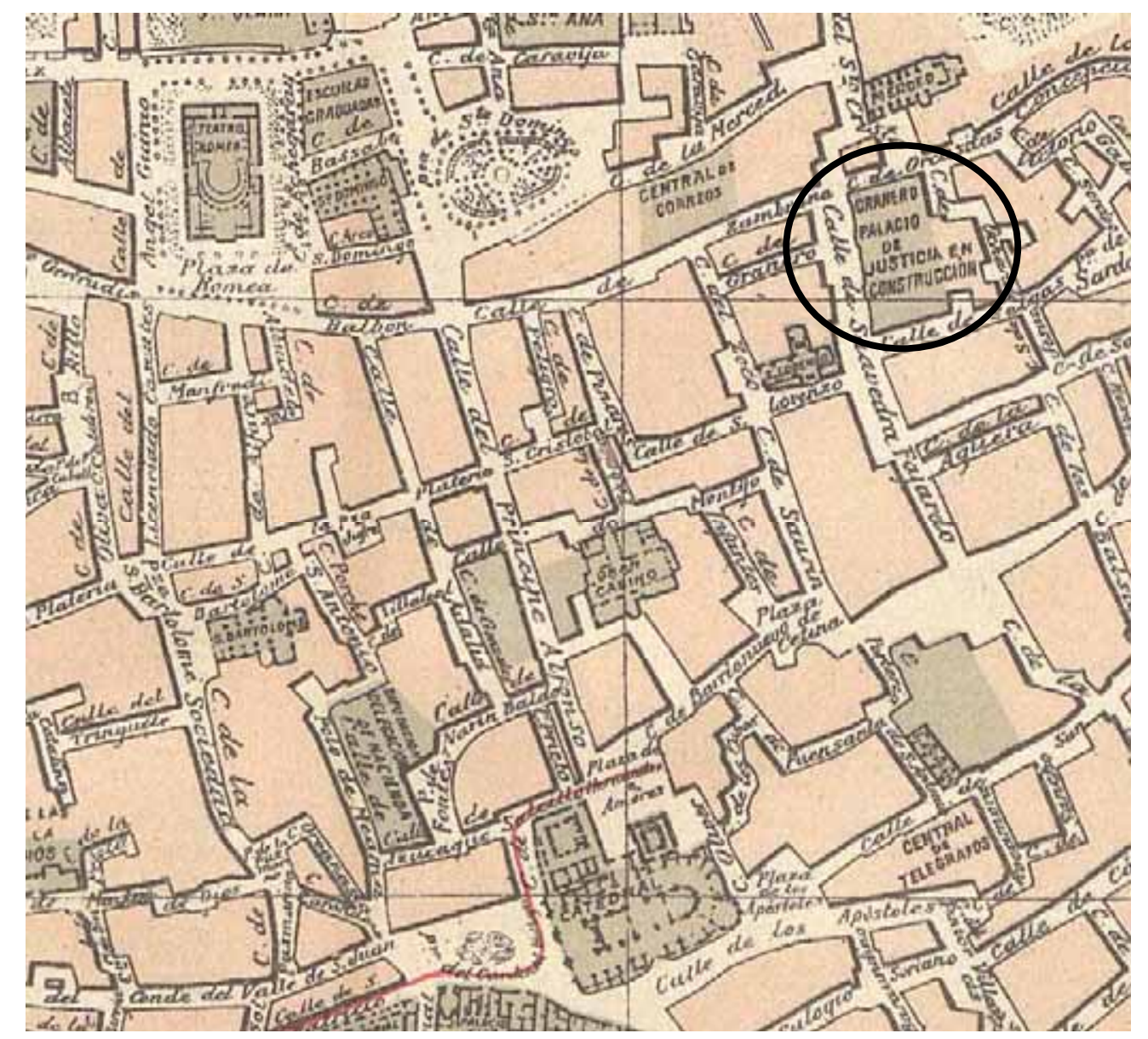

Figura 2. 8. Ubicación del Teatro Provisional sobre el callejero de la ciudad de Murcia. Pedro García Faria, Plano de Murcia (Barcelona: Alberto Martín, s.a.). E:Mpb. Accesible en: http://bibliotecadigital.carm.es (acceso el 16-07-2011).

El Teatro Provisional tenía una capacidad de 500 localidades divididas en palcos principales, plateas, lunetas y galería ${ }^{310}$. Las dimensiones del escenario y su capacidad para albergar grandes aparatos escénicos eran muy limitados ${ }^{311}$.

${ }^{308}$ La primera noticia que he hallado se publicó en La Paz de Murcia, I (1858), nº 19, 16 marzo, p. 4 y se refiere a la llegada de varias actores de la compañía de zarzuela y declamación dirigida por Bernardo Llorens. Crespo, Antiguos teatros, p. 15 sostiene que el teatro pudo utilizarse desde 1857 por los aficionados de la sociedad El Liceo.

${ }^{309}$ La Paz de Murcia, II (1859), no 506, 10 octubre, p. 2. El Teatro Provisional estaba instalado sobre el antiguo Granero del Cabildo: Crespo, Antiguos teatros, p. 82.

${ }^{310}$ La Paz de Murcia, II (1859), no 524, 30 octubre, pp. 2-3.

${ }^{311}$ Así lo afirmaba La Paz de Murcia, I (1858), nº 228, 1 diciembre, p. 2: "mas de esto no culpamos a nadie en razón a que lo reducido del escenario no lo permite". En La Paz de Murcia, II (1859), n 548, 23 noviembre, p. 2 se escribió: "el Teatro Provisional no permite mucho aparato". En Navidad, se ofrecían funciones de tarde y noche en este local: La Paz de Murcia, I (1858), nº 238, 14 diciembre, p. 1. 
Como se verá en los capítulos siguientes, el Teatro Provisional acogió compañías profesionales (dramáticas, de ópera, de zarzuela y coreográficas), así como compañías mixtas de profesionales y aficionados de la sociedad recreativa Liceo (1858-1859). Por este motivo, esta sociedad sufragó los gastos de remodelación y ampliación del Teatro Provisional en agosto de $1858^{312}$. La última compañía que actuó en él, según los periódicos conservados, fue la de zarzuela y baile de Manuel Rodríguez Sáez (temporada de Pascua de 1860) ${ }^{313}$. En 1863, el Teatro Provisional se utilizó para acoger bailes de máscaras y es probable que se siguiera usando con esta finalidad durante los meses siguientes $^{314}$. En enero de 1864 parte del edificio del Teatro Provisional se derrumbó a causa de las obras de ensanche de la calle del Cura ${ }^{315}$.

El segundo Teatro Provisional (también llamado de la Rambla o Teatro Granero $^{316}$ ) comenzó el 9 de marzo de 1878, tras el incendio sufrido por el Teatro Romea en febrero de 1877. Seguía ubicado en la calle del Cura:

Hoy debe inaugurarse el Teatro Provisional establecido en la calle del Cura, en la casa en construcción para el Tribunal de Justicia y en donde estuvo en otra época el anterior Teatro Provisional. La empresa constructora, animada del mejor deseo y de que el público murciano tenga un local agradable donde concurrir mientras se reconstruye el antiguo Teatro de Romea, ha contratado a la primera actriz doña Luisa González [...]. El local estará bien acondicionado en comodidad y decencia ${ }^{317}$.

El segundo Teatro Provisional fue un local de "modestas pretensiones", con una sala reducida y poco confortable: "El local no es muy capaz y las localidades pudieran tener mayor comodidad, especialmente las sillas, si estuvieran fijas" ${ }^{\text {318 }}$. La mayor parte de

${ }^{312}$ La Paz de Murcia, I (1858), n 142, 22 agosto, p. 2. No ha quedado constancia de cuáles fueron las reformas, salvo la sustitución del tejado: La Paz de Murcia, II (1859), nº 257, 7 enero, p. 2. La prensa sugirió mejoras como colocar los quinqués más bajos para no incomodar con sus reflejos a los asistentes a palcos y sillones y evitar el lodazal que se formaba a la entrada del teatro cuando llovía: La Paz de Murcia, I (1858), $\mathrm{n}^{\text {os }} 195,24$ octubre, p. 2; 203, 2 noviembre, p. 1 y 215, 16 noviembre, p. 1. A pesar de la remodelación en enero de 1859 las fuentes revelan que había goteras.

${ }^{313}$ No se conservan ejemplares periodísticos de 1861 y 1862 . Cabe suponer que el teatro siguiera utilizándose como local de representaciones teatrales hasta la inauguración del Teatro de los Infantes en 1862.

${ }^{314}$ El Segura, I (1863), no 14, 16 enero, p. 2.

${ }^{315}$ El Sacamuelas, I (1864), $\mathrm{n}^{\mathrm{o}}$ 14, 24 enero, p. 8.

316 El periódico El Semanario Murciano, I (1878), nº 5, 17 marzo, p. 8 denominó al Teatro Provisional, Teatro de la Rambla. En cambio, en junio de 1879, la prensa lo denominaba indistintamente Teatro Provisional y Teatro Granero. Por ejemplo, con este último nombre apareció en el anuncio del baile de sociedad publicado por El Diario de Murcia, I (1879), nº 96, 12 junio, p. 3, así como en el de la velada teatral y baile anunciados en La Paz de Murcia, XXII (1879), n 6612, 1 junio, p. 4. En otros, como La Paz de Murcia, XXII (1879), $\mathrm{n}^{\text {os }}$ 6618, 8 junio, p. 4 y 6621, 12 junio, p. 4 se empleó Teatro Provisional.

${ }^{317}$ La Paz de Murcia, XXI (1878), $\mathrm{n}^{\text {os }} 6205,9$ marzo, p. 1 y 6206, 10 marzo, p. 1. En el mismo ejemplar se advertía que "por no haberse podido dar oportunamente el permiso" no pudo inaugurarse ese día. Para Crespo, la diferencia entre el primer Teatro Provisional y el segundo fue que el primero se instaló en el antiguo Granero del Cabildo, en cambio, el que se hizo en 1878 aprovechó el edificio que se construía para el Tribunal de Justicia: Crespo, Antiguos teatros, pp. 81-82.

${ }^{318}$ El Semanario Murciano, I (1878), nº 6, 24 marzo, p. 8. La Paz de Murcia, XXI (1878), $\mathrm{n}^{\circ}$ 6225, 2 abril, p. 1 también publicó comentarios similares. No he hallado datos sobre la capacidad del teatro aunque sus localidades estaban divididas entre palcos y sillas: La Paz de Murcia, XXI (1878), nº 6206, 10 marzo, p. 4. 
las obras representadas en él fueron teatrales y no propiamente musicales. Desde marzo hasta mayo de 1878, actuó un elenco mixto de profesionales y aficionados bajo la dirección escénica de Rafael Muñoz $^{319}$. Desde mayo de 1878 hasta enero del año siguiente, hubo otras actuaciones de aficionados ${ }^{320}$. Durante los meses siguientes se representaron funciones esporádicas de aficionados y se celebró un concierto del guitarrista Pedro Paredes, del que trataré más adelante ${ }^{321}$. Estas actuaciones se alternaron con bailes de sociedad en el mismo teatro, organizados por el Centro Gastro $^{322}$.

A partir de 1880, el local fue rehabilitado y comenzó a denominarse Teatro del Circo o Teatro del Circo de la Rambla, como se verá en el apartado siguiente.

\subsection{EI Teatro Circo de la Rambla (1880-1885)}

El Teatro Circo de la Rambla surgió de la rehabilitación del antiguo Teatro Provisional y por iniciativa del Centro Gastro ${ }^{323}$. Fue inaugurado el 16 de abril de 1880 con la actuación de una compañía ecuestre y, al menos durante todo ese mes, acogió una función semanal "ecuestre-acrobático-cómica"324. El local (llamado inicialmente "circo provisional) contaba con una cubierta de lona sobre el patio del antiguo granero. Las obras, llevadas a cabo con celeridad, dieron como resultado un espacio teatral con "condiciones de comodidad y buena visibilidad para los concurrentes" $" 325$. A mediados de julio de 1880 , volvió a ser modificado para reconvertirlo en un teatro de verano:

${ }^{319}$ La compañía actuó hasta el 5 de mayo de 1878: La Paz de Murcia, XXI (1878), nº 6208, 5 mayo, p. 4. Véanse más detalles sobre sus actuaciones en Crespo, Antiguos teatros, pp. 81-87.

${ }^{320}$ El 8 de enero de 1879 hubo una función a beneficio del asilo de San José, regentado por las Hermanitas de los Pobres: La Paz de Murcia, XXII (1879), nº 6393, 8 enero, p. 1. Véase Crespo, Antiguos teatros, p. 85.

${ }^{321}$ La Paz de Murcia, XXII (1879), nº 6602, 20 mayo, p. 1. La mayor parte de estas funciones fueron representadas por una compañía de aficionados que estaba actuando en el Teatro de la Trinidad: La Paz de Murcia, XXII (1879), n 6552, 19 marzo, p. 1, La Paz de Murcia, XXII (1879), nº 6561, 30 marzo, p. 1, La Paz de Murcia, XXII (1879), $\mathrm{n}^{\circ}$ 6571, 12 abril, p. 1, El Noticiero Murciano, VIII (1879), $\mathrm{n}^{\circ}$ 1873, 28 diciembre, p. 2

${ }^{322}$ La Paz de Murcia, XXII (1879), $\mathrm{n}^{\text {os }}$ 6510, 28 enero, p. 1 y 6515, 2 febrero, p. 1. El Centro Gastro fue uno de los grupos "sardineros" participantes en el tradicional "Entierro de la Sardina", una fiesta muy popular entre los murcianos y aún vigente. Otros "centros" o grupos "sardineros" en 1879 fueron, además del citado, Mono, Nocturno, Remolcador, Brujo, Chino, Marítimo, Sport, Taurino y Acuario. Sobre el Centro Gastro y, en general, sobre la citada fiesta véase: Pérez Crespo, El Entierro, vol. 1 (2001), pp. 317 322 .

${ }^{323}$ Las primeras noticias aparecieron en El Diario de Murcia, II (1880), n 349, 7 abril, p. 3. En él se advertía sobre "la construcción de un circo ecuestre en el gran local del Granero". Más tarde, el mismo periódico afirmaba: "El Entierro de la Sardina ha dado origen al Teatro Circo": La Paz de Murcia, XXIV (1881), nº 6946, 9 enero, p. 1.

${ }^{324}$ El Semanario Murciano, III (1880), nº 114, 18 abril, p. 128. Véanse más detalles en Crespo, Antiguos teatros, pp. 121-165: 121-123.

${ }^{325}$ El Diario de Murcia, II (1880), nº 351, 17 abril, pp. 2-3. 
Mil enhorabuenas al popular Centro-Gastro por la inauguración de su teatro de la calle de Saavedra Fajardo. El local del Circo ha sido, con una actividad y acierto verdaderamente notables, trasformado en un bonito y cómodo teatro de verano. Algunos pequeños detalles quedan por arreglar, que deben serlo pronto. Las decoraciones del señor Montesinos, pintadas en angustioso plazo, son de bastante buen efecto. El telón, sobre todo, es muy feliz. [...]. El teatro
concurrencia

El Teatro Circo de la Rambla se inauguró el 2 de septiembre de 1880 (coincidiendo con los días de feria) con la zarzuela de Barbieri, Jugar con fuego, a cargo de la compañía lírica de Tomás Gómez, bajo la dirección escénica de Rafael Villalonga $^{327}$. En el elenco de esa función figuraba el conocido tenor cómico murciano Pablo López ${ }^{328}$. La programación escénica de este teatro fue irregular y con periodos de inactividad. Las condiciones del Circo de la Rambla, propias de un teatro de verano, provocaron a menudo la suspensión de las representaciones a causa de la climatología, como veremos en el Capítulo 3. Por este motivo, fue usual que las compañías abandonaran al Teatro del Circo y se trasladaran al Teatro Romea, buscando comodidad y mejores medios. Este fue el caso de la compañía lírica de Juan García Catalá, que debutó en el Circo el 1 de septiembre de 1883 y pasó, al día siguiente, al Romea:

La empresa de la compañía de zarzuela [del Teatro Circo] ha decidido dar las funciones en Romea para que los forasteros disfruten de sus comodidades. Hace muy bien y creemos que ha de ganar con la variación. En Romea no hace calor, se está con comodidad y lucen las señoras y de ahí la preferencia que obtiene ${ }^{329}$.

E1 Teatro Provisional y posteriormente, el Circo de la Rambla ocupaban parte del espacio destinado al Palacio de Justicia. En septiembre de 1884 el local del teatro fue incautado por esta razón ${ }^{330}$; aunque siguió registrando algunas actuaciones teatrales y conciertos quizás hasta junio de $1885^{331}$.

${ }^{326}$ El Semanario Murciano, III (1880), $\mathrm{n}^{\mathrm{o}}$ 134, 5 septiembre, p. 288. El telón de boca se empezó a pintar a mediados de agosto: El Diario de Murcia, II (1880), $\mathrm{n}^{\text {os }} 454,13$ agosto, pp. 2-3 y 468, 29 agosto, p. 2. Representaba "una pareja de huertano y huertana que se destacan graciosamente de un fondo copiado de este cielo, con un paisaje en el que se ve nuestra hermosa torre [de la Catedral], que todo él llena nuestra vista": El Diario de Murcia, II (1880), n 472, 3 septiembre, p. 3.

${ }^{327}$ El Diario de Murcia, II (1880), nº 472, 3 septiembre, p. 3.

${ }^{328}$ Las gestiones para contratarlo comenzaron en julio de 1880: El Diario de Murcia, II (1880), $\mathrm{n}^{\circ} 438$, 25 julio, p. 3 . El elenco de artistas se publicó en El Diario de Murcia, II (1880), n 471, 2 septiembre, pp. 12. Sobre sus representaciones, véase el capítulo sobre Zarzuela.

${ }^{329}$ La Paz de Murcia, XXVI (1883), no 7717, 5 septiembre, p. 1.

${ }^{330}$ La Paz de Murcia, XXVII (1884), nº 8014, 10 septiembre, p. 1.

${ }^{331}$ En junio de 1885 una epidemia de cólera asoló la ciudad, cerrando teatros y paralizando la vida social y comercial. Sobre su repercusión, véase Sáez Gómez, Marset Campos y Crespo León, "El cólera", pp. 273-292. 


\subsection{El Teatro del Circo Villar (1892-1895)}

El Teatro del Circo Villar fue, después del Romea, el teatro más importante de la ciudad. El edificio fue proyectado y construido por Justo Millán, siguiendo las pautas de los célebres "teatros-circo" parisinos presentes en muchas ciudades europeas. Millán fue también el responsable de la remodelación del Teatro Romea tras el incendio de 1899 y autor de otros emblemáticos edificios murcianos, como la Plaza de Toros, el Hospital Provincial, el Colegio San José y la portada de San Bartolomé ${ }^{332}$.

El Teatro del Circo Villar comenzó a planificarse en julio de 1889 por iniciativa de Enrique Villar Bas, impulsor y principal promotor de la empresa constructora conocida como Sociedad de los nueve $e^{333}$. Estuvo ubicado en la antigua calle Caravija (actual calle de Enrique Villar Bas), muy cerca del Teatro Romea y de la céntrica plaza de Santo Domingo (ver su ubicación sobre la Figura 2.9).

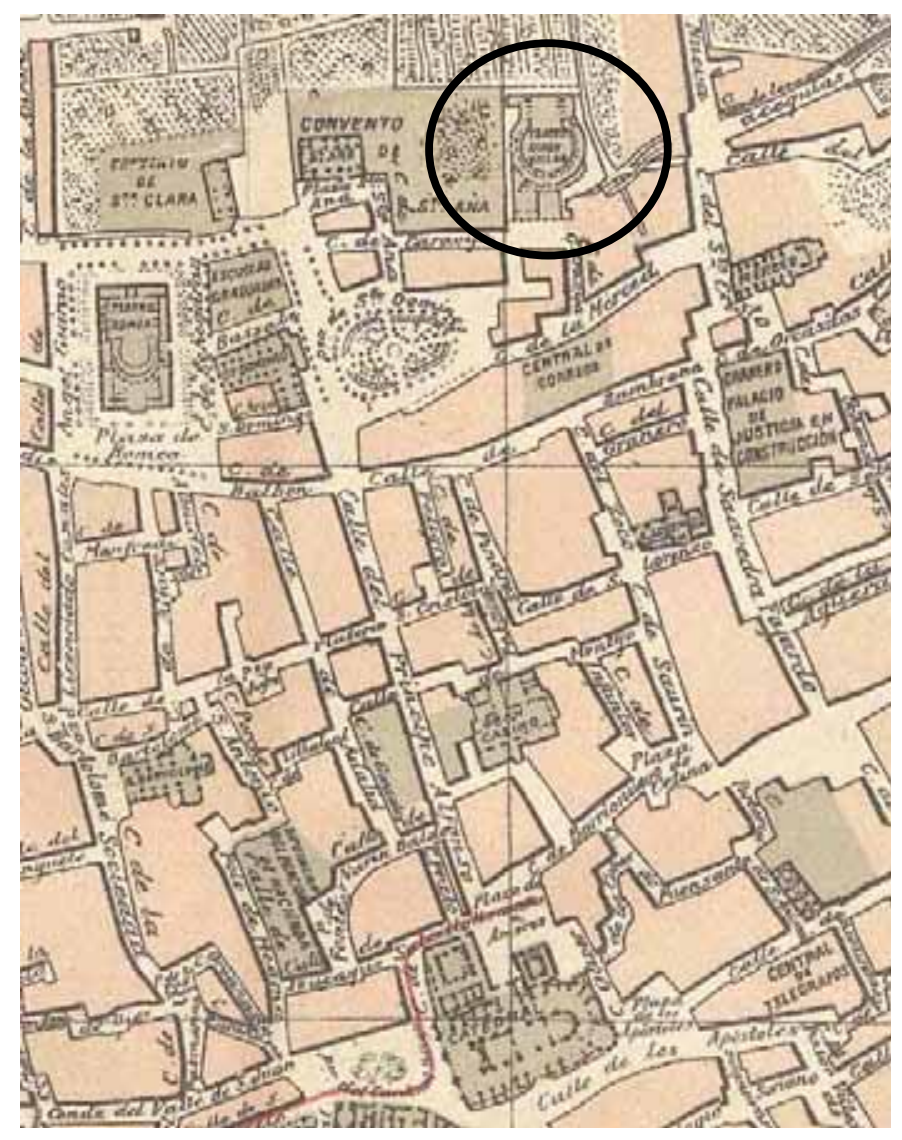

Figura 2. 9. Ubicación del Teatro Circo Villar sobre el callejero de la ciudad de Murcia. Pedro García Faria, Plano de Murcia (Barcelona: Alberto Martín, s.a.). E:Mpb. Accesible en: http://bibliotecadigital.carm.es (acceso el 16-07-2011).

${ }^{332}$ Sobre la vida y obra de este arquitecto véase, Nicolás, Arquitectura, pp. 151-153.

333 Según Crespo, la empresa constaba de treinta socios accionistas para levantar el teatro: Crespo, Antiguos teatros, pp. 205-206. La Paz de Murcia sugirió que se le llamase Teatro Padilla, en homenaje al ilustre barítono murciano: La Paz de Murcia, XXXIII (1890), $\mathrm{n}^{\mathrm{o}}$ 11038, 27 mayo, p. 4 e incluso así se anunció en la prensa nacional: La Época, XLIII (1891), no 13822, 19 febrero, p. 3. Sin embargo, se le denominó finalmente Circo de Villar (o teatro Circo Villar). Véase más información sobre Enrique Villar en El Diario de Murcia, XIV (1892), nº 5047, 15 julio, p. 1. 
Las obras de construcción del teatro comenzaron en noviembre de $1889^{334}$ y coincidieron con la construcción del Teatro Circo de Cartagena, cuyos decorados fueron realizados por el pintor y escenógrafo Manuel Sanmigue ${ }^{335}$. El techo, decorado y telones del Teatro Circo Villar de Murcia fueron encargados también a Manuel Sanmiguel ${ }^{336}$. Un año después, el edificio ofrecía el siguiente aspecto (ver Figura 2.10):

[...] El perímetro del local es espacioso: sólo ocho columnas (que marcan igual número de ochavas y que miden 32 metros de diámetro. La obra resulta sólida y sencilla. Los que han visto y aún estudiados los principales circos de Europa estiman el que se está construyendo como uno de los mejores modelos. La cubierta parece sostenida en el aire. No tiene ni un solo tirante. Los ingenieros de Barcelona, en donde se ha fundido, la califican de grandiosa y elegante, reconociendo en el señor Millán los atrevimientos propios del arquitecto que sabe calcular concienzudamente las resistencias en sus complicadas relaciones con las alturas. Tendrá el futuro circo de Murcia 600 butacas en el patio, treinta y ocho plateas y sobre éstas una amplia y hermosa galería $[\ldots]^{337}$.

De planta dodecagonal de 40 metros de diámetro, sobre el edificio tenía una cúpula de hierro con cubiertas de madera y barandillas de forja policromada. 205-210.

${ }^{334}$ Los trabajos de construcción del teatro han sido descritos en Antonio Crespo, Antiguos teatros, pp.

${ }^{335}$ El Diario de Murcia, XI (1889), $\mathrm{n}^{\circ} 3751,12$ junio, p. 3. Una descripción de su obra apareció en La Paz de Murcia, XXXII (1889), nº 9851, 15 junio, p. 1.

${ }^{336}$ El telón de boca no estuvo a tiempo la noche de la inauguración. Como solución provisional se colocó el telón de anuncios que más tarde se utilizaría en los entreactos de las funciones: El Diario de Murcia, XV (1893), nº 6064, 14 octubre, p. 3. En Las Provincias de Levante, VIII (1893), n 2029, 27 julio, p. 2 se describen algunos detalles: "Ayer tuvimos ocasión de ver un trozo de la escocia que está pintado el notable artista Sr. Sanmiguel, que merece los mayores elogios. Uno de los bustos que figuran en este lienzo es el del eminente músico murciano don Fernández Caballero y está bien terminado y, es tal su parecido que, de seguro, no habrá una sola persona que no lo conozca".

${ }^{337}$ Las Provincias de Levante, VI (1891), $\mathrm{n}^{\circ}$ 1502, 25 septiembre, pp. 1-2. Ver transcripción completa en Documentario. 


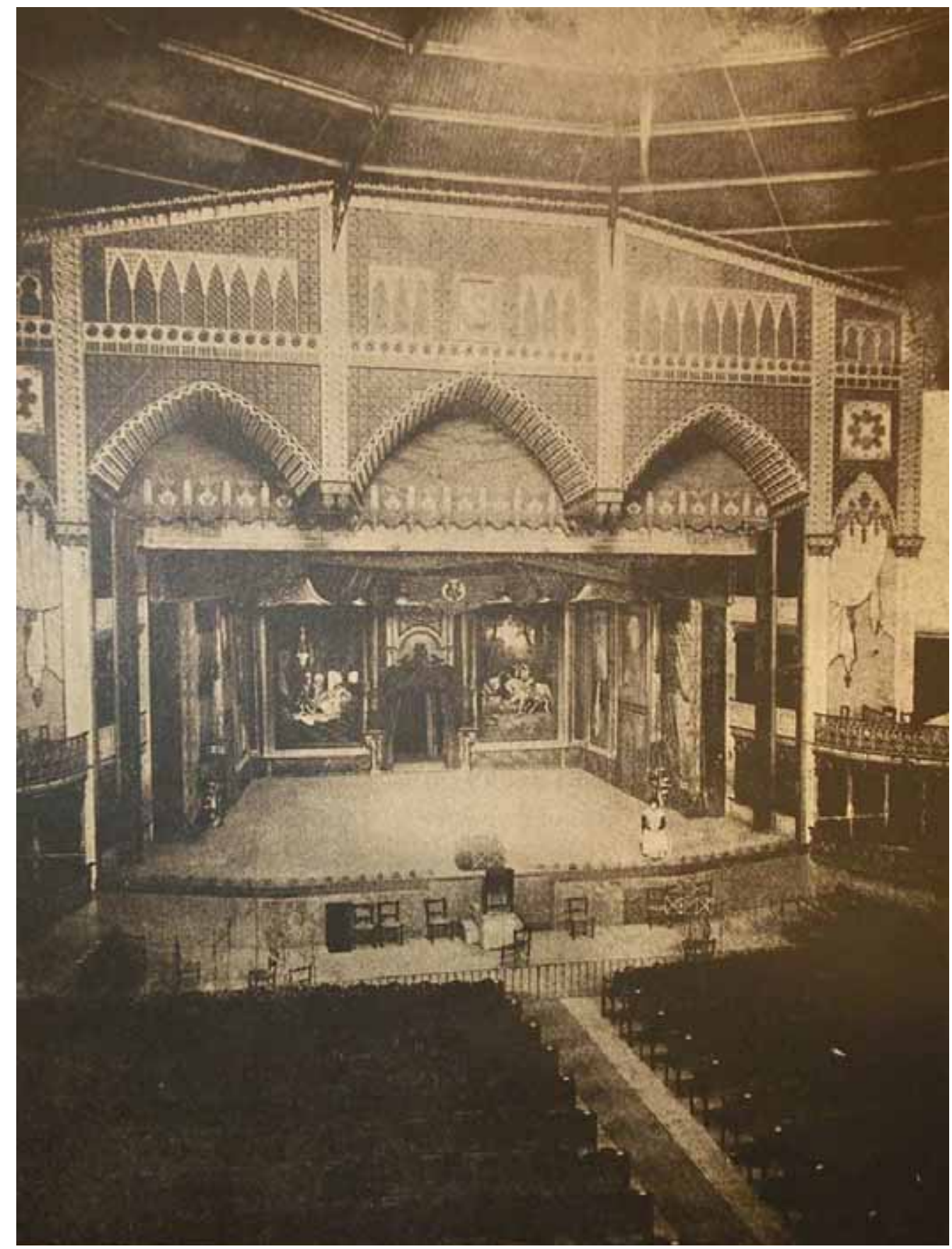

Figura 2.10 Interior del Teatro Circo Villar. ¿Principios del siglo XX?. Accesible en http://www.regmurcia.com (acceso el 15-07-2011).

El Teatro Circo Villar se inauguró como circo el 5 de noviembre de 1892 con una compañía de espectáculos variados, la "compañía ecuestre, gimnástica, acrobática, cómica, mímica y musical” de Arturo Magrini ${ }^{338}$. En el acto intervino la orquesta dirigida por Ángel Mirete. En enero de 1893 se reanudaron las obras para que el Circo Villar

${ }^{338}$ La reseña de su inauguración fue publicada en La Paz de Murcia XXXV (189), 7 noviembre, pp. 12. Durante el mes de diciembre de 1893, actuó la compañía de Jean Christiany. Véanse más detalles en Crespo, Antiguos teatros, pp. 209-213. 
pudiera funcionar como teatro propiamente dicho ${ }^{339}$. En agosto del mismo año, Enrique Villar constituyó el Especta-Club Murciano, una sociedad constituida inicialmente por cincuenta socios y futuros empresarios del teatro, bajo la presidencia del médico Agustín Ruiz $^{340}$. Los socios se ampliaron posteriormente, y entre sus actividades estuvo la contratación de compañías de zarzuela:

La sociedad "Especta-Club" ha acordado ampliar el número de sus socios hasta 80 y además han comisionado a los señores don Jesualdo Cañadas y don José Muñoz para que vayan a Madrid y traigan si la encuentran formada, una compañía de zarzuela que inaugure el Teatro Circo el 15 de septiembre y si no, que la formen contratando en primer lugar a los murcianos que estén libres de compromiso, pues dicha sociedad quisiera, si pudiera ser, inaugurar el Teatro Circo con los Barreras, López (don Pablo), Barrenas, Rex Torrano, López (don Antonio), y otros jóvenes murcianos que en todas partes son aplaudidos ${ }^{341}$.

La reinauguración del Teatro Circo Villar tuvo lugar el 14 de octubre de 1893 con la compañía de zarzuela dirigida por Eduardo Ortiz ${ }^{342}$. Se llevó a escena el apropósito titulado Villar y compañía, como se verá en un apartado posterior.

La construcción del nuevo teatro fue valorada positivamente por la prensa. Se resaltó el hecho de que los dos teatros más importantes de la ciudad se hallaran concentrados en un punto de la ciudad de fácil acceso desde el centro:

[...] El de Romea tiene ya historia y tradiciones; el de Villar empezará esta noche a ser, llevando sobre su frente como bautismo patrio la sal del ingenio de dos murcianos.

El de Romea lleva este nombre por derecho artístico y el de Villar, lleva este apellido por derecho propio.

Uno y otro tienen la misma orientación. La misma Caravija refresca los cimientos de uno y otros. Ambos tienen una misma vecindad de religiosas, en cuyos claustros no dejarán de oírse como ruidos mundanales los ecos de los aplausos al par que de las sillas.

Ese lado de Murcia que no tiene los ruidos del barrio del Carmen, que es abrigado, que respira holgura y tranquilidad, estaba verdaderamente llamado a tener los teatros. Colocadlos en otro lado cualquiera y no resultaría. Ponedlos en la vía Funeraria y parecería que el duelo se despide en las Agustinas.

Las distancias de la población están más promediadas para todos tomando ese sitio por punto de partida o de llegada, que desde cualquier otro que no fuese el centro.

${ }^{339}$ Durante el mes de septiembre de 1893 se instaló el alumbrado eléctrico. Tal y como relata Crespo, Antiguos teatros, p. 214 se colocaron cuatro focos: en la puerta principal, en el rincón de santo Domingo por donde tenía acceso el teatro, en la calle de La Merced y en la torre de Santo Domingo, frente a Trapería.

${ }^{340}$ El acta de constitución y su reglamento fue publicado en El Diario de Murcia XV (1893), nº 6014, 17 agosto, p. 2. Según recoge la fuente, "esta sociedad tiende a ser más que lucrativa, de distracción y recreo". El vicepresidente de la sociedad fue José María Palazón, el depositario, Juan de Dios Ayuso y el secretario-contador Germán Mauricio. Otras noticias relacionadas con la sociedad se publicaron en El Diario de Murcia XV (1893), $\mathrm{n}^{\circ}$ 6081, 2 noviembre, p. 2

${ }^{341}$ El Diario de Murcia, XV (1893), nº 6025, 30 agosto, p. 3. Quince días más tarde, la misma sociedad acordó elevar a cien el número de sus acciones: El Diario de Murcia, XV (1893), nº 6039, 15 septiembre, p. 3.

${ }^{342}$ A comienzos de octubre ya se habían vendido las plateas y parte de las butacas para la función de reinauguración del teatro Circo Villar: El Diario de Murcia, XV (1893), nº 6055, 4 octubre, p. 3. 
Por todas partes se va a esos teatros y desde ellos hay facilidad para acortar mejor las distancias. $[\ldots]^{343}$.

Sin embargo, la competencia por atraer público afectó a la actividad escénica y a la afluencia de público en ambos teatros, como veremos en los capítulos siguientes. En enero de 1894 el número de socios accionistas de la sociedad "Especta-Club" había decrecido $^{344}$. El escenario del Teatro Circo Villar acogió diversas compañías teatrales, de zarzuela y de ópera y algún concierto esporádico. Uno de los estrenos más relevantes en él fue la zarzuela Los mostenses, en la que la orquesta fue dirigida por su compositor Ruperto Chapí (23-01-1894) ${ }^{345}$. En 1908, el Teatro Circo Villar se habilitó para cine, aunque también se usó para otros espectáculos (ver Figura 2.11).

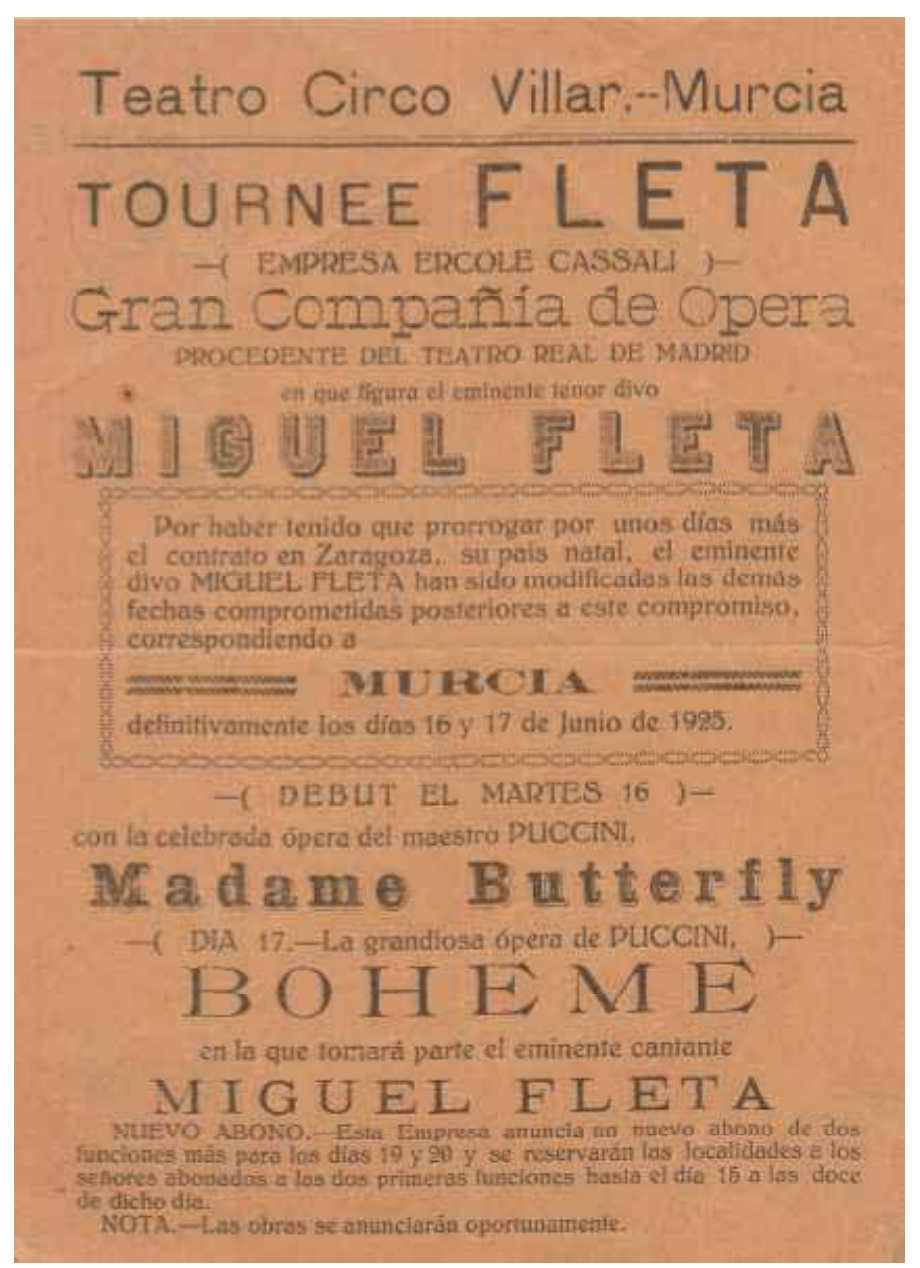

Figura 2.11 Cartel de la "Gran Compañía de Ópera del Teatro Real de Madrid" con el tenor Miguel Fleta en el Teatro Circo Villar (junio de 1925). Accesible en: http://bibliotecadigital.carm.es (acceso el 8-08-2011).

${ }^{343}$ El Diario de Murcia, XV (1893), nº 6064, 14 octubre, p. 1.

${ }^{344}$ Incluso Agustín Ruiz había abandonado la presidencia: La Paz de Murcia, XXXVI (1894), nº 12588, 5 enero, p. 1.

${ }^{345}$ Ver más detalles en el Capítulo 3. 
El Teatro Circo Villar cerró sus puertas en el último tercio del siglo XIX. Recientemente el Teatro Circo Villar ha sido remodelado y rehabilitado para acoger el Centro Experimental y Alternativo de Artes Escénicas de Murcia (ver Figura 2.12).

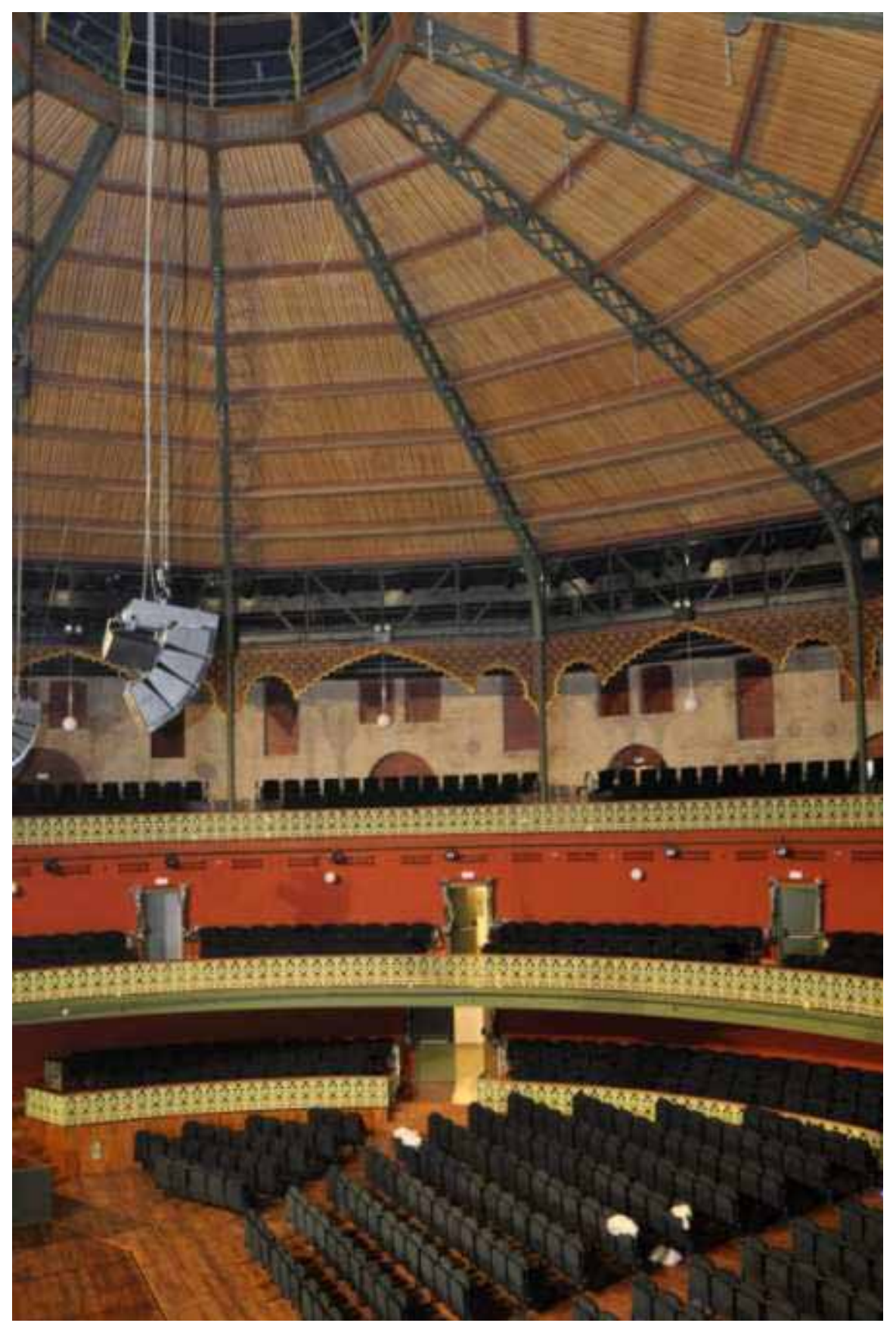

Figura 2. 12. Aspecto actual del Teatro Circo Villar de Murcia, recientemente reconstruido. Accesible en: http://www.infocirco.com (acceso el 8-08-2011) 


\subsection{Otros teatros}

Durante la segunda mitad del siglo XIX hubo en Murcia otros teatros o salones teatrales, como el teatro de la Cárcel Vieja ${ }^{346}$; el del Puente ${ }^{347}$; el del Comercio $^{348}$; el del Salitre $^{349}$; y el de la Trinidad ${ }^{350}$. Todos estos teatros desarrollaron una actividad teatral de carácter dramático, no propiamente musical. Si hubo representaciones musicales lírico, no ha quedado constancia.

El Teatro de la Posada del Malecón estuvo instalado en el hospedaje de la Posada del Malecón, en el edificio que fue convento de los franciscanos. Las únicas noticias que datan de él datan del año 1873 y refieren generalmente funciones de zarzuelas.

Hubo, además, teatros ambulantes, como el Teatro de la Ambulancia. En él se presentó "un gran museo militar y religioso, movido a vapor, en el que hay grupos que representan diferentes escenas de la guerra". Estuvo situado en la plaza de la Reina (actual plaza de Martínez Tornel), a la bajada del puente ${ }^{351}$.

${ }^{346}$ Sobre este teatro véase, Crespo, Antiguos teatros, pp. 249-251. El Teatro de la Cárcel Vieja es el primer teatro del de Murcia del que existen datos fiables, después de los primitivos corrales o casa de comedias del Azoque, del Trinquete y del Toro. Su actividad fue escasa y bastante esporádica. Estuvo situado en la antigua prisión murciana de la Inquisición y, más tarde, las casas de Zabálduru (entre el plano de San Francisco y la calle de Crédito Público, hoy Poeta Jara Carrillo. Solía funcionar en Navidad y en él se representaban dramas sacros y pastoriles, como El rosario perseguido. Durante la temporada teatral 1858-1859 se llevaron a escena diversas obras de género dramático. En sus funciones se intercalaron comedias, sainetes y bailes. Se sabe muy poco acerca de lo que ocurrió con este teatro y si funcionó a partir de los sesenta. Probablemente, dado su pésimo estado de conservación, cerrase sus puertas. El E:MUm, Leg. 4188 conserva documentación relevante sobre este teatro, entre otros documentos, planos e informes municipales.

${ }^{347}$ Los datos sobre el Teatro del Puente (o Teatro de la Posada del Puente) son muy escasos. Crespo sugiere que fue local muy modesto situado en el edificio posterior al tradicional local de Lotería, donde hay constancia de que existió un hospedaje en el siglo XIX: Crespo, Antiguos teatros, pp. 252-253.

${ }^{348}$ Se inauguró el día de San José de 1868 con el drama de Camprodón Flor de un día. Se le denominó bastantes veces "Teatro de la plaza de Cofré" [sic] y no aparece como "Teatro del Comercio" hasta finales de abril de 1869. Acogió diversas representaciones entre los años 1868 y 1870. Tuvo más actividad que el Teatro del Puente. Se estableció "en la casa de don Elías Lahorra y que antes fue almacén de los señores Server, en la plaza de Jofré” (Joufré). Crespo, Antiguos Teatros, pp. 253-255.

${ }^{349}$ La Paz de Murcia, XII (1869), n 3493, 12 febrero, p. 1 menciona que, con "objeto de pasar en agradable y útil recreo las veladas de este invierno,[...] hase arreglado un teatro en una de las habitaciones de la fábrica de salitres de esta capital".

${ }^{350}$ Fue construido en la planta baja del convento de la Trinidad. Las Noticias denunció las malas condiciones en que se encontraba este teatro, lo que dio lugar a la suspensión del permiso hasta la revisión técnica en diciembre de 1877 (este suceso nos idea del poder de la prensa). Superados los inconvenientes, se abrió al público en la Navidad de 1877. Por su escenario desfilaron compañías de aficionados. Su actividad teatral fue muy espaciada y corta, concentrándose en épocas navideñas donde se daba mayor número de funciones. Las representaciones fueron predominantemente dramáticas. Su actividad cesó en febrero de 1880. En alguna ocasión, los aficionados del Teatro de la Trinidad actuaron en el Provisional: $L a$ Paz de Murcia, XXII (1879), nº 6552, 19 marzo, p. 1.

${ }^{351}$ La Paz de Murcia, XXII (1879), nº 6539, 4 marzo, p. 1. 


\subsection{Teatros de centros de enseñanza}

Algunos centros de enseñanza de la ciudad tuvieron un teatro propio y programaron, en la mayor parte de los casos, funciones a cargo de jóvenes aficionados, probablemente alumnos. La información que he podido recopilar sobre su actividad teatral o concertística es muy escasa.

Los colegios con teatros fueron, al menos: Colegio de "Jesuitas",352, Colegio "Nuestra Señora de las Mercedes", Colegio de "La Inmaculada", Colegio de la calle Victorio, Colegio "Saavedra Fajardo", Colegio "La Purísima" y Colegio de los "Sagrados Corazones". Excepto en los cuatro primeros, en el resto he hallado datos sobre actividad lírica teatral y concertística. El Apéndice 2.10 muestra su ubicación sobre el callejero de la ciudad.

El Colegio "Saavedra Fajardo" estuvo situado en la plaza de Santo Domingo, 2, y lo dirigían los sacerdotes Pedro González Adalid y Pedro Martínez Garre y el abogado Agustín Hernández del Águila ${ }^{353}$. A finales de junio de 1880 se estrenó en su "espaciosa" sala la obra de Juan Antonio Soriano, Un instante de placer, con decorados de Federico Mauricio (julio de 1880) ${ }^{354}$. En enero de 1882, la sociedad artístico-musical Santa Cecilia celebró una velada musical en su teatro ${ }^{355}$.

El teatro del Colegio de "La Purísima" también acogió veladas teatrales y musicales, por ejemplo, la de abril de 1886, en la que actuaron Julián Calvo y Quetglas ${ }^{356}$.

En el teatro del Colegio de los "Sagrados Corazones de Jesús y María" hubo tres funciones lírico-dramáticas en enero de $1888^{357}$. Los actores, que eran alumnos del centro, representaron En el pecado el castigo (drama escrito para niños por el murciano Virgilio Guirao), Los aguinaldos (apropósito del mismo autor) y el estreno de la zarzuela Mala siembra, mala siega, de Guirao (libreto) y Mariano Moreno Pretel (música) (ver Capítulo 3).

${ }^{352}$ En él hubo, al menos, una función dramática infantil: La Paz de Murcia, XXIX (1886), nº 9080, 30 diciembre, p. 1.

${ }^{353}$ Crespo, Antiguos Teatros, pp. 263-264.

${ }^{354}$ El Diario de Murcia, II (1880), n ${ }^{\text {os }} 417,1$ julio, p. 3 y 418, 2 julio, pp. 1-2. La obra escenificaba una visita del célebre diplomático Saavedra Fajardo a su pueblo natal, Algezares.

${ }^{355}$ La Paz de Murcia, XXV (1882), nº 7231, 4 enero, p. 1. Ver más detalles en el Capítulo 6.

${ }^{356}$ El Diario de Murcia, VIII (1886), no 2123, 6 abril, p. 2. En la velada se representaron la pieza en un acto Pepita, Acertar por carambola y Me conviene esta mujer, a cargo de varios alumnos y alternados con números musicales.

${ }^{357}$ Las funciones, con el mismo programa, se celebraron los días 6 a 8 de enero de 1888: La Paz de Murcia, XXXI (1888), no 9399, 10 enero, p. 1. 


\section{Capítulo 3. Zarzuela y opereta en Murcia durante la segunda mitad del siglo XIX}

La intensa actividad de zarzuela y opereta que tuvo Murcia en la segunda mitad del siglo XIX generó una ingente cantidad de documentación. Los principales datos sobre las compañías de zarzuela y opereta, así como sus actividades se presentan esquemáticamente en los Apéndices 2.2 y 3.1 a $3.11^{1}$. En los apartados siguientes comentaré algunos aspectos que derivan de la información consultada y presentada en dichos apéndices.

\section{La zarzuela hasta la apertura del Teatro de los Infantes (1849-1862)}

\subsection{Las primeras representaciones documentadas de zarzuela en el Teatro del Toro (1849-1855)}

La zarzuela está documentada en la prensa de Murcia al menos desde $1849^{2}$. En la Casa-Teatro o Teatro del Toro se representaron zarzuelas en un solo acto, como Jeroma la Castañera y El Tío Caniyitas, ambas del compositor murciano Mariano Soriano Fuertes, con libretos de Mariano Fernández y José Sanz Pérez, respectivamente; ${ }^{3}$ y también obras más rupturistas, como El duende, con música de Rafael Hernando y libreto de Luis Olona (representada en Murcia en 1851), primera zarzuela moderna en dos actos y precursora de la zarzuela grande en tres actos ${ }^{4}$.

\footnotetext{
${ }^{1}$ Para el análisis de la actividad teatral de este teatro, así como de los coliseos que trato en este y sucesivos apartados he confeccionado varios anexos: el Apéndice 2.2 contiene una relación de las compañías y espectáculos teatrales en los teatros de Murcia capital por temporadas; en el Apéndice 3.1 he transcrito los anuncios en prensa que indican composición, repertorio y precios de abono de las compañías de zarzuela que actuaron en los teatros de Murcia (1858-1895); en el Apéndice 3.2, especifico la estructura de las compañías profesionales indicando el número de componentes, tipos de voces, directores y apuntadores, entre otros; en los Apéndice 3.3, 3.4 y 3.8 aporto los programas de las funciones de zarzuela de las compañías especializadas en este género que actuaron en los distintos teatros de la ciudad durante los años 1858-1895; el Apéndice 3.5 contiene una selección de funciones benéficas del Teatro Romea durante los años 1873-1895; los Apéndices 3.6 y 3.7 desglosan los compositores y obras, especificando el número representaciones en el Teatro Romea por etapas y en todos los teatros estudiados, respectivamente; y los Apéndices 3.9 a 3.11, complementan a su vez los apartados de este capítulo sobre zarzuelas de autores murcianos y opereta.

${ }^{2}$ Véase, Clares, “La música”, pp. 451-478.

3 Jeroma la Castañera se estrenó el 3 de abril de 1843 en el Teatro del Príncipe de Madrid y se representó durante veinte días seguidos. Fue calificada por el compositor como "tonadilla española". El tío Caniyitas se estrenó en el Teatro San Fernando de Sevilla en 1849 su éxito fue enorme en España y América. Cortizo, "Jeroma”, pp. 5-7 y Cortizo, “Tío Caniyitas”, pp. 803-804.

${ }^{4}$ A través de un complejo desarrollo, la zarzuela en España evolucionó de espectáculo cortesano en el siglo XVII a espectáculo popular y de grandes masas a mediados del siglo XIX. Según Casares, "Zarzuela", pp. 963-983: 964, tras el periodo de restauración de la zarzuela (1849-1851), la historia del género pasó por las siguientes etapas: desde 1851 hasta 1880, establecimiento de los modelos de zarzuela grande y chica y nacimiento del género bufo (desde 1863); desde 1880 hasta 1905, etapa del género chico y pervivencia de la zarzuela grande; de 1905 a 1960, implantación de los géneros frívolo e ínfimo, nueva revista, varietés, opereta y restauración de la zarzuela grande; el periodo final, que abarca desde 1939 hasta 1960, se caracteriza por la pervivencia de la zarzuela grande y la revista. Véanse más detalles sobre esas etapas, tipologías, recepción de la zarzuela en diferentes puntos de España (Cataluña, Castilla y Andalucía), así como su influencia en Hispanoamérica en la colección de artículos La zarzuela en España e
} 
Entre 1851 y 1858 no existen datos periodísticos sobre representación de zarzuelas en los teatros de Murcia. En El Liberal Murciano se aludió a la falta de obras teatrales cantadas en la ciudad en 1855 :

[...] Y puesto que estamos en el terreno de los consejos les diremos a los actores de verso de otros puntos que pretenden este teatro para dar algunas funciones, que desistan de tales proyectos porque no ha de darles resultados. Otra cosa sería que viniese una compañía de zarzuela. La grande afición que hay en este pueblo a la música y el tiempo que hace que no se ha cantado en este teatro, atraería bastante concurrencia 5 .

\subsection{La zarzuela en el Teatro Provisional de Murcia (1858-1860)}

La zarzuela vertebró la vida teatral de los teatros murcianos y, de forma especial la de los teatros Provisional e Infantes-Romea. Siete de las ocho compañías que actuaron en el Teatro Provisional entre 1858 y 1860 ofrecieron representaciones de zarzuela.

Las compañías que actuaban en el Teatro Provisional solían tener secciones o cuadros especializados en los géneros dramático, lírico (ópera y/o zarzuela) y coreográfico y las funciones alternaban las representaciones con números de baile, si la compañía contaba con un cuadro de baile. Las denominaciones de las compañías eran muy variadas: "declamación con cuadro de zarzuela" de Bernardo Llorens (marzo de 1858) ${ }^{6}$; "lírico-dramática" del primer actor Coronado (julio de 1858) ${ }^{7}$; "de ópera y zarzuela" con "pequeña sección de verso" de Juan Cavaletti (octubre de 1858); "dramático-coreográfica" de Francisco del Val (mayo de 1859); "de zarzuela" de Hermenegildo Manzanedo" (octubre de 1859) o "lírico-coreográfica" de Manuel Rodríguez Sáez (mayo de 1860) ${ }^{8}$.

Los elencos que actuaron en el Teatro Provisional tenían pocos integrantes, si se comparan con las compañías del Teatro Infantes-Romea en años posteriores. Solían contar con una decena de voces principales, un coro de al menos doce cantantes y dos directores (uno de escena y otro de orquesta). Entre las voces principales solía haber de tres a cinco tiples, uno o dos tenores, un barítono y entre uno y tres bajos 9 .

Hispanoamérica. Centro y periferia, 1800-1950; Barce (coord.), Actualidad y Cortizo, "La zarzuela". Sobre la zarzuela en el área mediterránea, consúltese: Galbis López, "La zarzuela", pp. 327-349.

${ }^{5}$ El Liberal Murciano (1855), $\mathrm{n}^{\mathrm{o}}$ 20, 24 junio, [sin paginar].

${ }^{6}$ Según el anuncio publicado en La Paz de Murcia, I (1858), no 20, 18 marzo, p. 2, esta compañía pensaba actuar desde Pascua de Resurrección hasta mediados de junio de 1858.

${ }^{7}$ Se anunciaron seis funciones de esta compañía en La Paz de Murcia, I (1858), nº 93, 29 junio, p. 2. En su debut (4-07-1858) representaron La cisterna encantada de Gaztambide y Ventura de la Vega y un baile titulado La linda gaditana, según La Paz de Murcia, I (1858), nº 98, 4 julio, p. 2.

${ }^{8}$ La polivalencia de las compañías, especialmente las que viajaban a provincias, fue un fenómeno común a toda España, como estudia Casares, "Compañías de zarzuela".

${ }^{9}$ La compañía de Juan Cavaletti, sin embargo, presenta algunas particularidades. Los cantantes principales fueron una tiple para ópera y zarzuela indistintamente, una tiple-contralto, cuatro tenores (uno para ópera, otro para zarzuela, un tenor cómico y un segundo tenor para ópera y zarzuela) y dos bajos. 
Era frecuente que las representaciones se iniciaran con elencos incompletos, dado que estas compañías se formaban ex profeso y, en muchas ocasiones, con demasiada celeridad. La compañía de Hermenegildo Manzanedo ( $1^{\text {a }}$ temporada 1859-1860), por ejemplo, comenzó sus representaciones el 28 de octubre de 1859 a falta de una primera tiple que no llegó a contratarse ${ }^{10}$. Fue la primera compañía especializada únicamente en zarzuela que llegó a Murcia en la segunda mitad del siglo XIX, y encontró circunstancias difíciles, ya que una epidemia de cólera había asolado la ciudad durante los meses de agosto y septiembre de $1859^{11}$. El miedo al contagio y el riguroso luto por los fallecidos retrasaron la temporada y provocaron un descenso del número de espectadores, al menos en las primeras representaciones de la compañía ${ }^{12}$. Además, la compañía sufrió una indisposición del tenor cómico Hermenegildo Manzanedo que retrasó el estreno de $E l$ Vizconde de Barbieri ${ }^{13}$ y el cambio de empresa teatral ${ }^{14}$. Aún así, las representaciones de la compañía de Manzanedo tuvieron buenas críticas de la prensa $\mathrm{y}$, paulatinamente, mayor número de espectadores.

La Tabla 3.1 muestra las zarzuelas más representadas durante los años 1858-1860 en el Teatro Provisional:

Tabla 3. 1. Zarzuelas más interpretadas en el Teatro Provisional de Murcia (1858-1860). Elaboración propia. Véase las fuentes documentales en los Apéndices 3.3.

\begin{tabular}{|l|l|c|l|}
\hline Compositor & Título/s (actos) & Representaciones & Compañía/s \\
\hline Arrieta, & Marina (2) & 9 & Cavaletti, Manzanedo \\
\cline { 2 - 4 } Emilio & El dominó azul (3) & 4 & Cavaletti \\
\hline [Asenjo] & Earbieri, \\
Francisco & & 6 & $\begin{array}{l}\text { Manzanedo } \\
\text { Rodríguez Sáez }\end{array}$ \\
\cline { 2 - 4 } & Jugar con fuego (3) & & Cavaletti y Manzanedo \\
\cline { 2 - 4 } & Los diamantes de la corona (3) & 3 & Cavaletti y Manzanedo \\
\cline { 2 - 4 } & El diablo en el poder (3) & 3 & Manzanedo \\
\cline { 2 - 4 } & El Vizconde (1) & 3 & Manzanedo \\
\cline { 2 - 4 } & Un caballero particular (1) & 3 & $\begin{array}{l}\text { Manzanedo } \\
\text { Rodríguez Sáez }\end{array}$ \\
\cline { 2 - 4 } & & 2 & Rodríguez Sáez \\
\hline
\end{tabular}

10 "Lo avanzado en que se ha formado esta compañía ha embarazado a la empresa lo bastante para no poder presentar hoy una primera tiple no conocida de este público": La Paz de Murcia, II (1859), no 346, 18 abril, p. 2.

${ }^{11}$ Casares, "Compañía de zarzuela", p. 531, menciona, sin embargo, una compañía estable que actuaba en Murcia y Cartagena y que se desplazaba a Ciudad Real en ciertas épocas del año. Según el autor, esa compañía era dirigida por Nicolás Molas, la primera tiple Carlota Jiménez, Manuela Cubas, Josefa Calvo, José Corcolés y Dionisio Marín. Desconozco si la citada compañía estaba especializada en zarzuela o formaba parte de un conjunto teatral polivalente.

${ }^{12}$ La Paz de Murcia, II (1859), nº 524, 30 octubre, p. 2. En La Paz de Murcia, II (1859), nº 524, 30 octubre, p. 2 se propuso que el Ayuntamiento diera a la empresa teatral una cantidad de dinero que sería reembolsada al municipio si los beneficios teatrales aumentaban.

${ }^{13}$ Véase, La Paz de Murcia, II (1859), $\mathrm{n}^{\text {os }}$ 533, 8 noviembre, p. 3; 535, 10 noviembre, p. 3 y 542,17 noviembre, p. 2. Finalmente se representó el 16 de noviembre de 1859.

14 “A consecuencia de haber dado por terminado su compromiso con la compañía que actúa en nuestro teatro la empresa que la formó, otra nueva se ha encargado de continuar las funciones respetando, lo primero, los abonos que había": La Paz de Murcia, II (1859), n 541, 16 noviembre, p. 2. La nueva empresa se hizo cargo de la compañía desde el 12 de noviembre de 1859 y para incentivar las ventas de entradas, rebajó un 20\% los precios de las funciones: La Paz de Murcia, II (1859), n 541, 16 noviembre, p. 1. 


\begin{tabular}{|l|l|l|l|}
\hline \multirow{3}{*}{$\begin{array}{l}\text { Gaztambide, } \\
\text { Joaquín }\end{array}$} & Catalina (3) & 6 & Manzanedo \\
\cline { 2 - 4 } & Los magyares $(4)$ & 6 & $\begin{array}{l}\text { Manzanedo } \\
\text { Rodríguez Sáez }\end{array}$ \\
\cline { 2 - 4 } & El amor y el almuerzo (1) & 4 & Cavaletti y Manzanedo \\
\cline { 2 - 4 } & El lancero $(1)$ & 4 & Manzanedo \\
\cline { 2 - 4 } & El juramento (3) & 2 & Rodríguez Sáez \\
\hline $\begin{array}{l}\text { Oudrid, } \\
\text { Cristóbal }\end{array}$ & El postillón de la Rioja $(2)$ & 4 & Manzanedo \\
\cline { 2 - 4 } & El último mono $(1)$ & 2 & Manzanedo \\
\hline
\end{tabular}

Los compositores más representados fueron Barbieri y Gaztambide $^{15}$ y predominaron las zarzuelas en dos o tres actos. Entre los títulos representados estuvieron Jugar con fuego, considerada como la primera zarzuela grande en tres $\operatorname{actos}^{16}$ y Los diamantes de la corona, obra fundamental de la zarzuela española del siglo XIX y muy representada en Murcia durante los años siguientes ${ }^{17}$. Otras obras representadas en el Teatro Provisional de Murcia fueron la "zarzuela chica" El Vizconde y las zarzuelas grandes, estrenadas después de la inauguración del Teatro de la Zarzuela de Madrid (1110-1856), El diablo en el poder, Los magyares, El juramento y Entre mi mujer y el negro. Este hecho indica que a Murcia llegaron con relativa prontitud las obras más destacadas de los compositores que protagonizaron el primer período de la historia de la zarzuela romántica tanto de zarzuela grande como chica.

Al margen de las compañías profesionales, hay que mencionar la presencia de compañías de aficionados a lo largo del periodo estudiado. El Capítulo 6 analiza la actividad teatral de varias sociedades murcianas (algunas de carácter dramático) que organizaron temporadas más o menos estables en sus propios teatros o en otros locales teatrales ${ }^{18}$. Junto a estos hay que mencionar otras funciones esporádicas, habitualmente organizadas con fines benéficos en teatros como el que nos ocupa. En febrero de 1860 actuó en él una compañía de estudiantes varones del Instituto Provincial de Murcia, dirigidos por el organista y compositor murciano Julián Calvo, que fue el "maestro de partes". Intervinieron Miguel Yagües Fernández (maestro de coros), diversos apuntadores para letra y música, ocho cantores aficionados y un coro de catorce niños ${ }^{19}$. Se estrenaron para la ocasión dos zarzuelas del citado Julián Calvo: Una broma de

${ }^{15}$ Otras zarzuelas que no aparecen en la Tabla 3.1 fueron representadas en una única ocasión: Azón Visconti, Arrieta; Mis dos mujeres y Amar sin conocer, Barbieri; Un cocinero, de Fernández Caballero; Los conspiradores, de Javier Gaztambide; Un pleito y El valle de Andorra, de Joaquín Gaztambide; La colegiala, de Molberg; y, finalmente Buenas noches, señor don Simón, de Oudrid.

${ }^{16}$ Espín, "Panorama”, p. 57.

${ }^{17}$ Los diamantes de la corona se estrenó en el Teatro Provisional de Murcia el 16 de noviembre de 1858, cuatro años más tarde que en el Teatro Circo de Madrid (15-09-1854): Casares, "Diamantes", pp. 632-635.

${ }^{18}$ Por ejemplo, la prensa dejó constancia de una representación de Jeroma la Castañera por socios de la sociedad dramática "La Unión" en el teatro del mismo nombre en febrero de 1859: La Paz de Murcia, II (1859), n 293, 10 febrero, p. 2.

${ }^{19}$ Una parte de los beneficios de la función se destinó a pagar los estudios del hijo del primer oficial murciano que muriera en la batalla de Tetuán; la otra parte, al padre o madre del primer soldado murciano que sucumbiera en la mencionada contienda. Los ocho cantantes aficionados fueron: Julio Usera, José Soro, Ramón Marín, Avelino Ruiz, Hilario Gris, Pedro Delbalzo, Eduardo Jaén e Ildefonso Martínez: La Paz de Murcia, III (1860), nº 610, 5 febrero, p. 1. 
estudiantes (en dos actos, con libreto de Ramón Guerrero) y Travesuras de Quevedo (en un acto, libreto de Francisco Villegas), sobre las que volveré más adelante ${ }^{20}$.

\section{La zarzuela en el Teatro de los Infantes-Romea (1862-1895)}

La zarzuela estuvo presente en la programación del Teatro Infantes-Romea de forma casi permanente, especialmente a partir de la década de los ochenta y hasta el final del siglo XIX ${ }^{21}$.

\subsection{La zarzuela hasta la introducción del género bufo (1862-1871)}

La función inaugural del Teatro de los Infantes (26-10-1862) corrió a cargo de la compañía dramática de José Dardalla (empresario del coliseo junto a Antonio Romero Saavedra ${ }^{22}$ ) y contó con la actuación del actor murciano Julián Romea ${ }^{23}$. La compañía, que disponía de una sección de baile, actuó ininterrumpidamente hasta enero de $1863^{24}$. Las críticas teatrales que semanalmente publicó El Segura evidencian el cansancio del público murciano por la frecuente repetición de algunas obras:

[...] Empresario, señor empresario, suplicamos a usted encarecidamente no nos ponga tales comediones que el público se disgusta, las niñas se aburren y los abonados juran y perjuran no seguir callando y sufriendo. Esperamos pues la enmienda y pocas repeticiones porque si no charlaremos, aclarando que no es verdad lo de la muletilla de a petición de varios abonados o si no, a ruego de bastantes personas que se quedaron sin localidad, etcétera... Con que agur y hasta más ver ${ }^{25}$.

Los empresarios Dardalla y Romero plantearon entonces un recurso eficaz: el intercambio de compañías entre teatros cercanos. Así, llevaron a los Infantes a la compañía de teatro y zarzuela de Marina Albini, procedente de Lorca, y enviaron a Lorca la compañía dramática de Dardalla ${ }^{26}$.

\footnotetext{
${ }^{20}$ La función se completó con un Himno Guerrero para coro y orquesta, compuesto por Ángel Mirete. El programa completo puede consultarse en el Apéndice 3.3. En La Paz de Murcia, III (1860), $\mathrm{n}^{\circ}$ 639, 15 marzo, p. 1 se anunció otra función de estos estudiantes para el día 19 de marzo de 1860 con las obras $L a$ tienda del Rey Don Sancho, de Luis de Olona, la repetición de la zarzuela Travesuras de Quevedo y ejercicios gimnásticos en los intermedios.

${ }^{21}$ Los años en los que no hubo zarzuela fueron: 1864-1865, 1868 a 1870, 1871-1872 y 1880-1881.

${ }^{22}$ E:MUm, AC 10-10-1862, fols. 129 v.-130 r.

${ }^{23}$ Véase la crónica del evento en Arróniz, Crónica.

${ }^{24}$ Según Crespo, Historia del Teatro, p. 68, los empresarios tenían un contrato para actuar hasta el Jueves Santo de ese año (2-04-1863). El estreno del baile Potpurrí de aires nacionales por esta compañía fue comentado por El Segura, I (1863), n 11, 13 enero, p. 2.

${ }^{25}$ El Segura, I (1863), no 22, 25 enero, pp. 2-3.

${ }^{26}$ El Segura, I (1863), no 20, 23 enero, p. 3.
} 
Las zarzuelas representadas en el debut de la compañía de Marina Albini en Murcia capital fueron El vizconde, de Barbieri y Una vieja, de Gaztambide, ambas pertenecientes a la "zarzuela chica" 27 . La prensa criticó que eran obras breves ("dos piececitas en un acto" ${ }^{28}$ ) y demasiado conocidas para el público murciano, entre otros aspectos negativos:

[...] La empresa nadie ignora que ha hecho todo lo posible para malquistar a la población con la compañía. Promete no alterar los precios y los altera. Ofrece no repetir una función más de tres veces dentro del abono y no lo cumple. Sabe que la venta de las localidades en la contaduría es para la población que no está a ello acostumbrada, muy repugnante, y no la suprime. Ve que el dar función diaria es insoportable para los contados y siempre los mismos concurrentes y no deja ni siquiera un día franco a la semana. En una palabra, jamás supo o no quiso complacer a una ciudad que le probó siempre su galantería y su nobleza $[\ldots]^{29}$.

De la compañía de Marina Albini también se criticó la falta de ensayos y, como consecuencia, la deficiente puesta en escena de las obras ${ }^{30}$, la continua repetición del mismo repertorio ${ }^{31}$ y la escasa motivación de los actores por los bajos sueldos que cobraban. Los actores expresaban así su punto de vista ante la situación en una carta al director del diario El Segura:

$[\ldots]$ ¿Qué quiere usted que hagamos, si nos ensayan mal y poco, nos dirigen peor y luego para coronar la fiesta no nos dan más que un triste real? ¿Qué quiere usted que hagamos si nos vuelven locos en los ensayos, sin gratificarnos nada, y cada vez dirige el baile un nuevo bastonero? Antes, cuando estaba en auge nuestra carrera, cuando se funcionaba en el teatro antiguo y después en el Provisional, nos daban dos reales, teníamos tres o cuatro ensayos y por ellos nos daban alguna gratificación; pero ahora, que estamos a media paga y mal ensayados ¿qué hemos de hacer? $[\ldots]^{32}$.

La segunda temporada teatral de 1862-1863 llevó hasta el Teatro de los Infantes una compañía de zarzuela dirigida por el compositor y empresario Manuel Fernández Caballero $^{33}$. La compañía estaba formada por figuras del canto de primer orden, como la

${ }^{27}$ En el intermedio entre una y otra se cantó la cavatina de Norma. Véase la reseña crítica en El Segura, I (1863), n 35,10 febrero, p. 1.

${ }^{28}$ El Segura, I (1863), no 26, 30 enero, p. 3.

${ }^{29}$ El Segura, I (1863), no 70, 24 marzo, pp. 1-2. Al parecer hubo incluso abucheos: “Antes de anoche y cual teníamos previsto, sufrió la compañía de zarzuela que actúa en nuestro teatro la grita más espantosa que darse puede", en El Segura, I (1863), n 37, 12 febrero, p. 2.Véase el artículo "Totum revolutum", publicado en El Segura, I (1863), nº 70, 24 marzo, pp. 1-2.

${ }^{30}$ El Segura, I (1863), no 47, 24 febrero, pp. 1-2.

${ }^{31}$ Nueve de las quince zarzuelas representadas por la compañía de Marina Albini en Murcia fueron repetidas en más de una ocasión: Los magyares, tres veces; Marina, Amar sin conocer, Los diamantes de la corona, ;Tramoya!, Una vieja, Campanone y El Juramento, hasta en dos ocasiones cada una. En conjunto, de 24 representaciones, 18 fueron repeticiones y sólo seis zarzuelas fueron interpretadas en una única ocasión.

${ }^{32}$ El Segura, I (1863), no 48, 25 febrero, p. 1.

${ }^{33}$ A finales de febrero 1863, Manuel Fernández Caballero había solicitado el teatro para dar treinta representaciones líricas y dramáticas durante la temporada de Pascua (abril de 1863): El Segura, I (1863), 
tiple Elisa Zamacois (contratada para el estreno de la zarzuela grande El sargento Federico, de Barbieri y Gaztambide), Manuela Cubas, Cristina Corro, Dionisia Guzmán, los tenores Francisco Cortabitarte, Gregorio Rey y Miguel Torno y los bajos Santiago Santacoloma y Juan Cubas ${ }^{34}$. Se conservan los títulos de las obras representadas en las dos primeras semanas y una crítica correspondiente sobre las funciones de la primera semana.

A pesar de los elevados precios de las entradas, las representaciones del elenco de Fernández Caballero debieron obtener un rotundo éxito, pues en agosto de 1863 el empresario Javier de Mendoza y Morán se comprometió a llevar a Murcia una compañía de zarzuela con Elisa Zamacois (o "una calidad igual o mejor"). Las actuaciones, iniciadas en octubre de 1863, recibieron reseñas favorables a la empresa, aunque hubo poco público $^{35}$. Las pérdidas económicas obligaron al empresario Mendoza a solicitar en dos ocasiones la rescisión del contrato y la devolución de la fianza ${ }^{36}$. Una de las causas del fracaso de la compañía de Mendoza fue la reforma realizada en el teatro unos meses antes, en la que se habían reservado demasiadas localidades para la aristocracia, en detrimento de las localidades para las clases medias:

[...] Sin embargo, tenemos que hacer una protesta a favor de nuestra honrada y laboriosa clase media. A esta se le ha quitado una localidad cómoda y barata, para sustituirla con localidades para la aristocracia. Tal reforma mereció siempre nuestra más pronunciada reprobación, tanto por el pensamiento que ella envolvía, como porque desde luego preveíamos el resultado funesto que iba a producir para todas las empresas sucesivas. Hoy la práctica ha venido a demostrarlo. Cerca de la mitad de los palcos, según nuestras noticias, han quedado sin abonar, por lo menos casi todas las noches los vemos desiertos, y esto prueba que la reforma fue impremeditada y que con ella se han perjudicado muy gravemente los intereses de las empresas y se ha inferido una injuria a nuestra laboriosa clase trabajadora, si, lo que no creemos, la intención hubiera sido separarla de la aristocrática. $[\ldots]^{37}$.

Otra causa del fracaso fue el numeroso personal de la compañía de Mendoza, inviable en un teatro como el de los Infantes, como veremos en el Capítulo siguiente ${ }^{38}$.

$\mathrm{n}^{\mathrm{o}}$ 49, 26 febrero, p. 2. E:MUm, AC 23-03-1863, fol. 59v. El compositor y empresario pensaba llevar una compañía de zarzuela con las tiples Santamaría y Zamacois: El Segura, I (1863), nos 54, 4 marzo, p. 3.

${ }^{34}$ Casares, “Compañías de zarzuela”, p. 531.

${ }^{35}$ Véase, El Sacamuelas, I (1863), $\mathrm{n}^{\text {os }}$ 1, 25 octubre, p. 6; 2, 1 noviembre, p. 7 y 3,8 noviembre, p. 6 , así como Crespo, Historia del Teatro, p. 72.

${ }^{36}$ E:MUm, AC 16-10-1863, "Instancia del empresario del teatro solicitando rescisión del contrato", fol. 183 r. y AC 23-10-1863, "Instancia del empresario del teatro exponiendo las muchas pérdidas que viene sufriendo", fols. 185 v. a 186 v. La primera petición fue rechazada y antes de que el Ayuntamiento contestara a la segunda, el empresario escribió una tercera instancia en la que pedía la retirada de la segunda porque esperaba recuperar parte de las pérdidas: E:MUm, AC 29-10-1863, "Instancia del empresario del teatro sobre retirar la que tiene presentada pidiendo rescisión del contrato", fol. $188 \mathrm{v}$.

${ }^{37}$ El Sacamuelas, I (1863), n ${ }^{\circ}$ 1, 25 octubre, p. 6. Véase también, El Sacamuelas, I (1863), $\mathrm{n}^{\circ} 3,8$ noviembre, p. 6 u Crespo, Historia del Teatro, p. 78.

${ }^{38}$ El Sacamuelas, I (1863), $\mathrm{n}^{\mathrm{o}}$ 2, 1 noviembre, p. 7. Las cursivas son editoriales. 
El 7 de noviembre de 1863 la compañía de Mendoza anunció en Murcia que se trasladaba temporalmente a Cartagena y poco después la empresa quebró ${ }^{39}$. El Teatro de los Infantes permaneció cerrado la mayor parte del mes de noviembre de 1863, hasta que Francisco Miguel Fernández formó una compañía para representar zarzuelas con la primera tiple Ana Rodríguez Carrillo (en sustitución de Elisa Zamacois) y el barítono Joaquín Fernández Pló. Las funciones se reanudaron a mediados de diciembre de 1863 y se prolongaron hasta principios de enero del año ${ }^{40}$.

La temporada 1864-1865 fue íntegramente de género dramático en el Teatro de los Infantes $^{41}$ y desde el año cómico 1865-1866 hasta el de 1867-1868 se advierte una tendencia a contratar compañías dramáticas para las primeras temporadas y de zarzuela para las segundas (véase Apéndice 2.2). No obstante, en algunas ocasiones, hubo también zarzuela durante las primeras temporadas, aunque representada por aficionados o por actores y actrices de las compañías dramáticas. Un ejemplo de este tipo fue el estreno de En busca de un marido, "disparate lírico-dramático" en un acto con música de Esteban Capdepón Pérez y libreto de Felipe Blanco de Ibáñez (21-01-1865).

Entre 1865 y 1868 actuaron en los Infantes las compañías de zarzuela de Francisco Villegas, Eugenio Fernández y Miguel Tormo. La de Tormo contaba, además, con una sección dramática. El elenco de estas compañías estaba formado por:

1. Entre doce y quince cantantes para los papeles principales y secundarios, divididos en cuatro o cinco tiples (una de ellas característica), dos o tres tenores, dos barítonos y dos bajos $^{42}$.

2. Un coro de veinte cantantes aproximadamente.

3. Tres o cuatro directores (uno o dos de escena, uno para coro y otro para la orquesta).

4. Tres apuntadores (dos para verso y uno para música) y un número variable de oficios complementarios, como maquinistas, peluqueros y sastres, entre otros.

${ }^{39}$ Mientras que, en el Teatro de los Infantes, se realizaban los preparativos y ensayos de Galanteos en Venecia y La cisterna encantada para llevarlos a escena a su vuelta: El Sacamuelas, I (1863), $\mathrm{n}^{\circ}$ 4, 15 noviembre, p. 6. Véase también, E:MUm, AC 26-11-1863, "Se declara en quiebra el empresario del teatro", fol. $201 \mathrm{r}$.

${ }^{40}$ Francisco Miguel solicitó el teatro hasta el 9 de febrero de 1864: E: MUm, AC 27-11-1863, "Instancia de don Francisco Miguel Fernández en solicitud de funcionar en el Teatro de los Infantes", fol. 202v. A finales de 1863, el Ayuntamiento de Murcia autorizó a los empresarios Francisco del Val (del teatro Principal de Cartagena) y Francisco Miguel Fernández (de los Infantes de Murcia) a intercambiar sus compañías temporalmente. La compañía de zarzuela de Francisco Miguel se trasladó a Cartagena y la compañía dramática de Francisco del Val pasó a Murcia a mediados de enero de 1864 . No ha quedado constancia de las representaciones de esta última. Véase, Crespo, Historia del Teatro, pp. 76-78.

${ }^{41}$ A principios de 1865 actuó en el Teatro Infantes la compañía de Francisco Coria. Para la temporada de abril a mayo, el arrendatario de los Infantes, Prudencio Soler, contrató la compañía de Antonio Zamora y José María Dardalla, con la primera actriz Cándida Dardalla. Véase: La Paz de Murcia, VIII (1865), $\mathrm{n}^{\text {os }}$ 2132, 19 marzo, p. 1; 2138, 28 marzo, p. 2 y 2150, 11 abril, p. 2.

${ }^{42}$ La compañía de Marina Albini (1 ${ }^{a}$ temporada de 1862-1863) contó, sin embargo, con la mitad de miembros: ocho cantantes y un coro de catorce voces. (Véase Apéndice 3.2). 
Durante los años en los que el teatro principal de la ciudad se denominó de la Soberanía Nacional (1868-1872) actuaron cuatro compañías dramáticas (una de ellas con cuadro de baile). Las fuentes periodísticas ponen en evidencia que durante estos años el teatro sufrió una situación crítica, explicada en gran parte por el ambiente político, económico y social de la Revolución de septiembre de 1868 y la caída de Isabel II $^{43}$. La empresa teatral que contrató a la compañía dramática de Rafael Farro para actuar durante la primera temporada de 1868-1869, por ejemplo, quebró y sus actores se vieron obligados a organizar una función benéfica con el fin de obtener una ayuda económica para subsistir ${ }^{44}$.

Los empresarios teatrales recurrieron durante estos años a la rebaja de precios de las localidades, a los abonos condicionados y a contratar a actores famosos para atraer público ${ }^{45}$. La prensa animaba a los murcianos a asistir al teatro, tratando de difundir la idea de estabilidad política: "Los temores que en un principio se tuvieron a turbulencias [...], hoy son excusas vanas" ${ }^{\prime 4}$. En abril de 1869, tras las últimas actuaciones de la compañía dirigida por José Mata, el Teatro de la Soberanía Nacional de Murcia cerró sus $\operatorname{puertas}^{47}$.

Durante 1869-1870, el teatro continuó clausurado por falta de empresarios y sus puertas únicamente se abrieron para funciones benéficas y/o de aficionados. Pondré varios ejemplos. Los días 27 de marzo y 3 de abril de 1870 se ofrecieron dos funciones a beneficio de presos y emigrados políticos, cuyo programa constó de una sinfonía, el drama en tres actos de José Palanca y Roca titulado Valencianos con honra, y la pieza en un acto Un ente singular ${ }^{48}$; los beneficios de la función del día 22 de mayo de 1870 se destinaron a redención de quintas (sistema para evitar el servicio militar mediante pagos $)^{49}$; y la compañía de aficionados de la sociedad murciana del Círculo Industrial representó, el 12 de noviembre de 1870, El amor y el almuerzo de Gaztambide (música) y Olona (libreto), Un caballero particular de Barbieri (música) y Frontaura (libreto), Otra noche toledana, o un caballero y una señora (juguete cómico en un acto de Juan del Peral) y En las astas del toro, con música de Gaztambide y libreto de Frontaura ${ }^{50}$. En julio de 1870 también se celebró un concierto de la soprano Amalia Pellizari y el barítono Antonio del Valle (ver Capítulo 5).

La incapacidad del Teatro de los Infantes-Romea para mantener una compañía estable provocó la proliferación de otros teatros en 1870, la mayoría de aficionados:

${ }^{43}$ Véase, Espadas y De Urquijo, Guerra, pp. 86-92.

${ }^{44}$ La Paz de Murcia, XI (1868), n 3421, 22 noviembre, p. 3.

${ }^{45}$ Véase, por ejemplo, La Paz de Murcia, XII (1869), ${ }^{\text {os }} 3549,20$ abril, p. 1 y 3550, 21 abril, p. 1.

${ }^{46}$ Véase, La Paz de Murcia, XII (1869), ${ }^{\text {os }} 3541,10$ abril, p. 1 y 3542, 11 abril, p. 1.

${ }^{47}$ Mata llegó a solicitar al Ayuntamiento que se le perdonase el alquiler del Teatro de la Soberanía Nacional dada su precaria situación económica: La Paz de Murcia, XII (1869), nº 3542, 11 abril, p. 1.

${ }^{48}$ Véase, La Paz de Murcia, XIII (1870), nºs 3834, 25 marzo, p. 4; 3836, 27 marzo, p. 1 y 3837, 29 marzo, p. 1

${ }^{49}$ La Paz de Murcia, XIII (1870), nos 3882, 21 mayo, p. 1 y 3884, 24 mayo, p. 1.

${ }^{50}$ Véase más información sobre esta función en: La Paz de Murcia, XIII (1870), $\mathrm{n}^{\mathrm{os}} 4017,12$ noviembre, p. $1 ; 4019,15$ noviembre, p. 1 y 4022, 18 noviembre, p. 1. 
OTRO TEATRO. La continuada clausura del principal ha dado margen a la creación de otros, en que los aficionados que no pueden satisfacer este recreo, lo consiguen por la representación por sí mismos de las obras dramáticas que están a su alcance. En este caso se halla el teatrito que con el título La Confianza han construido varios niños en la casa del señor Miró, al cual tuvimos el gusto de asistir en la noche del sábado. $[\ldots]^{51}$.

El cierre del Teatro de la Soberanía Nacional coincidió con la época de esplendor del Teatro del Círculo Industrial y del Teatro del Comercio, dos coliseos dependientes de sociedades recreativas y creados para acoger representaciones teatrales de aficionados, como se detallará en el Capítulo 6.

En julio de 1870 el empresario y actor Rafael Muñoz Prolongo fue contratado para actuar en el Teatro de la Soberanía Nacional a partir de octubre con una compañía dramática con cuadro de zarzuela y baile ${ }^{52}$. El miedo al contagio por la proximidad de un brote epidémico en Alicante obligó al empresario a retrasar el inicio de las representaciones hasta el 1 de diciembre de $1870^{53}$. Tras los dos años anteriores de sequía musical, la temporada de 1870-1871 marcó un hito en el ámbito de la zarzuela en Murcia, ya que coincidió con la introducción del género bufo y su presencia casi ininterrumpida en las temporadas siguientes.

\subsection{Del género bufo al teatro por horas (1871-1888)}

\subsubsection{La polémica consolidación del género bufo (1871): zarzuela bufa versus zarzuela seria}

En abril de 1871 comenzaron en el Teatro Infantes-Romea las actuaciones del empresario Ramón Ros, con la dirección escénica de Manuel Iglesias ${ }^{54}$.

Las primeras representaciones obtuvieron comentarios muy negativos por parte de la prensa, que atribuyó el fracaso inicial de la compañía a que los actores eran desconocidos para el público murciano, a la obra elegida para el debut, Campanone, de "difícil ejecución", y al pésimo ambiente que reinaba entre los instrumentistas de la orquesta del teatro (véase Capítulo 2) . $^{55}$.

${ }^{51}$ La Paz de Murcia, XIII (1870), nº 3777, 18 enero, p. 1.

${ }^{52}$ La Paz de Murcia, XIII (1870), no 3919, 19 julio, p. 1. Además, el Ayuntamiento le favoreció sin exigirle una fianza como garantía ni un número fijo de representaciones: La Paz de Murcia, XIII (1870), $\mathrm{n}^{\circ}$ 4042, 14 diciembre, p. 1.

${ }^{53}$ La Paz de Murcia, XIII (1870), n 3996, 18 octubre, p. 1. La lista de la compañía (que finalmente no tuvo cuadro de zarzuela) se puede consultar en: La Paz de Murcia, XIII (1870), n 4030, 27 noviembre, p. 1. Sus actuaciones se prolongaron hasta el 1 de marzo de 1871 con dos abonos de veinte funciones y uno de diez.

${ }^{54}$ El anuncio en prensa prometía restaurar definitivamente la actividad teatral del coliseo de la plaza de Romea: La Paz de Murcia, XIV (1871), n 4136, 9 abril, p. 1. La compañía se había formado con artistas procedentes de Madrid, Barcelona y otras capitales, y pensaba iniciar sus actuaciones el domingo de Pascual: La Paz de Murcia, XIV (1871), n 4134, 6 abril, p. 1.

${ }^{55}$ Véanse, La Ilustración Murciana, I (1871), n 12, 12 abril, p. 7 y La Paz de Murcia, XIV (1871), ${ }^{\circ}$ 4137, 11 abril, p. 1. 
El empresario Ros se justificó alegando que había tenido muy pocos días para hacer las contrataciones y preparar los ensayos:

[...] Dignísimas personas de esta capital, saben muy bien que el día 3 del mes corriente [abril de 1871] di en Barcelona principio a la formación [de la compañía]; y sabe el público todo que el 9 del mismo di principio a los trabajos, quedando explicado que en solo seis días vencí numerosas dificultades, viajé a las capitales de Valencia y Madrid, escrituré compañía, vestuario y músicas, vencí en ésta nuevas dificultades, ensayé y funcioné $(3)^{56}$. Digo en sólo seis días $(4)^{57}$; y si hoy la empresa realmente carece en su cuadro de compañía de segundo barítono y de alguna otra pequeñez $(5)^{58}$, no es porque no hubiese contratado a aquél, ni culpable porque no se haya presentado. $[\ldots]^{59}$.

Tras las seis primeras representaciones, que contenían sobre todo obras de dos o más actos (a excepción de Pascual Bailón), la séptima función llevó a escena la zarzuela bufa Barba azul de Offenbach y con ella, el imperio del género bufo durante las representaciones siguientes: "Lo que no hizo la selecta música y excelentes libretos de Jugar con fuego y Las hijas de Eva, lo realizó anoche Barba azul, llevando una concurrencia extremada a nuestro coliseo"60. El empresario logró "magnetizar al público" con La gran duquesa de Gerolstein, Los dioses del Olimpo y El joven Telémaco, alternadas cada dos o tres representaciones con una zarzuela en tres o más actos (Los magyares, El dominó azul y Los diamantes de la corona, por ejemplo).

No cabe duda de que la compañía supo, en primer lugar, ofrecer a los espectadores variedad y novedad en su repertorio, contentando incluso al sector más conservador del público; $\mathrm{y}$, en segundo, mantener la dosis justa de funciones, no sólo por los días de descanso (muy útiles para preparar los estrenos de las obras), sino también porque su permanencia en la ciudad no duró más de dos meses, evitando el cansancio de los espectadores.

A pesar del éxito de público y crítica, la recepción del género bufo en Murcia no estuvo exenta de polémica ${ }^{61}$ y desató "una furibunda cruzada" periodística que terminó

${ }^{56}$ [Nota a pie de página original, escrita por la redacción del periódico]: (3) “¿Con quién? ¿Cuándo?... que no lo hemos visto".

${ }^{57}$ [Nota a pie de página original, escrita por la redacción del periódico]: (4) “ ¿Y el séptimo no descansó usted? Dios hizo el mundo en seis días y usted dijo ¿he de ser yo menos? Y en seis días hizo usted una compañías pero el mundo fue perfecto y la compañía...”.

${ }^{58}$ [Nota a pie de página original, escrita por la redacción del periódico]: (5) ¿Con que carece de pequeñeces y otras cosas que no son pequeñeces? Al cabo vendrá a tener razón el público.

${ }^{59}$ La Paz de Murcia, XIV (1871), n 4140, 14 abril, p. 1.

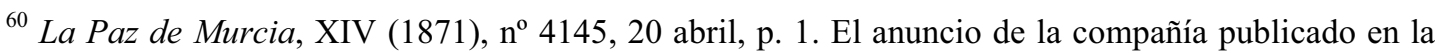
prensa distinguía entre repertorio de zarzuelas "nuevas" y "zarzuelas bufas del maestro Offembach [sic]". Véase el Apéndice 3.1.

${ }^{61}$ En noviembre 1866, la prensa se había hecho eco de los éxitos de El joven Telémaco (música de Rogel sobre libreto de Eusebio Blasco), en el teatro de los Bufos madrileños sin ningún comentario negativo: La Paz de Murcia, IX (1866), n 2808, 10 noviembre, p. 2. En abril y junio de 1867, apenas unos meses más tarde de su estreno en la capital, El Joven Telémaco y Un sarao y una soirée ("caricatura de costumbres" con música de Arrieta y libreto de Ramos Carrión y Lustonó), se representaron en el Teatro de los Infantes de Murcia, pasando inadvertidas. Sólo se veía como negativa la influencia extranjera sobre el teatro lírico español. Tras el estreno de El secreto de una dama (3-05-1867) (música de Barbieri sobre 
bautizándose como "cuestión bufa" Murciana, explica esta reacción:

Con motivo de la primera obra bufa ejecutada en nuestro teatro [Barba Azul], casi todos nuestros colegas de la capital se han ensañado contra el género bufo, presentándolo como la degradación de nuestra escena, sin más objeto que excitar la hilaridad del público, pero sin utilizar este efecto como un correctivo para las costumbres $[\ldots]^{63}$.

Los dos periódicos más importantes del momento, La Paz de Murcia y el recién creado semanal literario La Ilustración Murciana, ejemplifican la división de opiniones. El primero ofreció una visión muy negativa, tanto del género bufo como del empresario y actores que los habían llevado a la ciudad. La Paz de Murcia publicó críticas en las que se hablaba de teatros vacíos, localidades sin vender, obras mal representadas, escenografía pobre y precios elevados ${ }^{64}$. Desde el periódico se aconsejaba no repetir las representaciones bufas e incluso no hacer reseñas sobre ellas ${ }^{65}$. La Ilustración Murciana, en cambio, valoró positivamente el género bufo y vio en "las zarzuelas de Offenbach un retrato fiel de nuestra época, bufa de por sí comparándolas a las chistosas caricaturas de nuestros periódicos satíricos, que consiguen lo que no lograría tal vez el artículo más filosófico" ${ }^{\text {" }}$. Con todo, el género bufo conseguía llenar cada noche el teatro, estimulando la actividad teatral y beneficiando al empresario:

[...] fijándonos solamente en la aceptación que ha podido tener entre nuestro público, creemos que no estará quejoso de ella el señor Ros, pues rara es la noche que no tiene un lleno completo, por más que algún periódico haya dicho que ha sido recibido con frialdad. Lo cierto es que las zarzuelas bufas, y en parte también el deseo de agradar al público que se nota en la compañía, han salvando a ésta del completo fiasco que les anunciábamos, aplaudiendo el público repetidas veces algunas de ellas con justicia [...]. En resumen, las zarzuelas bufas, que contribuyeron al fabuloso abono que según nuestras noticias disfruta la empresa, han de proporcionar al señor Ros pingües resultados $[\ldots]^{67}$.

libreto de Luis Rivera) recordemos que se llegó a afirmar: "hace tiempo que se adorna el castellano con macarrones italianos y trufas a la francesa [...]; y, por último, nos parece una obra digna de haberse escrito en la breve temporada en que la zarzuela, vestida aún de musa, no exhibía los cascabeles y cintajos que después le han colgado payasos y bufones": Homoquidam, "Variedades", La Paz de Murcia, X (1867), n 2875, 5 mayo, p. 2. Sobre zarzuela y ópera bufa, véanse: Casares, "Historia"; Casares, "El teatro"; Cortizo, "Zarzuela y ópera bufa" y Huertas, El teatro. Sobre la influencia extranjera en la zarzuela, consúltese Salaün, "La zarzuela".

${ }^{62}$ La Ilustración Murciana, I (1871), $\mathrm{n}^{\circ}$ 13, 4 mayo, pp. 6-7.

${ }^{63}$ La Ilustración Murciana, I (1871), n $\mathrm{n}^{\mathrm{1}}$ 13, 4 mayo, pp. 6-7. La primera obra bufa a la que se refiere fue Barba azul, representada hasta en cuatro ocasiones por la compañía (19-20, 22 y 23-04-1871), según muestro en el Apéndice 3.4.

${ }^{64}$ La Paz de Murcia, XIV (1871), no 4161, 9 mayo, p. 1.

${ }^{65}$ La Paz de Murcia, XIV (1871), n 4163, 11 mayo, p. 1: "Juzgar en serio una obra bufa es la mayor bufonada que a un revistero puede ocurrírsele": La Paz de Murcia, XIV (1871), n 4152, 28 abril, p. 1.

${ }^{66}$ La Ilustración Murciana, I (1871), nº 13, 4 mayo, p. 6.

${ }^{67}$ La Ilustración Murciana, I (1871), nº 13, 4 mayo, pp. 6-7: 7. 
Entre los aficionados murcianos hubo también división de opiniones sobre el género bufo. "Un partidario de Zorongo" lo defendía así en La Paz de Murcia:

[...] Yo no veo en el género bufo un nuevo arte, y claro es que no tiene tales pretensiones, cuando él mismo se llama género.

Es más, yo no lo creo un género definido: yo lo comprendo como una nueva fase de lo cómico; como un extravío artístico; como una nueva mezcla de sal cómica. Creo que lo bufo es un género naciente que ha de llegar a ser perfecto, aunque haya nacido como una excrecencia dañosa. Tienen las zarzuelas bufas en conjunto una grandeza tan ridícula, una majestad tan vulgar y unos rasgos tan sublimes y prosaicos que producen aturdimiento en nuestro espíritu y risa sonora y escéptica en nuestros labios. Y no es la parodia, que es una fase inversa de una forma determinada, el rebajamiento casi matemático de una cosa sublime o el sublimamiento de una vulgaridad, no, porque la parodia es estéril e infecunda y lo bufo tiene sus creaciones $[\ldots]$.

Con derecho o sin él figura entre los hijos de las gracias y como tiene más votos que cualquier otro género, no hay más remedio que darle cédula de vecindad y adoptarle. Una vez dentro del templo se encargará Talía de educarle, de purificarle, de embellecerle y no hay duda que lo enseñará a los mortales como su hijo predilecto.

¡Si la sociedad está así! ¿qué le vamos a hacer? [...] estamos condenados a vivir en nuestro siglo.

Si lo bufo no tiene razón de ser, morirá indefectiblemente y contribuirá a su muerte el que más alto lo levante, porque la muerte empieza en el apogeo de todas las cosas.

Yo no tengo esa esperanza. Creo que lo bufo, tal como lo comprendo ha de enseñorearse en el teatro, porque es lo cierto que el género bufo es el único que hace reír a una sociedad que no quiere sentir.

[...] El can-can es el baile bufo que ha contribuido más a desacreditar al género que le ha dado vida; pero que me diga a mí el literato más escrupuloso, poniendo la mano en su pecho, o en cualquier otra parte, si no le mueve más el voluptuoso movimiento del baile bufo que el insulso y monótono del rigodón. $[\ldots]^{68}$.

El escrito anterior fue contestado por "Un rojo de la comunée", que aceptaba lo cómico pero negaba la categoría de género a lo bufo:

Si lo bufo es fase de lo cómico, es género; porque lo cómico es género y, sin embargo, habíamos partido de acuerdo sentado que lo bufo no es género. Es más, en lo cómico hay verdad, hay realidad. Lo cómico nos rodea, lo estamos tocando, pero lo bufo es "una excrecencia dañosa", es una cosa fugaz, no es real. No tiene más realidad que la de la exageración de lo ridículo y eso no es la verdad, eso es lo que se llama en buen francés bouffonerie y lo que no puede ser en manera alguna "la síntesis de la sociedad presente". De ahí que lo bufo no sea un género definitivo y por consiguiente que tampoco sea una nueva fase de lo cómico ${ }^{69}$.

A pesar de estas polémicas y de los detractores del género, los empresarios vieron en las zarzuelas bufas cierta garantía de éxito. La compañía dramático-lírica de Victorino Tamayo y Baus (segunda temporada de 1870-1871), por ejemplo, llevó a escena mayoritariamente obras de carácter dramático, aunque las zarzuelas escogidas para ser

${ }^{68}$ La Paz de Murcia, XIV (1871), no 4160, 7 mayo, p. 4. Este artículo fue la respuesta al de "Un rojo de la comunée" hoy perdido, que había sido contrario al género bufo.

${ }^{69}$ La Paz de Murcia, XIV (1871), no 4164, 12 mayo, p. 1. 
representadas por su cuadro lírico fueron Pascual Bailón, de Guillermo Cereceda $(15,18$ y 26-06-1871) y Canto de ángeles, de José Rogel (27 y 29-06-1871), ambas pertenecientes al género bufo y con libreto de Ricardo Puente y Brañas ${ }^{70}$.

A mediados de abril de 1873, se anunció la "compañía de zarzuela seria y cómicobufa" dirigida por Nicolás Rodríguez, elenco que por primera distinguía entre el género serio y el bufo. La compañía de Rodríguez fue la más numerosa que hasta el momento visitaba Murcia aunque sus representaciones se prolongaron poco más de un mes combinándose un repertorio de zarzuelas en tres actos con títulos bufos como Robinson (Barbieri/Santisteban), Pepe Hillo (Cereceda/Ricardo Puente), Pascual Bailón y los arreglos El barón de la castaña (Le testament de Monsieur de Crac de Charles Lecocq) y La soirée de Cachupin de Offenbach.

No obstante, no todas las compañías optaron por combinar los géneros serio y bufo. Debido a la situación política de Murcia, el año cómico de 1873-1874 comenzó en el mes de diciembre con la compañía de zarzuela del director de escena Tomás Brotons ${ }^{71}$. Comparada con la de Nicolás Rodríguez, la compañía de Brotons era inferior en número, ya que esta última disponía de cuatro y seis voces menos en las partes principales y el coro, respectivamente ${ }^{72}$. A pesar de ello, fue una de las temporadas más largas y estables del Romea. Se llevaron a cabo cuatro abonos ininterrumpidos de treinta, quince, diez y veinte funciones entre diciembre de 1873 y marzo de 1874 a base de zarzuelas serias predominantemente ${ }^{73}$. Estos datos demuestran que las compañías con menos personal podían hacer frente a una temporada íntegra de zarzuela obteniendo beneficios ${ }^{74}$ y que, por otro lado, la inclinación por zarzuelas como El dominó azul (Arrieta/Camprodón), Los diamantes de la corona y El relámpago (Barbieri/Camprodón), Un caballero particular (Barbieri/Carlos Frontaura), Jugar con fuego y Un tesoro escondido (Barbieri/De la Vega) o El relámpago (Barbieri/Camprodón), por citar sólo algunas, también llenaban el Teatro Romea.

${ }^{70}$ Véanse, La Paz de Murcia, XIV (1871), $\mathrm{n}^{\text {os }}$ 4194, 15 junio, p. 4; 4197, 18 junio, p. 4; 4203, 25 junio, p. 4; 4204, 27 junio, p. 4; 4206, 29 junio, p. 4; 4207, 1 julio, p. 1 y 4208, 2 julio, p. 1.

${ }^{71}$ Con anterioridad al mes de diciembre de 1873 las puertas del Romea sólo se abrieron para acoger una función benéfica por las familias necesitadas de Cartagena tras la insurrección cantonal (Véase Apéndice 3.5). Es preciso recordar que en junio de 1873, las Cortes Constituyentes, que preparaban una nueva Constitución Republicana Federal, nombraron Presidente a Pi i Margall. La rebelión contra el Estado se alzó en forma de levantamientos cantonales por toda España, especialmente virulentos en Cartagena (1207-1873). Entre tanto, las Cortes españolas rechazaron el proyecto de Constitución, provocando la dimisión de Pi i Margall. Los partidarios del Cantón cartagenero, que disponían de armamento militar y una base naval, resistieron a los ataques de las tropas del Gobierno. Después de seis meses de asedio en Cartagena, y cuando la Primera República había sido sustituida por un Gobierno provisional al mando del general Serrano, el general López Domínguez consiguió la rendición de la plaza (12-01-1874), poniendo fin a los planes de Antón Gálvez, líder del Cantón.

72 Además, su elenco sufrió algunas modificaciones en el trascurso de sus actuaciones. En enero de 1874, por ejemplo, se incorporó la famosa cantante Teresa Rivas: La Paz de Murcia, XVI (1873), nº 4963, 31 diciembre, p. 1. A principios de febrero del mismo año, la tiple Josefina Castilla se marchó a Sevilla, sustituyéndose por la cantante murciana Fuensanta Pinar: La Paz de Murcia, XVII (1874), n ${ }^{\text {os }}$ 5003, 18 febrero, p.1 y 5010, 26 febrero, p. 1.

${ }^{73}$ La compañía de Tomás Brotons dio, en total, ochenta y nueve funciones documentadas (setenta y cinco por la noche, ocho por la tarde y seis extraordinarias).

${ }^{74}$ La Paz de Murcia, XVII (1874), no 5021, 24 marzo, p. 1. Prueba de su éxito fue la ampliación del número de localidades con sillas colocadas en los pasillos: La Paz de Murcia, XVII (1874), n 4978, 20 enero, p. 1. 
La compañía de Nicolás Rodríguez regresó a Murcia durante la temporada de Pascua de 1874. En esta ocasión, su elenco de actores fue inferior en número a su primera visita. La gallina ciega, del murciano Fernández Caballero, fue la obra escogida para el debut de la compañía, aunque las novedades de la temporada fueron Los brigantes y Sueños de oro (de Barbieri sobre libreto de Larra). La primera, zarzuela bufa adaptada de Les brigands de Offenbach, se representó en dos ocasiones, reabriendo la polémica en torno al género bufo, ahora calificado como decadente:

[...] Poca, muy pocas palabras hemos de dedicar a las del género bufo, hoy por fortuna desacreditado y en visible decadencia. Obedeciendo a esa ley ineludible que rige todo lo creado y según la cual debe inevitablemente perecer en breve plazo cuanto no encierra en sí las necesarias condiciones de existencia. Importado en mala hora de la vecina Francia, a donde tenemos los españoles el talento de ir a buscar siempre lo peor para exagerarlo después, poniéndolo en armonía con nuestra imaginación meridional, sorprendió al público con sus extravagancias, su aparato escénico y lo licencioso de los trajes y de las palabras, hasta que el hastío producido por tantas obscenidades y la valiente campaña de contraria propaganda sostenida por la prensa crítica, han logrado herirle de muerte y ya le señalan el inevitable y perentorio término de su carrera ${ }^{75}$.

Por otro lado, las zarzuelas consideradas del viejo repertorio recibían los elogios de la prensa:

[...] Un pleito, Una vieja, Mis dos mujeres que podemos llamar antigüedades porque su mérito las hace venerables y dignas de que en todo tiempo sean representadas y aplaudidas y Catalina y Los magyares que colocamos en la categoría de antiguallas porque de escasas bellezas literarias y música es, sólo pueden agradar cuando están bien ensayadas, lo que sucede raras veces y se representan con ostentoso aparato por un personal numeroso e inteligente. ${ }^{76}$.

La guerra contra el género bufo siguió presente en la prensa murciana en años posteriores. Cuando en diciembre de 1881 saltó a la prensa el rumor de que la compañía de bufos Arderíus actuaría en Murcia, la reacción fue muy negativa:

La noticia es de todo punto desoladora y triste y mal juzgaríamos de la sensatez y buen gusto del público si acogiera con benevolencia los bufos que, según han dicho, tratan de traer a Romea.

Cuando en Madrid, en donde a la vez que público discreto y entendido hay otro abigarrado, de dudoso gusto, que toma lo que le dan y que aplaude a rabiar las extravagancias más grandes o los disparates que no pasarían en cualquiera provincia, no han llegado a arraigar esos espectáculos, rebajamiento y fea caricatura del arte escénico. Cuando ha habido una capital próxima a la nuestra, como Valencia, en donde al asomo no más de los bufos los despidió a silbidos, en la época más sobresaliente de la bufonería, acreditándose de país culto, mal parecería que nuestro público, en esos últimos resplandores de los espectáculos bufos, consintiera sin protestar que nos trasladaran una sucursal del estragado gusto francés que todo lo resuelve a la altura de la cancanista mejor dislocada.

\footnotetext{
${ }^{75}$ La Paz de Murcia, XVII (1874), n 5093, 21 junio, p. 1. Las cursivas son editoriales.

${ }^{76}$ La Paz de Murcia, XVII (1874), nº 5093, 21 junio, p. 1.
} 
Sería, en verdad, muy lamentable que apenas abierto el teatro se empleara en semejantes espectáculos, mucho más cuando nuestro público, que ha estado tanto tiempo privado de espectáculos serios y cómicos, tiene avidez de conocer el repertorio de obras nuevas para él y que se han representado con éxito en los principales teatros de España ${ }^{77}$.

Desde 1871, sin embargo, el género bufo siempre estuvo presente en la cartelera teatral del Teatro Romea durante los años siguientes. La nómina de zarzuelas bufas representadas en él contiene tanto títulos originales de compositores españoles (especialmente de José Rogel, como Los infiernos de Madrid, Los órganos de Móstoles y Las tres Marías, por ejemplo) como traducciones, adaptaciones y arreglos de Offenbach (Barba azul, La gran duquesa de Gerolstein, La vida parisién o Los dioses del Olimpo) y Lecocq (Adriana Angot y El barón de la castaña), por citar algunos.

\subsubsection{Problemática de las compañías de zarzuela del Teatro Romea hasta el primer incendio (1872-1877)}

Una de las características más sobresalientes de las compañías que actuaron en el teatro Romea hasta su primer gran incendio (1877) fue la inestabilidad de los conjuntos profesionales que llegaron a Murcia, y aunque las compañías de zarzuela de años posteriores fueron progresivamente más organizadas, su vulnerabilidad siempre fue un rasgo predominante.

El personal que actuó en el Teatro Romea (e incluso en el Teatro Provisional) podía sufrir múltiples alteraciones por motivos muy diversos: fracasos económicos, desavenencias entre cantantes y empresa, quejas del público, ofertas a los cantantes para actuar en otros teatros con mejores condiciones, enfermedades o muertes de los artistas.

A juzgar por los comentarios periodísticos, fueron muy excepcionales los elencos con artistas importantes y los empresarios con recursos suficientes para formar compañías de profesionales competentes ${ }^{78}$. La mayor parte de las reseñas ponen en evidencia que muchas compañías eran mediocres y con actores y cantantes poco preparados. Buena parte de los actores eran contratados para una ocasión concreta y, tras finalizar su contrato, quedaban libres y a la espera de futuros trabajos. Las compañías se disolvían cuando expiraban sus contratos con el teatro o cuando concluían inesperadamente las representaciones a causa de los fracasos económicos ${ }^{79}$. Cuando la

\footnotetext{
${ }^{77}$ El Semanario Murciano, IV (1881), n 150, 26 diciembre, p. 419. La compañía no llegó a actuar en Murcia.

${ }^{78}$ La mediocridad y la inestabilidad fue una característica generalizada en las compañías españolas del momento. Véase: Benito, La vida, p. 68.

${ }^{79}$ Algunas compañías dramáticas también sufrieron disoluciones por causas económicas. La compañía dramática de Francisco de Paula Gómez quebró en enero de 1872. Parte de sus miembros se marcharon de Murcia y el resto formó una sociedad con el objetivo de continuar las representaciones: La Paz de Murcia, XV (1872), $\mathrm{n}^{\text {os }} 4374,21$ enero, p. 1 y 4367, 13 enero, p. 1. Quizá para incentivar la asistencia de público, la compañía había ofrecido, antes de su quiebra, alguna función esporádica de zarzuela. En la función a beneficio de Matilde Val y José María Gómez (actores principales de la compañía), por ejemplo, se interpretó la zarzuela de Barbieri Por seguir a una mujer. Véase, La Paz de Murcia, XV (1872), nº 4364, 10 enero, p. 1.
} 
compañía se disolvía, una parte de la compañía permanecía unida y se recomponía para proseguir sus actuaciones en Murcia o bien proseguían sus giras por otras ciudades. Sin embargo, en otras ocasiones los actores quedaban desamparados y en precarias situaciones económicas. En las próximas líneas, describiré algunos de los problemas a los que se enfrentaron las compañías de zarzuela que actuaron en el Teatro Romea desde 1872 hasta 1877.

La temporada 1872-1873 estuvo marcada por tres acontecimientos: el cambio de denominación a Teatro Romea desde el 6 de mayo de 1872; la concesión del arriendo para el año cómico al hábil empresario Ramón Ros y las reformas en el interior y en el exterior del coliseo que retrasaron el inicio de las representaciones hasta el mes de noviembre de 1872 .

Ramón Ros había formado una compañía de zarzuela bajo la dirección de José González Orejuela para actuar en el Teatro Romea durante treinta funciones. Las críticas de su debut (Los diamantes de la corona) y de las funciones siguientes fueron muy negativas. Hubo quejas por los altos precios del abono, por la ortografía de los anuncios que el empresario enviaba a la prensa, por las repeticiones de las obras y por anunciar cantantes que luego no actuaban, entre otras ${ }^{80}$. A petición del municipio ${ }^{81}$, el empresario hizo varias reformas: sustituir a los cantantes que no gustaban al público, ampliar el coro, establecer precios más económicos, evitar las repeticiones de las obras e incorporar funciones de acrobacia y prestidigitación en los intermedios de algunas funciones (véase Apéndice 3.4).

Las gestiones dieron su fruto, ya que, a juzgar por los comentarios de la prensa, hubo una mayor afluencia de público en las funciones posteriores. De hecho, fue una larguísima temporada de zarzuela (ochenta funciones entre el 3 de noviembre de 1872 y el 16 de febrero del año siguiente ${ }^{82}$ ), cuyo éxito se basaba (además de las modificaciones arriba planteadas) en la combinación de un repertorio basado en zarzuelas en tres actos, zarzuelas bufas y funciones de prestidigitación y acrobacia.

El año cómico de 1874-1875 se inauguró a mediados de noviembre con un abono de treinta funciones de la compañía de zarzuela dirigida por Nicanor Sanmartín y León Carvajal $^{83}$. Los comentarios periodísticos sobre la escasa calidad de la compañía se hicieron patentes desde las primeras representaciones: "esperamos que la empresa no retarde la reforma de la compañía" ${ }^{84}$. Se contrató una tiple conocida para el público

${ }^{80}$ La Paz de Murcia, XV (1872), no 4633, 5 noviembre, p. 1. La prensa sugirió a Ros la implantación del sistema de turnos organizado por la propia empresa: La Paz de Murcia, XV (1872), n ${ }^{\circ}$ 4685, 12 diciembre, p. 1. Véanse más detalles sobre las críticas a la compañía de José González Orejuela y al empresario Ramón Ros en: El Noticiero Murciano, I (1872), nº 182, 5 noviembre, p. 3, La Paz de Murcia, XV (1872), no 4634, 6 noviembre, p. 1 y El Avisador Murciano, I (1872), nº 4, 5 noviembre, p. 1, entre otras.

${ }^{81}$ La Paz de Murcia, XV (1872), no 4664, 17 noviembre, p. 1.

${ }^{82}$ La compañía se marchó a Lorca: La Paz de Murcia, XVI (1873), nº 4688, 18 febrero, p. 1.

${ }^{83}$ En su anuncio no se hizo referencia al repertorio de la compañía. Según La Paz de Murcia, XVII (1874), $\mathrm{n}^{\mathrm{o}} 5213,11$ noviembre, p. 1 no se había publicado el repertorio porque: "se incluyen multitud de obras nuevas de las que como siempre sólo algunas se pondrán en escena”.

${ }^{84}$ La Paz de Murcia, XVII (1874), n ${ }^{\text {os }} 5221,20$ noviembre, p. 1; 5236, 8 diciembre, p. 1. 
murciano (Eloísa Morera) y un tenor cómico (Agustín Ballós) ${ }^{85}$, aunque esta ampliación no contribuyó a mejorar la situación ${ }^{86}$. Las reseñas periodísticas indican actuaciones de poco mérito y escasa concurrencia hasta el punto de que "una unánime demostración de desagrado" llevó a "ausentarse todos los concurrentes y dejar solo en la escena a los actores" en la representación de Los estanqueros aéreos (10-12-1874) ${ }^{87}$.

La Paz de Murcia solicitó al Gobernador que cesaran las representaciones u obligara a la empresa a reformar la compañía ${ }^{88}$. Entre el 11 y 25 de diciembre de 1874 el teatro permaneció cerrado. La empresa incorporó una tiple más y un bajo (Abreu y Ortiz, respectivamente) pero nada cambió ${ }^{89}$. Abreu dejó la compañía después de la segunda representación y, en su lugar, tuvieron que ocuparse de los personajes principales otros cantantes, originariamente contratados para papeles segundarios ${ }^{90}$.

Las extensas críticas publicadas en la primera página de La Paz de Murcia reiteran las escasas cualidades de los cantantes y la falta de ensayos. Sólo los decorados, realizados por el pintor escenógrafo murciano Sanmiguel, obtuvieron una crítica positiva.

A mediados de enero de 1875 se realizó una tercera reforma en la compañía, aumentando el coro e incorporando una tiple (Constantina Martínez de Carbonell) y dos tenores (Rojas, tenor cómico, y Obón) ${ }^{91}$. Se anunció un nuevo abono con los estrenos de Violeta y El Barberillo de Lavapiés pero, inesperadamente, la compañía se marchó a Cartagena ${ }^{92}$.

Tres meses más tarde, se iniciaron las funciones de zarzuela de la compañía de Julio L. Perié y Juan Aparicio (15-05-1875). Tras once representaciones la prensa cedió sus derechos a los artistas para que pudieran constituir una sociedad y continuar con el abono $^{93}$. Los beneficios económicos no debieron ser suficientes para los empresarios y la compañía pasó sin pena ni gloria ${ }^{94}$.

${ }^{85}$ La Paz de Murcia, XVII (1874), $\mathrm{n}^{\text {os }} 5215,13$ noviembre, p. 1; 5217, 15 noviembre, p. 1; 5218, 17 noviembre, p. 1; 5222, 21 noviembre, p. 1 y 5223, 22 noviembre, p. 1.

${ }^{86}$ Incluso, el director de la orquesta, Ángel Mirete dejó la compañía a principios de diciembre de 1874 "por razones que se reserva pero que haría publicase si preciso fuese": La Paz de Murcia, XVII (1874), nº 5234, 5 diciembre, p. 1

${ }^{87}$ La Paz de Murcia, XVII (1874), $\mathrm{n}^{\mathrm{o}}$ 5238, 11 diciembre, p. 1.

${ }^{88}$ La Paz de Murcia, XVII (1874), no 5238, 11 diciembre, p. 1. Véase la transcripción en el Apéndice Documental.

${ }^{89}$ La Paz de Murcia, XVII (1874), ${ }^{\text {os }} 5242,16$ diciembre, p. 1; 5245, 19 diciembre, p. 1 y 5247, 24 diciembre, p. 1 .

${ }^{90}$ Véase, a modo de ejemplo, la crítica publicada en: La Paz de Murcia, XVII (1874), $\mathrm{n}^{\mathrm{o}}$ 5251, 30 diciembre, p. 1.

${ }^{91}$ La Paz de Murcia, XVIII (1875), n ${ }^{\text {s }}$ 5260, 12 enero, p. 1; 5261, 13 enero, p. 1. Es probable que las tiples Morera y Abreu dejaran también la compañía, ya que no son citadas en las críticas periodísticas desde el mes de enero de 1875 .

${ }^{92}$ La Paz de Murcia, XVIII (1875), $\mathrm{n}^{\text {os }}$ 5287, 13 febrero, p. 1; 5291, 18 febrero, p. 1.

${ }^{93}$ La Paz de Murcia, XVIII (1875), nº 5370, 25 mayo, p. 1. Sólo se ofrecieron cuatro funciones más. Véase Apéndice 3.5.

${ }^{94}$ La Paz de Murcia, XVIII (1875), no 5369, 23 mayo, p. 1. 
La temporada 1875-1876 comenzó puntualmente el 7 de octubre de 1875 con la compañía lírica de Miguel Soler, en la que figuraron la conocida tiple Teresa Rivas y el tenor Juan Salces. Su particularidad fue la alternancia de funciones en el Teatro Romea de Murcia y en Lorca con toda o parte de la compañía ${ }^{95}$. La compañía de Miguel Soler estrenó un gran número de obras en los tres abonos ofrecidos ${ }^{96}$. La prensa valoró positivamente la calidad de los artistas, la variedad del repertorio y los esfuerzos para ensayar las zarzuelas concienzudamente. Además, contaban con la ventaja de que las obras eran muy conocidas por los actores de la compañía ${ }^{97}$. Las discrepancias entre el arrendatario del Teatro Romea (Manuel Soler) y el empresario de la compañía (Del Castillo) acabaron con el cese de las representaciones el 11 de enero de $1876^{98}$. A partir de entonces los salones del teatro Romea sólo se abrieron para albergar bailes de máscaras, la actuación del escamoteador, prestidigitador y "copólogo" Blanch a mediados de febrero y la del prestidigitador Fructuoso Canonge a finales de marzo de 1876.

El siguiente año cómico, 1876-1877, comenzó a mediados de noviembre a causa de la demora en la sub-contrata de arrendamiento del Romea para la temporada 1876-1877. La inauguró la compañía lírico-dramática del director de escena Federico G. de Marín. El empresario de la compañía, Eleuterio Linarejos, consiguió formar una compañía de zarzuela en poco más de una semana aunque sin una primera tiple cómica y un primer barítono $^{99}$. Durante el primer mes de representaciones, Linarejos realizó gestiones con teatros de Alicante, Madrid, Barcelona, Santander, Sevilla y Reus, para contratar a los cantantes que faltaban pero los trámites fracasaron. El empresario llegó a pedir públicamente los artistas que le faltaban: "Si hubiera alguien que tuviera conocimiento de algún artista de este género y que llene las condiciones que se exigen en este teatro, que se acerque a mí y me lo manifieste en la completa seguridad que lo contrato enseguida" 100 .

${ }^{95}$ Durante los días 25 y 26 de noviembre de 1875 la compañía se desplazó a Lorca para representar Pepe Hillo y El tributo de las cien doncellas: La Paz de Murcia, XVIII (1875), $\mathrm{n}^{\circ}$ 5605, 24 noviembre, p. 1. Repitieron en la misma localidad los días 15 a 17 de diciembre de 1875 con Pan y toros, Dos leones y El Rey Midas: La Paz de Murcia, XVIII (1875), n 5621, 14 diciembre, p. 1 . El 18 de diciembre de 1875, una parte de la compañía permaneció en Lorca con Sensitiva y Fuego en guerrillas mientras que otra parte se desplazó hasta el Teatro Romea para llevar a escena El barberillo de Lavapiés: La Paz de Murcia, XVIII (1875), no 5626, 19 diciembre, p. 1.

${ }^{96}$ Dos abonos de 30 representaciones y uno más de diez, del que sólo se efectuaron seis. En total, 80 funciones documentadas (66 por la noche y 14 por la tarde).

${ }^{97}$ La Paz de Murcia, XVIII (1875), no 5485, 30 octubre, p. 1. No obstante, también estrenaron alguna zarzuela, como Los infiernos de Madrid, con sólo un ensayo general: La Paz de Murcia, XVIII (1875), $\mathrm{n}^{\circ}$ 5620, 12 diciembre, p. 1 .

98 Del Castillo desmintió que la compañía tuviera asumida una deuda de 28000 reales con el arrendatario Manuel Soler, que le atribuían a través de rumores. Véanse, La Paz de Murcia, XIX (1876), n ${ }^{\text {os }}$ 5635, 1 enero, p. 1 y 5636, 4 enero, p. 1. La compañía se marchó finalmente a Vitoria: La Paz de Murcia, XIX (1876), no 5642, 11 enero, p. 1.

${ }^{99}$ Linarejos tomó posesión del Teatro Romea el 6 de noviembre de 1876 y las representaciones, como he apuntado, comenzaron el 15 de noviembre del mismo año.

${ }^{100}$ La Paz de Murcia, XIX (1876), no 5927, 10 diciembre, p. 1. Véase también, La Paz de Murcia, XIX (1876), $\mathrm{n}^{\text {os }} 5914,24$ noviembre, p. 1; 5917, 28 noviembre, p. 1 y 5919, 30 noviembre, p. 1. El bajo Vendrell cantó de barítono durante el segundo abono y la nueva tiple, Manuela Cubas, no llegó hasta mediados de diciembre: La Paz de Murcia, XIX (1876), nº 5932, 16 diciembre, p. 1. 
El estreno más significativo de la temporada fue La marsellesa de Fernández Caballero, estrenada el 9 de enero de 1877, para la que el escenógrafo Reyes realizó decorados ex profeso $^{101}$. Dos días más tarde, los autores de la zarzuela prohibieron que siguiera escenificándose, a pesar de que la compañía había pagado por los derechos de representación y de que el compositor era murciano:

Contra los intereses de la empresa de nuestro teatro, que a fuerza de sacrificios e inconvenientes ha logrado poner en escena de un modo aceptable la zarzuela La marsellesa, los autores de esta obra, a pesar de ser uno de ellos murciano, impiden se continúe representando y lo hacen cuando tenemos seguridad, en vista del éxito obtenido en el estreno, de que un numeroso público hubiera favorecido las sucesivas representaciones. Sentimos en extremo que los derechos de propiedad sean tan elásticos, que a pesar de pagar los derechos de representación se pueda privar el que ésta tenga lugar, dándose motivo a que se crea que hay móviles interesados y secretos que son los que motivan la prohibición ${ }^{102}$.

La prohibición de repetir la obra en los teatros murcianos dio lugar a una polémica periodística, calificada como "cuestión Marsellesa". El periodista José Martínez Tornel la resumió de la siguiente manera:

La cuestión Marsellesa es la siguiente: que, después de ensayados, hechos nuevos telones y los demás gastos que exige su anárquico argumento, se oponen los autores a su representación por esta compañía; pero el empresario actual de este teatro, contra todas las tradiciones de los campanones, es un hombre que tiene, al parecer, dinero y, con seguridad, tesón y dignidad, y una vez comprometido con el público, por los anuncios fijos en las esquinas, a riesgo de su bolsillo, dio anteanoche la primera representación de La marsellesa, a pesar de la oposición telegráfica y epistolar de los autores. Sí. Este buen empresario me proporcionó con su terquedad el gusto de oír la música de Fernández Caballero. En esta obra, que si como libreto es de brocha gorda, como partitura (yo no lo entiendo) me parece que es deliciosamente original. [... $]^{103}$.

El empresario Linarejos obtuvo el permiso para representar La Marsellesa por segunda vez, a condición de que el propio compositor la dirigiera ${ }^{104}$. La segunda representación tuvo lugar el 13 de enero de $1877^{105}$ y su éxito animó al empresario a planificar el estreno de Las nueve de la noche, obra que sin embargo no llegó a representarse. Las desavenencias surgidas entre los actores de la compañía y la empresa teatral, originaron el cese de las representaciones en la séptima función del tercer

${ }^{101}$ La Paz de Murcia: XIX (1876), n ${ }^{\text {s }}$ 5917, 28 noviembre, p. 1 y 1153, 29 noviembre, pp. 2-3; 5931, 15 diciembre, p. 1 y XX (1877), no 5948, 6 enero, p. 1.

${ }^{102}$ La Paz de Murcia, XX (1877), n 5951, 11 enero, p. 1.

${ }^{103}$ José María Tornel, “Cosas de Murcia”, en La Paz de Murcia, XX (1877), nº 5952, 12 enero, p. 1.

${ }^{104}$ La Paz de Murcia, XX (1877), no 5953, 13 enero, p. 1. Fernández Caballero llegó el mismo día de la representación. Véase la extensa crítica teatral de José María Tornel, en La Paz de Murcia, XX (1877), $\mathrm{n}^{\circ}$ 5954, 14 enero, p. 1 y la de Antonio Ibáñez González y Julián Calvo, "La marsellesa", en La Paz de Murcia, XX (1877), n ${ }^{\circ}$ 5956, 17 enero, p. 1. En La Paz de Murcia, XX (1877), $\mathrm{n}^{\circ}$ 59595, 20 enero, p. 1 se describe el banquete posterior a la representación en homenaje a Fernández Caballero. Tuvo lugar en la fonda de los Cremades y a él acudieron los periodistas, escritores y compositores más relevantes de la ciudad.

105 La Paz de Murcia, XX (1877), n ${ }^{\text {os }}$ 5958, 19 enero, p. 1; 59595, 20 enero, p. 1. 
abono $^{106}$. En el resto de la temporada no hubo más zarzuela, ya que la noche del 7 de febrero de 1877 el Teatro Romea ardió en llamas, como explico con más detalle en el Capítulo 2.

\subsubsection{Compañías de zarzuela del Teatro Romea después del incendio (1880- 1887)}

Tras la reapertura del Teatro Romea (1880) se iniciaron unos años brillantes para la actividad teatral de Murcia ${ }^{107}$. La zarzuela volvió a su escenario a mediados de octubre de 1881 con la compañía de zarzuela de Daniel Banquells, procedente de Cartagena ${ }^{108}$. El elenco de Banquells introdujo en el Teatro Romea obras del incipiente género chico (por ejemplo, el "disparate cómico-lírico" Música clásica de Ruperto Chapí y libreto de José Estremera) y zarzuelas paródicas, como El suicidio de Alejo basado en la ópera Ernani de Verdi (que había sido estrenada en octubre de 1880 en el Teatro Circo de la Rambla por la compañía de Rafael Villalonga).

Desde estas fechas hasta la introducción del teatro por horas (1888) desfilaron por el Romea veintidós compañías de zarzuela (incluidas las mixtas de teatro y zarzuela), con una actividad generalmente más estable que el periodo anterior (1862-1877), aunque no exenta de percances, y con mayores éxitos.

El número de cantantes de cada compañía osciló entre ocho (compañía de Ventura de la Vega, $2^{\mathrm{a}}$ temporada 1885-1886) y veinticuatro (compañía de Eugenio Fernández, primera temporada de de 1882-1883) (véase Apéndice 3.2).

En esta etapa fue frecuente la actuación de una compañía en distintos teatros de la ciudad. Por ejemplo, en septiembre de 1882, la compañía de teatro y zarzuela encabezada por Juan Espantaleón, que actuaba en el Teatro Circo de la Rambla desde finales de

106 La prensa albergó la esperanza de que los cantantes pudieran continuarlas hasta el carnaval formando una sociedad: La Paz de Murcia, XX (1877), $\mathrm{n}^{\text {os }} 5963,25$ enero, p. 1 y 5966, 28 enero, p. 1. Las representaciones no tuvieron lugar aunque sí se creó una nueva compañía de zarzuela, probablemente con integrantes de la temporada anterior, para actuar en el Romea durante la temporada de Pascua de 1877: $L a$ Paz de Murcia, XX (1877), $\mathrm{n}^{\mathrm{o}}$ 5978, 15 febrero, p. 1. El incendio obligó a los actores a desplazarse a Cartagena, donde representaron, entre otras, La marsellesa (dirigido por el propio Fernández Caballero) y Blancos y azules: La Paz de Murcia, XX (1877), $\mathrm{n}^{\text {os }}$ 5978, 15 febrero, p. 1; 5981, 18 febrero, p. 1; 5993, 4 marzo, p. 1; 5994, 6 marzo, p. 1; 5995, 7 marzo, p. 1; 5996, 8 marzo, p. 1; 5998, 10 marzo, p. 1; 6002, 15 marzo, p. 1; 6006, 20 marzo, p. 1 y 6007, 21 marzo, p. 1. El elenco de artistas para actuar en Cartagena apareció publicado en: La Paz de Murcia, XX (1877), nº 5982, 20 febrero, p. 1.

${ }^{107}$ La función de reinauguración del Teatro Romea tuvo lugar el 11 de diciembre de 1880 con la compañía dramática de Pedro Delgado, que contaba con los famosos actores Julia Cirera y Juan Espantaleón. La orquesta, dirigida por Ángel Mirete, abrió el acto estrenando una de sus sinfonías para banda y orquesta. Se representaron las obras Deudas de gloria, (una loa al actor Julián Romea escrita por Sánchez Madrigal), La jura de Santa Gadea (de Hartzenbusch) y el juguete cómico ;Sin cocinera! (de Manuel Matoses), alternándose éstas con lecturas de poesías y piezas musicales de los compositores murcianos Fernando Verdú (Aires Murcianos) y Julián Calvo (no trascendió su título). La prensa dedicó varias páginas a la inauguración del teatro: El Diario de Murcia, II (1881), $\mathrm{n}^{\circ}$ 555, 12 diciembre, p. 2; 556, 14 diciembre, p. 3 y El Semanario Murciano, III (1880), no 148, 12 diciembre, p. 404 (R). Véase más información en Antonio Crespo, El Teatro, pp. 38-39.

${ }^{108}$ Véase, La Paz de Murcia, XXIV (1881), $\mathrm{n}^{\text {os }} 7131,3$ septiembre, p. 1; 7134, 7 septiembre, p. 1; 7138, 12 septiembre, p. 1; 7146, 21 septiembre, p. 1 y 7148, 23 septiembre, p. 1. 
agosto, se trasladó al Romea porque varias de sus funciones fueron suspendidas a causa del clima ${ }^{109}$.

A mediados de octubre de 1882 comenzó a actuar la compañía de zarzuela de Eugenio Fernández ${ }^{110}$. La primera semana de representaciones fue buena: "una función diaria con distintas obras, generalmente bien dirigidas y representadas, faltando solo novedades, obras desconocidas" ". Además, a finales de octubre tuvo lugar un concierto muy aclamado de Isaac Albéniz, lo que contribuyó a animar la afluencia de público (véase Capítulo 4).

El estreno de Los mosqueteros grises de Luis Varney sobre libreto arreglado de Serrat, fue muy criticado por la inherencia del argumento:

El desarrollo de su argumento nos va alarmando de modo que creemos vamos a asistir a algo poco conveniente. A cada escena pensamos que en el siguiente va a suceder aquello, lo grave o escandaloso que se teme y, cuando terminan los tres actos, recobramos nuestra calma, viendo que al fin no ha sucedido nada.

Todo ello, lo grave, es que unos mosqueteros penetran en un convento disfrazados de frailes, que uno de ellos se embriaga y que en este estado echa un sermón en el que no dice más que vulgaridades a las educandas. [...].

El arte que ofende la fe no es arte, ni tiene influencia, ni es nada. Porque se escriba una zarzuela de personajes tan lisonjeros de cascos como son todos los que intervienen en Los mosqueteros no se pierde la moral, como no se pierde ni se conculca el derecho de la propiedad, ni la santidad de la familia, porque haya manifestaciones comunistas o socialistas $[\ldots]^{112}$.

La música de la obra, sin embargo, gustó porque "es preciosa, fácil, original, que se pega al oído y que deleita. La música tiene de can-can lo que necesita para ser bailable, nada más y la letra no tiene de español más que el acento catalán que ha recibido de los traductores"113.

El segundo estreno de la temporada fue La tempestad, cuyos autores, Chapí y Ramos Carrión, felicitaron a la compañía por el éxito de su interpretación en Murcia ${ }^{114}$. Se comercializaron arreglos de algunos números de la obra, que se vendían en casa del compositor Julián Calvo (ver Figura 3.1).

${ }^{109}$ La mayor parte del repertorio escenificado fue de carácter dramático. Muy esporádicamente llevó a escena algunas zarzuelas, casi siempre en un acto. Véanse más detalles en Crespo, El Teatro, p. 82.

${ }^{110}$ La empresa abrió un abono de 60 funciones en series de veinte funciones y subdivididas, además, en turnos. Ofrecían obras nuevas como La Tempestad, Los mosqueteros y Los sobrinos del capitán Grant, entre otras: El Diario de Murcia, IV (1882), no 1099, 10 octubre, p. 3.

${ }^{111}$ El Diario de Murcia, IV (1882), n 1111, 24 octubre, p. 3.

112 José Martínez Tornel, “Teatro de Romea. Los mosqueteros grises”, El Diario de Murcia, IV (1882), $\mathrm{n}^{\circ} 1117,31$ octubre, pp. 1-2. Este artículo obtuvo una respuesta por parte de La Paz de Murcia, XXV (1882), $\mathrm{n}^{\mathrm{o}} 7413,31$ octubre, p. 1.

113 José Martínez Tornel, "Teatro de Romea. Los mosqueteros grises", p. 2.

${ }^{114}$ El Diario de Murcia, IV (1882), n ${ }^{\text {os }} 1126,10$ noviembre, p. 3. 


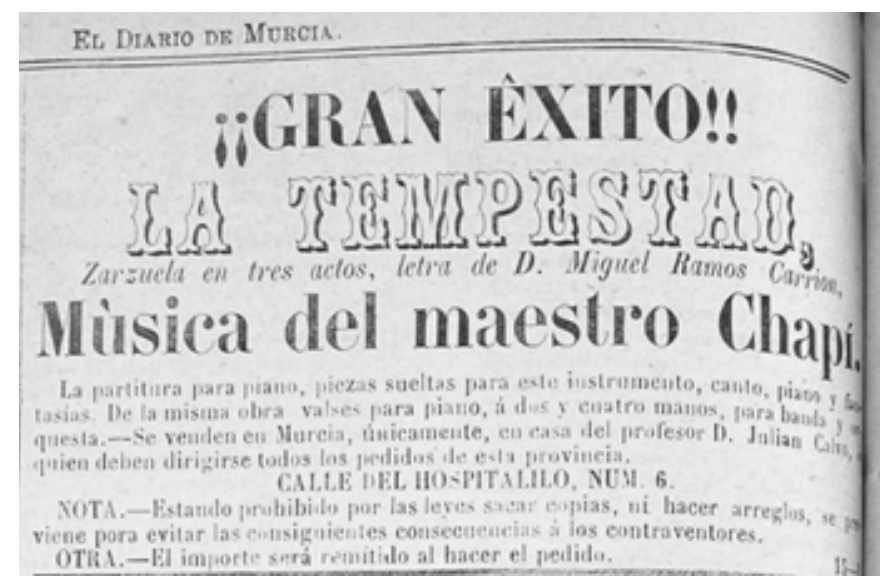

Figura 3.1. Anuncio de arreglos de números de La Tempestad. El Diario de Murcia, IV (1882) n 1120, 3 noviembre, p. 4, E:MUm.

El 13 de noviembre de 1882 la compañía de Eugenio Fernández se fue a Lorca para actuar en quince representaciones ${ }^{115}$. A su regreso a Murcia capital, la empresa ofreció llevar a escena las zarzuelas grandes Los sobrinos del capitán Grant (música Fernández Caballero y libreto de Ramos Carrión), Un estudiante de Salamanca (música de Oudrid sobre libreto de Rivera) y Galanteos en Venecia (compuesta por Barbieri sobre libreto de Luis de Olona), así como los arreglos a la escena española de Zampa (Hérold) y Gran duquesa (Offenbach) ${ }^{116}$. La compañía ofreció noventa funciones repartidas en cuatro abonos, uno de treinta y tres de veinte representaciones ${ }^{117}$. Es la compañía que más tiempo actuó en el Teatro Romea y el repertorio que llevó a escena demuestra la pervivencia que la zarzuela grande tenía en Murcia, en combinación con otros géneros.

La segunda temporada teatral del año 1883 en el Romea fue exclusivamente de género dramático, seguramente para variar después de la larga temporada de zarzuela.

La temporada de 1883-1884 comenzó con una compañía de zarzuela dirigida por Juan García Catalá que, tras su debut en el Teatro Circo de la Rambla se trasladó al Teatro Romea para continuar sus representaciones aunque no por motivos climatológicos sino para ofrecer más comodidad a los espectadores ${ }^{118}$. Después de actuar durante los días de la feria de septiembre, la compañía se marchó a Lorca donde permaneció hasta finales de septiembre de $1883^{119}$.

115 El Diario de Murcia, IV (1882), no 1130, 15 noviembre, pp. 2-3. La compañía fue muy bien recibida en Lorca, donde representó El diablo en el poder, El anillo de hierro, Mis dos mujeres y Las dos princesas, entre otras obras: El Diario de Murcia, IV (1882), n 1134, 19 noviembre, p. 3; La Paz de Murcia, XXV (1882), $\mathrm{n}^{\text {os }}$ 7426, 16 noviembre, p. 1; 7427, 17 noviembre, p. 1; 7499, 30 noviembre, p. 1.

${ }^{116}$ La Paz de Murcia, XXV (1882), no 7435, 26 noviembre, p. 1.

${ }^{117}$ Tras éstas, los cantantes se dispersaron: Alemany actuó más tarde en Cádiz: El Diario de Murcia, V (1883), n 1273, 12 mayo, p. 3 y Pablo López se marchó a Santander desde donde embarcaría rumbo a México, contratado por un año: El Diario de Murcia, V (1883), n 1204,15 febrero, p. 3. Junto a él viajaría la tiple Mercedes Bona, un tenor apellidado Alcaraz y Giuseppe Palou (barítono de la compañía de ópera de de Cecilio Sanmarti que actuó en el Romea en 1881).

${ }^{118}$ La Paz de Murcia, XXVI (1883), nº 7717, 5 septiembre, p. 1. Igual noticia publicó El Diario de Murcia, V (1883), no 1368, 6 septiembre, p. 2.

${ }^{119}$ El Diario de Murcia, V (1883), no 1372, 11 septiembre, p. 3 y La Paz de Murcia, XXVI (1883), $\mathrm{n}^{\circ}$ 7737, 29 septiembre, p. 1. 
Desde finales de septiembre hasta principios de noviembre de 1883 tuvieron lugar varias funciones de prestidigitación, una función benéfica y, finalmente, la compañía de Miguel Cepillo, que ofreció más de cien funciones de género dramático hasta enero de $1884^{120}$. Los espectadores ansiaban el retorno de la zarzuela:

Después de una buena temporada de comedia y drama, había verdadero deseo de canto y música. La regocijada musa zarzuelera parece que viene a ahuyentar las emociones horripilantes de ciertos dramas modernísimos de discutible ejemplaridad ${ }^{121}$.

La vuelta de la zarzuela estuvo a cargo de la compañía de Eduardo Ortiz, que ofreció obras de género bufo y con la participación del tenor murciano Abelardo Barrera $^{122}$, a la que siguió, ya en la temporada de Pascua de 1884, representaciones variadas de género dramático, ópera, conciertos y varias funciones de aficionados ${ }^{123}$.

${ }^{120}$ Las funciones indicadas son: el prestidigitador y copólogo Paulino Blanch: La Paz de Murcia, XXVI (1883), $\mathrm{n}^{\text {os }} 7737,29$ septiembre, p. 4; 7743, 6 octubre, p. 4; 7745, 9 octubre, p. 4; una función benéfica destinada a recaudar fondos para los afectados de las inundaciones de Villena (Alicante) el 12 de octubre de 1883 con la banda de la Misericordia y el tenor murciano Mariano Blaya (véase Apéndice 3.6) y la compañía "científica y artística” de Auboin Brunet (28-10-1883 a 4-11-1883), que incluyó juegos de escamoteo, números de equilibrismo, prestidigitación y magia. La compañía de Miguel Cepillo actuó desde el 10 de noviembre hasta el 21 de enero de 1884: La Paz de Murcia, XXVI (1883), $\mathrm{n}^{\text {os }} 7765,8$ noviembre, p. 1 y 7838,7 febrero, p. 1.

${ }^{121}$ Antonio Ramírez Pagán, “Teatro Romea”, en El Diario de Murcia, VI (1884), nº 1485, 24 enero, pp. 1-2: 1

${ }^{122}$ El Diario de Murcia, VI (1884), no 1485, 24 enero, p. 2. Las novedades fueron San Franco de Sena, una comedia de Moreto, refundida por Estremera y puesta en música por Arrieta; Rosa de mar, con libreto de Puente y Brañas y música de Guillermo Cereceda; y, La mascota del compositor Edmundo Audrán. Llevaron a escena obras distintas cada noche, a pesar de algunas fueron muy poco ensayadas y ello perjudicó la calidad de las interpretaciones: El Diario de Murcia, VI (1884), nº 1500, 10 febrero, p. 1.

${ }^{123}$ Durante el mes de marzo de 1884, actuó en el Romea la compañía dramática de Francisco Almada junto a Miss Leona Doré. Los espectáculos combinaron la representación de comedias y dramas, así como ejercicios circenses. También esta compañía prosiguió su gira por Cartagena: La Paz de Murcia, XXVII (1884), n ${ }^{\circ} 7887,5$ abril, p. 1. Durante el mes de abril de 1884, actuó la compañía de ópera de Pedro Urrutia (Véase Capítulo 4) y durante el mes de mayo y primeros días de junio de 1884 el teatro acogió un concierto del pianista capitán Voyer (véase Capítulo 5), un homenaje a Saavedra Fajardo, promovido por la sociedad Talía, y tres funciones benéficas destinadas a recaudar fondos para los afectados de la inundación que asoló la ciudad de Murcia a mediados del mes de mayo de 1884 (véase Apéndice 3.5). La riada fue tres o cuatro veces superior a la que se produjo en 1879. De hecho, el teatro permaneció cerrado durante algunos días a finales del citado mes. La primera de estas funciones benéficas tuvo lugar el 1 de junio y fue organizada por la sociedad La Juventud, como veremos en el capítulo correspondiente. La segunda de ellas se organizó sólo unos días más tarde y gracias a la iniciativa del tenor murciano Pablo López. Contó para la ocasión con un grupo de aficionados y se llevaron a escena las zarzuelas El lucero del alba, de Fernández Caballero, y Para una modista un sastre, de Ruperto Chapí; un monólogo en verso de Juan Antonio Soriano titulado El embajador de los inmundaos [sic] (escrito en el dialecto murciano panocho). En la puerta del teatro y antes de comenzar la función, la banda de Antonio Raya interpretó varias piezas. Ya en el escenario, y a telón corrido, la banda de la Misericordia tocó la Retreta austriaca y estrenó la obra titulada Zambra morisca, del murciano Antonio López. La tercera función benéfica se celebró el 15 de junio de 1884. Fue organizada por un grupo de aficionados que llevaron a escena las zarzuelas en un acto ; Ya somos tres!, de Ángel Rubio, Don Sisenando de Oudrid y Picio, Adán y compañía de Carlos Mangiagalli. A punto de concluir la temporada, el teatro Romea acogió cuatro representaciones de la compañía de Antonio Vico, que se encontraba en Murcia de paso para Almería y una función "de convite" por iniciativa de la nueva empresa arrendataria de Medina (6-07-1884): La Paz de Murcia, XXVII (1884), nº 7954, 26 junio, p. 1. 
La temporada teatral de 1884-1885 fue especial por dos motivos: la creación de la orquesta del Teatro Romea con músicos que accedieron mediante oposición y el arrendamiento del teatro a cargo de la sociedad Santa Cecilia. Dado que los encargados de programar el teatro eran músicos, una de las características más notables de esa temporada fue la calidad de los intérpretes que actuaron, tanto de zarzuela como de ópera.

Las representaciones comenzaron el 30 de agosto de 1884 con la compañía dramática del prestigioso actor José Valero. El abono contratado ascendía a quince representaciones. Sin embargo, una epidemia de cólera procedente de Francia e Italia invadió la ciudad a principios de septiembre. El Ayuntamiento suspendió todos los espectáculos, dejando a los actores de la compañía en una precaria situación económica que les impidió regresar a sus ciudades. Después de diversos trámites en el Ayuntamiento y ante el Gobernador Civil de Murcia, varios escritos a la prensa y alguna función en su beneficio (con escasa concurrencia), la Sociedad de Artistas y Escritores de Madrid prestó el dinero para que los actores volvieran a sus ciudades ${ }^{124}$. El Romea permaneció cerrado hasta mediados de octubre de 1884, cuando actuó la compañía de Casimiro Espino (director de Unión Artístico-Musical de Madrid desde 1883) a pesar de que las condiciones no eran óptimas para las representaciones teatrales ${ }^{125}$.

Con la compañía de Espino participaron varios murcianos: el barítono Abelardo Barrera, los partiquinos Felipa Gimeno y Antonio López, varios cantantes aficionados que habían tomado parte en funciones benéficas y Adolfo Gascón, dueño del Café Oriental y músico asiduo de los círculos musicales de la ciudad, que era archivero de la compañía. Es evidente que la empresa murciana arrendataria del Teatro Romea favoreció los contratos de artistas murcianos.

Las cincuenta representaciones de abono programadas por Espino comenzaron el 18 de octubre de 1884 con El anillo de hierro de Miguel Marqués ${ }^{126}$. La prensa subrayó las dificultades que tenía sostener una compañía tan numerosa:

[...] Pensar que una empresa puede sostener una compañía tan costosa como la de zarzuela para el día de fiesta que nos plazca concurrir al teatro, es pensar en lo imposible. Y la empresa pierde y no poco, y la compañía, en su conjunto, es muy aceptable y con relación a casi todas las partes principales es una de las mejores que pueden formarse en la actualidad $[\ldots]^{127}$.

${ }^{124}$ Véanse más detalles en La Paz de Murcia, XXVII (1884), $\mathrm{n}^{\text {os }}$ 7994, 12 agosto, p. 1; 7996, 14 agosto, p. 1; 8003, 24 agosto, p. 1; 8007, 29 agosto, p. 1 y en Crespo, El Teatro, pp. 127-128.

${ }^{125}$ Un gran número de familias habían sido afectadas por el cólera y las autoridades desaconsejaban la asistencia al teatro para evitar la congregación de personas y la propagación de la epidemia: La Paz de Murcia, XXVII (1884), n 8035, 4 octubre, p. 1. Los miembros de la compañía fueron contratados durante el verano. Por ejemplo, la tiple Lacrox y el barítono Vázquex en junio: La Paz de Murcia, XXVII (1884), $\mathrm{n}^{\circ}$ 7952, 24 junio, p. 1 y el bajo cómico Rafael Villalonga en julio: La Paz de Murcia, XXVII (1884), $\mathrm{n}^{\circ} 7977$, 23 julio, p. 1.

${ }^{126}$ La prensa anunció la llegada de los componentes a la ciudad y los primeros ensayos: La Paz de Murcia, XXVII (1884), ${ }^{\text {os }} 8039,9$ octubre, p. 1; 8040, 10 octubre, p. 1; 8041, 11 octubre, p. 1; 8043, 14 octubre, p. 1.

${ }^{127}$ La Paz de Murcia, XXVII (1884), nº 8062, 6 noviembre, p. 1. También hubo quejas por la larga duración de los entreactos: La Paz de Murcia, XXVII (1884), nº 8062, 6 noviembre, p. 1 
A mediados de diciembre de 1884, la sociedad Santa Cecilia arrendataria del Romea programó "funciones de moda", que en parte pretendían superar las repeticiones del repertorio y consistían en

señalar un día de la semana, que será los jueves para funciones de moda como se acostumbra en los principales teatros, donde con novedades se lleva a la más escogida sociedad. La de aquí hará en esos días los estrenos de las obras, o las primeras representaciones de aquellas más excelentes de repertorio, y no sabemos si alguna otra novedad más que sea del agrado de los concurrentes y que demuestre su decidido afán de complacer. La primera función de moda tiene lugar esta noche con la primera representación de la preciosa y popular zarzuela Bocaccio de cuyo protagonista está encargada la señora Montañés ${ }^{128}$.

A pesar de esta innovación las denuncias sobre la monotonía del repertorio arreciaron y consiguieron que fueran programadas algunas obras nuevas ${ }^{129}$ :

La empresa de Romea ha mejorado las proposiciones a la señora Franco de Salas y la ha arrebatado a la de Valencia que se le llevaba. Con este motivo, desde mañana no habrá repeticiones y tendremos el gusto de ver en escena las obras tan deseadas El reloj de Lucerna, La familia del tío Maroma, La tempestad, Entre mi mujer y el negro y otras que como las anteriores desean ver los abonados ${ }^{130}$.

Tal y como se indica en las líneas precedentes, el público murciano demandó obras tanto de la zarzuela grande como del género chico (ya plenamente incorporado) con obras como De Getafe al paraíso o La familia del Tío Maroma, de Barbieri sobre libreto de Ricardo de la Vega o el sainete lírico Política y tauromaquia, de Ángel Rubio y Casimiro Espino sobre libreto de Javier de Burgos, ambas representadas por la compañía de Espino en diciembre de $1884^{131}$. Una de las obras más esperadas de la temporada fue la "ópera cómica" en tres actos La mascota (letra de Alfredo Duru y Enrique Chivot y música de Edmundo Audran). Su estreno, sólo parcial, hizo que la empresa teatral fuera sancionada por el Ayuntamiento ${ }^{132}$. El ambiente estaba muy caldeado por la "cuestión

\footnotetext{
${ }^{128}$ La Paz de Murcia, XXVII (1884), nº 8091, 11 diciembre, p. 1.

${ }^{129}$ La Paz de Murcia, XXVII (1884), nº 8104, 27 diciembre, p. 1. Véase la transcripción en el Documentario.

${ }^{130}$ La Paz de Murcia, XXVII (1884), nº 8105, 28 diciembre, p. 1. La cantante Carmen Llorens se incorporó a la compañía el 2-12-1884 y cesó a la tiple Emilia Rosales: El Diario de Murcia, VII (1885), nº 1767, 7 enero, p. 2.

${ }^{131}$ En Murcia, La canción de la Lola (música de Federico Chueca y Joaquín Valverde sobre libreto de Ricardo de la Vega), considerada como el primer sainete lírico moderno y que sirvió de modelo a gran cantidad de obras sobre el molde del sainete lírico, según Sobrino, "Canción de la Lola", pp. 374-378, fue estrenada en el Teatro Circo de la Rambla por la compañía de Eugenio Fernández en febrero de 1881 (ver Apéndice 3.6). Sobre el sainete lírico, véanse los estudios de Barce, "El sainete lírico"; Espín, "El sainete" y Casares, "Sainete".

${ }^{132}$ El estreno de La Mascota estaba previsto para el día 14-01-185, ya que al día siguiente tendría lugar una función benéfica con una segunda representación de esta zarzuela, pero el estreno fue pospuesto un día, haciéndose coincidir con la función benéfica. La repentina indisposición de la primera tiple (Matilde Montañés), que obligó a suspender la representación de los últimos actos de La Mascota, levantó las sospechas de la prensa. El Noticiero y El Profeta creyeron que la enfermedad de Montañés era, en el fondo, una maniobra de la empresa teatral para no estrenar la obra en una función benéfica, ya que la empresa
} 
orquesta", la falta de organización de la empresa teatral y las desavenencias de ésta con algunos cantantes.

Durante los últimos días de enero de 1885 el Romea acogió una nueva función benéfica de aficionados destinada a recaudar fondos para los afectados por los terremotos de Andalucía (26-01-1885) y una función del prestidigitador Fonseca (29-01-1885). Las últimas funciones de la compañía de zarzuela de Espino se llevaron a cabo sin los cantantes Cros, Barrera, Povedano y Gimeno, ya que se habían marchado de la ciudad. A pesar de todo, algunos músicos de la compañía permanecieron en la ciudad y reanudaron las representaciones ${ }^{133}$ aunque después de cinco funciones, volvieron a aflorar las quejas por la repetición del repertorio $\mathrm{y}$, finalmente, la prensa anunció el cese de las representaciones ${ }^{134}$.

Tras las actuaciones de la compañía de Espino, el Romea se abrió puntualmente en 1885 para acoger espectáculos del prestidigitador Fonseca, de la compañía acrobática de Miss Emma, del barítono Mariano Padilla y de la compañía dramática de Victorino Tamayo $^{135}$. Las funciones de esta última fueron dramáticas aunque la compañía tenía una pequeña sección lírica que interpretó ocasionalmente zarzuelas ${ }^{136}$. Una semana después, el Romea acogió representaciones de ópera de la compañía de Giovanni Goula (véase Capítulo 4).

Durante el verano de 1885 la ciudad vivió una tremenda epidemia de cólera que fue debilitándose durante los meses de septiembre y octubre. En noviembre, el teatro abrió sus puertas con la compañía dramática de Pedro Delgado, que actuó hasta el 11 de enero de 1886. En febrero, el Romea acogió un homenaje a José Zorrilla, que se encontraba de visita en la ciudad (20-01-1886) y tres funciones de aficionados (24 y $31-$ 02-1885 y 11-02-1885) ${ }^{137}$. El 16 de febrero de 1886 debutó la compañía de Salvador Grajales y Pablo Gorgé ${ }^{138}$, que llevó a escena sobre todo zarzuelas en un acto, a excepción, entre otras, de

teatral perdería los beneficios económicos. El Ayuntamiento consideró el hecho como una alteración del orden público y penalizó a la empresa teatral con una multa de 250 pesetas. La Paz de Murcia apoyó incondicionalmente a la compañía, en parte porque era murciana, y solicitó la remisión de la multa. Véase: La Paz de Murcia, XXVIII (1885), n ${ }^{\text {os }} 8111,6$ enero, p. 1; 8113, 8 enero, p. 1; 8117, 13 enero, p. 1; 8118, 14 enero, p. 1; 8122, 17 enero, p. 1; 8124, 20 enero, p. 1; 8125, 21 enero, p. 1; 8128, 24 enero, p. 1 y 8129, 25 enero, p. 1, así como El Diario de Murcia, VII (1885), n 1769, 9 enero, p. 3 y Rafael de Garay, "La obra de la caridad", en El Diario de Murcia, VII (1885), n 1770, 10 enero, pp. 1-2.

${ }^{133}$ La Paz de Murcia, XXVIII (1885), nº 8136, 3 febrero, p. 1. Ver Apéndice 3.2.

${ }^{134}$ La Paz de Murcia, XXVIII (1885), nº 8139, 6 febrero, p. 1. Los cantantes se marcharon de la ciudad tomando distintas direcciones: la tiple Rosales se dirigió a Valencia y Espino a Madrid: La Paz de Murcia, XXVIII (1885), n ${ }^{\text {os }} 8139,6$ febrero, p. 1 y 8140, 7 febrero, p. 1.

${ }^{135}$ Véase, Crespo, El Teatro, pp. 139-141.

${ }^{136}$ Llevaron a escenas seis zarzuelas en un acto: ¡iYa somos tres!, Artistas para la Habana, Música clásica, ¡Eh!, a la plaza, Dos siglos en una hora, Salón Eslava y Torear por lo fino (música de Isidoro Hernández y libreto de Francisco Macarro).

${ }^{137}$ La primera función de aficionados se celebró en beneficio de los actores que habían quedado sin recursos en Murcia tras la disolución de la compañía de Pedro Delgado. Los fondos recaudados en la tercera función de aficionados se donaron al asilo de San José de las Hermanitas de los Pobres. Véanse más detalle en Crespo, El Teatro, pp. 154-158.

${ }^{138}$ La Paz de Murcia, XXIX (1886), nos 8430, 26 enero, p. 4 y 8434, 30 enero, p. 1. 
Un regalo de boda, la que con decir que es de los autores de El anillo de hierro, la letra de don Marcos Zapata y la música del maestro Marqués hace esperar que no será un esperpento como mucho de lo que suele venir de la parte allá de los Pirineos ${ }^{139}$.

En la temporada de Pascua de 1886, actuó en el Romea la compañía líricocoreográfica del malagueño Ventura de la Vega Rodríguez. Casi todas las zarzuelas que llevaron constaban de un acto (gran número de ellas de Ángel Rubio) aunque propusieron precios económicos (dos reales por función) y el aliciente de ver sobre la escena números bailables a cargo de bailarines que eran miembros del coro ${ }^{140}$. La temporada de Pascua de 1886 concluyó con la actuación de la compañía de ópera de Cecilio Sanmartí.

El ciclo 1886-1887 en el Romea comenzó con la compañía de zarzuela de la primera tiple Encarnación Fabra, que actuó durante los días de feria (desde el 5 hasta el 12 de septiembre) y, a pesar de que durante estos días la ciudad se llenaba de extranjeros, no tuvo demasiado éxito.

La compañía de Guillermo Cereceda debutó en el Romea en octubre de 1887, con novedades como Fatinitza (Suppé), Rip Rip (Planquette) y Niniche (Boullard), así como dos operetas de Suppé y Plantequett, para las que se alquilaron decorados completos ${ }^{141}$.

La compañía de ópera de la empresa Leiva dio representaciones en Murcia desde el 13 hasta el 23 de noviembre de 1886 (ver Capítulo 4) y, dada la proximidad de las fechas navideñas y para que el teatro no permaneciera cerrado en días tan señalados, se contrató también la compañía de zarzuela de Juan Cubas, que había actuado en el Romea durante la primera temporada teatral de $1885-1886^{142}$. De esta se criticó la desigual calidad de los cantantes principales: "Es lástima que una compañía buena como podía ésta ser, si hubiera un bajo y un barítono, dignos de las tiples y tenor cómico que forman de ella parte, sólo pase por regular" ${ }^{\text {"143 }}$. Fueron contratados nuevos cantantes, como el barítono Loitia y un tal Chaves, lo que hizo mejorar los resultados ${ }^{144}$.

Con todo, el balance de la compañía no fue muy favorable, en parte por problemas vinculados a las condiciones del alquiler:

${ }^{139}$ La Paz de Murcia, XXIX (1886), nº 8458, 27 febrero, p. 1. Las cursivas son editoriales.

${ }^{140}$ Tuvieron buena acogida: La Paz de Murcia, XXIX (1886), $\mathrm{n}^{\text {os }} 8922,16$ mayo, p. 1 y 8908,30 abril, p. 1. La misma compañía había estrenado algunas de sus obras de repertorio en los teatros de Madrid, como El puesto de castañas (música de Ángel Rubio y libreto de Casimiro Espino) que, según la prensa murciana, causó un gran revuelo en la capital porque se ridiculizaba a varios políticos, hasta el punto de que se requirió la intervención del Gobernador: La Paz de Murcia, XXIX (1886), $\mathrm{n}^{\text {os }} 8915,8$ mayo, p. 1 y 8918, 12 mayo, p. 1.

${ }^{141}$ La Paz de Murcia, XXIX (1886), n ${ }^{\text {os }}$ 9026, 24 septiembre, p. 1 y 9030, 29 septiembre, p. 1. Sobre las estancias anteriores de la compañía, véase: La Paz de Murcia, XXIX (1886), n ${ }^{\text {os }}$ 8990, 10 agosto, p. 1, 8992, 12 agosto, p. 1; 9006, 29 agosto, p. 1 y 9026, 24 septiembre, p. 1.

${ }^{142}$ Hasta el debut de la compañía, el 18 de diciembre de 1886, los salones del teatro se utilizaron para bailes de sociedad y algún concierto esporádico.

${ }^{143}$ La Paz de Murcia, XXX (1887), nº 8082, 1 enero, p. 1.

${ }^{144}$ La Paz de Murcia, XXX (1887), n ${ }^{\text {os }} 8085,5$ enero, p. 1; 8092, 14 enero, p. 1 y 8096, 19 enero, p. 1. 
Tiene razón "El Criterio": temporada teatral tan sosa como la presente, con tantas interrupciones y disgustos fuera y dentro del telón, no la hemos visto; pues si el público ha tenido razón para quejarse más de una vez, la empresa, que no ha visto concurrencia más que en las Pascuas y todos los días unos gastos de hoja que suben a tanto como la compañía, también ha tenido razón para no estar satisfecha. Preciso es que se estudien las condiciones de arriendo de modo que a las empresas les sea más llevadero el negocio y a la vez se les pueda exigir con más rigor el que las compañías no desdigan de la categoría de nuestro teatro y que los precios estén al alcance de todas las fortunas para facilitar la concurrencia con lo que aquellas ganarán como ganará el nombre de la población y se apartará a muchos de otros diferentes recreos menos convenientes.

También se hace necesario que no haya lucha en la subasta, tanto que en ella aceptaríamos lo que creemos debe perseguirse en otras que es la inteligencia de los que quieran, no el negocio, sino la intervención en esos recreos. [... $]^{145}$.

La compañía de Juan Cubas volvió a Murcia a principios de febrero de 1887 con dos nuevos tenores: Juan B. Pons y el tenor murciano Mula. Entre las diez funciones que ofreció, estuvo el estreno de Pepa la Frecachona, de Ángel Rubio ${ }^{146}$. Finalizado el tercer abono de la compañía de Cubas, el Teatro Romea acogió funciones esporádicas de aficionados y espectáculos circenses y de prestidigitación durante el mes de marzo de $1887^{147}$.

La compañía de teatro y zarzuela de Julia Cirera inició sus funciones de abono en el Romea el 10 de abril de $1887^{148}$. La primera serie de representaciones (íntegramente con obras dramáticas fue un fracaso de público ${ }^{149}$ ). Para la segunda serie la compañía sustituyó la pieza en un acto con la que normalmente se terminaba cada función por una zarzuela en un acto, lo que permitió iniciar un segundo abono de seis funciones. La compañía interpretó las siguientes zarzuelas, sainetes y juguetes cómico-líricos: Pepa la Frescachona, La Gran Vía de Chueca y Joaquín Valverde (que se llevó a escena hasta en siete ocasiones distintas), el juguete cómico lírico El pan de la emigración, de Rafael Leopoldo Palomino, y el sainete Los parvulillos ${ }^{150}$. La parte musical era interpretada por

${ }^{145}$ La compañía de Juan Cubas marchó desde Murcia capital a Cartagena, con el compromiso de volver después al Teatro Romea. Véase, La Paz de Murcia, XXX (1887), $\mathrm{n}^{\mathrm{os}} 8100,23$ enero, p. 1 y 8103 , 27 enero, p. 1.

${ }^{146}$ La Paz de Murcia, XXX (1887), nº 8111, 5 febrero, p. 1. La compañía de Cubas permaneció en la Región hasta el mes de mayo, actuando en distintas localidades, entre ellas Mula. A mediados de este mes, se marcharon a Albacete: La Paz de Murcia, XXX (1887), nº 8197, 12 mayo, p. 1.

${ }^{147}$ El 3 de marzo de 1887 un grupo de aficionados ofreció una función destinada a redimir del servicio militar al escrito Luis Marco Ramírez. El programa estuvo compuesto de las siguientes obras dramáticas en un acto: Las codornices de Vital Aza, El rizo de doña Marta de José Estrañi y ¡Chillón! de Ramos Carrión y Campo Arana. Intervino la orquesta de plectro (bandurrias y guitarras) de Manuel Alarcón: La Paz de Murcia, XXX (1887), $\mathrm{n}^{\text {os }}$ 8130, 27 febrero, p. 1; 8133, 3 marzo, p. 1; 8137, 8 marzo, p. 1. En marzo, la actividad del Romea se redujo a dos funciones del prestidigitador Pierre Adrieny: La Paz de Murcia, XXX (1887), $\mathrm{n}^{\text {os }} 8143,15$ marzo, p. 1; 8143, 15 marzo, p. 1; una función benéfica de aficionados el 23 de marzo de 1887: La Paz de Murcia, XXX (1887), $\mathrm{n}^{\text {os }}$ 8148, 20 marzo, p. 1; 8150, 23 marzo, p. 1; 8152, 25 marzo, p. 1; y, finalmente, dos funciones circenses a cargo de Los Pinauds con la cantante y bailarina Mis Robina: La Paz de Murcia, XXX (1887), nº 8154, 29 marzo, p. 1.

${ }^{148}$ La Paz de Murcia, XXX (1887), nos 8156, 31 marzo, p. 1 y 8163, 9 abril, p. 1

${ }^{149}$ Véase más detalles en Crespo, El Teatro, pp. 183-184.

${ }^{150}$ Tras su estreno en Murcia, el 4 de abril de 1887, La Gran Vía se repitió cuatro veces seguidas (hasta el 8 de mayo) y los días 15 y 16 de mayo de 1887 . 
los actores de la compañía, que no contaba con una sección lírica. Concluidas las funciones de la compañía Cirera se inició un abono de veinte representaciones con la compañía de zarzuela del empresario murciano Pablo López ${ }^{151}$ que estrenó la zarzuela Cádiz, de Chueca y Valverde.

Durante el año cómico de 1887-1888, el Teatro Romea tuvo que competir con la programación de los teatros del Barrio del Carmen, de los "Amigos del Progreso", de los "Amigos del Porvenir" y de espectáculos taurinos, de gran popularidad en la ciudad ${ }^{152}$. La temporada del Teatro Romea fue inaugurada el 5 de septiembre de 1887, en plena feria de septiembre, con la compañía de zarzuela de Manuel Rojas ${ }^{153}$. La compañía programó un solo abono de cinco funciones (la última se suspendió) con gran afluencia de público ${ }^{154}$ y el Teatro Romea cerró sus puertas entre el 12 de septiembre y el 23 de octubre de $1887^{155}$.

Durante esta clausura del teatro principal de Murcia, el Ayuntamiento se planteó vender el inmueble o enajenarlo para su gestión a manos privadas, como vimos en el capítulo anterior. El debate enfrentó a la prensa en dos bandos: Las Provincias de Levante era partidaria de la venta del teatro, mientras que La Paz de Murcia, El Criterio y El Diario de Murcia, se situaron en el bando contrario.

Las Provincias publicó críticas teatrales muy negativas contra la citada compañía de Paulino Delgado, que actuó desde el 29 de octubre de 1887. El Noticiero, El Diario de Murcia y La Paz de Murcia, en cambio, no consideraban tan malas sus actuaciones ${ }^{156}$.

La disputa periodística fue pareja a otros problemas que enfrentaron a la empresa, a la compañía teatral y al Ayuntamiento y que terminaron con el cese de las representaciones antes de concluir el segundo abono de la compañía de Paulino Delgado. La compañía se había comprometido con el Ayuntamiento a aumentar el cuadro lírico en el tercer abono, aunque se marchó antes de iniciarlo ${ }^{157}$.

151 Para La Paz de Murcia, XXX (1887), no 8202, 18 mayo, p. 1, la clausura de la temporada de Pascua de 1887 con la compañía de Pablo López no podía concluirse mejor.

152 Sobre la inauguración de la Plaza de Toros de Murcia y el ambiente taurino murciano del siglo XIX, véase: Pérez Crespo, El Lagartija.

${ }^{153}$ La compañía había actuado a finales de agosto en el teatro Circo de la Riba de Cartagena, donde representó con mucho éxito La tempestad y La Gran Vía, entre otras: La Paz de Murcia, XXX (1887), $\mathrm{n}^{\circ}$ 9286, 28 agosto, p. 1; 8287, 30 agosto, p. 1.

${ }^{154}$ La Paz de Murcia, XXX (1887), $\mathrm{n}^{\text {os }} 8304,10$ diciembre, p. 1; 8297, 11 septiembre, p. 4. Durante los días de feria se programaban numerosas actividades en sociedades, teatros cafés y conciertos al aire libre, lo que atraía a numerosos visitantes de poblaciones cercanas.

${ }^{155}$ El 23 de octubre de 1887 el Romea acogió una función benéfica destinada a recaudar fondos para los afectados por la epidemia de paludismo que había causado numerosas víctimas en Cartagena y Murcia. (Véase Apéndice 3.6).

${ }^{156}$ La Paz de Murcia, XXX (1887), nº 8274, 3 noviembre, p. 1. Véanse más detalles sobre el debate en torno a la venta del Teatro Romea en La Paz de Murcia, XXX (1887), $\mathrm{n}^{\text {os }} 8276,5$ noviembre, p. 1 y 8287, 17 noviembre, p. 1 (transcritos en el Documentario), así como La Paz de Murcia, XXX (1887), n ${ }^{\circ} 8289,20$ noviembre, p. 1.

157 Sobre el cese de las representaciones, véase, La Paz de Murcia, XXX (1887), n ${ }^{\circ}$ 8275, 4 noviembre, p. 4 y La Paz de Murcia, XXX (1887), nº 8260, 22 noviembre, p. 1 (este último transcrito en el Documentario). La compañía de Delgado actuó después en Albacete, Córdoba y Granada: La Paz de Murcia, XXX (1887), no 8304, 10 diciembre, p. 1 y La Paz de Murcia, XXXI (1888), n ${ }^{\text {os }}$ 9410, 22 enero, p. 4; 9417, 31 enero, p. 1; 9417, 12 febrero, p. 1; 9422, 18 febrero, p. 1 y 9423, 19 febrero, p. 1. 
La compañía de zarzuela de Galinier, que desde hacía meses daba representaciones en el Teatro Porvenir, actuó en el Romea durante cuatro días (8 a 11 de diciembre de 1887) ${ }^{158}$. Casi en Navidad, comenzó sus representaciones la compañía de zarzuela de los directores Juan Cubas y Rafael Pastor ${ }^{159}$. La afluencia de público fue irregular, quizás por las fechas y por la competencia de otros teatros en la ciudad. El empresario José Amorós Vázquez solicitó el traspaso del arriendo del Teatro Romea sin perder la fianza y se constituyó una sociedad artística ajena a la empresa teatral que consiguió ofrecer funciones durante cuatro días ${ }^{160}$; pero la sociedad tuvo que disolverse y algunos de sus actores (junto a otros del Teatro Porvenir) se integraron en la compañía que actuaba en el Teatro del Progreso. El 25 de enero de 1888 se firmó el contrato un contrato que cedía los enseres y efectos del teatro al nuevo empresario, Anselmo Arques $^{161}$. El cambio de arrendamiento llevó de nuevo a la zarzuela al Romea, con la compañía de Guillermo Cereceda, que comenzó a actuar a principios de febrero de 1888 . El conjunto de Cereceda fue percibido como sólido y estable:

En ella no sobresalen grandes actores ni la compañía lleva de los que se aplican el adjetivo de eminencia pero reúne ésta una cualidad que la levanta sobre otras de más consumados artistas y es que lleva un repertorio fijo y se halla formada hace años recorriendo los teatros, todos unidos, así que el conjunto es inmejorable y en obras de tanto movimientos escénico como Cádiz, no se puede pedir más. El decorado y el vestuario completan el buen éxito ${ }^{162}$.

Además, la compañía de Cereceda invirtió en buenas escenografías y refuerzos musicales, algo que no estaba al alcance de otras empresas. Por ejemplo, en el estreno en Murcia de La bruja de Chapí, Cereceda contrató a varios músicos de Alicante que conocían la obra, alquiló vestuario y decorados y, en algunos números musicales, hizo participar a la orquesta de bandurrias y guitarras dirigida por Manuel Alarcón ${ }^{163}$. Para afrontar los elevados gastos de esta producción, incluidos los de derechos de autor, la empresa tuvo que elevar el precio de las butacas (hasta catorce reales cada una) cuando el precio normal era de 10 reales $(2,50$ pesetas $)$ por butaca ${ }^{164}$.

La compañía de Felipe Carsí, procedente de Albacete, aunque centrada sobre todo en el género dramático, interpretó zarzuelas como Niña Pancha (música de Romea y Valverde) y estrenó la "pesca cómico-lírica" de los compositores Federico Chueca y Joaquín Valverde titulada Vivitos y coleando (15-03-1888) ${ }^{165}$.

${ }^{158}$ La Paz de Murcia, XXX (1887), nos 8292, 24 noviembre, p. 1 y 8294, 27 noviembre, p. 1.

${ }^{159}$ Puntualmente, los salones del Romea acogieron algún baile de sociedad antes del comienzo de las representaciones: La Paz de Murcia, XXX (1887), $\mathrm{n}^{\circ}$ 8311, 18 diciembre, p. 1.

${ }^{160}$ Las funciones de la nueva sociedad del Teatro Romea sociedad comenzaron el 14 de enero y se prolongaron hasta el 17 de enero de 1888 y contaron con el tenor de Alicante Francisco Rameta y el murciano Blaya: La Paz de Murcia, XXXI (1888), n 9401, 12 enero, p. 1; 9403, 14 enero, p. 1.

${ }^{161}$ El Diario de Murcia, X (1888), $\mathrm{n}^{\text {os }} 3220,26$ enero, p. 3 y 3223, 31 enero, p. 1.

${ }^{162}$ La Paz de Murcia, XXXI (1888), n 9411, 4 febrero, p. 1. Las cursivas son editoriales.

${ }^{163}$ La Paz de Murcia, XXXI (1888), no 9414, 8 febrero, p. 4.

${ }^{164}$ La paz de Murcia, XXXI (1888), no 9417, 12 febrero, p. 1.

${ }^{165}$ La temporada incluyó tres representaciones del drama La pasión y muerte de Jesús de Enrique Pérez Escrich y habrían sido más si el Obispo no hubiera advertido a los murcianos que era "pecado grave asistir a las representaciones de La Pasión”: La Paz de Murcia, XXXI (1888), nº 9456, 17 marzo, p. 1. 
La temporada de Pascua de 1888 llevó al escenario del Romea a la compañía del barítono y director José Palou, que preveían ofrecer nueve representaciones de zarzuela. Sin embargo, tras la quinta función la compañía pensó en abandonar por tener menos público del que esperaba y porque prefería representar en Barcelona:

Anoche corrió la voz en Romea de que la función de hoy es la última de la actual compañía, y que devolverá el dinero a los que tengan pagadas las cuatro restantes. Que así debe serlo autoriza a creerlo el anunciar para hoy el estreno de La campana milagrosa con una única representación.

Como siempre, al circular esta noticia no faltó quien culpara al Ayuntamiento, como si éste pudiese evitar el hacer una subasta, que haya muchos aficionados y que en vez de avenirse y formar una sociedad para quedarse por el tipo de la subasta que era económico, cada uno quiera para sí sólo el negocio y eleve su proposición para ver de evitar que otro se lo lleve.

A cambio de ésto, se dice que la compañía se va por causa de la falta de concurrencia, pues sólo ha tenido una buena entrada en los cuatro días que funciona con el estreno de Blanca [de Saldaña], cuando calculaba tener un lleno y esto no le da ánimos para seguir, mayormente cuando en Barcelona la están esperando ${ }^{166}$.

El diario Las Provincias calificó de mártires a los componentes de la compañía de Palou. La Paz de Murcia, por el contrario, apoyándose en otros diarios (como El Criterio, El Diario de Murcia y El Correo) consideraba injustificado el inesperado abandono de la compañía de Palou ${ }^{167}$.

Durante el mes de mayo actuó en el Romea la compañía dramática de José González y el día 28 del mismo mes se celebró una función conjunta entre actrices profesionales de estas compañías y los aficionados José González y César Carreras, Federico Capdepón, Ramón Casalduero, Arcadio Valcárcel, Enrique Rael, Antonio Masuti, Luis Casalduero y Salvador Esteve. Se representó Los amantes de Teruel y el sainete de Ricardo de la Vega, Pepa la Frescachona ${ }^{168}$.

A pesar de la polémica que habían causado, la compañía de José Palou volvió a Murcia para iniciar la temporada teatral $1888-1889$ con diez nuevas funciones durante los días de feria (primera quincena de septiembre). Lo más novedoso que se ofreció fue la posibilidad de escuchar por teléfono las funciones tras efectuar un pago estipulado ${ }^{169}$.

${ }^{166}$ La Paz de Murcia, XXXI (1888), nº 9471, 5 abril, p. 1.

${ }^{167}$ La Paz de Murcia, XXXI (1888), n $\mathrm{n}^{\circ}$ 9473, 7 abril, p. 1. Al día siguiente, el periódico El Criterio (citado por La Paz de Murcia) publicó que la compañía de Palou había obtenido un beneficio de 21531 reales (5382 pesetas), lo que corroboraría su infundada huída de Murcia.

${ }^{168}$ La Paz de Murcia, XXXI (1888), nos 9515, 27 mayo, p. 1 y 9517, 30 mayo, p. 1.

${ }^{169}$ La Paz de Murcia, XXXI (1888), nº 9598, 6 septiembre, p. 1: “Los abonados al teléfono podrán escuchar desde sus casas la función del teatro de Romea, por tres pesetas cada noche. Los billetes se recogerán en la taquilla del teatro Romea". 


\subsection{La zarzuela y el teatro por horas desde 1888 hasta 1895}

Las compañías de zarzuela que actuaban en Murcia apenas podían mantenerse más allá de una treinta de representaciones, lo que no garantizaba temporadas teatrales estables ${ }^{170}$. La interrupción inesperada de las representaciones de una compañía perjudicaba a los abonados ${ }^{171} \mathrm{y}$ a los empresarios teatrales, que se veían obligados a formar y reformar nuevas compañías, contratando cantantes de aquí y de allá. Con frecuencia la actividad teatral cesaba mientras se tramitaban las nuevas contrataciones y las empresas teatrales eran presionadas para estrenar obras a diario, siguiendo los dictados de Madrid. Sin embargo, en Murcia no había público suficiente para una actividad teatral tan dinámica, como se comentaba en la prensa local en 1888:

[...] La experiencia ha hecho ver que Murcia no puede sostener una temporada de cinco meses seguidos, abierto el coliseo con compañías de primer orden y precios subidos. Se ha dado caso al contrario, pero lo han abonado circunstancias excepcionales.

El contrato exige solo al arrendatario que las compañías sean de actores que hayan funcionado en teatros de la categoría del nuestro y éste está considerado para los derechos, que son los que norman con más acierto, como de tercera clase.

Conveniente sería que alguna que otra traba que tiene Romea no existiera; pero mientras que haya necesidad absoluta de arrendarlo, mientras el Ayuntamiento no pueda tenerlo sin arrendar para darlo en cada temporada al que mejor proposición y más garantías ofreciese, es inútil cuanto se declame. [...]

Nos debemos dar por satisfechos con tener una compañía aceptable en el género a que se dedique, puesto que es libre la empresa de elegirlo. Nos debemos dar por más satisfechos con que los espectáculos sean más bien baratos que a catorce reales butaca como se ha hecho pagar alguna vez, sin una causa justificada, sólo para beneficiar el bolsillo de un empresario de esos que nada exponen, pues no toman el teatro para estar a las eventualidades de una larga temporada, sino que además de escogerla vienen por un corto número de funciones. Es preciso que las muchas familias que viven de que funcione el coliseo, no pierdan el auxilio que en él alcanzan al estar cerrado, porque el público diario no es bastante para grandes gastos ni esta ciudad tiene población flotante que dé movimiento y vida a todos los centros.

Cuando hemos llegado a una época / [p. 2] en la que ni los teatros del barrio tienen público, que se encuentran cerrados porque no hay quien se arriesgue a perder en ellos, a pesar de que no tienen lo que "Las Provincias" encuentra de malo en Romea. Debemos darnos por satisfechos con que se haga fácil el tener un recreo lícito que pueda evitar en mucho o en poco la concurrencia de una parte de nuestros paisanos a otros centros perjudiciales a las familias ${ }^{172}$.

En este contexto se introdujo en Murcia el teatro por horas en 1888, contribuyendo a dinamizar la actividad del Romea. Los protagonistas de esta novedad

${ }^{170}$ Durante el periodo 1871-1887, actuaron en el Teatro Romea una o dos compañías de zarzuela por año, ofreciendo una media anual de 99 funciones de zarzuela. En cambio, entre los años 1888 y 1895 , desfilaron por el citado teatro tres o cuatro compañías de zarzuela por año, con una media de 116 funciones de zarzuela anuales.

171 A principios de la temporada 1888-1889, el Ayuntamiento incorporó en el contrato de arrendamiento del teatro una nueva cláusula para que los abonados no perdieran el derecho a sus localidades (que pasarían de una temporada a otra) si la compañía cesaba antes de concluir el abono: $L a P a z$ de Murcia, XXXI (1888), nº 9624, 7 octubre, p. 1.

${ }^{172}$ La Paz de Murcia, XXXI (1888), nº 9618, 30 septiembre, pp. 1-2. 
fueron Francisco Galván y Félix Berros, cuya compañía de zarzuela actuó en Murcia desde principios de octubre de 1888 hasta febrero del año siguiente. En el teatro por horas, las funciones se dividían en secciones de una hora (por lo general, desde las ocho de la tarde) y el espectador podía elegir entre asistir sólo a una sección, a varias (seguidas o no) o a todas. Cada sección ofrecía una obra completa en un acto (zarzuela, juguete cómico-lírico, sainete, revista, opereta o cualquier otro) y las obras con más de un acto se interpretaban en secciones seguidas. La entrada general a cada sección costaba 15 céntimos, un precio asequible a los bolsillos de muchos ciudadanos. Los beneficios de las funciones por horas fueron rápidamente advertidos por la prensa, como atestiguan las siguientes líneas publicadas por La Paz de Murcia:

Según tenemos entendido, en las funciones que se dan en Romea habrá entradas y localidades para toda la noche, y por horas, así que el público podrá elegir. Por tanto, Romea no se convertirá en teatro de verano, sino que se pondrá al alcance de todas las fortunas siguiendo la costumbre con buen éxito realizada en Madrid, en Sevilla, en Cádiz, en Córdoba, en Cartagena y en otras poblaciones en teatros de mucha y de poca importancia.

Lo que importa es que el teatro no quede para temporadas de diez funciones cada dos o tres meses, en los días de coger las ganancias con perjuicio del público que carece de espectáculos en una población donde no hay distracciones y de las familias que vienen de esas funciones.

Por tanto, tranquilícese "El Noticiero" y procure porque el teatro esté abierto el mayor tiempo posible que es lo principal, barato y con funciones admisibles ${ }^{173}$.

La implantación del teatro por horas contribuyó a elevar la asistencia de público, que en algunos casos fue extraordinaria: "los espectadores de los anfiteatros y paraíso estaban como patatas en saco"174. Sin embargo, también tuvo su lado negativo, especialmente en lo que se refiere al mal comportamiento que a veces tenían "los espectadores de 15 céntimos" $"$. Las fuentes periodísticas mencionan reiterados comportamientos negativos por parte de los espectadores, escándalos en la sala y algún que otro destrozo en el local ${ }^{176}$.

${ }^{173}$ La Paz de Murcia, XXXI (1888), nº 9615, 27 septiembre, p. 1.

${ }^{174}$ La Paz de Murcia, XXXI (1888), nº 9631, 16 octubre, p. 1. Véase más detalles en Crespo, El Teatro, pp. 212-217. Esta circunstancia fue aprovechada por la empresa, que vendió más localidades de las permitidas colocando sillas en los pasillos. El Gobierno Civil intervino sellando las entradas: La Paz de Murcia, XXXI (1888), n 9652, 13 noviembre, p. 1.

${ }^{175}$ El artículo "Los abusos del Romea”, La Paz de Murcia, XXXI (1888), no 9643, 30 octubre, p. 1 (transcrito en el Documentario) aporta numerosos detalles al respecto. El público de estas sesiones por horas insistía para que se repitiesen todos los números cantados de las zarzuelas, hasta el punto de entorpecer "hasta la saciedad a los actores que, por no desagradar, aunque no puedan, tienen que complacer de un modo forzoso a ese insaciable público de las alturas"; además, los espectadores reclamaban obras no anunciadas y "que quizá no sepa el artista, lo que no venga bien dentro de la obra que se represente [o] lo que no tenga la orquesta papeles para acompañarlo". El autor del texto opinaba que "el orden y la compostura deben ser las cualidades que distingan y diferencien ese espectáculo de los que se dan al aire libre" y pidió a la prensa que contribuyera a educar a la población: "Nuestros colegas [...] debían ayudarnos a ilustrarlo [al público] haciéndole conocer sus derechos y deberes, sin temor a perder una suscripción, pues la misión de la prensa es, tanto el ilustrar [y] civilizar, como el velar por los intereses morales y materiales de ese mismo pueblo. La prensa periódica tiene misión más importante que la de servir de entretenimiento y recreo".

${ }^{176}$ El Ayuntamiento de Murcia emitió un informe recomendando la clausura del teatro dados los desperfectos y suciedad que presentaba el local: La Paz de Murcia, XXXI (1888), $\mathrm{n}^{\circ}$ 9652, 13 noviembre, p. 1. El Correo informó de la recogida de firmas para cerrar el coliseo: El Correo citado por La Paz de 
El público se quejaba por la repetición de números, por la falta de ensayos, por variaciones de última hora en la programación y por deficiencias en los actores y cantantes, entre otros ${ }^{177}$. Los frecuentes alborotos en la sala fueron la excusa idónea para que la prensa debatiera la pertinencia del sistema por horas y, de paso, la idoneidad del repertorio. El periódico Las Provincias propuso directamente el cierre del Teatro Romea: "Los gritos obscenos, los silbos y escándalos... demuestran que el coliseo municipal se está destruyendo moral y materialmente y que el público se educa con espectáculos de mal gusto" $" 178$.

La Paz de Murcia, en cambio, consideraba el teatro como el lugar idóneo para educar "en sociedad", aún a costa de sacrificar la calidad literaria y musical del repertorio:

A nosotros nos gusta más la sublimidad de Norma que Niña Pancha, pero no dude "Las Provincias" que una compañía buena para Norma, aún quitando la gabela de la guardarropía, única que podrá citar y que es hija no de la voluntad, sino de un litigio, no se sostiene en Murcia más allá de 20 días y otra compañía con Niña Pancha y otras obras de este género, con entrada pagada en pequeñas cantidades, quizá se sostenga toda esta larga temporada, la más difícil de atravesar en nuestro teatro. De tan diferentes resultados no son culpables las empresas ni el Ayuntamiento ni nadie, pues en todas partes sucede que lo que cuesta poco tiene más salida que lo caro.

Aquí no estamos en Madrid donde se costea un abono en el Real por el hecho de titularse abonado al regio coliseo. Aquí ni barato ni caro acuden a diario todas las familias que a nuestro juicio debían ocupar los palcos y plateas y parte de las butacas, base para asegurar el sostén de una buena compañía y con los que pueden no hay que contar por falta de afición o por otras causas y sólo los de menos recursos son los que acuden hay que halagar su gusto y poner a su alcance el recreo.

Respecto a algunas inconveniencias de parte de ese público que es preferible que esté en Romea a verle en la taberna, en el juego o quizá en el lupanar, esas con rigor en las autoridades pueden irse corriendo, enseñando a estar en sociedad a los que de seguro están acostumbrados a estar en centros de los que nos alegramos se $\operatorname{aparten}^{179}$.

Murcia, XXXI (1888), n $\mathrm{n}^{\circ}$ 9654, 15 noviembre, p. 1. Las familias murcianas que dependían económicamente del teatro llegaron a convocar una manifestación en contra del cierre: La Paz de Murcia, XXXI (1888), $\mathrm{n}^{\circ}$ 9653, 14 noviembre, p. 1. El aspecto del Teatro Romea era "altamente deplorable": La Paz de Murcia, XXXI (1888), nº 9721, 25 diciembre, p. 1.

${ }^{177}$ En 1888, la empresa sustituyó en tres ocasiones a la tiple por los continuos pateos del público: $L a$ Paz de Murcia, XXXI (1888), no 9634, 19 octubre, p. 1. A principios de noviembre de 1888 el Ayuntamiento obligó a los empresarios Galván y Berros a aumentar el conjunto y especialmente el número de voces del coro. Las representaciones se interrumpieron entre el 21 y el 24 de noviembre para que los empresarios contrataran en Madrid una nueva tiple (Isabel Mantilla), un barítono (Gustavo Carrasco) y cinco voces femeninas para el coro. Véanse La Paz de Murcia, XXXI (1888), nº 9660, 22 noviembre, p. 1 (transcrito en el Documentario), así como La Paz de Murcia, XXXI (1888), ${ }^{\text {os }}$ 9664, 27 noviembre, p. 1; 9699, 28 noviembre, p. 1; 9700, 29 noviembre, p. 1 y 9702, 1 diciembre, p. 1. La hostilidad del público hacia la tiple Mantilla le hizo abandonar la compañía unos días más tarde, y marchar a Cartagena, donde fue contratada: La Paz de Murcia, XXXI (1888), n 9706, 6 diciembre, p. 1. A finales de 1888 se contrató a una nueva cantante, Carolina Fernández: La Paz de Murcia, XXXI (1888), nº 9700, 29 diciembre, p. 1.

${ }^{178}$ Las Provincias de Levante, IV (1888), 5 noviembre, citado por Crespo, El Teatro, p. 216. Como mencioné anteriormente, este periódico era partidario de la venta del Teatro Romea, de manera que cualquier escándalo le serviría de excusa para afianzarse en su postura.

${ }^{179}$ La Paz de Murcia, XXXI (1888), nº 9648, 8 noviembre, p. 1. 
Los excesos del público fueron paliados con la presencia de cuatro parejas de agentes de seguridad dentro de la sala, aunque los alborotos siguieron produciéndose e incluso fueron detenidos varios espectadores que portaban armas. La compañía de Galván y Berros terminó sus representaciones en Murcia capital el 10 de febrero de 1889 y marchó después a Lorca ${ }^{180}$.

A pesar de los problemas surgidos durante las actuaciones de la compañía de Galván y Berros, con ella el público murciano se acostumbró rápidamente a asistir al sistema del teatro por horas, de manera que la única función sin secciones que programó esta compañía, a beneficio del Ayuntamiento, apenas contó con asistentes por lo "retraído que el público va poniéndose al ser función completa"181. Lo mismo ocurrió con elenco que actuó a continuación, la compañía dramática de Miguel Cepillo, que ofreció funciones completas con escasa concurrencia, como atestiguan las fuentes documentales $^{182}$.

El teatro por horas no siempre daba beneficios económicos. La compañía de Francisco Povedano actuó por horas y con un repertorio similar al de la compañía Galván-Berros pero no obtuvo los resultados económicos que esperaba y el 31 de marzo de 1889 se marchó de Murcia, dando paso a una compañía rusa que ocupó el Romea con dos funciones de prestidigitación e hipnotismo los días 6 y 7 de abril de 1889 . Tras ésta, ocupó de nuevo el escenario la compañía de Miguel Cepillo (desde el 21 al 30 de abril de 1889).

La compañía de José Bosch, procedente de Alicante, actuó en el Romea durante el mes de mayo de 1889 con funciones completas a precios asequibles para estimular la asistencia de un público más "selecto". El repertorio de zarzuela que escogieron mereció el aplauso de la prensa, precisamente por ser más relevante que el del teatro por horas: "Romea estuvo muy concurrido, lo que prueba de que el público está ávido de zarzuelas de más importancia que las que otras veces han servido para postres"183.

La compañía de Eduardo Ortiz, que inauguró el año cómico 1889-1890 tampoco empleó el teatro por secciones. Su repertorio estuvo casi exclusivamente compuesto por zarzuela grande.

El 12 de octubre de 1889 volvieron al Romea las representaciones por horas del elenco de actores dirigidos por Enrique Lloret, procedentes de Lorca ${ }^{184}$. Como otros casos anteriormente comentados, la compañía de Lloret estaba incompleta: faltaban dos tiples,

${ }^{180}$ La Paz de Murcia, XXXII (1889), no 9757, 7 febrero, p. 1. Según La Paz de Murcia, XXXII (1889), nº 9776, 1 marzo, p. 1 el periódico de Lorca La Defensa criticó duramente a la compañía GalvánBerros, llegando a afirmar que el teatro se había convertido con ella en una "casa de prostitución". La compañía tampoco obtuvo reseñas favorables en sus posteriores actuaciones en Albacete: La Paz de Murcia, XXXII (1889), nº 97896, 17 marzo, p. 1.

${ }^{181}$ La Paz de Murcia, XXXII (1889), nº 9757, 7 febrero, p. 1.

${ }^{182}$ La Paz de Murcia, XXXII (1889), n $\mathrm{n}^{\mathrm{o}}$ 9774, 27 febrero, p. 1 afirmaba: "el teatro disminuye su ingreso cuando el tiempo no favorece [...]. Esto, unido a los quince céntimos, hacen ahora difícil dar cincuenta de una vez, aunque sea por toda la función": La Paz de Murcia, XXXII (1889), n 9774, 27 febrero, p. 1.

\footnotetext{
${ }^{183}$ La Paz de Murcia, XXXII (1889), nº 9820, 8 mayo, p. 1. Véase Apéndice 3.1

${ }^{184}$ La Paz de Murcia, XXXII (1889), nº 9946, 11 octubre, p. 4.
} 
una característica y cuatro coristas, entre otros ${ }^{185}$. A eso hubo que añadir el comportamiento abusivo del público de las galerías altas:

[...] Los de arriba van a una sección y quisieran les durara toda la noche y con esto y con el agrado que oyen algunos cantos y ven otras escenas, no se cansan en pedir repeticiones. Los de abajo, que van a toda la función y tienen bastante con lo que se anuncia, sólo desean que se acabe temprano.

Resultado: que los de arriba aplauden para que se repita. Los de abajo patean para que no y que los imparciales pasen un mal rato, pues ni oyen ni entienden nada. Con alguna indulgencia de parte de los de abajo, teniendo en cuenta que esta clase de espectáculos no son como los de función entera, se podía llegar a un acuerdo pero si se toma por sistema decir unos día y otros no, el teatro será lo que fue anoche mientras el simpático Puerta repitió la escena del trabajo del Certamen Nacional, una plaza de toros alborotada ${ }^{186}$.

La compañía de Lloret se marchó inesperadamente el 27 de octubre de 1889, sin concluir sus representaciones comprometidas y dejando a ocho artistas sin pagar.

Las compañías de zarzuela de Manuel Rodríguez y la de Manuel Martínez programaron funciones por horas a finales de 1889 y comienzos del $1890^{187}$.

En agosto de 1890 se planteó un nuevo sistema de alquiler del teatro, basado en la contratación directa de las compañías o de las empresas que las representaban. Además, el Ayuntamiento suprimió la orquesta del teatro (creada por oposición en 1884) y prohibió las funciones por horas, dados los continuos altercados que se producían en ellas $^{188}$. Con el nuevo sistema, fue contratado en octubre de 1890 la compañía de Daniel Banquells, que contaba con los tenores murcianos Abelardo Barrera y Carlos Barrenas ${ }^{189}$. $\mathrm{Su}$ repertorio estuvo compuesto mayoritariamente por zarzuelas en tres actos.

La empresa no tuvo buena acogida y se criticó la falta de ensayos:

185 Algunos abonados, entre ellos el conde Roche y Sebastián Servet, pidieron al Gobernador que hiciera cumplir a la empresa no sólo lo acordado sobre los artistas, sino también sobre la limpieza de aparatos de gas y escenografía. A pesar de la intervención del Gobernador, y después de diez días de representaciones, la compañía seguía incompleta y todos los personajes femeninos de importancia eran interpretados por la tiple Josefa Alvarado. El empresario Lloret se marchó a Madrid "en busca de tiples". Véanse, La Paz de Murcia, XXXII (1889), $\mathrm{n}^{\text {os }}$ 9954, 20 octubre, p. 1; 9955, 22 octubre, p. 1 y 9955, 22 octubre, p. 1, así como Crespo, El Teatro, p. 232.

${ }^{186}$ La Paz de Murcia, XXXII (1889), nº 9954, 20 octubre, p. 1. Dos días más tarde, La Paz de Murcia, XXXII (1889), n 9955, 22 octubre, p. 1 publicó: altas "Entre las dos clases de público que asiste a Romea [...] se está creando un antagonismo que puede dar malos resultados". El Gobernador mandó fijar por los pasillos y salas del teatro un edicto con los artículos del Reglamento de Espectáculos y "rogando al público se le evite tomar medidas enérgicas".

${ }^{187}$ En la compañía de Manuel Martínez figuró el actor murciano Mariano Guillén: La Paz de Murcia, XXXIII (1890), nº 10033, 25 enero, p. 4.

${ }^{188}$ E:MUm, AC 30-07-1890, fols. 434v-440v. Véanse más detalles sobre los incidentes en el teatro en Crespo, El Teatro, pp. 242-244.

${ }^{189}$ La empresa de esta compañía, representada por José Muñoz, era murciana: E: MUm, AC 24-091890, fol. 534v. Antes de contratar la compañía de Banquells, el Ayuntamiento de Murcia había desechado varias propuestas del director y empresario Francisco Gueri, basadas en combinar funciones completas y por secciones. Véase: La Paz de Murcia, XXXIII (1890), nº 11137, 25 septiembre, p. 1. 
Los abonados no están contentos. Las obras no alcanzan el feliz desempeño de las primeras por la falta de unión en las partes y de otros talles. Un ensayo no es bastante para una compañía que no trae las obras ya concertadas y para una orquesta en que muchos de los profesores no tenían por costumbre ejecutar las que se les ponen delante, y si luego en los ensayos hay demasiada bondad en el director y no se hacen con toda la formalidad necesaria, resulta que son poco y mal ensayadas las obras.

La compañía no debe fiarse en que en éste o el otro número, en ésta o la otra nota se tributen aplausos parciales y se calle en otros que merecieran otras demostraciones, debido a que el público ilustrado de las principales localidades se contenta con el silencio, pero pudiera alguna vez cansarse, y por eso hacemos esta advertencia con tiempo y en virtud de lo que hemos oído y notado. [... ${ }^{190}$.

Una parte de los abonados (sobre todo de las localidades bajas), preferían asistir a representaciones de zarzuela grande pero las funciones por horas reportaban más público $\mathrm{y}$, en consecuencia, mayores beneficios a las empresas. A través de la prensa se sugirió que convendría alternar funciones completas y por secciones:

[...] Verdad es que Jugar con fuego, Marina y otras son las perlas de la zarzuela y que se oirán con gusto, pero esto no debe privar a la empresa el que los domingos y algún otro día se pongan en escena obras de las que dan entrada para salvar la nómina, de esas que llevan llenos. A la empresa no se le puede exigir tal desprendimiento, que atienda solo al gusto de una parte del público y que se contente con lo que produzca el abono y venta diaria. Para que el espectáculo dure, debe tolerársele el que apele a obras de las que dan entradas, y no ponerle limitaciones tan estrechas, lo que debe exigirse solo es que huya de lo inmoral y puesto que la lista es de actores de reputación, que trabajen como a ella corresponden y se oigan las obras como fueron concebidas por sus autores ${ }^{191}$.

La compañía de Daniel Banquells inició un segundo abono en Murcia a mediados de noviembre de 1890 y en las primeras representaciones consiguió una mayor afluencia de público gracias a la rebaja en los precios de las localidades ${ }^{192}$; pero a medida que el abono avanzaba, el número de espectadores decrecía y la prensa siguió insistiendo en la convencía de incluir sesiones por horas, que darían mejores beneficios:

una temporada larga con un mismo espectáculo, con repeticiones, no la resiste Romea, pues sea el motivo el que fuere, más o menos justificado, no existe el afán en las clases acomodadas [...]. Por eso una temporada larga se habría llevado bien (como se propuso al Ayuntamiento) con un espectáculo mixto, mitad de funciones de zarzuelas serias y otra mitad de funciones por horas, alternando, y de ese modo se habría facilitado mayor ingreso en taquilla por la concurrencia de personas que ahora no siempre puede $\mathrm{ir}^{193}$.

${ }^{190}$ La Paz de Murcia, XXXIII (1890), nº 11161, 23 octubre, p. 1.

${ }^{191}$ La Paz de Murcia, XXXIII (1890), n ${ }^{\text {os }} 11148,8$ octubre, p. 1 y 11163, 25 octubre, p. 1.

${ }^{192}$ Los precios fueron: Plateas y palcos principales, 7.50 pesetas (en el primer abono habían costado 10 pesetas). Butacas de patio con entrada, 1.12 pesetas (antes 1.50 pesetas). Delanteras de paraíso, 0.50 pesetas (antes 0.75 pesetas): La Paz de Murcia, XXXIII (1890), n $\mathrm{n}^{\circ} 11177,11$ noviembre, p. 1.

${ }^{193}$ La Paz de Murcia, XXXIII (1890), nº 11199, 6 diciembre, p. 1. La compañía de Daniel Banquells permaneció en la ciudad hasta enero de 1891. 
Para la segunda temporada de 1890-1891 fue contratada la compañía de ópera de Tomás Bretón y, tras su estrepitoso fracaso (ver Capítulo 4) llegó la compañía de Andrés López que, a diferencia de la compañía de Banquells, llevó a escenas obras del género chico, aunque programadas en funciones completas. Esta solución no gustó al sector conservador de los espectadores aunque la oferta se admitió siempre que el repertorio escogido no fuera inmoral ${ }^{194}$ y desde luego, la compañía seleccionó bien los títulos a representar, como explica La Paz de Murcia:

[...] Ahora lo que se necesita es que la dirección de escena, -puesto que el repertorio del género es extenso y hay obras que entretienen sin tener nada de inmorales-, escoja éstas con preferencia para evitar censuras fundadas y el que algunos padres rehúyan de llevar a sus hijas y esposas. De ese modo, uniendo lo barato con el buen deseo de agradar de las partes al respeto a la moral de la dirección y empresa, podrán hacer un buen negocio ${ }^{195}$.

El debate sobre las funciones por horas y la moralidad de algunas obras del género chico continuó en Murcia durante el año cómico 1891-1892. La Paz de Murcia defendía el teatro por secciones, acorde con los intereses de empresarios y público. Si estas funciones estaban permitidas en Madrid y si se admitían representaciones de piezas breves en funciones completas, no había razón para prohibirlas por horas. El problema era, sin embargo, que las funciones por horas favorecían la asistencia de espectadores de todas las condiciones sociales, lo que producía incidentes.

La llegada en octubre de 1891 de la primera compañía infantil de zarzuela al Romea, dirigida por Francisco Perín, calmó las tensiones sobre el teatro por horas, pero abrió un nuevo debate sobre la participación de niños en el teatro. Con Perín actuaron una veintena de niños de entre cuatro y once años, que ofrecieron un repertorio íntegro de zarzuela y contaban, además, con una pequeña sección de baile ${ }^{196}$.

El director de El Diario de Murcia, Martínez Tornel, aconsejó a los murcianos que llevasen a sus hijos al teatro, mientras que La Enseñanza Católica publicó un duro artículo de Gabino Arroyo denunciando que los argumentos de algunas zarzuelas eran indecorosos para ser representados por niños. Arroyo apuntó, incluso, la posibilidad de que los pequeños artistas fuesen objeto de explotación, puesto que debían estar sometidos a trabajo nocturno, largos ensayos y viajes de una ciudad a otra sin un domicilio

${ }^{194}$ De este sentir era La Paz de Murcia, XXXIV (1891), no 11298, 8 abril, p. 1: "No es zarzuela seria, como en un principio se dijo, y sí de las llamadas por horas; y en vista a que el Ayuntamiento no arrienda el teatro para esta clase de funciones, piensan ejecutar tres piececitas y que resulte función completa. Pues esto es peor, porque obliga a los abonados y porque de ser función completa en vez de por horas, ni mejoran el espectáculo ni la compañía". Véase, como ejemplo, la opinión de un espectador en El Diario de Murcia, XII (1890), n 4102, 15 agosto, p. 3.

${ }^{195}$ La Paz de Murcia, XXXIV (1891), n 11303, 14 abril, p. 1. No obstante y a pesar de la prohibición del Ayuntamiento, la compañía de Andrés López dio algunas durante el mes de mayo: "El Ayuntamiento conservador se conoce que no es tan escrupuloso": La Paz de Murcia, XXXIV (1891), nº 11321, 5 mayo, p. 1. Véase Apéndice 3.5.

${ }^{196}$ Salvo la representación de Los sobrinos del capitán Grant, zarzuela en cuatro actos de Fernández Caballero con libreto de Ramos Carrión, el resto de zarzuelas fueron en un acto. 
estable $^{197}$. A pesar de la polémica, el éxito de los pequeños artistas en Murcia fue abrumador $^{198}$.

La compañía de zarzuela de Francisco de la Vega, que actuó en el Teatro Romea desde noviembre de 1891 hasta enero del año siguiente, reabrió la cuestión de las funciones por horas. Esta compañía prometía representaciones por secciones las tardes de festivos y tres noches a la semana (lunes, miércoles y sábados) y funciones completas cuatro noches semanales (martes, jueves, viernes y noches del domingo), pero antes de comenzar el segundo abono, la empresa solicitó al Ayuntamiento la reducción de las funciones completas a los jueves y domingos por la noche. Los siguientes párrafos muestran las interesantes argumentaciones que La Paz de Murcia publicó en defensa del empresario:

El arrendatario del Teatro va a presentar una solicitud al Ayuntamiento pidiendo se le autorice el reducir el número de funciones completas a la semana, ofreciendo a cambio para las que se verifiquen el considerarlas funciones de moda, obsequiando además a las señoras en esas noches.

Lo cierto es que las funciones completas no son las que tienen cuenta a la empresa para sostener el espectáculo y que se la debe conceder sin límites lo que pide.

Está probado que hoy, en temporadas largas, no se puede salir adelante sin las funciones por secciones. Tanto es esto verdad que hasta las compañías de verso adoptan ese sistema. En Córdoba actúa la compañía de don Victorino Tamayo en el teatro Principal y trabaja de ese modo a 25 céntimos la entrada principal y a 15 en el paraíso, para cada sección.

Las compañías que pueden salir adelante con las funciones completas son las que, formadas y con un repertorio corto, van dado un número de funciones en cada teatro, como ocurre con la de Cepillo, la de Pablo López, las de ópera, la de los niños y otras muchas que pudiéramos citar, que no hacen temporadas largas.

Esperamos, por tanto, se conceda lo que se pide, si hemos de tener compañías para este invierno ${ }^{199}$.

El Ayuntamiento aprobó la petición y el nuevo abono de la compañía redujo el número de funciones completas, el precio de las mismas ${ }^{200} \mathrm{y}$, además, sustituyó a uno de sus tenores e incorporó un tenor y una tiple más ${ }^{201}$. Los escándalos en el teatro continuaron a pesar de que se aumentó la presencia policial durante las funciones ${ }^{202}$ y el Ayuntamiento acordó prohibir las funciones por secciones el 7 de enero de 1892, una vez que finalizase el tercer abono de la compañía de Francisco de la Vega.

${ }^{197}$ Véase: Crespo, El Teatro, p. 283. El debate sobre la ética de ver niños actores sobre la escena no fue exclusivo de Murcia. Quejas similares fueron formuladas sobre Madrid por Luis Taboada, "De todo un poco", Madrid Cómico, XII (1892), nº 472, 5 marzo, p. 2.

${ }^{198}$ Véase Crespo, El Teatro, p. 283.

${ }^{199}$ La Paz de Murcia, XXXIV (1891), n 11480, 14 noviembre, p. 3. Las cursivas son editoriales. Ideas similares se publicaron en La Paz de Murcia, XXXIV (1891), $\mathrm{n}^{\text {os }} 11479,13$ noviembre, p. 2; 11481, 16 noviembre, p. 1 y 11483, 18 noviembre, p. 3 (este último incluido en el Documentario).

${ }^{200}$ La Paz de Murcia, XXXIV (1891), nº 11486, 21 noviembre, p. 3. En el primer abono una entrada de butaca de patio en una función completa costaba dos pesetas mientras que en el segundo abono, la misma localidad costaba 1.25 pesetas.

${ }^{201}$ Los nuevos cantantes fueron Concepción Cubas, Miguel Tormo y Las Santas: La Paz de Murcia, XXXIV (1891), $\mathrm{n}^{\circ} 11481,16$ noviembre, p. 3.

${ }^{202}$ Véase “Abusos en Romea”, La Paz de Murcia, XXXIV (1891), n 11493, 30 noviembre, p. 2. 
La compañía de Guillermo Cereceda comenzó a actuar dos días más tarde con funciones completas a base de zarzuelas de uno, dos o tres actos ${ }^{203}$. Esta compañía estrenó en Murcia obras como El rey que rabió (música de Chapí, libreto de Ramos Carrión y Vital Aza), El mismo demonio (música de Chapí, libreto de Fernando Manzano), y Ki-ki-ri-ki (traducida por Granés). Las dos últimas reanimaron la cuestión sobre la moralidad del repertorio y la pertinencia de las funciones por horas. Sobre $E l$ mismo demonio se afirmó: "Toda ella es una majadería de cuerpo entero, sin gracia, sin caracteres, con ribetes, en ocasiones, de estúpida pornografía. La música corre pareja con el libro: no hay nada absolutamente que se eleve sobre lo vulgar, lo ramplón, lo ordinario" ${ }^{204}$. Desde El Diario de Murcia se propuso censurar las obras "inmorales":

[...] Es loable el fin que persigue el Ayuntamiento de concluir con la corrupción e inmoralidad que reina en algunas obritas indignas de un templo del arte (bien entendido éste) y de la cultura que posee o debe adquirir allí el público que a él asiste; pero creo que no ha encontrado aún la fórmula racional y lógica que el buen sentido reclama para terminar de una vez con esas disidencias. ¿Creen los señores concejales que se oponen a la representación por secciones que con prohibir esa forma de explotación está conjurado el mal?. Paréceme que no, puesto que esas mismas obras groseras e inmorales puede ponerlas la empresa en función completa, no dejando por ello de tener la misma grosería e inmoralidad. [i]Será que en las obras de más de un acto no se halla absolutamente una escena, un chiste, que pueda ofender la cultura y aún el pudor de cierta parte del público? [...]. No está ahí, pues, la solución del problema, puesto que suprimir la representación por horas para evitar ese mal, equivaldría a querer curar, por ejemplo, el dolor en una pierna amputándola. Lo que hay que hacer, lógicamente pensando, es no permitir la representación de obras indignas de ello y, para conseguirlo, nada más fácil y racional que someterlas previamente a la censura de una persona de conocida ilustración y moralidad que el Ayuntamiento podría escoger de entre sus miembros algunos de ellos con sobradas condiciones $^{205}$.

A finales de enero de 1892, Juan Hernández Guijarro, arrendatario del Teatro Romea, pidió al Ayuntamiento el permiso para ofrecer funciones por horas, permiso que obtuvo para el mes de febrero ${ }^{206}$. Hernández contrató a la compañía de zarzuela de Manuel Taberner y José María Lorente, que alternó las funciones completas con zarzuelas en un acto y por horas. Una vez más, el Teatro Romea fue escenario de repetidos escándalos por parte del público ${ }^{207}$ y el debate sobre el teatro por horas continuó en la prensa local $^{208}$.

${ }^{203}$ El día 25 de enero la compañía Cereceda se marchó a Cartagena y, posteriormente, a Málaga: $L a$ Paz de Murcia, XXXV (1892), n 11558, 19 febrero, p. 3. En total, actuaron durante 16 días.

${ }^{204}$ La Paz de Murcia, XXXV (1892), $\mathrm{n}^{\circ}$ 11537, 25 enero, p. 1. Algunos periódicos como La Enseñanza Católica y La Verdad fueron muy "reaccionarios" contras las zarzuelas que atentaban a la moral y las buenas costumbres, según Crespo, El Teatro, p. 295.

${ }^{205}$ El Diario de Murcia, XIV (1892), no 4549, 30 enero, pp. 1-2.

${ }^{206}$ El Diario de Murcia, XIV (1892), nº 4547, 28 enero, p. 1.

${ }^{207}$ Véanse más detalles en Crespo, El Teatro, pp. 296-297.

208 A la compañía de Taberner y Lorente le sucedió el elenco de representaciones dramáticas de Wenceslao Bueno, que actuó durante el mes de marzo de 1892. La afluencia de público a los espectáculos de Bueno fue escasa y La Paz de Murcia, XXXV (1892), n 11552, 7 marzo, p. 1 se extrañó de que la clase pudiente, que no se había abonado a las funciones por horas de la compañía de Taberner y Lorente "por los escándalos [...], por no confundirse con cierto público, y hasta por no agradarles el espectáculo" tampoco lo 
El año cómico 1892-1893 fue el que mayor número de compañías y espectáculos de zarzuela incluyó. Salvo los inicios de las dos temporadas del año, que tuvieron funciones dramáticas (con las compañías de Enrique Borrás y Ricardo Calvo, respectivamente), el resto de espectáculos fueron de zarzuela, con seis compañías profesionales, dos de ellas infantiles.

La compañía infantil de alumnos del colegio Progreso y Porvenir de la Infancia de Cartagena, dirigida por Vicente Fuster, tuvo en el Teatro Romea seis actuaciones (dos de ellas por horas) en octubre de 1892. La Paz de Murcia se apresuró a subrayar que la participación de los niños en este espectáculo no era perjudicial para ellos:

[...] El director de ese colegio, que parece trata y cuida bien a los alumnos, ha merecido la confianza de algunos de nuestros paisanos, que les han confiado sus niños para aumentar el personal. En el trabajo que se les hace hacer no hay más molestias que las que pasarían estando de internos en un colegio, donde tendrían que madrugar, horas de estudio y otras de descanso y distracción. Para sacar partido de ellos tienen que instruirlos para que sepan decir bien, para que comprendan hasta dónde es posible lo que dicen y le den el sentido correspondiente y les han de enseñar algo de música así que en nada está en contra de las leyes proyectoras de la infancia, el trabajo que desempeñarán ${ }^{209}$.

La mayor parte de su repertorio fueron zarzuelas en un acto, aunque la empresa ofreció también funciones con zarzuelas en tres actos, como El rey que rabió y La bruja (ambos con música de Chapí y libreto de Ramos Carrión), la opereta Los mosqueteros grises (música de Luis Varney Casademunt y Serrat que fue arreglada al español) y otras más antiguas como Jugar con fuego (música de Barbieri, libreto de De la Vega y Barbieri). La afluencia de público fue buena, incluso en las obras largas ${ }^{210}$.

La compañía estrenó en Murcia varias zarzuelas como La madre del cordero (música de Gerónimo Giménez Bellido, libreto de Yrayzoz), Los aparecidos (música de Fernández Caballero, libreto de Arniches y Lucio) y Las campanadas (música de Chapí, libreto de Arniches y Cantó), entre otras, y dos zarzuelas de artistas murcianos Malasangre (llevada a la escena por primera vez unos meses antes) y Monín, estrenada en el Teatro Romea de Murcia el 29 de octubre de 1892, ambas con música de Muñoz Pedrera y libreto de Joaquín Arques. La compañía de Taberner permaneció en el Teatro Romea hasta el 8 de enero de 1893, fecha en que se desplazó a Cartagena para retornar a la capital pocos días después.

hicieran con las funciones completas de la compañía de Bueno. La Paz de Murcia, XXXV (1892), nº 11553, 8 marzo, p. 1 llegó a afirmar: “¿Habrá que apelar a dar actos por horas para buscar en las clases pobres la protección que no dan las privilegiadas?”.

${ }^{209}$ La Paz de Murcia, XXXV (1892), nº 11727, 10 octubre, p. 1. Las compañías infantiles fueron a menudo objeto de crítica por parte de la prensa. El periódico cartagenero El Álbum, I (1891), $\mathrm{n}^{\circ}$ 14, 15 septiembre, p. 114 afirmaba: "tanta precocidad es a mi juicio perjudicial, así por la emulación que despierta en los niños de Cartagena que pasan todo el día cantando, sin ocuparse en otra cosa, como por el incesante trabajo que para seres de tan corta edad representan tres o cuatro actos a diario, ensayos y demás. [...] Cuando debían estar jugando están aprendiendo a ser chulos y tenorios de baja estofa, tenores de zarzuela corta".

${ }^{210}$ Adolfo Balboa, "Espectáculos", en La Paz de Murcia, XXXV (1892), n 11753, 10 noviembre, p. 2. 
Durante la ausencia de la compañía de Taberner, actuó en el Teatro Romea la compañía de Ventura de la Vega con funciones por horas, que dieron lugar a nuevos altercados en el teatro ${ }^{211}$. El día 22 de enero de 1893, la compañía suspendió inesperadamente sus representaciones, aunque había anunciado un segundo abono. Ventura de la Vega y otros artistas del grupo formaron una nueva compañía que actuó en el Teatro Princesa de Valencia ${ }^{212}$.

Inmediatamente volvió al Romea la compañía de Taberner, que combinó funciones de zarzuela grande con género chico y estrenó Bernal y compañía, zarzuela creada por los artistas murcianos Muñoz Arques y Joaquín Arques y música de Muñoz Pedrera. La primera temporada de 1892-1893 se completó con la compañía infantil de Elías Serna y Daniel Prats que sólo duró dos días en cartelera con zarzuelas del género chico.

Durante la segunda temporada del año cómico 1892-1893 actuaron en el Teatro Romea dos compañías especializadas zarzuelas de gran formato. La primera, dirigida por Miguel Soler obtuvo un éxito contundente y llevó a escena zarzuelas de Barbieri (Los diamantes de la corona), Barbieri y Gaztambide (El sargento Federico), Chapí (La tempestad y La bruja), Fernández Caballero (La marsellesa), Arrieta (La guerra santa) y Oudrid (El molinero de Subiza) y estrenaron la zarzuela cómica El Húsar, con música de Vicente Roger ${ }^{213}$.

La segunda compañía de zarzuela grande, que actuó en Murcia en junio estaba dirigida por el empresario Eduardo Ortiz y estrenó en el Teatro Romea la zarzuela en tres actos El cañón (música de Miguel Marqués, libreto de Guillermo Perrín) y el juguete cómico-lírico en uno titulado El gran petardo (con música y libreto de Vicente Peydró).

Entre 1893 y 1895 sólo actuaron dos compañías de zarzuela en el Teatro Romea: una en la primera temporada de 1893-1894 y otra en la primera temporada del año cómico siguiente. El 14 de septiembre de 1893 se inauguró el Teatro Circo Villar, por lo que la afluencia al Teatro Romea disminuyó: "Los teatros han tenido esta semana algunas noches de lleno y otras de entrada floja. Dos teatros funcionando diariamente y sin cesar son muchos teatros para Murcia"214. Las empresas teatrales se veían perjudicadas con esta duplicación de la oferta de espectáculos similares:

[...] En Murcia, por nuestra desgracia, no tenemos población flotante de forasteros que entran y salen como en otras poblaciones y los que aquí acuden, no son suficientes para sostener los dos teatros.

Las empresas apelaron en 1893-94 a todos los medios, novedad en los espectáculos, buenos artistas, variación de género, precios baratos, hicieron todo lo que se puede hacer por atraer público y lo consiguieron, pero no el suficiente para cubrir gastos y todas las empresas perdían, lo cual es lo que causa el desaliento de hoy.

${ }^{211}$ Entre sus miembros, además de Ventura de la Vega, estaban Francisca Fernani y Alfredo Suárez. Sobre los altercados véase, por ejemplo, El Diario de Murcia, XV (1893), nº 5831, 18 enero, pp. 1, 4.

${ }^{212}$ El Diario de Murcia, XV (1893), ${ }^{\text {os }} 5839,27$ enero, p. 3 y 5844, 2 febrero, p. 2.

${ }^{213}$ El Diario de Murcia, XV (1893), no 5932, 16 mayo, p. 2. Entre los integrantes de la compañía estaba Almerinda Soler y el tenor Berges.

${ }^{214}$ El diario de Murcia, XV (1893), n ${ }^{\text {os }} 6077,29$ octubre, p. 1 y 6065, 15 octubre, p. 1. 
Luego, allá en la Pascua, estarán abiertos los dos y es de creer que aún a pesar del deseo que hay de ese espectáculo, que no tengan los teatros los llenos que necesitan, ni las ganancias que en años anteriores se obtenían en Romea cuando estaba sólo.

Si el nuevo teatro hubiera podido tener vida como de verano y con espectáculos propios de Circo, nada de esto sucedería, entonces cada teatro funcionaría en su temporada. ${ }^{215}$.

El año cómico 1894-1895 comenzó en el mes de diciembre en ambos coliseos; en el Romea, con la compañía de zarzuela de Florencio de la $\mathrm{Cruz}^{216}$. Probablemente para diferenciarse de la compañía que actuaba en el Teatro Circo Villar con funciones por horas, las siete primeras representaciones de la compañía de Florencio de la Cruz fueron de zarzuela grande con obras como Jugar con fuego, La tempestad, El anillo de hierro, Marina y La marsellesa, entre otras. Después, la compañía dio dos funciones por secciones y se disolvió ${ }^{217}$. Algunos de los artistas que permanecieron en Murcia formaron una nueva compañía con otros actores procedentes de Madrid como la primera tiple María Medina y el tenor cómico y director de escena Gabriel Sánchez de Castilla y Juan G. Catalá como maestro concertador ${ }^{218}$. La nueva compañía de Sánchez Castilla programó veinte funciones para Navidad, todas por horas, que contaron con gran afluencia de público y críticas favorables:

Romea

Anoche reanudó sus funciones este coliseo con cambio de género y de personal.

La numerosa concurrencia que favoreció las cuatro secciones, en las cuales vimos en plateas, palcos y butacas el personal que siempre ha asistido a Romea, y echábamos de menos en las funciones serias de la anterior compañía, ha demostrado palpablemente que el anatematizado género chico en años anteriores, ha logrado vencer y el público prefiere el reír y oír música ligera y fácil de aprender, al género serio para el cual los autores no dan obras nuevas y hay que apelar al repertorio ya tan conocido. [...]. El resultado del debut de la nueva compañía presagia que Romea se verá muy favorecido en las funciones sucesivas ${ }^{219}$.

La compañía de Sánchez Castilla estrenó un gran número de obras en Murcia, entre ellas, El martes se la llevan o Al monte, al monte, de los murcianos Muñoz Pedrera (música) y Joaquín Arques (libreto). Sin embargo, por desavenencias con la empresa

${ }^{215}$ La Paz de Murcia, XXXVI (1894), no 12816, 25 octubre, p. 1. La compañía del maestro director y concertador Ramón Blasco con el primer actor José Portes comenzó en octubre de 1893 y permaneció hasta enero del año siguiente. Todas sus representaciones fueron por horas, salvo la función de estreno de Los riffeños (zarzuela en dos actos con texto de Joaquín Arques y música de Adolfo Gascón) a finales del mes de noviembre de 1893.

${ }^{216}$ La Paz de Murcia, XXXVI (1894), no 12816, 25 octubre, p. 1. En noviembre de 1894, aún no se había contratado ninguna compañía en el Teatro Romea. Según La Paz de Murcia, XXXVI (1894), n 12838, 20 noviembre, p. 4 a finales de este mes el arrendatario del teatro Ramón Sierra se desplazó a Madrid para la contratación de personal.

${ }^{217}$ Se acusó a la empresa arrendataria del Romea de haber dejado de pagar una semana a los actores y cantantes, aunque esto fue desmentido en La Paz de Murcia, XXXVI (1894), nº 12857, 15 diciembre, p. 2.

${ }^{218}$ La Paz de Murcia, XXXVI (1894), nº 12857, 15 diciembre, p. 2.

${ }^{219}$ La Paz de Murcia, XXXVI (1894), nº 12862, 21 diciembre, p. 2. Las cursivas son editoriales. 
teatral Sánchez Castilla dejó la compañía a principios de enero de $1895^{220}$. Fue sustituido por José Moncayo y se contrató un nuevo tenor cómico, José Ángeles ${ }^{221}$, lo que permitió que las representaciones de la compañía continuaran hasta finales de febrero de $1895^{222}$.

Desde 1895 hasta el incendio del Teatro Romea (10-12-1899) desfilaron por su escenario veintitrés compañías, de las cuales diez fueron de zarzuela, diez de teatro declamado, dos de ópera y una de opereta (ver Tabla 3.2). Destacó entre ellas la compañía del murciano Pablo López, arrendatario a su vez del Teatro Romea durante el año 18961897.

Tabla 3.2. Compañías teatrales del Teatro Romea (1895-1899)

Fuente: Crespo, Historia, pp. 363-430.

B: compañía de baile; C: Concierto; O: compañía de ópera; Opt.: compañía de opereta; T: compañía teatral no específicamente musical; Z: compañía de zarzuela.

\begin{tabular}{|l|l|}
\hline Año cómico & Compañías, tipo de espectáculo (fecha de debut) \\
\hline $1895-1896$ & Juan Bosch, Z infantil (3-10-1895) \\
& Manuel Espejo, T (finales de octubre-1895) \\
& Francisco de la Vega, Z (22-12-1895) \\
& Emilio Giovannini, Opt (principios de mayo de 1896) \\
\hline $1896-1897$ & Emilio Mario y Carmen Cobeña, T (27-09-1896) \\
& Pablo López, Z (31-10-1896) \\
& Juan Espantelón, T (finales de noviembre de 1896) \\
& Pablo López, Z (25-12-1896) \\
& Antonio Vico, T (17-02-1897) \\
& Galvani, O (principios de marzo 1897) \\
\hline $1897-1898$ & Juan Bosch, Z infantil (septiembre 1897) \\
& Juan Espantaleón, T (diciembre 1897) \\
& Pablo López, Z (5-02-1898) \\
& Guillermo Cereceda, Z (10-04-1898) \\
& Francisco Fuentes, T (finales de abril de 1898) \\
\hline Antonio Vico, T (21-09-1898) & Pablo Gorgé, Z (19-11-1898) \\
& Wenceslao Bueno, T (1-04-1899) \\
& Rosa Caligari (primera tiple), O (14-04-1899) \\
& Juan Espantaleón, T (principios de mayo de 1899) \\
& Ceferino Palencia, T (8-06-1899) \\
\hline Guillermo Cereceda, Z (28-9-1899) \\
& Ricardo Sendra, Z (principios de noviembre de 1899) \\
\hline $1898-1899$ & 10-12-1899 Incendio del Teatro Romea \\
\hline &
\end{tabular}

\subsection{Características de las compañías}

Si se comparan el periodo de años de 1871 a 1888 (fecha de introducción del género bufo e implantación del sistema por horas, respectivamente) con los años siguientes, 1888-1895 se obtiene que las compañías de esta segunda franja de años dieron

${ }^{220}$ La Paz de Murcia, XXXVII (1895), no 12872, 3 enero, p. 2.

${ }^{221}$ La Paz de Murcia, XXXVII (1895), n 12876, 8 enero, pp. 1-2. Por este motivo, los días 8 y 9 de enero no hubo función en el teatro.

${ }^{222}$ Durante la Cuaresma de 1895, la compañía se trasladó al Teatro Circo de Alicante: La Paz de Murcia, XXXVII (1895), nº 12911, 23 febrero, p. 2. 
un número menor de funciones por compañía, lo que implica menos tiempo de permanencia en la ciudad y la ausencia de larguísimas temporadas con los mismos artistas. Entre 1871 y 1888 las compañías ofrecieron una media de 61 funciones (incluidas las sesiones de la tarde), mientras que durante 1888-1895 se reduce a poco más de la mitad (33 funciones de media por compañía). Algunas compañías de los años 1871 a 1888 superaron las 200 funciones (por ejemplo, la de Daniel Banquells), mientras que en los años 1888-1895, ninguna llegó a esta cifra (la que más representaciones dio fue la de Francisco Galván y Félix, con 123 funciones).

La polivalencia de las compañías de los primeros años de la segunda mitad del siglo XIX (compuestas por secciones o cuadros especializados en género dramático, lírico y coreográfico) se fue perdiendo a medida que avanzó el siglo y sustituyéndose por compañías que estaban especializadas en género chico, zarzuela grande (o "seria") o en ambas.

Las cuarenta y cinco compañías que he podido documentar durante la segunda mitad del siglo XIX tuvieron una media de quince voces principales, veinticinco integrantes en el coro, una orquesta de más de 30 músicos (y muy frecuentemente de 40), de dos a cuatro directores (raramente cinco) de escena, orquesta y coro, dos o tres apuntadores (uno o dos de verso y otro de música) y otros colaboradores (peluquería, sastrería, maquinista, escenógrafos, maquinaria y escenografía, guardarropía y archivero, entre otros $)^{223}$.

Todas las compañías que actuaron en el Teatro Infantes-Romea recalaron en la ciudad en el curso de giras más amplias y generalmente llegaban desde ValenciaAlicante, Andalucía o Madrid-Albacete. Cuando abandonaban Murcia capital, las compañías solían seguir sus giras por otras poblaciones de la región murciana (principalmente Cartagena $\mathrm{y}$, en menor medida, Lorca) y/o dirigirse después hacia el Norte (Alicante, Valencia, Barcelona) o hacia el oeste, en dirección a Andalucía (Almería, Granada).

Como ejemplo, he reconstruido el circuito de actuaciones de la compañía de Manuel Taberner desde enero de 1892 hasta febrero del año siguiente (véase Tabla 3.3 y Figura 3. 2).

Tabla 3.3. Circuito de actuaciones de la compañía de Manuel Taberner (1892-1893).

\begin{tabular}{|c|c|c|}
\hline Fecha & Teatro, ciudad & Fuente \\
\hline$?-01-1892$ & $\begin{array}{l}\text { Teatro Circo, Cartagena } \\
\text { (Murcia) }\end{array}$ & $\begin{array}{l}\text { La Paz de Murcia, XXXV (1892), } \mathrm{n}^{\mathrm{o}} \\
\text { 11523, } 8 \text { enero, p. } 2\end{array}$ \\
\hline $\begin{array}{l}30-01-1892 \text { a } \\
1-03-1892\end{array}$ & Teatro Romea, Murcia & $\begin{array}{l}\text { La Paz de Murcia, XXXV (1892), } \mathrm{n}^{\text {os }} \\
\text { 11541, 29 enero, p. 3; 11542, } 30 \\
\text { enero, p. 3; 11547, } 29 \text { febrero, p. } 3 \text { y } \\
\text { 11548, } 2 \text { marzo, p. } 1\end{array}$ \\
\hline$?-03-1892$ & [No consta], Albacete & $\begin{array}{l}\text { La Paz de Murcia, XXXV (1892), } \mathrm{n}^{\circ} \\
\text { 11548, } 2 \text { marzo, p. } 1\end{array}$ \\
\hline$?-04-1892$ & [No consta], Lorca (Murcia) & $\begin{array}{l}\text { La Paz de Murcia, XXXV (1892), } \mathrm{n}^{\text {os }} \\
\text { 11590, } 24 \text { abril, p. 3; 11590, } 25 \\
\text { abril, p. } 3\end{array}$ \\
\hline
\end{tabular}

${ }^{223}$ De las 45 compañías estudiadas, cuatro tuvieron 23 voces principales y otra, 24 (véase Apéndice 3.2). 


\begin{tabular}{|c|c|c|}
\hline$?-05-1892$ & [No consta], Cuevas, Almería & $\begin{array}{l}\text { La Paz de Murcia, XXXV (1892), } \mathrm{n}^{\circ} \\
\text { 11610, } 18 \text { mayo, p. } 3\end{array}$ \\
\hline$?-08-1892$ & [No consta], Alicante & $\begin{array}{l}\text { La Paz de Murcia, XXXV (1892), } \mathrm{n}^{\circ} \\
\text { 11675, } 8 \text { agosto, p. } 3\end{array}$ \\
\hline $\begin{array}{lrr}2 & \mathrm{a} & 18-09- \\
1892 & \end{array}$ & Teatro Circo, Albacete & $\begin{array}{l}\text { La Paz de Murcia, XXXV (1892), n }{ }^{\text {os }} \\
\text { 11692, } 30 \text { agosto, p. } 3 \text { y } 11705,17 \\
\text { septiembre, p. } 2\end{array}$ \\
\hline $\begin{array}{l}20-09-1892 \text { a } \\
8-10-1892\end{array}$ & $\begin{array}{lll}\text { Teatro } & \text { Guerra, } & \text { Lorca } \\
\text { (Murcia) } & & \end{array}$ & 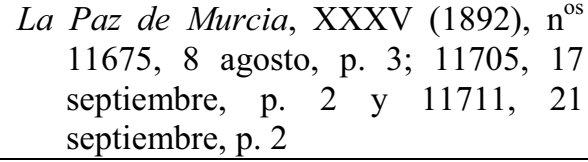 \\
\hline $\begin{array}{l}15-10-1892 \text { a } \\
8-01-1893\end{array}$ & Teatro Romea, Murcia & $\begin{array}{l}\text { La Paz de Murcia, XXXV (1892), nos } \\
\text { 11731, } 14 \text { octubre, p. 3; 11732, } 15 \\
\text { octubre, p. } 3 \text { y } 11733,17 \text { octubre, p. } \\
\text { 1; El Diario de Murcia, XV (1893), } \\
\mathrm{n}^{\mathrm{o}} \text { 5823, } 8 \text { enero, p. } 3\end{array}$ \\
\hline $\begin{array}{l}13-01-1893 \text { a } \\
\text { ¿23?-01-1893 }\end{array}$ & $\begin{array}{l}\text { [No consta], } \\
\text { (Murcia) }\end{array}$ & $\begin{array}{l}\text { El Diario de Murcia, XV (1893), } \mathrm{n}^{\circ} \\
5828,14 \text { enero, p. } 2\end{array}$ \\
\hline $\begin{array}{l}24-01-1893 \text { a } \\
14-02-1893\end{array}$ & Teatro Romea, Murcia & $\begin{array}{l}\text { El Diario de Murcia, XV (1893), n }{ }^{\text {os }} \\
5835,22 \text { enero, p. } 4 ; 5854,14 \\
\text { febrero, p. } 4 ; 5856,16 \text { febrero, p. } \\
3\end{array}$ \\
\hline$?-02-1893$ & [No consta], Almería & $\begin{array}{l}\text { El Diario de Murcia, XV (1893), } \mathrm{n}^{\mathrm{o}} \\
\text { 5855, } 15 \text { febrero, p. } 2\end{array}$ \\
\hline
\end{tabular}

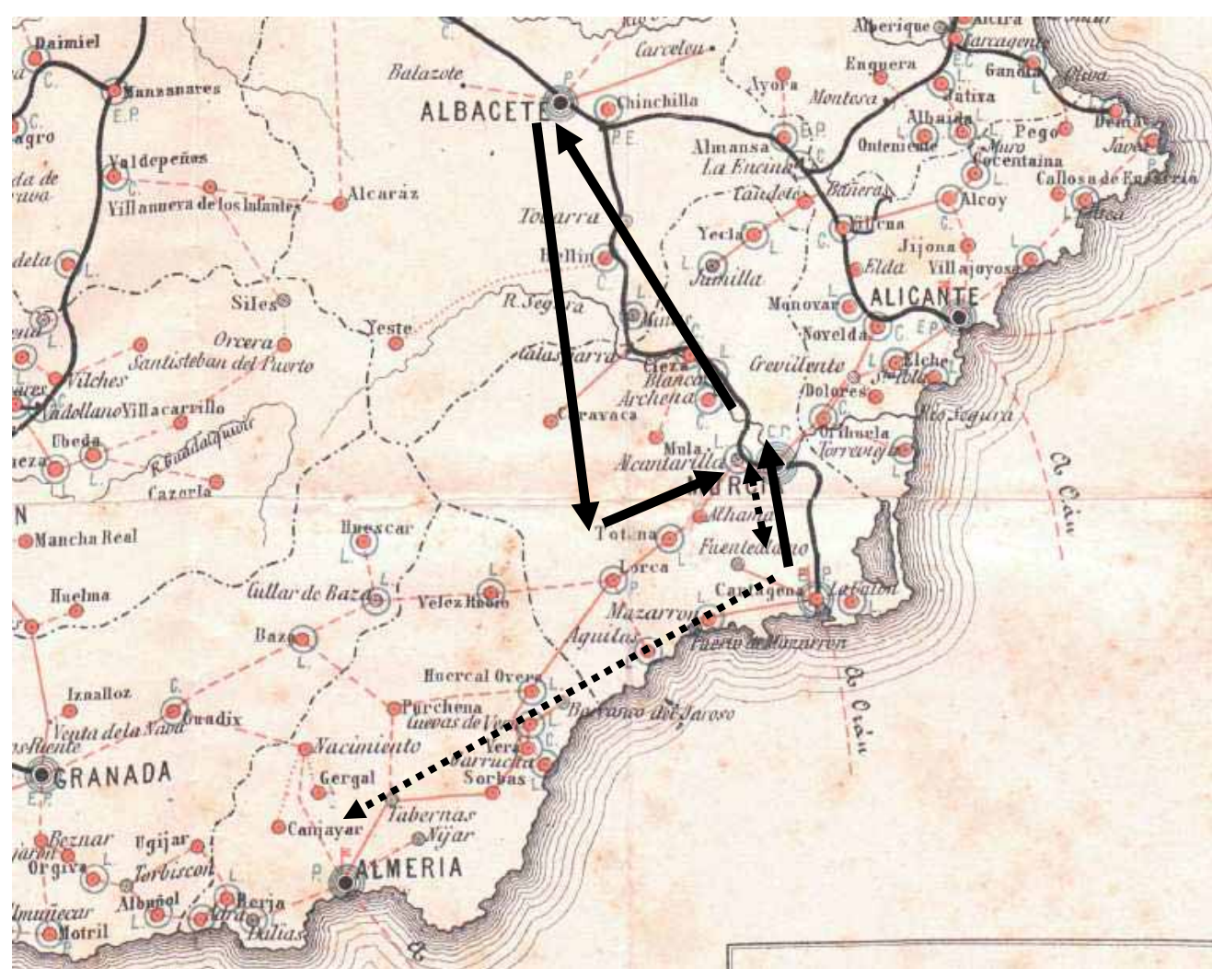

Figura 3. 2. Gira de la compañía de Manuel Taberner por el sur de España (1892-1893). Carta Postal y telegráfica de España, 1884. Biblioteca Regional de Murcia. Accesible en: http://bibliotecadigital.carm.es (acceso el 16-08-2011).

Flechas continuas: año 1892; Flechas discontinuas: 1893. 
Con mucha frecuencia, estas compañías visitaban otros puntos de la Región, especialmente Cartagena y, en menor medida, Lorca. Como hemos comprobado, existieron vínculos entre el Teatro Principal de Cartagena y el Romea, hasta el punto de intercambiarse sus compañías.

No fue usual que llegaran a la ciudad compañías estables y cohesionadas. Una excepción fue la compañía de Guillermo Cereceda. Muchas de las compañías estudiadas eran dirigidas escénicamente por un cantante principal que a veces era también el empresario de la compañía ${ }^{224}$. El nombre del director y de las voces principales bastaba para atraer al público antes incluso de saber el repertorio que se iba a representar.

Fue frecuente que las compañías profesionales comenzaran sus actuaciones en los teatros murcianos sin el elenco completo, y que algunos artistas (especialmente las voces principales) fueran cambiadas en el curso de las actuaciones. La falta de ensayos, la escasa adecuación del reparto de papeles y la precipitación de la puesta en escena de las obras fueron críticas constantes a las compañías de zarzuela, que revelan las limitaciones que sus resultados artísticos tuvieron que tener ${ }^{225}$.

La mayor parte de las compañías de aficionados actuaron en teatros o locales teatrales dependientes de sociedades recreativas (ver Capítulo 6), aunque a veces daban funciones benéficas en el Teatro Romea. Generalmente, estas actuaciones contaban con actores varones aficionados y actrices profesionales contratadas (procedentes de las compañías que estaban actuando en ese momento en la ciudad).

Las compañías infantiles de zarzuela que actuaron en el Teatro Romea eran de dos tipos: de aficionados o profesionales. Del primer tipo era la compañía de alumnos del Instituto de Secundaria, dirigida por Julián Calvo que actuó en 1860. La primera compañía infantil profesional de zarzuela que actuó en el Teatro Romea en 1891-1892 fue la dirigida por Francisco Perín cuyo elenco es el único que detalló la prensa. El conjunto estaba integrado por quince voces principales, el mismo número de cantantes que la compañía infantil de Juan Bosch, que actuó en el Teatro Circo Villar en 1894, aunque con un reparto de tiples, contraltos, tenores y bajos diferente en cada una. Ambas contaron con una sección de baile de tres y nueve bailarines, además de un número variable de actores para papeles secundarios (véase Apéndice 3.2). La Paz de Murcia menciona una "compañía infantil de zarzuela de esta ciudad" a propósito de sus representaciones en el Teatro de Alhama aunque no se especifica si había formado en Murcia ${ }^{226}$. Las representaciones de zarzuelas llevadas a cabo por niños actores no fue un fenómeno exclusivo de Murcia 227.

224 Casares, "Compañías de zarzuela", pp. 527-528 observa cuatro variedades de compañías de zarzuela, formadas a partir de: 1) la asociación de diversas personas integradas en el mismo proyecto en los que solía haber músicos, cantantes y libretistas; 2) un empresario no músico; 3) uno o dos compositores más o menos importantes; 4) un cantante famoso, un actor o una pareja de artistas.

${ }^{225}$ Véase, Benito, La vida, p. 68.

${ }^{226}$ Los beneficios de sus funciones se destinaron al Manicomio Provincial: La Paz de Murcia, XXXV (1892), n ${ }^{\circ} 11544,3$ febrero, p. 3. También es probable que se refiera a la compañía de alumnos del colegio Progreso y Porvenir de la Infancia de Cartagena, dirigidos por Vicente Fuster, que actuó en el Teatro Romea desde octubre de 1892.

${ }^{227}$ En Cartagena, el aficionado José Jumilla formó una compañía de infantil zarzuela en 1891 y en Lorca, se proyectó otra con niños de tres a ochos años en el mismo año: Diario de Cartagena, II (1891), $\mathrm{n}^{\circ}$ 


\subsection{El repertorio}

La zarzuela fue el género más cultivado en los teatros murcianos de la segunda mitad del siglo XIX, muy por delante de la ópera, la música sinfónica y todo tipo de conciertos. Esa preferencia se consideraba un rasgo nacional:

No somos apasionados ni mucho menos de la música alemana. A fuer de españoles y de españoles meridionales, confesamos que nos gusta la música de nuestra patria y por ende su representación más completa, la música de zarzuela. Nuestro gusto, nuestra inteligencia musical no se ha elevado a más altas regiones $[\ldots]^{228}$.

El repertorio era mayoritariamente escogido por los empresarios de las compañías, aunque con frecuencia la prensa se erigió en portavoz del público y formuló peticiones expresas a las empresas teatrales para que representaran o repitieran obras ${ }^{229}$.

Las funciones de zarzuela solían comenzar por una "sinfonía" inicial, a la que seguían una o varias zarzuelas, dependiendo del número de actos que éstas tuvieran ${ }^{230}$. En algunas funciones se alternaban obras sólo teatrales con obras musicales, si la compañía disponía de un cuadro de actores y otro de cantantes.

Las funciones "a beneficio de" y las funciones benéficas tenían una estructura similar, aunque eran más largas y variadas. En las primeras, el "beneficiado" solía escoger todo o parte del repertorio ${ }^{231}$.

En algunas zarzuelas se suprimía la música de algunos números. Así ocurrió con El juicio final (primera producción musical de Miguel Albelda con libreto de Santisteban) en 1866 en el Teatro de los Infantes. La supresión de la música no pasó desapercibida por la prensa:

[...] Se terminó con la zarzuela nueva El juicio final y, a pesar de esta circunstancia, no pasó desapercibido que se presentaba mutilada en su parte más importante cual es la música, pues se le había suprimido los números dos y tres. Más aceptable sería que se diesen piezas nuevas de las muchas que aún no hemos visto, que

521, 18 noviembre, p. 2 y La Paz de Murcia, XXXV (1892), n 11711, 21 septiembre, p. 2. Sobre las compañías infantiles en Albacete, véase: Sánchez Huedo, La actividad, pp. 151-156.

${ }^{228}$ La Paz de Murcia, XVII (1874), no 5249, 27 diciembre, p. 1.

${ }^{229}$ Véase La Paz de Murcia, II (1859), $\mathrm{n}^{\mathrm{o}}$ 567, 14 diciembre, p. 1 transcrito en el Documentario y otros ejemplos La Paz de Murcia: II (1859), no 569, 16 diciembre, p. 1 y XXVIII (1885), n ${ }^{\text {os }} 8110,4$ enero, p. 1 y 8111, 6 enero, p. 1.

${ }^{230}$ Estas sinfonías no parecen haber sido obras sinfónicas propiamente dichas. En 1882, se interpretó una sinfonía-potpurrí de fragmentos de zarzuela del compositor Marqués, a cargo de la orquesta del Teatro Romea y la Banda de la Misericordia que fue descrita así: "La sinfonía de Marqués sobre motivos de zarzuela no es un hilvanado de trozos escogidos a capricho. Es una obra magistral, es una fusión artística, en cuya ejecución se distinguieron la orquesta del teatro y la banda de Misericordia [...]": El Diario de Murcia, IV (1882), nº 904, 17 febrero, p. 2 (ver Capítulo 5).

${ }^{231}$ La Paz de Murcia, XVII (1874), nº 5005, 20 febrero, p. 1. 
obras en que hemos de notar muchos defectos por precisión, por la falta de elementos que la compañía tiene para presentarlas ${ }^{232}$.

A veces también se mutilaban algunas secciones de las zarzuelas. Por ejemplo, la compañía de Ramón Blasco incluyó en varias funciones por horas el segundo acto de Los riffeños y de Marina, pero no con los consiguientes primeros actos ${ }^{233}$.

Las compañías viajaban con un archivo limitado y procuraban alternar obras que habían sido estrenadas recientemente en Madrid con otras de "repertorio", esto es, más antiguas pero habían sido elegidas de forma natural por parte del público ${ }^{234}$. Cuando era necesario, las partituras solían pedirse a Madrid y el retraso de su llegada alteraba la programación. Por ejemplo, en la función a beneficio de Adela Leyda, prevista para el 8 de febrero de 1873, la cantante había solicitado que se interpretara Los órganos de Móstoles. Una semana más tarde la música no había llegado y hubo de ser sustituida por El joven Telémaco y La soirée de Cachupin ${ }^{235}$. Las obras para el debut de la compañía de Manuel Martínez tuvieron que ser variadas, ya que la música no llegó a tiempo. Se utilizaron partituras facilitadas por el músico Adolfo Gascón, que regentaba un almacén de música ${ }^{236}$.

La compañía de Miguel Soler prometió el estreno de la zarzuela Las nueve de la noche, del murciano Fernández Caballero en 1876 pero no llegó a ponerla en escena probablemente porque recibió las partituras apenas una semana antes del estreno ${ }^{237}$.

Desde la apertura del Teatro de los Infantes (1862) hasta la introducción del género bufo en Murcia (en 1871) los compositores de los que más zarzuelas se representaron en el Teatro de los Infantes-Romea de Murcia fueron Barbieri, seguido de Gaztambide y Arrieta (por este orden). En ese periodo de tiempo se llevaron a cabo 168 funciones, con 49 títulos diferentes de 16 compositores (ver Apéndice 3.6). Algunos de los títulos más representados se presentan en la Tabla 3.4:

${ }^{232}$ La Paz de Murcia, IX (1866), nº 2431, 28 enero, p. 1.

${ }^{233}$ La Paz de Murcia, XVII (1874), n 4996, 10 febrero, p. 1.

${ }^{234}$ Benito, La vida, p. 69.

${ }^{235}$ La Paz de Murcia, XVI (1873), n ${ }^{\text {os }}$ 4690, 6 febrero, p. 1; 4691, 7 febrero, p. 1; 4692, 8 febrero, p. 1 y 4697, 14 febrero, p. 1. Un ejemplo similar ocurrió en la función a beneficio de Eloísa Morera: "por no haber recibido hasta ayer la partitura de El tesoro escondido, que había elegido para su beneficio, ha tenido que optar entre las obras hechas y como la que más ha agradado, Barba-azul [sic]": La Paz de Murcia, XIV (1871), $\mathrm{n}^{\mathrm{o}}$ 4175, 25 mayo, p. 1.

${ }^{236}$ La obra inicialmente anunciada para el debut (25-01-1889) fue Las hijas del Zebedeo (zarzuela en dos actos con música de Ruperto Chapí y libreto de Estremera) y fue sustituida por Niña Pancha y El gorro frigio. En este caso, además, el empresario alquiló las partituras para una orquesta reducida, dejando a las trompas, fagotes, oboe y dos contrabajos sin tocar en varias funciones: La Paz de Murcia, XXXIII (1890), $\mathrm{n}^{\text {os }} 10036,29$ enero, p. 1 y 10037,30 enero, p. 1.

${ }^{237}$ La Paz de Murcia, XVIII (1875), $\mathrm{n}^{\text {os }} 5628,22$ diciembre, p. 1 y 5632, 29 diciembre, p. 1 y La Paz de Murcia, XIX (1876), nº 5636, 4 enero, p. 1. 
Tabla 3.4. Compositores y zarzuelas más representadas en el Teatro de los Infantes de Murcia (1862-1871).

Elaboración propia. Véase las fuentes documentales en el Apéndice 3.4 y 3.6.

\begin{tabular}{|l|c|c|l|}
\hline Compositor & $\begin{array}{c}\mathbf{N}^{\mathbf{0}} \\
\text { representaciones }\end{array}$ & $\begin{array}{l}\mathbf{N}^{\mathbf{o}} \text { Títulos } \\
\text { diferentes }\end{array}$ & $\begin{array}{l}\text { Título más representados } \\
\text { (actos) }\end{array}$ \\
\hline Arrieta, Emilio & 17 & 6 & Marina (2) \\
\hline $\begin{array}{l}\text { [Asenjo] Barbieri, } \\
\text { Francisco de Asís } \\
\text { Esteban }\end{array}$ & 52 & 14 & $\begin{array}{l}\text { Un caballero particular }(1) \\
\text { El secreto de una dama (3) }\end{array}$ \\
\hline $\begin{array}{l}\text { Fernández Caballero, } \\
\text { Manuel }\end{array}$ & 5 & 1 & El loco de la guardilla (1) \\
\hline Gaztambide, Joaquín & 48 & 10 & $\begin{array}{l}\text { El juramento (3) } \\
\text { Un pleito }(1) \\
\text { Las hijas de Eva }(3) \\
\text { Una vieja }(1)\end{array}$ \\
\hline Mazza, Giuseppe & 9 & 1 & Campanone (3) \\
\hline Oudrid, Cristóbal & 12 & 4 & $\begin{array}{l}\text { Nadie se muere hasta que } \\
\text { Dios quiere }(1)\end{array}$ \\
\hline Rogel, José & 11 & 3 & Las amazonas del Tormes $(2)$ \\
\hline
\end{tabular}

El predominio numérico de las zarzuelas en dos o más actos en esta etapa es evidente: entre las representadas en más de cinco ocasiones hubo diez zarzuelas en dos o tres actos. Se llevaron a escena catorce títulos diferentes de Barbieri, casi todos ellos representados de nuevo en años posteriores, tanto de su etapa compositiva de los años cincuenta (Los diamantes de la corona, El diablo en el poder, El relámpago, Los dos ciegos, El sargento Federico, en colaboración con Gaztambide, y Mis dos mujeres) como de años posteriores ${ }^{238}$. Las zarzuelas de Barbieri siempre tuvieron buena recepción en Murcia, de las que se ensalzaba la calidad de su música. Sobre El secreto de una dama, con libreto de Luis Rivera y representada en Murcia el 4 de mayo de 1867, se afirmó:

[...] El señor Barbieri, cuyo nombre ha traspasando la valla que encierra a las medianías [y] ha adquirido los títulos de un justo renombre, ha puesto la música. El spartito, como dirían los dilettantis de pur sang, pues hace tiempo que se adorna el castellano con macarrones italianos y trufas a la francesa [sic].

El señor Luis Rivera, muy conocido en las columnas del "Gil Blas" ha sacado de su cabeza los versos, peripecias, accidentes y enredos que constituyen el libreto. $[\ldots]$.

Ahora sólo podemos decir que nos han gustado mucho la introducción, un cuarteto, un dúo, un concertante y el coro del brindis; que hemos reído con alguna de las gracias que salpican la obra; que no nos parece siempre sal pura de Minglanilla, la sal que se ha derramado por su páginas; y, por último, que nos parece una obra digna de haberse escrito en la breve temporada en que la zarzuela, vestida aún de musa, no exhibía los cascabeles y cintajos que después le han colgado payasos y bufones $[\ldots]^{239}$.

${ }^{238}$ Hubo dos zarzuelas de Barbieri que no se representaron en Murcia después de 1871: Tramoya (libreto de Olona) y El niño (libreto de Mariano Pina), según la documentación consultada.

${ }^{239}$ Homoquidam, "Variedades", La Paz de Murcia, X (1867), n 2875, 5 mayo, p. 2. Véase otra crítica a El secreto de una dama en Homoquidam, "Teatro. Estreno de Perico", La Paz de Murcia, X (1867), n 2884, 14 mayo, pp. 1-2, transcrito en el Documentario. 
También en mayo de 1867 se estrenó en Murcia Pan y toros de Barbieri (libreto de José Picón), de nuevo con buena acogida ${ }^{240}$.

Varias zarzuelas de Gaztambide fueron representadas en el Teatro Provisional de Murcia durante los años 1858-1860 (por ejemplo, Catalina, Los magyares y El juramento) y posteriormente volvieron al Teatro de los Infantes-Romea junto con otros títulos del mismo compositor, como Las hijas de Eva, El diablo las carga, La edad en la boca, El estreno de una artista, Un pleito, Una vieja y En las astas del toro.

De Emilio Arrieta se representaron en 1862-1871 seis zarzuelas diferentes, entre ellas El toque de ánimas, que recibió una buena crítica ${ }^{241}$.

Las amazonas del Tormes de José Rogel fue una de las zarzuelas más repetidas en la ciudad, aunque en su estreno ( 24 de abril de 1866) recibió críticas negativas:

[...] El libreto, destinado a hacer reír, lo consigue casi en general pero por lo demás, poco ha tenido que agudizar su ingenio pues examinando con detenimiento, no encontramos en él argumento alguno ni razón del título, y sí sólo una miscelánea de escenas de Las travesuras de Juana y de Catalina con otras nuevas en su mayoría inverosímiles.

La música original del señor Rogel [es] de mucho ruido, con algunos números muy altos y con poco de notable $[\ldots]^{242}$.

Tras la introducción del género bufo en 1871, las representaciones de zarzuela se multiplicaron (casi 1500 representaciones de zarzuelas de 52 compositores y 205 títulos diferentes). Barbieri fue el compositor que se llevó en más ocasiones al escenario del Teatro Infantes-Roma en ese periodo y del que más títulos diferentes fueron interpretados. Le siguieron Fernández Caballero, Gaztambide, Oudrid y Arrieta, aunque también destacó la música de Chapí que, con sólo siete zarzuelas, superó ampliamente el medio centenar de representaciones y la de Miguel Marqués, que con cinco zarzuelas diferentes superó la treintena de representaciones. También fueron muy exitosas algunas zarzuelas arregladas o adaptadas, como Barba Azul (19 veces representada), Bocaccio (18) y Campanone (16). La siguiente Tabla 3.5 muestra los compositores y títulos más representados en el periodo 1871-1888:

${ }^{240}$ La Paz de Murcia, X (1867), no 2898, 28 mayo, p. 2. La obra se había estrenado en el Teatro de la Zarzuela en diciembre de 1864, según Casares, “Asenjo", p. 173.

${ }^{241}$ La Paz de Murcia, IX (1866), nº 2547, 28 mayo, p. 2.

${ }^{242}$ La Paz de Murcia, IX (1866), nº 2515, 25 abril, p. 2. 
Tabla 3.5. Compositores y zarzuelas más representadas en el Teatro Romea (1871-1888) Elaboración propia. Véase las fuentes documentales en el Apéndice 3.4 y más detalles en el Apéndice 3.6.

\begin{tabular}{|c|c|c|c|}
\hline Compositor & $\begin{array}{c}\mathbf{N}^{\mathbf{o}} \\
\text { Representaciones }\end{array}$ & $\begin{array}{l}\mathbf{N}^{0} \text { Títulos } \\
\text { diferentes }\end{array}$ & Títulos más representados (actos) \\
\hline Aceves, Rafael & 28 & 4 & Sensitiva (2) \\
\hline Arche, José Vicente & 11 & 1 & Don Pompeyo en carnaval (1) \\
\hline Arrieta, Emilio & 96 & 11 & $\begin{array}{l}\text { Marina }(2) \\
\text { El dominó azul }(3) \\
\text { La guerra santa }(3) \\
\text { El potosí submarino }(3)\end{array}$ \\
\hline $\begin{array}{ll}\text { Asenjo] } & \text { Barbieri, } \\
\text { Francisco } & \end{array}$ & 286 & 26 & $\begin{array}{l}\text { Robinson (3) } \\
\text { El hombre es débil (1) } \\
\text { Jugar con fuego (3) } \\
\text { Un caballero particular (1) } \\
\text { Los diamantes de la corona (3) } \\
\text { El diablo en el poder (3) } \\
\text { De Getafe al paraíso o La familia } \\
\text { del tío Maroma (2) } \\
\text { El tributo de las cien doncellas (3) } \\
\text { Un tesoro escondido (3) }\end{array}$ \\
\hline $\begin{array}{l}\text { Asenjo] Barbieri, } \\
\text { Francisco-Gaztambide, } \\
\text { Joaquín }\end{array}$ & 11 & 1 & El sargento Federico (4) \\
\hline Audran, Edmond & 21 & 1 & La mascota $(3)$ \\
\hline Cereceda, Guillermo & 57 & 9 & $\begin{array}{l}\text { Pepe Hillo (4) } \\
\text { Pascual Bailón (1) }\end{array}$ \\
\hline Chapí, Ruperto & 67 & 7 & $\begin{array}{l}\text { La tempestad (3) } \\
\text { Música clásica }(1)\end{array}$ \\
\hline $\begin{array}{lll}\text { Chueca, } & \text { Federico } & \text { y } \\
\text { Valverde, Joaquín } & \end{array}$ & 32 & 2 & $\begin{array}{l}\text { La Gran Vía (1) } \\
\text { Cádiz (2) }\end{array}$ \\
\hline $\begin{array}{l}\text { Fernández Caballero, } \\
\text { Manuel }\end{array}$ & 165 & 17 & $\begin{array}{l}\text { La marsellesa }(3) \\
\text { Las dos princesas }(3) \\
\text { La gallina ciega }(2) \\
\text { El salto del Pasiego }(3) \\
\text { El lucero del alba (1) } \\
\text { Luz y sombra }(2)\end{array}$ \\
\hline Gaztambide, Joaquín & 138 & 13 & $\begin{array}{l}\text { El juramento }(3) \\
\text { Los magyares }(4) \\
\text { En las astas del toro }(1) \\
\text { Catalina }(3) \\
\text { Un pleito }(1) \\
\text { La conquista de Madrid o sea el } \\
\text { triunfo del cristianismo (3) }\end{array}$ \\
\hline Hernández, Isidoro & 28 & 3 & $\begin{array}{l}\text { Torear por lo fino }(1) \\
\text { Toros de puntas }(1)\end{array}$ \\
\hline Lecocq, Charles & 23 & 4 & El barón de la castaña (1) \\
\hline Mangiagalli, Carlos & 20 & 4 & Picio, Adán y compañía (1) \\
\hline Marqués, Miguel & 34 & 5 & $\begin{array}{l}\text { El anillo de hierro }(3) \\
\text { El reloj de Lucerna }(3)\end{array}$ \\
\hline Mazza, Giuseppe & 16 & 1 & Campanone \\
\hline Nieto, Manuel & 37 & 10 & Coro de señoras (1) \\
\hline Offenbach, Jacques & 42 & 8 & Barba azul \\
\hline Oudrid, Cristóbal & 98 & 12 & $\begin{array}{l}\text { El molinero de Subiza (3) } \\
\text { El postillón de la Rioja (2) }\end{array}$ \\
\hline Planquette, Robert & 22 & 2 & Las campanas de Carrión (3) \\
\hline Rogel, José & 47 & 8 & $\begin{array}{l}\text { El joven Telémaco }(2) \\
\text { Las amazonas del Tormes (2) }\end{array}$ \\
\hline Rubio, Ángel & 48 & 13 & ¡iYa somos tres!! (1) \\
\hline Suppé, Franz von & 28 & 3 & Bocaccio (3) \\
\hline
\end{tabular}


El repertorio interpretado entre 1871 y 1888 incluye todos los géneros: desde la zarzuela grande hasta la chica, pasando por el género bufo, el sainete lírico, la revista y subgéneros o tipologías muy diversas, como la zarzuela histórica (El dominó azul, Los diamantes de la corona, Catalina y Los magyares, entre otras) o la zarzuela parodia (por ejemplo, El suicidio de Alejo, parodia de Ernani de Verdi) ${ }^{243}$.

Destacan, con más de treinta representaciones Robinson, El molinero de Subiza y La Tempestad. Descendiendo en número, aunque llevadas a escena en veinte ocasiones o más: Sensitiva, Marina, Jugar con fuego, El barberillo de Lavapiés, Los comediantes de antaño, El hombre es débil, Música clásica, La Gran Vía, La mascota, La marsellesa, La gallina ciega, Las dos princesas, Los magyares, El juramento, El postillón de la Rioja, El molinero de Subiza y Las campanas de Carrión ${ }^{244}$.

A este elenco hay que añadir otra larga lista de zarzuelas que fueron interpretadas en menos de diez ocasiones (ver Apéndice 3.6). Casi todas las zarzuelas de Arrieta, Barbieri, Guillermo Cereceda, Chapí, Chueca, Chueca y Valverde, Fernández Caballero, Gaztambide, Tomás Gómez, Isidoro Hernández, Carlos Mangiagalli, Manuel Nieto, Oudrid, José Rogel y Ángel Rubio fueron representadas en más de una ocasión. Algunos títulos de compositores como Miguel Marqués fueron muy representadas (El anillo de hierro y El reloj de Lucerna, por ejemplo) mientras que otras zarzuelas del mismo autor se llevaron a escena en una única ocasión (Camöens y Un regalo de boda).

Todas las zarzuelas representadas en el Teatro de la Soberanía Nacional-Romea de Murcia fueron estrenadas en distintos teatros españoles entre los años 1851 y 1888 . Entre los más antiguos figuran Jugar con fuego, de Barbieri; y Por seguir a una mujer, de Barbieri, Oudrid, Hernando, Inzenga y Gaztambide con libreto de Olona. Entre los estrenos más recientes figuran La campana milagrosa, drama lírico en tres actos de Miguel Marqués y García Catalá con texto de Zapata, estrenada en el mes de marzo de 1888 en el Teatro Circo de Price de Madrid. Un mes más tarde, la compañía de José Palou, en la que figuró como maestro concertador y director de orquesta el citado García Catalá, la llevó a escena en Murcia (5-04-1888).

La siguiente Tabla 3.6 compara los años de estreno de algunas zarzuelas bufas en Madrid y Murcia, respectivamente.

${ }^{243}$ Sobre la zarzuela histórica y la zarzuela parodia, véanse: Espín, "Panorama”, pp. 57-72 y Huertas Vázquez, "La zarzuela paródica”, pp. 165-181.

244 Son, por otro lado, títulos muy representados en otros teatros españoles. Compárese, por ejemplo, con el catálogo de obras representadas en A Coruña entre 1873 y 1879 que presenta Alén, "Teatro lírico", pp. 67-73. 
Tabla 3.6. Comparativa de años de estreno de algunas zarzuelas bufas en Madrid y Murcia. Elaboración propia. Las fechas de estreno de Madrid han sido consultadas en Casares, "Historia del teatro de los Bufos", pp. 116-118.

\begin{tabular}{|l|l|l|l|}
\hline Título de la zarzuela & $\begin{array}{l}\text { Estreno en } \\
\text { Madrid }\end{array}$ & $\begin{array}{l}\text { Primera } \\
\text { representación } \\
\text { documentada en } \\
\text { Murcia }\end{array}$ & $\begin{array}{l}\text { Diferencia } \\
\text { de años }\end{array}$ \\
\hline El joven Telémaco & $23-09-1866$ & $27-04-1867$ & Menos de 1 \\
\hline Un sarao y una soirée & $31-12-1866$ & $08-06-1867$ & 1 \\
\hline Bazar de novias & $9-03-1867$ & $13-05-1871$ & 4 \\
\hline Los órganos de Móstoles & $14-09-1867$ & $28-11-1874$ & 7 \\
\hline Pablo y Virginia & $11-10-1867$ & $29-03-1889$ & 22 \\
\hline Los infiernos de Madrid & $19-12-1867$ & $11-12-1875$ & 8 \\
\hline Los novios de Teruel & $24-12-1867$ & $13-01-1892$ & 25 \\
\hline Pascual Bailón & $15-10-1868$ & $10-04-1871$ & 3 \\
\hline Las tres Marías & $21-02-1869$ & $20-11-1874$ & 5 \\
\hline Dos truchas en seco & $20-10-1869$ & $15-04-1873$ & 4 \\
\hline Mefistófeles & $13-11-1869$ & $7-02-1888$ & 19 \\
\hline El Rey Midas & $22-12-1869$ & $20-11-1875$ & 6 \\
\hline Robinson & $18-03-1870$ & $23-11-1872$ & 2 \\
\hline Los estanqueros aéreos & $04-09-1870$ & $02-12-1874$ & 4 \\
\hline $\begin{array}{l}\text { El tributo de las cien } \\
\text { doncellas }\end{array}$ & $07-11-1872$ & $24-01-1874$ & 2 \\
\hline Pepe Hillo & & & 3 \\
\hline El matrimonio & $01-10-1870$ & $30-04-1873$ & 3 \\
\hline El potosí submarino & $23-11-1870$ & $17-11-1875$ & 5 \\
\hline El carbonero de Subiza & $29-12-1870$ & $6-02-1875$ & 5 \\
\hline Tocar el violón & $02-11-1871$ & $10-05-1873$ & 2 \\
\hline Sueños de oro & $09-11-1871$ & $12-02-1874$ & 3 \\
\hline El proceso del can can & $21-12-1872$ & $16-06-1874$ & 2 \\
\hline La vuelta al mundo & $08-07-1873$ & $16-11-1881$ & 8 \\
\hline $\begin{array}{l}\text { Los sobrinos del capitán } \\
\text { Grant }\end{array}$ & $18-08-1875$ & $08-02-1888$ & 13 \\
\hline & $25-08-1877$ & $06-12-1882$ & 5 \\
\hline
\end{tabular}

El Joven Telémaco llegó a Murcia apenas siete meses más tarde de su estreno en Madrid. En el caso contrario, por ejemplo Los novios de Teruel, se llevó a los escenarios murcianos con una diferencia de veinticinco años. Según los datos arrojados por esta tabla, la media de tiempo entre el estreno de una obra en Madrid y su representación en Murcia es de seis años y medio (16 de las 23 obras señaladas en la tabla se estrenaron en cinco años o menos con respecto a Madrid).

Como hemos comprobado, desde 1888 hasta 1895, año en el que concluye mi documentación, no tuvo lugar una implantación definitiva el teatro por horas, ya que las autoridades las prohibieron en determinados momentos. A pesar de todo, durante estos años se superaron las 2100 representaciones de zarzuela (253 títulos de 72 compositores diferentes). Los compositores más representados en esta etapa (1888-1895) son ahora Ruperto Chapí, Manuel Fernández Caballero, Manuel Nieto y, descendiendo, Ángel Rubio, Federico Chueca y Joaquín Valverde, y Apolinar Brull, todos ellos protagonistas del género chico, nacidos entre 1840 y 1860 (excepto Fernández Caballero) y pertenecientes a la generación de compositores que sustituyó a los artífices de la restauración de la zarzuela grande (Barbieri, Hernando, Arrieta, Gaztambide, Inzenga y 
Oudrid, entre otros) ${ }^{245}$. La siguiente Tabla 3.7 muestra los compositores más representados y el número de zarzuelas diferentes por autor representadas en el Teatro Romea durante los años 1888-1895:

Tabla 3.7. Compositores de zarzuelas más representadas en el Teatro Romea (1888-1895).

Elaboración propia. Véase las fuentes documentales y más detalles en los Apéndice 3.4 y 3.6.

\begin{tabular}{|c|c|c|c|}
\hline Autor & $\begin{array}{c}\mathbf{N}^{\mathbf{0}} \\
\text { Representaciones }\end{array}$ & $\begin{array}{l}\mathbf{N}^{0} \text { Títulos } \\
\text { diferentes }\end{array}$ & $\begin{array}{l}\text { Títulos más } \\
\text { (actos) }\end{array}$ \\
\hline Arnedo, Luis & 17 & 2 & La iluminada $(1)$ \\
\hline Arrieta, Emilio & 25 & 6 & Marina (2) \\
\hline $\begin{array}{l}\text { [Asenjo] Barbieri, } \\
\text { Francisco }\end{array}$ & 70 & 16 & $\begin{array}{l}\text { El señor Luis el Tumbón o } \\
\text { despacho de huevos frescos (1) }\end{array}$ \\
\hline Bretón, Tomás & 18 & 1 & La verbena de la paloma (1) \\
\hline Brull, Apolinar & 120 & 9 & $\begin{array}{l}\text { Lucifer }(1) \\
\text { El alcalde interino }(1) \\
\text { Colegio de señoritas }(1) \\
\text { El fuego de San Telmo }(1) \\
\text { La boda del cojo }(1)\end{array}$ \\
\hline $\begin{array}{l}\text { Brull, Apolinar } \quad \mathrm{y} \\
\text { Mangiagalli, Carlos }\end{array}$ & 22 & 1 & El cabo Baqueta $(1)$ \\
\hline Cereceda, Guillermo & 15 & 5 & Los sacamuelas $(1)$ \\
\hline Chapí, Ruperto & 280 & 22 & $\begin{array}{l}\text { ¿Las doce y media y sereno! (1) } \\
\text { La leyenda del monje (1) } \\
\text { Las campanadas (1) } \\
\text { Las tentaciones de San Antonio } \\
(1) \\
\text { El tambor de Granaderos (1) } \\
\text { Los lobos marinos (2) } \\
\text { Las hijas del Zebedeo (2) } \\
\text { Los alojados (1) } \\
\text { Música clásica (1) } \\
\text { A casarse tocan o La misa a gran } \\
\text { orquesta }(1)\end{array}$ \\
\hline Chueca, Federico & 53 & 3 & $\begin{array}{l}\text { La caza del oso o El tendero de } \\
\text { comestibles }(1) \\
\text { El chaleco blanco }(1)\end{array}$ \\
\hline $\begin{array}{l}\text { Chueca, Federico } \quad \mathrm{y} \\
\text { Valverde, Joaquín }\end{array}$ & 130 & 8 & $\begin{array}{l}\text { De Madrid a París (1) } \\
\text { La Gran Vía (1) } \\
\text { El año pasado por agua (1) } \\
\text { Cádiz (2) } \\
\text { Caramelo (1) } \\
\text { La canción de la Lola }(1) \\
\end{array}$ \\
\hline $\begin{array}{l}\text { Fernández Caballero, } \\
\text { Manuel }\end{array}$ & 237 & 25 & $\begin{array}{l}\text { El dúo de la Africana (1) } \\
\text { Chateau Margaux (1) } \\
\text { Los aparecidos (1) } \\
\text { Los zangolotinos }(1) \\
\text { El lucero del alba (1) } \\
\text { Para casa de los padres }(1)\end{array}$ \\
\hline $\begin{array}{lr}\text { Fernández } & \text { Caballero, } \\
\text { Manuel y } & \text { Sedó, } \\
\text { Francisco } & \\
\end{array}$ & 11 & 1 & El golpe de gracia $(1)$ \\
\hline $\begin{array}{lr}\text { Fernández } & \text { Caballero, } \\
\text { Manuel y Hermoso, } \\
\text { Mariano }\end{array}$ & 17 & 1 & Campanero y sacristán (1) \\
\hline
\end{tabular}

${ }^{245}$ Casares, "Zarzuela”, pp. 963-983: 973. 


\begin{tabular}{|c|c|c|c|}
\hline Gascón, Adolfo & 22 & 1 & Los riffeños (2) \\
\hline Gaztambide, Joaquín & 13 & 5 & Los magyares (4) \\
\hline $\begin{array}{l}\text { Giménez } \\
\text { Gerónimo }\end{array}$ & 51 & 10 & $\begin{array}{l}\text { Viento en popa }(1) \\
\text { La madre del cordero (1) }\end{array}$ \\
\hline Hernández, Isidoro & 36 & 3 & Toros de puntas (1) \\
\hline $\begin{array}{l}\text { Hervé } \\
\text { Florimond] }\end{array}$ & 20 & 1 & Mam-zelle Nitouche (2) \\
\hline $\begin{array}{ll}\text { López } & \text { Torregrosa, } \\
\text { Tomás } & \\
\end{array}$ & 14 & 1 & Las amapolas (1) \\
\hline Mangiagalli, Carlos & 21 & 2 & I comici tronati $(1)$ \\
\hline Marqués, Miguel & 84 & 5 & El monaguillo (1) \\
\hline Muñoz Pedrera, Pedro & 54 & 6 & $\begin{array}{l}\text { Murcia (1) } \\
\text { Malasangre (1) }\end{array}$ \\
\hline Nieto, Manuel & 234 & 15 & $\begin{array}{l}\text { Certamen nacional (1) } \\
\text { Los trasnochadores (1) } \\
\text { El gorro frigio (1) } \\
\text { Los inútiles (1) } \\
\text { Coro de señoras (1) } \\
\text { Los baturros (1) }\end{array}$ \\
\hline Offenbach, Jacques & 31 & 3 & La diva \\
\hline Oudrid, Cristóbal & 19 & 4 & La isla de San Balandrán (1) \\
\hline Reig, Tomás & 25 & 4 & Carmela $(1)$ \\
\hline $\begin{array}{l}\text { Romea y Valverde, } \\
\text { Joaquín }\end{array}$ & 56 & 3 & $\begin{array}{l}\text { Niña pancha }(1) \\
\text { Los domingueros }(1)\end{array}$ \\
\hline Rubio, Ángel & 138 & 21 & $\begin{array}{l}\text { Al agua patos (1) } \\
\text { iViva mi niña! (1) } \\
\text { iYYa somos tres!! (1) }\end{array}$ \\
\hline $\begin{array}{l}\text { Rubio, Ángel y Espino, } \\
\text { Casimiro }\end{array}$ & 41 & 5 & ¡Cómo está la sociedad!(1) \\
\hline $\begin{array}{l}\text { Rubio, Ángel y García } \\
\text { Catalá, Juan }\end{array}$ & 23 & 4 & Receta infalible (1) \\
\hline San José, Teodoro & 13 & 3 & Los embusteros (1) \\
\hline Taboada, Rafael & 18 & 5 & Un gatito de Madrid (1) \\
\hline $\begin{array}{l}\text { Valverde Sanjuán, } \\
\text { Joaquín (Quinito) }\end{array}$ & 28 & 3 & La fuente de los milagros (1) \\
\hline
\end{tabular}

Tal y como se desprenden de estos datos, Chapí fue el autor más representado aunque el compositor que más zarzuelas llevó a los escenarios murcianos fue Fernández Caballero. Otros músicos como Miguel Marqués, con solo cinco zarzuelas, sobrepasaron las ochenta representaciones, lo que indica que sus obras fueron repetidas con mucha frecuencia. Sobresalen también las zarzuelas del murciano Pedro Muñoz Pedrera, cuyas obras superaron el medio centenar de representaciones.

Entre los títulos interpretados en más de veinte ocasiones destacan: El señor Luis el Tumbón, de Barbieri; Lucifer y El alcalde interino, de Apolinar Brull; El cabo Baqueta, de Brull y Carlos Mangiagalli; La leyenda del monje, Las campanadas, El tambor de Granaderos, ;Las doce y media y sereno! y Las tentaciones de San Antonio, de Chapí; La caza del oso o El tendero de comestibles, de Chueca; La Gran Vía, De Madrid a París y El año pasado por agua, de Chueca y Valverde; Chateau Margaux, Los aparecidos y, El dúo de la Africana, de Fernández Caballero; Los riffeños, del murciano Adolfo Gascón; Toros de puntas, de Isidoro Hernández; Plato del día y El monaguillo, de Miguel Marqués; Murcia, de Muñoz Pedrera, Los trasnochadores, El gorro frigio, Certamen Nacional y Los inútiles, de Manuel Nieto; Niña Pancha, de Romea y Valverde; Al agua patos, de Ángel Rubio; ;Cómo está la sociedad!, de Rubio y Casimiro Espino; La 
fuente de los milagros, de Joaquín Valverde (hijo), La diva, de Offenbach y la opereta de Hervé, Mam-zelle Nitouche.

Las zarzuelas más antiguas del catálogo de obras representadas en el Teatro Romea entre 1888 y 1895 fueron compuestas por Arrieta y Barbieri a comienzos de la década de los cincuenta (Marina, El Grumete, Los diamantes de la corona y Jugar con fuego). La mayoría de las restantes fueron estrenadas al final de la década de los 1880 y primeros años de la siguiente. Por tanto, se acortó el tiempo que transcurría entre el estreno absoluto de una obra y su primera representación en Murcia. La media durante estos años es de aproximadamente un año ${ }^{246}$. Especialmente abundante en estrenos fue 1889, año en el que se llevaron por primera vez a la escena murciana títulos como Panorama nacional, El fuego de San Telmo, Colegio de señoritas, Las hijas del Zebedeo, La iluminada, Término medio, Ortografía, Caramelo, A casarse tocan, Los baturros, Detalles para la historia, Toros embolados, Los domingueros, ¡Zaragoza!, El cosechero de Arganda, Nina, El teatro nuevo, Los embusteros y Un gatito de Madrid ${ }^{247}$. Muchas de estas obras fueron representadas en Murcia pocos meses después de su estreno nacional (por ejemplo, Panorama nacional, El fuego de San Telmo, Colegio de señoritas, Las hijas del Zebedeo).

La zarzuela chica y posteriormente el género chico crecieron claramente en proporción desde la inauguración del Teatro de los Infantes en 1862 hasta 1895, en detrimento de la zarzuela grande (ver Tabla 3.8):

Tabla 3.8. Evolución de la extensión de las zarzuelas representadas en el Teatro Infantes-Romea de Murcia (1862-1895).

\begin{tabular}{|l|l|c|c|c|}
\hline Años & $\begin{array}{l}\text { Total de } \\
\text { zarzuelas } \\
\text { representadas }\end{array}$ & $\begin{array}{c}\text { 3 ó 4 actos } \\
\mathbf{( \% )}\end{array}$ & $\begin{array}{c}\mathbf{2} \text { actos } \\
\mathbf{( \% )}\end{array}$ & $\begin{array}{c}\mathbf{1} \text { acto } \\
\mathbf{( \% )}\end{array}$ \\
\hline $1862-1871$ & 49 & 47 & 19 & 34 \\
\hline $1871-1888$ & 205 & 39.5 & 11 & 49.5 \\
\hline $1888-1895$ & 253 & 16 & 9 & 75 \\
\hline
\end{tabular}

\section{La zarzuela en otros teatros de Murcia}

\subsection{EI Teatro Circo de la Rambla (1880-1885)}

El Teatro Circo de la Rambla surgió de la rehabilitación del antiguo Teatro Provisional y por iniciativa del Centro Gastro. Fue inaugurado inicialmente como Circo Provisional el 16 de abril de 1880. Posteriormente, se llevaron a cabo diversas obras de remodelación, reinaugurándose el 2 de septiembre de 1880 con el nombre de Teatro Circo de la Rambla (ver Capítulo 2).

${ }^{246}$ Tiempo medio calculado sobre las zarzuelas que indico en el Tabla 3 del Apéndice 3.6, cuyos datos he consultado de Casares (dir.), Diccionario de la zarzuela, diferentes páginas.

247 Algunos de ellos, por ejemplo El fuego de San Telmo, Panorama nacional, Colegio de señorita y, Las hijas del Zebedeo fueron estrenados en Murcia con una diferencia escasa de meses 
Aunque sus condiciones eran más propias de un teatro de verano, el local ofreció también representaciones en invierno ${ }^{248}$. Sin embargo, la climatología determinó a menudo su programación y provocó la suspensión de las funciones o la interrupción inesperada de alguna representación ${ }^{249}$.

Durante el periodo en el que estuvo activo el Teatro Circo de la Rambla (18801885) desfilaron por él tres compañías de zarzuela: la dirigida por Rafael Villalonga, la de Eugenio Fernández (ambas durante la primera temporada 1880-1881) y la compañía de Juan García Catalá (primera temporada de 1883-1884), aunque esta última, tras la primera función, se trasladó al Teatro Romea.

La compañía de Villalonga fue la encargada de la reinauguración del Teatro Circo de la Rambla. La integraban doce voces principales y cinco más para papeles secundarios ${ }^{250}$ y estaba especializada en ópera y zarzuela aunque, en la documentación consultada, no consta que representaran ninguna ópera en Murcia ${ }^{251}$.

Esta compañía interpretó mayoritariamente zarzuelas en más de un acto, tanto del "viejo repertorio" como del moderno. Barbieri fue el compositor más representado y con mayor número de zarzuelas diferentes llevadas a la escena (ver Tabla 3.9):

Tabla 3.9 Zarzuelas representadas por la compañía de Rafael Villalonga en el Teatro Circo de la Rambla de Murcia (1880)

Elaboración propia. Véanse fuentes documentales en Apéndice 3.8.

\begin{tabular}{|c|c|c|}
\hline Compositor & Título (actos) & $\begin{array}{c}\mathrm{N}^{\mathbf{0}} \mathrm{de} \\
\text { representaciones }\end{array}$ \\
\hline Arrieta, Emilio & Guerra Santa (3) & 3 \\
\hline \multirow{5}{*}{$\begin{array}{l}\text { [Asenjo] Barbieri, } \\
\text { Francisco }\end{array}$} & El diablo en el poder (3) & 1 \\
\hline & Jugar con fuego (3) & 1 \\
\hline & El barberillo de Lavapiés (3) & 2 \\
\hline & Los comediantes de antaño (3) & 1 \\
\hline & Artistas para la Habana (1) & 1 \\
\hline \multirow{3}{*}{$\begin{array}{l}\text { Fernández Caballero, } \\
\text { Manuel }\end{array}$} & El salto de pasiego (3) & 5 \\
\hline & Las dos princesas (3) & 3 \\
\hline & El lucero del alba (1) & 1 \\
\hline
\end{tabular}

248 Según El Diario de Murcia, II (1880), no 551, 8 diciembre, p. 3, el local reunía condiciones aceptables: "En primer lugar debemos decir al público que en el teatro circo se está bien, que no hace frío, ni hay humedad y se está todo lo perezosamente que se quiere: embozado, fumando y en confianza".

249 Por ejemplo, "A causa de la lluvia del día, el toldo del Circo derramaba anoche sobre los espectadores el agua que había recogido": La Paz de Murcia, XXIV (1881), nº 6958, 22 enero, p. 1. En La Paz de Murcia, XXVIII (1885), $\mathrm{n}^{\circ}$ 8171, 15 marzo, p. 1 se relata: “Anoche se inauguraron las funciones en el Circo, aunque el local no ofrecía buena estancia por no haber[se] concluido de secar. Hoy, si continúa el buen tiempo, ya estará mejor". La prensa denunció reiteradamente las carencias del local y la necesidad de instalar en él un toldo y mejorar el sistema de alumbrado. Véase: El Diario de Murcia, VII (1885), ${ }^{\text {os }} 1866$, 26 mayo, p. 2; 1872, 31 mayo, p. 2 y 1877, 6 junio, pp. 1-2; La Paz de Murcia, XXIV (1881), nº 6947, 10 enero, p. 1; La Paz de Murcia, XXVIII (1885), nº 8231, 27 mayo, p. 1 y Crespo, Antiguos teatros, p. 163.

${ }^{250}$ El elenco publicado por la prensa, transcrito en el Apéndice 3.1, detalla las voces sin que éstas estuvieran especializadas en zarzuela y ópera: dos primeras tiples, una tiple cómica, una primera "tiple contralto" y una "tiple matrona"; dos primeros tenores y un primer tenor cómico (el murciano Pablo López); dos primeros barítonos; y, finalmente, un primer bajo (Rafael Villalonga).

251 Salvo la interpretación de una Romanza de La Favorite, en la función a beneficio de la tiple Matilde Williams (8-10-1880). Véase Apéndice 3.8. 


\begin{tabular}{|l|l|c|}
\hline \multirow{3}{*}{ Gaztambide, Joaquín } & Una vieja (1) & 1 \\
\cline { 2 - 3 } & Las hijas de Eva (1) & 1 \\
\cline { 2 - 3 } & Catalina (3) & 2 \\
\hline Cereceda, Guillermo & Pepe Hillo (4) & 2 \\
\cline { 2 - 3 } & Para una modista un sastre (1) & 1 \\
\hline Oudrid, Cristóbal & $\begin{array}{c}\text { Nadie se muere hasta que Dios quiere } \\
(1)\end{array}$ & 1 \\
\hline Planquette, Robert & Las campanas de Carrión (3) & 1 \\
\hline Verdi, Giuseppe & $\begin{array}{c}\text { El suicidio de Alejo (parodia de } \\
\text { Ernani) (1) }\end{array}$ & \\
\hline
\end{tabular}

A pesar de las condiciones del local, algunas zarzuelas como El Salto del Pasiego fueron representadas con decorados pintados para la ocasión ${ }^{252}$. La compañía de Villalonga tuvo buena afluencia de público y una recepción favorable, en parte porque el Teatro Romea estaba reconstruyéndose tras el incendio de $1877^{253}$. La prensa destacó especialmente la labor del director de orquesta, Tomás Gómez:

El fin de las representaciones se aproxima. La empresa ha recogido beneficios y casi todos los artistas aplausos. El público, que ha visto casi todas las noches funciones nuevas, que ha aplaudido a diestro y siniestro, se ha olvidado de un profesor incansable, del director de orquesta, don Tomás Gómez, cuya batuta ha salvado a todos los demás de un naufragio, como podrían decirlo, si hablaran, las partituras de "Las dos princesas" y "Salto del Pasiego". Reciba este modesto profesor nuestro humilde aplauso ${ }^{254}$.

Villalonga y sus artistas concluyeron sus representaciones a mediados de octubre de 1880 en el Teatro Circo de la Rambla y hasta el mes de diciembre no se registró ninguna función ${ }^{255}$. Durante este paréntesis, no obstante, el local fue "preparado convenientemente para la estación de invierno",256.

La actividad teatral en el Teatro Circo de la Rambla se recobró durante el mes de diciembre de 1880 con la compañía de Eugenio Fernández, dirigida por Fernández Caballero y procedente del Teatro Jovellanos de Madrid ${ }^{257}$. Fue una compañía menos numerosa que la anterior, aunque según El Noticiero era "seguramente la mejor de España". Se mantuvo en cartel hasta el mes de marzo de 1881, atrayendo de forma

${ }^{252}$ El Diario de Murcia, II (1880), $\mathrm{n}^{\text {os }}$ 492, 28 septiembre, p. 3 y 493, 29 septiembre, p. 2.

${ }^{253}$ En el Teatro Circo de la Rambla también se dieron comportamientos no deseables del público. Véase, por ejemplo, el descrito en El Semanario Murciano, III (1880), nº 137, 26 septiembre, p. 312.

${ }^{254}$ El Diario de Murcia, II (1880), $\mathrm{n}^{\mathrm{o}}$ 504, 13 septiembre, p. 2.

${ }^{255}$ La última función de la compañía en Murcia fue en homenaje a las víctimas de la Riada de Santa Teresa (1879) organizada por iniciativa de Pablo López; véase El Diario de Murcia, II (1880), n 508, 16 octubre, p. 3. Algunos cantantes tenían otros compromisos y no podían alargar más sus actuaciones en la ciudad. Véanse más detalles en El Semanario Murciano, III (1880), nº 143, 7 noviembre, p. 359 y Crespo, Antiguos teatros, pp. 128-130.

${ }^{256}$ El Diario de Murcia, II (1880), n 541, 26 noviembre, p. 3 citando El Noticiero.

${ }^{257}$ El Noticiero, citado por El Diario de Murcia, II (1880), n ${ }^{\circ}$ 541, 26 noviembre, p. 3. Sin embargo, el nombre de Fernández Caballero no figuró en el anuncio con el elenco de actores, directores y demás personal de la compañía publicado por La Paz de Murcia. 
continua el interés del público ${ }^{258}$. Su éxito se debió a que programaba un repertorio variado, con estrenos frecuentes (que incluían obras de compositores murcianos y esmerada escenografía ("todo lo bien que permite el escenario"259), así como numerosas "funciones a beneficio" de cantantes y público:

Los beneficios al público se repiten con frecuencia en el Teatro Circo y son un incentivo muy eficaz pues llenan herméticamente aquel espacioso local. El real y medio de la entrada general y los tres reales de silla y entrada, atraen espectadores hasta de nuestros partidos rurales. A esto se agrega que estos beneficios se efectúan con obras populares o de espectáculo ${ }^{260}$.

Diecisiete de las ochenta y ocho funciones que ofreció en Murcia la compañía de Eugenio Fernández fueron del tipo "beneficio"261. Estas funciones conllevaban programas especiales. Pondré dos ejemplos. En la "función a beneficio" de la orquesta (11-01-1881), ésta interpretó la sinfonía El ramillete, de Fernando Verdú, que había sido recientemente estrenada en la reapertura del Teatro Romea (diciembre 1880). En la "función a beneficio" del director de escena Eugenio Fernández (24-02-1881) se estrenó una revista murciana "de costumbres y tipos populares" en dos actos y en verso, titulada ;Murcia de mi corazón!. El autor del libreto fue el periodista y director de El Diario de Murcia, José Martínez Tornel, y la música de Fernando Verdú y Salvador Grajales, director de la orquesta.

El Teatro Circo de la Rambla acogió varias reuniones de la junta organizadora del Entierro de la Sardina, así como dos funciones a beneficio de las fiestas del Carnaval en enero de 1881. En la primera de ellas (18-01-1881) se estrenó un apropósito titulado Habrá entierro, de Juan Antonio Soriano, que fue encargado al autor por la empresa teatral para la ocasión. Esta primera función quedaba "fuera de abono y de todas otras concesiones" 262 .

El Teatro Romea se reinauguró en diciembre de 1880 y de momento, contar con los dos teatros abiertos parecía favorecer la concurrencia a ambos:

La afición al Teatro se ha despertado de un modo que no tenía ejemplo. Cuando solo teníamos uno apenas si se conseguía una mediana entrada en los días festivos una vez pasadas las pascuas. Ahora tenemos dos y si no se llenan falta poco

${ }^{258}$ Véase, como ejemplo, El Semanario Murciano, III (1880), nº 148, 12 diciembre, p. 404, El Diario de Murcia, II (1880), nº 567, 28 diciembre, p. 2 y La Paz de Murcia, XXIV (1881), nº 6941, 3 enero, p. 1.

${ }^{259}$ La Paz de Murcia, XXIV (1881), nº 6977, 16 febrero, p. 1.

${ }^{260}$ La Paz de Murcia, XXIV (1881), n 6976, 15 febrero, p. 1. Como expliqué en el Capítulo 2, era habitual destinar las últimas representaciones de la compañía a las llamadas "funciones a beneficio de" (también llamadas "beneficio"), que han de entenderse como homenajes y no como funciones benéficas.

${ }^{261}$ Generalmente, las compañías solían programar uno o dos "beneficios"; en cualquier caso, no solían pasar de cuatro o cinco. La compañía de Rafael Villalonga, por ejemplo, ofreció dos: una a "función a beneficio" de la primera tiple y otra al tenor cómico.

${ }^{262}$ La Paz de Murcia, XXIV (1881), $n^{\circ}$ 6953, 16 enero, p. 1. Véanse más detalles en La Paz de Murcia, XXIV (1881), $\mathrm{n}^{\text {os }} 6945,8$ enero, p. 1 y 6954, 18 enero, p. 1. 
en los días festivos y en los demás días fluctúa la más o menos concurrencia a cada local, según la novedad de los espectáculos $[\ldots]^{263}$.

La compañía de Eugenio Fernández representó un total de treinta y siete zarzuelas diferentes, de las que once se veían por primera vez en Murcia $^{264}$ (ver Tabla 3.10):

Tabla 3.10. Representaciones de zarzuela y ópera de la compañía de Eugenio Fernández en el Teatro Circo de la Rambla (1880-1881).

Elaboración propia. Ver fuentes documentales en Apéndice 3.8.

\begin{tabular}{|c|c|c|}
\hline Compositor & Título (actos) & $\begin{array}{c}\mathrm{N}^{\circ} \text { de } \\
\text { representaciones }\end{array}$ \\
\hline Arche, José Vicente & Don Pompeyo en carnaval (1) & 3 \\
\hline \multirow[t]{4}{*}{ Arrieta, Emilio } & El dominó azul (3) & 2 \\
\hline & Entre el alcalde y el rey (3) & 1 \\
\hline & La guerra santa (3) & 4 \\
\hline & Marina (2) & 2 \\
\hline \multirow{9}{*}{$\begin{array}{l}\text { [Asenjo] Barbieri, } \\
\text { Francisco }\end{array}$} & El sargento Federico (4) & 2 \\
\hline & El diablo en el poder (3) & 2 \\
\hline & Los diamantes de la corona (3) & 2 \\
\hline & Jugar con fuego (3) & 3 \\
\hline & El barberillo de Lavapiés (3) & 1 \\
\hline & Sueños de oro (3) & 8 \\
\hline & El hombre es débil (1) & 2 \\
\hline & Los comediantes de antaño (3) & 2 \\
\hline & Pan y toros $(3)$ & 3 \\
\hline Chapí, Ruperto & Las dos huérfanas (3) & 2 \\
\hline $\begin{array}{l}\text { Chueca, Federico y } \\
\text { Valverde, Joaquín }\end{array}$ & La canción de la Lola (1) & 4 \\
\hline \multirow{5}{*}{$\begin{array}{l}\text { Fernández Caballero, } \\
\text { Manuel }\end{array}$} & Las nueve de la noche (3) & 5 \\
\hline & El sacristán de San Justo (3) & 5 \\
\hline & El salto del Pasiego (3) & 3 \\
\hline & La marsellesa (3) & 1 \\
\hline & Luz y sombra (2) & 3 \\
\hline Flotow, Friedrich von & Martha $^{265}(4)$ & 1 \\
\hline \multirow[t]{5}{*}{ Gaztambide, Joaquín } & Estebanillo Peralta (3) & 3 \\
\hline & Catalina (3) & 1 \\
\hline & El diablo las carga (3) & 1 \\
\hline & Las hijas de Eva (3) & 1 \\
\hline & La conquista de Madrid (3) & 4 \\
\hline
\end{tabular}

${ }^{263}$ La Paz de Murcia, XXIV (1881), n 6967, 4 febrero, p. 1. Véase también La Paz de Murcia, XXIV (1881), n $\mathrm{n}^{\circ}$ 6941, 3 enero, p. 1. En algunos momentos el público murciano se inclinó por el Teatro de la Rambla, quizás por ser más barato y popular: La Paz de Murcia, XXIV (1881), nº 6951, 14 enero, p. 1.

${ }^{264}$ Sus títulos son: Estebanillo (Oudrid y Gaztambide/Ventura de la Vega), El pañuelo de yerbas (Ángel Rubio/Pina Domínguez), Picio, Adán y compañía (Carlos Mangiagalli/Rafael María Liern), El anillo de hierro (Miguel Marqués/Marcos Zapata), La tela de araña (Manuel Nieto/Navarro y Lamadrid), Monomanía musical (Manuel Nieto/Guillermo Perrín y Vicente Torres), Las dos huérfanas (Ruperto Cahpí/Pina Domínguez), El sacristán de San Justo (Fernández Caballero y Manuel Nieto/Luis Blanc y Calixto Navarro), La canción de la Lola (Chueca y Valverde/Ricardo de la Vega), Entre el alcalde y el rey (Arrieta/Gaspar Núñez de Arce) y iMurcia de mi corazón! (Fernando Verdú y Salvador Grajales/José Martínez Tornel).

${ }^{265}$ Las fuentes mencionan específicamente que se trataba de la ópera: El Diario de Murcia, III (1881), $\mathrm{n}^{\mathrm{o}} 605,24$ febrero, p. 2. 


\begin{tabular}{|l|l|c|}
\hline Mangiagalli, Carlos & Picio, Adán y compañía (1) & 9 \\
\hline Marqués, Miguel & El anillo de hierro (3) & 2 \\
\hline Mazza, Giuseppe & Campanone & 4 \\
\hline \multirow{2}{*}{ Nieto, Manuel } & Monomanía musical (1) & 5 \\
\cline { 2 - 3 } & La tela de araña (2) & 7 \\
\hline \multirow{2}{*}{ Oudrid, Cristóbal } & $\begin{array}{c}\text { Nadie se muere hasta que Dios quiere } \\
(1)\end{array}$ & 1 \\
\cline { 2 - 3 } & El molinero de Subiza (3) & 5 \\
\hline Rogel, José & Las amazonas del Tormes (2) & 4 \\
\hline Rubio, Ángel & El pañuelo de yerbas (2) & 3 \\
\hline Vázquez, Mariano & Il feroci romani (1) & 1 \\
\hline $\begin{array}{l}\text { Verdú, Fernando } \\
\text { Grajales, Salvador }\end{array}$ & iMurcia de mi corazón! (2) & 2 \\
\hline
\end{tabular}

Salvo Dos huérfanas y ¡Murcia de mi corazón!, el resto de zarzuelas representadas por la compañía de Eugenio Fernández en el Circo de la Rambla formaron parte de la cartelera del Teatro Romea en los años posteriores. Sorprende el elevado número de zarzuelas en tres o más actos representadas en el Teatro de la Rambla, sobre todo si tenemos en cuenta que el género chico estaba en auge en los teatros madrileños desde la década anterior ${ }^{266}$.

Una vez más, con la compañía de Eugenio Fernández fue Barbieri el compositor más escuchado y con mayor número de zarzuelas diferentes llevadas a escena, seguido por Fernández Caballero, Gaztambide, Arrieta y Oudrid, en ese orden. Caballero:

Una de las obras que más gustó fue Las nueve de la noche, de Fernández

La zarzuela "Las nueve de la noche" que se puso anoche en el Circo es verdaderamente deliciosa por su delicada música, digna del autor de la "Marsellesa", "Salto del Pasiego", "Dos princesas", etcétera. La jota es un prodigio de instrumentación y toda la obra es rica en melodías y motivos nuevos y originales. Los actores estuvieron bien y ya daremos más detalles sobre esta obra que proporcionará buenas entradas ${ }^{267}$.

Para El molinero de Subiza de Oudrid, el pintor Montesinos realizó varias decoraciones "del mejor gusto" 268 . La escenografía y decorados fueron también elogiados a propósito de la representación de Sueños de oro de Barbieri:

[...] Verdaderamente por tres reales no se puede dar más oro, ni más decoraciones, ni más pinturas, ni más música.

${ }^{266}$ Espín, “Panorama”, p. 59.

${ }^{267}$ El Diario de Murcia, II (1880), n ${ }^{\circ}$ 557, 15 diciembre, p. 3. También en el Teatro del Circo de la Rambla fue usual achacar a los actores falta de ensayos, como ocurrió con esta zarzuela: "El estreno de Las nueve de la noche se resintió de falta de ensayos, a nuestro entender, circunstancia que se ha advertido en alguna otra obra": El Semanario Murciano, III (1880), n 149, 19 diciembre, p. 412. No he hallado, por el contrario, grandes reformas en las compañías de este coliseo, salvo una ampliación del coro de la compañía de Eugenio Fernández en febrero de 1881.

${ }^{268}$ El Diario de Murcia, II (1880), nº 565, 24 diciembre, p. 2. 
El señor Montesinos, pintor de la decoraciones ha estado feliz en algunos pensamientos. Es muy atrevido el haber pintado a la Eva de siempre, cabalgando sobre una asquerosa serpiente. Parece que esto no tenga relación con los sueños de oro, pero conviene ahondar un poco en la metáfora y se comprenderá que lo que ha querido significar con esto el artista es que los sueños de oro de la humanidad se tienen desde el primer pecado, desde que la serpiente del paraíso trastornó el sentido de nuestra primera madre. [...]

Al terminar la zarzuela, cuando la Virtud subía para el cielo en una nube bien movida, el público tuvo el buen acierto de llamar al maquinista del teatro, don Rafael Martínez, el cual lo merecía de sobra, pues dirigir la maniobra de aquel escenario es navegar en un lago lleno de escollos y se necesita ser tan buen piloto como es el señor Martínez, para producir con arte el efecto de esas mutaciones y movimientos sorprendentes de la escena $[\ldots]^{269}$.

Al terminar sus representaciones en Murcia, la compañía de Eugenio Fernández se dispersó. La siguiente noticia nos aporta los itinerarios seguidos por los cantantes.

\begin{abstract}
Varios artistas de la compañía del teatro circo marcharon ayer mismo a otras poblaciones, en donde están ya contratados y otros a Madrid para salir pasada la cuaresma a provincias:

La señorita Plaza marchó anoche a Valencia y los señores Grajales y Senís.

El señor Gimeno va contratado al teatro de Apolo, de Madrid en donde trabajará ya pasado mañana.

La señora Martí, con su esposo el señor Moragas y el tenor cómico señor Guerra, van a Cartagena como núcleo de la compañía que allí actuará esta Cuaresma $^{270}$.
\end{abstract}

Durante los años cómicos de 1881-1882 y 1882-1883 el Teatro Circo de la Rambla sólo registró actividad teatral entre finales de agosto y mediados de septiembre. La mayor parte de las funciones fueron de carácter dramático, aunque esporádicamente se representó zarzuela. La compañía de Vallés-Luján, especializada en teatro declamado y baile, llevó a escena varias veces La canción de la Lola (De la Vega/Chueca y Valverde $)^{271}$ y la compañía de Juan Espantaleón (1 $1^{\mathrm{a}}$ temporada de 1882-1883) representó El lucero del alba (Fernández Caballero/Pina Domínguez), el sainete lírico en un acto Una tiple de café (Casimiro Espino/Barón de Cortés), La salsa de Aniceta (Ángel Rubio/Liern), Torear por lo fino (Isidoro Hernández/Francisco Macarro), Música clásica (Chapí/José Estremera) y la revista en un acto ;Eh! A la plaza (Ángel Rubio/Pina Domínguez $)^{272}$. En el debut de la compañía de Juan García Catalá (1-09-1883) se escenificó El anillo de hierro (Miguel Marqués/Marcos Zapata) y como he comentado anteriormente, se trasladaron al Teatro Romea.

${ }^{269}$ El Diario de Murcia, III (1881), n ${ }^{\circ} 595,6$ febrero, p. 1. Los vestuarios también eran de Montesinos: La Paz de Murcia, XXIV (1881), nº 6968, 5 febrero, p. 1. Véase también, El Diario de Murcia, III (1881), $\mathrm{n}^{\circ} 593,4$ febrero, p. 3.

${ }^{270}$ El Diario de Murcia, III (1881), nº 611, 3 marzo, p. 3.

${ }^{271}$ Crespo, Antiguos teatros, pp. 149-153.

${ }^{272}$ La compañía de Juan Espantaleón alternó funciones en el Teatro Romea y en el Circo de la Rambla. Entre el 26 de agosto y el 2 de septiembre de 1882 actuó sólo en el Circo. Desde esa fecha hasta el 11 de septiembre de 1882, en ambos. El cuadro lírico estaba compuesto por ocho cantantes: cuatro voces femeninas y cuatro masculinas: La Paz de Murcia, XXV (1882), n 7414, 21 agosto, p. 1. Véase también Crespo, Antiguos teatros, pp. 153-156. 
Los compositores más representados en los cinco años de representaciones del Teatro Circo de la Rambla (1880-1885) fueron Barbieri y Fernández Caballero, seguido por Gaztambide y Arrieta, todos ellos también muy interpretados en el Teatro Romea en los años 1871-1888 (ver Tabla 3.11).

Tabla 3.11. Compositores y obras más representadas en el Teatro Circo de la Rambla de Murcia (1880-1885). Véanse más detalles en el Apéndice 3.7.

\begin{tabular}{|l|c|c|l|}
\hline Compositor & $\begin{array}{c}\mathbf{N}^{\mathbf{0}} \\
\text { representaciones }\end{array}$ & $\begin{array}{c}\mathbf{N}^{\mathbf{0}} \text { Títulos } \\
\text { diferentes }\end{array}$ & \multicolumn{1}{|c|}{$\begin{array}{c}\text { Títulos más } \\
\text { interpretados (actos) }\end{array}$} \\
\hline Arrieta, Emilio & 12 & 4 & Guerra Santa (3) \\
\hline $\begin{array}{l}\text { [Asenjo] Barbieri, } \\
\text { Francisco }\end{array}$ & 31 & 10 & Sueños de oro (3) \\
\hline $\begin{array}{l}\text { Fernández } \\
\text { Caballero, Manuel }\end{array}$ & 26 & 7 & El salto de pasiego (3) \\
\hline $\begin{array}{l}\text { Gaztambide, } \\
\text { Joaquín }\end{array}$ & 14 & 6 & $\begin{array}{l}\text { La conquista de Madrid } \\
(3)\end{array}$ \\
\hline $\begin{array}{l}\text { Mangiagalli, Carlos } \\
\text { Oudrid, Cristóbal }\end{array}$ & 7 & 1 & $\begin{array}{l}\text { Picio, Adán y compañía } \\
(1)\end{array}$ \\
\hline
\end{tabular}

\subsection{El Teatro Circo Villar (1893-1895)}

El Teatro Circo Villar se inauguró como circo el 5 de noviembre de 1892 y, a diferencia del Teatro Circo de la Rambla, tuvo una actividad teatral más regular. Entre 1893 y 1895, desfilaron por este teatro ocho compañías: seis de zarzuela (entre ellas, una infantil y otra de aficionados), una de ópera y otra dramática (véase Apéndice 2.2).

La reinauguración del Circo Villar como teatro propiamente dicho el 14 de octubre de 1893 contó con la compañía de zarzuela de Eduardo Ortiz ${ }^{273}$, que estrenó Villar y Compañía, un apropósito escrito para la ocasión por los murcianos Antonio Puig y Pedro Muñoz Pedrera (música) y Mariano Perní (libreto). No fue la única zarzuela estrenada en el Circo Villar de autores murcianos. A mediados de diciembre de 1893, la compañía de Ortiz estrenó Por una patria, del compositor Mariano Marín con letra del tipógrafo y redactor de El Diario de Murcia, José Balsalobre. Sobre ambas trataré en el apartado siguiente.

La compañía de Eduardo Ortiz trabajó ininterrumpidamente en el Teatro Circo Villar hasta el 24 de enero de 1894 alternando funciones completas y por horas. En las

${ }^{273}$ La compañía de Eduardo Ortiz había actuado con anterioridad en el Teatro Romea durante las primeras temporadas de 1883-1884 y 1889-1890 y en la segunda de 1892-1893. Según el elenco de cantantes publicado por la prensa, en cada ocasión actuó con una estructura diferente. En la primera temporada de 1883 constaba de 23 cantantes (6 tiples, 1 tiple característica, 4 partiquinas, 3 tenores, 2 barítonos, 3 bajos, 4 partiquinos), mientras que en 1889-1890, lo hizo con 14 (6 tiples, 3 partiquinas, 2 tenores, 2 barítonos, 1 bajo). En el Teatro Circo la compañía de Ortiz tenía 17 voces principales: 8 tiples (tres primeras tiples, una tiple cómica y contralto, dos segundas tiples, una primera y una segunda tiple característica), dos partiquinas, dos tenores, dos barítonos y dos bajos. Véase Apéndice 3.2 y Crespo, Antiguos teatros, p. 214. 
112 funciones documentadas, llevaron a escena 60 zarzuelas diferentes ${ }^{274}$, con un predominio numérico de zarzuela grande (ver Tabla 3.12).

Tabla 3.12. Representaciones de zarzuela de la compañía de Eduardo Ortiz en el Teatro Circo Villar de Murcia (1893-1894).

Elaboración propia. Véanse más detalles en el Apéndice 3.7.

\begin{tabular}{|c|c|c|}
\hline Compositor & Título (actos) & $\begin{array}{l}\mathrm{N}^{0} \text { de } \\
\text { representaciones }\end{array}$ \\
\hline \multirow[t]{3}{*}{ Arrieta, Emilio } & El grumete $(1)$ & 1 \\
\hline & La guerra santa (3) & 4 \\
\hline & Marina (2) & 5 \\
\hline \multirow{9}{*}{$\begin{array}{ll}\text { [Asenjo] } & \text { Barbieri, } \\
\text { Francisco } & \end{array}$} & El sargento Federico (4) & 2 \\
\hline & El diablo en el poder (3) & 1 \\
\hline & Los diamantes de la corona (3) & 1 \\
\hline & Jugar con fuego (3) & 1 \\
\hline & El relámpago (3) & 2 \\
\hline & El barberillo de Lavapiés (3) & 1 \\
\hline & Robinson (3) & 4 \\
\hline & El hombre es débil (1) & 1 \\
\hline & Un tesoro escondido (3) & 2 \\
\hline Audrán, Edmundo & La mascota $(3)$ & 1 \\
\hline \multirow[t]{13}{*}{ Chapí, Ruperto } & Las campanadas (1) & 5 \\
\hline & Via libre (1) & 20 \\
\hline & Los mostenses (3) & 4 \\
\hline & ¡Las doce y media y sereno! (1) & 1 \\
\hline & El mismo demonio (2) & 3 \\
\hline & La Czarina (1) & 11 \\
\hline & El milagro de la Virgen (3) & 5 \\
\hline & Los lobos marinos $(2)$ & 2 \\
\hline & El rey que rabió (3) & 5 \\
\hline & La bruja (3) & 3 \\
\hline & La tempestad $(3)$ & 4 \\
\hline & Las hijas del Zebedeo (2) & 1 \\
\hline & Música clásica $(1)$ & 2 \\
\hline Chueca, Federico & El chaleco blanco (1) & 4 \\
\hline $\begin{array}{l}\text { Chueca, Federico y } \\
\text { Valverde, Joaquín }\end{array}$ & Cádiz (1) & 2 \\
\hline \multirow{10}{*}{$\begin{array}{l}\text { Fernández Caballero, } \\
\text { Manuel }\end{array}$} & Chateau Margaux (1) & 3 \\
\hline & Los aparecidos $(1)$ & 6 \\
\hline & La hija de la mascota $(1)$ & 1 \\
\hline & $\begin{array}{l}\text { De Herodes a Pilatos o El rigor de las } \\
\quad \text { desdichas (1) }\end{array}$ & 3 \\
\hline & El salto del Pasiego (3) & 3 \\
\hline & El lucero del alba (1) & 2 \\
\hline & El dúo de la africana (1) & 12 \\
\hline & La marsellesa (3) & 2 \\
\hline & La revista $(1)$ & 3 \\
\hline & Las dos princesas (3) & 3 \\
\hline \multirow[t]{3}{*}{ Gaztambide, Joaquín } & Los magyares (4) & 3 \\
\hline & La conquista de Madrid (3) & 3 \\
\hline & El juramento (3) & 1 \\
\hline Marín, Mariano & Por la patria $(1)$ & 14 \\
\hline \multirow[t]{3}{*}{ Marqués, Miguel } & El monaguillo (1) & 5 \\
\hline & El anillo de hierro (3) & 1 \\
\hline & El reloj de Lucerna (3) & 2 \\
\hline
\end{tabular}

${ }^{274}$ De las 60 zarzuelas, 27 eran en tres o cuatro actos, ocho en dos actos y 24 en un acto. 


\begin{tabular}{|l|l|c|}
\hline \multirow{2}{*}{ Nieto, Manuel } & Coro de señoras (1) & 2 \\
\cline { 2 - 3 } & La tela de araña (2) & 4 \\
\hline \multirow{2}{*}{ Oudrid, Cristóbal } & El molinero de Subiza (3) & 3 \\
\cline { 2 - 3 } & El postillón de la rioja (2) & 2 \\
\hline Peydró, Vicente & El gran petardo (1) & 2 \\
\hline Planquette, Robert & Las campanas de Carrión (3) & 2 \\
\hline $\begin{array}{l}\text { Puig, Antonio y } \\
\text { Muñoz Pedrera, } \\
\text { Pedro }\end{array}$ & Villar y compañia (1) & \\
\hline Rogel, José & Las amazonas del Tormes (2) & 2 \\
\hline Rubio, Ángel & iViva mi niña! (1) & 4 \\
\cline { 2 - 3 } & El pañuelo de yerbas (2) & 1 \\
\hline $\begin{array}{l}\text { Romea Parra, Julián } \\
\text { y Valverde, Joaquín }\end{array}$ & Niña Pancha (1) & 3 \\
\hline Mazza, Giuseppe & Campanone (3) & 3 \\
\hline Suppé, Franz von & Bocaccio (3) & 1 \\
\hline Offenbach, Jacques & La diva (1) & 4 \\
\hline [No consta] & La cuadrilla del merengue & 1 \\
\hline
\end{tabular}

Ruperto Chapí fue el autor más interpretado (66 representaciones documentadas) y de él eran los títulos más veces llevados a escena: Vía Libre y La Czarina. Fernández Caballero estuvo presente en 38 representaciones y Barbieri en 15 representaciones. De Chapí se representaron 13 zarzuelas diferentes, de Fernández Caballero, 10 y de Barbieri, 9.

Es sorprendente el elevado número de zarzuelas representadas en el Teatro Circo Villar, teniendo que en cuenta que el Teatro Romea ofrecía simultáneamente funciones de este género (ver Tabla 3.13):

Tabla 3.13. Géneros teatrales en los teatros Romea y Circo Villar de Murcia (1893-1895)

T: Teatro declamado; Z: zarzuela, O: Ópera, Op: Opereta

\begin{tabular}{|c|c|c|c|c|c|c|c|c|c|c|c|c|c|c|c|}
\hline & \multicolumn{7}{|c|}{ 1 $^{\mathrm{a}}$ TEMPORADA } & \multicolumn{8}{|c|}{$2^{a}$ TEMPORADA } \\
\hline & \multicolumn{4}{|c|}{1893} & \multicolumn{3}{|c|}{1894} & \multicolumn{5}{|c|}{1894} & \multicolumn{3}{|c|}{1895} \\
\hline & 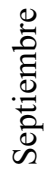 & 苛 & 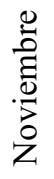 & 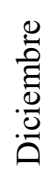 & 过 & $\begin{array}{l}\text { 워 } \\
0 \\
0 \\
0 \\
0\end{array}$ & 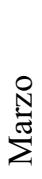 & $\begin{array}{l}0 \\
0 \\
0 \\
0\end{array}$ & & 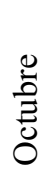 & 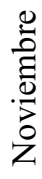 & 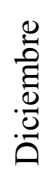 & $\begin{array}{l}\text { 워 } \\
\text { |I }\end{array}$ & $\begin{array}{l}\text { O } \\
\text { d. } \\
0 \\
0 \\
0\end{array}$ & $\stackrel{\stackrel{N}{N}}{\stackrel{\Xi}{\Sigma}}$ \\
\hline Romea & $\mathbf{T}$ & \multicolumn{4}{|c|}{$\mathbf{Z}$} & $\mathbf{O}_{1}$ & & & & & & \multicolumn{3}{|c|}{$\mathbf{Z}$} & \\
\hline Circo Villar & & \multicolumn{4}{|c|}{$\mathbf{Z}$} & & Z & $\mathbf{Z}$ & O & \multicolumn{5}{|c|}{$\mathbf{Z}$} & \\
\hline
\end{tabular}

Desde mediados de octubre de 1893 hasta mediados de enero de 1894 ambos teatros ofrecieron zarzuela, al igual que en los meses de diciembre a febrero de 1895 . Martínez Tornel describió así el ambiente teatral de la ciudad a finales de octubre de 1893:

Los teatros han tenido esta semana algunas noches de lleno, y otras de entrada floja. Dos teatros funcionando diariamente y sin cesar son muchos teatros para Murcia. No hay público que voluntariamente vaya a los dos para darles el concurso necesario a su subsistencia.

Sin embargo, como ponen el espectáculo tan barato, como dan tanta y tan variada música, tanta letra, coros tan numerosos, actores de tantas calidades, zarzuela 
grande y chica, género superior y rafalí... por tres perricas ¿pero qué digo por tres perricas? ipor diez céntimos! va la gente, por no perder la ocasión, como dicen en los baratos $^{275}$.

Las empresas de ambos coliseos competían entre sí para ganar afluencia, contratando actores de prestigio ${ }^{276}$, ofertando estrenos de obras nunca representadas en Murcia o invirtiendo en la escenografía de suntuosos decorados y vestuarios. Por ejemplo, en octubre de 1893, tanto el Romea como el Teatro Circo Villar negociaron con el murciano Fernández Caballero el estreno de El dúo de la africana y su representación en exclusiva en un solo teatro. Finalmente el estreno tuvo lugar en el Romea, al parecer por decisión del libretista de la obra, Echegaray:

Ayer recibimos una carta de nuestro querido amigo y paisano el eminente maestro don Manuel Fernández Caballero, que publicamos íntegra en la edición de anoche.

El objeto de dicha carta es sincerarse el señor Caballero, ante los que hayan podido dudarlo, de la delicadeza con que ha obrado en la cuestión de conocer o no el derecho de representación de su obra "El dúo de la africana" a la empresa del Teatro de Romea o del Teatro Circo de Villar; pues si él hubiera podido decidir por sí solo, hubiera dejado en libertad a las dos empresas para que la pudiesen explotar como quisiera; pero teniendo un compañero, cuyos intereses ni puede ni debe perjudicar, dejó la solución del asunto al señor Echegaray, el cual, decidió que "El dúo de la africana" lo pusiese la compañía en que figurase en el señor Moncayo, cuando no se sabía en qué teatro iba a colaborar este actor.

Algo apenado y aún lastimado vemos al ilustre maestro por las especies apasionadas que han llegado a él, relativas a su actitud en este asunto. Pero es justo y necesario que se despreocupe, pues todos nos hacemos cargo de su situación y conociéndola no le suponemos de ningún modo inclinado a unos con ánimo de perjudicar a otros. Habiendo dos teatros, a alguno había de tocarle la obra africana.

Pero tenga el señor Caballero la seguridad que como resentidos con él personalmente no hay un solo murciano, ni el que más interés pueda tener en el Teatro Villar.

Hay un medio, sin embargo, de que el maestro Caballero complazca a los que han quedado desairados y es ofreciendo al Circo de Villar la exclusiva de la primera pieza que estrene en Madrid, con el buen éxito de las suyas. Esto lo decimos por nuestra cuenta, nosotros, que no nos sentimos ni favorecidos ni desairados, sino con más cariño cada día al ilustre murciano y maestro ${ }^{277}$.

El dúo de la africana fue finalmente estrenada el 14 de octubre de 1893 en el Teatro Romea con la compañía de Ramón Blasco y el primer actor José Moncayo, alcanzando un gran número de representaciones posteriores en este teatro. Sin embargo, Fernández Caballero y Echegaray permitieron que también fuese llevada a escena en el Circo Villar, tras su estreno en el Romea.

Dado que El dúo de la africana había obtenido un contundente éxito en el Teatro Romea, su puesta en escena en el Circo Villar tenía que ofrecer algún aliciente más. La

\footnotetext{
${ }^{275}$ El Diario de Murcia, XV (1893), no 6077, 29 octubre, p. 1.

${ }^{276}$ Véase El Diario de Murcia, XV (1893), nº 6049, 27 septiembre, p. 3.

${ }^{277}$ El Diario de Murcia, XV (1893), nº 6062, 12 octubre, p. 1.
} 
empresa teatral del Teatro Circo Villar alquiló expresamente varios decorados en Madrid y pensó reunir en Murcia a Chapí y a Fernández Caballero:

[...] Querían, me dijo, nuestros paisanos que yo [Fernández Caballero] hubiera ido a Murcia a dirigir El dúo de la africana [y] que el maestro Chapí hubiera dirigido otra de sus muchas obras pero, de un parte me lo ha impedido el estado de la vista y de otra el cariño que profeso al referido maestro Chapí.

Yo no quería, ni hubiera encontrado bien, que nadie creyese que aquello era un / [p. 2] pugilato. Estimo mucho al maestro Chapí y si la ovación que a él se le hubiera tributado no hubiera ido como la mía, le habría sentido, y si hubiera sido más, después hubiera habido alguna que otra murmuración, y no he querido ir allí por todo eso.

El señor Fernández Caballero está satisfechísimo de que en su país se haya puesto su obra El dúo de la africana en los dos teatros que hay en la población. $[\ldots]^{278}$.

Los dos compositores no llegaron a Murcia a la vez, aunque sí visitaron la ciudad en diferentes momentos. Fernández Caballero había estado Murcia en septiembre de 1893 para colaborar en diversos eventos musicales de la ciudad ${ }^{279}$. Chapí llegó a Murcia el 16 de enero de 1894, para dirigir los ensayos para el estreno de Los mostenses en el Teatro Circo Villar ${ }^{280}$, coincidiendo con un momento de cierre en el Teatro Romea. Esta obra, al menos durante los años estudiados, nunca fue representada en el Teatro Romea ${ }^{281}$.

A pesar de los esfuerzos de las empresas teatrales, la afluencia a ambos teatros fluctuaba. La Paz de Murcia retrató así la situación de los teatros murcianos en enero de 1894:

Amigo "Liberal" no hay que extrañarse de que deje de funcionar la empresa de Romea, ni de que el señor don Agustín Ruiz y otros se hayan separado de aquel número de cien socios que formaron el Especta-Club.

${ }^{278}$ Eduardo Bermúdez, "Correspondencia. Madrid, 21 de enero de 1894”, El Diario de Murcia, XVI (1894), no 6161, 23 enero, p. 1, transcrito también por La Paz de Murcia, XXXVI (1894), n 12603, 24 enero, p. 1.

${ }^{279}$ El 6 de septiembre de 1893 Fernández Caballero participó en un concierto en el Círculo Católico de Obreros de Murcia y al día siguiente, otro en el Jardín de Floridablanca: El Diario de Murcia, XV (1893), $\mathrm{n}^{\text {os }}$ 6031, 6 septiembre, p. 3, 6032, 7 septiembre, 1 y 6033, 8 septiembre, p. 4 y Julián Calvo, "Una velada concierto dirigida y organizada por el maestro Fernández Caballero", El Diario de Murcia, XV (1893), n 6036, 12 septiembre, pp. 1-2 y. El 13 de septiembre de 1893 la empresa Especta-Club celebró un banquete homenaje al compositor en el Teatro Circo Villar: Las Provincias de Levante, VIII (1893), $\mathrm{n}^{\circ}$ 2097, 13 septiembre, p. 2 y El Diario de Murcia, XV (1893), nº 6038, 14 septiembre, p. 3. El compositor fue también homenajeado con un banquete en Madrid por las trescientas representaciones de El dúo de la africana en diversos teatros de España. El evento, organizado por la colonia murciana de la capital, se celebró el 2 de febrero de 1894: El Diario de Murcia, XVI (1894), $\mathrm{n}^{\text {os }}$ 6159, 21 enero, p. 2; 6169, 31 enero, p. 1; 6170, 1 febrero, p. 1 y 6179, 10 febrero, p. 1; La Paz de Murcia, XXXVI (1894), n ${ }^{\text {s }}$ 12603, 24 enero, p. 1; 12612,4 febrero, p. 2; 12613, 6 febrero, p. 1 y 12619, 12 febrero, p. 2.

${ }^{280}$ La Paz de Murcia, XXXVI (1894), nº 12596, 16 enero, p. 1. El estreno tuvo lugar el 23 de enero de 1894. Véase El Diario de Murcia XVI (1894), nº 6154, 16 enero, p. 1 y La Paz de Murcia, XXXVI (1894), $\mathrm{n}^{\text {os }} 12598,18$ enero, p. 2 y 12602, 23 enero, p. 1.

${ }^{281}$ La Paz de Murcia, XXXVI (1894), nº 12590, 8 enero, p. 1. La expectación fue tal que las entradas se vendieron por encargo. 
Dolorosamente se ha visto que en Murcia no hay afición o dinero suficiente para sostener dos teatros y las dos empresas están muy castigadas por las pérdidas que han venido teniendo.

Esta lección debe no olvidarse y hacer, para lo sucesivo, convenios o acuerdos por los que los dos teatros puedan funcionar sin perjudicarse y sin apelar a precios desastrosos que de nada han servido ${ }^{282}$.

Entre marzo y abril de 1894 actuó en el Teatro Circo Villar la compañía de zarzuela de Ventura de la Vega, que llegó a la ciudad procedente de Orán (Argelia) y "sin anunciarse de ningún modo" 283 . Su repertorio, en el que no hubo zarzuelas grandes, incluía géneros como el sainete, la revista, la zarzuela parodia, la zarzuela cómica y la opereta, entre otros. Ocho de las veintidós zarzuelas representadas por esta compañía en el Circo Villar no se repitieron posteriormente en el Teatro Romea ${ }^{284}$ (ver Tabla 3.14).

Tabla 3.14. Zarzuelas representadas por la compañía de Ventura de la Vega en el Teatro Circo Villar de Murcia (1894).

Elaboración propia. Ver fuentes documentales en Apéndice 3.8.

\begin{tabular}{|c|c|c|}
\hline Compositor & Título (actos) & $\begin{array}{c}\mathrm{N}^{\mathbf{0}} \\
\text { representaciones }\end{array}$ \\
\hline Alvira, José María & Jai-Alai (1) & 4 \\
\hline Arnedo, Luis & Miss Erere (1) & 4 \\
\hline $\begin{array}{ll}\text { [Asenjo] } & \text { Barbieri, } \\
\text { Francisco } & \end{array}$ & Los carboneros (1) & 2 \\
\hline Audrán, Edmundo & Mis Helyett (3) & 4 \\
\hline \multirow[t]{2}{*}{ Brull, Apolinar } & Colegio de señoritas (1) & 1 \\
\hline & Lucifer (1) & 1 \\
\hline $\begin{array}{l}\text { Brull, Apolinar y } \\
\text { Mangiagalli, Carlos }\end{array}$ & El cabo Baqueta (1) & 4 \\
\hline \multirow[t]{3}{*}{ Chapí, Ruperto } & ¡Las doce y media y sereno! (1) & 1 \\
\hline & La Czarina (1) & 2 \\
\hline & Los alojados (1) & 1 \\
\hline Chueca, Federico & Los descamisados (1) & 4 \\
\hline $\begin{array}{l}\text { Chueca, Federico y } \\
\text { Valverde, Joaquín }\end{array}$ & El año pasado por agua (1) & 1 \\
\hline $\begin{array}{l}\text { Fernández Caballero, } \\
\text { Manueo }\end{array}$ & El dúo de la africana (1) & 4 \\
\hline $\begin{array}{l}\text { Hervé } \\
\text { Florimond] }\end{array}$ & Mam-zelle Nitouche (2) & 4 \\
\hline
\end{tabular}

${ }^{282}$ La Paz de Murcia, XXXVI (1894), no 12588, 5 enero, p. 1. Sin embargo, las críticas de cada representación no indican escasa concurrencia. Véase, por ejemplo, las referencias que aporto en las funciones del mes de enero de 1894, en el Apéndice 3.7.

${ }^{283}$ La Paz de Murcia, XXXVI (1894), $\mathrm{n}^{\text {os }}$ 12635, 3 marzo, p. 3 y 12636, 4 marzo, p. 3. Esta compañía había actuado en abril de 1885 y enero de 1893 en el Teatro Romea de Murcia y, durante el mes de octubre de 1893 en el Teatro Circo de Cartagena: El Diario de Murcia, XV (1893), nº 6061, 11 octubre, p. 3.

${ }^{284}$ Sus títulos y compositores son: Jai Ala, pasillo cómico de José María Alvira; la zarzuela Miss Erere (parodia de la opereta de Audrán Miss Helyett) del albaceteño Luis Arnedo con libreto de Gabriel Merino; el sainete lírico Los descamisados, de Federico Chueca con libreto de Arniches y López Silva; la zarzuela cómica El cornetilla de Miguel Marqués con libreto de Perrín y Palacios; Las varas de la justicia, zarzuela en un acto del reusense Manuel Nieto que "no fue del agrado del público": La Paz de Murcia, XXXVI (1894), nº 12661, 4 abril, p. 2; El mocito de barrio, juguete cómico-lírico de Julián Romea Parra; el cuadro dramático Gota serena, de Ángel Rubio Laínez y, finalmente Era de noche y llovía, compuesto por José Rogel con libreto del cartagenero Julio Hernández, cuyo estreno absoluto tuvo lugar el 5 de abril de 1894. 


\begin{tabular}{|l|l|c|}
\hline Marqués, Miguel & El cornetilla $(1)$ & 2 \\
\hline Nieto, Manuel & Las varas de la justicia $(1)$ & 2 \\
\hline Rogel, José & Era de noche y llovía & 1 \\
\hline Romea Parra, Julián & El mocito del barrio (1) & 3 \\
\hline $\begin{array}{l}\text { Romea Parra, Julián } \\
\text { y Valverde, Joaquín }\end{array}$ & Niña Pancha $(1)$ & 2 \\
\hline Rubio, Ángel & Gota serena (1) & 2 \\
\cline { 2 - 3 } & Al agua patos $(1)$ & 3 \\
\hline $\begin{array}{l}\text { Saco del Valle, } \\
\text { Arturo }\end{array}$ & La indiana $(1)$ & 1 \\
\hline
\end{tabular}

Durante la primera temporada 1894-1895, casi exclusivamente dedicada la zarzuela, actuaron en el Teatro Circo Villar de Murcia tres compañías: una infantil, una de aficionados y otra profesional. La compañía infantil de Juan Bosch alternó funciones completas y por horas coincidiendo con la feria de septiembre. En su repertorio hubo obras de Arrieta (Marina), Chapí (El rey que rabió, la única en tres actos), Fernández Caballero (Chateau Margaux y El dúo de la africana), Isidoro Hernández (Toros de puntas) y las zarzuelas bufas La diva, de Offenbach y El Húsar, arreglada para la escena española por Roger, Vidal y Llimona.

La compañía de aficionados del tenor Manuel Pérez Cabrero actuó en el Circo Villar durante los meses octubre y noviembre de 1894. Es la única compañía de aficionados documentada de este teatro y la única que se formó en Murcia con el propósito de ofrecer representaciones durante una temporada y no para una sola función benéfica. Contó con veintitrés cantantes y actores, lo que la hacía equiparable a las compañías profesionales mejor dotadas. La compañía debutó el 4 de octubre de 1894 en una función organizada por Juan de la Cierva, Adolfo Gascón, Muñoz Pedrera, Joaquín Arques y Vicente Pastor a beneficio del Manicomio Provincial ${ }^{285}$. Entre otras obras, se llevó a escena la zarzuela Malasangre de los citados Arques y Muñoz Pedrera ${ }^{286}$. Todo parece indicar que los problemas económicos impidieron las representaciones regulares de la compañía, que sólo ofreció dos funciones más los días 4 y 7 de noviembre de 1894 , en las que alternaron obras dramáticas y líricas ${ }^{287}$.

A finales de noviembre de 1894 debutó en el Circo Villar la compañía de zarzuela de Lino Ruiloa, que fue la que más tiempo permaneció en el escenario de este teatro ${ }^{288}$. La compañía de Ruiloa dio 102 funciones en el Circo Villar, todas por horas, entre noviembre de 1894 y mayo del año siguiente y representó 59 títulos de 28 compositores diferentes, 20 de ellos estrenos (ver Tabla 3.15). Fue, por tanto, una de las compañías que

${ }^{285}$ El Diario de Murcia, XVI (1894), nº 6415, 6 octubre, p. 2.

${ }^{286}$ Los artistas tuvieron problemas para cobrar sus sueldos. Véase, El Diario de Murcia, XVI (1894), nº 6453, 13 noviembre, p. 2 y La Paz de Murcia, XXXVI (1894), nº 12833, 14 noviembre, p. 1.

${ }^{287}$ Por ejemplo, el juguete cómico en un acto de Mariano Chacel, Lanceros y otras líricas como El monaquillo de Miguel Marqués (en dos ocasiones), Coro de señoras, de Manuel Nieto; Meterse en honduras, de Ángel Rubio y Casimiro Espino y La fuente de los milagros de Quinito Valverde (ver Apéndice 3.8).

${ }^{288}$ El Diario de Murcia, XVI (1894), nº 6442, 2 noviembre, p. 2. Contaba con ocho cantantes (tres primeras tiples, un tenor cómico, un barítono, un bajo, cinco actrices y cinco actores). A finales de marzo de 1895, su principal atractivo era la tiple Lucrecia Arana. Véase, El Diario de Murcia, XVII (1895), $\mathrm{n}^{\text {os }} 6568$, 22 marzo, p. 3 y 6570, 24 marzo, p. 3. 
más estrenos realizó en los teatros murcianos de la segunda mitad del siglo XIX ${ }^{289}$. Destacó cuantitativamente La verbena de la paloma, sainete lírico de Bretón con libreto de Ricardo de la Vega, que fue llevado a las tablas en más de cuarenta ocasiones.

Tabla 3.15. Representaciones de zarzuela de la compañía de Lino Ruiloa en el Teatro Circo Villar de Murcia (1894-1895).

$\mathrm{El} *$ indica que fue representada por primera vez en Murcia. Ver fuentes documentales en Apéndice 3.8.

\begin{tabular}{|c|c|c|}
\hline Compositor & Título (actos) & $\begin{array}{l}\mathrm{N}^{\circ} \\
\text { representaciones }\end{array}$ \\
\hline \multirow[t]{2}{*}{ Arrieta, Emilio } & Marina $(2)$ & 4 \\
\hline & El grumete $(1)$ & 1 \\
\hline \multirow[t]{2}{*}{$\begin{array}{l}\text { [Asenjo] Barbieri, } \\
\text { Francisco }\end{array}$} & $\begin{array}{l}\text { El señor Luis el Tumbón o } \\
\text { despacho de huevos frescos, } \\
\text { sainete (1) }\end{array}$ & 6 \\
\hline & Jugar con fuego (3) & 1 \\
\hline Bretón, Tomás & $\begin{array}{l}\text { La verbena de la paloma, } \\
\text { sainete (1)* }\end{array}$ & 44 \\
\hline \multirow[t]{3}{*}{ Brull, Apolinar } & $\begin{array}{l}\text { El alcalde interino, juguete } \\
\text { cómico-lírico (1) }\end{array}$ & 5 \\
\hline & Lucifer (1) & 1 \\
\hline & La cruz blanca (1) & 4 \\
\hline $\begin{array}{l}\text { Chalons, Manuel; } \\
\text { Álvarez, Antonio y } \\
\text { Merino, Gabriel }\end{array}$ & $\begin{array}{l}\text { La venida de Jesús o La estrella } \\
\text { con rabo, apropósito (1) }\end{array}$ & 6 \\
\hline \multirow[t]{3}{*}{ Chapí, Ruperto } & $\begin{array}{l}\text { Las tentaciones de San Antonio } \\
\text { (1) }\end{array}$ & 1 \\
\hline & Las campanadas $(1)$ & 2 \\
\hline & El cura del regimiento $(1)^{*}$ & 1 \\
\hline \multirow[t]{3}{*}{ Chueca, Federico } & La caza del oso (1) & 4 \\
\hline & Los descamisados (1)* & 4 \\
\hline & Cádiz (2) & 2 \\
\hline \multirow[t]{2}{*}{$\begin{array}{l}\text { Chueca, Federico y } \\
\text { Valverde, Joaquín }\end{array}$} & $\begin{array}{l}\text { El año pasado por agua, revista } \\
\text { (1) }\end{array}$ & 7 \\
\hline & La Gran Via (1) & 6 \\
\hline Cotó, Alberto & Los tres claveles $(1)^{*}$ & 4 \\
\hline \multirow{11}{*}{$\begin{array}{l}\text { Fernández Caballero, } \\
\text { Manuel }\end{array}$} & Campanero y sacristán $(1)^{*}$ & 16 \\
\hline & Los africanistas $(1)^{*}$ & 29 \\
\hline & Los aparecidos $(1)^{*}$ & 8 \\
\hline & La una y la otra $(1)^{*}$ & 3 \\
\hline & Tiple alianza $(1)$ & 3 \\
\hline & Un punto filipino $(1)^{*}$ & 11 \\
\hline & Los dineros del sacristán (1)* & 14 \\
\hline & Las cuatro estaciones (1) & 3 \\
\hline & El dúo de la Africana (1) & 19 \\
\hline & Chateau Margaux (1) & 3 \\
\hline & Los zangolotinos (1) & 4 \\
\hline Gascón, Adolfo & $\begin{array}{l}\text { El tío Tragaderas o El alcalde } \\
\text { de mi pueblo }(1)^{*}\end{array}$ & 3 \\
\hline Hernández, Isidoro & Toros de puntas $(1)$ & 2 \\
\hline \multirow{2}{*}{$\begin{array}{l}\text { Giménez } \text { Bellido, } \\
\text { Gerónimo }\end{array}$} & El hijo de su Excelencia (1) & 2 \\
\hline & La madre del cordero (1) & 4 \\
\hline
\end{tabular}

${ }^{289}$ Véase el interesante resumen teatral del año 1894 en el que se aportan datos como el número de funciones y los estrenos llevados a cabo en los teatros Romea y Circo Villar escrito por Emilio Ramírez Valiente: El Diario de Murcia, XVII (1895), nº 6500, 1 enero, p. 2. 


\begin{tabular}{|c|c|c|}
\hline $\begin{array}{l}\text { López } \\
\text { Tomás }\end{array}$ & Las amapolas (1)* & 21 \\
\hline $\begin{array}{l}\text { López Torregrosa, } \\
\text { Tomás y Valverde } \\
\text { (Quinito) }\end{array}$ & Los puritanos (1)* & 10 \\
\hline Mangiagalli, Carlos & Picio, Adán y compañía (1) & 2 \\
\hline \multirow[t]{4}{*}{ Marqués, Miguel } & La salamanquina $(1)$ & 4 \\
\hline & El anillo de hierro (3) & 1 \\
\hline & Plato del día (1) & 6 \\
\hline & El monaguillo (1) & 5 \\
\hline Mazza, Giuseppe & Campanone (3) & 1 \\
\hline \multirow[t]{3}{*}{ Nieto, Manuel } & Los baturros (1) & 3 \\
\hline & Certamen nacional (1) & 3 \\
\hline & El muñeco $(1)^{*}$ & 6 \\
\hline Offenbach, Jacques & La diva (1) & 4 \\
\hline Picón, José & La isla de San Balandrán (1) & 6 \\
\hline Romea Parra, Julián & El carnaval del amor $(1)^{*}$ & 3 \\
\hline Romea y Valverde & Los domingueros (1) & 4 \\
\hline \multirow[t]{6}{*}{ Rubio, Ángel } & ¡Alto! ¿Quién vive? (1) & 1 \\
\hline & Nadar en seco $(1)^{*}$ & 3 \\
\hline & ¡Viva mi niña! (1) & 7 \\
\hline & Oro, plata, cobre y... nada (1) & 5 \\
\hline & Al agua patos $(1)$ & 6 \\
\hline & Nina $(1)$ & 2 \\
\hline Ruiz, Julio & Los tíos (1) & 3 \\
\hline \multirow{2}{*}{$\begin{array}{lll}\text { Saco del } & \text { Valle, } \\
\text { Arturo } & & \\
\end{array}$} & La indiana $(1)^{*}$ & 5 \\
\hline & La flor de la montaña $(1)^{*}$ & 3 \\
\hline Santoja, Miguel & Cosas de pueblo $(1)^{*}$ & 3 \\
\hline $\begin{array}{l}\text { Valverde, Joaquín } \\
\text { (Quinito) }\end{array}$ & La fuente de los milagros (1) & 7 \\
\hline Viaña, Joaquín & La sultana de Marruecos (1)* & 4 \\
\hline
\end{tabular}

La actividad teatral de la segunda temporada del año cómico de 1894-1895 en el Teatro Circo Villar se completó con las actuaciones dramáticas de la compañía dirigida por Manuel Llorens y Jaime Rivelles (ver Apéndice 2.2).

Analizados globalmente, los compositores y títulos más representados en el Teatro Circo Villar entre 1893 y 1895 indican resultados similares a los mostrados en el Teatro Romea en el periodo 1888-1895. Sobresalen Manuel Fernández Caballero y Ruperto Chapí, con 160 y 76 representaciones respectivamente, y con más títulos diferentes llevados a escena (ver Tabla 3.16):

Tabla 3.16. Compositores y obras más representadas en el Teatro Circo de Villar entre 1893 y 1895. Véanse más detalles en el Apéndice 3.7.

\begin{tabular}{|l|c|c|l|}
\hline Compositor & $\begin{array}{c}\mathbf{N}^{\mathbf{0}} \\
\text { representaciones }\end{array}$ & $\begin{array}{l}\mathbf{N}^{\mathbf{0}} \text { Títulos } \\
\text { diferentes }\end{array}$ & \multicolumn{1}{|c|}{$\begin{array}{c}\text { Títulos más interpretados } \\
\text { (actos) }\end{array}$} \\
\hline Arrieta, Emilio & 17 & 3 & Marina (2) \\
\hline $\begin{array}{l}\text { [Asenjo] Barbieri, } \\
\text { Francisco }\end{array}$ & 24 & 11 & $\begin{array}{l}\text { El señor Luis el Tumbón o } \\
\text { despacho de huevos frescos }(1)\end{array}$ \\
\hline Bretón, Tomás & 44 & 1 & La verbena de la paloma $(1)$ \\
\hline Brull, Apolinar & 12 & 4 & El alcalde interino (1) \\
\hline Chapí, Ruperto & 76 & 16 & $\begin{array}{l}\text { Vía libre (1) } \\
\text { La Czarina (1) }\end{array}$ \\
\hline
\end{tabular}




\begin{tabular}{|c|c|c|c|}
\hline Chueca, Federico & 12 & 4 & $\begin{array}{l}\text { La caza del oso }(1) \\
\text { Los descamisados }(1) \\
\text { El chaleco blanco }(1)\end{array}$ \\
\hline $\begin{array}{l}\text { Chueca, Federico y } \\
\text { Valverde, Joaquín }\end{array}$ & 20 & 3 & El año pasado por agua (1) \\
\hline $\begin{array}{l}\text { Fernández Caballero, } \\
\text { Manuel }\end{array}$ & 160 & 18 & $\begin{array}{l}\text { El dúo de la Africana (1) } \\
\text { Los africanistas (1) } \\
\text { Campanero y sacristán (1) } \\
\text { Los aparecidos (1) } \\
\text { Los dineros del sacristán (1) }\end{array}$ \\
\hline $\begin{array}{ll}\text { López } & \text { Torregrosa, } \\
\text { Tomás } & \end{array}$ & 21 & 1 & Las amapolas (1) \\
\hline Marín, Mariano & 14 & 1 & Por la patria $(1)$ \\
\hline Marqués, Miguel & 28 & 6 & El monaguillo (1) \\
\hline Nieto, Manuel & 21 & 6 & El muñeco (1) \\
\hline Rubio, Ángel & 34 & 8 & $\begin{array}{l}\text { ¡Viva mi niña! (1) } \\
\text { Al agua patos (1) }\end{array}$ \\
\hline
\end{tabular}

\section{Zarzuelas de autores murcianos}

Durante la etapa estudiada se estrenaron en teatros murcianos más de una veintena de zarzuelas compuestas por autores de la región (compositores y/o libretistas) ${ }^{290}$, al igual que en otras zonas de la península ibérica ${ }^{291}$. Los detalles de estas obras pueden verse en la siguiente Tabla 3.17:

Tabla 3.17. Zarzuelas de autores murcianos estrenadas en los teatros Provisional,

Romea y Circo Villar de Murcia (1860-1895).

Fuentes: ver Apéndices 3.3, 3.4 y 3.8.

$\mathrm{El} *$ indica autor no murciano, ni afincado en Murcia.

\begin{tabular}{|l|l|c|c|}
\hline \multicolumn{1}{|c|}{ Compositor } & Libretista & Título, género (actos) & $\begin{array}{c}\text { Teatro, fecha de } \\
\text { estreno }\end{array}$ \\
\hline Julián Calvo & Ramón Guerrero & $\begin{array}{c}\text { Una broma de estudiantes, } \\
\text { zarzuela infantil (2) }\end{array}$ & Provisional, 9-02-1860 \\
\cline { 2 - 4 } & Francisco Villegas & $\begin{array}{c}\text { Travesuras de Quevedo, } \\
\text { zarzuela infantil (1) }\end{array}$ & Provisional, 9-02-1860 \\
\hline $\begin{array}{l}\text { Esteban } \\
\text { Capdepón }\end{array}$ & $\begin{array}{l}\text { Felipe Blanco de } \\
\text { Ibáñez }\end{array}$ & $\begin{array}{c}\text { En busca de un marido, juguete } \\
\text { cómico lírico (1) }\end{array}$ & Infantes, 21-01-1865 \\
\hline Fernando Verdú & $\begin{array}{l}\text { Ignacio } \\
\text { Basterrechea }\end{array}$ & $\begin{array}{c}\text { Un hallazgo a tiempo, zarzuela } \\
\text { de costumbres de la huerta } \\
(1)\end{array}$ & $\begin{array}{l}\text { Círculo Industrial, } \\
24-06-1872\end{array}$ \\
\hline $\begin{array}{l}\text { Antonio López } \\
\text { Almagro }\end{array}$ & Ricardo Gil & \begin{tabular}{c} 
Dar posada al peregrino, $(i 1 ?)$ \\
\hline
\end{tabular} & Romea, 14-02-1874 \\
\hline
\end{tabular}

${ }^{290}$ Me limito a comentar las zarzuelas de autores murcianos estrenadas en teatros de Murcia, dejando a un lado aquéllas estrenadas en otras poblaciones de España (principalmente Madrid) y posteriormente representadas en Murcia. Un ejemplo de este último tipo fue el sainete lírico Los aficionados, con música del pianista Antonio Puig y libreto de Mariano Perní, estrenado en Madrid en marzo de 1890 y que tuvo numerosas representaciones. Al Teatro Romea llegó el 23 de diciembre de 1890 con la compañía de Daniel Banquells y con éxito de crítica. Sobre estrenos de obras murcianas posteriores a 1895, véase: Crespo, Historia, pp. 366-430; Crespo, “Apuntes”, pp. 107-116 y Crespo, “Algunos autores”, pp. 69-88.

291 Sobre la zarzuela de autores locales en el ámbito no madrileño véase, entre otros: Alén, "Reflexiones", Álvarez Cañibano, "La zarzuela" y "Nagore, "La vida". 


\begin{tabular}{|c|c|c|c|}
\hline $\begin{array}{l}\text { Esteban } \\
\text { Capdepón }\end{array}$ & $\begin{array}{l}\text { Javier Fuentes y } \\
\text { Ponte }\end{array}$ & $\begin{array}{l}\text { Mari Cruz Verde, zarzuela } \\
\text { original de costumbres } \\
\text { murcianas (3) }\end{array}$ & Romea, 3-12-1875 \\
\hline $\begin{array}{l}\text { Fernando } \\
\text { Verdú/Carmelo } \\
\text { Grajales }\end{array}$ & $\begin{array}{l}\text { José Martínez } \\
\text { Tornel }\end{array}$ & $\begin{array}{l}\text { ¡Murcia de mi corazón!, revista } \\
\text { de costumbres y tipos } \\
\text { populares en verso }(2 \\
\text { actos, seis cuadros) }\end{array}$ & $\begin{array}{l}\text { Circo de la Rambla, } \\
24-02-1881\end{array}$ \\
\hline $\begin{array}{l}\text { Casimiro } \\
\text { Espino* }\end{array}$ & $\begin{array}{l}\text { Antonio Ibáñez } \\
\text { González }\end{array}$ & $\begin{array}{c}\text { Será lo que tase un sastre, } \\
\text { zarzuela (1) }\end{array}$ & Romea, 19-01-1885 \\
\hline $\begin{array}{l}\text { Mariano Moreno } \\
\text { Pretel }\end{array}$ & Virgilio Guirao & $\begin{array}{l}\text { Mala siembra, mala siega, } \\
\text { zarzuela }\end{array}$ & $\begin{array}{l}\text { Colegio de los } \\
\text { "Sagrados Corazones } \\
\text { de Jesús y María" } \\
\text { 6-01-1888 }\end{array}$ \\
\hline $\begin{array}{l}\text { Pedro Muñoz } \\
\text { Pedrera }\end{array}$ & Joaquín Arques & Murcia, revista (1) & Romea, 25-10-1888 \\
\hline Julián Calvo & José Frutos Baeza & $\begin{array}{c}\text { Correo interior, ¿zarzuela? } \\
(¿ 1 ?)\end{array}$ & Romea, 5-02-1889 \\
\hline \multirow{4}{*}{$\begin{array}{l}\text { Pedro Muñoz } \\
\text { Pedrera }\end{array}$} & \multirow[t]{4}{*}{ Joaquín Arques } & Murcia mercantil, zarzuela (1) & Romea, 7-12-1889 \\
\hline & & Malasangre, zarzuela (1) & Romea, 22-02-1892 \\
\hline & & Monín, zarzuela (1) & Romea, 29-10-1892 \\
\hline & & $\begin{array}{l}\text { Bernal y compañía, apropósito, } \\
\text { (1) }\end{array}$ & Romea,¿13?-02-1893 \\
\hline $\begin{array}{l}\text { Antonio Puig y } \\
\text { Pedro Muñoz } \\
\text { Pedrera }\end{array}$ & Mariano Perní & $\begin{array}{l}\text { Villar y compañia, apropósito, } \\
\text { un acto }\end{array}$ & $\begin{array}{l}\text { Circo Villar, 14-10- } \\
1893\end{array}$ \\
\hline $\begin{array}{l}\text { Mariano Martín } \\
\text { García }\end{array}$ & José Balsalobre & Por la patria, zarzuela, un acto & $\begin{array}{l}\text { Circo Villar, 12-12- } \\
1893\end{array}$ \\
\hline Adolfo Gascón & Joaquín Arques & El mono sabio, juguete, un acto & Romea, 10-03-1894 \\
\hline José Rogel & Julio Hernández & Era de noche y llovía & $\begin{array}{l}\text { Circo Villar, ¿5?-04- } \\
1894\end{array}$ \\
\hline $\begin{array}{l}\text { Miguel Santonja } \\
\text { Cantó }\end{array}$ & $\begin{array}{l}\text { Mariano Herrero } \\
\text { Lax y Calixto } \\
\text { Navarro }\end{array}$ & $\begin{array}{c}\text { Cosas de pueblo, juguete } \\
\text { cómico-lírico, un acto }\end{array}$ & $\begin{array}{l}\text { Circo Villar, 4-12- } \\
1894\end{array}$ \\
\hline Adolfo Gascón & Joaquín Arques & Los $\begin{array}{c}\text { riffeños, zarzuela } \\
\text { posteriormente } 2)\end{array}$ & Romea, 28-10-1893 \\
\hline $\begin{array}{l}\text { Adolfo Gascón y } \\
\text { Julián Calvo } \\
\text { (instrumentación) }\end{array}$ & $\begin{array}{l}\text { Juan Martínez } \\
\text { Espinosa }\end{array}$ & $\begin{array}{l}\text { El tío Tragaderas o El alcalde } \\
\text { de mi pueblo }\end{array}$ & $\begin{array}{l}\text { Circo Villar, 18-01- } \\
1895\end{array}$ \\
\hline
\end{tabular}

La producción zarzuelística de factura murciana en todos los teatros de Murcia se triplicó durante las décadas ochenta y noventa del siglo XIX: dieciséis obras en 18801895, frente a las seis del periodo 1860-1879. Casi todas estas composiciones tenían un acto y pertenecían a géneros variados: zarzuela propiamente dicha, juguete cómico-lírico, apropósito, sainete, revista y la "proposición cómico-lírica" titulada Los aficionados. A continuación comentaré los datos recopilados sobre estas zarzuelas creadas en Murcia, que eran prácticamente desconocidas hasta ahora, y de las que en algunos casos he podido localizar toda o parte de la música.

Los estrenos más antiguos de este tipo documentados son las zarzuelas infantiles Una broma de estudiantes (en dos actos y con libreto de Ramón Guerrero) y Travesuras de Quevedo (en un acto y con letra de Francisco Villegas), ambas de Julián Calvo, estrenadas en febrero de 1860 en el Teatro Provisional por una compañía infantil de alumnos del Instituto Provincial de Murcia. El Archivo Particular de la Familia Martínez Calvo conserva en la actualidad una copia manuscrita de la primera de ambas, aunque en mal estado. (Véase Figura 3.3). 


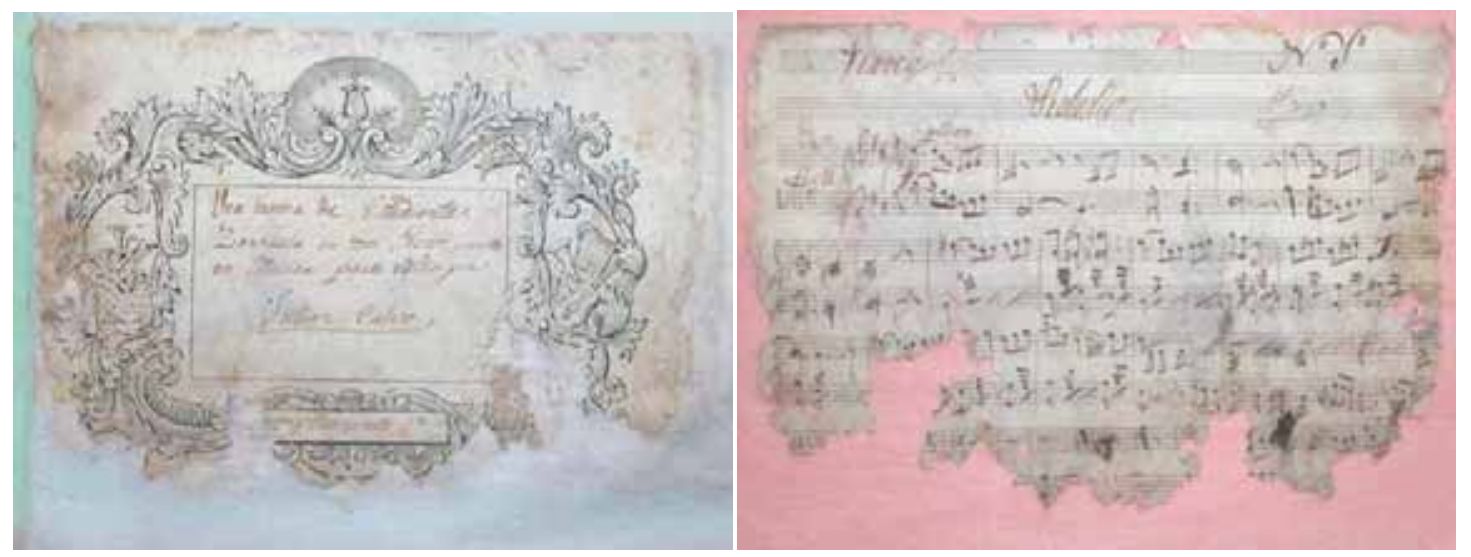

Figura 3. 3. Portada e introducción de la zarzuela infantil Una broma de estudiantes de Julián Calvo (1860), Archivo particular de la familia Martínez Calvo, Murcia.

Lamentablemente, no se conserva el libreto original de Una broma de estudiantes y no es posible reconstruir el argumento. La partitura indica los números musicales de cada acto y los personajes que intervienen:

Tabla 3.18. Números musicales de la zarzuela infantil en dos actos, Una broma de estudiantes, de Julián Calvo (1860).

Fuente: Archivo particular Familia Martínez Calvo, Murcia.

1. Preludio

\section{Primer acto}

2. Introducción Cuarteto (Carlos, Juan, Jorge, Nicolás) y coro

3. Estudiantina (Jorge y coro)

4. Terceto (Carlos, Juan y Nicolás)

5. Brindis y Final (Carlos, Juan, Jorge y coro)

6. Introducción

\section{Segundo acto}

7. Tutti (coro)

8. Dúo recitado (Carlos y don Toribio) y coro (municipales)

9. Dúo (Carlos, don Cosme) y coro

10. Cuarteto (Carlos, Juan, Toribio, Cosme) y coro

11. Coro Final (Carlos, Juan, Jorge, Nicolás y coro)

Una broma de estudiantes fue una zarzuela pensada y compuesta para ser interpretada por niños, con armonía y acompañamiento pianístico muy sencillos, como puede verse en el coro final del segundo acto (Véase "Partituras"). El breve coro, precedido de una breve introducción para piano solo, está escrito al unísono, en Do M y 6/8. Las dos frases principales: Libres estamos, fuera la pena, noche serena se pasará / Vamos al punto por la comida hoy nueva vida se gozará corresponden a dos secciones musicales ligeramente contrastantes (A y B) que a su vez se repiten. En la primera (compases 9-16), la mano derecha del piano refuerza la melodía principal del coro doblándola con una segunda voz a distancia de tercera. La mano izquierda, entre tanto, presenta un acompañamiento acordal basado en el motivo rítmico negra-corchea. En la segunda sección (compases 17-32) la mano derecha imita la melodía del coro, mientras la 
izquierda despliega los acordes en arpegios. La pieza termina con una breve coda de cinco compases al piano solo y de textura acordal.

De la zarzuela Travesuras de Quevedo de Calvo se mencionaron algunos números en La Paz de Murcia, como una romanza de barítono titulada "Ya no hay nada que se oponga", dos coros, uno "llamado del silencio" y otro "Por Dios compañeros", "un parlante entre Fray Policarpo y el colegial [...] que la orquesta acompañó a pizzicato y sirve de introducción a las seguidillas" y una tonadilla que fue descrita así:

[...] No menos esmerada en su ejecución fue la tonadilla entre los señores Marín Barnuevo, vestido de manola, y Soro y Jaén de manolos, acompañada del coro. Policarpo, que con tanta oportunidad interrumpe la escena para reconvenir severamente a todos -quedando estupefacto al ver profanado el santuario de las letras por una mujer-, fue del mejor efecto, en el cual han estado felicísimos, no solo el autor del libreto, sino el de la partitura. El señor Marín Barnuevo, a quien sentó muy bien su femenil atavié, hizo una voluptuosa manola y, con tanta propiedad, que muchos le creyeron pertenecer al sexo que representaba $[\ldots]^{292}$.

También del compositor Julián Calvo es la zarzuela titulada Correo interior, con libreto del periodista José Frutos Baeza, estrenada en 1889. De ella se comentó que su preludio "haría honor a los más reputados autores" y el libreto estaba escrito "con la gracia que resalta en todas sus composiciones, con chistes muy admisibles" ${ }^{293}$. No he podido documentar cuántos actos tenía la obra, aunque por la estructura de la función en la que se representó, pudo haber sido de un acto. En el estreno fue interpretada por la compañía de zarzuela de Francisco Galván y Félix Berros (5-02-1889) y la obra se repitió hasta en tres ocasiones más (véase Apéndice 3.5).

A diferencia de las obras de Julián Calvo, las zarzuelas compuestas por Fernando Verdú se inscriben claramente en la línea de la zarzuela de costumbres, vinculadas temáticamente a Murcia por su ambientación y sus personajes. La primera representación documentada de Un hallazgo a tiempo, de Fernando Verdú (música) e Ignacio Basterrechea (libreto) $)^{294}$, tuvo lugar en junio de 1872 en el Teatro del Círculo Industrial ${ }^{295}$ y sobre ella se especificó que era una "zarzuela de costumbres de la huerta". En la misma línea regionalista se desarrolló la zarzuela en dos actos y seis cuadros ¡Murcia de mi corazón! (1881) de Fernando Verdú, estrenada en el Teatro Circo Villar y compuesta en colaboración con Carmelo Grajales, como después veremos.

${ }^{292}$ La Paz de Murcia, III (1860), nº 616, 15 febrero, p. 1.

${ }^{293}$ La Paz de Murcia, XXXII (1889), nº 9756, 6 febrero, p. 1.

${ }^{294}$ El escritor aficionado Ignacio Basterrechea y Godínez era Jefe de Bomba de la Brigada de Zapateros Bomberos de Murcia. Murió en 1895: El Diario de Murcia, XVII (1895), nº 6516, 19 enero, p. 2.

${ }^{295}$ La Paz de Murcia, XV (1872), nº 4502, 23 junio, p. 4. Esta representación no es mencionada como estreno, así que es probable que fuera estrenada en fechas anteriores. Los alumnos de la "Escuela de Canto y Declamación Padilla" la repitieron el 30 de marzo de 1873, esta vez, en el Teatro Romea: La Paz de Murcia, XVI (1873), $\mathrm{n}^{\text {os }}$ 4725, 30 marzo, p. 1 y 4726, 1 abril, p. 1; y dos meses más tarde, también en este teatro, la puso en escena la compañía de zarzuela de Nicolás Rodríguez (10-05-1873). Sobre la Escuela de Canto y Declamación Padilla, véase el Capítulo 6. 
Sobre Dar posada al peregrino, zarzuela de Antonio López Almagro con libreto de Ricardo Gil, sólo he podido localizar la fecha de estreno en el Teatro Romea (14-02$1874)^{296}$.

Mari Cruz Verde (1875), "zarzuela original de costumbres murcianas" en tres actos y en verso, nació de la colaboración entre el aficionado Esteban Capdepón Pérez (música) y Javier Fuentes y Ponte (libreto) ${ }^{297}$. Su argumento se basó en la figura del médico y poeta murciano del siglo XVIII Francisco Meseguer Ingolotti ${ }^{298}$ y fue estrenada por la compañía de Miguel Soler en el Teatro Romea el 3 de diciembre de $1875^{299}$. Para Esteban Capdepón era su segunda incursión teatral y para Javier Fuentes y Ponte, la primera y última, según Crespo $^{300}$. El estreno fue un fracaso debido, principalmente, al gran número de personajes y la falta de claridad y concisión en la presentación del argumento: "¿Quién es el protagonista? ¿Cuál es el personaje que logra interesar al público? Ninguno.- ¿Qué desea saber el espectador después del acto primero?.- Nada.- ¿Y después? - Menos aún", según la crítica del momento ${ }^{301}$. A partir de los comentarios periodísticos es posible reconstruir la estructura musical de esta zarzuela (ver Apéndice 3.9), que constaba de trece números: cuatro en el primer acto, seis en el segundo y tres en el tercero. Mari Cruz Verde reunía muchas de las características que según Cortizo definían a la "zarzuela" restaurada ${ }^{302}$ :

1. Empleo de formas musicales autóctonas de la tradición musical española, provenientes, especialmente, de la tonadilla. Es el caso del número 3, "Tirana para soprano con coro" y el 7, "Seguidillas cantadas y bailadas".

${ }^{296}$ La única referencia periodística que hallado sobre esta obra, aparecida en La Paz de Murcia, XVII (1874), $\mathrm{n}^{\circ}$ 5002, 17 febrero, p. 1, prometía publicar una extensa crítica en los números siguientes que, sin embargo, no se publicó. La zarzuela fue repetida el 15 de febrero de 1875 en una función a beneficio del director Vicente Rodrigo ante "un numerosísimo concurso que llenó las localidades ordinarias y las extraordinarias de sillas que se colocan en los pasillos". Como obertura inicial, se ejecutó una sinfonía para orquesta y banda del músico murciano Julián Calvo.

${ }^{297}$ Javier Fuentes y Ponte (1830-1905) fue un erudito, ensayista y tratadista murciano. Colaboró con varios periódicos murcianos, entre ellos, El Semanario Murciano y fue el iniciador de los Juegos Florales de Murcia (véase Capítulo 11).

${ }^{298}$ Francisco Meseguer (1760-1810) fue un activo periodista y redactor principal de El Diario de Murcia de 1792. Véanse más datos sobre su biografía en Tejera, Biblioteca, t. I, pp. 455-467.

${ }^{299}$ El estreno se efectuó en una función a beneficio de la primera tiple Teresa Rivas. Los ensayos comenzaron un mes antes: La Paz de Murcia, XVIII (1875), $\mathrm{n}^{\text {os }}$ 5488, 3 noviembre, p. 1; 5600, 17 noviembre, p. 1; 5601, 19 noviembre, p. 1 y 5607, 26 noviembre, p.1.

${ }^{300}$ Crespo, "Algunos autores", pp. 73-74. La primera composición teatral de Esteban Capdepón fue el juguete cómico-lírico en un acto En busca de un marido, sobre libreto de Felipe Blanco de Ibáñez, estrenado en enero de 1865 en el Teatro de los Infantes. Los actores Adela Serra y el primer actor cómico Camino representaron los papeles principales, entre otros artistas aficionados. Junto a la mencionada zarzuela, se representó el drama de García Gutiérrez Venganza catalana. La crítica elogió dos romanzas para tiple y un dúo de tenor y tiple y, en general, la música de esta obra. Sobre el libreto, en cambio, se criticaron las "faltas naturales de una primera obra" aunque se alabaron sus situaciones cómicas y sus chistes: La Paz de Murcia, VIII (1865), nº 2088, 24 enero, pp. 2-3. En busca de un marido fue repetida el 8 de febrero de 1865 en el Teatro de los Infantes de Murcia y, en junio del mismo año, en Almería: La Paz de Murcia, VIII (1865), $\mathrm{n}^{\text {os }} 2100,7$ febrero, p. 2; 2200, 9 junio, p. 1.

${ }^{301}$ La reseña fue escrita por varios colaboradores y no fue firmada. Unos días más tarde, La Paz de Murcia se vio obligada a matizar algunas de las ideas vertidas en la crítica inicial. Véase, La Paz de Murcia, XVIII (1875), $\mathrm{n}^{\text {os }} 5615,5$ diciembre, p. 1; 5616, 7 diciembre, p. 1 y 5618, 10 diciembre, p. 1.

${ }^{302}$ Cortizo, "La zarzuela", pp. 186-194. 
2. Utilización del coro para la apertura y cierre de la zarzuela, así como para números intermedios. El primer acto de Mari Cruz Verde presenta dos números con coro (1 y 3 ); en el segundo, uno (el 6) y, finalmente, en el tercero, otro (el 11).

3. Utilización de romanzas a solo para presentar a los personajes principales. El plan habitual era presentar a la soprano, al tenor (su pareja) y un barítono que replica a ambos. Sin embargo, esta zarzuela presenta, en primer lugar, a la mezzosoprano (acto primero, número dos). La romanza de soprano (número ocho) aparece en el acto segundo y la romanza de tenor (número 12) en el tercer acto.

4. Empleo de números con combinaciones de voces de distintos registros. En el caso que nos ocupa aparece un dúo para soprano y tenor (número 9, acto segundo).

5. Comienzo de cada acto con un número instrumental y finalización con un concertante al final de segundo acto (número 10). En el caso de Mari Cruz Verde se concluye con un tutti.

La música de Mari Cruz Verde de Capdepón "fue regularmente recibida" "303. Los comentarios ofrecen datos curiosos sobre la parte musical. El crítico consideró el mejor número las seguidillas cantadas y bailadas porque sus "acentos trascienden a parrandas murcianas", y señaló que el dúo de tiple y tenor "ha querido nacer en el estilo de Wagner" ${ }^{304}$. Se valoró negativamente la utilización excesiva de instrumentos de viento metal: "El que compone para el teatro debe usar con mucha prudencia todo el instrumental y, en particular, la familia del latón [...] los trompetazos deben quedar relegados al olvido"305.

En 1885 se estrenó en el Teatro Romea Será lo que tase un sastre, zarzuela en un acto con música del compositor madrileño Casimiro Espino (1845-1888) y el periodista murciano Antonio Ibáñez González (libreto). El libretista era colaborador de La Paz de Murcia, razón por la que no se publicaron críticas de esta obra en este periódico ${ }^{306}$.

Entre 1888 y 1893 el compositor Pedro Muñoz Pedrera estrenó seis zarzuelas con libretos del periodista y actor aficionado Joaquín Arques. La primera de ellas fue la revista en un acto y cinco cuadros titulada Murcia, estrenada el 25 de octubre de 1888 por la compañía de Francisco Galván y Félix Berros. Fue un gran éxito por la combinación de varios elementos: la reciente implantación en la ciudad del teatro por horas (precisamente por esa compañía), que abarató el precio de las localidades; la popularidad de sus autores y la expectación previa preparada por la crítica. Se reunieron tantos espectadores fuera del coliseo que

hubo necesidad de que la guardia civil acudiera, y aún así resultó ésta impotente y tuvo que retirarse, lo mismo que los porteros, y dejar que el público asaltara el coliseo, entrando sin entregar el billete, lo cual no perjudicó a la empresa por estar vendido

\footnotetext{
${ }^{303}$ La Paz de Murcia, XVIII (1875), no 5615, 5 diciembre, p. 1.

${ }^{304}$ La Paz de Murcia, XVIII (1875), no 5615, 5 diciembre, p. 1.

${ }^{305}$ Ibídem.
}

306 "para evitar torcidas interpretaciones, nos priva de ocuparnos de su producción”. También se representó en Cartagena. Véanse: La paz de Murcia, XXVIII (1885), $\mathrm{n}^{\text {os }} 8124,20$ enero, p. 1 y 8203, 23 abril, p. 1. 
todo y más con antelación. Romea contuvo un número de espectadores aumentado lo menos en un veinte por ciento de su cabida legal $[\ldots]^{307}$.

Murcia (1888) de Muñoz Pedrera presenta muchas similitudes con la revista La Gran Vía (Chueca y Valverde, con libreto de Felipe Pérez, estrenada en 1886): los espacios y edificios más significativos de Murcia (Glorieta, Malecón, Floridablanca, Casino y la Diputación, entre otros) aparecían sobre el escenario personificados por los actores. En la presentación de cada personaje se ponía en evidencia, además, los aspectos más negativos del espacio que representaba:

[...] Presentóse la Glorieta, la cual viste bien y lleva una diadema que figura una de las entradas en día de feria; el Malecón, por un hombre del pueblo que lleva un león y, si no vimos mal, una sartén y la estatua de Floridablanca. Cada uno de estos personajes se encomia: al Malecón le dice la Glorieta que sus noches es lo peor que tiene por lo que allí se oye; Floridablanca disputa por llevarse la feria, y aparece a poner paz un conocido Inspector, personaje que, compitiendo con nuestro amigo Almagro, fotografió al señor Berros de tal modo que muchos creyeron era el auténtico que se ingería indebidamente, y ciertas voces que de las alturas se oyeron fue el más cumplido aplauso para el señor Berros. Esta escena hubo que repetirla.

Sigue la presentación de los teatros: Romea busca compañía, el Progreso se queja de la falta de dinero y dice que ha tenido que ocuparse en la fotografía, el Porvenir solo espera abrir sus puertas a la familia Galinier. Por último, Romea manifiesta que ha encontrado la solución con las piezas divertidas, los 15 céntimos y más si hay algo $[\mathrm{de}]$ flamenco $[\ldots]^{308}$.

La acción estaba basada en la Murcia de la época y alude a sus problemas cotidianos. Un personaje inglés, Mr. Bairon, llega a Murcia para conocer la ciudad. En la estación le espera Luis "para servirle de cicerone". Otros personajes son: un mendigo "que representa a lo que va a venir a parar esta ciudad con las adulteraciones, las inundaciones y la no realización de las obras de defensa"; un ciego llamado Roque; un municipal "que va a llevar al Ayuntamiento unos listones con muchas revueltas, los cuales representan las alineaciones de nuestras calles"309. Algunos números musicales de Murcia eran: "coro de cocheros", "coro de floristas", "coro general representando, las señoras, las harinas y los caballeros el pimiento molido", coplas de Roque y "coro de telefonistas". La obra también contenía números bailables aunque en la prensa consultada no se especifican más detalles.

La obra alcanzó el éxito, probablemente porque en ella "sale a relucir todo lo que tiene actualidad en la población, las cuestiones interesantes y las pequeñas, los tipos y los personajes, los paseos y las sociedades, la chulería y la prensa, lo que puede ridicularizarse y lo que excita la hilaridad". La prensa reconoció que "el patrón de esta clase de revistas [...] tiene cierta gracia y mucho color local" ${ }^{310}$. Desde octubre de 1888

${ }^{307}$ La Paz de Murcia, XXXI (1888), nº 9640, 26 octubre, p. 4. Los incidentes fueron en aumento y el Gobernador llegó a estipular multas de hasta 100 pesetas. Las elevadas sanciones surtieron cierto efecto durante algunos días.

308 [Anónimo], “Murcia”, La Paz de Murcia, XXXI (1888), n 9640, 26 octubre, p. 4 (ver Documentario). Véase también: La Paz de Murcia, XXXI (1888), nº 9641, 27 octubre, p. 1.

${ }^{309}$ [Anónimo], “Murcia”, La Paz de Murcia, XXXI (1888), n 9640, 26 octubre, p. 4.

${ }^{310}$ El Diario de Murcia, X (1888), no 3553, 27 octubre, p. 1. 
hasta febrero del año siguiente, Murcia llegó a representase hasta en diecinueve ocasiones diferentes y cinco más tras su reposición en diciembre de 1891 (véase Apéndice 3.4) ${ }^{311}$.

La segunda revista musical de Muñoz Pedrera y Arques estrenada en la capital murciana fue Murcia mercantil (un acto, tres cuadros), dada a conocer en el Teatro Romea por la compañía de Manuel Rodríguez el 7 de diciembre de 1889. La trama de la obra se inicia con la presentación de Don José, un rico comerciante murciano, que reúne en el Arenal (actual Glorieta) a otros vendedores de la ciudad con la finalidad de crear un Círculo Mercantil (véase Figura 3.4). El argumento, que guarda ciertos paralelismos con el anterior, busca en esta ocasión llevar a escena los comercios y establecimientos más populares de la Murcia contemporánea como pretexto para la crítica y el sarcasmo ${ }^{312}$.

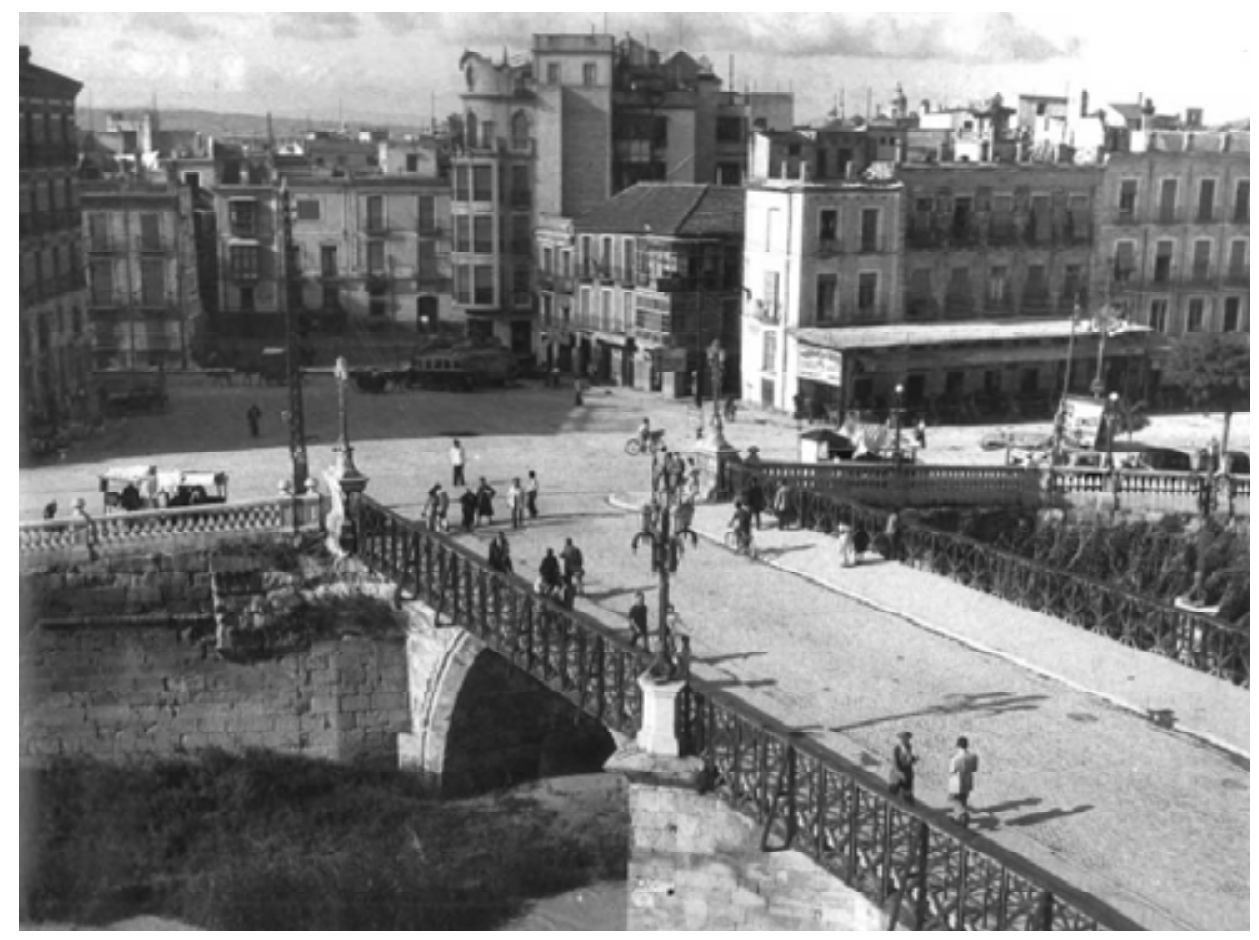

Figura 3. 4. Puente Viejo y explanada del Arenal de Murcia. Principios del siglo XX. E: MUm. Accesible en: http://www.archivodemurcia.es/ (acceso 1-08-2011).

${ }^{311}$ La compañía de Francisco de la Vega (Romea, $1^{\text {a }}$ temporada de 1891-1892) repuso la obra sobre el escenario del Teatro Romea, aunque en una versión revisada. Se suprimieron algunas partes que hacían alusión a hechos ya superados y se incorporaron varios números musicales, por ejemplo, una pareja flamenca. Véanse más detalles en Crespo, El Teatro Romea, p. 291.

${ }^{312}$ La Paz de Murcia, XXXII (1889), no 9994, 8 diciembre, p. 1 (ver Documentario). A Don José le acompañaba "un viajante que hace notar la pobreza del comercio murciano al manifestar que no ha encontrado cambio de un billete de mil pesetas". Algunos de los comercios mencionados en la trama eran "La tienda del Rollo", "La tienda del Gallo", "La Joya Literaria", "El buen tono", "El buen gusto", "La Cooperativa", "El bazar veneciano", "La Campana", "La tienda de los muchachos", "El diamante", "La dalia azul", "La cuba de oro": La Paz de Murcia, XXXII (1889), no 9993, 7 diciembre, p. 4. Según La Paz de Murcia, XXXII (1889), n $\mathrm{n}^{\circ}$ 9994, 8 diciembre, p. 1 no se escatimaron esfuerzos para caracterizar a los comercios en el escenario, aunque la decoración del paseo del Arenal fue la misma que se utilizó en el último cuadro de la revista Murcia (1888). 
La primera representación de Murcia mercantil, abarrotada de público, resultó un éxito. Sin embargo, la obra motivó la protesta de algunos comerciantes, "a quienes no habrá agradado el verse llevados a la escena aunque sea alegóricamente. Todas las manifestaciones fueron contra el libreto, cesado en los números de música"313. La obra solo se representó en cuatro ocasiones diferentes, incluyendo su estreno. De la música sabemos que había una introducción "de música alegre y ligera", un "Coro de Los muchachos" interpretado por los huérfanos de la Misericordia, unas coplas cantadas por el personaje de "El Romancero" y un "Vals veneciano" coreado por los niños.

En la década de los noventa, los citados Arques y Muñoz Pedrera estrenaron en el Teatro Romea las zarzuelas Malasangre, en un acto (22-02-1892) y Monín, también en un acto (29-10-1892); el apropósito Bernal y compañia (¿13?-02-1893) y el sainete lírico El martes se la lleva o ;Al monte al monte! (5-01-1895). Malasangre fue estrenada por la compañía de Guillermo Cereceda, en una función a beneficio de las obras del nuevo Manicomio (véase Apéndice 3.4). La expectación era elevada, no sólo por ver la tercera obra de Pedrera-Arques en la ciudad, sino también porque en la función participaron varios aficionados muy conocidos entre los habituales al teatro. La crítica, muy superficial, afirmó que la obra contenía "una música muy agradable y está escrita con soltura y salpicada de frases ingeniosas que delatan a su autor" ${ }^{214}$. En la Biblioteca Nacional de España se conserva un manuscrito de los autores con las partes de piano y canto de Malasangre ${ }^{315}$, que permite reconstruir su estructura (ver Tabla 3.19).

Tabla 3.19. Malasangre (1892) de Pedro Muñoz Pedrera (música) y Joaquín Arques (libreto), zarzuela en un acto: estructura musical.

Fuente: $E: M n, \mathrm{M} / 3546$. Manuscrito original de los autores. Partes para canto y piano.

\begin{tabular}{|l|l|l|l|}
\hline \multicolumn{2}{|l|}{ Números (tempo) y personajes } & Tonalidad & Compás \\
\hline 1 & $\begin{array}{l}\text { Coro general: Virtudes, Perico, Lola, Ricardo, } \\
\text { León, Bruno y cazadores } 1^{\mathrm{o}}, 2^{\mathrm{o}} \text { y } 3^{\mathrm{o}} \text {. }\end{array}$ & $\begin{array}{l}\text { La Mayor-Re } \\
\text { Mayor- La Mayor }\end{array}$ & $3 / 4-2 / 4-3 / 4$ \\
\hline 2 & Allegro: Perico, León y coro general & Sol Mayor & $2 / 4$ \\
\hline 3 & Mazurka: Virtudes, Ricardo, León y Antoñito & Re Mayor & $3 / 4$ \\
\hline 4 & Andante: Ricardo y cazadores $1^{\circ}, 2^{\circ}$ y 3 & Fa Mayor & $2 / 4$ \\
\hline 5 & $\begin{array}{l}\text { Allegro Vivo: Virtudes, Lola, Perico, León, Bruno } \\
\text { y Cazadores y coro }\end{array}$ & Mi b Mayor & $2 / 4$ \\
\hline 6 & Coro final: Perico y coro & Mi b Mayor & $2 / 4$ \\
\hline
\end{tabular}

El primer número de Malasangre es un largo coro (que incluye una jota) en el que las voces dialogan con varios personajes y tres cazadores. Está dividido en tres secciones: allegretto (compases 1-120), allegro (compases 121-156) y jota (compases 157-275) ${ }^{316}$.

${ }^{313}$ La Paz de Murcia, XXXII (1889), no 9996, 11 diciembre, p. 1.

${ }^{314}$ La Paz de Murcia, XXXV (1892), nº 11551, 23 febrero, p. 1.

${ }^{315}$ E:Mn, M/3546. En la portada del manuscrito se lee: "Ejemplar presentado al Registro General de Propiedad Intelectual. Madrid 25 noviembre 1895".

${ }^{316}$ La jota es introducida por las tiples (Venga la jota, venga de ahi) a la que le sigue León (cuánto nos vamos a divertir), continua Perico (No hay cantar como la jota / en el pueblo de Aragón, / ni para los españoles / hay otro cantar mejor); retorna de nuevo el coro de tiples (Viva la jota del segador / que alegra el alma y el corazón,/ aunque se canse de trabajar / no lo está nunca para bailar), sigue Perico con la segunda letra (En los trigos la otra tarde / un segador se perdió / su novia fue a buscarlo / y al punto se lo encontró) y concluye el coro de tiples con la misma letra que la anterior (Viva la jota del segador). 
No hay números para un personaje solo (tipo romanza) sino que todos combinan uno o varios personajes con el coro. El piano presenta una escritura muy simplificada, casi siempre apoyando las voces, con largos pasajes al unísono en ambas manos o con sencillos acordes en la mano izquierda. Desde la fecha de su estreno hasta enero de 1893, Malasangre fue llevada a las tablas en diez ocasiones más.

Monín de Pedrera y Arques, fue estrenada seis meses después de Malasangre (octubre de 1892), por la compañía de Manuel Taberner y representada hasta en siete ocasiones diferentes, siempre por los mismos artistas. Su libreto estaba salpicado de situaciones cómicas y la música fue considerada como la mejor de Muñoz Pedrera hasta entonces. En ella se incluían un "coro de colegiales" y "un número de música que imita el paso del ferrocarril" ${ }^{\prime 317}$.

La compañía de Manuel Taberner también estrenó en febrero de 1893 el apropósito Bernal y compañía de Muñoz Pedrera y Arques, cuyo argumento se basaba en "la presentación de todos los artistas, proporcionándoles ocasión de lucir sus facultades en varias escenas que se suceden ante el que es tomado por los actores por empresario del teatro [Bernal]" 318 . Era pues, una obra que utilizaba el conocido recurso del teatro en el teatro: la acción dramática tenía lugar en el mismo tiempo de la representación, mezclando el juego teatral con la realidad de los personajes ${ }^{319}$. La música incluía "un bonito bolero, bailado por el señor Verdejo y la niña Taberner" ${ }^{320}$. Bernal y compañía sirvió de modelo para Villar y compañía, otro apropósito de Muñoz Pedrera y Antonio Puig escrito para el Teatro Circo Villar y estrenado ocho meses después.

En enero de 1895, dos años más tarde del estreno de Bernal y compañía, Muñoz Pedrera y Arques estrenaron su sexta obra, el sainete El martes se la llevan o ;Al monte, al monte! inspirado en la célebre romería de la Virgen de la Fuensanta, patrona de los murcianos (véase Figura 3.5) ${ }^{321}$ :

${ }^{317}$ El Diario de Murcia, XIV (1892), no 5137, 1 noviembre, p. 2. Véase también, La Paz de Murcia, XXXV (1892), no 11745, 31 octubre, p. 1.

${ }^{318}$ El Diario de Murcia, XV (1893), no 5855, 15 febrero, pp. 1-2: 1.

319 Sin embargo, no era novedoso. El apropósito de Sánchez Madrigal, titulado Querer es poder, estrenado en el Teatro Romea en 1876 utilizaba el mismo recurso. Su argumento se basa en el montaje de la zarzuela El juramento. Véanse más detalles en: Díez de Reventa y De Paco, Historia, pp. 292-293.

${ }^{320}$ El Diario de Murcia, XV (1893), no 5855, 15 febrero, pp. 1-2: 2.

${ }^{321}$ Sobre esta fiesta véase la descripción de Modesto Mirambell, "La fiesta del monte", La Paz de Murcia, XXXVI (1894), nº 12787, 19 septiembre, p. 1. 


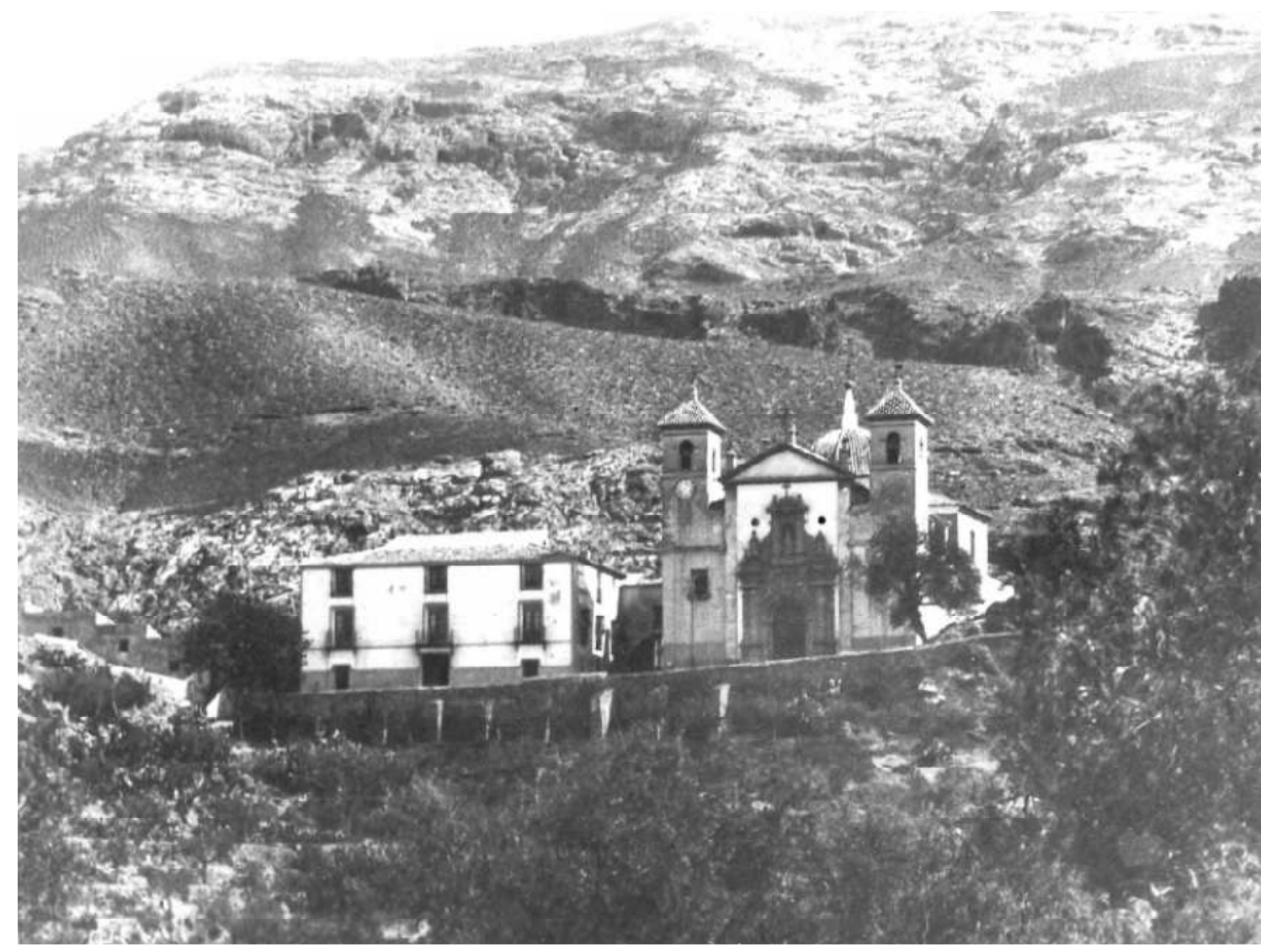

Figura 3. 5. Santuario de la Fuensanta, enclavado en el paraje natural del Valle en la Sierra de Carrascoy, Algezares (Murcia). ¿Principios del siglo XX? E: MUm. Accesible en: http://www.archivodemurcia.es/ (acceso 1-08-2011)

En la música de El martes se la llevan se destacó un "dúo de tenor y barítono del primer cuadro, el preludio entre éste y el segundo, el terceto del tercero, el baile y coplas"322. Arques escribió el libreto en tan poco tiempo "que ni tiempo de corregirla ha tenido" "323. El martes se la llevan o iAl monte, al monte! fue repetida hasta en siete ocasiones diferentes por la compañía de Sánchez Castilla.

Sin lugar a dudas, el éxito de los murcianos Muñoz Pedrera y Arques radicó en su acertada elección de temas murcianos y en la identificación del público con las tramas y personajes. Según Crespo, el traslado de Arques a La Unión interrumpió las exitosas colaboraciones entre ambos autores aunque sus producciones literarias y musicales prosiguieron por separado en los años siguientes ${ }^{324}$.

La producción posterior de Muñoz Pedrera fue amplia. En febrero de 1898, estrenó en el Romea Me gustan todas, un "pretexto en un acto, en verso y música", con letra de Mariano Perní. La obra se llevó a los escenarios en una función a beneficio de Paquita Fernani, integrante de la compañía de Pablo López. Crespo cita cuatro números

${ }^{322}$ La Paz de Murcia, XXXVII (1895), nº 12876, 8 enero, pp. 1-2.

${ }^{323}$ El Diario de Murcia, XXII (1895), nº 6511, 13 enero, p. 1.

${ }^{324}$ Muñoz y Arques fueron autores de la zarzuela en dos actos El príncipe Angelín, estrenada por la compañía del empresario murciano y cantante Pablo López en noviembre de 1896. Véanse más detalles en: Crespo, “Apuntes”, p. 109-110; Crespo, El Teatro, p. 377. 
musicales: una polca, una canción flamenca, una jota y un vals. Durante los primeros años del siglo XX, Muñoz Pedrera estrenó títulos como Partida disuelta, zarzuela en un acto y cuatro cuadros, con texto de José Selgas Ruiz (Teatro Romea, 22 de diciembre de 1908); y dos zarzuelas con libreto de Jara Carrilo, El predicador y Andando por Murcia $^{325}$.

El libretista Joaquín Arques (además de con Muñoz Pedrera) colaboró con otros compositores que estrenaron obras en el Teatro Romea de Murcia. Su proyección llegó hasta el Teatro Gran Vía de Barcelona, donde llevó a las tablas una "humorada trágico bufo cómico lírico bailable" en un acto y cuatro cuadros titulada Tenorio en Nápoles o Yo a los palacios subí, / yo a las cabañas bajé / y en todas partes dejé / memoria amarga de $m i$, con música de Liñán y Salvador Videgain (31-10-1900) ${ }^{326}$.

Joaquín Arques escribió el libreto de Los riffeños, primera producción escénica junto al compositor invidente Adolfo Gascón, que inicialmente fue zarzuela en un acto (28-10-1893), aunque un mes más tarde se le añadió otro acto (28-11-1893) ${ }^{327}$. Esta zarzuela tuvo mucho éxito, ya que su argumento era de rabiosa actualidad. La trama giraba en torno a Pascual Verdú, un soldado de caballería murciano en la Guerra de Melilla de $1893^{328}$. Además, la obra "está escrita con facilidad, hay escenas graciosísimas las unas, conmovedoras las otras que hacen que el público estalle en delirante entusiasmo",329. Una de las escenas más aplaudidas fue la que muestra la fe del militar en la Virgen de la Fuensanta. La música incluía, además, un "pasodoble, el terceto de los moros y la combinación del toque de cornetas" ${ }^{330}$.

También de Adolfo Gascón con libreto de Arques fue el juguete titulado El mono sabio, estrenado en castellano por actores romanos de la Compañía Romana de Opereta y Baile de Gaetano Tani el 10 de marzo de 1894. La obra y su interpretación gustaron ${ }^{331}$.

Fuera del Teatro Romea también se estrenaron zarzuelas de autores murcianos. La citada ;Murcia de mi corazón!, con música de Fernando Verdú y Carmelo Grajales

${ }^{325}$ Véanse: Crespo, “Apuntes”, p. 110; Selgas, Partida; Díez de Reventa y De Paco, Historia, p. 380 y Crespo, “Apuntes sobre compositores”, pp. 107-110.

${ }^{326}$ El Globo, XXVI (1900), no 9099, 2 noviembre, p. 3. Según Crespo, "Algunos autores”, p. 82 Arques fue también autor del libreto de Noche de novios (1898) con música de ¿Arturo? Baratta: El Diario de Murcia, XX (1898), $\mathrm{n}^{\circ}$ 7578, 16 febrero, p. 2; y de un cuadro añadido a Certamen nacional (1889), de Perrín, Palacios y Nieto, todas ellas estrenadas en Murcia.

${ }^{327}$ Para el reestreno de Los riffeños se realizaron nuevas decoraciones del pintor Sanmiguel: El Diario de Murcia, XV (1893), $\mathrm{n}^{\mathrm{o}}$ 6095, 16 noviembre, p. 2. Hasta ese momento la obra se había representado doce veces. Tras la incorporación del segundo acto y hasta enero de 1894 se llevó a escena en dieciséis ocasiones más.

${ }^{328}$ En 1890, el periodo de paz que venía gozando España tras los tratados firmados entre el sultán de Marruecos y el gobierno español en los años sesenta, se rompió con la llamada crisis de Melilla. Desde 1890 hasta 1893, las tropas españolas frenaron en varias ocasiones los ataques de las tribus de la región del Rif, limítrofes con Melilla. La ciudad española fue atacada los días 27 y 28 de octubre de 1893, falleciendo en el ataque el general Margallo, Gobernador Militar de Melilla. En el segundo esteno de Los riffeños se suprimió por orden del Gobernador el personaje Margallo, debido a su reciente fallecimiento: El diario de Murcia, XV (1893), nº 6094, 15 noviembre, p. 3.

\footnotetext{
${ }^{329}$ La Juventud Literaria, V (1893), no 186, 5 noviembre, pp. 3-4: 3.

${ }^{330}$ La Juventud Literaria, V (1893), $\mathrm{n}^{\mathrm{o}} 186,5$ noviembre, p. 4.

${ }^{331}$ La Paz de Murcia, XXXVI (1894), nº 12642, 11 marzo, p. 3.
} 
(director de la orquesta del Teatro Circo de la Rambla) y libreto del periodista Martínez Tornel (director de El Diario de Murcia), era una "revista de costumbres y tipos populares" y fue un encargo de la empresa teatral para la compañía de Eugenio Fernández, estrenada en el Teatro Circo de la Rambla el 24 de febrero de $1881^{332}$. El argumento, similar a Murcia de Muñoz Pedrera, trataba sobre la visita a Murcia de un periodista francés (Mr. Canard) que recorría la huerta y la ciudad "admirando sus encantos y criticando la pereza o ignorancia de sus habitantes" (ver Figura 3.6) ${ }^{333}$. La obra constaba de seis cuadros, escritos en verso ("La esquina del Contraste", "Los murmuradores", "Por bailar las parrandas", "La Virgen del Carmen", "La rifa del borrego" y "El más ilustre murciano") ${ }^{334}$. ¡Murcia de mi corazón! provocó opiniones divergentes en la prensa murciana aunque todos coincidieron en lo acertado de la temática. En La Paz de Murcia se elogió la fidelidad con la que estaban caracterizados los personajes y sus grandes similitudes con los tipos y caracteres murcianos de la época. El mayor defecto para el crítico de este periódico fue la falta de ensayos y ciertos desajustes en algunas escenas:

[...] La escena en que salen montados en dos burras el corresponsal francés, su cicerone y LA PAZ, habría desaparecido desde luego. Los carteles de los teatros no hay necesidad de que salgan a ponerlos pues habrían podido estar puestos. Se habrían bailado las parrandas y se hubieran cantado más malagueñas y seguidillas, y menos jota, lo cual le hubiera quitado a la escena cierto saborcillo de Las nueve de la noche muy marcado que tuvo.

En el segundo cuadro la gente que va a ver el castillo fue muy poca y pareció la escena floja y desanimada; y el final del cuadro de Carmen y su marido fue tan rápido que muchos no supieron darse cuenta de lo que allí había pasado.

La música gustó en general, excepto la serenata del segundo acto que era muy innecesaria. La romanza de Juana, tal vez demasiado excelente, los coros y todo lo demás bien $[\ldots]^{335}$.

Para El Semanario Murciano, en cambio, los actores no consiguieron retratar con fidelidad sus personajes: "¿Cómo exigirles que en tres meses conozcan nuestras costumbres hasta copiarlas con la exactitud del detalle, que es el que presta relieve a lo representado?" 336 . Este periódico criticó la rapidez con la que se había escrito, ensayado y estrenado la obra, pero elogió la gracia de algunas escenas, la acertada intención de

${ }^{332}$ En El Diario de Murcia, III (1881), n ${ }^{\circ}$ 595, 8 febrero, p. 1 se menciona que también colaboró Ángel Mirete. Véase, La Paz de Murcia, XXIV (1881), n ${ }^{\text {os }}$ 6969, 6 febrero, p. 1 y 6986, 25 febrero, p. 1.

${ }^{333}$ La Paz de Murcia, XXIV (1881), nº 6988, 27 febrero, p. 1.

${ }^{334}$ La Paz de Murcia, XXIV (1881), nº 6975, 13 febrero, p. 1; El Diario de Murcia, III (1881), nº 600, 12 febrero, p. 1 y El Semanario Murciano, IV (1881), $\mathrm{n}^{\circ}$ 157, 13 febrero, p. 55. Los personajes eran: “Carmen, Juana, la Fama, la Historia, una mamá, LA PAZ DE MURCIA, la señorita Rosario, una niña, Lirio, cartel del Circo, tío Pedro, tío Blas, Mr. Canard, Antonio, un beato, el cartel de Romea, Luis, el tío Migalo, el tío Juan, Alcalde barrio, un hermano de [el eremitorio de] La Luz, una hija, otra ídem, una modista, Pepe, un huertano, una huertana, criadas, huertanas, huertanos, mozos y mozas del pueblo". Véase, La Paz de Murcia, XXIV (1881), nº 6985, 24 febrero, p. 1.

${ }^{335}$ La Paz de Murcia, XXIV (1881), n 6988, 27 febrero, p. 1. Según el periódico de este periódico Martínez Tornel no presenció ningún ensayo a causa de una enfermedad.

${ }^{336}$ El Semanario Murciano, IV (1881), nº 159, 27 febrero, p. 72. 
algunos cuadros y su buena versificación y el diálogo fácil. Opiniones similares se vertieron en El Diario de Murcia ${ }^{337}$.

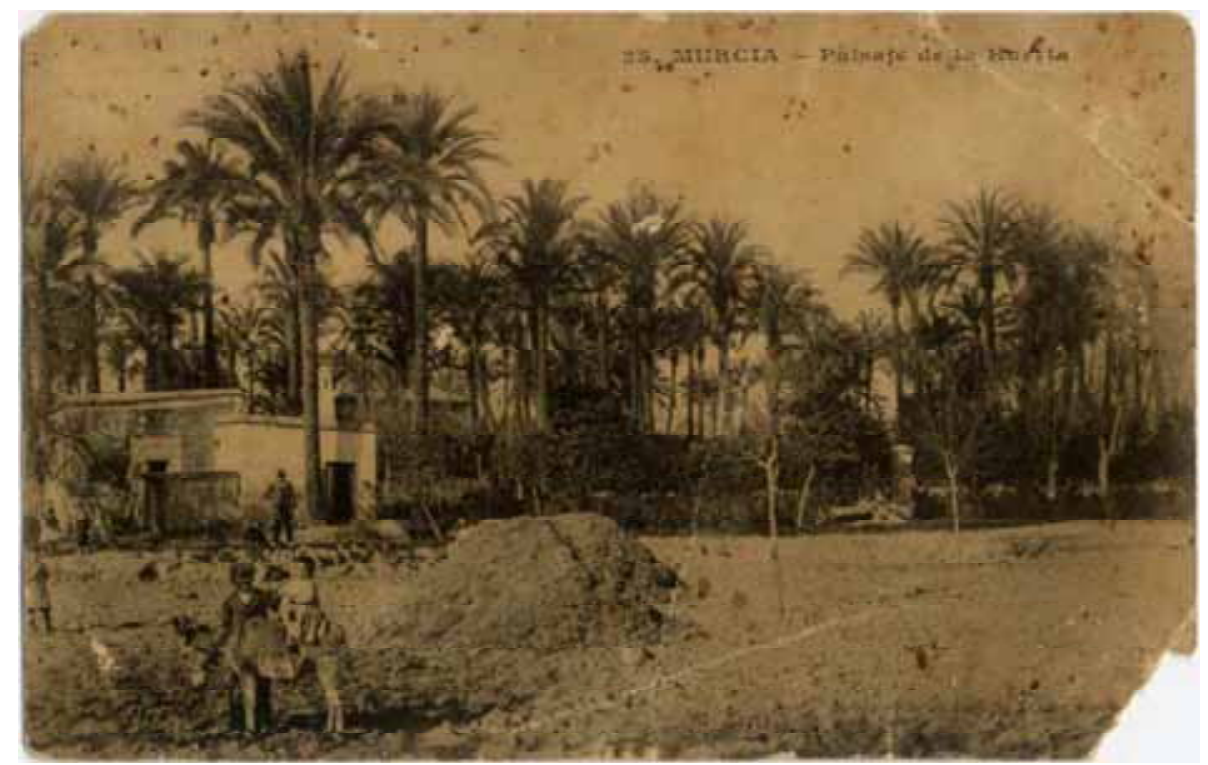

Figura 3.6. Paisaje de la huerta murciana. Murcia: Sucesores de Nogués, ca. 1905. E:MUbr. Accesible en: http://bibliotecadigital.carm.es (acceso el 1-08-2011).

En el Teatro del Colegio de los "Sagrados Corazones de Jesús y María" se estrenó el 6 de enero de 1888 la zarzuela en un acto Mala siembra, mala siega, con música de Mariano Moreno Pretel, un joven compositor alumno del centro y libreto de Virgilio Guirao. Fueron sus intérpretes los niños Eduardo Martínez, Ángel Hernández, José María Ponce, Tomás Moreno, Pedro Conejero y Dionisio Terrer y un coro de quince voces (cuyos apellidos eran Durán, Moreno, Sánchez, Mula, Guirao, Ródenas Fargas, Gil Pareja, Miguel y José Nicola, Novella, Moreno, Zacarías Lázaro, Moreno Alarcón, Andreu y Guillén) $)^{338}$.

Después del Teatro Romea, el coliseo que más estrenos de zarzuelas de autores murcianos acogió fue el Circo Villar. El primero de ellos tuvo lugar el mismo día de su re-inauguración como teatro propiamente dicho (14-10-1893), con el apropósito titulado Villar y compañía, encargado por la empresa del teatro para esta ocasión. La música corrió a cargo de Antonio Puig y Muñoz Pedrera y el libreto fue obra de Mariano Perní. El elenco encargado de llevar la obra a escena fue el dirigido por Eduardo Ortiz. Es de suponer que su argumento presentaba similitudes con la anteriormente citada Bernal y compañía (ver Figura 3.7) 339 .

${ }^{337}$ El Diario de Murcia, III (1881), nº 606, 25 febrero, p. 3.

${ }^{338}$ El resto de obras representadas en la misma función fueron: En el pecado el castigo (drama escrito para niños por el murciano Virgilio Guirao) y Los aguinaldos (apropósito del mismo autor). La misma función se repitió los días 7 y 8 de enero de 1888 .

339 Según Crespo, “Algunos autores", p. 84, los personajes de Villar y compañía encarnaban simbólicamente espacios relevantes de Murcia, como la acequia de Caravija, la Plaza de Toros, el convento de Santa Ana, la Carnicería, el Teatro Romea, el Contraste y el cuartel de la Trinidad. 


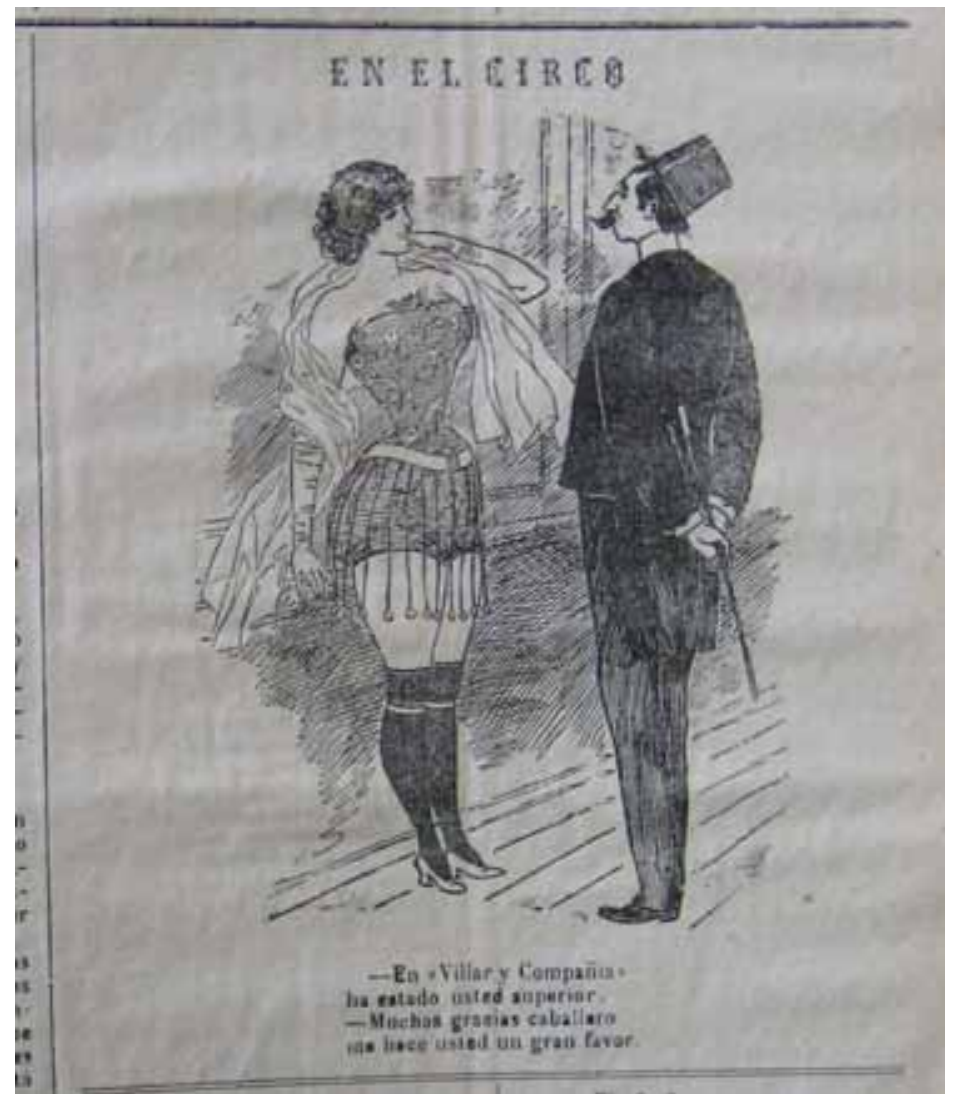

Figura 3. 7. Viñeta alusiva a la zarzuela Villar y Compañía, música de Antonio Puig y Muñoz Pedrera y libreto de Mariano Perní. La Juventud Literaria, V (1893), nº 183, 15 octubre, p. 1, E: MUm.

La zarzuela Por la patria, con música del organista de la Iglesia Parroquial de San Antolín de Murcia, Mariano Marín ${ }^{340}$, y libreto del tipógrafo y redactor de El Diario de Murcia, José Balsalobre, se estreno el 12 de diciembre de 1893 por la compañía de Eduardo Ortiz, que la repitió hasta en trece ocasiones más hasta enero del año siguiente. La trama, inspirada en los sucesos de Melilla (1890-1893) combinaba escenas dramáticas con situaciones cómicas y giraba en torno a "las despedidas entre los soldados y voluntarios que embarcan en Málaga para la guerra y las madres y esposas de éstos" ${ }^{341}$. Especialmente aplaudidos fueron el "coro de mujeres" con el que daba comienzo la obra y un pasodoble para orquesta, banda y cornetas que llegó a hacerse muy popular ${ }^{342}$. Según El Diario de Murcia, la música y la escenografía de Por la patria (esta última obra de Martínez Mollá) fueron las razones de su éxito ${ }^{343}$.

En 1894 se representaron en el Teatro Circo Villar las zarzuelas Era de noche y llovía y Cosas de pueblo, ambas con libretos escritos por murcianos y la música de

340 Mariano Marín García fue nombrado organista de la citada iglesia La Paz de Murcia, XXXVI (1894), n 12629, 24 febrero, p. 2.

${ }^{341}$ El Diario de Murcia, XV (1894), no 6122, 14 diciembre, p. 2.

342 Tanto fue así que la Banda de Música del Regimiento de León pidió a su autor la partitura de la pieza para ejecutarla en Madrid: La Paz de Murcia, XXXVI (1894), $\mathrm{n}^{\circ}$ 12605, 26 enero, p. 2. La interpretación del pasodoble en Por la patria corrió a cargo de la Banda de Música de la Misericordia, dirigida por Francisco Fresneda: El Diario de Murcia, XV (1894), nº 6131, 23 diciembre, p. 2.

${ }^{343}$ El Diario de Murcia, XV (1894), nº 6125, 17 diciembre, p. 1. 
compositores foráneos. Fueron escasamente reseñadas por la prensa y tuvieron muy pocas representaciones. El libreto de Era de noche y llovía fue escrito por el cartagenero Julio Hernández Costa y su música por el oriolano José Rogel Soriano (1829-1901), prolífico autor de zarzuelas, entre ellas El Joven Telémaco (1866), que se había retirado de la escena madrileña, estableciéndose en Cartagena en $1881^{344}$. Era de noche y llovía fue estrenada a principios de abril de 1894 por la compañía de Ventura de la Vega y tuvo una única representación, que simplemente "entretuvo a la concurrencia"345. Cosas de pueblo tenía libreto de Mariano Herrero Lax en colaboración con Calixto Navarro y música del alicantino Miguel Santonja Cantó (1859-1940). Fue estrenada el 4 de diciembre de 1894 por la compañía de Lino Ruiloa y la crítica alabó el libreto, "bien versificado", y un número bailable que no fue especificando ${ }^{346}$.

El tío Tragaderas o El alcalde de mi pueblo, tercera zarzuela del compositor Adolfo Gascón, instrumentada por Julián Calvo y con libreto de Juan Martínez Espinosa, fue estrenada el 18 de enero de 1895 en el Teatro Circo Villar. De ella se elogió el coro inicial, una romanza para tiple y uno de sus concertantes ${ }^{347}$. La obra se llevó a escena hasta en tres ocasiones durante el citado mes de enero. Adolfo Gascón compuso una cuarta zarzuela, El asistente de Zaragata, estrenada en el Teatro Romea en enero de 1896 y basada en el libreto del oficial de telégrafos y escritor eventual de la prensa murciana, Enrique Gallego. Fue estrenada por la compañía de Vicente Lleó y Francisco de la Vega y tuvo mucho éxito ${ }^{348}$.

\section{La Compañía Romana de Opereta y Baile de Gaetano Tani (1894)}

La Compañía Romana de Opereta y Baile dirigida por Gaetano Tani actuó en el Teatro Romea de Murcia en la primera temporada del año cómico 1893-1894, desde enero hasta marzo de 1894.

Como hemos comprobado en las páginas anteriores, muchas de las compañías que actuaron en los teatros murcianos dieron representaciones de opereta aunque adaptadas o arregladas para la escena española y, por tanto, en castellano ${ }^{349}$. La mayor parte del repertorio de la Compañía Romana de Tani, a diferencia de las anteriores, fue representado en italiano. Es más, como su título indica, estuvo especializada en este género.

La expectación entre los murcianos fue máxima. Los retratos de los artistas se exhibieron en diferentes comercios de la Platería y El Diario de Murcia se preguntaba:

\footnotetext{
${ }^{344}$ Véase Casares, "Rogel Serrano”, pp. 585-586. Según La Paz de Murcia, XXXVI (1894), n 12660, 3 abril, p. 1, Rogel compuso Era de noche y llovía "durante su corta permanencia en esta ciudad".

${ }^{345}$ La Paz de Murcia, XXXVI (1894), nº 12664, 7 abril, p. 2.

${ }^{346}$ El Diario de Murcia, XVI (1894), nº 6476, 6 diciembre, p. 2. Cosas de pueblo se representó en Murcia al menos en dos ocasiones más.

${ }^{347}$ La Paz de Murcia, XXXVII (1895), nº 12877, 20 enero, p. 3.

${ }^{348}$ Crespo, “Apuntes”, p. 113.

349 Sobre la opereta en España véanse Casares, “Opereta”, pp. 369-377 y el estudio de Kaufmann, Jacques Offenbach, que analiza las representaciones del compositor francés en España, Italia y Portugal.
} 
"No sabemos cómo tomará el público este género, nuevo en esta ciudad, ni tampoco qué tal será el género" 350 . Probablemente porque los empresarios fueron conscientes de ello, el anuncio publicado en prensa con el elenco de artistas, las condiciones de abono y los precios advertía:

[...] Anoche se repartieron las listas de la Compañía Tani y debemos llamar la atención hacia sus últimas líneas, que son una garantía de que el espectáculo que ofrece es superior y de novedad, pues dice:

"Los señores abonados que después de visto el primer espectáculo no quisieran continuar el abono, se les reintegrará en Contaduría el importe del resto de las funciones" ${ }^{\prime 351}$.

El hecho de que las funciones transcurriesen en italiano no fue un impedimento para los espectadores. La Paz de Murcia escribía: "El mejor elogio de la compañía Tani es que, a pesar de representar las obras en italiano, uno de los que más han contribuido a prolongar su estancia en Murcia es el público de las alturas, que la ha favorecido mucho a pesar de no conocer el idioma" 352 . No obstante, a algunos artistas "se le escapan algunas veces frases enteras en español en las situaciones culminantes, que hacen un gran efecto" ${ }^{353}$.

La compañía estuvo integrada por cuarenta y seis italianos (no se especificaron sus voces), sin contar al maestro concertador y director de la orquesta (Paolo Balsimelli) y el resto del personal encargado de la maquinaria y escenografía (Véase Apéndice 3.10).

El elenco era un conjunto compacto y homogéneo de artistas, que llevó en repertorio un catálogo nutrido de obras "perfectamente ensayadas [y] cantadas con afinación [...]; compañía unidísima en la que no flojea ninguno y todos aceptan el papel que se les da" ${ }^{354}$. Junto a ello, las "decoraciones, todas de la propiedad de la compañía y el vestuario con que se presentan las obras, contribuyen también grandemente al éxito de las funciones" $" 355$. Estas características son otra prueba más de las diferentes con respecto a la mayoría de conjuntos que actuaron en los teatros de Murcia.

Su debut tuvo lugar el 13 de enero de 1893 con la opereta de Sauvage, Richelieu e le sue prime armi. En líneas generales, todas las representaciones de la compañía fueron elogiadas por la prensa: "por más que las obras sean italianas, reúnen muchos atractivos" $"$. Se elogiaron "los decorados, [los] vestuarios lujosos y nuevos y el atrezzo

${ }^{350}$ El Diario de Murcia, XVII (1894), nº 6152, 14 enero, p.2.

${ }^{351}$ La Paz de Murcia, XXXVI (1894), nº 12587, 4 enero, p. 2.

${ }^{352}$ La Paz de Murcia, XXXVI (1894), nº 12633, 1 marzo, p. 1.

${ }^{353}$ El Diario de Murcia, XVI (1894), nº 6156, 12 enero, p. 1.

${ }^{354}$ La Paz de Murcia, XXXVI (1894), nº 12633, 1 marzo, p. 1.

${ }^{355}$ El Diario de Murcia, XVI (1894), nº 6153, 15 enero, p. 1.

${ }^{356}$ La Paz de Murcia, XXXVI (1894), no 12612, 4 febrero, p. 1. De Las primeras hazañas de Richelieu, de Sauvage, se escribió: "El argumento [...] es tan sencillo que aún los que no pescantuada del italiano, no dejan de comprender las situaciones cómicas y picarescas en que abunda la obra, que no llega, bajo cierto aspecto a las de las "Dos princesas": El Diario de Murcia, XVI (1894), n 6154, 16 enero, p. 2. 
correspondiente" $^{\text {357 }}$. Tanto fue así que, después del abono inicial de quince representaciones, se dieron tres más de nueve, doce y doce funciones cada uno ${ }^{358}$.

Sus representaciones fueron diarias aunque, ocasionalmente, el teatro cerró sus puertas para los ensayos de los nuevos estrenos (Véase Apéndice 3.11).

La mayor parte del repertorio interpretado eran operetas de factura italiana o traducidas a este idioma ${ }^{359}$. Para incorporar mayor variedad a las funciones, la compañía interpretó otras obras españolas "a pesar de las dificultades de pronunciación" ${ }^{360}$, como El dúo de la africana, de Fernández Caballero; El polichinela, según la prensa, de González y la zarzuela El mono sabio escrita ex profeso para estos artistas por los murcianos Arques y Adolfo Gascón. Las representaciones teatrales se alternaron con números bailes (Las flores, Paso gitano y Can can) y conciertos instrumentales ${ }^{361}$.

Según la documentación consultada, la compañía llevó adelante 65 funciones de tarde y noche, representó 23 obras diferentes de 19 compositores $^{362}$. Todas ellas fueron estradas en Murcia, salvo El dúo de la africana. La siguiente Tabla 3.20 las muestra:

Tabla 3.20. Representaciones de zarzuela de la Compañía Romana de Opereta y Baile de Gaetano Tani en el Teatro Romea de Murcia (1894).

Las fuentes documentales pueden consultarse en el Apéndice 3.11.

\begin{tabular}{|l|l|c|c|}
\hline \multirow{2}{*}{ Compositor } & Título (actos) & \multicolumn{2}{|c|}{$\mathbf{N}^{0}$ representaciones } \\
\cline { 3 - 4 } & & completas & incompletas \\
\hline Cesare Bacchini & Le damigelle di Saint-Cyr & 3 & - \\
\hline Jean-Jacque Canard & Lubino & 2 & - \\
\hline Oreste Carlini & I diavoli della Corte & 4 & - \\
\hline Fernández Caballero & El dúo de la africana & 11 & - \\
\hline Adolfo Gascón & El mono sabio & 5 & - \\
\hline González & El polichinela & 10 & - \\
\hline Paolo Lanzi & Don Pedro di Medina & 4 & 1 \\
\hline
\end{tabular}

${ }^{357}$ La Paz de Murcia, XXXVI (1894), nº 12612, 4 febrero, p. 1.

${ }^{358}$ El último abono de la compañía quedó incompleto: "sabemos que ha dejado en poder del taquillero la parte correspondiente a dichas dos funciones para que sea devuelta a los abonados que tanto le han favorecido. Así cumplen los buenos empresarios": La Paz de Murcia, XXXVI (1894), nº 12650, 21 marzo, p. 2. Desconozco las causas. No cabe duda de que los murcianos apoyaron con su asistencia a esta compañía. El segundo abono fue iniciado en febrero de 1894 y aunque "la cuaresma retrae a algunas familias, por costumbre inmemorial, sin embargo, la empresa no puede quejarse, pues la concurrencia ha sido la suficiente, a nuestro parecer, para no perder efecto de las simpatías que aquí han alcanzado los principales artistas de esa compañía, de la novedad de sus espectáculos y de su buena presentación": La Paz de Murcia, XXXVI (1894), $\mathrm{n}^{\circ}$ 12619, 13 febrero, p. 2. Otros comentarios similares se pueden leer en $L a$ Paz de Murcia, XXXVI (1894), n 12625, 20 febrero, p. 2: "La compañía Tani vino para quince funciones, pero si otros compromisos no lo impidieran podría continuar en Pascua, pues tiene mucho repertorio que nos es desconocido y un vasto material de decorado y sastrería de gran efecto y lujo.

${ }^{359}$ Las fuentes no indican quiénes fueron los traductores al italiano.

${ }^{360}$ La Paz de Murcia, XXXVI (1894), n 12625, 20 febrero, p. 2.

${ }^{361}$ El grupo instrumental Los tres bemoles actuó durante los intermedios de algunas funciones tocando "piezas [...] en los raros instrumentos que con tanta maestría manejan": El Diario de Murcia, XVI (1894), $\mathrm{n}^{\mathrm{o}} 6175,6$ febrero, p. 2. En otras, se interpretó L'Albe, un concierto para ocarina compuesto por Zenobio Navarini, integrante de la compañía.

${ }^{362}$ Sin contar con los compositores de cuyas obras no he identificado. 


\begin{tabular}{|l|l|c|c|}
\hline Albert Milhaud & Lili & 3 & - \\
\hline Zanobio Navarini & El regreso del desterrado & 1 & - \\
\cline { 2 - 4 } & El campanero & 1 & - \\
\hline \multirow{5}{*}{ Offenbach } & Kakatoa & 4 & - \\
\cline { 2 - 4 } & Un matrimonio fra due donne 363 & 8 & - \\
\cline { 2 - 4 } & La bella Elena & 2 & - \\
\cline { 2 - 4 } & Orfeo all'inferno & 4 & 1 \\
\hline Offenbach, Ricci & L'Augellino Belvedere & 1 & 1 \\
\hline \multirow{2}{*}{ Agostino Sauvage } & Richelieu e le sue prime armi & 3 & 2 \\
\cline { 2 - 4 } & Bacio proibito & 3 & - \\
\hline \multirow{3}{*}{ Scalvini } & $\begin{array}{l}\text { Le amazzoni, ovvero Dodici figlie } \\
\text { ed un padre }\end{array}$ & 2 & 6 \\
\hline \multirow{2}{*}{ Nincenzo Valente? } & Flik e Flok & 3 & 1 \\
\cline { 2 - 4 } & La mascarada & 2 & - \\
\cline { 2 - 4 } & La mujer de mármol & 2 & - \\
\cline { 2 - 4 } & Un proceso en el teatro & 1 & - \\
\cline { 2 - 4 } & Un telegrama & & - \\
\hline
\end{tabular}

Como se aprecia en la tabla, algunas obras fueron representadas de forma incompleta, es decir, uno o dos de sus actos. Sorprenden las once representaciones de $E l$ dúo de la africana, una zarzuela que, como hemos comprobado, fue frecuentemente llevada a escena por compañías españolas. Según La Paz de Murcia, el conjunto de Tani ofreció algo diferente a las demás en las representaciones de esta zarzuela:

Ha sido tan extraordinario el éxito alcanzado por Adelina Tani en el papel de la Antonelli, ya en el verso, ya en el canto, especialmente en la soleá y en la jota, cantadas magistralmente, interpretándolo de tal modo que ha ganado en vez de perder, dada su nacionalidad italiana, que no es de extrañar la unanimidad de la prensa local en tributarle calurosos elogios, así como a Navarini que nos ha hecho conocer el dúo del tenor que hasta ahora no se había oído y otros detalles; y a igual altura está Elena Tani, que hace una característica superior y la señora Casez en Amina; y Delle Cece en Giuseppini; y Bassini en el bajo; y los demás artistas en los otros papeles; y los coros; y el director señor Balmisille; y la orquesta $[\ldots]^{364}$.

El dúo que se indica en este testimonio, interpretado por los personajes Antonelli (tiple) y Giuseppini (tenor) y titulado "Comprende lo grave de mi situación", pone de manifiesto, una vez más, la supresión de números en algunas zarzuelas.

Tras sus actuaciones en Murcia, la compañía se dirigió a Andalucía ${ }^{365}$.

${ }^{363}$ Esta opereta se atribuye a Offenbach. Según Kaufmann, Jacques, p. 239 es de Scotti y Cesare Casiraghi.

${ }^{364}$ La Paz de Murcia, XXXVI (1894), n 12626, 21 febrero, p. 1.

365 A finales del mes de marzo de 1894 actuaron en Málaga: La Paz de Murcia, XXXVI (1894), ${ }^{\circ}$ 12651, 22 marzo, p. 2 


\section{Capítulo 4. Ópera y crítica teatral en Murcia durante la segunda mitad del siglo XIX}

En este capítulo estudio las compañías profesionales de ópera que actuaron en Murcia o llegaron a la ciudad durante la segunda mitad del siglo XIX, tomando como punto de partida la tradición operística de la ciudad en la primera mitad del siglo XIX ${ }^{1}$. Analizo también en este Capítulo la crítica teatral sobre representaciones de ópera y otros artículos que sobre este género publicó la prensa murciana. El cultivo de la ópera por parte de aficionados se estudia en el Capítulo 6.

\section{La ópera en Murcia durante la primera mitad del siglo XIX}

El repertorio operístico en Murcia durante la primera mitad del siglo XIX fue similar al documentado en otras ciudades españolas, con una presencia mayoritaria de ópera italiana ${ }^{2}$. En el ámbito de la costa mediterránea, Valencia presenció una fuerte entrada de Rossini en los primeros años de la década de los veinte, seguida por un predominio de los títulos de Bellini en los treinta y de Donizetti y Verdi en los cuarenta. En Alicante, ciudad a la que llegaron asiduamente compañías de ópera italiana procedentes de Valencia, las obras de Rossini fueron sustituidas por las de Bellini en los treinta, y posteriormente por las de Donizetti y Verdi ${ }^{3}$.

La prensa murciana comienza a aportar datos sobre la ópera a partir del año 1821 . La estructura de las funciones era todavía dieciochesca, con piezas cortas en un acto, intermedios de baile, sainetes y tonadillas que se intercalaban entre las comedias, tragedias, dramas y óperas. Se llevaron a escena obras de Pavesi y Generali, compositores muy representados en los teatros de Madrid, Barcelona y Valencia (véase Apéndice 4.1 $)^{4}$.

Un testimonio periodístico escrito por el organista y compositor Julián Calvo y publicado en 1883 confirma que hubo compañías de ópera en Murcia durante los años $1839,1840,1843,1847$ y $1849^{5}$. Las fuentes periodísticas no aportan datos sobre la actividad teatral de Murcia desde 1822 hasta $1839^{6}$. Probablemente el repertorio durante

\footnotetext{
${ }^{1}$ Clares, "La música teatral".

${ }^{2}$ Como señaló Subirá, Historia de la música, pp. 1247-1250: "Tras Rossini pronto imperaron Bellini, Donizetti y Meyerbeer. Después Verdi, mucho después Gounod y Wagner, sin contar otros muchos productores". Para una visión panorámica sobre la ópera en España desde el siglo XVIII en adelante, véase Casares, "L'Opera", pp. 469-528. Centrados en el siglo XIX son los estudios de Casares, "La creación operística”, pp. 21-57; Cortizo, “La ópera”, pp. 7-62 y Sobrino, “La ópera”, pp. 77-142.

${ }^{3}$ Galbis, "La zarzuela", pp. 327-349.

${ }^{4}$ Clares, "La música teatral", pp. 451-478. Además de las obras de referencia de Carmena y Millán, Crónica y Peña y Goñi, La ópera, sobre la ópera en Madrid, Barcelona, Valencia y en otras ciudades españolas como Sevilla, véanse los citados en la nota 2 y Alier, El Gran Teatro; Subirá, La ópera y Virella i Cassañes, La ópera, todos ellos centrados en Barcelona; Galbis, “Ópera”, pp. 531-538, en Valencia y Moreno Mengíbar, La ópera, en Sevilla.

5 Julián Calvo, “La ópera en Murcia”, La Paz de Murcia, XXVI (1883), n 7655, 19 junio, p. 1.

${ }^{6}$ En un informe al Juez Protector de Teatros, fechado en 16 de julio de 1833, se dio cuenta de las representaciones de Vicente Castroverde, autor de la Compañía Cómica, y de la dificultad para representar ópera: "Podría haber dicho Castroverde que una Sola Opera que he podido conseguir se ejecute en toda la
} 
la década de los treinta siguiera en la línea de preeminencia de la ópera italiana. Así se desprende de los datos sobre las obras representadas por la "Compañía Filarmónica" de Murcia entre 1839 y 1849: La straniera (Bellini); Chiara di Rosemberg (Luigi Ricci); Il furioso nell'isola di San Domingo (Donizzetti); Norma (Bellini); L'elisir d'amore (Donizetti); Il pirata (Bellini); La Cenerentola (Rossini) y Lucrezia Borgia (Donizzeti) (ver Apéndice 4.1).

Las representaciones de ópera en Murcia eran en castellano desde 1839, siguiendo una práctica habitual en otros muchos teatros españoles. Según Julián Calvo, fue el célebre tenor Leandro Valencia quien introdujo esa costumbre para evitar "un tremendo fracaso al encontrarse con un público que desconocía lo que era este espectáculo", . El Archivo Municipal de Murcia conserva varias ediciones de libretos en español de diversas óperas italianas, prueba del grado de popularidad y difusión que alcanzó este género entre el público murciano ${ }^{8}$.

Las funciones documentadas de los años 1839 a 1849 formaron el grueso de las jornadas teatrales y, ocasionalmente, el Teatro del Toro de Murcia ofreció dos sesiones: la primera, a las tres de la tarde, incluía obras de declamado; la segunda, a las siete de la tarde, exclusivamente una ópera.

En abril de 1840 se formó una Compañía de Ópera en Murcia, gracias al apoyo de la Compañía Filarmónica, que existía desde el año anterior ${ }^{9}$. Para gestionar los fondos necesarios para la Compañía de Ópera se creó una sociedad, cuyas primeras reuniones de accionistas sirvieron para nombrar las comisiones encargadas de la dirección y administración de esa sociedad ${ }^{10}$. La prensa animó a los murcianos a colaborar económicamente con la suscripción abierta al efecto ${ }^{11}$. Se abrió un abono de noventa funciones, iniciado con L'elisir d'amore (Donizetti), a la que le siguieron Norma (Bellini) e Il pirata (Bellini) ${ }^{12}$. Los miembros de la Compañía de Ópera fueron, en parte, los mismos que los de la Compañía Filarmónica en la temporada anterior (Mariana Lewis,

temporada me costó después de vencer otras mil dificultades hacer de mi bolsillo ciertos vestidos que faltaban". Véase, E:MUm, Legajo nº 1327.

7 Julián Calvo, "La ópera italiana en Murcia", en La Paz de Murcia, XXVI (1883), no 7655, 19 junio, p. 1. Los títulos de todas las óperas extranjeras aparecen en la prensa en castellano y con intérpretes mayoritariamente españoles.

${ }^{8}$ Por ejemplo, las óperas de Verdi I due Foscari, con libreto de Piave y traducida en Murcia como Los dos foscaris: tragedia lírica en tres actos (Murcia: Imprenta de José Carlos Palacios, 1846), así como I Lombardi alla prima crociata, libreto de Solera y publicada en Murcia como Los lombardos: ópera seria en cuatro actos (Murcia: Imprenta de José Carles Palacios, 1847). En el E:MUm hay otros libretos traducidos al español, impresos durante la segunda mitad del siglo XIX en diversas ciudades españolas (especialmente en Barcelona y Madrid).

${ }^{9}$ El Segura (1840), no 35, 15 abril, p. 4. No me ha resultado posible determinar el año de formación de la Compañía Filarmónica ya que no se han conservado periódicos entre marzo de 1837 y diciembre de 1840. Su recepción fue tan positiva que en febrero de 1840 se pidió a sus componentes que permanecieran en la ciudad otra temporada más. Véase, El Segura (1840), nº 16, 9 febrero, p. 4.

${ }^{10}$ Las reuniones se celebraron en el Salón de Santo Domingo y en el del Estado (plaza del Esparto) los días 20 de febrero y 9 de marzo 1840, respectivamente. El Segura (1840), ${ }^{\text {os }} 19,19$ febrero, p. 4 y 24, 8 marzo, p. 4.

${ }^{11}$ El Segura, no 18, 1840, febrero, 16, domingo, p. 4.

${ }^{12}$ Las condiciones y precios del abono aparecieron publicadas por El Segura (1840), $\mathrm{n}^{\mathrm{o}} 35,15$ abril, p. 4. 
Elisa y Leandro Valencia, Juan Herrera y Carlos de Magnán). Además, se contrató al tenor Carlo Sentiel y a Juan Bautista Jourdan, "primer bajo cantante que ha estado en los teatros de Italia, Madrid y Barcelona"13. Se ampliaron el coro y la orquesta, bajo la dirección de Julián Gil, y se mejoró el aparato escénico con la renovación de algunas decoraciones y la construcción de otras nuevas. Los trajes y decorados de Il pirata, por ejemplo, fueron montados y confeccionados específicamente para la ocasión ${ }^{14}$.

Lamentablemente, no se han conservado periódicos que permitan analizar la trayectoria de esta compañía durante los años siguientes. La última noticia que nos ofrece la prensa sobre la Compañía de Ópera fue su cuarta función en mayo de 1840, Chiara di Rosemberg de Luigi Ricci, en la que debutaron Sentiel y Jourdan. Además de las compañías profesionales en Murcia, también actuaron algunas compañías de ópera formadas por aficionados locales. Una de ellas llevó a escena en 1849 Lucrezia Borgia en una representación elogiada por la interpretación del cantante murciano Emilio Almela. La crítica, que reconoció la falta de preparación de los restantes, la mala interpretación de la orquesta y la ausencia de una buena dirección escénica, valoró sin embargo el esfuerzo de los aficionados: "Orgullosos nosotros de que en nuestro país se dé una muestra tan clara de adelanto y deseosos de estimular el germen filarmónico que comienza a desarrollarse" $"$.

\section{La ópera en Murcia desde mitad de siglo hasta la apertura del Teatro de los Infantes (1851-1862)}

Durante la segunda mitad del siglo XIX, la ópera fue, junto a la zarzuela, el género vertebrador de la producción musical murciana. Su presencia fue obligada en los diversos espacios de la vida musical pública (teatros, salones de sociedades, cafés, conciertos y festejos al aire libre) y privada (salones domésticos). Sin embargo, hubo una notable diferencia en la presencia del repertorio operístico dependiendo del tipo de local en el que tenía lugar su difusión. En salones, cafés y conciertos al aire libre los arreglos de números de ópera predominaron por encima de los de otros géneros, como la zarzuela, mientras que en el ámbito teatral, la presencia de ópera fue más esporádica ${ }^{16}$. En muchas

${ }^{13}$ El Segura (1840), no 42, 10 mayo, p. 4. Carmena y Millán, Crónica, pp. 81-84 menciona a estos cantantes en diversas representaciones de los años 1835 y 1836 en los teatros madrileños de la Cruz y del Príncipe.

${ }^{14}$ El Segura (1840), no 41, 6 mayo.

${ }^{15}$ La Palma (1849), no 9, 1 junio, p. 119. Desconozco si su representación tuvo lugar en el Teatro del Toro, ya que la fuente periodística no lo indica. Tampoco ha quedado constancia de los nombres de los aficionados.

${ }^{16} \mathrm{Al}$ repertorio de títulos de ópera representados en los teatros murcianos se le unen otros muchos que tuvieron un gran difusión en salones, cafés, ámbito doméstico y conciertos al aire libre de Murcia, popularizados principalmente a través de las versiones (transcripciones, arreglos y reducciones de fragmentos operísticos) siguiendo variados formatos y combinaciones de instrumentos y voces. Este mismo fenómeno ha sido estudiado por Ester-Sala, "La presencia" quien, tras analizar la destacada presencia de obras de Rossini (gran parte versionadas) en los archivos catalanes concluye que el consumo de obras del compositor de Pésaro estuvo al alcance de casi cualquier intérprete fuera del teatro y su música se popularizó en la vida cotidiana catalana del ochocientos; y también por Esposito, "O sucesso", que describe la popularidad de las obras de Verdi, a través de las numerosas composiciones basadas en los temas principales de sus óperas, publicadas en el siglo XIX por las editoras musicales de Portugal. 
funciones de teatro en las que se representaban comedias, dramas $u$ otras piezas de género dramático, se interpretaron también sinfonías provenientes de óperas o inspiradas en las $\operatorname{mismas}^{17}$ pero las representaciones de ópera propiamente dichas fueron ocasionales y se concentraron sólo en unos pocos años del siglo, como explicaré después.

Los teatros de provincias periféricas como Murcia no pudieron sostener largas temporadas de ópera y garantizar al mismo tiempo un público regular y numeroso. Era difícil llevar hasta Murcia compañías profesionales y las precarias condiciones de los teatros murcianos tampoco ayudaron, dadas las exigentes puestas en escena que muchas óperas requerían. Además, las precarias comunicaciones con Murcia (sobre todo hasta el segundo tercio del siglo), las frecuentes epidemias y la inestabilidad política llegaron a impedir en varias ocasiones el normal desarrollo de la actividad teatral.

Durante la segunda mitad del siglo XIX actuaron en Murcia compañías de ópera en $1851,1858,1864,1881-1886,1890-1892,1894-1895,1897$ y $1899^{18}$. Hasta la década de los ochenta, la presencia de este género en los escenarios murcianos fue muy escasa y esporádica. Desde 1851 hasta 1864 sólo actuaron tres compañías (dos de las cuales eran mixtas: una de ópera y zarzuela; y otra de declamación, ópera y zarzuela) y desde 1865 hasta 1880 no actuó ninguna, a pesar de que llegaron a la ciudad varias, como detallaré más adelante. Las últimas dos décadas del siglo presentan, por el contrario, un panorama bien diferente, caracterizado por la regularidad y constancia en la contratación de compañías profesionales de ópera, especialmente en el Teatro Romea. El número de compañías profesionales que actuaron en Murcia se multiplicó por cinco durante estos años. Además, eran compañías especializadas en género operístico, algunas de ellas con artistas de mucho prestigio.

Las primeras representaciones de ópera en Murcia durante la segunda mitad del siglo XIX tuvieron lugar en 1851 en el antiguo Teatro del Toro. El elenco, que se anunciaba como Compañía Lírica, estaba formado por artistas españoles e italianos, e incluía primeras y segundas damas, tenores, bajos, "caricatos" y "partiquinos", designándose como "absolutas" las voces principales (véanse Apéndices 4.2 y 4.3) ${ }^{19}$.

${ }^{17}$ Por ejemplo, la compañía del primer actor Antonio Vico, que actuó en el teatro del Toro de abril a mayo de 1851, incluyó sinfonías de Anna Bolena de Donizetti, Giovanna d'Arco de Verdi, La Vestale de Spontini y Las treguas de Tolemaida de Hilarión Eslava: Diario de Murcia, (1851), n ${ }^{\text {os }} 97,24$ abril, p. 4; 119, 20 mayo, 20, p. 3; 125, 27 mayo, p. 4 y 139, 17 junio 17, p. 2; así como arias de ópera y piezas de baile entre las obras dramáticas: Diario de Murcia, (1851), $\mathrm{n}^{\circ}$ 105, 3 mayo, p. 4. La función del 21 de mayo de 1851, a beneficio de la primera actriz Marta Delgado, comenzó con la sinfonía de La vestale e incluyó también un aria de tiple de la misma ópera: Diario de Murcia, (1851), nº 119, 20 mayo, 20, p. 3.

${ }^{18}$ No se han conservado datos periodísticos para el año 1864.

${ }^{19}$ Véase el Apéndice 4.2, que contiene las transcripciones de los anuncios en prensa con el listado de miembros, repertorio y precios de abono de las compañías de ópera que actuaron en los teatros de Murcia durante la segunda mitad del siglo XIX. Según Pedrell, Diccionario, p. 71, el "caricato" es el "cantante que desempeña el papel de gracioso en las óperas bufas". Para otras definiciones de "caricato", véase, Morales Villar, Los tratados, t. 2, p. 193. Según el Diccionario, t. II, p. 1689 de la Real Academia Española de la Lengua un "partiquino" es "un cantante que ejecuta en las óperas parte muy breve o de muy escasa importancia". 
El director musical fue Ignacio Patriossi y el director de coros, Angelo Fontana. El bajo y acordeonista José Gasparini fue contratado desde Murcia $^{20}$ y, cuando la compañía ya había iniciado los ensayos de Ernani (primera de las óperas que iban a representar), se incorporaron el tenor Abrosio Volpini y el bajo profundo Joaquín Becerra $^{21}$. Gasparini, Volpini y Becerra actuaron, junto a la Compañía Lírica de Patriossi, en dos representaciones de Ernani de Verdi y tres de Gemma di Vergy de Donizetti. Las críticas teatrales publicadas no escatimaron elogios ante tal elenco de profesionales ${ }^{22}$ y algunos amateurs pidieron a Patriosi y Gasparini que dieran lecciones de canto italiano ${ }^{23}$. En total, la compañía dio desde octubre de 1851 veinte funciones de ópera italiana "de las más modernas" y otras de zarzuela (ver Apéndice 4.4) ${ }^{24}$.

Tras un paréntesis de varios años sin actuaciones operísticas, en octubre de 1858 actuó en el Teatro Provisional de Murcia la "Compañía de Ópera y Zarzuela" de Juan Cavaletti, que permaneció en la ciudad hasta enero de $1859^{25}$. Era una compañía con más artistas que la de Patriossi; tenía cantantes distintos para ópera y para zarzuela (salvo la primera tiple, el segundo tenor y el primer bajo que cantaban ambos géneros) y una sección de verso para representar obras dramáticas. La compañía de Cavaletti llevó a escena obras líricas (ópera, zarzuela) y dramáticas (comedias en tres actos y piezas en uno), aunque no en igual número. De las cuarenta y ocho funciones que he podido reconstruir, veinticuatro fueron de ópera, quince de zarzuela, cuatro fueron dramáticas y cinco combinaciones de los tres géneros. Estos datos indican un claro predominio del género operístico porque la compañía contaba con cantantes especializados en él, probablemente algo poco habitual en esa época en Murcia ${ }^{26}$. Antes de concluir sus

${ }^{20}$ En Diario de Murcia (1851), $\mathrm{n}^{\mathrm{o}}$ 225, 25 septiembre, p. 4 se publicó la lista de integrantes de la compañía y se anunció el primer bajo y caricato Juan Silingardi, que aún estaba sin contratar. La llegada a Murcia de José Gasparini se anunció en: Diario de Murcia, (1851), n² 235, 7 octubre, p. 3.

${ }^{21}$ El Diario de Murcia (1851), no 237, 1851, 9 octubre, p. 1 avisó de la llegada a la ciudad de estos dos cantantes: "Damos este aviso al director empresario de la 'Compañía Lírica' que va a dar principio a sus funciones en este teatro, para que aproveche la ocasión”. Ambos se dirigían a Madrid. Ambrosio Volpini venía de ofrecer unos conciertos en Alicante, entre ellos uno en la Sociedad de Amigos de la ciudad: Diario de Murcia, I (1851), n 186, 10 agosto, pp. 1-2.

${ }^{22}$ Diario de Murcia, I (1851), no 241, 14 octubre, p. 1.

${ }^{23}$ Los cantantes aceptaron "condescender a las plegarias de varios señores para perfeccionarlos en esa hermosa arte": Diario de Murcia, no 241, 1851, octubre, 14, martes, p. 3. Los precios se fijarían una vez oídos a los alumnos, y en función a sus propias necesidades. Los interesados debían acudir para recibir las lecciones al teatro en noches de ensayos o de representación o los domicilios de los profesores (de Patriossi en la calle de la Corredera, número 22 y el de Gasparini, en la calle de Pinares "casa de pupilos de Baltrina").

${ }^{24}$ Las funciones comenzaron el 10 de octubre de 1851 . No he podido documentar todas las funciones de la compañía por la falta de fuentes periodísticas. Tras actuar en Murcia, la compañía de Patriossi continuó su gira por Valencia.

${ }^{25}$ La compañía ofreció cuatro abonos en el Teatro Provisional: los dos primeros de veinte funciones cada uno, el tercero de diez y en el último sólo constan tres funciones (aunque probablemente fueron más). Como la compañía ofreció funciones de ópera y zarzuela, he incluido sus representaciones en el Apéndice 3.3 .

${ }^{26}$ En cambio, el anuncio en prensa de esta compañía, reproducido en el Apéndice 3.1, anunció un repertorio compuesto por seis óperas y once zarzuelas. La prensa publicó resúmenes de los argumentos de las óperas de esta compañía, como fue el caso de La Favorite en La Paz de Murcia, I (1858), n 221, 23 noviembre, p. 2. 
representaciones, la compañía de Cavaletti quedó contratada para la temporada siguiente, aunque no regresó a Murcia ${ }^{27}$.

\section{La ópera en el Teatro de los Infantes-Romea (1862-1899)}

\subsection{La compañía de Peruzzi (1864)}

Tras las representaciones operísticas de 1858, parece haber habido un nuevo paréntesis de varios años sin ópera en Murcia y hubo que esperar hasta el año 1864 para ver sobre el escenario del Teatro de los Infantes representaciones de este género. Al parecer durante la segunda temporada del año cómico 1863-1864 actuó en Murcia la compañía de la primera dama Peruzzi, que gustó mucho y se quería contratar de nuevo para la segunda temporada de $1864-1865^{28}$, aunque no ocurrió así, ya que actuó el conjunto de teatro declamado y baile de José María Dardalla y Antonio Zamora, con la famosa Cándida Dardalla ${ }^{29}$.

\subsection{Paréntesis sin compañías profesionales de ópera (1865-1880)}

Entre 1865 y 1880 no actuó ninguna compañía profesional de ópera en Murcia, en parte porque el Teatro Romea permaneció cerrado en 1877 y 1880 debido al incendio que sufrió (ver Capítulo 2). Según la prensa, este largo paréntesis de quince años sin ópera se debió a la nula demanda del público, poco preparado para entender el género (a pesar de que era "el más culto y espiritual de todos los que al alma proporcionan placer" ${ }^{30}$ ), a la escasa rentabilidad económica de los espectáculos y a la falta de apoyo económico de las autoridades y de las sociedades recreativas de la ciudad. Para que pudiera haber al menos diez representaciones anuales de ópera en Murcia, se propuso que el Ayuntamiento ayudara económicamente (o no cobrara un arriendo mensual del teatro), que las sociedades recreativas pagaran los gastos de iluminación e impresión de programas y carteles y que el Casino contribuyera con una cantidad entre 8000 y 10000 reales ó 20002500 pesetas para los gastos de personal ${ }^{31}$. Estas propuestas no llegaron a materializarse, aunque desde 1881 hubo más intentos de llevar compañías profesionales de ópera a los teatros murcianos.

${ }^{27}$ El empresario de la compañía de Cavaletti, Claudio Coello formó, con cantantes distintos, una nueva compañía con la que actuó en Albacete durante la temporada teatral de 1859-1860: La Paz de Murcia, II (1859), no 484, 14 septiembre, p. 1.

${ }^{28}$ La Paz de Murcia, VIII (1865), no 2097, 2 febrero, p. 1. La noticia menciona que la compañía de Peruzzi había actuado en el año anterior. Quizás se trataba de Soffia Peruzzi, esposa del tenor Selva y asidua soprano de los teatros barceloneses en los años cincuenta del siglo XIX. Algunos datos biográficos sobre esta cantante constan en El Mundo Pintoresco, Ilustración Española, II (1859), nº 22, 29 mayo, p. 9. También podría tratarse de la tiple llamada "Peruzzi Selva", miembro de una compañía de ópera que iba a actuar en Alicante durante la primera temporada de 1863-1864. Véase, La Gaceta Musical Barcelonesa, IV (1864), $\mathrm{n}^{\mathrm{o}} 122,24$ enero p. 4.

\footnotetext{
${ }^{29}$ La Paz de Murcia, VIII (1865), nº 2132, 19 marzo, p. 1.

${ }^{30}$ La Paz de Murcia, XXIV (1881), nº 7034, 24 abril, p. 1.

${ }^{31}$ Ibídem.
} 
Entre 1865 y 1880, en realidad, sí llegaron a la ciudad varias compañías de ópera, pero no fueron contratadas, bien porque las negociaciones entre empresarios y arrendatarios del teatro no prosperaban, o bien porque no se reunía un número suficiente de abonados. En mayo de 1866, El Indicador publicó el anuncio de una compañía de ópera, actuando como mediador entre las empresas teatrales, las autoridades y el público:

AL CONTRATISTA DE NUESTRO TEATRO. Dice "El Indicador":

"Una compañía de ópera, de artistas conocidos y que tiene el repertorio puesto, desea pasar a otro teatro del que hoy se encuentra, a dar un número de funciones, tomándolo por cuenta de su empresa, o bien entrando en combinación con otra. Tampoco tiene inconveniente en contratar el número de funciones por un tanto alzado. $[\ldots]^{32}$.

En julio de 1869, La Paz de Murcia publicó también el ofrecimiento de una "Compañía de ópera italiana" para trabajar en Murcia con una considerable rebaja de $\operatorname{precios}^{33}$.

La prensa murciana consultada pedía una y otra vez que hubiera ópera en la ciudad y constantemente publicaba noticias sobre el trasiego de compañías de ópera en otras ciudades españolas (especialmente entre provincias cercanas). En estas crónicas es frecuente leer expresiones laudatorias hacia las ciudades que programaban ópera en sus teatros del tipo: "Están de enhorabuena los granadinos"34.

\subsection{Compañías de ópera desde 1881 hasta 1899}

El periodo 1881-1899 fue el más fructífero para la ópera en los teatros murcianos de la segunda mitad del siglo XIX. Actuaba, al menos, una compañía de ópera por año (en 1886 y 1891, incluso dos), aunque hubo algunos años sin representaciones operísticas $^{35}$. En líneas generales, las compañías cumplieron con los abonos previstos, lo que indica que existió un cierto público interesado en el género ${ }^{36}$, capaz de sostenerlo (al

${ }^{32}$ La Paz de Murcia, IX (1866), nº 2530, 11 mayo, p. 2.

${ }^{33}$ La Paz de Murcia, XII (1869), no 3619, 10 julio, p. 1 afirmaba: “Aunque el tiempo es malo por lo avanzado, hace tanto tiempo que no hemos oído una ópera y es tan regular el cuadro que se nos ofrece, por lo que hemos leído en los diarios de Alicante y Córdoba, que nos alegraríamos se reuniese el suficiente número para que pudiese funcionar en el nuestro". Al día siguiente se publicó la composición de la compañía, en la que estaban incluidos Fanny Marie Gordosa (primera tiple absoluta) y Conrado Conti (primer tenor absoluto): La Paz de Murcia, XII (1869), $\mathrm{n}^{\circ} 3620,11$ julio, p. 1. No se publicó ninguna noticia más en relación a esta compañía por lo que es probable que no se reuniera el número mínimo de abonados.

${ }^{34}$ La Paz de Murcia, XVIII (1875), n $\mathrm{n}^{\circ}$ 5371, 26 mayo, p. 1. La noticia informaba sobre las compañías de ópera que actuaban en los teatros Principal y de Isabel la Católica de Granada. En La Paz de Murcia, XIX (1876), n ${ }^{\circ} 5691,17$ junio, p. 1 se anuncia que la compañía que estaba actuando en el teatro de Alicante iba a dar representaciones en el de Cartagena, sin pasar por Murcia. Véanse más ejemplos en: La Paz de Murcia, IX (1866), $\mathrm{n}^{\mathrm{o}}$ 2560, 10 junio, p. 1; XI (1868), $\mathrm{n}^{\mathrm{o}}$ 3114, 10 enero, p. 3; XXII (1879), $\mathrm{n}^{\circ} 6559,27$ marzo, p. 1 y El Semanario Murciano, II (1879), nº 59, 30 marzo, p. 7.

${ }^{35}$ Los años en los que no hubo representaciones de ópera son: 1887-1889, 1893, 1896 y 1898.

${ }^{36}$ A pesar de las valoraciones que los críticos murcianos publicaron en la prensa murciana, como veremos en el punto 5 de este Capítulo 4 . 
menos por una decena de representaciones) y que resultaba beneficioso económicamente para las empresas. Las temporadas no solían ser muy largas. En la década de los ochenta del siglo XIX, la mayoría de las compañías que llegaron a Murcia dieron entre 10 y 28 representaciones (la compañía de Tamberlick en 1883, dio sólo ocho) y durante los noventa, no solían pasar de diez representaciones (aunque la de Camaló en 1895, dio trece) ${ }^{37}$ (ver Apéndice 4.4).

La prensa murciana comentaba los éxitos y fracasos de las compañías en otras ciudades, especialmente cuando ya había estado en Murcia ${ }^{38}$. El itinerario habitual de las compañías por el Levante español fue Alicante-Murcia-Cartagena, aunque en algunas ocasiones se invertía este recorrido, se suprimía alguna de estas ciudades si los empresarios teatrales no llegaban a un acuerdo con los administradores de los teatros ${ }^{39}$, o se añadían otras poblaciones murcianas (por ejemplo, Lorca) ${ }^{40}$. Algunas compañías proseguían sus giras desde Murcia hacia Andalucía. Ese fue el caso de la compañía de Andrés Porcell y Pedro Urrutia que, tras actuar en Murcia, se marchó a Alicante, Cartagena y finalmente Córdoba ${ }^{41}$.

El número total de integrantes de las compañías de ópera que actuaron en el Teatro Romea entre 1881 y 1899 osciló entre los ochenta y los noventa, aunque hubo elencos que superaron ampliamente este número. La compañía del director Achille

${ }^{37}$ Mientras que entre los años 1881 a 1889 se dieron 123 funciones documentadas de ópera, entre 1890 y 1899, se ofrecieron 53 (ver Apéndice 4.4).

${ }^{38}$ Por ejemplo, las actuaciones de la compañía de Benigno Giardini en el Teatro Principal de Alicante en marzo de 1882 fueron seguidas por los periódicos de Murcia. Véase: La Paz de Murcia, XXV (1882), $\mathrm{n}^{\circ}$ 7281, 7 marzo, p. 1 y El Diario de Murcia, IV (1882), nº 925, 16 marzo, p. 2.

${ }^{39}$ En julio de 1881 los diarios murcianos especularon sobre la posibilidad de que la compañía de ópera del tenor famoso Tamberlick, que estaba actuando en Alicante, visitara Murcia: La Paz de Murcia, XXIV (1881), nº 7093, 21 julio, p. 1. Tamberlick firmó un contrato para actuar en Cartagena a partir de noviembre de 1881. El recién estrenado empresario del Romea, Medina, inició sin éxito gestiones para que la compañía actuara también en Murcia: La Paz de Murcia, XXIV (1881), nº 7162, 23 noviembre, p. 1. Véase: La Paz de Murcia, XXIV (1881), n ${ }^{\text {os }} 7193,17$ noviembre, p. 1; 7158, 6 octubre, p. 1 y 7172, 22 octubre, p. 1.

${ }^{40}$ Mencionaré algunos ejemplos. La compañía de Cecilio Sanmartí actuó en febrero de 1886 en Valencia y después lo hizo en Alicante, Cartagena y Murcia, por este orden. La compañía estuvo en tratos con algún teatro de Granada y no habría actuado en Murcia si hubiera conseguido un contrato en esa ciudad. Véase, La Paz de Murcia, XXIX (1886), n ${ }^{\text {os }} 8442$, 9 febrero, p. 1 y 8446, 13 febrero, p. 1, así como El Diario de Murcia, VIII (1886), n 2163, 23 mayo, p. 3. El elenco de artistas dirigidos por Andrés Porcell y Regino Martínez, en el que figuró el famoso Tamberlick, dio cuatro funciones en Albacete a finales de mayo de 1883 y, posteriormente en Murcia y Cartagena durante los meses de junio y julio del mismo año. Ver, El Diario de Murcia, V (1883), n ${ }^{\text {os }}$ 1283, 24 mayo, p. 3 y 1289, 1 junio, p. 2. El conjunto de Enrico Serazzi (director de escena) y Esteban Puig (maestro director y concertador), después de subirse al escenario del Teatro Romea de Murcia, hizo lo propio en el Teatro Guerra de Lorca, donde representaron Faust, Il Trovatore, Lucrezia di Borgia, Rigoletto y La Favorite. Desde Lorca la compañía se marchó a Cartagena y posteriormente a Barcelona. Véanse, La Paz de Murcia, XXXV (1892), n ${ }^{\text {os }} 11643$, 28 junio, p. 3; 11660,20 julio, p. 2; 11641, 25 junio, p. 1 y 11643, 28 junio, p. 1.

${ }^{41}$ La compañía debutó en el Teatro Principal de Alicante el 29 de abril de 1884 con la ópera $I l$ Trovatore (exactamente, dos días después de su última actuación en el Teatro Romea de Murcia): El Constitucional Dinástico de Alicante, XVIII (1884), no 4789, 1 mayo, p. 3. Sus actuaciones fueron seguidas por la prensa murciana. Véase, por ejemplo, La Paz de Murcia, XXVII (1884), nº 7909, 2 mayo, p. 1. El 13 de mayo de 1884 partieron para Cartagena, donde actuaron hasta el 18 del mismo mes y año: $E l$ Constitucional Dinástico de Alicante, XVIII (1884), nº 4799, 13 mayo, p. 3. Desde Cartagena, la compañía se marchó a Córdoba, donde iniciaron una gira por Andalucía: La Paz de Murcia, XXVII (1884), nº 7926, 22 mayo, p. 1. 
Babacci, por ejemplo, estaba formada por noventa y nueve personas sin contar los bailarines y la banda militar. Los conjuntos solían contar con una media de quince cantantes distribuidos en no menos de tres triples (en algunas compañías, se distingue una dramática, otra ligera y una "comprimaria"42); al menos una mezzosoprano y contralto; dos o tres tenores, uno de ellos "comprimario"; dos barítonos; al menos dos bajos (aunque varias compañías llevaban tres) y un número variable de "partiquinos", "caricatos" y "segundas partes"43. Entre las compañías con mayor número de cantantes destaca el elenco del director artístico Achille Babacci, con veinte cantantes, y el de Arturo Serrajordia y Tomás Bretón, con diecinueve (ver Apéndice 4.3). Como es lógico, las compañías de ópera también sufrieron variaciones de personal en el transcurso de las actuaciones ${ }^{44}$.

Era frecuente que algunos artistas actuaran en Murcia con diferentes compañías. El maestro director y concertador Cecilio Sanmartí actuó en el Teatro Romea durante las segundas temporadas de los años cómicos 1880-1881 y 1885-1886 aunque los cantantes que integraron estas dos compañías fueron diferentes (ver el Apéndice 4.2). Sanmartí también fue director de orquesta de la compañía de Arturo Serrajordia y Tomás Bretón, que actuó en la segunda temporada de 1890-1891. El director de escena Andrés Porcell actuó en las segundas temporadas de 1882-1883 y 1883-1884 con los maestros concertadores y directores Regino Martínez y Pedro Urrutia, respectivamente. Algunos cantantes, como la contralto Concepción Mantilla, estuvieron presentes en ambas compañías. Arturo Serrajordia también fue director de escena con dos compañías, la del maestro concertador y director Francisco Camaló (primera temporada de 1886-1887) y la del maestro director Tomás Bretón (segunda temporada de 1890-1891). El director de escena Enrico Serazzi y el maestro director y concertador Eusebio Bosch actuaron con una compañía durante la segunda temporada de 1889-1890. Serazzi y Esteban Puig también dieron representaciones en la segunda temporada de 1891-1892.

La soprano Blanca Montesini actuó con las compañías de Cecilio Sanmartí (segunda de temporada de 1885-1886) y con la de Arturo Serrajordia y Francisco Camaló (primera de temporada 1886-1887); Giuseppina Huguet, actuó con las compañías de Serazzi y Bosch (segunda temporada de 1889-1890) y con la de Arturo Baratta en el Teatro Circo Villar (primera temporada de 1894-1895), mientras que Antonio Benzi fue tenor comprimario de las compañías de Achille Babacci y de Pablo Lorenzano.

Durante el periodo estudiado desfilaron por el Teatro Romea prestigiosos cantantes de ópera la época como Enma Nevada, Ludmila Kupfer, Bianca Montesini, la alicantina Luisa Fons ${ }^{45}$, Elisa Volpini, la norteamericana Ella Russell, Rosa Caligaris,

\footnotetext{
${ }^{42}$ Morales Villar, Los tratados, t. 2, p. 196 recoge las definiciones de "comprimario" según Feliciano Agero: "artista de segundo orden encargado de un papel algo importante" y Carlos José Melcior: "El que sustituye a un primer papel, sea de soprano, de contralto, de tenor o bajo".

${ }^{43}$ La media de cantantes se ha calculado a partir de los anuncios en prensa de las compañías de ópera que actuaron en el Teatro Romea en 1881-1899.

${ }^{44}$ Por ejemplo, tres días después del comienzo de las representaciones de la compañía de ópera de Regino Martínez, la prensa anunció que se incorporarían la tiple Ella Russell y el bajo Giuseppe Buetti (o Belleti): La Paz de Murcia, XXVI (1883), nº 7650, 13 junio, p. 1.

${ }^{45}$ Luisa Fons Ruiz (1867-1925) estudió en la Escuela Nacional de Música y Declamación de Madrid, donde obtuvo el "premio de auxilio y estímulo" Nilson, según Ramos, El Teatro Principal, p. 173-174. Debutó en el Teatro Real de Madrid con El barbero de Sevilla en la temporada 1883-1884 y más tarde, formó parte, junto a Manuel Carbonell, en la compañía de Achille Babacci. A partir de 1885 la cantante
} 
Giuseppina Huguet, María Mantilla, Ida Lumley, Naponelón Gnone, el famoso tenor Enrique Tamberlick, Napoleón Verger y Mariano Padilla, entre otros; y directores como el catalán y también compositor, Juan Goula, Cecilio Sanmartí, Regino Martínez Basso ${ }^{46}$, Tomás Bretón y el italiano Manlio Bavagnoli.

La media de integrantes de los coros de las compañías de ópera era de veinticinco. No obstante, seis de las trece compañías analizadas tuvieron un coro mayor: los conjuntos de Pablo Lorenzano y Vicente Petri, por ejemplo, contaron con un coro de treinta miembros y el de Andrés Porcell y Pedro Urrutia, así como el de Cecilio Sanmartí, de veintiocho. Como apunté en el Capítulo 2, la orquesta solía constar de cuarenta músicos, aunque el elenco de Regino Martínez trajo a Murcia una formación de sólo veinticuatro músicos y, por el contrario, la de Benigno Giardini actuó con una orquesta de cincuenta y un miembros (dos concertinos, ocho violines primeros, diez violines segundos, dos violas, tres violonchelos, cinco contrabajos, tres flautas, tres oboes, dos clarinetes, dos saxofones, cuatro trompas, dos cornetines, cuatro trombones, bombo y timbales). Algunas compañías contaron para sus representaciones con bandas de música, como por ejemplo, la de Benigno Giardini y la Achille Babacci. Cuatro de las trece compañías analizadas tuvieron un cuadro de baile y dos de aquéllas cuatro estaban formadas por nueve bailarines (ver Apéndice 4.3).

No todos los anuncios publicados en prensa especifican el personal técnico de los conjuntos operísticos, aunque cabe suponer que tenían encargados de archivo, sastrería, vestuario, utilería e iluminación, entre otros ${ }^{47}$. El célebre "maquinista" Rafael Martínez (fallecido en marzo de 1895$)^{48}$ y el peluquero José Clavel fueron dos murcianos frecuentemente contratados por las compañías de ópera y también por otras de teatro declamado y zarzuela.

A partir de los años ochenta del siglo XIX algunas compañías de ópera dieron sus representaciones en Murcia en italiano, algo que no había ocurrido en la primera mitad de la centuria. La actuación de la compañía de Benigno Giardini en 1882 fue muy bien recibida, a pesar de que el público no entendía el idioma:

Indudablemente con una compañía como la que hay en Romea se puede formar el gusto delicado necesario para apreciar las bellezas de la ópera. Sin entender una palabra de lo que dicen los actores, se puede comprender todo. Los públicos, acostumbrados nada más que a la zarzuela, la encuentran desabrida, pantomímica,

inició una triunfal carrera por el extranjero, especialmente por Italia. Gravemente enferma, se retiró de los escenarios para establecerse en Barcelona. Navarro Sales, Diccionario, p. 131 afirma que Luisa Fons fue una de las tiples más importantes en la historia de la lírica alicantina, especialmente en las dos última décadas del siglo XIX. Véanse más detalles en Lloret, Personatges, p. 36.

${ }^{46}$ Véase, Delgado, "Regino Martínez".

${ }^{47}$ El aparato escenográfico de algunas compañías de ópera fue muy relevante. El estreno en Murcia de Aida de Verdi (18-04-1882) por la compañía de Benigno Giardini utilizó decorados de D’El Hera, pintor escenógrafo del teatro Manzoni de Milán y vestuarios y utilería de Arambol. La sastrería de la compañía de Andrés Porcell (director de escena) y Pedro Urrutia (maestro director y concertador) procedía del Teatro Principal de Zaragoza (véase Apéndice 4.2).

${ }^{48}$ Los testimonios de la prensa sobre la profesionalidad del maquinista Rafael Martínez son muy numerosos. En El Diario de Murcia, XVII (1895), n 6509, 11 enero, p. 3 se afirma: “'La Tarde’ llama la atención de la comisión del teatro sobre la conveniencia de que vayan reponiéndose algunas decoraciones en el teatro de Romea, donde hay mucho lienzo viejo que parece algo gracias a las combinaciones y trabajos del hábil maquinista don Rafael Martínez". 
pero la repetida audición de esas desconocidas bellezas les va seduciendo poco a poco $[\ldots]^{49}$.

Lamentablemente, no siempre es posible conocer en qué idioma se cantaban las óperas, ya que las fuentes raramente lo especifican y los títulos aparecen indistintamente en italiano y castellano. En ocasiones, los libretos de las óperas se vendían en la taquilla del teatro unos días antes del estreno ${ }^{50}$ y los diarios de la ciudad publicaban el argumento de las obras, sin duda para facilitar su comprensión ${ }^{51}$.

Las representaciones pactadas por las compañías de ópera se llevaban a escena en un alto porcentaje de casos (ver Tabla 4.1):

Tabla 4. 1. Representaciones de las compañías de ópera del Teatro Romea (1881-1899) I: primera temporada; II: segunda temporada.

Fuentes: La Paz de Murcia (1858-1899) y El Diario de Murcia (1881-1899) ${ }^{52}$

\begin{tabular}{|c|c|c|c|}
\hline Compañía & $\begin{array}{l}\text { Temporada, } \\
\text { año cómico }\end{array}$ & $\begin{array}{l}\text { Funciones } \\
\text { previstas }\end{array}$ & $\begin{array}{c}\text { Representaciones } \\
\text { efectuadas }\end{array}$ \\
\hline $\begin{array}{l}\text { Cecilio Sanmartí (maestro director y } \\
\text { concertador) }\end{array}$ & II, $1880-1881$ & 20 & 19 \\
\hline Benigno Giardini & II, 1881-1882 & 20 & 28 \\
\hline $\begin{array}{l}\text { Andrés Porcell (director de escena) y } \\
\text { Regino Martínez (maestro concertador } \\
\text { y director) }\end{array}$ & II, $1882-1883$ & $9^{53}$ & 9 \\
\hline $\begin{array}{l}\text { Andrés Porcell (director de escena) y } \\
\text { Pedro Urrutia (maestro director y } \\
\text { concertador) }\end{array}$ & II, 1883-1884 & 12 & 14 \\
\hline Achille Babacci (director artístico) & II, 1884-1885 & [No consta] & 19 \\
\hline $\begin{array}{l}\text { Cecilio Sanmartí (maestro director y } \\
\text { concertador) }\end{array}$ & II, $1885-1886$ & 9 & 25 \\
\hline $\begin{array}{l}\text { Arturo Serrajordia (director de escena) } \\
\text { y Francisco Camaló (maestro } \\
\text { concertador y director) }\end{array}$ & I, 1886-1887 & 20 & 10 \\
\hline $\begin{array}{l}\text { Enrico Serazzi (director de escena) y } \\
\text { Eusebio Bosch (maestro director y } \\
\text { concertador) }\end{array}$ & II, $1889-1890$ & 8 & 8 \\
\hline $\begin{array}{l}\text { Arturo Serrajordia (director de escena) } \\
\text { y Tomás Bretón (maestro director) }\end{array}$ & II, 1890-1891 & 20 & 1 \\
\hline Pablo Lorenzano & I, 1891-1892 & 6 & 6 \\
\hline $\begin{array}{l}\text { Enrico Serazzi (director de escena) y } \\
\begin{array}{l}\text { Esteban Puig (maestro director y } \\
\text { concertador) }\end{array}\end{array}$ & II, 1891-1892 & 15 & 9 \\
\hline Gioachino Rossi & I, 1894-1895 & [No consta] & 13 \\
\hline Maria Galvani (primera tiple) & I, 1896-1897 & 4 & 4 \\
\hline $\begin{array}{l}\text { Vicente Petri (maestro concertador y } \\
\text { director) }\end{array}$ & II, 1898-1899 & 8 & 12 \\
\hline
\end{tabular}

${ }^{49}$ El Diario de Murcia IV (1882), no 947, 13 abril, p. 3.

${ }^{50}$ La Paz de Murcia, XXV (1882), nº 2295, 17 abril, p. 1.

${ }^{51}$ Por ejemplo, La Paz de Murcia, I (1858), n 221, 23 noviembre, p. 2 resumió la trama de $L a$ Favorite; el argumento de Aida apareció en El Diario de Murcia, IV (1882), nº 950, 16 abril, p. 2 y en La paz de Murcia, XXV (1882), nº 2995, 17 abril, p. 1.

${ }^{52}$ Sobre las funciones previstas y las efectuadas, véanse Apéndices 4.2 y 4.4 .

${ }^{53}$ Sin embargo, según El Diario de Murcia, V (1883), nº 1293, 6 junio, p. 2, el abono constó de cuatro funciones más dos extraordinarias. 
Como ocurría con las compañías de zarzuela, aunque con mucha menor frecuencia, se dieron representaciones con elencos incompletos de cantantes, disoluciones de las compañías en el transcurso de sus actuaciones y anulaciones de los contratos sin contemplaciones, entre otros problemas ${ }^{54}$. No obstante, como se deduce de esta tabla, las compañías cumplieron con las funciones previstas y, en algunos casos, las superaron.

Tras el largo paréntesis de quince años sin representaciones profesionales de ópera en Murcia (1865-1880), la primera compañía que actuó en la ciudad fue la de Cecilio Sanmartí, que despertó gran expectación en 1881. En la prensa se afirmaba: "Nuestro coliseo va a ser uno de los principales puntos de reunión" ${ }^{55}$. Las condiciones de actuación fueron negociadas por el tenor Conrado Conti: se alternarían días con funciones y días para ensayar las obras a puerta cerrada ${ }^{56}$, se estrenarían las óperas Un ballo in maschera y La Favorita y se contrataría para catorce representaciones al tenor Lorenzo Abruñedo ${ }^{57}$. Las cinco primeras representaciones de la compañía de Cecilio Sanmartí ( $2^{\mathrm{a}}$ temporada de 1880-1881) se llevaron a cabo sin los prometidos tenores Lorenzo Abruñedo y Vittorio Cantoni. Finalmente, en la sexta función debutó el tenor De Luca. Las promesas incumplidas fueron jocosamente comentadas en la prensa:

La empresa del teatro de Romea va haciendo algo de lo que hacía Saturno: devora tenores, precedidos de telegramas de esta sensación, ique va a venir! "ique viene!”, “ique ya ha venido!”, como aquel dios cruel devoraba sus propios hijos.

Cada cual sabe sus cuentas, y dicha empresa las suyas, pero no gana el público nada con ese trasiego de tenores $[\ldots]^{58}$.

La compañía de Sanmartí estaba especializada en un repertorio exclusivamente operístico, compuesto por doce óperas del más puro estilo belcantista, como se verá más

${ }^{54}$ Durante los años ochenta y noventa también llegaron a Murcia propuestas de algunas compañías de ópera que finalmente no fueron contratadas, como ocurrió durante el periodo de años en los que no actuó ninguna compañía profesional de ópera en los teatros murcianos (1865-1880). En julio de 1890, por ejemplo, la compañía de José Tolosa, con Emma Nevada y Mariano Padilla, se encontraba realizando una gira por tierras andaluzas. Se aseguró que Nevada y Padilla actuarían a continuación en Murcia, Cartagena y Alicante, aunque con la compañía de Luciano Rodrigo. La propuesta de Rodrigo para actuar en el Teatro Romea se llevó a cabo pero no se contrató y el elenco se dirigió a Cartagena sin pasar por Murcia. Véanse, La Paz de Murcia, XXXIII (1890), $\mathrm{n}^{\text {os }}$ 11066, 29 junio, p. 4; 11110, 23 agosto, p. 1; 11117, 31 agosto, p. 1; 11121, 5 septiembre, p. 1 y 11122, 6 septiembre, p. 1.

${ }^{55}$ La Paz de Murcia, XXIV (1881), n n $^{\text {7012, }} 29$ marzo, p. 1. Véase también, La Paz de Murcia, XXIV (1881), no 7011, 27 marzo, p. 1 y El Diario de Murcia, III (1881), nº 639, 5 abril, p. 3. Cecilio Sanmartí también aparece escrito en las fuentes como Sanmarty o Sanmarti.

${ }^{56}$ Según La Paz de Murcia, XXIV (1881), nº 7038, 29 abril, p. 1, sólo los abonados podían asistir a los ensayos pero, ante los abusos por la masiva asistencia de gente a los mismos, el empresario tomó nuevas medidas que no se mencionan.

${ }^{57}$ La Paz de Murcia, XXIV (1881), no 7009, 24 marzo, p. 1 y El Diario de Murcia, III (1881), $\mathrm{n}^{\mathrm{o}}$ 631, 26 marzo, p. 2. Según El Diario de Murcia, III (1881), nº 644, 10 abril, p. 3, el contrato se ultimó en Barcelona. Las catorce representaciones de Abruñedo iban a costar al empresario 8000 pesetas, causando un incremento en el precio de las entradas. Quizás por ello Abruñedo fue sustituido por Vittorio Cantoni: $L a$ Paz de Murcia, XXIV (1881), n 7027, 16 abril, p. 1; El Semanario Murciano, IV (1881), $\mathrm{n}^{\circ}$ 166, 17 abril, p. 128 y El Diario de Murcia, III (1881), nº 677, 21 mayo, p. 3. La compañía llegó a Murcia el 14 de abril de 1881: La Paz de Murcia, XXIV (1881), nº 7026, 14 abril, p. 1, El Diario de Murcia, III (1881), nº 647, 14 abril, p. 2.

${ }^{58}$ El Semanario Murciano, IV (1881), n 169, 8 mayo, p. 152. 
adelante. El abono de veinte funciones fue cumplido casi íntegramente y la prensa no menciona fracasos económicos ${ }^{59}$. Sin embargo, la empresa de la compañía de Benigno Giardini (segunda temporada de 1881-1882) tuvo "pérdidas de consideración" y aún así superó en ocho el número de representaciones previstas ${ }^{60}$. Es probable que estas pérdidas se debieran al alto número de componentes de la compañía que, como ya he apuntado, contaba con un nutrido conjunto de cantantes, coro, orquesta, bailarines y banda militar.

A principios de junio de 1886, tras suspenderse en dos ocasiones las funciones de la compañía de Cecilio Sanmartí (segunda temporada de 1885-1886), la empresa anunció su disolución ${ }^{61}$. Las representaciones se reanudaron con una nueva empresa ("Sociedad de Artistas de Romea"), constituida ex profeso por iniciativa de los artistas de la compañía, que empezó a actuar el 9 de junio de 1886 y dio catorce representaciones (cuatro funciones correspondientes al segundo abono iniciado con la anterior empresa y diez de un nuevo abono).

La empresa Leiva, para la que trabajó la compañía de Arturo Serrajordia y Francisco Camaló (primera temporada de 1886-1887) sólo representó diez de las veinte funciones previstas, aunque se habían rebajado los precios de las localidades y se había dado todo tipo de facilidades a los abonados ${ }^{62}$. Las representaciones se sustituyeron por bailes y el teatro Romea quedó cerrado al público ${ }^{63}$.

Entre los años 1887 y 1889 no actuó ninguna compañía de ópera en el Teatro Romea de Murcia ${ }^{64}$. La prensa refirió movimientos de diversos conjuntos operísticos por teatros de Valencia, Alicante y Cartagena ${ }^{65}$ y la suscripción abierta en Murcia para enviar fondos a los siniestrados por el incendio del teatro de la Ópera Cómica de París, acaecido el 27 de mayo de $1887^{66}$.

${ }^{59}$ La Paz de Murcia y El Diario de Murcia no fueron publicados a diario, por lo que cabe suponer que pudo haber más de las 19 representaciones.

${ }^{60}$ La Paz de Murcia, XXV (1882), no 7341, 12 mayo, p. 1.

${ }^{61}$ La Paz de Murcia, XXIX (1886), no 8940, 8 junio, pp. 1, 4 y El Diario de Murcia, VIII (1886), $\mathrm{n}^{\circ}$ 2175,8 junio, p. 3. Hasta ese momento se habían ofrecido once representaciones: siete de Verdi y las restantes de Ricci -Luigi y Federico-, Gounod, Rossini y Donizetti.

${ }^{62}$ En El Diario de Murcia, (1886), nº 13 noviembre, p. 3 apareció: “Los abonados tendrán que tomar diariamente la entrada, lo cual les favorece, pues la noche que no puedan ir, se ahorran su importe. Además podemos asegurar que el abonado podrá, la noche que no vaya, disponer de su butaca para quien quiera". Las reseñas periodísticas ponen de manifiesto actuaciones muy mediocres y transmiten la idea de público insatisfecho. Según El Diario de Murcia, VIII (1886), n 2856, 23 noviembre, p. 3 la representación de El Trovador tuvo un "desconsolador" resultado y el público salió "disgustadísimo".

${ }^{63}$ La Paz de Murcia, XXIX (1886), nº 9050, 24 noviembre, p. 1.

${ }^{64}$ Tampoco me consta la solicitud de ninguna compañía de ópera para actuar en el Teatro Romea de Murcia.

${ }^{65}$ Véase, por ejemplo, La Paz de Murcia, XXX (1887), no 8143, 15 marzo, p. 1, La Paz de Murcia, XXX (1887), no 8304, 10 diciembre, p. 1, La Paz de Murcia, XXXI (1888), nº 8424, 21 febrero, p. 1, La Paz de Murcia, XXXI (1888), no 8492, 29 abril, p. 1. Algunos testimonios periodísticos dieron cuenta de posibles visitas de compañías de ópera al Teatro Romea de Murcia. La Paz de Murcia, XXX (1887), $\mathrm{n}^{\circ}$ 8242, 29 septiembre, p. 1, por ejemplo, se hacía eco del rumor sobre la llegada a Murcia de un elenco con la cantante Luisa Fons. Consúltense otros ejemplos en La Paz de Murcia, XXXI (1888), nºs 8505, 16 mayo, p. 1 y 8508,19 mayo, p. 1.

${ }^{66}$ El Ayuntamiento de Murcia donó 250 pesetas de su capítulo de imprevistos a las víctimas del mencionado incendio y abrió una suscripción pública entre los murcianos con el mismo fin. La lista de los 
Después de este intervalo de años sin ópera, en mayo de 1890 actuó la compañía de Enrizo Serazzi y Eusebio Bosch que dio ocho representaciones en el Teatro Romea con buena crítica. Para el compositor y organista de la Catedral de Murcia, Julián Calvo, el retorno de la ópera a Murcia fue la respuesta a las reiteradas peticiones de los "buenos aficionados murcianos [que] manifestaban los más vivos deseos por tener el ilustrado espectáculo musical, o sea ópera" ${ }^{67}$. Según él:

El interregno de este tiempo ha pasado como si hubiese sido de huelga. En esta capital lo mismo que en toda España, el género chulo e indecoroso musical se ha enseñoreado tanto en el teatro, orquestas, bandas, pianos de café, sextetos de recreo y por último hasta en los salones, que a los profesores que no han tocado música ratera o flamenca no se les concedía gusto y no se les oía con atención $[\ldots]^{68}$.

No es de extrañar, por tanto, que músicos como Calvo asumieran el rol de críticos y aprovecharan las actuaciones de las compañías de ópera para educar con sus reseñas al público murciano, como veremos más adelante.

Un fracaso aún mayor que el de la empresa Leiva fue el de la compañía del empresario Francesco Gueri con el director de escena Arturo Serrajordia y el maestro director y concertador, Tomás Bretón (segunda temporada de 1890-1891). Gueri se comprometió a formar una compañía de artistas con experiencia en el Teatro Real de Madrid y en el Liceo de Barcelona y a presentar dos óperas nuevas para el público murciano: Carmen de Bizet y Los amantes de Teruel de Tomás Bretón. La primera se pondría en escena con decorados especiales y la segunda sería dirigida por el propio Bretón, lo que "constituiría una solemnidad artística de las que pocas veces se consiguen en Murcia"69 (ver Figura 4.1).

suscritos apareció publicada en: La Paz de Murcia, XXX (1887), n ${ }^{\text {os }} 8211,28$ mayo, p. 1 y 8232, 16 junio, p. 1.

${ }^{67}$ Julián Calvo, "La ópera en Murcia". En: La Paz de Murcia, XXXIII (1890), nº 11029, 15 mayo, p. 1.

${ }^{68}$ Julián Calvo, "La ópera en Murcia", p. 1.

${ }^{69}$ La Paz de Murcia, XXXIII (1890), $\mathrm{n}^{\circ}$ 11150, 10 octubre, p. 1. Además, Gueri instó a los músicos murcianos a formar parte de la orquesta del teatro: "Deseando la empresa de Romea que la orquesta que ha de actuar en la próxima temporada de Resurrección sea de tanta importancia como la notable compañía de ópera [...] invita a los artistas murcianos que quieran formar parte de aquella corporación y tengan cabida en ella, a inscribir sus nombres e indicar condiciones, al almacén de música de don Adolfo Gascón, desde hoy hasta el domingo ocho del actual, inclusive. Los que sean admitidos, firmarán sus contratos": El Diario de Murcia, XIII (1891), $\mathrm{n}^{\circ}$ 4271, 5 marzo, p. 3. La orquesta del teatro había sido suprimida en mayo de 1890, lo que explica la necesidad de reunir músicos mediante este llamamiento (ver Capítulo 2). Véase también: La Paz de Murcia, XXXIV (1891), no 11246, 30 enero, p. 1 y 3 y El Diario de Murcia, XIII (1891), no 4266, 27 febrero, p. 3. 


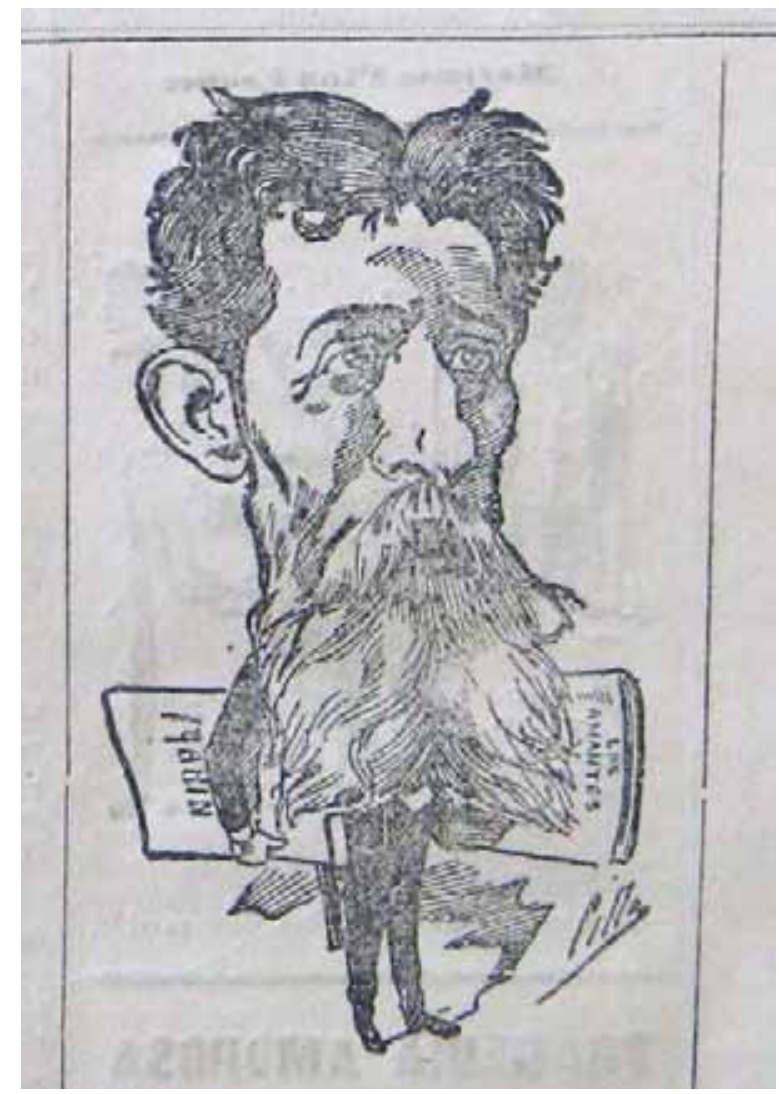

Figura 4. 1. Caricatura de Tomás Bretón.

E:MUm, La Juventud Literaria, VII (1895), nº 252, 17 febrero, p. 1.

El ensayo general de Il Trovatore, ópera con la que la compañía debutó en Murcia, obtuvo una buena crítica en $L a P a z$ de Murcia $^{70}$. La veteranía de algunos músicos conocidos por el público murciano (por ejemplo, los directores de orquesta Francisco Gueri y Cecilio Sanmartí) y la buena impresión del primer ensayo auguraban una magnífica temporada de ópera. Sin embargo, la compañía fracasó estrepitosamente en su primera representación. Según El Diario de Murcia ninguno de sus miembros, excepto la orquesta, estuvo a la altura adecuada. La cantante Isabel Petrolani estaba "bastante constipada"; el tenor (Luciano Gasparini) y el barítono no destacaron con sus personajes (Manrique y Conde de Luna) y faltaba parte del personal de la compañía que aún no había llegado a la ciudad ${ }^{71}$. En realidad, ninguno de los cantantes que tomaron parte en esta representación aparecía en el elenco publicado por la prensa antes del debut. En otras palabras, Gueri había sustituido las partes principales con cantantes no previstos,

${ }^{70}$ La Paz de Murcia, XXXIV (1891), nº 11292, 29 marzo, p. 1. El director del periódico había tomado parte en la contratación de la compañía, como él mismo afirmó: "nos servirá de satisfacción por la parte indirecta que hemos tenido en la venida de esta compañía, como agentes amistosos solamente del señor Gueri, tanto cerca del Ayuntamiento como de las personas a quienes proporcionamos el que a dicho señor se asociaran para formar la empresa y quizá hacer un buen negocio".

${ }^{71}$ El Diario de Murcia, XIII (1891), no 4292, 31 marzo, p. 2. La crítica de La Paz de Murcia fue más benevolente, sin duda porque su director había intervenido en la contratación de la compañía. De los artistas dijo este periódico que "se hallaban bajo la presión de un debut que siempre les cohíbe, tanto es así que el tenor que fue bien recibido en el ensayo no fue tan afortunado en dicha noche": La Paz de Murcia, XXXIV (1891), no 11292, 31 marzo, p. 1 . 
probablemente menos experimentados ${ }^{72}$. Ante las críticas, la Comisión de Teatro del Ayuntamiento de Murcia exigió al empresario Gueri que renovase los artistas en un plazo máximo de cinco días, una medida bien acogida por la prensa:

La comisión mixta del teatro Romea, en vista del horrible fracaso de la compañía de ópera y celosa del buen hombre de esta ciudad y de su coliseo, se reunió anteayer tarde, acordando dirigir una enérgica comunicación al empresario señor Gueri, en la que le previenen que con suspensión del espectáculo, modifique en el plazo de cinco días el cuadro de compañía presentando los artistas anunciados u otros de su categoría, el que trascurrido sin hacerlo, procederá la comisión a rescindir el contrato de arrendamiento con pérdida por parte del arrendatario de las cantidades que tiene adelantadas. La primera representación de ópera reveló de qué modo el señor Gueri burlaba las legítimas aspiraciones de los abonados y del público, burla que la citada comisión no podía consentir y por ello le enviamos nuestro aplauso ${ }^{73}$.

Sin embargo, Gueri no encontró sustitutos adecuados "por no estar conformes sus exigencias con lo que prometía el negocio". El empresario perdió la fianza entregada al Ayuntamiento y la compañía se disolvió ${ }^{74}$.

Tampoco el siguiente año cómico 1891-1892 estuvo exento de problemas. Las actuaciones de la compañía de Pablo Lorenzano con los cantantes Enma Nevada (véase Figura 4.2) y Mariano Padilla transcurrieron con normalidad. En abril de 1892 la prensa anunció que la compañía dirigida por Luis Medini (dirección artística), José Suárez (dirección escénica) y Arturo Baratta (maestro director y concertador) daría veinte representaciones en el Teatro Romea durante la temporada de Pascua ${ }^{75}$. Aunque los ensayos comenzaron el 22 de abril de 1892, dos días más tarde la prensa anunció la cancelación de las representaciones por falta de abonados ${ }^{76}$.

${ }^{72}$ Ni la tiple dramática Petrolani, ni la contralto Ruano ni el citado tenor Gasparini aparecían en el elenco de artistas anunciado (ver Apéndice 4.2).

${ }^{73}$ El Diario de Murcia, XIII (1891), no 4293, 1 abril, p. 3

${ }^{74}$ La Paz de Murcia, XXXIV (1891), n 11294, 2 abril, p. 1. Véase también El Diario de Murcia, XIII (1891), no 4295, 3 abril, p. 3 y La Paz de Murcia, XXXIV (1891), nº 11297, 7 abril, p. 1.

${ }^{75}$ El Diario de Murcia, XIV (1892), n 4596, 27 marzo, p. 2. El contrato entre la sociedad arrendataria del Romea y el empresario Medini se formalizó a finales de marzo de 1892: La Paz de Murcia, XXXV (1892), $\mathrm{n}^{\mathrm{o}}$ 11568, 29 marzo, p. 3. A mediados del mes siguiente se publicó el elenco de artistas y las condiciones de abono: La Paz de Murcia, XXXV (1892), $\mathrm{n}^{\text {os }} 11584,18$ abril, p. 2 y 11585, 19 abril, p. 3. Era una compañía numerosa en la que destacaban Amalia Nicelli y Enriqueta de Baillou (sopranos dramática y ligera, respectivamente), Asia Marchesi (mezzocontralto y contralto), Pedro Satorra y Miguel Roura (tenores), Leopoldo Borgioli (barítono) y Antonio Noguera (bajo). El repertorio anunciado prometía llevar a escena óperas de Verdi (Rigoletto, Un ballo in maschera, Il Trovatore), Donizetti (Lucia di Lamermoor, Lucrezia Borgia, La favorite), Bellini (La Sonnambula, I Puritani), Rossini (Il Barbiere di Siviglia), Gounod (Faust), Meyerbeer (Dinorah, L’Africaine, Les Huguenots) y Bizet (Carmen).

${ }^{76}$ La Paz de Murcia, XXXV (1892), $\mathrm{n}^{\text {os }} 11588,22$ abril, p. 3 y 11590, 24 abril, p. 2; El Diario de Murcia, XIV (1892), $\mathrm{n}^{\text {os }}$ 4978, 23 abril, p. 3 y 4979, 24 abril, pp. 3-4. 


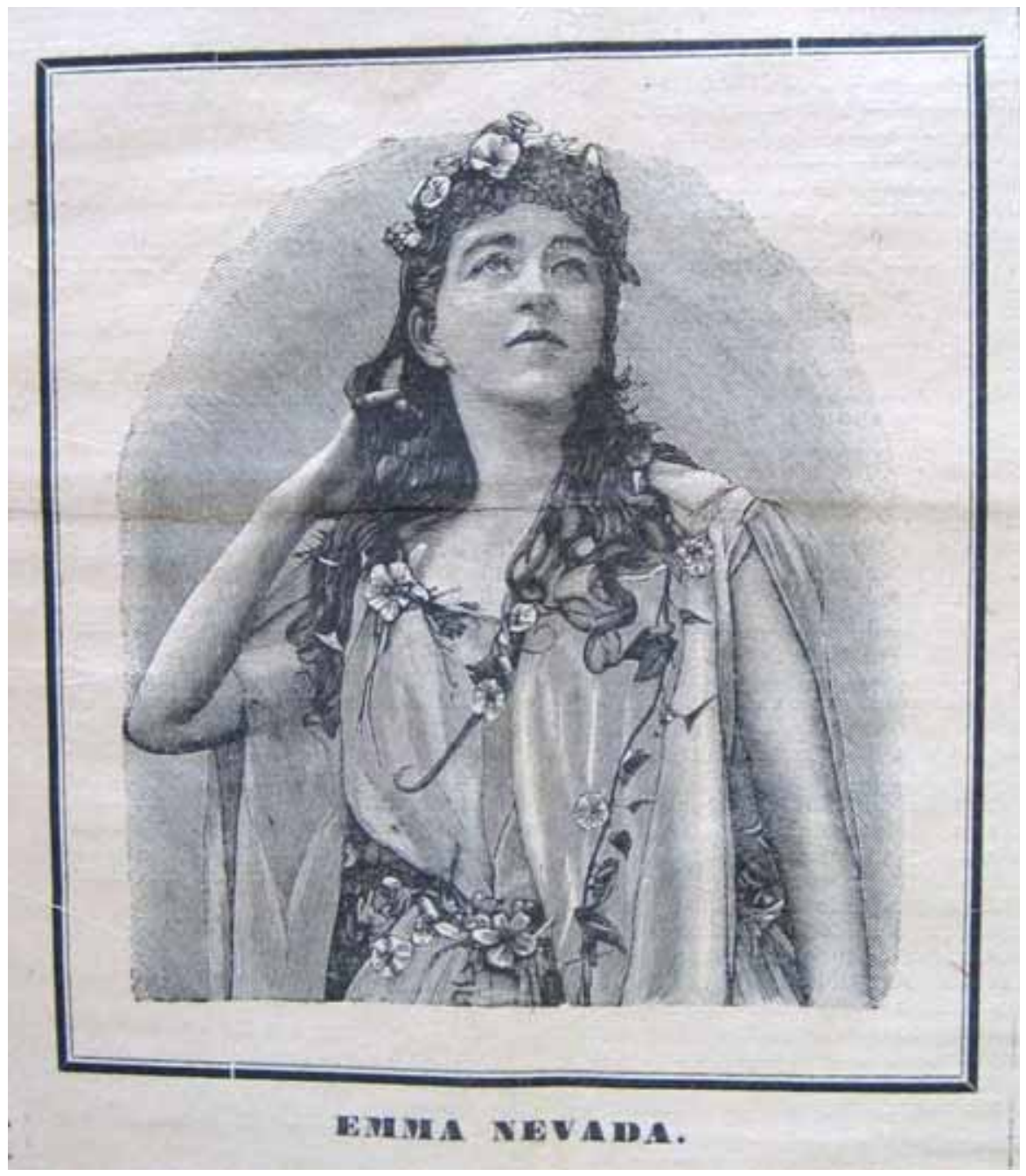

Figura 4. 2. Emma Nevada.

E:MUm, Las Provincias de Levante, VI (1891), n 1522, 19 octubre, p. 1.

A pesar de ello, durante el mes de mayo de 1892 la sociedad arrendataria del Teatro Romea entabló negociaciones con una nueva compañía dirigida por Enrico Serazzi (director de escena) y Esteban Puig (maestro director y concertador) ${ }^{77}$. Sus representaciones tuvieron lugar durante el mes de junio del mismo año. El conjunto había actuado en tres funciones cuando surgieron dificultades entre empresario y cantantes por la escasa concurrencia de público ${ }^{78}$. Después de suspenderse varias representaciones, el empresario de la compañía, Toratti, se declaró en quiebra ${ }^{79}$.

${ }^{77}$ Desde principios de mayo de 1892 la prensa anunció que la empresa del Romea estaba en tratos con esta compañía. El contrato fue firmado en Murcia por el representante de la compañía, Alfredo Serazzi, el 15 de octubre de 1892, mientras que en ese momento la compañía se encontraba en Barcelona. Una semana después de firmar el contrato llegó a Murcia el director Esteban Puig y el resto del personal durante los primeros días de junio de 1892. Véanse: El Diario de Murcia, XIV (1892), nº 4996, 14 mayo, p. 2 y La Paz de Murcia, XXXV (1892), $\mathrm{n}^{\text {os }} 11599,5$ mayo, p. 2; 11608, 16 mayo, p. 2; 11614, 23 mayo, p. 3; 11616, 25 mayo, p. 3; 11617, 27 mayo, p. 2; 11621,1 junio, p. 3 y 11624, 4 junio, p. 3.

${ }^{78}$ El Diario de Murcia, XIV (1892), n 5026, 21 junio, p. 3 apunta dos causas: las altas temperaturas (poco apropiadas para acudir al teatro) y las "diversiones gratuitas" que diariamente se ofrecían en la calle.

${ }^{79}$ La Paz de Murcia, XXXV (1892), n 11633, 15 junio, p. 1. La representación de Il Barbiere di Sivilia fue suspendida "a causa de los disgustos de artistas y empresario", aunque se habían imprimido ya 


\subsection{El repertorio de ópera en el Teatro de los Infantes-Romea desde 1862 hasta 1899}

Entre 1850 y 1880 actuaron únicamente tres compañías de ópera en Murcia (sólo dispongo de datos sobre dos de ellas), que permiten deducir dos tendencias muy claras: el predominio de la ópera italiana sobre la francesa o la alemana y la predilección por Verdi $^{80}$.

De la prensa murciana se desprende que, hasta la década de los ochenta, la ópera italiana se identificaba con la ópera en general. Mientras que La Traviata de Verdi era considerada ya en 1858 como "una composición que gusta mucho" ${ }^{81}$; la primera representación que he documentado de una ópera no italiana, Fra Diavolo de Auber, representada en noviembre de 1858, mereció la siguiente crítica:

[...] Las dos primeras representaciones [de Fra Diavolo] no dejaron satisfecho al público, no porque fueran mal ejecutadas, pues otras lo han sido peores, sino porque acostumbrado éste a la música italiana y a la española de las zarzuelas, no le agradó la francesa que acompaña esta producción; pero en la tercera salió más contento a causa de lo mejor desempeñada que fue y de haberse acostumbrado algo más a este nuevo género $[\ldots]^{82}$.

La introducción de óperas no italianas fue lenta y tardía (sobre todo en las últimas dos décadas del siglo). De los operistas italianos, Verdi y Donizetti eran los más representados (ver Tabla 4.2):

los carteles y programas. Según El Diario de Murcia, XIV (1892), nº 5022, 15 junio, p. 3: “A pesar de este fracaso, todos los que forman la citada compañía de ópera han formado sociedad para dar las dos funciones que faltan para cumplir la primera serie del abono anunciado en obsequio a los señores abonados y dos funciones más con el fin de obtener lo necesario para poderse trasladar a otro punto". Según la documentación consultada, la compañía efectuó nueve de las quince funciones programadas (véase Apéndice 4.4).

${ }^{80}$ Esta predilección por Verdi es común a otras ciudades españolas, como estudia García Caballero, $L a$ vida musical, p. 195 en los teatros de Santiago de Compostela o Moreno Mengíbar, La ópera, p. 242 en los de Sevilla, donde, según el autor, los compositores más interpretados entre los años 1855-1875 fueron Donizetti y Verdi. En Canarias la primera ópera italiana que pudo ser escuchada fue, precisamente, de Verdi (Ernani, en 1861) a la que siguieron otros títulos y compositores como Il Trovatore (Verdi), Norma (Bellini), La traviata (Verdi), Lucia di Lammermoor (Donizetti) y El Barbiere di Siviglia (Rossini): Álvarez Martínez, "L’opera", p. 143. Fuera de España, la preeminencia y popularización del repertorio verdiano se hizo patente, por ejemplo, en los teatros portugueses. Cymbron, "L'egemonia", p. 133 afirma que desde el estreno de Nabucco de Verdi en el Teatro de São Carlos de Lisboa en 1843, al que siguieron otros títulos en años posteriores, las óperas verdianas fueron las preferidas del público lisboeta durante los cuarenta años siguientes. Véase también Cymbron, “A produção”, pp. 21-40.

${ }^{81}$ La Paz de Murcia I (1858), nº 234, 9 diciembre, 1.

${ }^{82}$ La Paz de Murcia, I (1858), nº 228, 1 diciembre, p. 1. 
Tabla 4. 2. Representaciones completas de ópera en los teatros del Toro y Provisional de Murcia (1851-1880).

Fuentes: ver Apéndice 4.4.

\begin{tabular}{|l|l|l|}
\hline \multicolumn{1}{|c|}{ Compositor } & \multicolumn{1}{|c|}{ Título } & $\begin{array}{c}\mathbf{N}^{\mathbf{0}} \text { de } \\
\text { representaciones }\end{array}$ \\
\hline Auber & Fra Diavolo & 2 \\
\hline \multirow{5}{*}{ Donizetti } & La Favorite & 3 \\
\cline { 2 - 3 } & Gemma di Vergy & 3 \\
\cline { 2 - 3 } & Lucrezia Borgia & 3 \\
\hline Meyerbeer & Rober le diable & 2 \\
\hline Verdi & Il Trovatore & 9 \\
\cline { 2 - 3 } & La traviata & 7 \\
\cline { 2 - 3 } & Ernani & 6 \\
\cline { 2 - 3 } & I due foscari & 1 \\
\cline { 2 - 3 } & Rigoletto & 1 \\
\hline
\end{tabular}

Las óperas más conocidas alcanzaban en poco tiempo un alto número de representaciones. La compañía de Juan Cavaletti, por ejemplo, repitió entre octubre de 1858 y enero de 1859 hasta nueve veces Il Trovatore y siete La Traviata. La proporción de representaciones de Verdi y Donizetti puede verse en el Gráfico 4.1:

Gráfico 4. 1 Representaciones de obras de Verdi y Donizetti

en los teatros del Toro y Provisional de Murcia (1851, 1858-1859).

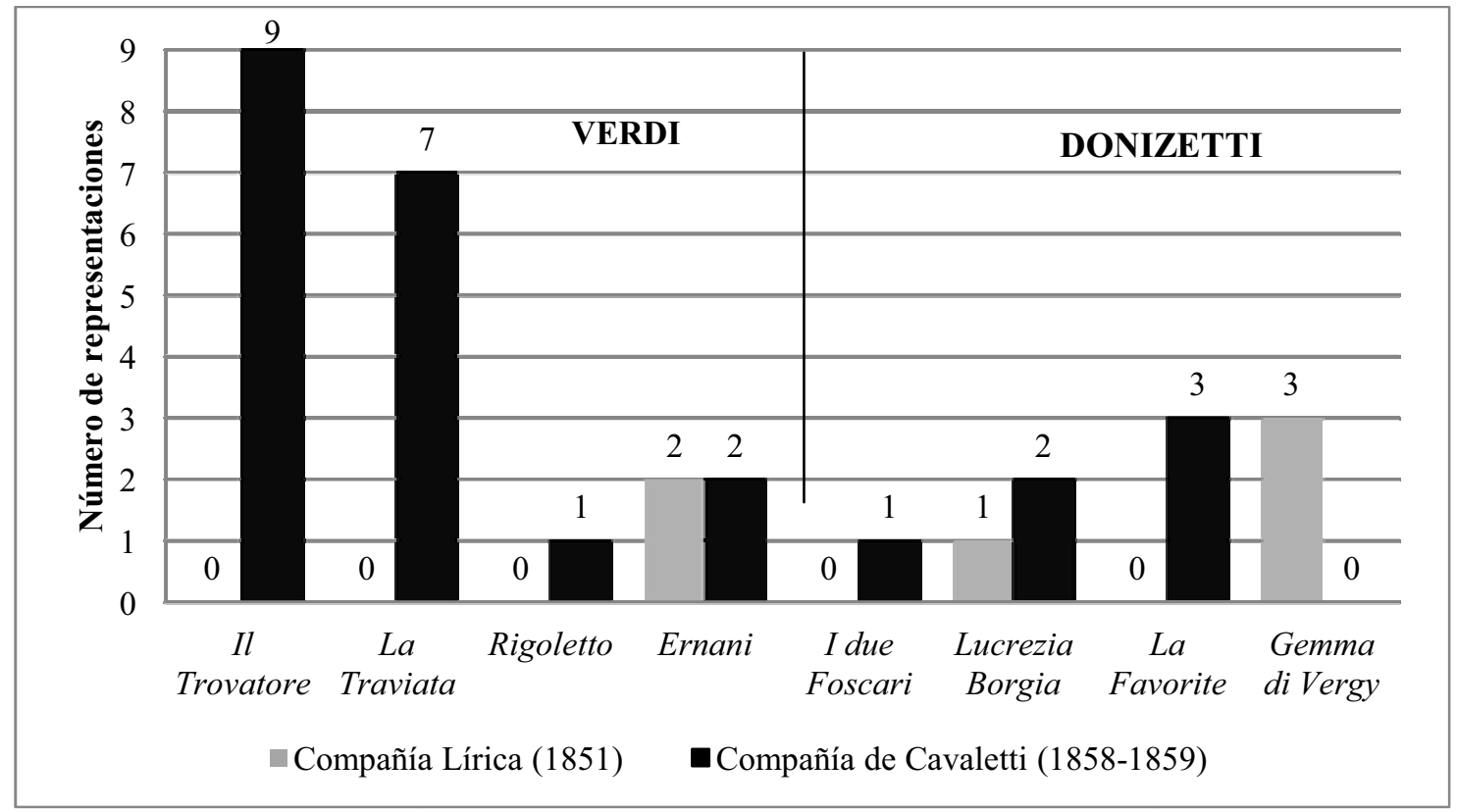

Los anuncios enviados por las compañías de ópera a la prensa para su difusión reflejan las tendencias, gustos y preferencias del público murciano (ver Tabla 4.3): 
Tabla 4. 3. Repertorio de títulos anunciados por las compañías de ópera que actuaron en el Teatro Romea (1881-1899) ${ }^{83}$

I: primera temporada II: segunda temporada

\begin{tabular}{|c|c|c|}
\hline $\begin{array}{l}\text { Compañía, } \\
\text { (temporada, año } \\
\text { cómico) }\end{array}$ & $\begin{array}{c}\mathrm{N}^{0} \text { óperas } \\
\text { anunciadas }\end{array}$ & Títulos y compositores anunciados \\
\hline $\begin{array}{l}\text { Cecilio } r \text { Sanmartí } \\
\text { (maestro director y } \\
\text { concertador) (II, 1880- } \\
1881 \text { ) }\end{array}$ & 12 & $\begin{array}{l}\text { Verdi (Ernani, Un ballo in maschera, Nabucco, La } \\
\text { Traviata, Rigoletto e Il Trovatore); Donizetti } \\
\text { (Poliutto, Lucrezia Borgia, La Favorite y Lucia di } \\
\text { Lammermoor); Bellini (Norma) y Gounod (Faust) }\end{array}$ \\
\hline $\begin{array}{l}\text { Benigno Giardini (II, } \\
\text { 1881-1882) }\end{array}$ & 1 & Verdi $($ Aida $)$ \\
\hline $\begin{array}{l}\text { Andrés Porcell } \\
\text { (director de escena) y } \\
\text { Pedro Urrutia (maestro } \\
\text { director y concertador) } \\
(\mathrm{II}, 1883-1884)\end{array}$ & 11 & $\begin{array}{l}\text { Verdi (La Traviata, Il Trovatore, Rigoletto, Un ballo } \\
\text { in maschera); Donizetti (La Favorite, Lucia di } \\
\text { Lammermoor, Lucrezia Borgia); Meyerbeer (Les } \\
\text { Huguenots, L'Africaine); Gounod (Faust) y Bellini } \\
\text { (La Sonnambula) }\end{array}$ \\
\hline 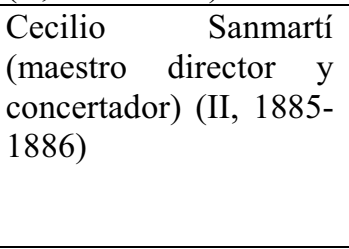 & 13 & $\begin{array}{l}\text { Verdi (Il Trovatore, Ernani, La Traviata, Rigoletto); } \\
\text { Donizetti (Lucia di Lamermoor, Lucrezia Borgia, } \\
\text { Maria di Rohan, La Favorite); Bellini (La } \\
\text { Sonnambula); Rossini (Il barbiere di Siviglia); } \\
\text { Gounod (Faust); Luigi Ricci y Federico Ricci } \\
\text { (Crispino e la comare) y Meyerbeer (L'Africaine) }\end{array}$ \\
\hline $\begin{array}{l}\text { Arturo Serrajordia y } \\
\text { Francisco Camaló } \\
\text { (maestro concertador y } \\
\text { director) (I, 1886- } \\
1887 \text { ) }\end{array}$ & 15 & $\begin{array}{l}\text { Verdi (La Traviata, Rigoletto, Nabucco, Macbeth); } \\
\text { Donizetti (Lucrezia Borgia, Lucia di Lamermoor, } \\
\text { Maria di Rohan, Linda de Chamounix); Bellini (La } \\
\text { Sonnambula, I puritani, Norma); Rossini (Il barbiere } \\
\text { di Siviglia); Meyerbeer (Les Huguenots, L'Africaine) } \\
\text { y Auber (Fra diavolo) }\end{array}$ \\
\hline $\begin{array}{lrr}\text { Compañía } & \text { de } & \text { Arturo } \\
\text { Serrajordia } & \text { (director de } \\
\text { escena) } & \text { y } & \text { Tomás } \\
\text { Bretón } & \text { (maestro } \\
\text { director) } & \text { (II, } & 1890- \\
1891) & & \end{array}$ & 21 & $\begin{array}{l}\text { Verdi (La Traviata, Rigoletto, Nabucco, Macbeth, Il } \\
\text { Trovatore, Un ballo in maschera, Ernani); Donizetti } \\
\text { (La Favorite, Lucrezia Borgia, Lucia di Lamermoor, } \\
\text { Linda de Chamounix, L'elisir d'amore); Meyerbeer } \\
\text { (Les Huguenots, L'Africaine, Dinorah, Robert le } \\
\text { diable); Bellini (I puritani, Norma); Bizet (Carmen); } \\
\text { Bretón (Los amantes de Teruel y Gounod (Faust) }\end{array}$ \\
\hline $\begin{array}{l}\text { Enrico Serazzi } \\
\text { (director de escena) y } \\
\text { Esteban Puig (maestro } \\
\text { director y concertador) } \\
\text { (II, 1891-1892) }\end{array}$ & 17 & $\begin{array}{l}\text { Verdi (Rigoletto, Il Trovatore, Un ballo in maschera, } \\
\text { Ernani); Meyerbeer (Les Huguenots, L'Africaine, } \\
\text { Dinorah, Robert le diable); Donizetti (La Favorite, } \\
\text { Lucrezia Borgia, Lucia di Lamermoor ); Bizet } \\
\text { (Carmen, La jolie fille de Perth); Bretón (Los } \\
\text { amantes de Teruel); Rossini (Il barbiere di Siviglia); } \\
\text { Gounod (Faust) y Auber (Fra diavolo) }\end{array}$ \\
\hline $\begin{array}{lll}\text { Gioachino } & \text { Rossi } \\
\text { 1894-1895) } & & \end{array}$ & 17 & $\begin{array}{l}\text { Verdi (Rigoletto, Il Trovatore, La Traviata, Un ballo } \\
\text { in maschera, Ernani); Meyerbeer (Les Huguenots, } \\
\text { L'Africaine, Robert le diable); Donizetti (La } \\
\text { Favorite, Linda de Chamounix, Lucrezia Borgia, } \\
\text { Lucia di Lamermoor ); Bellini (I puritani); Bizet } \\
\text { (Carmen); Gounod (Faust); Auber (Fra diavolo) y } \\
\text { Ponchielli (La gioconda) }\end{array}$ \\
\hline $\begin{array}{l}\text { Vicente Petri (maestro } \\
\text { concertador y director) } \\
\text { (II, 1898-1899) }\end{array}$ & 8 & $\begin{array}{l}\text { Verdi (Aida, Rigoletto,Otello); Meyerbeer } \\
\text { (L'Africaine); Donizetti (La Favorite); Bellini (La } \\
\text { Sonnambula); Ponchielli (La gioconda) y Wagner } \\
\text { (Lohengrin) }\end{array}$ \\
\hline
\end{tabular}

${ }^{83}$ Se han actualizado los títulos de las óperas. He suprimido las compañías cuyo repertorio no apareció reflejado en prensa. Las fuentes pueden consultarse en el Apéndice 4.2 
Casi todas las compañías (excepto la de Benigno Giardini) enviaron un listado de al menos diez óperas diferentes para representar en Murcia y de nuevo se advierte el predominio de los compositores italianos de ópera sobre los franceses, alemanes y españoles. En todos los anuncios se incluían obras Verdi, que fue el compositor del que más títulos se anunciaron, seguido por Donizetti y Meyerbeer ${ }^{84}$. Con respecto a etapas anteriores, se introdujeron nuevos compositores, como Bellini, Meyerbeer, Bizet y Wagner, entre otros.

El anuncio de la compañía de Enrico Serazzi y Esteban Puig, publicado en mayo de 1892, distinguía entre obras del "antiguo repertorio" (Les Huguenots, L'Africaine, Robert le diavolo, Il Trovatore, La Favorite, Un ballo in maschera, Ernani, Lucia di Lammermoor, Il barbiere di Siviglia, Fra diavolo, Lucrezia Borgia y Rigoletto) y otras de estreno en Murcia (Carmen, Los amantes de Teruel y La jolie fille de Perth). Sin embargo, muchas de las consideradas antiguas no se habían representado nunca (y aún menos de forma completa) en la ciudad ${ }^{85}$.

No todos los títulos de ópera anunciados en la prensa fueron posteriormente representados. La compañía de Cecilio Sanmartí (segunda temporada de 1880-1881), por ejemplo, no llevó a escena ni Rigoletto ni Lucrezia Borgia. Tampoco la de Andrés Porcell y Pedro Urrutia interpretó Rigoletto, Un ballo in maschera, Lucrezia Borgia y L'Africaine. Muchos títulos anunciados por la compañía de Arturo Serrajordia y Francisco Camaló no se pusieron en escena, mientras que sí se interpretaron Il trovatore, La favorite y Faust, óperas inicialmente no incluidas y que fueron las más representadas durante estos años.

La Tabla 4.4 muestra los títulos y el número de representaciones completas de las óperas programadas en el Teatro Romea en 1881-1899. El compositor más representado en Murcia fue Verdi, seguido por Donizetti, Gounod y Meyerbeer y, a mayor distancia, Bellini, Rossini, Bizet, Ponchielli, Luigi y Federico Ricci y Wagner, cuya primera representación no tuvo lugar en Murcia hasta $1899^{86}$.

${ }^{84}$ Los títulos más anunciados fueron Rigoletto, Il Trovatore y La Traviata, de Verdi; Lucia di Lammermoor, La Favorite y Lucrezia Borgia, de Donizetti; y, finalmente, L'Africaine -siempre presente en los anuncios en los que aparece Meyerbeer- y Les Huguenots.

${ }^{85}$ Otra cuestión era que se conocieran determinadas arias, dúos y otros números musicales sueltos gracias a las funciones en las que se ofrecían arreglos o fragmentos de diversas óperas (ver Apéndice 4.4).

${ }^{86}$ En su estudio sobre la vida musical en Santiago de Compostela, García Caballero afirma que títulos como Lohengrin, Aida y Carmen no fueron estrenados en Santiago de Compostela, mientras en que en otras ciudades como A Coruña, Oviedo y Valladolid fueron representadas por primera vez en diversos años de las décadas ochenta y noventa. Según García Caballero, La vida musical, p. 195, Lohengrin se estrenó en A Coruña en 1897; en el Teatro Campoamor de Oviedo, Aida y Carmen se llevaron a escena por primera vez en 1894, mientras que La Gioconda lo hizo en 1895 (igual que en Murcia) y Lohengrin en 1897. En Valladolid, Aida se estrena en la misma fecha que la capital murciana, 1882 y Carmen en 1897. En Valencia, la temporada 1899-1900 del Teatro Principal destacó por el estreno Lohengrin, La Walkiria (ambas de Wagner) y Sansón y Dalila (Saint-Säens), entre otros: Galbis, "Valencia”, p. 535. 
Tabla 4. 4. Óperas representadas de forma íntegra en el Teatro Romea de Murcia (1881-1899) Fuentes: ver Apéndice 4.4.

\begin{tabular}{|c|c|c|c|}
\hline Compositor & Ópera & $\begin{array}{c}\mathrm{N}^{0} \mathrm{de} \\
\text { representaciones }\end{array}$ & $\begin{array}{l}\text { Totales por } \\
\text { compositor }\end{array}$ \\
\hline \multirow[t]{3}{*}{ Bellini } & Norma & 2 & \multirow[t]{3}{*}{9} \\
\hline & I puritani & 1 & \\
\hline & La sonnambula & 6 & \\
\hline Bizet & Carmen & 3 & 3 \\
\hline \multirow[t]{5}{*}{ Donizetti } & La Favorite & 9 & \multirow[t]{5}{*}{41} \\
\hline & Lucia di Lammermoor & 16 & \\
\hline & Lucrezia Borgia & 10 & \\
\hline & Maria di Rohan & 1 & \\
\hline & Poliuto & 5 & \\
\hline Gounod & Faust & 15 & 15 \\
\hline \multirow[t]{4}{*}{ Meyerbeer } & Dinorah & 2 & \multirow[t]{4}{*}{14} \\
\hline & $\begin{array}{ll}\text { Gli } & \text { Ugonotti/Les } \\
\text { Huguenots } & \\
\end{array}$ & 4 & \\
\hline & L'Africaine & 7 & \\
\hline & Robert le diable & 1 & \\
\hline Ponchielli & La gioconda & 2 & 2 \\
\hline $\begin{array}{l}\text { Ricci, Luigi y } \\
\text { Federico }\end{array}$ & Crispino e la comare & 1 & 1 \\
\hline Rossini & Il barbiere di Siviglia & 8 & 8 \\
\hline \multirow[t]{7}{*}{ Verdi } & Il Trovatore & 17 & \multirow[t]{7}{*}{61} \\
\hline & La Traviata & 11 & \\
\hline & Rigoletto & 10 & \\
\hline & Aida & 9 & \\
\hline & Ernani & 7 & \\
\hline & Un ballo in maschera & 4 & \\
\hline & Otello & 3 & \\
\hline Wagner & Lohengrin & 1 & 1 \\
\hline & TOTAL & & 155 \\
\hline
\end{tabular}

La siguiente Tabla 4.5 recoge las fechas de las primeras representaciones en Murcia de algunas óperas, según las referencias de que dispongo ${ }^{87}$. La mayor parte de las óperas estrenadas en Murcia se llevaron a escena con más de veinte años de diferencia respecto de su estreno mundial. Esta diferencia temporal se acorta hasta la mitad en las óperas de Verdi o incluso menos, como por ejemplo las célebres Il Trovatore y La Traviata, estrenadas en Murcia con sólo cinco años de diferencia de la première. En el caso contrario, títulos como I puritani de Bellini se interpretaron en los teatros murcianos con sesenta años de retraso.

${ }^{87}$ Es probable que las fechas de estrenos de algunas óperas de la primera mitad del siglo XIX fuesen representadas por primera vez con anterioridad a la fecha que indico en la Tabla 4.5. Es el caso de $I l$ barbiere di Siviglia cuya primera representación tiene lugar, según mis datos, en 1885 y parece probable que se estrenara con anterioridad. 
Tabla 4. 5. Primeras representaciones documentadas de ópera en Murcia Fuentes: ver Apéndice 4.4.

\begin{tabular}{|c|c|c|}
\hline Compositor & $\begin{array}{c}\text { Ópera / Estreno mundial } \\
\text { (año) }^{88}\end{array}$ & $\begin{array}{c}\begin{array}{c}\text { Primera representación en } \\
\text { Murcia / Teatro }\end{array} \\
\end{array}$ \\
\hline $\begin{array}{l}\text { Auber, Daniel- } \\
\text { François-Esprit }\end{array}$ & Fra Diavolo $(1830)$ & 25-11-1858 / Provisional \\
\hline \multirow[t]{2}{*}{ Bellini, Vincenzo } & La sonnambula $(1831)$ & 19-04-1884 / Romea \\
\hline & I puritani $(1835)$ & 14-03-1895 / Romea \\
\hline Bizet, Charles & Carmen (1875) & 16-03-1895 / Romea \\
\hline \multirow[t]{5}{*}{ Donizetti, Gaetano } & Gemma di Vergy (1834) & 21-10-1851/De Toro \\
\hline & Lucia di Lammermoor (1835) & 30-04-1881 / Romea \\
\hline & La Favorite (1840) & 11-01-1859 / Provisional \\
\hline & Maria di Rohan (1843) & 30-05-1885 / Romea \\
\hline & Poliuto (1848) & 21-04-1881 / Romea \\
\hline $\begin{array}{l}\text { Gounod, Charles- } \\
\text { François }\end{array}$ & Faust (1859) & 11-05-1881 / Romea \\
\hline \multirow[t]{4}{*}{ Meyerbeer, Giacomo } & Dinorah (1859) & 22-06-1886 / Romea \\
\hline & Robert le diable $(1831)$ & 1865 / Romea \\
\hline & $\begin{array}{l}\text { Gli Ugonotti/Les Huguenots } \\
(1836)\end{array}$ & 17-04-1884 / Romea \\
\hline & L'Africaine (1865) & 16-06-1883 / Romea \\
\hline Ponchielli, Amilcare & La gioconda (1876) & 07-03-1895 / Romea \\
\hline $\begin{array}{l}\text { Ricci, Luigi y Ricci, } \\
\text { Federico }\end{array}$ & Crispino e la comare (1850) & 05-06-1886 / Romea \\
\hline Rossini, Gioachino & Il barbiere di Siviglia (1816) & 28-05-1885 / Romea \\
\hline \multirow[t]{8}{*}{ Verdi, Giuseppe } & I due foscari (1844) & 23-01-1859 / Provisional \\
\hline & Ernani (1844) & 10-10-1851 / Del Toro \\
\hline & Rigoletto $(1851)$ & 24-12-1858 / Provisional \\
\hline & Il Trovatore (1853) & 06-11-1858 / Provisional \\
\hline & La Traviata $(1853)$ & 24-10-1858 / Provisional \\
\hline & Un ballo in maschera (1859) & 14-05-1881 / Romea \\
\hline & Aida $(1871)$ & 18-04-1882 / Romea \\
\hline & Otello (1887) & 14-04-1899 / Romea \\
\hline Wagner, Richard & Lohengrin (1850) & 25-04-1899 / Romea \\
\hline
\end{tabular}

Títulos frecuentemente estrenados en otras capitales de España, también fueron llevados a escena en Murcia (La gioconda, Dinorah, Carmen, Aida, Otello y Lohengrin, por ejemplo) y con respecto a Madrid, se detecta un gran retraso ${ }^{89}$.

Verdi fue el compositor de ópera más representado globalmente en Murcia, y todas las compañías que actuaron en la ciudad dieron obras suyas (ver Tabla 4.6):

${ }^{88}$ Datos extraídos de Sadie (ed.). The New Grove.

${ }^{89}$ Dinorah se estrenó en el Teatro Real el 22-02-1872; Aida el 13-12-1874; Lohengrin, el 26-03-1881; La gioconda el 9-02-1884; Carmen, el 17-03-1888 y el Otello de Verdi, el 11-10-1890. Véase, Turina, Historia, pp. 368, 372, 384, 400 y 404. 
Tabla 4. 6. Compositores y títulos más representados en el Teatro Romea de Murcia por las diferentes compañías de ópera (1881-1899).

I: primera temporada. II: segunda temporada ${ }^{90}$

\begin{tabular}{|c|c|c|c|}
\hline $\begin{array}{l}\text { Compañía (temporada y año } \\
\text { cómico) }\end{array}$ & Compositores & $\begin{array}{c}\mathbf{N}^{\mathbf{0}} \\
\text { representaciones }\end{array}$ & Títulos \\
\hline \multirow[t]{2}{*}{$\begin{array}{l}\text { Cecilio Sanmartí (maestro } \\
\text { director y concertador) (II, } \\
1880-1881 \text { ) }\end{array}$} & Verdi & 7 & $\begin{array}{l}\text { Il Trovatore, Ernani } \\
\text { La Traviata y Un ballo in } \\
\text { maschera }\end{array}$ \\
\hline & Donizetti & 7 & $\begin{array}{l}\text { Lucia di Lammermoor, La } \\
\text { Favorite y Poliuto }\end{array}$ \\
\hline \multirow[t]{2}{*}{$\begin{array}{l}\text { Benigno Giardini (II 1881- } \\
\text { 1882) }\end{array}$} & Verdi & 15 & $\begin{array}{l}\text { Aida, Il Trovatore, La Traviata, } \\
\text { Un ballo in maschera y } \\
\text { Rigoletto }\end{array}$ \\
\hline & Donizetti & 4 & $\begin{array}{l}\text { La Favorite y Lucia di } \\
\text { Lammermoor }\end{array}$ \\
\hline \multirow{2}{*}{$\begin{array}{l}\text { Andrés Porcell (director de } \\
\text { escena) y Regino Martínez } \\
\text { (maestro concertador y } \\
\text { director) (II, 1882-1883) }\end{array}$} & Verdi & 2 & Il Trovatore y Rigoletto \\
\hline & Donizetti & 3 & $\begin{array}{l}\text { La Favorite, Lucrezia Borgia y } \\
\text { Poliuto }\end{array}$ \\
\hline \multirow{2}{*}{$\begin{array}{l}\text { Andrés Porcell (director de } \\
\text { escena) y Pedro Urrutia } \\
\text { (maestro director y } \\
\text { concertador) (II, 1883- } \\
1884 \text { ) }\end{array}$} & Verdi & 4 & La Traviata e Il Trovatore \\
\hline & Donizetti & 4 & $\begin{array}{l}\text { Lucia di Lammermoor, Lucrezia } \\
\text { Borgia y La Favorite }\end{array}$ \\
\hline \multirow[t]{2}{*}{$\begin{array}{l}\text { Achille Babacci (director } \\
\text { artístico) (II, 1884-1885) }\end{array}$} & Verdi & 6 & $\begin{array}{l}\text { La Traviata, Ernani } \\
\text { Rigoletto, Un ballo in maschera } \\
\text { e Il Trovatore }\end{array}$ \\
\hline & Donizetti & 5 & $\begin{array}{l}\text { Lucia di Lammermoor, Maria } \\
\text { di Rohan y La Favorite }\end{array}$ \\
\hline \multirow{3}{*}{$\begin{array}{l}\text { Cecilio Sanmartí (maestro } \\
\text { director y concertador) (II, } \\
1885-1886)\end{array}$} & Verdi & 7 & $\begin{array}{l}\text { La Traviata, Ernani } \\
\text { Rigoletto e Il Trovatore }\end{array}$ \\
\hline & Donizetti & 6 & $\begin{array}{l}\text { Lucia di Lammermoor, Lucrezia } \\
\text { Borgia, La Favorite y Poliuto }\end{array}$ \\
\hline & Meyerbeer & 7 & L'Africaine y Dinorah \\
\hline \multirow{2}{*}{$\begin{array}{l}\text { Arturo Serrajordia (director } \\
\text { de escena) y Francisco } \\
\text { Camaló (maestro } \\
\text { concertador y director) (I, } \\
\text { 1886-1887) }\end{array}$} & Donizetti & 4 & $\begin{array}{l}\text { Lucia di Lammermoor, Lucrezia } \\
\text { Borgia y La Favorite }\end{array}$ \\
\hline & Verdi & 3 & La Traviata e Il Trovatore \\
\hline \multirow[b]{2}{*}{$\begin{array}{l}\text { Enrico Serazzi (director de } \\
\text { escena) y Eusebio Bosch } \\
\text { (maestro director y } \\
\text { concertador) (II, 1889- } \\
1890 \text { ) }\end{array}$} & Verdi & 4 & Ernani, Rigoletto e Il Trovatore \\
\hline & Donizetti & 3 & $\begin{array}{l}\text { Lucia di Lammermoor y } \\
\text { Lucrezia Borgia }\end{array}$ \\
\hline $\begin{array}{l}\text { Arturo Serrajordia (director } \\
\text { de escena) y Tomás Bretón } \\
\text { (maestro director) (II, } \\
\text { 1890-1891) }\end{array}$ & Verdi & 1 & Il Trovatore \\
\hline \multirow{4}{*}{$\begin{array}{l}\text { Pablo Lorenzano (I, 1891- } \\
\text { 1892) }\end{array}$} & Bellini & 1 & La Sonnambula \\
\hline & Donizetti & 1 & Lucia di Lammermoor \\
\hline & Gounod & 1 & Faust \\
\hline & Rossini & 1 & Il barbiere di Siviglia \\
\hline
\end{tabular}

${ }^{90}$ Los compositores y títulos representados por las compañías de Pablo Lorenzano (I, 1891-1892) y Maria Galvani (primera tiple) (I, 1896-1897) fueron interpretados en igual número. 


\begin{tabular}{|l|l|l|l|}
\hline Enrico Serazzi (director de & Gounod & 3 & Faust \\
\cline { 2 - 4 } $\begin{array}{l}\text { escena) y Esteban Puig } \\
\text { (maestro director y } \\
\text { concertador) (II, 1891- } \\
1892)\end{array}$ & Verdi & 2 & Rigoletto e Il trovatore \\
\cline { 2 - 4 } & Meyerbeer & 2 & Gli Ugonotti \\
\hline $\begin{array}{l}\text { Gioachino Rossi (I, 1894- } \\
1895)\end{array}$ & Bizet & 3 & Carmen \\
\cline { 2 - 4 } & Donizetti & 3 & La Favorite y Lucrezia Borgia \\
\cline { 2 - 4 } & Verdi & 2 & La traviata \\
\hline $\begin{array}{l}\text { Maria Galvani (primera } \\
\text { tiple) (I, 1896-1897) }\end{array}$ & Bellini & 1 & La Sonnambula \\
\cline { 2 - 4 } & Donizetti & 1 & Lucia di Lammermoor \\
\cline { 2 - 4 } & Rossini & 1 & Il barbiere di Siviglia \\
\cline { 2 - 4 } & Verdi & 1 & La Traviata \\
\hline $\begin{array}{l}\text { Vicente Petri (maestro } \\
\text { concertador y director) (II, } \\
1898-1899)\end{array}$ & Verdi & 7 & Aida, Rigoletto y Otello \\
\hline
\end{tabular}

El público exigía a veces la puesta en escena de alguna obra. Ese fue el caso, por ejemplo, de Il barbiere di Siviglia de Rossini, que fue representada en octubre de 1891 por el conjunto de Pablo Lorenzano, a petición reiterada de público y de los medios periodísticos de la ciudad (la última vez que se había representado en la ciudad antes de esa fecha había sido en de junio de 1886, ver Apéndice 4.4).

Algunas compañías ofrecían funciones con representaciones parciales de ópera combinadas con números instrumentales, de otras óperas, de zarzuela o de cualquier otro género vocal. La compañía de Achille Babacci, por ejemplo, incluyó el 1 de junio de 1885 el primer y cuarto acto de La Favorite (Donizetti), el tercer acto de Lucia di Lammermoor (Donizetti), la "Fantasía para violonchelo sobre motivos de El Trovador" de Gaetano Braga (interpretada por el tenor Campanari al violonchelo y el director de la orquesta Goula al piano), un Scherzo de Braga (por Campanari al violonchelo), un "Capricho sobre un tema suizo" (por Campanari, al piano), el "Andante del gran concertante de Poliuto" de Donizetti (por Campanari al violonchelo y Goula al piano; y, finalmente, el tercer acto de la ópera Marina, de Arrieta. Tres días más tarde, la misma compañía incluyó como sinfonía inicial de una función la obertura de Rienzi (Wagner). Esta interpretación de Wagner en 1885 es la primera que he documentado de este compositor en los teatros murcianos, aunque la obra no fue representada.

La función de despedida de Murcia de la compañía de Arturo Serrajordia en noviembre de 1886 constó de un programa variado de música de Arrieta (Marina), Bellini (Norma), Meyerbeer (Les Huguenots), Verdi (Il Trovatore, don Carlo), Donizetti (La Favorite) y Gomes (Il Guarany).

Este tipo de funciones misceláneas se programaban con más frecuencia en las despedidas de las compañías, aunque también se ofrecía a veces en funciones normales. Por ejemplo, la quinta actuación en Murcia de la compañía de Pablo Lorenzano constó de diversos actos de La Favorite (Donizetti), Il Trovatore (Verdi) y Les Huguenots (Meyerbeer), provocando una reacción negativa en la prensa local: "Tres actos de otras tantas óperas tiene poco atractivo para los aficionados y son de censurar cuando, como 
ahora ocurre, el número de funciones es tan corto y se desea oír mucho nuevo, sin repeticiones, sin retazos, obras enteras... y nada más" ${ }^{\text {91 }}$.

A menudo, las compañías de ópera representaban también zarzuelas (y viceversa). Por ejemplo, el elenco operístico de Gioachino Rossi llevó a escena en marzo de 1895 las zarzuelas El monaguillo (música de Marqués y libreto de Sánchez Pastor) y Meterse en honduras (música de Rubio y libreto de Flores García). En el Apéndice 4.4 se pueden consultar otros ejemplos de esta práctica.

\section{4. Ópera en otros teatros murcianos: la compañía de Arturo Baratta en el Teatro Circo Villar (1894)}

La única compañía de ópera que actuó en Murcia fuera del Teatro Romea fue la de Arturo Baratta, que dio cinco funciones en el Teatro Circo Villar de Murcia en septiembre de 1894. Sus voces principales parecen haberse reducido a una soprano, un primer tenor, un primer barítono, un primer bajo, un "caricato" y dos "comprimarios" (véase Apéndice 4.3). La gran atracción de la compañía fue la prestigiosa soprano Josefina Huguet, quien aprovechó su estancia en Murcia para ofrecer un concierto en el Casino.

La compañía de Baratta representó Lucia di Lamermoor (Donizetti), La Sonnambula (Bellini) e Il Barbiere di Siviglia (Rossini). La última función (30-09-1894), a beneficio de la citada soprano y como despedida de la compañía ofreció el segundo acto de Il Barbiere di Siviglia, un Vals de la ópera Dinorah de Meyerbeer, y los actos segundo y tercero de Lucia di Lammermoor, de Donizetti.

\section{La crítica teatral}

\subsection{La crítica no especializada}

Desde mitades del siglo XIX, la crítica musical fue teniendo una importancia cada vez mayor en España, tanto en las grandes ciudades como en provincias ${ }^{92}$. Una de las primeras reflexiones que he hallado en la prensa murciana en torno a la función que debía cumplir la crítica musical es un artículo publicado en 1867 en La Paz de Murcia, en el que se subraya la responsabilidad y formación que había de tener el buen crítico teatral:

Es preciso cortar los vuelos a la pluma y tener el pensamiento muy a raya cuando se trata de escribir una revista de teatros, pues no son asunto baladí (ni cosa liviana el arte) la empresa, unos artistas que cobran y un público que paga.

${ }^{91}$ Andrés Blanco García, “Teatro”, La Paz de Murcia, XXXIV (1891), nº 11460, 22 octubre, p. 2.

${ }^{92}$ Véase Casares, "La crítica", pp. 464-468. Fue significativa la aparición del artículo "De la crítica musical”, de José Inzenga, en La Gazeta Musical, I (1855), n 2, 11 febrero, pp. 9-11. Sobre crítica teatral, véanse los estudios de López Cabrera, "Sobre la crítica", pp. 255-276, centrado en la prensa grancanaria entre 1853 y 1900 y Galbis, "Crítica musical”, pp. 269-270 sobre la crítica en Valencia durante el siglo XIX. 
No ha de ser un crítico un dómine que a diestra y siniestra largue palmetas y pescozones, ni su crítica murmuraciones de cazuela. Criticar es formar juicios razonados que pongan de bulto los defectos pero que pongan también de relieve las bellezas.

Cuando nos viene a la mente la multitud de circunstancias que debe reunir una crítica, nos pasma, maravilla y sobrecoge la ligereza con que unos dan y otros reciben el título de críticos.

Conocimientos no vulgares, gusto ejercitado, perspicacia suma, mirada que abrace el conjunto y escudriñe los detalles, mano que marque segura el verdadero rumbo del arte por los océanos de la fantasía, el sentimiento de la belleza y las bellezas del sentimiento. Todo eso necesita y aún más el que aspire a la alta investidura de la crítica $[\ldots]$.

Es añeja costumbre que escritores noveles pongan tildes en obras que el estudio perfeccionó, tachar reputaciones que el tiempo depuró y que el público, siempre bonachón, toma como verdaderos juicios, palos de ciego o habladurías de Sibilas y Pitonisas.

Da grima ver que gacetilleros zarramplines, copleros desdichados o periodistas de brocha gorda, vierten los cascabeles de su ignorancia allí donde los Quevedos y los Larras dejaron los mejores brillantes de su inteligencia $[\ldots]^{93}$.

La mayor parte de las críticas periodísticas murcianas sobre representaciones teatrales con música eran en realidad reseñas, necesariamente limitadas en espacio y tiempo, en las que (salvo excepciones) no se pretendía realizar un exhaustivo análisis de las obras representadas ${ }^{94}$. Estas reseñas informaban sobre los aspectos más significativos de la representación (afluencia de público, ejecución de los artistas o escenografía) y también controlaban a las empresas y gestores teatrales, como es patente en muchas noticias de prensa que comento en esta Tesis.

Los críticos musicales que publicaban en la prensa murciana solían tener escasos conocimientos musicales ${ }^{95}$, como reconocía Diego Espinosa, crítico de La Paz de Murcia en 1860, a propósito del estreno de la zarzuela Una broma de estudiantes de Julián Calvo:

[...] No somos músicos y aunque la razón de incompetencia nos embarace algún tanto al emitir nuestro juicio sobre algunos números de zarzuela, cuyo bosquejo vamos haciendo, diremos, sin embargo, que el concertante "Terrible momento", cantado por los señores Martínez, Marín Barnuevo, Delbalzo, Gris y coro, es lo mejor de esta partitura; no solo por la ejecución, que fue muy esmerada, sino por la novedad que notamos en los giros de la instrumentación, en lo cual el señor Calvo, y lo decimos en su justo elogio, ha interpretado fielmente el pensamiento del autor del libreto $[\ldots]^{96}$.

${ }^{93}$ Homoquidam, "Principio quieren las cosas", La Paz de Murcia, X (1867), no 2868, 28 abril, pp. 1-2: 1. El artículo puede consultarse íntegro en el Documentario. Véase también: "Algunas reflexiones sobre la crítica”, firmado por C. y publicado en El Aura Murciana, I (1871), nº 8, 24 marzo, pp. 57-58 y José Agulló Muñoz, “Crítica teatral”, El Aura Murciana, I (1871), n 19, 16 junio, pp. 150-151.

${ }^{94}$ Véase Polanco, La crítica, pp. 69 y 304-315. Según Casares, "La crítica”, p. 174, la mayoría de compositores españoles del siglo XIX fueron valorados por críticos teatrales, sin la adecuada formación musical.

95 Algunas afirmaciones se hacían "por haberlo oído a la generalidad de la concurrencia": La Paz de Murcia, II (1859), n 547, 22 noviembre, p. 2; o "en conformidad a la opinión emitida por los inteligentes que en gran número asisten a nuestro coliseo": La Paz de Murcia, VIII (1865), n 2166, 1 mayo, p. 1.

${ }^{96}$ Diego Espinosa, "Teatro Provisional”, La Paz de Murcia, III (1860), nº 616, 15 febrero, p. 1. 
Las reseñas periodísticas eran con frecuencia anónimas o aparecían firmadas bajo un pseudónimo ${ }^{97}$. Sólo en ocasiones especiales (representaciones de ópera, conciertos de prestigiosos intérpretes o estrenos teatrales significativos), los periódicos murcianos solicitaban la colaboración de músicos de reconocido mérito para que hicieran las críticas, como trataré más adelante ${ }^{98}$.

El lenguaje empleado en las críticas musicales solía ser recargado, pero rara vez técnico ${ }^{99}$. Era frecuente que una misma representación diera lugar a reseñas contradictorias y aún opuestas en diferentes periódicos, a veces relacionadas con sobornos a los periodistas para que las críticas contribuyeran al éxito de una obra o a consolidar las representaciones de una compañía por más tiempo ${ }^{100}$. Agulló Muñoz, en su artículo "Crítica teatral", publicado en junio de 1871 en el periódico El Aura Murciana, reconoció explícitamente las presiones que había sobre los críticos: "Lo repetimos: la verdadera crítica debe ser imparcial. La verdadera crítica debe ser independiente. En ella no han de prevalecer acciones de ningún género a favor de determinada empresa. Tampoco debe doblegar al crítico las intrigas de bastidores, ni las recomendaciones de la amistad"101. La imparcialidad se veía como un ideal difícil de conseguir, como se expresaba en el primer número de La Lira del Táder (20-04-1845):

\section{TEATRO}

Difícil y penosa es la empresa que vamos a acometer y más difícil, más penosa to / [p. 15] davía cuando es un compromiso contraído que no podemos dejar de cumplir. El prospecto de "La Lira del Tader" ofreció artículos de teatro y sus redactores no pueden menos de prestarse a semejante deber, a pesar de la escasez de sus conocimientos y a despecho del giro que su buena intención e imparcial juicio le supongan estudiadas interpretaciones. Vamos a formular una opinión crítica sobre las cualidades cómicas que acompaña a los actores que hoy se ofrecen [en] el teatro de esta capital y vamos a formularla con la franqueza propia de la imparcialidad, e impulsados únicamente con la idea de que si acertamos en la manifestación de algunos defectos tengan remedio éstos, proporcionándonos al par la satisfacción de verlos corregidos. Repetimos que tamaña empresa es superior a nuestras fuerzas, pero que nuestro deseo es recomendable y que vamos a satisfacer una obligación que a nuestro propósito cumple $[\ldots]^{102}$.

${ }^{97}$ V. C. "La crítica y la música", El Artista, I (1866), no 3, 22 junio, pp. 1-2: 1. Véase el análisis que hace Polanco, La crítica, pp. 241-248 sobre la autoría de las reseñas en la prensa valenciana en las primeras décadas del siglo XX.

98 Algunas veces se pidió la realización de una reseña a varios colaboradores. Así ocurrió con la extensa reseña sobre la zarzuela Mari Cruz Verde, de los murcianos Esteban Capdepón (música) y Javier Fuentes y Ponte (libreto), inserta en la sección "Variedades" de La Paz de Murcia sin firma: Anónimo, "Mari Cruz Verde, zarzuela de costumbres murcianas", La Paz de Murcia, XVIII (1875), no 5615, 5 diciembre, p. 1. Es una de las críticas más especializadas que he encontrado, abordó el libreto, la música y la ejecución y "no iba firmada porque no era producto de un solo colaborador": La Paz de Murcia, XVIII (1875), $n^{\circ} 5616,7$ diciembre, p. 1. Ocasionalmente los lectores también enviaban sus propios comentarios críticos, como fue el caso de J. A. [¿Juan Ayala?], "Revista de teatro. (Remitido)", La Paz de Murcia, IX (1866), $\mathrm{n}^{\mathrm{o}} 2548,29$ mayo, p. 2.

${ }^{99}$ Gimeno, Las publicaciones, p. 395.

${ }^{100}$ Gimeno, Las publicaciones, p. 393.

${ }^{101}$ José Agulló Muñoz, “Crítica teatral”, El Aura Murciana, (1871), n 19, 16 junio, pp. 150-151: 150.

${ }^{102}$ La Lira del Táder, I (1845), n 1, 1845, 20 abril, pp. 14-15. Ideas similares pueden verse en La Paz de Murcia: I (1858), $\mathrm{n}^{\mathrm{o}} 234,9$ diciembre, p. 1; IX (1866), $\mathrm{n}^{\mathrm{os}} 2832,4$ diciembre, p. 1; 2840, 13 diciembre, p. 1 y 2849, 19 diciembre, p. 1 ; y X (1867), no 2759, 3 enero, p. 1. 
A pesar de sus buenas intenciones, el crítico de La Lira del Táder debió de sufrir tales presiones que decidió retirar un artículo y hacer en adelante sólo comentarios vagos y generales sobre las representaciones teatrales:

Compuesto nuestro artículo de teatro hemos renunciado a su publicación. Hay más, hemos decidido no ocuparnos circunstanciada e individualmente por ahora ni de las personas, ni de las cosas, ni de la ejecución, ni de las piezas que merezcan esta honra. Guardaremos silencios a medias y la censura y el elogio reducirémoslas a términos generales y vagos. Aunque en esto no se complazca a la mayoría numérica, no importa, conseguiremos al menos, si puede ser, que nos dejen vivir en paz y gracia de Dios; que no nos roan los huesos ni se nos tiendan redes, que no se saque a plaza nuestra inocencia y nuestro candor indubitados y, por último, que esa cruzada de moscones que pican sin sentir y sin anunciar primero la proximidad de sus envenenados aguijones, tome otro rumbo y se apodere de otras pobres humanidades más corpulentas [...], nos contentaremos con el anuncio de las funciones de cada quincena que sean notables a nuestro humilde juicio y un ligero comentario en globo. ¿Lo entendéis?. No trabajaremos más que por quincenas. ¡Oh mágica influencia de esa encantadora palabra para el actor que cobra! ¡Oh acento dolorido para la empresa que paga!.

Leviatán: Redactor en Jefe $e^{103}$.

Las reseñas sobre música eran normalmente breves y en La Paz de Murcia se insertaban casi siempre en la sección dedicada a la crónica local, como un simple "suelto" o noticia breve, con informaciones muy concisas ${ }^{104}$. A veces los críticos adoptaban tono epistolar para comunicarse con los lectores, como en el escrito publicado en 1863 en $\mathrm{El}$ Segura por un redactor de nombre Leopoldo:

[...] para escribir una revista crítica de teatros se necesita que el autor de ella reúna a los conocimientos del arte; el buen gusto de la escena formado por el estudio que de ella haya practicado; que pueda juzgar del mérito de los artistas de quien hable, después de haber admirado los principales de España; que al emitir su juicio haya comparado los unos con los otros; haya raciocinado lógicamente $\mathrm{y}$, sobre todo sea imparcial y no se transforme ni en pebetero, do incesantemente se queme el incienso de la lisonja, ni en despiadado cómitre que hiera sin respeto ni consideración. Tú sabes muy bien que al escribir una revista de teatros hay necesidad de hacerlo con alguna detención por cuanto la escribes para todos, es decir, hay entre quienes la leen personas de muy buenos conocimientos que se transforman en críticos de ella, que comprenden las faltas de que adolece, que censuran con arreglo al arte, que ven las cosas sin pasión y que al notar alguno de esos defectos en que hacen incurrir a los escritores sus afecciones personales, lanzan sobre el autor el anatema poco grato de no saber escribir ni tener conocimientos de aquello que ha escrito. Y he aquí la razón, amigo mío, de por qué es crítica y embarazosa la posición en que me constituye tu exigencia.

Pero hay más: tiene el escritor de tales revistas necesidad de arrostrar no tan solo la mal querencia de los autores cuyas producciones se sujetan a su crítica, cuanto la de los artistas que las desempeñan. Los unos se juzgan, por lo menos Calderones, Rojas o Moretos. Los otros se creen López de Ruedas, Talmas o Máiquez, y unos y

${ }^{103}$ La Lira del Tader, I (1845), nº 3, 4 mayo, p. 48.

104 Por ejemplo: “Anoche se verificó, como estaba anunciada, la primera representación de la linda zarzuela El Relámpago. Su éxito fue muy bueno. El público, entusiasmado, aplaudió casi todas sus escenas tanto por la ejecución como por las bellezas que encierran el libreto y la música, que es de lo mejor que en zarzuelas hemos oído. La concurrencia fue en más número que en las funciones anteriores": La Paz de Murcia, II (1859), nº 542, 17 noviembre, p. 2. 
otros creen herida su susceptibilidad al ver que en el revistero, como ellos llaman, guiado única y exclusivamente por su amor al arte apunta algún pequeño lunar en las obras, algún pequeño defecto en la ejecución de ellas que, corregidos convenientemente, realzarían más y más el mérito de las unas, más y más la gloria de los otros.

Sin embargo, y a pesar de todos estos inconvenientes pienso complacerte cuanto dable me sea, pienso escribirte las revistas que de nuestro teatro me exiges, y al hacerlo bueno será confesar que falto de los conocimientos necesarios, nada tendrá de extraño incurra en algún error $[\ldots]^{105}$.

En las reseñas predominaban los comentarios sobre la ejecución musical por encima de los dedicados a aspectos literarios o compositivos, como reconoce un redactor en 1863:

[...] no he juzgado el mérito de las composiciones no sólo porque carezco de las facultades necesarias para ello, cuanto porque las conoces bien. Me ocuparé únicamente del de los artistas que en ellas han tomado parte y que forman el personal de la compañía" ${ }^{\prime 106}$.

El orden de las descripciones solía repetirse en muchas reseñas. En primer lugar se daba una impresión sobre la compañía en general: si tuvo éxito o no, si satisfizo los deseos del público y si hubo muchos aplausos y repeticiones de números. Después se mencionaban los aspectos más destacados de las obras representadas y los intérpretes (primero actrices, después actores). En ocasiones, se concluía la reseña apuntando algún comentario sobre el coro y la orquesta.

Las primeras representaciones de una compañía solían ser juzgadas con cautela, pero los comentarios con frecuencia eran más positivos a medida que avanzaban las representaciones ${ }^{107}$. Cuando se señalaban aspectos negativos, los temas más recurrentes eran:

1. La falta de ensayos $y$, en consecuencia, los errores cometidos en las representaciones. Valga como ejemplo un caso de 1859: "Las entradas y salidas no se hacían a tiempo, ni por donde se decían, se dieron muchos cortes, casi no se sabían los papeles [y] se hablaba en la escena" ${ }^{108}$.

2. La escasa calidad de los cantantes contratados, a pesar de que los anuncios prometían elencos de actores de primera categoría.

${ }^{105}$ Leopoldo, "Revista de teatros", El Segura, I (1863), no 5, 6 enero, p. 2. Véanse otros ejemplos en las revistas teatrales publicadas durante el mes de mayo de 1860 en el periódico La Paz de Murcia. En otros casos, el crítico se dirigía al director del periódico, como en la crítica firmada por X, "Revista de la semana", La Paz de Murcia, VIII (1865), n 2071, 3 enero, p. 2.

${ }^{106}$ Leopoldo, "Folletín. Revista de teatro", El Segura, I (1863), no 35, 10 febrero, pp. 1-2:1. Véase también Polanco, La crítica, p. 74

${ }^{107}$ Característica también observada por Gimeno, Las publicaciones, p. 393 en las críticas publicadas por la prensa zaragozana. Véanse ejemplos en La Paz de Murcia, II (1859), n 524, 30 octubre, pp. 2-3 y en El Diario de Murcia, III (1881), nº 800, 16 octubre, p. 3

${ }^{108}$ La Paz de Murcia, II (1859), nº 570, 17 diciembre, p. 1. 
3. Las representaciones con conjuntos incompletos de actores.

4. La excesiva duración de los intermedios, aunque estaban regulados por normas:

También vemos que dice uno de los artículos que los entreactos durarán a los más 15 minutos y por lo regular este espacio de tiempo se multiplica por tres, lo que si bien puede ser dispensado cuando hay mutaciones difíciles y variación de trajes es muy extraño cuando nada de esto sucede $[\ldots]^{109}$.

5. La deficiente escenografía y la pobreza de vestuario, maquinaria e iluminación. Por ejemplo, se criticó la reutilización de los decorados en El rey que rabió de Chapí, representada en Murcia en $1893^{110}$, o las deficiencias escenográficas de una representación de Guzmán el Bueno de Antonio Gil de Zárate en 1863:

[...] El servicio de escena con lujo y la decoración gótica bizantina de los tres primeros actos, obra del pintor señor Muriel, a medio concluir, con diferentes clases de puertas, pues que las había de salón y de casa pobre; con unos pabellones en la puerta del foro que parecía se habían quitado para ponerlos allí de alguna horchatería; con unos guerreros a caballo que no tiene base y con unos plumeros los casos de los jinetes que no parecen otra que espantamoscas y, ipásmate!, ha costado al Ayuntamiento (según se dice) la tal decoración ¡tres mil reales...!. Tú preguntarás, como todos lo hacemos, el por qué la comisión del Ayuntamiento, que recibió la obra, la tomó sin concluir y una vez tomada, por qué no obliga al pin /[p. 2] tor para que la concluya. A semejante pregunta no me es dado contestar, ni sé la razón o motivo de tal condescendencia por parte de la Comisión del cuerpo municipal que en ello entiende $[\ldots]^{111}$.

De los cantantes se esperaba que comprendieran los personajes y los ubicaran adecuadamente en la trama, es decir, los caracterizaran. Las interpretaciones exageradas y el escaso estudio de los papeles eran criticados negativamente, lo mismo que el inadecuado reparto de personajes ${ }^{112}$. Abundan comentarios superficiales del tipo "estuvo admirable", "fue muy aplaudido", "obtuvo un triunfo", "cantó con gusto y arte" o "el público le prodigó merecidos aplausos" " $"$. Las cualidades de cada artista se vinculaban a

${ }^{109}$ La Paz de Murcia, IX (1866), no 2523, 4 mayo, p. 2. En La Paz de Murcia, XXXIII (1890), n ${ }^{\circ}$ 10038, 31 enero, p. 1 se denunció que las funciones por horas comenzaban con una hora de retraso, haciendo "que se salga a horas muy avanzadas de la noche y [...], acud[a] poco público".

${ }^{110}$ Véase, El Diario de Murcia, XV (1893), no 5935, 19 mayo, p. 4 y 5937, 21 mayo, p. 1.

111 “Leopoldo", "Folletín. Revista de teatro", El Segura, El Segura, I (1863), no 17, 20 enero, pp. 1-2.

112 Véase, por ejemplo, La Paz de Murcia, II (1859), n 570, 17 diciembre, p. 1 y El Segura, I (1863), $\mathrm{n}^{\mathrm{o}} 5,6$ enero, p. 2.

${ }^{113}$ Las expresiones citadas constan en la crítica a la representación de La Africana, firmadas por "Un lego”, “La Africana”, La Paz de Murcia, XXIX (1886), no 8949, 18 junio, p. 1. "Un lego" utilizó expresiones como la que transcribo a continuación, dirigidas a la contralto Carmen Bustos (integrante de la compañía de Cecilio Sanmartí en el Romea en 1886) por su participación en Lucrezia Borgia (1-06-1886): "que cada día gusta más, que tiene una buena voz, que canta con mucho gusto y que hizo un Orsini admirable, sobresaliendo en el brindis en el cuarto acto, en el que fue muy aplaudida" "Un lego", [Sin título], La Paz de Murcia, XXIX (1886), nº 8936, 2 junio, p. 1. Los críticos no trataban igual a todos los artistas. Véase, como ejemplo la crítica de Leopoldo, "Folletín. Revista de teatro", El Segura, I (1863), no 35, 10 febrero, pp. 1-2, reproducida en el Documentario. 
la respuesta del público, con lo que el "crítico" se convertía en una especie de calibrador de aplausos, que eran un indicativo "seguro" de la recepción de las interpretaciones, acertadas o no, de los artistas. La ambigüedad en las descripciones era la norma. Al comentar el timbre de un cantante en 1881, se decía, por ejemplo: "El barítono señor Palou tiene en su voz un timbre algo extraño, parece estar siempre emocionado, lo cual hace que el público no se deleite cual debiera oyendo este artista" ${ }^{\text {"14 }}$. Muchas de las críticas negativas ponían en evidencia la falta de preparación de los artistas y/o su escasa experiencia.

Los fallos de los directores escénicos no pasaban inadvertidos. En 1863 se criticó así a la compañía de Marini Albini: "falta a la compañía un buen director de escena, ensayos bien dirigidos y el aparato escénico conveniente; y el director debe ser de la misma compañía para que conozca al personal a fondo y pueda corregir los defectos de cada uno" "115. En la representación de Mis dos mujeres (Barbieri/Olona) por la compañía de zarzuela de Francisco Villegas (Teatro de los Infantes, 1866) se criticó que el director de escena no había tenido presente "que la condesa necesitaba un pabellón en el primer acto y no habiéndolo puesto se vio 'Don Diego' en la necesidad de abrir la biblioteca donde antes había encerrado al notario para que su esposa se retirase a dormir y este descuido no pasó desapercibido de nadie"116.

Los críticos vigilaban el cumplimiento de las promesas anunciadas por las empresas teatrales respecto a artistas, repertorio y escenografía, la poca o mucha variación del repertorio, la ausencia de estrenos o los elevados precios de las entradas, entre otros aspectos. Las quejas sobre los empresarios fueron muy numerosas (ver Capítulos 2 a 4 de esta Tesis), pero también se reconoció la labor honesta de determinadas empresas. Por ejemplo, El Heraldo, teniendo en cuenta los elevados gastos que tuvo que afrontar la compañía de Cecilio Sanmartí (Teatro Romea, $2^{\mathrm{a}}$ temporada de 1885-1886), concluía que su calidad era aceptable:

[...] El teatro, dadas las condiciones de nuestra localidad, solo puede producir de 2000 a 2500 reales diarios de abono y para esto es preciso que el número de representaciones no sea mucho y que el precio de la localidad no pase sino apenas llegue al que hoy tiene.

El ingreso diario en la taquilla apenas puede llegar a 1000 reales en general.

Los gastos del teatro son mayores de lo que el público cree. Por efecto de monopolios irritantes de la falta organización social y administrativa de nuestro país, hay una porción de gastos excesivos e inútiles, pero obligatorios. Una guardarropía mitológica, puesto que se paga aún cuando no se usa, un gas que alumbra poco y se paga más caro que el que en otras partes alumbra bien, y otros excesos. Todo esto constituye un gasto que se llama de hora y que llega a 1500 reales por noche. El coro, la orquesta con su director y el atrezzo, cuestan unos 2500 reales.

El empresario, que se supone no ha de ser por afición, porque el asunto es muy penoso, algo ha de ganar.

Resulta que el asunto tiene difícil solución y por lo que llevamos expuesto (que la actual empresa nos ha presentado) [es] una compañía más que suficiente. [... $]^{117}$.

\footnotetext{
${ }^{114}$ La Paz de Murcia, XXIV (1881), no 7034, 24 abril, p. 1.

115 Anónimo, “Revista de teatros”, El Segura, I (1863), n 47, 24 febrero, pp. 1-2.

${ }^{116}$ La Paz de Murcia, IX (1866), nº 2511, 20 abril, p. 2.

${ }^{117}$ Tomado de El Heraldo y publicado por La Paz de Murcia, XXIX (1886), nº 8940, 8 junio, p. 1.
} 
Los coros y la orquesta no fueron habitualmente punto de mira de los críticos, que estaban más preocupados por los solistas: “¿Quién, después de un negocio dirige una mirada, siquiera de compasión al cuerpo de coros y a la orquesta? [...] Lo que se hace es mirar, cuando más, a la prima donna" "118. Sin embargo, la orquesta del Teatro de los Infantes-Romea fue objeto de reiteradas críticas durante algunos años, desencadenándose la polémica "cuestión orquesta" (1881-1898). Las quejas sobre los coros y orquestas solían referirse a la falta de ensayos, la mala afinación y el número insuficiente de cantantes o instrumentistas ${ }^{119}$.

\subsection{La crítica especializada}

La crítica musical especializada tuvo presencia ocasional en la prensa murciana, generalmente después de estrenos teatrales muy significativos o conciertos de grandes intérpretes ${ }^{120}$. Entre los críticos musicales más preparados destacaron el organista y compositor Julián Calvo y el pianista Antonio Ramírez Pagán, colaboradores de La Paz de Murcia y El Diario de Murcia, respectivamente. El escritor y abogado murciano Andrés Blanco García, aunque no era un profesional de la música, publicó críticas musicales con un nivel de conocimiento muy superior al de un mero aficionado. En general, las críticas de músicos especializados solían contener comentarios más técnicos y precisos que las escritas por redactores no músicos ${ }^{121}$.

\subsection{1. Ópera versus zarzuela}

Los críticos murcianos especializados en música consideraban que la ópera era un género superior a la zarzuela y dedicaron en proporción más reseñas a representaciones de ópera (esporádicas en los escenarios murcianos) que a las mucho más frecuentes de zarzuela. Las críticas operísticas se centraron sobre todo en algunas compañías (ver Tabla 4.7).

${ }^{118}$ V. C. "La crítica y la música”, El Artista, I (1866), no 3, 22 junio, pp. 1-2

119 Un ejemplo: "Los coros estuvieron fatales, lo mismo que la orquesta, que no ensaya con el detenimiento que debe las obras que han de ejecutarse": Anónimo, "Revista teatral", El Sacamuelas, I (1863), $\mathrm{n}^{\circ}$ 9, 20 diciembre, p. 6.

${ }^{120}$ Véanse las críticas a conciertos de solistas en el Capítulo 5.

${ }^{121}$ Julián Calvo y Andrés Blanco solían comentar en sus críticas, en primer lugar, aspectos referentes a los cantantes (frecuentemente por orden de aparición) y después lo relativo al coro y la orquesta. Antonio Ramírez, en cambio, acostumbraba comentar en orden los actos, escenas y números musicales de cada ópera, e incluía referencias históricas sobre los compositores y las obras. Véase la biografía de Julián Calvo en el Capítulo 9. 
Tabla 4.7. Críticas sobre óperas representadas en el Teatro Romea (1881-1899).

Fuentes: ver Apéndice 4.4. No se incluyen las críticas no firmadas.

I: primera temporada. II: segunda temporada.

\begin{tabular}{|l|l|l|c|}
\hline Compañía (temporada, año cómico) & Nombre del crítico & $\begin{array}{c}\text { Periódico con el } \\
\text { que colabora }\end{array}$ & $\begin{array}{c}\text { No de } \\
\text { críticas }\end{array}$ \\
\hline Benigno Giardini (II, 1881-1882) & Antonio Ramírez Pagán & El Diario de Murcia & 3 \\
\hline $\begin{array}{l}\text { Andrés Porcell (director de escena) y } \\
\text { Regino Martínez (maestro concertador y } \\
\text { director) (II, 1882-1883) }\end{array}$ & Julián Calvo & La Paz de Murcia & 1 \\
\hline \multirow{2}{*}{$\begin{array}{l}\text { Achille Babacci (director artístico) (II, } \\
1884-1885)\end{array}$} & Antonio Ramírez Pagán & El Diario de Murcia & 2 \\
\hline \multirow{2}{*}{$\begin{array}{l}\text { Cecilio Sanmartí (maestro director y } \\
\text { concertador) (II, 1885-1886) }\end{array}$} & Antonio Ramírez Pagán & La Paz de Murcia & 6 \\
\cline { 2 - 4 } & "Un lego" & La Paz de Murcia & 2 \\
\cline { 2 - 4 } & Antonio Ramírez Pagán & El Diario de Murcia & 3 \\
\hline $\begin{array}{l}\text { Enrico Serazzi (director de escena) y } \\
\text { Eusebio Bosch (maestro director y } \\
\text { concertador) (II, 1889-1890) }\end{array}$ & Julián Calvo & La Paz de Murcia & 3 \\
\cline { 2 - 4 } & Antonio Ramírez Pagán & El Diario de Murcia & 3 \\
\hline Pablo Lorenzano (I, 1891-1892) & & & 2 \\
\hline $\begin{array}{l}\text { Vicente Petri (maestro concertador y } \\
\text { director) (II, 1898-1899) }\end{array}$ & Andrés Blanco García & El Diario de Murcia & 2 \\
\cline { 2 - 4 } & Antonio Ramírez Pagán & El Diario de Murcia & 2 \\
\cline { 2 - 4 } & Mariano Manco Garcín García & El Diario de Murcia & 1 \\
\hline
\end{tabular}

Para Ramírez la ópera era "la poesía elevada a la mayor potencia"122, mientras que la zarzuela era "pasto ordinario de nuestras aficiones filarmónicas" ". Andrés Blanco atacó duramente a la zarzuela y despectivamente la calificó como "arte del flamenquismo" (término que no ha de identificarse con el flamenco propiamente dicho):

[...] Cuando de la zarzuela contemporánea (que con raras excepciones parece hecha únicamente para sostener la depravación del gusto artístico) pasamos a oír las grandes concepciones de la ópera, se nos figura que entramos en un oasis, después de haber caminado fatigosamente a través de arenales inmensos y sentimos una frescura inexplicable en el corazón, porque la belleza viene a recrearnos el alma, ansiosa de otro mundo más elevado que el que nos ofrece lo que podemos llamar arte del flamenquismo $[\ldots]^{124}$.

${ }^{122}$ Antonio Ramírez Pagán, “Teatro Romea”, El Diario de Murcia, XII (1890), n 4029, 17 mayo, p. 2 (ver Documentario).

${ }^{123}$ Antonio Ramírez, "Primera representación de Aida", El Diario de Murcia IV (1882), n 953, 20 abril, pp. 2-3, crítica a la representación de Aida por la compañía de Benigno Giardini (Romea, 2a temporada de 1881-1882). En la reseña que Ramírez escribió sobre las últimas representaciones de la compañía Enrico Serazzi y Eusebio Bosch (1890) llegó a calificar la zarzuela de "pornografía lírica": "Y con esto se ha extinguido la breve luz de ese brillante meteoro que se llama ópera italiana y que, al cabo de cuatro años de ausencia, ha cruzado por nuestro horizonte. Vendrá de nuevo esa pornografía lírica que es ya el ambiente ordinario del teatro en todas partes": Antonio Ramírez Pagán, "Teatro Romea", El Diario de Murcia, XII (1890), nº 4031, 20 mayo, pp. 1-2: 2 (ver Documentario).

${ }^{124}$ Andrés Blanco García, “Teatro", El Diario de Murcia, XIII (1891), nº 4463, 20 octubre, pp. 1-2: 1. Comentarios referidos a la compañía de Pablo Lorenzano (1 ${ }^{\mathrm{a}}$ temporada de 1891-1892). 
A los críticos murcianos especializados en música les preocupaba la preparación musical del público y deseaban que hubiera funciones de ópera cada año para educar a los espectadores $^{125}$. Julián Calvo comentaba en 1883:

[...] La cultura de los pueblos se muestra muy especialmente en la afición a los buenos espectáculos tanto dramáticos como líricos. En los primeros se aprende a conocer las costumbres y sucesos más culminantes de la vida. En los segundos, se conoce lo antes dicho, pero ayudado por la música las impresiones son siempre más gratas, puesto que atenúa el efecto que puede producir en el ánimo la escena más trágica, como acontece en las óperas Rigoletto, Lucia di Lammermoor, Aida y otras muchas de este género.

Es verdad que en el drama lírico, o sea la ópera italiana, se necesita mucha constancia y riegos por parte de las empresas, para que el público llegue a conocer su gran mérito, pues el carecer en España de este género de arte, en nuestro propio idioma, y que fuera característico, hace que muchas veces el auditorio se hastíe y comprometa los intereses más graves $[\ldots]^{126}$.

Antonio Ramírez también opinaba que el público murciano se iría educando a medida que fuera escuchando más ópera:

[...] sucede también que el público empieza ya a familiarizarse con la ópera italiana. Esta es la tercera temporada, después de larguísimo interregno que oímos esta clase de música y es lo cierto que para saborear las innumerables bellezas de estos maravillosos spartitos se necesita, indudablemente, cierta más o menos larga preparación.

Pues bien: la primera vez que se oye una ópera como "Aida", como "Africana", como "Hugonotes" y como "Fausto", el espectador, así sea músico, no puede apreciar de una vez todas las bellezas que se presentan. Es una corriente rápida de notas, de armonías, de efectos instrumentales, de tantas cosas reunidas que superan, que embotan la sensibilidad; pero volvedlo a escuchar, volvedlo a oír y cada día encontraréis una belleza nueva y antes ignorada. He aquí por qué razón yo digo que nuestro público, si hoy llena nuestro teatro, es porque comienza ya a familiarizarse con la ópera $[\ldots]^{127}$.

Probablemente la preocupación que tenía Ramírez por educar al público le llevó a escribir los artículos "Dinorah" y "Lohengrin", en los que describió estas óperas de Meyerbeer y Wagner con motivo de sus primeras representaciones en Murcia ${ }^{128}$.

${ }^{125}$ Anónimo, "La semana", La Paz de Murcia, XXIV (1881), n 7034, 24 abril, p. 1. Hubo sugerencias similares en otros periódicos. Véase, por ejemplo, Rodolfo Carles, "Crónica de la semana", El Semanario Murciano, IV (1881), no 169, 8 mayo, p. 152 (transcrito en el Documentario).

${ }^{126}$ Julián Calvo, "La ópera italiana en Murcia”, en La Paz de Murcia, XXVI (1883), n 7655, 19 junio, p. 1 (ver Documentario).

${ }^{127}$ Antonio Ramírez, "La compañía de ópera", El Diario de Murcia, V (1883), no 1301, 15 junio, p. 2 (ver Documentario). Como Julián Calvo, Ramírez censuró también la falta de objetividad de algunos críticos, por ejemplo, en "La nacionalidad en el arte", El Diario de Murcia, VIII (1886), n 2175, 8 junio, pp. 1-2: 2 .

128 Antonio Ramírez Pagán, "Dinorah”, El Diario de Murcia VIII (1886), no 2187, 22 junio, p. 2 y Antonio Ramírez Pagán, "Lohengrin”, El Diario de Murcia, XXI (1899), n 7992, 27 abril, p. 2 (ambas transcritas en el Documentario). En "Dinorah", Ramírez aportó numerosos detalles sobre la obra: fecha de estreno, autores del libreto, argumento, características musicales del estilo de Meyerbeer, referencias 


\subsection{2. Ópera italiana versus ópera wagneriana}

Para Antonio Ramírez, mientras en la ópera italiana la música primaba sobre el texto, en la ópera alemana (ejemplificada en La Africana de Meyerbeer) la música no era "reina absoluta" sino "reina constitucional":

He aquí dos óperas que caracterizan de un modo muy marcado dos escuelas distintas, o dos géneros opuestos: el género italiano y el género alemán.

"Lucia" es acaso la ópera de Donizetti en que el genio de este músico se manifestó en todo su más brillante esplendor. El estilo de este maestro se distingue no sólo por la amplitud de formas melódicas que le es peculiar, sino además por ese sello de distinción y de elegancia exquisita que se advierte en todas sus producciones. No es tan apasionado como Bellini, ni tan brillante y enérgico como Rossini, pero supera a ambos, sin duda, en sentimiento dramático y en la mejor adaptación de su música a las situaciones escénicas. Sin embargo, son tres genios hermanos. Son los tres grandes maestros que forman el núcleo de la escuela italianísima. Para los tres, el drama lírico es esencia il bel canto. Para los tres, el libreto es un accidente, es una causa ocasional tan sólo que da margen a que el cantante haga brillar, con el alarde de sus facultades vocales, el genio y la inspiración. ¿Qué resulta de esto? Pues resulta la música supeditando completamente a la poesía que la acompaña, haciéndola doblegarse dócilmente a todas sus exigencias [...] / [p. 2].

Pero no olvidemos una cosa esencial en esta cuestión: el drama lírico, antes que lírico, es drama [...]. La ópera es una síntesis artística cuya base, cuyo substratum es el libreto. El libreto es el foco a donde todos los rayos han de converger. La música, pues, no debe reinar en el drama lírico como reina absoluta, sino como reina constitucional, permítaseme la frase.

Ahora bien: ¿quién ha comprendido mejor estas doctrinas a mi modo de ver evidentísimas? La escuela alemana seguramente. Testigo: "La Africana".

"Lucia" es una ópera bellísima, pero de los que se llaman ya decididamente los antiguos moldes. Fijaos, si no, en la escena de la locura. Es la escena más larga de la ópera y eso que se le suprime todo un tiempo entero. ¿Qué pasa allí en tan larga pieza musical? Pues nada, Lucía aparece in sucinta e bianca veste y da a manifestar que está loca, pero eso no quita para que real y positivamente nos dé un concierto de canto, flauta y acompañamiento de orquesta. [...] El concierto, por otra parte, es bellísimo pero ¿y la acción? La acción languidece de una manera extraordinaria. La acción, mejor diríamos, que se eclipsa.

"La Africana" es todo lo contrario. El argumento de la ópera es ya por sí mismo una gran dificultad para un compositor [...].

Sólo Meyerbeer ha sabido vencer en "El Profeta" y en los "Hugonotes", pintando las pasiones y las luchas religiosas. Así como en "La Africana" ha pintado con soberana maestría la ambición de la gloria y de los descubrimientos de Vasco de Gama. Esta ópera no puede comprenderse, ni es posible que pueda gustar, como no se oiga repetidas veces. Pero no lo dudéis, como os lleguéis a familiarizar con ella, la encontraréis superior a las óperas italianas. Hay en ella melodías abundantes y de formas a veces tan claras como las melodías italianas. Esto, junto a tal riqueza, junto a tal exuberancia de armonía, que parece como un río que se desborda $[\ldots]^{129}$.

Meyerbeer representaba la fusión perfecta de las dos escuelas: "El progreso del arte ha traído como consecuencia la influencia recíproca de unos compositores sobre

escenográficas para ayudar a comprender la trama e incluso fragmentos en italiano de algunas arias. El artículo sobre "Lohengrin" sirvió al autor para exponer sus teorías sobre el drama musical de Wagner.

${ }^{129}$ Antonio Ramírez Pagán, "La Lucia y La africana”, en El Diario de Murcia, V (1883), n 1304, 19 junio, pp. 1-2 (véase Documentario). 
otros. Meyerbeer representa la fusión de las dos escuelas y por eso, sin duda, reina hoy sin rival en el teatro"130. Incluso Verdi, "el genio dramático por excelencia"131, había evolucionado desde el estilo de Rossini, Donizetti y Bellini hacia los nuevos rumbos de la escuela alemana, proceso que Ramírez denominó la transformación hacia el "realismo":

[...] Tal vez ningún maestro ha sufrido tanto como Verdi los embates de la crítica. Él ha escrito sus obras en una época harto difícil para el arte. En una época de transición y de reforma, en una época colocada entre las melodías sencillas, candorosas, pero sublimemente inspiradas, de los maestros italianos anteriores a él y el nuevo rumbo adoptado por la llamada escuela vagneriana. Para los primeros, la realización de la belleza estaba principalmente en la invención de la melodía verdadera creación ex nihilo, porque es dar forma y realidad a lo que antes no existía de una manera absoluta. Para los segundos, lo esencial es hallar el concepto, la idea melódica más apropiada, o como si dijéramos, la melodía correspondiente a cada situación, a cada idea y hasta cada palabra.

Desde el Verdi del Nabuco hasta el Verdi de Aida ¡qué transformación, qué inmensa distancia! Siempre la inspiración y el genio -eso no cabe duda- pero, ¡cómo ha roto el maestro en esta ópera los antiguos moldes! ¡Con qué profundidad se inspira en el asunto que interpreta y llega hasta lo que pudiéramos llamar el realismo en la música, si este arte divino, esencialmente vago, esencialmente incoloro, pudiera ser realista ${ }^{132}$.

Al comparar el Otello de Rossini con el de Verdi, Ramírez afirmó: "mirando hoy aquella partitura no parece solo música antigua, sino música de la antigüedad. Ha sido tan grande y tan rápida la transformación que no parecen años sino siglos los que median entre una y otra [ópera]. [...] Pero la revolución ha entrado también por aquí, barriéndolo todo, arrasando el edificio entero del arte antiguo, sin dejar rastro, ni forma, ni sombra, siquiera, de lo que fue" ${ }^{, 133}$.

En una crítica de 1890, Ramírez lamentaba, sin embargo, que el estilo wagneriano hubiera hecho desaparecer la clásica sencillez de óperas italianas como Lucia di Lammermoor de Donizetti e Il Trovatore de Verdi, o que se hubieran reemplazado antiguas zarzuelas como El grumete de Emilio Arrieta y Los diamantes de la corona de Barbieri por otras como La Bruja de Chapí:

[...] Qué me importa a mí que exista Vagner y su escuela si ésta se ha subido a un séptimo cielo, tan distante de este mundo que nos hemos de quedar sin oírle ni entenderlo la inmensa mayoría de los mortales. Reniego del progreso musical que ha hecho imposibles nuevas Lucías y nuevos Trovadores. Todo quiero concedérselo a los vagnerianos, menos que esos músicos italianos, a quienes tanto desprecian, han conmovido con sus melodías insuperables el mundo entero. Sólo el sufragio universal puede dar ya a las cosas su sanción definitiva. Mientras yo vea y sepa que hay personas y muchas, capaces de analizar técnicamente cualquier obra vagneriana y, sin

${ }^{130}$ Antonio Ramírez Pagán, "La nacionalidad en el arte”, El Diario de Murcia, VIII (1886), n 2175, 8 junio, pp. 1-2: 2 .

${ }^{131}$ Antonio Ramírez Pagán, “Teatro Romea”, El Diario de Murcia, XII (1890), n 4029, 17 mayo, p. 2.

132 Antonio Ramírez, "Primera representación de Aida", El Diario de Murcia IV (1882), n 953, 20 abril, pp. 2-3, crítica a la representación de Aida por la compañía de Benigno Giardini (Romea, $2^{\mathrm{a}}$ temporada de 1881-1882).

${ }^{133}$ Antonio Ramírez Pagán, “Otello”, El Diario de Murcia, XXI (1899), no 7984, 18 abril, pp. 1-2. 
embargo, salen después de oírlas ejecutar como el negro del sermón, tengo el derecho de dudar de que lo presente sea, en absoluto, superior al pasado.

Esto es un gongorismo musical, un desvarío del saber hacer que ha sofocado y dado muerte a la antigua y clásica sencillez.

Y como en todas partes pasa igual, también en España desde que hay "Brujas" no hay "Grumetes" ni "Diamantes de la corona".

Alaban los vagnerianos de acá a la "Bruja" todo cuanto quieran, yo lamento la muerte de la antigua zarzuela como lamento la muerte de la antigua ópera italiana ANTONIO RAMÍREZ PAGÁN ${ }^{134}$.

En el debate sobre las escuelas operísticas, Julián Calvo optó por una posición ecléctica, que no ocultaba su abierta admiración por Wagner:

[...] No quiero terminar sin felicitar una vez más a mi querido amigo y compañero señor don Antonio Ramírez Pagán, por su magistral e importante revista que ha publicado "El Diario de Murcia" en el que sustenta doctrinas con las cuales me encuentro asimilado, advirtiendo que no por esto estoy lejos de Wagner, pues todo el que estudia las obras de Beethoven, Mozart y demás maestros alemanes no tiene más remedio que reconocer la grandeza del talento del maestro revolucionario. Ahora bien, no debe confundirse la escuela italiana, representada por Rossini, Bellini, Donizetti y Mercadante con la alemana, y sus comparaciones no son siempre atinadas. En una y otra nación la forma del libro para la ópera es muy distinta y es la base sobre la que están fundadas ambas escuelas, diferente en todo completamente. Además, mientras la ópera alemana hoy va a su apogeo la italiana sufre una gran decadencia, desde que el célebre Verdi rompió con el pasado musical de su nación.

Y aún cuando tuvo la inmarcesible gloria en su Aida y Otello al haber sabido hermanar las melodías de la patria del cisne de Pésaro con la forma impuesta por la escuela alemana, a pesar de todo, la música italiana de vez en cuando nos demuestra lo que fueron sus grandes maestros y más cuando se oye la Lucrecia.

Julián Calvo ${ }^{135}$

Andrés Blanco García contribuyó al debate sobre el wagnerianismo con tres artículos sobre "La música del Porvenir", publicados por entregas en el periódico Cartagena Artística ${ }^{136}$. El estreno en Murcia de Lohengrin (Teatro Romea, 1899), primera ópera de Wagner representada en la ciudad, animó a la publicación de nuevos artículos sobre la música wagneriana ${ }^{137}$. La expectación por poder escuchar la música de Wagner era máxima ${ }^{138}$, aunque la recepción del público no fue entusiasta:

134 Antonio Ramírez Pagán, “Teatro Romea”, El Diario de Murcia, XII (1890), no 4031, 20 mayo, pp. 1-2: 2 (ver Documentario). Sobre la influencia de la ópera wagneriana en la zarzuela, entre otras influencias, véase: Salaün, "La zarzuela”, pp. 235-264.

135 Julián Calvo, "La ópera en Murcia”, La Paz de Murcia, XXXIII (1890), nº 11029, 15 mayo, p. 1. Las cursivas son editoriales.

${ }^{136}$ Andrés Blanco García, "La música del porvenir (I, II y III)” en Cartagena Artística, I (1890), n 22, 10 noviembre, pp. 93-94; 24, 1 diciembre, pp. 100-101 y 26, 20 diciembre, pp. 109-110. Véanse texto íntegros de los artículos en el Documentario.

${ }^{137}$ Sobre la recepción de la obra de Richard Wagner en Madrid véase Suárez, "La recepción... entre 1861 y 1876"; Suárez, "La recepción... entre 1877 y 1893” y Ortiz-de-Urbina, "La recepción... entre 1900 y 1914"; y en Barcelona, Aviñoa, "Barcelona". El estreno de Lohengrin en la ciudad condal (1882) suscitó también interesantes debates, como describe Alier y Mata, El Gran Teatro, pp. 50-51.

${ }^{138}$ Según Antonio Ramírez Pagán, "Lohengrin”, El Diario de Murcia, XXI (1899), nº 7992, 27 abril, p. 2, "cuando sentado en mi grada esperaba impaciente que empezara la ópera, no podía aún convencer de 
[...] El acto segundo empieza por dos dúos larguísimos de Ortruds y el barítono, y de Ortruds y Elsa, cuyos dúos confieso que no entiendo y que me parecen muy pesados. [...] El acto tercero es el mejor. No parece ópera italiana porque no es posible, pero es la música de Vagner cuando Vagner se humaniza, cuando Vagner no se sube a las nubes y se esconde para que nadie lo vea, cuando Vagner se acuerda de que es hombre y no Dios, y escribe un dúo de amor como podría escribirlo cualquier simple mortal que se llamara Verdi, Rossini o Meyerveer. [...] Ahora, si hemos de ser sinceros tenemos que declarar que la obra en general no despertó el entusiasmo que las anteriores [óperas representadas por la compañía] y pudo ser por dos cosas. Primero: la obra es desconocida y oscura para la generalidad. Segundo: la obra es tan grande, mejor dicho, tan enorme que por mucho que valgan los elementos todos de la compañía, y es positivo que valen mucho y que constituyen la mejor compañía de ópera que hemos oído en Murcia, no obstante esto, las dificultades son tantas que algunas deficiencias se pudieron notar. Por ejemplo: en muchos pasajes de madera sola faltaba o no se oía el bajo fundamental, en otros se oían acordes demasiado disonantes que pudieran ser legítimos porque Vagner no se para en disonancias con tal que, y esto es de su sistema, vengan al fin y al cabo a tener resolución; pero también podía ser porque faltasen notas encomendadas al corno inglés, al tercero y cuarto fagot, a algún clarinete bajo y tal vez a algún saxofón [...].

También la música tiene sus matemáticas sublimes, solo que parece que a Vagner se le ha olvidado que los números rigen el mundo; que las leyes de la proporción de la simetría y de la medida, que son casi como las formas plásticas de la música y las que han practicado sencillamente genios acaso tan grandes como él, han creado una especie de sensualismo musical, al cual estamos tan habituados que cuando vemos derribado todo esto, no hay fuerzas ni razones que nos puedan convencer $[\ldots]^{139}$.

La reseña de Andrés Blanco García sobre el estreno murciano de Lohengrin se centró en criticar la ausencia de melodía y el desdén hacia los sentimientos de la música wagneriana, un estilo que a él le resultaba incomprensible:

[...] ¿Por qué su música no deja grandes recuerdos en el oído y el mérito de sus maravillosas armonías pasa desapercibido para toda clase de personas, excepto para aquellas pocas que han encanecido en el estudio del tecnicismo del arte? ¿Es éste el objeto de la música?. ¿Se realiza así la belleza sensible o es que el desiderátum de lo bello musical ha de tener precisamente algo de jeroglífico para que los oyentes se den de calabazadas y al fin de tanto oír y pensar venga a sentir admiración, no por la grandiosidad de los pensamientos sino por los acordes atrevidos, raros y difíciles, presentados en rica profusión y desenvueltos con gallardía y talento pasmosos?.

Si el objeto del arte es hacer perceptible lo bello (y será de tanto mayor mérito cuando más fácil sea la percepción) ¿por qué nadie siente con Wagner y únicamente se habla de entender, no de sentir su música, entendiéndola, tras muchas audiciones, tan sólo los que la estudian con verdadera competencia? [...].

Yo soy de los que paladinamente confiesan que no entienden al gran maestro alemán. Mis aficiones musicales no alcanzan a ese punto. Tampoco siento la belleza cuando escucho sus notas. Fijo cuanto puedo mi oído y observo únicamente una estructura preciosa que me halaga a ratos pero que termina por fatigarme. El recreo principal me lo dan el libro y el efecto escénico [...].

Wagner, a mi juicio, es el que mejor ha entendido el drama lírico teatral, esto es, el que más ha procurado que el libro no sea absorbido por la música. Pero creo que

que fuera cierto que se iba a alzar el telón para oír aquí en mi tierra uno de los grandes jeroglíficos del arte musical". Véase el texto completo en el Documentario.

${ }^{139}$ Antonio Ramírez Pagán, "Estreno de Lohengrin”, El Diario de Murcia, XXI (1899), n 7992, 27 abril, p. 2. 
su vehemente prurito de innovador le ha llevado más allá de sus deseos, pues al suprimir o al obscurecer la melodía con alardes titánicos de compositor, que no son de exclusiva necesidad para demostrar exuberancia de conocimientos técnicos, ha empequeñecido el círculo del arte musical y ha hecho algo parecido al no alabado gusto de poner en el pentagrama la metafísica nebulosa de los alemanes ${ }^{140}$.

Antonio Ramírez también creía que la música debía ser más sencilla que la wagneriana, capaz de ser entendida por todos los oyentes:

el vagnerismo, que es una cosa admirable como desarrollo armónico y amplificación instrumental, puede acarrear, por la creciente megalomanía que heredó de su autor, la decadencia más o menos rápida del arte musical.

Se está viendo que todos los compositores jóvenes son vagneristas. Parece de mal tono escribir para todo el mundo. Ya es cosa muy antigua escribir con claridad y es dar pruebas de ignaros musicantes no seguir los patrones inconmensurables del vagnerismo y no cortar para todos los cuerpos camisas de once varas.

Pues bien. Si se destierra del arte la sencillez, si se posterga en la música la melodía, si sólo se atiende ya en la ópera a formar conglomerados de notas, llenos de ciencia arquitectónica y vacíos de inspiración y de sinceridad, yo creo firmemente que esa música no puede ser y no será la música del porvenir ${ }^{141}$.

El entusiasmo por la música de Wagner es patente, sin embargo, en el artículo publicado por Mariano Marín García, exdirector de la Banda Municipal de Música de Cehegín (Murcia). Según él, la melodía y la armonía estaban tan indisolublemente unidas en la música de Wagner que "se hace preciso para ser oída y comprendida muchísima atención y buena educación del oído, que aquí en Murcia no se posee, no por culpa del público, sino por la falta de espectáculos de esta índole". Según Marín, las disonancias que Ramírez y Blanco habían escuchado en Lohengrin se debían a que varios instrumentos (trombones, basstuba y oboes) estaban desafinados la noche del estreno. Marín no estaba de acuerdo en que faltara melodía en Lohengrin y puso como ejemplos el Preludio, la Plegaria de Elsa y la Marcha Nupcial del segundo acto, entre otros fragmentos de la obra. Sin paliativos, Marín valoraba a Wagner como el mayor genio musical después de Beethoven:

[...] Resumiendo: estoy conforme con lo que dice el señor Blanco que a su juicio, Wagner es el que mejor ha entendido el drama lírico teatral y al contrario de lo que dice el señor Ramírez creo que Ricardo Wagner no ya la posteridad sino en los momentos actuales, es juzgado no como poeta sino como el genio que después de Beethoven ha elevado la música al más alto grado de perfección y dado excepcional importancia al drama lírico ${ }^{142}$.

${ }^{140}$ Andrés Blanco García, “Sobre Wagner”, El Diario de Murcia, XXI (1899), no 7994, 29 abril, p. 1. Véase también Andrés Blanco, "Teatro", El Diario de Murcia, XIII (1891), nº 4465, 22 octubre, pp. 1-2.

${ }^{141}$ Antonio Ramírez, “Sobre Wagner”, El Diario de Murcia, XXI (1899), no 7997, 3 mayo, p. 1.

${ }^{142}$ Mariano Marín, “Sobre Wagner”, El Diario de Murcia, XXI (1899), no 7996, 2 mayo, p. 1. Según El Diario de Murcia, XX (1898), n ${ }^{\circ}$ 7538, 7 febrero, p. 3, Marín García renunció a su cargo de director de la Banda Municipal de Cehegín en marzo de 1898. 


\subsubsection{La cuestión de la ópera española ${ }^{143}$}

Julián Calvo afirmó rotundamente que no existía una ópera genuinamente española, lo que hacía más difícil que el público conociera este género y que los empresarios invirtieran en él, pues "el carecer en España de este género de arte [la ópera], en nuestro propio idioma, y que fuera característico, hace que muchas veces el auditorio se hastíe y comprometa los intereses más graves"144.

El estreno murciano de "La Bruja" de Chapí en febrero de 1888 inspiró dos interesantes críticas de Antonio Ramírez y Andrés Blanco en las que, más que formular opiniones sobre los intérpretes, se dieron opiniones sobre las influencias musicales wagnerianas en esta obra. Ramírez observó que La Bruja resultaba para unos "admirable", pero para otros era una obra "confusa y desigual" o incluso "fastidiosa y pesada", y él mismo la consideró "un progreso inmenso y a la vez una perturbación" ${ }^{145}$ : progreso por la sabiduría de Chapí en armonía e instrumentación; perturbación porque su música dejaba indiferente a los espectadores, que sólo parecían vibrar en los números de carácter español (como la jota "No extrañéis, no, que se escapen"). Según Ramírez, este comportamiento del público se debía a que lo habitual en los teatros era una “españolización del género" que impedía apreciar las innovaciones menos conocidas de la música de Chapí:

[...] El público español que oiga esta zarzuela no tiene motivos más que para rendir un homenaje de profunda admiración a un artista eminentísimo, pero después de todo esto, el pueblo español tal vez eche de ver que la factura sabia y riquísima de bastantes números de esta obra sobrepasa el género de la ópera cómica española. No digo yo que nuestro espectáculo lírico nacional sea mejor ni sea peor que el extranjero, pero ni Suppé, ni Offembach, ni Straus, ni Andran, ni Panquett, ni Varney, ni Lecon, ni ninguno, en fin, de los cultivadores de la ópera cómica van por el camino de Chapí, sin dejar por eso de tener muchísima gracia, muchísima originalidad y muchísimas bellezas. Luego, nuestro público está tan acostumbrado a la españolización del género, que me temo que pase en muchas partes lo que pasó la noche de que hablo entre nosotros: permaneció frío hasta que estalló la jota que es riente, apasionada, enérgica, magnífica $[\ldots]^{146}$.

En el artículo de Andrés Blanco, también titulado La Bruja, se afirmaba que la obra de Chapí había dejado indiferentes a los espectadores por su imitación de recursos musicales extranjeros, y especialmente por el predominio de la armonía y "rasgos y giros alemanes" sobre la melodía ${ }^{147}$. El equilibrio entre melodía y armonía (o, en otras palabras, sentimiento y razón) se daba según Blanco en las composiciones de Meyerbeer:

${ }^{143}$ El debate sobre la ópera nacional española ha sido ampliamente tratado en los últimos años. Véase Casares, "La creación"; Casares, "L’opera"; Cortizo, "La ópera romántica"; Iberni, "Controversias", pp. 157-164; Matía, José Inzenga, pp. 192-235 y Sobrino, "La ópera española”, entre otros estudios.

${ }^{144}$ Julián Calvo, "La ópera italiana en Murcia”, en La Paz de Murcia, XXVI (1883), nº 7655, 19 junio, p. 1 (ver Documentario).

145 Antonio Ramírez Pagán, “La Bruja”, El Diario de Murcia, X (1888), nº 3235, 14 febrero, pp. 1-2. $\mathrm{Su}$ texto puede consultarse en el Documentario de esta Tesis.

${ }^{146}$ Antonio Ramírez Pagán, El Diario de Murcia, X (1888), nº 3235, 14 febrero, pp. 1-2: 2.

${ }^{147}$ Andrés Blanco García, "La bruja”, El Diario de Murcia, X (1888), no 3237, 16 febrero, pp. 1-2: 1. 
[...] Cuando estaba en boga la melodía, llegó un momento de languidez y empalago que dieron al traste con tan hermosa escuela [la italiana]. Lo dulzón pudo extenderse de manera tal que producía en el ánimo de los oyentes el fastidio. Hoy predomina la escuela de la armonía, pero no como el gran Meyerbeer la cultivó, sino a la manera de Ricardo Wagner, árida, seca, académica, lejos del alcance de los profanos y hasta de los que no conocen profundamente el arte.

De continuar las exageraciones ya iniciadas, día llegará en que una obra teatral sea un conjunto de insoportables recitados embutidos en una orquestación riquísima en acordes y giros no oídos, pero más pensados y soñolientos que los de las exageraciones melódicas. [...]

No pretendo con esto abogar por la escuela melódica. Los tiempos aquellos han desaparecido, y hoy no se toleraría el estreno del dulcísimo dúo de "Norma" [...]. Tampoco estoy por la escuela exclusivamente armónica. Acordes y más acordes que quieren imitar lo que tiene sus medios de imitación en otros elementos distintos a los de la música, es tocar el extremo contrario.

Estoy con Meyerbeer, el genio que más comprendió el arte y que mejor interpretó la escena. Opto por la melodía que expresa la letra, armonizada y orquestada con la mayor riqueza y gusto posibles, para que marchen unidos el corazón y la cabeza, el sentimiento y el talento, porque la misión de la música es la realización de la belleza por medio del sonido rítmico. $[\ldots]^{148}$.

A pesar de todo, Blanco alabó las innovaciones de La Bruja de Chapí, su armonización "sublime", y su rica orquestación, e instó a los compositores españoles a intentar conseguir una ópera nacional propia.

Las opiniones de Andrés Blanco sobre cómo conseguir una ópera nacional española fueron expuestas con más detalle en dos artículos suyos publicados en El Semanario con el título "Consideraciones sobre la ópera española", que aparecieron en abril de 1888 (apenas dos meses después del estreno de La Bruja de Chapí en Murcia) ${ }^{149}$. En el primero de los artículos, Blanco comparó las escuelas de ópera italiana, alemana y francesa, caracterizándolas con tópicos subjetivos y poco técnicos:

[...] El músico italiano es el artista del Mediodía. El músico alemán / [p. 125] es el artista del Norte. El músico del Mediodía, más espontáneo, le fatiga la meditación y la calma y en alas de su fecunda fantasía canta el amor y la lucha de las pasiones, arrebatado, potente, lleno de fuego y energía, y corre su imaginación a través de las infinitas variedades de la naturaleza. El músico del Norte busca el sentimiento por la meditación, canta la idea y, cuando se inspira es un arpa que gime concentrando sus vibraciones como el ave que busca en la espesura oculto retiro para entonar sus gorjeos $^{150}$.

La escuela francesa, según Blanco, había tomado "lo mejor de la alemana y mezclándolo con los giros propios de su país y con invenciones de gran riqueza y

${ }^{148}$ Blanco García, "La bruja”, p. 2. Sobre la recepción de Meyerbeer en España véase, Casares, "La ópera española", pp. 41-58: 47-48.

${ }^{149}$ Andrés Blanco García, "Consideraciones sobre la ópera española (I)" y "Consideraciones sobre la ópera española (II)”, en El Semanario Murciano, III (1880), no 114, 18 abril, pp. 124-125 y 116, 2 mayo, pp. 138-139, respectivamente. Ambos pueden consultarse en el Documentario.

${ }^{150}$ Blanco García, “Consideraciones (I)”, pp. 124-125. 
galanura, presenta obras de un mérito indisputable"151. En cambio España, según él, no había conseguido un modelo genuino de ópera nacional. Aunque los cantos populares españoles contenían rasgos nacionales propios y algunos compositores como Ramón Carnicer, Mariano Soriano Fuertes, Hilarión Eslava "y muchos otros [...] podían competir con los mejores del mundo", la zarzuela había sido un camino equivocado que había impedido conseguir una ópera nacional:

[...] cuando los triunfos escénicos excitaban el entusiasmo y la inspiración de los compositores, España dio al teatro la zarzuela, engendro híbrido de música y poesía donde, si se encuentran algunos rasgos ingeniosos e inspirados, se ostentan con abundancia vulgaridades y ridiculeces que solo han conseguido retrasar o detener el arte, inculcando en el pueblo un gusto -que pudiéramos llamar negativo-, para desterrar el cual, han de necesitarse muchos y poderosos esfuerzos.

La zarzuela, dominando por todas partes, no solo consiguió bastardear la música e inutilizar hombres eminentes que hubieran podido lucir sus dotes y sus conocimientos en otras composiciones más dignas, sino que en época determinada extendió su perversión a la poesía, viéndose puestas en escena disparatadas concepciones que se aplaudían con frenesí cuando merecían la reprobación universal.

Cierto es que en diferentes ocasiones algunos músicos han intentado oponerse a los desaciertos de la zarzuela escribiendo óperas, unas veces sobre literatos italianos y otras sobre libros españoles, pero resultando las obras inferiores en mérito a las extranjeras, y no encontrando estímulos de ningún género, ni en los desalientos, sucedió inmediatamente al bien deseo o al entusiasmo, y la música española continuó en su punto de estacionamiento ${ }^{152}$.

Según Blanco, las artes, las ciencias, la industria y el comercio habían decaído en la España del siglo XIX por el escaso apoyo institucional y, en el terreno musical, por la falta de fomento de la música nacional:

[...] La España del siglo XIX ha escrito su historia en la zarzuela y la zarzuela retrata exactamente lo que España vale y significa. Si ha habido grandes poetas, grandes músicos, grandes pintores y grandes hombres científicos entre nosotros, apenas han brillado. Han tenido que reducirse a un mezquino e inquebrantable círculo de hierro y la muerte los ha sorprendido sin haber cumplido con que vinieron al mundo.

Concretándonos únicamente a la música, los gobiernos, en vez de proteger la nacional, la han despreciado altamente, facilitando toda clase de recursos a la extranjera $[\ldots]^{153}$.

Los cantos populares españoles no eran (según Blanco) el camino para lograr la ópera nacional por su rudeza y porque, fuera de su contexto original, perderían su verdadera esencia, a diferencia de los cantos populares italianos, que él consideraba "más cultos":

[...] Los cantos populares italianos, menos variados y con menos hermosura que los españoles son, sin embargo, más cultos. Son como trozos de composiciones

\footnotetext{
${ }^{151}$ Blanco García, “Consideraciones (I)”, p. 125.

152 Blanco García, “Consideraciones (I)”, p. 125.

${ }^{153}$ Blanco García, “Consideraciones (II)”, pp. 138-139:138.
} 
hechas por verdaderos músicos [...]. Por eso en los cantos populares italianos se ofrecen con abundancia motivos que los buenos músicos aprovechan y mejoran, fundando en ellos sus combinaciones melódico-armónicas, obteniendo hasta el presente magníficos resultados.

¿Podrá decírsenos, por ventura, cuál de nuestros cantos populares sea el más a propósito para servir de tema a cualquier trozo musical de carácter trágico o dramático?. La filosofía de nuestros cantares pertenece a la esfera puramente del pueblo; es su pasado y su presente, es su sencillez y sus costumbres [...] por lo mismo no pueden tener otra aplicación que la que el mismo pueblo les ha dado, porque él los forma de una manera espontánea, no buscándolo más que en su manera de sentir y de pensar. Muy lejos de querer que sean rechazados totalmente de la ópera, deben admitirse en las ocasiones en que el asunto lo requiera, pues en esta clase de composiciones, la idea dominante del músico debe ser la misma del poeta, y todo ha de sujetarse a la verdad escénica, al carácter de los personajes y al asunto de que se trata, rechazándose lo que pueda apartar de la propiedad al compositor ${ }^{154}$.

La inspiración para la ópera española había de buscarse en la música meridional (italiana y española), sin desechar la germánica:

[...] La filosofía, a imitación de los alemanes, debe presidir en el carácter de las notas, y desechando todo lo que sea superficial o ridículo, ha de intentarse imprimir cierta majestad hasta en los pasajes más sencillos y ligeros. Entonces la especialidad de la música brotaría por sí mima sin rebusco de ningún género. Estudiando y no imitando autores ni escuelas, nacería la originalidad, pues un español que conociera el arte con la profundidad de un Weber o un Wagner, sin apartarse de la estética e inspirándose en sus propios sentimientos, crearía música nada parecida a la de aquellos autores por más que tan grandes maestros le hubieren servido de estudio $^{155}$.

Blanco no consideraba que la zarzuela fuera un camino para llegar a la ópera española, y llegó incluso a proponer la desaparición de la zarzuela y la interpretación de las óperas extranjeras en español, para que el público pudiera así entender su significado $^{156}$

y la extrañeza que al principio se causara, pronto se convertiría en necesidad para que el pueblo se enseñara a conocer las bellezas de las obras. Con esto se conseguiría indudablemente que, así como en la sociedad particular se cantan hasta por distracción trozos de zarzuela, se sustituirían por otros de ópera, los cuales por expresarse en la lengua patria, irían poco a poco despertando la afición de los que han de sancionar con su inapelable fallo el mérito de las obras.

[...] Preparado el pueblo español para escuchar su ópera, la ópera vendrá al primer soplo de gloria que se sintiese en el hoy nebuloso cielo de España, y esta gran nación donde las artes han tenido siempre un respetable trono, sabría en lo porvenir corresponder a la magnificencia de su pasado, presentando al mundo una música monumental de tanto mérito como las joyas que hoy se pulverizan en los archivos de sus Catedrales $[\ldots]^{157}$.

${ }^{154}$ Blanco García, “Consideraciones (II)”, p. 139.

${ }^{155}$ Blanco García, "Consideraciones (II)”, p. 139.

${ }^{156}$ Sobre la defensa de la musicalidad del idioma castellano y los apoyos institucionales para fomentar las representaciones en castellano desde finales del siglo XVIII, véase: García Fraile, "Reivindicación".

${ }^{157}$ Blanco García, “Consideraciones (II)”, p. 139. 


\subsubsection{La calidad de las representaciones operísticas}

La prensa subrayó constantemente las ínfimas condiciones en las que se representaban las óperas en una ciudad de provincias como Murcia, y se mostró muy benevolente con las compañías, como puede verse en una crítica de 1839:

[...] No somos nosotros tan intolerantes como ciertos sujetos que al hablarles de la compañía de ópera de Murcia hacen señales de desaprobación porque intentan compararla con la de Valencia, Barcelona y demás. A estos les diremos que todo es relativo, y que las compañías de dichos puntos valen bien poco si se comparan con la de Escala y otras de primer orden $[\ldots]^{158}$.

Casi cincuenta años más tarde, el pianista y colaborador de El Diario de Murcia, Antonio Ramírez, repitió la misma idea en una de sus críticas a la compañía de ópera de Cecilio Sanmartí, dando por hecho que no podía haber ópera de calidad en los teatros de provincias:

[...] La ópera en provincias tiene que ser deficiente. No podemos oír artistas de primísimo pero, puesto que el público acude, puesto que el público va al teatro con la benevolencia por delante, justo es también que no se le den artistas imposibles. La actual compañía de ópera es inferior a lo que el público tiene derecho a esperar. Hay en ella, ciertamente artistas buenos, pero están en una desconsoladora minoría. Concluyo, pues, diciendo que está bien que no haya artistas notables pero no suspensos que están a punto de perder el curso.

ANTONIO RAMÍREZ PAGÁN ${ }^{159}$.

En las reseñas de Andrés Blanco también se asume que un teatro de provincias no podía aspirar a contratar compañías "que sólo se atreven a costear públicos como los de Madrid y Barcelona". Según él, elencos como el de Lorenzano, que contaban con los prestigiosos Emma Nevada y Mariano Padilla, era "de lo mejor que se puede desear dados los elementos de esta población" ${ }^{\prime 60}$.

En definitiva, se aceptaban y consentían con resignación, y teniendo en cuenta el contexto de precariedad, tanto las buenas como las malas interpretaciones: "la ejecución de La Extranjera ha superado las esperanzas de los que conocen los pocos elementos con

${ }^{158}$ El Segura (1839), n 2, 1839, p. 3.

${ }^{159}$ Antonio Ramírez Pagán, "La ópera en provincias", El Diario de Murcia, VIII (1886), n 2170,1 junio, p. 2 (ver Documentario). Los ejemplos en los que Ramírez aprovecha para recalcar las dificultades de representar ópera en los teatros de provincias son innumerables: "hablemos con sinceridad y digamos que ópera de primera no es posible que tengamos en nuestro teatro. ¿Por qué razón? Por una razón de números que no tiene vuelta de hoja: porque cuesta más dinero del que nuestro teatro da. Esta verdad no necesita demostración. Partiendo de esta base que yo doy por evidente, es preciso ir al teatro con ánimo de aplaudir lo bueno y tolerar lo mediano o lo malo". Véase Antonio Ramírez Pagán, "La compañía de ópera", El Diario de Murcia, VII (1885), $\mathrm{n}^{\circ}$ 1865, 24 mayo, p. 3, crítica a las primeras representaciones de la compañía de Achille Babacci, así como Antonio Ramírez Pagán, "Teatro Romea”, El Diario de Murcia, XII (1890), n 4028, 14 mayo, p. 3 y Antonio Ramírez Pagán, "Teatro Romea", El Diario de Murcia, XII (1890), $n^{\circ} 4031,20$ mayo, pp. 1-2, ambos transcritos en el Documentario.

${ }^{160}$ Andrés Blanco García, "Teatro”, El Diario de Murcia, XIII (1891), n 4463, 20 octubre, pp. 1-2: 1. 
que se cuenta en esta capital para esta clase de espectáculos", publicaba El segura en $1839^{161}$; mientras que en El Diario de Murcia se afirmaba en 1886: "El público, que comprende bien hasta qué punto se puede exigir en esta clase de espectáculos, ha estado discreto y se ha inclinado más aplaudir que a censurar" ${ }^{\prime 62}$.

Los comentarios de Julián Calvo sobre los artistas casi siempre se refieren al tipo de voz y a la interpretación, especialmente en los pasajes más virtuosísticos. Por ejemplo, comentó así la actuación de la soprano alicantina Luisa Fons, integrante de la compañía de Achille Babacci:

Esta sublime creación musical [Lucia di Lammermoor] estuvo a cargo de la perla que honra a la Escuela Nacional de Música (Conservatorio) y al arte lírico español: es la señorita doña Luisa Fons que, además de su belleza y las simpatías que desde el primer momento inspira, posee el arte de cantar con tanta corrección que no es posible oírla sin tributarle los más justos y espontáneos aplausos. En toda la obra obtuvo una gran ovación y, en particular, en la cavatina del primer acto y en la gran aria del terceto en la que hizo gala de un difícil portamento bajando desde el si bemol agudo al de tercera línea del pentagrama; y en la variación de la segunda cavaletta de esta misma pieza que ejecutó unos arpegios descendentes con gran limpieza y como mandan las buenas reglas de vocalización $[\ldots]^{163}$.

De los coros, Calvo solía comentar sus faltas: "únicamente en el coro de monjas [de La Africana] hubo algún descuido, notándose alguna vez la falta de una de las cuatro cuerdas, resaltando el mal efecto que es consiguiente" "64. Una apreciación semejante hizo Ramírez a la misma representación: "El coro de monjas muy endeble, o faltaba realmente una cuerda, o no se oía"165.

Son innumerables las ocasiones que aprovecha Calvo para poner de manifiesto la escasez de ensayos y la obligación de cada instrumentista de dedicar tiempo de estudio a su instrumento, como en este texto de 1890:

[...] Sentimos tener que manifestar que la melodiosa ópera Hernani, que siempre ha sido escuchada con gusto y por lo tanto bien cantada y tocada, en esta ocasión, sea digna de vituperio, cantantes, músicos y danzantes. Los primeros, por más que en algunos momentos estuvieron bien, parecía en otros que estaban confabulados para hacerlo muy mal, ya desafinando unos y otros, entrando cuando les

${ }^{161}$ El Segura (1839), nº 2, 22 diciembre, pp. 3-4.

${ }^{162}$ El Diario de Murcia, VIII (1886), no 2850, 16 noviembre, p. 1.

163 Julián Calvo, "La ópera italiana en el coliseo Romea", en La Paz de Murcia, XXVIII (1885), nº 8224, 19 mayo, p. 1.

${ }^{164}$ Julián Calvo, "La ópera italiana en Murcia”, La Paz de Murcia, XXVI (1883), no 7655, 19 junio, p. 1, fragmento de crítica a la segunda representación de La Africana por la compañía de Andrés Porcell y Regino Martínez (ver Documentario).

165 Antonio Ramírez, "La compañía de ópera", El Diario de Murcia, V (1883), no 1301, 15 junio, p. 2 (ver Documentario). Los ejemplos son muy similares en otras críticas de Calvo. La representación de Rigoletto por la compañía de Enrico Serazzi y Eusebio Bosch mereció esta valoración: "Los coros pudieron hacerlo mejor, puesto que las obras les son bien conocidas y no debieron dar lugar a que les acompañaran con el piano en el cuarto acto". Véase, Julián Calvo, "La ópera en Murcia", La Paz de Murcia, XXXIII (1890), $\mathrm{n}^{\circ}$ 11029, 15 mayo, p. 1, transcrito en el Documentario. 
parecía y hasta manifestando miedo o falta de seguridad. Los segundos parece increíble el que esa ópera que tan manoseada está por todos los músicos de Murcia y que tantos años se viene tocando casi toda en los intermedios de dramas y comedias, decimos que produjo un efecto infernal el estar oyendo un contrabajo haciendo un $m i$ por un $f a$. Otros instrumentos de cuerda tomaron un do grave con tanto entusiasmo y que, repercutido en algunos compases, causaron la hilaridad de cuantos se fijaron pues aquello parecía más bien una zambomba que delicados instrumentos. En las butacas hubo quien creyó de buena fe que cierto profesor en el tercer acto estaba haciendo pucheros como si fuese un niño mamón y, por último, en el mismo acto, un solista que iba unis con una de las partes principales de la escena, tuvo por lo visto que hacer alguna cosa imprevista del entusiasmo porque se dejó arrebatar y terminó un compás antes que su compañero.

Los señores interesados creen que esto son exageraciones y mal compañerismo (porque sepa el lector que en nuestro juventud tuvimos el honor de pertenecer a las orquestas de los teatros de aquella época) y que es necesario hacer y acontecer... y lo que tienen que hacer es estudiar, ESTUDIAR Y ESTUDIAR. De seguro que si esta hubiese sido la primera vez que en la ópera Hernani se hubiera visto en Murcia, de seguro, repetimos, la reputación del maestro Verdi habría quedado mal parada $[\ldots]^{166}$.

Los escasos ensayos que hacían los músicos no eran suficientes para ofrecer representaciones de calidad, pero tampoco ayudaban las exigentes demandas del público murciano, que a veces eran poco fundadas:

[...] casi ninguna [de las funciones] ha brillado por un conjunto acabado, aún cuando ya hemos manifestado que la falta de ensayos es la causa pero también es verdad que la parte de esta culpa la vemos en que la mayoría del público quiere tener función distinta en las pocas o muchas representaciones que se le ofrecen. Este no es el mejor medio para formar buen gusto sobre un arte tan delicado.

El público murciano es quizá uno de los que más sostienen el espectáculo teatral, pero como no son suficientes los productos para dejar dos o tres días en semana sin función y poder estudiar las obras con el esmero que deben ser presentadas, todas las empresas se ven en la necesidad de llevar el trabajo diario a costa de imperfecciones, no siendo posible establecer derechos, deberes, ni obligaciones entre el público y aquéllas, sino de una manera ficticia. Y por más que lo dicho está en la conciencia de todos, muchas veces se sobreponen las exigencias, sin motivo fundado, como aconteció al omitir al señor Abruñedo el do de pecho en el aria del Trovador, variante que solo depende de la condescendencia de los artistas para manifestar en ciertas oportunidades sus buenas facultades; pero al autor no se le ocurrió escribir tal do ni para hacerlo de pecho ni de cabeza. Por consiguiente, el señor Abruñedo cumplió con lo escrito en la partitura, siendo intempestiva la demostración que algunos iniciaron $[\ldots]^{167}$.

Calvo denunció también que los críticos poco formados influían injustamente en la recepción de las representaciones:

[...] La segunda representación de El Barbero de Sevilla nos confirmó lo que expusimos en la segunda revista de que es el público quien tiene la mayor parte de

166 Julián Calvo, "La ópera en Murcia", La Paz de Murcia, XXXIII (1890), nº 11033, 21 mayo, p. 1 (ver Documentario). Véase otro ejemplo en Julián Calvo, "La ópera en Murcia”, La Paz de Murcia, XXXIII (1890), $\mathrm{n}^{\circ}$ 11029, 15 mayo, p. 1, transcrito en el Documentario.

${ }^{167}$ Julián Calvo, “Teatro Romea”, en La Paz de Murcia, XXVIII (1885), nº 8232, 28 mayo, p. 1 (ver Documentario) 
culpa en que las obras se pongan generalmente con premura, lo que hace no salgan bien ni mucho menos en su conjunto.

¿No ha sido El Barbero la ópera mejor acabada de todas las que se han puesto? ¿No ha sido la más aplaudida y encomiada? ¿Qué público acudió a la repetición? Apenas estaban los señores abonados. ¿Es esto para animar a los artistas? ¿Deja de ser esto prueba del afán de querer función distinta y diaria?.

A esto dan lugar algunos que son inteligentes en música (a su modo), porque dicen que tienen un oído muy fino y que no se les escapa el vuelo de una mosca, aún cuando (tenemos esta seguridad) no son capaces de tararear la Cachucha.

Estos son los críticos, que lo mismo entienden de música que de toros que, en el café o en las Cuatro Esquinas de San Cristóbal, se vanaglorian de que por una peseta patean a cualesquiera artista, pues se creen con tal derecho por los cuatro reales, no dignándose siquiera en hacer diferencia de un teatro a una plaza de toros, ni en el respeto de un público a otro.

Bueno, muy bueno que se desaprueben los abusos que se puede y deban remediarse, pues al público se le debe respetar y dar con la propiedad debida los espectáculos.

Las anteriores reflexiones son hijas del buen deseo de poner nuestras apreciaciones en el lugar más próximo a la justicia, sin menoscabo de lo que corresponde al que paga, ni a los que exponen su reputación a un fracaso muchas veces por causas imprevistas o irremediables al pronto. Tampoco es nuestro ánimo de echarla de padre maestro donde, si bien es cierto que acude a todas partes público dispuesto a manifestaciones inoportunas, también lo es que la mayoría representa una ilustración digna para nosotros del mayor respeto $[\ldots]^{168}$.

Ramírez se mostró más comprensivo ante la escasez de ensayos que tenían los músicos: "Yo concedo que la orquesta tiene la obligación de tocar bien, pero no tiene la obligación de improvisar óperas ni de repentizar transportes. Ensayar por la tarde y tocar una ópera a la noche, con aquel ensayo, es más de lo que humanamente se puede pedir" $" 169$.

Los comentarios sobre los directores de escena por parte de la crítica especializada fueron escasos. De Giuseppe Reparaz, director de escena de la compañía de Achille Babacci escribió, por ejemplo, Julián Calvo:

[...] El señor director de escena no debió consentir se pusieran sillas valencias (entendidas, de la Glorieta) siendo mal hecho suprimir la banda militar en escena, como también lo fue en el primer acto de Rigoletto y en el último acto del Baile de máscaras pues aún cuando es verdad que tales trozos están arreglados para no ne / [p. 4] cesitar banda y que en muchas partes se suprime ésta, en este coliseo se está acostumbrado a que en las tres obras no se omita, primero por el distinto efecto y segundo porque existen elementos para dar al público las obras con todo el aparato debido $[\ldots]^{170}$.

168 Julián Calvo, “Teatro Romea”, en La Paz de Murcia, XXVIII (1885), nº 8238, 4 junio, p. 1 (ver Documentario).

169 Antonio Ramírez Pagán, "La compañía de ópera”, El Diario de Murcia, VII (1885), nº 1865, 24 mayo, p. 3.

${ }^{170}$ Julián Calvo, "Teatro Romea", en La Paz de Murcia, XXVIII (1885), nº 8238, 4 junio, p. 1. Sobre bandas de música en Murcia, véanse mis trabajos "Bandas" y "Murcia". 


\subsection{Polémicas periodísticas relacionadas con la crítica}

La prensa murciana fue cauce de difusión de dos polémicas musicales locales de amplias proporciones, las denominadas "cuestión orquesta" (1881-1898) y "cuestión fermata" (1876-1877) ${ }^{171}$. La primera es descrita en el Capítulo 2. Me detendré a continuación la "cuestión fermata".

La "cuestión fermata" fue un debate sobre si podían o no improvisarse adornos en las fermatas cantadas ${ }^{172}$ y tuvo como protagonistas a los pianistas ciegos Adolfo Gascón y Juan Diego Manresa, aunque en ella también se vieron inmersos el maestro de capilla de la Catedral de Murcia, Mariano García, y un anónimo periodista, corresponsal del periódico La Paz de Murcia en Cehegín (Murcia). La discusión se resumía así:

[...] El señor L[eante], que dicen que es un joven ciego premiado siempre en los Juegos Florales, sostiene que el cantante no está autorizado para quitar notas en las fermatas. Juan Diego [Manresa] dice que el arte es libre y las trabas de todo género son enemigas de la inspiración y principalmente en las fermatas que cada artista ejecuta a piacere en la medida de sus facultades. Es decir, que L[eante] es clásico; Juan Diego, romántico.

La cuestión como usted ved es baladí pero así y todo ha removido este pequeño mundo musical hasta el punto de que anteanoche discutía muy acalorado el pacífico Cayetano Prieto en las mismas Cuatro Esquinas y el Maestro de Capilla se ha creído obligado a terciar en el debate, diciendo que el señor Manresa tiene muchísima razón ${ }^{173}$.

Al parecer, el debate surgió a raíz de una crítica teatral (hoy no conservada) de Adolfo Gascón Leante para el periódico murciano El Comercio, en la que se aludía a una fermata interpretada por una de las tiples de la compañía de zarzuela de Federico G. Marín, que actuaba entonces en el Teatro Romea ( $1^{\mathrm{a}}$ temporada de 1876-1877) ${ }^{174}$. Gascón

171 Eran frecuentes también las réplicas a críticas publicadas anteriormente. Como ejemplo del ambiente de susceptibilidad que vivían los críticos murcianos, véase un texto de Antonio Ramírez, "Teatro Romea. Compañía de ópera. Fausto", El Diario de Murcia, IV (1882), no 958, 26 abril, pp. 1-2 a propósito de la representación de Fausto por la compañía de Benigno Giardini: "Con verdadero temor cogemos la pluma para hacer una ligera reseña de la ópera representada anoche. Vivimos (al menos en lo tocante a los señores músicos) en el país de las susceptibilidades. Quien tiene, como yo, la desgraciada ocurrencia de relatar al público sus impresiones y sus ideas sobre las representaciones líricas que se están verificando, ya puede disponerse a sufrir las reticencias intencionadas del uno, los ataques directos del otro, las quejas amistosas del de más allá, o las terribles amenazas de una nueva e interminable cuestión fermata".

172 Según Pedrell, Diccionario, p. 176, una "fermata" (también llamada "corona", "cadenza", "comune" o "calderón") equivale en italiano a pausa, de la acción de fermarsi, pararse". En su Diccionario técnico, histórico y biográfico de la música (Madrid, 1868), José Parada y Barreto afirma que "Esta palabra italiana [fermata] significa una sucesión melódica, que antecede o precede al calderón. La fermata se ejecuta siempre con la medida ad libium y viene a ser como un adorno o diálogo que forma una voz o un instrumento antes o después de haber quedado suspensa en un sonido prolongado. En pasajes de esa naturaleza es en donde se admira a veces la brillantez y el gusto de la ejecución de un cantante o de un instrumentista”. Cita tomada de Morales Villar, Los tratados, t. 2, p. 210.

${ }^{173}$ J. M. T [¿¿José Martínez Tornel?], “Cosas de Murcia”, La Paz de Murcia, XIX (1876), nº 5931, 15 diciembre, p. 1.

${ }^{174}$ Solo se conservan tres ejemplares de El Comercio y ninguno pertenece a las fechas en las que se surgió esta polémica. Probablemente la citada crítica fue publicada a finales del mes de noviembre de 1876. El seguimiento de esta querella ha sido posible gracias a las noticias publicadas por La Paz de Murcia y a la 
sostenía que las fermatas debían ser interpretadas sin suprimir o añadir ninguna de las notas escritas por el compositor. Para Juan Diego Manresa, sin embargo, la fermata permitía no sólo llevar el tempo ad libitum, sino también introducir notas improvisadas por el cantante:

el que dice que la palabra apiaceri solo sirve para hacer más vivo o más lento el aire de una fermata, ha dicho una tontería, pues la apiaceri no solo significa llevar el aire que mejor convenga al cantante, sino también el de agregar notas con arreglo las facultades de cada uno, pues de otro modo sería sujetar al cantante, cosa que jamás ha sucedido.

Hubo una época en que los autores jamás ponían ninguna fermata al final de las piezas y solo con la palabra apiaceri bastaba para que los cantantes hicieran dichas fermatas con arreglo a sus facultades, sin salirse de la tonalidad. Creo que esto es bastante para probar al señor $\mathrm{L}$ [eante] lo equivocado que está en sus censuras $[\ldots]^{175}$.

El maestro de capilla de la Catedral de Murcia, Mariano García, apoyó los argumentos defendidos por Manresa, que era discípulo suyo, y su intervención en la polémica fue muy criticada. Un anónimo corresponsal de La Paz de Murcia en Cehegín opinaba así del maestro de capilla García:

[...] no había motivo para que el señor Maestro de Capilla descendiera desde el pináculo a donde le han clavado sus conocimientos musicales, a terciar en el debate y, si era de alguna importancia, debiera haber razonado su resolución para convencer al señor Gascón y a todos los que piensan como él. [...]

Después de alardear del tiempo que lleva dedicado a la enseñanza y de que el señor Gascón ha sido discípulo suyo (lo cual no viene muy al caso porque poco importaba que fuese algo novicio en el arte con tal de que en su fallo hubiera dado razones convincentes y expuesto argumentos incontestables), deja la cuestión casi en el mismo estado en que estaba, dando una definición algo lata de la palabra fermata; y es lástima que ya que tenía la pluma en la mano, nos haya privado a los que tenemos la desgracia de estar sumergidos en el mismo crasísimo error en que está el señor Gascón, según él, del gusto de saber las poderosas razones que guarda para exponerlas en la lección que no tiene inconveniente de darle ante personas inteligentes ${ }^{176}$.

A lo largo del mes de diciembre de 1876 , toda la prensa murciana se fue haciendo eco de la "cuestión fermata", proponiendo, incluso, soluciones para terminar con ella. En La Paz de Murcia se planteó que un jurado de fuera de Murcia diera su dictamen:

[...] Nosotros creemos que en el estado en que está la polémica no hay otra solución que someterla a un jurado de maestros compositores, ajenos a esta localidad y que estos den la razón a quien la tenga. Un jurado lo componen regularmente tres

obra de Juan Diego Manresa, Memoria de la cuestión fermata. Promovida con motivo de haber usado una cantante, de la facultad que este signo le concede, en una obra representada en el teatro Romea de esta capital (Murcia: Establecimiento Tipográfico de La Paz de Murcia, 1877), conservado en el E:MUm.

${ }^{175}$ El Noticiero de Murcia, II (1876), $\mathrm{n}^{\mathrm{o}}$ 1157, 2 diciembre, pp. 2-3: 2.

${ }^{176}$ La Paz de Murcia, XIX (1876), nº 5937, 22 diciembre, p. 1. 
individuos y puesto que hoy son tres los que cuestionan, nombre cada uno un jurado y esperen su voto autorizado ${ }^{177}$.

Gascón y Manresa publicaron un comunicado conjunto aceptando llevar la polémica "al terreno de la discusión científica", mediante un "jurado musical" que dictaminara la resolución ${ }^{178}$. Sin embargo, Manresa retiró después su compromiso y redactó un ensayo sobre la cuestión, que fue anunciado por La Paz de Murcia:

[...] Juan Diego Manresa ha concluido de redactar una extensa memoria comprensiva de numerosos antecedentes científicos como filosóficos en apoyo de las opiniones que ha sostenido en la prensa sobre la cuestión fermata, y a la que acompañan multitud de citas y textos de autores respetables en el arte musical $[\ldots]^{179}$.

Pocos días más tarde, se anunció que El Comercio publicaría un "folleto" con los argumentos de Adolfo Gascón, avalado con firmas de "López Almagro, Saldoni, Fernández Caballero, Carrera y González y Romero Andía, las que favorecen su opinión" ${ }^{180}$. Por la correspondencia de Barbieri sabemos también que Adolfo Gascón solicitó la opinión del compositor madrileño y que éste le dio la razón ${ }^{181}$.

${ }^{177}$ La Paz de Murcia, XIX (1876), nº 5934, 19 diciembre, p. 1. Los tres individuos en los que se dice estaba centrada la polémica eran Adolfo Gascón, Mariano García y Juan Diego Manresa.

${ }^{178}$ El comunicado fue publicado por El Noticiero y más tarde transcrito por La Paz de Murcia, XIX (1876), n 5940, 27 diciembre, p. 1. Véase también La Paz de Murcia, XIX (1876), nº 5936, 21 diciembre, p. 1.

${ }^{179}$ La Paz de Murcia, XX (1877), nº 5945, 3 enero, p. 1.

${ }^{180}$ La Paz de Murcia, XX (1877), n 5972, 6 febrero, p. 1 y 5980, 17 febrero, p. 1.

${ }^{181}$ En la primera carta, fechada el 21 de febrero de 1877, Adolfo Gascón solicitaba a Barbieri su opinión sobre si la indicación a piacere facultaba al cantante para improvisar notas y si los cantantes debían o no atenerse estrictamente a lo reflejado en una partitura, entre otras cuestiones. En la segunda carta (4-031877), Gascón agradeció a Barbieri su contestación (fechada el 26 de febrero de 1877) y le transmitió su complacencia por haber visto avalada su opinión. En la tercera carta, de 17 de marzo de 1877, Gascón le comunica a Barbieri que había publicado en la prensa murciana su respuesta a la primera carta y se disculpa si ello le ocasionaba “algún disgusto". Francisco Asenjo, vol. II, pp. 623-624. 


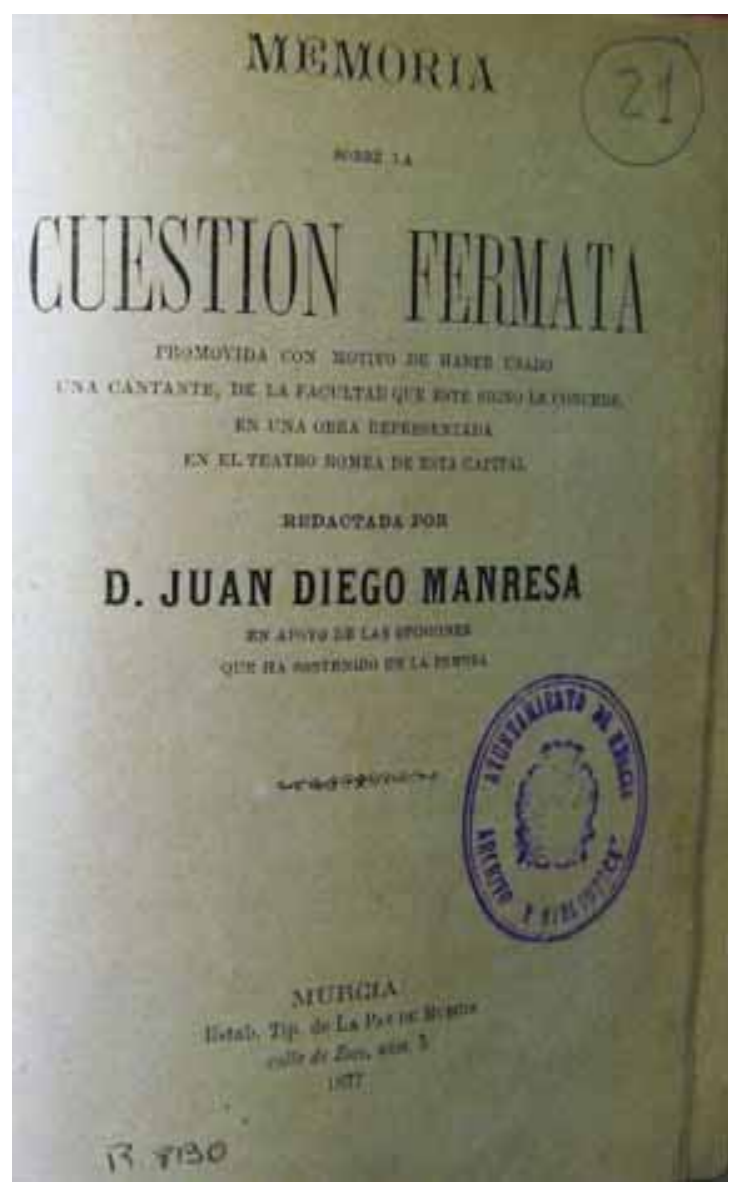

Figura 4. 3. Portada de la Memoria sobre la cuestión fermata, de Juan Diego Manresa (Murcia: Establecimiento Tipográfico de La Paz de Murcia, 1877). Ejemplar en E:MUm.

El ensayo de Manresa, titulado Memoria sobre la cuestión fermata, fue publicado en Murcia en 1877 (ver Figura 4.3) ${ }^{182}$ y provocó nuevas reacciones. El corresponsal de La Paz de Murcia en Cehegín se enfrentó de nuevo a Manresa y al maestro de capilla Mariano García:

dicho señor [Manresa] y sus parciales [entre ellos Mariano García] no han querido someterse al fallo de un jurado madrileño y sí tenían grandísimo interés en que este se compusiera de individuos de Murcia. [...] Pues sepa el señor Manresa que si este ha de ser competente e imparcial no debe ser murciano porque en Murcia habrá competencia, no lo dudamos, pero imparcialidad no es fácil que la haya, dada la mayor o menos simpatía o la más o menos íntima amistad que pueda unirles con cualquiera de los dos debatientes. Mientras en Madrid aquellas eminencias musicales, aquellos profesores encanecidos en la enseñanza tal vez no conozcan a ninguno de ambos señores. Esperamos pues con ansia la publicación del indicado folleto por ver si encontramos algún nuevo e irrefutable argumento que nos convenza; porque que los filarmónicos de aquí, si bien nos humillamos ante la razón, aunque esta parta de los labios del más insignificante infantillo de una Catedral, no nos sometemos nunca al capricho de ningún individuo por muchos y justísimos títulos que posea, aunque este individuo sea todo un señor maestro de capilla $[\ldots]^{183}$.

\footnotetext{
${ }^{182}$ Ver referencia completa en nota 174.

${ }^{183}$ La Paz de Murcia, XX (1877), nº 5953, 13 enero, p. 1.
} 
En un artículo (hoy desaparecido) de El Comercio se sostuvo que la Memoria sobre la cuestión fermata había sido escrita por varias personas, y no sólo por Manresa, y que éste había retrasado su publicación para "sacar partido de la tardanza" pidió al periodista de Cehegín que saliera del anonimato y diera "su nombre y sus opiniones" $" 185$. El anónimo redactor de Cehegín publicó un nuevo comunicado afirmando que representaba a un gran número de músicos de su localidad; que Manresa no había entendido su comunicado anterior porque un "amanuense [...] le ha tergiversado intencionadamente su verdadero sentido para ponerle en ridículo, como lo ha conseguido" y lamentando que "la reputación artística de esa persona tan respetable [el maestro de capilla] haya desmerecido tanto no solo en el concepto de los músicos cehegineros, sino que también el de los de muchos pueblos de esta provincia y de algunas poblaciones importantes de España"186.

Bajo el pseudónimo "El amanuense" apareció en La Paz de Murcia una contestación al corresponsal de Cehegín, invitándole a dirigirse "al señor García para preguntarle lo que quiera sobre el debate en cuestión, siempre que no sea por medio de la prensa periódica sino en particular y privadamente"187. El corresponsal contestó "que no nos urge saber la opinión del señor Maestro de Capilla respecto de la cuestión fermata, porque ya la hemos sabido confidencialmente por uno de sus amigos, y segundo, que si tantos deseos de terciar en el debate tiene el escribiente de don Juan Diego, puede dirigirse a dicho señor o a su contrincante don Adolfo Gascón, que son entre los que hasta ahora está la polémica" ${ }^{, 188}$.

La "cuestión fermata" se zanjó a principios de abril de 1877, al parecer amigablemente, después de cuatro meses de escritos, cartas, folletos y memorias:

\begin{abstract}
"Por indicación de los señores don Francisco Gil y don Julián Calvo, han celebrado una conferencia hace pocos días los profesores de esta capital don Mariano García, maestro de capilla y los señores Manresa y Gascón, los cuales han depuesto todos los resentimientos que pudieran tener, por las palabras que involuntariamente se hubieran dicho cuando la polémica sostenida en la prensa sobre la fermata, retirándose completamente y teniéndolas por no dichas $[\ldots]^{\prime 189}$.
\end{abstract}

${ }^{184}$ El artículo de El Comercio fue rebatido por el periódico La Paz de Murcia mediante dos nuevos artículos. El primero defendía a Manresa y admitía que "por su falta de vista ha necesitado quien le escriba a su dictado": La Paz de Murcia, XX (1877), n 5960, 21 enero, p. 1. El segundo artículo aclaraba que la tardanza en aparecer la obra había sido causada por "la impresión y encuadernación", que habían sido realizadas en el establecimiento tipográfico del mismo periódico: La Paz de Murcia, XX (1877), $\mathrm{n}^{\circ}$ 5964, 26 enero, p. 1.

185 Juan Diego Manresa, “Comunicado”, La Paz de Murcia, XX (1877), nº 5956, 17 enero, p. 1. Este comunicado fue nuevamente rebatido por el corresponsal de Cehegín, aunque no fue publicado por La Paz de Murcia "por lo mucho que se extiende nuestro corresponsal y lo neutral que LA PAZ se ha mantenido en la cuestión fermata": La Paz de Murcia, XX (1877), n 5966, 28 enero, p. 1.

${ }^{186}$ Anónimo, "Comunicado", La Paz de Murcia, XX (1877), nº 5969, 1 febrero, p. 1.

${ }^{187}$ El amanuense, "Remitido", La Paz de Murcia, XX (1877), n 5971, 4 febrero, p. 1.

${ }^{188}$ El corresponsal, “Correspondencia particular”, La Paz de Murcia, XX (1877), n 5980, 17 febrero, p. 1

${ }^{189}$ La Paz de Murcia, XXI (1878), nº 6203, 7 abril, p. 1. 
Los ecos de la "cuestión fermata" seguían vivos en Murcia años después del aparente fin del debate. Todavía en 1891 Andrés Blanco García se refirió a esa polémica al comentar una representación de Lucia di Lammermoor por la compañía de Lorenzano:

[...] La peripecia es la siguiente: en el dúo de tiple y barítono, la señora Nevada acostumbra a suprimir algún trozo (capricho que suelen tener ciertos artistas quia nominantur leones) y una parte de cierto público que parece ir al teatro a caza de descuidos, creyendo no sabemos qué, hizo una fuerte manifestación de desagrado. Un individuo de la compañía tuvo la imprevisión de decir, sin otras explicaciones, que la orquesta no había ensayado lo suprimido y entonces el público repitió el desagrado.

Comprendemos que la compañía, conceptuada en general, no está a la altura de los precios que exige; y si bien Emma Nevada y aún Mariano Padilla merecen todavía más que lo mucho que nuestra población hace en su obsequio, el público tiene derecho a exigir de las demás partes otra cosa. La culpa no estuvo en la orquesta sino en la prevención que existe entre ciertos elementos que revelan un egoísmo injustificado. Parece que tiende a eternizarse la cuestión fermata $[\ldots]^{190}$.

190 Andrés Blanco, "Teatro", El Diario de Murcia, XIII (1891), nº 4465, 22 octubre, pp. 1-2:2. El periódico El Mercantil de Alicante se lamentó de que los espectadores alicantinos no reaccionaran de la misma manera que el público murciano, según La Paz de Murcia, XXXIV (1891), n 11462, 26 octubre, p. 1. Para Andrés Blanco García, “Teatro”, El Diario de Murcia, XIII (1891), n 4463, 20 octubre, pp. 1-2, las supresiones eran admisibles sólo en cierto tipo de repertorio, especialmente en la ópera italiana; ver texto completo en Documentario. 


\section{Capítulo 5. Repertorio orquestal y conciertos de solistas en los teatros murcianos de la segunda mitad del siglo XIX}

\section{El repertorio orquestal}

La orquesta estuvo presente en todo tipo de representaciones teatrales. Durante la segunda mitad del siglo XIX fue usual que la orquesta iniciara las funciones con una "sinfonía", término amplio que solía indicar una obertura, introducción o preludio, procedentes de óperas y zarzuelas. El repertorio de estas piezas orquestales fue renovado por José Calvo López (1812-1876), padre del compositor Julián Calvo, como explicó El Semanario Murciano en 1878:

[...] Uno de los primeros cuidados de don José Calvo fue dar a conocer la importancia y belleza del género instrumental, arreglando e introduciendo paulatinamente las reformas en la orquesta, según los preceptos y plantillas del maestro Bonifacio Assioli [Bonifazio Asioli], amoldándolos con gran inteligencia a los elementos de que podía disponer.

La orquesta del teatro, dirigida por don Julián Gil Yuncas, gran profesor de violín y buen director, pero muy escaso de conocimientos en la composición, fue el ancho campo donde Calvo lució por muchos años sus buenos conocimientos y donde dio a conocer, sobre todo, su genio reformador y creador. $[\ldots]^{1}$.

En los intermedios de las representaciones teatrales también fue usual que la orquesta interpretase números musicales y/o bailables, incluso en las funciones con compañías dramáticas y en las de espectáculos de magia, prestidigitación y equilibrismo. Al parecer, el repertorio era el mismo tanto en las representaciones teatrales como en los bailes de máscaras, según un testimonio de 1867:

[...] La orquesta sigue lo mismo, dándonos en los intermedios a todo pasto cierta coleccioncita de polcas, valses y otras piezas de baile que luego nos vuelve a repetir en los de máscaras. Y la cual venimos oyendo lo menos desde la fundación de la banda de música del señor Mirete [en 1858], si no es que la tocaba también la extinguida hace años de don Julián Gil. Si es que quiere que aprendamos de memoria ya puede variar, pues de seguro que el que menos concurre al teatro se atreve ejecutarla. $[\ldots]^{2}$.

El catálogo completo de sinfonías interpretadas en los teatros de Murcia no se puede determinar, ya que los títulos no solían especificarse en la prensa, aunque probablemente se recurría a oberturas de los compositores y obras en boga ${ }^{3}$. Algunos ejemplos documentados pueden verse en los Apéndices 3.3 a 3.5, 3.8, 3.11 y 4.4 correspondientes a los Capítulos 3 y 4 .

1 "Un aficionado", “Apuntes para la Historia de la Música en Murcia (X)”, El Semanario Murciano I (1878), n 44, 15 diciembre, pp. 4-5. Sobre Julián Gil Yuncas, véase el Capítulo 9.

${ }^{2}$ La Paz de Murcia, X (1867), no 2778, 23 enero, p. 2

${ }^{3}$ En los teatros de Valencia se interpretaban con frecuencia obras orquestales de Rossini (el más interpretado entre los años 1832 y 1877), Auber, Bellini, Verdi y Meyerbeer, según Sancho, Romanticismo, pp. 27-30. 
En 1884 se interpretó la Sinfonía $n^{\circ} 1$ en Do Mayor, Op. 21 de Beethoven en 1884, a cargo de la recién creada orquesta del Teatro Romea. La obertura de Rienzi de Wagner fue interpretada en el Romea de Murcia la noche del 4 de junio de 1885, en la que fue la primera audición documentada de una obra orquestal del compositor alemán en la ciudad ${ }^{4}$. No fue ejecutada al inicio de la función sino a la mitad, enmarcada entre otros números instrumentales y la representación de Il barbiere di Siviglia (véase Apéndice 4.3). Al frente del conjunto orquestal estuvo el catalán Juan Goula, director de orquesta de varias compañías del Teatro Real de Madrid con las que efectuó durante los años ochenta y noventa estrenos de óperas tan relevantes como Il Guaraní del brasileño Carlos Antonio Gomes, Lohengrin de Wagner, La gioconda de Ponchielli, Fidelio de Beethoven y Falstaff de Verdi ${ }^{5}$. La crítica murciana no hizo comentarios sobre la recepción entre el público de Rienzi, salvo las siguientes líneas de Julián Calvo, que revelan una acogida favorable del estilo wagneriano:

[...] La sinfonía de Rienzi sirvió para demostrar el señor Goula al público su agradecimiento y el que no le es extraña la música que dieron en llamar del porvenir $[\ldots]$.

De buen grado escribiríamos algunas páginas sobre la influencia que la música del maestro Wagner viene ejerciendo hace algunos años sobre muchos maestros [...]. El conocer nuestra impotencia sobre tan grave materia nos abstiene de hacer un trabajo en el que verdaderas autoridades extranjeras y españolas han mostrado sus opiniones diversas. Pero, al estudiar éstas, se concluye por observar que todos, con voluntad o sin ella, van rindiendo culto a lo que aún se combate quizá por sistema. Los franceses, a pesar de su odio a Wagner, hoy ya le hacen justicia.

Reanudando nuestra tarea, nos complacemos en manifestar que el señor Goula se lució mucho, pues aunque la tal Sinfonía es una obra dificilísima para la orquesta, ésta hizo más [de lo que] que se podía esperar, dada la premura con que se ha puesto, por haber recibido los papeles a última hora. El público la recibió con benevolencia y colmó de aplausos al joven director $[\ldots]^{6}$.

Eran también frecuentes en Murcia las sinfonías-potpurrís o las inspiradas en aires nacionales, como Gran sinfonía potpurrí sobre motivos de zarzuelas modernas de Miguel Marqués (interpretada por la orquesta del teatro y la Banda de la Misericordia en febrero de 1882 bajo la dirección de Tomás Reig y el murciano Acisclo Díaz, respectivamente ${ }^{7}$ ) y la "Sinfonía de aires españoles" de Gevaert, interpretada en una de las funciones de la compañía de ópera de Cecilio Sanmarti en mayo de $1881^{8}$.

\footnotetext{
${ }^{4}$ A la prensa murciana llegaban, no obstante, noticias sobre Wagner. En El Popular, diario nacional publicado conjuntamente con La Paz de Murcia, hay numerosos ejemplos, como el comentario escrito a propósito de la interpretación de una obertura (no especificada) de Wagner en los jardines del Retiro de Madrid: "Respecto de la música de Wagner es al pronto de un efecto casi incomprensible pero de una novedad tan exacta, que suplicamos al señor director de la orquesta procure repetirla de nuevo": El Popular inserto en La Paz de Murcia, XVI (1873), nº 4849, 17 agosto, p. 3.

${ }^{5}$ Turina, Historia, pp. 137, 140-141, 144, 146, 174-175, 181, 184-185, 187 y 189.

${ }^{6}$ Julián Calvo, "Despedida de la compañía de ópera italiana que ha actuado en el Teatro Romea", $L a$ Paz de Murcia, XXVIII (1885), nº 8240, 7 junio, p. 1.

${ }^{7}$ La Paz de Murcia, XXV (1882), n ${ }^{\text {o } 7264, ~} 14$ febrero, p. 4 y El Diario de Murcia, IV (1882), ${ }^{\text {os }} 903$, 16 febrero, p. 2 y 904, 17 octubre, p. 2. 4.4 .

${ }^{8}$ La paz de Murcia, XXIV (1881), n ${ }^{\text {os }} 7051,18$ mayo, pp. 1, 4; 7052, 19 mayo, p. 1. Véase Apéndice
} 
Las sinfonías de autores murcianos tuvieron su espacio en el repertorio orquestal de la ciudad. En la función de la compañía de alumnos del Instituto Provincial de Murcia, dirigidos por el compositor Julián Calvo, se interpretó una de sus sinfonías antes del estreno de las zarzuelas infantiles Una broma de estudiantes y Travesuras de Quevedo, también de su autoría ${ }^{9}$. La Sinfonía para orquesta y banda y una Gran sinfonía a dos bandas y orquesta de Calvo fueron ejecutadas, respectivamente, en febrero de $1874 \mathrm{y}$ enero de 1885 en el Teatro Romea ${ }^{10}$.

En septiembre de 1886, se interpretó en el Teatro Romea una "Sinfonía para banda y orquesta sobre motivos de zarzuela" de Fernández Caballero. En el concierto homenaje a este compositor, celebrado en septiembre de 1893 en el Teatro Circo Villar, tres bandas de la ciudad interpretaron la "Jota de El dúo de la Africana" y, conjuntamente con la orquesta del teatro, una "Fantasía sobre motivos de sus mejores zarzuelas"11. El evento fue calificado de "éxito fastuoso para los anales de nuestra querida Murcia" $"$. Lo cierto es que el público murciano no debió tener muchas más ocasiones de ver reunidos a tantos músicos de la ciudad y es probable que fuera el único concierto "monstruo" como se denominaba en la época- basado exclusivamente en repertorio orquestal.

\section{Conciertos de intérpretes solistas}

\subsection{Tipos y rasgos generales de los conciertos}

Dado que el Teatro Romea fue el coliseo más importante de la ciudad, centro de la vida teatral y musical de Murcia durante la segunda mitad del siglo XIX, en él tuvieron lugar los conciertos más relevantes, a cargo de reputados intérpretes de fama nacional o internacional y cuyas giras eran anunciadas por la prensa especialmente si transcurrían por ciudades cercanas. Ejemplo de ello es el anuncio del agente teatral Petro Rizzoli, publicado en 1877:

Procedente de Cartagena y de paso en esta ciudad el conocido agente teatral don Petro Rizzoli, fundador de una sociedad de conciertos que con notable éxito ha recorrido varias capitales importantes, es muy posible que dé algunas soirées musicales bajo la dirección del célebre artista Césare Augusto Casella, violonchelista de Cámara de Su Majestad el Rey de Italia, Caballero de número de la Real Orden de Carlos III, del Hábito de Cristo de Portugal, etcétera, etcétera y secundado por otros artistas tan distinguidos como la señora Elisa Rosental (contralto) y la señorita Laura Sanz (soprano) y el señor don German Castro (bajo), primer premio del Conservatorio de Madrid. Oportunamente anunciaríamos el programa ${ }^{13}$.

\footnotetext{
${ }^{9}$ La Paz de Murcia III (1860), n 610, 5 febrero, p. 1 y Diego Espinosa, "Teatro Provisional”, La Paz de Murcia III (1860), nº616, 15 febrero, pp. 1-2.

${ }^{10}$ La Paz de Murcia, XVII (1874), ${ }^{\text {os }} 5001,15$ febrero, p. 4; 5002, 17 febrero, p. 1; La paz de Murcia, XXVIII (1885), nº 8132, 29 enero, p. 4; 8134, 31 enero, p. 1 (R); 8135, 1 febrero, p. 1 y Julián Calvo, "Deuda de agradecimiento público", en La Paz de Murcia, XXVIII (1885), nº 8138, 5 febrero, p. 1.

${ }^{11}$ El Diario de Murcia, XV (1893), nº 6032, 7 septiembre, p. 3.

12 Julián Calvo, "Una velada concierto dirigida y organizada por el maestro Fernández Caballero", El Diario de Murcia, XV (1893), nº 6036, 12 septiembre, pp. 1-2: 2.

${ }^{13}$ La Paz de Murcia, XX (1877), no 5986, 24 febrero, p. 1. Véanse otros ejemplos en La Paz de Murcia: XI (1868), nº 3236, 15 mayo, p. 3; 3268, 18 junio, p. 2 y XIV (1871), nº 4284, 4 octubre, p. 1.
} 
Por otro lado, los músicos locales encontraron en él un lugar donde exhibirse y estrenar sus composiciones en las frecuentes funciones benéficas (ver Apéndice 3.5) y en las organizadas por las sociedades recreativas de la ciudad (ver Capítulo 6).

Durante las décadas de los cincuenta y sesenta del siglo XIX, la mayor parte de los conciertos que se celebraron en Murcia tuvieron lugar en salones de sociedades recreativas o en casa particulares ${ }^{14}$. En 1866, por ejemplo, fueron frecuentes los conciertos organizados en el Casino de Murcia y en casas particulares de algunos músicos murcianos como López Almagro. En cambio, a partir de esos años fue más habitual organizarlos en el Teatro Romea.

Los conciertos más numerosos fueron los de cantantes y guitarristas, seguidos por violinistas, pianistas $y$, finalmente, formaciones instrumentales de diversa categoría (ver Tabla 5.1).

Tabla 5.1. Conciertos en los teatros murcianos $(1859-1899)^{15}$

Fuentes documentales: ver Apéndice 5.1.

\begin{tabular}{|c|c|c|}
\hline & Intérprete & Teatro: fecha/s \\
\hline \multirow[t]{5}{*}{ Violinistas } & Catalina Lebouys & Infantes: 26 a $28-11-1866$ \\
\hline & Julia Blechschmidt & Romea: 16 y 19-07-1874 \\
\hline & Pablo Sarasate & Romea: 9-05-1881; 1-05-1891 \\
\hline & $\begin{array}{l}\text { Claudio José Domingo Brindis } \\
\text { de Salas }\end{array}$ & Romea: 28 y 30-05-1889 \\
\hline & Gabriele von Amann Neusser & Romea: 18-11-1889 \\
\hline \multirow[t]{5}{*}{ Pianistas } & Isaac Albéniz & Romea: 24 y 27-10-1882 \\
\hline & Capitán Voyer & Romea: 3-05-1884 \\
\hline & $\begin{array}{l}\text { Cristóbal García de las } \\
\text { Bayonas }\end{array}$ & Romea: 24-04-1891 \\
\hline & Enrique Granados & Romea: 27-09-1896 \\
\hline & Domingo Bosch & Romea: 13-03-1898 \\
\hline \multirow[t]{3}{*}{ Guitarristas } & Julián Arcas & $\begin{array}{l}\text { Provisional: } 23-12-1859 \\
\text { Infantes: } 29-06-1866 \text { y 2-07-1866 } \\
\text { Soberanía Nacional: } 18-07-1869 \text {, } \\
23 \text { y } 28-05-1871 \\
\text { Romea: } 28 \text { y } 29-01-1881\end{array}$ \\
\hline & Federico Cano & Infantes: $12-09-1866$ \\
\hline & Pedro Paredes & Provisional: 17-05-1879 \\
\hline \multirow[t]{9}{*}{ Cantantes } & $\begin{array}{l}\text { Eloísa D'Herbil } \quad \begin{array}{l}\text { (voz y } \\
\text { piano), [Alice] }\end{array} \text { Bernardi } \\
\text { (contralto) y Juan } \\
\text { Manresa (piano) }\end{array}$ & Infantes: $15-05-1864$ \\
\hline & Amalia Pellizzari (soprano) & Soberanía Nacional: 24-07-1870 \\
\hline & Jeanne de Valfort (soprano) & Romea: 19-04-1883 \\
\hline & Mariano Padilla (barítono) & Romea: 26-02-1885 \\
\hline & Bianca Montessini (soprano) & Romea: 4-12-1886 \\
\hline & Napoleón Verger (barítono) & Romea: 4 y 7-07-1889; 2-07-1891 \\
\hline & Linda Díaz (soprano) & Romea: $27-07-1890$ \\
\hline & Rafael Rex Torrano (barítono) & Romea: 26-09-1892 \\
\hline & Antonio Noguera (bajo) & Romea: 16-03-1893 \\
\hline
\end{tabular}

${ }^{14}$ Conviene recordar que la prensa murciana de los años sesenta que se conservan en la actualidad es muy escasa ya que no hay ejemplares de La Paz de Murcia de los años 1861 a 1864, ambos inclusive.

${ }^{15}$ Las fuentes que he consultado concluyen con el último periódico conservado de La Paz de Murcia (31-03-1895). Los datos sobre los años 1896-1899 proceden de Crespo, Historia del Teatro, pp. 373-403. 


\begin{tabular}{|c|c|c|}
\hline & Vittoria Domenici (tiple) & $\begin{array}{l}\text { Circo Villar: 19-08-1894 } \\
\text { Romea: 9-09-1894 }\end{array}$ \\
\hline & $\begin{array}{l}\text { Emma Nevada (soprano) y } \\
\text { José Gomis (tenor) }\end{array}$ & $16-05-1895$ \\
\hline & $\begin{array}{l}\text { Eloísa D’Herbil (piano), } \\
\text { Agostino Robbio (violín) }\end{array}$ & Soberanía Nacional: 9-07-1871 \\
\hline & $\begin{array}{l}\text { Pedro Paredes (guitarra), José } \\
\text { Palazón (guitarra), Hernández } \\
\text { (violín) y José Solano (piano) }\end{array}$ & Romea: 26-03-1886 \\
\hline & \begin{tabular}{lll} 
Clara & \multicolumn{2}{c}{ Swchartz (violín), } \\
Agustín Rubio (violonchelo), \\
Antonio Puig (armonio y \\
piano)
\end{tabular} & Romea: 11 y 12-03-1893 \\
\hline & $\begin{array}{l}\text { Jerónimo Fuster (guitarra) y } \\
\text { Matilde Bol (piano) }\end{array}$ & Romea: 3-01-1899 \\
\hline $\begin{array}{l}\text { Formaciones } \\
\text { de cámara }\end{array}$ & Sexteto Arche & $\begin{array}{l}\text { Romea: } 26,28,29-04-1883 ; 2,3- \\
05-1883 ; 5,8,9,10-05-1884\end{array}$ \\
\hline Otros: & Vincenzo Bruncioli (arpa) & Infantes: 6-02-1863 \\
\hline & $\begin{array}{l}\text { Maggiocco (flauta), Tassara } \\
\text { (violín) y Nicora (guitarra) y } \\
\text { William Walter (óptico) }\end{array}$ & Infantes: 16,17 y 24-03-1867 \\
\hline & $\begin{array}{l}\text { Blanch (“copólogo", armónica } \\
\text { de cristal) }\end{array}$ & $\begin{array}{l}19 \text { al } 26-02-1876 ; 30-09-1883 \text { y } 7- \\
10-1883\end{array}$ \\
\hline & Estudiantina Española & Romea: 19 y $20-01-1883$ \\
\hline & $\begin{array}{l}\text { Familia Box (dos guitarras y } \\
\text { bandurria) }\end{array}$ & $\begin{array}{l}\text { Circo de la Rambla: 25, 28-09- } \\
1884\end{array}$ \\
\hline & Juan Marcos y Mas (saxofón) & Romea: $15-03-1885$ \\
\hline & Zenobio Navarini (ocarina) & Romea: 19 a 27-01-1894 \\
\hline & $\begin{array}{l}\mathrm{J}[?] \text { Cela, violinista ciego } \\
\text { imitador de sonidos }\end{array}$ & Romea: 15 a 17-01-1898 \\
\hline
\end{tabular}

El nivel de los solistas que actuaron en Murcia fue muy variado. Entre los grandes intérpretes que llegaron a la ciudad estuvieron los españoles Pablo Sarasate, Isaac Albéniz y Enrique Granados y los extranjeros Catalina Lebouys, Julia Blechschmidt, Clara Schwartz, Agostino Robbio y Capitán Voyer. El Sexteto Arche estuvo entre las formaciones instrumentales más relevantes. Algo más de la mitad de los intérpretes solistas eran extranjeros (excluyo las formaciones instrumentales y los conciertos de varios instrumentos combinados). El grupo más numeroso de instrumentistas nacionales fue el de los guitarristas ${ }^{16}$.

A diferencia de las representaciones teatrales, sujetas a la programación de años cómicos y temporadas, los conciertos no tuvieron una periodicidad regular. Únicamente he constatado el intento de la sociedad Santa Cecilia para organizar una serie de conciertos sacros en uno de los salones del Teatro Romea ${ }^{17}$. En Murcia se formaron varias sociedades que impulsaron a pequeña escala la música sinfónica y la de cámara con una cierta regularidad, aunque muy lejanamente equiparables a la Sociedad ArtísticoMusical de Socorros Mutuos, la Sociedad de Cuartetos y la Sociedad de Conciertos de Madrid, creadas respectivamente en 1860, 1863 y 1866 (ver Capítulo 6).

${ }^{16}$ Las cifras son cercanas a las aportadas en el caso de Valencia. Según Sancho, Romanticismo, p. 239, el $60 \%$ de los concertistas eran extranjeros, predominando los italianos, seguidos de los franceses.

${ }^{17}$ El Diario de Murcia, V (1883), nº 1200, 10 febrero, p. 2. Se pidió autorización para el ciclo al Ayuntamiento, aunque no he podido documentar si llegó a realizarse. 
La mayor parte de los concertistas que actuaron en Murcia procedían de Valencia y/o Alicante y proseguían su gira por Cartagena. Ese fue el caso de los hermanos Arcas, que actuaron en Murcia en julio de 1869; Agostino Robbio y Eloísa D'Herbil; la violinista Julia Blechschmidt; Albéniz; y, finalmente, Brindis de Salas ${ }^{18}$. Sin embargo, también hubo otros circuitos. El sexteto Arche, procedente de Albacete, actuó en Cieza antes de llegar a Murcia. Después actuó en Cartagena, en un concierto privado en casa del banquero Ehlers ${ }^{19}$. La cantante Domenici se dirigió a Lorca y Águilas tras su concierto en Murcia $^{20}$, al igual que Linda Díaz ${ }^{21}$. Muchos de estos artistas, después de abandonar Murcia se dirigían a Andalucía. La gira de 1881 de Sarasate, por ejemplo, transcurrió de la siguiente manera: Valencia, Murcia, Málaga y Granada ${ }^{22}$. En algunas ocasiones, los intérpretes ofrecían en Murcia más de un concierto consecutivo o en días alternos y algunos eran invitados a tocar en salones o teatros de sociedades recreativas, como Isaac Albéniz que tocó en el Teatro del Liceo después de actuar en el Romea.

En el Teatro de los Infantes-Romea, los conciertos solían celebrarse en el propio escenario principal o en alguno de los salones adyacentes, especialmente el de "descanso" (ver Figura 5.1). Este es el caso de la velada ofrecida por Amalia Pellizari junto al barítono Antonio del Valle y los pianistas murcianos José Antonio Ramírez y Juan Diego Manresa en abril de 1870.

${ }^{18}$ La Paz de Murcia: XII (1869), nº 3629, 29 julio, p. 1; XIV (1871), nº 4215, 11 julio, p. 1; XVII (1874), $\mathrm{n}^{\mathrm{o}} 5118,22$ julio, p. 1; XXV (1882), $\mathrm{n}^{\mathrm{o}} 7425,15$ noviembre, p. 1 y XXXII (1889), $\mathrm{n}^{\circ} 9856,22$ junio, p. 1

\footnotetext{
${ }^{19}$ La Paz de Murcia, XXVI (1883), no 7621, 26 abril, p. 1.

${ }^{20}$ La Paz de Murcia, XXXVI (1894), nº 12765, 26 agosto, p. 4.

${ }^{21}$ La Paz de Murcia, XXXIII (1890), no 11122, 6 septiembre, p. 4.

${ }^{22}$ Del Campo, "La visita", p. 85.
} 


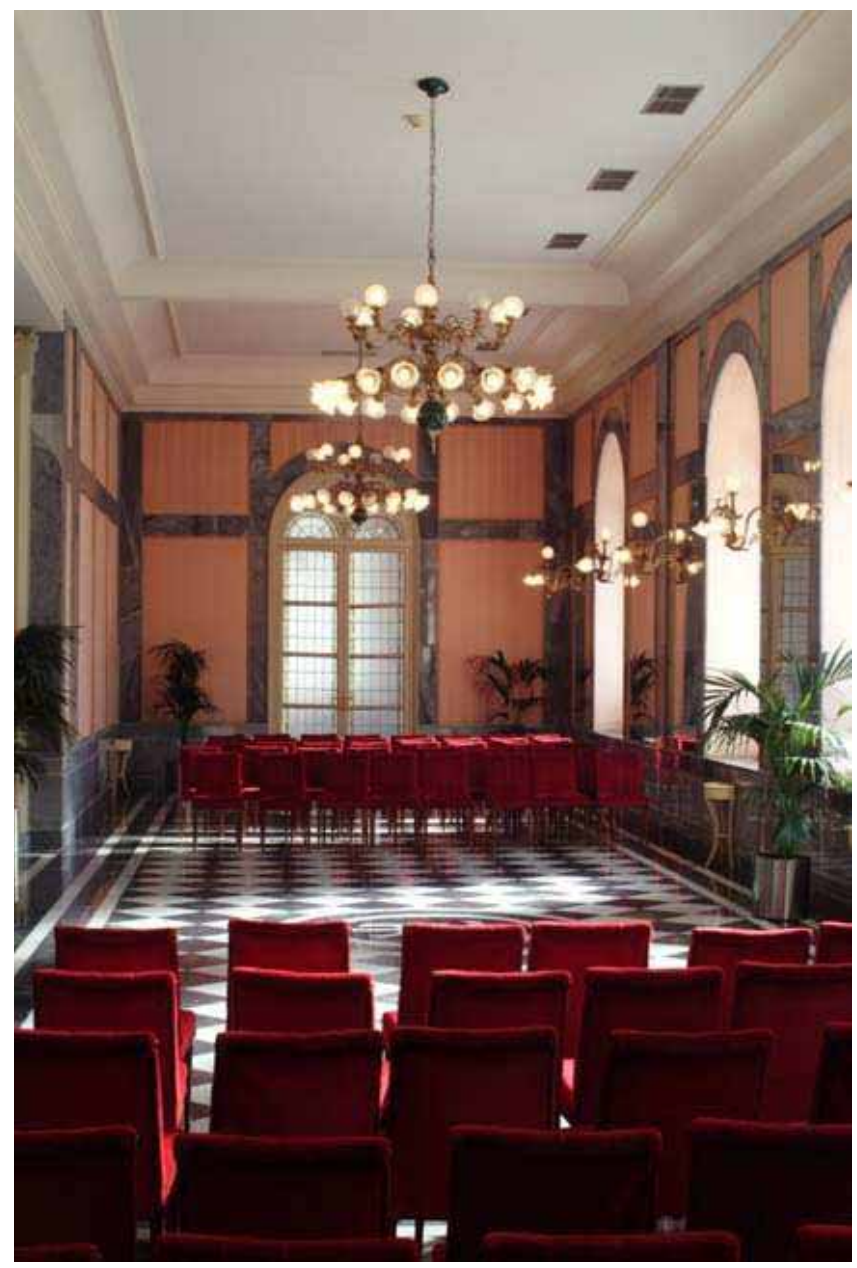

Figura 5. 1. Sala de descanso y de celebración de conciertos del Teatro Romea, antes de su cierre en 2007. Accesible en: Región de Murcia Digital: http://www.regmurcia.com (acceso el 11-07-2011)

La estructura de los recitales adoptaba diversos formatos y, en ocasiones, incluía elementos no musicales, como lecturas de poesías y representaciones de obras teatrales breves. Una muestra representativa son los tres conciertos benéficos por la recién creada Tienda Asilo de Murcia en 1898. El primero de ellos, celebrado en marzo, tuvo tres partes. En la primera se escenificó el juguete cómico en un acto de Vital Aza, Parada y Fonda, por actores aficionados; y hubo baile infantil y lectura de poesías. En la segunda parte, dos aficionadas (canto y piano) interpretaron el "Quinto concierto de Hertz", Le Fileuse de Joachim Raff y "Dormi pure" de Scuderi; el pianista Domingo Bosch ejecutó la Rapsodia Húngara de Listz; y una orquesta femenina de bandurrias y guitarras acompañó diversas canciones andaluzas y bailes andaluces. En la tercera parte se interpretaron bailes y cantos de la huerta de Murcia y hubo ejercicios de prestidigitación a cargo de Adolfo Pérez Hidalgo ${ }^{23}$. La tercera función benéfica a favor del Asilo de Murcia tuvo lugar en diciembre e incluyó una sinfonía, "un asalto de armas por los socios de la sala de esgrima del Casino", lectura de dictámenes de un certamen artístico, obertura de Rienzi de Wagner, a dos pianos y ocho manos, la "Canción de la zagala" de María del Carmen (recientemente estrenada en Madrid), fragmento de Weber al piano; Siciliana de

${ }^{23}$ El Diario de Murcia, XX (1898), n $\mathrm{n}^{\mathrm{o}}$ 7602, 12 marzo, p. 1. La crítica se publicó en El Diario de Murcia, XX (1898), $\mathrm{n}^{\mathrm{o}} 7605,15$ marzo, p. 2. 
Cavalleria Rusticana, "Fantasía sobre la ópera Lucia" a dos pianos y estreno del "Himno de la Caridad", del malagueño José Cava Galván ${ }^{24}$.

Las reseñas periodísticas comentaban sobre todo los conciertos con elevadas dosis de acrobacias técnicas. Como es sabido, el fenómeno del virtuosismo instrumental se desarrolló ampliamente durante el siglo XIX auspiciado por figuras como Paganini, Listz o Sarasate ${ }^{25}$. A propósito del concierto de Julián Arcas en Murcia en junio de 1866, se comentó, por ejemplo:

[...] En las diferentes piezas que tocó hizo gala del dominio que en todos sentidos ejerce sobre el instrumento. Escalas veloces ejecutadas con singular limpieza y valentía, trémolos, arrastres, armónicos, imitación de otros instrumentos y voz humana. A todos los recursos, en fin, apeló este distinguido artista para conmover a los oyentes, no prodigados de una manera caprichosa, sino aplicados con oportunidad suma. $[\ldots]^{26}$.

Las proezas virtuosísticas de los ejecutantes eran recibidas con reacciones entusiásticas del público:

[...] La segunda pieza que ejecutó la concertista fue el Souvenir de Bellini, obra lindísima, de difícil ejecución y que con la facilidad de costumbre dejó oír. En esta fue obsequiada de nuevo con lindísimas palomas adornadas de preciosos lazos; grandes y hermosos ramos de fragantes flores de las más bellas de nuestro suelo; poesías dedicadas por varios jóvenes entusiastas del arte y que al final copiamos, y otra bonita corona.

Durante ésta y la anterior pieza, interrumpieron más de una vez la ejecución entusiastas bravos, frenéticos y generales aplausos hijos del entusiasmo y satisfacción que producía $[\ldots]^{27}$.

Como era habitual en muchos otros teatros españoles, una de las costumbres más arraigadas entre el público era pedir la repetición de una pieza o número musical cuando el intérprete gustaba ${ }^{28}$. Desde 1885 era habitual que se interpretara un bis diferente y no incluido en el programa. Así se explica en las siguientes líneas, publicadas en el mencionado año:

[...] Al terminar esta pieza, el público pidió su repetición para volver a admirar lo que tanto había llamado la atención. Mas el señor Espino, atendiendo a la moda establecida hoy en todo concierto que en lugar de repetir la pieza ejecutada se hace oír otra más ligera no anunciada en el programa, esto lo llevó a cabo haciendo tocar una

\footnotetext{
${ }^{24}$ El Diario de Murcia, XX (1898), n 7873, 10 diciembre, pp. 1-2 y Crespo, El Teatro Romea, p. 401.

${ }^{25}$ Véase Iberni, Pablo Sarasate, pp. 22-30.

${ }^{26}$ La Paz de Murcia, IX (1866), n 2579, 30 junio, p. 2.

${ }^{27}$ La Paz de Murcia, IX (1866), no 2828, 30 noviembre, p. 2. Crítica al tercer concierto de la violinista Catalina Lebouys en el Teatro de los Infantes.

${ }^{28}$ La Paz de Murcia, XXIV (1881), nº 6995, 8 marzo, p. 1: "la segunda [la zarzuela El hombre es débil] hubo casi tantas repeticiones como números de música tiene".
} 
preciosa POLKA MILITAR original de tan aplaudido maestro y que tuvo un gran éxito $[\ldots]^{29}$.

En el repertorio concertístico escuchado en Murcia predominaron las fantasías, las variaciones y los caprichos inspirados en fragmentos operísticos y, en menor medida de zarzuela, así como piezas populares españolas, aires nacionales y pequeñas piezas románticas.

\subsection{Violinistas}

Los violinistas constituyeron un grupo numeroso de intérpretes solistas. Una de las primeras violinistas documentadas en la ciudad es Catalina Lebouys, que ofreció tres conciertos en días consecutivos en noviembre de $1866^{30}$. En sus programas interpretó fantasías sobre motivos operísticos, como la "Fantasía sobre motivos de Linda di Chamounix" de Jean-Delphin Alard (véase Apéndice 5.1).

En julio de 1874 el Teatro Infantes-Romea acogió una velada a cargo de la joven violinista alemana Julia Blechschmidt. En sus programas aparecen obras de la literatura violinística y predominan las fantasías, las variaciones, los potpurrís y fragmentos de conciertos de autores como Bériot (el más interpretado), Alard, Linder, Premier y Léonard, entre otros. Destaca el Adiós a la Alhambra de Jesús de Monasterio y el Concierto Laculdler. Brillantes variaciones, op.1, compuesto por la propia intérprete.

Sin lugar a dudas, el violinista más relevante fue Pablo Sarasate, discípulo del violinista cartagenero Manuel Rodríguez y Sáez (ver Figura 5.2), que dio dos conciertos en Murcia en los meses de mayo de 1881 y 1891, respectivamente ${ }^{31}$.

${ }^{29}$ La Paz de Murcia, XXVIII (1885), n’ 8138, 5 febrero, p. 1.

${ }^{30}$ Catalina Lebouys nació en Roma en 1849. Era hija del célebre pintor francés Augusto Lebouys. Se inició con el profesor florentino Eciovacchini. Debutó a los once años en Florencia. Actuó en numerosas ciudades de Italia, Francia, Alemania e Inglaterra: Revista de Bellas Artes, (1866), $\mathrm{n}^{\circ} 54$ noviembre, p. 3. A España llegó contratada por Bertolini para dar una gira de conciertos en Alicante, Murcia, Cartagena, Málaga, Granada, Gibraltar, Cádiz y Sevilla: Revista de Bellas Artes, (1866), nº 7, 18 noviembre, p. 8.

${ }^{31}$ Sarasate ofreció dos conciertos en Cartagena en mayo de 1887 , aunque no he podido constatar que también actuara en Murcia: La Paz de Murcia, XXX (1887), nº 8190, 4 mayo, p. 1. Sarasate actuó en Valencia en los años 1881, 1887 y 1891: Sancho, Romanticismo, pp. 264-266. Sobre Sarasate, véase: Altadill, Memorias e Iberni, Pablo Sarasate. 


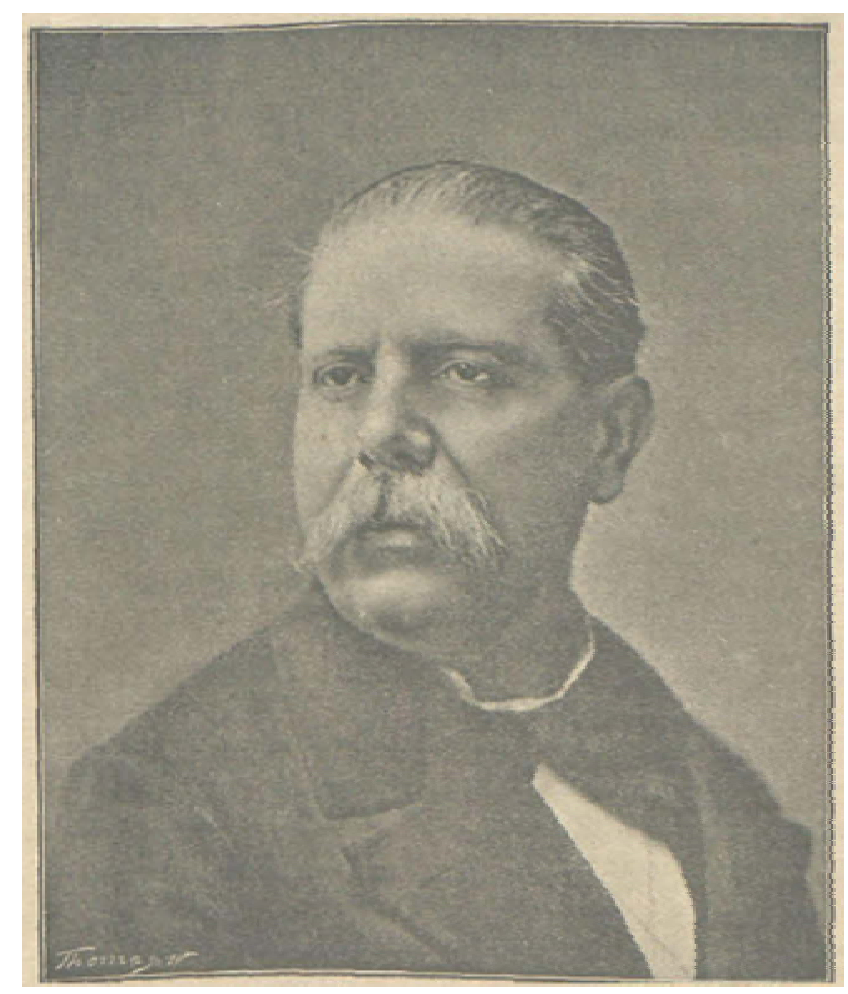

Figura 5. 2. Manuel Rodríguez y Sáez (1826-1885), célebre violinista cartagenero. E:CARm. Cartagena Artística, II (1891), nº 28, 10 enero, p. 1. Accesible en: http://archivo.cartagena.es (acceso el 21-08-2011).

En el primero de ellos actuó junto a la compañía de ópera de Benigno Giardini. El programa se dividió en cuatro partes. En la primera, se representó el cuarto acto de Poliutto (Donizetti). Cada una de las otras tres partes comenzó con las oberturas La Figlia del Reggimento y Don Pasquale, de Donizetti, y Stiffelio de Verdi. Tras éstas, Sarasate ofreció una Fantasía apasionante; un Nocturno de Chopin (no se especifica cuál) ${ }^{32}$; Danza de las brujas de Antonio Bazzini y su Caprice basque, op.24.

El concierto de 1891 fue diferente e incluyó tres piezas más ${ }^{33}$. El violinista se acompañó de sus pianistas habituales: el matrimonio formado por Berthe Marx y Otto Goldschmidt $^{34}$. Interpretó un concierto íntegro para violín de Mendelssohn, acompañado al piano por Marx ${ }^{35}$; un Nocturno de Chopin; El baile de las brujas, de Antonio Bazzini;

${ }^{32}$ Sarasate transcribió los Nocturnos Mi bemol, op. 9 n 2 y Re Mayor, op. 27 no 2 de Chopin: Iberni, "Pablo Sarasate", p. 667.

${ }^{33}$ Según El Diario de Murcia, XIII (1891), no 4321, 3 mayo, p. 2 Julián Calvo intervino activamente en la contratación del violinista en esta ocasión. En esta gira levantina Sarasate dio dos conciertos en Cartagena, dos en Jerez, Sevilla y Cádiz, tres en Gibraltar, uno en Algeciras, otro en Utrera, otro en Córdoba, tres en Valencia y uno en Barcelona. Véase, según Altadill, Memorias, p. 230.

${ }^{34}$ Berthe Marx fue discípula de Henri Herz y acompañante habitual de Sarasate. Otto Goldschmidt fue secretario personal de Sarasate y pilar indispensable en la carrera del navarro. Véanse más detalles en Iberni: Pablo Sarasate, pp. 27, 81 y siguientes.

${ }^{35}$ La prensa no especificó cuál, aunque parece lógico pensar que fuera el Concierto en mi menor, op. 64 de Mendelssohn. 
la famosa "Fantasía para violín sobre motivos de Otello de Rossini" de Ernst" ${ }^{36}$; la Leyenda, op. 17 de Wieniawski y dos obras de su composición: Habanera (no se especifica cuál) y El canto del ruiseñor, op. 29. Complementaron el concierto dos obras ejecutadas por Marx (una Balada de Chopin, un Estudio de Rubinstein y la Rapsodia n $^{\circ}$ 12 de Liszt).

Ambos se componen de obras frecuentemente interpretadas en sus conciertos, pensados para apabullar al espectador con las piruetas virtuosísticas ${ }^{37}$.

La recepción de Sarasate en Murcia fue extraordinaria, a pesar de que, en el primer concierto, algunos murcianos consideraron que su participación iba a ser escasa. La Paz de Murcia, en un intento por acallar estos comentarios, justificó públicamente: "Cada una de las piezas que anuncia se pueden considerar como dos o tres y además este artista tiene por costumbre adicionar lo anunciado con otras piezas para satisfacer los deseos del público" 38 .

El primer recital fue reseñado en La Paz de Murcia por un redactor que firmó bajo el pseudónimo El Pacífico ${ }^{39}$. En sus líneas se percibe la impresión de alguien que ha visto en persona a un verdadero mito, incluso hasta el modo en que describe la salida del violinista al escenario:

[...] Dio unos cuantos pasos hasta colocarse en la embocadura de la escena. Allí levantó el violín sobre el hombro, hizo sonar sus cuerdas débilmente, mudó de sitio dos o tres veces hasta encontrar el de mejores resonancias y entonces oímos algo así como sobrenatural o extraordinario $[\ldots]^{40}$.

De alguna manera, el crítico intuyó la cuidad actitud del artista ante su público, aunque solo fuera por el hecho de relatar esta escena ${ }^{41}$. El aspecto que más llama la atención al escritor era la capacidad expresiva de Sarasate, casi por encima de su capacidad técnica para el virtuosismo: "nos decía una porción de sentimientos [y] de afectos que no sé si a la palabra solamente le sería fácil expresar. Unas veces su acento era débil en extremo, tenue y delicado; otras violento y fuerte cual si no fuera un violín sino cientos de donde partiera" ${ }^{, 2}$.

\footnotetext{
${ }^{36}$ Otra de las asiduas piezas de su repertorio de conciertos. Según relata Iberni fue muy interpretada por Sarasate a lo largo de su vida; hasta el punto de que el público creyó que era de su autoría: Iberni, "Pablo Sasarate", p. 663.

${ }^{37}$ Iberni, Pablo Sarasate, p. 660.

${ }^{38}$ La Paz de Murcia, XXIV (1881), nº 7044, 6 mayo, p. 1.

39 Resulta llamativo, por otro lado, que ninguno de los músicos que colaboraron con la prensa murciana reseñando actuaciones de compañías, por ejemplo de ópera, lo hiciera en esta ocasión. El Diario de Murcia apenas le dedicó tres párrafos.

${ }^{40}$ El Pacífico, "El concierto de anoche”, La Paz de Murcia, XXIV (1881), no 7047, 10 mayo, p. 1.

${ }^{41}$ Iberni, Pablo Sarasate, p. 28 habla de "poderoso sentido del espectáculo". Cada pose e imagen ante el espectador era cuidadosamente planificada por el artista.

${ }^{42}$ El Pacífico, "El concierto", p. 1.
} 
La combinación de obras incluidas en los programas era ciertamente atinada para el público. El Diario de Murcia publicaba, tras su primera actuación: "Los que no entendieron la música clásica fueron dominados por el encanto de los aires populares" $"$.

La reseña de La Paz de Murcia sobre el concierto de 1891 no fue firmada y los comentarios, bastante superficiales desde el punto de vista musical, están encaminados a elogiarle: "fue un acto de entusiasmo popular, de admiración extraordinaria; y perdimos la cuenta de las veces que el eminente don Pablo tuvo que presentarse a satisfacer los deseos del público que atronaba el local con sus aplausos y bravos" 44 .

En mayo de 1889, el Romea acogió dos conciertos del cubano Brindis de Salas (1852-1911) junto a la compañía de José Bosch (ver Figura 5.3). La breve reseña a sus conciertos señala que el teatro estaba lleno y que el violinista interpretó varios bises ante las peticiones entusiastas del público ${ }^{45}$. En el mes de noviembre del mismo año tuvo lugar un recital de la violinista Gabriele von Amann Neusser, acompañada al piano por el murciano José Antonio Ramírez ${ }^{46}$. Este último fue organizado por la empresa del Teatro Romea a ruego de varios abonados y aunque según la prensa triunfó, fueron pocos espectadores. Para $\mathrm{La} \mathrm{Paz}$ de Murcia el problema estribaba en que la función iba "dedicada al público ilustrado, más que al que llena el teatro en las funciones por horas" $"$. No ha quedado constancia de los programas de ninguno de ellos.

${ }^{43}$ El Diario de Murcia, III (1881), nº 667, 10 mayo, p. 3.

${ }^{44}$ La Paz de Murcia, XXXIV (1891), nº 11319, 2 mayo, p. 1.

${ }^{45}$ La Paz de Murcia, XXXII (1889), nº 9839, 1 junio, p. 1.

${ }^{46}$ La Paz de Murcia, XXXII (1889), nº 9978, 20 noviembre, p. 1 publicó una breve biografía sobre Gabriele von Amann Neusser. Nació en 1867 y estudió en el Conservatorio de Viena piano y violín aunque poco más tarde, según el periódico, se dedicó por completo a este último instrumento. Dio clases con Grüm, Sarasate y Joachim, director del Conservatorio de Berlín, y debutó en el Teatro Real de Madrid el 11 de mayo de 1887 con gran éxito. Después prosiguió una gira de conciertos en Lisboa, Oporto, Islas Azores y Canarias. Se casó con el empresario austríaco de teatro, Ebo Amann, director de la Gaceta Musical de Brasil. La actuación de Murcia se enmarca en una gira más amplia sobre otras capitales del Sur de España. Llegó procedente de Cartagena, donde ofreció dos conciertos en el Teatro Principal y en el Casino de la localidad. Amann tocaba con un violín Guarnerio tasado en 20000 pesetas de la época. La Paz de Murcia, XXXII (1889), no 9966, 5 noviembre, p. 4

${ }^{47}$ La Paz de Murcia, XXXII (1889), nº 9977, 19 noviembre, p. 1. Aún así, trataron de organizar un nuevo concierto que no llegó a realizarse. No se especificaron las causas: La Paz de Murcia, XXXII (1889), $\mathrm{n}^{\circ}$ 9980, 22 noviembre, p. 1. 


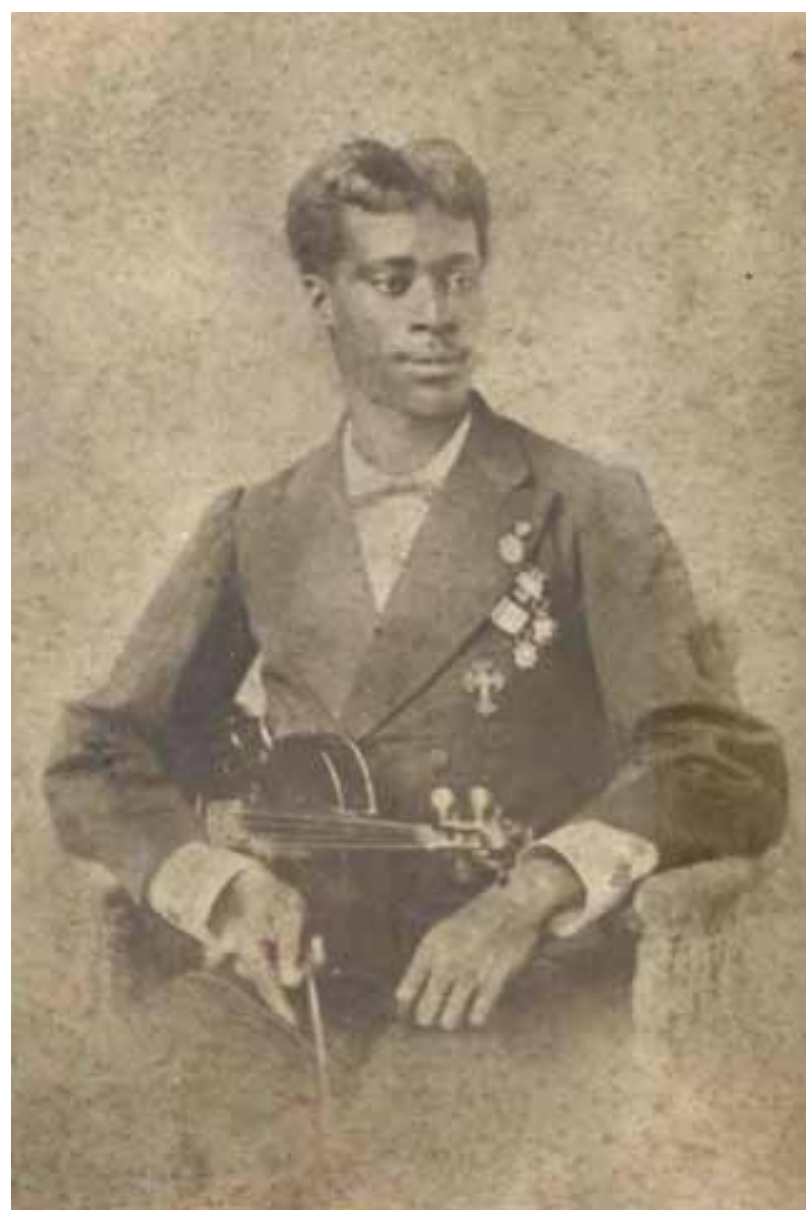

Figura 5. 3. Retrato del violinista cubano Claudio José Domingo Brindis de Salas y Garrido. C:HABn. Accesible en: http://www.arnac.cu (acceso el 3-10-2011).

\subsection{Pianistas}

Según Julián Calvo los primeros concertistas españoles de piano que actuaron en Murcia fueron Emilio Anchorena en 1853 y, unos meses más tarde, el gaditano José Miró $^{48}$. Lamentablemente no se conserva prensa murciana de ese año aunque es posible conocer, por un documento posterior, que Anchorena interpretó una pieza de concierto de Prudent, Cuarteto de los Puritanos y un Potpurrí sobre aires nacionales"49. Sobre José Miró sólo se tiene constancia de que actuó en más de una ocasión ${ }^{50}$.

${ }^{48}$ Julián Calvo, La Paz de Murcia, XXI (1878), nº 6313, 22 septiembre, p. 1. En el mismo documento afirma Calvo que "en 1848 al 49, el [primer] concertista que vino era francés, que tocó en el teatro de la calle de Baraundillo y en un piano cuadrilongo del Padre Fernando Pérez". Contestaba así al artículo de "Un aficionado", “Apuntes para la Historia de la Música en Murcia (V)", El Semanario Murciano I (1878), núm. 28, 25 agosto, pp. 2-3 en el que se afirmaba que fue Anchorena el que actuó en 1848.

49 "Un aficionado", “Apuntes para la Historia de la Música en Murcia (V)”, El Semanario Murciano I (1878), núm. 28, 25 agosto, pp. 2-3: 2.

${ }^{50}$ José Miró y Anoria se inició en el piano con Eugenio Gómez y estudió, más tarde, con Kalkbrenner y Thalberg, cuya escuela introdujo en España. Tuvo una brillante carrera como concertista en Europa y América. Miró fue profesor del Conservatorio madrileño desde 1854. En 1856 publicó un interesante Método de piano en el que recomienda los estudios de Thalberg, Alkan, Liszt y Chopin, entre otros. Sobre su método de piano, así como el de otros españoles, véase: Vega-Toscano, "La escuela”, vol. I, pp. 93-130. 
Con posterioridad a éstos, actuaron Albéniz, el pianista francés Capitán Voyer, Cristóbal García de las Bayonas, Enrique Granados y Domingo Bosch ${ }^{51}$.

La primera aparición pública de Albéniz en Murcia tuvo lugar en octubre $1882^{52}$. Ofreció dos conciertos en los entreactos de tres zarzuelas y junto a la compañía de zarzuela de Eugenio Fernández ${ }^{53}$. Los programas incluyeron obras de dos figuras clave de la primera generación romántica, Chopin, Mendelssohn, así como otras de Liszt, Gottschalk, Bach y tres composiciones propias (Estudio impromptu, Pavana $n^{o} 2$ y Serenata andaluza ${ }^{54}$. En total, dieciocho piezas (incluidas las repeticiones de algunas) (ver Apéndice 5.1). Las críticas a ambos conciertos fueron escritas por Julián Calvo y se publicaron en La Paz de Murcia.

En su crítica al primero, Calvo destaca la capacidad técnica del compositor catalán: "si mucho nos esperábamos de su gran talento, mayor fue nuestra sorpresa al verle vencer los más atrevidos pasajes, ejecutados con la perfección más concienzuda que pudieran exigir los autores de las obras que nos dejó oír" ${ }^{55}$. Para el crítico, el estudio de todo instrumento musical se dividía en dos partes, denominadas "mecánica" e "inteligencia" y Albéniz era un pianista indiscutible en ambas:

[...] En la parte de mecanismo hace prodigios el señor Albéniz, siendo de gran mérito la soltura y naturalidad que ha sabido imprimir en sus movimientos de brazo y antebrazo, así como la independencia de muñeca para los staccatos y en particular para las grandes ejecuciones de octavas y martellatos.

De su inteligencia y talento solo diremos que hay grandes pianistas que se inclinan generalmente a un solo estilo y a una sola escuela, pero los artistas de la raza de RUBISNTEIN dominan con la misma facilidad las filigranadas obras de CHOPIN, que las gigantescas de MENDELSHONN, BACH, WEBER o las intrincadísimas de LISTZ. Esto acontece con el concertista señor Albéniz.

El modo que tiene de interpretar los andantes más delicados es sublime, pues hay momentos en que las cuerdas parecen ser vibradas por algún fluido magnético, o que entre aquéllas y sus dedos no existe intermediación alguna... parece un arpa eoliana... qué modo tan peregrino para pulsar el teclado...

La gradación desde el pianissimo al fortísimo, y viceversa, la opera con la mayor seguridad y perfección que puedan desearse. En cuanto a la elección de las

${ }^{51}$ Sin embargo, el listado se eleva si tenemos en cuenta los teatros de sociedad recreativas, como veremos en el Capítulo 6. El Círculo Industrial acogió actuaciones de la citada Eloísa D’Herbil (septiembre de 1867) y Oscar Camps y Soler (diciembre de 1876) y El Liceo a Albéniz, en noviembre de 1882, probablemente a su vuelta de Cartagena. Este hecho indica que los concertistas que llegaban a Murcia, actuaban tanto en teatros como en sociedades recreativas.

${ }^{52}$ La prensa no escatimó elogios al joven pianista: "La aureola de que viene revestido este joven profesor nos revela de todo encomio. Los triunfos los cuenta por el número de sus conciertos en cuantas poblaciones visita": La Paz de Murcia, XXV (1882), nº 7462, 18 octubre, p. 1.

${ }^{53}$ Las zarzuelas fueron: Música Clásica (de Ruperto Chapí sobre libreto de Estremera) y Picio, Adán y compañía (de Carlos Mangiagalli y libreto de Liern) el primer concierto; y, Las Amazonas del Tormes, (José Roger sobre libreto de Álvarez), el segundo.

${ }^{54}$ Según Begoña López, "L'activitat”, p. 255, que ha estudiado la actividad concertística de Isaac Albéniz en Barcelona entre los años 1874 y 1895, el hecho de que Albéniz interpretara a Chopin y Mendelssohn demostró poseer una conciencia clara de su legado musical más inmediato, la "música moderna" que sentía y tocaba desde la infancia y adolescencia.

55 Julián Calvo, "Concierto de piano dado por don Isaac Albéniz”, La Paz de Murcia, XXV (1882), nº 7409, 26 octubre, p. 1. 
piezas que presentó fue en armonía con su propósito de presentación y en consonancia del ilustrado público que le escuchaba con el mayor interés y recogimiento [...].

Isaac Albéniz no solo es una notabilidad en el piano, sino que es un excelente compositor y así lo demuestran sus obras y en particular las que tocó en este concierto. En ellas se encuentra el estilo del género clásico, buenas conclusiones y originalidad armónica, sobriedad y oportunidad en las modulaciones, como en otro lugar indicamos, gran experiencia del instrumento $[\ldots]^{56}$.

En el segundo concierto y al margen del programa establecido, Albéniz tocó la Jota aragonesa de Liszt y realizó dos improvisaciones sobre temas proporcionados por el público, una práctica muy habitual en la época. El propio Calvo propuso a Albéniz uno de sus melodías, como él mismo explica:

[...] Después de ejecutar las piezas, se le presentaron dos temas para improvisar instantáneamente sobre ambos, siendo el primero de don Teodoro Bartoli y el segundo del que suscribe, cuyo motivo fue trabajado públicamente a instancias del señor Albéniz y mientras éste ejecutó la primera pieza de las anunciadas.

[...] Este difícil trabajo lo ejecutó el señor Albéniz sin preparación y en ambos temas lució sus conocimientos de compositor, así como una gran práctica en el arte de improvisar, quedando lucidísimo en esta importante prueba, digna de unas oposiciones.

A ruegos del público terminó el concierto con la "Jota Aragonesa" del pianista Liszt, en cuyo hermoso canto popular, el jefe de la moderna escuela de piano, no sólo ha acumulado dificultades, sino que la forma que ha sabido darle hace de ella una obra de gran importancia $[\ldots]^{57}$.

La gira de Albéniz prosiguió por Cartagena aunque volvió a Murcia a principios de noviembre de 1882 para ofrecer el citado concierto en $E l$ Liceo $^{58}$. Sobre él volveré en el capítulo siguiente.

En mayo de 1884 actuó en el Teatro Romea el pianista Capitán Voyer (véase Figura 5.4) $)^{59}$. El concierto revistió especial importancia porque unió en el mismo concierto a la orquesta del teatro y a la Banda de la Misericordia, con los que interpretó el Capricho Brillante, op. 22 de Mendelssohn y una versión arreglada por él mismo para

${ }^{56}$ Calvo, "Concierto", p. 1.

${ }^{57}$ Julián Calvo, "Concierto de piano", en La Paz de Murcia, XXV (1882), n 7415, 3 noviembre, p. 1. Tal y como escribe, Liszt era para Calvo "el jefe de la moderna escuela de piano". No es de extrañar que sus obras "di bravura", concebidas para impresionar a los espectadores con los más variados e imposibles efectos viruosísticos, supusieran para muchos críticos el máximo escalafón al que un pianista podía aspirar. Para Calvo, todo pianista que se preciase debía afrontar obras de este compositor. En sus numerosos escritos periodísticos, reiteró con frecuencia esta idea. Refiriéndose a dos de sus discípulos, expresaba: "hoy sólo ellos tocan en Murcia la música de Hummel, Mozart, Beethoven, Chopin y Liszt": Julián Calvo, "Remitido", La Paz de Murcia, XXI (1878), nº 6313, 22 septiembre, p. 1.

${ }^{58}$ La Paz de Murcia, XXV (1882), nº 7411, 28 octubre, p. 1.

59 Tras dedicarse varios años a la vida militar como capitán del ejército francés, en los que se vio inmerso en la guerra franco-prusiana que le exilió de París, Voyer retomó el piano en 1871. La Paz de Murcia, XXVII (1884), n 7907, 30 abril, p. 1 resaltaba el lado más caritativo del pianista: "Cuando conoció que su mano volvía a tomar seguridad como en sus mejores días, dedicó su talento al socorro de interesantes infortunios. Siempre y en todas partes ha tocado a propósito de obras de caridad" (Noticia transcrita del periódico francés "La Patrie"). Según El Imparcial, (1883), 26 febrero, p. 1, Voyer perteneció a la escuela pianística de Rubinstein. 
piano y banda del Konzertstück de Carl Maria von Weber ${ }^{60}$. Según mis datos, fue la primera vez que un concertista ofrecía una pieza de concierto junto a una formación instrumental distinta de la orquesta. La banda encargada fue la formada por niños huérfanos de la Casa de Misericordia de Murcia. El repertorio de Voyer incluyó también otras obras de Mendelssohn, Thalberg, Chopin, Hummel y Prudent.

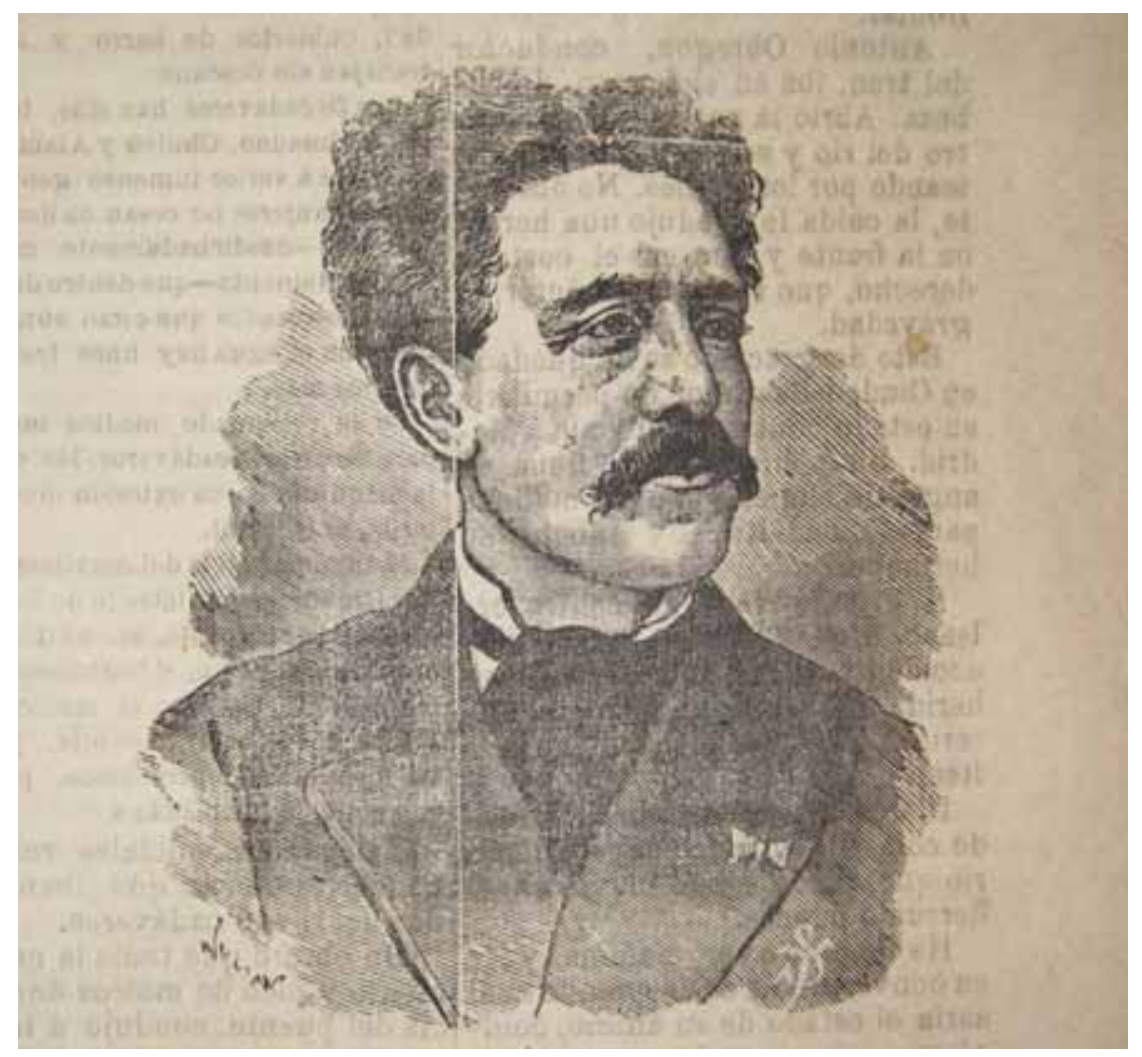

Figura 5. 4. Retrato del pianista Capitán Voyer,

E:MUm, La Paz de Murcia, XXVII (1884), no 7907, 30 abril, p. 1.

Una iniciativa singular en el campo de los conciertos pianísticos de Murcia fue el proyecto de estrenar en 1886 un arreglo de Julián Calvo de una Rhapsodie Hongroise de Listz [sic] para diez pianos, cuyo manuscrito conservan los descendientes del compositor (ver Capítulo 9) ${ }^{61}$.

${ }^{60}$ En su anuncio apareció la siguiente aclaración: “Creación hecha en París en 1879 por el Capitán Voyer, con la música de la Guardia Francesa y repetida en las principales capitales de España y tres veces en Madrid y Barcelona últimamente": El Diario de Murcia, VI (1884), n ${ }^{\circ}$ 1568, 3 mayo, p. 3. El Konzertstück, op. 79 para piano y orquesta de Weber es una pieza de concierto de un único movimiento en varias secciones contrastantes: Tusa, Michael C., "Carl Maria”, pp. 142, 158.

${ }^{61}$ Los organizadores del evento fuero algunos miembros de la Sociedad Belluga y representantes de la prensa local: La Paz de Murcia, XXIX (1886), $\mathrm{n}^{\text {os }}$ 9006, 29 agosto, p. 1 y 9007, 31 agosto, p. 4. Sin embargo, no he podido constatar que el concierto pudiera efectuarse en este año. En 1890, se retomó la idea, según apareció publicado en La Paz de Murcia, XXXIII (1890), nº 11037, 25 mayo, p. 4, aunque al parecer tampoco se llevó a cabo. 
El pianista lorquino Cristóbal García de las Bayonas actuó junto a la compañía de zarzuela de Andrés López y Pablo Gorgé en un concierto que tuvo lugar en abril de 1891 aunque no ha quedado constancia del programa ${ }^{62}$.

La actuación de Enrique Granados en Murcia en septiembre de 1896 fue diferente especial y diferente a otras ${ }^{63}$. Granados no llegó a la ciudad simplemente para ofrecer un concierto, sino "para estudiar nuestros aires populares", es decir, para conocer in situ la música sobre la que habría de inspirarse para componer María del Carmen ${ }^{64}$. En Murcia, Granados dio a conocer como primicia los primeros números que había compuesto para la citada ópera, basada en la obra teatral de José Feliú.

Granados, el escritor José Feliú Codina y la esposa de éste coincidieron en Murcia desde, al menos, el día 22 de septiembre de $1896^{65}$. El matrimonio Feliú había llegado a la ciudad para asistir al estreno de María del Carmen, una obra de costumbres inspirada en Murcia, sobre la que Granados basó su homónima ópera. En mi opinión, fue una ocasión idónea para el compositor catalán ya que, por una parte, tomaba contacto con la música tradicional murciana $\mathrm{y}$, por otra, asistía a la primera representación de la obra de Feliú a cargo de la compañía dramática de Emilio Mario en el Teatro Romea (26-09$1896)^{66}$.

El 24 de septiembre de 1896 el pianista ofreció una velada íntima en el almacén de música de Adolfo Gascón ante un selecto público, entre ellos Feliú y su esposa, y compuesto, en su mayoría, por compositores murcianos ${ }^{67}$. El programa es realmente interesante porque interpretó "Canción de Pepuso" y "Romanza de Pencho" (dos futuros

${ }^{62}$ La Paz de Murcia, XXXIV (1891), nº 11312, 24 abril, p. 4.

${ }^{63}$ No fue la única ocasión en la que vino a Murcia. En diciembre de 1898, dio un concierto en el Círculo de Bellas Artes en el que interpretó Danza andaluza, Valenciana, Valses poéticos, Bayadera y la “Jota de Miel de la Alcarria”, entre otras: El Diario de Murcia, XX (1898), no 7873, 10 diciembre, p. 1.

${ }^{64}$ El Diario de Murcia, XVIII (1896), nº 7109, 29 diciembre, p. 3.

${ }^{65}$ El Diario de Murcia, XVIII (1896), $\mathrm{n}^{\text {os }}$ 7100, 20 septiembre, p. 3 y 7102, 22 septiembre, p. 3. Según El Diario de Murcia, XVIII (1896), n ${ }^{\circ}$ 7104, 24 septiembre, p. 2 una comisión de representantes del Ayuntamiento se encargó de visitar oficialmente al matrimonio. Las fuentes no mencionan a Granados, aunque cabe suponer que viajara con ellos. Recordemos que en 1896, el catalán aún no había adquirido fama de compositor a nivel nacional. En opinión de Perandones, "María del Carmen", p. 208, fue a partir del estreno de María del Carmen (1898) cuando se dio a conocer en el campo de la creación musical española, pues hasta entonces, a pesar de su carrera como concertista, sólo se le conocía en Barcelona y Madrid.

${ }^{66}$ El estreno de María del Carmen de Feliú fue precedido de una gran expectación en Murcia. Las entradas se agotaron el día antes, a pesar del alto precio de las localidades (4.20 pesetas). Las críticas a la representación se reseñaron en El Diario de Murcia, XVIII (1896), nº 7107, 27 septiembre, p. 3; José Pío Tejera, "María del Carmen", El Diario de Murcia, XVIII (1896), no 7109, 29 septiembre, pp. 1-2 y Mariano Perní García escribió una poesía titulada "María del Carmen", publicada en El Diario de Murcia, XVIII (1896), n $n^{\circ} 7108,28$ septiembre, p. 1. Crespo, El Teatro Romea, pp. 373-374 menciona que fue la compañía de Emilio Thuiller y no la de Emilio Mario. Sin embargo, todas las fuentes periodísticas que he consultado mencionan a Mario como el director del elenco.

${ }^{67}$ Feliú y Granados habían colaborado en Miel de la Alcarria, estrenada en el Teatro de la Comedia de Madrid el 8 de enero de 1895. Según Perandones, "María del Carmen", p. 203 la idea de componer una ópera en español sobre el texto de María del Carmen se gestó en enero de 1896. Esta ópera fue, por tanto, su segundo trabajo en colaboración con el escritor y se inserta en el contexto de los intentos finiseculares de los compositores españoles por conseguir el anhelado establecimiento de la ópera española. Además, del citado trabajo, véanse más detalles en Hess, "Enric Granados, pp. 47-56: 53-54. 
números de María del Carmen), así como Seguidillas y Jota de Miel de la Alcarria ${ }^{68}$. Recordemos que, según Perandones, fue en enero de 1896 cuando Feliú y Granados gestaron el proyecto de creación de esta ópera. La premier de María del Carmen, como es sabido, tuvo lugar en el Teatro-Circo de Parish de Madrid el 12 de noviembre de $1898^{69}$.

E1 27 de septiembre de 1896 Granados actuó en el Teatro Romea, entre la segunda representación dramática de María del Carmen y el juguete cómico en un acto de Vital Aza, Parada y fonda. El programa estuvo compuesto íntegramente por obras de su autoría: una Danza española; la "Canción de la zagala" de María del Carmen y Jota alcarreña de Miel de la Alcarria ${ }^{70}$.

Aludía anteriormente a la oportunidad que supuso para Granados tomar contacto directo con la música tradicional murciana. Dos eventos tienen relación con ello. El primero fue un "gran baile huertano de malagueñas y parrandas" organizado, según la prensa, con el propósito de festejar el éxito de María del Carmen y homenajear a Feliú ${ }^{71}$. Granados asistió al baile huertano "provisto de su correspondiente lápiz y papel de diapasón con el fin de tomar apuntes del tono y compás de nuestras clásicas malagueñas y parradas" $" 72$. El segundo evento fue un encuentro con una cuadrilla murciana de Auroros

dirigida por el antiguo Juan Giménez Sánchez (a[lias]) Chuschús, quien le obsequió con el canto de las varias clases de salves acostumbradas y la clásica correlativa de Semana Santa. Tocó la campana, con gran destreza, por cierto, y echó una buena mano en el canto el antiguo y honrado maestro de obras Ramón Pagan y fue muy del agrado de todos los oyentes, la admirable uniformidad y entonación de todos los cantores $[\ldots]^{73}$.

De todo lo expuesto se deduce: primero, que la visita de Granados a Murcia no se desarrolla en el contexto de una gira de conciertos sino con el propósito de conocer los bailes y cantos de la huerta de Murcia y, segundo, que el compositor ya tenía algunas partes de María del Carmen compuestas con anterioridad al mes de septiembre de 1896.

${ }^{68}$ El Diario de Murcia, XVIII (1896), nº 7105, 25 septiembre, p. 2.

${ }^{69}$ El estreno de María del Carmen en Barcelona se llevó a cabo en el Teatre Tívoli de Barcelona el 31 de mayo de 1899 y en Valencia, el 29 de abril de 1899 en el Teatro Apolo de Valencia.

${ }^{70}$ El Diario de Murcia, XVIII (1896), no 7107, 27 septiembre, p. 3.

${ }^{71}$ El Diario de Murcia, XVIII (1896), n $\mathrm{n}^{\mathrm{0}}$ 7109, 29 diciembre, p. 3. Se celebró en la hacienda TorrePeñas de Puente Tocinos por iniciativa de Pencho Illescas y Fulgencio Fuster, labrador y dueño de la finca.

${ }^{72}$ El Diario de Murcia, XVIII (1896), nº 7109, 29 diciembre, p. 3.

${ }^{73}$ El Diario de Murcia, XVIII (1896), n n 7109, 29 septiembre, p. 3. El canto de Auroros, de carácter religioso y folclórico, cuenta con una larga tradición en Murcia. También se denomina "Campanas de Auroros" ya que se emplea únicamente este instrumento. Se trata de grupos o cuadrillas herederas de las hermandades que nacieron en los albores del siglo XVII y que se desarrollaron durante los siglos siguiente bajo la advocación de María. Sus actuaciones tienen lugar en ciertas madrugadas a lo largo del año (la despierta). Cada cuadrilla, dispuestos en forma circular, consta de dos coros que interpretan de manera antifonal sus cantos. El guía del primer coro porta la campana y es el encargado de dirigir y decidir el lugar donde se canta y la salve a interpretar. Véanse más detalles en Flores, "Los auroros"; Gris (coord.), Los auroros; Rocamora, Los auroros y Martínez y Narejos, Pasionaria murciana. 


\subsection{Guitarristas}

Formaron el grupo de intérpretes que más conciertos dio, si se unen los conciertos dados en el ámbito teatral y en el del salón (público y privado). Sorprende que dadas las condiciones acústicas del instrumento, más acordes para las salas pequeñas que los escenarios teatrales, el número de conciertos sea tan elevado en estos últimos. Si se observa con detenimiento las fechas de todos conciertos de guitarra, insertas en la anterior Tabla 5.1, se deduce que abarcaron $\operatorname{los}$ años 1859 a 1886 , hecho que indica que la popularidad de la guitarra fue decreciendo a medida que avanzó el siglo.

La nómina de guitarristas eleva al célebre Julián Arcas al podio de los que más frecuentaron Murcia ${ }^{74}$. Durante sus estancias en la ciudad, Arcas solía actuar en varios salones y teatros de la ciudad a su paso por Murcia. Por ello, a la relación arriba indicada de conciertos en los teatros, habría que sumarle otras actuaciones en salones de diversas sociedades recreativas y cafés públicos, de los que hablaré posteriormente.

No he hallado datos sobre la programación de todos ellos. El siguiente cuadro muestra un resumen de las piezas que interpretó (sólo o con su hermano Manuel Arcas, también guitarrista) en los diferentes teatros de Murcia:

Tabla 5.2. Obras interpretadas por Julián Arcas en los teatros murcianos (1859-1881)

Cuando se especifica "a dos guitarras" debe entenderse: interpretado conjuntamente por Julián y Manuel Arcas

\begin{tabular}{|c|c|c|}
\hline & Obras & Fecha \\
\hline \multirow[t]{3}{*}{ Fantasías } & $\begin{array}{l}\text { Gran fantasía sobre un tema de la } \\
\text { ópera El pirata }\end{array}$ & $23-12-1859$ \\
\hline & $\begin{array}{c}\text { Fantasía sobre motivos } \text { de } \\
\text { Trovattore }\end{array}$ & $\begin{array}{l}29-06-1866 \\
18-07-1869\end{array}$ \\
\hline & $\begin{array}{l}\text { Fantasía sobre motivos de la ópera } \\
\text { Traviata }\end{array}$ & $18-07-1869$ \\
\hline \multirow{6}{*}{$\begin{array}{l}\text { Sinfonías y } \\
\text { otras piezas } \\
\text { sobre temas } \\
\text { operísticos }\end{array}$} & $\begin{array}{l}\text { Gran sinfonía de la ópera Norma, a } \\
\text { dos guitarras }\end{array}$ & $18-07-1869$ \\
\hline & Cuarteto y motivos de Rigoletto & $\begin{array}{l}18-07-1869 \\
28-01-1881\end{array}$ \\
\hline & $\begin{array}{l}\text { Julián Arcas (arr.), "Gran sinfonía de } \\
\text { la ópera Semíramis" }\end{array}$ & $\begin{array}{l}29-06-1866 \\
28-01-1881\end{array}$ \\
\hline & $\begin{array}{l}\text { Julián Arcas (arrg.), Gran sinfonía de } \\
\text { la ópera Semíramis }\end{array}$ & $\begin{array}{l}18-07-1869 \\
28-01-1881 \\
\end{array}$ \\
\hline & Miserere del Trovador & \multirow{2}{*}{$\begin{array}{l}29-01-1881 \\
29-01-1881\end{array}$} \\
\hline & Serenata de la ópera Fausto & \\
\hline Variaciones & $\begin{array}{l}\text { "Grandes variaciones sobre motivos } \\
\text { tiroleses" }\end{array}$ & $\begin{array}{l}23-12-1859 \\
29-01-1881\end{array}$ \\
\hline \multirow{2}{*}{$\begin{array}{l}\text { Populares } \\
\text { españolas y } \\
\text { aires } \\
\text { nacionales }\end{array}$} & La $\begin{array}{c}\text { Rondeña, fantasía de aires } \\
\text { nacionales }\end{array}$ & $\begin{array}{l}23-12-1859 \\
29-06-1866 \\
\text { y } 18-07-1869\end{array}$ \\
\hline & Jota Aragonesa & $\begin{array}{l}23-12-1859 \\
29-06-1866\end{array}$ \\
\hline
\end{tabular}

${ }^{74}$ Para una visión sobre los guitarristas españoles del siglo XIX, véase: Suárez Pajares, "Guitarra. Siglo XIX”, pp. 104-108. Los estudios sobre Julián Arcas son, entre otros: Suárez Pajares, "Julián Arcas", pp. 3344-3368; Suárez y Rioja, El guitarrista; Rioja, "El guitarrista”; Rioja, "Julián Arcas”, así como el de Suárez, "Julián Arcas". 


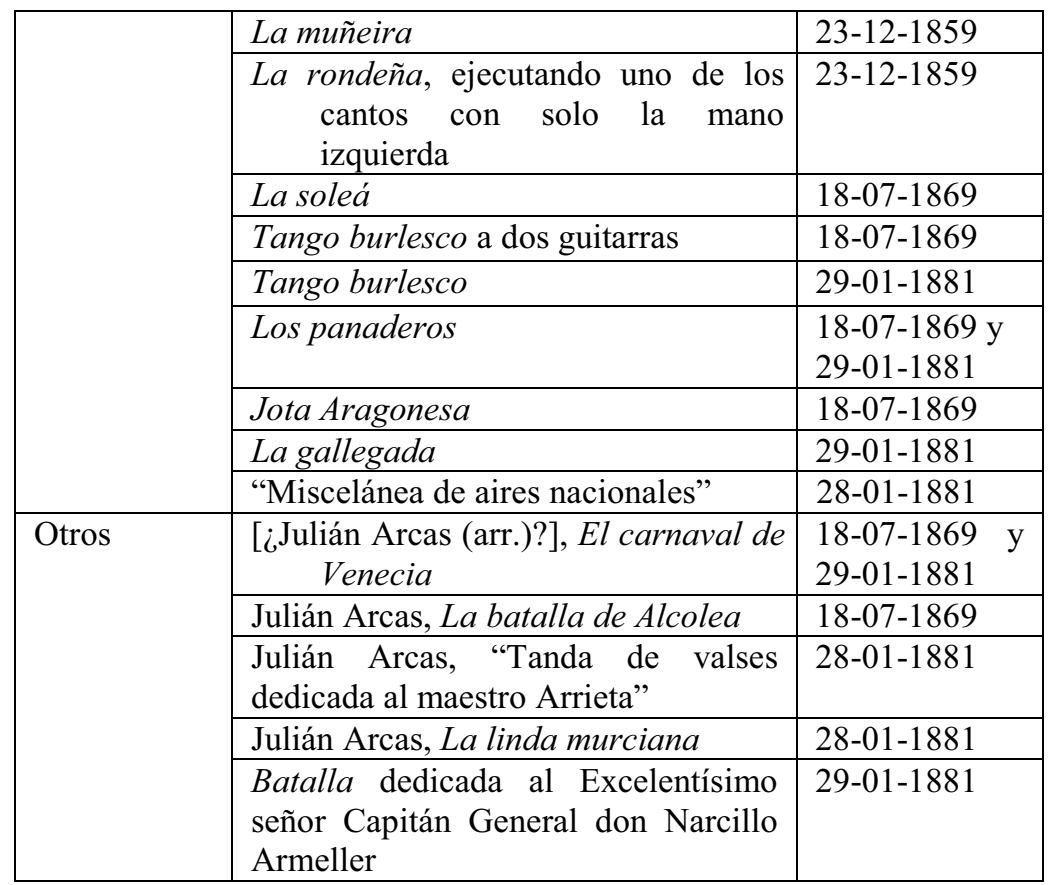

Si comparamos los datos de esta tabla con los aportados en otros estudios sobre el almeriense, se observa que eran obras frecuentemente interpretadas por Arcas ${ }^{75}$. Destaca La linda murciana, composición creada por Julián Arcas expresamente para la ocasión.

Los programas del resto de guitarristas (solos o acompañados) que actuaron en los teatros murcianos no fueron muy diferentes. El de Federico Cano, hijo del célebre Antonio Cano, que actuó en el salón de descanso del Teatro de los Infantes en septiembre de 1866, constó de unas "Variaciones sobre un tema de Himmel", una Gallegada, una "Fantasía sobre un motivo de Meyerbeer" y una Jota aragonesa (Véase Apéndice 5.1) 76 . Al cotejarlo con las actuaciones de otros guitarristas en salones de sociedades recreativas el resultado es el mismo. José Rivera, por ejemplo, actuó en septiembre de 1883 en el Teatro de la Sociedad Apolo. Las obras interpretadas fueron: "Gran trémolo. El delirio de Rossellen" y "Colección de melodías en forma de fantasía sobre motivos de óperas célebres", en la primera parte; fantasía Recuerdos de Cádiz, Gallegada y Tango burlesco, en la segunda; y, El carnaval de Venecia, "Preludios sobre un tema de El trovador", "Aria de la gitana de El Trovador", varias piezas bailables (no especificadas) y Malagueñas y Peteneras, en la tercera ${ }^{77}$.

Resta mencionar que los conciertos de guitarristas apenas se reseñaron y, desde luego, no por especialistas.

${ }^{75}$ Compárese, por ejemplo, el programa que dio en diciembre de 1858 en el monasterio El Conventico de Málaga: Rioja, "El guitarrista", p. 77.

${ }^{76}$ En esta ocasión, le acompañaron al piano y armonio los murcianos Juan Diego Manresa, José Quercop y [¿José?] Egea.

${ }^{77}$ La Paz de Murcia, XXVI (1883), nº 7719, 7 septiembre, p. 1. 


\subsection{Conciertos de varios instrumentistas}

conjuntamente.

En ellos intervinieron diferentes instrumentistas alternándose y/o actuando

Eloísa D’Herbil actuó en el Teatro Romea en julio de 1871, junto al violinista genovés Agostino Robbio, a quien la prensa lo anunciaba como discípulo de Paganini ${ }^{78}$. Se trata, por tanto, de un concierto mixto, en el que ambos intérpretes ofrecieron obras por separado y juntos. Además, D'Herbil cantó una Habanera y una Malagueña que ella misma había arreglado. Las obras instrumentales interpretadas por ella fueron el Quinto Concierto de $\mathrm{Hertz}^{79}$ y la fantasía para piano Jerusalem, de Gottschalk; las interpretadas por Robbio fueron: una fantasía titulada Souvenirs de Bellini y Gran vals diabólico para violín solo. Juntos tocaron un "Dúo para violín y piano sobre motivos de Guillermo Tell y un "Gran dúo de variaciones concertantes para violín y piano" (no constan autores).

El guitarrista lorquino Pedro Paredes, asiduo de los círculos musicales de Murcia, ofrecieron un concierto en marzo de 1886 junto a los murcianos José Palazón (guitarra), Sixto Hernández (violín) y José Solano (piano). No actuaron conjuntamente, salvo el violín y el piano. El programa se desarrolló a base de fantasías, malagueña, valses y dos obras de Antonio Cano, Polca y El delirio, entre otras.

Siguiendo la trayectoria cronológica, hay que mencionar los dos conciertos de la violinista alemana Clara Swchartz, "discípula del famoso Joachim" y el violonchelista murciano Agustín Rubio celebrados en el Teatro Romea en marzo de $1893^{80}$. Les acompañó al piano y armonio el murciano Antonio Puig. Actuaron por separado, a excepción del acompañamiento al piano para el violín y el violonchelo. En la pieza final interpretaron conjuntamente un Cuarteto para violín, violonchelo, armonio y piano de Bring Conrg ayudados por el pianista murciano Vicente Espada (véase Apéndice 5.1). Según la prensa, "en ninguno de los dos [conciertos] ha habido tanto público como debía esperarse" 81 .

El programa del recital fue interesante por inclusión de repertorio compuesto por murcianos. Se interpretaron un buen número de piezas del propio Agustín Rubio (Romanza, Arlequín, Adagio, Estudio de concierto y Sevillanas) así como otras de

78 Procedían de Madrid y, según La Correspondencia de España, D’Herbil y Robbio iniciaban en Murcia una gira por "el mediodía de España": La Correspondencia de España, XXII (1871), n 4963, 29 junio, p. 2.

${ }^{79}$ En el programa que publicó La Paz de Murcia no aparecen los nombres de los compositores. Sin embargo, he rastreado los programas de otros conciertos ofrecidos por D'Herbil en la prensa nacional encontrando algunas similitudes. El 20 de mayo de 1870, la violinista actuó en el entonces Teatro Nacional de la Ópera (hoy Teatro Real de Madrid) junto a la célebre actriz Matilde Díez. Ejecutó el Quinto concierto para piano de Hertz (así consta en la fuente) y un scherzo compuesto por ella misma. Cantó, además, una Habanera y un Tango: Avisos de Madrid, CXII (1870), nº 138, 20 mayo, p. 4.

${ }^{80}$ Diario Oficial de Avisos de Madrid, CXXXVI (1893), nº 59, 28 febrero, p. 3. Sobre Agustín Rubio Sánchez volveré más adelante.

${ }^{81}$ El Diario de Murcia, XV (1893), n 5878, 14 marzo, pp. 1-2:1. A pesar de que, según El Diario de Murcia, XV (1893), no 5880, 16 marzo, p. 3 se programó un tercer concierto. No tengo constancia de su realización. Con posterioridad, actuaron en Alicante, Lorca y Cartagena: El Diario de Murcia, XV (1893), $\mathrm{n}^{\text {os }} 5885,22$ marzo, p. 3; 5896, 2 abril, p. 3; 5898, 6 abril, p. 2. 
Tchaikovsky y Popper. La violinista tocó Beethoven (Romanza en Fa, op. 50), Brahms (Danza Húngara) y Wieniawski, entre otros; mientras que Puig ejecutó dos obras para armonio del murciano Antonio López Almagro (Andante cantábile y Zambra).

Resta mencionar el concierto del guitarrista invidente Jerónimo Fuster y la pianista Matilde Ros junto a la compañía de zarzuela de Pablo Gorgé Soler. En el primer intermedio interpretaron Paragraph III y El Carnaval de Venecia y, en el segundo, "Variaciones sobre Lucia" y Aires españoles.

\subsection{Formaciones de cámara}

La formación de cámara más importante que actuó en Murcia durante el periodo estudiado fue la Sociedad de Sextetos de Madrid, dirigida por José Vicente Arche ${ }^{82}$. Estuvo integrada por Ibarguren (primer violín), Lizarralde (segundo violín), el murciano Carlos Beltrán (viola), Mateo Espinosa de los Monteros Jiménez (violonchelo, discípulo del célebre Cesare Augusto Casella), Vicente Carvajal (contrabajo) y Carlos Sobrino (piano) ${ }^{83}$. Hay documentados nueve conciertos en el Teatro Romea en diversas fechas de los años 1883 (cinco de ellos) y 1884 (los restantes cuatro). Comenzaré analizando los cinco primeros, correspondientes a los meses de abril y mayo de $1883^{84}$.

En líneas generales, se pueden establecer algunas pautas sobre la estructura de todos los conciertos. Cada programa se dividió en tres partes; comenzando por una obertura de ópera o una sinfonía propiamente dicha. A ésta le seguían ${ }^{85}$ : en la primera parte, una pieza de corte romántico y una obra de inspiración operística (por ejemplo, una fantasía) o folclórica (Rapsodia Húngara de Listz en el caso del primer concierto); en la segunda parte, un fragmento de los clásicos Haydn, Mozart y Beethoven (por ejemplo, un movimiento de sonata o cuarteto) y una fantasía operística; finalmente, en la tercera parte, a la sinfonía u obertura inicial le seguía una pieza de autores españoles y dos danzas

82 José Vicente Bermejo Arche (1829-?) fue violinista, director y compositor. Formó parte de las orquestas de los teatros más importantes del momento, entre ellos el Teatro Real y el Teatro de la Zarzuela. Fue socio fundador de la Sociedad de Conciertos de Madrid y de la Sociedad Artístico-Musical de Socorros Mutuos. En ambas ocupó diversos cargos, algunos de los cuales fueron directivo. En 1880 dirigió el segundo de los conciertos de esta sociedad, en sustitución de Mariano Vázquez. Como director del Sexteto Arche, creados en los primeros años de la década de los ochenta, ofreció innumerables recitales por diversos puntos de la geografía española y portuguesa, entre otros. Fue autor de dos sinfonías, varias zarzuela, fantasías, adaptaciones, potpurrís y piezas bailables: Sobrino, "Vicente Bermejo", pp. 847-848.

${ }^{83}$ La Paz de Murcia, XXVI (1883), nº 7621, 22 abril, p. 1. La misma formación, que recorrió Galicia, Portugal, Santander y otras ciudades del Norte de España entre los meses de mayo a octubre de 1882, mencionan a Aguirre como pianista: Crónica de la Música, V (1882), n ${ }^{\text {os }} 192,24$ mayo, p. 6 y 211, 4 octubre, p. 7. Véase también García Caballero, La vida musical, pp. 218-219 y García Segura, Músicos, p. 482.

${ }^{84}$ La formación llegó a Murcia con el propósito de ofrecer tres conciertos $(26,28$ y 29 de abril de 1883) y proseguir su gira por Lorca, Águilas y otras poblaciones cercanas: La Paz de Murcia, XXVI (1883), $\mathrm{n}^{\circ}$ 7615, 19 abril, p. 1. Sin embargo, después de actuar en Murcia la formación se desplazó a Lorca para regresar más tarde al Teatro Romea, donde actuaron en dos ocasiones más ( 2 y 3 de mayo de 1883). El músico Adolfo Gascón, propietario de un famoso almacén de música de Murcia, prestó un piano para la ocasión: La Paz de Murcia, XXVI (1883), nº 7624, 29 abril, p. 1.

${ }^{85}$ Excepto en el tercer concierto que se interpretó la Cuarta Polonesa de Concierto de Pedro Miguel Marqués (véase Apéndice 5.1). 
(valses y gavotas, entre otras). Esta estructura, muy ágil en la variedad de estilos y composiciones, abarcó un amplio periodo de la historia de la música: desde Mozart, Haydn, Beethoven y Boccherini hasta llegar a los románticos, tanto españoles como extranjeros. Por supuesto, entre ellos también figuraron los habituales compositores de ópera Verdi, Bellini, Meyerbeer y Gounod. La siguiente Tabla 5.3 muestra un resumen de las obras:

Tabla 5.3. Obras interpretadas por el Sexteto Arche en el Teatro Romea de Murcia (1883)

Las fuentes documentales pueden consultarse en el Apéndice 5.1.

\begin{tabular}{|c|c|c|}
\hline Tipo & Obras & Fecha \\
\hline \multirow{21}{*}{$\begin{array}{l}\text { Oberturas operísticas y } \\
\text { piezas inspiradas en } \\
\text { óperas }\end{array}$} & Auber, La Part du dable, obertura & $2-05-1883$ \\
\hline & $\begin{array}{c}\text { Bellini, Fantasía sobre motivos de la ópera } \\
\text { Puritanos }\end{array}$ & $28-04-1883$ \\
\hline & [Donizetti], Romanza de La Favorita & $2-05-1883$ \\
\hline & $\begin{array}{l}\text { Donizetti, Fantasía sobre motivos de la ópera } \\
\text { Poliutto }\end{array}$ & $3-05-1883$ \\
\hline & Gevaert, Le Billet de Margaritte, obertura & $26-04-1883$ \\
\hline & Gevaert, El diablo en el molino, obertura & $3-05-1883$ \\
\hline & Herold, Zampa, obertura & $28-04-1883$ \\
\hline & $\begin{array}{l}\text { Meyerbeer, Gran Fantasía sobre motivos de la } \\
\text { ópera Roberto el Diablo }\end{array}$ & $26-04-1883$ \\
\hline & Meyerbeer, Gran Fantasía de la ópera Africana & $28-04-1883$ \\
\hline & Meyerbeer, Fantasía sobre motivos de Dinorah & $29-04-1883$ \\
\hline & Meyerbeer, Primera Marcha de las Antorchas & $2-05-1883$ \\
\hline & Pedrotti, Tutti in Maschera, obertura & $3-05-1883$ \\
\hline & Petrella, Ione, obertura & $28-04-1883$ \\
\hline & Suppè, Poeta y aldeano, obertura & $26-04-1883$ \\
\hline & Suppé, Paragraph III, obertura & $29-04-1883$ \\
\hline & Thomas, Mignon, obertura & $28-04-1883$ \\
\hline & Thomas, Sueños de una noche de verano, obertura & $29-04-1883$ \\
\hline & Thomas, El carnaval de Venecia, obertura & $2-05-1883$ \\
\hline & $\begin{array}{l}\text { Verdi, Gran Fantasía sobre motivos de la ópera } \\
\text { Macbeth }\end{array}$ & $29-04-1883$ \\
\hline & Verdi, Fantasía sobre motivos de la ópera Aida & $2-05-1883$ \\
\hline & Verdi, Recuerdos de la ópera Visperas Sicilianas & $2-05-1883$ \\
\hline \multirow[t]{2}{*}{ Obras sinfónicas } & Listz, Rapsodia Húngara & $\begin{array}{l}26-04-1883 \\
3-05-1883\end{array}$ \\
\hline & Saint-Saens, Danza Macabra, poema sinfónico & $3-05-1883$ \\
\hline \multirow{6}{*}{$\begin{array}{l}\text { Composiciones de corte } \\
\text { romántico }\end{array}$} & Bazzini, Plegaria de concierto militar & $28-04-1883$ \\
\hline & Dunkler, Au Bord de la mer, reverie & $2-05-1883$ \\
\hline & Gounod, Serenata & $26-04-1883$ \\
\hline & Gounod, Himno a Santa Cecilia & $3-05-1883$ \\
\hline & Mendelssohn, Canzonetta & $2-05-1883$ \\
\hline & Michelli, Serenata Veneciana & $29-04-1883$ \\
\hline \multirow{8}{*}{$\begin{array}{l}\text { Obras de compositores } \\
\text { españoles }\end{array}$} & Chapí, Meditación de la Fantasía Morisca & 26-04-1883 \\
\hline & Chapí, Serenata de la Fantasía Morisca & $26-04-1883$ \\
\hline & Espadero, Canto del Esclavo (escena americana) & $28-04-1883$ \\
\hline & Espinosa [de los Monteros], Moraima, gavota & $29-04-1883$ \\
\hline & Marqués, Cuarta Polonesa de concierto & $29-04-1883$ \\
\hline & Marqués, Primera Lágrima & $2-05-1883$ \\
\hline & Márquez, Primera polonesa de concierto & $26-04-1883$ \\
\hline & Paganini, Movimiento continuo & $3-05-1883$ \\
\hline \multirow[t]{3}{*}{ Clásicos } & Beethoven, Andante de la Sonata Pastoral & $29-04-1883$ \\
\hline & Boccherini, Minuetto del Quinteto & $29-04-1883$ \\
\hline & Haydn, Andante en Fa \# Mayor & $3-05-1883$ \\
\hline
\end{tabular}




\begin{tabular}{|l|l|l|}
\hline \multirow{4}{*}{ Danzas } & Haydn, Largo Assai, Cuarteto en si menor, op. 71 & $28-04-1883$ \\
\cline { 2 - 3 } & Mozart, Adagio del Cuarteto, Op. 458 & $26-04-1883$ \\
\cline { 2 - 3 } & Mozart, Marcha Turca & $3-05-1883$ \\
\hline & Delahaye, Colombine, minuetto & $3-05-1883$ \\
\cline { 2 - 3 } & Glieger, Regente, gavota & $28-04-1883$ \\
\cline { 2 - 3 } & Gung'l, Amorette Tanze, suite de valses & $26-04-1883$ \\
\cline { 2 - 3 } & Gung'l, Elfen Regen, suite de valses & $2-05-1883$ \\
\cline { 2 - 3 } & Leo Delibes, Vals lento y pizzicato & $28-04-1883$ \\
\cline { 2 - 3 } & Strauss, Bouquet, suite de valses & $29-04-1883$ \\
\hline
\end{tabular}

Como puede apreciarse en la tabla, cada concierto incluyó repertorio diferente y no fue repetida ninguna obra. El corpus más numeroso lo forman las oberturas y obras de inspiración operística, seguido por los compositores españoles, las obras de corte romántico $\mathrm{y}$, finalmente, las de grandes maestros.

Lamentablemente las obras correspondientes a los cuatro conciertos que ofrecieron en 1884 no han sido halladas, salvo la indicación de algunas obras que sugieren un repertorio muy similar o incluso igual al mostrado en la Tabla 5.3. Sí consta, en cambio, que el violinsita Antonio Fernández Bordas actuó junto al sexteto en el segundo de los conciertos ofrecidos en $1884^{86}$.

Los recitales del Sexteto Arche revistieron especial importancia en la ciudad. El director de La Paz de Murcia, Rafael Almazán, pidió expresamente a Julián Calvo que escribiera las críticas para su diario ${ }^{87}$; mientras que Antonio Ramírez lo hizo para $E l$ Diario de Murcia. Sorprende, por tanto, que otros concertistas relevantes no recibieran comentarios especializados en la prensa murciana.

A juzgar por los comentarios de ambos, los conciertos fueron un éxito manifiesto en el aumento de público con cada nueva cita y la adición de dos conciertos más sobre los previstos.

Una de las primeras ideas que, tanto Calvo como Ramírez, ponen de manifiesto es la idoneidad del repertorio. Calvo expresaba así la acertada elección de las obras, especialmente por la incorporación de autores españoles:

[...] La elección de obras ha sido hecha con un tacto exquisito como lo prueba cada uno de los programas y hasta en el orden que se ha guardado, viendo hermanadas la elegante música francesa, con la más severa alemana y con las deliciosas melodías italianas, llenas de pasión y de ternura. Nunca morirán los nombres de Bellini, Bazzini, Petrella y Michell que enlazados a los de Thomas, Herold, Meyerbeer, Haydn, Beethoven, Glieger, Strauss, Suppe y Leo-Delibes, sus esclarecidos nombres en la historia del arte serán siempre timbre de inmarcesible gloria. Pero al escribir las anteriores líneas he experimentado la más grata emoción y creo, discreta lectora, que

${ }^{86}$ El orensano interpretó Playera y Zapateado de Sarasate. El Sexteto Arche, aunque en formación de quinteto, participó en una Misa celebrada en el Catedral en la que se interpretaron obras de Beethoven (Sonata Pastoral) y Haydn: Julián Calvo, "Los dos conciertos últimos", La Paz de Murcia, XXVI (1883), $\mathrm{n}^{\circ} 7629,6$ mayo, p. 1 .

${ }^{87}$ Julián Calvo, "Los conciertos del sexteto del maestro señor don José Vicente Arche, "La Paz de Murcia, XXVI (1883), no 7623, 28 abril, p. 1, 4: 1. La prensa nacional se hizo eco de los éxitos del sexteto Arche en Murcia en sus diversas actuaciones: El Liberal, V (1883), nº 1395, 12 mayo, p. 3; La República, I (1884), no 83, 7 mayo, p. 3 y El Día, (1884), nº 1432, 6 mayo, p. 2. 
sentirás la misma satisfacción siendo española y con más motivo si eres murciana. Dime, ¿no es para sentir un legítimo orgullo al ver junto a los ilustres nombres antes citados lo de Marques, Chapí, Espadero y el de nuestro querido paisano don Gaspar Espinosa? $\left({ }^{88}\right)$ ¿no es de admirar el ver estos nuestros ya célebres compatriotas ocupando un lugar digno entre los maestros de gran reputación en toda Europa y compartiendo con ellos los aplausos? $[\ldots]^{89}$.

Ramírez afirmaba que, fuera de los conciertos de la Sociedad Santa Cecilia, "era la primera vez que nuestro público se congregaba en nuestro bello teatro para oír música, exclusivamente música, sin canto, sin declamación, sin decoraciones, sin otro aliciente de ninguna clase" $" 90$. En otras palabras, se inauguraba el recital en el sentido actual del término y enmarcado en un teatro como sinónimo de sala de conciertos; algo que para Calvo tampoco pasó desapercibido: "no solo por lo bien que tocan sino por ser los primeros que han traído a Murcia esta nueva vivificación musical"91.

Los beneficios para aficionados y profesionales murcianos son obvios para estos críticos: educan al público y enseñan al músico. Ambos coinciden en la idea de que estos conciertos contribuyeron a inculcar la necesidad de establecer la enseñanza musical en los niveles más básicos de la educación: "la educación artística debe completar a la educación física, intelectual y moral”, escribía Ramírez, mientras que Calvo expresaba:

[...] Estamos persuadidos de que estos grandes trabajos serán beneficiosos tanto a cuantos aficionados estén dedicados al estudio de la música, no dudando que pronto fructificará el gusto y la propaganda más lata tanto en lo que incumba al conocimiento de obras que merecen un estudio meditado, cuanto en lo que sea concerniente al desarrollo de la enseñanza.

Respecto al primer punto tenemos la obligación cuantos estamos dedicados a este gran arte de dar a conocer, conforme a las fuerzas de cada uno, la buena música, siendo de advertir que de algún tiempo a hoy se ha trabajado mucho y con muy bien éxito en pro de lo que dejamos consignado, habiéndose dado a conocer un gran repertorio de las obras más selectas y nuevas que se ejecutan en Madrid, sintiéndose tan saludable reacción hasta en el género religioso donde las obras de los maestros Eslava, Mercadante, Fernández Caballero, P. Hernández, Calahorra, Chueca y algunos fragmentos de las composiciones de Mozart, Durant, Haydn, Rossini y otras, son oídas con frecuencia $[\ldots]$.

El segundo punto a que hacíamos referencia es sobre lo conveniente que sería la enseñanza de la música en los establecimientos oficiales de niños de ambos sexos, así como lo útil que podría ser el fomento de orfeones y de las bandas militares que en los pueblos se crearan $[\ldots]^{92}$.

\footnotetext{
${ }^{88}$ [Nota al pie original de Julián Calvo]: “El maestro Espadero es natural de La Habana".
}

${ }^{89}$ Julián Calvo, "Los conciertos segundo y tercero por el sexteto del maestro Arche", La Paz de Murcia, XXVI (1883), $\mathrm{n}^{\circ}$ 7626, 2 mayo, p. 1. Obsérvese que Julián Calvo dirige la crítica a las mujeres lectoras.

90 Antonio Ramírez, "Primer concierto de la sociedad de Sextetos dirigida por el señor Arche", El Diario de Murcia, V (1883), n 1262, 298 abril, pp. 1-2: 2.

91 Julián Calvo, “Los dos conciertos últimos”, La Paz de Murcia, XXVI (1883), no 7629, 6 mayo, p. 1.

${ }^{92}$ Calvo, "Los dos conciertos últimos", p. 1. 
La ausencia de la educación musical en la enseñanza general básica es un tema crucial en las relaciones entre música y sociedad en el siglo XIX español ${ }^{93}$. En Murcia, como en muchas otras ciudad, buena parte de la formación musical recayó en la sociedades recreativas (e instructivas) de la ciudad, como veremos más adelante. La eclosión de éstas durante los años ochenta y la programación de conciertos de este tipo abrieron las fronteras musicales de Murcia: los espacios de actuación se diversificaron y multiplicaron, y el público pudo entrar en contacto con el repertorio centroeuropeo y la música española contemporánea. También en esta década y en la siguiente, se produjo un fuerte impulso en el campo de la creación musical murciana. Varios teatros acogieron estrenos de zarzuelas, entre otras obras, realizadas por compositores de Murcia.

La recepción en Murcia de las obras de los grandes maestros centroeuropeos interpretados por el Sexteto Arche fue buena. Ramírez escribía: "La dos obras clásicas de Haydn y de Beethoven ejecutadas por la cuerda sola, fueron bien interpretadas y oídas con un silencio que podríamos calificar de respetuoso. Eran los dioses mayores del Olimpo musical los que tenían la palabra"94.

Por otro lado, el sexteto Arche marcó la impronta de la música de cámara en Murcia. Las sociedades recreativas de la ciudad formaron, a semejanza de esta formación, otros sextetos que desarrollaron una notable difusión. Ejemplo de ello es el concierto organizado por los arrendatarios del Teatro Romea para celebrar la creación de la orquesta del citado coliseo (6-07-1884) ${ }^{95}$. Además de la formación orquestal, colaboraron la Banda Municipal y varias formaciones instrumentales (un quinteto y un sexteto) cuyos músicos pertenecían a la sociedad Santa Cecilia. En este concierto de presentación de la recién creada orquesta del Teatro Romea se interpretó la Sinfonía $n^{\circ} 1$ en Do Mayor, op. 21 de Beethoven y se anunció el "Quinteto $\mathrm{n}^{\circ} 2$ para instrumentos de cuerda y piano" de Haydn, aunque parece que en su lugar se interpretó una sinfonía de Aida arreglada para quinteto. Además se ejecutó una Polonesa de Julián Calvo para sexteto instrumental y una Marcha Triunfal para orquesta y banda (ver Apéndice 5.1).

\subsection{Cantantes}

Se trata del conjunto de conciertos más numeroso, junto con los guitarristas. La mayor parte de ellos se concentraron en las décadas ochenta y noventa y, en líneas generales, las voces más usuales fueron las de soprano y barítono (véase Tabla 5.1).

La nómina de artistas está formada mayoritariamente por artistas extranjeros (Amalia Pellizzari, Jeanne de Valfort, Bianca Montessini, Napoleón Verger, Linda Díaz, Vittoria Domenici y Emma Nevada), así como por los murcianos Mariano Padilla (a quien trataré ampliamente en un capítulo posterior), Rafael Rex Torrano y Antonio Noguera (ver Apéndice 5.1).

\footnotetext{
${ }^{93}$ Casares, “Conceptos fundamentales”, pp. 19-21.

${ }^{94}$ Antonio Ramírez, "Los dos últimos conciertos”, El Diario de Murcia, V (1883), n 1264, 1 mayo, p. 2.

95 Recordemos que el arriendo del Teatro Romea desde julio de 1884 a junio de 1886 recayó en una empresa formada para esta finalidad en el seno de la sociedad artístico-musical Santa Cecilia; promotores, por otro lado, de la creación por oposición pública de la mencionada orquesta (Véase Capítulo 2).
} 
Por norma general, otros cantantes se unían al artista principal, permitiendo la interpretación de dúos y/o tríos que aportaban más variedad al espectáculo. En el caso de Napoleón Verger, por ejemplo, le acompañaron la valenciana Amparo Romaguera (soprano), Carmen Pérez de Isaura (soprano) y Leandro Valencia (barítono) (julio de 1889) ${ }^{96}$. Además, solían ser acompañados por los pianistas de la ciudad, entre otros instrumentistas. En el recital de Linda Díaz, primera tiple del Teatro Academia de Nueva York $^{97}$, intervinieron Antonio Puig (con obras como el Scherzo $n^{\circ} 2$ en Si bemol menor, op. 31 y Polonesa, de Chopin; y, Primera escena campestre y "Fantasía sobre Faust" de Dámaso Zalbalza) y el violinista Baldomero Navarro (Adiós a la Alhambra de Jesús de Monasterio) (véanse más ejemplos en el Apéndice 5.1).

Como cabe esperar, casi todos los programas estuvieron compuestos a base de arias de ópera (Verdi, Rossini, Donizetti y Bellini, entre otros) y, en menor medida, zarzuela y canción (Tosti, Serrano, Arditi y Álvarez, por ejemplo).

Cuando los conciertos no se realizaban entre los actos de las representaciones teatrales, solían mantener una estructura divida en dos o tres partes, cada una de las cuales empezaba por una obertura o sinfonía operística a cargo de la orquesta o, en su defecto, arreglada para piano o para pequeñas formaciones instrumentales ${ }^{98}$. A continuación se interpretaba un número variable de entre cinco y siete piezas musicales.

Las funciones benéficas protagonizadas por los murcianos Padilla, Rex Torrano y Antonio Noguera contaron con más cantantes e instrumentistas que los recitales habituales e incluyeron elementos no musicales (lecturas de poesías y representaciones de obras teatrales breves).

En el concierto de Padilla, celebrado en febrero de 1885 se interpretó a Haydn y una Gavota del murciano Ángel Mirete, escrita para la ocasión y dedicada a Mariano Padilla $^{99}$; en el del barítono Rafael Rex Torrano, se ejecutaron obras como el Adagio y Rondó de la Sonata Patética, $n^{\circ} 8$ en do menor, op. 13 de Beethoven, el primer movimiento del Concierto $n^{\circ} 1$ para violín de Charles Auguste Bériot o el Cuarteto para cuerdas de Pedro Tintorer, entre otras; y, en el del bajo Antonio Noguera, se pudo escuchar el tercer movimiento del Concierto para piano $n^{\circ} 1$ en sol menor, op. 25 de Mendelssohn (véase Apéndice 5.1). Casi todas estas obras fueron interpretadas por músicos profesionales, aunque resultan minoritarias frente al repertorio procedente de la ópera y la zarzuela, muestran el paulatino interés de los músicos por mostrar un género alternativo al teatro en Murcia.

Considerando los comentarios de la prensa de manera global, se deduce que los conciertos de los cantantes tuvieron un éxito relativo. Hay ejemplos de fracasos

\footnotetext{
${ }^{96}$ Amparo Romaguera era valenciana. Estudió en el Conservatorio de esta ciudad hasta que ingresó en 1885 en el Conservatorio Nacional de Música: La Época, XXXVII (1885), nº 11970, 14 noviembre, p. 3.

${ }^{97}$ La Paz de Murcia, XXXIII (1890), nº 11122, 6 septiembre, p. 4.

${ }^{98}$ La obertura de Il Barbiere di Siviglia, con la que se dio comienzo al recital de Bianca Montessini, por ejemplo, fue interpretado por un violín, una flauta y un piano (véase Apéndice 5.1).

${ }^{99}$ La fuente periodística menciona: "Andante y minueto del séptimo quinteto, arreglado para cuerdas" de Haydn y, aunque se mencionan los nombres de los intérpretes no he podido constatar con certeza los instrumentos de todos ellos. Desconozco, por tanto, cuál es la pieza original de Haydn sobre la que se basó el arreglo (véase Apéndice 5.1).
} 
estrepitosos, como el "desconcierto", según la prensa, de la soprano Vittoria Domenici en el teatro Circo de Villar y en pleno mes de agosto de $1894^{100}$. A pesar de ello, se programó un nuevo concierto de Domenici en uno de los salones del Teatro Romea unas semanas más tarde ${ }^{101}$. Probablemente para llamar la atención del público, se anunció que el concierto tendría un fin benéfico y que participaría el sexteto de bandurrias y guitarras de la ciudad. La siguiente cita nos explica el resultado:

Aun cuando en el concierto del domingo no hubo ingreso suficiente para abonar los gastos, gracias a las precauciones de los arrendatarios de Romea se cubrieron casi la mayor parte de los gastos y no sucedió como otras veces que hayan estado a pérdidas, los que solo están a las ganancias.

Así debía suceder siempre, pues las dependencias y sobre todo las que hacen gastos, no cobran más que cuando ganan las empresas ${ }^{102}$.

\subsection{Otros conciertos}

Los teatros murcianos acogieron no sólo conciertos de instrumentos relevantes en el repertorio, sino también rondallas, estudiantinas, espectáculos con instrumentos raros o infrecuentes y otras curiosidades.

En febrero de 1863 actuó el arpista Vincenzo Bruncioli [sic], "imitador y célebre en los cantos de los pájaros"103. La imitación de sonidos con instrumentos musicales aparece en varios de los conciertos que he reconstruido. En la "Gran Fantasía sobre un tema de la ópera El pirata" interpretada por Julián Arcas en diciembre de 1859 se explicita "se oirán las imitaciones a una caja de música, al fagot y al figle"104. De esta categoría fue el concierto ofrecido por el violista ciego apellidado Cela en enero de 1898. La empresa de la compañía de Juan Espantaleón le contrató para actuar en los entreactos de dos funciones ${ }^{105}$. Solo he hallado una breve indicación sobre la interpretación de una "combinación titulada 'El perro del hortelano"”, ${ }^{106}$. Al parecer, el músico era capaz de

imita[r] diestramente en el violín los cantos de las aves, las voces humanas, los toques militares, las campanas, la despedida de los quintos, la marcha de un tren y otras cosas que demuestran en el ciego Cela mucha habilidad y paciente estudio. Saca de su trabajo efectos graciosos que al público sorprendieron y agradaron $[\ldots]^{107}$.

${ }^{100}$ La Paz de Murcia, XXXVI (1894), nº 12760, 21 agosto, p. 1.

${ }^{101}$ La artista probó suerte en Lorca y Águilas para regresar finalmente a Murcia a principios de septiembre de 1894: La Paz de Murcia, XXXVI (1894), nº 12765, 26 agosto, p. 4.

${ }^{102}$ La Paz de Murcia, XXXVI (1894), nº 12780, 13 septiembre, p. 1.

${ }^{103}$ El Segura, I (1863), no 31, 6 febrero, p. 3.

${ }^{104}$ La Paz de Murcia, II (1859), nº 574, 22 diciembre, p. 4. Véanse más ejemplos en el Apéndice 5.1.

${ }^{105}$ El Diario de Murcia, XX (1898), n $n^{\circ} 7546,15$ enero, p. 2. Actuó durante los días 15 a 17. Además de la fuente citada, véase: El Diario de Murcia, XX (1898), nº 7547, 16 enero, p. 3.

${ }^{106}$ El Diario de Murcia, XX (1898), nº 7546, 15 enero, p. 4.

${ }^{107}$ El Diario de Murcia, XX (1898), no 7548, 17 enero, p. 2. 
De diferentes características fueron los conciertos de los italianos Maggiocco (flauta), Tassara (violín) y Nicora (guitarra) junto al óptico y químico londinense William Walter. Actuaron en dos ocasiones en el Teatro de los Infantes en marzo de 1863. Las funciones comenzaban con un concierto a cargo de los mencionados intérpretes. Las referencias sobre la programación señalan obras como El carnaval de Venecia, una "Fantasía sobre motivos de Lucrezia Borgia" de Alard y una pieza de concierto del flautista y compositor Giulio Briccialdi, titulada Las delicias de la primavera. Tras el recital, tenía lugar una exposición de "cuadros disolventes" producidos por el "Gran Polyscopio Universal" ${ }^{108}$. Las siguientes líneas describen en qué consistía:

\section{[...] GRAN POLYSCOPIO UNIVERSAL o los prodigios de la óptica por medio de la luz eléctrica,}

produciendo la descripción general del mundo antiguo y moderno, refiriéndose a la historia, a la religión, a las costumbres de las naciones, etcétera, etcétera. Las principales ciudades del universo y monumentos artísticos que en ellas se encuentran, como también escenas de doble efecto, invierno y verano, de noche y de día, de calma y de borrasca, cuadros cómicos burlescos y mitológicos.

Este POLYSCOPIO, compuesto de elementos sacados de las salas politécnicas de Londres y de París, tiene el privilegio de ofrecer al público una transformación continua, lenta o rápida, de un gran número de cuadros de variedad inesperada, cuya disposición hará el efecto más agradable y bonito $[\ldots]^{109}$.

Al igual que los anteriores, los espectáculos del catalán Paulino Blanch pueden considerarse conciertos espaciales. Procedente de Valencia, Blanch actuó en el Teatro Romea en febrero de 1876 y en septiembre de $1883^{110}$. Los espectáculos de este músico (denominado en la prensa como "copólogo") ofrecían una combinación de ejercicios de adivinación, prestidigitación y escamoteo para concluir con la interpretación de fragmentos concertantes y arias operísticas en una armónica de cristal compuesta de treinta y dos copas, con la que interpretó fragmentos de diferentes óperas.

Los conciertos de rondallas, estudiantinas y otras formaciones con instrumentos de cuerda pulsada son relativamente numerosos. En 1883 y 1884 actuaron, respectivamente, la célebre Estudiantina Española en el Teatro Romea y la familia Box con una formación de dos guitarras y una bandurria en el Teatro Circo de la Rambla ${ }^{111}$.

La Estudiantina Española fue una formación instrumental de estudiantes universitarios integrada por guitarras, bandurrias, laúdes, violines, flautas traveseras, castañuelas y panderetas. Al menos en 1883 eran dirigidos por Fernando Poveda e Isaac

${ }^{108}$ La Paz de Murcia, X (1867), nº 2828, 16 marzo, p. 3. Según La Correspondencia de España, XVIII (1865), no 2566, 26 mayo, p. 3, el conjunto había actuado en varios teatros de España, entre ellos el Teatro Romea de Barcelona.

${ }^{109}$ La Paz de Murcia, X (1867), nº 2828, 16 marzo, p. 3.

${ }^{110}$ Según La Paz de Murcia, XIX (1876), nº 5595, 19 febrero, p. 1, Blanch gozaba de una notoria fama como atestiguaba la prensa de países como Cuba, Argentina, Chile, Inglaterra, Portugal, Italia, Méjico, Grecia y España.

${ }^{111}$ Como hago constar en el Apéndice 5.1, no tengo datos sobre la programación de los conciertos de la familia Box. 
Vaya y Villa ${ }^{112}$. En el repertorio de sus dos conciertos priman los aires nacionales en formatos como potpurrís, pasodobles, schotis, mazurcas, habaneras, entre otros arreglos para guitarras y bandurrias de fragmentos de zarzuela, variaciones y el típico "Wals por los panderetólogos", es decir, el vistoso y tradicional baile de pandereta ${ }^{113}$.

La afición en Murcia por las orquestas de plectro y púa cobró importancia en la década de los ochenta y, especialmente en 1886, fecha de creación de la formación de guitarras y bandurrias de Manuel Alarcón ${ }^{114}$. Estuvo integrada por seis bandurrias, siete guitarras, dos laúdes y una "octavilla", todos ellos aficionados ${ }^{115}$. Intervinieron en un gran número de funciones teatrales (especialmente en las organizadas por las sociedades murcianas de carácter teatral, como veremos en el Capítulo 6), así como en cafés, bailes, verbenas y serenatas a personajes ilustres.

Las fuentes periodísticas también mencionan un sexteto de guitarras y bandurrias dirigidos por Fernando Verdú, que acompañó a Vittoria Domenici en un concierto en el Teatro Circo Villar en 1894 (véase apéndice 5.1).

En líneas generales, el repertorio de estas formaciones abarcaba numerosos arreglos de ópera y zarzuela, polcas, mazurcas, valses, pasodobles, jotas, habaneras, malagueñas, javeras y tangos, por citar algunos.

Resta mencionar los conciertos de instrumentos infrecuentes como el de ocarina de Zenobio Navarini y el de saxofón de Juan Marcos Mas ${ }^{116}$. Navarini fue el tenor cómico de la Compañía Romana de Opereta y Baile y autor de L'albe, concierto para ocarina y orquesta que ofreció en diversas funciones de enero de 1894.

Juan Marcos y Mas llevó a cabo un programa a base de fantasías de diversas óperas, así como otras de su propia creación, incorporando, además, una fantasía titulada Los Ecos del murciano Gaspar Espinosa de los Monteros.

${ }^{112}$ La Paz de Murcia, XXVI (1883), nº 7532, 11 enero, p. 1. La Estudiantina Española actuó en países como Italia, Suiza y París, donde causó sensación en 1878 (Le Monde Illustré le dedicó la portada del $\mathrm{n}^{\circ}$ 1094, correspondiente al 16 de marzo del citado año).

${ }^{113}$ El Diario de Murcia, V (1883), $\mathrm{n}^{\text {os }} 1182,19$ enero, p. 1.

${ }^{114}$ La creación de rondallas y estudiantinas fue un fenómeno común a otras ciudades españolas. Véase, por ejemplo, las que cita Sancho: Romanticismo, pp. 295-298 en el caso de Valencia.

${ }^{115}$ La Paz de Murcia, XXIX (1886), nº 8975, 23 julio, p. 1.

116 Juan Marcos y Mas fue director de la Banda Municipal de Albacete, según El Diario de Murcia, VII (1885, n 1807,12 marzo, p. 4. 
48 


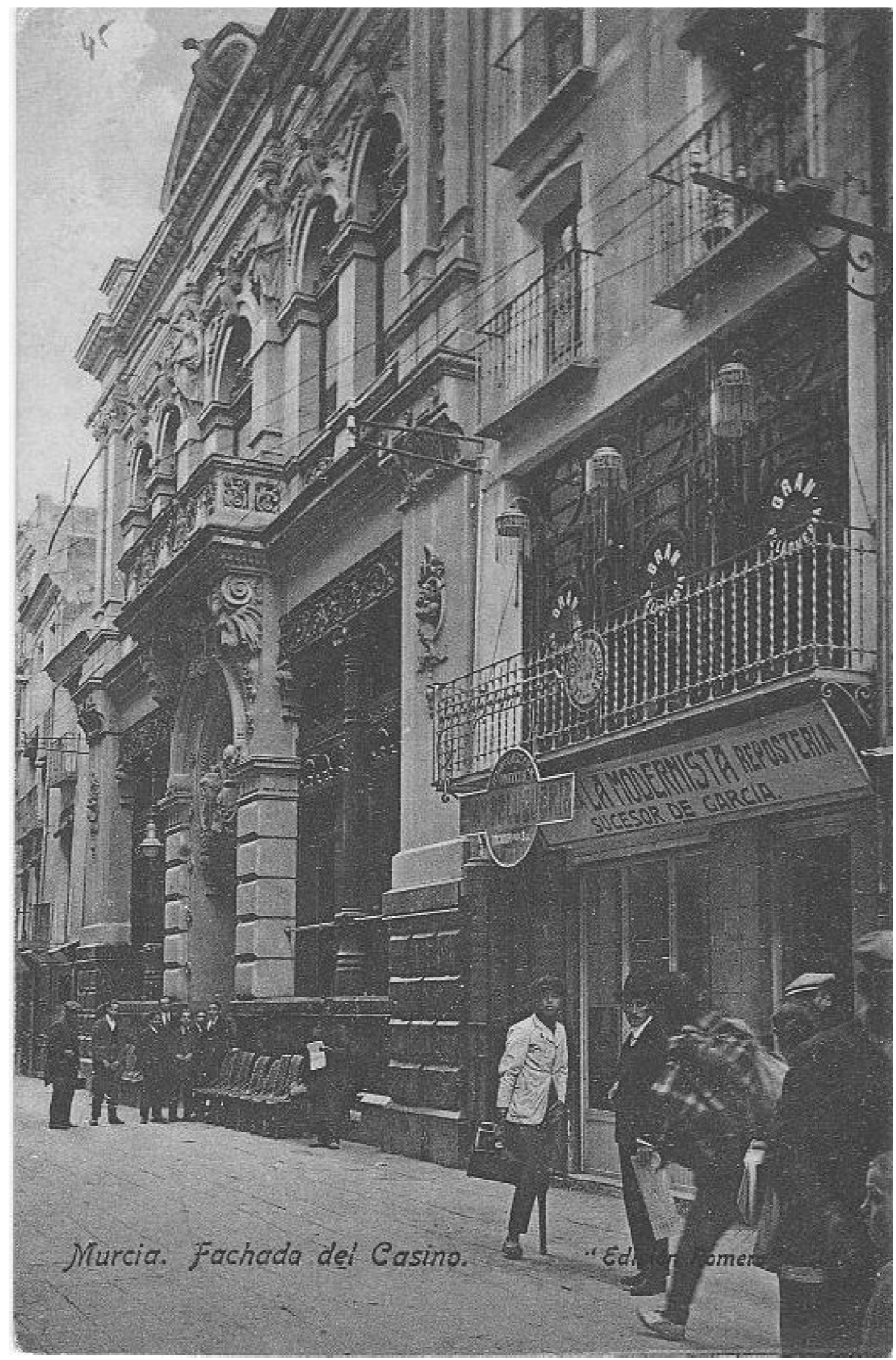

III. Fachada del Casino de Murcia a principios del siglo XX. Edición Romero. Colección particular 


\section{Capítulo 6. Sociedades, escuelas y academias musicales en Murcia durante la segunda mitad del siglo XIX}

\section{La música en las sociedades murcianas de la segunda mitad del siglo XIX}

El asociacionismo fue un fenómeno relevante de la sociedad europea del siglo XIX. En España, la proliferación de asociaciones de todo tipo se observa desde la década de los treinta $\mathrm{y}$, en especial, desde los cuarenta ${ }^{1}$. La fundamentación ideológica del espíritu asociativo se repitió en la prensa murciana en numerosas ocasiones. Por ejemplo, en 1867 se afirmaba en La Paz de Murcia:

\section{[... $1^{\circ}$ El hombre ha nacido para vivir en sociedad.}

$2^{\circ}$ La humanidad se ha desarrollado por asociaciones.

$3^{\circ} \mathrm{A}$ medida que el progreso aumente el patrimonio de los hombres, el número de las asociaciones será mayor y sus resultados más fecundos.

[...] Así como la Humanidad sin la sociedad sería una agrupación de seres y no una suma de facultades, del mismo modo la sociedad sin asociaciones sería un conjunto desordenado, del que no resultarían hechos fecundos, como nunca resultarían fórmulas algebraicas de unas cuantas letras tiradas al acaso.

[...] Reunirse, juntarse, agruparse para producir con los esfuerzos individuales resultados colectivos, esto es casi la sociedad, pero asociarse y colocarse en torno de un núcleo todos los elementos afines, esto es ya la asociación, la cual como idea más especulativa señala un progreso mayor que la sociedad. [... $]^{2}$.

La prensa informaba puntualmente de la fundación de sociedades y les daba publicidad y apoyo cuando necesitaban subvención pública ${ }^{3}$. En Murcia, el asociacionismo como fenómeno general $\mathrm{y}$, en particular, el musical, tuvo su época de esplendor durante la segunda mitad del siglo XIX.

Las asociaciones recibieron numerosos calificativos: liceos, círculos, sociedades, casinos, ateneos, con apelativos como científicos, recreativos, mineros, políticos, teatrales, dramáticos, artísticos, literarios y/o musicales, según su naturaleza. En todas las que he podido documentar se daban al mismo tiempo dos finalidades:

${ }^{1}$ Diversos autores han apuntado como factores de esta eclosión los cambios políticos y sociales transcurridos durante la regencia de María Cristina (1833-1840), entre otros. Véase el número monográfico Sociedades musicales en España. Siglos XIX-XX publicado en Cuadernos de Música Iberoamericana, 8-9 (2001), así como Música Iberoamericana de Salón, coord. José Peñín; AA.VV., "Sociedades", pp. 10651102; Alonso, "Los salones"; Álvarez Cañibano, "Academias"; Díez Huerga, "Las sociedades"; Saavedra y Siemens, "El asociacionismo"; Virgili, "Asociaciones" y Virgili, "El pensamiento".

${ }^{2}$ La Paz de Murcia, X (1867), n 2866, 26 abril, p. 1. Los subrayados en cursiva son originales.

3 Un tal "Homoquidam", en cuatro artículos de 1865, distinguía entre asociaciones "humanas" y "sociales": "las primeras las que contribuyen directamente a las evoluciones de las sociedades, y las segundas las que directamente influyen sobre una clase dada, y reflejan unas en más, otras en menos, la bondad de sus efectos sobre la sociedad entera", La Paz de Murcia, X, 1867, n 2866, 26 abril, p. 1. Dentro de las asociaciones "humanas" distinguirá "guerreras, políticas, religiosas y científicas". Véase: La Paz de Murcia, X (1867), $\mathrm{n}^{\mathrm{os}} 2866,26$ abril, pp. 1-2; 2867, 27 abril, p. 1; 2872, 2 mayo, p. 1; 2879, 9 mayo, pp. 12. 
1. La instrucción como ideal de progreso, que llevaba a fomentar la enseñanza de determinadas materias (entre ellas la música).

2. La diversión y organización del ocio, que convertía a estas sociedades en centros de recreo.

Ambas finalidades, inseparables, me han llevado a estudiar conjuntamente todo tipo de sociedades en este capítulo, aunque en algunos de ellos el elemento educativo fuera predominante y en otras, por el contrario, descara más el carácter lúdico.

En general, se trata de sociedades de corta existencia. Algunas acababan reconvirtiéndose, transformándose o uniéndose a otras de similares intereses cuando el número de los socios descendía o aumentaban sus deudas. Habitualmente, los socios se reunían para recibir clases, conversar, leer la prensa o asistir a conferencias, conciertos o veladas literarias ${ }^{4}$.

Desde el ámbito de la música, este fenómeno contribuyó a dinamizar el panorama musical de Murcia por varios motivos:

1. A través de las asociaciones se introdujo un tipo de repertorio musical que difícilmente tenía cabida en teatros y locales teatrales (Las siete últimas palabras de Haydn y el Stabat Mater de Rossini, por ejemplo).

2. Las asociaciones encauzaron, en muchos casos, la labor creativa de compositores locales que produjeron para estos centros un corpus musical.

3. Las sociedades proporcionaban el espacio adecuado para la actuación de formaciones instrumentales poco usuales en los teatros (cuartetos, quintetos y octetos) y para la difusión del repertorio de cámara de grandes compositores extranjeros (Haydn, Mozart, Beethoven, Menselssohn).

4. Muchos de los músicos integrados en este tipo de sociedades estaban vinculados a la iglesia, a la vida teatral y a la de las orquestas y bandas de música, lo que favorecía la convivencia y los intercambios entre sectores musicales muy variados.

5. Las sociedades promocionaron la enseñanza de la música, como respuesta a las demandas de una sociedad que generó nuevas formas de consumo musical ${ }^{5}$.

6. Las sociedades integraban tanto a músicos profesionales como a diletantes aficionados de medio y alto nivel, entre ellos aristócratas, directores y redactores de periódicos, médicos y escritores.

Salvo excepciones, las asociaciones que trato en este capítulo no tuvieron un carácter exclusivamente musical (éstas fueron, frente a las de cualquier otro tipo, inferiores en número). Algunas se centraron únicamente en el ámbito educativo general.

${ }^{4}$ Muñoz Zielinski, "Lugares 'selectos"”, pp. 241-270 ha trazado recientemente un breve panorama sobre los vínculos sociales que la burguesía murciana encontraba en este tipo de instituciones.

${ }^{5}$ Véase Nagore, "La Escuela Municipal”, 537-540, trabajo en el que su autora ofrece una visión sobre la enseñanza musical en el siglo XIX, antes de analizar la trayectoria de la Escuela Municipal de Música de Pamplona, institución pionera en España en el siglo XIX. 
Otras, en el dramático, literario, científico o incluso benéfico. Sin embargo, en mayor o menor medida, todas contaron con una sección que veló por la enseñanza musical, la organización de conciertos y la presencia de la música en eventos cívicos y religiosos de la ciudad.

En total, he documentado veintiocho sociedades cuyas características más relevantes (carácter, años de vigencia y actividad musical) presento en el Apéndice 6.1. A continuación presento el estudio de las sociedades murcianas de la segunda mitad del siglo XIX con mayor importancia musical, en orden cronológico. Éste resulta más claro que otras posibles clasificaciones, debido a que en varios casos, hubo sociedades que se fundieron en otras.

\section{El Liceo Artístico y Literario de Murcia (1839) y otros liceos posteriores (1859, 1867)}

El Liceo Artístico y Literario de Murcia es la sociedad más antigua que he documentado ya que existió desde al menos $1839^{6}$ (apenas unos días más tarde de la Real Orden de 28 de febrero de 1839, que permitía a los españoles el derecho de reunión y asociación $^{7}$ ) y una fecha muy temprana si se compara con otras sociedades del mismo nombre, creadas en otras ciudades españolas ${ }^{8}$. Su finalidad fue "el fomento de las letras y de las artes, y el deseo de sus adelantos por el estímulo recíproco de las personas que la componen" a través de exposiciones de pintura, publicaciones literarias y conciertos ${ }^{9}$. Tuvo tres secciones: ciencias y literatura, bellas artes y música. El equipo directivo del Liceo Artístico y Literario estaba formado por un presidente, un secretario, un "conservador" y un tesorero, y cada sección, a su vez, tenía un presidente y secretario propios $^{10}$. Los socios eran de tres tipos: colaboradores (sólo para hombres), "amigas del Liceo" (sólo para mujeres), corresponsales y honorarios. Para ser admitido como socio colaborador, "amiga" o corresponsal, los interesados o interesadas debían presentar un trabajo a la sección a la que deseaban pertenecer (por ejemplo, una pintura, un dibujo o una composición musical) y contar con la propuesta favorable de admisión de tres socios que ya formaran parte del Liceo. Como su propio nombre indica, los "corresponsales" residían fuera de la ciudad. Los socios honorarios eran elegidos por votación y debían reunir el suficiente prestigio en alguna de las secciones indicadas ${ }^{11}$. Todos los socios

${ }^{6}$ Estatutos de reglamento interior del Liceo Artístico y Literario de Murcia. (Murcia: Oficina de Hernández, 1839). Sus estatutos fueron aprobados el 14 de marzo de 1839.

${ }^{7}$ Cortizo y Sobrino, “Asociacionismo”, pp. 12.

${ }^{8}$ El Liceo Artístico y Literario vallisoletano se creó, por ejemplo, en 1842 como estudia Virgili, “Asociaciones", pp. 369-380. En Madrid, el Liceo Artístico y Literario se creó en 1837 y un año más tarde, otro con el mismo nombre en Sevilla. Granada también contaba con un Liceo en 1839 y Córdoba en 1844, según Virgili, "El pensamiento", pp. 21-22. Sobre el Liceo Artístico y Literario de Madrid véase Díez Huerga, "Las sociedades", pp. 260-264.

${ }^{9}$ Estatutos de reglamento, p. 3.

${ }^{10} \mathrm{Su}$ finalidad era la conservación de las pinturas, dibujos, libros y demás objetos que la sociedad iba adquiriendo. La Junta Directiva de 1839 recayó en Manuel Alarcón (presidente), Mariano Alonso (conservador), Rafael Mancha (tesorero) y Francisco Vallespinosa (secretario); la del año 1839 puede consultarse en Estatutos de reglamento, p. 8.

${ }^{11}$ Véanse más detalles en Estatutos de reglamento, pp. 5-6. 
debían realizar anualmente y con carácter obligatorio un trabajo de su especialidad (ciencias, bellas artes, literatura o música). En la prensa consultada no he hallado datos que permitan reconstruir su trayectoria posterior $\mathrm{y}$, a juzgar por los documentos consultados, tampoco parece probable que sea la misma sociedad que, con el título del Liceo, mencionó La Paz de Murcia en varias ocasiones en 1858 y 1859.

La actividad del Liceo de 1858 consistió en organizar representaciones teatrales con sus socios aficionados y actrices profesionales de las compañías que actuaban en el Teatro Provisional ${ }^{12}$.

Desde noviembre de 1858 hasta enero de 1859, se llevaron a cabo al menos cinco funciones con diversas comedias, dramas y piezas en un acto. En las dos primeras intervinieron tres cantantes de la compañía de ópera, zarzuela y verso del director de escena Juan Cavaletti (ver Capítulos 3 y 4). En la cuarta, Julián Calvo y Leopoldo Cavaletti (director de orquesta de la mencionada compañía) ofrecieron una pieza musical en el intermedio al piano y violín ${ }^{13}$. Este hecho muestra que se incluía música instrumental intercalada entre las piezas representadas. En la última función, la sociedad contrató a tres actrices de la compañía dramática de Francisco del Val ${ }^{14}$. La tabla 6.1 muestra los principales datos sobre estas funciones.

Tabla 6. 1. Funciones teatrales organizadas por la sociedad Liceo de Murcia (1858-1859).

\begin{tabular}{|c|c|c|c|}
\hline Fecha & $\begin{array}{l}\text { Obras representadas } \\
\text { (género y número de actos } \\
\text { según la fuente periodística) }\end{array}$ & $\begin{array}{l}\text { Actores, actrices } \\
\text { músicos mencionados }\end{array}$ & Fuente periodística \\
\hline \multirow[t]{2}{*}{$30-11-1858$} & $\begin{array}{l}\text { El rey y el aventurero } \\
\text { (drama, cinco actos) }\end{array}$ & \multirow[b]{2}{*}{$\begin{array}{l}\text { Actrices: Ramona Coronel, } \\
\text { Adelaida Hordán } \\
\text { Concepción Torres }{ }^{15} \text {. } \\
\text { Actores: [?] Villegas, José } \\
\text { Ibáñez, Alfonso } \\
\text { Clemencín, Jerónimo } \\
\text { González, José Monzón, } \\
\text { Antonio Villegas, José } \\
\text { Sánchez Oliva, Rafael } \\
\text { Rubio, Francisco Villegas } \\
\text { y Felipe Ibáñez Mirabete. }\end{array}$} & \multirow{2}{*}{$\begin{array}{l}\text { La Paz de Murcia, I } \\
(1858), \mathrm{n}^{\text {o } 229,2} \\
\text { diciembre, pp. } 1-2\end{array}$} \\
\hline & $\begin{array}{l}\text { A un cobarde, otro mayor } \\
\text { (pieza, un acto) }\end{array}$ & & \\
\hline $14-12-1858$ & $\begin{array}{l}\text { ¡Don Tomás! (juguete } \\
\text { cómico) }\end{array}$ & $\begin{array}{l}\text { Actrices: Ramona Coronel, } \\
\text { Adelaida Hordán, [?] }\end{array}$ & $\begin{array}{l}\text { La Paz de Murcia, I } \\
(1858), \mathrm{n}^{\text {o }} 239,15\end{array}$ \\
\hline
\end{tabular}

${ }^{12}$ En agosto de 1858, los miembros del Liceo costearon las obras de arreglo y ensanche del teatro Provisional: La Paz de Murcia, I (1858), n 142, 22 agosto, p. 2. Ver más información en Crespo, Antiguos teatros, pp. 15-16.

${ }^{13}$ Siete días antes estos dos músicos habían tocado una "Fantasía sobre motivos de Guillermo Tell" en el Teatro Provisional. Cabe suponer que repitieran la pieza en el Liceo (Ver Capítulo 3).

${ }^{14}$ La compañía de Francisco del Val actuó en Murcia en febrero de 1859, a continuación de la compañía de Cavaletti. Paulina Andrés fue la primera actriz, Victoria Saavedra, la primera actriz cómica y, Amparo Sira, característica. El listado completo de miembros de esta compañía se publicó en La Paz de Murcia, II (1859), n 346, 1859, 18 abril, p. 2.

15 Adelaida Hordán (primera tiple contralto), Ramona Coronel (característica de zarzuela) y Concepción Torres (partiquina) fueron integrantes de la compañía de Juan Cavaletti. 


\begin{tabular}{|c|c|c|c|}
\hline & $\begin{array}{l}\text { El rival de charol (juguete } \\
\text { cómico) }\end{array}$ & $\begin{array}{l}\text { Gómez y [?] Martínez. } \\
\text { Actores: [?] Villegas, } \\
\text { Jerónimo González y [?] } \\
\text { Monzón }\end{array}$ & diciembre, p. 1 \\
\hline 07-01-1859 & No consta, salvo El Trípili & $\begin{array}{l}\text { Actrices: [?] Gómez } \\
\text { Actores: José Sánchez } \\
\text { Oliva, [?] Ibáñez }\end{array}$ & $\begin{array}{l}\text { La Paz de Murcia, II } \\
(1859), \mathrm{n}^{\mathrm{os}} 254,3 \\
\text { enero, p. } 2 \text { y } 262, \\
13 \text { enero, p. } 2\end{array}$ \\
\hline $28-01-1859$ & No constan & 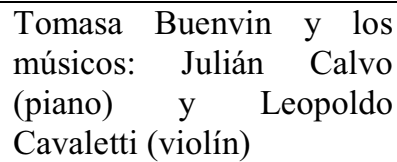 & $\begin{array}{l}\text { La Paz de Murcia, II } \\
\text { (1859), n } \text { n }^{\circ} 277,31 \\
\text { enero, p. } 1\end{array}$ \\
\hline $06-05-1859$ & $\begin{array}{l}\text { ¡Don Tomás! (comedia, tres } \\
\text { actos) } \\
\text { Una apuesta (pieza, un acto) }\end{array}$ & 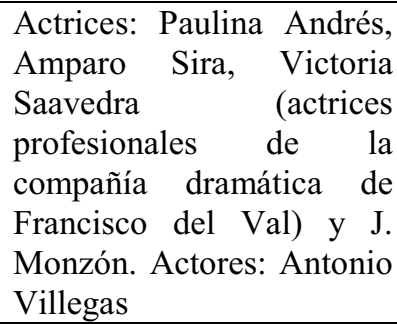 & $\begin{array}{l}\text { La Paz de Murcia, II } \\
\text { (1859), no } 363,7 \\
\text { mayo, p. } 2\end{array}$ \\
\hline
\end{tabular}

En junio de 1859 el Liceo acogió el estreno de La Locomotora una composición del murciano Julián Calvo ${ }^{16}$. Sobre este Liceo no he localizado noticias posteriores a 1859.

A finales de enero de 1867 se creó un Liceo Lírico-Dramático (1867) por iniciativa de un grupo de jóvenes aficionados al teatro ${ }^{17}$, cuyo reglamento general fue aprobado por unanimidad en el mes de febrero ${ }^{18}$ y un mes más tarde se constituyeron las secciones lírica, dramática y literaria ${ }^{19}$. El primer presidente del Liceo Lírico-Dramático de 1867 fue Antonio Villegas, un actor aficionado que también había pertenecido al Liceo de los años 1858-1859 como se muestra en la anterior Tabla 6.1.

En el momento de constituirse el Liceo Lírico-Dramático, las cuotas de entrada y cuotas mensuales se fijaron en doce y ocho reales, respectivamente. Sin embargo, a partir del mes de marzo de 1867, ambas cuotas se elevaron con el fin de aumentar los ingresos de la sociedad. Las nuevas cuotas del Liceo Lírico-Dramático dividían a los socios en dos clases, según la cantidad que aportaran al ingresar en la sociedad: cien reales (fragmentados en pagos mensuales de 40, 40 y 20 reales) o cuarenta reales. Los primeros tenían más posibilidades para conseguir localidades en los días de representaciones

${ }^{16}$ La Paz de Murcia, II (1859), nº 389, 2 junio, p. 1.

17 En la primera reunión (27-01-1867 en el "en el salón o parque de bomberos del edificio del Ayuntamiento") se nombró una comisión para que redactara el reglamento de la sociedad: La Paz de Murcia, X (1867), no 2784, 29 enero, p. 2.

${ }^{18}$ La junta general que constituyó formalmente el Liceo se celebró el 17 de febrero de 1867 en el salón de descanso del Teatro de los Infantes. Los interesados en formar parte de la sociedad debían ser propuestos por un socio a la Junta de Gobierno. La sociedad contaba en este momento con cien socios: La Paz de Murcia, X (1867), n ${ }^{\text {s }} 2802,17$ febrero, p. 2 y 2804, 19 febrero, p. 2.

${ }^{19}$ Durante el mes de marzo de 1867 la sociedad celebró dos juntas generales. En la primera (19-031867) se aprobaron los reglamentos especiales de las secciones lírica y dramática: La Paz de Murcia, X (1867), $\mathrm{n}^{\mathrm{o}}$ 2832, 21 marzo, p. 2. En la segunda (26-03-1867) se aprobó el reglamento de la sección literaria y se modificaron varios artículos del Reglamento General $\left(5^{\circ}, 23^{\circ}, 24^{\circ}, 25^{\circ}\right.$ y $\left.26^{\circ}\right)$ : La Paz de Murcia, X (1867), no 2838, 27 marzo, p. 2. 
teatrales u otras actividades organizadas la sociedad, ya que el reparto de entradas se efectuaba por sorteo. Las localidades se dividían en cinco partes: cuatro se sorteaban entre todos los socios y la quinta parte únicamente entre los socios que pagaban por su ingreso cien reales. La cuota mensual era para todos de diez reales y salvo en lo señalado, todos los miembros del Liceo Lírico-Dramático tenían los mismos derechos ${ }^{20}$.

No dispongo de más datos para analizar la trayectoria del Liceo Lírico-Dramático de 1867, aunque esta sociedad no debe confundirse con El Liceo, nacida en 1878 por la unión del Círculo Industrial y el Ateneo, como veremos más adelante.

\section{El Casino de Murcia (desde 1847)}

El Casino de Murcia, fundado en 1847 y que sigue siendo una institución activa en la actualidad, tuvo una importantísima actividad musical que merece una monografía propia $^{21}$. Aquí presentaré sólo una primera aproximación a la presencia de la música en el Casino durante la segunda mitad del siglo XIX, a partir de una selección de noticias representativas.

La sociedad del Casino se fundó el 12 de junio de 1847 por iniciativa de un grupo de burgueses capitalistas murcianos $\mathrm{y}$, gracias al prestigio social que alcanzó la institución, en ella se integraron los aristócratas e intelectuales más importantes de Murcia $^{22}$. La sede de la sociedad hasta 1853 fue un local alquilado en el Pasaje Cetina, en una antigua residencia del marqués de Campohermoso (posteriormente propiedad del marqués del Vado). En 1852 la Junta General del Casino decidió constituir una empresa por acciones para comprar el primer inmueble propio, que fue el germen del actual edificio, un suntuoso edificio que ocupa $2.228 \mathrm{~m}^{2}$ de superficie y alberga en su interior importantes obras artísticas (ver Figura 6.1).

${ }^{20}$ Véase, La Paz de Murcia, X (1867), no 2838, 27 marzo, p. 2. Las cuotas del Liceo Lírico-Dramático de Murcia fueron muy similares a los del Liceo Artístico y Literario Vallisoletano (1842), a pesar de que entre ellos existieron veinticinco años de diferencia. Según Virgili, “Asociaciones”, p. 373 los socios del Liceo Artístico y Literario vallisoletano pagaban una cuota de entrada de ochenta reales y una mensual de diez reales.

21 Sobre los fondos musicales del Casino de Murcia, véase: Sánchez Alcolea, Proyecto de automatización. Desde 2009 la institución pasó a denominarse Real Casino de Murcia, pero en este trabajo empleo la denominación que tenía en el siglo XIX (Casino de Murcia). El edificio del Casino fue declarado monumento histórico-artístico nacional en 1983 y en la actualidad tiene reconocida la categoría de "Bien de interés cultural" en la modalidad de monumento: Guirao, El casino, p. 22.

${ }^{22}$ Guirao, El casino, pp. 15, 58, ofrece un listado de presidentes del Casino de Murcia desde su fundación hasta 1994, en el que aparecen, entre otros, el Conde de Roche y el Marqués de Villalba. La crónica de la inauguración y el discurso del primer Presidente del Casino, Juan López Somalo, pueden consultarse en Diario de Murcia, (1847), n 141, 12 octubre, pp. 1-2. Los estatutos del Casino de Murcia fueron aprobados el 17 de noviembre de 1867, según Moreno y Vera, "El edificio-calle", p. 227. Sobre el Casino de Murcia, además de los trabajos citados, véase: Vera, El casino; Vera, "El Casino" y Pérez Rojas, Casinos. 


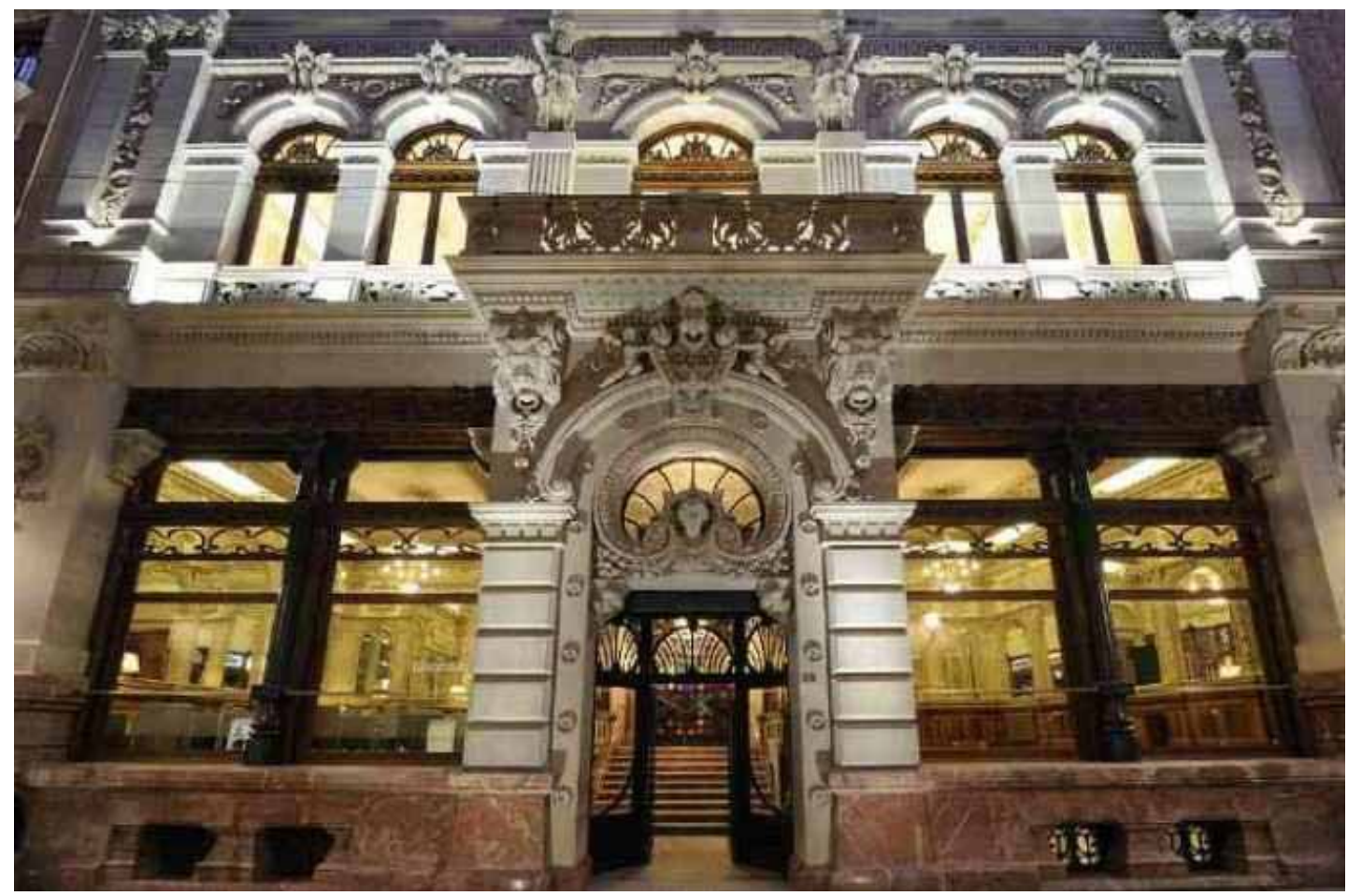

Figura 6.1. Fachada del Casino de Murcia después de su última restauración. Accesible en: http://www.casinomurcia.com (acceso el 1-10-2011).

El edificio del Casino de Murcia no siguió una idea unitaria de construcción, sino que fue anexionando espacios gradualmente hasta formar un edificio que responde a la tipología de edificio-calle, a semejanza de otras construcciones europeas de la época, como la Galería de Orleans de París (1829-1831) o la Galería Vittorio Emanuele de Milán $(1863-1878)^{23}$ (véanse Figuras 6.2 y 6.3). En la primera fase constructiva (1852-1879) se adquirieron diversas casas situadas entre la calle de Lucas y la calle de Buen Aire (antiguo Montijo). En una segunda fase (1891-1898) se compraron nuevos inmuebles que posibilitaron la apertura del edificio a la calle Trapería, importante eje viario del trazado urbano del centro de Murcia de origen medieval (véase Figura 6.4) ${ }^{24}$. Las obras de ornato y decoración de las salas del Casino culminaron con la finalización del tocador de señoras en $1922^{25}$. El edificio sufrió diversas reformas posteriores, la última de ellas entre 2006 y 2009.

${ }^{23}$ Vera, "El Casino", p. 9.

${ }^{24}$ Los arquitectos que intervinieron en la obra fueron Justo Millán (1882-1895), Marín Baldo (18851890) y Pedro Cerdán (1893-1916). Véanse más detalles en Moreno y Vera, "El edificio-calle”, pp. 227248 y Vera, "El Casino", pp. 8-29.

${ }^{25}$ Véanse más detalles sobre la decoración del Real Casino de Murcia en Vera, "El Casino”, pp. 8-29 y Melendreras, "Escultura decorativa". 


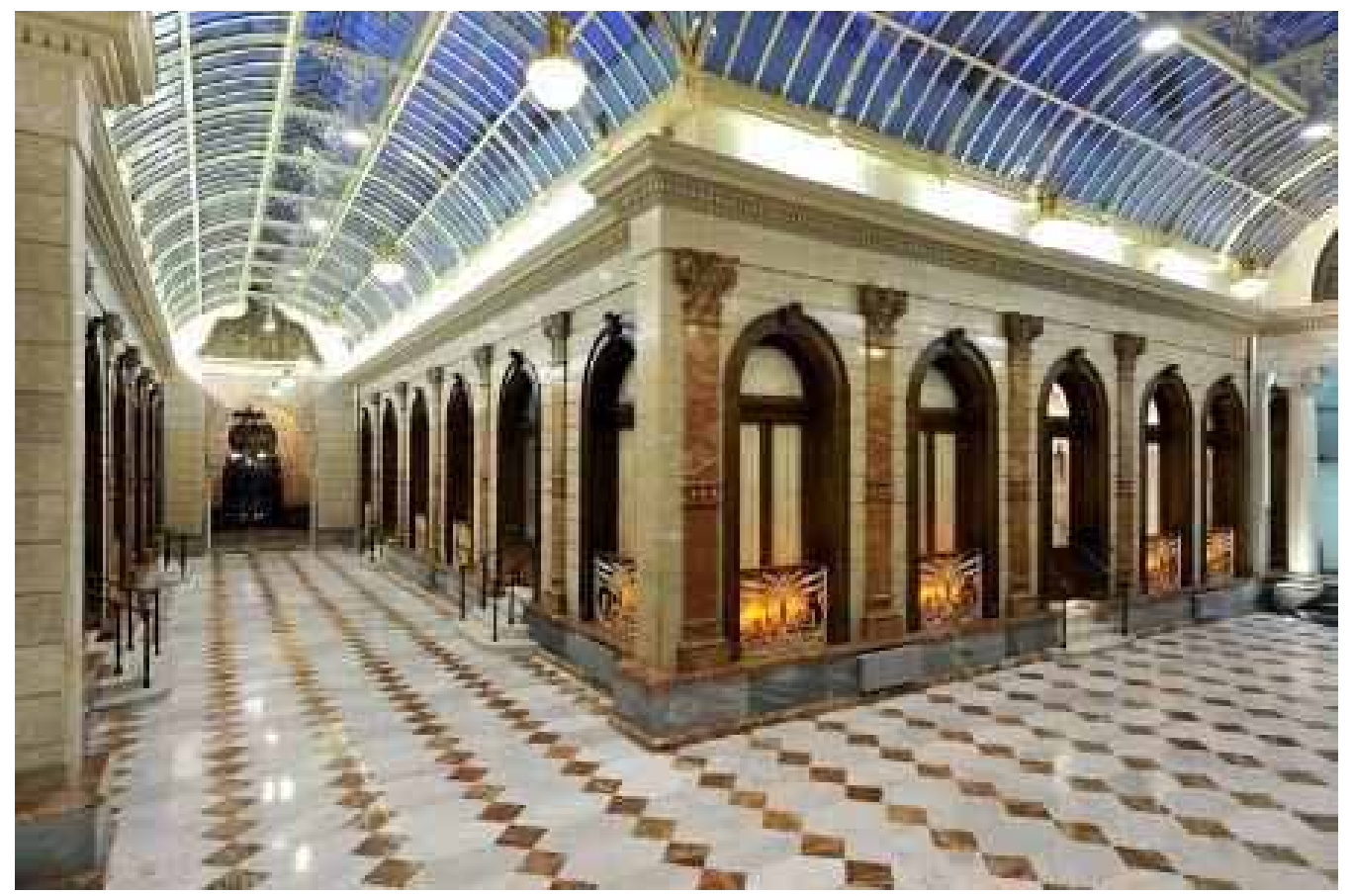

Figura 6.2. Galería central del Casino de Murcia en la actualidad. Accesible en: http://www.casinomurcia.com (acceso el 1-10-2011)

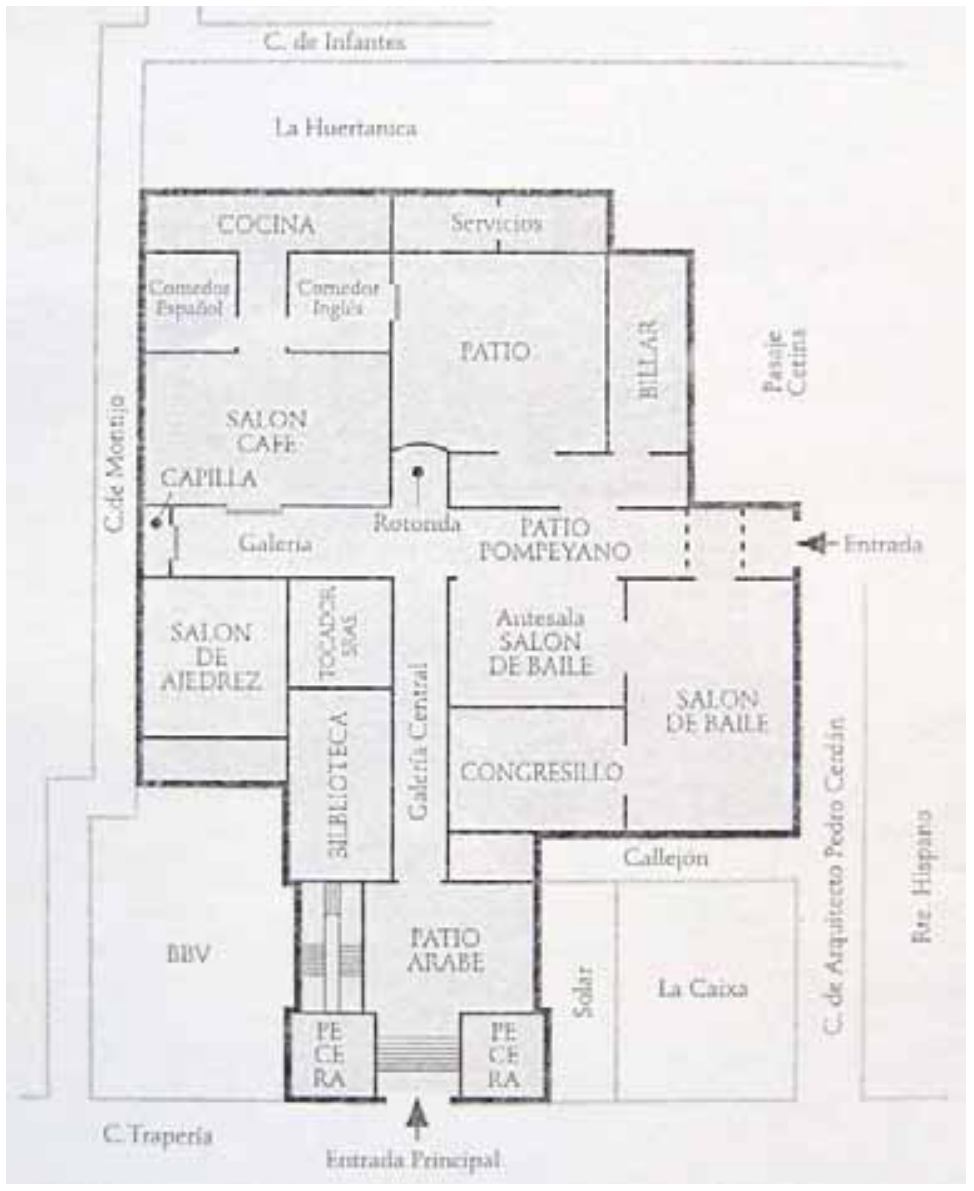

Figura 6.3. Configuración actual del Casino de Murcia. Guirao, El Casino, p. 18. 


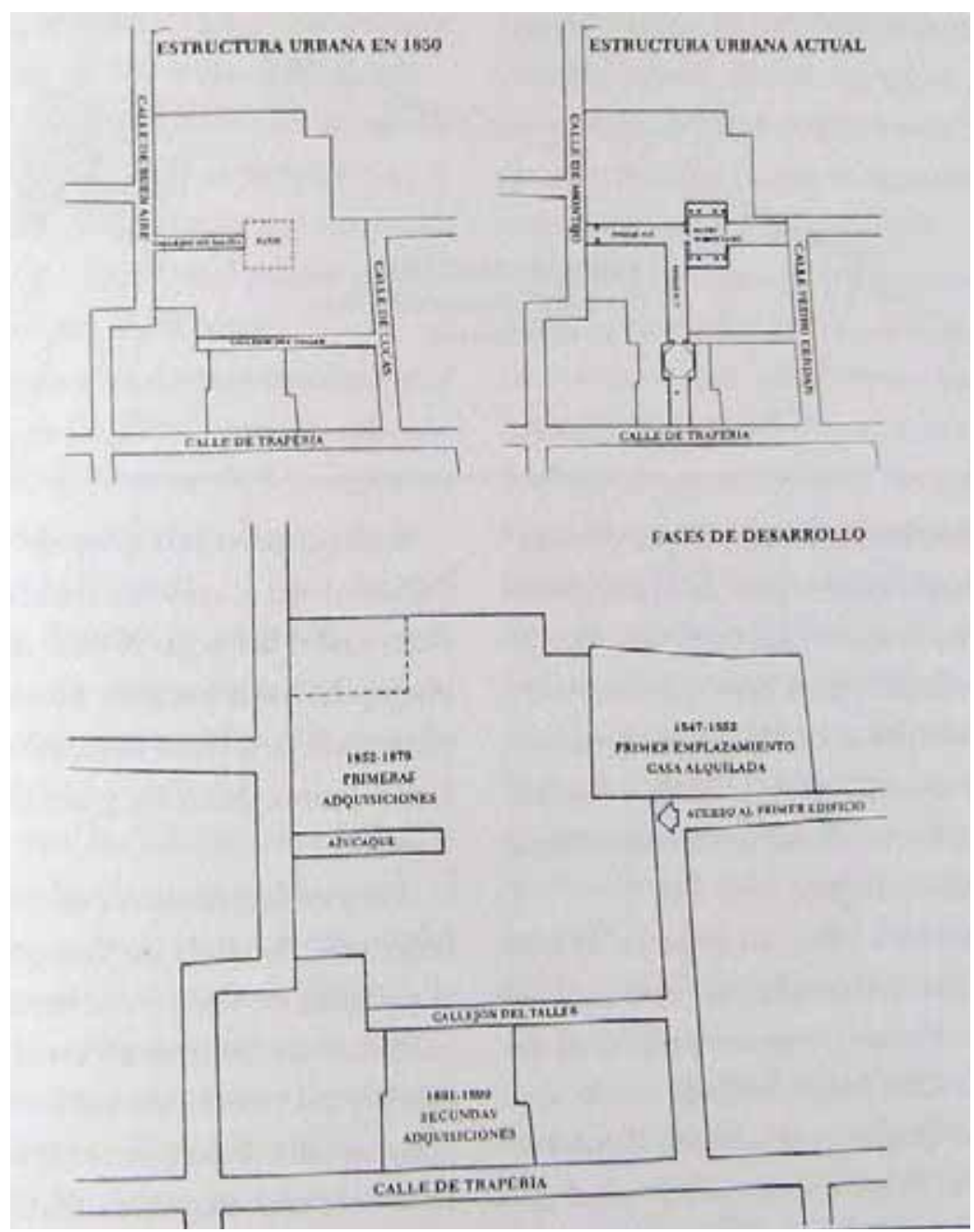

Figura 6.4. Fases de construcción del Casino de Murcia. Vera, "El Casino", p. 5.

\subsection{La actividad musical del Casino de Murcia}

Durante el siglo XIX, los casinos fueron entidades asociativas de carácter recreativo que organizaban actividades de ocio para sus socios. Los asociados solían acudir a los casinos a leer el periódico, charlar o jugar a los naipes y al billar ${ }^{26}$. El Casino de Murcia tuvo un destacado protagonismo en la vida cultural y musical murciana desde su origen hasta la actualidad. En el siglo XIX era un espacio exclusivo y selecto de reunión: contaba con 220 socios a finales de 1847 que se incrementaron hasta 600 a principios de la década de los noventa ${ }^{27}$. Un redactor de La Paz de Murcia y socio del Casino describía así en 1868 las actividades habituales en él:

${ }^{26}$ Alonso, "Un espacio", pp. 21-22.

${ }^{27}$ Vera, El Casino, p. 6. Según Botella, Guía, p. 227, en 1890 los 600 socios del Casino de Murcia pagaban una cuota de cinco pesetas mensuales. Durante la segunda mitad del siglo XIX, el Casino de Murcia era gestionado por una Junta Directiva que en 1851, por ejemplo, estaba formada por un presidente, un vicepresidente, un secretario, un contador, un depositario y cuatro vocales, según Guirao, El Casino, p. 54; en 1891, además de los cargos mencionados, había un bibliotecario: La Paz de Murcia, XXXIV (1891), $\mathrm{n}^{\circ} 11220,1$ enero, p. 1. Los socios se dividían en "socios de número", "socios accidentales" y "socios suscriptores". Dependiendo de la clase, los socios gozaban de mayores o menores privilegios. Los socios de 
[...] el Casino se ha encontrado siempre dividido en otros grupos en los que servía y sirve como medio de atracción las inclinaciones, los hábitos, usos y costumbres de cada cual y a veces su profesión, sus afecciones políticas y hasta sus vicios. Estos grupos han tenido siempre sus sitios preferentes y algunos concurren únicamente a las habitaciones destinadas a lo que constituye su recreo y su capricho.

Hay constantes contertulios de la sala de café que sólo van al Casino a descansar de sus faenas ordinarias saboreando una taza que debería ser de productos ultramarinos, amenizada con un rato de agradable conversación, retirándose de allí a su casa: estos son los inofensivos. Hay quien no conoce del Casino más habitación que el gabinete de lectura y en él pasa largos ratos en horas determinadas, bien dedicadas al estudio de la alta política, bien otros ansiosos de encontrar en los periódicos esperanzas contra una rebelde y mortificadora cesantía o seguridades a favor de su confortable destino ganado en las luchas electorales: estos también podemos considerarlos como gente pacífica. Hay asiduos concurrentes a las salas de ajedrez, de tresillo y de billar, según la especial predilección con que cada cual mira estos juegos. Hay quien va a todas ellas. [...]

El Casino tiene, por tener de todo, su mentidero, su cátedra de murmuración estacional. No es decir con esto que deje de murmurarse en el resto de año, no. Solamente que los excesivos calores nos llevan en busca de un sitio donde encontrar algún fresco y desde el cual muellemente arrellanados en butacas resolvemos en alta voz y en todo magistral las más graves cuestiones sociales, de política y de administración, si es que no nos parece penetrar en la vida privada, destrozando al que se levanta por los mismos que vienen a ocupar su puesto y siendo éstos a su vez desollados por los que les suceden $[\ldots]^{28}$.

El Casino de Murcia contó con una orquesta propia para amenizar sus veladas musicales desde el 4 de octubre de 1848:

[...] a esta asociación donde hemos visto desde su fundación (en 1847) dar no sólo su protección a cuantos artistas extranjeros, nacionales y del país la han solicitado, sino que siempre fue la primera en honrar el ya mencionado arte músico por medio de grandes manifestaciones, como ocurrió al desear tener orquesta propia este centro (4 de octubre de 1848); al celebrar la inauguración del gran órgano de la Catedral (7 de julio de 1857) y en honor de nuestros grandes y queridos artistas Fernández Caballero, Padilla, Rubio y Mondéjar y de nuestros insignes comprovincianos las señoritas doña Ana y doña Rosario López Peñafiel, don Emilio Ejea y otros muchos que sería prolijo enumerar y a los que el casino murciano ha abierto sus suntuosos salones para manifestar al mundo que no sólo es un centro donde poder pasar un rato el socio ente sus compañeros y amigos $[\ldots]^{29}$.

El germen de la orquesta del Casino fue un cuarteto de flauta, violín, viola y violonchelo dirigido por Mariano Esbrí (ver Capítulo 9) ${ }^{30}$. Algunos músicos de esta orquesta también colaboraban con las orquestas teatrales de la ciudad (ver Capítulo 2). El

número tenían voz y voto y eran los únicos que podían ser nombrados para cargos directivos. Véanse más detalles en Guirao, El Casino, pp. 63-65.

${ }^{28}$ El Caballero Particular, "Revista de Murcia. El Casino", La Paz de Murcia, XI (1868), n 3185, 22 marzo, p. 1.

${ }^{29}$ El Diario de Murcia, XVI (1894), nº 6268, 11 mayo, p. 2.

30 "Un aficionado", “Apuntes para la Historia de la Música en Murcia (X)”, El Semanario Murciano I (1878), n $\mathrm{n}^{\circ}$ 44, 15 diciembre, pp. 4-5:4. Mariano Esbrí participó en la comisión encargada de reunir los fondos necesarios para adquirir en propiedad el primer edificio del Casino, según Guirao, El Casino, p. $52 .$. 
Casino tenía además pianistas a sueldo y otras formaciones musicales que tocaban regularmente en sus veladas, como describió Julián Calvo:

[...] Al instalarse esta sociedad en la calle de Lucas, número 4, casa que fue del opulento don Antonio Lucas, esta sociedad puso un piano para distracción de los socios aficionados, siendo su primer pianista el distinguido discípulo de don Agustín Jiménez, señor don Joaquín Córdoba. Después, a temporadas hubo otros profesores $\left(1^{31}\right)$ hasta que en 1865 quedó definitivamente el célebre y malogrado, nuestro querido amigo, señor don José Quercop, al que los señores socios supieron estimar y atender hasta después de su muerte por su talento y honradez.

Desde el señor Quercop siguieron sosteniendo el piano en esta corporación hasta llegar hoy a tener un precioso armonio y un piano de primer orden, siendo los actuales profesores don Pedro Muñoz Pedrera y don José Antonio Ramírez, ambos son reputados y aplaudidos merecidamente y no debo decir más porque ambos nos honraron tomando nuestras humildes consejos musicales, y basta.

El distinguido lector preguntará ¿pero todo esto a qué viene? Esto es querer por nuestra parte [...] hacer público la manifestación más completa de agradecimiento al digno presidente señor don José Cayuela, a los señores que componen esa junta inspirada en los deberes más grandes y a ese gran número de caritativos socios que han hecho por medio de sus firmas se realice un acto de los más bellos bajo el noble pretexto de proteger el arte y especialmente a un antiguo artista... es decir, que no ha vacilado ningún socio ni puesto objeción alguna al tomar la junta el acuerdo solicitado por multitud de firmas de aquellos suplicando poner otro profesor de piano sin menoscabo de los que tienen, y que éste lo fuera don Juan Diego Manresa que había llegado a sus últimos años a una situación muy crítica.

[...] El señor Manresa ya fue profesor de piano del Casino en tiempos atrás, pero hoy lo será hasta su último día $[\ldots]^{32}$.

Al menos desde 1878, el Casino de Murcia tenía un piano de cola Boisselot de Barcelona $^{33}$ y en 1887 adquirió un armonio que fue inaugurado el 12 de noviembre de ese año por un intérprete de Archena (cuyo nombre no consta), acompañado al piano por Antonio Ramírez ${ }^{34}$. A los conciertos del Casino asistía lo más selecto de la sociedad murciana, y algunos socios parece que acudían con traje de etiqueta:

En la velada de esta noche en el Casino, tocará diferentes piezas el niño violinista señor Buey. Se trata de que la reunión sea de toda etiqueta, pero como no todos los socios pueden vestir así, y a ninguno se le puede privar el derecho a asistir a ella, habrá más trajes democráticos que aristocráticos y todos con el mismo derecho ${ }^{35}$.

${ }^{31}$ [Nota al pie original de Julián Calvo]: "Desde principios de 1859 fue pianista del Casino pero en mayo de 1860 caí enfermo y tuve que dejarlo y a pesar de esto siempre he tenido el honor de ser atendido por cuantas juntas se han sucedido y siempre he sido invitado a tomar parte en las diferentes grandes fiestas que han celebrado y omitimos un rasgo de generosidad por haber sido para con nosotros directamente": Julián Calvo, "El Casino de Murcia y D. Juan Diego Manresa", El Diario de Murcia, XVI (1894), nº 6268, 11 mayo, p. 2.

${ }^{32}$ Julián Calvo, "El Casino de Murcia", p. 2. Las cursivas son originales.

33 "Un aficionado", “Apuntes para la Historia de la Música en Murcia (IV)”, El Semanario Murciano I (1878), $\mathrm{n}^{\mathrm{o}} 27,18$ agosto, pp. 3-5:4.

${ }^{34}$ La Paz de Murcia, XXX (1887), nº 8283, 13 noviembre, p. 1.

${ }^{35}$ La Paz de Murcia, XXX (1887), nº 8297, 11 septiembre, p. 4. 
Los conciertos se celebraban probablemente en el Salón del Té, que en la prensa del siglo XIX era denominado "salón del café" (ver Figura 6.5).

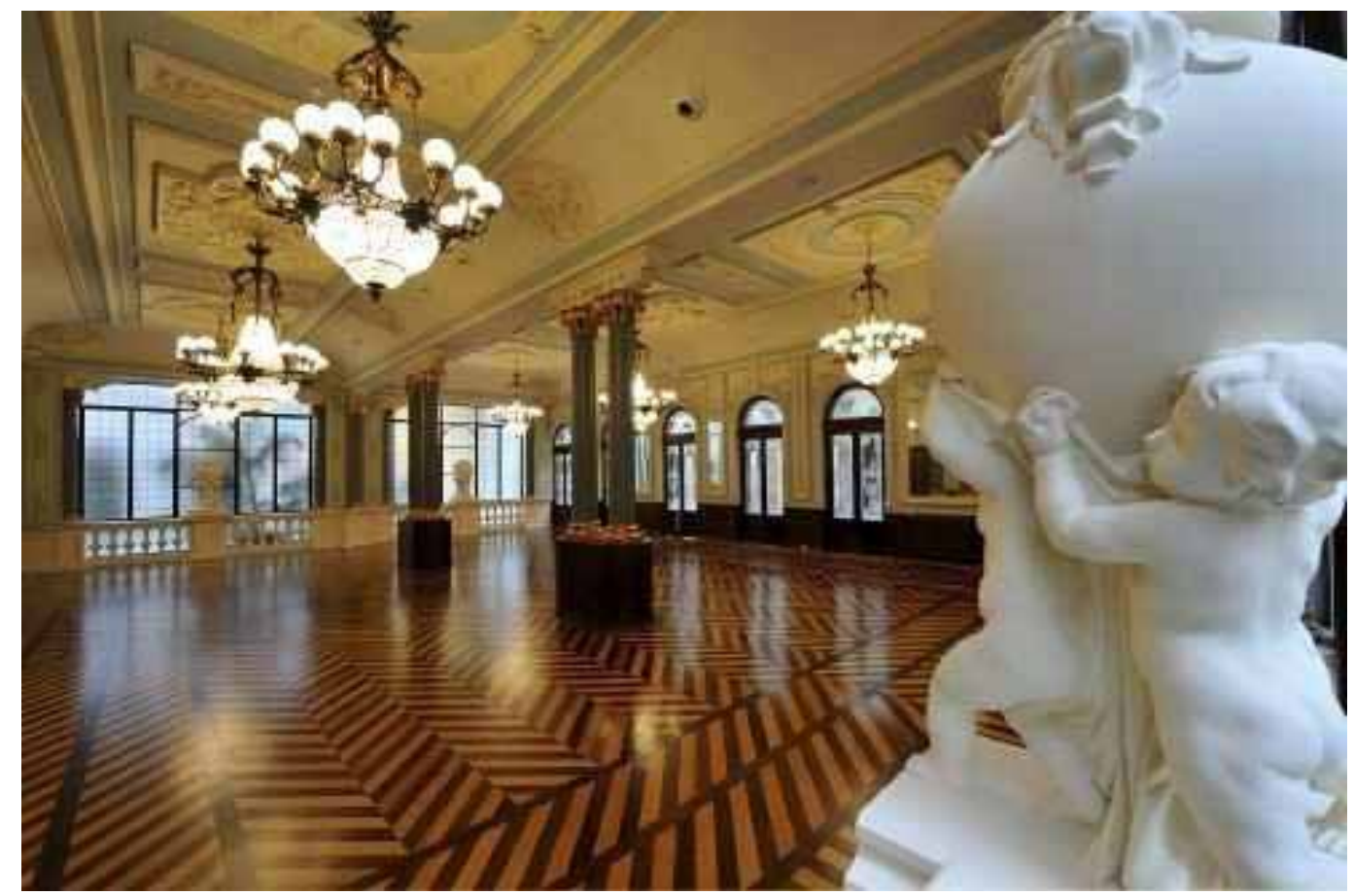

Figura 6.5. Salón del Té del Casino de Murcia en la actualidad. Accesible en: http://www.casinomurcia.com (acceso el 1-09-2011)

El Casino de Murcia organizó conciertos regulares al menos durante los meses de octubre y noviembre de $1878^{36}$ y reuniones de matinée los domingos en $1887^{37}$. En estos y otros muchos conciertos organizados en el Casino participaron músicos profesionales y aficionados murcianos, a veces en una misma velada ${ }^{38}$. Así ocurrió, por ejemplo, en un concierto celebrado en mayo de 1866, en el que actuaron Juan Diego Manresa (piano), Antonio López Almagro (armonio), José Quercop (violín) y las cantantes aficionadas Adela Davin y Dolores Martini; en esa ocasión el repertorio estuvo compuesto por arias de ópera de Mercadante, Donizetti, Bellini y Verdi, alternando con obras instrumentales

${ }^{36}$ Véase, por ejemplo, La Paz de Murcia, XXI (1878), n ${ }^{\text {s }}$ 6329, 11 octubre, p. 1; 6344, 27 octubre, p. 1; 6345, 29 octubre, p. 1 y 6347, 12 noviembre, p. 1. No queda constancia de los programas interpretados, a excepción del publicado en La Paz de Murcia, XXI (1878), n $\mathrm{n}^{\mathrm{0}}$ 6345, 9 noviembre, p. 4 que incluyó las siguientes obras: Sinfonía de La Sirena, Aria de tiple del tercer acto de Lucia di Lammermoor, Wals Todo Corazón, Introducción de la ópera Lucrezia Borgia, Dúo de tiple y barítono de Lucia, y como final un Rigodón y Lanceros.

${ }^{37}$ El término matinée se empleó como sinónimo de función dominical (no necesariamente por la mañana). Véase, por ejemplo, La Paz de Murcia, XXX (1887), nº 8143, 15 marzo, p. 1: "La reunión de la noche del domingo en el Casino, o sea el matinée como han dado en llamarla los que apelan al francés"; y La Paz de Murcia, XXX (1887), n 8302, 7 diciembre, p. 1: "Nos alegramos de que "El Diario" rechace como nosotros la palabra francesa matinée, que además se aplica con gran impropiedad, y que use la que tiene nuestro idioma, que expresa más clara y propiamente lo que significa y [que] son las reuniones domingueras en el Casino".

${ }^{38}$ El Casino también acogió veladas con prestidigitadores como Luis Juárez de Negrón, en mayo de 1887. Véase, La Paz de Murcia, XXX (1887), nº 8207, 24 mayo, p. 1. 
como el Gran Galop de Lefébure-Wély, unas Variaciones para violín y piano de autor no especificado y un Trío para violín, piano y armonio de Antonio López Almagro ${ }^{39}$ (ver Apéndice 6.2).

Entre los numerosos músicos profesionales que actuaron en el Casino de Murcia algunos eran locales, como Mariano Padilla, el pianista Luis Mondéjar ${ }^{40}$ y la soprano cartagenera Ana López Peñafiel en septiembre de 1888 (ver Figura 6.6) ${ }^{41}$, y también hubo concertistas extranjeros de paso por la ciudad, como los violinistas italianos Luis Brusa y Pedro Dionese acompañados a la guitarra por Fiorentina Dionesi (julio de 1869) y la soprano Josefina Huguet (septiembre de 1890). En el Casino actuaron diversas formaciones instrumentales murcianas y músicos de otras sociedades de la ciudad. Por ejemplo, la Banda de la Misericordia actuó en el Casino de Murcia en diciembre de 1879, poco después de ser creada $^{42}$ y los músicos de la sociedad Santa Cecilia de Murcia ofrecieron una velada literario-musical en marzo de $1883^{43}$. Una velada celebrada en el Casino en septiembre de 1869 estuvo a cargo de "unos concertistas de bombardino, cuya repetición creemos no se apetecerá si hemos de juzgar por el poco interés que los concurrentes manifestaron" 44 .

El Casino de Murcia acogió regularmente la entrega de premios de los Juegos Florales de Murcia (ver Capítulo 11) y participó en grandes acontecimientos festivos de la ciudad y en homenajes a artistas y personajes ilustres murcianos ${ }^{45}$. Por ejemplo, el Casino tomó parte activa en los festejos por la inauguración del gran órgano de la Catedral de Murcia, que tuvo lugar el 8 de julio de 1857. En torno a este evento el Cabildo catedralicio y otras entidades locales organizaron diversos actos ${ }^{46}$. En las noches de los días 5 y 7 de julio se celebraron dos conciertos de piano y armonio en el Palacio Episcopal y en el Casino de Murcia, respectivamente. A ambos conciertos acudieron Hilarión Eslava (maestro de la Real Capilla), el compositor Ambrosio Arriola, Merklin y Schütze (constructores del órgano), Reinaldo de Vilbac (organista de San Eugenio en París) y Julián Calvo, entre otros personajes ilustres y artistas de la ciudad. En ambos conciertos se "tocaron piezas de un modo admirable". Vilbac y Arriola interpretaron una Jota Aragonesa a cuatro manos de Arriola; Vilbac al armonio y Julián Calvo al piano interpretaron además un arreglo del Miserere de la ópera Il Trovadore para piano y armonio. En el concierto del Casino, el "auditorio fue obsequiado con refrescos, dulces y

${ }^{39}$ La Paz de Murcia, IX (1866), $\mathrm{n}^{\text {os }}$ 2546, 27 mayo, pp. 1-2 y 2549, 30 mayo, p. 2.

${ }^{40}$ La Paz de Murcia, XXVII (1884), nº 7901, 23 abril, p. 1.

${ }^{41}$ Ana López Peñafiel nació en Cartagena en 1866. Estudió piano y canto y como cantante se formó con Manuel Rodríguez (en Cartagena) y con María Mantilla y Napoleón Verger. En el Conservatorio de Madrid recibió clases de declamación lírica de José Mirall. Ana López Peñafiel dio numerosos conciertos en Madrid, en el Salón Romero y otros locales. Véanse más detalles en Antonio Ramírez Pagán, "Ana López Peñafiel”, Cartagena Artística, I (1890), no 16, 10 septiembre, p. 1, pp. 1-2 y en García Segura, Músicos, p. 281.

${ }^{42}$ El Noticiero Murciano, VIII (1879), $\mathrm{n}^{\circ}$ 1852, 2 diciembre, p. 3.

${ }^{43}$ La Paz de Murcia, XXVI (1883), ñ 7576, 3 marzo, p. 1.

${ }^{44}$ La Paz de Murcia, XII (1869), no 3673, 14 septiembre, p. 1.

${ }^{45}$ Véase, por ejemplo, La Paz de Murcia, XXVI (1883), $\mathrm{n}^{\text {os }} 7572,26$ febrero, p. 1 y 7577, 4 marzo, p. 1 sobre el homenaje a Salzillo.

${ }^{46}$ En la ceremonia religiosa de bendición del órgano se cantó una Misa de José María Gazque Llopis y otras obras de Hilarión Eslava y Reinaldo de Vilbac. Véanse más detalles en Calvo, Reseña, pp. 10-12. 
flores y los señores artistas fueron invitados a lunch que fue presidido por el maestro Eslava y el digno presidente del Casino, señor don José Monassot”, ${ }^{\natural 7}$.

En los festejos organizados en mayo de 1884 por el bicentenario del diplomático algezareño Diego de Saavedra Fajardo (1584-1684), el Casino organizó una velada literaria y musical en la que hubo intervenciones de intelectuales y directivos del Casino, lectura de poesías y piezas musicales. La pianista Julia Guerra interpretó el Concierto en mi menor de Chopin y una Pavana, la soprano cartagenera Ana López Peñafiel (ver Figura 6.6), acompañada al piano por Antonio Ramírez, cantó una romanza de tiple de $L a$ forza del destino de Verdi, Rosario López Peñafiel, acompañada al piano por su hermana Ana López, tocó una melodía para violín de Gastaldón y el pianista Luis Mondéjar interpretó junto a los músicos Antonio Ramírez (armonio) y Antonio Puche (violín) un Trío de Gounod ${ }^{48}$. En septiembre de 1886 los actos celebrados en Murcia en homenaje al compositor Manuel Fernández Caballero incluyeron una velada literario-musical en el Casino en la que se leyeron poesías de escritores murcianos dedicadas a Fernández Caballero y se interpretaron varias obras instrumentales ${ }^{49}$.

${ }^{47}$ Calvo, Reseña, pp. 11-12. Otros festejos por la inauguración del órgano fueron: una merienda en el Huerto de los Marqueses en Espinardo; una gran fiesta en homenaje a Hilarión Eslava en el domicilio de Francisco Yagüe se en la que varios huertanos bailaron parrandas, malagueñas y murcianas; y una velada ofrecida por la familia Gisbert a la que asistieron el organista Vilbac y varios literatos murcianos como Selgas, Arnao y José Marín Baldo.

${ }^{48}$ La Paz de Murcia, XXVII (1884), no 7913, 7 mayo, p. 1.

${ }^{49}$ Las poesías se publicaron en La Paz de Murcia, XXIX (1886), n ${ }^{\text {os }} 9019,14$ septiembre, p. 1 y 9020 , 15 septiembre, p. 1. El repertorio musical incluyó la sinfonía Paragraf III de Suppé arreglada para sexteto (no consta plantilla), interpretada por Antonio Ramírez, Julián Calvo, Amores, Pérez, Esbrí y Guzmán; una "Fantasía para piano y armonio sobre motivos de Guillermo Tell" interpretada por Francisco Leante (pian) y Julián Calvo (armonio); y una Serenata de Braga ejecutada por Trinidad Ballesteros (violín), Antonio Ramírez (piano) y Julián Calvo (armonio). Ver también Apéndice 6.1. Las crónicas de los actos en homenaje a Fernández Caballero pueden verse en: "Fernández Caballero", La Paz de Murcia, XXIX (1886), n 9007, 31 agosto, p. 1; Antonio Ramírez Pagán, “Don Manuel Fernández Caballero”, El Diario de Murcia, VIII (1886), n 2251, 5 septiembre, p. 2; La Paz de Murcia, XXIX (1886), n 9011, 4 septiembre, p. 1; "Fernández Caballero", La Paz de Murcia, XXIX (1886), no 9012, 5 septiembre, p. 1; La Paz de Murcia, XXIX (1886), $\mathrm{n}^{\circ}$ 9013, 6 septiembre, p. 1; El Diario de Murcia, VIII (1886), $\mathrm{n}^{\circ} 2252,7$ septiembre, p. 2; "Fiesta de mañana", La Paz de Murcia, XXIX (1886), no 9015, 9 septiembre, p. 1; La Paz de Murcia, XXIX (1886), no 9016, 10 septiembre, p. 1; "La velada de anoche", La Paz de Murcia, XXIX (1886), $\mathrm{n}^{\circ}$ 9017, 11 septiembre, p. 1; "Solemnidad popular", El Diario de Murcia, VIII (1886), nº, 11 septiembre, p. 1. 


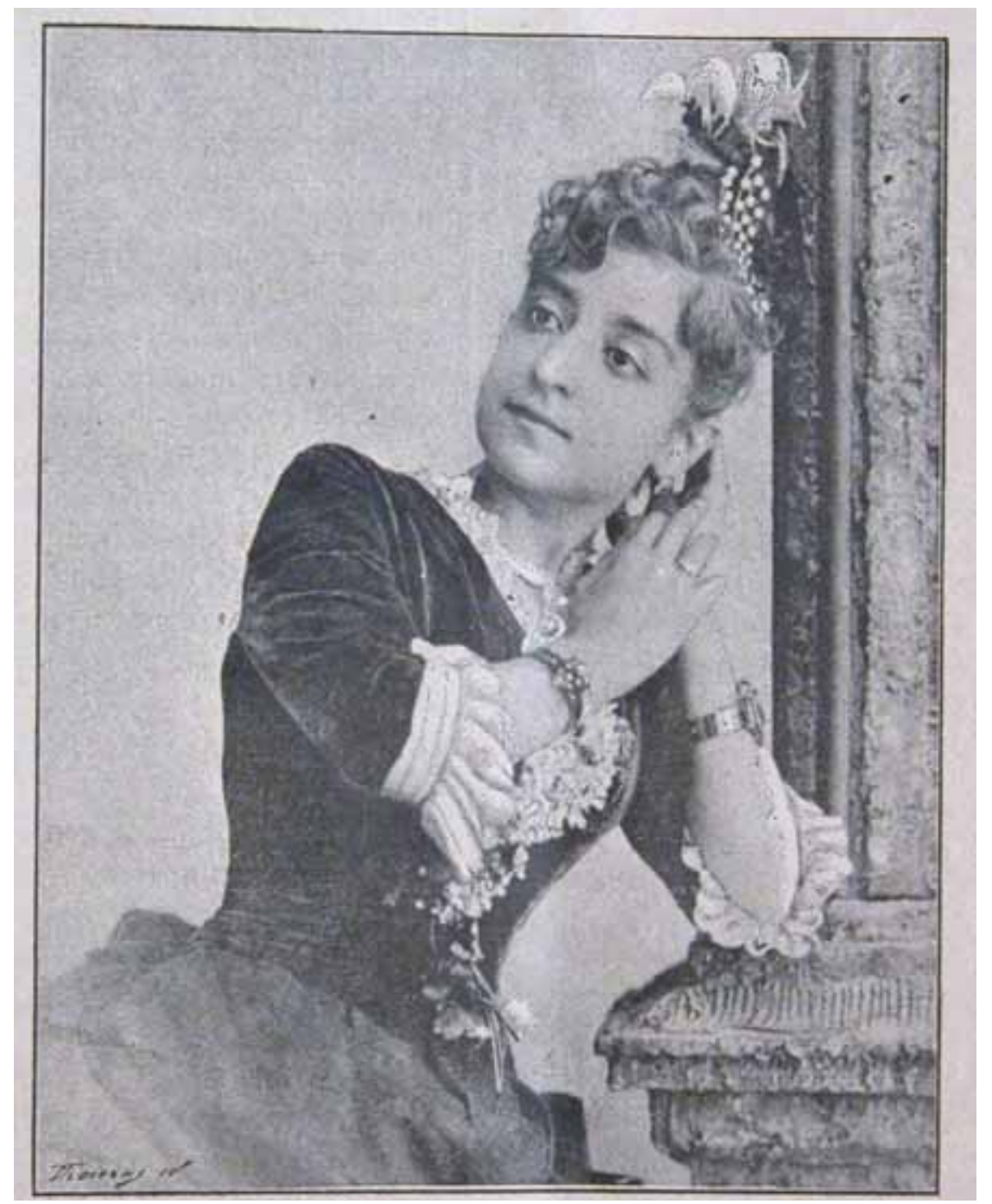

Figura 6.6. La cantante de Cartagena Ana López Peñafiel (1866-?).

E:CARm. Cartagena Artística, I (1890), nº 16, 10 septiembre, p. 1.

En conjunto, el repertorio interpretado en los conciertos vocales e instrumentales del Casino de Murcia (casi siempre con piano y/o armonio) no difiere del ejecutado en otros salones de la ciudad (ver los programas interpretados en el Apéndice 6.1). Los números de óperas y zarzuelas, por ese orden, fueron las piezas preferidas por los cantantes. Entre las composiciones instrumentales destacan las fantasías inspiradas en óperas ("Fantasía concertante con la ópera Il Due Foscari", "Fantasía sobre Lucrezia Borgia"), variaciones y otras piezas de salón. De la literatura para tecla se interpretaron obras de Johann Sebastian Bach (Fuga a cuatro voces), Domenico Scarlatti (Sonata), Johannes Brahms (Danzas Húngaras), Frederic Chopin (Balada y Polonesa en mi bemol mayor, op. 22), Franz Liszt (Nocturno y Rapsodia Húngara), Louis Lefébure-Wély (Gran Galop a cuatro manos) y Nikolái Rubinstein (Tarantella), entre otros. Las veladas interpretadas en el Casino eran a veces mixtas, e incluían géneros difíciles de clasificar. Por ejemplo, en marzo de 1868, después de la velada con "juegos de magnetización" que Reynaud ofreció en el Casino, hubo una soirée "del género alegre" cuyo protagonista fue 
el cantante Roger, que interpretó "distintas piezas de los géneros francés, italiano y andaluz" ${ }^{\circ 0}$.

\subsection{Los bailes de sociedad del Casino}

El Casino de Murcia organizó regularmente bailes de sociedad (ver Lámina 6.6) en festividades como San Fulgencio (14 enero), la Candelaria (2 de febrero), San Juan (24 junio), San Pedro (29 junio), el Corpus, Carnaval y en los días de la feria de septiembre. Estos bailes eran amenizados por la orquesta del propio Casino ${ }^{51}$ que, ocasionalmente, acogía a otros músicos. Por ejemplo, los bailes de máscaras del Carnaval de 1868 contaron con la orquesta del Casino y con participación de los alumnos de la Sociedad Filarmónica, que cantaron arreglos para coro de varias piezas ${ }^{52}$. Fueron interpretadas la sinfonía de Campanone, el "vals coreado" La lisonjera, la "mazurca coreada" El gabán azul, lanceros, la "danza coreada" Don José, la "polca vals coreada" titulada Besitos al niño, un rigodón, y una danza coreada titulada Los elogios y cotillón. Es posible que las piezas "coreadas" fuesen arreglos de Antonio López Almagro, que era el director de la Sociedad Filarmónica. El baile de máscaras con orquesta y coro gustó al público, a juzgar por los comentarios publicados en La Paz de Murcia:

[...] Coreados según dejamos dicho estos bailes por los alumnos de la Sociedad Filarmónica, pudimos observar los adelantos de éstos y su asiduidad y constancia en los trabajos para en tan poco tiempo poderse presentar con tanto lucimiento, acompañando a la orquesta con acierto, precisión y seguridad, sintiendo que fijada la atención de lleno, como es natural, en el baile y sus bromas, nos distrajera, como sucedía a muchos, el oírlos con toda la atención que se merecen jóvenes tan aventajados ${ }^{53}$.

Uno de los festejos del Carnaval más populares en Murcia durante el siglo XIX era el Entierro de la Sardina, al que acudían vecinos de otras poblaciones cercanas, e incluso de Valencia ${ }^{54}$, y en el que el Casino también participaba de diferentes maneras. La fiesta se celebraba durante tres días. En el primero tenía lugar el "Bando de la Huerta" o anuncio del programa de fiestas, con mascaradas que recorrían la ciudad anunciando los actos y lanzando papeles con versos, algunos escritos en panocho, en los que se hacían críticas a la administración y a los políticos locales ${ }^{55}$. El segundo día tenía lugar el "Testamento de la Sardina"; durante la mañana, una comparsa con el pregonero a caballo

${ }^{50}$ La Paz de Murcia, XI (1868), no 3189, 27 marzo, pp. 2, 3.

${ }^{51}$ La Paz de Murcia, I (1858), no 154, 5 septiembre, p. 1.

${ }^{52}$ La Paz de Murcia, XI (1868), nº 3148, 14 febrero, p. 2. Veáse también la sección posterior dedicada a la Sociedad Filarmónica de Murcia.

${ }^{53}$ La Paz de Murcia, XI (1868), n 3153, 19 febrero, p. 2; ver también Documentario.

${ }^{54}$ El inicio de esta festividad en Murcia suele situarse en 1851; véase Pérez Crespo, El Entierro de la Sardina; y Rubio Arróniz, El Carnaval.

${ }^{55}$ En 1859, por ejemplo, hubo dos comparsas que, desde distintos puntos de la capital, recorrieron las calles con las bandas de música y carrozas recreando escenas típicas de la vida en la huerta. La primera de esas comparsas iba encabezada por Banda de Artillería y la Banda Municipal. La otra, por la banda de música de Mariano Esbrí. La Paz de Murcia, II (1859), nº 317, 19 marzo, p. 1. 
y dos bandas de música recorrían la ciudad anunciando la muerte de la Sardina ${ }^{56}$. El tercer día, el del "Entierro de la Sardina", era el más importante de los festejos. Las descripciones de 1859 y 1865 describen una procesión con carrozas mitológicas (Baco, Vulcano y Tetis), y alegóricas (el Destino y la Libertad), figuras de enanos, escoltas de caballería y magyares, el imprescindible carro de la Sardina, y bandas de música en la parte inicial, central y final de la procesión. En los dos años citados hubo también un "Carro simulando un teatro, donde un violín y redoblante parodiaba la última escena de la ópera El Trovador" "57. Las comparsas interpretaban canciones escritas ex profeso, probablemente con ayuda de los músicos de las bandas ${ }^{58}$. El "Entierro" de 1865 fue organizado y costeado por el Casino, el Círculo Industrial y los gremios, y no por el Ayuntamiento, como hasta entonces ${ }^{59}$. Posteriormente, el Casino de Murcia ha participado en este evento de diversas maneras ${ }^{60}$.

Durante los días de Carnaval el Casino de Murcia organizaba bailes de máscaras que solían empezar a las once de la noche, alargándose hasta las dos o las tres de la madrugada (e incluso más). El último baile de los Carnavales se denominaba "de piñata" y en él se repartían bouquet de flores a las señoras y otros regalos a los asistentes: "vistosas bandas y condecoraciones para los caballeros y bonitos adornos de plumas, abanicos, cajitas de sorpresa, caprichosas panderetas y otros mil objetos de señoras" ${ }^{\prime \prime 1}$. A los bailes de máscaras del Casino sólo podían asistir sus socios, pero no las clases más populares $^{62}$, y en ellos se seguían las convenciones habituales en los bailes de la época (ver Figura 6.7). Entre los disfraces y máscaras que se veían en ellos los había de personajes conocidos de las óperas y zarzuelas de moda. En 1870, por ejemplo, una persona iba disfrazada como la protagonista de La Africana de Meyerbeer ${ }^{63}$. En febrero de 1885, hubo una comparsa "de colegialas como los [sic] del Hermano Baltasar alegraron el salón",64, apenas un mes después del estreno en Murcia de la zarzuela en tres actos El Hermano Baltasar de Fernández Caballero y libreto de José Estremera, representada en el Teatro Romea el 8 de enero de $1885^{65}$.

${ }^{56}$ La Paz de Murcia, I (1859), no 317, 19 marzo, p. 1. Los carnavales del año siguiente fueron similares, según puede leerse en La Paz de Murcia, III (1860), nº 617, 17 febrero, pp. 1-2.

${ }^{57}$ La Paz de Murcia, I (1859), no 317, 19 marzo, p. 1.

${ }^{58}$ La Paz de Murcia, VIII (1865), n 2118, 3 enero, p. 2.

59 Véase La Paz de Murcia, VIII (1865), $\mathrm{n}^{\text {os }}$ 2082, 17 enero, p. 1; 2118, 3 marzo, pp. 1-2 y 2124, 8 marzo, p. 1 y la descripción del Carnaval del año 1874 de Comellas, "El Carnaval de Murcia", La Paz de Murcia, XVII (1874), nº 5009, 25 febrero, p. 1.

${ }^{60}$ Ver Pérez Crespo, El Entierro de la Sardina.

${ }^{61}$ [Anónimo], "Últimas fiestas. Apoteosis del Carnaval en el Casino", La Paz de Murcia, XXX (1887), nº 8131,1 marzo, p. 1.

62 “[...] en estas noches [se] ha demostrado la falta de un local donde se den bailes a los que pueda ir la numerosa y honrada clase que no puede asistir a los aristocráticos del Casino". La Paz de Murcia, XXVIII (1885), n 8148, 17 febrero, p. 1. Las crónicas de estos bailes suelen contener largos listados de asistentes. Véase, por ejemplo, "Variedades. Bailes del Casino", La Paz de Murcia, XIII (1870), n 3815, 3 marzo, p. 1.

63 "Entre ellas [las máscaras] llamó la atención una que vestía el rico traje de la protagonista de la última ópera de Meyerbeer, La Africana [Sélika]": La Paz de Murcia, XIII (1870), n 3813, 1 marzo, p. 1.

${ }^{64}$ La Paz de Murcia, XXVIII (1885), nº 8137, 4 febrero, p. 1.

${ }^{65}$ La paz de Murcia, XXVIII (1885), nos 8112, 7 enero, p. 4; 8114, 9 enero, p. 1 y 8116, 11 enero, p. 1. 


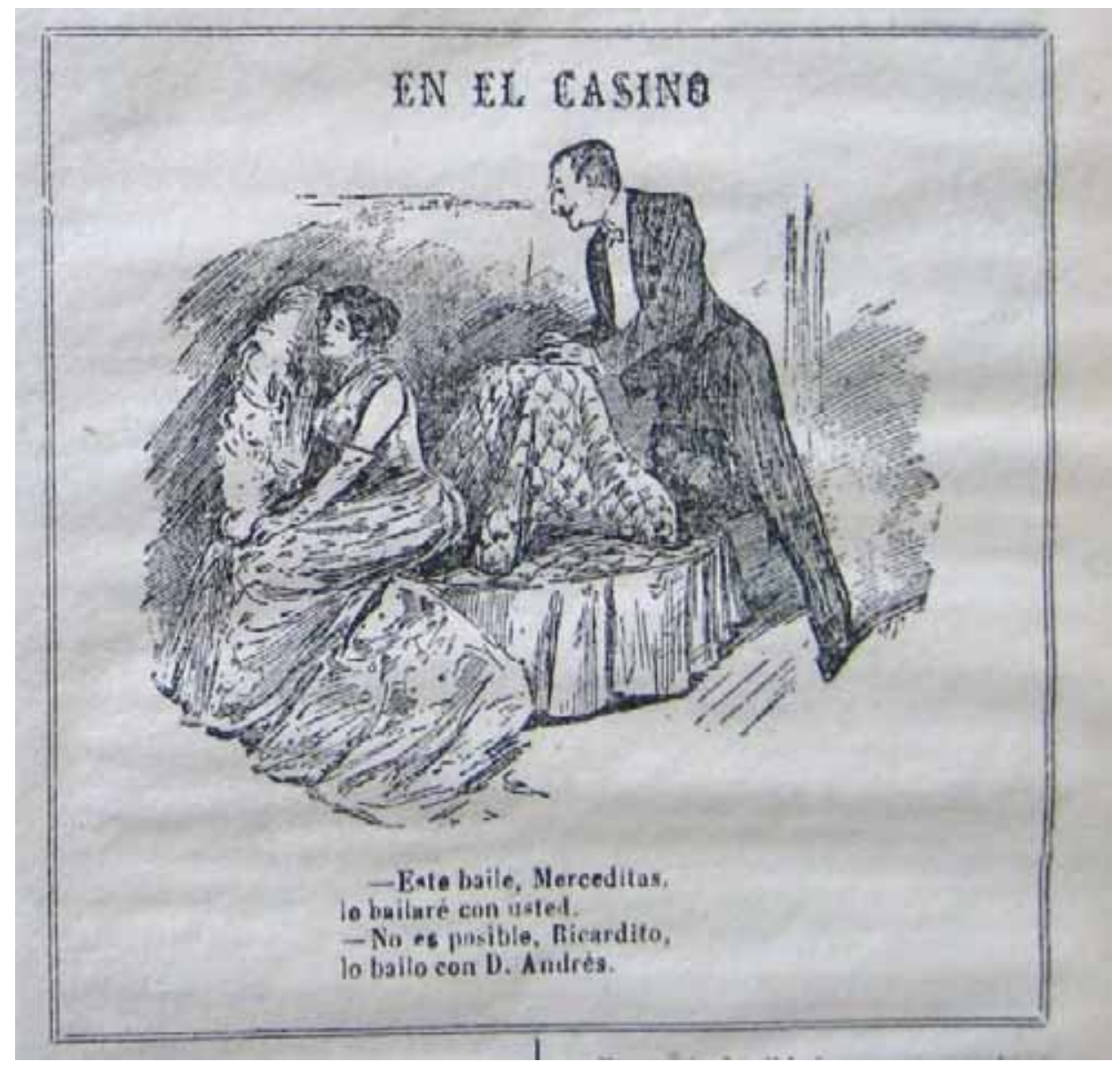

Figura 6.7. Viñeta sobre los bailes del Casino de Murcia.

E:MUm. La Juventud Literaria V (1893), nº 167, 2 julio, p. 1.

Los bailes del Casino se celebraban en su fastuoso "salón de baile"66 (ver Figura 6.8) y solían ser organizados por una comisión especial de jóvenes socios, denominada "comisión de recibo", "para que reciban a todas las señoras que concurran a los bailes y las obsequien con bonitos ramos de flores"67. Hacia la mitad de la velada los miembros de la citada comisión solían repartir dulces y refrescos ${ }^{68}$. El repertorio habitual de la orquesta, tanto en los bailes de máscaras como en otros, estaba compuesto por rigodones, polcas, habaneras, lanceros y valses, entre otras piezas, que se interpretaban individualmente o por tandas ${ }^{69}$. La repetición de repertorio parece haber sido habitual. En 1867, en La Paz de Murcia se preguntaba retóricamente: “¿Nos podrá decir el señor Presidente del Casino, que tanto está trabajando para que los bailes de este año se den con el mayor lucimiento, concurrencia y animación, si la orquesta que lleve dejará oír los valses y polcas que ya sabemos de memoria? ${ }^{70}$.

${ }^{66}$ Construido entre 1870 y 1875, el "salón de baile" del Casino es de estilo neobarroco de inspiración francesa y en su techo hay un majestuoso lienzo pintado, entre otros, por Manuel Arroyo y Eduardo Gil Montejano. Véanse más detalles en Vera, El Casino, pp. 11-13.

${ }^{67}$ La Paz de Murcia, X (1867), no 2779, 24 enero, p. 2.

${ }^{68}$ Véase, por ejemplo, La Paz de Murcia, XI (1868), nº 3166, 3 marzo, p. 2.

${ }^{69}$ Véase, La Paz de Murcia, XII (1869), no 3496, 16 febrero, p. 1 y La Paz de Murcia, X (1867), no 2923, 26 junio, p. 2

${ }^{70}$ La Paz de Murcia, X (1867), no 2779, 24 enero, p. 2. 


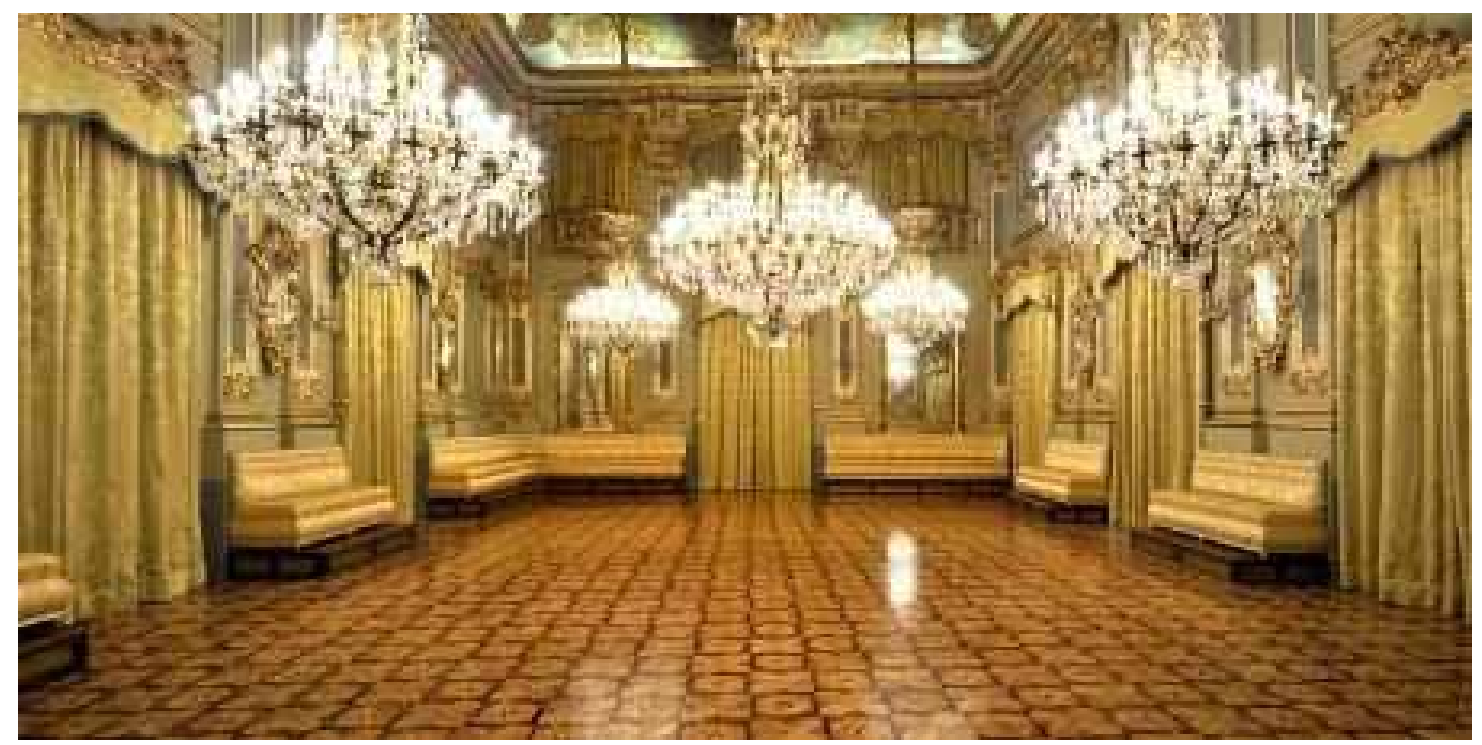

Figura 6.8. Salón de baile del Casino de Murcia en la actualidad. Accesible en: http://www.casinomurcia.com (acceso el 1-10-2011)

\section{El Círculo Industrial (1862-1878)}

El Círculo Industrial fue una de las sociedades recreativas e instructivas más relevantes y estables del panorama murciano de la segunda mitad del siglo XIX. No fue una asociación de ámbito exclusivamente musical, aunque contó con secciones especializadas en música y con un teatro propio. El teatro del Círculo Industrial fue, en el ámbito de los teatros dependientes de sociedades, el más relevante de Murcia durante la segunda mitad del siglo XIX y el que más música programó, tanto de género instrumental como vocal (ópera y zarzuela).

\subsection{Primeras noticias sobre la fundación de la sociedad del Círculo Industrial (1862-1866)}

Los trámites para la fundación del Círculo Industrial se remontan a julio de $1862^{71}$. Sus fines y metas fueron: "la instrucción combinada con el recreo, estableciendo [...] cátedras de distintas clases para que sirviera de base a la formación de un Ateneo"72. El primer presidente del Círculo Industrial fue Pedro María Sánchez y la sede de la

\footnotetext{
${ }^{71}$ Según Antonio Crespo un grupo de murcianos solicitaron al Gobernador permiso para constituir una asociación con el título de Círculo Industrial en julio de 1862. No hay constancia de los nombres de los solicitantes. Según Crespo, Antiguos teatros, p. 47, la primera reunión de esta sociedad tuvo lugar el 1 de enero de 1863 y en ella se tomaron varios acuerdos, según consta en El Segura, I (1863), nº 3, 2 enero, p. 2: aplazamiento de la inauguración del Círculo al 6 de enero de 1863, elección de los miembros de la directiva (no figuran nombres), cesión perpetua de los anticipos reintegrables que algunos socios habían depositado en la sociedad como ayuda para la constitución de la misma y formulación de los fines del Círculo Industrial.
}

${ }^{72}$ El Segura, I (1863), nº 3, 2 enero, p. 2. 
sociedad se fijó en la plaza de los Gatos (actual plaza de Fernández Caballero) ${ }^{73}$. En el Reglamento del Círculo Industrial de Murcia, publicado en 1863 se estableció que su finalidad era "proporcionar a sus individuos el recreo e instrucción posibles" "74. Para ser socios se requería tener dieciocho años o más, ser propuesto por individuos de la sociedad y "tener buena conducta, profesión y u oficio conocido"75. Desde 1865, la sociedad disponía de gabinete de lectura ${ }^{76}$. La sociedad se comprometía a tener en su local al menos una mesa de billar y diversos juegos de mesa, como por ejemplo, la baraja o el ajedrez. La Junta Directiva era la encargada de programar "los bailes, conciertos o funciones que puedan proporcionar ingresos en los fondos de la sociedad", aunque el local quedaba a disposición de los socios si un cierto número de ellos lo solicitaba y corría con los gastos extraordinarios ${ }^{77}$.

Hasta 1867 no he hallado documentación sobre la labor artística de esta sociedad, salvo un conjunto de noticias sobre bailes organizados en sus salones, de los que trataré más adelante.

\subsection{La construcción del teatro del Círculo Industrial y la creación de la sección lírico-dramática (1867-1869)}

En febrero de 1867 se incorporaron al Círculo Industrial ciento veinte nuevos socios provenientes de otra sociedad dramática ${ }^{78}$. Los nuevos miembros formaron la sección lírico-dramática del Círculo destinada a organizar funciones teatrales de aficionados. Contaban con un director propio (distinto del Círculo) renovable anualmente. La actividad teatral de esta sección fue, a lo largo de los años siguientes, muy constante. Aunque las representaciones eran de carácter aficionado, en algunas ocasiones contrataron actores profesionales y las obras llevadas a escena eran tanto del género dramático como lírico.

Apenas estuvo constituida, la nueva sección lírico-dramática solicitó al Círculo Industrial en febrero de 1867 la construcción de un teatro en "la habitación que hay a la

${ }^{73}$ La Paz de Murcia, XVII (1874), n ${ }^{\circ}$ 5210, 7 noviembre, p. 1. El local era amplio y tenía un café propio, La Paz de Murcia, IX (1866), nº 2642, 4 septiembre, p. 2. Según El Avisador (1869), [sin n ${ }^{\circ}$ ], 22 enero, p. 3 estuvo situado en el número 4.

${ }^{74}$ Reglamento del Círculo Industrial de Murcia. (Murcia: Imprenta de Francisco Bernabeu, 1863), p. 1. Uno de sus artículos prohibía a los socios discutir sobre religión o política, según el Reglamento del Círculo, pp. 2-3. Los fines de la sociedad en 1865 quedaron regulados en el Reglamento orgánico del Círculo Industrial de Murcia. (Murcia: Imprenta de Francisco Bernabeu), 1865, p. 3 y eran: "proporcionar a sus asociados el recreo, ilustración y pasatiempos lícitos que proporciona la buena sociedad, siendo enteramente extraña a la política". Véanse también, Reglamentos orgánico e interior del Círculo Industrial de Murcia. (Murcia: Establecimiento Tipográfico de "La Paz", 1870) y Reglamento del Círculo Industrial de Murcia. (Murcia: Establecimiento Tipográfico de "El Obrero", 1873).

75 Reglamento del Círculo (1863), p. 2. Desde 1865, la admisión de socios recayó en una Junta de Admisión compuesta de nueve individuos. Véanse más detalles sobre el equipo directivo de la sociedad y sus funciones en Reglamento orgánico, pp. 5-8. alta".

${ }^{76}$ Reglamento para el buen régimen (1865), p. 5 aunque "se prohíbe comentar noticias, [y] leer en voz

${ }^{77}$ Reglamento del Círculo (1863), p. 6.

${ }^{78}$ Desconozco cuál fue. No puede tratarse de los socios del recién formado Liceo Lírico-Dramático. 
espalda del salón bajo", una sala que años atrás había sido utilizada como aula ${ }^{79}$. Un mes más tarde, la Junta Directiva del Círculo, encabezada por José María Meseguer Andreu, aprobó los presupuestos necesarios para iniciar las obras del escenario y los "modelos para decoraciones" $"$. Los trabajos se prolongaron hasta finales de junio de 1867, momento en el que se inauguró ${ }^{81}$. Los trabajos de construcción del teatro fueron seguidos diariamente por la prensa murciana y se aplaudió la abnegación y el entusiasmo de los socios del Círculo Industrial. La creación del teatro provocó la proliferación de artículos periodísticos sobre los beneficios de la asociación en la sociedad murciana del momento ${ }^{82}$.

La sociedad del Círculo programó conciertos con diversos cantantes e instrumentistas que se hallaban de paso por la ciudad, como los hermanos D'Herbil Eloísa (pianista) y Arturo (barítono) en septiembre de 1867 y, al menos en proyecto, con la contralto Locatelli y el tenor Montechini, en octubre del mismo años ${ }^{83}$. El Apéndice 6.3 muestra los conciertos ofrecidos por el Círculo Industrial entre 1867 y 1877.

La actividad durante los dos años siguientes (1868-1869) fue, según la documentación consultada, más exigua. En febrero de 1868 sólo hubo una función teatral de aficionados y en mayo del año siguiente, otra en beneficio de una actriz en paro ${ }^{84}$. La

${ }^{79}$ La Paz de Murcia, X (1867), no 2804, 19 febrero, p. 2.

${ }^{80}$ La Paz de Murcia, X (1867), n 2821, 9 marzo, p. 2. Los ingresos ordinarios de la sociedad no fueron suficientes para levantar el teatro. Algunos socios colaboraron prestando materiales, sumas de dinero e incluso, mano de obra: La Paz de Murcia, X (1867), nº 2925, 28 junio, p. 1.

${ }^{81}$ La función inaugural del teatro del Círculo Industrial se celebró el día de San Pedro (29 de junio). Debido al crecido número de socios y el reducido espacio del teatro, la Junta Directiva se vio obligada a repetir hasta cuatro veces distintas esta función (la última, el 7 de julio de 1867). Los turnos de asistencia de los socios se establecieron por sorteo y se limitó, además, el número máximo de entradas que cada socio podía adquirir. El acto comenzó con la sinfonía de la zarzuela Amar sin conocer arreglada para banda y dirigida por Córdoba. Tras ésta se interpretaron El amor y el interés, de Luis Mariano de Larra, y la pieza en un acto La casa de campo, de José Sánchez Albarrán. Ambas contaron con la dirección escénica de José Esbrí y Romero; la participación de los actores aficionados Tomás Valderrábano, Carolina Servaty, Luisa Yagüe, Antonio Jubés, Benigno Díez y Sanz de Revenga, Pedro Servaty, Francisco Almela y Rafael Corral y la del apuntador José Oliva. Las decoraciones fueron realizadas por los pintores Ramón Mauricio (telón de boca) y Arturo González (decoración de selva). Además, se leyeron composiciones poéticas de, entre otros, Ecequiel Díez y Sanz de Revenga, Baltasar Meoro y Pío José Tejera. La crónica de la función inaugural, firmada por Diego Espinosa, apareció en La Paz de Murcia, X (1867), no 292893 julio, p. 1. Véanse más detalles en: La Paz de Murcia, X (1867), $\mathrm{n}^{\mathrm{os}}$ 2921, 23 junio, p. 2; 2923, 26 junio, p. 2; 2930,7 julio, p. 2 y 2935, 9 julio, p. 2.

${ }^{82}$ Citaré como ejemplo el extenso artículo de "Homoquidam", escrito en diversas fechas entre mayo y junio de 1865, y que fue publicado por partes (quizá por segunda vez) en las primeras páginas del periódico La Paz de Murcia. Véanse: La Paz de Murcia, X (1867), n ${ }^{\text {os }}$ 2866, 26 abril, pp. 1-2; 2867, 27 abril, p. 1; 2872, 2 mayo, pp. 1-2; 2875, 5 mayo, p. 1 y 2879, 9 mayo, pp. 1-2. "Homoquidam" también fue el autor de "El Círculo Industrial y las asociaciones", publicado en La Paz de Murcia, X (1867), n 2859, 17 abril, pp. 1-2. De él extraigo el siguiente fragmento: “¿Qué recursos llenan las arcas del "Círculo"? ¿Qué donación da con largueza extraña a la modesta sociedad, medios para tan soberbia empresa? ¿Quién? El genio de la asociación, que para comenzar y llevar a cabo sus MARAVILLAS, sólo necesita juntar al inestimable don de la fe el firme propósito de una buena voluntad".

${ }^{83}$ No consta el día. Su anunció apareció en La Paz de Murcia, X (1867), no 3018, 2 octubre, p. 2. Los cantantes también ofrecieron un concierto en la Sociedad Filarmónica el 4 de octubre de 1867. Cabe pensar que finalmente no se realizara en las dependencias del Círculo Industrial.

${ }^{84}$ El 24 de febrero de 1868 se representó en el teatro del Círculo las comedias de Tomás Rodríguez Rubí Honra y provecho y De potencia a potencia. Esta función fue repetida el 19 de marzo de 1868: La Paz de Murcia, XI (1868), $\mathrm{n}^{\text {os }}$ 3160, 26 febrero, p. 2 y 3182, 19 marzo, p. 2. Las obras representadas el 9 de 
escasa animación de la sociedad fue puesta en evidencia por algunos medios periodísticos, que veían al Círculo Industrial abocado a su disolución:

[...] El "Círculo Industrial" ya no presenta esas señales externas que denuncian el método y buen arreglo en una casa, en una familia, en una corporación y hasta en un individuo. Hay algo de sombrío, algo que aflige y entristece el alma en aquellas desmanteladas paredes, en aquellos escasos, destruidos y desvencijados muebles y en aquellas frías habitaciones. Hay bastante en su aspecto externo e interno que traduce el desarreglo de ciertas gentes, al ver gastadas cantidades de consideración en un teatro que pronto destruiremos como innecesario, en tanto que se carece hasta de lo más preciso. Hay mucho en todo aquel conjunto que está demostrando el que hay cierta clase de ingresos señalados como malditos por el dedo de Dios, que no pueden llevar la prosperidad y la dicha a ninguna parte, siendo por el contrario ocasión de ruina, de miseria y de desgracia. Todo revela que esta sociedad marcha a pasos agigantados a su disolución. [...] ¿Por qué el "Círculo Industrial” no siguió siendo lo que fue en la época de su fundación? ¿Por qué siendo reunión de artesanos abrió las puertas a todas las gentes de incierto vivir y holgazana conducta? ¿Por qué no tuvo en inestimable honra el ser siempre presidido por una honrada y honrosa chaqueta?. $[\ldots]^{85}$.

En 1869 había 245 miembros en la sociedad (según datos de febrero) y los escasos beneficios del teatro no generaban una situación económica floreciente en el Círculo ${ }^{86}$. Sin embargo, la sociedad tomó un nuevo rumbo desde 1870 y comenzó a recuperarse, como prueba la reforma de ampliación de su teatro en febrero de $1870^{87}$.

mayo de 1869 no constan en la prensa y tampoco el nombre de la actriz en paro: La Paz de Murcia, XII (1869), no 3569, 11 mayo, p. 1.

85 "Un caballero particular, "Revista de Murcia. El Círculo Industrial”, La Paz de Murcia, XI (1868), $\mathrm{n}^{\circ}$ 3191, 29 marzo, p. 2. Las cursivas son editoriales.

${ }^{86}$ La nómina de los socios y sus profesiones era: “Agrónomos, 1; agentes, 1; ayudantes de obras públicas, 3; operadores, 1; abastecedores de carnes, 1; abogados, 5; administradores de fincas, 4; boticarios, 1; barberos, 2; carpinteros, 13; comerciantes, incluso los dependientes, 25; corredores, 4; cesantes, 7; catedráticos, 1; caldereros, 1 ; curtidores, 1 ; cereros, 1 ; cordoneros, 1; cantareros, 1; canteros, 1, confiteros, 1; doradores, 1; escribanos, 1, encuadernadores, 1; empleados de todas clases, 51; estudiantes, 4; fondistas, 2; fabricantes de chocolate, 1; herreros, 4; ingenieros, 2; impresores y libreros, 5; jubilados, 1; militares, 2; de administración militar, 1; médicos, 2; molineros, 1; hojalateros, 1; plateros, 10; pintores, 1; propietarios, 45; procuradores, 1; practicantes, 2; retirados, 2; oficio conocido, 8; tahoneros, 1; torcedores, 3; taberneros, 1; telegrafistas, 2; tintoreros, 2; tapiceros, 3. Total, 245": La Paz de Murcia, XII (1869), n 3496, 16 febrero, p. 1. En abril de 1869, la Junta Directiva se reunió para aprobar las cuentas del año anterior: $L a P a z$ de Murcia, XII (1869), n $\mathrm{n}^{\mathrm{o}}$ 3552, 23 abril, p. 1. En octubre, La Paz de Murcia, XII (1869), n 3695, 9 octubre, p. 1 atestiguaba que el estado financiero de la sociedad no era floreciente:.

\footnotetext{
${ }^{87}$ El Presidente General del Círculo Industrial durante el año 1870 fue Pascual Abellán.
} 


\subsection{La actividad concertística y teatral del Círculo Industrial desde 1870 a 1872}

Debido a las dimensiones reducidas del teatro del Círculo (la "escasa capacidad que hay entre bastidores" ${ }^{\prime 88}$ ) y el limitado número de socios que podían asistir a las funciones, la sociedad amplió con una galería el espacio del salón en febrero de $1870^{89}$. Ese año las representaciones teatrales fueron muy numerosas (ver Apéndice 6.4). El socio de número Pedro María Sánchez dirigió la sección lírico-dramática. Manuel Castillo y Ángel Mirete se encargaron, respectivamente, de la dirección escénica y de la orquesta ${ }^{90}$. Los músicos Mariano García, Julián Calvo, José Esbry y José Antonio Ramírez colaboraron en estas veladas ${ }^{91}$. Se incluyeron piezas vocales de ópera y zarzuela, obras instrumentales, poesías de escritores murcianos, comedias, dramas y sainetes. Las funciones solían durar varias horas (a veces más de cuatro), con extensísimos programas y grandes intermedios, necesarios para cambiar los decorados ${ }^{92}$. El repertorio no difiere del representado en otros teatros murcianos del momento. Se interpretaron fragmentos de óperas de Mercadante (Oraci e curiaci), Rossini (Il Barbiere di Siviglia), Donizetti (L'elisir d'amore), Federico Ricci (Le prigione di Edimburgo) y, muy especialmente Verdi, del que representó íntegro el cuarto acto de Il Trovatore y diversas arias de Attila, así como representaciones completas de zarzuelas en un acto de Gaztambide (El amor y el almuerzo, Una vieja y iEn las astas del toro!), Gaztambide y Barbieri (Un caballero particular) y Oudrid (Nadie se muere hasta que Dios quiere).

Las funciones teatrales también dieron lugar a la interpretación de música instrumental, tanto de autores extranjeros como locales. En esas funciones se estrenó, por ejemplo, una "Sinfonía" de Fernando Verdú, un "Wals coreado" de Julián Calvo y una "Mazurca de salón para piano" de Adolfo Gascón. En ocasiones esas obras alternaban con otras, como el "Capricho Húngaro" de Ketterer, ejecutado al piano a cuatro manos por Adolfo Gascón y Pedro Lozano. En junio de 1870 hubo también un concierto a cargo del guitarrista Miguel Cebrián (ver Apéndice 6.3) y en enero del año siguiente se representó la zarzuela de Oudrid El postillón de la Rioja y se estrenó el "capricho humorístico" iQué guasón!, para coro y orquesta de Fernando Verdú ${ }^{93}$.

En 1872 se creó la "Sección científico-literaria e industrial" del Círculo Industrial, dirigida por Juan López Somalo, Antonio Hernández Amores y Luciano Diez y Sanz de

${ }^{88}$ La Paz de Murcia, XIII (1870), nº 3793, 5 febrero, p. 1.

89 “Con objeto de poder satisfacer el deseo de los muchos socios que piden billete para estas funciones se ha construido al final del salón una galería en que cómodamente pueden colocarse un buen número de espectadores". Véase, La Paz de Murcia, XIII (1870), n 3789, 1 febrero, p. 1.

${ }^{90}$ Entre los actores y cantantes que actuaron en el Círculo estuvieron: Juana Ruiz, Purificación Baño, Carmen Pinilla, Arturo González, Abelardo Valero, Luis Marco Padilla (hermano del barítono Mariano Padilla), Antonio Dubois, Fuensanta Mateos, Antonia Sánchez, Faustina Leirado, Teresa Herrera, Carmen Pinilla, Dolores Sánchez y los señores Valero, Verdú, Villar, Corral Mejía, Martín Martínez, Antonio María Márquez, Arturo González, Joaquín Barceló, Eduardo Bermúdez, Enrique Romero y Pedro Alcántara Soriano: La Paz de Murcia, XIII (1870), no 3772, 12 enero, p. 1.

${ }^{91}$ Al final de este año debutó Luis Marco Padilla, hermano del barítono Mariano Padilla.

${ }^{92}$ Las funciones solían empezar entre las siete y media y las ocho y acababan entre las doce y la una de la madrugada. El crítico Espinosa, desde la sección "Variedades" del periódico La Paz de Murcia pidió en diversas ocasiones que se acortaran las funciones.

${ }^{93}$ La Paz de Murcia, XIV (1871), nos 4079, 28 enero, p. 1 y 4217, 13 julio, p. 1. 
Revenga ${ }^{94}$. También comenzaron a impartirse clases de "Matemáticas", a cargo de Eduardo Cabero; de "Francés", por José María Báguena y Francisco Tarín García; y, finalmente, de "Teneduría de libros" "95, cuyo profesor fue José Agulló y Muñoz. Además, el edificio fue reformado: se empapelaron los salones, se compraron alfombras y estatuas, se acondicionaron habitaciones que estaban inservibles y se hicieron nuevas libreas a los mozos ${ }^{96}$.

La actividad teatral y concertística durante el año 1872 fue, comparándola con la del año anterior, más prolija. Se programaron abonos teatrales a cargo de la sección líricodramática, un concierto y "ejercicios prácticos" o exhibiciones públicas de alumnos y profesores, que fueron el germen de la "Escuela de Canto y Declamación Padilla, como analizaré en el apartado siguiente.

Las representaciones teatrales se iniciaron en mayo de 1872 y se prolongaron hasta julio ${ }^{97}$. En total, se ofrecieron quince funciones: dos independientes y un abono de diez con tres funciones extra (una de ellas a beneficio de la actriz Aurora Pareja) ${ }^{98}$. Los actores y actrices eran miembros de la sección lírico-dramática de aficionados $\mathrm{y}$, como novedad, el Círculo contrató a dos actrices profesionales "que formaban parte de la compañía de zarzuela que últimamente ha actuado en Cartagena"99.

Antes de 1872, a los conciertos y funciones teatrales del Círculo Industrial sólo podían asistir sus socios (previo sorteo de las entradas entre los mismos). El abono de representaciones de 1872 permitió el acceso a cualquiera que pagase una entrada de tres reales, aunque no fuera socio. De esta forma, el teatro del Círculo entró en el circuito de teatros murcianos del momento y rivalizó en la captación de público de la ciudad.

La mayoría de estas funciones ofrecían un repertorio variado de obras en un acto: zarzuelas -gran parte del género bufo-, o piezas dramáticas (comedias o juguetes cómicos). Los compositores y obras interpretadas fueron: Gaztambide (El amor y el almuerzo, ¡En las astas del toro!), Cereceda (Pascual Bailón), José Rogel (Dos truchas en seco), Barbieri y Gaztambide (Un caballero particular), Oudrid (Nadie se muere hasta que Dios quiere, D. Sisenando), Luis Arche (;Diez mil duros!), Cereceda y Federico Bardán (Los estanqueros aéreos), Offenbach (La soirèe de Cachupin y El general Bum Bum) y Fernando Verdú (Un hallazgo a tiempo, zarzuela "de costumbres murcianas") ${ }^{100}$. De ese listado, se representaban por primera vez en la ciudad Dos truchas en seco, El

${ }^{94}$ La Paz de Murcia, XV (1872), nº 4368, 14 enero, p. 1.

${ }^{95}$ La teneduría de libros se puede considerar como una parte de la contabilidad. Consiste en la elaboración de los registros contables. Es decir, es el proceso rutinario de registrar, clasificar y resumir la información de las transacciones efectuadas por una entidad.

${ }^{96}$ Véanse las reseñas que publicó La Paz de Murcia, XV (1872), $n^{\text {os }} 4487,8$ febrero, p. 1 y 4498, 22 febrero, p. 1 sobre las reformas del edificio.

${ }^{97}$ La última representación tuvo lugar el 7 de julio de 1872, según La Paz de Murcia, XV (1872), ${ }^{\circ}$ 4514, 9 julio, p. 1 .

${ }^{98}$ Las funciones teatrales del abono tenían lugar cada jueves y domingo en el Teatro del Círculo Industrial: La Paz de Murcia, XV (1872), nº 4468, 14 mayo, p. 1 (ver Apéndice 6.4).

4.

${ }^{99}$ No constan los nombres: La Paz de Murcia, XV (1872), n ${ }^{\text {os }}$ 4468, 14 mayo, p. 1 y 4478, 25 mayo, p.

${ }^{100}$ Algunas de las obras se repitieron a lo largo del abono, por expreso deseo de sus socios. La Paz de Murcia, XV (1872), n 4487, 6 junio, p. 1. 
general Bum Bum y D. Sisenando. La presencia de títulos en el repertorio teatral del Círculo Industrial es un indicativo de que el género de Arderíus gustaba al público, a pesar de las polémicas suscitadas en torno al género bufo (ver Capítulo 3).

En el concierto de abril de 1872, que contó con la colaboración del cornetín Amer, intervinieron además, los cantantes Juana Ruiz y Abelardo Valero, y el pianista Juan Diego Manresa. Se interpretaron composiciones de autores murcianos, como la pieza vocal para coro Danza bufa escrita por Verdú con letra de Basterrechea, entre otras ${ }^{101}$.

Tras el paréntesis del verano de 1872, el Círculo programó una serie de representaciones teatrales con una compañía mixta de socios aficionados y cantantes profesionales (la soprano Amalia Pallizari y el barítono Antonio del Valle). Se ofrecieron en total diecisiete funciones desde octubre hasta diciembre de 1872 (ver Apéndice 6.5). Las dos primeras funciones tenían varias partes e incluían potpurrís de ópera, zarzuela y composiciones de autores murcianos. El resto se programaron en abono. Cada función ofrecía una sinfonía, una zarzuela en dos actos y una pieza dramática en un acto (o bien, dos zarzuelas en un acto: una después de la sinfonía inicial y otra tras la pieza en un acto). Estas funciones, calificadas como "ejercicios prácticos" o "ejercicios lírico-dramáticos", fueron el germen de la "Escuela de Canto y Declamación", que terminaría formalizándose al año siguiente.

\subsection{La "Escuela de Canto y Declamación Padilla" y los ejercicios prácticos lírico- dramáticos (1873)}

En enero de 1873 se anunció la creación de una "Escuela de Canto y Declamación intitulada Padilla", en homenaje al barítono murciano Mariano Padilla y dependiente de la sociedad del Círculo Industrial ${ }^{102}$. Su finalidad fue la educación musical gratuita para jóvenes y niños que querían desarrollar una futura carrera teatral ${ }^{103}$. Los profesores fueron Amalia Pellizzari y Antonio del Valle Quirós. La escuela pretendió organizar una sesión mensual en el teatro Romea para que los alumnos exhibieran sus resultados académicos:

[...] con objeto de que los jóvenes de ambos sexos que tengan las facultades necesarias puedan encontrar a su alcance los medios para dedicarse a tan importante carrera.

La enseñanza alcanzará [también] a los niños que se albergan en la casa provincial de Misericordia y que se crean adornados de las disposiciones necesarias.

Para dar a conocer los resultados y alentar a los alumnos en sus estudios habrá sesiones mensuales en el teatro de Romea, si como es de esperar cede el

${ }^{101}$ La Paz de Murcia, XV (1872), nº 4542, 14 abril, p. 1.

${ }^{102}$ La idea partió de Tomás Valderrábano, entonces presidente del Círculo: La Paz de Murcia, XVI (1873), no 4719, 22 marzo, p. 1.

103 Hay que diferenciar la mencionada Escuela de Canto y la sección lírico-dramática, ambas dependientes de la sociedad Círculo Industrial. De la lectura de los documentos periodísticos se deduce que la sección lírico-dramática no tuvo un fin educativo sino que funcionó más bien como un grupo de aficionados al teatro que daban representaciones con cierta periodicidad (con o sin actores profesionales). 
municipio el local para una noche en cada mes, que se combinará sea en una de esas en que la empresa que actúe no tenga función ${ }^{104}$.

La inauguración de la escuela de canto tuvo lugar en marzo de 1873 con la representación íntegra de la ópera Norma de Bellini en el Teatro Romea (ver Apéndice $6.5)^{105}$. El teatro se iluminó “con dobles luces [...], adornándose lujosamente su palco presidencial, en el que se colocará el retrato del eminente artista don Mariano Padilla,

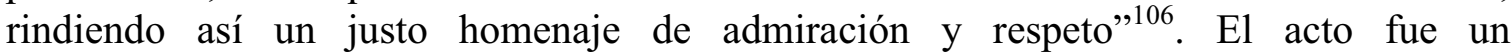
acontecimiento para la ciudad: los socios jóvenes del Círculo entregaron a la entrada del teatro ramilletes de flores a las damas y la banda dirigida por Antonio Raya amenizó los entreactos de la ópera tocando en los salones del teatro ${ }^{107}$. La ópera se montó "en poco más de veinte días" a pesar de que, excepto Amalia Pellizzari -que encarnó el personaje Norma-, "la mayor parte o mejor dicho todos los alumnos inscritos en la expresada escuela no tenían conocimiento alguno del arte musical y, por consiguiente, ha sido necesario hacerles aprender de viva voz todos los cantos de la Norma, empresa mucho más difícil de realizar que lo que algunos creen"108. Norma fue la única ópera en representarse, sin duda, por las dificultades que entrañó montar una obra de tal magnitud con cantantes no profesionales ${ }^{109}$. Los ejercicios posteriores incluyeron obras dramáticas y líricas en un acto y piezas instrumentales y/o vocales. En los intermedios, se leían poesías o se presentaban números de prestidigitación. Se llevaron a escenas zarzuelas completas de los compositores en boga: Barbieri, Oudrid, Cereceda, con una presencia mayoritaria de género bufo.

${ }^{104}$ La Paz de Murcia, XVI (1873), no 4702, 3 enero, p. 1. Desconozco los motivos para no utilizar el teatro del Círculo. Cabe suponer que, dada la magnitud de las obras pensadas para representarse (óperas italianas) considerasen más idóneo el teatro Romea.

${ }^{105}$ La Correspondencia de Murcia, I (1873), $\mathrm{n}^{\circ}$ 8, 30 enero, p. 3.

${ }^{106}$ La Paz de Murcia, XVI (1873), no 4710, 12 marzo, p. 1. El Chocolate, II (1873), nº 12, 20 marzo, pp. 99-100 describió así la entrada al teatro: "Vimos un vestíbulo artísticamente decorado, con magníficas arañas, jarrones de flores, estatuas y cortinas de damasco, en cuyo centro y sirviendo de base a dos laureadas inscripciones de 'Gloria al arte' y 'Gloria a Murcia' descollaba un bonito trofeo musical, como diciendo a los ojos que le miraban: 'Aquí mando yo esta noche' [...]. La prensa alentó la asistencia de los murcianos al evento, argumentando que la ejecución de la obra sería sobresaliente tanto por la intervención de los cantantes principales como por los coros: La Paz de Murcia, XVI (1873), n 4709, 11 marzo, p. 1.

${ }^{107}$ La orquesta de Raya amenizó la entrada con Ernani, de Verdi: La Paz de Murcia, XVI (1873), $\mathrm{n}^{\circ}$ 4718, 21 marzo, p. 1. Tras el segundo acto se leyeron textos poéticos dedicados al evento por los escritores José Pío Tejera, Lorenzo Llinares, Arturo Cayuela, Antonio García Alix, y Pellizzari, entre otros: La Paz de Murcia, XVI (1873), $\mathrm{n}^{\mathrm{os}}$ 4715, 18 marzo, p. 1 y 4719, 22 marzo, p. 1. Algunas de las poesías fueron publicadas en El Obrero, (1873), n 11, 22 marzo, p. 3 y números siguientes. La noche del estreno, el Presidente del Círculo Industrial, Tomás Valderrábano, resultó herido en la muñeca izquierda por el disparo de un individuo que pretendía entrar sin el billete correspondiente: La Paz de Murcia, XVI (1873), nº 4719, 22 marzo, p. 1.

${ }^{108}$ Ibáñez Gónzález, "Escuela Padilla. Norma”, en La Paz de Murcia, XVI (1873), no 4718, 21 marzo, p. 1. Según el crítico, "La música de Bellini es el sentimiento llevado hasta su más alto grado de perfección y los que interpretan sus sublimes melodías necesitan no tan sólo cantarla sino demostrar al público que escucha religiosamente los afectos más encontrados que puede existir en el mundo moral y metafísico".

109 La segunda representación prevista de Norma tuvo que ser suspendida durante seis días por la indisposición de Amalia Pellizzari. 
Las noticias sobre la Escuela de Canto y Declamación dejaron de aparecer en la prensa en noviembre de 1873, aunque la actividad teatral y musical del Círculo Industrial prosiguió durante los años posteriores.

El 4 de mayo de 1873 se celebró una junta general ordinaria en la que se trataron y aprobaron los siguientes puntos: relación de cuentas del año 1872, prohibición de sacar cualquier objeto de la sociedad de sus dependencias, renovación del reglamento, constitución de una comisión encargada de la redacción del nuevo (Mariano Espinosa, Pedro María Sánchez, Salvador Victoria y Juan Piqueras), dimisión del depositario José María Esbry (cargo que recayó en Francisco Padilla y, como vocal, Francisco Luis Giovannielli) y donación de dos colecciones de libros de Nicolás Díaz Pérez y del Ministerio de Fomento ${ }^{110}$.

\subsection{La actividad teatral y concertística del Círculo Industrial desde 1873 hasta 1877}

La sección lírico-dramática del Círculo Industrial organizó actividades propias e independientes de la Escuela de Canto. Durante el año 1873 las representaciones teatrales de la sección lírico-dramática gozaban de reputación en la ciudad, aunque a veces eran criticadas por su decaimiento y falta de animación:

[...] Nos alegraremos que tengan la concurrencia necesaria, cual otras veces, mayormente cuando los aficionados de esa sociedad tienen adquirida una excelente reputación en ese concepto, y cuando no esperamos por hoy tener otro centro donde pasar las largas noches de otoño o invierno. Además, el círculo, por vicisitudes que son conocidas, está algo decaído y necesario es reanimarlo para que no desaparezca, pues no basta el Casino, aún en el estado floreciente en que se halla, para llenar las necesidades de esta capital. Hay clases que no pueden ser socios de él por motivo de la cuota y necesitan otro centro más modesto, cuya necesidad viene llenado el Círculo, razón que obliga a sostenerlo, y fin al que trabaja siempre su Junta Directiva ${ }^{111}$.

La temporada teatral de 1873 llevó a escena nuevas zarzuelas y actores (ver Apéndice 6.5) y la sección lírico-dramática era dirigida por el portugués Arturo Santos ${ }^{112}$. Fueron contratadas dos tiples y una actriz característica. Las zarzuelas representadas en septiembre de 1873 fueron: El hombre es débil, de Barbieri, El último mono y Nadie se muere hasta que Dios quiere, ambas de Oudrid, y Los estanqueros aéreos de Bardán. Tras marcharse de la ciudad los actores y cantantes Enriqueta Imperial y Lino Alpuente, la Junta Directiva se vio obligada a suspender las funciones y emprender nuevas gestiones

${ }^{110}$ Véase, La Paz de Murcia, XVI (1873), n ${ }^{\text {os }} 4753,3$ de mayo, p. 1 y 4755, 6 mayo, p. 1. En octubre de 1873, la sociedad inició obras en una nueva sede, ubicada en la plaza Fontes, número 4: La Paz de Murcia, XVI (1873), $\mathrm{n}^{\text {os }} 4899,15$ de octubre, p. 1 y 4679, 24 de enero, p. 1.

${ }^{111}$ La Paz de Murcia, XVI (1873), n 4878, 20 de septiembre, p. 1.

${ }^{112}$ La Paz de Murcia, XVI (1873), n 4881, 24 septiembre, p. 1. Las representaciones comenzaron el 20 de septiembre de 1873 y se preveía dar dos funciones semanales: La Paz de Murcia, XVI (1873), $\mathrm{n}^{\circ}$ 4878, 20 de septiembre, p. 1 . 
para completar el cuadro de actores ${ }^{113}$. Esta situación coincidió con un momento de crisis económica de la sociedad, aunque a mediados de octubre de 1873 se inició una suscripción voluntaria reintegrable que permitió dotar a la sociedad de los fondos necesarios para la contratación de actores y la reanudación de la temporada teatral ${ }^{114}$.

Las funciones comenzaron de nuevo a principios de noviembre de 1873 y se prolongaron hasta mediados de diciembre. Antes de las fechas navideñas se anunció la disolución de la compañía y sus miembros, al menos los cantantes profesionales, se marcharon a Lorca ${ }^{115}$. En ese periodo se representaron obras de Gaztambide (El amor y el almuerzo, Una vieja, Casado y soltero y Un pleito), Barbieri (El niño, El vizconde, Entre mi mujer y el negro), Gaztambide-Barbieri (Un caballero particular) y otros como José Rogel (Dos truchas en seco), Cereceda (Pascual Bailón), Oudrid (Nadie se muere hasta que Dios quiere) y Mollberg (La colegiala).

La situación de crisis que estaba atravesando el Círculo Industrial de Murcia afectó no sólo a la programación de su teatro sino también a la Junta Directiva, que sufrió continuos cambios en los meses siguientes. La renovación anual de sus cargos para el año 1874 tuvo lugar a finales de diciembre de 1873: "cuyo acto, por efecto de las circunstancias que viene atravesando esa sociedad, fue tan reñido que no hubo elección de presidente por empate entre los señores don Pedro María Sánchez y don Luciano Díez y Sanz, que figuraban como candidatos" $" 116$. Quedó constituida la Junta Directiva aunque seguía pendiente la elección del cargo más relevante, el presidente ${ }^{117}$.

Durante el primer semestre del año 1874 se reorganizaron de nuevo algunos cargos directivos ${ }^{118}$ y en el mes de mayo se aprobó un nuevo reglamento para la sociedad, que regulaba cuestiones como "deslindar los derechos y deberes de los socios y las atribuciones de las juntas directivas, y alterar las cuotas que por entrada y mensual se pagan a fin de que correspondan a las necesidades de este establecimiento"119, además de nombrarse una nueva Junta Directiva, bajo la presidencia de Domingo Colombo ${ }^{120}$.

${ }^{113}$ Uno de los miembros de la Directiva a viajó a Madrid para agilizar las contrataciones: La Paz de Murcia, XVI (1873), $\mathrm{n}^{\circ} 4899,15$ de octubre, p. 1. Las gestiones se prolongaron hasta principios de noviembre de 1873: La Paz de Murcia, XVI (1873), n 4910, 28 de octubre, p. 1. La nueva tiple, Victoria Franco, llegó a la ciudad (8-11-1873) cuando las representaciones ya habían comenzado: La Paz de Murcia, XVI (1873), n ${ }^{\circ} 4918,7$ noviembre, p. 1. Aunque no constan todos los integrantes de la compañía, algunos de ellos fueron cantantes y actores aficionados. Véase también, La Paz de Murcia, XVI (1873), $\mathrm{n}^{\text {os }} 4898,14$ octubre, p. 1; 4907, 24 octubre, p. 1 y 4908, 25 octubre, p. 1.

${ }^{114}$ La Paz de Murcia, XVI (1873), no 4899, 15 de octubre, p. 1.

${ }^{115}$ La Paz de Murcia, XVI (1873), nº 4951, 16 diciembre, p. 1.

${ }^{116}$ Además "hubo que recontar y examinar varias veces las papeletas y rectificar la primera operación. Por fin, después de todas esas peripecias y de alguna discusión algo enojosa, se terminó la elección". La Paz de Murcia, XVI (1873), no 4960, 27 diciembre, p. 1.

117 No tengo constancia de quién asumió el cargo de presidente. La Junta quedó formada de la siguiente manera: Tomás Valderrábano (Presidente Honorario), Ventura Ibáñez (Vicepresidente), Francisco Luis Giovannelli (depositario), Miguel Terrer (contador), Antonio López Palarca (secretario), Adrián Giménez, José Campillo, José Lacárcel y Francisco Almansa (vocales): La Paz de Murcia, XVI (1873), nº 4960, 27 diciembre, p. 1.

${ }^{118}$ La Paz de Murcia, XVII (1874), nº 5022, 25 marzo, p. 1.

${ }^{119}$ La Paz de Murcia, XVII (1874), nº 5071, 26 mayo, p. 1.

${ }^{120}$ El resto de la directiva fue: Ventura Ibáñez (vicepresidente), Pedro María Sánchez (contador), José Erades (depositario), José Albadalejo, Enrique Reina, Marín Baldo, Jacinto Cayuela, Maximiliano Ayuso, 
Recuperada cierta estabilidad, el Círculo Industrial programó nuevas actividades, como un concierto con la violinista alemana Julia Blechsmidt en julio de $1874^{121}$ y al menos tres funciones benéficas con repertorio de comedias y dramas ${ }^{122}$. Una de las tareas constantes de la sociedad fue mantener el número suficiente de socios que permitieran una estabilidad económica. En este sentido, la prensa apoyó constantemente al Círculo Industrial animando a los lectores a ingresar en ella. En noviembre de 1874, por ejemplo, se menciona en los periódicos que entró a formar parte de la sociedad un "gran número de socios" 123 , probablemente como consecuencia de las medidas adoptadas un mes antes por los directivos del Círculo Industrial: suprimir la cuota de entrada y rebajar la tarifa mensual en dos reales ${ }^{124}$.

En 1875 y 1876 el Círculo Industrial continuó siendo centro de reuniones y tertulias, aunque su actividad musical se redujo a conciertos esporádicos de instrumentistas de paso por la ciudad, como el guitarrista Pedro Paredes en junio de 1875 y el famoso pianista Oscar Camps Soler en diciembre de $1876^{125}$.

La crisis del Círculo llegó a su punto álgido en 1876. A finales de este año se renovaron los cargos de la Junta Directiva como un voto de confianza "para que tome todas cuantas medidas juzgue oportunas para nivelar los gastos con los ingresos y salvar la crisis económica porque atraviesa aquella sociedad"126. El presidente elegido fue Adolfo Ayuso ${ }^{127}$. Los continuos cambios en la dirección se manifestaron de nuevo a lo largo de 1877. En marzo, la dimisión del presidente llevó al cargo a Ventura Ibáñez y en octubre, a Pagán ${ }^{128}$. A pesar del enorme declive económico, los directivos del Círculo Industrial se esforzaron por promover una actividad cultural acorde con los fines de la sociedad $^{129}$. El agente teatral Petro Rizzoli, fundador de una sociedad de conciertos que

Francisco Luis Giovannel, José Pelegrín, don Rafael Almazán y Martín (vocales), Adolfo Plañiol (secretario): La Paz de Murcia, XVII (1874), nº 5071, 26 mayo, p. 1.

${ }^{121}$ La Paz de Murcia, XVII (1874), n ${ }^{\text {os }} 5117,21$ julio, p. 1 y 5118, 22 julio, p. 1.

${ }^{122}$ Las funciones tuvieron lugar los días 10 y 13 de noviembre de 1874 en el Teatro del Círculo Industrial a beneficio de varios soldados heridos en Cieza y a una viuda. Los gastos y beneficios de estas dos funciones se publicaron en La Paz de Murcia, XVII (1874), $\mathrm{n}^{\circ}$ 5223, 22 noviembre, p. 1. La tercera de las funciones benéficas, "cuyo producto se destina a crear fondos con que atender a los gastos que se ocasionen en la comisión de Poniente de la Cruz Roja" se dio el 20 de noviembre de 1874: La Paz de Murcia, XVII (1874), $\mathrm{n}^{\circ}$ 5219, 18 noviembre, p. 1. Véase la información que La Paz de Murcia publicó sobre estas representaciones en: La Paz de Murcia, XVII (1874), $\mathrm{n}^{\text {os }}$ 5211, 8 noviembre, p. 1; 5212, 10 noviembre, p. 1 ; 5214, 12 noviembre, p. 1; 5215, 13 noviembre, p. 1; 5217, 15 noviembre, p. $1 ; 5219,18$ noviembre, p. 1 y 5222, 21 noviembre, p. 1 .

${ }^{123}$ La Paz de Murcia, XVII (1874), nº 5210, 7 noviembre, p. 1.

${ }^{124}$ La Paz de Murcia, XVII (1874), no 5200, 27 octubre, p. 1.

${ }^{125}$ La trayectoria del compositor, pianista y musicógrafo Óscar Camps Soler ha sido estudiada por Casares, "Camps", pp. 1003-1004.

${ }^{126}$ La Paz de Murcia, XIX (1876), nº 5923, 5 diciembre, p. 1.

127 "Ha sido elegido presidente del Círculo Industrial el señor don Adolfo Ayuso. No le damos la enhorabuena": La Paz de Murcia, XIX (1876), n 5941, 28 diciembre, p. 1.

${ }^{128}$ En ambas Juntas figuró como vocal el periodista Rafael Almazán.

${ }^{129}$ Durante los años 1876, se plantearon diversas actividades. Una de ellas fue su participación en el tradicional Entierro de la Sardina con un carro Entierro de la Sardina en enero de 1876: La Paz de Murcia, XIX (1876), $\mathrm{n}^{\circ}$ 5647, 18 enero, p. 1. Otra, la organización de un certamen científico e industrial en mayo del año siguiente: La Paz de Murcia, XX (1877), n 5952, 12 enero, p. 1. 
ofrecía soirèes musicales en varias capitales, organizó dos veladas en el Círculo a principios de marzo de 1877 con el violonchelista Cesare Augusto Casella, la soprano Lausa Sainz y la contralto Elisa Rosenthal ${ }^{130}$.

El teatro del Círculo Industrial recobró un nuevo impulso desde enero de 1877, aunque las funciones llevadas a cabo por la sección lírico-dramática no incluyeron obras teatrales musicales ${ }^{131}$. A comienzos de abril el teatro del Círculo Industrial se cerró temporalmente para reformarse:

[...] El salón bajo se ha convertido en plateas, patio y galería. Las primeras son ocho, cuatro en cada lado, que ocupan los intercolumnios: son espaciosos atendido el local, están más elevadas que las sillas del patio y tienen su entrada por un paso que hay a la espalda de ellas. El patio se ocupa con buen número de filas de sillas, así como la galería baja. Lo que era antes galería alta se ha convertido en cuatro palcos no muy reducidos, guardando el mismo orden que las plateas. Esta reforma da motivo a que todas las clases de la sociedad tengan localidad a su agrado $[\ldots]^{132}$.

Finalizadas las obras, el teatro se abrió con la promoción de un abono de quince funciones de teatro declamado que dieron comienzo el 22 del mismo mes y se prolongaron hasta junio ${ }^{133}$.

A finales de septiembre de 1877 una nueva Junta Extraordinaria otorgó la presidencia del Círculo Industrial a Pedro Pagán ${ }^{134}$. En noviembre y diciembre hubo

${ }^{130}$ Los conciertos tuvieron lugar el 1 y el 4 de marzo de 1877. Las noticias referentes a estos conciertos se publicaron en: La Paz de Murcia, XX (1877), $\mathrm{n}^{\mathrm{os}}$ 5986, 24 febrero, p. 1; 5988, 27 febrero, p. 1; 5990, 1 marzo, p. 1; 5991, 2 marzo, p. 1 y 5994, 6 marzo, p. 1.

${ }^{131}$ Las funciones dieron comienzo el 28 de enero de 1877 . Actuaron actores y aficionados de años anteriores, como Carmen Faisá, Carmen Pinilla, Mariano Sánchez, José María Balboa, José María Ibáñez, Federico Bernal, Enrique Romero y Miguel López y otros nuevos, como Fernando Zarrachaga: La Paz de Murcia, XX (1877), $\mathrm{n}^{\text {os }}$ 5983, 21 febrero, p. 1 y 5965, 27 enero, p. 1. Algunos títulos representados fueron: Viva la libertad (Enrique Zumel), La mujer de Ulises, Como el pez en el agua y La casa de campo, entre otros. En febrero hubo una sesión conjunta del prestidigitador portugués Miguel de Fonseca y el barítono Miguel Maiquez, que interpretó entre otras obras un aria de Un ballo in maschera: La Paz de Murcia, XX (1877), $\mathrm{n}^{\circ}$ 5972, 7 febrero, p. 1. Tras esta sesión, Fonseca ofreció, al menos, dos funciones más de prestidigitación: La Paz de Murcia, XX (1877), $\mathrm{n}^{\text {os }}$ 5972, 6 febrero, p. 1; 5976, 11 febrero, p. 1; 5981, 18 febrero, p. 1 y 5982, 20 febrero, p. 1.

${ }^{132}$ La Paz de Murcia, XX (1877), n 6035, 25 abril, p. 1. La reforma, sin embargo, no gustó a todos los medios de comunicación. Según La Paz de Murcia, XXI (1878), nº 6221, 21 mayo, p. 1 se había "perjudicado el quitar los palcos y galería, lo cual ha retraído de él a cierto público".

${ }^{133}$ La Paz de Murcia, XX (1877), no 6008, 31 marzo, p. 1. Las obras representadas, entre otras, fueron: Del enemigo, el consejo (Zamora Caballero, comedia en tres actos y verso), Las citas a media noche, El loco de la guardilla (Narciso Serra, pieza en un acto), El que nace para ochavo (Pelayo del Castillo), Viva la libertad, Pepita, Dios sobre todo (Luis Mariano de Larra, comedia en tres acto y verso), La mujer de Ulises, Candidito, La vaquera de la Finojosa, ¿Quién vive?, Pobres mujeres, Servir para algo (Miguel Echegaray), Los dos sordos, La campana de la Almudaina, Dos iniciales, Como el pez en el agua y El amante espíritu, Un tigre de Bengala y Marcela o cuál de los tres (Bretón de los Herreros).

${ }^{134}$ Los restantes miembros de la Junta Directiva fueron Maximiliano Ayuso (vicepresidente), Fermín Dominguez (contador), Francisco de la Villa (depositario), Marcos Peñalver (secretario), Carlos Díaz, José Albaladejo Pérez, Rafael Almazán, José López Pelegrin, Juan López Parra, Francisco Hernández, Leopoldo Lluch y Soler, Miguel Quetglas (vocales): La Paz de Murcia, XX (1877), nº 6173, 9 octubre, p. 1. 
nuevas representaciones teatrales coincidiendo con el aniversario de Lope de Vega ${ }^{135}$. En la Navidad de 1877 se inauguró en Murcia el nuevo Teatro de la Trinidad y algunos miembros aficionados del Círculo Industrial dejaron esta institución para actuar en el citado teatro.

La sociedad del Círculo Industrial se disolvió en las primeras semanas de 1878 y sus socios, junto a otros procedentes de la sociedad Ateneo, formaron una nueva sociedad denominada El Liceo (ver punto 8 de este Capítulo).

\subsection{Los bailes de sociedad en el Círculo Industrial (1865-1878)}

Durante la dilatada existencia del Círculo Industrial (1862-1878) se organizaron numerosos bailes en sus salones que rivalizaron con otros de la ciudad, como los del Casino, los del Teatro Romea y el Teatro Circo de la Rambla e incluso, con los bailes de sociedades dedicadas exclusivamente a este tipo de eventos, como la Sociedad de los Pollos ${ }^{136}$.

Los bailes del Círculo Industrial eran organizados por una comisión especial que velaba por su buen funcionamiento (también denominadas "comisiones de recibo") ${ }^{137}$. En 1872, por ejemplo, esa comisión debía descubrir las máscaras de todos asistentes al baile para comprobar que no entrara ninguno que no fuera socio ${ }^{138}$. Las primeras noticias sobre bailes se remontan a febrero de 1865 y en ellas se describen bailes de máscaras que se celebraban cada domingo y martes de febrero y marzo, mientras en 1866 se celebraron en enero $^{139}$. Tal y como se desprende de la documentación periodística, los bailes de máscaras de los primeros años (1865-1867) no gozaron de mucha animación. Como reclamo para una mayor afluencia de público, los directivos y la comisión nombrada por el Círculo Industrial para la preparación de estos eventos se esmeraron en los adornos de

${ }^{135}$ La Paz de Murcia, XX (1877), nº 6211, 23 noviembre, p. 1. El acto homenaje a Lope de Vega tuvo lugar el 25 de noviembre de 1877 e incluyó las piezas dramáticas Las hijas de Elena, Un par de alhajas y El que nace para ochavo. Una vez más, los intérpretes fueron los habituales aficionados María Crespo, Balboa, Bermúdez, Bernal, López, Plañiol y Romero: La Paz de Murcia, XX (1877), nº 6214, 27 noviembre, p. 1.

136 Desde la época isabelina, las sociedades dedicadas únicamente a la programación de bailes adquieren un desarrollo aún mayor que en épocas precedentes. Virigili, "El pensamiento", p. 25, señala que sus organizadores pertenecen además a capas sociales más amplias, en las que la clase media adquirió un mayor protagonismo. Virgili menciona sociedades de baile como la Juventud vascongada, la sociedad Terpsícore, la Juventud española, la sociedad El Ariel, entre otras. El dinamismo de estas sociedades también queda patente en la descripción que aporta Capmany, Un siglo sobre el baile en la Barcelona del siglo XIX.

${ }^{137}$ Como ejemplo, citaré la formada para los bailes de máscaras del año 1867: Francisco de Izu, José Albadalejo López, José María Esbry, José María Martínez, Anselmo Lorencio Rubio y Juan Pedro Sánchez. Véase, La Paz de Murcia, X (1867), n² 2760, 4 enero, p. 1.

${ }^{138}$ Fueron sus miembros: José María Báguena, Manuel del Castillo, Rafael Almazán Martín, Ignacio Pérez de Lema, José Illán González y Ventura Ibáñez: La Paz de Murcia, XV (1872), nº 4368, 14 enero, p. 1. Véase también, La Paz de Murcia, XV (1872), nº 4498, 22 febrero, p. 1.

${ }^{139}$ La Paz de Murcia: VIII (1865), ${ }^{\text {os }}$ 2098, 4 febrero, p. 2; 2111, 19 febrero, p. 2; 2119, 2 marzo, p. 2 y 2123, 7 marzo, p. 1; IX (1866), $\mathrm{n}^{\text {os }} 2410,7$ enero, p. 1; 2412, 9 enero, p. 1; 2415, 12 enero, p. 1; 2418, 15 enero, p. 1 y 2419, 16 enero, p. 1. 
los salones y la música ${ }^{140}$. En diciembre de 1867, una Junta General del Círculo Industrial aprobó dar bailes de máscaras cada sábado y, para no sobrecargar de gastos extraordinarios la economía de la sociedad, se propuso abrir una suscripción por acciones de cuatro reales vellón para hombres, de manera que cada socio suscriptor podía asistir con las señoras que deseara ${ }^{141}$. Los bailes de 1871 también fueron costeados por los propios socios $^{142}$. Los bailes solían empezar entre las diez y las once de la noche y se prolongaban hasta altas horas de la madrugada.

Son pocos los datos sobre la música en estos eventos y quiénes eran los encargados de interpretarla, salvo algunas excepciones. En los bailes de máscaras del año 1867 actuó la orquesta dirigida por Mariano Esbrí143. En 1870: "Numerosas parejas circularon por el salón cada vez que la orquesta tocaba polcas, vals, danzas y otros bailes" $" 144$. El día de la Candelaria (dos de febrero) de 1872, hubo un concierto musical antes del baile y coros que actuaron con la orquesta en las piezas de danza.

\section{La Sociedad Filarmónica y Coral de Murcia (1867-1868)}

La Sociedad Filarmónica y Coral comenzó a gestarse en enero de 1867 por iniciativa de Antonio López Almagro ${ }^{145}$. Se pretendía crear en Murcia una sociedad coral semejante a las que existían en otras ciudades españolas ${ }^{146}$ y “dar conciertos que, a más de proporcionar recreo, contribuyan a que progresen en el arte musical, ya vocal como instrumentalmente, los muchos jóvenes de ambos sexos que con buenas disposiciones existen en esta capital"147.

${ }^{140}$ La Paz de Murcia, X (1867), n ${ }^{\text {os }} 2761,5$ enero, p. 2; 2797, 12 febrero, p. 2; 2802, 17 febrero, p. 2; 2804, 19 febrero, p. 2; 2809, 24 febrero, p. 2 y 2816, 3 marzo, p. 2.

${ }^{141}$ La Paz de Murcia; X (1867), $\mathrm{n}^{\text {os }} 3084,8$ diciembre, p. 3 y 3100, 24 diciembre, p. 2; XI (1868), $\mathrm{n}^{\text {os }}$ 3112, 8 enero, p. 2; 3139, 5 febrero, p. 2; 3135, 1 febrero, p. 2; 3152, 18 febrero, p. 2 y 3157, 23 febrero, p. 2. Sobre los bailes de los años 1869-1877, véase: La Paz de Murcia: XII (1869), ${ }^{\text {os }} 3485,3$ febrero, p. 1; 3489, 7 febrero, p. 1; 3490, 9 febrero, p. 1; 3492, 11 febrero, p. 1; XIII (1870), no 3776, 16 enero, p. 1; 3777, 18 enero, p. 1; 3781, 22 enero, p. 1; 3801, 15 febrero, p. 1; 3811, 26 febrero, p. 1; 3815, 3 marzo, p. 1; 3818, 6 marzo, p. 1 y 3819, 8 marzo, p. 1; XVI (1873), n ${ }^{\circ}$ 4708, 27 febrero, p. 1; XVII (1874), $\mathrm{n}^{\circ} 5251$, 30 diciembre, p. 1; XIX (1876), $\mathrm{n}^{\circ}$ 5580, 2 febrero, p. 1; XIX (1876), $\mathrm{n}^{\circ}$ 5588, 11 febrero, p. 1; XX (1877), $\mathrm{n}^{\mathrm{os}}$ 5964, 26 enero, p. 1; 5969, 1 febrero, p. 1; 5971, 4 febrero, p. $1 \mathrm{y}^{\circ} 6234,11$ diciembre, p. 1.

${ }^{142}$ La Paz de Murcia, XIV (1871), $\mathrm{n}^{\text {os }}$ 4091, 12 febrero, p. 1; 4084, 4 febrero, p. 1; 4092, 14 febrero, p. 1 y El Obrero, (1871), no 35, 26 febrero, p. 4

${ }^{143}$ La Paz de Murcia, X (1867), nº 2797, 12 febrero, p. 2.

${ }^{144}$ La Paz de Murcia, XIII (1870), nº 3783, 25 enero, p. 1. En La Paz de Murcia, XIII (1870), nº 3777, 18 enero, p. 1 se hace mención de "lanceros y otros bailes".

${ }^{145}$ En las primeras reuniones celebradas en casa del citado Antonio López Almagro (días 6 y 20 de enero de 1867) se discutió el reglamento de la Sociedad Filarmónica: La Paz de Murcia, X (1867), $\mathrm{n}^{\text {os }}$ 2764, 8 enero, p. 2 y 2777, 22 enero, p. 2 . El 9 de abril de 1866, Antonio López Almagro había ofrecido una velada musical en su casa con los músicos Juan Diego Manresa, José María Avilés (piano) y Adela Davin (soprano), a la que sucedieron otras durante los meses posteriores (ver Capítulo 8). Probablemente, fue en este entorno donde nació la idea de constituir una asociación musical. El anuncio y programa del citado concierto se publicaron en La Paz de Murcia, IX (1866), $\mathrm{n}^{\mathrm{os}} 2501,9$ abril, p. 1 y 2503, 11 abril, p. 2.

146 Sobre asociaciones corales, véase: Bagües "El coralismo"; Carbonell, "Aportaciones"; Nagore, $L a$ revolución coral y Nagore, "Aportaciones".

${ }^{147}$ La Paz de Murcia, X (1867), nº 2764, 8 enero, p. 2. Un año más tarde, se reiteró la finalidad de la sociedad: "Hace un año que con júbilo vimos formarse una Sociedad Filarmónica que, al proporcionar 
En la Junta inicial hubo destacados músicos y aristócratas diletantes de Murcia: Joaquín Codorniu (Presidente), Enrique Fulgencio Fuster y López, Conde de Roche (Vicepresidente); Antonio López Almagro (Director); Luciano Díez y Sanz (Secretario) y Emilio Bujart (encargado de la redacción del reglamento) ${ }^{148}$.

En febrero de 1867 se establecieron clases de "Música” y "Orfeón” (estas últimas a cargo de Antonio López Almagro), que tenían lugar en el piso bajo del Instituto de Segunda Enseñanza, ya que la sociedad no tenía local propio ${ }^{149}$.

La Sociedad Filarmónica fue inaugurada oficialmente el 19 de marzo de $1867^{150}$ con un concierto en el Teatro de los Infantes que comenzó con una sinfonía coral de Mariano García, maestro de capilla de la Catedral de Murcia, con partes solistas para flauta interpretadas por Rotllán ${ }^{151}$, de quien la prensa escribió: "Demostró ser solista por su ejecución, artista por su gusto. Muy correcto, muy ceñido a la nota, tal vez por modestia economizó trinos y crescendos, aunque su talento puede permitirse fiorituras que no todas las manos puede afiligranar" ${ }^{, 52}$. Tras la sinfonía inicial se interpretó, entre otras obras (ver Apéndice 6.6), un trío de Antonio López Almagro para violín, piano y armonio (ejecutado por Quercop, Juan Diego Manresa y su autor) calificada "una composición bellísima en la que se reúnen períodos clásicos"153, una "Fantasía sobre motivos de la Norma", de Julián Calvo y un trío de Beriot, comentado así en la prensa:

[...] El delicioso trío de Beriot fue magistralmente interpretado, pero el público lo recibió con cierta frialdad que tiene natural explicación. La música clásica exige mucha costumbre de gustar sus dulzuras y, tanto Murcia como toda nuestra

honesta distracción y culto recreo a sus muchos asociados, abría las puertas del divino arte de Rossini a multitud de jóvenes que con ansiedad acuden a aprenderle llenos de entusiasmo y fe": La Paz de Murcia, XI (1868), no 3108,3 enero, p. 1.

${ }^{148}$ La Paz de Murcia, X (1867), no 2764, 8 enero, p. 2. Antes de febrero de 1867, la institución era mencionada en la prensa como "sociedad coral" y desde esta fecha, como Sociedad Filarmónica.

149 Las solicitudes de ingreso se presentaron a Joaquín Codorniu durante la primera quincena de febrero, en la calle de la Administración: La Paz de Murcia, X (1867), no 2793, 8 febrero, p. 2. La prensa colaboró publicando breves noticias que reclamaban alumnos para la sociedad: La Paz de Murcia, X (1867), no 2799, 13 febrero, p. 1. No consta el número de alumnos matriculados inicialmente aunque sí que aumentó durante todo el mes de febrero: La Paz de Murcia, X (1867), ${ }^{\text {os }} 2802,17$ febrero, p. 2 y 2811,26 febrero, p. 1.

${ }^{150}$ La preparación de los actos inaugurales de la sociedad comenzaron en el mes de febrero. Se formaron diversas comisiones para la recepción del público asistente, así como para el ornato y arreglo del escenario. Los salones del teatro se decoraron para la ocasión con tapices procedentes de la colección del Conde de Roche: La Paz de Murcia, X (1867), $\mathrm{n}^{\circ}$ 2832, 21 marzo, p. 2. No hay constancia documental del programa del concierto inaugural, aunque la extensa crítica de "Homoquidam" La Paz de Murcia, X (1867), $\mathrm{n}^{\mathrm{o}}$ 2834, 23 marzo, pp. 1-2 permite reconstruir gran parte de él.

${ }^{151}$ La letra de esta "sinfonía coreada" era: Templo del arte/ abre tus puertas,/ muestra del genio/ la inspiración./ Dulces cantares/ doquier resuenen/ cantos que broten/ del corazón./ Lauro esplendente/ de excelsa gloria/ siempre en ti brille:/ luz del saber./ Y el mundo, al eco/ de su armonía, / sienta en su alma/ grato placer./ Hoy Murcia alegre/ tu acento escucha,/ tu nombre augusto,/ claro, inmortal./ Ensalza henchida/ de amor inmenso,/ y mil aplausos/ te da leal": La Paz de Murcia, X (1867), no 2834, 23 marzo, p. 2. En la actualidad esta obra es ilocalizable.

152 “Homoquidam”, "Inauguración de la Sociedad Filarmónica”, La Paz de Murcia, X (1867), n 2834, 23 marzo, p. 1.

153 "Homoquidan”, "Inauguración”, p. 1. 
nación, ha gozado muy poco hasta el presente las deliciosas notas del clasicismo profano $[\ldots]^{154}$.

El concierto concluyó con un himno para voces y orquesta compuesto por Julián Calvo, cuyo texto conserva el Archivo Municipal de Murcia (véase Figura 6.9), y después se ofreció un banquete para obsequiar a los socios y alumnos de la Sociedad Filarmónica y Coral de Murcia $^{155}$.

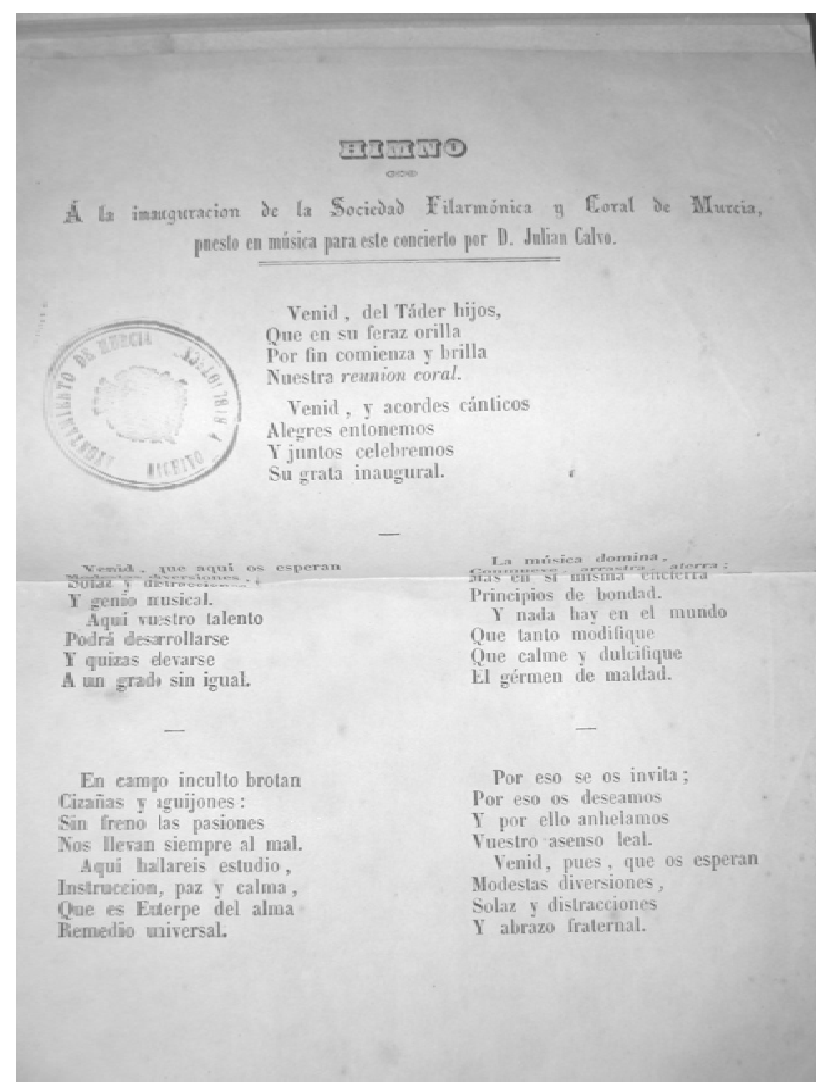

Figura 6. 9. Himno "Venid del Táder hijos", música de Julián Calvo y letra de autor desconocido, escrita para la inauguración de la Sociedad Filarmónica y Coral de Murcia (marzo de 1867), E:MUm.

Desde la sesión inaugural, la Sociedad Filarmónica programó conciertos semanales a cargo de profesores y alumnos que se prolongaron desde marzo hasta mediados de abril de $1867^{156}$. Las veladas tenían lugar en el Instituto de Segunda

${ }^{154}$ La Paz de Murcia, X (1867), nº 2834, 23 marzo, p. 1.

${ }^{155}$ En el intermedio el público pidió la interpretación de "una danza del género cómico". También se leyeron poesías de Acosta, Sans y Beltrán. La crónica del banquete se publicó en La Paz de Murcia, X (1867), no 2835, 24 marzo, p. 1.

${ }^{156}$ Los primeros conciertos de la Sociedad Filarmónica se celebraron los sábados del 23 y 30 de marzo y 13 de abril: La Paz de Murcia, X (1867), $\mathrm{n}^{\text {os }} 2838,27$ marzo, p. 2 y 2846, 4 abril, p. 2. Las breves reseñas publicadas por la prensa no incluyeron los programas de los conciertos de marzo. En el de abril, se interpretó las Siete Palabras de Haydn por José Quercop, Ángel Mirete, Mariano Esbrí y Francisco Jover: La Paz de Murcia, X (1867), n 2855, 13 abril, p. 1. Sobre las biografías de algunos de estos músicos véase el Capítulo 9 de esta Tesis. 
Enseñanza de Murcia, que se engalanaba ricamente para la ocasión, como se describe en las siguientes líneas:

[...] Figuraos, en primer lugar, queridísimos lectores, un patio de colosales proporciones rodeado en toda su extensión de una ancha galería convenientemente iluminada y cubierto por un dosel en forma de pabellón. Imaginaos sus paredes tapizadas de verde ramaje que, al llegar a los arcos que se comunican con la citada galería, caía sobre ellos en forma de guirnaldas, de las que se divisaban suspendidos caprichosos faroles de colores. Suponed en el centro un entarimado cubierto de alfombra, al que se llegaba por graderías abiertas en dos de sus lados, hallándose circundado el resto de un bien tejido cordón de hojas naturales posado de trecho en trecho en preciosos jarrones que cobijaban lindos ramilletes. Añadir a todo esto una especie de columnata que dejábase ver en medio completamente oculta por los productos más bellos de un jardín, sobre la que se cruzaban en el aire dos cadenas de rosas y claveles, de las que parecía surgir un grupo de luces, y os habréis podido formar una idea, aunque imperfecta, de aquel palacio encantado $[\ldots]^{157}$.

Los intérpretes de estos conciertos fueron en su mayoría músicos profesionales murcianos, como Joaquín Codorniu (guitarra), Francisco Jover (violonchelista), Mariano Esbrí (violín), Ángel Mirete (violín), Antonio López Almagro (armonio y piano), José Quercop (violín), Julián Calvo (piano) y José Leante (barítono), entre otros, aunque también intervinieron aficionados como las sopranos Dolores Martín y Mariana Ramírez. En ocasiones, junto a esos artistas actuaron músicos de paso por la ciudad, como el oboísta Daniel Ortiz (junio de 1867), los cantantes Locatelli y Montechini (octubre de 1867), el pianista Javier Giménez Delgado (mayo de 1868), el tenor Juan Bautista Garulli (junio de 1868) y el barítono murciano Mariano Padilla que dio dos conciertos en julio y agosto de 1867 , y otros dos en julio de $1868^{158}$. Los programas de todos los conciertos pueden consultarte en el Apéndice $6.6^{159}$.

Del repertorio de las veladas mencionadas se deduce que hubo una presencia mayoritaria de repertorio operístico (sinfonías, arias, cavatinas, dúos y coros) o de

${ }^{157}$ A. G. Apousa, "Revista musical", La Paz de Murcia, X (1867), no 2918, 19 junio, pp. 1-2.

${ }^{158}$ Las visitas de Mariano Padilla a Murcia siempre eran muy celebrada y se anunciaban con mucha anterioridad. En julio de 1867, por ejemplo, su visita fue anunciada varias veces: La Paz de Murcia, X (1867), $\mathrm{n}^{\text {os }} 2940,14$ julio, p. 2; 2942, 16 julio, p. 2; 2942, 16 julio, p. 2; 2945, 19 julio, p. 2; 2947, 21 julio, p. $2 ; 2949,23$ julio, p. 2 y 2953, 28 julio, p. 2 . En el concierto de Mariano Padilla del 28 de julio de 1867, que se organizó para donar los beneficios a la sociedad La Caridad, también iba a participar el cantante Emilio Egea, aunque murió repentinamente cuando se preparaba para salir a escena. Días más tarde del concierto, se publicaron tres cartas. La primera, de Joaquín Codorniu a Mariano Padilla, le agradecía su participación en la velada. La segunda, de Mariano Padilla a Cordorniu, le expresaba su gratitud y condolencias a la familia de Egea. La tercera fue escrita por la presidenta de la sociedad benéfica $L a$ Caridad a Mariano Padilla, y en ella le reconocía su gratitud por los beneficios obtenidos. Todas fueron publicadas en La Paz de Murcia, X (1867), n² 2970, 14 agosto, p. 1.

${ }^{159}$ En algunas ocasiones los músicos de la Sociedad Filarmónica se unieron a la orquesta del teatro. En el verano de 1867 ambas instituciones ofrecieron una serenata a Joaquín Codorniu (presidente de la Filarmónica) para celebrar su onomástica, y un concierto con el barítono Mariano Padilla en la casa de Codorniu (ver Capítulo 8). La serenata tuvo lugar el 24 de agosto de 1867 en la plaza de Cetina, lugar de residencia de Joaquín Codorniu. Se proyectó ofrecer otra serenata para despedir de la ciudad al barítono Mariano Padilla, aunque no se consiguieron los permisos necesarios para que ésta tuviera lugar. Ver, La Paz de Murcia, X (1867), n 2982, 27 agosto, p. 2. 
inspiración operística (fantasías sobre motivos de ópera), obras de compositores españoles y, especialmente, murcianos, así como obras religiosas (ver Tabla 6.2):

Tabla 6. 2. Autores y obras más interpretadas en los conciertos de la Sociedad Filarmónica y Coral de Murcia (1867-1868)

Ver fuentes en Apéndice 6.6.

\begin{tabular}{|c|c|c|}
\hline & Autores & Obras \\
\hline \multirow[t]{6}{*}{$\begin{array}{l}\text { Arias } y \quad \text { otros } \\
\text { números de óperas }\end{array}$} & Verdi & $\begin{array}{l}\text { Il Trovatore, Nabucco, Ernani, Rigoletto y } \\
\text { Stifelio }\end{array}$ \\
\hline & Donizetti & $\begin{array}{l}\text { La Favorite, Lucia di Lammermoor, } \\
\text { Belisario, Pia de' Tolomei, Anna Bolena y } \\
\text { Roberto de Bereux }\end{array}$ \\
\hline & Bellini & $\begin{array}{l}\text { Norma, Il Puritani, La Sonnambula y } \\
\text { Beatrice di Tenda }\end{array}$ \\
\hline & Rossini & Il barbiere di Siviglia y Guillermo Tell \\
\hline & Gounod & Faust \\
\hline & Meyerbeer & $\begin{array}{l}\text { Il crociato in Egitto, Africana y Les } \\
\text { Huguenots }\end{array}$ \\
\hline \multirow{6}{*}{$\begin{array}{l}\text { Fantasías sobre } \\
\text { motivos de óperas }\end{array}$} & Thalberg & "Fantasía sobre Elixir d'amor" \\
\hline & Hetterer y Herman & $\begin{array}{l}\text { "Concertante para violín y piano sobre } \\
\text { Norma" }\end{array}$ \\
\hline & Prudent & "Cuarteto sobre I Puritani" \\
\hline & Giménez & $\begin{array}{l}\text { "Fantasía sobre motivos de Il Trovatore" } \\
\text { para piano }\end{array}$ \\
\hline & Julián Calvo & "Fantasía sobre motivos de Norma" \\
\hline & Autores desconocidos & $\begin{array}{l}\text { "Fantasía sobre motivos de Linda de } \\
\text { Chamounix" para violín } \\
\text { "Fantasía sobre Norma" para violín }\end{array}$ \\
\hline \multirow{7}{*}{$\begin{array}{ll}\text { Otras obras } & \text { de } \\
\text { compositores } & \\
\text { españoles } & \mathrm{y} \\
\text { murcianos } & \end{array}$} & Cepeda & Polca \\
\hline & Daniel Ortiz & "Solo de concierto para corno inglés" \\
\hline & Ruiz & "Romanza de barítono Ramona" \\
\hline & $\begin{array}{l}\text { Antonio } \quad \text { López } \\
\text { Almagro }\end{array}$ & $\begin{array}{l}\text { Danzas, tríos, himnos, melodías, mazurcas y } \\
\text { el nocturno Adiós a Murcia }\end{array}$ \\
\hline & Julián Calvo & $\begin{array}{l}\text { "Sinfonía a orquesta, banda, armonio y } \\
\text { piano" }\end{array}$ \\
\hline & $\begin{array}{ll}\text { Mariano } & \text { Soriano } \\
\text { Fuertes } & \end{array}$ & Canción Déjate querer \\
\hline & Mariano García & Sinfonía coral \\
\hline \multirow[t]{4}{*}{ Obras religiosas } & Rossini & Stabat Mater \\
\hline & Mercadante & Gloria \\
\hline & Gounod & Ave Maria \\
\hline & Haydn & Las siete palabras de Cristo en la Cruz \\
\hline
\end{tabular}

A principios de 1868, se renovó la Junta Directiva de la Filarmónica y se nombró presidente a Rafael Minio, vicepresidente al Conde de Roche y director a Antonio López ${ }^{160}$. Joaquín Codorniu, aquejado de una enfermedad, ocupó la presidencia honoraria ${ }^{161}$. En febrero de ese año, el coro formado por los alumnos del "Orfeón" de la Sociedad Filarmónica amenizaron uno de los bailes de carnaval del Casino, como mencioné anteriormente, con danzas, valses, lanceros, rigodones, polcas y cotillones.

${ }^{160}$ Esteban Capdepón (vicedirector), Bernardino Sánchez (depositario), Agustín Juan Ruiz (contador), Luciano Díez y Sanz (secretario) y Emilio Bojart (vicesecretario), José Roca, Ramón Abril, Vicente Ochando y Tomás Fernández (vocales): La Paz de Murcia, XI (1868), nº 3108, 3 enero, p. 2.

${ }^{161}$ La Paz de Murcia, XI (1868), no 3224, 3 mayo, pp. 2-3. 
En 1868 la Sociedad Filarmónica tenía más de ochenta socios pero quizá por la enfermedad de Codorniu, uno de los individuos más activos de la sociedad, los conciertos semanales dejaron de programarse. Aún así, hubo cinco conciertos durante este año, entre mayo y octubre (la mitad de los organizados en el año anterior) ${ }^{162}$.

La inactividad de la Sociedad Filarmónica provocó, en mayo de 1868, la publicación de un artículo en la prensa en el que se afirmaba que la sociedad había muerto, por la ausencia de Joaquín Codorniu, principal impulsor de la Filarmónica, y la "resistencia pasiva" de los murcianos que no favorecían con su asistencia a los actos organizados por la sociedad ${ }^{163}$. Un tal Apousa, en su artículo "Revista musical", respondió afirmando: "La Sociedad Filarmónica vive"164. Según el autor la falta de "soirées musicales" en la Sociedad Filarmónica se debía a tres causas:

1. El director del Orfeón, Antonio López Almagro, tropezaba con dificultades para que su coro aprendiera "trozos musicales dignos de ser escuchados". Sus alumnos no tenían unas mínimas nociones musicales.

2. La finalidad de la sociedad era la educación musical de jóvenes, no la organización de conciertos.

3. La Filarmónica no tenía local propio, "pues no se encuentra uno cuyo alquiler se halle en proporción con los fondos con que cuenta la sociedad" $" 165$.

A finales de 1868 la Sociedad Filarmónica y Coral se disolvió y algunos de sus miembros se integraron en la sociedad La Juventud (probablemente, en el mes de noviembre) ${ }^{166}$.

${ }^{162}$ Los conciertos pueden consultarse en el Apéndice 6.6. Por la importancia e implicación de otras instituciones de la ciudad, destaca el concierto en el Teatro de los Infantes de Murcia a beneficio del Monumento de artistas célebres murcianos (5-07-1868). El concierto reportó una cantidad de 408 reales que fueron entregados al Gobernador de la Provincia para su empleo en el Monumento. La cuenta detallada de los gastos y beneficios se publicaron en La Paz de Murcia, XI (1868), n 3295, 17 julio, p. 2. Debido la gran afluencia que se esperaba, se creó una "Comisión del Monumento" que, entre otras tareas, se encargó de formular las bases para asistir al concierto. La primera reunión fue celebrada el 1 de julio de 1868 y contó con la asistencia de los secretarios de la mencionada comisión, abonados del teatro y miembros de la Sociedad Filarmónica. Se confeccionó un listado donde se anotaron las localidades preferidas por cada miembro (lo no asistentes podían delegar por medio de carta y oficio al presidente de la Filarmónica) y el procedimiento para vender las entradas se estableció mediante un sorteo inicial que establecía un riguroso orden. Los socios de la Filarmónica y secretarios de la Comisión podían pedir una platea, un palco o un máximo de cuatro butacas; los abonados del Teatro de los Infantes, una localidad igual a la de su abono. Las localidades sobrantes se sacaron a venta pública en un plazo determinado de días al precio de dieciséis reales. La complicada organización fue seguida puntualmente por la prensa: La Paz de Murcia, XI (1868), $\mathrm{n}^{\text {os }} 3273,23$ junio, p. 1 y 3279,1 julio, p. 1 .

${ }^{163}$ El artículo, firmado con el pseudónimo "El caballero particular", se publicó en La Paz de Murcia, XI (1868), no 3224, 3 mayo, pp. 2-3 (ver Documentario) y concluía con la afirmación: "Hoy nos toca gritar La Sociedad Filarmónica ha muerto, viva la Juventud'.

${ }^{164}$ La Paz de Murcia, XI (1868), no 3248, 28 mayo, p. 2 (ver Documentario).

${ }^{165}$ La Paz de Murcia, XI (1868), no 3224, 3 mayo, p. 2.

${ }^{166}$ La noticia que informa sobre el traspaso de socios de la Filarmónica a la Juventud no precisa el momento exacto del cambio. Véase, La Paz de Murcia, XII (1869), nº 3488, 6 febrero, p. 1. Como veremos más adelante, algunos músicos de la primera estaban ya plenamente integrados en La Juventud en noviembre de 1868 . 


\section{La sociedad de enseñanza La Juventud (1867-1884)}

\subsection{Objetivos y carácter de La Juventud}

La Juventud. Sociedad de Enseñanza fue oficialmente inaugurada en septiembre de $1867^{167}$. Su fin fue "proporcionar a la clase obrera y artesana los conocimientos más indispensables para mejorar su educación moral, intelectual y artística" ${ }^{\text {168 }}$. La iniciativa partió de "cuatro amigos reunidos en un taller de carpintería" 169 que querían "establecer en esta hermosa capital una de esas academias donde casi gratuitamente se da la instrucción más indispensable a los que por circunstancias poco favorables para ellos, no pudieron adquirirla en sus primeros años" ${ }^{" 170}$. La Juventud fue una escuela nocturna para adultos cuyos requisitos de ingreso eran: tener dieciséis años cumplidos, ser propuesto por dos socios y pagar una cuota mensual de cinco reales (ver Figura 6.10) ${ }^{171}$.

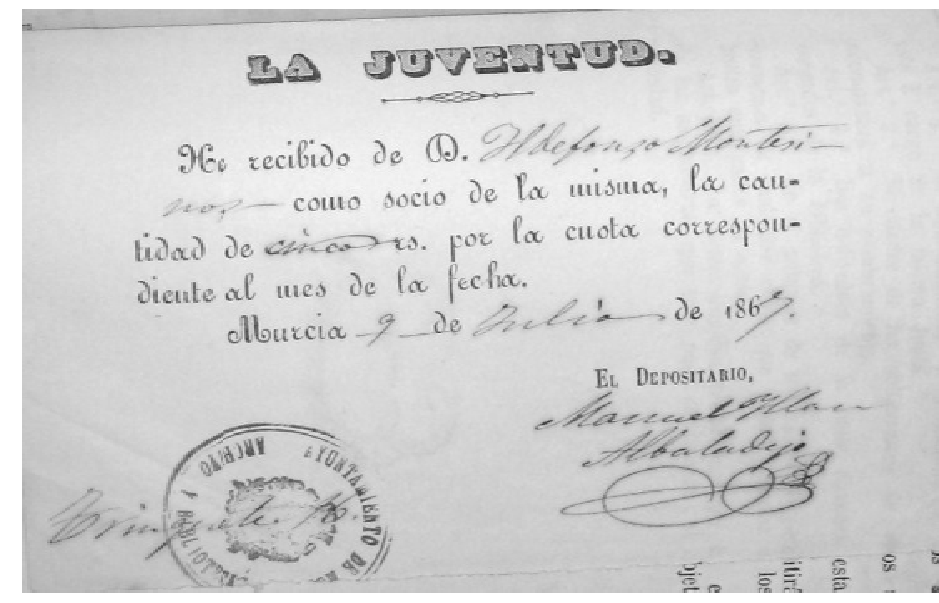

Figura 6. 10. Recibo mensual de la sociedad La Juventud. Reglamento orgánico de la sociedad de enseñanza La Juventud. (Murcia: Imprenta de Pedro Belda, 1867). E:MUm.

${ }^{167}$ El acto de inauguración tuvo lugar el 21 de septiembre de 1867 en el salón bajo del Instituto. A él acudió una banda de música que amenizó la velada. Véase, La Paz de Murcia, X (1867), n ${ }^{\text {os }} 3007,21$ septiembre, p. 2 y 3010, 24 septiembre, p. 2 así como Reglamento orgánico de la sociedad de enseñanza La Juventud. (Murcia: Imprenta de Pedro Belda, 1867) y Reglamento de La Juventud, sociedad de enseñanza. (Murcia: Imprenta de J. Sellés, 1868). Los comienzos de la Juventud también fueron descritos en La Paz de Murcia: X (1867), no 3011, 25 septiembre, p. 2 y XII (1869), n 3548, 18 abril, p. 1.

${ }^{168}$ La Paz de Murcia, XI (1868), no 3108, 3 enero, p. 1. Este periódico publicó tres artículos con motivo del nacimiento de la nueva sociedad, que intentaba la apertura de la sociedad murciana al mundo moderno: La Paz de Murcia, XI (1868), $\mathrm{n}^{\text {os }}$ 3108, 3 enero, p. 1; 3112, 8 enero, p. 1 y 3115, 11 enero, p. 1.

${ }^{169}$ La Paz de Murcia, XI (1868), no 3108, 3 enero, p. 1. No constan los nombres de los promotores. Véase,

${ }^{170}$ La Paz de Murcia, X (1867), nº 3011, 25 septiembre, p. 2. La Juventud impartió sus clases en horario diurno y nocturno en la calle de la Rambla, número 14. Desde octubre de 1868, la sede de la sociedad estuvo ubicada en la calle de Lucas, número 4: La Paz de Murcia, XI (1868), n 3378, 9 octubre, p. 2.

${ }^{171}$ La Paz de Murcia, XII (1869), no 3677, 18 septiembre, p. 1. 
Los socios de La Juventud tenían derecho a asistir a las clases de las diferentes materias $^{172}$. De forma complementaria, La Juventud contó con varias secciones: una dedicada a programar conferencias "artístico-científicas", cuyo contenido no podía ser “en ningún sentido, ni aún incidentalmente, cuestiones políticas y religiosas" "173 y otras secciones de instrucción y recreo como Orfeón, Baile, Declamación y Gimnasia ${ }^{174}$, cuyas clases se pagaban aparte. De esta forma, las conferencias científicas y las clases complementarias permitían el acceso de las clases sociales más altas, que buscaron en $L a$ Juventud la ampliación de conocimientos, el recreo y el aprendizaje de la música. Anualmente se celebraban exámenes públicos y se adjudicaban premios a los alumnos más destacados, que consistían en libros de enseñanza. En la sociedad, además, hubo un gabinete de lectura con periódicos nacionales y regionales.

\subsection{La anexión de la Filarmónica y la actividad musical de La Juventud (1868- 1883)}

A finales de 1868 se incorporaron a La Juventud los miembros de la antigua Sociedad Filarmónica y los músicos Antonio López Almagro, Julián Calvo y José Quercop, entre otros, se convirtieron en protagonistas de sus actividades musicales. Los estudios se ampliaron con las materias "Esgrima" (noviembre de 1868) y "Flauta" y "Piano" (diciembre de 1868), lo que favoreció el aumento de socios, en especial, de las clases acomodadas ${ }^{175}$.

A finales de noviembre de 1868 , por iniciativa de varios socios, se planificaron "sesiones de cuartetos" para ejecutar "trozos escogidos de los mejores clásicos y los más selectos de la música concertante de nuestros autores modernos". Con los beneficios obtenidos se compraría un piano, imprescindible para las clases de música ${ }^{176}$.

172 En 1867, las materias eran: "Doctrina cristiana", "Lectura", "Escritura", "Aritmética" y "Geometría". Véase, Reglamento de La Juventud (1867), p. 3. En 1868, se establecieron dos clases de instrucción primaria, una de párvulos (para hijos de socios) y una para socios adultos, esta última con materias como "Francés", "Aritmética" y "Geometría aplicada a las artes". Véase más detalles en La Paz de Murcia, XI (1868), no 3112, 8 enero, p. 1. En La Paz de Murcia, XI (1868), no 3115, 11 enero, p. 1 se propuso ampliar la oferta de clases para alumnos con oficios de artesanos (carpinteros, albañiles, cerrajeros y tapiceros, por ejemplo) con clases como "Dibujo lineal, figura y adorno", "Matemáticas", "Física y Química aplicadas a las artes", "Mecánica industrial", "Agricultura", "Higiene doméstica e industrial de talleres y manufacturas", "Nociones de estética" ("o sean preceptos de fácil aplicación a la bella composición de productos industriales"), "Geografía e Historia", "Economía industrial" y "Gimnasia higiénica".

${ }^{173}$ Reglamento de La Juventud (1867), p. 5.

${ }^{174}$ La sociedad se regía por una Junta Directiva y cada sección contaba con un presidente y un secretario propios. Para poder formar una sección, el reglamento establecía un número mínimo de cinco socios, reunirse mensualmente y levantar actas de los acuerdos tomados. Véase, Reglamento de La Juventud (1867), p. 4.

175 De forma complementaria, la sociedad se planteó establecer un gimnasio y acondicionar un picadero: La Paz de Murcia, XI (1868), no 3402, 3 noviembre, p. 3.

${ }^{176}$ Hubo inmediatamente treinta socios inscritos e interesados en acudir cada domingo, de doce a dos, a las "sesiones de cuartetos", que pagaban ocho reales al mes con tres entradas extra para las mujeres: $L a$ Paz de Murcia, XI (1868), n 3427, 28 noviembre, p. 2. 
Los músicos encargados de llevar a cabo las sesiones de cuarteto fueron Julián Calvo (piano), Antonio López (armonio), Daniel Ortiz (oboe), José Quercop (violín) y Ángel Mirete (violín). El primer concierto tuvo lugar el 13 de diciembre de 1868 y el programa incluyó piezas de Ambroise Thomas, Gounod y Perni, en distintas combinaciones instrumentales (Véase el Apéndice 6.7). Las "sesiones de cuartetos" se suspendieron en febrero del año siguiente ${ }^{177}$.

En enero de 1869 se eligió como presidente de La Juventud a Luciano Díez Sanz $^{178}$. Entre los meses de enero y marzo de 1869 , se introdujeron las siguientes novedades. Se implantaron clases de "Equitación"179; las secciones "Dramática", "Filarmónica" y de "Gimnasia", cada una de ellas con un equipo directivo distinto de la dirección general de la sociedad y un reglamento que se aprobaba en Junta General. La sección Dramática se formalizó en enero de 1869 bajo la presidencia de Antonio Villegas ${ }^{180}$. La "Filarmónica", impulsada por antiguos miembros del Orfeón (Sociedad Filarmónica), se creó en febrero ${ }^{181}$ para "dar la enseñanza instrumental y vocal y preparar conciertos"182 y quedó presidida por Joaquín Codorniu (con carácter honorario), Rafael Minio (presidente efectivo) y Antonio López Almagro (director) ${ }^{183}$. La sección de “Gimnasia" se implantó antes de febrero ${ }^{184}$. La creación de las secciones conllevó que La Juventud diversificara sus perfiles, ampliando sus iniciales objetivos educativos con una

${ }^{177}$ La prensa no explicó las causas de la suspensión. Se creía que los conciertos se reanudarían a partir de febrero de 1869: La Paz de Murcia, XII (1869), nº 3488, 6 febrero, p. 1.

${ }^{178}$ El 20 de diciembre de 1868 se propuso la siguiente composición de la Junta Directiva para 1869: Joaquín Codorniu (presidente honorario), Demetrio Castagnola (presidente), Ramón Abril (vicepresidente), José Gascón (depositario), Miguel Gandulla (contador), Antonio López Almagro, Diego Cantero y Benigno Revenga (vocales), Rafael Almazán y Emilio Bojart (secretarios primero y segundo): La Paz de Murcia, XI (1868), $\mathrm{n}^{\mathrm{o}} 3449,22$ diciembre, p. 2. Aceptaron los cargos el depositario y dos vocales pero quedaron vacantes de momento los cargos de presidente, vicepresidente, depositario, contador, vocal primero y secretario segundo: La Paz de Murcia, XII (1869), no 3464, 9 enero, p. 3. En enero de 1869 se eligieron para ocuparlos a Luciano Díez Sanz (presidente), Gregorio Sanz (vicepresidente), Antonio Quercop (contador), Juan Antonio Alarcón (vocal primero) y Ramón Molina (secretario segundo): La Paz de Murcia, XII (1869), nº 3467, 12 enero, p. 2.

${ }^{179}$ La Paz de Murcia, XII (1869), no 3498, 18 febrero, p. 1.

${ }^{180}$ La Paz de Murcia, XII (1869), n ${ }^{\text {os }} 3474,21$ enero, p. 1; 3478, 26 enero, p. 1 y 3482, 30 enero, p. 1.

${ }^{181}$ La sección "Filarmónica" fue aprobada en la Junta General Extraordinaria (19-02-1869). La prensa informó puntualmente de todas las reuniones previas a la constitución de ésta: La Paz de Murcia, XII (1869), $\mathrm{n}^{\text {os }} 3474,21$ enero, p. 1; 3478, 26 enero, p. 1; 3482, 30 enero, p. 1; 3488, 6 febrero, p. 1, 3489, 7 febrero, p. 1, 3498, 18 febrero, p. 1, 3499, 19 febrero, p. 1 y 3501, 21 febrero, p. 1. Lamentablemente, la prensa no menciona los nombres de los antiguos componentes del Orfeón que promovieron la sección "Filarmónica". Es de suponer que tomaran parte activa los miembros del cuarteto, impulsores y fundadores de otras sociedades musicales, como la Filarmónica y el Círculo Industrial.

${ }^{182}$ La Paz de Murcia, XII (1869), n 3501, 21 febrero, p. 1. Con ello, "la enseñanza musical se robustecerá al propio tiempo que dará lugar a proporcionar reuniones que sean objeto de dar a conocer los adelantos de esa misma enseñanza, y que los socios tengan trato más íntimo, recreo útil y ocasión de admirar los desvelos de sus paisanos y amigos": La Paz de Murcia, XII (1869), nº 3498, 18 febrero, p. 1.

${ }^{183}$ La dirección de la sección "Filarmónica" recayó en las siguientes personas y cargos: Presidente Honorario: Joaquín Codoniu -también lo era de la sociedad Filarmónica-; Secretario primero: Bernardino Sánchez Vidal; Secretario segundo: José María Castillo; Director: Antonio López Almagro [La Paz de Murcia, XII (1869), no 3501, 21 febrero, p. 1].

${ }^{184}$ Las fuentes periodísticas la mencionan desde el mes de febrero de 1869. 
variada oferta recreativa ${ }^{185}$. Esto favoreció además la consolidación de los socios no activos, que no tomaban clases en ninguna materia, pero participaban de la vida cultural de la sociedad.

En marzo de 1869 se habilitó un teatro en el salón de juntas de La Juventud para dar conciertos y representaciones teatrales ${ }^{186}$. Su inauguración tuvo lugar el 16 de abril de $1869^{187}$. En el teatro los socios aficionados representaron comedias y, más puntualmente, hubo conciertos con músicos de paso por Murcia ${ }^{188}$. En julio de 1869 , por ejemplo, actuaron los violinistas italianos Luis Brusa y Pedro Dionesi y la guitarrista Florentina Dionesi $^{189}$ y, a comienzos de julio, los guitarristas Manuel y Julián Arcas ${ }^{190}$ (ver Apéndice 6.7).

No todas las secciones de La Juventud llegaron a desarrollar una actividad plena. En 1870 parece que sólo se salvaron de la "apatía general" las clases de Primaria aumentadas con nuevos alumnos ${ }^{191}$. Las clases de "Matemáticas", "Francés", "Solfeo", "Piano" y "Flauta" no obtuvieron el éxito esperado y en ese año no parecen haberse organizado conciertos.

${ }^{185}$ Aún así la sociedad no desatendió nunca sus labores educativas. En La Paz de Murcia, XII (1869), $\mathrm{n}^{\mathrm{o}} 3517,12$ marzo, p. 1 se recuerda que las clases eran gratuitas para los socios, sus hijos o hermanos, así como para los niños pobres y se anuncia la donación de una colección de mapas para las clases de geografía.

${ }^{186}$ La Paz de Murcia, XII (1869), $\mathrm{n}^{\text {os }} 3513,7$ marzo, p. 1 y 3534, 2 abril, p. 1. El teatro fue construido con fondos ajenos a la sociedad: La Paz de Murcia, XII (1869), n 3560, 2 mayo, p. 1. Los decorados, telón de boca y demás enseres fueron pintados por jóvenes pintores murcianos: Atalaya, Sobejano, Boronat, Rubio, Baquero y Seiquer, cuyos esfuerzos fueron recompensados nombrándoles socios de mérito: La Paz de Murcia, XII (1869), $\mathrm{n}^{\circ}$ 3556, 28 abril, p. 1.

${ }^{187}$ No he localizado el programa de las funciones inaugurales, en los que me consta que participaron los jóvenes Seiquer, Rubio, Atalaya, Boronat y Soberano; Sofonisba Troissi; y los señores Chicheri, Usera, Díez y Sanz y Atalaya: La Paz de Murcia, XII (1869), n $\mathrm{n}^{\circ}$ 3548, 18 abril, p. 1. Las entradas para las funciones se organizaban mediante sorteo en dos turnos, en días distintos, para que todos los socios pudieran asistir: La Paz de Murcia, XII (1869), $\mathrm{n}^{\text {os }} 3546,16$ abril, p. 1 y 3556, 28 abril, p. 1. En mayo de 1869 se llevaron a cabo varias funciones teatrales (no musicales). En la celebrada el 23 de mayo se contó con la participación de la profesional Sofonisba Troissi y los decorados para la ocasión fueron pintados por Atalaya: La Paz de Murcia, XII (1869), no 3581, 25 mayo, p. 1

${ }^{188}$ La prensa animaba a los interesados en el arte dramático a inscribirse como socios. Véase, por ejemplo La Paz de Murcia, XII (1869), nº 3710, 27 octubre, p. 1.

${ }^{189}$ La Paz de Murcia, XII (1869), nº 3611, 1 julio, p. 1.

${ }^{190}$ Los hermanos Arcas dieron dos conciertos, el 16 y 18 de julio de 1869, en los salones de $L a$ Juventud y del Teatro de la Soberanía Nacional, respectivamente. Desde Murcia, los intérpretes se marcharon a Cartagena: La Paz de Murcia, XII (1869), nº 3629, 29 julio, p. 1.

${ }^{191}$ La Paz de Murcia, XIII (1870), nº 3975, 23 septiembre, p. 1. En La Paz de Murcia, XIII (1870), n 3917, 2 julio, p. 1 se afirma: "esa sociedad se sostiene con los constantes esfuerzos de sus juntas directivas, no con la protección desinteresada de todos. Los socios, ahora como siempre, son en corto número [...], son indolentes y solo para obtener un recreo positivo es para lo que pisan las salas de «La Juventud»". Los cargos directivos del año 1870 se otorgaron a: Bernardino Sánchez Vidal (presidente), Manuel Ibáñez (vicepresidente), José María Fuentes (contador), José María Callejas (depositario), Antonio Vidal y Giner, Jesús García y Pablo Nogués (vocales), Pedro González Adalid (secretario primero), Juan Bautista Gallur (secretario segundo): La Paz de Murcia, XIII (1870), nº 5766, 4 enero, p. 1. 
Las dificultades por las que estaba atravesando la sociedad La Juventud en 1870 quedan confirmadas por el intento de fusionarse con la recién creada sociedad $L a$ Ilustración ${ }^{192}$ y por los problemas que hubo para renovar la Junta Directiva ${ }^{193}$.

A pesar de todo, La Juventud organizó en marzo y abril de 1870 varias representaciones teatrales de aficionados que pusieron en escena obras como Las cuatro esquinas de Mariano Pina y No más muchachos de Manuel Bretón de los Herreros ${ }^{194}$.

Entre 1871 y 1874, la prensa apenas publicó noticias relacionadas con La Juventud, salvo las constituciones de las nuevas juntas directivas de esos años y su labor docente (aperturas de cursos, horarios y exámenes públicos). En todas ellas la institución es denominada "sociedad de enseñanza"195.

Desde 1872 el número de socios de La Juventud descendió considerablemente y su actividad se limitó a la enseñanza en horario nocturno para adultos ${ }^{196}$. En 1875, el número de alumnos no sobrepasó los cincuenta y apenas podían cubrirse los gastos de profesorado, local y material ${ }^{197}$. En 1881, La Juventud subsistía con menos de una treintena de socios $^{198}$.

${ }^{192}$ La Paz de Murcia, XIII (1870), n 5770, 9 enero, p. 1 informó de varias reuniones entre los directivos de ambas sociedades. Uno de los puntos más debatidos fue el nombre que habría de adoptar la nueva asociación. La anexión no llegó a ser realidad: La Paz de Murcia, XIII (1870), n ${ }^{\text {os }} 5770,9$ enero, p. 1 y 5786, 28 enero, p. 1.

${ }^{193}$ La Junta Directiva de La Juventud fue reelegida, pero sus miembros no aceptaron los cargos y tuvo que celebrarse una Junta General Extraordinaria que otorgó la presidencia a Bernardino Sánchez Vidal: $L a$ Paz de Murcia, XIII (1870), n 3765, 1 enero, p. 1. El resto de componentes fueron: Vice-presidente, Manuel Ibáñez; Depositario, José María Callejas; Vocales: Antonio Vidal y Giner, Jesús García, Pablo Nogués, Secretario $1^{\circ}$, Pedro González Adalid y Secretario $2^{\circ}$, Juan Bautista Gallur: La Paz de Murcia, XIII (1870), $\mathrm{n}^{\text {os }} 3766,2$ enero, p. 1 y 3807, 22 febrero, p. 1. A finales del mes de marzo de 1870 el secretario segundo dimitió y la elección del nuevo cargo recayó en Jesualdo Pelluz: La Paz de Murcia, XIII (1870), $\mathrm{n}^{\text {os }} 3837,29$ marzo, p. 1 y 38415 abril, p. 1 .

${ }^{194}$ Las funciones dramáticas se inauguraron el 21 de marzo de 1870: La Paz de Murcia, XIII (1870), $n^{\circ} 3829,19$ marzo, p. 1. En abril de 1870, la dirección de la sección dramática corrió a cargo de Primitivo José de Soria: La Paz de Murcia, XIII (1870), n ${ }^{\text {os }} 3850,13$ abril, p. 1 y 3865, 1 mayo, p. 1. Véase también, La Paz de Murcia, XIII (1870), n ${ }^{\text {os }} 3831,22$ marzo, p. 1 y 3864, 30 abril, p. 1.

195 De la consulta a los diarios murcianos del momento se deducen tres ideas: 1) las "difíciles circunstancias" que La Juventud estaba atravesando, a pesar de los constante esfuerzos de sus directivos: $L a$ Paz de Murcia, XV (1872), $\mathrm{n}^{\circ}$ 4363, 9 enero, p. 1; 2) la falta de apoyo por parte de autoridades y corporaciones de la ciudad, aunque las denuncias de la prensa fueron realmente numerosas: La Paz de Murcia; XIV (1871), n ${ }^{\circ} 4210,5$ julio, p. 1; XV (1872), $\mathrm{n}^{\text {os }} 4363,9$ enero, p. 1; 4368, 14 enero, p. 1; 4514, 9 julio, p. 1; 4589, 13 septiembre, p. 1 y 4698, 28 diciembre, p. 1; XVI (1873), nº 4706, 7 marzo, p. 1 y 4804 , 24 junio, p. 1; XVII (1874), $\mathrm{n}^{\text {os }} 5161,11$ de septiembre, p. 1; 5203, 30 de octubre, p. 1; 5215, 13 de noviembre, p. 1; 5161, 11 de septiembre, p. 1; 5203, 30 de octubre, p. 1 y 5215, 13 de noviembre, p. 1, así como Juan Mañé Flaquer, "Las escuelas nocturnas", La Paz de Murcia, XVIII (1875), n 5335, 13 abril, p. 1; y 3) la dirección de la sociedad en manos de un grupo de directivos comunes a unos y otros años. Los directivos de La Juventud de los años 1871-1873 y 1875 pueden consultarse en La Paz de Murcia: XIV (1871), no 4057, 1 enero, p. 1; XV (1872), n 4363, 9 enero, p. 1; XVI (1873), nº 4701, 1 enero, p. 1 y XVIII (1875), $\mathrm{n}^{\circ} 5254,3$ enero, p. 1.

${ }^{196}$ La Paz de Murcia, XV (1872), nº 4363, 9 enero, p. 1.

197 “el estado económico de la misma sigue siendo poco desahogado [...]. El número de socios que sostienen esa escuela es reducidísimo y como también es pequeña la cuota mensual que abonan, no se cubren los gastos de profesor, local y material": La Paz de Murcia, XVIII (1875), n 5590, 18 junio, p. 1.

${ }^{198}$ La Juventud es mencionada entre las asociaciones benéficas de Murcia en 1878, con 29 socios: La Paz de Murcia, XXI (1878), n 6212, 10 mayo, p. 1. En enero de 1881 se habla de ella como "la única 
Las actividades no docentes de La Juventud durante los años 1883 y 1884 parecieron limitarse a la organización de conferencias científicas y veladas literarias, así como alguna función benéfica. En diciembre de 1883, por ejemplo, se programaron las siguientes conferencias: "Idea general de la Justicia, definiciones que se han dado de ella" (por Antonio López), "Origen del Teatro Español” (por Pedro María López) y "Anibal" (por Luis Marco Ramírez) ${ }^{199}$ y el 1 de junio de 1884, se organizó una función a beneficio de los afectados por las inundaciones que hubo en Murcia en la segunda quincena de mayo de ese año ${ }^{200}$.

\subsection{La unión de La Juventud y El Progreso: la Unión Literaria (1884-1885)}

En diciembre de 1884 las sociedades La Juventud y El Progreso se fusionaron y adoptaron como nuevo nombre La Unión Literaria. Las finalidades de la nueva sociedad fueron: cultivar conjuntamente las ciencias y la literatura, proyectar la fundación de un Liceo donde se recibiera enseñanza gratuita para los que carecieran de recursos y crear, dentro del mismo Liceo, una escuela de artes y oficios ${ }^{201}$. Sin embargo, nada de ello se efectuó. Las únicas actividades documentadas son una función benéfica en el Teatro Romea en enero de $1885^{202}$ y el proyecto para actuar en Orihuela de una estudiantina que, al parecer, dependía de La Unión Literaria ${ }^{203}$.

A finales de enero de 1885 El Diario de Murcia advertía que "se han separado de 'La Unión Literaria' algunos antiguos socios de 'La Juventud' que tratan de reconstruir nuevamente esta sociedad" y La Unión Literaria deja de mencionarse en la prensa murciana a principios de febrero del mismo año ${ }^{204}$.

escuela particular subvencionada por el Ayuntamiento" a cargo del profesor José María Fuentes: El Diario de Murcia, III (1881), nº 571, 1 enero, p. 2.

${ }^{199}$ El Diario de Murcia, V (1883), no 1460, 23 diciembre, p. 3. Véanse otras veladas literarias y científicas en El Diario de Murcia, VI (1884), $\mathrm{n}^{\text {os }} 1500,10$ febrero, p. 1, 1569, 4 mayo, p. 1 y 1570,6 mayo, p. 1. En ellas no se interpretó música.

${ }^{200}$ Véanse más detalles en: La Paz de Murcia, XXVII (1884), $\mathrm{n}^{\text {os }} 7932,30$ mayo, p. 1; 7933, 31 mayo, p. 1; 7936, 4 junio, p. 1 y 7956, 28 junio, p. 1.

${ }^{201}$ El acto oficial de fusión tuvo lugar el 21 de diciembre de 1884 en uno de los salones del Instituto de Enseñanza de Murcia: El Diario de Murcia, VI (1884), n 1757, 23 diciembre, pp. 1-2 y La Paz de Murcia, XXVII (1873), nº 8104, 27 de diciembre, p. 1.

${ }^{202}$ La Paz de Murcia, XXVIII (1885), nº 8112, 7 enero, p. 1 y 8113, 8 enero, p. 1.

${ }^{203}$ El Alcalde de Orihuela (Alicante) denegó el permiso a la estudiantina de La Unión Literaria de Murcia porque había sido contratada con anterioridad la de Orihuela: La Paz de Murcia, XVIII (1885), $\mathrm{n}^{\circ}$ 8128, 24 de enero, p. 1.

${ }^{204}$ El Diario de Murcia, VII (1885), no 1785, 28 enero, p. 3. 


\section{La Ilustración. Sociedad científico-literaria y artística (1869-1871)}

La Ilustración nació en diciembre de 1869, poco después del fundarse la Universidad Libre de Murcia $^{205}$ :

Reunidos varios jóvenes dedicados al estudio de diferentes carreras, creyeron que sería utilísima y hasta necesaria una sociedad exclusivamente científica, literaria y artística, con el objeto de ampliar los conocimientos de sus asociados por medio de la discusión y la lectura, y difundirlos por la enseñanza y la imprenta ${ }^{206}$.

La sociedad se planteó desde su inicio la difusión de conocimientos científicos sobre Legislación, Política, Agricultura e Industria, entre otros, a través de debates, conferencias y la edición de una publicación periódica. Los debates y conferencias comenzaron a celebrarse apenas estuvo constituida la sociedad ${ }^{207}$, pero la publicación de la revista tardó más tiempo.

La literatura y la música tuvieron especial cabida en los certámenes o "veladas artístico-literarias" que La Ilustración organizó habitualmente, en los que se leían poesías (en su mayoría de escritores murcianos) alternadas con música y discursos. En estas sesiones actuaron antiguos miembros del Orfeón: Ángel Mirete (violín), Juan Diego Manresa (armonio), Lozano (piano), Antonio Puche (viola) y Calvo (flauta). Hubo cuatro certámenes en 1870 y dos más en 1871. Las piezas musicales ejecutadas y el número de músicos participantes fueron en aumento, como muestra el Apéndice 6.8.

Dos tercios del repertorio musical interpretado en los certámenes eran arreglos de óperas de Bellini (un tercio) y de los compositores Donizetti, Verdi y Rossini (otro tercio). En una ocasión se interpretaron las oberturas de las óperas Martha, de Flotow y Campanone, de Giuseppe Mazza. El tercio restante de obras incluía composiciones diversas de Julián Calvo (nocturno Ecos de Euterpe y el capricho Los cantos del Segura), Vincenzo Gabussi ("Dúo italiano") y las obras "Capricho Húngaro", "Serenata Valaca" y "La oración de los bardos", cuyos autores no constan.

${ }^{205}$ La Universidad Libre de Murcia, "centro científico donde acudiesen los jóvenes de esta provincia y sus limítrofes a emprender o continuar sus carreras literarias", se inauguró el 14 de noviembre de 1869: La Paz de Murcia, XII (1869), no 3727, 16 noviembre, p. 1. Algunos de sus profesores fueron miembros de la sociedad La Ilustración.

${ }^{206}$ El reglamento de la sociedad se preparó en dos reuniones previas, celebradas los días 25 y 27 de diciembre de 1869. La sede estaba en el arco del Vizconde, número 8: La Paz de Murcia, XIII (1870), $\mathrm{n}^{\circ}$ 5786, 28 enero, p. 1. La Junta Directiva la formaban: Francisco Sandoval (presidente), Olayo Díaz (vicepresidente primero), Gonzalo Baños (vicepresidente segundo), Luciano Díez y Sanz (vocal primero), Francisco García de las Bayonas (vocal segundo), Miguel A. Stático (vocal tercero), Juan López Gómez (vocal cuarto), Baltasar Meoro (depositario), Ezaquiel Díez y Sanz (secretario contador): La Paz de Murcia, XII (1869), no 3764, 31 diciembre, p. 1. Véase también, La Ilustración Murciana, I (1871), $\mathrm{n}^{\circ}$ 1, 20 enero, p. 1. En febrero de 1870, fueron designados Juan López Somalo como vicepresidente primero y Gerardo Vicente Selgas como bibliotecario. Desde este momento, la sede de la sociedad se localizó en la calle de San Antonio, número uno: La Paz de Murcia, XIII (1870), $\mathrm{n}^{\circ}$ 3807, 22 febrero, p. 1 y en mayo de 1870 en la calle Frenería, "esquina de Palacio": La Paz de Murcia, XIII (1870), n 3865, 1 mayo, p. 1.

${ }^{207}$ Las conferencias se iniciaron el 3 de enero de 1870, a cargo de la sección de "Academia práctica de jurisprudencia". Existió otra sección destinada a programar los debates ("sección de discusiones"). Todas estas sesiones eran públicas y se anunciaban en "un cuadro, fijado a la entrada de la sociedad": La Paz de Murcia, XIII (1870), nº 5786, 28 enero, p. 1. 
En noviembre de 1870 La Ilustración llevó a cabo una importante reforma que la reestructuró en las siguientes secciones: "Ciencias morales y políticas", "Agricultura e Industria", "Bellas artes", "Legislación y Jurisprudencia", "Ciencias físicas y exactas" y "Literatura" 208 . Los socios se inscribían en la sección o secciones más afines a sus conocimientos y proponían discursos, conferencias o debates científicos ${ }^{209}$.

Las secciones "Bellas Artes" y "Literatura" solían celebrar juntas sus reuniones y eran las únicas con música. En ellas intervinieron regularmente los pianistas Martínez Velasco y José Gil Prieto. El género predominante fue, de nuevo, la ópera en versiones que iban en la línea de los arreglos, transcripciones o reducciones ${ }^{210}$.

A comienzos de 1871, La Ilustración emprendió la publicación de la revista $L a$ Ilustración Murciana, "Eco de la sociedad del mismo nombre y de la Universidad Libre" y dirigida por Andrés Baquero Almansa (Secretario de la sociedad en 1871). Se publicaron veinticuatro números en los días 2, 12, 20 y 27 de cada mes desde enero hasta junio de 1871 y su contenido incluyó: "artículos doctrinales, de ciencia, de historia, de moral, de arte... Una sección de literatura que comprenda artículos de costumbres, leyendas, cuentos, anécdotas... y poesías de todas clases $\mathrm{y}$, por último, otras de variedades, con revistas de teatros, de tertulias, certámenes y alguna charadita"211. Sus redactores fueron, mayoritariamente, estudiantes universitarios ajenos al periodismo, que pretendían "ser un vivo reflejo de lo que en la Universidad se piensa y se dice, lo mismo por profesores que por alumnos"212. Sin embargo, su subtituló (Revista de ciencias, artes, literatura, industria, etcétera, eco de la sociedad del mismo nombre y de la Universidad Libre) causó susceptibilidad entre un grupo de profesores y catedráticos de la Universidad, que no aceptaban que la revista se erigiese como la voz escrita de la institución $^{213}$.

${ }^{208}$ La Paz de Murcia, XIII (1870), nº 4015, 8 noviembre, p. 1. Se estableció una cuota mensual de diez reales igual para todos los socios (fundadores o no) y la entrada gratuita para el público asistente a las conferencias: La Paz de Murcia, XIII (1870), n 4015, 8 noviembre, p. 1. La entrada a los certámenes literario-artísticos quedó limitada a los socios, aunque éstos podían entrar con el número de señoras que deseasen: La Paz de Murcia, XIII (1870), n 4019, 15 noviembre, p. 1 y La Ilustración Murciana, I (1871), $\mathrm{n}^{\mathrm{o}}$ 2, 27 enero, p. 1. La Junta Directiva de La Ilustración estuvo constituida, en noviembre de 1870, por: Antonio Hernández Amores (presidente), Adolfo Rodríguez Gámez (depositario), Rafael Almazán y Martín (contador), Federico Chapuli Cayuela (vocal) y José María Garcerán (bibliotecario): La Paz de Murcia, XIII (1870), $\mathrm{n}^{\mathrm{o}} 4015,8$ noviembre, p. 1. Cada sección estaba dirigida por un presidente y un secretario propios y diferentes de la Junta Directiva general.

${ }^{209}$ Cada sección tenía asignado un día de la semana para realizar sus actividades, aunque con mucha frecuencia había cambios en función de la disponibilidad de los socios. Las conferencias comenzaron el 10 de noviembre de 1870 con una sesión inaugural en la que se interpretó al piano la sinfonía de Semíramis por el pianista Martínez Velasco. Véase la crónica en La Paz de Murcia, XIII (1870), n 4016, 11 noviembre, p. 1 .

${ }^{210}$ Entre las obras interpretadas estuvieron Semíramis y tandas de valses en la sesión del 15 de noviembre de 1870, la sinfonía de Guillermo Tell y tanda de valses en la sesión del 26 de noviembre de 1870, sinfonía de Juana de Arco y Miserere de Il Trovatore, en la del 2 de diciembre de 1870. Véase: La Paz de Murcia, XIII (1870), $\mathrm{n}^{\text {os }}$ 4020, 16 noviembre, p. 1; 4029, 26 noviembre, p. 1; 4034, 3 diciembre, p. 1 y 4039, 10 diciembre, p. 1.

${ }^{211}$ La Ilustración Murciana, I (1871), nº 1, 20 enero, p. 1 (ver Capítulo 1).

${ }^{212}$ La Ilustración Murciana, I (1871), $\mathrm{n}^{\circ}$ 2, 27 enero, p. 1.

${ }^{213}$ La polémica obligó a la redacción del periódico a escribir un artículo justificando que "creíamos candorosamente que la Universidad, que después de dos años de creada no tenía ni un miserable papelucho, eco de lo que en ella se decía y se pensaba, acogería gustosa un acto de pura galantería": La Ilustración 
También en 1871 La Ilustración programó dos certámenes artístico-literarios (frente a los tres del año anterior) y alguna sesión, más esporádica, de conferencias ${ }^{214}$. El balance de la sociedad era muy favorable, según la prensa:

"La Ilustración" [...] va adquiriendo cada día más importancia. Hoy es muy considerable el número de socios con que cuenta y el de los que cada día se inscriben en sus listas. En estas se encuentran lo más escogido de nuestra capital. Los profesores de nuestra Universidad se hallan allí confundidos con sus discípulos, que roban gustosos algunas horas a sus distracciones para dedicarlas a beber en las puras fuentes de la verdad y de la ciencia. $[\ldots]^{215}$.

En junio de 1871 los directivos de la sociedad se reunieron para redactar un nuevo reglamento "con objeto de levantar a la sociedad de la inacción en que se hallaba" ${ }^{216}$ por la situación política y el teatro: "Si las elecciones y el teatro no ocuparan a muchos de los socios sería, sin duda, mayor la concurrencia" ${ }^{217}$. De hecho, las funciones diarias del teatro retrasaron la celebración del segundo de los certámenes artístico literarios que se pensaba celebrar en junio pero finalmente tuvo lugar el 14 de julio de $1871^{218}$.

Tras el paréntesis estival, La Ilustración reanudó su ciclo de conferencias en octubre de $1871^{219}$. Las últimas noticias que he podido localizar describen una sociedad muy mermada de socios y en estado "agonizante": "La sociedad "La Ilustración" se halla agonizante. ¡Qué muerte tan ignominiosa le espera!"220.

Murciana, I (1871), no 2, 27 enero, pp. 1-2. Véase, también, La Paz de Murcia, XIV (1871), n 4020, 22 enero, p. 1.

${ }^{214}$ El primer certamen literario artístico del año 1871 tuvo lugar el 23 de enero, con asistencia del Gobernador de la Provincia. El acto fue descrito por Diego Espinosa en La Ilustración Murciana, I (1871), $\mathrm{n}^{\circ}$ 2, 27 enero, pp. 7-8 y, por el redactor con pseudónimo Abu-Bequer en La Paz de Murcia, XIV (1871), $\mathrm{n}^{\circ}$ 4079, 28 enero, p. 1. La composición de la Junta Directiva General en 1871 fue: Antonio Hernández Amores (presidente), Juan López Somalo (vicepresidente primero), Gonzalo Baño López (vicepresidente segundo), Andrés Baquero Almansa (secretario), Adolfo Rodríguez Gámez (depositario), Rafael Almazán y Martín (contador), Adolfo Terrer, José Baleriola, Benigno Díez y Sanz y Pascual María Massa (vocales) y Miguel A. Stárico (bibliotecario): La Paz de Murcia, XIV (1871), no 4065, 12 enero, p. 1 y El Aguijón, (1871), no 6, 8 enero, p. 1.

${ }^{215}$ La Ilustración Murciana, I (1871), $\mathrm{n}^{\text {os }}$ 1, 20 enero, p. 8 y 4, 12 febrero, p. 7.

${ }^{216}$ La Ilustración Murciana, I (1871), n 17, 4 junio, p. 8. La Ilustración estaba "llamada a sufrir una metamorfosis completa": La Ilustración Murciana, I (1871), n 17, 4 junio, p. 8. También en 1871 se arreglaron el gabinete de lectura y la biblioteca: La Paz de Murcia, XIV (1871), nº 4199, 21 junio, p. 1.

${ }^{217}$ La Ilustración Murciana, I (1871), nº 4, 12 febrero, p. 7.

${ }^{218}$ Antes del certamen se estableció un plazo para que los socios presentasen sus trabajos literarios. El presidente de la sociedad y el presidente y secretario de la sección literaria habían de seleccionar los que se harían durante el evento. Se encargó la coordinación musical a Julián Calvo: La Paz de Murcia, XIV (1871), $\mathrm{n}^{\text {os }} 4183,2$ junio, p. 1 y 4291, 12 octubre, p. 1. Hubo piezas musicales al comienzo, a mitad y al final de cada una de las partes (ver Apéndice 6.8). El programa fue publicado en La Ilustración Murciana, XIV (1871), no 22, 12 julio, p. 1 y en La Paz de Murcia, XIV (1871), nº 4216, 12 julio, p. 1.

${ }^{219}$ La Paz de Murcia, XIV (1871), n 4290, 11 octubre, p. 1. La primera conferencia se celebró el 11 de ese mes. Antes de cada conferencia se confeccionaba un listado de socios interesados en asistir para que pudieran acordar la hora más favorable para todos: La Paz de Murcia, XIV (1871), n 4292, 13 octubre, p. 1.

${ }^{220}$ El Aguijón. Desahogo quincenal, II (1871), no 5, 15 de diciembre, p. 4. En La Paz de Murcia, XIV (1871), $\mathrm{n}^{\mathrm{o}}$ 4308, 1 noviembre, p. 1 se describe: "Mientras este establecimiento [la Universidad Libre de 


\section{El Liceo (1878-1883)}

\subsection{La unión del Círculo Industrial y la sociedad Ateneo: El Liceo (1878-1883)}

Como apunté anteriormente, en las primeras semanas de 1878, la sociedad del Círculo Industrial se disolvió y sus socios se unieron a otros procedentes del Ateneo, formando una nueva sociedad que pasó a denominarse El Liceo. El proceso transcurrió como expongo a continuación.

El Ateneo se había gestado en una reunión celebrada el 19 de enero de 1878 en uno de los salones del Instituto Provincial ${ }^{221}$, en la que se constituyó una comisión organizadora para gestionar, entre otros puntos, la búsqueda de local. Al mismo tiempo, el debilitado Círculo Industrial mostró su interés de unirse al Ateneo. Tras varias reuniones, acordaron fusionarse $\mathrm{e}^{222}$. En enero de 1878 quedó redactado un borrador de reglamento $^{223}$. La cuestión del local se solventó con la cesión de la sede del Círculo Industrial en la antigua plaza de los Gatos y el 14 de febrero tuvo lugar la unión formal de ambas sociedades: "hermanadas en la nueva sociedad la ciencia y la industria, cuando en el día por los adelantos que la segunda experimenta es un auxiliar tan poderoso de la primera que, sin ella, no saldrían del gabinete del sabio los nuevos y más importantes descubrimientos"224. La prensa aplaudió la unión de ambas sociedades y, a diario, publicó pequeñas reseñas y artículos más extensos impulsando la labor de la nueva sociedad ${ }^{225}$.

Una vez que se vencieron las dificultades administrativas, económicas y de reglamentación general de El Liceo, se crearon tres secciones: filosófica, literaria y artística $^{226}$ y poco después las “de declamación” y “de canto" (o coral) ${ }^{227}$.

Murcia] adquiere más vida y nombradía, su hermana gemela, "La Ilustración", se muere de plétora de socios. Así lo cuentan".

${ }^{221}$ Según Crespo, Antiguos teatros, pp. 87-88.

${ }^{222}$ Aunque según Crespo, Antiguos teatros, p. 87 no fue una fusión sino una absorción, puesto que la directiva y la titularidad fueron del Ateneo.

${ }^{223}$ La Junta Directiva se constituyó de la siguiente forma: Presidente: Olayo Díaz (director del Instituto Provincial). Vicepresidentes: Antonio Hernández Amores y Julián Pagán. Censores: Lorenzo Pelegrín, José Albaladejo Pérez y don Rafael Megías. Contador: Luis Peñafiel. Depositario: Antonio Beldar. Secretarios: Gabriel Baleriola y Juan López Parra: La Paz de Murcia, XXI (1878), nº 6189, 17 febrero, p. 1.

${ }^{224}$ La Paz de Murcia, XXI (1878), no 6187, 15 febrero, p. 1. Véanse los detalles del acto en el citado periódico. En El Semanario Murciano, I (1878), n 1, 17 febrero, p. 8 se afirmó que "Desde que por el fallecimiento de una dama ilustre [Leonor Guerra, impulsora de la revista literaria El Album] se suspendieron las reuniones literarias en casa del Excelentísimo señor don Pedro Pagán, el pueblo ilustrado de Murcia pensó en crear la sociedad que con el mayor aplauso se ha bautizado con el nombre de "Liceo"”.

${ }^{225}$ El nacimiento de El Liceo dio lugar a la publicación de numerosos artículos sobre el beneficio de las asociaciones para la sociedad, como el escrito por José Baleriola, "El Liceo", El Semanario Murciano, I (1878), $\mathrm{n}^{\mathrm{o}}$ 3, 3 marzo, p. 1 y otros publicados sin firma en El Semanario Murciano, I (1878), $\mathrm{n}^{\mathrm{os}} 14,19$ mayo, p. 8 y 15, 26 mayo, p. 1.

${ }^{226}$ La sección artística quedó conformada el 18 de marzo de 1878 , la literaria y la filosófica, los días 19 y 20 respectivamente. Se asignaron dos días a la semana para que cada sección se reuniera: "la artística, los lunes y jueves; la literaria, martes y viernes; y, la filosófica, miércoles y sábado" : La Paz de Murcia, XXI (1878), n 6214, 20 marzo, p. 1. Los cargos de "Sección filosófica" recayeron en Juan López Somalo (presidente), Francisco Holgado Toledo (vicepresidente) y Napoleón Terrer y Agustín Ruiz Martínez (secretarios). Los de la "Sección literaria", en Zacarías Acosta (presidente), Antonio Escartin 
La función inaugural de la sociedad tuvo lugar en marzo de $1878^{228}$. Al mismo tiempo, las diversas secciones comenzaron a celebrar sesiones periódicas en las que se programaban conferencias, debates y lecturas de composiciones poéticas y piezas dramáticas. Un ejemplo fue la sesión ofrecida por Gabriel Baleriola, redactor de La Paz de Murcia, que dio una conferencia sobre el teatro moderno ${ }^{229}$.

El Liceo se propuso crear bajo su patrocinio un coro de hombres y una orquesta estable. El coro fue una iniciativa del vicepresidente de la sección artística y pianista, Francisco Gil $^{230}$ y para dirigirlo se nombró al pianista Antonio Ramírez. La creación de la orquesta originó un intenso debate en la prensa que sacó a la luz pública el malestar de los músicos murcianos y las relaciones, a veces tensas, que existieron entre ellos. La reyerta comenzó con el artículo "Los músicos de Murcia", escrita por un anónimo "músico viejo" ${ }^{231}$. En este escrito se sostenía que los músicos estaban en todas partes bien considerados, menos en Murcia, a pesar de que existían en la ciudad buenos profesionales, y que la música no producía "lo suficiente para vivir con decencia". Los músicos se veían obligados a vivir la tiranía de unos sobre otros:

[...] Los maestros que han llegado a sobresalir entre los maestros de segundo orden absorben y monopolizan a los demás músicos, sin que éstos puedan hacer nada sin el conocimiento y aprobación del principal. Esto es inconveniente hasta lo sumo, y da por resultado, en primer término, la postración musical del país, $y$ en segundo, las cuestiones irreconciliables y enconadas que tienen los maestros con los discípulos que han llegado ya casi a hombrearse con ellos; originando estas cuestiones despechos y odios que vienen a favorecer poco a la clase. Y a tanto llega la absorción y dominio sobre los músicos, que pudiéramos llamar de segundo orden, que bien patente la hemos visto y nos hemos lamentado de ella, al contemplar lo sucedido en "El Liceo" de esta capital. En esta sociedad no se ha podido formar orquesta, porque allí donde se

(vicepresidente) y Ricardo Sánchez Madrigal y Ezequiel Díez y Sanz (secretarios). Los de la "Sección artística" en Juan Albacete (presidente), Francisco Gil López (vicepresidente), José María Callejas y Enrique Romero (secretarios): La Paz de Murcia, XXI (1878), nº 6199, 1 marzo, p. 1.

${ }^{227}$ El Semanario Murciano, I (1878), $\mathrm{n}^{\circ}$ 6, 24 marzo, p. 8 informó del proyecto de formación de una sección coral que sirviera de "escuela donde aprender y perfeccionarse". Unos días más tarde, el mismo periódico distinguía entre las secciones "de canto" y "de declamación": El Semanario Murciano, I (1878), $n^{\circ}$ 7, 31 marzo, p. 6. Es probable que éstas fuesen subsecciones de la artística.

${ }^{228}$ La sesión inaugural dio lugar a la publicación de numerosas noticias sobre la preparación e intervención de todas las secciones: El Semanario Murciano, I (1878), $\mathrm{n}^{\mathrm{os}}$ 5, 17 marzo, p. 8; 6, 24 marzo, p. 8 y 7, 31 marzo, p. 6; La Paz de Murcia, XXI (1878), ${ }^{\text {os }}$ 6212, 17 marzo, p. 1 y 6223, 30 marzo, p. 1. Constó de dos partes: la primera, por la mañana, fue sólo para autoridades. En ella se leyó un discurso a cargo del Presidente y lectura de poesías; en la segunda, se estrenaría una obra dramática de un literato murciano: La Paz de Murcia, XXI (1878), n 6214, 20 marzo, p. 1. Las noticias sobre las reuniones de preparación de la sesión inaugural se encuentran en: La Paz de Murcia, XXI (1878), nº 6223, 30 marzo, p. 1; El Semanario Murciano, I (1878), nº 7, 31 marzo, p. 6.

${ }^{229}$ El Semanario Murciano, I (1878), $n^{\circ} 8,7$ abril, pp. 6-7. La conferencia fue seguirá por un discurso de José Pío Tejera. Otras conferencias versaron sobre la respiración (conferencia de la sección filosófica por Maestre), el teléfono (por Cantero): El Semanario Murciano, I (1878), n 13, 12 mayo, pp. 7-8; y sobre las obras dramáticas de Echegaray (ofrecida por Antonio Hernández Almansa): La Paz de Murcia, XXI (1878), $\mathrm{n}^{\mathrm{o}}$ 6222, 22 mayo, p. 1.

${ }^{230}$ El Semanario Murciano, I (1878), $\mathrm{n}^{\mathrm{o}}$ 7, 31 marzo, p. 6.

${ }^{231}$ Desconozco quién fue el "músico viejo". En La Paz de Murcia, XXI (1878), nº 6216, 15 mayo, p. 1 se menciona: "Hoy continúa en el Liceo la discusión que en la semana anterior inició nuestro amigo señor Maestro". Probablemente se refería a Mariano García, maestro de capilla de la Catedral de Murcia (al que la prensa siempre se refirió a él como "Maestro") aunque entonces Mariano García contaba sólo con 42 años. 
ven los pensamientos más elevados, han de contemplarse las más pequeñas miserias. Ningún músico se ha atrevido a ir a aquella sociedad a ofrecerse, no porque algunos y muy buenos no tuviesen deseo de hacerlo, sino porque sus jefes se lo han prohibido en absoluto $[\ldots]^{232}$.

Para el autor del artículo, la creación de una orquesta suponía superar muchos obstáculos e intrigas "jesuíticas". Según él, los músicos murcianos "dejan mucho que desear en sus adelantos, pues solamente se contentan con tocar el pasodoble, la polca y juguetes de esos [...]. No existe la idea de dar conciertos, ni de hacer nada a favor del progreso artístico de Murcia”. Los críticos de la prensa también fueron atacados por los "sacrilegios artísticos" que cometían.

El artículo del "Músico viejo" obtuvo una contundente réplica también anónima ${ }^{233}$, que desmintió la prohibición de colaborar a "músicos de segundo orden", puesto que Francisco Gil, Ángel Vázquez, Antonio Ramírez y Emilio Raya, entre otros, ya se habían ofrecido para trabajar en la nueva orquesta. El replicante admitió que existían en la ciudad buenos músicos, aunque carentes de estímulo, y exhortó a evitar más divisiones entre los músicos: "concluyan para siempre desavenencias que a todos irrogan perjuicios". La discusión debió de solventarse por otros medios fuera de la prensa ya que no se volvió a publicar ningún artículo en los siguientes meses (aunque el tema sentó un precedente que acabó desencadenando en 1881 la denominada "cuestión orquesta", como vimos en el Capítulo 2).

Durante el mes de abril de 1878 se dieron varias conferencias en los salones del Liceo y en mayo se acondicionó el teatro: se suprimieron las plateas y la galería, y se colocaron espejos, arañas y otros adornos ${ }^{234}$. Durante los primeros días de mayo se organizaron dos funciones benéficas a cargo de socios aficionados ${ }^{235}$. A finales del mes, los músicos de la sección artística prepararon dos conciertos, cuyos programas pueden consultarse en el Apéndice 6.9 $9^{236}$.

A pesar de su aparente actividad, la situación económica de El Liceo era precaria. Tenía deudas acumuladas, no sufragadas con los apoyos "que era de esperar de ciertas clases sociales" ${ }^{, 237}$. Esta situación dio lugar a la cesión del teatro a la compañía dramática

${ }^{232}$ El Semanario Murciano, I (1878), $\mathrm{n}^{\circ}$ 12, 5 mayo, p. 2. Las cursivas son editoriales.

${ }^{233}$ El Semanario Murciano, I (1878), no 13, 12 mayo, pp. 7-8. No consta el autor.

${ }^{234}$ La Paz de Murcia, XXI (1878), nº 6209, 7 mayo, p. 1.

${ }^{235}$ La Paz de Murcia, XXI (1878), nº 6211, 9 mayo, p. 1. Las funciones se realizaron los días 11 y 12 de mayo y los fondos recaudados fueron donados a las víctimas de una catástrofe en el Cantábrico. Ver también, La Paz de Murcia, XXI (1878), n 6215, 14 mayo, p. 1. Las obras representadas fueron: ¡Bienaventurados los que lloran! de Luis Mariano de Larra; la zarzuela en un acto Don Sisenando, de Cristóbal Oudrid; la comedia en tres actos Del enemigo, el consejo, de Eduardo Zamora y la pieza en un acto Echar la llave, de Miguel Echegaray.

${ }^{236}$ En los dos conciertos, celebrados los días 29 y 31 de mayo de 1878, se interpretó el mismo programa. Los números musicales fueron alternados con recitales de poesías de Gabriel Baleriola, Sánchez Madrigal, Virgilio Guirao, Rodolfo Carles, Adolfo Terrer y Martínez Tornel): La Paz de Murcia, XXI (1878), $\mathrm{n}^{\text {os }} 6219,18$ mayo, p. 1; 6227, 28 mayo, p. 1; 6228, 29 mayo, p. 1 y 6231, 2 junio, p. 1.

${ }^{237}$ Según una noticia publicada por La Paz de Murcia, XXI (1878), nº 6236, 8 junio, p. 1 se acordó suspender el cobro de la cuota de entrada hasta la inauguración solemne de El Liceo en otoño de 1878. Se esperaba que el posterior aumento de socios reportara los beneficios necesarios para cubrir las deudas pendientes. 
profesional de Victorio Tamayo, en la que también participaba Matilde Díaz, viuda de Julián Romea ${ }^{238}$. La compañía, procedente de Cartagena, ofreció once representaciones en el Teatro de El Liceo en el mes de julio de $1878^{239}$, antes de pasar a Torrevieja ${ }^{240}$.

A principios de septiembre de 1878, algunos directivos de El Liceo dimitieron, lo que provocó la elección anticipada de una nueva Junta a principios de octubre, presidida por Julián Pagán y con la vicepresidencia compartida entre Juan López Somalo y Juan López Parra ${ }^{241}$. La actividad teatral volvió a iniciarse a mediados de octubre de 1878 (ver Apéndice 6.10). Se organizó una función a beneficio del tenor cómico Antonio Díaz para librarle del servicio militar e impedir que su carrera profesional como cantante se viera truncada $^{242}$. Se interpretaron obras de compositores murcianos, como el himno $A$ la patria, música de Adolfo Gascón y letra de Ricardo Sánchez Madrigal y Serenata, música de Fernando Verdú y letra de Aldeguer. Además, se representaron las zarzuelas CaféTeatro y restauran cantante, de Oudrid y Tres ruinas artísticas de Federico Chueca ${ }^{243}$. A partir de noviembre, la compañía profesional del bajo cómico Luis Boggiero inició un abono de veinte funciones en el Teatro de El Liceo, de las que finalmente sólo se llevaron a cabo quince. El público no reportó suficientes beneficios y la empresa renunció a seguir sus representaciones antes de concluir sus compromisos ${ }^{244}$.

La marcha de la compañía de Luis Boggiero a Cuevas (Almería) coincidió con una nueva renovación de los cargos directivos (esta vez, de todos sus miembros) ${ }^{245}$.

${ }^{238}$ La Paz de Murcia, XXI (1878), $\mathrm{n}^{\mathrm{os}}$ 6252, 28 junio, p. 1 y 6253, 29 junio, p. 1. Véase también, Crespo, Antiguos teatros, p. 90.

${ }^{239}$ El Semanario Murciano, I (1878), $\mathrm{n}^{\mathrm{o}}$ 21, 7 julio, p. 5. Las once funciones generaron 50 pesetas para el Ayuntamiento por el impuesto ("arbitrio") sobre entradas. Se vendieron 360 billetes de abono (18 pesetas de "arbitrio") y 640 en diversas funciones (32 pesetas de "arbitrio"): La Paz de Murcia, XXI (1878), $\mathrm{n}^{\circ}$ 6268,18 julio, p. 1. De ello se deduce que, en total, asistieron mil espectadores: unos noventa por función.

${ }^{240}$ La Paz de Murcia, XXI (1878), nº 6266, 16 julio, p. 1.

${ }^{241}$ No constan los nombres de los cargos dimitidos: La Paz de Murcia, XXI (1878), n $^{\circ}$ 6326, 8 octubre, p. 1. El resto de cargos de la nueva Junta se asignaron a Marcos Peñalver (censor), José Pío Tejera (secretario primero), Enrique Romero (secretario segundo): La Paz de Murcia, XXI (1878), n ${ }^{\circ}$ 6326, 8 octubre, p. 1. Unos días más tarde, La Paz de Murcia, XXI (1878), nº 6329, 11 octubre, p. 1 informó que la nueva junta se había dividido en comisiones, aunque no especifica cuáles.

${ }^{242}$ La Paz de Murcia, XXI (1878), nº 6337, 19 octubre, p. 1. Sobre las redenciones de quintas ("redención a metálico"), véase Fernández Vargas, Sangre o dinero.

${ }^{243}$ Las funciones tuvieron lugar el 20 y 30 de octubre de 1878. El anuncio se publicó en La Paz de Murcia, XXI (1878), nº 6329, 11 octubre, p. 4.

${ }^{244}$ A finales de noviembre, la empresa rebajó los precios de las entradas (de ocho reales a cuatro con 99 céntimos), aunque el público no aumentó: La Paz de Murcia, XXI (1878), nº 6361, 28 noviembre, p. 1. Entre el 2 y el 10 de diciembre, la compañía marchó Orihuela para representar, entre otras zarzuelas, El barberillo de Lavapiés: La Paz de Murcia, XXI (1878), $\mathrm{n}^{\mathrm{os}}$ 6364, 1 diciembre, p. 1; 6367, 5 diciembre, p. 1; 6368, 6 diciembre, p. 1; 6372, 11 diciembre, p. 1 y 6383, 24 diciembre, p. 1. A su regreso a Murcia, la compañía continuó en el teatro de El Liceo hasta el 22 de diciembre de 1878: La Paz de Murcia, XXI (1878), $\mathrm{n}^{\text {os }} 6362,29$ noviembre, p. 1 y 6378, 18 diciembre, p. 1.

${ }^{245}$ La Paz de Murcia, XXI (1878), nº 6383, 24 diciembre, p. 1. Los nuevos cargos directivos fueron: Pedro Pagán (presidente honorario), Julián Pagán (presidente), Juan López Somalo (vicepresidente primero), Juan López Parra (vicepresidente segundo), Antonio Belmar (depositario), Rafael Almazán (contador), José López Pelegrín, José Albaladejo Pérez y Rafael Megías (vocales), Lorenzo Pausa y Marcos Peñalver (censores), José Pío Tejera y Enrique Romero (secretarios): La Paz de Murcia, XXI (1878), $\mathrm{n}^{\circ}$ 6388, 31 diciembre, p. 1 . 
A principios de 1879 el teatro de El Liceo abrió sus puertas con funciones representadas por los aficionados de la entidad ${ }^{246} \mathrm{y}$, desde mediados de enero, por la compañía de Luis Boggiero ${ }^{247}$. Se pusieron en escena Los magyares (Joaquín Gaztambide) y le siguieron otros títulos como El barberillo de Lavapiés, Jugar con fuego, Los diamantes de la corona, El hombre es débil (todas de Barbieri), Marina (Emilio Arrieta), La marsellesa (Fernández Caballero), Sensitiva (Rafael Aceves), La cola del diablo (Oudrid) y Catalina (Gaztambide), entre otras ${ }^{248}$. La novedad fue la ampliación de la orquesta "con algunos profesores forasteros que parece ha contratado la empresa. Nos extraña éstos, siendo así que no faltan en Murcia muchos y buenos"249.

La compañía de Boggiero ofreció total de diez funciones (todas, excepto una, en el mes de enero). La compañía se disolvió y algunos de sus componentes, entre ellos el propio Luis Boggiero, se marcharon a Orihuela para completar la compañía que estaba trabajando allí.

Desde mediados de febrero de 1879 se efectuaron otras representaciones (aunque no musicales) en el Teatro de El Liceo por compañías mixtas de actores profesionales y socios aficionados ${ }^{250}$. En mayo hubo un concierto del violinista y creador del instrumento "marmorofónno" [sic], Achiles Tosi ${ }^{251}$. Los guitarristas Pedro Paredes y Cayetano Belda

${ }^{246}$ La actividad teatral continuó durante el año siguiente en la sociedad de El Liceo. Los aficionados de la entidad dieron una función extraordinaria el 12 de enero con la zarzuela en dos actos Levantar muertos y las piezas en uno El rizo de doña Marta, de José Estrañi, y La casa de campo, de José Sánchez Albarrán: La Paz de Murcia, XXII (1879), nº 6497, 12 enero, p. 4.

${ }^{247}$ A principios de enero de 1879, solicitaron actual en el Teatro de El Liceo dos compañías: la de Luis Boggiero, que estaba en Cuevas (Almería), y la del tenor Enrique García, que se hallaba en Castellón. Fue contratada la primera desde el 15 de enero hasta el 15 de febrero de 1879 y las representaciones se iniciaron el 22 de enero de 1879: La Paz de Murcia, XXII (1879), nº 6389, 1 enero, p. 1.

${ }^{248}$ La prensa criticó que las funciones no comenzaban puntualmente, se alargaban en extremo los entreactos, el personal entre bastidores se asomaba al público y los actores hablaban durante las representaciones. Además, las obras sufrían "cortes escandalosos". La concurrencia fue escasa, lo que provocó, probablemente, la disolución de la compañía. Ver, La Paz de Murcia, XXII (1879), n ${ }^{\text {os }}$ 6506, 23 enero, p. 1 y 6507, 24 enero, p. 1.

${ }^{249}$ La Paz de Murcia, XXII (1879), nº 6507, 24 enero, p. 1.

${ }^{250}$ La compañía mixta de aficionados y actores profesionales ("una dama, dama joven, característica y galán director") para el Teatro de El Liceo daría dos funciones por semana hasta el 2 de marzo de 1879: La Paz de Murcia, XXII (1879), $\mathrm{n}^{\circ}$ 6526, 15 febrero, p. 1. Las representaciones de teatro declamado se prolongaron durante los meses de marzo, abril y junio en varios abonos. En el último, se estrenaron dos obras de autores murcianos: Una buena obra, de Sánchez Madrigal y La politica en Garres, de Juan Antonio Soriano. Sobre estas representaciones véase Crespo, Antiguos teatros, p. 100-108. En agosto de 1879, el toldo que cubría el patio de la sociedad se incendió, hiriendo en la mano derecha al conserje del establecimiento apellidado Galindo, que consiguió impedir que el fuego se propagase al salón del teatro: $L a$ Paz de Murcia, XXII (1879), n 6671, 12 agosto, p. 1. Tras el verano, las representaciones de género dramático se reiniciaron en octubre de 1879 con una compañía de aficionados. El abono quedó interrumpido por la riada Santa Teresa que sembró de desolación la huerta. Como consecuencia, la actividad teatral cesó hasta diciembre de 1879, momento en el que se reanudaron las funciones con esa compañía y se estrenó el drama murciano en dos actos y verso Los horrores del Segura, original de Juan Antonio Soriano: La Paz de Murcia, XXII (1879), nº 6702, 14 diciembre, p. 1.

${ }^{251}$ Tosi era "Discípulo del Conservatorio de Milán, miembro de la Real Academia de Italia, inventor del nuevo instrumento denominado Marmorofónno premiado en la última Exposición de París y con el que tantos aplausos ha alcanzado en Madrid, Lisboa, Valencia y principales capitales de España, conocedor también con admirable inteligencia del violín, por cuya ejecución ha merecido el título de Maravilla del arte". En los dos conciertos que dio Tosi, interpretó obras en las que se imitaban distintos animales: La Paz de Murcia, XXII (1879), $\mathrm{n}^{\circ}$ 6590, 4 mayo, p. 4. 
y el intérprete de bandurria Manuel Valero dieron un concierto en el mes de octubre con obras de Verdi, Rossini y otros autores de ópera italiana ${ }^{252}$.

\subsection{El fin de El Liceo y el nacimiento del Círculo Taurino (1880-1883)}

En 1880 El Liceo emprendió un nuevo proyecto de ámbito educativo y estableció clases de diferentes materias, entre ellas "Contabilidad", "Francés", "Dibujo", "Acuarela" y "Matemáticas" $" 53$. Sin embargo, su situación económica era difícil, muchos socios no estaban al corriente de los pagos y la lista de morosos ascendía. Al menos durante los años 1881 y 1882, El Liceo alquiló esporádicamente su salón-teatro a otras sociedades e instituciones de la ciudad para recaudar ingresos extraordinarios ${ }^{254}$. La Escuela de Canto y Declamación para la carrera artística italiana (nacida en febrero de 1881), dirigida por Lucas, solicitó el local de El Liceo para instalarse provisionalmente en sus dependencias en agosto de $1881^{255}$. La Sociedad Santa Cecilia, surgida en noviembre de 1881, ofreció dos conciertos en los salones de El Liceo en marzo y noviembre de $1882^{256}$. La Sociedad Dramática Romea (creada en mayo de 1882) dio varias representaciones teatrales en El Liceo en ese mismo mes.

Al parecer, desde 1880 hasta 1883 no hubo actividad teatral de la sección líricodramática de $\mathrm{El} \mathrm{Liceo}{ }^{257}$. Sin embargo, la actividad concertística, aunque puntual, fue muy significativa, tanto por la calidad de los instrumentistas como por el repertorio interpretado: en febrero de 1880 actuaron las hermanas Carolina y Vicentina Ferni (violín y soprano, respectivamente); en abril, los guitarristas José Martínez Toboso y Enrique Romans; el 23 de diciembre, concierto del guitarrista Mas (probablemente Benito Mas) con los músicos Ramírez, Sola y Gascón ${ }^{258}$. En marzo de 1881, hubo un concierto

${ }^{252}$ El guitarrista Pedro Paredes ya había actuado en otras dos ocasiones en la ciudad durante 1879: en mayo en el Teatro Provisional y el 8 de septiembre en una velada musical en casa de Manuel Fontes y Álvarez de Toledo. Sobre el concierto de octubre en El Liceo véase: La Paz de Murcia, XXII (1879), ${ }^{\text {os }}$ 6718,8 octubre, p. 4; 6719, 9 octubre, p. 4; 6720, 10 octubre, p. 4 y 6721, 11 octubre, p. 4.

${ }^{253}$ Este proyecto educativo se inauguró el 2 de mayo de 1880 con una velada literaria y musical, a la que asistieron las autoridades civiles de la ciudad (entre ellas, el Gobernador) y el presidente de El Liceo, Adolfo Ayuso. Se leyeron poesías de Virgilio Guirao, Ricardo Sánchez Madrigal y Adolfo Terrer y actuaron los músicos Ángel Mirete, Julián Calvo, Antonio Ramírez y la banda de Emilio Raya. Esta última interpretó una sinfonía de "Guillermo" y la obertura de la inauguración de la Exposición de Londres: El Diario de Murcia, II (1880), no 372, 4 mayo, pp. 1-2. Sobre las materias impartidas, véase: El Diario de Murcia, II (1880), $\mathrm{n}^{\text {os }} 399,8$ junio, p. 2 y 494, 30 septiembre, p. 3.

${ }^{254}$ En agosto de 1881 la sociedad recibió dos solicitudes para arrendar su salón teatro: una para bailes de máscaras y otra para reuniones de una sociedad minera no especificada. El local se alquiló a la segunda de ambas: La Paz de Murcia, XXIV (1881), nos 7119, 20 agosto, p. 1; 7152, 28 septiembre, p. 1 y 7154, 1 octubre, p. 1.

\footnotetext{
${ }^{255}$ La Paz de Murcia, XXIV (1881), no 7119, 20 agosto, p. 1.

${ }^{256}$ La Paz de Murcia, XXV (1882), nº 7280, 29 marzo, p. 1.
}

${ }^{257}$ La sección lírico dramática de El Liceo no aparece en la prensa desde 1879. Probablemente, sus miembros pasaron a formar parte de otras sociedades de aficionados al teatro, como la Sociedad Dramática Romea o la Apolo.

${ }^{258}$ Sobre estos guitarristas y las generaciones a las que pertenecen, véanse Suárez Pajares, "Guitarra"; Suárez Pajares, "Martínez Toboso" y Suárez Pajares, "Mas, Benito". 
del guitarrista Julián Arcas ${ }^{259}$. En mayo de 1882, actuaron la sociedad dramática Romea y el guitarrista Francisco Tárrega; en noviembre, concierto de Isaac Albéniz (que había actuado previamente en el Teatro del Romea) y en enero de 1883, otro de Julián Arcas (ver Apéndice 6.9) $)^{260}$.

Al margen de la programación de conciertos, El Liceo arrendó sus salones a empresas de organización de bailes desde $1880^{261}$. En octubre de 1881, por ejemplo, El Liceo recibió dos peticiones para alquilar su salón bajo: una de una sociedad minera y otra de una empresa de bailes. A pesar de que en un primer momento la directiva de $E l$ Liceo se inclinó por la primera, se le concedió finalmente permiso a la empresa de organización de bailes, a petición de algunos socios de El Liceo ${ }^{262}$.

A principios de 1883, El Liceo estaba sumido en una profunda crisis: "Sus socios habían disminuido y sus pagos no iban bien por la disminución de ingresos que antes habían sido muy crecidos y por los gastos extraordinarios que aparecen en cuentas"263. La sociedad cambió su sede a la calle Montijo en enero de ese año ${ }^{264} \mathrm{y}$, al mes siguiente se subastaron los enseres de su teatro ${ }^{265}$. Además, se eligió una Junta Directiva que dimitió después, quedando El Liceo sin dirección durante varios meses ${ }^{266}$.

259 También se celebraron veladas de "magia moderna, taumaturgia y sorprendentes apariciones y desapariciones" por el doctor Nicolay a finales de diciembre de 1879; espectáculos "morales e instructivos" de una compañía franco-belga-española con el profesor Pietro Adrieny, a finales de febrero de 1880; y la presentación del fonógrafo Edison en marzo de 1880. El 20 de noviembre de este año, tuvo lugar un espectáculo del mago Adolfo Santaló.

${ }^{260}$ Los conciertos de Albéniz en Murcia (tanto en el Romea como en el Teatro de El Liceo) tuvieron lugar dentro de una gira con compañías de zarzuelas que Albéniz emprendió por tierras andaluzas y levantinas y que, según Kalfa, "Albéniz. Biografía”, p. 189 fue un fiasco económico para el compositor. Tras esa gira, Albéniz inició una serie de recitales para piano. Sobre su actuación en el Teatro Romea de Murcia en octubre de 1882, ver Capítulo 5. Julián Arcas actuó en reiteradas ocasiones en Murcia (ver Capítulo 5).

${ }^{261}$ La Paz de Murcia, XXIV (1881), n 7152, 28 septiembre, p. 1. Además, en La Paz de Murcia, XXIV (1881), nº 6999, 12 marzo, p. 1 se informa de que la empresa encargada de los bailes repartiría pan con las ganancias obtenidas de los bailes. Las crónicas de los bailes organizados por El Liceo entre los años 1879 y 1881 pueden consultarse en La Paz de Murcia: XXII (1879), n 6504, 21 enero, p. 1; 6523, 12 febrero, p. 1; 6527, 16 febrero, p. 1; XXIV (1881), n 7154,1 octubre, p. 1 y 7173, 24 octubre, p. 1; El Diario de Murcia: I (1879), n 3, 18 febrero, p. 2; III (1881), nº 786, 30 septiembre, p. 3; 787, 1 octubre, p. 3 y 788,2 octubre, p. 3.

${ }^{262}$ Desde el mes de octubre de 1881, los bailes se organizaron los jueves y domingos de cada semana: La Paz de Murcia, XXIV (1881), $\mathrm{n}^{\circ}$ 7173, 24 octubre, p. 1; El Diario de Murcia; III (1881), $\mathrm{n}^{\circ}$ 819, 8 noviembre, p. 3 y IV (1882), nº 944,9 abril, p. 3.

${ }^{263}$ La Paz de Murcia, XXVI (1883), no 7751, 23 octubre, p. 1.

${ }^{264}$ El local se situó en la calle Montijo, esquina con la calle Saurín, número 21, mientras el antiguo local estaba en obras. Al acto de inauguración de la nueva sede acudió la banda de música dirigida por Mirete: La Paz de Murcia, XXVI (1883), nº 7537, 17 enero, p. 1.

${ }^{265}$ La subasta prevista para el 4 de febrero de 1883 a las doce de la mañana no tendría en cuenta las propuestas por debajo de la tasación oficial y daría ventaja a los socios, a igualdad de condiciones económicas: El Diario de Murcia, V (1883), nº 1089, 28 enero, p. 2.

${ }^{266}$ La Junta Directiva para el año 1882 (elegida en octubre de 1881) estaba constituida por José Albaladejo Pérez (presidente), José María Martínez Motos (vicepresidente), Ignacio Pérez de Lema, José María Ibáñez, Federico Bernal, Antonio Mengua (vocales), Ramón Pérez (secretario), Antonio Soriano (contador), José Albaladejo Lillo (tesorero): El Diario de Murcia, III (1881), n 796, 12 octubre, p. 3. La Junta Directiva para 1883 se constituyó en enero de la siguiente manera: Ignacio Pérez de Lema (presidente), Antonio Albacete (vicepresidente), Ambit, Albaladejo, Guillamón y Ródenas (vocales), José 
Para evitar la desaparición, se eligió una Junta Directiva en octubre de 1883 cuyo presidente, José María Ballester, era también presidente de la Sociedad Taurina. El Liceo admitió la entrada de un buen número de socios procedentes de esta sociedad y ambas sociedades se unieron y cambiaron el nombre por el de Círculo Taurino $^{267}$.

\section{La Sociedad Artístico Musical Santa Cecilia (1881-1887)}

\subsection{El proyecto de creación de un conservatorio de música murciano (1881)}

Las primeras noticias sobre la creación de un conservatorio de música murciano se remontan a junio de 1881, por iniciativa de Julián Calvo ${ }^{268}$, Mariano García, Acisclo Díaz y Antonio Ramírez, entre otros. El proyecto surgió en plena polémica periodística por la formación de la orquesta del Teatro Romea, suscitada en mayo del mismo año. La idea, en principio, fue bien acogida, a pesar de algunos periódicos de la ciudad se aventuraron a atisbar una nueva disputa entre los músicos murcianos ${ }^{269}$.

El 19 de junio de 1881 tuvo lugar una reunión en la casa del maestro de capilla, Mariano García, a la que acudieron diversos músicos de la ciudad. El encuentro fue fructífero y se nombró una comisión para atender los trabajos preliminares del proyecto, formada por Mariano García (Presidente), Julián Calvo y Ángel Mirete (Vicepresidentes), Mariano Esbrí, Simón Espín, José Juvés, Antonio Ramírez, Juan Ayala y Adolfo Gascón (vocales), así como Fernando Verdú y José Solarno (secretarios) ${ }^{270}$. El plan de estudios contemplaría materias como "Elementos generales de la música" y tres años más de solfeo, tres años de canto, estética e historia de la música, tres años de armonía, siete años de piano, contrapunto y fuga, órgano común y expresivo, violín, violonchelo, contrabajo,

María Ibáñez (depositario), Alfonso Rodríguez (contador) y Ramón Pérez (secretario): El Diario de Murcia, V (1883), $n^{\circ} 1074,6$ enero, p. 3 y La Paz de Murcia, XXVI (1883), n ${ }^{\text {os }} 7529,8$ enero, p. 1 y 7532 , 11 enero, p. 1. En marzo de 1883, una nueva elección otorgó la presidencia a Ramón Pérez, la secretaría a Félix Viñas y una vocalía a Ángel García Parra: El Diario de Murcia, V (1883), n 1221, 8 marzo, p. 3. Sin embargo, en octubre de 1883 los directivos habían dimitido y una "comisión reorganizadora" se encargó de la dirección hasta la constitución de otra Junta en octubre de 1883: La Paz de Murcia, XXVI (1883), $\mathrm{n}^{\circ}$ 7751, 23 octubre, p. 1. Esta última Junta estuvo formada por José María Ballester Arenas (presidente, además, de la Sociedad Taurina), Eduardo Cabero (vicepresidente), Celestino Muñoz (contador), Juan Antonio Romero (depositario), Jesualdo Pelluz, José Sandoval, Federico Fernández y don Eduardo Sánchez Cortés (vocales) y José Campillo (secretario): La Paz de Murcia, XXVI (1883), nº 7751, 23 octubre, p. 1.

${ }^{267}$ La Paz de Murcia, XXVI (1883), no 7751, 23 octubre, p. 1; y El Diario de Murcia, V (1883), $\mathrm{n}^{\circ}$ 1419, 4 noviembre, p. 3 .

${ }^{268}$ Según El Semanario Murciano, IV (1881), nº 175, 19 junio, p. 197, Julián Calvo fue uno de los más interesados en crear el conservatorio murciano.

${ }^{269}$ Según El Diario de Murcia, III (1881), nº 693, 10 junio, p. 2, tomado de El Eco de Murcia, algunos músicos pusieron impedimentos para crear el conservatorio murciano. El Eco de Murcia achacó estos impedimentos a los odios y rencores "muy reconcentrados desde tiempo antiguo". Las afirmaciones vertidas en El Eco de Murcia fueron desmentidas por Mariano García, ["Carta remitida"], El Diario de Murcia, III (1881), $\mathrm{n}^{\circ}$ 695, 12 junio, p. 2. Véase también, La Paz de Murcia, XXIV (1881), n 7072,13 junio, p. 1 y el Documentario.

${ }^{270}$ La Paz de Murcia, XXIV (1881), no 7071, 10 junio, p. 1. Entre los asistentes estuvieron, además de Mariano García, Mariano Esbrí, Juan Ayala, Antonio Ramírez, Espín, Francisco de Lucas, Adolfo Gascón, José Juvés, Ballester, Juan Diego Manresa, José Solano, Fernando Verdú y Emilio Raya, así como otros que acudieron en representación de Ángel Mirete, Julián Calvo, Jover, Bacho y Arcusa. 
varios instrumentos de viento madera y metal, así como clases especiales para ciegos ${ }^{271}$. Los profesores y sus asignaturas se detallan en la Tabla 6.3:

Tabla 6. 3. Enseñanzas y profesorado según el proyecto de creación de un conservatorio murciano (1881)

El Diario de Murcia, III (1881), nº 699, 18 junio, p. 3 (ver Documentario).

\begin{tabular}{|l|l|}
\hline Materia & Profesor \\
\hline $\begin{array}{l}\text { Elementos generales de la } \\
\text { música }\end{array}$ & Pedro Bacho \\
\hline $1^{\text {er }}$ solfeo & Bonifacio Ballester \\
\hline $2^{\circ}$ solfeo & Juan Ayala \\
\hline $3^{\circ}$ solfeo & Remigio Alcusa \\
\hline $1^{\circ}$ canto & Francisco Lucas \\
\hline $2^{\circ}$ canto & Mariano García \\
\hline $3^{\circ}$ canto & Francisco Lucas \\
\hline $1^{\circ}$ piano & José Jubés \\
\hline $2^{\circ}$ piano & José Solano \\
\hline $3^{\circ}$ piano & José Solano \\
\hline $4^{\circ}$ piano & Mariano García \\
\hline $5^{\circ}$ piano & Antonio Ramírez \\
\hline $6^{\circ}$ piano & Antonio Ramírez \\
\hline $7^{\circ}$ piano & Julián Calvo \\
\hline $1^{\circ}$ violín & Jorge Coderch \\
\hline $2^{\circ}$ violín & José Fresneda \\
\hline $3^{\circ}$ violín & José Fresneda \\
\hline Complemento de violín & Angel Mirete \\
\hline Flauta y violín & Mariano Esbrí \\
\hline Complemento de flauta & José Jubés \\
\hline Contrabajo & Francisco Jover \\
\hline Violonchelo & Francisco Jover \\
\hline $\begin{array}{l}\text { Instrumentos de viento } \\
\text { madera }\end{array}$ & Acisclo Díaz \\
\hline $\begin{array}{l}\text { Instrumentos de viento } \\
\text { metal }\end{array}$ & Emilio Raya \\
\hline $1^{\circ}$ armonía & Fernando Verdú \\
\hline $2^{\circ}$ armonía & Julián Calvo \\
\hline $3^{\circ}$ armonía & Fernando Verdú \\
\hline Organo & Simón Espín \\
\hline Estudio sobre la melodía & Julián Calvo \\
\hline Cuarto año de piano & Mariano García \\
\hline Instrumentación & Mariano García \\
\hline Estética & Mariano García \\
\hline Historia de la música & Mariano García \\
\hline Contrapunto y fuga & Julián Calvo \\
\hline $\begin{array}{l}\text { Clases especiales para } \\
\text { ciegos }\end{array}$ & $\begin{array}{l}\text { Adolfo Gascón y Juan } \\
\text { Diego Manresa }\end{array}$ \\
\hline & \\
\hline
\end{tabular}

El proyecto llegó a formalizarse, aunque no bajo la denominación de “conservatorio", como veremos en el punto siguiente ${ }^{272}$.

${ }^{271}$ Sobre la enseñanza musical a ciegos en España durante el siglo XIX, véanse, entre otros: Burgos Bordonau, "La enseñanza musical del colectivo invidente", pp. 65-82 y Burgos Bordonau, "La enseñanza musical en el Colegio Nacional", pp. 67-78.

${ }^{272}$ Hubo, no obstante, cierta reticencia para llevar a cabo el proyecto del conservatorio por parte de algunos diarios. Para El Semanario Murciano, IV (1881), nº 175, 19 junio, p. 198, la idea de crear el conservatorio era buena aunque creyó mejor opción dar más apoyo a la recién creada Escuela de canto y 


\subsection{Fundación y actividad musical de la sociedad Santa Cecilia hasta 1884}

El reglamento que constituyó legalmente la Sociedad Artístico Musical Santa Cecilia se aprobó el 9 de noviembre de 1881, cinco meses después de iniciarse la idea de crear un conservatorio para Murcia ${ }^{273}$, y en él se marcaba como objetivo la enseñanza gratuita de la música y su difusión a través de conciertos. La nueva sociedad Santa Cecilia tuvo su sede en la plaza de Fontes, "en el mismo local en que ya lo estuvo otra sociedad de individuos separados del Casino" 274 y su presidente honorario fue Mariano García, maestro de capilla de la Catedral de Murcia $^{275}$. Una de las primeras actividades de la sociedad Santa Cecilia fue participar en los eventos organizados para festejar Santa Cecilia (22 de noviembre), junto a la Capilla de Música del convento de las Agustinas, como estudiaré detalladamente en el apartado 9.3.

En diciembre de 1881, la sociedad Santa Cecilia organizó un concierto y celebró elecciones a la Junta Directiva, de las que resultó presidente Fernando Verdú ${ }^{276}$. Se quería diseñar un plan de enseñanza musical pública y gratuita "a fin de completar la educación de todo el que aspire a llamarse artista"277. El proyecto no comenzó a ser realidad hasta octubre de 1882, con la inauguración de la "Academia Santa Cecilia". (Ver Figura 6.11). La Academia Santa Cecilia estuvo ubicada en la calle de las Balsas, número $24^{278}$, dependió de la sociedad del mismo nombre, fue dirigida por Mariano García y fue diferente del Colegio de Primera Enseñanza "Santa Cecilia", ubicado en la plaza de los Gatos (hoy de Fernández Caballero). El Colegio "Santa Cecilia", destinado sólo para niñas, estuvo dirigido por Remedios Valiente y Antonio Ramírez Pagán. En él se dieron

Declamación: "no vayamos a abarcar tanto, que no podamos apretar nada". De igual pensamiento fue $L a$ Paz de Murcia, XXIV (1881), nº 7078, 21 junio, p. 1.

${ }^{273}$ Inicialmente, la Santa Cecilia fue denominada "sociedad artístico-musical": La Paz de Murcia, XXIV (1881), n 7188, 11 noviembre, p. 1. Desde la inauguración de las clases de música, en octubre de 1882, también se llamó "Academia Santa Cecilia", como veremos más adelante. Desconozco si esta sociedad tiene vinculación con la Capilla de Música de Santa Cecilia de Murcia, que Pina, "La capilla de música", pp. 379-393 describe como un temprano ejemplo de asociacionismo en el siglo XVIII. Según la autora, esa Capilla prosiguió tras la Guerra de la Independencia, aunque mis referencias sobre la sociedad Santa Cecilia datan de 1881.

${ }^{274}$ La Paz de Murcia, XXIV (1881), nº 7188, 11 noviembre, p. 1.

${ }^{275}$ El Diario de Murcia, III (1881), no 839, 1 diciembre, p. 3.

${ }^{276}$ El Semanario Murciano valoró muy positivamente el concierto, que ponía fin a la polémica en torno a la creación de la orquesta del teatro, que tanta divisiones había generado entre los músicos de la ciudad: El Semanario Murciano, IV (1881), nº 198, 25 diciembre, p. 390. Sobre esta polémica, véase, el Capítulo 2. Fernando Verdú sucedió como presidente a Mariano García, maestro de capilla de la Catedral de Murcia: La Paz de Murcia, XXV (1882), nº 7231, 3 enero, p. 1.

${ }^{277}$ El violinista y director Ángel Mirete propuso ofrecer clases elementales públicas y gratuitas de música. El maestro de capilla Mariano García opinó que éstas debían ampliarse con la enseñanza de otras materias, como Estética y Literatura. Ambas posturas fueron discutidas por Julián Calvo, Serradell e Icalbaceta y el resto de socios. Finalmente, se aprobó el diseño de un plan básico de enseñanza, coordinado por la Junta Directiva y los músicos García, Mirete e Icabalceta: La Paz de Murcia, XXV (1882), nº 7231, 3 enero, p. 1 y El Diario de Murcia, III (1881), nº 863, 31 diciembre, p. 2.

${ }^{278}$ El Diario de Murcia: IV (1882), n ${ }^{\text {os }} 1093,03$ octubre, p. 3 y V (1883), no 1390, 2 octubre, p. 2. 
clases gratuitas de solfeo y canto, además de las de primera enseñanza (ver Figura $6.12)^{279}$.

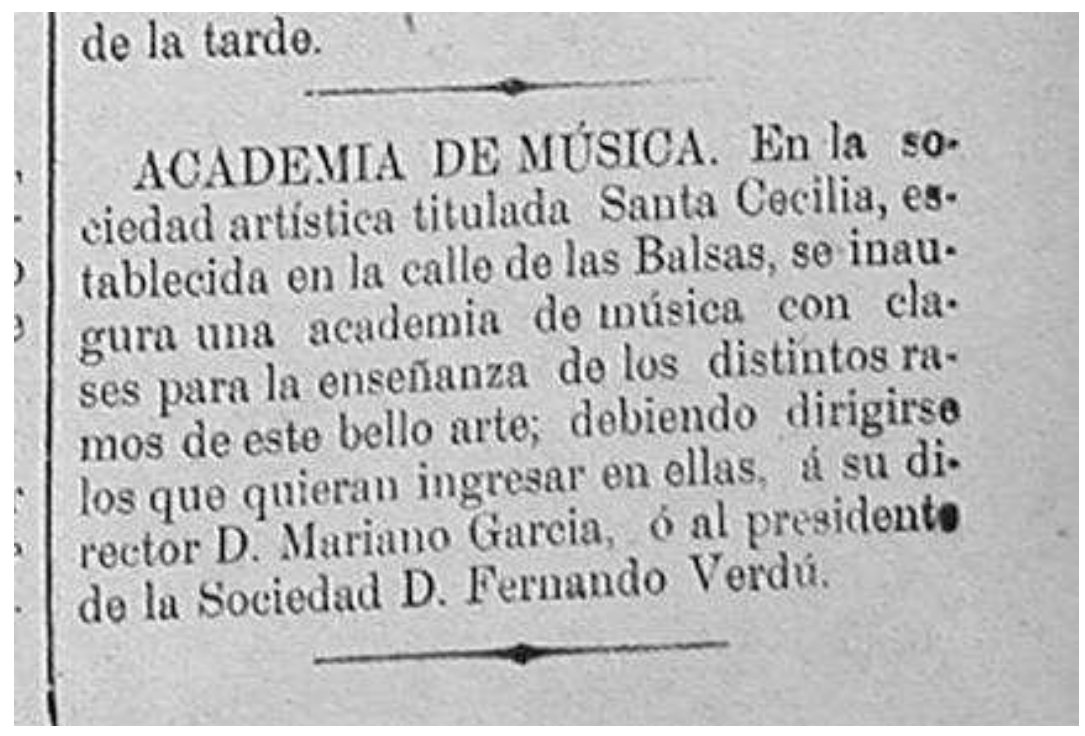

Figura 6. 11 Anuncio de la Academia de música Santa Cecilia. El Diario de Murcia, IV (1882), nº 1093, 3 octubre, p. 3, E: MUm.

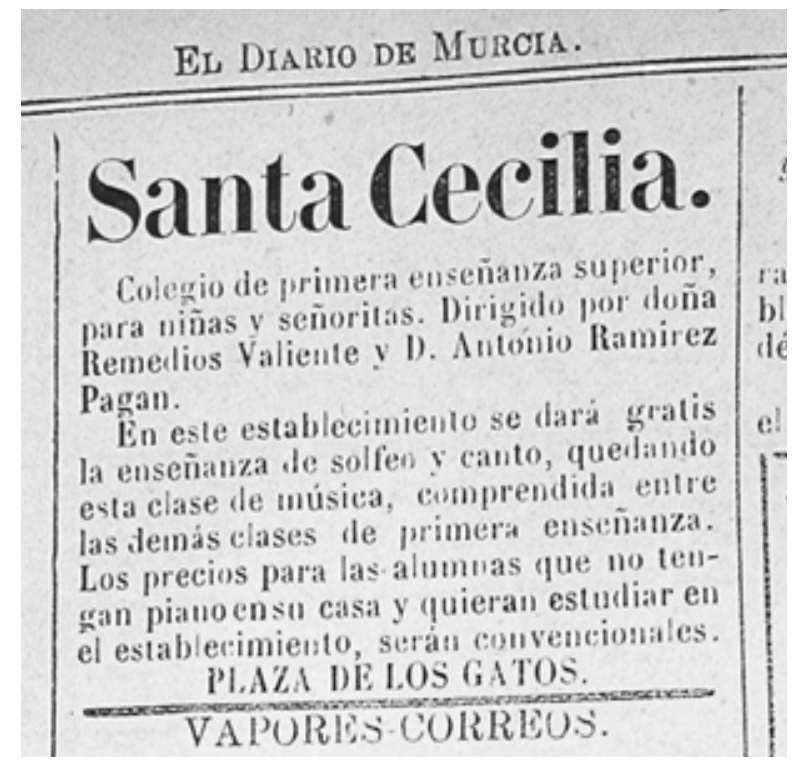

Figura 6. 12. Anuncio del Colegio de Primera Enseñanza Santa Cecilia. El Diario de Murcia, IV (1882), nº 1055, 18 agosto, p. 4, E: MUm.

Lamentablemente, la prensa no ha dejado constancia de las materias impartidas en la Academia Santa Cecilia aunque es probable que, al menos en parte, fuesen semejantes al proyecto del conservatorio.

En paralelo a la actividad docente, la sociedad Santa Cecilia promovió nuevos conciertos a lo largo de 1882 . Ese año, la sociedad contaba ya con noventa y siete

${ }^{279}$ El Diario de Murcia, III (1881), $\mathrm{n}^{\text {os }} 763,2$ de septiembre, p. 4 y 777, 20 septiembre, p. 1. Véase también, El Diario de Murcia, V (1883), nº 1315, 1 julio, p. 4. 
$\operatorname{socios}^{280}$. En enero, por ejemplo, se organizó una larga velada musical, cuyo programa, en tres partes, contenía obras de Beethoven, Haydn, Ambroise Thomas, Bériot y diversos compositores murcianos $^{281}$ (ver Apéndice 6.11). Este programa desvela los intereses de una sociedad preocupada por difundir otro tipo de piezas "clásicas", como ellos denominaron, diferentes al hasta entonces habitual repertorio de óperas y zarzuelas. Además, la interpretación de esta música conllevó una mayor riqueza de formaciones instrumentales: desde las orquestales hasta las de cámara en formatos como dúos, cuartetos y quintetos. En el concierto del 30 de marzo de 1882 los músicos de la Santa Cecilia actuaron en las dependencias de El Liceo $^{282}$. El programa, nuevamente dividido en tres partes, desvela una presencia mayor de compositores españoles, como los mallorquines Pedro Tintorer y Pedro Miguel Marqués y los murcianos Fernando Verdú y Pastor. A ellos se unieron otras obras más habituales, como sinfonías y fantasías sobre óperas de Rossini y Donizetti. Especialmente significativa es la presencia de Las siete palabras de Cristo en la Cruz de Haydn "para instrumentos de cuerda y piano"283. En julio del mismo año la sociedad ofreció un nuevo concierto a sus asociados, aunque no ha quedado constancia del programa interpretado ${ }^{284}$.

Durante el año 1883, la sociedad Santa Cecilia programó tres conciertos en enero, abril y junio ${ }^{285}$ a cargo de los "profesores que componen la sección de conciertos"286. En febrero, además, se solicitó al Ayuntamiento el salón del teatro Romea para dar "conciertos sacros", aunque omo he comentado no he podido constatar que se celebrase ninguno ${ }^{287}$. La nómina documentada de intérpretes murcianos que participaron en los

${ }^{280}$ La Paz de Murcia, XXV (1882), no 7231, 4 enero, p. 1. El Diario de Murcia, IV (1882), no 911, 25 febrero, p. 2 informó de una reunión de sus socios para tratar una reforma del reglamento de la sociedad. Se nombró una comisión para estudiar los puntos a modificar y aprobarlos más tarde en Junta General, aunque no tengo constancia de cuáles fueron las reformas.

${ }^{281}$ El concierto tuvo lugar en el salón del Colegio Saavedra Fajardo el 6 de enero de 1882. Dado que el número de asistentes probablemente fue mayor a la capacidad del salón, dos días antes del concierto se sortearon las entradas entre los socios: La Paz de Murcia, XXV (1882), n ${ }^{\circ}$ 7231, 4 enero, p. 1. La crítica del concierto, firmada por Miguel Lario, apareció en La Paz de Murcia, XXV (1882), nº 7233, 7 enero, p. 1.

${ }^{282}$ Con anterioridad a este concierto, la prensa informó de una velada literaria en homenaje al escritor murciano José Selgas Carrasco. El Eco propuso que fuera la sociedad Santa Cecilia quien, “en unión de los jóvenes literatos de Murcia, hiciera lo posible" por llevar la velada a efecto: El Diario de Murcia, IV (1882), nº 903, 16 febrero, p. 1. La organización de la parte literaria fue encargada al director del periódico El Diario Murcia, José Martínez Tornel y, la musical, a Ceferino Icabalceta: El Diario de Murcia, IV (1882), n 911, 25 febrero, p. 2 y El Diario de Murcia, IV (1882), n 925, 16 marzo, p. 2. El programa de la velada, publicado en El Diario de Murcia, IV (1882), nº 928, 19 marzo, p. 2, no anunció las obras musicales que se interpretarían y tampoco se hizo alusión en la crítica, publicada al día siguiente en el mismo periódico. La única referencia fue la participación de la orquesta de Emilio Raya y una sinfonía que se interpretaría en la segunda parte. El resto, fueron discursos y lecturas en verso y prosa, tanto del homenajeado como de otros escritores murcianos.

${ }^{283}$ La Paz de Murcia, XXV (1882), $\mathrm{n}^{\text {os }}$ 7280, 29 marzo, p. 1. El concierto se celebró el 30 de marzo de 1882 en el salón del Liceo. La crítica apareció en La Paz de Murcia, XXV (1882), nº 7282, 31 marzo, p. 1.

${ }^{284}$ El Diario de Murcia, IV (1882), nº 1038, 26 julio, p. 2.

${ }^{285}$ El Diario de Murcia, V (1883), n ${ }^{\text {os }} 1091,31$ enero, p. 2; 1258, 24 abril, p. 3 y 1314, 30 junio, p. 3; La Paz de Murcia, XXVI (1883), n ${ }^{\text {s }}$ 7549, 31 enero, p. 1; 7620, 21 abril, p. 1, 7622, 24 abril, p. 1; 7664, 29 junio, p. 1 y 7668,5 julio, p. 1.

${ }^{286}$ La Paz de Murcia, XXVI (1883), nº 7572, 26 febrero, p. 1. En fechas anteriores a febrero de 1883, las fuentes periodísticas no mencionan esa "sección de conciertos".

287 Así lo anunció El Diario de Murcia, V (1883), n 1200, 10 febrero, p. 2 haciéndose eco de otro periódico local no especificado. 
conciertos de la sociedad Santa Cecilia se muestra en la Tabla 6.4 y es probable que esos artistas integraran la "sección de conciertos". Este listado desvela que algunos músicos profesionales como José y Ángel Mirete, Julián Calvo y Fernando Verdú, entre otros, también fueron colaboradores de otras sociedades e integrantes de las formaciones orquestales de Murcia (por ejemplo, la orquesta del Teatro Romea). Por tanto, la participación los músicos de Santa Cecilia con otras instituciones y sociedades murcianas fueron muy habituales, especialmente en las funciones benéficas que se organizaban en los distintos teatros de la ciudad y en colaboración con compañías teatrales, orquestas y bandas de música ${ }^{288}$.

Tabla 6. 4. Músicos documentados que participaron en los conciertos de la Sociedad Santa Cecilia (1882-1883)

Fuentes: ver Apéndice 6.11.

\begin{tabular}{|l|l|}
\hline Nombre & Instrumento \\
\hline Ángel Mirete & dir. y violín \\
\hline Antonio Canales & viola \\
\hline Antonio Leante & trompa \\
\hline Antonio Ramírez & piano \\
\hline Concha Rodríguez & piano \\
\hline Bonifacio Ballester & trombón y bombardino \\
\hline Fernando Verdú & dir. y violín \\
\hline Francisco Calvo & clarinete \\
\hline Francisco Jover & violonchelo y contrabajo \\
\hline Francisco Leante & piano \\
\hline Isidoro Vela & violín \\
\hline Jorge Coderch & violín \\
\hline José García ¿Pujol? & contrabajo \\
\hline José María Carrasco & flauta \\
\hline José Mirete & violín \\
\hline José Puche & violín \\
\hline José Solano & piano \\
\hline Julián Calvo & piano y armonio \\
\hline Vicente Espada & piano \\
\hline
\end{tabular}

Según La Paz de Murcia los músicos de la sociedad Santa Cecilia colaboraban "desinteresadamente" y su éxito residía en la difusión de la música a través de la enseñanza y de la programación de conciertos:

La Sociedad artístico-musical Santa Cecilia va cada día dando muestras inequívocas de progreso. [...] Son dignos de alabanza, no tan solo por lo que llevamos

${ }^{288}$ Por ejemplo, citaré la participación de los músicos de Santa Cecilia en la función a beneficio del tenor Blaya en el teatro Romea (30-11-1883) (ver Apéndice 6.11): La Paz de Murcia, XXVI (1883), $\mathrm{n}^{\circ}$ 7780, 25 noviembre, p. 1; y la función benéfica del 21 de enero de 1884 por la compañía de Miguel Cepillo, la banda de la Casa de la Misericordia y la "sección de cuartetos" de la sociedad Santa Cecilia. En esta última se interpretó la obertura de Ruy Blas de Mendelssohn: La Paz de Murcia, XXVII (1884), nº 7826, 20 enero, p. 1. Véanse más testimonios sobre actuaciones de la sociedad en el Romea en: La Paz de Murcia, XXVII (1884), $\mathrm{n}^{\text {os }} 7817,10$ enero, p. 1 y 7823, 17 enero, p. 1. Los músicos de Santa Cecilia también tomaron parte en algunos bailes de máscaras organizados en el Casino: La Paz de Murcia, XXVI (1883), $\mathrm{n}^{\circ}$ 7576, 3 marzo, p. 1.

${ }^{289}$ Alumna de Mariano García. 
dicho, sino por los grandes servicios que desinteresadamente y sin miras lucrativas, están prestando a la juventud estudiosa de esta capital.

Con sus propios recursos han establecido clases de enseñanza musical, logrando formar un pequeño Conservatorio de donde podrán brotar artistas que honren a Murcia, y a los iniciadores de tan noble institución.

Ellos han logrado con la constancia y fe de todo artista que mira por el engrandecimiento del arte, afianzar una Academia, difícil de sostener en este país. Ellos procuran propagar la afición a la música clásica, presentándonos con toda verdad las sublimes concepciones de Beethoven, Mozart, Haydn, Mendelson, Weber, Rossini y otros maestros ilustres.

En poco más de un año que tiene de vida esta sociedad, no ha decaído en lo más mínimo.

La sociedad Santa Cecilia de Murcia impulsó a pequeña escala la música sinfónica y la de cámara (especialmente esta última) y su labor es equiparable en cierto modo a la Sociedad Artístico-Musical de Socorros Mutuos, la Sociedad de Cuartetos y la Sociedad de Conciertos de Madrid, creadas respectivamente en 1860, 1863 y 1866 o la Sociedad de Conciertos de Valencia $(1878)^{290}$.

Como en aquellas sociedades, el repertorio de los conciertos de la sociedad Santa Cecilia no se nutrió en exclusiva de fragmentos de ópera, fantasías operísticas o pequeñas piezas de salón, habituales en otras sociedades recreativas del momento, sino que también incluyó grandes obras de compositores nacidos en el siglo XIX, así como un grupo reducido de autores del Clasicismo, como Boccherini, Haydn y Mozart (ver Tabla 6.5). Los programas de los conciertos siguieron una estructuración tripartita a semejanza de los programados por la Sociedad de Cuartetos de Madrid ${ }^{291}$.

Tabla 6. 5. Repertorio interpretado en los conciertos de la sociedad Santa Cecilia (1882-1883).

Fuentes: Ver Apéndice 6.11.

Se indica mediante $*$ las obras que fueron interpretadas en dos ocasiones.

\begin{tabular}{|c|c|}
\hline Compositor & Títulos de las obras ${ }^{292}$ \\
\hline Alard, Jean- Delphin & $\begin{array}{l}\text { "Fantasía para violín y piano sobre motivos de la } \\
\text { ópera Guillermo Tell" }\end{array}$ \\
\hline Arditi, Luigi & Gavota \\
\hline Bazzini, Antonio & $\begin{array}{l}\text { "Fantasía para violín y piano sobre motivos de la } \\
\text { ópera Anna Bolena" }\end{array}$ \\
\hline \multirow[t]{4}{*}{ Beethoven, Ludwig van } & Gran Séptuor, op. 20 \\
\hline & $\begin{array}{l}\text { Grave y Allegro ma non troppo del Quinteto, op. } \\
16\end{array}$ \\
\hline & Sinfonía en Do Mayor, op. 21, no. 1 \\
\hline & $\begin{array}{l}\text { Andante de la Sonata } n^{\circ} 15 \text { "para instrumentos de } \\
\text { cuerda y piano" }\end{array}$ \\
\hline Bériot, Charles- Auguste de & Fantasía para violín y piano \\
\hline Boccherini, Luigi & Minuetto del Quinteto, $\mathrm{n}^{\circ} 11^{*}$ \\
\hline Cossoul, Guilherme António & $\begin{array}{l}\text { Variaciones para violín con acompañamiento de } \\
\text { piano }\end{array}$ \\
\hline
\end{tabular}

290 Sobre estas sociedades, véase: García, "La Sociedad de Cuartetos", pp. 149-193; Sobrino, "La Sociedad de Conciertos”, pp. 125-148 y Sancho, Romanticismo, pp. 45-86.

${ }^{291}$ García, "La Sociedad de Cuartetos”, p. 164.

${ }^{292}$ Presento los títulos, géneros y números de actos y movimientos de las obras tal y como aparecen en las fuentes periodísticas. 


\begin{tabular}{|c|c|}
\hline Chapí, Ruperto, & Serenata morisca* \\
\hline Espinosa, Gaspar & Ondalina, polca de concierto \\
\hline Flege, & Gavota en La Mayor \\
\hline Flotow, Friedrich & Sinfonía de la ópera Martha \\
\hline Gariboldi, G. & Melodía apassionatta (op. 46) \\
\hline Gounod, Charles- François & Serenata \\
\hline Gounod & Danza de las bacantes \\
\hline Hascher, J. & $\begin{array}{l}\text { "Fantasía de concierto sobre motivos de la ópera } \\
\text { Lucrecia Borgia" }\end{array}$ \\
\hline \multirow[t]{2}{*}{ Haydn, Franz Joseph } & $\begin{array}{l}\text { Las siete palabras de Cristo en la Cruz "para } \\
\text { instrumentos de cuerda y piano" }\end{array}$ \\
\hline & $\begin{array}{l}\text { Quinteto en Re Mayor "para instrumentos de } \\
\text { cuerda, flauta y piano" }\end{array}$ \\
\hline Hetterer, & $\begin{array}{l}\text { "Fantasía brillante para piano sobre motivos de la } \\
\text { ópera Martha" }\end{array}$ \\
\hline \multirow[t]{2}{*}{ Marqués, Pedro Miguel } & La Heroica, cuarta marcha de concierto \\
\hline & $\begin{array}{c}\text { Primera lágrima, melodía de concierto para } \\
\text { orquesta* }\end{array}$ \\
\hline Mazas, Jacques-Féréol & Dúo de violines \\
\hline \multirow[t]{2}{*}{ Mendelssohn, Felix } & Obertura del Rey Blas [Ruy Blas] \\
\hline & Andante del Gran Octuor, op. 20 \\
\hline Mozart, Wolfgang Amadeus & Cuarteto en Mi b, (¿op. 74?)* \\
\hline Nicolai, Otto & $\begin{array}{l}\text { Obertura de Les joyeusses commeres de Windsor } \\
\text { [Die lustigen Weiber von Windsor] }\end{array}$ \\
\hline Pastor, M. J. & $\begin{array}{l}\text { A Selgas. Marcha triunfal escrita en honor a socio } \\
\text { Selgas }\end{array}$ \\
\hline Rossini, Gioachino & Sinfonía de la ópera Guillermo Tell \\
\hline Schubert, Fran & Ave María \\
\hline Strauss, Johann & $\begin{array}{c}\text { Vals Le trémolo. La Sante Cecile (op. 120) } \\
\text { [Cäcilien-W mit dem beliebten Tremolo] }\end{array}$ \\
\hline Suppé, Franz von & Obertura de Paragraph III \\
\hline Thomas, Ambroise & $\begin{array}{l}\text { Obertura El sueño de una noche de verano [Le } \\
\text { songe d'une nuit d'été] }\end{array}$ \\
\hline Tintorer, Pedro & Un souvenir \\
\hline Tosti, Paolo & Melodía \\
\hline \multirow[t]{2}{*}{ Verdi, Giuseppe } & "Romanza de tenor de Aida" \\
\hline & Sinfonía de Giovanna d'Arco \\
\hline \multirow[t]{6}{*}{ Verdú, Fernando } & Quinteto \\
\hline & Barcarola \\
\hline & Vals Prima Vellatta \\
\hline & Gavota Aixaráh \\
\hline & Polca de Constant arreglada para madera y cuerda \\
\hline & Tanda de valses* \\
\hline Weber, Carl Maria von & Trio (op. 63) para violín, violonchelo y piano \\
\hline \multirow[t]{3}{*}{ No consta autor } & El arpa de oro, pieza para piano \\
\hline & Fantasía sobre motivos de la ópera Rigoletto* \\
\hline & Tige Brisée, revérie \\
\hline
\end{tabular}

Tal y como se aprecia en la Tabla 6.5, los conciertos de la sociedad Santa Cecilia incluyeron obras sinfónicas, de cámara y de salón, y de compositores tanto locales, como españoles y extranjeros. Algunas obras interpretadas, como el Cuarteto en Mi bemol, op. 74 de Mozart o Las siete palabras de Haydn también fueron escuchadas en los salones de la Sociedad de Cuartetos de Madrid ${ }^{293}$. Las obras interpretadas en los conciertos de la

${ }^{293}$ García, "La Sociedad de Cuartetos”, pp. 168-169. 
sociedad Santa Cecilia (o al menos algunas) se arreglaban a priori para las formaciones instrumentales disponibles y, a juzgar por los datos hallados, estas adaptaciones eran efectuadas por los mismos músicos de la sociedad. En el concierto por la festividad de Santa Cecilia del año 1883, por ejemplo, los arreglos fueron efectuados por el músico Vicente Espada, discípulo del maestro de capilla de la Catedral Mariano García:

[...] Como conclusión de esta revista, diremos que el joven don Vicente Espada dio a conocer en el concierto sus felices disposiciones y la doctrina de su maestro don Mariano García, pues además de acompañar al piano al señor Blaya de una manera magistral, había instrumentado concienzudamente el Paragraph tercero de Suppé, la "Cuarta Marcha" de Marques y la Danza de las Bacantes de Gounod ${ }^{294}$.

La labor de difusión del repertorio clásico en Murcia desempeñada por la Santa Cecilia (aunque dirigido a un público minoritario en comparación con los de la ópera y la zarzuela) fue ensalzado continuamente por la prensa, como se expresa en las siguientes líneas:

No nos cansamos de felicitar a esta sociedad que está ofreciendo el raro caso en nuestra localidad de ser la única que ha llegado a alcanzar dos años de vida, sin desmayo de sus socios, y presentando siempre motivos de utilidad y recreo a la población, al contrario de los literatos que, con su afán de crear sociedades y dar veladas y reuniones, apenas pueden mostrar vida unas cuantas semanas a pesar de tener sobrados elementos para ofrecer un centro de instrucción y recreo análogo al de "Santa Cecilia"295.

\subsection{La Sociedad Santa Cecilia, arrendataria del teatro Romea (1884-1887)}

La sociedad Santa Cecilia sin ánimo de lucro asumió, sin embargo, el arrendamiento del Teatro Romea en abril de 1884 (ver Capítulo 2). La nueva sociedad arrendataria, nacida en el seno de Santa Cecilia, marcó el rumbo de la asociación durante los años siguientes. El lado positivo fue el control, por parte de músicos entendidos, de la programación del teatro más importante de la ciudad y probablemente la iniciativa de crear una orquesta estable para el Teatro Romea, hecho que terminó siendo realidad en mayo de 1884 (ver Capítulo 2). Fue negativo, en cambio, que decrecieron los conciertos o exhibiciones musicales por parte de los alumnos de la sociedad Santa Cecilia.

Para festejar la nueva empresa del Romea y la recién creada orquesta del Teatro Romea se celebró el 6 de julio de 1884 un concierto en el que participaron la banda de música de Ángel Mirete, la citada orquesta del Romea y algunos músicos de la sociedad Santa Cecilia (ver Capítulo 5) ${ }^{296}$.

${ }^{294}$ La Paz de Murcia, XXVI (1883), no 7779, 24 noviembre, p. 1.

${ }^{295}$ La Paz de Murcia, XXVI (1883), nº 7668, 5 julio, p. 1.

${ }^{296}$ La Paz de Murcia, XXVII (1884), no 7961, 4 julio, p. 1. El programa se publicó en El Diario de Murcia, VI (1884), n 1619, 5 julio, p. 1 y las crónicas en La Paz de Murcia, XXVII (1884), nº 7964, 7 julio, p. 1; El Diario de Murcia, VI (1884), no 1621, 8 julio, p. 1 y La Paz de Murcia, XXVII (1884), $\mathrm{n}^{\circ}$ 7968,12 julio, p. 1. 
En enero de 1885, la sociedad dio una velada en la que se interpretó un quinteto de Verdú, premiado en los Juegos Florales de 1878 "y otros trozos de obras clásicas"297.

Son numerosos los testimonios de colaboraciones de éstos en representaciones teatrales a beneficio de algún músico, generalmente de la compañía contratada, u otras funciones extraordinarias con músicos que se hallaban de paso por la ciudad ${ }^{298}$.

En 1886 se había producido ya la escisión entre la sociedad Santa Cecilia arrendataria del Romea y la Santa Cecilia "artística":

[...] El estado de la sociedad, financieramente hablando, atendida la reducción de los gastos, no es desesperado, pues su deuda de lo corriente es muy corta y la del empréstito está casi garantizada con el valor del mobiliario. Sin embargo, lo exiguo a que ha quedado reducido el número de socios y el no ser posible cumplir hoy el objeto que tuvo la sociedad, hizo surgiera el pensamiento de disolverla [...].

Santa Cecilia vivía con un buen número de socios, daba sus conciertos y tenía sus clases. Surgió la idea de adquirir el teatro y no faltó quien hiciera proposiciones para ceder después sus derechos a la sociedad. Consiguióse y de la sociedad Santa Cecilia nació la Santa Cecilia arrendataria de Romea, puesto que a las obligaciones que creaba la adquisición del teatro no se podía obligar a todos -pero sí se obliga a que no pudiesen ser socios de esa hijuela los que no lo fueran de la sociedad madre: así sucedió al principio. Luego, ocurrió lo que ocurrió en la hijuela y hoy resulta que ésta, sin ninguna cesión, sin saber cómo, se ha emancipado y los socios de la sociedad arrendataria no lo son de la sociedad artística, ni éstos saben nada de cuentas ni nada de aquélla. Por eso decimos que con Santa Cecilia se ha cometido un parricidio, pues la hija ha sido causa de la separación de muchos socios que no han encontrado en la madre lo que deseaban y después de causar ese daño, con su emancipación ilegal, la han dejado sin ingresos ${ }^{299}$.

La diversificación de intereses entre los socios y la concentración de la actividad en los acontecimientos de la vida teatral del Romea provocaron la escisión en dos $\operatorname{organismos}^{300}$. La parte "artística" de Santa Cecilia había dejado de organizar conciertos y dar clases de música. En enero de 1887, la prensa vaticinaba la desaparición de ambas:

Si hoy muere la sociedad filarmónica Santa Cecilia nos quedará de ella el buen recuerdo de unos excelentes conciertos que dio en su salón de la casa de la calles de las Balsas, y del último que tuvo lugar en el teatro al posesionarse de él como arrendataria del mismo y dejarán saldadas sus cuentas con todos, como era deseo de todos sus socios.

${ }^{297}$ El Diario de Murcia, VII (1885), nº 1091, 31 enero, p. 2.

${ }^{298}$ Por ejemplo, la función a beneficio del director de compañía Casimiro Espino en el concierto de Mariano Padilla, ambos celebrados en enero de 1885. Ver: La Paz de Murcia, XXVIII (1885), $\mathrm{n}^{\circ} 8134,31$ enero, p. 1; 8142, 10 febrero, p. 1; 8156, 26 febrero, p. 1 y 8157, 27 febrero, p. 1. En abril de 1885, la sociedad Santa Cecilia arrendadora del Romea eligió como presidente a Ceferino Icabalceta: La Paz de Murcia, XXVIII (1885), nº 8185, 1 abril, p. 1.

${ }^{299}$ La Paz de Murcia, XXIX (1886), nº 9024, 22 septiembre, p. 1.

${ }^{300}$ Hasta tal punto de que se anunciaba en la prensa: "Sociedad Artística Santa Cecilia, en la calle Algezares, 4": La Paz de Murcia, XXIX (1886), n 9053, 27 noviembre, p. 1. Desconozco cuándo se produjo el cambio de domicilio de la sociedad o si contaron con dos locales (uno de la Academia y otro para la arrendataria). 
También quedará como recuerdo en la hija la sociedad arrendataria Santa Cecilia que, aunque parece muerta vive, pues si no se reúne para nada, se espera lo haga al darle cuenta los que la dirigen, de la gestión administrativa de los tres años de arrendamiento para saber si han acrecentado el capital impuesto o, al menos, lo que es natural si pueden retirarlo sin pérdidas, que no es mucho aspirar ${ }^{301}$.

La sociedad Santa Cecilia, tanto la parte artística como la arrendataria del Romea, se disolvió a mediados de noviembre de $1887^{302}$.

\subsection{La sociedad y la festividad de Santa Cecilia}

La festividad de Santa Cecilia, patrona de los músicos, tenía una larga tradición en Murcia. Desde el siglo XVIII, se celebraban diversos actos de carácter cívico-religioso en los que participaba regularmente la Capilla de Música del convento de las Madres Agustinas Descalzas de Murcia ${ }^{303}$ :

[...] Hace muchos años (según tenemos entendido por 1783) la capilla de profesores músicos viene dando culto, sin interrupción, hasta hoy, a su esclarecida patrona Santa Cecilia. Unas veces ha sido con gran ostentación y otras con la mayor humildad, pero siempre con devoción y constancia ${ }^{304}$.

En 1783, la Capilla de músicos de las Agustinas encargó al escultor Roque López una imagen de Santa Cecilia para el citado convento y desde entonces la festividad de Santa Cecilia quedó vinculada a dicha comunidad. Hasta la década de los ochenta del siglo XIX la festividad fue ocasionalmente anunciada en las secciones religiosas de los periódicos sin mencionar el detalle de los actos. Posteriormente, la prensa murciana refleja un importante ornato y relevancia en la celebración, quizás a causa de las numerosas sociedades y academias musicales que se involucraron en ella: sociedad Santa Cecilia, El Liceo, La Juventud y la Escuela de Canto y Declamación. La sociedad Santa Cecilia, fundada en 1881, se implicó desde su nacimiento en la organización de esta fiesta, como hemos visto anteriormente. La Tabla 6.6 muestra un resumen de los eventos celebrados por la festividad de Santa Cecilia en los años 1880-1884, 1886, 1889 y $1891^{305}$.

${ }^{301}$ La Paz de Murcia, XXX (1887), no 8100, 23 enero, p. 1.

${ }^{302}$ La Paz de Murcia, XXIX (1886), $\mathrm{n}^{\circ}$ 9055, 30 noviembre, p. 1. En este momento, quedaban inscritos en la sociedad diez y ocho socios. Ver, El Diario de Murcia, IX (1887), $\mathrm{n}^{\text {os }} 2907,25$ enero, p. 3; 3146, 6 noviembre, p. 3 y 3158, 20 noviembre, p. 1.

${ }^{303}$ La capilla de música de este convento ha sido estudiada por Pina, La música civil, pp. 316-330. La autora recoge los datos publicados por el historiador murciano Ramón Blanco, que apunta como fecha de fundación de la Capilla de Música del convento de Madres Agustinas el 15 de marzo de 1768. Según estos datos, el primer maestro de capilla fue el violinista catalán Jaime Prats quien, el 23 de agosto de 1768 reunió en su casa a los músicos José Jover, Nicolás Marín, Manuel Lispao, Ambrosio Ponce, Tadeo Tornel, Esteban Hidalgo, Cesáreo López, Francisco Ceferino García, Isidro Napar, Francisco Cándido, Jerónimo Guirado y Miguel Mondique con el propósito de aprobar las disposiciones de la capilla. Véase: Pina Caballero, La música, pp. 321-322.

\footnotetext{
${ }^{304}$ La Paz de Murcia, XXV (1882), no 7433, 24 noviembre, p. 1.

${ }^{305}$ No he hallado datos en la prensa de los años 1885, 1887-1888 y 1890.
} 
Tabla 6. 6 Eventos celebrados por la festividad de Santa Cecilia en los años 1880-1884, 1886, 1889 y 1891.

Fuentes: ver Apéndice 6.12.

\begin{tabular}{|c|c|c|}
\hline Año & $\begin{array}{l}\text { Eventos celebrados el día anterior a } \\
\text { Santa Cecilia ( } 21 \text { de noviembre) }\end{array}$ & $\begin{array}{c}\text { Eventos celebrados el día de Santa } \\
\text { Cecilia } \\
\text { (22 de noviembre) }\end{array}$ \\
\hline 1880 & - & Misa \\
\hline 1881 & - & $\begin{array}{l}\text { Dos misas: una en el Convento de las } \\
\text { Agustinas y otra cantada por los } \\
\text { niños de la Casa de Beneficencia en } \\
\text { un lugar no especificado } \\
\text { Concierto en la sociedad Santa Cecilia }\end{array}$ \\
\hline 1882 & $\begin{array}{l}\text { Pasacalles de la Banda Municipal por las } \\
\text { calles de la ciudad (desde sociedad } \\
\text { Santa Cecilia hasta convento } \\
\text { agustino) } \\
\text { Serenata en la puerta del convento de las } \\
\text { Agustinas por los músicos de la } \\
\text { sociedad Santa Cecilia } \\
\text { Repique de campanas en San Andrés } \\
\text { Iluminación y colgaduras en los balcones } \\
\text { de la sociedad Santa Cecilia } \\
\text { Fuegos artificiales }\end{array}$ & $\begin{array}{l}\text { Misa en el convento en el templo de las } \\
\text { Agustinas } \\
\text { (colgaduras e iluminación del altar mayor } \\
\text { con velas "de cera gruesa") } \\
\text { Concierto en el salón de la sociedad } \mathrm{El} \\
\text { Liceo }\end{array}$ \\
\hline 1883 & $\begin{array}{l}\text { Pasacalles de la Banda Municipal desde } \\
\text { las Academia Santa Cecilia hasta el } \\
\text { convento agustino } \\
\text { Serenata en la puerta del convento }\end{array}$ & $\begin{array}{l}\text { Misa solemne } \\
\text { Concierto en la sociedad Santa Cecilia }\end{array}$ \\
\hline 1884 & - & $\begin{array}{l}\text { Misa solemne en el convento agustino } \\
\text { Función extraordinaria en el teatro Romea }\end{array}$ \\
\hline 1886 & - & $\begin{array}{l}\text { Misa solemne en las Agustinas } \\
\text { Serenata de la banda de la Casa de } \\
\text { Misericordia en el convento }\end{array}$ \\
\hline 1889 & - & $\begin{array}{l}\text { Misa solemne en las Agustinas } \\
\text { Orquesta de Julián Calvo }\end{array}$ \\
\hline 1891 & - & $\begin{array}{l}\text { Misa solemne en el convento agustino } \\
\text { Pasacalles de la Banda Municipal }\end{array}$ \\
\hline
\end{tabular}

El acto más importante de la festividad de Santa Cecilia era la celebración de una misa, por la mañana, en el convento de las Agustinas. El Apéndice 6.12 muestra el repertorio musical interpretado en estas funciones entre 1880 y 1891 . Generalmente, la Liturgia comenzaba y terminaba con una sinfonía, a menudo de alguna ópera o zarzuela conocida $^{306}$ y los demás números musicales de la misa fueron en gran número de compositores locales. En el Ofertorio y la Consagración se interpretaban, en ocasiones, piezas como un Ave María, una Melodía, una sinfonía, un motete, un himno o la "Marcha Real" (esta última para la Elevación). En estas funciones participaron diversas formaciones instrumentales murcianas, como la Capilla de Música de las Agustinas, orquestas teatrales y bandas de música (la de Misericordia y, en especial, la Municipal) y,

${ }^{306}$ En 1880, la sinfonía elegida para iniciar la Misa fue una compuesta por el murciano Fernando Verdú, premiada en los Juegos Florales de Murcia en 1879. Otras sinfonías interpretadas fueron: Sinfonía de El sueño de una noche de verano de Mendelssohn (en 1881) y Sinfonía de Juana de Arco de Verdi (en 1883). 
en menor medida, colaboraron cantantes y músicos de las compañías teatrales que actuaban en ese momento en Murcia ${ }^{307}$.

El concierto de la noche previa a Santa Cecilia era otro evento fundamental (en algunos casos, incluso, una función teatral extraordinaria ${ }^{308}$ ), en el que se escucharon "obras clásicas" 309 y, al menos en una ocasión, orquestas y bandas de los alumnos de academias y sociedades locales.

La festividad más solemne que he documentado es la del año 1882, cuyos festejos se prolongaron durante dos días. A los músicos de la Capilla de las Madres Agustinas se unieron en esa ocasión otras instituciones musicales de la ciudad: la banda municipal de Ángel Mirete y los músicos de la sociedad Santa Cecilia ${ }^{310}$.

La fiesta comenzó el día anterior ( 21 de noviembre) con repique de campanas en San Andrés, ornato de balcones con colgaduras e iluminación de la sede de la sociedad Santa Cecilia. A las siete de la tarde, la banda municipal inició desde ese punto un pasacalles que recorrió las calles principales de la ciudad con fuegos artificiales. El trayecto finalizó en el convento de las Agustinas, donde "trataron de tocar algunas piezas a papeles, lo que no se pudo conseguir por el viento norte que hacía tan fuerte y frío" 311 . A las nueve de la noche, la banda inició un nuevo pasacalles en el que se interpretaron pasodobles hasta el punto inicial (la sociedad Santa Cecilia) ${ }^{312}$.

Al día siguiente ( 22 de noviembre) la celebración comenzó a las diez de la mañana con una función religiosa en las Agustinas. Las naves de la iglesia se engalanaron con colgaduras de terciopelo y raso carmesí. El retablo mayor se iluminó con multitud de velas y se dispuso la imagen de Santa Cecilia "al lado del Evangelio, a la parte de fuera del presbiterio, por no caber en este sitio"313.

La ceremonia fue oficiada por los sacerdotes Simón Espín, José Juvés e Ildefonso Barberán, todos miembros de la sociedad Santa Cecilia, como también lo era Julián López Clares, ecónomo de Molina de Segura, que se encargó del panegírico a la Santa. La parte musical fue dirigida por el maestro de capilla de las Madres Agustinas, Ángel Mirete. Una numerosa orquesta y un "gran coro" interpretaron una Misa de Mercadante, dos sinfonías al comienzo y al final del culto, un capricho del compositor catalán Rodó en el ofertorio y un motete de Hilarión Eslava durante la Consagración ${ }^{314}$.

${ }^{307}$ En 1881 participaron algunos músicos de la compañía de zarzuela de Banquells, entre ellos, el mismo Banquells (bajo), Arcos (barítono) y Rex (maestro concertador).

${ }^{308}$ El Diario de Murcia, VI (1884), nº 1732, 22 abril, p. 3.

${ }^{309}$ La Paz de Murcia, XXVI (1883), no 7775, 20 noviembre, p. 1.

${ }^{310}$ La crónica el evento, anónima, se publicó con estilo epistolar y a petición del director del periódico La Paz de Murcia, Rafael Almázan en La Paz de Murcia, XXV (1882), nº 7433, 24 noviembre, p. 1.

${ }^{311}$ La Paz de Murcia, XXV (1882), no 7433, 24 noviembre, p. 1.

${ }^{312}$ Una de las piezas interpretadas fue el pasodoble Sansón, compuesto por "un niño hospiciano" y estrenado ese día: La Paz de Murcia, XXV (1882), nº 7433, 24 noviembre, p. 1.

${ }^{313}$ La Paz de Murcia, XXV (1882), no 7433, 24 noviembre, p. 1.

314 “cuyo principal pensamiento es el enlace del Tantum Ergo con la marcha nacional española": La Paz de Murcia, XXV (1882), n 7433, 24 noviembre, p. 1. 
Por la tarde, la Banda Municipal (dirigida por Ángel Mirete), la orquesta de la sociedad Santa Cecilia y otros músicos ofrecieron un concierto en los salones de la sociedad El Liceo, con obras de Beethoven, Mendelssohn, Weber, Strauss, Marqués, y Nicolai, ente otros ${ }^{315}$. La prensa resaltó que en poco más de tres meses de estudio estos alumnos habían conseguido interpretar, junto a sus compañeros, la "Obertura Ruy Blas de Mendelssohn "sin simplificar una nota", lo que revela que otras veces se tocaban adaptaciones facilitadas de las obras ${ }^{316}$.

La fiesta de Santa Cecilia de 1883 parece haber sido menos llamativa ${ }^{317}$. En el tradicional concierto, la prensa destacó que el programa era muy interesante por la interpretación de música alemana, italiana, francesa y española (ver Apéndice 6.11) y defendió abiertamente la labor de la sociedad Santa Cecilia frente a sus detractores:

\begin{abstract}
Cada vez que la sociedad "Santa Cecilia" celebra un nuevo concierto musical nos hace ver sus adelantos, hijos del trabajo y de la constancia que vienen a dar un mentis a los que se afanan en propagar la especie de que no existe cordialidad y estímulo entre los amantes de la armonía. [...] Sirva esto sólo de lección a otra clase de artistas que censuran las disidencias personales de ciertos músicos y que en cambio, ni forman una asociación como debiera, ni cuando logran reunirse saben salir de lecturas triviales, buscando solo un pasatiempo sin objeto determinado $[\ldots]^{318}$.
\end{abstract}

Dado que la sociedad Santa Cecilia asumió el arrendamiento del Teatro Romea en 1884, la festividad de la patrona de ese año comenzó la noche previa con una función de abono con la compañía del violinista y compositor Casimiro Espino y la orquesta del teatro (ver Capítulo 2) ${ }^{319}$. El día de Santa Cecilia se celebró la tradicional misa en la Capilla de las Agustinas con la banda de niños hospicianos de la Casa de la Misericordia $^{320}$. Los festejos por Santa Cecilia dejaron de celebrarse a finales del siglo XIX y fueron recuperados por Adolfo Gascón en $1905^{321}$.

${ }^{315}$ La Paz de Murcia, XXV (1882), no 7434, 25 noviembre, pp. 1,4. Véase el programa en el Apéndice 6.11. En el concierto debutaron dos nuevos contrabajistas discípulos de Jover.

${ }^{316}$ Véase, La Paz de Murcia, XXV (1882), no 7434, 25 noviembre, pp. 1, 4.

${ }^{317}$ El programa de eventos apareció en La Paz de Murcia, XXVI (1883), no 7775, 20 noviembre, p. 1. La banda ejecutó en la puerta del convento, tras el habitual pasacalles, la Tercera Marcha de las Antorchas y la Batalla de Inkerman. La misa se anunció en la sección religiosa del periódico La Paz de Murcia, XXVI (1883), $\mathrm{n}^{\mathrm{o}} 7775,20$ noviembre, p. 4. En ella, se estrenó una misa de Ángel Mirete y se interpretó la sinfonía de Juana de Arco. Por la noche, se ofreció un concierto en los salones de la sociedad cuyo programa puede consultarse en el Apéndice 6.11.

${ }^{318}$ La Paz de Murcia, XXVI (1883), no 7779, 24 noviembre, p. 1.

${ }^{319}$ Véase el Apéndice 6.12. La función constó de tres partes. En la primera se representó El loco de la guardilla. En la segunda se ofreció un concierto y en la tercera se estrenó la zarzuela en un acto de Casimiro Espino, Clínica: La Paz de Murcia, XXVII (1884), nº 8075, 21 noviembre, p. 1. El violinista madrileño Casimiro Espino (1845-1888) fue alumno de Arrieta, colaboró en la Sociedad de Conciertos de Madrid y dirigió la Unión Artístico Musical, después de Bretón, Chapí y Caballero, según Gómez Amat, Historia, p. 181.

${ }^{320}$ La misa, ofrecida en sufragio de los músicos fallecidos Felipe Agüera y José Rueda, fue oficiada por el presbítero José Jubés Palacios, coadjutor de la parroquia de San Miguel: La Paz de Murcia, XXVII (1884), $\mathrm{n}^{\mathrm{o}} 8075,21$ noviembre, p. 1.

321 Desconozco el año en que dejaron de celebrarse. La recuperación de esta festividad aparece descrita en José Martínez Tornel, El Liberal, IV (1905), nº 1209, 23 noviembre, p. 1. 


\section{Escuela de Canto y Declamación para la carrera artística teatral italiana y española (1881-1892)}

\subsection{Fundación y primer año de existencia de la Escuela de Canto (1881)}

La Escuela de Canto y Declamación para la carrera artística teatral italiana y española fue inaugurada el 1 de febrero de 1881 por el tenor murciano y maestro de canto Francisco de Lucas y Rodríguez (1834-1892) y su esposa, la contralto Juana Bonafí ${ }^{322}$, "artistas de valía en la carrera melodramática italiana reconocidos en los principales teatros del mundo" ${ }^{323}$. El proyecto se había planteado ya en diciembre del año anterior en la Sociedad Económica de Amigos del País de Murcia, que acordó su estudio y viabilidad $^{324}$. Finalmente, la escuela salió adelante "sin otra cooperación hasta ahora que sepamos, que la moral de los que siempre están dispuestos con sus conocimientos y su buena voluntad a la realización de lo bueno y lo verdaderamente útil, pero con la falta de apoyo de las corporaciones que pueden y deben prestarlo"325.

La escuela se proponía educar musicalmente a jóvenes con talento para la lírica escénica. La apertura de la Escuela de Canto de Murcia coincidió (apenas por unas horas de diferencia) con la inauguración del curso académico del Conservatorio de Música de Valencia $^{326}$, con cuyos medios fue comparada la escuela murciana ${ }^{327}$. La Escuela de Canto y Declamación ofertó también clases de primeras letras (lectura y escritura), ejerció como agencia teatral (única en la ciudad de Murcia durante la segunda mitad del siglo XIX) y ofertó a sus alumnos becas de estudio (completas y parciales) ${ }^{328}$. La Escuela

${ }^{322}$ La Paz de Murcia, XXIV (1881), no 6965, 30 enero, p. 1 y El Diario de Murcia, III (1881), n 590, 1 febrero, p. 3. En un documento periodístico posterior se indica, en cambio, la fecha de inauguración de la Escuela de Canto en el día 10 de febrero de 1879: El Diario de Murcia, VI (1884), nº 1523, 8 marzo, p. 2.

${ }^{323}$ El Semanario Murciano, IV (1881), n 160, 6 marzo, p. 80. La prensa menciona actuaciones de estos cantantes en teatros de Venecia, Milán, París, Londres y Berlín, entre otros lugares. También actuaron en América: El Diario de Murcia, XIV (1892), nº 4555, 7 febrero, p. 1. En la documentación manejada se utilizan indistintamente los nombres de Francisco Lucas y Francisco de Lucas. En adelante, utilizaré el primero. En La Paz de Murcia, XXX (1887), nº 9264, 31 julio, p. 1 se encuentra una detallada descripción del aspecto físico del cantante.

${ }^{324}$ El Diario de Murcia, II (1880), nº 565, 24 diciembre, p. 3.

${ }^{325}$ El Semanario Murciano, IV (1881), nº 156, 6 febrero, p. 47.

${ }^{326}$ Sobre el conservatorio valenciano véase, Fontestad, El conservatorio.

327 Por este motivo, El Diario de Murcia reflexionó sobre las carencias en medios y estímulos necesarios para crear una institución de estas características en Murcia. El periodista se lamentaba de que la escuela de canto murciana fuese solo "un pálido reflejo del establecimiento valenciano" y por ello sentía pena y "cierta complacencia": "Pena, porque las cosas buenas no toman [en Murcia] el vuelo que debían aún dentro de sus límites modestos, por consecuencia de nuestro carácter y dejadez. Complacencia, porque vemos con gusto lo que hace una voluntad como la del señor Lucas". Ver, "Coincidencia". En: El Diario de Murcia, III (1881), n 606, 25 febrero, pp. 1-2, "La educación y el arte" publicado por El Diario de Murcia, III (1881), no 659, 30 abril, p. 1 y El Diario de Murcia, IV (1882), n 953, 20 abril, p. 1.

${ }^{328}$ Francisco Lucas escogía a alumnos pobres con aptitudes artísticas y los mantenía económicamente durante el periodo de sus estudios. A veces, incluso, el director se encargaba de pensionar a familias enteras, como fue el caso de la viuda Nicolasa Caballero y sus siete hijos. Uno de ellos, José Ribera, recibió manutención completa de la Escuela de Canto: La Paz de Murcia, XXIV (1881), nº 6993, 5 marzo, p. 1. Desconozco de dónde procedían los ingresos para la manutención de estos alumnos y el modo de financiación de la Escuela de Canto y Declamación. Me consta, sin embargo, que Francisco Lucas trató 
de Canto ayudó a mujeres trabajadoras estudiantes de canto, mediante "contratos de obligación": la escuela se comprometía a pagar una parte de su jornal mientras duraba su aprendizaje y una vez contratadas por alguna empresa teatral, ellas habían de devolver parte de la ayuda recibida (ver Figura 6.13) ${ }^{329}$. Lucas llegó a educar y mantener económicamente a diez y ocho alumnos, simultáneamente ${ }^{330}$.

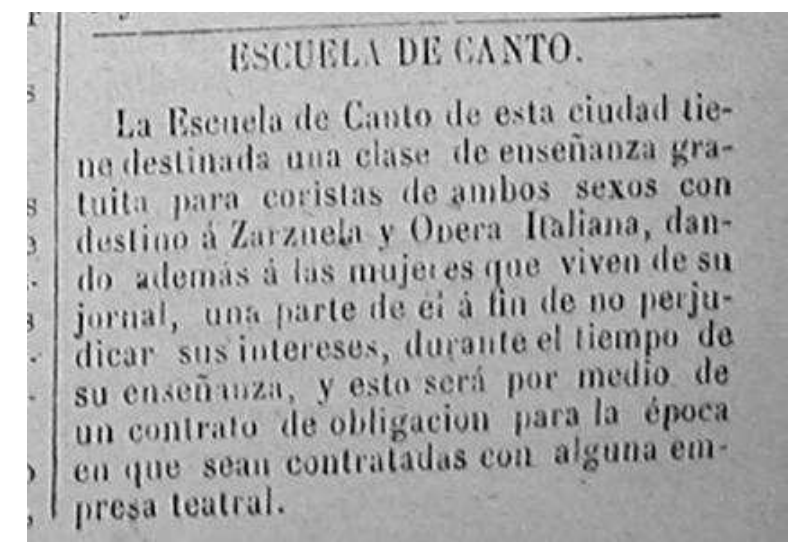

Figura 6. 13. Anuncio de la Escuela de Canto y Declamación para la carrera artística italiana y española (1881). El Diario de Murcia, III (1881), no 712, 3 julio, p. 3, E: MUm.

Durante sus seis primeros meses de existencia, la Escuela de Canto contó con un local espacioso en el centro comercial de la ciudad, con varias aulas, oficinas y otros espacios destinados a archivo y copistería. Algunas de estas dependencias se habilitaron como escenarios para uso teatral, aunque no disponían de un teatro propio. Probablemente por este motivo, en agosto de 1881 Lucas quiso alquilar el bien acondicionado teatro de la sociedad El Liceo ${ }^{331}$. La Escuela de Canto y Declamación disponía de tres pianos y "un armónium de gran costo por sus inmejorables condiciones vocales"332.

Los profesores de la Escuela de Canto fueron, además de Lucas y Bonafí ("Clases de canto"), Juan Diego Manresa ("Piano"), Ayala, Ramírez, Solano ("Obras teatrales"), Díaz ("Instrumentos de banda") y Murcia Dalmau ("Francés") 333 . Además de los docentes, la entidad contó con una "dama de compañía y directriz de las discípulas",334.

continuamente de buscar apoyo económico de las instituciones de Murcia. Véase, La Paz de Murcia, XXIV (1881), $\mathrm{n}^{\mathrm{o}} 7076,1$ julio, p. 1 .

${ }^{329}$ El Diario de Murcia, III (1881), no 712,3 julio, p. 3.

${ }^{330}$ El Diario de Murcia, VI (1884), nº 1744, 6 diciembre, p. 2.

${ }^{331}$ La Paz de Murcia, XXIV (1881), no 7119, 20 agosto, p. 1.

${ }^{332}$ El Semanario Murciano, IV (1881), nº 160, 6 marzo, p. 80. El periodista menciona los numerosos recuerdos y galardones que colgaban de las paredes, acumulados por los directores a lo largo de sus carreras artísticas. La Escuela de Canto estaba situada en la calle de San Cristóbal, número 8, cercana a la parroquia de San Lorenzo. Actualmente, es la calle que une Trapería y Pinares y es más conocida con el nombre de "las cuatro esquinas". Ortega Pagán et al., Callejero, pp. 340-343.

${ }^{333}$ Profesorado correspondiente al curso 1881-1882. Se menciona también al presbítero Jubés, aunque no se especifica qué materia impartiría: La Paz de Murcia, XXIV (1881), n 7143, 17 septiembre, p. 1. También estudiaban "Italiano", probablemente a cago de Lucas: El Diario de Murcia, III (1881), n 690, 7 junio, p. 3.

${ }^{334}$ Los alumnos tenían que ser mayores de veinte años y "saber leer, escribir y contar". Podían recibir un sueldo fijo mientras estudiaban o bien, la manutención y educación musical de la escuela. El Diario de Murcia, III (1881), nº 690, 7 junio, p. 3. 
Durante los cinco primeros años de su existencia, la academia formó a más de cien artistas de Murcia, Valencia, Madrid, Barcelona y País Vasco (entre otros lugares), que trabajaron posteriormente en la escena española y extranjera. Enrique Sala, por ejemplo, figuró entre los cantantes de la Ópera de París. Otros alumnos formados en la Escuela fueron Delfina Baglietto (soprano), Antonio Noguera (bajo), Juan Martínez (bajo), Rafael Pastor, Francisco Rizo y Rigoberto Rovira (bajo) ${ }^{335}$.

Al margen de las tareas docentes, la Escuela organizaba conciertos en los que intervenían profesores y alumnos. La primera exhibición pública tuvo lugar probablemente el 19 de de febrero de 1881 en el Teatro Romea, dentro del abono de representaciones de la compañía dramática dirigida por Pedro Delgado, que estaba actuando allí. La función se destinó a recaudar fondos para la Escuela. Participaron los profesores Lucas y Bonafí, el barítono Antonio López y los músicos Ramírez y Solano, que acompañaron diversas obras al piano y armonio ${ }^{336}$. Menos frecuentes fueron las colaboraciones de músicos de la Escuela de Canto en eventos religiosos ${ }^{337}$.

El matrimonio Lucas-Bonafí también organizaba conciertos privados en su domicilio, especialmente cuando se hallaban de paso por la ciudad cantantes e instrumentistas célebres. Por ejemplo, el 16 de mayo de 1882, los directores de la Escuela de Canto ofrecieron una velada en su casa con el guitarrista Francisco Tárrega (ver Capítulo 8) ${ }^{338}$.

\subsection{De Escuela de Canto y Declamación a Real Escuela de Canto y Declamación (1882-1885)}

En junio de 1882, la Escuela de Canto organizó un concierto para demostrar los adelantos de sus alumnos e invitó a la Sociedad Económica de Amigos del País, a la

335 Los tres primeros aparecen citados como alumnos distinguidos en los ejercicios prácticos o exámenes de la Escuela: La Paz de Murcia, XXV (1882), no 7374, 3 julio, p. 1. El Diario de Murcia, IV (1882), n ${ }^{\circ}$ 1034, 21 julio, p. 3 recoge una noticia publicada en El Constitucional de Alicante en la que se mencionan a Rafael Pastor y Francisco Rizo, alumnos de la Escuela de Canto y debutantes en la zarzuela Los diamantes de la corona, probablemente en el Teatro Principal de Alicante. La Paz de Murcia, XXV (1882), nº 7374, 3 julio, p. 1 recogió una crítica de Peña y Goñi publicada en el periódico alicantino El Eco de la Provincia en la que se menciona el éxito del cantante Rigoberto Rovira. Peña y Goñi elogió las facultades del bajo y su buena técnica vocal.

${ }^{336}$ El concierto fue la presentación pública del barítono Antonio López (alumno de Lucas desde hacía cuatro meses) y un estímulo para que otros jóvenes vieran en él una oportunidad para dedicarse al canto. El programa se basó en "trozos de ópera", entre ellos "dos romanzas de barítono de Lucrecia y de Lucia", cantadas por Antonio López: El Semanario Murciano, IV (1881), nº 160, 6 marzo, p. 80; La Paz de Murcia, XXIV (1881), $\mathrm{n}^{\text {os }}$ 6978, 17 febrero, p. 1; 6980, 19 febrero, p. 1; 6981, 20 febrero, p. 1 y El Diario de Murcia, III (1881), n 603, 22 febrero, pp. 2-3. El 24 de julio de 1881 los directores de la Escuela de Música, Lucas y Bonafí, colaboraron en una función benéfica por los emigrados españoles en África, organizada por una compañía de aficionados de la ciudad. Bonafí interpretó el Ave María de Luigi Luzzi y, en dúo junto a su esposo, un "Nocturno" de Rossini. Fueron acompañados al piano y armonio por Solano y Ramírez: El Diario de Murcia, III (1881), nº 730, 26 julio, p. 2.

${ }^{337}$ El 28 de marzo de 1885 los alumnos de la Escuela de Canto cantaron las novenas de la Virgen de los Dolores en la Iglesia de San Antolín: El Diario de Murcia, VII (1885), nº 1763, 1 enero, p. 2.

${ }^{338}$ El Diario de Murcia, IV (1882), nº 980, 17 mayo, p. 1. No ha quedado constancia de las piezas interpretadas. 
Diputación y al Ayuntamiento de Murcia "que son los que necesitan oír y conocer prácticamente esos nuevos artistas, a ver si se convencen de la conveniencia de dotar con recursos el establecimiento en que se hacen" ${ }^{, 33}$. La manutención de los alumnos sin recursos económicos, el escaso ingreso de las matrículas y la ausencia de ayudas por parte de las corporaciones municipales obligó a su director a anunciar una suscripción pública popular y voluntaria. Las cuotas no estarían preestablecidas y serían cobradas mensualmente hasta que el donante quisiese ${ }^{340}$. La iniciativa aportó, en principio, un buen número de protectores murcianos que aseguraban la financiación de la escuela. Incluso, la familia real concedió una importante suma de dinero, el título de Real Escuela de Canto y Declamación gratuita para la carrera artístico-teatral italiana y española, bajo el patrocinio de la Serenísima Señora Doña Mercedes de Borbón, Princesa de Asturias y de sus fundadores señores de Lucas y, lo más relevante, su patrocinio durante los años siguientes $^{341}$.

El curso académico comenzó en septiembre de 1882 con el tradicional concierto de apertura y una novedad: se abrió una clase nocturna de lectura y escritura a cargo del clero de la Parroquia de San Miguel de Murcia ${ }^{342}$.

Al menos hasta noviembre de 1883 la escuela pareció recobrar un nuevo impulso $^{343}$. Se aceptaron nuevos alumnos y se organizaron conciertos, como el de la onomástica de la Infanta de España, Isabel de Borbón, en noviembre de $1883^{344}$. Sin embargo, la situación económica de la escuela desde diciembre volvió a ser angustiosa, a pesar del apoyo real. La precariedad de los fondos provocó el traslado de la institución a

${ }^{339}$ La Paz de Murcia, XXV (1882), no 7367, 23 junio, p. 1. No consta el programa.

${ }^{340}$ La Paz de Murcia, XXV (1882), nº 7385, 15 julio, p. 1. En marzo, Lucas recibió un giro de José de Posada Herrero (entonces Presidente del Congreso nacional español) por valor de 250 pesetas. La donación se debió a las gestiones del murciano Pedro Pagán: El Diario de Murcia, IV (1882), n ${ }^{\text {os }}$ 919, 9 de marzo, p. 3 y 923, 14 de marzo, p. 2. A lo largo del mes de junio los periódicos de la ciudad publicaron varias noticias sobre la falta de apoyo a la Escuela de Canto por parte del Ayuntamiento, de la Diputación y de la Sociedad Económica de Amigos del País. En este sentido, la prensa reiteró la necesidad de subvencionarla en numerosas ocasiones: "hay quienes no comprenden la conveniencia de la subvención y de ahí los obstáculos con que viene tropezando, los cuales es menester combatir con pruebas más eficaces que las hasta ahora presentadas": La Paz de Murcia, XXV (1882), no 7371, 28 junio, p. 1. Véase también, La Paz de Murcia, XXV (1882), n ${ }^{\text {os }} 7363,19$ junio, p. 1; 7365, 21 junio, p. 1 y El Diario de Murcia, IV (1882), n $^{\text {os }}$ 1008, 21 de junio, p. 2; 1136, 22 noviembre, pp. 1-2 y 1016, 30 junio, p. 2.

${ }^{341}$ El Diario de Murcia, IV (1882), n 1059, 19 agosto, p. 2. La familia real ofreció, en total, una cantidad de 10500 reales: (el Rey, 6000 reales; la Reina, 3000 reales y la Infanta, 1500 reales). En diciembre de 1882, Lucas presentó a uno de sus discípulos al Rey. No consta su nombre, aunque sí que era bajo: El Diario de Murcia, IV (1882), nº 1158, 17 de diciembre, p. 3.

${ }^{342}$ El Diario de Murcia, IV (1882), n ${ }^{\circ}$ 1085, 23 septiembre, p. 3. Al menos desde el curso 1881-1882 la escuela fue un centro completo de educación de "primeras letras" y música: El Diario de Murcia, IV (1882), $\mathrm{n}^{\mathrm{o}}$ 1099, 10 de octubre, p. 3. La apertura del curso siempre era motivo de celebración. En 1882, se organizó un concierto y hubo música en la puerta de la escuela: La Paz de Murcia, XXV (1882), $\mathrm{n}^{\text {os }} 7441$, 22 septiembre, p. 1 y 7454, 7 octubre, p. 1, El Diario de Murcia, IV (1882), nº 1086, 24 de septiembre, p. 1. No he hallado programas de estas veladas.

${ }^{343}$ El curso 1883-1884 comenzó con diez y nueve alumnos: El Diario de Murcia, V (1883), nº 1399, 12 octubre, p. 3. Todos ellos llevaban uniforme con las insignias reales de la casa de Borbón.

344 En él se interpretó un "Dúo" de ¿Fabio? Campana, cantado por la soprano Teresa Martínez (“directriz" de las alumnas de la escuela) y el tenor José María Ruiz Cánovas, así como otras romanzas de las óperas Martha de Flotow, L'Elisire d'amore y La Favorite, ambas de Donizetti: El Diario de Murcia, V (1883), no 1433,21 noviembre, pp. 2-3. 
un local más pequeño y la limitación del número de alumnos (durante el año 1884 estudiaron en la escuela doce alumnos). De esta forma, se evitó, además, tener que contratar a más personal docente y de servicios ${ }^{345}$.

En junio de 1884, Lucas y algunos de sus alumnos emprendieron una gira de conciertos por varias ciudades españolas con una doble finalidad: darse a conocer y recaudar fondos a beneficio de los afectados por las inundaciones de mayo en Murcia y Orihuela. Recorrieron varias poblaciones de Murcia (incluida Cartagena) y estuvieron también en Almería (tanto en la capital como Dalias, Adra y Berja), Granada, Madrid y Alcalá de Henares ${ }^{346}$.

El programa de estos conciertos estuvo mayoritariamente formado por arias de ópera $^{347}$. Antes y después de estas veladas musicales, una estudiantina de los mismos alumnos recorría las calles cantando "coplas de costumbre"348.

\subsection{El traslado de la Real Escuela de Canto de Murcia a Madrid (1885-1892)}

Entre 1884 y 1885 Francisco Lucas viajaba constantemente de Murcia a Madrid, especialmente en verano. Finalmente, Lucas trasladó su residencia y la Real Escuela de Canto a la capital española a principios de 1885. El Diario Oficial de Avisos de Madrid de febrero de 1885 lo anunciaba así:

El distinguido maestro de canto don Francisco de Lucas, ha trasladado a Madrid la Real Escuela que había fundado en Murcia, donde con tan brillantes resultados ha funcionado por espacio de algunos años. En Madrid, continuará el señor Lucas dando enseñanza gratuita a los alumnos pobres de ambos sexos.

La academia se establece por ahora en la calle de la Villa, 2, donde se reciben las solicitudes ${ }^{349}$.

${ }^{345}$ El nuevo local estuvo situado en la calle del Aire, número 6 (actual calle de Obdulio Miralles): El Diario de Murcia, V (1883), $\mathrm{n}^{\circ}$ 1460, 23 diciembre, p. 3. En marzo de 1884, la Escuela de Canto aceptó el ingreso de los alumnos murcianos Ramón Sánchez, José Alfaro, José Agustín Palomo, Juan José Requena, Manuel Sánchez, Manuel Alfaro, José Leante, el sevillano Francisco Manteca Ortiz y el valenciano José García Vall. La demanda de solicitantes, en cambio, fue mayor, lo que provocó el malestar de los aspirantes. En El Diario de Murcia, VI (1884), n ${ }^{\circ}$ 1523, 8 marzo, p. 2, se explicaron las razones por las cuales Lucas limitó el número de alumnos.

${ }^{346}$ El Diario de Murcia, VI (1884), $\mathrm{n}^{\text {os }} 1601,14$ junio, p. 2; 1606, 20 junio, p. 3 y 1635, 24 julio, p. 2.

${ }^{347}$ En El Diario de Murcia, VI (1884), nº 1650, 10 agosto, pp. 1-2 apareció una extensa reseña sobre el concierto en el Círculo de Almería. El programa incluyó: "Viene la mia vendetta", aria de bajo del segundo acto de la ópera Lucrezia Borgia (Donizetti) por Juan Requena Martínez (bajo) y Enrique Villegas (piano); "Infelice", aria de bajo de Ernani (Verdi), por José Agustini Palomo (bajo) y Enrique Villegas (piano); "Spiritu gentil", aria de tenor de La Favorite (Donizetti), por José María Ruiz Cánovas (tenor) y Enrique Villegas (piano); Dúo de bajo y barítono de Marino Faliero (Donizetti), por Andrés Díaz Saldaña (bajo), Enrique Oña (barítono) y Enrique Villegas (piano); Obra no especifica de Antonio López Almagro, por Enrique Villegas (armonio); "Miserere" de Il Trovatore (Verdi), por Francisco Lucas (guitarra); El último pensamiento, por Francisco Lucas (guitarra). La reseña sobre los conciertos en Madrid se publicó en El Diario de Murcia, VI (1884), no 1744, 6 diciembre, p. 2. Véase también, La Paz de Murcia, XXVII (1884), $\mathrm{n}^{\circ}$ 8089, 7 diciembre, p. 1. La de Alcalá de Henares en El Diario de Murcia, VI (1884), $\mathrm{n}^{\circ} 1683,19$ de septiembre, p.3.

\footnotetext{
${ }^{348}$ El Diario de Murcia, VI (1884), nº 1650, 10 agosto, p. 2.
} 
No obstante, Lucas siguió viajando con frecuencia a Murcia, después de fijar su residencia en Madrid ${ }^{350}$. En la prensa murciana se siguieron publicando reseñas sobre algunos conciertos de la Escuela en su nuevo ámbito madrileño.

El 3 de abril de 1886 se celebró un concierto por la onomástica de Francisco Lucas en su casa madrileña de la calle Goya, al que fueron invitadas personalidades de la capital. Se cantaron arias de diferentes óperas de los compositores Rossini, Stradella, Donizetti (L'elisir d'amore, La Favorite), Verdi (Ernani, Il Trovatore, Rigoletto, Attila), Gounod (Faust), Arrigo Boito (Mefistofeles) y Bellini (La Sonnambula) ${ }^{351}$.

En marzo de 1887, los diarios madrileños La Correspondencia de España y El Liberal reseñaron una velada musical "en la escuela de canto que dirige el conocido maestro don Francisco de Lucas", en la que se cantó el romance "Spirto gentil" de La Favorite, por el tenor Urrimaga; un aria de La Sonnabula, por Teresa Martínez Costa; un aria de Faust, por el tenor Ruiz Cánovas; una cavatina de Ernani, por el barítono Villabella; un dúo de Aida, por la soprano Goya y el tenor Alonso; y, un aria de Il furioso $^{352}$. En septiembre de 1888 , se organizó una velada musical a beneficio de los afectados por las inundaciones de Almería ${ }^{353}$.

En noviembre de 1889, hubo una velada musical en Madrid con la asistencia de importantes personalidades de la política, la literatura, la música y, en general, de la cultura madrileña (Zabalza, López Almagro, Fernández Caballero, Napoleón Verger y José Ducazcal, entre otros). El programa incluyó arias de las óperas de Verdi (Aida, Luisa Miller, I Due Foscari, I Lombardi), Donizetti (Maria Padilla, Il furioso nell'isola di San Domingo) y Rossini ("Serenata"), entre otros ${ }^{354}$. En diciembre de 1891, se ofreció otro concierto en el Centro Instructivo del Obrero de Madrid, aunque no ha quedado constancia del programa ${ }^{355}$.

${ }^{349}$ Diario Oficial de Avisos de Madrid, CXXVII (1885), n ${ }^{\text {o }}$ 50, 19 febrero, p. 2 y La Correspondencia de España, XXXVI (1885), no 9830, 19 febrero, p. 2. En El Liberal VII (1885), nº 2043, 18 febrero, p. 3 se añadió al anuncio: "Además de las clases gratuitas se darán también lecciones particulares para artistas y diletantes".

${ }^{350}$ Véase El Diario de Murcia: VII (1885), no 1976, 1 de octubre, p. 3; IX (1887), no 2952, 18 marzo, pp. 1-2 y XI (1889), nº 3841, 4 de octubre, p. 3.

${ }^{351}$ Eduardo Bermúdez, "Don Francisco Lucas en Madrid”, El Diario de Murcia, VIII (1886), nº 2123 , 6 abril, pp. 1-2. Otro concierto ofrecido en Madrid se celebró en la real cámara "con mucha complacencia de la augusta familia": El Diario de Murcia, X (1888), n 3530, 30 septiembre, p. 2.

${ }^{352}$ El marqués de Altavilla también cantó algunas obras cuyos títulos no constan. El concierto convocó a un gran número de personalidades políticas, como los diputados Landecho y Masa, aristócratas (conde de Montefuerte, marqués de Fontanar, el príncipe de Solma, el conde de Morphy) y escritores como Echegaray y Arnao. El concierto fue reseñado en El Diario de Murcia, IX (1887), n 2952, pp. 1-2 y La Paz de Murcia, XXX (1887), no 9146, 18 marzo, p. 1.

${ }^{353}$ El Diario de Murcia, X (1888), n 3530, 30 septiembre, p. 2. No consta el lugar ni la fecha de realización.

${ }^{354}$ En concreto, constó de: "Aria de tenor de Luisa Miller", por Alberto Sianns (tenor); "Dúo de tiple y contralto de Aida", por Resurrección Alonso y la condesa de Castellá; "Dúo de tiples de Maria di Padilla", por Isabel Hernando y Adelaida Fernández; "Serenata de Rossini”, Ruiz Cánovas (tenor) y Trinidad Pérez (tiple); "Aria de Il Foscari" [I due Foscari], por Granco (tenor); "Aria de L'Orfona", por Carmen Montoro; "Aria de bajo de Il furioso", por Noguera (bajo); "Melodía La madre" del compositor Emilio Tuesta, por Isabel Hernando; y, "Gran terceto de Il Lombardi [sic]", por Fernández (tiple), Franco (tenor) y Asuar (bajo): El Diario de Murcia, XIII (1891), nº 4494, 25 noviembre, p. 2.

${ }^{355}$ La Correspondencia de España, XLII (1891), nº 12291, 1 diciembre, p. 2. 
Francisco Lucas murió el 4 de febrero de 1892 en Madrid ${ }^{356}$. Unos días más tarde, se organizó un concierto vocal e instrumental en Madrid a beneficio de su viuda, con obras de Mozart, Verdi, Saint-Saens, Gounod, Rubinstein, Durand, Thomas, Wieuxtemps, López Almagro, Campana, Denza y Álvarez. Tomaron parte los intérpretes Napoleón Verger, Peña Ruanova, Asuar, Ruiz Cánovas y Abad, en la parte vocal y, en la instrumental, María Luisa y Matilde Chevallier, Runio y el violinista Francés ${ }^{357}$. Es muy probable que la Real Escuela de Canto y Declamación desapareciera al morir Lucas.

\section{La Sociedad Filarmónica Amigos de Antonio Raya (1883-1884)}

Los músicos de la banda de música de Antonio Raya se asociaron bajo la denominación Sociedad Filarmónica Amigos de Antonio Raya en 1883, aunque los precedentes de esta sociedad se remontan a 1882, cuando Antonio Raya asumió la dirección de la banda de música que dirigía su hermano Emilio Raya (desde 1869) al fallecer éste el 11 de mayo de $1882^{358}$. Antes de marzo de 1883 , la formación de Raya se escindió en dos partes: una parte de sus músicos permanecieron unidos bajo la dirección de Lorenzo Llinares y la otra parte formó una nueva banda dirigida por Antonio Raya ${ }^{359}$. Con la separación, los músicos de la nueva banda de Antonio Raya constituyeron entonces la Sociedad Filarmónica Amigos de Antonio Raya ${ }^{360}$.

En junio de 1884, la Sociedad Filarmónica Amigos de Antonio Raya se planteó ligarse a la Brigada de Bomberos:

El domingo en la tarde se reunió la Sociedad Filarmónica "Amigos de Antonio Raya" con objeto de tratar de algunos asuntos concernientes a la misma.

Uno de los acuerdos que tomaron fue que en vista del pensamiento que existe de hacer dicha banda de la Brigada de Bomberos, para lo que tanta parte activa está tomando su presidente don José Clemares, que se proceda a hacerles los uniformes respectivos, para lo que quedaron comisionados los individuos de la Junta Directiva, habiendo ya comentado el señor presidente y tesorero a proporcionar el paño para dichos uniformes ${ }^{361}$.

${ }^{356}$ El Diario de Murcia, XIV (1892), no 4555, 7 febrero, pp. 1-2. Fue enterrado el 6 de febrero de 1892 según consta en: La Correspondencia de España, XLIII (1892), nº 12360, 8 de febrero, p. 3.

${ }^{357}$ El Diario de Murcia, XIV (1892), no 4570, 25 febrero, p. 2. Véase también Julio Nombela, "El maestro Lucas", La Última Moda, V (1892), nº 218, 6 marzo, p. 6.

${ }^{358}$ La Paz de Murcia: XXV (1882), ${ }^{\text {os }} 7340,11$ mayo, p. 1; 7341, 12 mayo, p. 1; 7342, 13 mayo, p. 1 y XXVI (1883), no 7632, 10 mayo, p. 1; El Diario de Murcia, IV (1882), no 973, 13 mayo, p. 1. Antonio Raya tomó posesión de la dirección de la banda de música de su hermano Emilio el 20 de mayo de 1882 según él mismo hizo constar en El Diario de Murcia, V (1882), nº 1232, 22 marzo, p. 2. Véase también, La Paz de Murcia, XXV (1882), nº 7350, 22 mayo, p. 1.

${ }^{359}$ El Diario de Murcia, V (1883), n $\mathrm{n}^{\mathrm{o}}$ 1231, 21 marzo, p. 2 y La Paz de Murcia, XXVI (1883), $\mathrm{n}^{\circ}$ 7586, 25 marzo, p. 1. La banda de Lorenzo Llinares se disolvió en 1885 y algunos de sus músicos pasaron entonces a la Banda Municipal, dirigida por Ángel Mirete, mientras que otros engrosaron las filas de la banda de música de Antonio Raya: La Paz de Murcia, XXVIII (1885), nº 8318, 8 septiembre, p. 4.

360 Así consta en La Paz de Murcia, XXVII (1884), no 7820, 16 enero, p. 1. Desconozco quiénes fueron sus integrantes y el régimen salarial al que estuvieron sometidos los músicos de la Sociedad Filarmónica Amigos de Antonio Raya.

\footnotetext{
${ }^{361}$ La Paz de Murcia, XXVII (1884), nº 7945, 15 junio, p. 4.
} 
A juzgar por la documentación hallada, el proyecto no se llevó a cabo y la banda de Antonio Raya continuó su trayectoria al menos hasta finales de 1889 o principios de 1890: "El señor Raya ha dejado la dirección de la banda de música de su apellido [...]. No sabemos si esta corporación continuará unida, eligiendo otro director, o se disolverá al retirarse el que la ha dirigido y ha sido su alma"362. Durante ese periodo de años, las actuaciones de la banda de Antonio Raya fueron muy frecuentes y, en ocasiones, llevaron a cabo estrenos de obras, como la Retreta escrita ex profeso por Casimiro Espino e interpretada por primera vez en el Teatro Romea el 30 de enero de $1884^{363}$.

\section{La Sociedad Belluga (1884-1887)}

La Sociedad Belluga se fundó el 15 de junio de 1884 con la finalidad de "rendir culto a la sublime virtud de la Caridad, y procurar el progreso intelectual y material de sus asociados, así como el de los acogidos en la Casa de Misericordia" ${ }^{\text {364 }}$. La sociedad protegía los establecimientos benéficos de Murcia, especialmente la Casa Provincial de Misericordia y Huérfanos de la ciudad. Los artículos tercero a sexto de su Reglamento (aprobado en mayo de 1885) recogen:

[...] $3^{\circ}$ Aprovechar todo género de recursos extraordinarios y practicar cuantas gestiones sean posibles para lograr el mejoramiento de la vida en los expresados establecimientos, siendo asunto muy preferente despertar y estimular en ellos, por medio de conferencias y lecturas, el amor al trabajo y a la honradez.

$4^{\circ}$ Honrar la memoria del Cardenal Belluga, no sólo con las prácticas benéficas ya expresadas, sino además con la celebración de ciertas solemnidades cuando convenga, como aniversarios, certámenes exclusivamente para los asilados, veladas literarias, y otras que se aprueben en Juan General.

$5^{\circ}$ Usar de la banda de música de asilados en cuantas ocasiones la sociedad necesite de una banda, y proporcionar a la misma servicios lucrativos como medios de allegar recursos a la Casa de Misericordia.

$6^{\circ}$ Llevarla por cuanta de la sociedad a amenizar los paseos, en especial la Glorieta, durante las mejores estaciones del año y a las horas de concurrencia, con el fin de despertar y sostener las simpatías del público hacia dicha banda de música y que estas simpatías sean el germen de otras más importantes a favor de la Casa de Misericordia, y por analogía a favor de los demás establecimientos benéficos $[\ldots]^{365}$.

Así pues, uno de sus cometidos fue financiar la banda de música de la Casa Provincial de Misericordia y promover sus actuaciones públicas. La banda de la Casa de Misericordia fue creada en enero de 1879 por iniciativa de Acisclo Díaz Rocher y estaba formada íntegramente por huérfanos de dicha institución caritativa (ver punto 2.4 del

\footnotetext{
${ }^{362}$ La Paz de Murcia, XXXIII (1890), nº 10020, 10 enero, p. 4.

${ }^{363}$ La Paz de Murcia, XXVIII (1885), n ${ }^{\text {s }}$ 8128, 24 enero, p. 1; 8134, 31 enero, p. 1 y 8138, 5 febrero, p. 1.

${ }^{364}$ Reglamento de la Sociedad Belluga aprobado por el señor Gobernador Civil de la Provincia en 2 de mayo de 1885. (Murcia: Establecimiento Tipográfico de "El Noticiero", 1885), p. 3.

365 Reglamento de la sociedad Belluga, pp. 4-5.
} 
Capítulo 9 $)^{366}$. La sociedad llevó el nombre del cardenal Luis de Belluga y Moncada (1662-1743), obispo de la diócesis de Cartagena (1705-1723), en homenaje a su extensa labor humanitaria y a su interés por atender y velar las instituciones benéficas de la ciudad. La sociedad Belluga fue presidida por Joaquín González Martínez y tuvo su sede en la calle Organistas, número seis ${ }^{367}$.

Cualquiera podía ser socio de la sociedad Belluga (incluidos los niños, aunque éstos no tenían voz ni voto hasta cumplir los dieciséis años) y no había requisitos especiales de ingreso. Cada integrante pagaba una cuota mensual de una peseta "aumentada voluntariamente por los que lo deseen"368. La sociedad Belluga estaba presidida por una Junta Directiva (formada por quince individuos), dividida a su vez en tres comisiones de "Administración, de Información de socios, de Honras al Cardenal Belluga, de Protección a los niños del Asilo y de Beneficencia general"369.

A lo largo de su existencia, la sociedad Belluga subvencionó regularmente las actuaciones al aire libre de la banda de música de la Casa de Misericordia y la organización de grandes eventos que involucraron a la ciudad en pleno. En noviembre de 1884, por iniciativa de la sociedad, se cambió el nombre de la antiquísima plaza de Palacio, frente a la Catedral, por la de Cardenal Belluga. El acontecimiento fue celebrado con una gran fiesta popular, organizada en colaboración con el Ayuntamiento, en la que participaron las autoridades y corporaciones civiles, militares y religiosas más relevantes de la ciudad.

Los actos tuvieron lugar los días 15 y 16 de noviembre de 1884. El día 15 por la mañana se adornó la plaza de Palacio y por la noche, la banda de la Misericordia en pasacalles anunció la fiesta ${ }^{370}$. A las diez de la mañana del día 16 , un redoble de la campana "Nona" de la Catedral dio paso a la procesión cívica que recorrió diversas calles desde el Ayuntamiento hasta la plaza que iba a cambiar de nombre (la plaza de Palacio) con cuatro bandas de música dirigidas respectivamente por Lorenzo Llinares, Acisclo Díaz (banda de la Casa de Misericordia), Antonio Raya y Ángel Mirete ${ }^{371}$. Un repique de campanas anunció la llegada de la comitiva a la plaza y tras él, se descubrió la placa con el nuevo nombre. A continuación, la banda de la Casa de Misericordia interpretó un nuevo Himno compuesto por Casimiro Espino y dedicado al Cardenal Belluga y dio un concierto por la tarde en la rebautizada plaza $^{372}$.

${ }^{366}$ El Diario de Murcia, VII (1885), $\mathrm{n}^{\mathrm{o}}$ 1763, 1 enero, p. 2.

${ }^{367}$ La Paz de Murcia, XXVII (1884), n ${ }^{0} 7991,8$ agosto, p. 1. La calle Organistas une la actual calle de Polo de Medina con la de la Puxmarina.

${ }^{368}$ La Junta Directiva podía también reducir la cuota mensual si el socio era "poco pudiente". Véanse más detalles en Reglamento de la sociedad Belluga, pp. 5-7.

${ }^{369}$ Cada una de estas comisiones estaba representada en la Junta Directiva por tres individuos. Las finalidades de cada sección pueden consultarse en el Reglamento de la sociedad Belluga, pp. 7 y siguientes.

${ }^{370}$ La Paz de Murcia, XXVII (1884), no 8070, 15 noviembre, p. 1.

${ }^{371}$ Las calles que recorrió la procesión fueron: Arenal, Puerta del Sol, Frenería, Pascual, plaza de Santa Catalina, Platería, Príncipe Alfonso y Salzillo.

${ }^{372}$ El orden de colocación de autoridades, corporaciones y bandas de música de la procesión puede consultarse en: El Diario de Murcia, VI (1884), no 1731, 13 noviembre, p. 1 y La Paz de Murcia, XXVII (1884), $\mathrm{n}^{\mathrm{0}} 8070,15$ noviembre, $\mathrm{p}$. 1. Las crónicas del evento y otras noticias relacionadas con el homenaje pueden leerse en La Paz de Murcia, XXVII (1884), $\mathrm{n}^{\text {os }}$ 8072, 18 noviembre, p. 1; 8072, 18 noviembre, p. 1 y 8097,18 diciembre, p. 1. 
Como complemento a estos actos, la Sociedad Belluga organizó un certamen poético-musical en homenaje al Cardenal Belluga que sirvió para premiar a los alumnos de la Casa de Misericordia que más destacaron en los exámenes extraordinarios convocados sobre contenidos de Primera Enseñanza y Solfeo ${ }^{373}$ y para premiar los mejores trabajos literarios y composiciones musicales originales que se presentaran (ver Apéndice 6.13). La Corona de Plata (primer premio) se concedería al autor de la mejor oda sobre la vida del Cardenal Belluga. Otros dos premios, denominados Laurel de plata, se destinaron al mejor soneto sobre la caridad y a la mejor fantasía para banda sobre motivos de la ópera Il Barbiere di Siviglia de Rossini. La Pluma de Plata se entregaría al mejor compositor de un himno dedicado al Cardenal Belluga. El tribunal de las composiciones musicales estuvo compuesto por los prestigiosos Manuel Fernández Caballero, Ruperto Chapí y Leopoldo Martín Elexpuru (director de la Real Banda de Alabarderos de Madrid) ${ }^{374}$. La relevancia de los integrantes del tribunal, cuyas carreras ya gozaban de renombre en España, pone de manifiesto el nivel que se pretendía dar al concurso $^{375}$.

Durante los años 1885 y 1886 la sociedad organizó nuevas veladas que tuvieron como finalidad entregar premios a los alumnos más destacados de la Casa de la Misericordia $^{376}$. En 1886, por ejemplo, se organizó un concierto cuyo programa se muestra en la Tabla 6.7.

${ }^{373}$ Los exámenes, presididos por el compositor y director Casimiro Espino, tuvieron lugar el 4 de noviembre de 1884 en la Casa Provincial de Misericordia. En el evento, Espino dirigió a la banda de huérfanos en las obras primera y tercera "Marcha de las Antorchas" y su polca titulada Las amazonas. Los jóvenes más sobresalientes fueron: Nicolás Sánchez Vigueras, Eugenio Llové, José Antonio Turpín, Francisco Gracia, José Mellado Zapata, Antonio Salmerón, Juan Antonio García, Ginés Guzmán Guerrero, Diego Martínez Navarro y Luis Huertas, entre otros: La Paz de Murcia, XXVII (1884), ${ }^{\text {os }} 8062,6$ noviembre, p. 1 y 8065, 9 noviembre, p. 1. En agradecimiento por la colaboración de Casimiro Espino en los homenajes al cardenal Belluga, la sociedad le regaló una batuta de ébano con remates y adornos de plata: El Diario de Murcia, VI (1884), nº 1736, 19 noviembre, p. 2.

${ }^{374}$ La Paz de Murcia, XXVII (1884), n 8079, 26 noviembre, p. 1. El certamen se celebró el 8 de diciembre de 1884 a las siete y media de la tarde en el salón de actos del Instituto Provincial de Segunda Enseñanza. Se otorgaron, además, menciones y diplomas honoríficos entre el resto de composiciones poéticas y musicales. El plazo de entrega de trabajos se prolongó desde el 8 de agosto (fecha en la que aparece el anuncio del certamen en La Paz de Murcia) hasta el 15 de octubre de 1884: La Paz de Murcia, XXVII (1884), no 7991, 8 agosto, p. 1 y El Diario de Murcia, VI (1884), nº 1649, 9 agosto, p. 1. El primer premio, realizado por José Gascón, fue donado por el Obispo Electo de la Diócesis de Cartagena, Tomás Bryan; un Laurel de Plata, por Mariano Aguado y Flores y la Pluma de plata, por la Sociedad Belluga: La Paz de Murcia, XXVII (1884), nº 8092, 12 diciembre, p. 1. Véase también, El Diario de Murcia, VI (1884), $\mathrm{n}^{\mathrm{o}} 8089,7$ diciembre, p. 1.

375 Fernández Caballero ya era un consagrado compositor de zarzuelas en 1884, con éxitos a sus espaldas como La gallina ciega (1873), La marsellesa (1875) y Las nueve de la noche (1875), entre otras. Chapí ha sido considerado como "el único valedor auténtico de la zarzuela clásica grande, heredera de Barbieri, Arrieta y Gaztambide" con títulos como La tempestad (1881), El milagro de la Virgen (1884) y La bruja (1887), entre otros: Iberni, "Chapí y Llorente", p. 461. El director y compositor logroñés Leopoldo Martín Elexpuru dirigió la Banda de Alabarderos de Madrid ente 1867 y 1895, según Fernández de Latorre, Historia, pp. 352-354.

${ }^{376}$ El Diario de Murcia, VII (1885), n ${ }^{\circ}$ 1860, 19 mayo, p. 1 y La Paz de Murcia, XXIX (1886), $\mathrm{n}^{\circ}$ 9066, 12 diciembre, p. 1 . 
Tabla 6. 7. Programa musical y discurso de la ceremonia de entrega de premios a los alumnos de la Casa de Misericordia de Murcia el 12 de diciembre de 1886 en el Instituto Provincial de Segunda Enseñanza.

Fuente: La Paz de Murcia, XXIX (1886), nº 9066, 12 diciembre, p. 1.

\begin{tabular}{|c|c|}
\hline $\begin{array}{l}\text { Repertorio interpretado: } \\
\text { Compositor, título y movimientos }\end{array}$ & $\begin{array}{l}\text { Intérpretes/lectores y/o agrupación } \\
\text { instrumental indicada en la fuente }\end{array}$ \\
\hline $\begin{array}{ll} & \text { Primera parte } \\
\text { Obertura } & \end{array}$ & Banda de la Misericordia \\
\hline Discurso de apertura & Gabriel Baleriola \\
\hline Gran fantasía de concierto para piano & Francisco Soler (piano) \\
\hline Gran sólo para contrabajo & $\begin{array}{l}\text { Ginés Guzmán (contrabajo) y Vicenta Díez } \\
\text { Romero (piano) }\end{array}$ \\
\hline Alegro $[\mathrm{sic}]$ & Francisco Leante y don Antonio Ramírez \\
\hline L'Amor funesto, romanza & $\begin{array}{l}\text { Joaquina Molina (voz) y Juan Diego Manresa } \\
\text { (piano) }\end{array}$ \\
\hline Gran galop & Antonio Puig (piano) \\
\hline $\begin{array}{l}\text { Gran fantasía para dos pianos y ocho } \\
\text { manos }\end{array}$ & $\begin{array}{l}\text { Carmen y Matilde Fernández, Antonio Puig y } \\
\text { Francisco Leante (piano) }\end{array}$ \\
\hline Reparto de premios & - \\
\hline $\begin{array}{l}\text { Segunda parte } \\
\text { Jesús de Nazaret }\end{array}$ & Banda de la Misericordia \\
\hline Obertura del Poeta y aldeano & Concepción Fernández y ¿Julián? Calvo \\
\hline Gran fantasía para piano & Concha Rodríguez (piano) \\
\hline Dormi pure, romanza & $\begin{array}{l}\text { Joaquín Cañeda (voz) y Vicente Espada } \\
\text { (¿piano?) }\end{array}$ \\
\hline Dúo de armonio y piano & Julián Calvo (armonio), Leal (piano) \\
\hline Rondó & Vicente Espada (¿piano?) \\
\hline Gran marcha del Profeta & Leante, Soler, Ayala, Calvo y Guzmán \\
\hline
\end{tabular}

La sociedad Belluga continuó al menos hasta $1887^{377}$.

\section{La Sociedad lírico-dramática Julián Romea (1888)}

Durante el mes de junio de 1888 se gestó la Sociedad lírico-dramática Julián Romea $^{378}$, cuya inauguración tuvo lugar el 2 de julio de ese año en el Teatro Romea con la representación de las comedias en un acto Como el pez en el agua y Aprobados y suspensos. El acto incluyó números musicales interpretados por el pianista Antonio Puig, discípulo de Julián Calvo, Ramírez, Muñoz y Solano ${ }^{379}$. No he hallado más noticias sobre la trayectoria posterior de la sociedad ${ }^{380}$.

377 En enero de 1887 la sociedad Belluga nombró socio honorario al compositor murciano Julián Calvo: La Paz de Murcia, XXX (1887), nº 8105, 29 enero, p. 1. Durante este año, también participaron en un acto en homenaje al poeta Selgas y al barítono murciano Mariano Padilla. Ver, La Paz de Murcia, XXX (1887), no 9291, 3 septiembre, p. 1.

${ }^{378}$ La primera reunión tuvo lugar en el salón de baile del Teatro Romea el 9 de junio de 1899. En ella se acordó el reglamento y la Junta Directiva, que quedó formada por José Zorrilla (presidente honorario), Ramiro Conde (presidente efectivo), Jesualdo Cañada (vicepresidente), Santos Ladrón de Guevara (secretario), José María Peñafiel (tesorero) y Juan de la Cierva, José Martínez Tornel y Salvador Esteve (vocales): La Paz de Murcia, XXXI (1888), nos 9521, 5 junio, p. 1; 9525, 9 junio, p. 1 y 9526, 10 junio, p. 1.

${ }^{379}$ Los preparativos y la reseña de la inauguración fueron comentados en: La Paz de Murcia, XXXI (1888), $\mathrm{n}^{\text {os }}$ 9538, 24 junio, p. 1; 9544, 3 julio, p. 1. Puig tocó al piano “dos piezas de concierto". Ramírez, 


\section{La Sociedad Filarmónica Fernández Caballero (1892-1893)}

La Sociedad Filarmónica Fernández Caballero fue una sociedad dedicada a la enseñanza de la música "de los que carecen de grandes recursos"381, cuyo primer presidente fue José Muñoz y después Gaspar de la Peña y Rodríguez. Su sede estuvo ubicada en la calle de la Merced y "salón principal está decorado con sencillez y gusto, sobresaliendo un cuadro del eminente maestro Fernández Caballero"382. El reglamento de la sociedad Fernández Caballero fue presentado ante el Gobierno Civil de Murcia a finales de marzo de $1892^{383}$ y en el mes de mayo se nombraron presidentes honorarios a los murcianos Manuel Fernández Caballero, Antonio López Almagro y Mariano Padilla, así como a los políticos Práxedes Mateo Sagasta y Antonio Cánovas del Castillo, entonces Presidente del Consejo de Ministros y Jefe del Gobierno de España, respectivamente:

[...] La misma sociedad [Filarmónica Fernández Caballero] ha nombrado al señor Sagasta socio honorario y ha recibido de dicho señor la siguiente carta:

'Madrid, 24 mayo 1892

Señores don José Muñoz y don Alfonso Córdoba.

Muy señores míos: Acepto gustoso y agradezco mucho el nombramiento de socio honorario de esa Sociedad Filarmónica de Murcia y tanto a ustedes como a los demás individuos de la misma, envío las más expresivas gracias de su afectísimo, suyo siempre que besa su mano.

$$
P \text { [ráxedes] Sagasta }{ }^{, 384}
$$

Al nombramiento de socio honorario remitido anteriormente al señor Presidente del Consejo de Ministros, ha contestado el Jefe del Gobierno con la siguiente carta dirigida al presidente de dicha sociedad:

'Señor don José Muñoz:

Madrid, 24 de mayo de 1892.

Muy señor mío y de toda mi consideración. Ruego a usted muy encarecidamente que se sirva dar en mi nombre las más cumplidas gracias a la Sociedad Filarmónica que tan dignamente preside, por el nombramiento de socio honorario que se ha servido conferirme cuya atención estimo mucho.

Con este motivo se repite de usted afectísimo, suyo siempre que besa su mano,

$$
\text { A[ntonio] Cánovas }{ }^{385}
$$

Muñoz, Solano y Puig interpretaron una "Fantasía sobre motivos de Lucía". Conde y Cañada cantaron un dúo de la ópera Los puritanos.

${ }^{380}$ En julio de 1888 se celebró una función en el Teatro del Barrio a beneficio del actor Enrique Manzano y dedicada a esta sociedad: La Paz de Murcia, XXXI (1888), nº 9547, 6 julio, p. 1.

381 [Anónimo], "Sociedad Fernández Caballero", La Paz de Murcia, XXXV (1892), n 11775, 6 diciembre, pp. 1-2:1. No tengo constancia de las materias impartidas en la sociedad, aunque cabe suponer que tuvieran clases de diversos instrumentos (entre ellos el piano), así como de canto. En la citada fuente se menciona al pianista murciano Antonio Ramírez como profesor de piano en la sociedad Fernández Caballero.

\footnotetext{
382 [Anónimo], "Sociedad Fernández Caballero", p. 1.

${ }^{383}$ La Paz de Murcia, XXXV (1892), nº 11595, 30 abril, 2.

${ }^{384}$ La Paz de Murcia, XXXV (1892), nº 11617, 27 mayo, p. 3.

${ }^{385}$ La Paz de Murcia, XXXV (1892), nº 11619, 30 mayo, p. 2.
} 
La inauguración oficial de la sociedad Fernández Caballero, sin embargo, tuvo lugar el 4 de diciembre de 1892 en una velada en la que intervinieron la orquesta y coro (formados por estudiantes de la propia sociedad), diversos alumnos de la asociación, el tenor murciano Mariano Blaya, el barítono de ópera Bayo y los pianistas e intérpretes de armonio Adolfo Gascón, José Solano y Antonio Ramírez. En el acto de apertura se interpretaron fragmentos de diversas zarzuelas, dos valses vocales de Arditi y Bizet y música instrumental de Weber y Mozart (ver Tabla 6.8):

Tabla 6. 8. Programa musical del acto de inauguración de la

Sociedad Filarmónica Fernández Caballero (4-12-1892)

Fuentes: La Paz de Murcia, XXXV (1892), no 11773, 3 diciembre, pp. 2-3

y [Anónimo], "Sociedad Fernández Caballero", pp. 1-2; [Anónimo], "Velada musical”, El Diario de Murcia, XIV (1892), n 5166, 6 diciembre, p. 1.

\begin{tabular}{|c|c|}
\hline $\begin{array}{l}\text { Repertorio interpretado: } \\
\text { Compositor, título y movimientos } \\
\text { según fuente }\end{array}$ & $\begin{array}{l}\text { Intérpretes/lectores y/o agrupación } \\
\text { instrumental indicada en la fuente }\end{array}$ \\
\hline $\begin{array}{c}\text { [Manuel] } \\
\text { Preludio de El salto del pasiego }\end{array}$ & Orquesta \\
\hline Discurso & $\begin{array}{l}\text { Gaspar de la Peña y Rodríguez, presidente de } \\
\text { la sociedad }\end{array}$ \\
\hline Discurso & Alfonso Córdoba, secretario de la sociedad \\
\hline $\begin{array}{l}\text { [Francisco Asenjo] } \\
\text { Introducción y "Coro de la } \\
\text { huelga" de El tributo de las cien } \\
\text { doncellas }\end{array}$ & Tenor (no especificado) y coro \\
\hline Mozart, Fantasía & Amelia Córdoba Tortosa (piano) \\
\hline $\begin{array}{c}\text { [Ruperto Chapí], Monólogo de La } \\
\text { tempestad }\end{array}$ & Bayo (voz) \\
\hline $\begin{array}{l}\text { ¿Carl Maria von?] } \text { Weber, Gran } \\
\text { concierto en do mayor, primer } \\
\text { tiempo }\end{array}$ & Enrique Martí (piano) \\
\hline $\begin{array}{l}\text { [Adolfo Gascón], El canto del Harem, } \\
\text { leyenda morisca dedicada a la } \\
\text { Sociedad Fernández Caballero }\end{array}$ & $\begin{array}{l}\text { "Pequeña orquesta formada por jóvenes } \\
\text { alumnos, en su mayoría niños", piano y } \\
\text { armonio }\end{array}$ \\
\hline $\begin{array}{l}\text { [Giuseppe Mazza], Andante y cabaletas } \\
\text { [sic] de Campanone }\end{array}$ & [Mariano] Blaya (tenor) \\
\hline [Luigi] Arditi, L'Encantatrice, vals & Orquesta \\
\hline $\begin{array}{l}\text { Emilio Arrieta, Coro y aria de tenor de } \\
\text { Marina }\end{array}$ & José María Celdrán (tenor) \\
\hline $\begin{array}{l}\text { Manuel Fernández Caballero Gran } \\
\text { serenata para piano a cuatro } \\
\text { manos }\end{array}$ & $\begin{array}{l}\text { Amelia Córdoba y Josefa Martínez Arroyo } \\
\text { (piano) }\end{array}$ \\
\hline $\begin{array}{l}\text { Hummel, Raconto }[\mathrm{sic}] \text { de } \text { El salto del } \\
\text { pasiego }\end{array}$ & Francisco Tomás \\
\hline Smith, Tarantela & Enrique Martí (piano) \\
\hline Godard, Vals cromático & Enrique Martí (piano) \\
\hline $\begin{array}{c}\text { [Chapí], Romanza de tenor de } L a \\
\text { tempestad }\end{array}$ & [Mariano] Blaya (tenor) \\
\hline [Georges] Bizet, Vals & Bayo (barítono) \\
\hline $\begin{array}{l}\text { [Barbieri], Final primero [sic] de El } \\
\text { diablo en el poder }\end{array}$ & $\begin{array}{l}\text { [Mariano] Blaya (tenor), Bayo (barítono) y } \\
\text { coro de hombres }\end{array}$ \\
\hline
\end{tabular}


Inmediatamente después de su inauguración, la sociedad Fernández Caballero acogió bailes de máscaras con el propósito de recaudar ingresos extraordinarios. La cuota de entrada para asistir a esos bailes ascendía a setenta y cinco céntimos de peseta para los socios y dos pesetas para los no socios:

Estos bailes tienen por principal objeto atender, si por este medio es posible, a los crecientes gastos que origina el desarrollo de la dicha sociedad. Por esta razón los que no siendo socios pretendan asistir podrán hacerlo abonando dos pesetas y quedando desde luego inscritos como socios en la secretaría si así lo desean. A los socios actuales que concurran a los bailes se les entregarán billetes, por los que abonarán 75 céntimos y que se considerarán como un suplemento voluntario a la cuota de una peseta mensual, insuficiente, hoy por hoy, para atender a todo ${ }^{386}$.

A juzgar por las noticias halladas, los gastos de la sociedad Fernández Caballero eran muy superiores a sus ingresos y en junio de 1893 se disolvió $^{387}$.

\section{Otras sociedades}

\subsection{Veladas con música de la Juventud Católica (1870-1872)}

La Juventud Católica, inaugurada en febrero de 1870, fue una sociedad de carácter religioso que contó con un salón propio para sus actos públicos ${ }^{388}$. Su principal actividad fue la celebración periódica de reuniones para sus socios, en los que se daban lectura a discursos, conferencias y poesías, todos de temática religiosa y sin música. Ocasionalmente (a menudo coincidiendo con días solemnes de índole religiosa o fiestas nacionales), la Juventud Católica ofreció veladas especiales con música, en los que el componente literario fue mayor que en las reuniones cotidianas de la sociedad, sobre todo si se trataba de un certamen poético en el que eran premiados los mejores trabajos presentados. Entre las lecturas solía intercalarse música, generalmente arreglos para piano y armonio de conocidas óperas italianas. Los músicos Julián Calvo, Ramírez y los hermanos Mondéjar fueron asiduos colaboradores en estos eventos ${ }^{389}$.

${ }^{386}$ La Paz de Murcia, XXXV (1892), nº 11776, 7 diciembre, p. 2.

${ }^{387}$ El Diario de Murcia, XV (1893), n ${ }^{\text {os }} 5942,27$ mayo, p. 2 y 5951, 8 junio, p. 2.

${ }^{388}$ La prensa se refirió a ella como academia científico-literaria. Se inauguró el 24 de febrero de 1870 y su sede estuvo ubicada en la calle del Conde, número 4 (actual calle de Lorenzo Pausa). Sus dos primeras reuniones se realizaron los días 19 y 20 de marzo de 1870. Algunos de sus ponentes fueron el catedrático Álvaro Landeira, Monreal, Diego García Alix, Antonio García Alix, Blanco y Chaumel, entre otros: La Paz de Murcia, XIII (1870), no 3831, 22 marzo, p. 1. Otras reuniones fueron descritas en: La Paz de Murcia: XIII (1870), $\mathrm{n}^{\mathrm{os}} 3858,23$ abril, p. 1; 3871, 8 mayo, p. 1; 3886, 26 mayo, p. 1; 3894, 5 junio, p. 1; 3908,23 junio, p. 1; 3910, 25 junio, p. 1; 4032, 1 diciembre, p. 1; 4047, 20 diciembre, p. 1 y XIV (1871), no 4100, 24 febrero, p. 1.

${ }^{389}$ El primer certamen poético tuvo lugar el 8 de diciembre de 1870 , en la fiesta de la Inmaculada. Se anunció en la prensa un mes antes para que los interesados en concursar (socios o no) pudieran enviar sus trabajos al secretario José Ferrer Céspedes. Se ofrecieron cinco premios: medalla de oro, dos medallas de plata y dos terceros premios. En esta ocasión, los músicos (que fueron socios académicos de la Juventud Católica) interpretaron diversas obras para piano y armonio, no especificadas en la prensa: La Paz de Murcia, XIII (1870), $\mathrm{n}^{\text {os }}$ 4041, 13 diciembre, p. 1; 4009, 3 noviembre, p. 1 y 4041, 13 diciembre, p. 1 . El 2 de mayo de 1871 la sociedad organizó una velada en la que se contó con los hermanos Mondéjar, que 
Aunque con menos frecuencia, la Juventud Católica también organizó conciertos con cantantes o instrumentistas célebres que se encontraban de paso por Murcia. Por ejemplo, el 26 de enero de 1872, tuvo lugar un concierto con el bajo italiano Emanuel Filibert y los músicos Ángel Mirete (violín), Julián Calvo (piano) y Antonio Santos (flauta). El repertorio interpretado incluyó arreglos de ópera de compositores como Verdi, Gounod, Flotow, Mazza y Mercadante con composiciones originales de Emanuel Filibert $\left(\right.$ ver Tabla 6.9) ${ }^{390}$.

Tabla 6. 9. Programa musical de la velada en los salones de la Juventud Católica (26-01-1872)

Fuentes: La Paz de Murcia, XV (1872), nos 4375, 20 enero, p. 1; 4477, 26 enero, p.4; 4478, 27 enero, p. 1.

\begin{tabular}{|c|l|l|}
\hline $\begin{array}{l}\text { Repertorio interpretado: } \\
\text { Compositor, título y movimientos } \\
\text { según fuente }\end{array}$ & $\begin{array}{l}\text { Intérpretes/lectores y/o agrupación } \\
\text { instrumental indicada en la fuente }\end{array}$ \\
\hline $\begin{array}{c}\text { Primera parte } \\
\text { Verdi, Sinfonía de Stiffelio para violín y } \\
\text { piano }\end{array}$ & Ángel Mirete (violín) y Julián Calvo (piano) \\
\hline $\begin{array}{c}\text { Verdi, Aria para bajo de la ópera Attila } \\
\text { Emanuel Filibert, "Romance Loin de } \\
\text { toi!" }\end{array}$ & $\begin{array}{l}\text { Emanuel Filibert (bajo) y Julián Calvo } \\
\text { (piano) }\end{array}$ & $\begin{array}{l}\text { Emanuel Filibert (bajo) y Julián Calvo } \\
\text { (piano) }\end{array}$ \\
\hline $\begin{array}{c}\text { Mercadante, "Nocturno para bajo Il } \\
\text { sogno" }\end{array}$ & $\begin{array}{l}\text { Emanuel Filibert (bajo), Ángel Mirete } \\
\text { (violín) y Julián Calvo (piano) }\end{array}$ \\
\hline $\begin{array}{c}\text { Segunda parte } \\
\text { Giuseppe Mazza, Sinfonía de de } \\
\text { Campanone para violín y piano }\end{array}$ & Ángel Mirete (violín) y Julián Calvo (piano) \\
\hline $\begin{array}{c}\text { Gounod, "Serenata para bajo de la } \\
\text { ópera Faust" }\end{array}$ & $\begin{array}{l}\text { Emanuel Filibert (bajo) y Julián Calvo } \\
\text { (piano) }\end{array}$ \\
\hline $\begin{array}{c}\text { Emanuel Filibert, "Nocturno Recuerdos } \\
\text { de Torcuato" }\end{array}$ & $\begin{array}{l}\text { Emanuel Filibert (bajo), Antonio Santos } \\
\text { (flauta) y Julián Calvo (piano) }\end{array}$ \\
\hline $\begin{array}{c}\text { Donizetti, "Aria de la ópera Lucrezia } \\
\text { Borgia para bajo y piano" }\end{array}$ & $\begin{array}{l}\text { Emanuel Filibert (bajo) y Julián Calvo } \\
\text { (piano) }\end{array}$ \\
\hline
\end{tabular}

\subsection{Las veladas musicales de la Real Sociedad Económica de Amigos del País (1881)}

La Real Sociedad Económica de Amigos del País no fue una sociedad de carácter musical aunque, ocasionalmente, cedió sus salones para veladas musicales. En abril de 1881, los músicos Julián Calvo, Antonio Ramírez y Mariano García organizaron una serie de conciertos con sus alumnos particulares, con la finalidad de estimular a los jóvenes a actuar para un público ${ }^{391}$. La Tabla 6.10 muestra los discípulos que tomaron parte en ellas.

interpretaron al piano y armonio un arreglo de la sinfonía de Campanone de Giuseppe Mazza y una romanza de Martha de Flotow. El acto terminó con la interpretación de un Himno a España de compositor no especificado: La Paz de Murcia, XIV (1871), n 4160, 7 mayo, p. 1.

${ }^{390}$ Emanuel Filibert había tomado parte en la función teatral del 13 de enero de 1872 junto a la compañía dramática de Francisco de Paula Gómez en el Teatro Romea, cantando un aria y una cavatina de las óperas Attila y Ernani, ambas de Verdi. El programa completo puede consultarse en: La Paz de Murcia, XV (1872), no 4367, 13 enero, p. 1 y la crítica en: La Paz de Murcia, XV (1872), nº 4369, 16 enero, p. 1.

${ }^{391}$ Los conciertos empezaron el 25 de abril de 1881: El Diario de Murcia, III (1881), nº 653, 23 abril, p. 3. Las veladas no fueron reseñadas críticamente por la prensa: "No nos creemos competentes para hacer 
Tabla 6. 10. Alumnos de Antonio Ramírez, Julián Calvo y Mariano García que tomaron parte en las veladas musicales de la Real Sociedad Económica de Amigos del País de Murcia (1881).

Fuentes: El Diario de Murcia, III (1881), $n^{\text {os }}$ 651, 21 abril, p. 2 y 652, 22 abril, p. 3.

\begin{tabular}{|c|c|c|c|}
\hline & \multicolumn{3}{|c|}{ Profesores } \\
\hline & Antonio Ramírez & Julián Calvo & Mariano García \\
\hline Alumnas & $\begin{array}{l}\text { señoritas } \\
\text { Llinaz }\end{array}$ & $\begin{array}{l}\text { Señoritas de Selgas y } \\
\text { Calvo, Encarnación } \\
\text { Álvarez, Patrocinio } \\
\text { Lario, María Fernández, } \\
\text { Fuensanta González y } \\
\text { Sacramento González }\end{array}$ & $\begin{array}{l}\text { Señoritas de Fernández } \\
\text { Rotenflué, Mazón, } \\
\text { Meseguer, Malvastre, } \\
\text { Tomas y Serrano. } \\
\text { Niñas: } \\
\text { Conchita Rodríguez, } \\
\text { Ángeles Plaza, Blanca } \\
\text { Marin Baldo, Guillerma } \\
\text { y Remedios ¿Ruiz?, } \\
\text { Isabel Navarro, Rosario } \\
\text { Valdes, raráa } \\
\text { Meseguer, Angustias } \\
\text { Cañadas, reresa } \\
\text { Gómez, Ángeles López } \\
\text { y Elisa Perea. }\end{array}$ \\
\hline Alumnos & $\begin{array}{lll}\text { hijos de } & \text { Gesuald } \\
\text { Piñeiro } & & \\
\end{array}$ & $\begin{array}{l}\text { Pedro Muñoz, Jesús } \\
\text { Amores, Juanito Selgas, } \\
\text { Antonio Alemán y } \\
\text { Enrique X, Antonio } \\
\text { Ruiz, alumnos de la } \\
\text { clase de Julián Calvo en } \\
\text { el colegio de Primera } \\
\text { Enseñanza de Miguel } \\
\text { Marco }\end{array}$ & $\begin{array}{l}\text { José María Pastor, } \\
\text { Antonio Miñano, } \\
\text { Antonio Lissón, José } \\
\text { Palazón, Luis Guerán y } \\
\text { Vicente Espada,Enrique } \\
\text { Visedo, Vicente Pastor, } \\
\text { Miguel Quetglas y } \\
\text { Pepito Verdú }\end{array}$ \\
\hline
\end{tabular}

\subsection{La música en las sociedades dramáticas Romea, Apolo, Amigos de Talía y Cervantes}

En la década de los ochenta existieron varias sociedades de carácter dramático cuya actividad consistió en dar representaciones teatrales a cargo de sus socios aficionados. En su mayoría fueron funciones con un repertorio de piezas teatrales no musicales (comedias, piezas en un acto y dramas, entre otros), aunque esporádicamente estas sociedades dieron representaciones de zarzuela y conciertos con músicos de paso por la ciudad.

La Sociedad Dramática Romea nació con esta finalidad a finales de marzo de 1882. Sus primeros directivos fueron Miguel López, Juan Antonio Soriano (reputado literato murciano y autor de varias obras teatrales) y Balboa y Carrillo ${ }^{392}$.

una crítica de la fiesta, ni creemos que es posible en su parte artística. [...] Por tanto, sólo nos creemos obligados a felicitar obligados a felicitar a ese plantel de artistas y sus reputados profesores": El Diario de Murcia, III (1881), $\mathrm{n}^{\circ}$ 656, 27 abril, pp. 2-3. Desconozco el programa de estos encuentros.

${ }^{392}$ La primera reunión de esta sociedad se celebró el 26 de marzo de 1882. En ella se aprobó el reglamento y se constituyó la Junta Directiva: El Diario de Murcia, IV (1882), nº 935, 28 marzo, p. 2. En diciembre de 1882, la sociedad Romea contaba con 35 socios: El Diario de Murcia, IV (1882), n 1159,19 diciembre, p. 3. 
La primera función teatral de la Sociedad Dramática Romea se celebró el 14 de mayo de 1882 en el teatro El Liceo. Las actrices Hernández, María Crespo y los actores Federico Martínez Terol, Enrique Salas, Balboa y Medina (entre otros) representaron el drama La mejor joya el honor y la comedia en un acto Me conviene esta mujer ${ }^{393}$. A finales del mismo mes, la sociedad ofreció una velada teatral junto al guitarrista Tárrega en $\mathrm{El} \mathrm{Liceo}{ }^{394}$. La sociedad estuvo establecida en "los bajos de la casa escuela", antigua casa de los condes de Clavijo, en la calle de las Capuchinas ${ }^{395}$. Durante el verano de 1882, la sociedad Romea emprendió la construcción de un teatro en su sede, conocido como teatro de la calle de las Capuchinas, que fue inaugurado el 13 de noviembre de $1882^{396}$. En él debió de tener lugar la función teatral que llevó a escena Levantar muertos y El hombre es débil, en enero de $1883^{397}$. Un mes más tarde, la prensa anunció que la Sociedad Dramática Romea se estaba reorganizando "en el mismo local"398, aunque la autorización del Gobernador no tuvo lugar hasta enero de $1884^{399}$. Durante los años 1884 y 1885, la sociedad Romea dio otras funciones teatrales (todas de teatro declamado), bailes de máscaras ${ }^{400}$ y un concierto de la familia Box a dos guitarras y bandurria ${ }^{401}$.

${ }^{393}$ El Diario de Murcia, IV (1882), no 963, 2 mayo, p. 3, El Diario de Murcia, IV (1882), nº 979, 16 mayo, p. 2 y La Paz de Murcia, XXV (1882), n 7343, 15 mayo, p. 1. Algunos de ellos, tenían experiencia teatral previa en diversos teatros murcianos de aficionados (como el mencionado Liceo o el de Saavedra Fajardo, entre otros).

${ }^{394}$ Los socios aficionados representaron las comedias Me conviene esta mujer y La mujer de Ulises. Las piezas musicales interpretadas por Tárrega no fueron mencionadas en la prensa: La Paz de Murcia, XXV (1882), n ${ }^{\circ} 7352,24$ mayo, p. 1.

${ }^{395}$ La Paz de Murcia, XXV (1882), ${ }^{\text {os }} 7400,3$ agosto, p. 1 y 7424, 14 noviembre, p. 1.

${ }^{396}$ La Paz de Murcia, XXV (1882), $\mathrm{n}^{\text {os }} 7399,2$ agosto, p. 1 y 7424, 14 noviembre, p. 1. No ha quedado constancia de las obras representadas. En el acto, se leyeron poesías de José Antonio Soriano, Hernández, García y Rubio. Véase también El Diario de Murcia, IV (1882), $\mathrm{n}^{\text {os }} 1131$, 16 noviembre, p. 3 y 1134, 19 noviembre, p. 3. El 17 de diciembre celebraron una nueva velada, representando Conflicto entre dos deberes, de Echegaray: El Diario de Murcia, IV (1882), nº 1159, 19 diciembre, p. 3.

${ }^{397}$ No se especifica el lugar: El Diario de Murcia, V (1883), nº 1074, 6 enero, p. 2.

398 "La sociedad dramática "Romea" se reunió anteayer, pero no acordó disolverse [...] sino reorganizarse nuevamente bajo distintas bases": La Paz de Murcia, XXVI (1883), nº 7566, 20 febrero, p. 1. En junio del año anterior, la prensa dio cuenta de ciertos "disgustos entre sus socios" lo que indica que hubo discrepancias entre sus miembros desde su fundación: El Diario de Murcia, IV (1882), nº 1012, 25 junio, p. 3. Véase también, La Paz de Murcia, XXVI (1883), n $\mathrm{n}^{\mathrm{0}} 7584,13$ junio, p. 1. Cabe suponer que la sociedad se dividiera en dos partes: una volvió a constituirse en sociedad Romea y la otra se formó una nueva sociedad (probablemente la Sociedad Dramática Amigos de Talía). La primera utilizó el teatro de la calle Capuchinas, mientras que la segunda usó el de la calle Administración, como veremos más adelante.

${ }^{399}$ El Diario de Murcia, VI (1884), nº 1471, 8 enero, p. 3.

${ }^{400}$ El Diario de Murcia, VI (1884), $\mathrm{n}^{\text {os }} 1475,12$ enero, p. 2 y 1482, 20 enero, p. 2; El Diario de Murcia, VI (1884), $\mathrm{n}^{\circ} 1516,29$ febrero, p. 3. La sociedad contaba con una compañía de niños dirigida por el profesor de párvulos José Hernández Molina. El 6 de mayo de 1884, los niños celebraron una velada en homenaje al diplomático algezareño Saavedra Fajardo en el teatro Romea junto al sexteto de músicos Arche y una estudiantina de Salamanca: El Diario de Murcia, VI (1884), no 1557, 20 abril, p. 3 y La Paz de Murcia, XXVII (1884), no 7912, 6 mayo, p. 1.Véanse más detalles en Crespo, Antiguos teatros, pp. 166173.

${ }^{401}$ La familia Box había actuado a finales del mes de septiembre de 1884 en el Teatro Circo de la Rambla, como traté en otro lugar. Según La Paz de Murcia, XXVII (1884), nº 8039, 9 octubre, p. 1, los concertistas regresaban de Archena población cercana a la capital murciana. Los días 9 y 12 de octubre de 1884 ofrecieron dos conciertos en el teatro de la sociedad Romea. En el segundo intervino el guitarrista murciano José Palazón. No ha quedado constancia de los programas interpretados: El Diario de Murcia, VI (1884), $\mathrm{n}^{\text {os }} 1700,8$ octubre, p. 1 y 1703,11 octubre, p. 2. 
En 1886, el teatro de la calle de Capuchinas había dejado de utilizarse ${ }^{402}$.

La Sociedad Dramática Apolo fue inaugurada el 1 de abril de 1883, con la misma sede que la Sociedad Dramática Romea: el "saloncito de la calle de Capuchinas"403. La sociedad programó una serie de nueve funciones que tendrían lugar los jueves y domingos de abril con una compañía de aficionados, cuyos actores fueron nombres ya conocidos de la Sociedad Dramática Romea.

En marzo de 1883, tras la nueva reorganización, la Sociedad Dramática Apolo acogió un concierto del barítono Rossi, que se hallaba de paso por la ciudad ${ }^{404}$. En abril de ese año, se programaron diversas representaciones teatrales a cargo de actores aficionados $^{405}$ y en el mes de septiembre actuó el guitarrista José Rivera (ver Capítulo 5). A mediados de octubre un grupo de socios ofrecieron una representación aunque ésta tuvo lugar en un teatro ubicado en la calle de la Administración (actual Vara de Rey). En el acto intervino un sexteto formado con músicos de la orquesta del Teatro Romea ${ }^{406}$.

Los socios que integraban la sociedad Amigos de Talía eran, como sus antecesores, aficionados al arte dramático. Contaron con un teatro situado en la calle de la Administración en el que se dieron diversas representaciones teatrales no musicales durante los años 1884 y $1885^{407}$. Es probable que este teatro fuese también utilizado por la sociedad Cervantes ${ }^{408}$.

${ }^{402}$ Así se confirma en La Paz de Murcia, XXIX (1886), n 8900, 20 abril, p. 1: "El teatrito de Romea de la calle de Capuchinas desapareció para convertirlo en un salón de baile y esto a su vez ha desaparecido para destinarlo a un taller".

${ }^{403}$ La coincidencia del local y algunos miembros comunes a ambas sociedades hacen pensar que fue a partir de la mencionada reorganización de la Sociedad Dramática Romea cuando algunos de sus miembros formaron la de Apolo, aunque ambas coexistieron por un breve espacio de tiempo. Esta última fue inaugurada con la representación de la comedia en dos actos El pilluelo de París y la comedia en uno Medias, suelas y tacones: La Paz de Murcia, XXVI (1883), n 7600, 1 abril, p. 1. Véase también: La Paz de Murcia, XXVI (1883), n ${ }^{\text {os }} 7602,4$ abril, p. 1; 7605, 7 abril, p. 1 y 7612, 15 abril, p. 1.

${ }^{404}$ Las obras interpretadas fueron: un aria de la ópera Lucia, Romanza de Un ballo in maschera, Sueño de Attila y la cavatina de L'elixir d'amore. Además, se interpretaron dos piezas en un acto. En su anuncio, consta que se vendieron entradas "en la relojería del señor Joubert, Platería, Plaza de Jufré y en la litografía del señor Arroniz, Trapería, esquina de la calle de Zambrana": El Diario de Murcia, V (1883), nº 1230, 18 marzo, p. 2. Es probable que este concierto fuera, por tanto, abierto al público.

${ }^{405}$ La compañía estuvo integrada por María Crespo, Dolores Martínez y Federico Martínez Terol (también miembros de la Sociedad Dramática Romea), además de Ana Olier, Concepción Molina, Soledad Molina, Enrique Salas, Juan Moreno, Andrés Bolarín, Manuel Ramos, Mariano Guillén, Mariano Leal y Serafín Molina. Las obras representadas fueron: Despertar en la sombra, Amor de madre, Ángel, El lobo marino, Otro gallo le cantara, Flores y perlas, La levita y La mejor joya el honor: La Paz de Murcia, XXVI (1883), $\mathrm{n}^{\mathrm{0}} 7602,4$ abril, p. 1. Las reseñas sobre estas funciones pueden consultarse en: La Paz de Murcia, XXVI (1883), n ${ }^{\text {os }} 7605,7$ abril, p. 1; 7612, 15 abril, p. 1; 7643, 5 junio, p. 1; 7645, 7 junio, p. 1 y 7684, 24 julio, p. 1; El Diario de Murcia, V (1883), n ${ }^{\text {os }} 1245,8$ abril, p. 3; 1251, 15 abril, p. 3; 1257, 22 abril, p. 3 y 1291, 3 junio, p. 3.

${ }^{406}$ La Paz de Murcia, XXVI (1883), nº 7766, 9 noviembre, p. 1. Desconozco la trayectoria posterior de la sociedad.

407 El Diario de Murcia, VI (1884), n $\mathrm{n}^{\mathrm{0}}$ 1507, 19 febrero, p. 2. En ella se mencionan a los actores Codorniu, Balsalobre y Albaladejo. Durante el mes de marzo y abril se celebraron tres sesiones. No ha quedado constancia de las obras interpretadas en la primera (9-03-1884): La Paz de Murcia, XXVII (1884), $\mathrm{n}^{\mathrm{o}}$ 7866, 11 marzo, p. 1. En la segunda (30-03-1884), a beneficio de la Casa de Misericordia y huérfanos de la ciudad, se representó Viva la libertad (comedia en verso en tres actos) y Salvarse en una tabla (pieza en un acto y prosa): La Paz de Murcia, XXVII (1884), n 7877, 25 marzo, p. 1 y El Diario de Murcia, VI (1884), $\mathrm{n}^{\circ}$ 1538, 27 marzo, p. 3. Las mismas obras fueron representadas el 3-04-1884: La Paz de Murcia, 


\subsection{La música en las sociedades del barrio del Carmen Amigos del Progreso (1886-1888) y Amigos del Porvenir (1886-1889)}

En el barrio del Carmen, al otro lado del río Segura, estuvieron ubicadas dos importantes sociedades de carácter dramático: los Amigos del Progreso (1886-1888) y los Amigos del Porvenir (1886-1889) ${ }^{409}$. Ambas sociedades contaron con un teatro propio, denominados respectivamente Progreso y Porvenir, en los que desfilaron compañías de aficionados y también compañías profesionales procedentes de otros teatros de la ciudad.

La sociedad Amigos del Progreso existía ya en febrero de $1886^{410}$ y sus socios eran en gran parte artesanos y obreros ${ }^{411}$. A principios de junio de 1886 la sociedad inauguró un teatro de verano "al final de la calle de Cartagena" "412 (ver Figura 6.14), que reunió condiciones idóneas para épocas estivales "pues como está cubierto con un toldo de lona, se disfruta de fresco y no molesta el relente. Su cabida es de unas 400 personas, está bien decorado y tiene buen alumbrado" ${ }^{413}$. Sus localidades estaban repartidas entre sillas y catorce palcos con cuatro, cinco o seis asientos. Hasta diciembre de 1886 se denominaba "Teatro del Barrio" y después "Teatro del Progreso".

A mediados de junio de 1886 se formó una compañía en el seno de la sociedad Amigos del Progreso compuesta de socios aficionados y "y otros que tienen ya larga práctica y conocimientos especiales en el arte dramático"414. La compañía dio funciones con obras teatrales no musicales entre junio y septiembre de $1886^{415}$ y ocasionalmente algunos músicos amenizaban los intermedios. Por ejemplo, la función del 7 de julio de 1886, que formó parte de los eventos festivos por la Virgen del Carmen, los músicos

XXVII (1884), $\mathrm{n}^{\text {os }}$ 7884, 2 abril, p. 4 y 7885, 3 abril, p. 1. Véanse más detalles en Crespo, Antiguos teatros, pp. 258-259.

${ }^{408}$ Las escasas noticias sobre la Sociedad Cervantes datan de octubre de 1885 y en ellas se informa de dos veladas en las que se representaron obras teatrales no musicales: La Paz de Murcia, XXVIII (1885), $\mathrm{n}^{\circ}$ 8348, 20 octubre, p. 1. Véanse más detalles en Crespo, Antiguos teatros, p. 259.

${ }^{409}$ El barrio del Carmen está situado al sur de la ciudad de Murcia y a él se accede atravesando el Puente de los Peligros o Puente Viejo. En el siglo XIX también era conocido como el Barrio de San Benito o simplemente "El Barrio". El Barrio del Carmen experimentó un notable crecimiento urbano durante la segunda mitad del siglo XIX como zona de ensanche de la ciudad e importante núcleo industrial gracias a la llegada del ferrocarril a Murcia en 1862. Las denominaciones de las sociedades Amigos del Progreso y Amigos del Porvenir transmiten la idea de adelanto futuro, probablemente en referencia al desarrollo que experimentó este barrio en los años ochenta del siglo XIX.

410 Según Crespo, Antiguos teatros, p. 178 esta sociedad se reorganizó, aunque no ha quedado constancia de su predecesora. En febrero de 1886 era presidente de la sociedad Amigos del Progreso Hernández Ardieta. Sus primeras actividades fueron una serie de conferencias: La Paz de Murcia, XXIX (1886), $\mathrm{n}^{\mathrm{o}} 8456,25$ febrero, p. 1.

${ }^{411}$ La Paz de Murcia, XXIX (1886), nº 8941, 9 junio, p. 1.

${ }^{412}$ La Paz de Murcia, XXIX (1886), nº 8938, 5 junio, p. 1. El anuncio informaba de la representación del drama Flores y perlas.

${ }^{413}$ La Paz de Murcia, XXIX (1886), nº 8941, 9 junio, p. 1.

${ }^{414}$ El Diario de Murcia, VIII (1886), n ${ }^{\circ}$ 2184, 18 junio, p. 3. La lista de sus integrantes se publicó en La Paz de Murcia, XXIX (1886), nº 8946, 16 junio, pp. 1, 4.

${ }^{415}$ Véase más detalles de las actuaciones de esa compañías en Crespo, Antiguos teatros, pp. 179-180. 
Guillermo López (acordeón), Salvador Illán (guitarra) y Mariano Sanz (guitarra) interpretaron un "Vals alemán", el "Dueto de Betina y Pippo del primer acto de La mascota", una pieza denominada "Completo", la mazurca Mercedes, el Vals de Mereyna, otro vals y un pasodoble ${ }^{416}$.

Dado que el Teatro del Barrio (o Progreso) era un teatro de verano, a mediados de octubre de 1886 se emprendieron obras "de cubierta, ensanche y decorado de su teatro" con la finalidad de adaptarlo para las temporadas de invierno ${ }^{417}$. A finales de noviembre la obra había avanzado: "la cubierta está colocada. Están hechos los pisos de la galería y palcos. El patio está preparado para recibir el tablazón y todo ofrece que aquel local quede muy cómodo, abrigado y con mayor cabida para las funciones que han de dar en este invierno" "418. El Teatro del Barrio se reabrió el 8 de diciembre de $1886^{419}$. La prensa acogió muy favorablemente la apertura del Teatro del Progreso y pronosticó éxito en sus programaciones, aunque también se advirtió una limitada capacidad:

Hemos visitado otra vez el Teatro del Barrio y sólo le hemos encontrado un defecto: el de ser pequeño, pues presentimos que dadas las condiciones de comodidad y de abrigo en que ha quedado y la de precios económicos que han de regir, la distancia que entre él y el de Romea existe y la creciente extensión que el barrio va alcanzando, nos parece que si no ahora, no ha de tardar mucho el que sea pequeño aquel local y que la empresa que la levanta se vea obligada a otras exigencias que hoy no tiene. Este teatro, si sigue bien dirigido y al público se le complace, ha de tener vida, como la tienen otros secundarios que hay en otras poblaciones sin perjuicio del principal, puesto que recogen un público que va atraído por lo cerca y por la economía del espectáculo, y que no concurre a diario ni mucho menos al teatro principal que aquí es el de Romea ${ }^{420}$.

Tal y como se pone de manifiesto en este párrafo, los precios de las entradas en este tipo de teatros secundarios eran la clave para que permanecieran abiertos. Las localidades eran competitivas porque los actores no eran profesionales y los gastos de representación eran muy inferiores a los grandes teatros de la ciudad, como el Romea. La actividad escénica del Teatro del Progreso se prolongó desde su apertura hasta marzo de 1887 y desde julio de 1887 hasta julio de $1888^{421}$ y, de forma complementaria, también acogió bailes de sociedad ${ }^{422}$. Todas las representaciones fueron de teatro no musical, salvo dos funciones a cargo de la compañía de zarzuela de Gaspar Galinier en los días 28

${ }^{416}$ Sacar El Diario de Murcia, VIII (1886), no 2201, 9 julio, p. 3. Véase otro ejemplo de funciones con intermedios musicales en El Diario de Murcia, VIII (1886), n 2233, 15 agosto, p. 3, en la que intervino una orquesta de guitarras y bandurrias.

${ }^{417}$ El Diario de Murcia, VIII (1886), n 2824, 15 octubre, p. 3.

${ }^{418}$ La Paz de Murcia, XXIX (1886), no 9055, 30 noviembre, p. 1.

${ }^{419}$ Las obras llevadas a escena durante este mes han sido descritas por Crespo, Antiguos teatros, pp. 181-182.

${ }^{420}$ La Paz de Murcia, XXIX (1886), no 9061, 7 diciembre, p. 1.

${ }^{421}$ Véanse más detalles en Crespo, Antiguos teatros, pp. 182-183. En abril de 1888 se estrenó la comedia del murciano Antonio Rubio, Una venganza frustrada, a cargo de la compañía de Federico Martínez Terol, futuro dueño del Teatro del Progreso: La Paz de Murcia, XXXI (1888), nº 9479, 14 abril, p. 1.

${ }^{422}$ Crespo, Antiguos teatros, pp. 184-186. 
y 29 de enero de $1888^{423}$, cuyos actores (entre ellos el tenor murciano Mariano Blaya) venían de actuar en otros teatros murcianos (Teatro Romea y Teatro del Porvenir). La compañía de Galinier llevó a escena El juramento, de Gaztambide y Olona en dos funciones de tarde y noche, la zarzuela de Roger El joven Telémaco y la zarzuela en un acto Un capitán de lanceros, de Isidoro Hernández con libreto de José Mota González ${ }^{424}$.

En septiembre de 1888, el Teatro del Progreso fue adquirido por Federico Martínez Terol y en adelante, este coliseo pasó a llamarse Teatro Terol ${ }^{425}$. Hasta $1891 \mathrm{el}$ Teatro Terol acogió representaciones teatrales y en ese año se puso a la venta ${ }^{426}$.

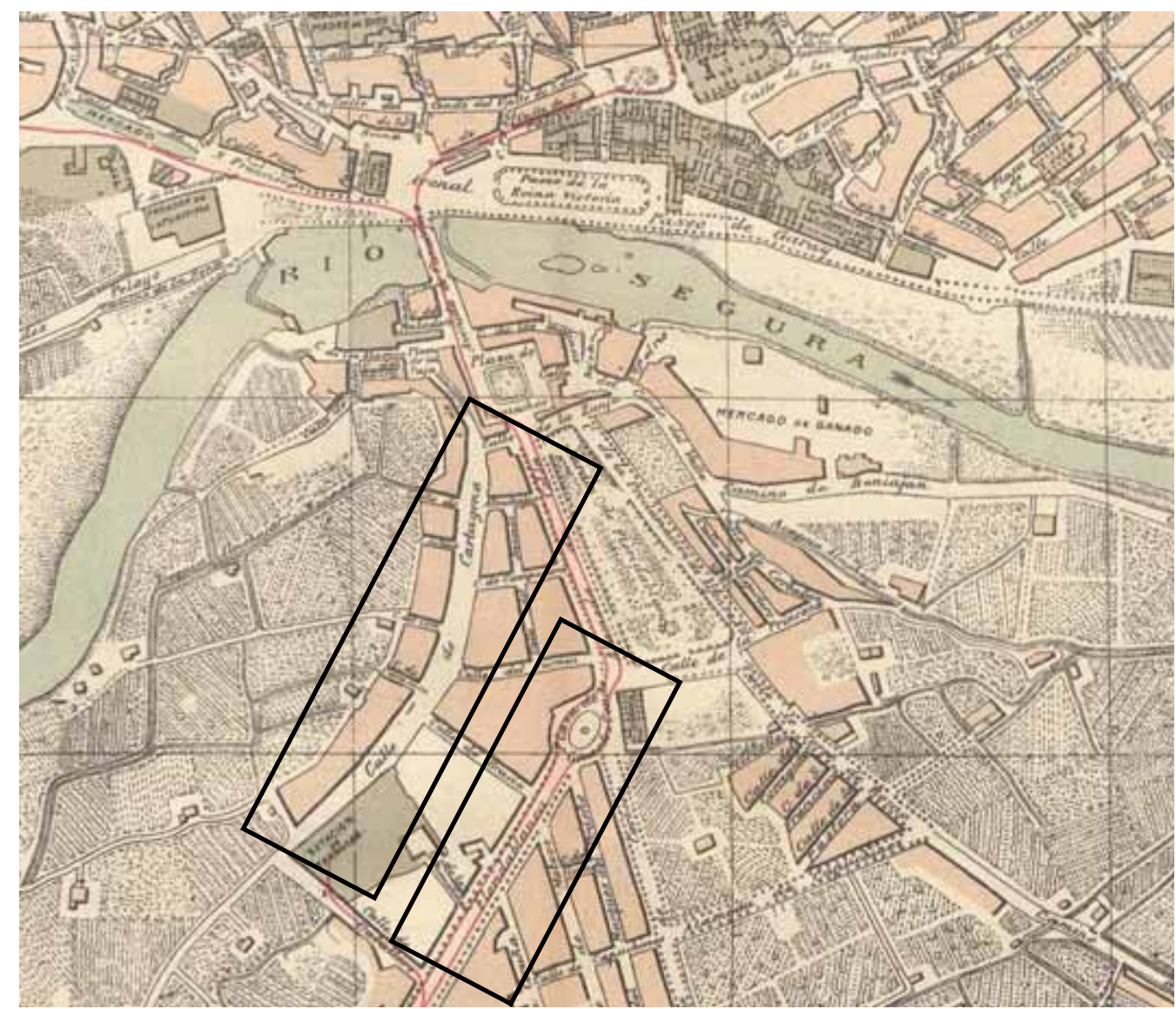

Figura 6. 14. Calle Cartagena (izquierda) y calle de Floridablanca (derecha), en el barrio del Carmen de Murcia. En la esquina superior derecha la Catedral de Murcia, al otro lado del Río Segura.

Pedro García Faria, Plano de Murcia (Barcelona: Alberto Martín, s.a.). E:Mpb. Accesible en: http://bibliotecadigital.carm.es (acceso el 16-07-2011).

La sociedad Amigos del Porvenir fue creada en $1886^{427}$ y en octubre del mismo año se propusieron "hacer un bonito y elegante coliseo que honre y sea digno de la cultura

\footnotetext{
${ }^{423}$ Véase La Paz de Murcia, XXXI (1888), n 9402, 13 enero, p. 1.

${ }^{424}$ La Paz de Murcia, XXXI (1888), nos 9414, 27 enero, p. 4 y 9416, 29 enero, p. 4.

${ }^{425}$ La Paz de Murcia, XXXI (1888), nº 9628, 12 octubre, p. 4 y 9707, 7 diciembre, p. 1.

${ }^{426}$ Crespo, Antiguos teatros, p. 189.
}

${ }^{427} \mathrm{Su}$ reglamento fue aprobado por el Gobernador Civil de la Provincia en octubre de 1886. La sociedad Amigos del Porvenir tenía como presidente honorario a Francisco Barnés Herández (apodado Sevilla y dueño del Café Sevilla) y como presidente efectivo a Juan Ramírez: El Diario de Murcia, VIII 
de su barrio" ${ }^{428}$. El Teatro del Porvenir estuvo ubicado en la calle de Floridablanca del barrio del Carmen (ver Figura 6.14), fue inaugurado el 26 de junio de $1887^{429}$ y tenía capacidad para seiscientas localidades repartidas entre butacas, palcos y gradas:

Es de admirar que en el próximo pasado febrero no existía nada y anoche se exhibía un local sólidamente construido, elegantemente decorado, con profesión de luces de gas y dispuesto a dar cabida cómodamente en sus gradas, palcos y butacas a unas seiscientas personas próximamente.

El escenario es bastante espacioso. Tiene cinco decoraciones de todo juego y algunos trastos especiales para determinadas obras.

El telón de boca es un bonito cuadro murciano. En primer término, la característica cortina y, en el fondo, la conocida fachada del Carmen, adornada con las frondosas copas de los primeros árboles de nuestra vega.

Lo mismo en el salón que en el escenario se manifiesta la finura y buen gusto con que el señor don Agustín González maneja los pinceles ${ }^{430}$.

La apertura del Teatro del Porvenir se vivió con cierto escepticismo. Por una parte se consideró apropiado "dotar [a la Sociedad Amigos del Porvenir] de un local decente donde se puedan presenciar espectáculos de los que deleiten a la vez que civilizan o instruyen" "431; por otra, se temía que la competencia con el Teatro de los Amigos del Progreso hiciera disminuir la afluencia de público a ambos teatros:

[...] Sólo sentimos, y lo decimos ahora que no se puede creer que tratamos de influir en ningún sentido, que entre esa sociedad y la de "Amigos del Progreso" no haya habido, o no se haya intentado que la hubiera, una inteligencia, pues creemos que dos teatros tan próximos no han de poder vivir y nos duele, sea por quien son, ver infructuosos los sacrificios que se hagan a favor del público. Aunados ambos esfuerzos aún podría haberse hecho algo más sin perjuicio, que creemos lo habrá, de nadie.

Mas siendo un hecho, debemos tomarlo tal como es y hacer nuestros los brindis en la parte que a la posteridad de aquel centro de recreo se refieran, felicitando desde luego a su pintor escenógrafo y encargado de la parte decorativa del local nuestro amigo don Agustín González, por lo satisfactoriamente que ha cumplido con la confianza que en él depositara la sociedad. $[\ldots]^{432}$.

(1886), n n $^{\text {2832, }} 24$ octubre, p. 3. En La Paz de Murcia, XXIX (1886), $\mathrm{n}^{\text {os }} 8442,9$ febrero, p. 1 y 8446, 13 febrero, p. 1 se menciona la participación de una sociedad denominada El Porvenir en una función benéfica celebrada en el Teatro Romea el 11 de febrero de 1886 de la que se deduce que esa sociedad era, en realidad, una "nueva orquesta de guitarras y bandurrias compuesta de jóvenes aficionados de esta capital". En la crítica sobre el evento se escribió: "La sociedad El Porvenir fue muy aplaudida, lo cual esperábamos, tuvo que añadir una pieza más para complacer al público que quedó muy satisfecho de la unidad, afinación y buen gusto con que ejecutó todas [las piezas] en las populares bandurrias y guitarras". La orquesta de guitarras y bandurrias fue dirigida por Manuel Alarcón Buendía: La Paz de Murcia, XXIX (1886), n 8972, 20 julio, p. 1. Desconozco si tuvo relación con los Amigos del Porvenir, aunque es razonable pensar que esta orquesta pudiera crearse en el seno de esa sociedad.

${ }^{428}$ El Diario de Murcia, VIII (1886), nº 2832, 24 octubre, p. 3.

${ }^{429}$ Probablemente también fue la sede de la sociedad: La Paz de Murcia, XXX (1887), nº 8240, 26 junio, p. 1. La inauguración fue relatada en La Paz de Murcia, XXX (1887), nº 8241, 28 junio, p. 1.

${ }^{430}$ J.S., “Apertura del Teatro del Porvenir”, El Diario de Murcia, IX (1887), n 3035, 28 junio, p. 2.

${ }^{431}$ La Paz de Murcia, XXX (1887), nº 8241, 28 junio, p. 1

${ }^{432}$ La Paz de Murcia, XXX (1887), nº 8241, 28 junio, p. 1 
Dos días después de la apertura del Teatro del Porvenir, se abrió un abono de ocho funciones de teatro declamado con la compañía de Manuel Sánchez Orihuela ${ }^{433}$ y a finales de julio de 1887, se contrató a la compañía de zarzuela cómica de Gaspar Galinier y Federico Montañés para seis funciones en las que se representaron: Picio, Adán y compañía (Carlos Mangiagalli música y Rafael María Liern libreto), Ya somos tres (Ángel Rubio y Pina), Salón Eslava (Joaquín Valverde y Calixto Navarro) en dos ocasiones, Sensitiva (Aceves y Pina), Torear por lo fino (Isidoro Hernández y Francisco Macarro), La gallina ciega (Fernández Caballero y Ramos Carrión), Don Sisenando (Oudrid y Juan de la Puerta), Marina (Emilio Arrieta y Camprodón), La cola del diablo (Oudrid y Luis de Olona), La calandria (Chapí y Ramón Carrión y Vital Aza), Un par de lilas (Carlos Mangiagalli y Rafael Liern), El lucero del alba (Fernández Caballero y Mariano Pina) y Casado y soltero (Gaztambide y Olona) ${ }^{434}$.

En septiembre de 1887 el Teatro del Porvenir fue arrendado por seis meses al empresario Ginés Frías que volvió a contratar a la compañía de Galinier (aunque con un elenco diferente de actores) para dar funciones por horas ${ }^{435}$. Además, se estableció un servicio de carruajes que llevaba a los espectadores desde la plaza de Belluga, en el centro de la ciudad, hasta el Teatro del Porvenir ${ }^{436}$ con el fin de facilitar a los concurrentes el acceso al teatro. Es preciso recordar que entonces estaban funcionando en Murcia, además del Teatro Porvenir, el Teatro Romea y el Teatro Progreso, entre otros salones teatrales.

La compañía de Galinier debutó por segunda vez el 21 de octubre de 1887 y sus actuaciones se prolongaron hasta el 19 de enero de 1888. En octubre y noviembre de 1887 los cantantes eran acompañados por un piano y un armonio y desde mediados de noviembre en adelante se contrató a una orquesta que fue dirigida por los murcianos Francisco Fresneda y Juan Ayala ${ }^{437}$.

${ }^{433}$ Sus precios se anunciaron en: La Paz de Murcia, XXX (1887), nº 8242, 29 junio, p. 1. Sobre estas representaciones véase: La Paz de Murcia, XXX (1887), $\mathrm{n}^{\text {os }} 8243,1$ julio, p. 1; 8239, 7 julio, p. 4; 8252, 17 julio, p. 1 y Crespo, Antiguos teatros, pp. 190-192.

${ }^{434}$ La Paz de Murcia, XXX (1887), nº 8240, 27 junio, p. 4. El elenco apareció en La Paz de Murcia, XXX (1887), $\mathrm{n}^{\mathrm{o}} 8263,30$ julio, p. 1 (ver Apéndice 6.14). Véanse las representaciones en: La Paz de Murcia, XXX (1887), nº 8264, 31 julio, p. 1.

${ }^{435}$ La Paz de Murcia, XXX (1887), nº 9241, 28 septiembre, p. 1. Los nuevos cantantes eran Enriqueta Pastor, Encarnación Guerrero y Manuel Gutiérrez. El elenco apareció en El Diario de Murcia, IX (1887), $\mathrm{n}^{\circ}$ 3125, 13 octubre, p. 3 (ver Apéndice 6.14). Las dos primeras funciones de la compañía de Galinier (días 21 y 22 de octubre de 1887) fueron por horas. Sin embargo, tras esas representaciones la compañía suprimió las funciones por horas: "La empresa del Teatro Amigos del Porvenir (calle de Floridablanca) ha visto prácticamente lo difícil que se hace el planteamiento de los espectáculos por horas, principalmente por las condiciones arquitectónicas del edificio": La Paz de Murcia, XXX (1887), nº 9264, 26 octubre, p. 1. Cabe suponer que el edificio no permitiera las entradas y salidas del público con agilidad entre las representaciones de zarzuelas por horas.

${ }^{436}$ El Diario de Murcia, IX (1887), nº 3136, 26 octubre, p. 3.

437 La Paz de Murcia, XXX (1887), n $\mathrm{n}^{\circ}$ 8283, 13 noviembre, p. 1. Otro de los cambios fue la incorporación de los cantantes Matilde Gallardo, Dolores Labayen, Julián Zavala y el tenor murciano Mariano Blaya: La Paz de Murcia, XXX (1887), n 8289, 20 noviembre, p. 1. Todos habían actuado en julio de 1887. Pocos días después, se publicó en prensa: "Por ser mayores los gastos por el aumento de personal en la compañía de zarzuela que actúa en el Teatro del Porvenir, se han subido, aunque poco, los precios de la entrada y localidades, siendo estos los siguientes: Plateas sin entrada, 4 pesetas. Butacas con ídem, 1.25. silla con ídem, 85 céntimos. Delantera de baranda con ídem, 65 céntimos. Entrada general, 50 céntimos": La Paz de Murcia, XXX (1887), n 8292, 24 noviembre, p. 1. 
Puntualmente, la compañía de Galinier trabajó simultáneamente en los teatros Porvenir y Romea (véase Apéndice 6.15) ${ }^{438}$, llevando a cabo representaciones de zarzuela del moderno y del antiguo repertorio ${ }^{439}$. Los títulos llevados a escena (según Crespo, 45 obras diferentes en 142 jornadas $^{440}$ ) fueron casi todas piezas en un acto y el compositor más representado fue Barbieri, como se muestra en la Tabla 6.11.

Tabla 6. 11. Zarzuelas representadas por la compañía de Galinier en el Teatro del Porvenir entre julio de 1887 y enero de 1888 .

Las fuentes pueden consultarse en el Apéndice 6.15.

\begin{tabular}{|c|c|c|}
\hline Compositor/es & $\begin{array}{l}\mathrm{N}^{0} \text { total de } \\
\text { representaciones }\end{array}$ & Zarzuela/s representada/s \\
\hline Aceves, Rafael & 1 & Sensitiva \\
\hline Arche, Luis Vicente & 4 & Don Pompeyo en Carnaval \\
\hline Arrieta, Emilio & 1 & Marina \\
\hline \multirow{8}{*}{\begin{tabular}{lr} 
[Asenjo] & \multicolumn{2}{r}{ Barbieri, } \\
Francisco de Asís \\
Esteban
\end{tabular}} & 3 & Un caballero particular \\
\hline & 2 & El relámpago \\
\hline & 1 & Aristas para la Habana \\
\hline & 2 & El barberillo de Lavapiés \\
\hline & 3 & El hombre es débil \\
\hline & 5 & Los carboneros \\
\hline & 3 & Entre mi mujer y el negro \\
\hline & 2 & Robinson \\
\hline Cereceda, Guillero & 1 & Para una modista un sastres \\
\hline \multirow[t]{2}{*}{ Chapí, Ruperto } & 6 & Música clásica \\
\hline & 1 & La calandria \\
\hline \multirow{2}{*}{$\begin{array}{l}\text { Fernández Caballero, } \\
\text { Manuel }\end{array}$} & 7 & El lucero del alba \\
\hline & 3 & La gallina ciega \\
\hline \multirow[t]{3}{*}{ Gaztambide, Joaquín } & 5 & Un pleito \\
\hline & 2 & En las astas del toro \\
\hline & 4 & Casado y soltero \\
\hline \multirow[t]{2}{*}{ Hernández, Isidoro } & 3 & Torear por lo fino \\
\hline & 5 & Un capitán de Lanceros \\
\hline Lecocq, Charles & 2 & El barón de la castaña \\
\hline \multirow[t]{3}{*}{ Mangiagalli, Carlos } & 3 & I comici tronati \\
\hline & 4 & Picio, Adán y compañía \\
\hline & 6 & Un par de lilas \\
\hline Molberg, Juan & 2 & La colegiala \\
\hline \multirow[t]{2}{*}{ Nieto, Manuel } & 2 & C. de L. \\
\hline & 4 & Fuego en guerrillas \\
\hline Offenbach & 4 & Los estanqueros aéreos \\
\hline \multirow[t]{5}{*}{ Oudrid, Cristóbal } & 4 & La cola del diablo \\
\hline & 3 & Nadie se muere hasta que Dios quiere \\
\hline & 3 & Don Sisenando \\
\hline & 2 & Buenas noches, señor don Simón \\
\hline & 2 & El postillón de la Rioja \\
\hline \multirow[t]{2}{*}{ Roger, José } & 1 & Las tres marías \\
\hline & 1 & El último figurín \\
\hline
\end{tabular}

${ }^{438}$ La Paz de Murcia, XXX (1887), nº 8304, 10 diciembre, p. 1.

439 “Además de La marsellesa se están ensayando en el Teatro del Porvenir para ponerlas en escena a la mayor brevedad algunas de las buenas zarzuelas del repertorio antiguo": La Paz de Murcia, XXXI (1888), no 9396, 5 enero, p. 1.

${ }^{440}$ Crespo, Antiguos teatros, pp. 199-200. 


\begin{tabular}{|l|l|l|}
\hline Romea, Valverde & 1 & Niña pancha \\
\hline Rubio, Ángel & 3 & $\begin{array}{l}\text { La salsa de Aniceta } \\
\text { iYa somos tres! }\end{array}$ \\
\hline $\begin{array}{l}\text { Soriano Fuertes, } \\
\text { Mariano }\end{array}$ & 1 & El Tío Caniyitas \\
\hline Valverde, Joaquín & 8 & Salón Eslava \\
\hline \multirow{2}{*}{ Otras } & 2 & Don Jacinto \\
\cline { 2 - 3 } & 1 & \begin{tabular}{l} 
La doña Inés fingida o Las esculturas \\
de carne \\
\cline { 2 - 3 }
\end{tabular} \\
\cline { 2 - 3 } & 1 & Pancho y mendrugo \\
\hline
\end{tabular}

El listado de zarzuelas llevadas a escena no difiere en exceso del representado en otros teatros de la ciudad, como por ejemplo el Teatro Romea (ver Capítulo 3). Destaca la representación de El Tío Caniyitas del murciano Mariano Soriano Fuertes, que no había sido representada en Murcia desde octubre de $1851^{441}$.

Las críticas a la compañía fueron en general buenas, a pesar de que algunas obras no eran aptas para un pequeño teatro: "La representación de El Tío Caniyitas en el Teatro del Porvenir no ha satisfecho. Es preciso convencerse de que no todas las obras son para todos los teatros ni para todos los actores "442. Al margen de las zarzuelas representadas y de forma excepcional (casi siempre en las funciones "a beneficio de") se interpretaron piezas como el Ave María (no consta autor) o la canción andaluza Las ventas de Cárdenas. A mediados de enero de 1888 la compañía Galinier se disolvió ${ }^{443}$ y el Teatro Porvenir no registró más representaciones teatrales musicales. Las últimas noticias publicadas sobre el Teatro del Porvenir datan de julio de $1889^{444}$.

\subsection{El Círculo Católico Obrero (1891-1900)}

La sociedad Círculo Católico Obrero (o Círculo Católico de Obreros), fundada en noviembre de 1891, se creó por iniciativa de Eduardo Martínez Balsalobre y Antonio Munera Martínez para dotar a la ciudad de Murcia de "un centro de recreo y de enseñanza para facilitar uno y otra sin mezcla de nada político, ni que sea contrario a la religión, a la moral y a las buenas costumbres" $" 445$. El Círculo Católico Obrero tenía tres clases de socios: los "protectores" abonaban las mayores cantidades de dinero, los "de número" pagaban una cuota mensual de una peseta y los socios "matriculados" podían beneficiarse de las clases y actividades que la sociedad programaba sin pagar la cuota mensual:

[...] Como se ve, las clases desheredadas, las que no pueden concurrir hoy más que a sitios inconvenientes por muchos conceptos, pueden tener un centro lícito y conveniente donde encuentren esparcimiento y enseñanzas útiles y el de que las enseñanzas todas han de esta basadas en la religión católica y que allí se ha de huir de

${ }^{441}$ Véase, Clares, "La música teatral".

${ }^{442}$ La Paz de Murcia, XXXI (1888), no 9398, 8 enero, p. 1.

${ }^{443}$ La Paz de Murcia, XXXI (1888), nº 9399, 10 enero, p. 1.

${ }^{444}$ Véanse más detalles sobre las funciones que acogió este teatro desde enero de 1888 hasta julio de 1889 en Crespo, Antiguos teatros, pp. 201-202.

${ }^{445}$ La Paz de Murcia, XXXIV (1891), n 11469, 2 noviembre, p. 2. La primera reunión tuvo lugar en la sede de la Real Sociedad Económica de Murcia. 
todo lo que a política se parezca y a nadie se le ha de preguntar en qué partido está afiliado, es indudable la conveniencia de la creación de este centro, que a pesar de los muchos que hay, llenará un vació que aquellos no cubren ${ }^{446}$.

Durante el mes de enero de 1892 el Círculo CAtólico adquirió un local y se nombraron distintas comisiones ("de ornato", "de enseñanza", "de mobiliario" y "de inauguración”) para acondicionar su sede con los elementos necesarios ${ }^{447}$.

Las clases y las conferencias del Círculo Católico Obrero comenzaron poco después de su fundación ${ }^{448}$ y desde entonces organizó numerosas veladas literarias en las que ocasionalmente se incluyeron números musicales. En junio 1892, por ejemplo, se organizó un concierto para la festividad del Corpus en los salones del Círculo Católico, cuyo programa se muestra en la Tabla 6.12 .

Tabla 6. 12. Programa musical de la velada en el Círculo Católico Obrero de Murcia (14-06-1892) La Paz de Murcia, XXXV (1892), nº 11633, 15 junio, p. 1.

\begin{tabular}{|c|c|}
\hline $\begin{array}{l}\text { Repertorio interpretado: } \\
\text { Compositor, título y movimientos según } \\
\text { fuente }\end{array}$ & $\begin{array}{l}\text { Intérpretes/lectores y/o agrupación } \\
\text { instrumental indicada en la fuente }\end{array}$ \\
\hline Alarcón (música) y Tolosa (texto), Himno & Coro de obreros \\
\hline Discurso & Pedro L. Balanza \\
\hline Verdi, "Aria de Don Carlo" & $\begin{array}{l}\text { Yarza (bajo) y Mariano Marín } \\
\text { (piano) }\end{array}$ \\
\hline Lecturas de poesía & Virgilio Guirao, Tolosa Hernández \\
\hline Weber, Gran concert & Enrique Martí (piano) \\
\hline Apólogo La adelfa y la mariposa & Miguel Gazque Llopis \\
\hline Soneto Naturalismo & Gerardo Vicente Selgas \\
\hline [¿Miguel?] Barrera, Romanza Desdenes & $\begin{array}{l}\text { Rafael Rex Torrano (tenor) y } \\
\text { Mariano Marín (piano) }\end{array}$ \\
\hline Balada El alma de sus amores & Antonio Acalde Valladares \\
\hline Poesía de José Selgas & Virgilio Guirao \\
\hline $\begin{array}{l}\text { A un sectario arrepentido, soneto de Virgilio } \\
\text { Guirao }\end{array}$ & Virgilio Guirao \\
\hline Mendelssohn, Caprice brillant & Enrique Martí (piano) \\
\hline Godard, Vals cromatique & Enrique Martí (piano) \\
\hline $\begin{array}{l}\text { En la cueva de la Mauta, poesía de Antonio } \\
\text { Osete }\end{array}$ & Antonio Osete \\
\hline Soneto Humorismo de Vicente Selgas & Juan García Clemente \\
\hline Tosti, Povera mamma!! & Yarza y Mariano Marín (piano) \\
\hline Verdi, Cavatina de Ernani & Yarza [¿y Mariano Marín, piano?] \\
\hline Discurso & Benigno Díez Sanz \\
\hline Alarcón (música) y Tolosa (texto), Himno & Coro de obreros \\
\hline
\end{tabular}

${ }^{446}$ La Paz de Murcia, XXXIV (1891), nº 11469, 2 noviembre, p. 2.

${ }^{447}$ El Diario de Murcia, XIX (1892), no 4348, 29 enero, p. 3. Para cubrir los gastos necesarios para la instalación de la sociedad se recurrió a una suscripción popular, que fue anunciada en La Paz de Murcia, XXXV (1892), nº 11558, 14 marzo, p. 2.

${ }^{448}$ En mayo de 1892, por ejemplo, el médico Andrés Martínez Rebollo dio una conferencia titulada "Examen del alcoholismo ante la moral y la ciencia y medidas que pueden adoptarse para su disminución". El Diario de Murcia, XIV (1892), n 4991, 8 mayo, p. 4. Véanse otras crónicas sobre discursos en La Paz de Murcia, XXXV (1892), n $\mathrm{n}^{\circ}$ 11619, 30 mayo, p. 2. No tengo constancia de las materias impartidas en el Círculo Católico Obrero. 
Los pianistas Enrique Martí y Mariano Marín fueron habituales en este tipo de veladas y tocaron solos o acompañando a cantantes invitados a tomar parte en esas veladas.

Dado que el Círculo Católico Obrero tuvo un carácter religioso, esa sociedad también organizó misas, especialmente en festividades relevantes. Una de las más celebradas era la de la Virgen de la Fuensanta, patrona de Murcia, cuyos festejos eran organizados por diferentes instituciones murcianas durante la primera quincena de septiembre. El Círculo Católico Obrero solía programar ese día una misa por la mañana y una velada literario-musical por la tarde. Los actos de esa festividad correspondientes al año 1892, por ejemplo, comenzaron la mañana del 25 de septiembre con una misa en la Iglesia de San Nicolás, oficiada por el Obispo de Murcia, a la que acudieron un gran número de obreros y otros socios del Círculo Católico. Durante la función religiosa se cantaron "las glorias de la Virgen de la Fuensanta" y se estrenó una Misa de Mariano Marín, sobre la que se escribió: "nos pareció muy buena y que los números en que toma parte principal el coro, resultan sumamente religiosos y producen sentimiento y fervor". La interpretación de la Misa de Marín corrió a cargo de Torrano, Millán, Yarza, Alarcón y un "Orfeón" constituido por treinta obreros del Círculo. Durante la Epístola se cantó el Ave María de Mercadante por el barítono Rex Torrano y durante el Ofertorio el tenor Millán cantó el $O$ salutari Hostia de Fauré, con acompañamiento de piano y armonio ${ }^{449}$. Sobre el coro se escribió en la prensa:

[...] Llamó la atención el desempeño de los coros, pues los jóvenes alumnos del Círculo que en él tomaron parte no tienen conocimientos musicales y sólo debido a los esfuerzos de los señores Marín, Moreno y Alarcón y a la buena voluntad de ellos, se ha debido que salieran airosos en su empresa, con mejor éxito cuanto más difícil era el número. En su honor debemos consignar los nombres de los obreros $[\ldots]^{450}$.

Por la tarde tuvo lugar la velada literario-musical, a la que asistieron el Obispo, los directivos de la sociedad Círculo Católico y otros personajes ilustres de Murcia. La parte musical de la velada estuvo a cargo de los pianistas Antonio Puig, Enrique Martí y Mariano Marín, entre otros, quienes acompañaron a los cantantes Juan Yarza, Rafael Rex Torrano y Rafael Martínez Silvestre. La velada comenzó con la interpretación de la "Gran Fantasía de Concierto sobre motivos de Fausto" de Zabalza, interpretado al piano por Enrique Martí; el bajo Juan Yarza cantó la romanza de Tosti, Povera mamma!!, acompañado por el pianista José María Peñafiel; Rex Torrano interpretó la Serenata para barítono de Moreno; Antonio Puig tocó Le fileuse (estudio) de Raff y la Tarantella brillante de Simitk; Enrique Martí tocó al piano un "Rondó para concierto" de Weber; Yarza, acompañado por Puig cantó un aria de Don Carlo de Verdi; Rafael Martínez cantó el Preta, Signori de Stradella y el acto se cerró con la intervención de la Banda Provincial que dirigía Francisco Fresneda.

Durante el mes de octubre de 1892 la prensa comentaba la buena marcha de la sociedad y el aumento de las clases a petición de los socios:

El Círculo Católico marcha.

\footnotetext{
${ }^{449}$ Véase la crónica del evento en La Paz de Murcia, XXXV (1892), nº 11716, 27 septiembre, pp. 1-2.

${ }^{450}$ La Paz de Murcia, XXXV (1892), nº 11716, 27 septiembre, p. 1.
} 
Como los jóvenes artesanos lo han invadido, pidiendo cada cual la enseñanza que más le conviene, la junta directiva habilita cada día más clases, sin que falten profesores idóneos para ellas. Recientemente se ha instalado una clase de música, y anteriormente se han abierto otras de mecánica, aplicada a la construcción para los albañiles, de geometría y de geografía estando encargos de ellas los señores don José Gallego y don Luis Romero Sainz ${ }^{451}$.

A juzgar por esa información, las clases de música se implantaron en el Círculo Católico durante el mes de septiembre de 1892, probablemente antes de la participación del coro de obreros en la festividad de la Fuensanta arriba comentada. En enero de 1893, el Círculo Católico adquirió un piano y un armonio para sus clases de música y, para celebrarlo, se organizó un concierto el 16 de enero de 1893. En el evento participaron los músicos habituales en otras veladas, probablemente profesores de las clases de música del Círculo Católico (Enrique Martí, Mariano Marín, José María Marín, Moreno Pretel y el cantante Juan Yarza $)^{452}$.

Durante los meses siguientes el Círculo Católico organizó numerosas reuniones literarias en las que los socios leían sus propios trabajos en prosa y/o en verso (o bien los de otros escritores murcianos), así como conferencias en las que ocasionalmente se interpretaba música ${ }^{453}$. A la velada literaria organizada el 25 de marzo de 1894 con el conferenciante Luis Siboni asistió Antonio López Almagro "cuya quebrantada salud le ha vuelto a la ciudad natal en busca de fuerzas y de energías, que encontrará sin duda". En homenaje al compositor murciano, Antonio Puig interpretó el célebre Canto de amor de Antonio López, probablemente en una adaptación para piano ${ }^{454}$.

El Círculo Católico Obrero continuó su actividad al menos hasta 1900.

\section{La Academia de Música de Mariano García López y Fernando Verdú Sánchez (1884)}

A comienzos de 1884, La Paz de Murcia publicó el anuncio de una academia de música dirigida por Mariano García López (maestro de capilla de la Catedral de Murcia) y el director y compositor murciano Fernando Verdú (Ver Figura 6.15) que, por tanto, debió crearse antes ${ }^{455}$. Estuvo situada en la calle de Santo Domingo, 35 y en ella se impartía: "solfeo, piano, instrumentos de cuerda, armonía y composición" 456.

${ }^{451}$ El Diario de Murcia, XVI (1892), nº 5119, 9 octubre, p. 1.

${ }^{452}$ El Diario de Murcia, XV (1893), nº 5832, 19 enero, pp. 1-2.

${ }^{453}$ Algunos ejemplos pueden consultarse en: El Diario de Murcia: XIV (1892), $\mathrm{n}^{\text {os }}$ 5132, 25 octubre, p. 1; 5160, 29 noviembre, p. 1; 5166, 6 diciembre, p. 1; XV (1893), n ${ }^{\circ}$ 5914, 25 abril, p. 1; XVIII (1896), $\mathrm{n}^{\circ}$ 6962, 5 mayo, p. 3; XIX (1898), nº 7447, 26 septiembre, p. 3; XX (1898), no 7612, 23 marzo, p. 1. En 1898, parece que las reuniones literarias se celebraban cada domingo: l Diario de Murcia, XX (1898), $\mathrm{n}^{\circ} 7892,30$ diciembre, p. 3.

\footnotetext{
${ }^{454}$ El Diario de Murcia, XVI (1894), no 6223, 27 marzo, p. 1.

${ }^{455}$ Véanse más detalles sobre Mariano García y Fernando Verdú en el Capítulo 9 de esta Tesis.

${ }^{456}$ El Diario de Murcia, VI (1884), no 1491, 31 enero, p. 3.
} 


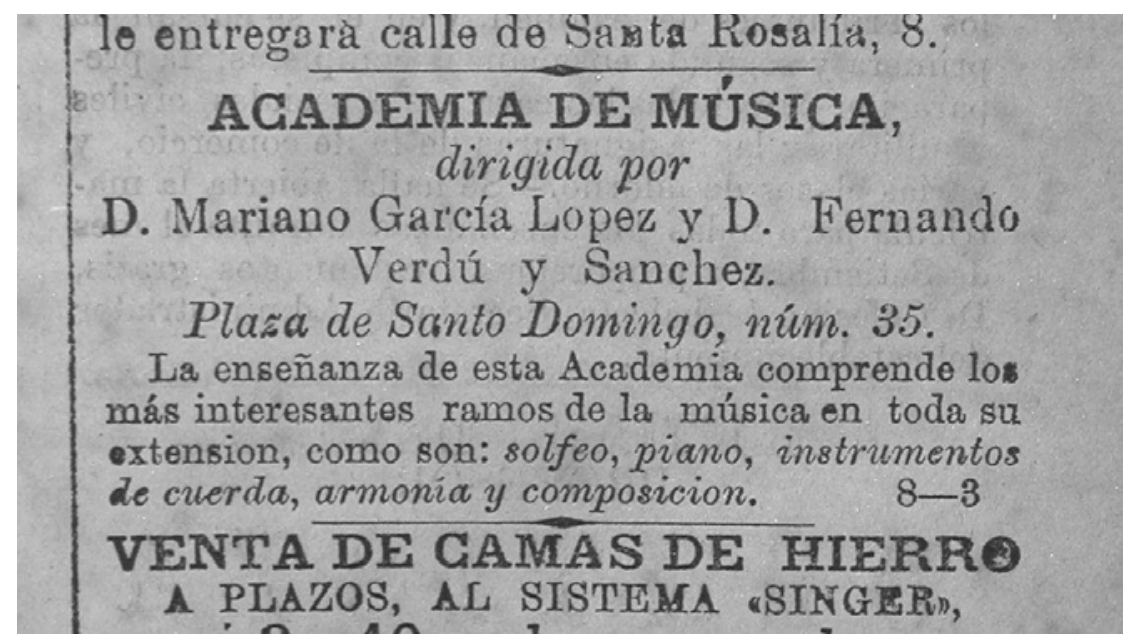

Figura 6. 15. Anuncio de la Academia de música de Mariano García y Fernando Verdú. El Diario de Murcia, VI (1884), n 1491, 31 enero, p. 3, E:MUm.

\section{La Academia de Música de Acisclo Díaz (1885)}

La Academia de Música de Acisclo Díaz Rocher existía ya en 1885, cuando se publicaron varios anuncios sobre ella. Este músico murciano fue el fundador y director de la Banda de Música de la Casa de Misericordia de Murcia, creada en 1879 (ver Capítulo 9). Él mismo expresó los fines de la institución educativa:

La idea que me mueve a tomar esta resolución no es solamente el lucro, sino el hacer, por el divino arte que profeso, cuanto pueda con mis débiles fuerzas y alentar la juventud que tanta predisposición artística tiene en este país. Unos se prepararán para tener carreras en el porvenir, y otros para brillar entre los aficionados o tener el gusto de poseer tan hermoso arte.

Creé una banda [Banda de Música de la Casa de Misericordia] donde, en seis años que lleva de existencia, he tenido tocando 175 individuos, siendo elogiada por cuantos la han oído, contándose entre estos los célebres artistas y eminencias en el arte Sarasate, Fernández Caballero, Padilla, Albéniz, Tamberlik, Verger, Espino, Regino y otros; y ya he conseguido hacer una banda militar de esta categoría. Con mis conocimientos propios, me propongo crear una orquesta completa en la misma forma.

Si el objeto que me propongo llega a realizarse, tal cual es mi deseo, se verán cumplidas mis aspiraciones, las que siempre han sido única y exclusivamente el progreso del arte musical en nuestra querida ciudad.

Acisclo Díaz ${ }^{457}$

Tal y como se deduce de estos párrafos, la academia formaba músicos que se integraban posteriormente en las agrupaciones musicales de la ciudad (bandas de música y orquesta), según las aspiraciones de Díaz (véase Figura 6.16).

La academia de Acisclo Díaz estuvo ubicada en la céntrica calle de San Nicolás (número 39) y en ella se impartía solfeo, piano, canto, "toda clase de instrumentos de cuerda y viento. El método que se seguirá será el mismo que se sigue en la Casa de

${ }^{457}$ El Diario de Murcia, VII (1885), no 1993, 21 octubre, p. 1. 
Misericordia". Se comenzaba con el estudio del solfeo y, cuando el alumno adquiría los conceptos básicos del lenguaje musical, se añadía el aprendizaje de un instrumento ${ }^{458}$.

El horario distinguía a los alumnos según su sexo: los jóvenes varones recibían clase a las seis de la tarde; las niñas y señoritas, a las doce de la mañana. El establecimiento también ofrecía la posibilidad de impartir lecciones de música en domicilios particulares ${ }^{459}$.

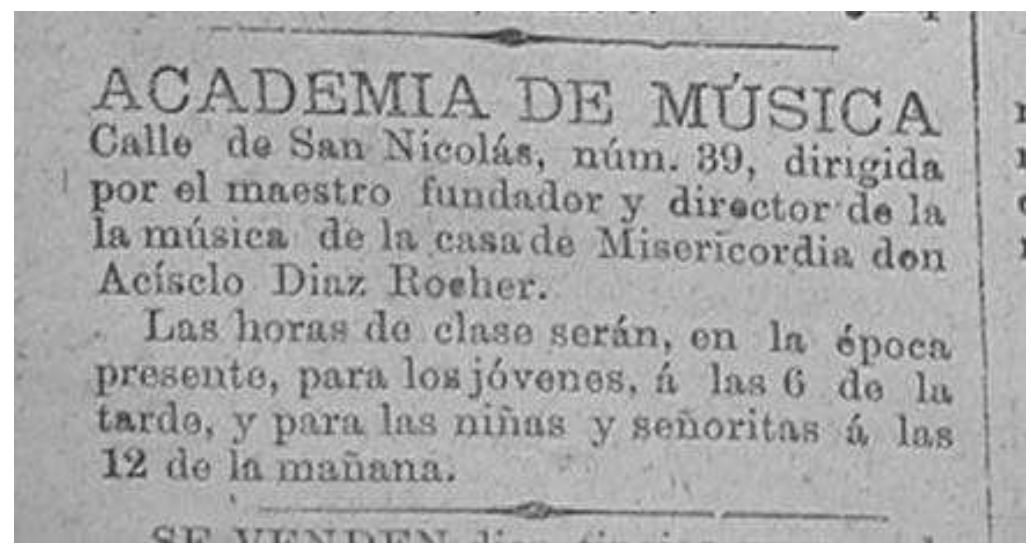

Figura 6. 16. Anuncio de la Academia de música de Acisclo Díaz Rocher. El Diario de Murcia, VII (1885), no 2018, 29 noviembre, p. 4, E: MUm.

\section{Profesores de música particulares}

La enseñanza musical a domicilio está documentada en Murcia desde al menos 1808 (ver Capítulo 11). La demanda de profesores de música fue paulatinamente mayor a lo largo del siglo XIX, como respuesta al consumo musical de una parte importante de la sociedad murciana. Este hecho se constata en el gran número de sociedades murcianas que incluyeron clases de música y también en la cantidad de anuncios de profesores de música particulares publicados en la prensa murciana. A la amplia labor docente de músicos como Julián Calvo, Adolfo Gascón, Antonio Ramírez y Mariano García durante la segunda mitad del siglo XIX (ver Capítulo 9 y 11) se le unieron otros profesores de música, cuyas clases se ofertaron puntualmente en los diarios murcianos. Pondré algunos ejemplos. En febrero de 1863, el antiguo alumno del Real Conservatorio de Madrid, Francisco Gil López, ofrecía clases de piano y canto a domicilio en su casa de la calle Agüera, número $12^{460}$, anunció que siguió publicándose casi treinta años más tarde (véase Figura 6.17).

${ }^{458}$ La Paz de Murcia, XXXVIII (1885), no 8357, 30 octubre, p. 1. El precio de las clases de solfeo era de veinte reales al mes y treinta reales cuando se añadían las clases de cualquier instrumento.

${ }^{459}$ Las clases particulares costaban 80 reales.

${ }^{460}$ El Segura, I (1863), no 49, 26 febrero, p. 4. 


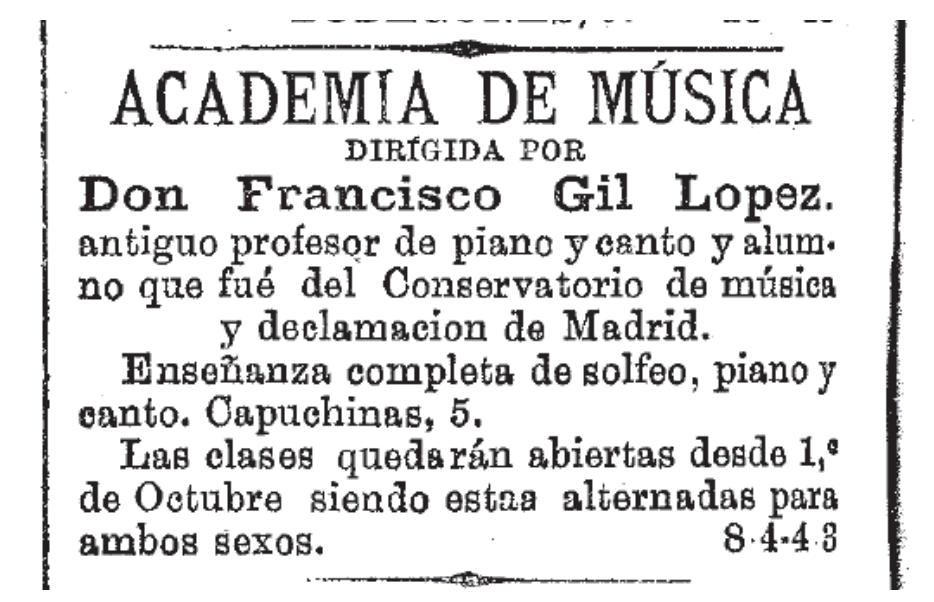

Figura 6. 17. Anuncio de la academia de música de Francisco Gil López. El Diario de Murcia, XIII (1891), n 4440, 23 septiembre, p. 4, E: MUm.

En 1880, Cayetano Belda daba clases particulares de guitarra, flauta y solfeo, a petición expresa de algunos interesados (ver Figura 6.18) y José Palazón Pérez en 1883, ofrecía clases de guitarra, según los métodos de Dionisio Aguado, Antonio Cano, Jaime Ruet y Tomás Damas (ver Figura 6.19) ${ }^{461}$.

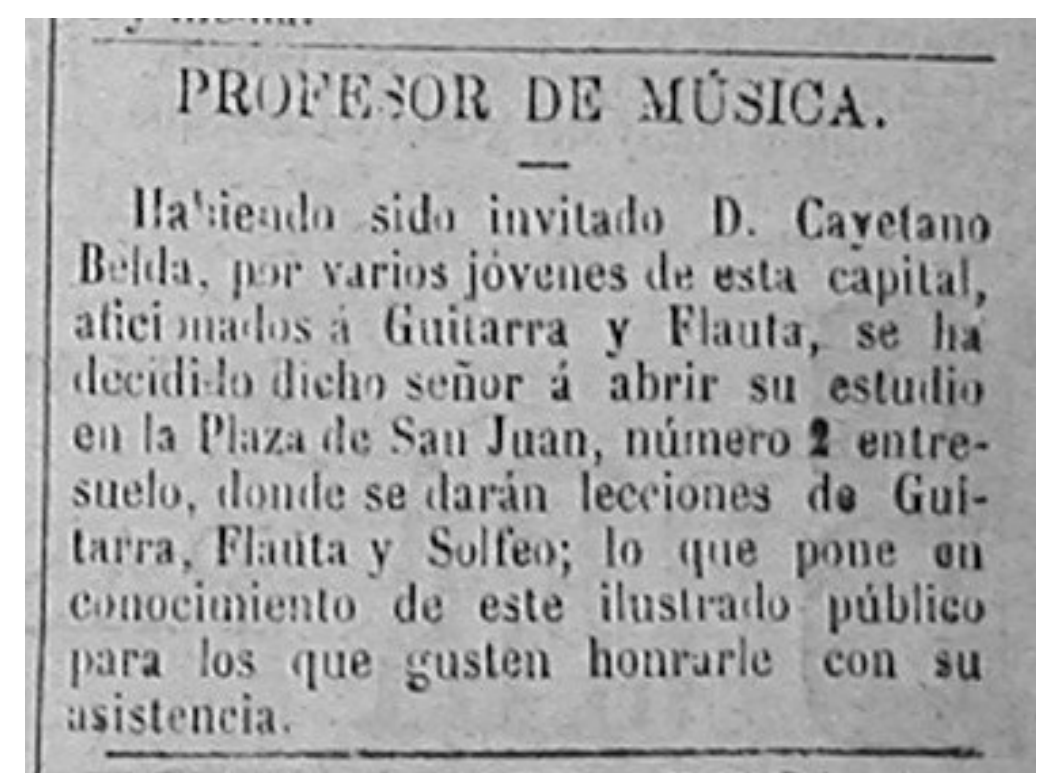

Figura 6. 18. Anuncio de las clases particulares de Cayetano Belda. El Diario de Murcia, II (1880), n 360, 20 abril, p. 2, E: MUm.

\footnotetext{
${ }^{461}$ Sobre estos métodos de guitarra, véase: "Guitarra. España Siglo XIX”, pp. 104-108.
} 


\section{PROFESOR DE GUITARRA.}

D. José Palazon Perez, ofrece su enseìanza \&́ domicilio con los métodos clísicos d• los seĩores Aguado y Cano y recreativo de Ruet y Damas. Vive callo do Jabonerias, núm. 1 . $\quad 80-6$

Figura 6. 19. Anuncio de las clases particulares de José Palazón Pérez. El Diario de Murcia, V (1883), no 1368, 6 septiembre, p. 3, E:MUm.

En 1899, Gloria de la Iglesia, también ex alumna del Conservatorio de Madrid daba clases de solfeo y piano, aunque únicamente a señoritas, en la calle de la Fábrica:

PROFESORA DE MÚSICA

Doña Gloria de la Iglesia, viuda, primer premio del Conservatorio, se ofrece a dar lecciones de solfeo y de piano a las señoritas que lo deseen. Precios muy módicos. Calle de la Fábrica, $5^{462}$.

${ }^{462}$ El Diario de Murcia, XXI (1899), no 7972, 4 abril, p. 4. 



\title{
Capítulo 7. La música en los cafés murcianos
}

\section{Los cafés de Murcia durante la segunda mitad del siglo XIX}

Los cafés fueron en Murcia, como en el resto de España, un foco de importante actividad musical durante el siglo XIX. Según Casares, podían ser cafés-cantantes (dedicados al género flamenco), cafés-concierto, cafés-líricos y cafés-teatro ${ }^{1}$. Las fuentes periodísticas que he consultado no distinguen entre cafés concierto y cafés líricos. En cambio, sí recogen referencias explícitas a cafés cantantes y cafés flamencos para referirse a locales con repertorio musical cercano al cante y baile flamenco ${ }^{2}$. Las noticias sobre este tipo de cafés, en los que actuaban cantaores y bailaores son abundantes. Uno de ellos fue el Café Habanero, inaugurado en mayo de 1886: "El local se halla bien acondicionado, con mesas de mármol, sillas de madera curvada, espejos, todo empapelado, luz de gas y se sirve bien a los parroquianos"3.

La Paz de Murcia definía en 1875 los cafés en los siguientes términos:

\begin{abstract}
Si nuestros abuelos dejasen sus tumbas y recorrieran las calles de nuestras grandes capitales encontrarían ciertos establecimientos que en verdad, habían de sorprenderles mucho por su objeto, disposición y decorado. En ellos pasa una numerosa concurrencia, parte del día y acaso toda la noche. Allí se habla murmurado, se conspira en voz alta, se hacen negocios y se arregla el mundo, allí se entra sin pedir permiso ni saludar a nadie, con palmadas se llama a los sirvientes que cumplen con su cargo eficazmente, se paga (o no se paga) y a veces los concurrentes disfrutan de espectáculos variados, música de piano y concertada, vocal e instrumental, teatro lírico, can-can por todo lo algo y soleá flamenca del más bajo estilo. Estos establecimientos, candentes hornos de la moderna civilización, son los cafés [... $]^{4}$.
\end{abstract}

Desde la mitad del siglo XIX, el café era, pues, un espacio más para el ocio y el entretenimiento de la sociedad murciana y formaba parte de lo que los historiadores denominan espacios de sociabilidad "popular e informal", Los cafés acogían a un

\footnotetext{
${ }^{1}$ Casares, "La música del siglo XIX. Conceptos fundamentales", p. 13-122: 44. Sobre el origen y desarrollo de los cafés en España véanse, entre otros: Agulló, "Los Cafés"; Casares, "El café concierto"; Casares, "La música del siglo XIX. Conceptos fundamentales", pp. 44-49; Casares, "Un espacio"; Díez Huerga, "Salones"; Pérez Samper, "Espacios" y Zamacois, Tipos de café. Sobre cafés murcianos de principios del siglo XX, véase: Valero, La música. Agradezco a Pilar Valero la consulta a su trabajo que aún permanece inédito.

2 José Blas Vega ha estudiado los cafés cantantes y cafés flamencos de Madrid, entre otras ciudades españolas. Véase, Blas, Los cafés cantantes.

${ }^{3}$ La Paz de Murcia, XXIX (1886), nº 8915, 8 mayo, p. 1. Véase también La Paz de Murcia, XXIX (1886), $\mathrm{n}^{\mathrm{o}} 8953,24$ junio, p. 1. Excluyo de mi estudio este tipo de locales ya que han sido exhaustivamente tratados por José Gelardo Navarro, Con el flamenco; Gelardo, El flamenco en Lorca; Gelardo, El flamenco, otra cultura; Gelardo, Las claras y Gelardo, "Los cafés cantantes".

${ }^{4}$ La Paz, XVIII (1875), $\mathrm{n}^{\circ}$ 5434, 20 agosto, p. 1. Las cursivas son editoriales. El artículo completo puede consultarse en el Documentario.

${ }^{5}$ Los espacios de sociabilidad formal están relacionados con el fenómeno del asociacionismo. Sobre el concepto de sociabilidad véase Guereña, "Espacios". Los cafés fueron espacios multifuncionales en los que
} 
público más variado que el teatro, los salones aristocráticos y burgueses o los de sociedades recreativas, y se convertían en lugar de diversión imprescindible cuando el teatro permanecía cerrado: "a no ser por el Café de Oriente y otros recreos eventuales, no tendríamos en qué distraer las largas veladas de esta estación”, se afirmaba en 1886 en la prensa murciana ${ }^{6}$. En estos locales había tertulias, conciertos, baile, juego, prensa y, claro está, café (véase Figura 7.1).

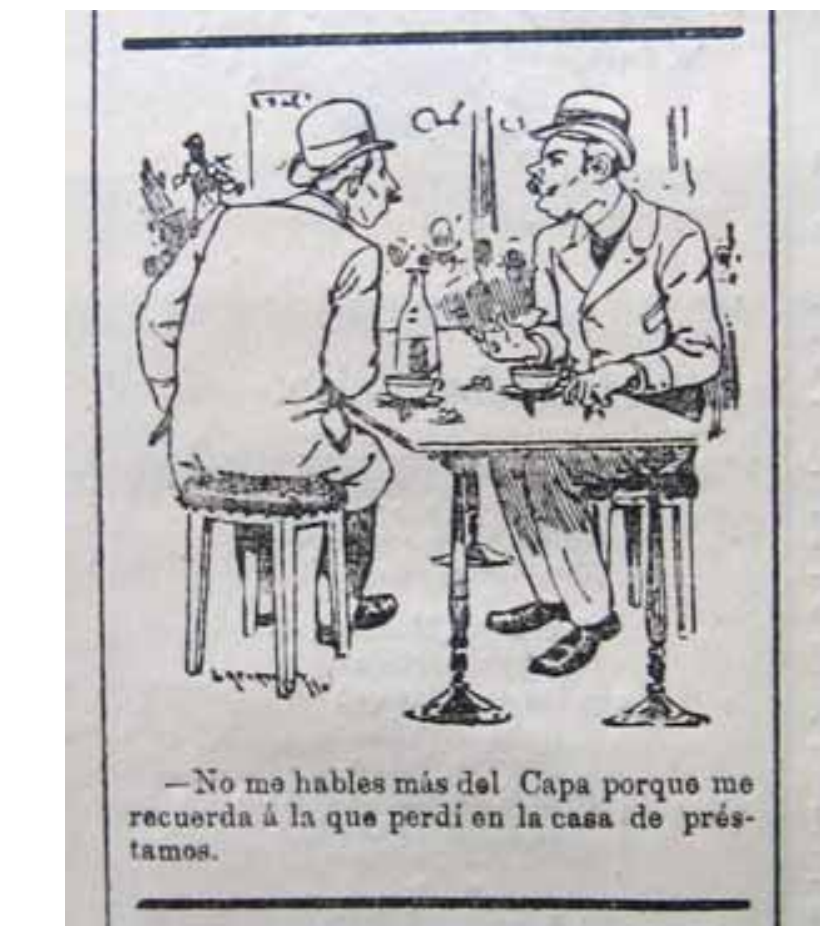

Figura 7. 1. En un café murciano.

E:MUm, La Juventud Literaria, VII (1895), n 267,2 junio, p. 3

Los cafés eran espacios de actividad musical con una extraordinaria respuesta social, consecuencia de la democratización de la cultura. En 1875, un periódico murciano describía así las diferencias entre los cafés de principios del siglo XIX y los creados desde mitades del mismo:

[...] Los cafés antiguos no eran más que una tienda o cuarto bajo [...]. En algunos había perchas donde colgaban los parroquianos los sombreros apuntados y las capas de lamparilla. Las mesas eran de pino y las sillas de Vitoria, y se hablaba bajo mientras los "Guardias de Corps" no armaban algún jaleo en que intervenían los

las tertulias y reuniones políticas también tuvieron cabida. Sobre la sociabilidad aplicada al ámbito de las tabernas, un espacio cercano en algunos aspectos a los cafés, véase: Uría, "La taberna".

${ }^{6}$ La Paz de Murcia, XXIX (1886), n $\mathrm{n}^{\circ}$ 9067, 16 diciembre, p. 1. En este sentido, los cafés pusieron en evidencia las deficiencias estructurales y la ausencia de espacios adecuados para la música, como las salas de concierto. El nuevo público que asistía a los cafés nació con la Revolución Francesa ante el estímulo de cultivar la música como parte de su formación y vida social: Casares, "Un espacio" pp. 67-92. Los cafés concierto no fueron exclusivos de España. Véase, por ejemplo Acquaviva, "Il "Café-Concerts"”, Il Mondo Artistico, XXII (1888), $\mathrm{n}^{\text {os }} 41-42,11$ octubre, pp. 1-2: 1, que publicaba en sus primeras páginas un extenso artículo en el que se afirmó: "il Café-Chantant si eleva, o tenta di elevarsi, a vero tempio dell'arte". 
alguaciles de casa y corte. En aquellos establecimientos no se servían comidas de ninguna clase y con mucho trabajo se leía la "Gaceta" o "El Diario de Avisos", únicos periódicos de la corte de España, verificándolo a la luz de un aparato nuevamente entonces inventado por Míster Quinqué. Al toque de ánimas se cerraba el establecimiento.

Los cafés modernos sirven de punto de partida para el proyecto de las casas en que se sitúan y a ellos se relaciona la demás distribución del edificio. Tienen jardines, tribunas y escenarios, los techos están atrevidamente apeados por esbeltas columnas, las paredes son de terciopelo y lunas venecianas, los muebles son de palo santo y multiplican la luz del gas millones de mecheros que forman parte de lujosos aparatos de bronce y cinc dorado a fuego. Allí circulan centenares de periódicos, se ahoga la concurrencia por el humo del tabaco, se come todo cuanto se quiere (a veces a más de diez duros el cubierto, lo cual paga el país cuando los banquetes son patrióticos) y no se cierran jamás algunos de estos establecimientos, en los cuales hay hasta tres o más turnos de camareros. Siempre están llenos de gente y sirven de colmena a los desocupados, a los cesantes o los que, faltando brazos a las artes e industria, dicen que por estar malo el oficio pretenden un empleo. Siguiendo el ejemplo de la Corte, Barcelona la ha excedido y tiene hoy los primeros cafés del mundo y Sevilla y otras ciudades rivalizan en el ornato de los grandes locales dedicados a este ramo de comercio $[\ldots]^{7}$.

Desde el punto de vista arquitectónico, los cafés de principios del siglo XIX ocupaban las plantas bajas de los edificios, mientras que los posteriores se construían con el café como elemento central de las casas. Los cafés fueron espacios muy sensibles a la introducción de los avances industriales de la época. En febrero de 1887, el Café de Oriente introdujo el sistema del alumbrado por petróleo: "anoche se probó en el salón del billar del Café de Oriente el sistema de alumbrado por petróleo, que tanto llama la atención hoy en Cartagena, desde que se inauguró el Café del señor Cartagena" ${ }^{\text {. }}$. Pero la diferencia más importante de los nuevos cafés fue precisamente la presencia de la música:

[...] No hace muchos años que el café era solo un centro en que los hombres se comunicaban y en donde daban quizá la primera o la última mano a algún negocio entre sorbo y sorbo del moka corregido pero ahora a esa corriente se ha añadido otra más simpática y dulce: la de la música. Un café donde no se haga música, como ahora se dice, produce frío y algo de tristeza $[\ldots]^{9}$.

Los cafés llegaron a convertirse en los lugares favoritos de los murcianos de cualquier condición social y también de las mujeres, aunque éstas no acudían diariamente a ellos ${ }^{10}$.

${ }^{7}$ La Paz de Murcia, XVIII (1875), no 5434, 20 agosto, p. 1.

${ }^{8}$ La Paz de Murcia, XXX (1887), nº 8110, 4 febrero, p. 1. Véase también, La Paz de Murcia, XXX (1887), $\mathrm{n}^{\mathrm{o}} 8113,8$ febrero, p. 1.

${ }^{9}$ El Semanario Murciano, I (1878), $\mathrm{n}^{\mathrm{o}} 36,20$ octubre, p. 8.

10 La mujer no frecuentaba diariamente estos establecimientos, salvo en días señalados o en temporadas festivas: "el bello sexo, [...] no concurre más que en ciertos y determinados días, lo cual priva a esos centros de la animación que ordinariamente debieran tener": La Paz de Murcia, XXVIII (1885), $\mathrm{n}^{\circ}$ 8379,25 noviembre, p. 4. En los cafés se vendían las entradas para algunos teatros de la ciudad o se exhibían las fotos de los artistas que actuaban en ellos. Por ejemplo, en La Paz de Murcia, XXVIII (1885), $\mathrm{n}^{\circ} 8142,10$ febrero, p. 1 se menciona que las entradas para el beneficio del actor Salvador García en el Teatro de Apolo serían vendidas en los cafés Oriental y del Comercio. 
Uno de los más antiguos fue el Café de Narcisa la Botillera, situado "en el extremo de la actual Trapería y puertas del mercado" y contaba con "modestas mesas y sus sillas de anea, blancas paredes, adornadas con cuadros y estampas de la historia de Atala y monumentales velones que alumbraban a los concurrentes" ${ }^{\prime 1}$.

El Café de Trifón fue otro antiguo café de Murcia, con una larga trayectoria. En él, "a más de haber albergado a cariñosas sílfides en más de un carnaval, ha servido de escuela de primeras letras a nuestra juventud estudiosa" ${ }^{\prime 2}$. En diciembre de 1881 cambió el nombre por el de Café Sevilla, por su dueño Francisco Barnés, apodado Paco Sevilla ${ }^{13}$. Estuvo situado en la bajada del Puente, junto a la Glorieta (entonces Puerta del Sol) ${ }^{14}$. Su actividad fue muy poco comentada en la prensa y no he hallado noticias sobre actividad musical en él, aunque hay constancia de que al menos desde 1896 cambió el nombre por el de Café del Arenal ${ }^{15}$.

Durante la segunda mitad del siglo XIX los cafés-concierto proliferaron en la ciudad de Murcia, especialmente durante las últimas décadas. La prensa recogía noticias relacionadas con sus inauguraciones, reformas, programas de las veladas musicales e intérpretes, críticas e información sobre los productos que vendían. Es obvio que la música servía de reclamo para atraer concurrencia, introducir "un toque de distinción" y rivalizar con otros locales por los servicios prestados.

Las veladas musicales se concentraban entre las siete y las diez de la noche. Algunos cafés tuvieron también veladas matutinas al mediodía y entre las tres y las cinco de la tarde. En su mayor parte, los intérpretes de estas veladas fueron músicos locales que obtenían en los cafés ingresos adicionales a sus sueldos habituales, incluso cuando eran músicos de iglesia. Ejemplo de ello es el compositor, pianista y organista de la Catedral Julián Calvo, que fue intérprete habitual en varios cafés murcianos. Los perfiles profesionales de estos artistas eran muy variados: ejercían la enseñanza de la música, eran intérpretes habituales de salones públicos y privados y/o del teatro. Eventualmente, los cafés acogieron actuaciones de músicos con prestigio nacional, como el compositor Federico Chueca o el guitarrista Julián Arcas, como veremos más adelante ${ }^{16}$.

Los cafés más concurridos estaban ubicados en el centro de la ciudad: en la calle del Príncipe Alfonso (actual calle Trapería) y en el Arenal (hoy Glorieta) (véase Figura 7.2).

${ }^{11}$ La Paz de Murcia, XVIII (1875), nº 5434, 20 agosto, p. 1. Este interesante documento se encuentra transcrito en el Apéndice Documental. Regentó más tarde este café su sobrina Rosario, célebre por los dulces que preparaba. Según la fuente tuvo cafés posteriormente en el Arenal, en la calle del Crédito Público y, finalmente, se encargó del Café de la sociedad Círculo Industrial.

${ }^{12}$ La Paz de Murcia, XVIII (1875), n 5434, 20 agosto, p. 1. Véase también, La Paz de Murcia, XIII (1870), nº 4054, 29 diciembre, p. 1.

${ }^{13}$ José Martínez Tornel, Guía de Murcia (Murcia: Imprenta de "El Diario de Murcia", 1887), p. 39.

${ }^{14}$ La Paz de Murcia, XXVII (1884), $\mathrm{n}^{\text {os }} 8008,30$ agosto, p. 1 y 11058, 20 junio, p. 1

${ }^{15}$ El Diario de Murcia, XVIII (1896), nº 7033, 14 julio, p. 3.

16 Según Casares, "Un espacio alternativo", pp. 74-75, el número de pianistas de renombre que actuaron en los cafés fue muy numeroso. Las actuaciones en estos establecimientos permitían además entablar relaciones entre músicos y empresarios. 


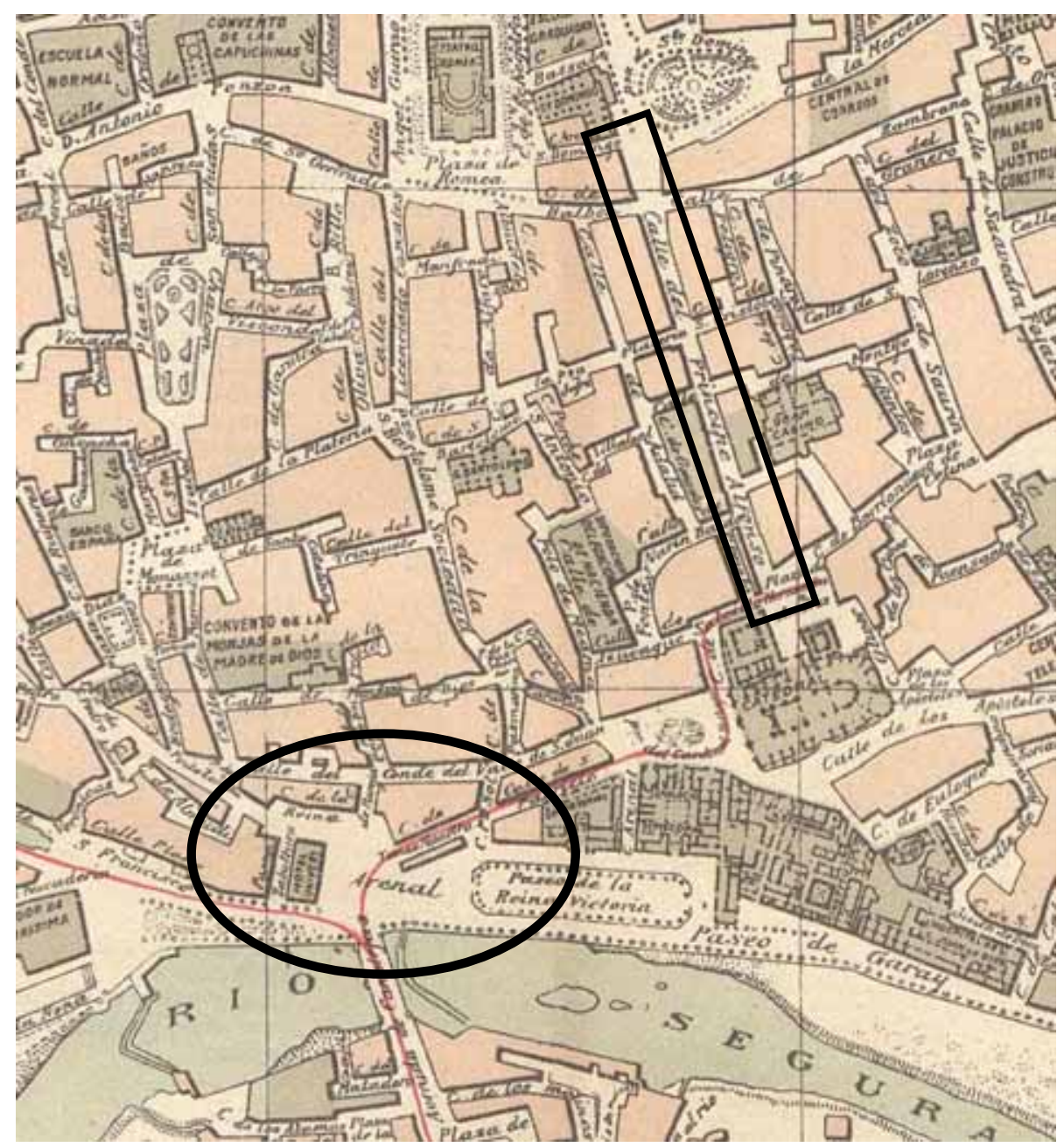

Figura 7. 2. Explanada del Arenal (círculo) y calle del Príncipe Alfonso (rectángulo), núcleos de concentración de cafés murcianos. Pedro García Faria, Plano de Murcia (Barcelona: Alberto Martín, s.a.). $E: M p b$. Accesible en: http://bibliotecadigital.carm.es (acceso el 16-07-2011).

En la calle del Príncipe Alfonso se encontraban el Café del Comercio, el Café Oriental, el Café del Casino y el Café del Siglo (véase Figura 7.3); en el Arenal estaban el Café de la Puerta del Sol y el Café Sevilla (después llamado Café del Arenal), aunque no he documentado actividad musical de este último durante el siglo XIX (véase Figura 7.4). 


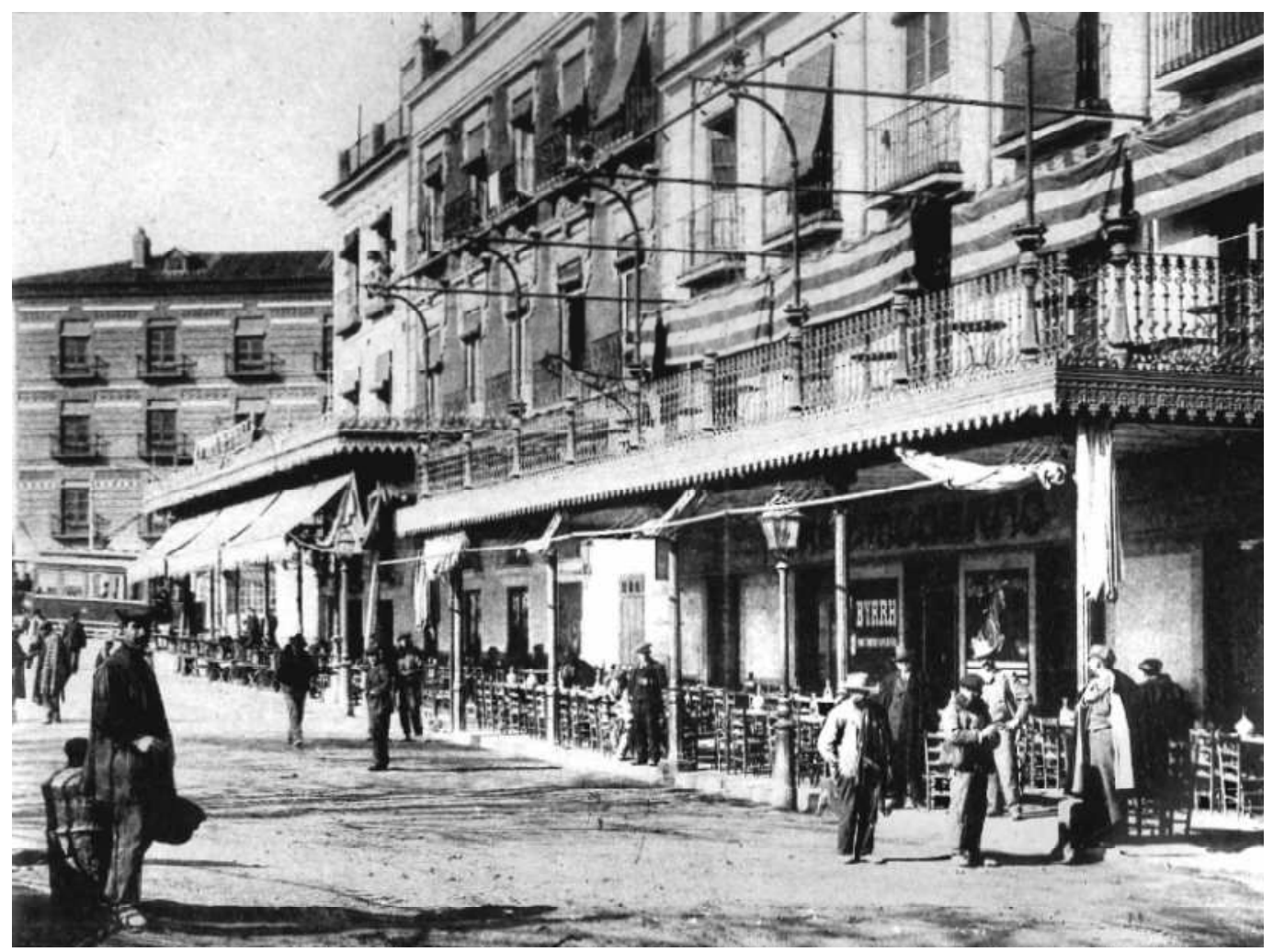

Figura 7. 3. Vista de los cafés Moderno (en primer plano) y Arenal (al fondo), ambos situados en la explanada del Arenal de Murcia ${ }^{17}$. Principios del siglo XX. E:MUm. Accesible en: http://www.archivodemurcia.es (acceso el 3-09-2011).

${ }^{17}$ Valero, La música, pp. 25, 33 afirma que ambos se inauguraron en 1909 y se cerraron en 1932 (Café Moderno) y 1935 (Café del Arenal). Sin embargo, como ya he aclarado, la prensa murciana menciona un Café del Arenal desde 1896 y un año más tarde se especifica "Café del Arenal (antes Sevilla)". Ver: El Diario de Murcia: XVIII (1896), $\mathrm{n}^{\text {os }} 7033,14$ julio, p. 3 y XIX (1897), no 7299, 9 abril, p. 3. A finales del siglo XIX, Juan Belando Meléndez y José María Perelló, Guía de Murcia (Murcia: José María Perelló, 1899) citan a José Sandoval y Braco como dueño del Café del Arenal y describen un local que "deja mucho que desear; pero en el exterior tiene una gran marquesina que, constituida en salón, lo mismo en invierno que en verano, hace que sea este el punto de recreo de más animación y vida". 


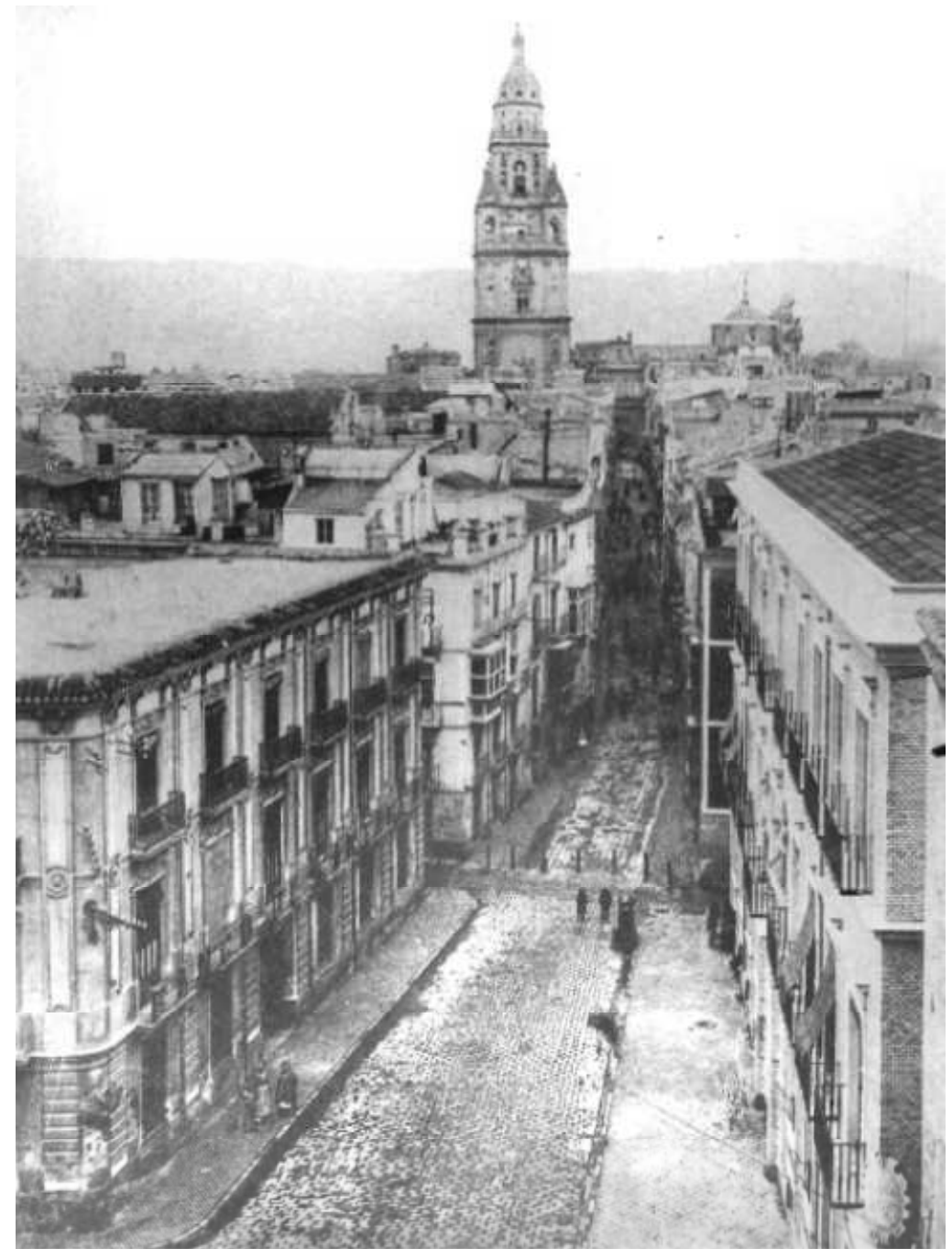

Figura 7. 4. Calle Trapería con la torre de la Catedral de Murcia al fondo. Principios del siglo XX. E:MUm. Accesible en: http://www.archivodemurcia.es (acceso el 3-09-2011).

Comentaré a continuación los cafés murcianos más relevantes que tuvieron actividad musical documentada.

\subsection{El Café del Comercio (1866-1893)}

Estuvo situado en "el entresuelo de la Fonda de Patrón, en la calle del Príncipe Alfonso" (ver Figura 7.5) ${ }^{18}$. Las fuentes periodísticas no recogen la fecha de inauguración

${ }^{18}$ La Paz de Murcia, IX (1866), n ${ }^{\text {os }} 2638,31$ agosto, p. 1 y 2642, 4 septiembre, p. 2. Un documento posterior ubica el café en la calle Azucaque, 4, frente a la plaza de Fontes y muy cercano a la calle del Príncipe Alfonso: El Diario de Murcia, XV (1893), n 6120, 12 diciembre, p. 2. Martínez Tornel, Guía, p. 39 menciona que el dueño del Café del Comercio, en 1887, era Juan Hernández. Camilo Botella, Guía consultiva de la ciudad de Murcia para el año 1891 (Murcia: Tipografía de Rafael Albaladejo, 1891), p. 250 menciona un café ubicado en la calle Azucaque y como su propietario a Tomás Maestre. 
de este café, salvo la indicación de una reforma en julio de 1866 y su inauguración en el mes de septiembre del mismo año ${ }^{19}$.

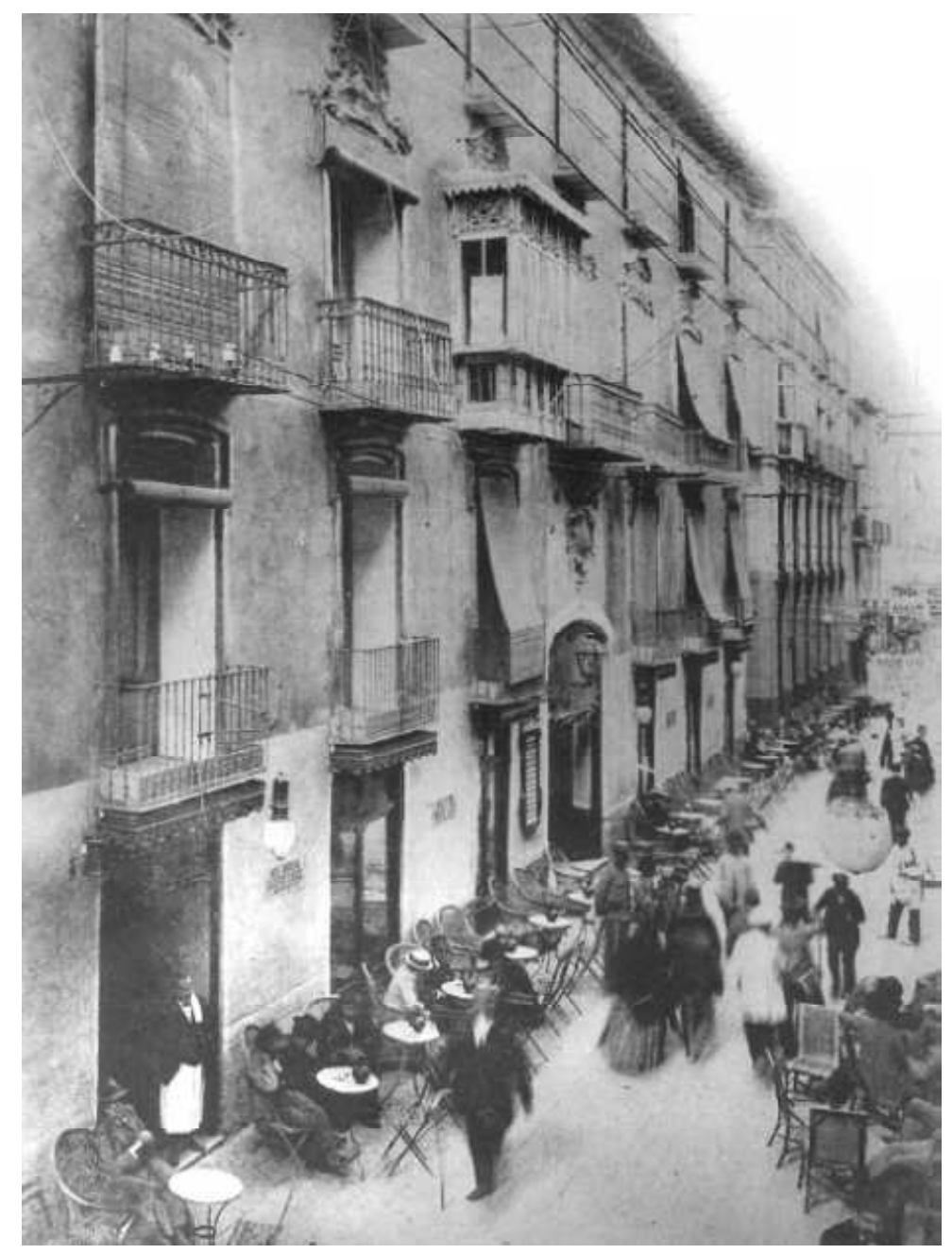

Figura 7. 5. Hotel Patrón de Murcia y su café en la calle del Príncipe Alfonso (frente al Casino de Murcia) a principios del siglo XX. E:MUm. Accesible en: http://www.archivodemurcia.es (acceso el 3-09-2011).

Hasta 1876 las referencias periodísticas aluden que a este Café del Comercio asistían "las altas clases de la sociedad que no concurren al Casino" y que en él actuaba diariamente un pianista ${ }^{20}$. En los años 1876 y 1877 fueron empleados de este local los pianistas Juan Diego Manresa y Juan Ayala. En él se tocaba el piano y el armonio, individual o conjuntamente ${ }^{21}$.

${ }^{19}$ El local se abrió de nuevo al público el 2 de septiembre de 1866: La Paz de Murcia, IX (1866), $\mathrm{n}^{\text {os }}$ 2610, 31 julio, p. 1; 2638, 31 agosto, p. 1. La noticia hacía hincapié en la necesidad de que se creara en Murcia "un establecimiento bueno de este género [...]. Su situación no puede ser más conveniente para todas las estaciones y para toda clase de festividades". En la velada de inauguración actuó la Banda de la Artillería y en los intermedios se ejecutaron obras al piano y armonio por los intérpretes Juan Diego Manresa y José Quercop.

${ }^{20}$ La Paz de Murcia, XV (1872), no 4483, 1 junio, p. 1 y El Aguijón, (1872), nº 15, 15 mayo, pp. 8-9.

${ }^{21}$ La Paz de Murcia, XIX (1876), $\mathrm{n}^{\text {os }}$ 5784, 8 octubre, p. 1; 5797, 4 noviembre, p. 1 y 5905, 14 noviembre, p. 1; La Paz de Murcia, XX (1877), n 5998, 10 marzo, p. 1. A veces, se ejecutaron óperas enteras al piano y armonio: La Paz de Murcia, XX (1877), $\mathrm{n}^{\circ}$ 5998, 10 marzo, p. 1. Las fuentes no 
En diciembre de 1877, se menciona que eran frecuentes las actuaciones de un coro junto a los citados músicos Manresa y Ayala:

[...] Para corresponder al creciente favor que el público viene dispensando a los concertistas y coro del café del Comercio, a partir de la próxima semana, estos que venían siendo de escogido repertorio de zarzuela, lo sean de las mejores obras de música alemana o italiana. Teniendo ya en estudio para ejecutarse próximamente varios coros de las óperas Los mártires, El pirata, Norma y otras. Tanto el señor Manresa, como el señor Ayala, se esmeran cuanto pueden para que el público que los honra con su asistencia, salga tan complacido como desear pueda. $[\ldots]^{22}$.

A partir de octubre de 1878, el Café del Comercio contó con una formación musical estable compuesta por seis instrumentistas: Juan Diego Manresa, Mariano Esbrí, Acisclo Díaz, Antonio Pérez, Juan Ayala y Pedro Martínez ${ }^{23}$. Ofrecían conciertos varias veces a la semana, aunque "se han hecho noches de moda las de los jueves y domingos, acudiendo la gente que es un portento, pues cada vez enriquécese más el repertorio de aquellos profesores" 24 . Los programas de las quince veladas que ofrecieron ente los meses de noviembre y diciembre de 1878 se recogen en el Apéndice 7.1. Esta formación no se vuelve a mencionar durante los años siguientes.

En septiembre de 1879, el guitarrista Paredes tocó en dos ocasiones en el Café del Comercio. En el primer concierto, interpretó "unas preciosas malagueñas, la estudiantina de París, la sinfonía de Norma y otras piezas de mucho gusto del señor Esbrí y del señor Paredes", acompañadas al piano por Juan Diego Manresa ${ }^{25}$. En el segundo, el guitarrista Paredes fue acompañado por Manresa en el piano y Valero en la guitarra y tocaron "variadas piezas de la Traviata, Luchia, escogidos valses y varios aires nacionales"26.

En febrero de 1885, actuó en el Café del Comercio el violinista Sixto Hernández, "contratado como concertino para el teatro de Cartagena",27. En octubre del mismo año, el periódico alicantino La Tarde se hacía eco de una velada en el Café del Comercio en la que participó la Banda de Música de la Casa de la Misericordia, dirigida por Acisclo

especifican quién de estos dos pianistas tocaba el armonio. Es posible que lo hicieran indistintamente. Sólo he hallado una noticia que informa de la actuación de unos cantantes, aunque no especifica nombres: $L a$ Paz de Murcia, XX (1877), nº 6145, 6 septiembre, p. 1.

${ }^{22}$ El Noticiero transcrito por La Paz de Murcia, XX (1877), nº 6227, 1 diciembre, p. 1.

${ }^{23}$ Pedro Martínez era contrabajista y aprobó las oposiciones de la orquesta del Teatro Romea en 1884. Sobre el violinista Mariano Esbrí, director de la orquesta de este coliseo, y Acisclo Díaz, véase el Capítulo 9. La formación participó en una velada musical en el Ateneo de Cartagena el 26 de octubre de 1878: La Paz de Murcia, XXI (1878), n 6343, 26 octubre, p. 1 y La Paz de Murcia, XXI (1878), nº 6345, 29 octubre, p. 1. Este hecho indica que ese conjunto musical actuaba también en otros ámbitos, incluso fuera de Murcia. En el último documento citado se afirma: "los que suscribimos [somos los] individuos que componemos el cuarteto del Café del Comercio de esta capital".

${ }^{24}$ El Semanario Murciano, I (1878), $\mathrm{n}^{\circ}$ 36, 20 octubre, p. 8. Las fuentes sobre las actuaciones del sexteto, véase: La Paz de Murcia, XXI (1878), no 6339, 3 noviembre, p. 1; 6347, 12 noviembre, p. 1; 6364, 1 diciembre, p. 1 y El Semanario Murciano, I (1878), nº 45, 22 diciembre, p. 7.

${ }^{25}$ La Paz de Murcia, XXII (1879), n 6706, 24 septiembre, p. 1 y El Diario de Murcia, I (1879), $\mathrm{n}^{\circ}$ 183, 25 septiembre, p. 3.

\footnotetext{
${ }^{26}$ La Paz de Murcia, XXII (1879), nº 6710, 28 septiembre, p. 1

${ }^{27}$ La Paz de Murcia, XXVIII (1885), no 8148, 17 febrero, p. 1.
} 
Díaz, lo que revela la repercusión de su actividad musical fuera de los límites de la ciudad $^{28}$.

En septiembre de 1887, el prestidigitador Enrique de Cayetano amenizó al menos dos veladas en el Café del Comercio $^{29}$. El día 28 de diciembre de los años 1887 y 1888, el local organizó un concierto "en recuerdo de que [...] no ha faltado, a Dios gracias, ninguno de los asistentes al salón y por este motivo tuvo la fiesta carácter de Te Deum"30. Actuaron en ellos varios miembros del coro del Teatro Romea y los aficionados Francisco Baeza y Juan Martínez Espinos. Juan Diego Manresa tocó al piano varios números de $L a$ Gran Via, Los trasnochadores y otras zarzuelas.

En marzo de 1890 comenzaron en el Café del Comercio las actuaciones de un sexteto formado por Juan Diego Manresa "que dará a conocer la música di cámera [sic] que se toca en el Salón Romea de Madrid"31. No tengo constancia de quiénes eran los restantes integrantes del grupo. La última noticia que he hallado sobre el Café del Comercio es que en 1893 se facilitó un listado de enseres del local que fueron subastados y entre las piezas que salieron a subasta estaba un armonio ${ }^{32}$. Es probable que el local volviera a abrirse al público a finales del siglo XIX o principios del XX con el nombre de Café Patrón, por estar ubicado en el piso bajo del Hotel del mismo nombre (ver Figura $7.5)^{33}$.

\subsection{El Café de la Puerta del Sol (1869-1935)}

El Café de la Puerta del Sol (o simplemente Café del Sol) era uno de los cafés más antiguos de Murcia ${ }^{34}$. Estaba abierto ya en junio de $1869^{35}$ y su propietario fue José Mollá (o Moya) Palmís ${ }^{36}$. Estuvo ubicado en la céntrica Puerta del Sol sobre un antiguo local

${ }^{28}$ La Tarde citado por La Paz de Murcia, XXVIII (1885), $\mathrm{n}^{\mathrm{o}} 8339,2$ octubre, p. 1. Únicamente se menciona en esta velada la interpretación del primer acto de La Africana, que sobresalió entre todas las obras ejecutadas por la banda.

${ }^{29}$ La Paz de Murcia, XXX (1887), nº 8242, 29 septiembre, p. 1

${ }^{30}$ La Paz de Murcia, XXXI (1888), no 9724, 29 diciembre, p. 1.

${ }^{31}$ La Paz de Murcia, XXXIII (1890), nº 10074, 7 marzo, p. 1.

${ }^{32}$ El listado de enseres incluyó: "Una mesa de billar con varios juegos de bolas, juego de piña, taquera y demás útiles; Un magnífico armonio; Grandes espejos; Mesas para café y cocina, de mármol y madera; Divanes, sillas y sillones de terciopelo, bejuco y otras clases; Juegos de dominó de varios precios; Tres molinos grandes para moler café; Servicio variado de bandejas y cafeteras de plata, Meneses y metal blanco; Garrapiñeras, corchos y moldes para quesillo helados; Un mostrador y una anaquelería; Un surtido variado de licores finos": El Diario de Murcia, XV (1893), nº 6120, 12 diciembre, p. 2.

${ }^{33}$ Valero, La música, p. 33 ha documentado actividad musical en el Café Patrón desde 1911.

${ }^{34}$ En José Martínez Tornel, Guía de Murcia (Murcia: Imprenta de "El Diario de Murcia”, 1887), p. 39 el nombre del local aparece como Café de la Puerta del Sol. Sin embargo, desde 1879 también se le venían llamando Café del Sol y así aparece, por ejemplo, en Belando y Perelló, Guía, pp. 186-187.

${ }^{35}$ Así parece desprenderse de La Paz de Murcia, XII (1869), n 3611, 1 julio, p. 1: “CAFÉ. Grande, abundante de mesas, de sillas, bien iluminado y con esperanzas de llegar a ser un buen café se ha inaugurado uno hace pocos días en la Puerta del Sol". A partir de 1879, es mencionado como Café del Sol.

${ }^{36}$ La Paz de Murcia, XXXV (1892), no 11709, 19 septiembre, p. 3. 
denominado Café de la Fraila ${ }^{37}$. Según La Paz de Murcia, su apertura supuso "una revolución de buen gusto"38.

A comienzos de la década los setenta el Café de la Puerta del Sol fue uno de los más concurridos de la ciudad, junto al Café del Comercio. El local contaba en 1878 con un piano vertical de la casa Guarro de Barcelona ${ }^{39}$. Al menos desde mayo de 1871, tocaba regularmente en el Café del Sol el pianista y organista de la Catedral de Murcia, Julián Calvo $^{40}$. La Tabla 7.1 que presento a continuación recoge las actuaciones puntuales de otros músicos:

Tabla 7. 1. Veladas musicales del Café del Sol

\begin{tabular}{|c|c|c|c|}
\hline Fecha & Intérpretes & Repertorio & Fuente periodística \\
\hline $22-06-1877$ & $\begin{array}{lr}\text { Francisco García } & \text { Rueda } \\
\text { (cornetín del } & \text { Quinto } \\
\text { Regimiento de } & \text { Artillería), } \\
\text { Bonifacio } & \text { Ballester } \\
\text { (bombardino) } & \text { Julián } \\
\text { Calvo (piano) } & \end{array}$ & $\begin{array}{l}\text { Rueda y Calvo: } \\
\text { Gounod, Serenata, por } \\
\text { Rueda } \\
\text { [No consta], Malagueña } \\
\text { Ballester y Calvo: } \\
\text { Donizetti, Amor funesto } \\
\text { Rueda y Ballester: } \\
\text { [¿Auteri?-] Manzocchi, Dúos }\end{array}$ & $\begin{array}{l}\text { La Paz de Murcia, XX } \\
(1877), n^{\circ} 6084,23 \text { junio, } \\
\text { p. } 1\end{array}$ \\
\hline $31-07-1886$ & $\begin{array}{l}\text { Orquesta de bandurrias y } \\
\text { guitarras, Manuel Alarcón } \\
\text { (dir.) }\end{array}$ & [No consta] & $\begin{array}{l}\text { La Paz de Murcia, XXIX } \\
(1886), \text { n }^{\circ} 8982,31 \text { julio, } \\
\text { p. } 1\end{array}$ \\
\hline ¿?-09-1892 & $\begin{array}{l}\text { Zaida (bandurria), Juan } \\
\text { Diego Manresa (piano) y } \\
\text { Quetglas (piano) }\end{array}$ & [No consta] & $\begin{array}{lll}\text { La Paz } & \text { de Murcia, } \\
\text { XXXV } & (1892), & \text { n }^{\text {oa }} \\
11702, & \text { septiembre, p. } \\
2 & \text { y } & 11709, \\
\text { septiembre, p. } 3\end{array}$ \\
\hline
\end{tabular}

En septiembre de 1879, hubo en el Café del Sol conciertos matutinos a cargo de un cuarteto dirigido por Julián Calvo:

[...] Por la mañana se pasea, se inspeccionan las tiendas, se compra tal o cual objeto y se toma chocolate en el Café del Sol, mientras que el cuarteto de músicos ameniza la reunión matutina tocando diferentes piezas del antiguo y moderno repertorio.

Julián Calvo, que dirige esa pequeña orquesta, procura complacer al público y lo complace efectivamente dándole a cada cual lo que más le gusta.

${ }^{37}$ El Diario de Murcia, II (1880), no 392, 30 mayo, p. 1. El Café Baró o del Fraile fue adquirido por José Mollá en noviembre de 1866, pasando a llamarse Café de los Artesanos: La Paz de Murcia, IX (1866), $\mathrm{n}^{\mathrm{o}} 2805,7$ noviembre, p. 2.

${ }^{38}$ La Paz de Murcia, XVIII (1875), n n $^{\circ} 434,20$ agosto, p. 1.

${ }^{39}$ El Semanario Murciano I (1878), núm. 27, 18 agosto, pp. 3-5: 4. Mariano Guarro Guim fue uno de los fabricantes más antiguos de pianos de Barcelona. Su empresa, creada en 1860, fue heredada por sus hijos en 1900. Ganó premios en varias distintas exposiciones (Exposición Aragonesa, Zaragoza, 1868; Exposición General Catalana, 1871, Exposición Universal de París, 1889, entre otras). Véanse más detalles en Fukushima, "Fabricantes", pp. 292-293.

${ }^{40}$ La Paz de Murcia, XIV (1871), nº 4155, 2 mayo, p. 1. 
En estos días de todos y jaleos, Julián calvo ha recordado Pepe Hillo, Pan y otor, En las astas y todo cuanto tiene ese aire español que tanto anima y entusiasma a las clases populares. $[\ldots]^{41}$.

El Café del Sol sufrió un incendio en septiembre de 1891 que arrasó el local y todos sus enseres. Fue reconstruido por el arquitecto Francisco Ródenas, decorado por José Huertas y abierto al público nuevamente en $1892^{42}$. Las veladas musicales se retomaron en septiembre de ese año con la concertista de bandurria Miss Zaida, acompañada al piano por Manresa y Quetglas ${ }^{43}$.

Durante el año 1893 las veladas musicales se hicieron más frecuentes. En mayo, se anunciaron nuevos conciertos de piano, violín, viola y violonchelo ${ }^{44}$; así como otras actuaciones puntuales, como por ejemplo, la del guitarrista Rafael Tost y Marías, en junio del mismo año ${ }^{45}$ o la del Quinteto Barcelonés, en noviembre de $1894^{46}$.

Durante los primeros años del siglo XX fueron frecuentes las actuaciones en el Café del Sol de una agrupación musical llamada El Turia, dirigida por el conocido director de bandas de música Vicente Espada que, en formación de sexteto o quinteto, también actuaba en el Café del Siglo. Valero $^{47}$.

La trayectoria del Café del Sol prosiguió hasta 1935, año de su cierre, según

\subsection{El Café Oriental (1875-1901)}

El Café Oriental (más tarde, llamado Café de Oriente ${ }^{48}$ ) fue uno de los cafés más prestigiosos de Murcia $^{49}$. La prensa publicó numerosas noticias sobre el local y su

${ }^{41}$ La Paz de Murcia, XXII (1879), nº 6694, 10 septiembre, p. 4.

${ }^{42}$ La Paz de Murcia, XXXIV (1891), nº 11439, 28 septiembre, p. 2. Belando y Perelló, Guía, p. 187.

${ }^{43}$ La Paz de Murcia, XXXV (1892), no 11702, 14 septiembre, p. 2. Se aclaró que en "los conciertos que se den por dicha artista no habrá bandeja ni rifas, sin que se moleste para nada a los parroquianos": $L a$ Paz de Murcia, XXXV (1892), nº 11709, 19 septiembre, p. 3.

${ }^{44}$ El Diario de Murcia, XV (1893), n $\mathrm{n}^{\mathrm{S}}$ 5942, 27 mayo, p. 3. No constan los nombres de los músicos. Desde octubre de 1893 se menciona una formación instrumental compuesta por piano, armonio, violín, viola y violonchelo: El Diario de Murcia, XV (1893), n 6053, 1 octubre, p. 3. En El Diario de Murcia, XV (1893), n 6060, 10 octubre, p. 3 se mencionan como intérpretes habituales Espada, Quetglas, López y Perea. Desconozco si estos nombres pueden asociarse a la formación citada y si se corresponden con el Cuarteto del Turia citado en El Diario de Murcia, XV (1893), nº 6100, 21 noviembre, p. 3.

${ }^{45}$ El Diario de Murcia, XV (1893), no 5956, 14 de junio, pp. 2-3.

${ }^{46}$ El Diario de Murcia, XVI (1894), nº 6456, 16 noviembre, p. 3.

${ }^{47}$ Véanse más detalles en Valero, La música, pp. 25-26.

${ }^{48}$ En abril de 1886 el local cambió el nombre por Café de Oriente, aunque un año más tarde volvió a denominarse Café Oriental: La Paz de Murcia, XXIX (1886), nº 8903, 24 abril, p. 1 y La Paz de Murcia, XXX (1887), nº 8182, 30 abril, p. 1.

${ }^{49}$ No sólo por su dilatada trayectoria o por las continuas reformas de ampliación y mejora del local sino, sobre todo, por su intensa actividad musical. Adolfo Gascón, uno de sus dueños, tenía también un almacén de música en el que se celebraron frecuentes veladas musicales (véanse los Capítulo 8 y 9 de esta 
decoración, reformas, intérpretes musicales habituales y ocasionales y 147 programas de sus actuaciones musicales entre los años 1876 y 1892 (ver Apéndice 7.2).

El Café Oriental se inauguró el 21 de agosto de 1875 y estuvo situado en la Calle del Príncipe Alfonso ${ }^{50}$. Se construyó "ad hoc según el gusto moderno" en la planta baja de la casa de uno de sus dueños y empresarios, el pianista Adolfo Gascón, que regentaba el local junto a Bojart, Arques y Boronat (véase Figuras 7.6 y 7.7 ${ }^{51}$. La distribución del espacio y del mobiliario en el café fueron muy elogiados en la época:

[...] el señor Gascón, al levantar su gran casa de la calle del Príncipe Alfonso, pensó en ello y en su planta baja le ha distribuido de tal modo que sin duda es hoy el mejor establecimiento de su clase en la capital: espacioso, cómodo y bien decorado. Nos vamos a permitir describirle.

Seis grandes huecos de puerta tiene a la calle y solo por uno es la entrada, estando cerrados los cinco por antepechos y persianas. En el interior se encuentra, con cuatro huecos de ellos, el salón principal pintado con sencillez por medio de recuadros color medias tintas, guarnecidos con baquetas y cantoneras doradas, estando apeado el techo por dos grupos de dos ligeras columnas de fundición entre las cuales penden tres magníficos aparatos de bronce adornados de estatuas, dorados a fuego y con multitud de mecheros.

Distribuidas espaciosamente hay veinticinco mesas de mármol y en el frente principal del salón está el magnífico mostrador adornado con tres pórticos y una tribuna para el piano y los conciertos: en los dos actos extremos de ellas se colocarán elegantes jardineras. Los divanes y las colgaduras son de terciopelo carmesí, y las sillas son de junco de Viena, con armadura de palo santo. Dos cortinas transparentes ocupan las dos ventanas de testero.

A la derecha y con dos huecos a la calle está el gabinete, decorado como el gran salón, con otro magnífico aparato de bronce y diez mesas. En uno de sus ángulos está la puerta del retrete para el público y, tanto este gabinete como el salón, tienen en sus paredes grandes espejos con marcos dorados y copetes del estilo de Luis XVI. $[\ldots]$.

Diferentes títulos querían darse a este café, siendo el del Café Gascón el más lógico, pero la modestia del dueño del edificio ha obligado a los individuos de la empresa del establecimiento a titular a este "Café Oriental" cuya inauguración a la que asistirá por la noche una banda de música, tendrá lugar mañana sábado. Desde este día ya tenemos un café más, hecho "ad hoc" según el gusto moderno, con elegantes vajillas para el servicio, desempeñado éste por atentos y prácticos camareros y para la cocina ha traído la empresa un excelente jefe de ella, notable culinario, que obtendrá el favor del público por los excelentes almuerzos y cenas que presente a las altas horas de la noche cuando salga la gente del teatro, hora en que nuestros abuelos en lugar de ir al café, despertaban a los ecos lastimeros del pecado mortal que pasaba por la calle, y ya no se acordaban de que no en el café, sino en su casa, a prima noche, había cenado muy frugalmente. $[\ldots]^{52}$.

Tesis). En el Café Oriental se exhibían habitualmente los retratos de los artistas que actuaban en el Teatro Romea. Por ejemplo, los de la compañía Lambertini, en octubre de 1886: La Paz de Murcia, XXIX (1886), no 9030,31 octubre, p. 1 .

${ }^{50}$ Según cita El Diario de Murcia, II (1880), no 392, 20 mayo, p. 1 el Café Oriental sustituyó la antigua Horchatería del Tío Paco. A la inauguración acudió la banda de música que dirigía Raya, interpretando varias obras fuera del local (en la calle del Testero) y dentro de él. Adolfo Gascón interpretó al piano "escogidas piezas" (no se especifica cuáles). Se sirvieron sorbetes, helados, refrescos, vinos y licores acompañados por diferentes entrantes fríos: La Paz de Murcia, XVIII (1875), nº 5436, 22 agosto, p. 1.

${ }^{51}$ La Paz de Murcia, XVIII (1875), no 5436, 22 agosto, p. 1.

${ }^{52}$ La Paz de Murcia, XVIII (1875), no 5434, 20 agosto, p. 1. Una descripción posterior indica que el local contaba también con una sala de billar: La Paz de Murcia, XXX (1887), nº 8110, 4 febrero, p. 1. 


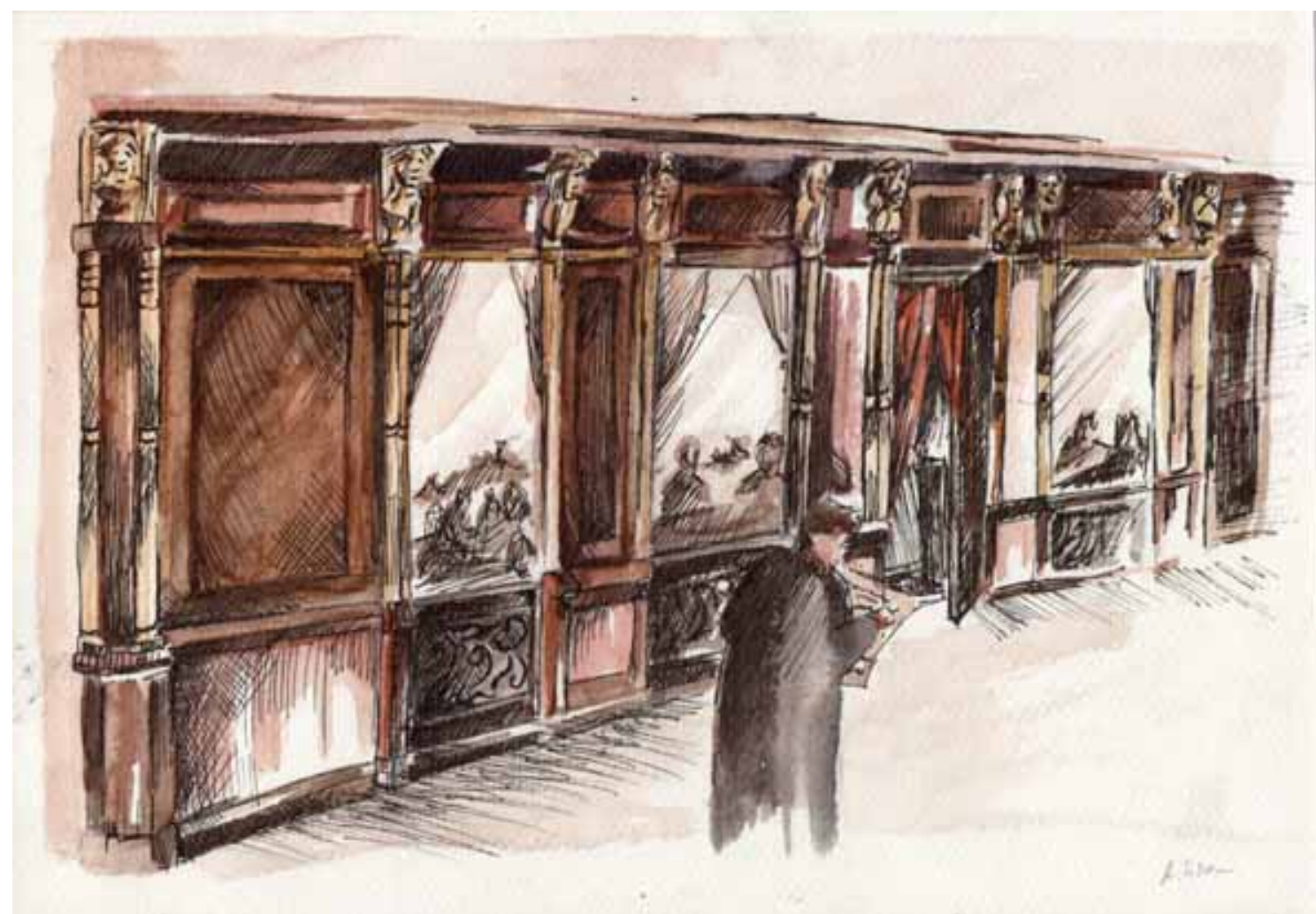

Figura 7. 6. Reconstrucción ideal del exterior del Café Oriental de Murcia, realizada por el pintor Adrián Liza Clares ${ }^{\mathbf{5 3}}$.

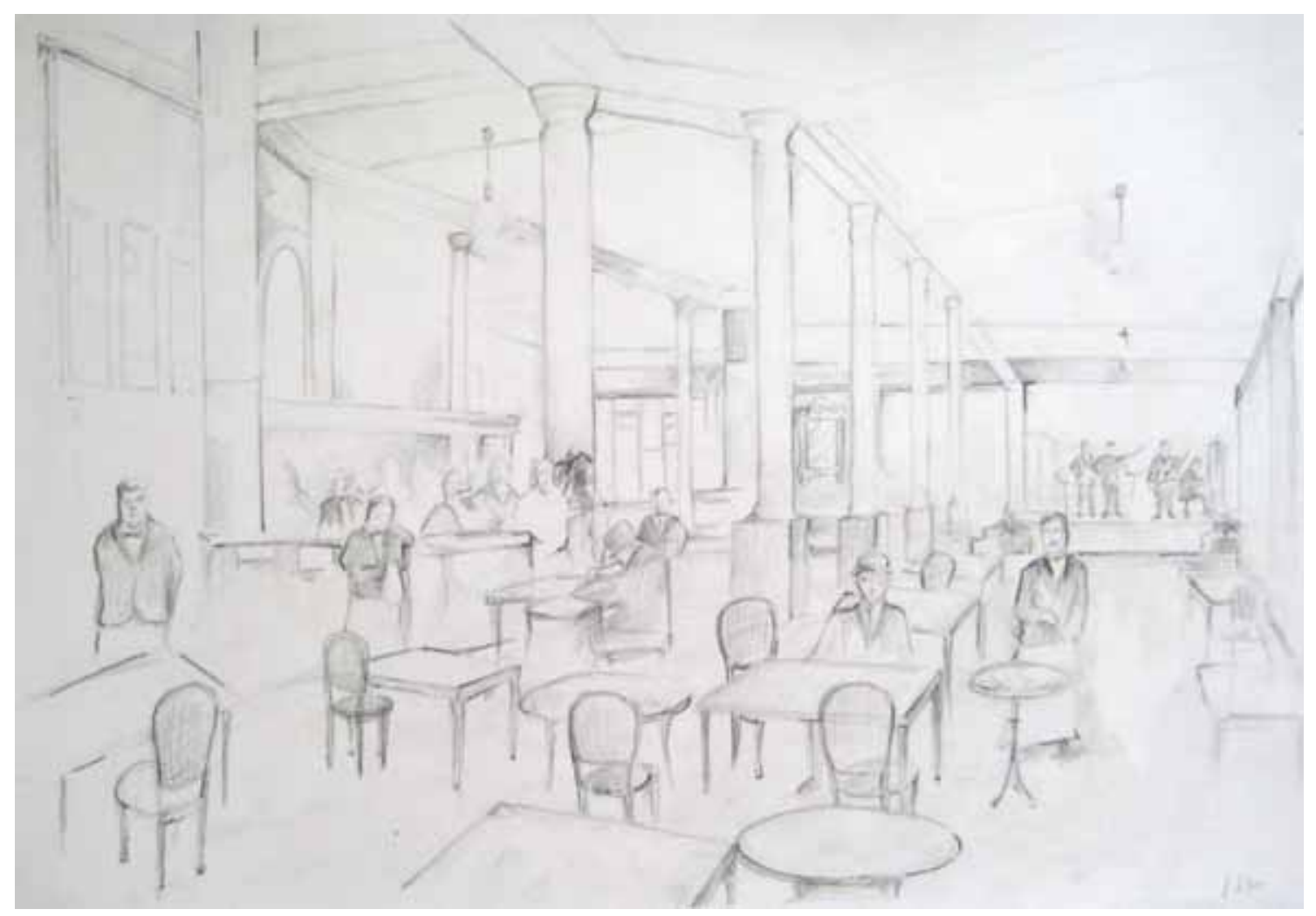

Figura 7. 7. Reconstrucción ideal del interior del Café Oriental de Murcia, realizada por el pintor Adrián Liza Clares.

${ }^{53}$ Agradezco a Adrián Liza Clares su inestimable colaboración en esta investigación. 
Desde su apertura, los amplios servicios que ofrecía el Café Oriental y el lujo del local hicieron que se erigiera como uno de los locales preferidos por los murcianos y uno de los de más amplia trayectoria en la ciudad ${ }^{54}$. A lo largo del periodo estudiado, el Café Oriental reformó y amplió su local hasta en cuatro ocasiones (julio de $1879^{55}$, enero de $1881^{56}$, marzo de $1885^{57}$ y durante el verano de 1888), un claro indicativo de la rentabilidad del negocio y de la visión comercial de sus dueños, que supieron adaptar el local a las modas imperantes. Tras la reforma de 1888, las consumiciones en el local eran más caras y el lujo de la decoración patente:

Anoche se inauguró reformado el Café Oriental, que sorprendió por el lujo desplegado en el papel que viste sus paredes en los cortinajes que guarnecen las puertas, en sus aparatos de alumbrado, en sus cómodos asientos y en todo lo que puede agradar al concurrente. Bien puede decir el señor Gascón que ha puesto su establecimiento a la altura de los primeros de su clase.

La novedad, el mucho tiempo que ha estado cerrado y lo selecto del concierto con que inauguró su reapertura llevaron una concurrencia numerosa y escogida en ambos sexos. También de los pocos favorecidos de la fortuna, de esos que no pueden gastar 50 céntimos en un café, aunque algunos hacen ese sacrificio a favor de un periódico; de esos, estuvo la calle llena, admirando por las ventanas la magnificencia desplegada y renovándose durante las horas de la velada ${ }^{58}$.

El Café Oriental imprimía los programas de las veladas para repartirlos entre sus clientes y, además, los publicaba en prensa para su mayor difusión ${ }^{59}$. Cada concierto duraba dos horas (a veces menos) y ofrecía entre seis y ocho números musicales. En días festivos (por ejemplo, los domingos, los días de la feria de septiembre o en Carnaval) las

${ }^{54}$ En mayo de 1893, La Juventud Literaria, V (1893), no 159, 7 mayo, p. 3 publicaba: "En el elegante Café Oriental, en una mesita que existe al lado de un balconcillo que da a la calle, todas las almediodías [sic] y todas las noches a las ocho, nos reunimos gran número de amigos, que todos simpatizamos por el franco carácter y alegre conversión que sostenemos. Allí hablamos de política, del toreo, de teatro, de gallos, porque en todos estos ramos entendemos cual un Cánovas, un Lagartijo, un Calvo o un Paco Sevilla. Pero la conversión más vehemente sostenida es la tocante a las nenas que cada uno de los reunidos tiene como novias o piensa tenerlas". Todavía en 1899 seguía considerándose como uno de los mejores locales de la ciudad. En Belando y Perelló, Guía, p. 187 afirman: "es indudablemente el mejor acondicionado de Murcia”. Por estas fechas, el Café Oriental era propiedad de la sociedad "Hijos de José Gascón”.

${ }^{55}$ Se inauguró el 23 de agosto de 1879 y las veladas musicales comenzaron a mediados del mes de noviembre. La decoración del nuevo mostrador fue obra de Antonio Gil Montejano: La Paz de Murcia, XXII (1879), n 6682, 26 agosto, p. 1. Véase el seguimiento de las obras en La Paz de Murcia, XXII (1879), $\mathrm{n}^{\text {os }} 6651,18$ julio, p. 1; 6675, 17 agosto, p. 1 y 6681, 24 agosto, p. 1.

${ }^{56}$ En enero de 1881, el Oriental se amplió con "nuevas salas para tresillo y dominó en el piso superior de la misma casa": La Paz de Murcia, XXIV (1881), n 6965, 30 enero, p. 1.

${ }^{57}$ En esta ocasión, las obras eran de "restauración y embellecimiento". Se encargó de la obra, Antonio Meseguer: La Paz de Murcia, XXVIII (1885), nº 8169, 13 marzo, p. 1.

${ }^{58}$ La Paz de Murcia, XXXI (1888), no 9594, 1 septiembre, p. 1. Las reaperturas del local siempre fueron celebradas con grandes conciertos. En el caso de la reforma de 1888, se efectuaron dos conciertos inaugurales con el cuarteto habitual del café y el tenor murciano Blaya (ver Apéndice 7.2). Tal y como se expresa en la cita, el precio de la consumición era de 50 céntimos en 1888, el doble de lo que costaba en 1886: "los 25 céntimos y propina que voluntariamente gastan los más, les da derecho a un asiento para toda la noche pues a nadie lo echan ni se le levanta": La Paz de Murcia, XXIX (1886), nº 8439, 7 febrero, p. 1.

59 A diferencia de otros cafés, por ejemplo el Comercio, cuyos anuncios en prensa indicaban únicamente la hora de inicio, intérpretes y alguna breve indicación sobre el repertorio. 
piezas musicales interpretadas se incrementaban hasta diez o doce ${ }^{60}$. La frecuencia de los conciertos era muy variable. En octubre de 1878, por ejemplo, había tres veladas musicales cada semana (martes, jueves y domingos) ${ }^{61}$. Desde noviembre de 1879 , el Oriental ofreció conciertos diarios con piano y armonio a cargo de los músicos José Antonio Ramírez, José Solano y Adolfo Gascón ${ }^{62}$. En febrero de 1886 los conciertos eran semanales y, desde el mes de octubre del mismo año, de nuevo diarios.

El Café Oriental casi siempre contó con formaciones instrumentales estables. En 1879 , los propietarios del local adquirieron "un magnífico armonio" que fue estrenado el 18 de diciembre y desde entonces, casi todas las veladas incluyeron invariablemente el piano y el armonio ${ }^{63}$. Por estas fechas, el local contaba con un cuarteto, un piano y un armonio, dirigidos por Mariano Esbrí ${ }^{64}$. A partir de 1886, las formaciones que tocaban habitualmente en el Oriental fueron más variadas, tal y como se muestra en la siguiente tabla:

Tabla 7. 2 Conjuntos instrumentales e intérpretes habituales del Café Oriental (1886-1894)

\begin{tabular}{|l|l|l|}
\hline Año & Formación instrumental & Intérpretes \\
\hline 1886 & Armonio & Julián Calvo \\
\cline { 2 - 3 } & Piano y violín & $\begin{array}{l}\text { Sixto Hernández (violín), Adolfo Gascón } \\
\text { y José Solano (piano) }\end{array}$ \\
\cline { 2 - 3 } & $\begin{array}{l}\text { Dos violines, armonio y piano (la más } \\
\text { habitual hasta diciembre) }\end{array}$ & $\begin{array}{l}\text { Sixto Hernández y Vicente Espada } \\
\text { (violines), Julián Calvo, Adolfo Gascón y } \\
\text { José Solano (piano y armonio, } \\
\text { indistintamente) }\end{array}$ \\
\cline { 2 - 3 } & Violín, flauta, piano y armonio & $\begin{array}{l}\text { Trinidad Ballester (violín), Sánchez } \\
\text { Vigueras (flauta), Gascón y Solano (piano } \\
\text { y armonio, indistintamente) }\end{array}$ \\
\hline 1888 & Violín, flauta, piano y armonio & José Mirete (violín y dir. ${ }^{65}$ ) \\
\hline
\end{tabular}

${ }^{60}$ Compárense, por ejemplo, los programas correspondientes a los días 11 y 12 de noviembre de 1876 : La Paz de Murcia, XIX (1876), n ${ }^{\text {os }} 5903,11$ noviembre, p. 1 y 5904, 12 noviembre, p. 1. A veces se rifaban botellas de licor: La Paz de Murcia, XX (1877), $\mathrm{n}^{\text {os }}$ 6187, 25 octubre, p. 1; 6245, 23 diciembre, p. 1 y

La Paz de Murcia, XXXI (1888), nº 9475, 10 abril, p. 1.

${ }^{61}$ No ha quedado constancia de los nombres de los músicos ni de su formación, aunque sabemos que eran dirigidos por Ángel Mirete: La Paz de Murcia, XXI (1878), n 6334, 16 octubre, p. 1 y El Semanario Murciano, I (1878), $\mathrm{n}^{\mathrm{o}}$ 36, 20 octubre, p. 8. Véase también: La Paz de Murcia, XXI (1878), $\mathrm{n}^{\mathrm{os}}$ 6344, 27 octubre, p. 1; 6345, 29 octubre, p. 1; 6339, 3 noviembre, p. 1 y 6364, 1 diciembre, p. 1.

62 Se interpretaron diversos números corales a cargo del "coro del teatro" de las zarzuelas Los diamantes de la corona, Capitán Negrero, El juramento, El diablo en el poder, Relámpago, Robinson. No ha quedado de qué teatro procedía la formación vocal, aunque cabe suponer que fuera del Teatro Romea. Tampoco se especifica quién o quiénes tocaban el piano y/o el armonio. Dado que todos eran pianistas, cabe suponer que los tres se sentaran indistintamente a uno u otro instrumento. Véase, La Paz de Murcia, XIX (1876), $\mathrm{n}^{\text {os }} 5670,21$ mayo, p. 1 y 5795, 3 noviembre, p. 1.

${ }^{63}$ El Noticiero Murciano, VIII (1879), nº 1865, 17 diciembre, p. 2. Véase también, La Paz de Murcia, XXII (1879), $\mathrm{n}^{\circ}$ 6705, 18 diciembre, p. 1. El armonio se estrenó en una velada a beneficio de los afectados por la "Riada de Santa Teresa", ocurrida 15 de octubre de 1879. La devastadora inundación causó cuantiosas pérdidas humanas y materiales en la Vega del Segura y en el Valle del Guadalentín.

${ }^{64}$ La Paz de Murcia, XXII (1879), nº 6749, 15 noviembre, p. 1 y El Noticiero Murciano, VIII (1879), $\mathrm{n}^{\mathrm{o}} 1854,4$ diciembre, p. 3. No tengo constancia de los nombres de los restantes instrumentistas.

${ }^{65}$ No ha quedado constancia de todos los intérpretes, salvo José Mirete (hijo de Ángel Mirete) como primer violín: La Paz de Murcia, XXXI (1888), nº 9475, 10 abril, p. 1. Cabe suponer que Adolfo Gascón y José Solano interpretaran el piano y armonio. 


\begin{tabular}{|c|c|c|}
\hline 1889 & Violín, piano y armonio & No constan \\
\hline & Violín, flauta, piano y armonio & $\begin{array}{l}\text { José Mirete (violín), Sánchez Vigueras } \\
\text { (flauta), José Solano y Adolfo Gascón } \\
\text { (piano y armonio, indistintamente) }\end{array}$ \\
\hline \multirow[t]{2}{*}{1891} & $\begin{array}{l}\text { Dos violines, violonchelo, piano } \mathrm{y} \\
\text { armonio }\end{array}$ & [No constan] \\
\hline & $\begin{array}{l}\text { Violín, violonchelo, flauta, oboe, piano y } \\
\text { armonio }\end{array}$ & $\begin{array}{l}\text { José Mirete (violín), Córcoles } \\
\text { (violoncelo), Galán (flauta), Hita (oboe), } \\
\text { José Solano (piano) y Adolfo Gascón } \\
\text { (armonio) }\end{array}$ \\
\hline 1894 & $\begin{array}{l}\text { Dos violines, violonchelo, flauta, piano y } \\
\text { armonio }\end{array}$ & $\begin{array}{l}\text { José Mirete y Gálvez (violines), Jover } \\
\text { (violonchelo), Galán (flauta), José Solano } \\
\text { y Adolfo Gascón (piano y armonio, } \\
\text { indistintamente }^{66} \text { ) }\end{array}$ \\
\hline
\end{tabular}

Tal y como se advierte en la tabla anterior, los instrumentos más utilizados en el Café Oriental después del piano y el armonio, eran el violín y la flauta. Sólo ocasionalmente se empleó el oboe.

Eventualmente, el local acogía actuaciones de músicos que se hallaban de paso por la ciudad. Fueron frecuentes los conciertos con actores y actrices, e incluso coros de las compañías que actuaban en los teatros de Murcia. Por ejemplo, en una velada celebrada el 21 de mayo de 1876 con el coro del Teatro Romea, el repertorio estuvo compuesto exclusivamente por números de zarzuela; el concierto del 4 de septiembre de 1877, corrió a cargo de Ramírez, Gascón, Solano y el tenor cómico Antonio Díaz ${ }^{67}$.

En marzo de 1882, actuaron en el Café Oriental la pianista Adela Brotons y el cantante Carlos Villanueva; en octubre de 1883, el violinista Pedro Brasó y el guitarrista Vicente Perairé del Colegio de Ciegos y Sordomudos de Barcelona ${ }^{68}$; en octubre de 1886, el cantaor de "cante lírico andaluz" Antonio Jiménez" bandurria y el guitarrista Jacobe, ${ }^{70}$; en enero de 1888, los guitarristas Agustín Resart (Rosales) y Juan Campoy ${ }^{71}$; y en enero de 1888, el hijo del famoso guitarrista Julián Arcas.

A esta nómina de músicos hay que añadir una pléyade de prestidigitadores, adivinadores y magos de cálculos matemáticos que también pasaron por el Café

${ }^{66}$ Ocasionalmente actuó con éstos el pianista murciano Enrique Martí: La Paz de Murcia, XXXVI (1894), $\mathrm{n}^{\text {os }} 12834,15$ noviembre, p. 1; 12836, 17 noviembre, p. 1; 12837, 18 noviembre, p. 1; 12838, 20 noviembre, p. 4 y 12839, 21 noviembre, p. 1.

${ }^{67}$ La Paz de Murcia, XX (1877), nº 6154, 16 septiembre, p. 4.

${ }^{68}$ Véase el Apéndice 7.2. No ha quedado constancia de todas las piezas interpretadas por Brasó y Perairé: La Paz de Murcia, XXVI (1883), $\mathrm{n}^{\circ} 7758,31$ octubre, p. 1 y El Diario de Murcia, V (1883), $\mathrm{n}^{\circ}$ 1415, 31 octubre, p. 3.

${ }^{69}$ La Paz de Murcia, XXIX (1886), nº 9041, 12 octubre, p. 1.

${ }^{70}$ La Paz de Murcia, XXX (1887), n 8124, 20 febrero, p. 1. La bandurrista Zaig fue una habitual del Café Oriental. En 1892, la prensa refiere frecuentes indicaciones de conciertos del dúo Zaida (bandurria) y Saura (piano).

${ }^{71}$ La Paz de Murcia, XXXI (1888), nº 9403, 14 enero, p. 1. 
Oriental $^{72}$. La variedad de los espectáculos es un claro indicativo del carácter misceláneo que reinó en estos locales.

Según Valero, el Café Oriental se mantuvo abierto al menos hasta 1901, año en el que ha documentado las actuaciones de un cuarteto compuesto por Gascón, Jover, Mirete y Solano ${ }^{73}$.

\subsection{El Café del Siglo (1891-1902)}

El Café del Siglo se inauguró el 23 de mayo de 1891, con el mismo nombre que el conocido local madrileño de la calle Mayor ${ }^{74}$. Estuvo situado en la calle del Príncipe Alfonso y fue regentado por Antonio Ortiz ${ }^{75}$. El local era cómodo y espacioso. Su decoración, obra de José Huertas, era en "estilo árabe, recordando en sus muchos y hermosos detalles la Alhambra de Granada"76. Fue, junto al Café Oriental, el local más concurrido de Murcia durante los años noventa del siglo XIX.

En el Café del Siglo se organizaron veladas musicales los jueves de cada semana a cargo de los pianistas Francisco Gil ${ }^{77}$ y, desde septiembre de 1891 , Julián Calvo ${ }^{78}$. (Véase Apéndice 7.3). Eventualmente, el establecimiento acogió conciertos de otros músicos como por ejemplo, el célebre compositor Federico Chueca en septiembre de $1891^{79}$ y el pianista murciano Antonio Puig, en agosto de $1892^{80}$.

${ }^{72}$ Entre los meses de septiembre a noviembre de 1887, por ejemplo, actuaron los prestidigitadores Juarez Negrón, el Conde Abel y Antenor de Gago: La Paz de Murcia, XXX (1887), ${ }^{\text {os }}$ 8233, 18 septiembre, p. 1; 6179, 16 octubre, p. 1; 61804, 17 octubre, p. 1 y 8285, 16 noviembre, p. 1.

${ }^{73}$ Valero, La música, p. 29 afirma que las noticias sobre el Café Oriental dejan de aparecer en la prensa murciana en 1901, aunque ha podido demostrar actuaciones en ese café de un dúo que llegó a tener mucha relevancia en Murcia, formada por el violinista Roberto Cortés y el pianista José Martínez Abarca en 1929. Valero desconoce si puede tratarse del mismo local.

${ }^{74}$ Casares, "Café”, pp. 873-874. En El Diario de Murcia, XIII (1891), n 4324, 7 mayo, p. 3 se había anunciado el día 24 de mayo como inauguración del Café del Siglo. En el concierto de inauguración actuó la Banda de la Misericordia: La Paz de Murcia, XXXIV (1891), ${ }^{\text {os }} 11330,16$ mayo, p. 1; 11332, 18 mayo, p. $1 ; 11332$ [sic], 19 mayo, p. 1.

${ }^{75}$ El Diario de Murcia, XIII (1891), nº 4433, 15 septiembre, p. 1.

${ }^{76}$ Belando y Perelló, Guía, p. 188. En El Diario de Murcia, XIII (1891), nº 4324, 7 de mayo, p. 3 afirmó que "por su magnificencia y espléndido decorado [era] el mejor de Murcia, pudiendo competir con los primeros de España”. La luz eléctrica se inauguró en el local, según el mismo documento, en la festividad del Corpus (24-05-1891). El local tenía "una pequeña cafetera a disposición de cada parroquiano para que éste se sirva el café", según la moda de los cafés londinenses: La Paz de Murcia, XXXIV (1891), $\mathrm{n}^{\mathrm{o}}$ 11411, 25 agosto de 1891, p. 3 y El Diario de Murcia, XIII (1891), n 4414, 23 agosto, p. 4.

${ }^{77}$ El Diario de Murcia, XIII (1891), $\mathrm{n}^{\circ}$ 4342, 30 mayo, p. 3. Las veladas musicales alternaban con otras de magia y prestidigitación. Por ejemplo, una velada de prestidigitación de Caballero Cayetano fue mencionada en El Diario de Murcia, XIII (1891), n 4409, 18 agosto, p. 3 y otra de "prestidigitación, escamoteos, arcos y juegos japoneses al doble escamoteo del ilusionista Calderet" en La paz de Murcia, XXXIV (1891), n 11463,27 octubre, p. 3.

${ }^{78}$ La Paz de Murcia, XXXIV (1891), $\mathrm{n}^{\text {os }} 11438,26$ septiembre, p. 3; 11446, 6 octubre, p. 3 y El Diario de Murcia, XIII (1891), n 4453, 8 octubre, p. 3.

${ }^{79}$ La Paz de Murcia, XXXIV (1891), n ${ }^{\mathbf{o}} 11417,1$ septiembre, p. 3. El documento no hace referencia al repertorio interpretado. Federico Chueca llegó a Murcia el 29 de agosto de 1891 con la intención de dirigir el estreno de su zarzuela La caza del oso en el Teatro Romea: La Paz de Murcia, XXXIV (1891), ${ }^{\text {os }} 11416$, 
En diciembre de 1892 el dueño del Café del Siglo adquirió "un hermoso armonio de la casa H. Perers, de Leipzig, que a sus dos teclados y veintiún registros reúne unas voces magníficas" $" 81$. Desde entonces, el local ofreció conciertos de piano y armonio a los que se unieron otras formaciones vocales e instrumentales: en noviembre de 1893, el cuarteto Turia ${ }^{82}$; en marzo de 1894, una formación compuesta por piano a cuatro manos, armonio, violín y flauta ${ }^{83}$; el barítono Oreste Pucci en octubre de $1894^{84} \mathrm{y}$, desde noviembre del mismo año, un sexteto de violín, viola, violonchelo, contrabajo, piano y armonio $^{85}$.

El baile también tuvo acogida en el Café del Siglo. En septiembre de 1894 se organizaron "una serie de representaciones de bailes nacionales y extranjeros por una pareja que ha sido muy aplaudida en todos los teatros donde se ha presentado y que se encuentra de paso en esta ciudad. Esta pareja ofrece al público el clásico baile nacional (no el flamenco), baile inglés, polaco y francés" ${ }^{\prime \prime 6}$.

Según Valero, el Café del Siglo se cerró en $1902^{87}$.

\subsection{Otros cafés}

\subsubsection{Café de Floridablanca (1886)}

Desconozco si este establecimiento tuvo actividad musical regular, aunque sí contribuyó con diversas cantidades a las fiestas del barrio del Carmen (50 pesetas) y a las de la calle Cartagena (12 pesetas) y pagó un tablado para que actuase la banda de música de Antonio Raya ${ }^{88}$.

31 agosto, p. 3; 11418, 2 septiembre, p. 3; 11422, 7 septiembre, p. 3. Actuaba en el Romea la compañía dramática y de zarzuela dirigida por Rafael Queralt. La noticia tuvo repercusión nacional: La Iberia, XXXVIII (1891), no 12526, 3 septiembre, p. 3 y El Heraldo, II (1891), n ${ }^{\text {os }}$ 307, 3 septiembre, p. 2; 309, 5 septiembre, p. 3

${ }^{80}$ El Diario de Murcia, XIV (1892), n $\mathrm{n}^{\mathrm{0}}$ 5074, 18 agosto, p. 3. En junio del mismo año tocó frente a la puerta del local la Banda Municipal, dirigida por José Ángel Mirete: El Diario de Murcia, XIV (1892), $\mathrm{n}^{\circ}$ 5020, 12 junio, p. 3.

${ }^{81}$ La Paz de Murcia, XIV (1892), nº 11777, 9 diciembre, p. 2.

${ }^{82}$ El Diario de Murcia, XV (1893), nº 6099, 20 noviembre, p. 1.

${ }^{83}$ La Paz de Murcia (1894), no 12644, 14 marzo, p. 2. El concierto se repitió el 17 de marzo de 1894: El Diario de Murcia, XVI (1894), nº 6214, 17 marzo, p. 3

${ }^{84}$ El Diario de Murcia, XVI (1894), nº 6435, 26 de octubre, p. 3.

${ }^{85}$ El Diario de Murcia, XVI (1894), $\mathrm{n}^{\text {os }} 6447,7$ noviembre, p. 3; 6450, 10 noviembre, p. 3; 6453, 13 noviembre, p. 3 y 6456, 16 noviembre, p. 3.

${ }^{86}$ El Diario de Murcia, XVI (1894), nº 6339, 20 septiembre, p. 2.

${ }^{87}$ Valero, La música, p. 26 ha documentado las actuaciones de la citada agrupación El Turia en formación de quinteto y sexteto, además de un trío que actuaba con menor frecuencia formado por un piano, un violín y un armonio en los primeros años del siglo XIX.

${ }^{88}$ La Paz de Murcia, XXIX (1886), no 8981, 30 julio, p. 1. 


\subsubsection{Repostería de Levante (1887)}

La Repostería de Levante estuvo regentada por Belmar y ubicada en la plaza de Fernández Caballero (ver Figura 7.8). En octubre de 1887 actuó en ella un sexteto de bandurrias dirigido por Manuel Alarcón. En la primera parte del concierto se interpretó un vals titulado "El brillante"; la gavota "Moraima" de Gaspar Espinosa y el chotis "Un suspiro". La segunda parte incluyó la mazurca "Pilar", la jota de "Los ratas" de la revista La gran vía, una gavota titulada "Regente" y, finalmente, un tango de la mencionada La gran vía ${ }^{89}$.

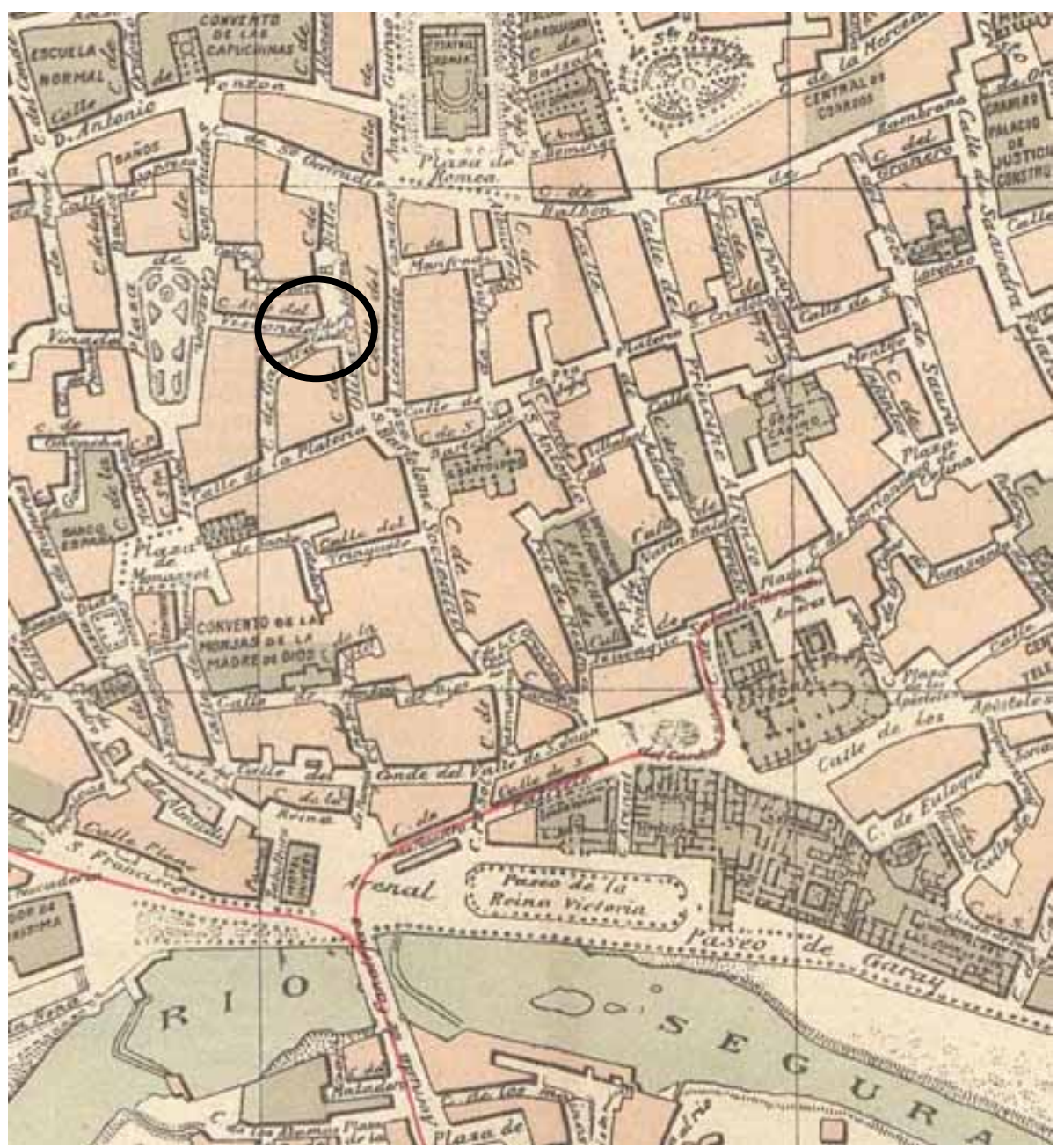

Figura 7. 8. Ubicación de la Repostería de Levante de Murcia, en la plaza Fernández Caballero. Pedro García Faria, Plano de Murcia (Barcelona: Alberto Martín, s.a.). E:Mpb. Accesible en: http://bibliotecadigital.carm.es (acceso el 16-07-2011).

${ }^{89}$ La Paz de Murcia, XXX (1887), nº 8257, 16 octubre, p. 1. 


\subsubsection{Café Cartagenero (1887)}

Este café, ubicado "frente a la casa de Zabalburu", acogió en 1887 la actuación de un niño violinista ${ }^{90}$.

\section{El repertorio musical en los cafés murcianos}

Tal y como se ha constatado en otros estudios sobre los cafés en España durante el siglo XIX, el repertorio musical en este tipo de locales murcianos no fue específico, ni puede distinguirse del habitual en la música de salón ${ }^{91}$. Un rasgo esencial fue el eclecticismo, tanto en el tipo de actividades (recitales, conciertos, funciones teatrales, sesiones de magia y prestidigitación, baile y juego, por citar algunas), como en el repertorio propiamente musical. Los cafés murcianos difundieron un gran abanico de géneros musicales, españoles y europeos, a través de múltiples combinaciones vocales, instrumentales o vocales-instrumentales. El instrumento más generalizado fue el piano (tocado sólo o a cuatro manos) aunque en Murcia el armonio, potenciado por figuras como López Almagro y Julián Calvo, se introdujo también con fuerza desde mediados del siglo y se impuso sólo o en unión al piano. El resto de formaciones instrumentales eran de lo más variopinto. En dúos, el piano o el armonio se asociaban a otros instrumentos como el violín, la flauta y más infrecuentes como el bombardino; en tríos, fueron frecuentes las formaciones con guitarra, bandurria y piano. También hubo con frecuencia formaciones de cuarteto de cuerda o con instrumentos tan dispares como violín, flauta, piano y armonio; quinteto (dos violones, violonchelo, piano y armonio); y sextetos (violín, viola, violonchelo, contrabajo, piano y armonio o bien violín, violonchelo, oboe, flauta, piano y armonio). Más excepcionales fueron las actuaciones en los cafés de coros, orquestas, orquestinas y bandas de música.

El repertorio de salón interpretado en los cafés de Murcia puede dividirse en: piezas arregladas o inspiradas en óperas y zarzuelas (principalmente, variaciones y fantasías) ${ }^{92}$; arreglos de obras sinfónicas para conjuntos instrumentales de cámara y "música de salón" propiamente dicha. En este último grupo se incluyen obras para piano, canciones para voz y acompañamiento, música de cámara (local, nacional o extranjera) y música popular. El Gráfico 7.1 muestra el reparto de géneros interpretados en el Café Oriental (el más rico de Murcia en información musical) durante los años 1876-1879, 1886-1888 y 1890-1892:

${ }^{90}$ La Paz de Murcia, XXX (1887), no 8292, 4 septiembre, p. 1. Parece ser que la casa estaba entre la calle de Jara Carrillo y el Plano de San Francisco de Murcia.

${ }^{91}$ Casares, "Un espacio alternativo", p. 81 habla del café como lugar de síntesis y de su repertorio como "estructura musical polivalente".

92 He separado conscientemente las piezas procedentes de óperas y las que provienen de zarzuelas, para poder estudiar los momentos en los que predominó uno u otro género. 
Gráfico 7. 1. Géneros interpretados en las veladas musicales del Café Oriental (1876-1879, 1886-1888, 1890-1892).

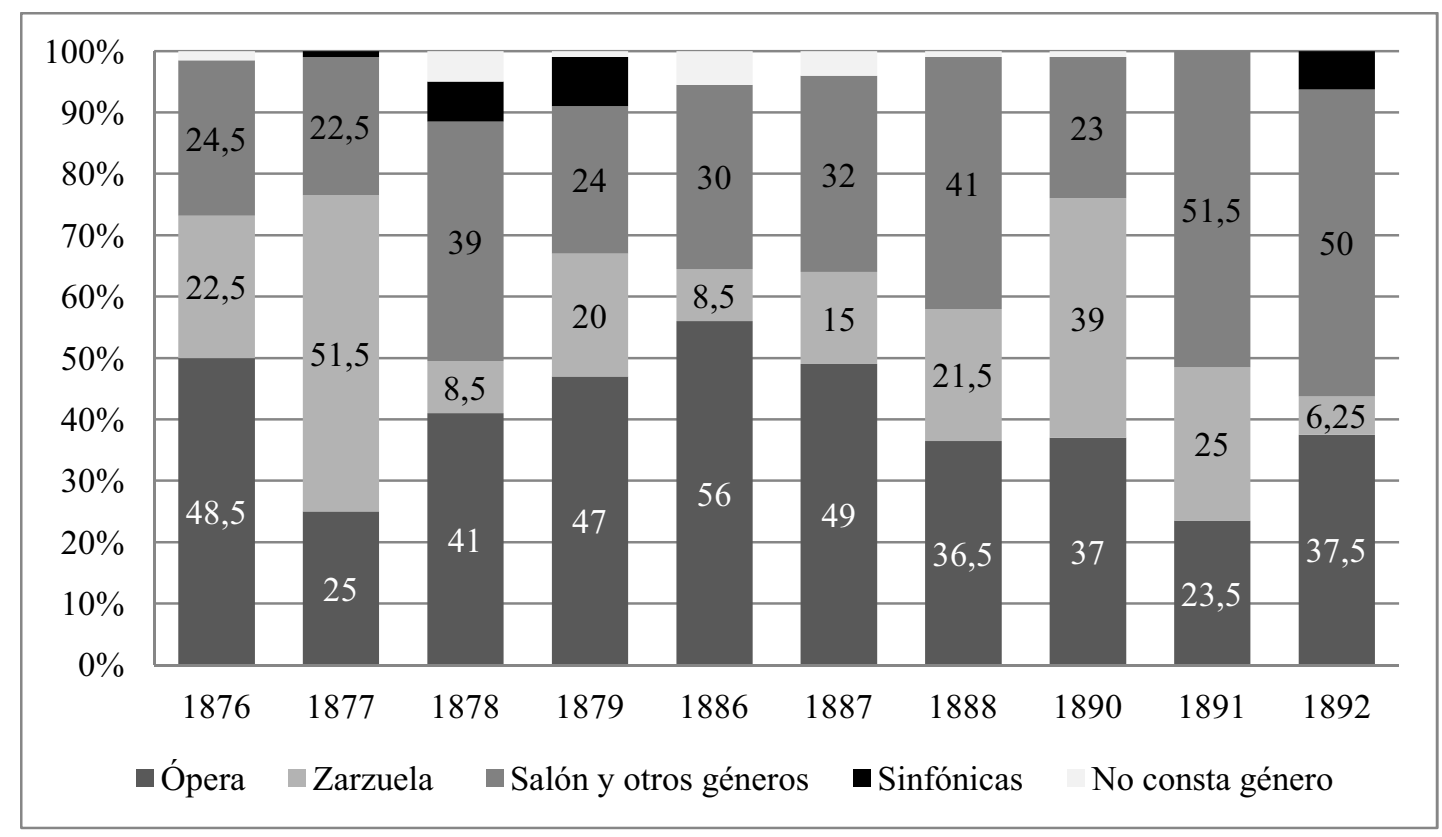

Lo más interpretado fueron arreglos de números de ópera que, excepto 1877 y 1891, siempre superaban ampliamente el 35\% del total llegando incluso hasta el 56\% en 1886. El compositor de ópera más escuchado fue Verdi, seguido por Donizetti, Bellini, Rossini y Offenbach. La siguiente Tabla 7.3 muestra los porcentajes:

Tabla 7. 3 Compositores de ópera interpretados en las veladas del Café Oriental (1876-1879, 1886-1888, 1890-1892)

\begin{tabular}{|l|c|}
\hline Compositor & Porcentaje (\%) \\
\hline Verdi & 35,8 \\
\hline Donizetti & 14,3 \\
\hline Bellini & 11,5 \\
\hline Rossini & 8,3 \\
\hline Offenbach & 6 \\
\hline Mazza & 4 \\
\hline Suppé & 3,2 \\
\hline Meyerbeer & 3 \\
\hline Flotow & 2,7 \\
\hline Auber & 2 \\
\hline Mercadante & 1,7 \\
\hline Ferninand Hèrold & 1,25 \\
\hline Thomas & 1,25 \\
\hline Gounod & 1 \\
\hline Ramón Carnicer & 0,75 \\
\hline Guglielmi & 0,75 \\
\hline Luigi Ricci & 0,5 \\
\hline No consta autor & 2 \\
\hline
\end{tabular}


Si comparamos estos datos con los hallados en las veladas musicales del Café del Comercio obtenemos un resultado similar, aunque de este último local sólo he localizado los programas de las veladas musicales de 1878 (ver Gráfico 7.2):

Gráfico 7. 2. Géneros interpretados en las veladas musicales del Café del Comercio (1878)

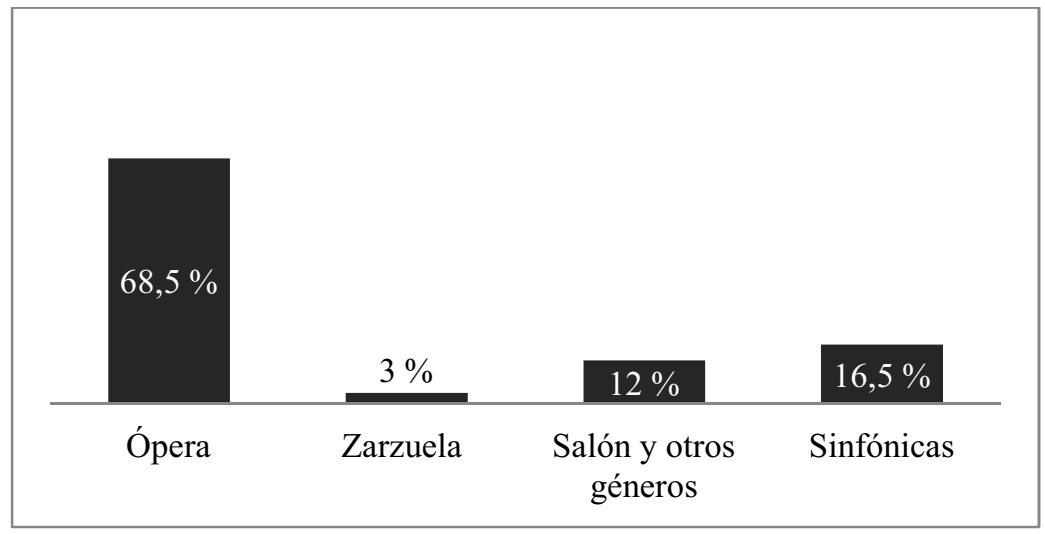

Los compositores de ópera más interpretados en el Café del Comercio fueron Donizetti (40\%), seguido de Verdi (31\%) y Mercadante (13\%), entre otros ${ }^{93}$.

Los géneros más interpretados en las veladas musicales del Café del Siglo durante el año 1891 pueden verse en el Gráfico 7.3:

Gráfico 7. 3. Géneros interpretados en las veladas musicales del Café del Siglo y porcentajes ente los mismos (1891)

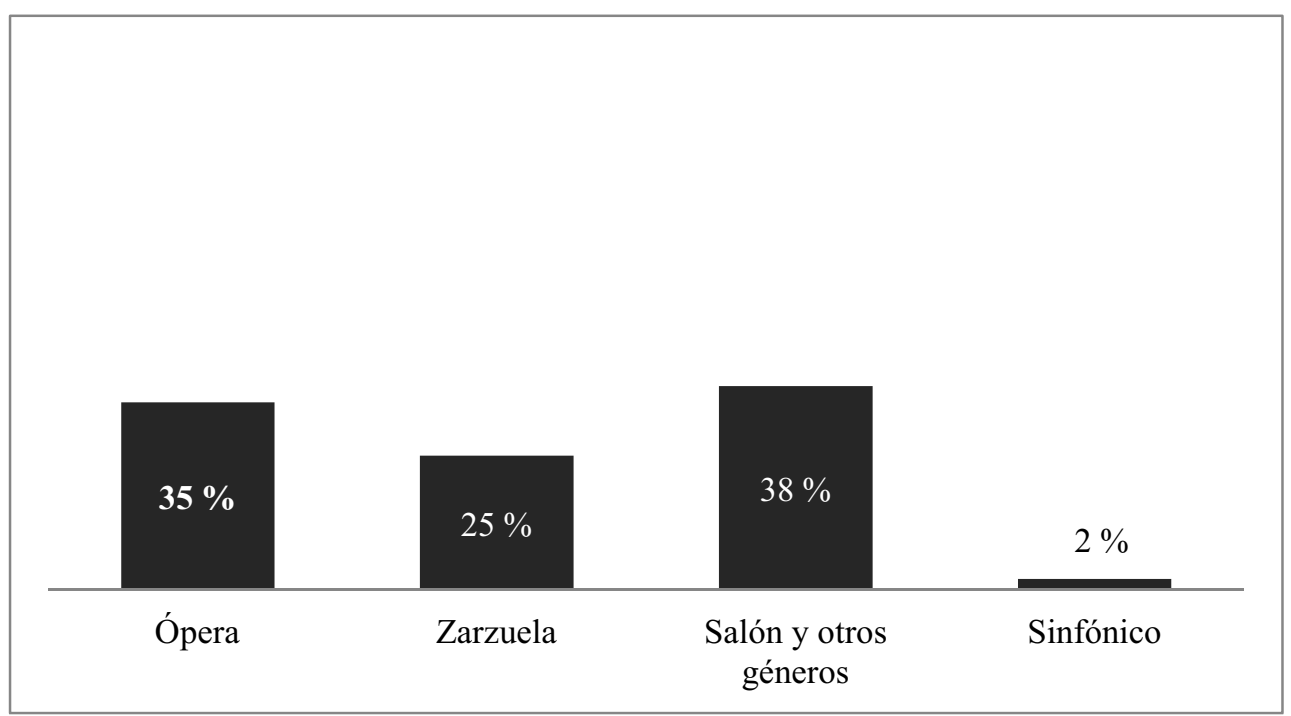

${ }^{93}$ El resto de compositores fueron Adam (7\%), Bériot (5\%) y Mazza (4\%). Las óperas más escuchadas de Donizetti fueron Marino Faliero, Anna Bolena y Maria Stuardo, entre otras. 
A diferencia de los cafés Oriental y del Comercio, las piezas de salón en el Café del Siglo constituyen el grupo más numeroso (38\%), ligeramente superior a la ópera (35\%). Además, los compositores de ópera más interpretados en el Siglo fueron más variados: Donizetti (17.5\%), seguido por Bellini, Flotow, Mercadante y Rossini $(10 \%$ cada uno $)^{94}$.

En conjunto, las piezas de salón fueron el segundo género más interpretado en estos cafés, por detrás de la ópera. En los diez años estudiados del Café Oriental, únicamente dos indican una tendencia diferente (1877 y 1890) con la zarzuela como segundo género más interpretado. En los cafés Comercio y del Siglo las piezas de salón superaron a los arreglos de zarzuelas.

Muchas piezas de salón que se interpretaban en Murcia eran habaneras, mazurcas, polcas, rigodones y valses (o tandas de valses) cuyos autores no constan. En el Café Oriental, hubo numerosas piezas compuestas por murcianos, como Adolfo Gascón, José Solano, Gaspar Espinosa y Julián Calvo (caprichos, valses, melodías, polcas, mazurcas y redowas). Algunos títulos estaban relacionados con Murcia, como el vals "A orillas del Tháder" y la mazurca de salón "La perla murciana", ambas de Adolfo Gascón. De este compositor murciano se interpretaron en el Café Oriental otras obras como "El capricho" (vals), "El estudio conduce a la inmortalidad" (cuarteto), "El nocturno" (vals), "Un recuerdo" (vals), "Una sonrisa" (mazurca), "Amor sin esperanzas" (melodía), "La caprichosa" (vals) y "La floresta" (mazurca), "Plácidas noches" (nocturno), "El amor a merced de las olas" (barcarola) y "Una sonrisa" (mazurca). Todas las obras de salón interpretadas en el Café del Comercio durante el año 1878 que he documentado eran valses.

Un grupo inferior de piezas interpretadas en todos los cafés estudiados eran melodías, serenatas, nocturnos, marchas, barcarolas, potpurrís y piezas de concierto, como la romanza "Penso", la serenata "Apri, amor mio, la perla" o "Vorrei morire", todas de Francesco Paolo Tosti; la serenata "Dormi pure" de Scuderi; el "Potpurrí de aires nacionales" de Fortuni; la chacona de Durand o el dueto de Gabussi; el "Adiós a la Alhambra" de Monasterio, o incluso obras religiosas, como el "Ave María" de Gounod.

Finalmente y en menor número, en los cafés murcianos se interpretaban obras del folclore y la música popular nacional y regional, como malagueñas, rondeñas, polos, soleás, seguidillas, serranas, jotas, parrandas y aguinaldos, en ocasiones, con variaciones.

En los arreglos de obras para zarzuela, los compositores más interpretados fueron Barbieri, Arrieta y Chueca y Valverde (ver Gráfico 7.4).

${ }^{94}$ El resto es un grupo amplio de compositores que fueron interpretados únicamente una vez (Herold, Gounod, Mazza, Meyerbeer, Ponchielli y Verdi). 
Gráfico 7. 4. Compositores de zarzuela más interpretados en las veladas de los cafés murcianos de la segunda mitad del siglo XIX.

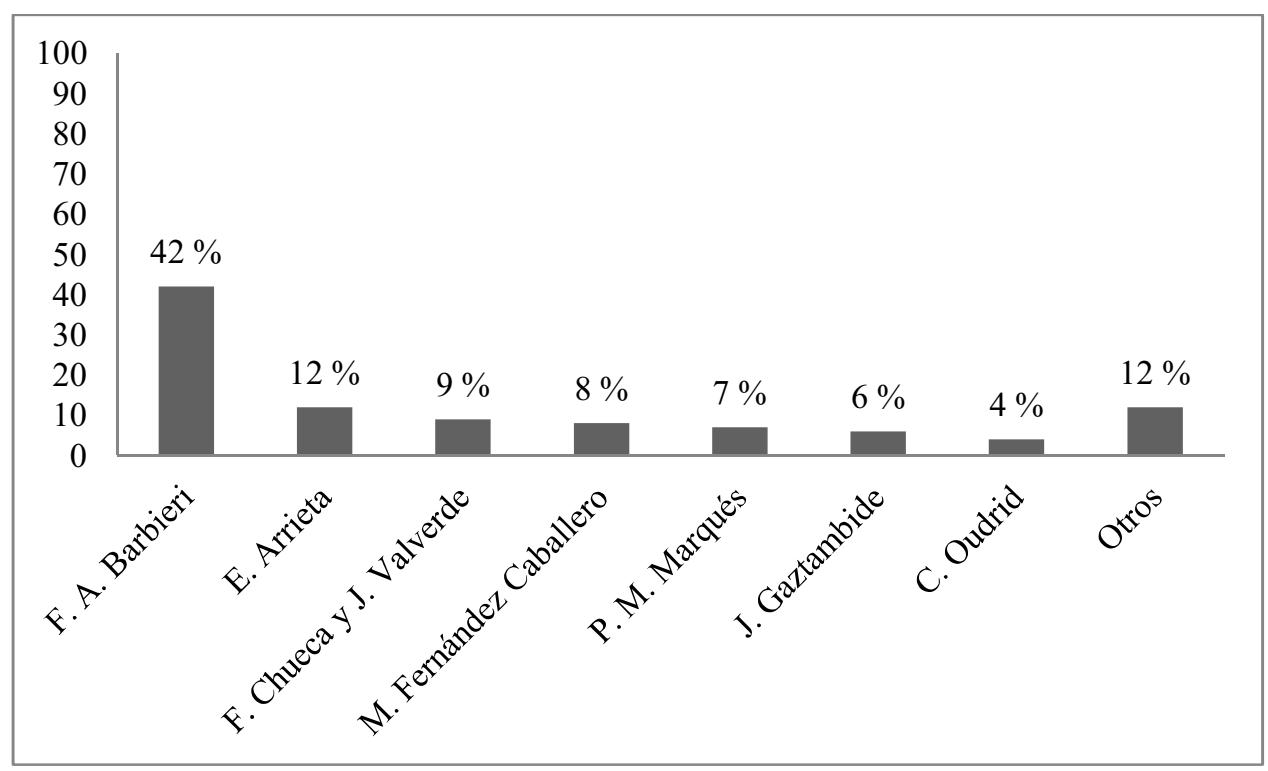





\section{Capítulo 8. La música en el ámbito doméstico}

En el siglo XIX, adquirió gran importancia la música de salón como parte del ocio doméstico, sobre todo en casas particulares de la aristocracia, de la burguesía y, en general, de los personajes relevantes del mundo de la cultura y de la política ${ }^{1}$. Los salones eran espacios ricamente decorados (ver Figura 8.1), en los que con frecuencia se regalaban flores a los asistentes y había buffets de licores, tés, dulces y helados. En estos salones particulares participaban profesionales (compositores, profesores de música, instrumentistas, cantantes e incluso maestros de capilla) y aficionados de mayor o menor talento.

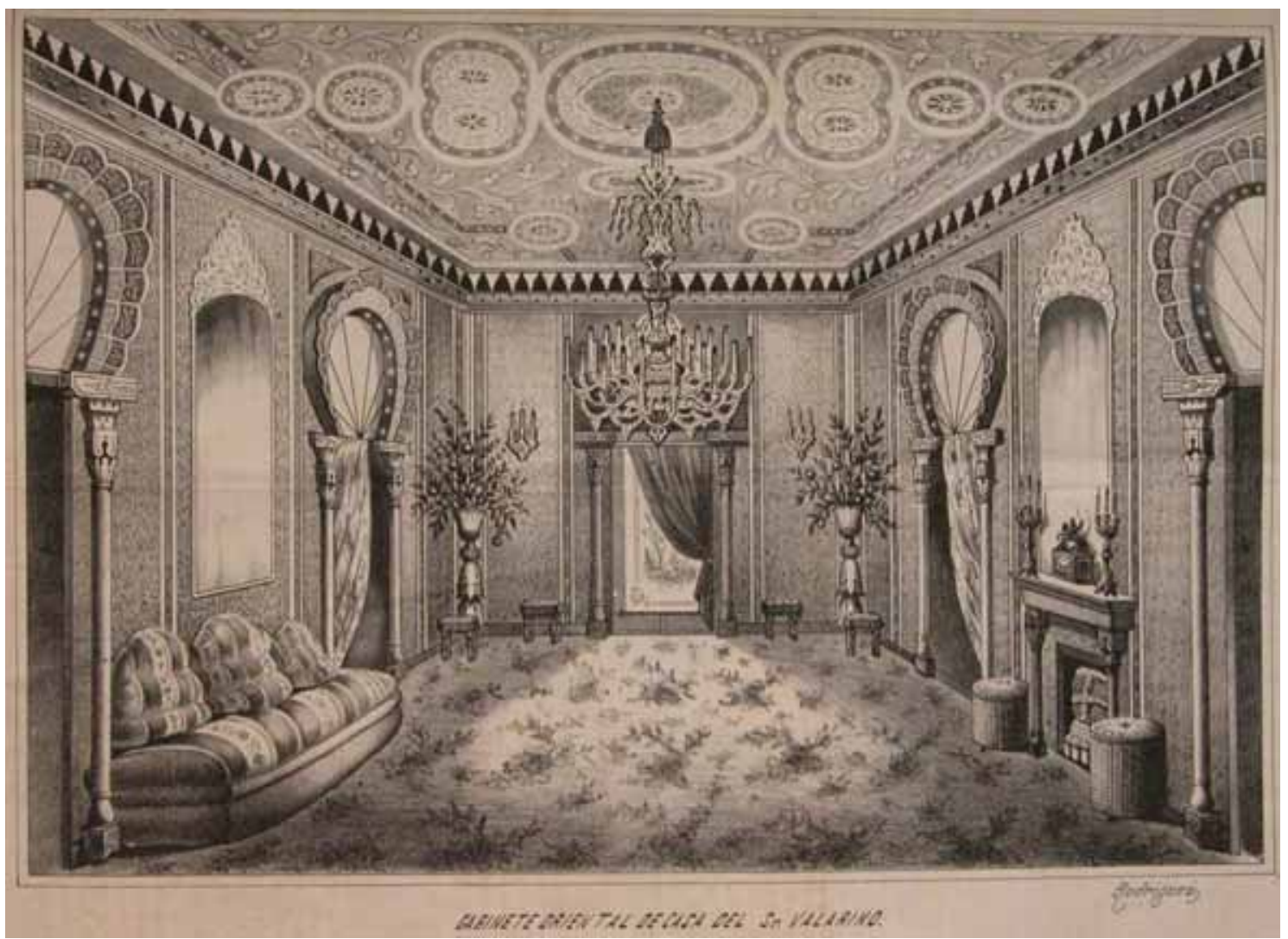

Figura 8. 1. Salón oriental de la casa particular del cartagenero Tomás Valarino Gattorno, conde de Santa Lucía. E:MUm, Cartagena Ilustrada, III (1873), nº 28, mayo, p. 111.

La proliferación de las soirées y los conciertos privados tuvo relación directa con el auge de instituciones privadas de enseñanza musical y sociedades recreativas. En Murcia, las veladas en salones privados se desarrollaron mucho a partir de los años setenta del siglo XIX y se mantuvieron en alza hasta el final de siglo.

\footnotetext{
${ }^{1}$ Mientras que durante la primera mitad del siglo XIX los salones donde se celebraban veladas musicales fueron espacios fundamentalmente aristocráticos, herederos del salón privado dieciochesco, o de la alta burguesía desde la década de los veinte, durante la segunda mitad de la centuria el salón burgués desplazó en importancia a los salones aristocráticos (aunque éstos prosiguieron su actividad), gracias a la apertura económica, política y social que experimentó el país desde la Regencia de María Cristina. Véanse más detalles en Alonso, "Los salones"; Alonso, La canción lírica; Casares, "La música del siglo XIX español. Conceptos fundamentales", pp. 39-49 y Virgili, "El pensamiento".
} 


\section{La música en los teatros de casas de particulares}

Los largos periodos de clausura del teatro principal de la ciudad favorecieron la aparición de teatros en salones de diversas sociedades recreativas, como se vio antes, y también en domicilios particulares, que son estudiados a continuación ${ }^{2}$. Los teatros domésticos solían ser locales reducidos en los que los aficionados conseguían "por la representación por sí mimos de las obras dramáticas que están a su alcance", recreo y entretenimiento ${ }^{3}$. En ellos predominó, fundamentalmente, un repertorio puramente teatral aunque a veces también acogieron teatro musical.

\subsection{Teatro de Francisco Gómez Angeler (1867)}

Se inauguró el 25 de enero de $1867^{4}$ y fue uno de los teatros domésticos más relevantes. Su creación se produjo en un momento de apogeo de la actividad teatral y musical en los salones privados de la ciudad. Estuvo ubicado en el domicilio del matrimonio Francisco Gómez y Manuela Pareja, cuya dirección exacta desconozco.

A juzgar por los comentarios de la prensa, la decoración de la casa, así como del espacio teatral (escenario, vestuario y decorados) se cuidaban hasta el mínimo detalle: "Desde la entrada de la casa, elegantemente adornada con estatuas y macetas llenas de flores hasta la sala del teatro, se veía ya el delicado gusto de sus dueños que la había sabido engalanar con esa sencillez encantadora que es el alma de la belleza",5. El salón tenía cabida para unas cien personas ${ }^{6}$. Los actores, entre ellos el propietario, eran aficionados. La compañía que actuaba en este salón estuvo dirigida por Antonio Villegas, un actor que participó en diversas funciones teatrales de El Liceo (18581859) y fue presidente de El Liceo lírico-dramático (1867) y de la sección dramática de La Juventud (1868-1883).

La función inaugural del teatro de Gómez Angeler contó con la colaboración del pianista Enrique Villegas, que tocó al piano la sinfonía inicial y es muy probable que también se hiciera cargo de otros números musicales en los intermedios ${ }^{7}$. Durante la representación de La cruz del matrimonio de Luis de Eguilaz, la actriz Adelaida Saravia interpretó sobre la escena un aria de La Traviata ${ }^{8}$.

\footnotetext{
${ }^{2}$ Sobre teatro en el ámbito doméstico, consúltese: Freire, Literatura.

${ }^{3}$ La Paz de Murcia, XIII (1870), no 3777, 18 enero, p. 1. Las casas se engalanaban con flores y numerosos elementos decorativos.

${ }^{4}$ La noche de la inauguración se representaron La mujer de un artista (comedia en dos actos de Ventura de la Vega) y A caza del premio grande (juguete en un acto de Antonio Mendoza): La Paz de Murcia, X (1867), $\mathrm{n}^{\text {os }} 2782,27$ enero, p. 2 y 2785, 30 enero, pp. 1-2.

${ }^{5}$ La Paz de Murcia, X (1867), no 2785, 30 enero, pp. 1-2: 1. Se añade: "El escenario estaba decorado con elegancia y buen gusto. Las escenas vestidas con mucha propiedad".

${ }^{6}$ La Paz de Murcia, X (1867), no 2785, 30 enero, pp. 1-2: 1.

${ }^{7}$ En ocasiones también se ofrecieron en este teatro juegos de prestidigitación, véase: La Paz de Murcia, X (1867), nº 2805, 20 febrero, p. 2.

${ }^{8}$ La Paz de Murcia, X (1867), no 2900, 30 mayo, pp. 2-3:3.
} 
El teatro de Gómez Angeler acogió representaciones dramáticas, al menos, hasta el mes de mayo de $1867^{9}$.

\subsection{Teatro de Elías Lahorra (1868)}

El 19 de marzo de 1868 se inauguró un nuevo teatro "en la casa que hoy habita don Elías Lahorra y que fue antes almacén de los señores Servet, en la plaza de Jofré" (ver Figura 8.2). Este teatro estaba "formado por una sociedad de la que una mayor parte son dependientes del comercio". El día de su inauguración (19-03-1867) se llevó a escena el drama de Camprodón, Flor de un día y el sainete Los palos deseados, de Juan Ignacio González del Castillo ${ }^{10}$.

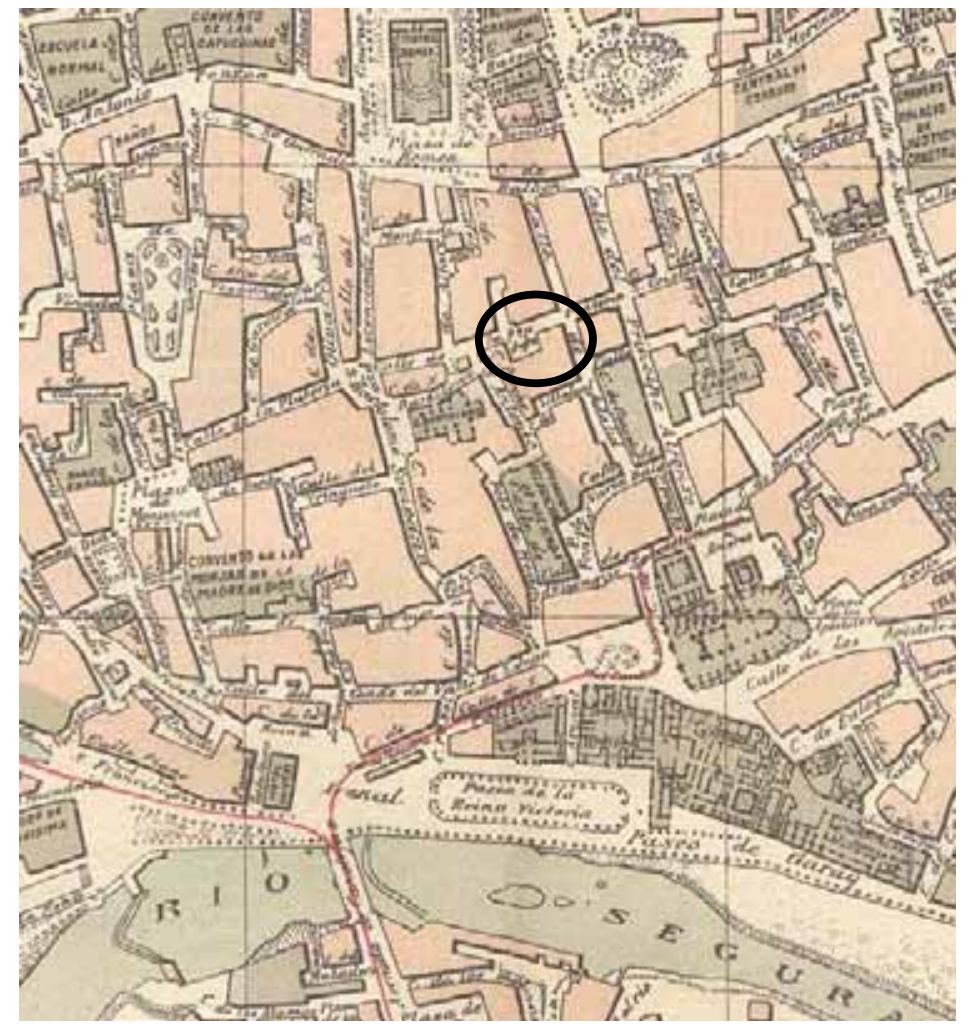

Figura 8. 2. Ubicación del Teatro de Elías Lahorra, en la plaza Jofré de Murcia. Pedro García Faria, Plano de Murcia (Barcelona: Alberto Martín, s.a.). E:Mpb.

Accesible en: http://bibliotecadigital.carm.es (acceso el 16-07-2011)

\footnotetext{
${ }^{9}$ En él se llevaron a escena obras como Corregir al que yerra (comedia en tres actos de Manuel Ortiz de Pinedo), República conyugal (comedia de Tomás Rodríguez Rubí), La frutera de Murillo (comedia en un acto de Rafael García Santisteban), Libertad en la cadena (comedia en tres actos de José Marco) y No siempre lo bueno es bueno (comedia en un acto de Luis de Loma y Corradi), entre otras. Véanse más detalles en: La Paz de Murcia, X (1867), $\mathrm{n}^{\text {os }}$ 2805, 20 febrero, p. 2; 2828, 16 marzo, p. $2 ; 2829,17$ marzo, p. 2; 2841, 30 marzo, p. 1; 2892, 22 mayo, p. 2.
}

${ }^{10}$ La Paz de Murcia, XI (1868), nº 3187, 24 marzo, p. 3. 
Durante el mes de mayo de 1868, el teatro acogió otras obras, como Juan sin tierra. En los intermedios, "la orquesta hacía oír piezas de todos los géneros", lo que indica que contaban con músicos para amenizar las veladas ${ }^{11}$.

\subsection{Teatro de la plaza de Santa Eulalia (1869)}

El 11 de julio de 1869 la prensa informó de la inauguración de "un nuevo templo dedicado a Talía en una casa de la plaza de Santa Eulalia" (ver Figura 8.3) ${ }^{12}$. En él actuaron actrices aficionadas, que llevaron a escena la comedia en dos actos $E l$ conde de nuevo cuño y la pieza cómica en un acto de Luis Valladares Por no escribirle las señas.

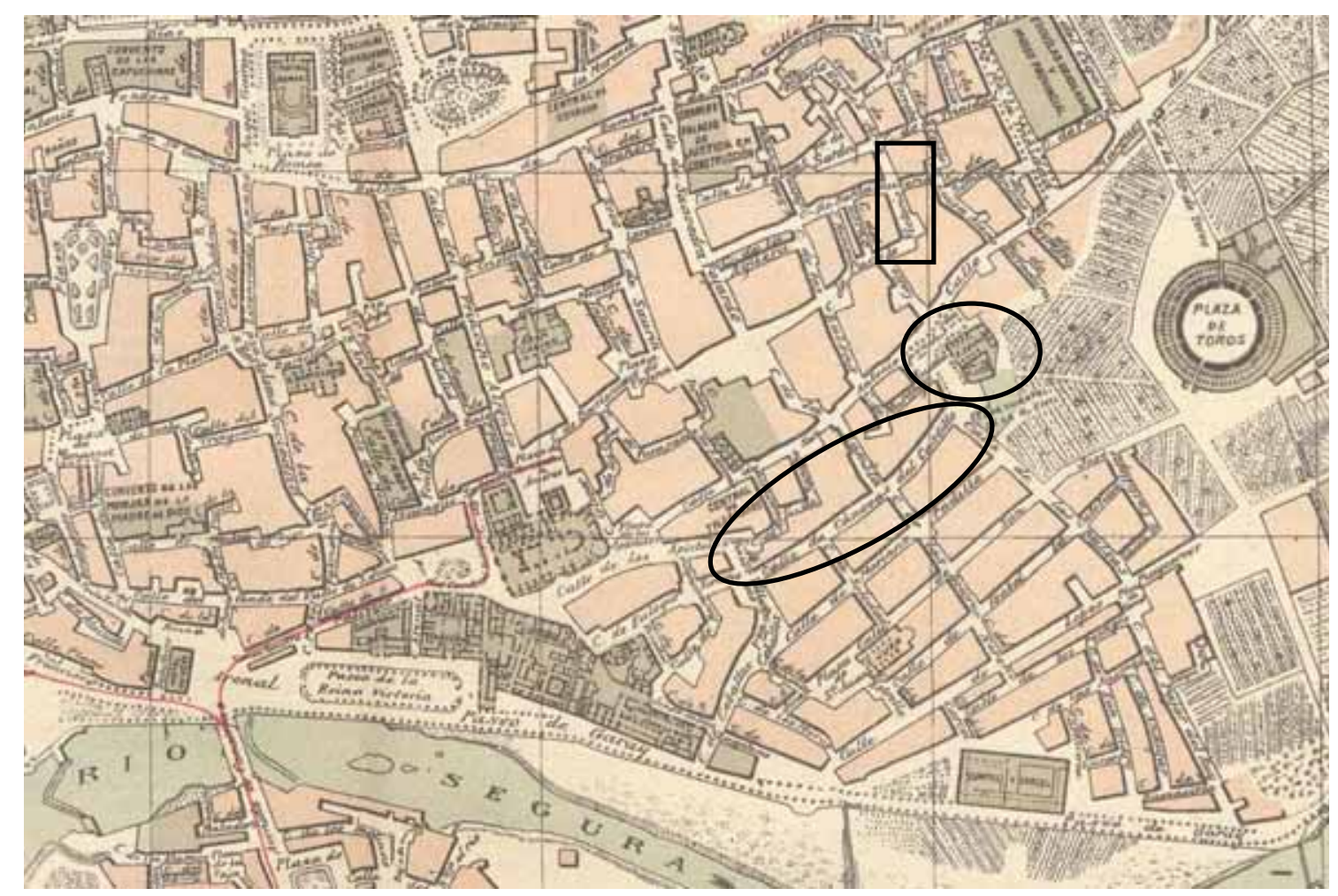

Figura 8. 3. Ubicación de los teatros particulares de la plaza de Santa Eulalia de Murcia (círculo superior), de la calle de Victorio (rectángulo) y del Val de San Juan (círculo inferior). Pedro García Faria, Plano de Murcia (Barcelona: Alberto Martín, s.a.). E:Mpb. Accesible en: http://bibliotecadigital.carm.es (acceso el 16-07-2011).

\subsection{Teatro infantil La Confianza (1870)}

El teatro "La Confianza" fue inaugurado en enero de 1870 "por varios niños en la casa del señor Miró". Era un local reducido que acogió la representación de las

${ }^{11}$ La Paz de Murcia, XI (1868), no 3247, 27 mayo, p. 3. En la representación del 24 de mayo de 1868 se estrenó un telón y dos decoraciones pintadas por Mateo Boronal.

${ }^{12}$ La Paz de Murcia, XII (1869), no 3621, 13 julio, p. 1. 
obras Alza y baja (comedia en un acto de Luis de Olona), Las hijas de Eva (zarzuela o comedia de Luis Mariano de Larra), De potencia a potencia (comedia en un acto de Tomás Rodríguez Rubí) y La mujer de Ulises (juguete cómico en un acto de Eusebio Blasco), la noche del 15 de enero de $1870^{13}$.

\subsection{Teatro de la calle de Victorio (1886)}

En 1886 este teatro estaba situado en "una elegante casa de la calle de Victorio" cercana a la plaza de Santa Eulalia, aunque no he localizado quiénes eran sus propietarios (ver Figura 8.3) ${ }^{14}$. Al igual que el resto de teatros de casas particulares, en él actuaban jóvenes aficionados al arte dramático, que pusieron en escena, por ejemplo, la comedia en dos actos de Miguel Ramos Carrión Robo en despoblado.

\subsection{Teatro de la calle del Val de San Juan $(1887)^{15}$}

La inauguración de este teatro tuvo lugar en enero de 1887. La prensa justificaba el auge de este tipo de teatros en los siguientes términos: "Se está despertando entre los jóvenes de esta ciudad una grandísima afición al arte escénico. Por la Merced sabemos que existe una sociedad que da funciones de convite, y trabaja pero muy bien, y en una casa de la calle del Val de San Juan se han formado otra de jóvenes, muy jóvenes, con el mismo objeto" (ver Figura $8.3{ }^{16}{ }^{16}$. En él se llevó a escena la zarzuela en un acto titulada Nicolasita, música de Tomás Gómez y libreto de Juan Antonio Soriano Hernández ${ }^{17}$.

\subsection{Teatro de la Puerta de Orihuela (1888)}

Hay constancia de que hubo "una función dramática por jóvenes aficionados" en una casa de la calle de la Puerta de Orihuela". En este teatro doméstico se representaron El puñal del godo de José Zorrilla, Pepita y Los valientes y una de las actrices "cantó una salve acompañándose a la guitarra, instrumento que toca admirablemente" 18 .

${ }^{13}$ La Paz de Murcia, XIII (1870), no 3777, 18 enero, p. 1. Una noticia publicada por La Paz de Murcia, XII (1869), n 3488, 6 febrero, p. 1 informaba de la representación de varias obras teatrales "en un teatrito hecho en una casa particular". Desconozco si se trata del mismo local.

${ }^{14}$ La Paz de Murcia, XXIX (1886), nº 9066, 12 diciembre, p. 1.

${ }^{15}$ La calle del Val de San Juan es denominada actualmente calle Cánovas del Castillo.

${ }^{16}$ La Paz de Murcia, XXX (1887), no 8090, 12 enero, p. 1

${ }^{17}$ Esta zarzuela se en el Teatro Romea el 19 de enero de 1882 y fue publicada en Murcia ese mismo año por la imprenta de El Diario.

${ }^{18}$ La Paz de Murcia, XXXI (1888), nº 9417, 31 enero, p. 1. 


\subsection{Teatro de Sánchez Font (1894)}

En octubre de 1894, dieron una función teatral en la casa de Sánchez Font "sus niños con otros amigos". Se llevaron a escena El marqués disfrazado, Un año en quince minutos y Providencia ${ }^{19}$.

\section{Veladas musicales de ámbito doméstico}

Los salones de casas particulares y las trastiendas de almacenes de música fueron importantes núcleos de actividad musical en Murcia. En los almacenes de música y casas de músicos los intérpretes eran mayoritariamente profesionales y su repertorio era más variado que en casas de aficionados. De las veladas documentadas entre 1865 y 1894, la mitad se organizaron en casas de músicos y el resto tuvieron lugar en domicilios de aristócratas o burgueses murcianos, como los de Manuel Fontes y Álvarez de Toledo, conde de Saucedilla o las familias Clavijo y Fernández Albaladejo. En todos los casos se daban las siguientes características:

1. Eran reuniones de familiares y amigos, a medio camino entre los conciertos propiamente dichos y las reuniones sociales. La finalidad principal era el entretenimiento $^{20}$.

2. El piano, el armonio, o ambos a la vez, eran los instrumentos predominantes $^{21}$.

3. Participaron con frecuencia músicos profesionales.

4. La mujer tenía gran presencia en estos salones como intérprete y, en ocasiones, también como compositora ${ }^{22}$.

En la prensa las funciones domésticas eran denominadas con frecuencia "funciones de convite" o "soirées de confianza"23. El Apéndice 8.1 muestra una relación de las veladas domésticas que he podido documentar en Murcia durante la segunda mitad del siglo XIX. A veces los músicos profesionales gestaron importantes proyectos de ámbito musical en los salones particulares. La idea de crear la Sociedad Filarmónica, por ejemplo, nació en la casa de Antonio López Almagro y la creación de un conservatorio murciano se debatió por primera vez en 1881 en la casa del

\footnotetext{
${ }^{19}$ La Paz de Murcia, XXXVI (1894), nº 12797, 2 octubre, p. 1.

${ }^{20}$ Los testimonios periodísticos sobre música doméstica fueron muy escasos y es seguro que representaron una mínima parte de la actividad que realmente tuvo lugar.

${ }^{21}$ El piano se erigió como instrumento dominante en los salones domésticos de los aficionados de la clase burguesa de toda Europa en el siglo XIX, como describe Plantiga, "The piano" y, en el caso de España, Vázquez Tur, "Piano". Sobre el armonio en España en el siglo XIX, véase Pliego de Andrés, “Armonio", así como la información referida a Murcia que aporto en el Capítulo 9.

${ }^{22}$ Sobre el papel de la mujer en la música doméstica del siglo XIX, véase, por ejemplo, Miranda, "A tocar" y Agostini, "Las mujeres".

${ }^{23}$ La Paz de Murcia, XXXII (1889), $n^{\circ} 9757,7$ febrero, $p .4$.
} 
Maestro de Capilla Mariano García, como se vio en el Capítulo $6^{24}$. En España, las veladas en casas de reconocidos compositores e instrumentistas comenzaron a desarrollarse con fuerza a partir de los años cincuenta del siglo XIX, aunque existen ejemplos muy representativos de fechas anteriores ${ }^{25}$.

Cualquier momento del año era idóneo para las veladas en salones particulares, aunque los datos hallados muestran una tendencia mayor a reunirse en los meses de verano (de junio a septiembre) ${ }^{26}$. En ocasiones el evento se organizaba con antelación, a propósito de la visita de un amigo o familiar, una onomástica o un natalicio, entre otros muchos motivos, o con carácter periódico (semanal o quincenal) y en ellos se seguían las convenciones sociales habituales en la época (ver Figura 8.4). Había también casos en los que la finalidad de la reunión era el baile y, alternado con él o al final de la velada, se improvisaban números musicales ${ }^{27}$. Las veladas solían comenzar a partir de las nueve de la noche y concluían de madrugada.

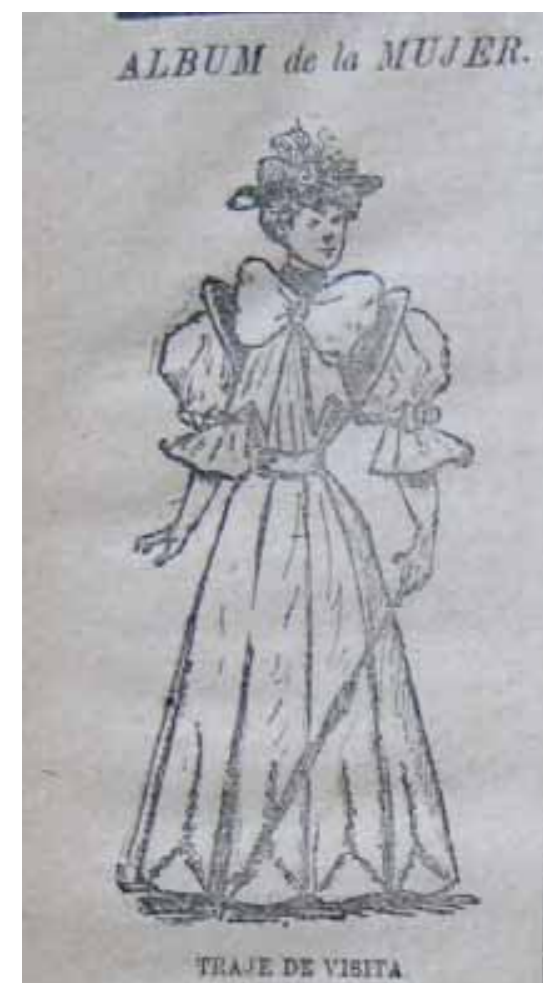

Figura 8. 4. Traje femenino "de visita".

La Juventud Literaria, VI (1894), n 214, 20 mayo, p. 2, E:MUm.

${ }^{24}$ Véase, respectivamente, La Paz de Murcia, X (1867), $\mathrm{n}^{\circ}$ 2764, 8 enero, p. 2 y La Paz de Murcia, XXIV (1881), nº 7079, 22 junio, p. 1.

${ }^{25}$ En 1835 y 1836, por ejemplo, el pianista y compositor Santiago de Masarnau organizaba veladas semanales en su domicilio particular con artistas e intelectuales de Madrid en los que el músico dio a conocer gran parte de sus obras interpretadas por él mismo, además de otras piezas para piano y para canto y piano. Ver Virgili, "El pensamiento", p. 29.

${ }^{26}$ De las treinta y siete veladas estudiadas, diecisiete tuvieron lugar entre junio y septiembre y las demás en el resto del año (excepto en noviembre).

${ }^{27}$ Fue el caso de las veladas organizadas en los domicilios de Francisco Useras (3-07-1865), Manuel Cantos (20-05-1866) y familia Clavijo (21 y 26-01-1877) cuyo programa musical aparece en el Apéndice 8.1. 
Los primeros conciertos domésticos que he podido documentar en la prensa murciana se remontan al año $1865^{28}$ y parece que fueron en aumento en los años siguientes $^{29}$. Una de las casas más concurridas y "uno de los puntos de más grato solaz en Murcia" fue la del compositor e instrumentista de armonio Antonio López Almagro, en la que se celebraban reuniones semanales ${ }^{30}$. También se dieron veladas en las casas de los músicos Joaquín Codorniu (guitarrista y Presidente Honorario de la Sociedad Filarmónica de Murcia) y Juan Diego Manresa (pianista y profesor de música).

Las reuniones domésticas con música cobraron un nuevo impulso en los años finales de la década de los setenta. Entre 1877 y 1879 se organizaron, al menos, catorce veladas. Este aumento se debió probablemente a la ausencia de actividad en el teatro principal de la ciudad, ya que el Romea se incendió en febrero de $1877^{31}$. Seis de las veladas documentadas tuvieron lugar en la casa del pianista y compositor Adolfo Gascón Leante ${ }^{32}$. Eran reuniones semanales muy concurridas, en las que se ocupaban todos los espacios de la casa e incluso parte de la calle de acceso a ella: "ocupaban los balcones del señor Gascón y los de sus convecinos y ante una inmensa concurrencia que invadía la calle de Saurín, dio principio a las diez en punto lo que, más que brillante concierto, pudiéramos llamar certamen musical"33. La prensa valoraba muy positivamente estas veladas particulares, que se sumaban a las organizadas en los cafés:

[...] Las veladas musicales que desde hace algún tiempo vienen repitiéndose en esta capital con aplauso de los amantes del divino arte, han ido acentuando de día en día su importancia hasta el punto de llegar a ser en ocasiones verdaderos acontecimientos artísticos. Sobre todo, para los que nos hallamos privados de saborear los más completos en el ya reducido a cenizas Teatro de Romea.

El público ha manifestado por este agradable pasatiempo predilección creciente y decidida, asistiendo primero a los conciertos iniciados por el señor Gascón, después a los cafés Oriental y del Comercio, y últimamente a los dos con que en las noches del viernes y domingo de la semana que acaba de transcurrir, obsequiaron a sus numerosos amigos los señores Fernández de Hermosa $[\ldots]^{34}$.

\footnotetext{
${ }^{28} \mathrm{Ha}$ de tenerse en cuenta que no se conservan ejemplares de La Paz de Murcia de los años 1861 a 1864 , ambos inclusive.

${ }^{29}$ La prensa alentó la proliferación de estos conciertos con textos como los siguientes: "Nos alegraremos que siga el estímulo entre las familias y se proporcionen ratos tan divertidos como el de la citada noche": La Paz de Murcia, IX (1866), no 2542, 23 mayo, p. 2 y "Con sumo gusto vemos que la música se halla en esta capital en un estado de progreso que nos honra. Los conciertos se suceden unos a otros y se habla de continuarlos": La Paz de Murcia, IX (1866), n² 2496, 4 abril, p. 1.
}

${ }^{30}$ La Paz de Murcia, X (1867), nº 2940, 14 julio, p. 2.

${ }^{31}$ La prensa se hizo eco del papel compensatorio de las veladas domésticas, aunque pidió también otras medidas: "Reuniones como la de esta noche compensarán en parte la falta del abrasado coliseo, pero ¿no es posible hacer más?. ¿Sería insuperable la dificultad de crear un Liceo, campo más ancho donde pudiera brillar como siempre la aptitud para las bellas artes de los hijos de Murcia?: La Paz de Murcia, XX (1877), n 6162, 26 septiembre, p. 1. El Liceo se creó, en efecto, a comienzos de 1878, por fusión entre el Círculo Industrial y el Ateneo.

\footnotetext{
${ }^{32}$ Según La Paz de Murcia, XX (1877), n 6137, 28 agosto, p. 1 estaba en la calle del Príncipe Alfonso (actual Trapería).

33 "Fulano de Tal", "Un concierto extraordinario", La Paz de Murcia, XXI (1878), n 6296, 23 agosto, p. 1.

${ }^{34}$ La Paz de Murcia, XX (1877), nº 6162, 26 septiembre, p. 1.
} 
En el período 1885-1888 hubo al menos catorce nuevas veladas particulares (coincidiendo con el desarrollo de academias y nuevas sociedades en Murcia, como se estudia en el Capítulo 6). Merecen destacarse, por su calidad artística, las veladas celebradas en el almacén de música de Adolfo Gascón (calle San Cristóbal, 4) (ver Figura 8.5$)^{35}$. Este local sirvió de escenario a músicos profesionales de paso por la ciudad, como el saxofonista Juan Marcos y Mas (14-03-1885), el guitarrista y también intérprete de bandurria Pedro Paredes junto al guitarrista Valero (25-031885) o el Quinteto del Colegio de Ciegos de Barcelona (26-04-1885). La tienda de música de Adolfo Gascón también acogió homenajes a músicos ${ }^{36}$ y fue local de ensayos $^{37}$.

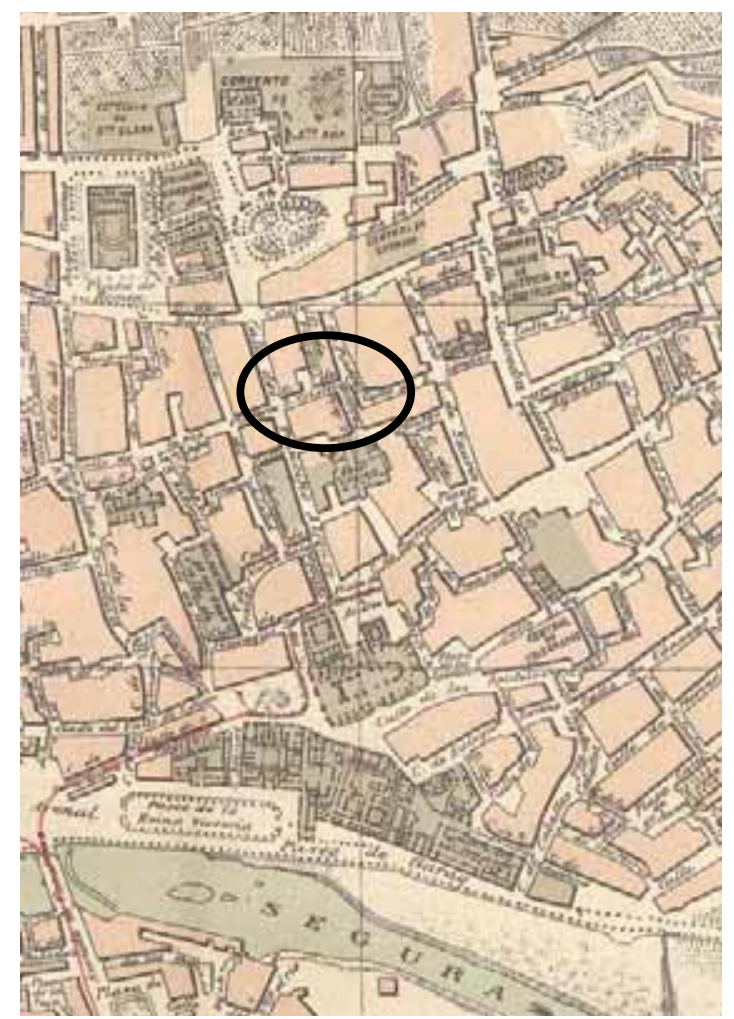

Figura 8. 5. Ubicación del almacén de música de Adolfo Gascón, en la calle San Cristóbal número 4 de Murcia. Pedro García Faria, Plano de Murcia (Barcelona: Alberto Martín, s.a.). E:Mpb. Accesible en: http://bibliotecadigital.carm.es (acceso el 16-07-2011)

${ }^{35}$ El Diario de Murcia, VIII (1886), $\mathrm{n}^{\mathrm{o}}$ 2222, 3 agosto, p. 1 (ver transcripción en el Documentario).

${ }^{36}$ En diciembre de 1885, hubo en el almacén de Gascón un concierto homenaje a Antonio López Almagro, interpretado por Manresa, Calvo, Díez, Ramírez, Ayala, Solano, Soler, Puig, Benavente y Leante, entre otros. Véase, El Diario de Murcia, VII (1885), nº 2040, 29 diciembre, p. 2.

${ }^{37}$ En julio de 1886, se ensayó en el almacén de Gascón un concierto que fue interpretado en los jardines de Floridablanca por la festividad del Carmen (16 de julio). Intervinieron en el ensayo Julián Clavo y Adolfo Gascón (armonio); Antonio Ramírez Pagán, Francisco Leante Caballero, Vicente Espada, Joaquín Arques, Juan Ayala, Juan Diego Manresa, Enrique Visedo, José Carrasco, Mariano Moreno, Jesús Torres, José Solano Gil, Manuel Benavente, Francisco Soler, Rafael Solera (piano) y José Gamúz (contrabajo). Véanse, La Paz de Murcia, XXIX (1886), nº 8962, 8 julio, p. 1; 8963, 9 julio, p. 1; 8964, 10 julio, p. 1; 8966, 13 julio, p. 1; 8967, 14 julio, p. 1; 8969, 16 julio, p. 1; 8970, 17 julio, p. 1; 8971, 18 julio, p. 1; 8972, 20 julio, p. 1 y El Diario de Murcia, VIII (1886), no 2206, 15 julio, p. 3. 
En las cuarenta veladas particulares documentadas (algunas reconstruidas sólo parcialmente) se interpretaron más de doscientas piezas de todos los géneros (ópera, zarzuela, opereta, baile, música de cámara y música religiosa). En cada reunión se incluía una media de diez piezas diferentes, aunque a veces llegaron a interpretarse quince ó incluso más y en otras, por el contrario, menos.

Como muestra el Gráfico 8.1, el 57.5\% del repertorio interpretado en las veladas domésticas eran arreglos de números de óperas y zarzuelas. El resto, eran canciones, pequeñas piezas de salón para piano y/o armonio (fantasías, variaciones, nocturnos, mazurcas y valses, entre otros), repertorio de cámara de grandes compositores, música religiosa y música popular. Muchas de las piezas de último grupo son transcripciones y adaptaciones para las formaciones instrumentales con las que contaban:

Gráfico 8. 1. Géneros musicales interpretados en las veladas de ámbito doméstico en Murcia (1865-1894)

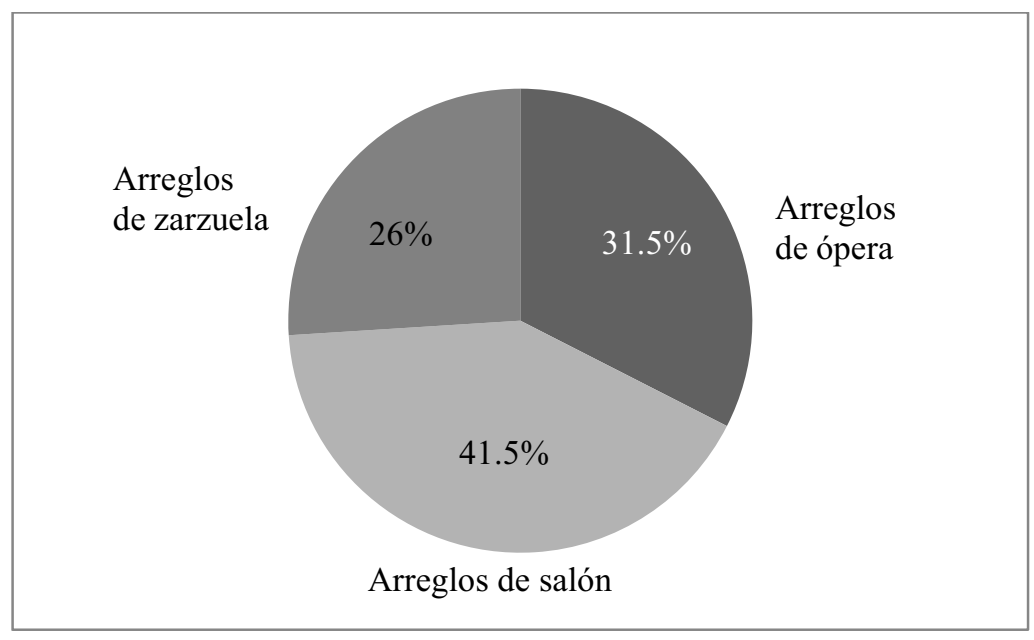

En términos generales, las veladas en casas de aficionados tenían sobre todo un repertorio constituido por arreglos de ópera y zarzuela. Por el contrario, los programas de las veladas en casas de músicos eran más variados, e incluían más géneros y obras con mayores dificultades técnicas. Por ejemplo, el concierto en la casa del compositor Antonio López Almagro (9-04-1866) incluyó varios números del Stabat Mater de Rossini arreglados para piano y armonio.

Durante la década de los sesenta del siglo XIX hubo un claro predominio de la ópera italiana ${ }^{38}$. La mayor parte de los fragmentos operísticos interpretados en las veladas domésticas se conocían en la ciudad porque sus óperas habían sido representadas en los teatros murcianos. Sin embargo, también se tocaron fragmentos de óperas como Semiramide de Rossini, Belisario o Pia de' Tolomei de Donizetti, I Lombardi, Nabucco o La forza del destino de Verdi, que no fueron llevadas a la escena murciana durante el siglo XIX, hecho que amplía considerablemente el

${ }^{38}$ Hubo veladas cuyo repertorio estuvo compuesto íntegramente por fragmentos de ópera, como la celebrada en los salones de Antonia Istúriz (24-07-1865): La Paz de Murcia, VIII (1865), nº 2245, 25 julio, p. 2; o la celebrada en el domicilio de Antonio López Almagro (9-04-1866), casi íntegramente constituida por este género: La Paz de Murcia, IX (1866), $\mathrm{n}^{\text {os }} 2501,9$ abril, p. 1 y 2503, 11 abril, p. 2. 
repertorio operístico conocido por los murcianos de la época (y aún más si se tienen en cuenta otros salones como los cafés o los dependientes de sociedades recreativas) ${ }^{39}$.

Durante la década de los setenta del siglo XIX se observa un aumento considerable de arreglos de zarzuela por encima de las de ópera ${ }^{40}$. Probablemente, este hecho ha de relacionarse con la actividad teatral del Romea, ya que entre los años 1865 y 1880 no actuó ninguna compañía de ópera en ese teatro. En las veladas domésticas de los años ochenta (la mayoría celebradas en el almacén de música de Adolfo Gascón) la zarzuela y la ópera quedaron igualadas en número de piezas interpretadas.

Entre los compositores de piezas para piano sólo interpretadas en los salones privados murcianos estuvieron Krüger, Ketterer y Louis Lefébure-Wély. Se tocaban al piano arreglos de oberturas operísticas, fantasías sobre óperas, danzas (valses y polcas), caprichos, marchas, romanzas, serenatas, baladas y nocturnos, entre otras piezas, y, ocasionalmente, estudios, sonatas o rondós pianísticos. Para piano a cuatro manos se ejecutaban también arreglos de oberturas de ópera y piezas como el Galop de bravura de Lefébure-Wély o el Vals para cuatro manos de Steinberg. En una ocasión, incluso, se interpretó un Capricho Húngaro para piano a seis manos de Reteres ejecutado por los pianistas Gascón, Solano y Leante (11-08-1878).

Un ejemplo de música de salón pensada para el consumo de aficionados es el $5^{\circ}$ Nocturno para piano titulado Orfeo y dedicado a Juana Navarro del compositor murciano Julián Calvo, en cuya portada ya aparece la indicación "fácil", a pesar de que algunos pasajes contienen rápidas figuraciones rítmicas de cierta dificultad. La estructura de la pieza es ternaria (A-B-A'), con secciones contrastantes, precedidas por una breve Introducción. Predomina la textura acompañada y en líneas generales, la mano derecha sostiene la melodía principal, con temas de inspiración belcantista, mientras la mano izquierda acompaña con figuraciones rítmicas sencillas. El tratamiento armónico es poco desarrollado y hay algunas modulaciones bruscas en los cambios de sección (véase "Partituras" en el Volumen 2 de esta Tesis).

En las veladas domésticas de Murcia se interpretaron numerosas canciones compuestas por murcianos, como el Vals de Julián Calvo sobre un poema de Ramón Guerrero, una canción del cantante Miguel Albelda con letra de Güell y Renté, una Barcarola de Adolfo Gascón y las famosas Déjate querer, de Mariano Soriano Fuertes y Canto de amor, de Antonio López Almagro.

La romanza Nella vita io son peregrino, para canto y piano, de autor anónimo y publicada en el periódico Diario de Murcia en 1851 es el único ejemplo de música para consumo doméstico que he hallado en la prensa murciana. Se repartió gratuitamente a sus suscriptores y era obra "de un joven de esta capital, y su escritura en la Litografía de otro joven también que hace el primer ensayo de este género" ${ }^{41}$.

\footnotetext{
${ }^{39}$ Algo similar a lo que describe Ester-Sala y Vilar, "La presencia" con las obras de Rossini en la Cataluña del siglo XIX.

${ }^{40}$ Los compositores más presentes eran Fernández Caballero, Barbieri, Gaztambide, Oudrid y Manuel Nieto.

${ }^{41}$ Diario de Murcia, I (1851), $\mathrm{n}^{\mathrm{o}} 52,1$. La partitura aparece entre la página 2 y 3 , encuadernada junto al resto de números de la colección. No consta autor ni de la letra ni de la música. En España, la
} 
Nella vita io son peregrino es una pieza para voz con acompañamiento de piano, compuesta sobre un poema en italiano de contenido amoroso. Sus versos forman dos cuartetas (quartina) de rima consonante (ABAB CDCD), cuyo texto original y traducción presento a continuación:

Nella vita io son peregrino;

Luce spléndida infiamma mia fe

Cerco al cuore felice cammino,

Ma la gioia in mia vita non é;

Tu che vedi de palpiti miei

Quest' ignoto el [e] orrendo martir...

Perché ingrata se bella tu sei?

Perché sempre il mio amore tu fuggir?
En la vida yo soy peregrino;

Luce en espléndida llama mi fe

Busco al corazón un feliz camino,

Pero no hay alegría en mi vida;

Tú que de mis pálpitos ves

Este desconocido y horrendo martirio...

¿Por qué eres ingrata si eres bella?

¿Por qué siempre a mi amor huyes?

Las dos cuartetas del poema plantean una disposición musical bipartita. Tanto en la parte A (compases 1-12) como en la B (13-24) se repiten los dos últimos versos con frases musicales diferentes.

La Romanza tiene una extensión apropiada para un tenor:

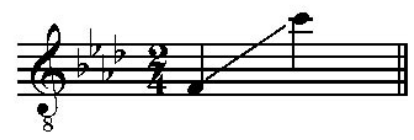

La parte vocal mantiene el predominio absoluto con respecto al piano y el tratamiento de la voz es muy lírico y efectista. No he observado preocupación por subrayar los contenidos expresivos del poema y tampoco hay matices ni indicaciones para el tempo. La armonía es sencilla, aunque con cierto interés cromático. No utiliza modulaciones complicadas a tonalidades lejanas ni ambiguas. La parte A comienza en fa menor y las cortas incursiones a re $b$ mayor y si $b$ menor terminan en una cadencia perfecta a la tonalidad originaria (compases 11 y 12). La sección B comienza en re $b$ mayor, su relativo, y termina, mediante otra cadencia perfecta, en $f a$ menor. El acompañamiento es bastante simple a lo largo de la obra. En la parte A, la mano izquierda reafirma la tonalidad mediante octavas sobre los grados básicos y acordes arpegiados en la mano derecha, mientras que permanecen sin arpegiar en la parte B. En el compás 23, un acorde de $V^{7}$ da paso finalmente a una pequeña cadencia del cantante con la que termina la pieza.

El estilo de esta obra se encuadra en las características típicas del género de salón de la época isabelina, destinado fundamentalmente al consumo privado de diletantes $^{42}$. La influencia de la ópera y de lo italiano es evidente en la ornamentación de la melodía vocal ${ }^{43}$.

práctica de repartir partituras en suplementos de revistas (de carácter general o específicamente musical) se importó desde Francia, país en el que estaba en boga desde los primeros años de la década de 1830. La litografía permitió incrementar considerablemente la producción bibliográfica durante el reinado de Isabel II, paralelo al incremento de las litografías en las publicaciones periódicas. En España fue introducida por José María Cardano en 1819, según García Melero, Arte español, pp. 214215.

${ }^{42}$ Los años de las regencias y de la época isabelina fueron de bastante actividad musical gracias al empuje de las diversas sociedades artísticas y filarmónicas de carácter burgués. La canción española, 
El repertorio local convivía con autores extranjeros, representados, por ejemplo, con la Melodía, de Schubert, Ave María de Gounod, El último pensamiento de Weber o La Poesía de Mercadante, entre otros.

Entre las composiciones para conjunto instrumental las más numerosas fueron para piano y armonio. Menos frecuente fue la combinación de violín y piano. El Adiós a la Alhambra de Jesús de Monasterio para violín y piano, interpretado en el almacén de Gascón en abril de 1885, es una de las pocas excepciones.

La música de cámara, de mayor complejidad, fue minoritaria ${ }^{44}$. El Grand Trio de Charles-Auguste de Bériot y un Trío de Hummel se interpretaron con violín, piano y armonio en los domicilios de los músicos Joaquín Codorniu y Antonio López Almagro en la década de los sesenta; ya en los ochenta, el Cuarteto en Si Bemol [¿Op. 18, n ${ }^{\circ}$ 6?] de Beethoven fue interpretado en el almacén de música de Gascón por músicos ciegos procedentes del Colegio de Ciegos de Barcelona ${ }^{45}$.

Un ejemplo del género popular interpretado en los salones particulares de Murcia fueron las Malagueñas, Peteneras y Baile Español con "postizas" (instrumento típico murciano equivalente a las castañuelas), cantadas el 8 de septiembre de 1879 en casa de Manuel Fontes y Álvarez de Toledo, conde de Saucedilla.

\section{EI baile en el ámbito doméstico}

El baile, inevitablemente ligado a la actividad musical, fue uno de los entretenimientos más característicos de la sociedad burguesa murciana del siglo XIX. Hubo numerosos bailes de salón en los teatros, sociedades y casas de aristócratas y burgueses de la ciudad.

la interpretación de música pianística de corte virtuosístico, la ópera italiana y la recitación de poesía se afianzaron como géneros de entretenimiento en las veladas musicales de aficionados. Véase, Alonso, "La canción española", pp. 259-260.

43 El italianismo de salón, como se ha denominado, contó desde la década de 1820 con la influencia de Rossini, para continuar en 1830-40 con las arias, dúos y tercetos de Bellini y Donizetti. Compositores profesionales de mayor o menor importancia, cantantes, maestros de canto o simplemente aficionados escribieron melodías y romanzas al estilo italiano, algunas de las cuales se escribieron con textos en italiano. Un considerable número de piezas de este género se difundieron en España por esta época.

${ }^{44}$ Alonso, "Los salones", p. 202 afirma que "la música de cámara en España no fue en el siglo XIX una necesidad social, como en Alemania, sino una práctica de importación, aristocrática, que se desarrollaba en ambientes demasiado restringidos". Afirmaciones similares se vierten en el análisis que sobre la música instrumental en Valencia durante el siglo XIX y primeros años de la centuria siguiente hace Sancho, Romanticismo, pp. 218-220.

${ }^{45}$ La formación instrumental estuvo integrada por los artistas ciegos Luis Vornades (violín I), Doroteo Esquirós (violín II), Pedro Roura (que tocaba tanto la viola como la flauta), José Reixach, (contrabajo) y José Cugar (clarinete). La reseña del concierto, publicada en La Paz de Murcia, XXVIII (1885), $\mathrm{n}^{\mathrm{o}} 8222,16$ mayo, p. 1 no menciona si el cuarteto fue arreglado para quinteto o si se tocó en la versión original para cuarteto de cuerdas, aunque parece lógico que fuera en esta última formación. 
Una velada doméstica de baile comprendía diversas danzas con una pausa para tomar un refrigerio y a menudo, incluía números de magia y prestidigitación y conciertos más o menos improvisados. Cualquier momento del año era idóneo para celebrar un baile de salón y los motivos eran muy diversos: festividades religiosas, civiles o cívico-religiosas, onomásticas y homenajes, entre otros motivos. Al igual que a los conciertos domésticos, a los bailes, que eran "reuniones de confianza" o veladas "de convite", se asistía sólo por invitación. Los invitados eran selectos miembros de la sociedad murciana, paradigma del "buen gusto" y la contención, y músicos importantes de la ciudad (que, con frecuencia, eran profesores de música de los hijos de los dueños de los salones). En más de una ocasión, tras el baile había un concierto $^{46}$.

La mayor parte de los bailes domésticos se concentraron en Carnaval o en casas cercanas al mar y en poblaciones con balnearios durante los veraneos. La situación privilegiada de la capital murciana, a pocos kilómetros del mar y cercana a varios balnearios, ofrecía las condiciones idóneas para este tipo de celebraciones (ver Figura 8.6).

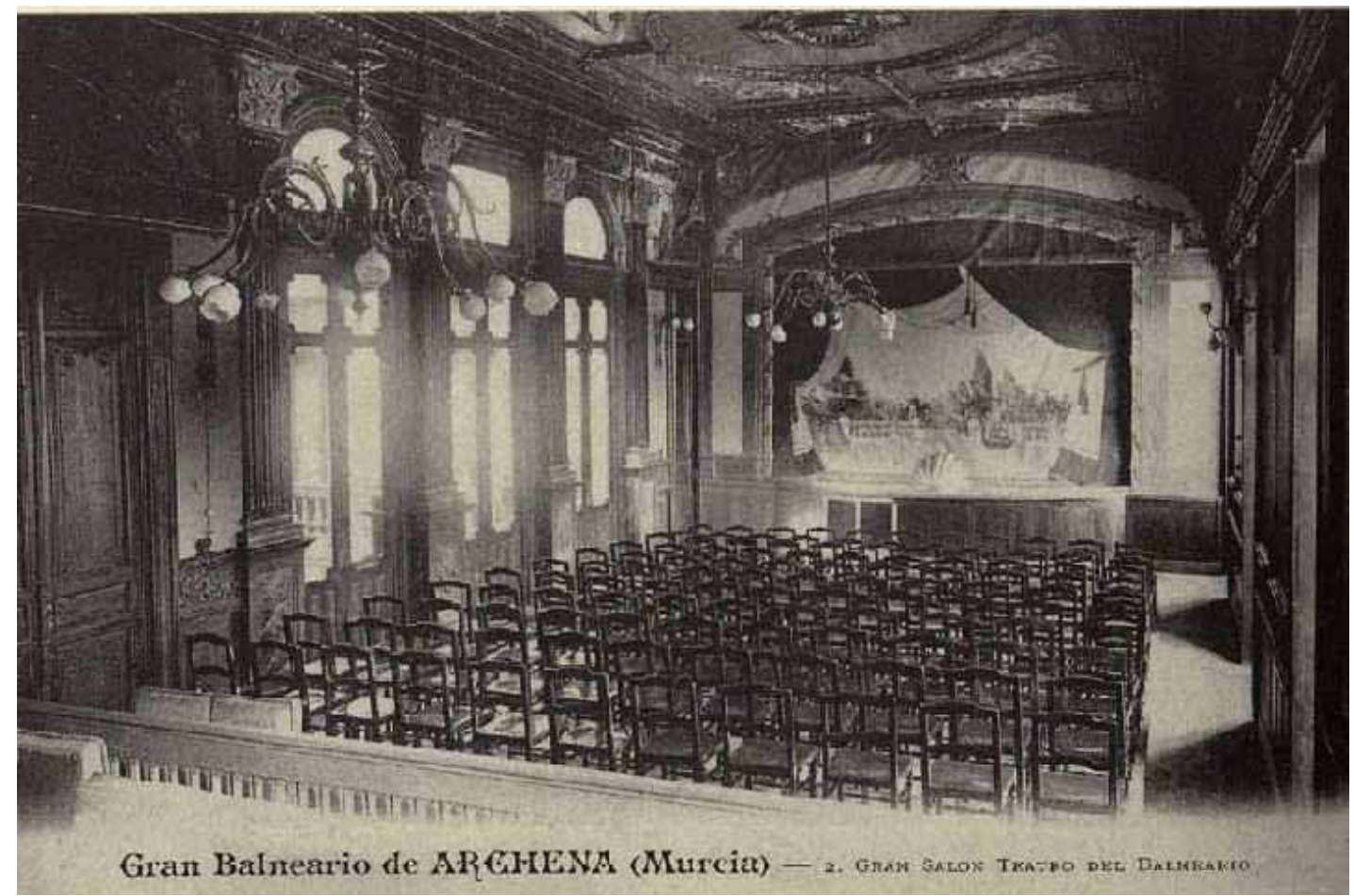

Figura 8.6. Teatro del Balneario de Archena, Murcia, ca. 1910. Ed. Andrés Fabert. Accesible en: http://www.regmurcia.com (acceso el 12-09-2011)

Los bailes de máscaras solían comenzar el día de la Candelaria (2 de febrero) y concluían en el domingo llamado "de piñata" (primer domingo después del Miércoles de Ceniza).

46 "No fue sólo el baile la parte principal de la reunión, pues a hora avanzada se improvisó un concierto": La Paz de Murcia, XX (1877), n 5961, 23 enero, p. 1. En el caso del baile ofrecido por la familia Stárico el 26 de enero de 1877, el concierto dio comienzo a las once de la noche. Véanse los programas de estas veladas en el citado Apéndice 8.1. 
La familia Stárico organizó semanalmente bailes de máscaras en febrero de 1876. Las mujeres iban disfrazadas de aldeanas italianas, molineras, damas francesas, escocesas, magas e incluso vestidas a semejanza de los personajes de las zarzuelas y óperas de moda. Leonor Guerra, por ejemplo, lució en uno de estos bailes "un rico y elegante traje de Pan y toros, representando el personaje Pepita en la zarzuela que lleva aquel título". Los hombres iban ataviados con trajes de diferentes épocas ("de Felipe II", de "pirata del siglo XV", de "la corte de Carlos V"), o bien de mosqueteros, diplomáticos, húsares, caballeros o personajes literarios (de "guerrero de Guzman el Bueno", de "Sullivan"), entre otros ${ }^{47}$. Las veladas solían empezar entre las nueve y las diez de la noche y concluían de madrugada. La familia Stárico tenía por costumbre servir refrescos y té a la una de la madrugada.

Los bailes y veladas musicales organizadas por la familia Pagán fueron habituales. El 20 de febrero de 1876 organizaron un "baile de trajes" en su domicilio de la plaza de Santo Domingo, en pleno corazón de la capital murciana ${ }^{48}$. La crónica del evento, redactada por el abogado, político y escritor murciano Antonio García Alix, da numerosos detalles sobre la decoración, el personal de servicio y el vestuario de los invitados, así como sobre las piezas bailadas:

[...] La orquesta ejecutó admirablemente un rigodón, mazurca, lanceros, mazurca y vals, que fueron bailadas con gran animación.

Apenas dejaron oír los últimos acordes nos trasladamos al espacioso salón del norte del edificio, donde se encontraba puesta con muchísimo gusto una mesa inmediata a la cual se sirvió un confortable té, el cual reparó los estómagos y dio nuevo aliento para continuar la fiesta. Concluido, volvióse de nuevo al salón, donde comenzó el baile, notándose mucha más animación.

En esta que podemos llamar segunda parte de aquella inolvidable velada la orquesta dejó oír un vals, rigodón, mazurca, lanceros, rigodón y cotillón, siendo todo esto bailado por gran número de parejas que, ligeras como plumas de deslizaban por la alfombra del salón. $[\ldots]^{49}$.

En diciembre de 1883, los Pagán organizaron un baile con motivo de las fiestas navideñas, en cuyos intermedios se intercalaron piezas para piano, armonio y piano, y canto:

[...] Después del primer rigodón, la bellísima señorita doña Rita Pagán y Pellicer, sentóse al piano y ejecutó magistralmente el difícil Trémolo de Gottchalh. Damos la enhorabuena a su profesor señor Ramírez por el envidiable adelanto de su joven discípula. Sucesivamente entre los intermedio de baile, ejecutáronse las siguientes piezas: una fantasía de Marta por la señorita doña Concha Rodríguez, ya ventajosamente conocida. Una pieza concertante de

${ }^{47}$ La Paz de Murcia, XIX (1876), nº 5585, 8 febrero, p. 1.

${ }^{48}$ Pedro Pagán Ayuso fue alcalde de Murcia en 1874. Su esposa, Leonor Guerra fue musa de la intelectualidad murciana y famosa por las tertulias literarias en su casa de la capital y en su quinta veraniega de "La Puntica" en la pedanía que adoptó el nombre de la familia, Lo Pagán. Por su casa desfilaron personajes importantes de la época, como Cánovas del Castillo, el barón de Benifayó y Emilio Castelar.

49 Antonio García Alix, "Baile de trajes en casa del Excelentísimo señor don Pedro Pagán", La Paz de Murcia, XIX (1876), n ${ }^{\circ}$ 5599, 24 febrero, p. 1. En la fuente se especifica que cuatro asistentes vestían trajes del personaje "Margarita" de Fausto y de "María Dolores" de la zarzuela Pepe Hillo. Véase también: La Paz de Murcia, XIX (1876), $\mathrm{n}^{\text {os }} 5588,11$ febrero, p. 1 y 5597, 22 febrero, p. 1. 
armonio y piano por los profesores don Julián Calvo y don Antonio Ramírez. Una melodía de Tito Matei cantada por la señorita doña Julia Guerra, discípula de don Juan Diego Manresa. Una fantasía de "Favorita" ejecutada al piano por la señorita doña Rita Pagán y acompaña al armonio por el profesor señor Ramírez y una pieza clásica ejecutada al piano por la señorita doña Julia Guerra $[\ldots]^{50}$.

Como ejemplo de bailes veraniegos, mencionaré el organizado el 20 de agosto de 1876 por los Pagán en su finca "Vistabella" a orillas del Mar Menor (en el paraje hoy denominado Lo Pagán). Hubo abundante decoración y refrigerios (chocolates, licores y repostería), una regata (carrera de embarcaciones), bandas de música tocando en tierra y otras sobre embarcaciones desde el mar, una cucaña marina, un concierto musical y un baile. García Alix relató así el alcance de los festejos:

[...] muchos días antes de que llegase el día señalado para la agradable distracción, se hablaba en los pueblos inmediatos y en los albergues donde cobijan las familias que veranean en este hermoso campo, de lo agradable que había de ser una tan escogida reunión, pues esta tiene para todas las clases verdaderos atractivos, porque en ella encuentra el pobre pescador la risueña esperanza de triunfar en la regata y obtener el premio, los sencillos habitantes de la comarca el escuchar los acordes de la música y ver empavesado el mar a la luz de las bengalas y la elegante y hechicera señorita la perspectiva agradable que ofrece el culto de Terpsícore en los revueltos giros del rápido vals y en los soñolientos acordes de la pausada polca. $[\ldots]^{51}$.

La fiesta comenzó a las cuatro y media de la tarde. La banda de música de Antonio Raya (llegada especialmente desde Murcia) y la banda de San Javier recorrieron las calles cercanas a la finca de los Pagán. En el mar, doce embarcaciones procedentes de Torrevieja anunciaron el comienzo de la regata. En una de ellas iba la Banda Municipal de Torrevieja. Al anochecer, "faroles a la veneciana y vasos de colores caprichosamente colocados iluminaban la suntuosa fachada del edificio" de la casa de la familia Pagán. Con bengalas en dos embarcaciones ("simulacro de una lucha naval") y con "varios caprichos pirotécnicos" se dio fin al brillante espectáculo al aire libre. Después comenzó el baile y el concierto musical. Antonio Ramírez acompañó al piano "algunas piezas de canto que ejecutaron la señora de la casa [Leonor Guerra], Asunción Fernández Albaladejo, Pedro Pagán, Antonio Albaladejo", entre otros. Ramírez y Luis Padilla, hermano del famoso barítono Mariano Padilla, "ejecutaron en el piano a cuatro manos difíciles composiciones musicales".

En el baile organizado por la familia Stárico (26-01-1877) hubo "más valses y polcas que cuadros de rigodón" 52 . El repertorio fue muy diferente en el baile organizado en la casa de Manuel Fontes y Álvarez de Toledo en 1879 el que, tras intervenciones de Paredes y Belda con guitarra y bandurria "lucieron su habilidad, destreza y agilidad en el baile español, acompañado de postizas (o palillos como

${ }^{50}$ El Diario de Murcia, V (1883), nº 1449, 11 diciembre, p. 2.

51 Antonio García Alix, "A orillas del Mar Menor. La casa del Excelentísimo señor don Pedro Pagán en la tarde del 20 de los corrientes", La Paz de Murcia, XIX (1876), nº 5745, 23 agosto, p. 1.

${ }^{52}$ La Paz de Murcia, XX (1877), nº 5968, 31 enero, p. 1. 
dicen en Andalucía) la señorita de Villa-Antonia y la señorita María de Zuzuarregui",53.

En el "baile de trajes" organizado por el director de la banda de música de la Casa de Misericordia, Acisclo Díaz, a mediados de febrero de 1885 una orquesta "compuesta de piano, violines, flautas y contrabajo" amenizó la fiesta. Se bailaron "mazurca, polca, rigodón, galop, etcétera" 54 .

La percepción que había en la sociedad acomodada murciana de los principales tipo de danzas puede conocerse a través de las crónicas periodísticas como el artículo de Agustín Medina Almela, publicado por El Semanario Murciano en 1878:

[...] Las fórmulas concretas del baile que admite la sociedad de buen tono son el vals y el ridogón. Ambas tienen su razón de ser, su filosofía, si es que el baile conoce a esta señora.

El vals en sus vueltas rápidas y vertiginosas, en su acompañamiento musical brillante y dulcemente cadencioso produce (en el que baila) una excitación extraordinaria. Bailando vals no se sueña: se delira. Acude en tropel a la imaginación mezcla confusa de recuerdos, de ideas, hechos y pasiones. Se siente la marcha veloz de un tren, la rapidez de una ascensión aérea, la vista de un espectáculo maravilloso, la idea de un porvenir inmenso, la satisfacción de una pasión grande, la gloria, el amor y más, mucho más [...]. Este baile, pues, es la expresión perfecta de un sentimiento que nace de la época. Si su fondo es la locura, de ella la recibe.

El rigodón es el polo opuesto, frío y reservado, sin compás pero con medida fija de tiempo, no significa otra cosa que la transacción entre la razón que se burla del baile y la tradición que ha impuesto la costumbre. Forma sin fondo, manifestación cosa de un sentimiento de placer que no existe, ni es preciso ni siquiera conveniente que aparezca... tal es el rigodón. La menor cantidad de baile posible, la indispensable de toda persona culta que concurra a sociedades.

Hay que conocerlo, como hay que saludar, calzar los guantes, ofrecer la casa, hacer una cortesía. Por eso, abunda tanto en ellas.

$\mathrm{Y}$ vean ustedes, aunque no lo parece, es el más razonable de todos ellos, tanto que su razón es ella misma... puesta en baile. [...]

Si tengo novia (que es posible) bailaré con ella vals. Si me caso (que es difícil) no bailaré nada. Si tengo suegra (que es seguro) bailaré rigodón con mi mamá política $[\ldots]^{55}$.

Medina también describió en el mismo artículo otros bailes, como la polca, que "bien puede llamarse tontería acompasada" por la monotonía de sus pasos; el chotis, "encanto de la gente cursi" y los lanceros que, según él, "son de caballería".

No sólo la alta sociedad murciana incluía el baile entre sus diversiones habituales (ver Figura 8.7). Las clases campesinas tenían también gran afición por la música y el baile, como describió Julián Calvo en un interesante artículo publicado en El Semanario Murciano, que extracto a continuación:

${ }^{53}$ La Paz de Murcia, XXII (1879), nº 6695, 11 septiembre, p. 1.

${ }^{54}$ La Paz de Murcia, XXVIII (1885), nº 8152, 21 febrero, p. 1.

55 Agustín Medina Almela, "El vals y el rigodón”, El Semanario Murciano, I (1878), n 3, 3 marzo, pp. 1-2: 2. Transcrito en el Documentario. 
[...] Mucha es la afición que estos hijos de la agricultura tienen a la música, no siendo menor su pasión por el BAILE. Sus bailes favoritos son las parrandas, las malagueñas, las torrás, el bolero (según su usanza) y el zángano, siendo este último más común en el campo de Corvera.

En el baile, tanto ellas como ellos gastan una circunspección admirable, no permitiéndose la más ligera libertad y, si se hablan, es de sus amores o quejas que entre sí puedan existir (pero siempre poco).

Todo huertano, al buscar pareja para bailar, es de rigor le ponga la montera y, al aceptarla la joven, es señal de que está conforme con la galantería del mancebo. De no admitirla, es que no baila o que está comprometida, lo cual muchas veces da lugar a sustos.

Las parrandas pueden ser bailadas por una, dos, tres o más parejas (llegando a veces a más de veinte).

Siendo de una, no varían de puesto los hombres mas, cuando es de dos en adelante, al indicar la copla, ellos dan la vuelta por la espalda de su pareja viniendo a colocarse frente a su contraria, empezando el baile en este momento y en esa forma.

Se cantan tres coplas haciendo una ligera suspensión el que toca, de una a otra. El mozo múdase a cada copla en la forma ya indicada y, a manera que se bailan las mollares o manchegas. Al terminarse las tandas de esta clase de baile se canta el retal que se baila brincando.

La música de este baile en la huerta es bulliciosa y animada, empleándose sólo la guitarra o ésta con guitarros o timpliquios, la bandurria y muchas veces forma parte en esta orquesta el violín.

Las coplas son cantadas por algún trovador o van alternando según el interés de los cantaores. [...]

La malagueña se baila por una sola pareja y generalmente son a cansar, relevándose los mozos en muchas ocasiones. Usan los mismos instrumentos que para las parrandas.

Las seguidillas, torrás y el bolero los bailan sólo una pareja en la forma que las parrandas y con los mismos instrumentos.

El zángano se baila como para final de fiesta por muchas parejas formando cadena y en movimiento vivo.

La música en la huerta es imprescindible para el baile, no es como en Andalucía, que muchos de estos son ejecutados al compás de uno que canta sin más acompañamiento que las palmas o el choque de los vasitos de caña. Nuestros huertanos solo cantan sin acompañamiento en el trabajo, lo cual demuestra que la música no la consideran como una parte secundaria en el baile, sino que éste depende de aquélla, como así se manifiesta en cuantos movimientos hacen, que van unidos al más riguroso RITMO. [...]

Las huertanas usan postizas (castañuelas) en los citados bailes, siendo estos pequeños instrumentos de boj, palo santo o marfil, sabiendo la generalidad de las jóvenes, sacar primorosos efectos de ellas. $[\ldots]^{56}$.

${ }^{56}$ Julián Calvo, "El baile”, El Semanario Murciano, II (1879), nº 97, 21 diciembre, pp. 2-3: 3 (ver Documentario). 


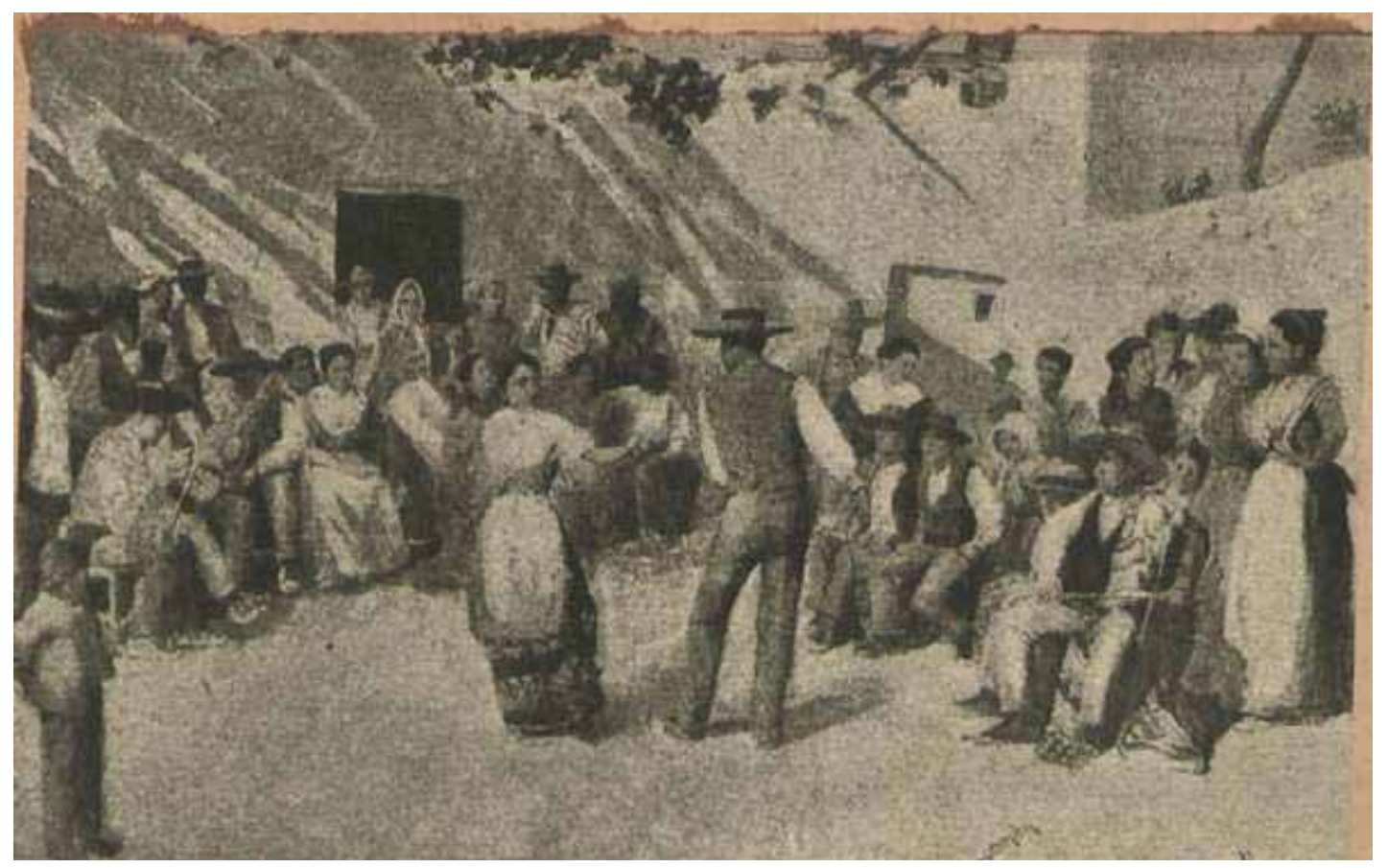

Figura 8.7. Escena típica de canto y baile murciano. Ilustración de Vicente Medina, incluida en Medina, Aires murcianos, p. 65. 

3 Num: 3

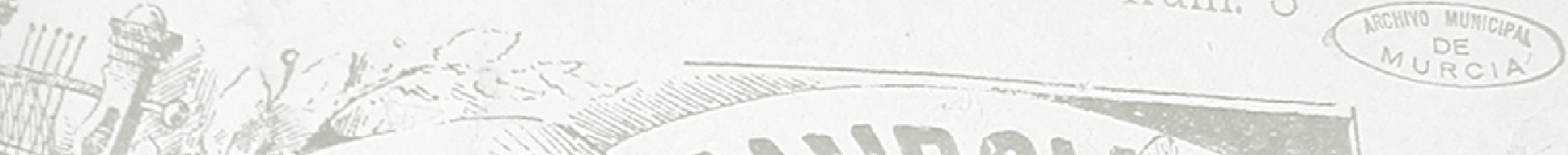

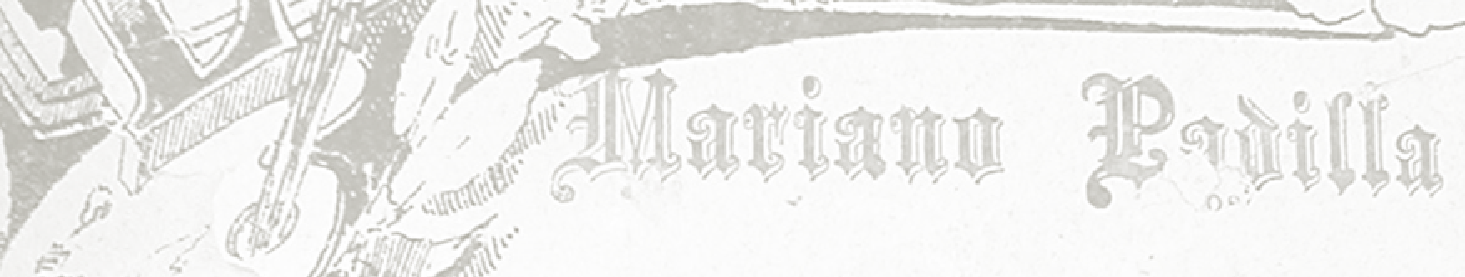

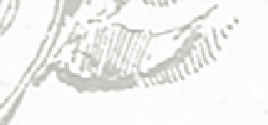

\section{LOS MÚSICOS DE LA CIUDAD}

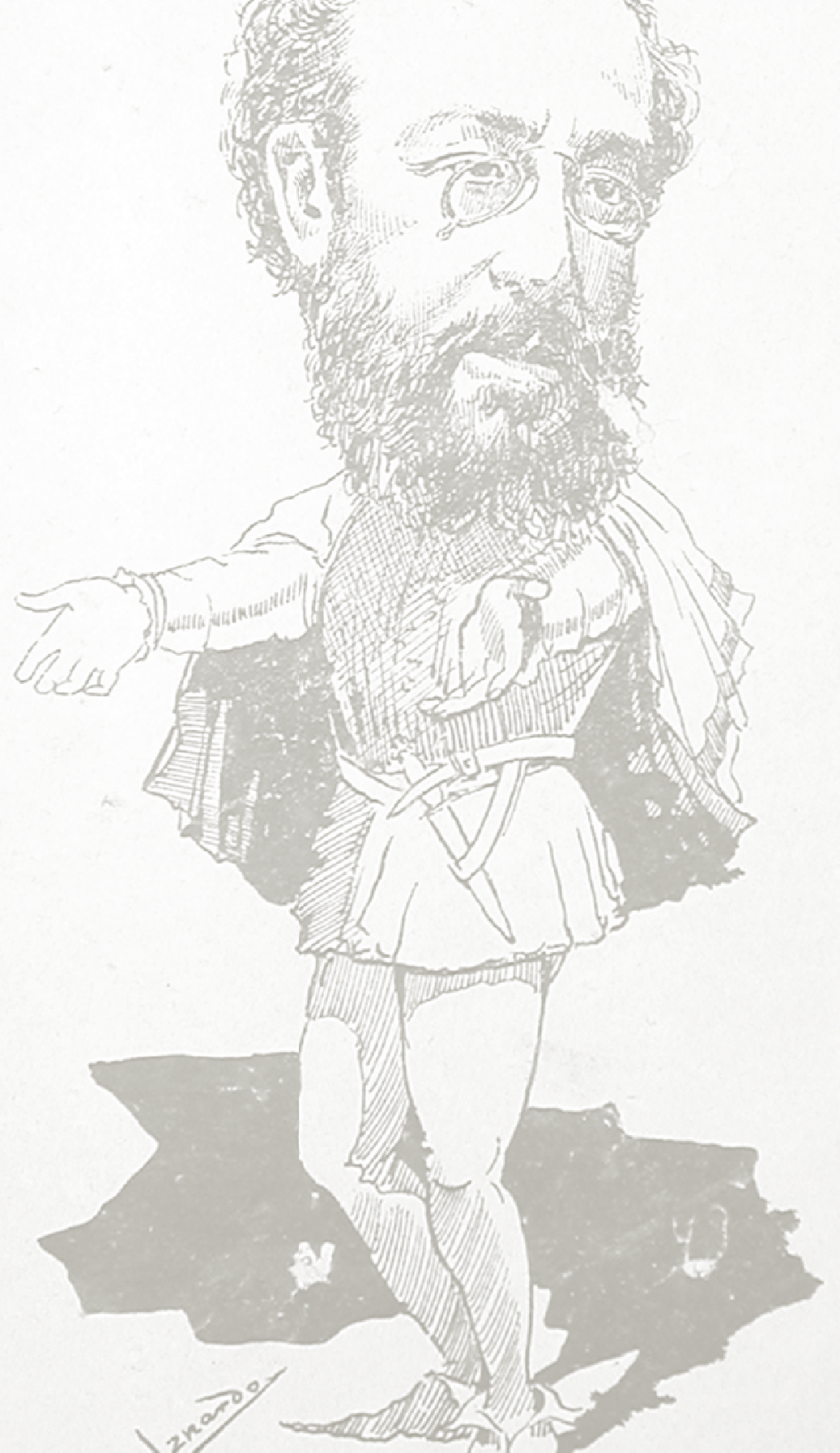




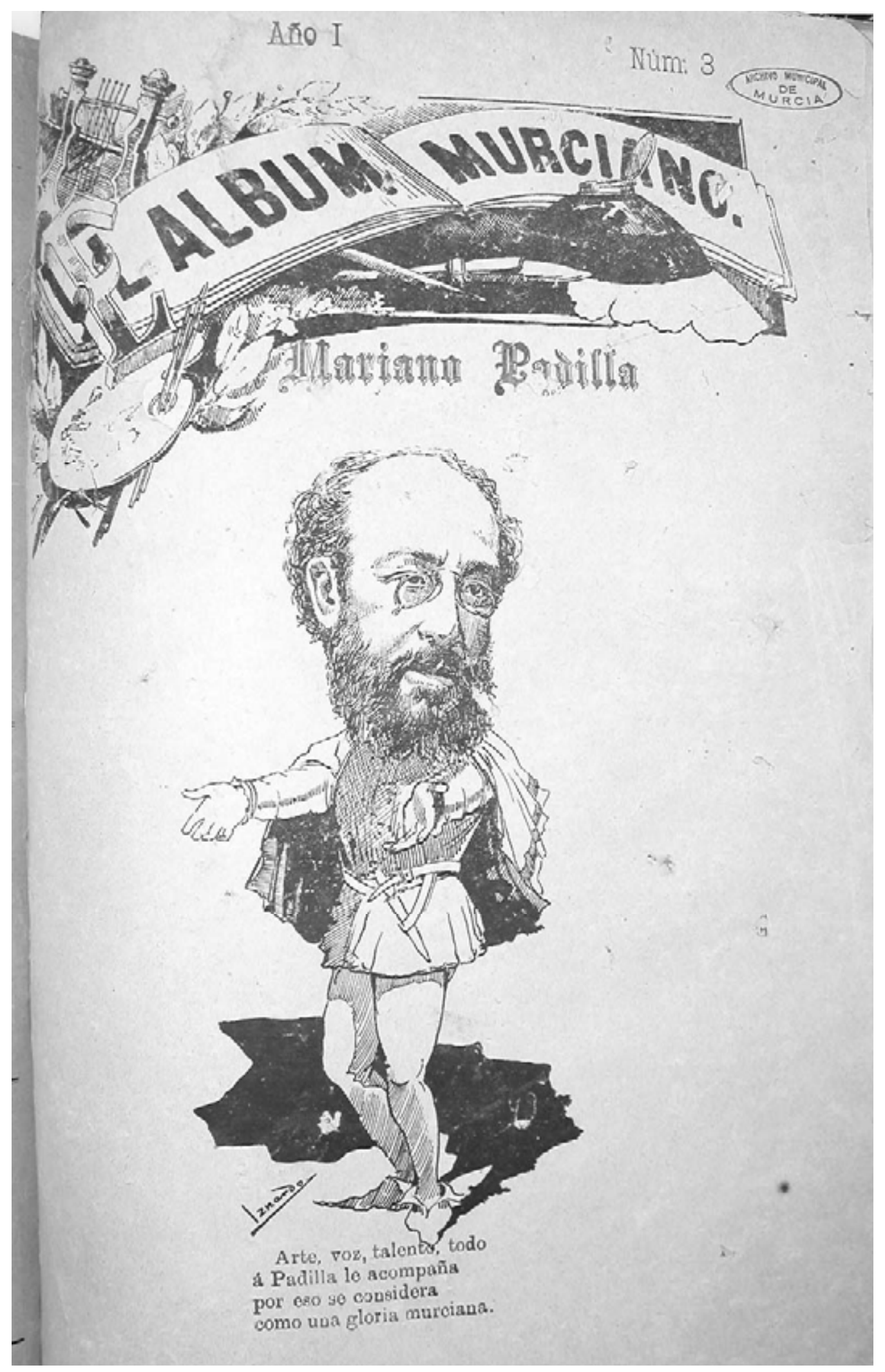

IV. Portada de El Álbum Murciano dedicada a Mariano Padilla. El Álbum Murciano, I (1895), nº 3, 16 junio, E: Mum. 


\section{Capítulo 9. Generaciones de músicos murcianos}

En Murcia, el desarrollo económico y cultural durante la segunda mitad del siglo XIX cambió algunos aspectos del perfil de los músicos murcianos y sus ámbitos laborales con respecto a épocas pasadas. La creciente afición por la música en la ciudad se reflejó en la presencia cada vez mayor de la música en la prensa escrita, en la proliferación de sociedades recreativas de carácter musical (o que incluían música), en el aumento del número de academias, orquestas, bandas de música y agrupaciones musicales de toda índole, en la actividad músico-teatral más o menos regular, en la oferta de conciertos en salones públicos, privados y al aire libre y en la creciente manufactura y venta de instrumentos, especialmente el piano (ver Capítulo 11). La actividad musical diaria amplió las posibilidades laborales de los músicos murcianos.

Los protagonistas de esta actividad musical en Murcia eran músicos sobre todo locales, en los que se pueden distinguir varias generaciones: una primera que denomino "de los maestros", nacidos a finales del siglo XVIII o principios del siguiente; una segunda generación de artistas que nacieron en la década de 1830, con destacadas personalidades como Ángel Mirete Sanz (1832-1888), Julián Calvo García (1835-1898), Manuel Fernández Caballero (1835-1906), Mariano García (1836-1906), Acisclo Díaz Rocher (1837-1887), Gaspar Espinosa de los Monteros (1836-1898), Luis Mondéjar Brocal (1837-?) y Antonio López Almagro (1839-1907), entre otros; y, finalmente, las generaciones de los músicos nacidos desde los años cuarenta en adelante.

En el presente capítulo analizo individualmente las trayectorias profesionales de los músicos que hasta ahora eran menos conocidos, revisando la bibliografía existente y aportando información hasta ahora inédita. En cambio, evito en esta Tesis abordar detalladamente músicos murcianos que han sido objeto de estudios monográficos o Tesis doctorales, como es el caso de Mariano Soriano Fuertes (1817-1880), Manuel Fernández Caballero (1835-1906), Ángel Rubio Sánchez (1856-1940) y Bartolomé Pérez Casas $(1873-1956)^{1}$.

Algunos músicos murcianos tenían estabilidad profesional porque estaban adscritos a un centro o formación instrumental de la ciudad (por ejemplo, la Catedral, la Capilla de Música de las Madres Agustinas, la Banda Municipal, la orquesta del Teatro). Ellos eran los artífices y organizadores de gran parte de la actividad musical murciana, pertenecían a la clase media ${ }^{2}$ (o media baja) y gozaban de prestigio en la ciudad. En ese grupo estaban, por ejemplo, Julián Calvo, Ángel Mirete, Acisclo Díaz, Antonio López

\footnotetext{
${ }^{1}$ Boïls, La "Historia" ha defendido recientemente su Tesis Doctoral que trata sobre la Historia de la Música Española de Mariano Soriano Fuertes; Manuel Fernández Caballero es actualmente objeto de estudio por parte del profesor Juan González Cutillas; Ana María Del Valle Collado, "El violonchelista" ha realizado un primer estudio del violonchelista Agustín Rubio Sánchez y María Dolores Cuadrado Caparrós, Bartolomé Pérez publicó su Tesis Doctoral sobre Bartolomé Pérez Casas.

2 Según Pérez Picazo, Oligarquía, pp. 353-354, la clase media murciana constituía una parte muy pequeña de la población. La autora engloba en la "clase media" a los trabajadores de las profesiones librales, los funcionarios (también militares y clero) y los pequeños propietarios agrícolas o industriales y matiza que no se pueden denominar "burgueses" en el sentido europeo del término ya que la clase media murciana se caracterizaba además por su "endeblez económica" en comparación con la europea. Sobre el consumo de la música en Europa desde la prespectiva de las clases sociales, véase Scott, "Music and social class" y Weber, Music and the Middle Class.
} 
Almagro y Mariano García que combinaban, como mínimo, dos de las facetas siguientes: compositor, profesor, director e instrumentista.

Nacidos en los años treinta, estos músicos fueron mayoritariamente discípulos de la generación que he denominado "de los maestros". Recibieron una amplia formación en conocimientos teóricos (solfeo, armonía y composición) e instrucción en varios instrumentos de cuerda y/o viento. En sus primeros años de actividad laboral estuvieron vinculados a capillas de música y formaciones instrumentales (principalmente orquestas y bandas), tanto del ámbito civil como religioso. Todos ellos trabajaron en la Catedral de Murcia y en el convento de las Madres Agustinas, unas veces como instrumentistas (principalmente, organistas) y otras como maestros de capilla ${ }^{3}$. Estos músicos estuvieron estrechamente vinculados a varias sociedades como fundadores o como socios (ver Capítulo 6) y todos educaron a músicos profesionales de generaciones posteriores, así como a un gran número de aficionados, con los que compartieron frecuentemente veladas musicales de ámbito doméstico.

Otro grupo de músicos de la generación de los treinta estuvo formado por artistas como Antonio López Almagro, Manuel Fernández Caballero, Gaspar Espinosa de los Monteros y el célebre pianista Luis Mondéjar, asentados principalmente en Madrid, que salieron pronto de Murcia y tuvieron un contacto sólo puntual con la ciudad.

Los músicos estudiados de la generación de los cuarenta y cincuenta del siglo XIX se ganaron su sustento económico a través de un negocio propio o de un cargo administrativo, compaginando estas ocupaciones laborales con su actividad musical, como el violinista Fernando Verdú y el pianista ciego Adolfo Gascón.

Los instrumentistas y cantantes que integraron las grandes formaciones instrumentales y vocales de la ciudad tuvieron presumiblemente una actividad intermitente y cabe suponer que combinaron la música con otras actividades, ya que percibían sueldos escasos y tenían condiciones laborales poco favorables.

A partir de la década de los sesenta surgieron notables músicos como Pedro Muñoz Pedrera, José Verdú, Emilio Ramírez y Manuel Benavente Montalvo ${ }^{4}$, todos compositores, así como el célebre pianista Antonio Puig Ruiz-Funes, cuyas carreras comenzaron a despuntar en los últimos años del siglo XIX, prolongándose en las décadas siguientes $^{5}$. La iniciación musical de estos artistas corrió a cargo de los músicos de la generación murciana de los treinta aunque muchos de ellos concluyeron su formación musical en el Conservatorio de Madrid, como fue el caso de Muñoz Pedrera y Puig. Pedro Muñoz Pedrera (Murcia, 28/12/1865-Murcia, 11/03/1925) tuvo una amplia trayectoria como compositor y sus obras fueron muy representadas en toda España (véase el punto 4 sobre zarzuelas de autoría murciana en el Capítulo 2). Antonio Puig (Murcia, 21/01/1870-

${ }^{3}$ Fernández de la Cuesta, "La Iglesia Católica", p. 760 reflexiona sobre la actividad seglar de los músicos eclesiásticos y afirma que la "alta preparación de los maestros de capilla y organistas de las catedrales [...] permitió la proyección 'civil' de los músicos adscritos a la Iglesia". La alternancia de actividades de los músicos eclesiásticos en el ámbito religioso y profano enriqueció la vida musical de las ciudades españolas, como expone Virgili, "La música religiosa”, p. 379.

4 Sobre Manuel Benavente Montalvo (Murcia, 1865- Murcia, 1920), véase García Laborda, "Benavente", pp. 354-355.

5 Véanse algunos datos biográficos en: Casares, "Muñoz Pedrera", p. 885; García Seco, "Muñoz Pedrera", p. 224; García Seco, "Puig Ruiz-Funes", p. 190; Ruiz Tarazona, "Puig, Antonio", p. 998. 
Murcia, 12/09/1920) fue un famoso pianista que, después de concluir sus estudios en Madrid, inició una carrera como concertista y pianista acompañante de grandes músicos españoles. A su vuelta a Murcia, Antonio Puig enseñó en el recién creado Conservatorio de Música de Murcia, inaugurado oficialmente el 5 de enero de 1919, donde fue Catedrático de Piano y Vicedirector del Centro hasta su muerte, en 1920.

\section{La generación de los maestros}

He denominado generación de los maestros murcianos del siglo XIX a varios músicos nacidos a finales del siglo XVIII y primeros años del XIX, artífices de legar conocimientos a los músicos que desarrollaron su actividad sobre todo en la segunda mitad del siglo XIX. Con los citados maestros se formaron músicos tan relevantes como Manuel Fernández Caballero, Mariano Soriano Fuertes, Mariano Padilla, Julián Calvo, Antonio López Almagro, Mariano Padilla, Mariano García, Agustín Rubio, los hermanos Espinosa de los Monteros y Luis Modéjar, entre otros. El común denominador de la generación de los maestros es su vinculación a los centros religiosos más importantes de la ciudad como la Catedral, el Convento de Madres Agustinas y el Colegio de San Leandro, centro esencial de enseñanza musical en la época (véase Figura 9.1) ${ }^{6}$.

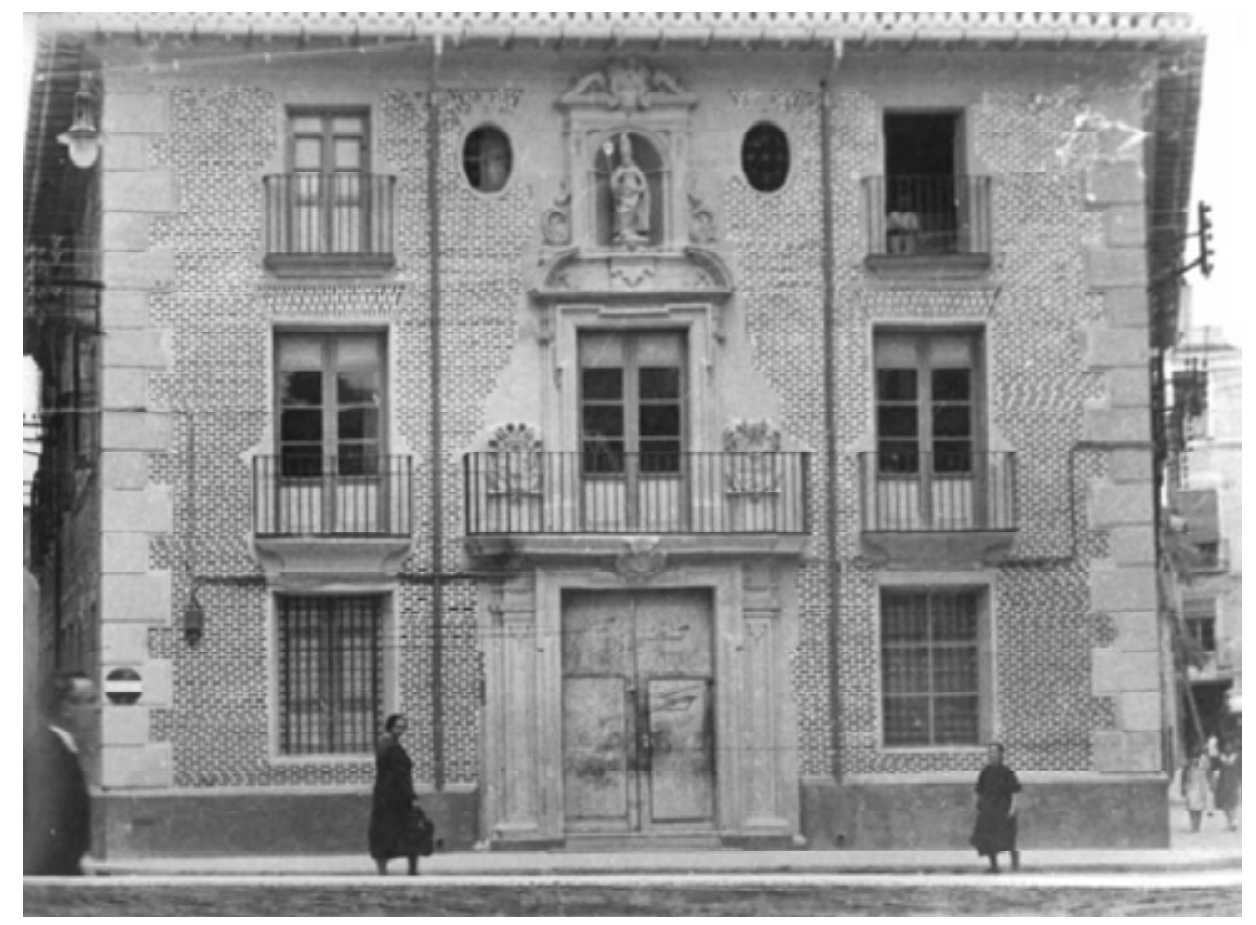

Figura 9. 1. Colegio de San Leandro en la Plaza de los Apóstoles de Murcia. Principios del siglo XX. E:MUm. Accesible en: http://www.archivodemurcia.es (acceso el 26-07-2011).

\footnotetext{
${ }^{6}$ El Colegio de San Leandro de Murcia fue creado por iniciativa del Cardenal Belluga en 1749. Sobre su fundación y desarrollo posterior, véase Prats, Educación Musical. Agradezco a la autora que me permitiera su consulta.
} 
Dentro de la generación de los maestros destacaron varios músicos de la familia Gil $^{7}$ : José Gil Huertos y sus hijos José, Julián y Carlos Gil Yuncas.

José Gil Huertos ingresó en la Capilla de Madres Agustinas a mediados del siglo XVIII y fue su director hasta que obtuvo la plaza de primer violín en la Catedral de Murcia. Enseñó flauta en el Colegio de San Leandro y, desde 1814, ejerció como profesor de piano ${ }^{8}$. Tuvo tres hijos, todos ellos ligados a la actividad musical: José, Julián y Carlos Gil Yuncas. Los tres se iniciaron en la flauta, piano, armonía y composición, probablemente con su padre y en el citado Colegio de San Leandro de Murcia. José Gil Yuncas fue maestro de capilla de la Catedral de Orihuela desde julio de 1833 hasta enero de 1843 , fecha en la que se trasladó como prebendado a la Catedral de Murcia ${ }^{9}$. Fue un destacado flautista y autor de una Salve a cuatro voces con violines, clarinetes, trompas, bajo y acompañamiento ${ }^{10}$. Carlos Gil Yuncas enseñó piano en Murcia desde $1834^{11} \mathrm{y}$ ocupó una plaza de flautista en la orquesta del Teatro del Toro (dirigida por su hermano Julián) ${ }^{12}$. Compuso, al menos, una Misa a dúo con órgano, conservada actualmente en la Catedral de Murcia ${ }^{13}$.

Julián Gil Yuncas (Murcia, 1808-Murcia, 1868) fue un reconocido violinista y director, que siendo aún muy joven consiguió la plaza de maestro de capilla del Convento de las Madres Agustinas, cargo que compatibilizó con la dirección de bandas de música y orquestas de teatro $^{14}$. Estuvo al frente de la orquesta del Teatro del Toro desde, al menos, 1839 hasta la mitad de la centuria ${ }^{15}$. Al frente de esta formación actuó en numerosas sesiones de ópera y zarzuela con compañías locales y/o nacionales y adaptó sus efectivos para actuar también con formaciones de cámara, orquestas y bandas de música ${ }^{16}$. Gozó de

${ }^{7}$ En "Un aficionado", “Apuntes para la historia de la música en Murcia (II)”, El Semanario Murciano, I (1878), no 24, 28 julio, pp. 3-4 se menciona a Alfonso Gil como primer Maestro de Capilla de la Catedral de Murcia, en 1477. Desconozco si tuvo vinculación familiar con los que menciono en este trabajo.

8 “Un aficionado", “Apuntes para la historia de la música en Murcia (X)”, El Semanario Murciano I (1878), $\mathrm{n}^{\mathrm{o}}$ 44, 15 diciembre, pp. 4-5: 4.

${ }^{9}$ López García, Los fondos musicales, cita las actas capitulares de 5-08-1833 y 23-01-1843 de la catedral oriolana, respectivamente, y afirma que José Gil ocupó el cargo de maestro de capilla en la Catedral de Murcia. Sin embargo, José Gil no aparece en la nómina de maestros de capilla que aporta García Seco, "Maestro de capilla", pp. 21-23. En "Un aficionado", "Apuntes para la historia de la música en Murcia (X)”, El Semanario Murciano, I (1878), n 44, 15 diciembre, pp. 4-5: 4 se menciona que José Gil fue prebendado de la citada catedral murciana. Climent, "Gil Yuncar [sic], José", pp. 609-610, menciona su nacimiento en Valencia hacia 1813 y afirma que el músico pasó de Orihuela a Cartagena en 1843.

10 "Un aficionado", “Apuntes para la historia de la música en Murcia (X)", El Semanario Murciano I (1878), $\mathrm{n}^{\mathrm{o}}$ 44, 15 diciembre, pp. 4-5: 4, José Gil "fue notabilísimo en este instrumento [flauta], teniendo todas las buenas condiciones que para escuchar un instrumentista de esta clase se requieren".

11 "Un aficionado", “Apuntes para la historia de la música en Murcia (X)”, El Semanario Murciano I (1878), $\mathrm{n}^{\mathrm{o}} 44,15$ diciembre, pp. 4-5: 4.

${ }^{12}$ Clares, La vida musical, p. 35.

${ }^{13}$ López García, Los fondos musicales.

${ }^{14}$ González Cutillas, “Gil Yuncas, Julián”, pp. 24-25.

${ }^{15}$ Saldoni, Diccionario, vol. IV, p. 122 menciona que Julián Gil Yuncas fue director de la orquesta del teatro "por los años 1859" [sic]. Julián Gil también es mencionado por Soriano Fuertes, Historia, p. 39 como director de orquesta.

\footnotetext{
${ }^{16}$ Véanse más detalles en Clares, "La música teatral”, pp. 451-478.
} 
prestigio en la ciudad, tanto en su faceta de violinista como de director ${ }^{17}$. Sin embargo, no escapó a las críticas y a la fuerte competencia que, desde 1849, mantuvo con la recién formada orquesta que dirigía Mariano Esbrí (ver Capítulo 2). Julián Gil Yuncas se retiró en $1855^{18}$. En su banda de música estuvieron José Calvo López, Julián Calvo y Fernández Caballero. Según Fernández de la Puente, "de él [Julián Gil Yuncas] son discípulos la mayoría o la casi totalidad de los buenos músicos que de dicha provincia han salido"19. Julián Gil se casó con Águeda Fernández Caballero, hermana del célebre compositor murciano Manuel Fernández Caballero, del que fue padrino, protector y amigo ${ }^{20}$. Julián Gil compuso al menos una popular Sinfonía sobre motivos murcianos, hoy desaparecida.

Otra de las dinastías musicales más relevantes de Murcia fue la de la familia Calvo, en la que destacaron Pedro Calvo, José Calvo López y Julián Calvo García. José Calvo López (Murcia, 1812-Murcia, 1876) se inició en la música con su padre, Pedro Calvo. En 1819 ingresó como niño cantor en la Capilla de la Catedral bajo la tutela del maestro de capilla, Jerónimo de los Ángeles. Durante los años siguientes, se instruyó en solfeo, clarinete, violín, piano, armonía y composición con músicos vinculados a esta institución, como Agustín Giménez ${ }^{21}$ e Indalecio Soriano Fuertes ${ }^{22}$. En 1827 obtuvo una beca para estudiar en el Colegio de San Leandro ${ }^{23}$. En 1834 fue admitido como miembro de la Capilla Musical de las Madres Agustinas y, más tarde, en la Capilla de la Catedral de Murcia. José Calvo fue un músico de amplios conocimientos y "uno de los introductores en Murcia del entonces nuevo movimiento musical [...]. De aquí que su inspirada obra retrate el gusto italiano de aquella época, con melodías en primer término a las que van subordinadas la armonía y la instrumentación" ${ }^{24}$. José Calvo introdujo repertorio italiano e importantes novedades en la orquesta (ver Capítulo 5), tanto en el teatro como en el ámbito religioso:

${ }^{17}$ González Cutillas, “Gil Yuncas, Julián”, pp. 24-25:25.

${ }^{18}$ Véanse más detalles en "Artistas notables de Murcia (III)", El Eco de Murcia, I (1881), nº 86, 5 agosto, p. 1, transcrito en el Documentario.

${ }^{19}$ Manuel Fernández de la Puente, "Julián Calvo", Boletín Musical y de las Artes Plásticas, VI (1898), n 109,10 abril, p. 241.

${ }^{20}$ González Cutillas, “Gil Yuncas, Julián”, pp. 24-25.

21 Agustín Giménez Arenas (Jumilla, Murcia, 1786-Murcia, 1869) estudió en el Colegio de San Leandro y fue discípulo de Bruno Molina (maestro de capilla de la Catedral de Murcia desde 1792 hasta 1811). Trabajó como primer organista de la Catedral de Orihuela, según [Anónimo], “Artistas murcianos notables (II)", El Eco de Murcia, I (1881), n 82, 31 julio, pp. 1-2. Más tarde, se trasladó de nuevo a Murcia, donde ocupó la plaza de organista en la Catedral de esta ciudad y, según García Seco, "Maestro de capilla", p. 22, la dirigió interinamente entre 1811 y 1814. Véanse más detalles en [Anónimo], "Artistas murcianos notables (II)", ibídem, transcrito en el Documentario. Giménez Arenas no era, por tanto, valenciano, como afirma Climent, "Giménez, Agustín”, p. 616.

${ }^{22}$ Entre 1811 y 1814 Indalecio Soriano Fuertes enseñó en el Colegio de seises de San Leandro de Murcia. Se hizo cargo de la dirección de la Capilla de Música de la Catedral entre 1827 y 1830, según Prats, "Murcia", p. 863. Véase: Casares, "Soriano (I). Soriano Fuertes, Indalecio", pp. 11-12 y García Seco, "Soriano Fuertes, Indalecio", pp. 143-144.

23 Según García Seco, "Calvo López, José”, pp. 288-289 por estos años ingresó también en el Seminario de San Fulgencio. Se ordenó y obtuvo los beneficios de una capellanía aunque más tarde abandonó el sacerdocio para ocupar una plaza como músico mayor del Regimiento de Caballería Tercero de Ligeros, cuyo cargo ocupó hasta 1833. Ver, [Anónimo], “Artistas murcianos notables (II)", El Eco, I (1881), $\mathrm{n}^{\mathrm{o}} 82,31$ julio, p. 1 ,

\footnotetext{
${ }^{24}$ La Paz de Murcia, XXVII (1884), no 7893, 13 abril, p. 1.
} 
[...] La orquesta del teatro, dirigida por don Julián Gil Yuncas [...] fue el ancho campo donde Calvo lució por muchos años sus buenos conocimientos y donde dio a conocer, sobre todo, su genio reformador y creador. Apenas entrado a formar parte de la orquesta, quita una vetusta tocada, mal llamada sinfonía, cuyos papeles estaban pegados en los atriles y que se tocaba en las grandes solemnidades teatrales, conocida por esta circunstancia entre los músicos por el ya tradicional nombre de Sinfonía de la tabla. Destierra además la bolanchera y las contradanzas y sustituye todas estas músicas ramplonas y de mal gusto con las piezas más brillantes de las óperas de Rossini, Bellini y Mercadante, magistralmente arregladas e instrumentadas por él en armonía con las facultades de los músicos murcianos de aquella época.

Es nombrado músico Mayor del Regimiento Tercero de Ligeros y la banda de música se levanta y regenera como por encanto, conociéndose la persona inteligente que la dirige. No abandona el género religioso, a pesar de sus muchas ocupaciones. Compone una pequeña "Misa" y en la última parte del "Credo" saca un partido extraordinario en unas sencillas pero bellísimas imitaciones entre el clarinete y la flauta. Da a conocer su "Gran Salve" y en ella llama la atención el dúo de tiple y tenor donde las flautas desempeñan un papel necesario e importante y con estas obras da a la flauta una verdadera importancia y le señala para siempre el lugar que debe ocupar en la orquesta $[\ldots]^{25}$.

Además de las obras citadas en el párrafo anterior, José Calvo compuso al menos un obra sinfónica estrenada en 1843 para una Exposición Cultural organizada por el Liceo Artístico-Literario de Murcia; un Tema con variaciones; unos Dolores para orquesta a ocho voces; una Salve (1845), un Septenario a la Virgen de los Dolores con letra de Antonio Arnao (1848) y un Miserere a cuatro y ocho voces mixtas y orquesta (1851). En el campo pedagógico, José Calvo escribió un Método de Solfeo, publicado en dos partes en Murcia (véase Figura 9.2), un Método de flauta y una zarzuela en dos actos. A su vuelta a Murcia, dirigió la capilla de música de las Madres Agustinas hasta su muerte en $1876^{26}$.

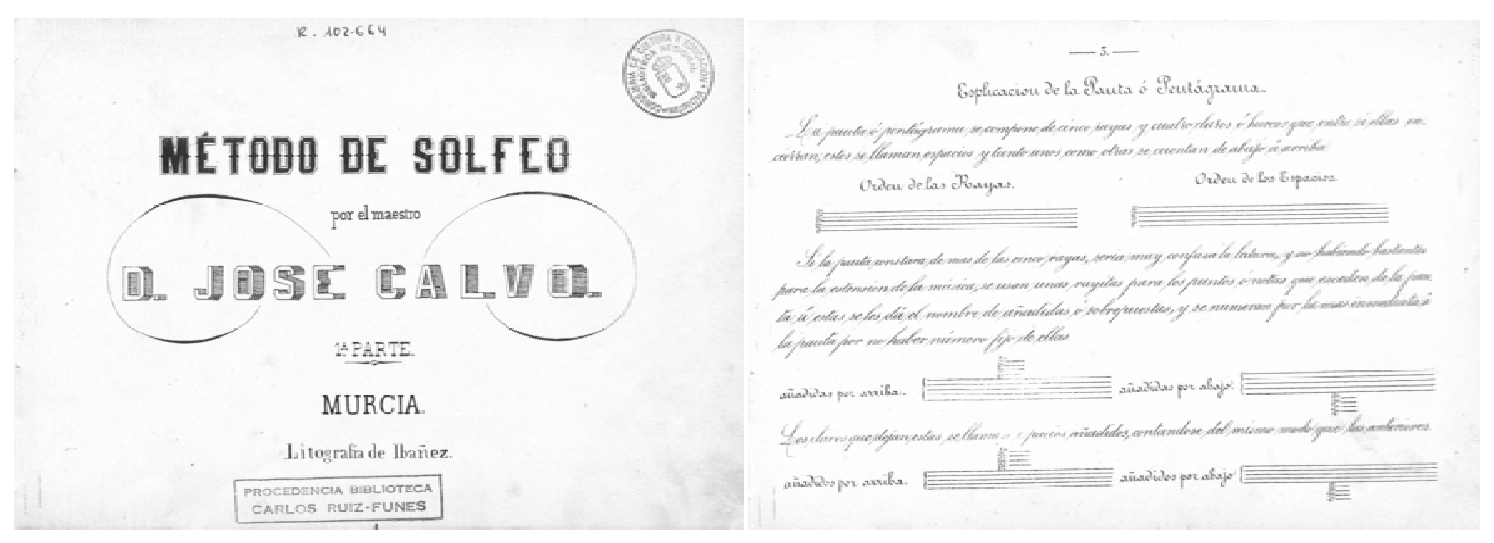

Figura 9. 2. Portada y página tres del Método de solfeo de José Calvo

(Murcia: Litografía de Ibáñez, [s.a.]), E:MUbr.

Accesible en: http://bibliotecadigital.carm.es (acceso el 13-07-2011).

25 "Un aficionado", “Apuntes para la historia de la música en Murcia (X)", El Semanario Murciano I (1878), $\mathrm{n}^{\mathrm{o}}$ 44, 15 diciembre, pp. 4-5: 4.

${ }^{26}$ García Seco, “Calvo López, José”, p. 289. Según Lacal, Diccionario, pp. 97-98:98 también fue profesor de violín y fagot en la Catedral de Murcia. 
En la generación de los maestros murcianos del siglo XIX hay que mencionar otros tres nombres: Juan Diego Manresa, Mariano Esbrí y Celestino Mondéjar. Juan Diego Manresa Caballero (Murcia, ca. 1817- Murcia, 9/11/1898) ${ }^{27}$, invidente, era pianista, organista, armonista, compositor y afinador de pianos ${ }^{28}$. Proyectó una publicación periódica musical titulada La Lira del Segura (véase Capítulo 1) con su propia vivienda (Santa Quiteria, 4) como punto de inscripción del periódico ${ }^{29}$, aunque no tengo constancia de que llegara a publicarse. Juan Diego Manresa enseñó piano en colegios femeninos como el de Nuestra Señora de los Dolores (calle Montijo) y el de Nuestra Señora del Pilar (calle San Pedro). Fue profesor de Antonio López Almagro, entre otros alumnos, y participó en numerosas veladas en el Casino de Murcia. También tocó en otros salones de la ciudad, como el Café del Comercio y fue profesor en la Escuela de Canto $^{30}$. En 1857, al menos, era organista de la Parroquia de San Lorenzo de Murcia $^{31}$. En sus últimos años, Juan Diego Manresa fue nombrado pianista del Casino de Murcia con un sueldo fijo. Sin embargo, su faceta más notable fue la de organista. Según Julián Calvo, con el órgano "se hace admirar. Posee una ejecución enérgica y limpia"32. Fue Manresa quien estrenó el órgano de la Iglesia de San Bartolomé en $1885^{33}$. Juan Diego Manresa compuso, entre otras obras, unos Gozos a tres voces estrenados en una novena a Santa Rita en la parroquia de San Bartolomé (24-05-1897) ${ }^{34}$ y protagonizó una enorme querella periodística contra Adolfo Gascón bautizada por la prensa como cuestión fermata (ver Capítulo 4).

Los datos sobre Mariano Esbrí Giménez (?- Murcia, 9/02/1890 35 ) son escasos y no se conoce nada sobre su iniciación musical. Fue un destacado flautista, aunque se dedicó más a la dirección, la composición y la enseñanza ${ }^{36}$. En 1848 fundó un cuarteto (flauta, violín, viola y violonchelo) promocionado por el Casino de Murcia para que participara de forma regular en sus veladas musicales ${ }^{37}$. Ese cuarteto fue el germen de una orquesta formada en 1848 (ver Capítulo 6):

${ }^{27}$ Las fechas de nacimiento y muerte han sido reconstruidas a partir de El Diario de Murcia, XIX

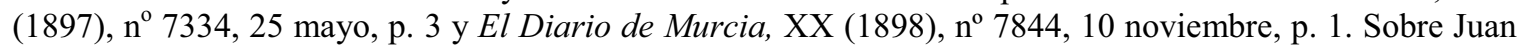
Diego Manresa véase, Julián Calvo, "El Casino de Murcia y D. Juan Diego Manresa”, El Diario de Murcia, XVI (1894), nº 6268, 11 mayo, p. 2.

28 "Un aficionado", “Apuntes para la historia de la música en Murcia (V)”, El Semanario Murciano I (1878), n 28, 25 agosto, pp. 2-3: 2; La Paz de Murcia, XXX (1887), nº 8283, 13 noviembre, p. 1.

${ }^{29}$ Diario de Murcia, I (1851), $\mathrm{n}^{\circ}$ 65, 16 marzo, pp. 2-3.

${ }^{30}$ La Paz de Murcia, XXIV (1881), nº 7143, 17 septiembre, p. 1.

${ }^{31}$ Calvo, Reseña, p. 26.

32 Julián Calvo, "Remitido", La Paz de Murcia, XXI (1878), nº 6313, 22 septiembre, p. 1.

${ }^{33}$ La Paz de Murcia, XXVIII (1885), nº 8358, 31 octubre, p. 1.

${ }^{34}$ El Diario de Murcia, XIX (1897), nº 7334, 25 mayo, p. 3.

${ }^{35}$ El Diario de Murcia, XII (1890), n 3952,11 febrero, p. 1.

${ }^{36}$ Fue profesor de flauta, según "Un aficionado", “Apuntes para la Historia de la Música en Murcia (X)”, El Semanario Murciano, I (1878, n 44, 15 diciembre, pp. 4-5:4 y La Paz de Murcia, XXXIII (1890), $\mathrm{n}^{\mathrm{o}} 10046,9$ febrero, p. 1.

37 “Un aficionado”, “Apuntes para la Historia de la Música en Murcia (X)”, pp. 4-5:4. El Clamor Público, (1848), n 1320, 18 octubre, p. 4. 
[...] También la nobleza se aficionó a este instrumento [la flauta], dedicándose muchos jóvenes a su estudio y consiguiendo algunos llamar la atención como diestros tocadores. Empleaban la flauta en sus saraos y bailes y después en sus reuniones, donde se escuchaban preciosos cuartetos, variaciones, fantasías y toda clase de piezas, dando esta afición origen a la formación de la gran banda y orquesta que por tantos años y con tanto acierto dirigió don Mariano Esbrí. El principio de ella fue un cuarteto de flauta, violín, viola y violonchelo que la sociedad del Casino, al formarse, llamó y protegió impulsando este germen de orquesta conforme la sociedad fue tomando fomento. $[\ldots]^{38}$.

La orquesta de Esbrí estaba formada por profesionales y aficionados y actuó en diversas temporadas del Teatro Romea, de la que Esbrí llegó a ser Presidente Honorario ${ }^{39}$. Esbrí también dirigió varias formaciones instrumentales con las que actuó regularmente en salones de cafés (ver Capítulo 7). En 1881, estrenó una Misa de la que se escribió: "es música verdaderamente religiosa que no tiene motivo ni recuerdo alguno zarzuelesco, impropio de la severidad de los templos" ${ }^{, 40}$.

Celestino Mondéjar (?- Murcia 7/02/1868) nació en Molina de Segura (Murcia) ${ }^{41}$ y fue Catedrático en el Seminario Conciliar de San Fulgencio de Murcia e iniciado en el canto por Leandro Valencia, "el cual le hizo representar con éxito algunas óperas",42. A causa de una enfermedad, Mondéjar dejó de cantar y se dedicó a enseñar armonía y composición a músicos murcianos de la generación de los treinta a los sesenta como Adolfo Gascón, Fernando Verdú, y a su propio hijo, el famoso pianista Luis Mondéjar (ver puntos 2.5.2 y 3 de este Capítulo).

La generación de los maestros fue percibida como tal por los músicos inmediatamente posteriores. Julián Calvo reconocía así la labor de esos maestros en $L a$ Crónica de la Música de 1880: "La enseñanza se halla en esta capital bastante decaída y parecen próximos a desaparecer los brillantes resultados que nos legaron los respetables maestros don Indalecio Soriano Fuertes, don Agustín Jiménez Arenas, don José Calvo, don José Celestino Mondéjar, don José Gil Prieto, don Julián Gil Yuncas y otros"43.

38 "Un aficionado”, “Apuntes para la historia de la música $(\mathrm{X})$, pp. 4-5: 4.

${ }^{39}$ El Diario de Murcia, IV (1882), nº 974, 14 mayo, p. 2.

${ }^{40}$ El Diario de Murcia, III (1881), n ${ }^{\circ}$ 576, 5 enero, p. 3. Véase también, El Diario de Murcia, III (1881), n $\mathrm{n}^{\mathrm{o}} 574,5$ enero, p. 2.

${ }^{41}$ Según Mariano García, "Las lápidas del monumento a los artistas murcianos ilustres. Músicos”, El Semanario Murciano, IV (1881), n 182, 1 septiembre, p. 251-252: 252.

42 No me consta la disciplina de la que fue Catedrático Mondéjar. Véase, [Anónimo], “Artistas murcianos notables (III)", El Eco, I (1881), nº 86, 5 agosto, p. 1. Leandro Valencia murió en Murcia en 1840 y fue un célebre cantante de ópera italiana: El Diario de Murcia, VII (1885), nº 1770, 10 enero, p. 3.

${ }^{43}$ Julián Calvo, [Carta remitida], Crónica de la Música, III (1880), nº 67, 1 enero, p. 2. 


\section{La generación de los años treinta}

\section{1. Ángel Mirete Sanz (1832-1888)}

Ángel Mirete Sanz (Murcia, 4/10/1832- Murcia, 19/06/1888) nació el 4 de octubre de 1832 y fue bautizado en la Iglesia Parroquial de San Juan Bautista (Figura 9.3). Fue discípulo de José Calvo López y estudió diversos instrumentos, entre ellos el piano, la flauta y el violín ${ }^{44}$. Mirete desarrolló una importante actividad musical, tanto en el ámbito de la música religiosa como en el de la profana y dirigió varias formaciones instrumentales, algunas de las cuales han sido tratadas en capítulos anteriores.

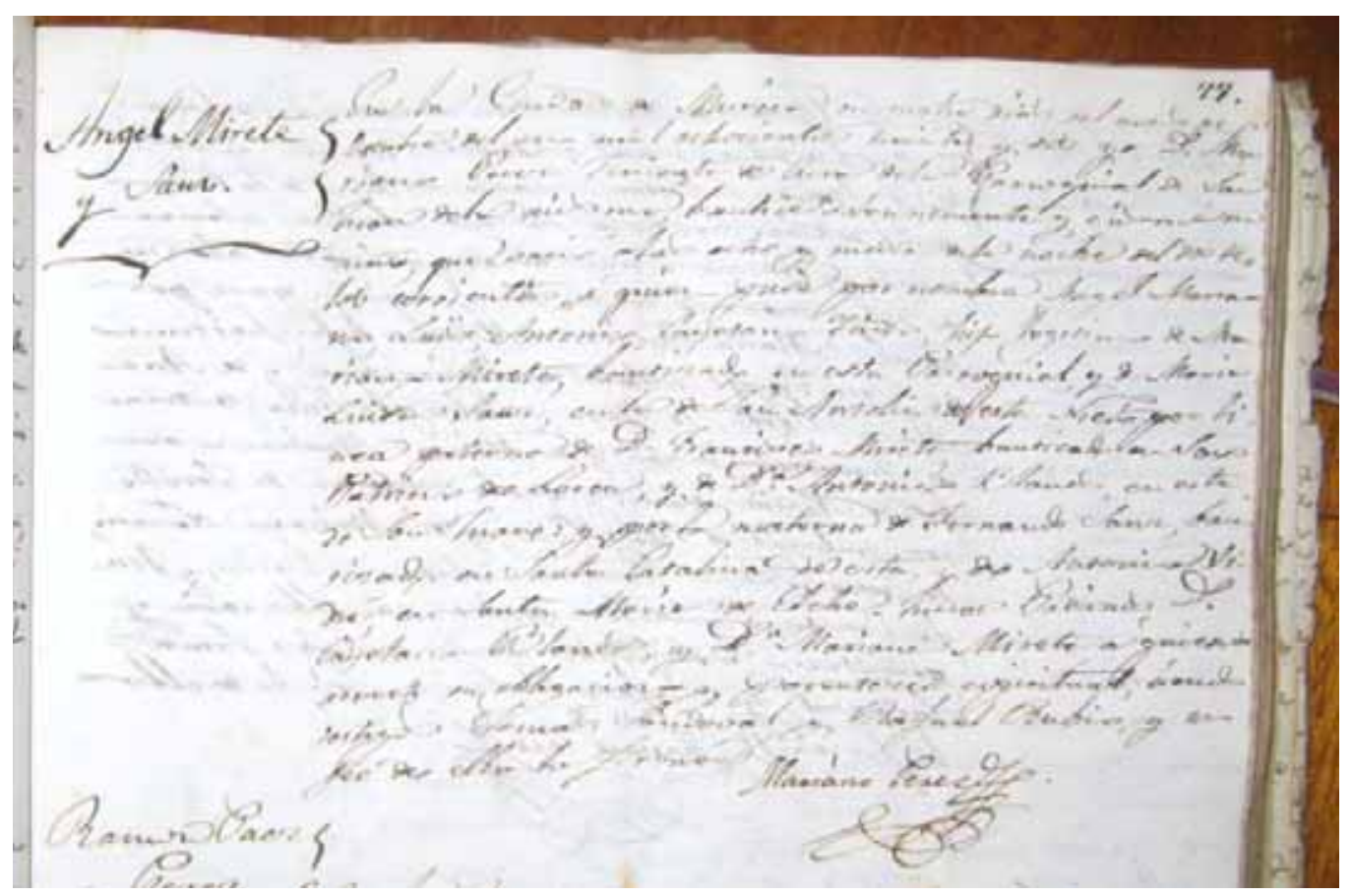

Figura 9. 3. Partida de bautismo de Ángel Mirete Sanz (1832-1888) E:MUpj, Libro de Bautismo n ${ }^{\circ} 17$ (1830-1839), fol. 77r.

Ángel Mirete fundó y dirigió la Banda Municipal de Murcia desde 1858 hasta su muerte, en 1888. Desde 1868 estuvo también al frente de la orquesta del Teatro de la Soberanía Nacional (más tarde Romea) con varias compañías teatrales, y en 1884 consiguió en propiedad la plaza de director de la orquesta del Romea tras opositar oficialmente a ella, manteniéndola también hasta el final de su vida (ver Capítulo 2).

Según García Seco, Mirete también dirigió la Capilla de Música de las Madres Agustinas, aunque no especifica en qué fechas ${ }^{45}$. Además, colaboró en reiteradas ocasiones con la Capilla de Música de la Catedral de Murcia y con su orquesta asistió a

\footnotetext{
44 García Seco, "Mirete Ramírez”, p. 146.

${ }^{45}$ García Seco, “Mirete Ramírez”, p. 146.
} 
diversas celebraciones religiosas o cívico-religiosas en diferentes iglesias y parroquias murcianas $^{46}$.

Como he comentado anteriormente, Mirete contaba con un amplio grupo de músicos a su disposición a los que organizaba según la ocasión. Además, Mirete prohibía a sus músicos formar otras orquestas o separarse de la suya por contrato y so pena de cuantiosa multa (cien duros, o sea, 500 pesetas) ${ }^{47}$.

Como otros músicos murcianos del momento, Mirete tomó parte activa en las sociedades recreativas y musicales del momento. En el Círculo Industrial, dirigió una sección denominada Liceo, en la que se representaron óperas como Norma de Bellini y zarzuelas como El postillón de la Rioja de Oudrid sobre libreto de Olona. Mirete formó parte del cuarteto creado en el seno de la sociedad La Juventud y amenizó los bailes de sociedad y de máscaras en el Casino de Murcia. Fue también violinista habitual de los conciertos organizados por la Sociedad Filarmónica, La Ilustración, Santa Cecilia, El Liceo y la Juventud Católica (véase Capítulo 6); de las veladas de varios cafés de Murcia, así como de salones privados domésticos y públicos como el almacén de música de Adolfo Gascón. En marzo de 1888 Ángel Mirete cayó gravemente enfermo y murió el 19 de junio ${ }^{48}$.

Como compositor, Ángel Mirete escribió obras de distintos géneros. Fue autor de una Sinfonía dedicada a la sociedad El Liceo y estrenada en junio de $1878^{49}$; la obertura La primavera para orquesta y banda, premiada con la "Flor Natural" de los Juegos Florales de $1881^{50}$; la Marcha Triunfal dedicada al Ayuntamiento de Murcia, como muestra de agradecimiento por el nombramiento del cargo de director de la orquesta del Romea en junio de $1884^{51}$; y el Himno Guerrero para coro, orquesta y banda con letra de G. Calvo, estrenado en $1885^{52}$. También compuso Mirete la música de un baile sobre costumbres murcianas titulado La Huerta de Murcia, con coreografía de Antonio Vadillo, director del cuadro de baile de la compañía de Eduardo Cortés ${ }^{53}$. La prensa también

${ }^{46}$ Por ejemplo, en la Iglesia Parroquial de Santa Eulalia de Murcia en febrero de 1874: La Paz de Murcia, XVII (1874), n 4996, 10 febrero, p. 1. Véanse otros ejemplos en La Paz de Murcia, XIII (1870), $\mathrm{n}^{\text {os }} 3788,30$ enero, p. 1; 3794, 6 febrero, p. 1; 3816, 4 marzo, p. 1 y 3837, 29 marzo, p. 1 .

${ }^{47}$ El Diario de Murcia, II (1880), nº 118, 13 enero, p. 2.

${ }^{48}$ La Paz de Murcia, XXXI (1888), nos 9450, 10 marzo, p. 1; 9508, 19 mayo, p. 1; 9519, 2 junio, p. 1; 9534, 20 junio, p. 1. La crónica de su entierro se publicó en: La Paz de Murcia, XXXI (1888), nº 9535, 21 junio, p. 1 y El Diario de Murcia, X (1888), no 3342, 21 junio, p. 1. La prensa nacional también dio cuenta de su fallecimiento: El Día, (1888), n 2923, 22 junio, p. 3.

${ }^{49}$ La Paz de Murcia, XXI (1878), nº 6228, 29 mayo, p. 1.

${ }^{50}$ Algunos datos de su biografía aparecieron en García Seco, "Mirete Ramírez, Ángel”, p. 146. La actividad de Ángel Mirete en el ámbito religioso puede ejemplificarse con los siguientes documentos: $L a$ Paz de Murcia, XIII (1870), ${ }^{\text {os }}$ 3816, 4 marzo, p. 1; 3837, 29 marzo, p. 1 y 3848, 10 abril, p. 1; La Paz de Murcia, XV (1872), n 4531, 2 abril, p. 1

${ }^{51}$ La Paz de Murcia, XXVII (1884), nº 7960, 3 julio, p. 1.

${ }^{52}$ Esta obra era un himno patriótico interpretado tras el estreno de las zarzuelas Una broma de estudiantes y Travesuras de Quevedo, ambas con música de Julián Calvo con libretos de Ramón Guerrero y Francisco Villegas, respectivamente. Como apunté anteriormente, la representación tuvo lugar en el Teatro Provisional y los actores fueron alumnos del Instituto de Segunda Enseñanza: La Paz de Murcia, III (1860), $\mathrm{n}^{\text {os }} 610,5$ febrero, p. 1 y 616,15 febrero, p. 1 .

${ }^{53}$ El baile La Huerta de Murcia fue estrenado el 25 de enero de 1868 en el Teatro de los Infantes por diez parejas: La Paz de Murcia, XI (1868), nos 3116,12 enero, p. 3 y 3128, 15 enero, p. 4. 
menciona, entre las obras de género religioso, varias misas; un Miserere interpretado en la procesión de la Cofradía del Santo Sepulcro en 1885; varias marchas fúnebres, entre otras piezas para las procesiones murcianas ${ }^{54}$.

Aunque Ángel Mirete no escribió críticas ni artículos de temática musical en la prensa murciana fue una verdadera autoridad en materia musical, a juzgar por las numerosas noticias aparecidas sobre él en los diarios murcianos y por la cantidad de escenarios musicales en los que el músico participó.

\subsection{Julián Calvo García (1835-1898)}

Julián Calvo (Murcia, 21/12/1835-Murcia, 28/02/1898) era hijo del músico José Calvo López y de María García Ramírez de Arellano (véase su retrato en la Figura 9.4$)^{55}$. Recibió su formación musical inicial de su padre y del compositor Julián Gil ${ }^{56}$. Estudió piano, violín y flauta y según Benavente, en 1846 entró como flautín en la Banda Municipal de Murcia ${ }^{57}$. Desde 1851, Julián Calvo estudió órgano, armonía y composición con el organista de la Catedral de Murcia, Agustín Giménez. Tres años más tarde, junto con el compositor Antonio López Almagro, comenzó a tocar de forma autodidacta el armonio en uno de los primeros instrumentos de este tipo que llegaron a la ciudad ${ }^{58}$.

\footnotetext{
${ }^{54}$ Una de sus misas fue interpretada en 1868 en una ceremonia dedicada a la Purificación, organizada por la Cofradía de la Buena Estrella de Murcia: La Paz de Murcia, XI (1868), n 3138, 4 febrero, p. 2. En 1883 se estrenó otra misa en la función religiosa dedicada a Santa Cecilia: La Paz de Murcia, XXVI (1883), $\mathrm{n}^{\mathrm{o}}$ 7779, 24 noviembre, p. 1. Sobre el Miserere, véase: La Paz de Murcia, XXVIII (1885), $\mathrm{n}^{\circ}$ 8187, 4 abril, p. 1; y sobre las marchas fúnebres: La Paz de Murcia, XVI (1873), nº 4735, 12 abril, p. 1.

${ }^{55}$ Los datos biográficos que presento sobre Julián Calvo se basan en las siguientes fuentes: Manuel Benavente, "Don Julián Calvo", El Diario de Murcia, XV (1893), nº 5895, 2 abril, pp. 1-2; García Seco, "Calvo García, Julián”, pp. 288; Crespo Pérez, "Apuntes sobre compositores”, pp. 107-116; Cano Benavente, Murcianos, pp. 151-154; Andrés Blanco García, "Don Julián Calvo", Cartagena Artística, II (1891), n 47, 20 julio, pp. 1-2; Andrés Blanco García, "Julián Calvo", El Diario de Murcia, XIII (1891), nº 4386, 22 julio, p. 1; Manuel Fernández de la Puente, "Julián Calvo", Boletín Musical y de las Artes Plásticas, VI (1898), n 109, 10 abril, pp. 240-241; Sobrino, “Calvo García, Julián”, pp. 942-944 y M. C. M., "Notas biográficas. D. Julián Calvo García", programa de mano del Concierto-Homenaje a Julián Calvo García celebrado el 28-02-1969 en el Conservatorio de Murcia (Murcia: Imprenta San Miguel, 1969).

${ }^{56}$ Fernández de la Puente, “Julián Calvo”, p. 241.

${ }^{57}$ Benavente, "Don Julián Calvo", p. 1 señala que, al mismo tiempo, ingresó en la citada corporación como cornetín el célebre compositor Fernández Caballero y que Calvo ocupó una plaza de segunda flauta en la Capilla de Música de las Madres Agustinas. En "Un aficionado", "Apuntes para la Historia de la Música en Murcia", El Semanario Murciano I (1878), n 44, 15 diciembre, pp. 4-5 se afirma "Don Manuel Fernández Caballero y don Julián Calvo estuvieron dedicados más o menos tiempo a este instrumento, especialmente Calvo que al fin tuvo que abandonarlo por serle perjudicial a su salud". Julián Calvo mantuvo una estrecha amistad con Fernández Caballero "su compañero de la infancia y amigo entrañable", según Fernández de la Puente, "Julián Calvo", p. 241.

${ }^{58}$ Según El Semanario Murciano, IV (1881), n 165, 10 abril, p. 113 ambos músicos aprendieron en un armonio "de dos juegos de la fábrica de Alexandre".
} 


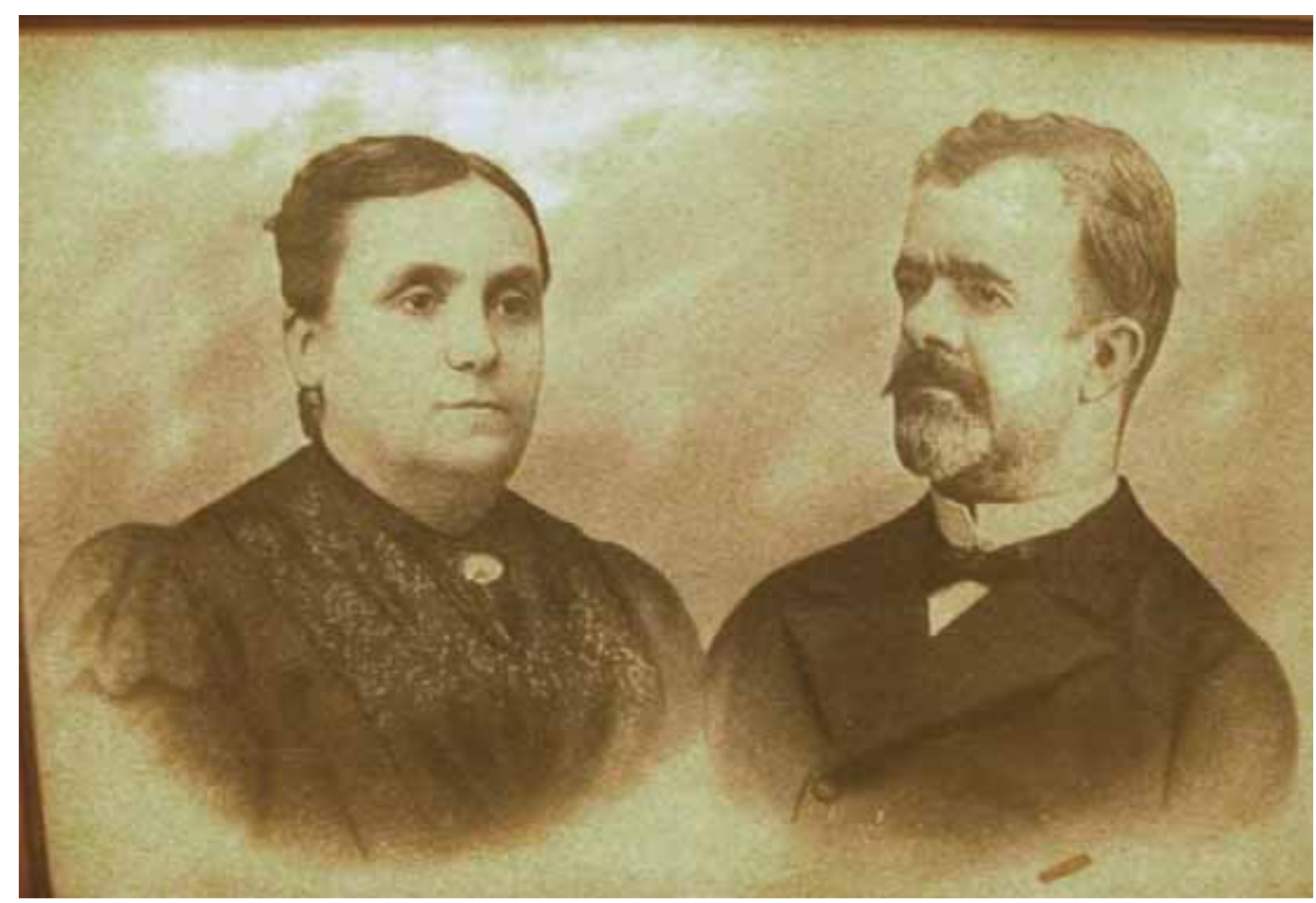

Figura 9. 4. Retrato de Julián Calvo y su esposa.

Archivo particular de la Familia Martínez Calvo, Murcia.

Julián Calvo tocaba habitualmente el piano y el armonio en conciertos benéficos del teatro y en los celebrados en los distintos salones de Murcia. Fue intérprete habitual del Café de la Puerta del Sol y, con menor frecuencia, del Café de Oriente. Profesionalmente fue sobre todo organista. Su alumno Antonio Ramírez Pagán describió así los inicios de Julián Calvo en el órgano, que aprendió también de forma autodidacta:

[...] Si hay entre nosotros algún profesor que trabaje, sin que sea ni por el interés ni por la gloria es, indudablemente, el señor Calvo. El señor Calvo es organista de la Catedral, por dos razones únicamente, por amor al órgano y por amor al culto.

Cuando nuestro prelado, de feliz memoria, don Mariano Barrio y Fernández, pensó en dotar a nuestra Iglesia Catedral de un órgano tan bueno como el mejor que pudiera existir en cualquier otro punto, no sé si pensaría que, el mejor de los órganos posibles, necesitaba como complemento uno de los organistas mejores posibles. Pero el órgano vino, que era lo principal, y el señor Calvo entonces, que según creo no era el organista, maravillado ante la magnificencia y la perfección del gran órgano, concibió una verdadera pasión por estudiar, comprender y dominar un instrumento tan prodigioso $[\ldots]^{59}$.

En diciembre de 1854, Julián Calvo ocupó la plaza de organista de la Parroquia de San Antolín de Murcia, en sustitución de Carlos Gil, cargo que compaginó con su nombramiento el 8 de octubre de 1859 como organista supernumerario sin sueldo en la Catedral de Murcia $^{60}$. El 16 de agosto de 1869 adquirió la plaza en propiedad de segundo

${ }^{59}$ Antonio Ramírez Pagán, "Revista Musical”, El Diario de Murcia, V (1883), nº 1373, 12 septiembre, pp. 1-2:2

${ }^{60}$ Sobrino, “Calvo, García, Julián”, pp. 942-944. 
organista de la Catedral y, desde el 1 octubre de 1885, como primero, puesto que desempeñó hasta su muerte (28-02-1898) ${ }^{61}$.

Calvo formó parte de varios tribunales a plazas de música de la Catedral de Murcia $^{62}$, participó en numerosos eventos religiosos de otras iglesias murcianas y sus obras fueron muy escuchadas en las festividades religiosas de Murcia. Pondré varios ejemplos. En junio de 1868, Calvo participó junto al Orfeón de la Sociedad Filarmónica y músicos como Quercop, Manresa y Prieto en una ceremonia religiosa en la parroquia de San Juan Bautista de Murcia (organizada por la Real Archicofradía de la Santísima Trinidad), en la que se interpretó una Misa de Mercadante y el Sanctus, Agnus y Benedictus de Antonio López Almagro ${ }^{63}$. En diciembre de 1864, se ejecutó la Gran Salve de Julián Calvo en un novenario organizado por las "Hijas y Siervas de María" en la parroquia de Nuestra Señora del Carmen ${ }^{64}$. El 3 de junio de 1888, se cantó una Misa de Calvo en la Iglesia de Santo Domingo, al frente de cuya orquesta estuvo el propio compositor $^{65}$. En junio de 1890, Calvo participó en el concierto inaugural del órgano de la Iglesia Parroquial del Carmen en Cartagena junto a otros músicos como Eduardo Lafuente, Leandro Morata y Julián Bas ${ }^{66}$. Además, Calvo colaboró habitualmente en las festividades de Santa Cecilia, celebradas en el Convento de las Madres Agustinas, que trato en otro lugar.

Julián Calvo estuvo muy ligado a sociedades como El Liceo, la Filarmónica, el Círculo Industrial, La Ilustración, La Juventud, el Casino, la Juventud Católica y la Real Sociedad Económica de Amigos del País de Murcia, entre otras; acompañó en numerosos conciertos a otros músicos; programó veladas con sus alumnos y alumnas; tomó parte activa en los certámenes artísticos y literarios de la ciudad; medió en las polémicas suscitadas entre los músicos murcianos; intervino en la comisión especial constituida por el Ayuntamiento para la creación de la orquesta del Romea y, más tarde, formó parte de su tribunal de oposiciones; fue uno de los promotores de la creación de un conservatorio en Murcia en junio de 1881 formalizado después en la sociedad Santa Cecilia) (ver Capítulo 6) ${ }^{67}$; y, en el campo de la enseñanza, fue un solicitado profesor de piano entre cuyos alumnos figuraron Lozano, Francisco Leante, Antonio Puig Ruiz-Funes (ver Figura 9.5), el compositor Pedro Muñoz Pedrera y José Antonio Ramírez, entre otros ${ }^{68}$.

61 Según el Almanaque Musical para el año 1885 (Madrid: Romero, 1885), p. 57, el organista beneficiado (clérigo) de la catedral era Simón Espín y el organista seglar Julián Calvo. Saldoni, Diccionario, IV, p. 50 mencionó a Julián Calvo como primer organista sin especificar el año, dato que fue corregido en El Semanario Murciano, IV (1881), n 178, 10 julio, p. 223.

${ }^{62}$ Benavente, “Don Julián Calvo”, p. 2. Calvo, Reseña, p. 26.

${ }^{63}$ La Paz de Murcia, XI (1868), no 3261, 10 junio, p. 1.

${ }^{64}$ La Paz de Murcia, XVII (1874), no 5237, 10 diciembre, p. 1.

${ }^{65}$ La Paz de Murcia, XXXI (1888), nº 9519, 2 junio, p. 1.

${ }^{66}$ La Paz de Murcia, XXXIII (1890), nº 11044, 3 junio, p. 4.

${ }^{67}$ El Semanario Murciano, IV (1881), no 175, 19 junio, p. 197.

${ }^{68}$ La Paz de Murcia: XVI (1873), no 4881, 24 septiembre, p. 1; XXI (1878), $\mathrm{n}^{\text {os }} 6231,2$ junio, p. $1 \mathrm{y}$ 6286, 10 agosto, p. 1. Sobre su labor como profesor de piano, véase el Capítulo 11. 


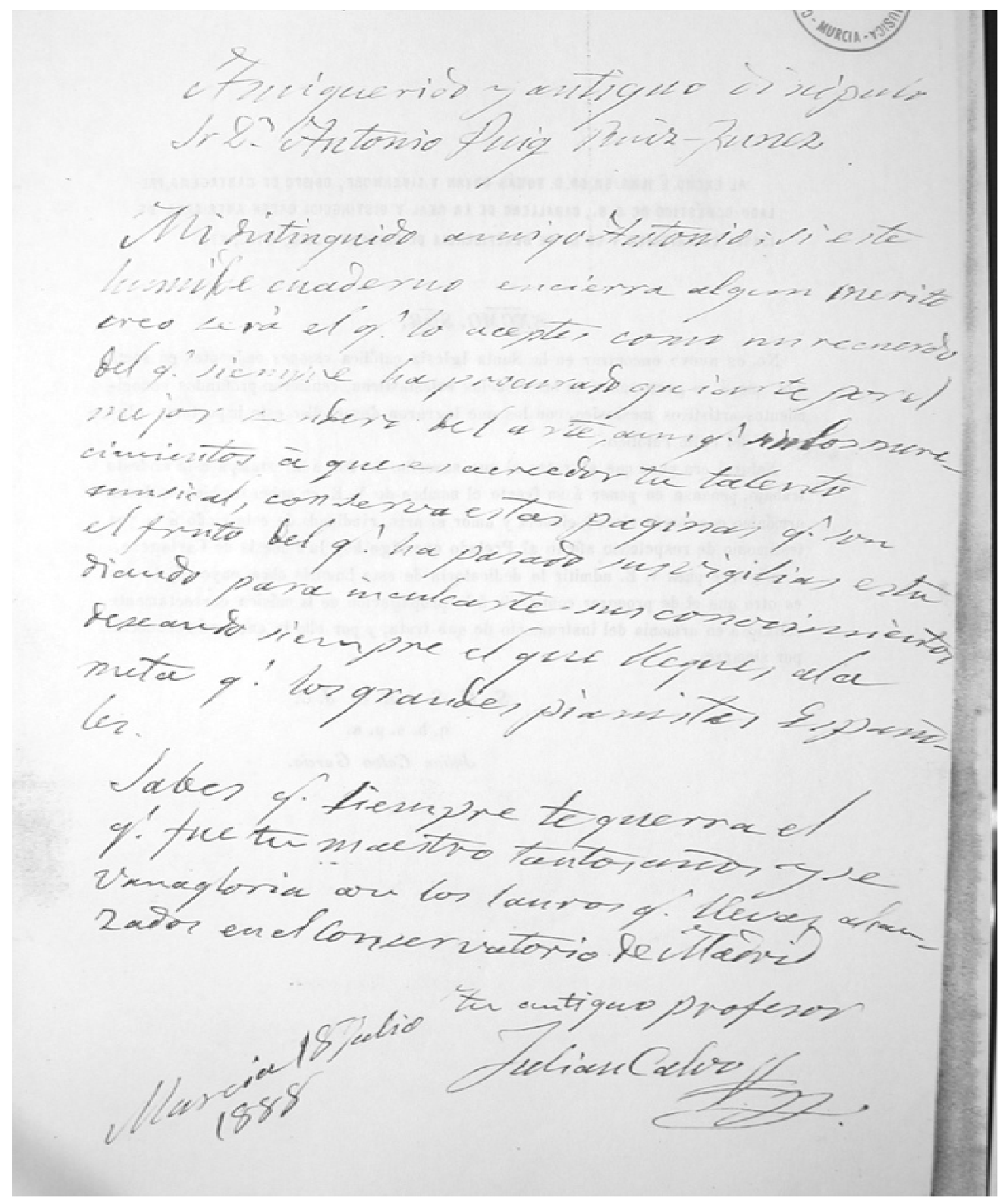

Figura 9. 5. Dedicatoria manuscrita de Julián Calvo a su discípulo, el pianista murciano Antonio Puig, sobre el reverso de la portada del Tratado Práctico del Teclado de Pedales en el Órgano Moderno. (Madrid: Romero, ca. 1888). E:Mc.

Calvo fue un hombre comprometido con la cultura murciana y tuvo gran prestigio dentro y fuera de Murcia capital. En 1891, el diario Cartagena Artística le dedicó un artículo monográfico firmado por Andrés Blanco García (véase Figura 9.6) ${ }^{69}$.

${ }^{69}$ Véase también el artículo de Ricardo Sánchez Madrigal, "La velada del Círculo Católico en honor de don Julián Calvo", El Diario de Murcia, XX (1898), n 7599, 9 marzo, p. 2, escrito tras el concierto homenaje que la sociedad Círculo Católico de Murcia organizó en memoria de Calvo. 


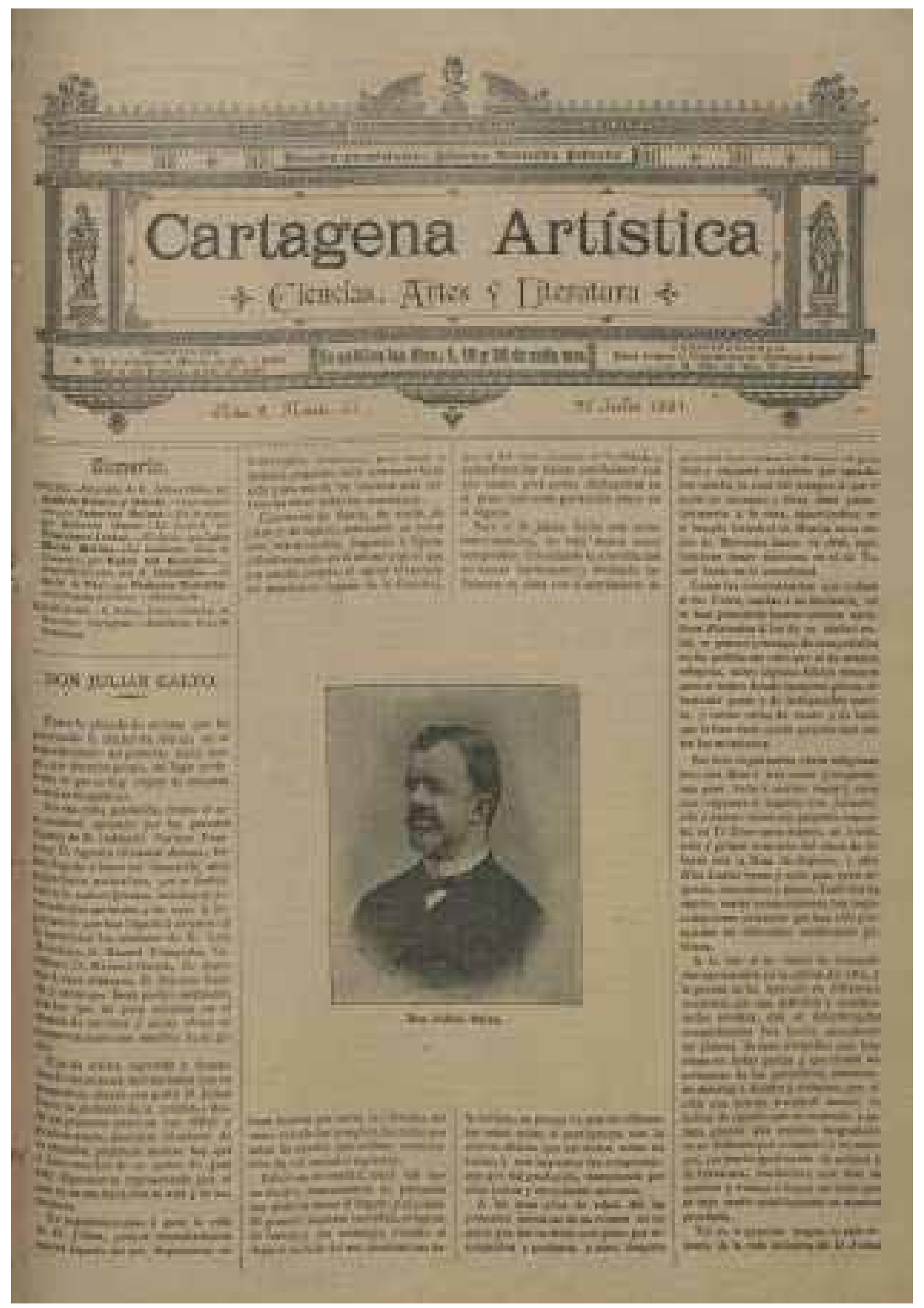

Figura 9. 6. Artículo de Andrés Blanco García sobre Julián Calvo en Cartagena Artística, II (1891), n 47, 20 julio, p. 1. E:CARm Accesible en: http://archivo.cartagena.es (acceso el 15-07-2011).

Calvo obtuvo varios premios en certámenes musicales de toda España, no sólo por sus composiciones sino también por sus obras pedagógicas (ver Tabla 9.1): 
Tabla 9. 1. Premios recibidos por Julián Calvo en certámenes de ámbito nacional (1879-1892)

Fuente: Benavente, "Don Julián Calvo”, pp. 1-2.

\begin{tabular}{|l|l|l|}
\hline Premio o distinción & Obra premiada & $\begin{array}{l}\text { Fecha, institución y } \\
\text { lugar }\end{array}$ \\
\hline Azucena de Plata & Sinfonía de cantos españoles & 1879, Murcia \\
\hline Medalla de Plata & Marcha & $\begin{array}{l}1880, \text { Sociedad El } \\
\text { Iris de Valencia }\end{array}$ \\
\hline Medalla de Cobre & Pasodoble & 1880, Valencia \\
\hline $\begin{array}{l}\text { Medalla de Oro } \\
\text { Laureada }\end{array}$ & $\begin{array}{l}\text { Sinfonía sobre cantos populares } \\
\text { gallegos }\end{array}$ & 1880, A Coruña \\
\hline Escribanía de Plata & Gran cantata para voces y orquesta & 1882 , A Coruña \\
\hline Accésit & $\begin{array}{l}\text { Fantasía sobre cantos gallegos para } \\
\text { banda militar }\end{array}$ & 1882 , A Coruña \\
\hline Medalla de Bronce & $\begin{array}{l}\text { Tratado Práctico del Teclado de } \\
\text { Pedales en el Órgano Moderno }\end{array}$ & 1888, Barcelona \\
\hline Batuta de Plata & $\begin{array}{l}\text { Marcha sobre motivos de los himnos } \\
\text { corales a la Virgen }\end{array}$ & 1889, Lérida \\
\hline Mención Honorífica & $\begin{array}{l}\text { Romanza para canto y piano } \\
\text { Exposición } \\
\text { Regional de León }\end{array}$ \\
\hline
\end{tabular}

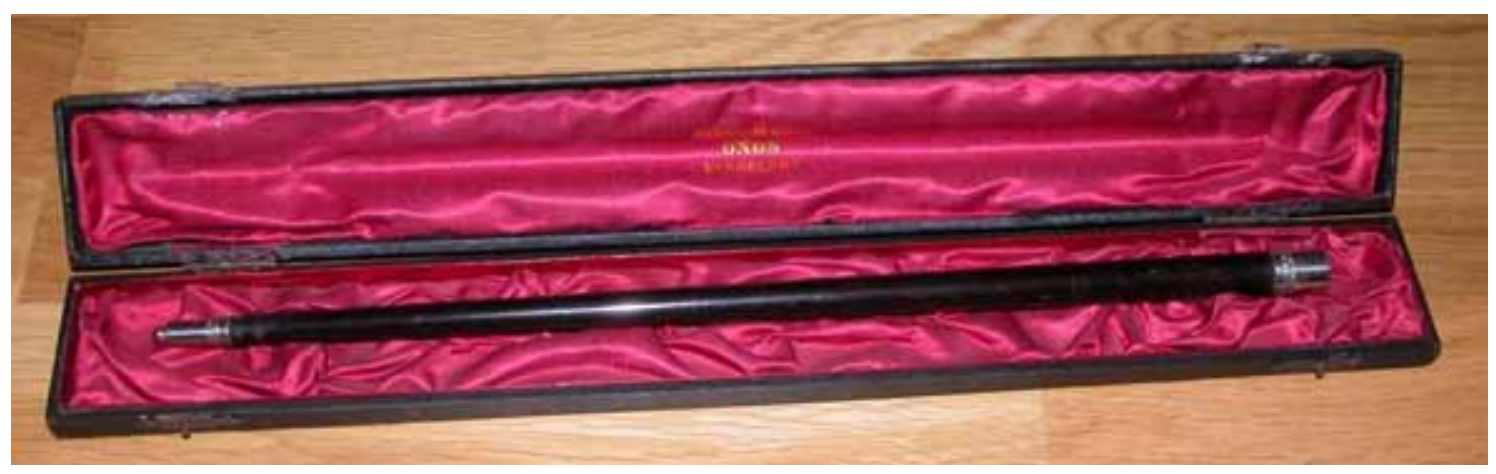

Figura 9. 7. Batuta de Julián Calvo. Archivo de la Familia Martínez Calvo, Murcia.

Julián Calvo fue un prolífico compositor que trabajó todos los géneros musicales imperantes en su época, como muestran los títulos de obras suyas incluidos en los apéndices de los capítulos anteriores. Según Lacal, su obra ascendió a 443 composiciones $^{71}$. El Apéndice 9.1 contiene un listado de obras de Julián Calvo localizadas en diferentes archivos españoles y el Apéndice 9.2 recoge las obras no litúrgicas del mismo, citadas por la prensa murciana de la segunda mitad del siglo XIX. Hasta la hecha he podido localizar menos del $10 \%$ de su obra.

La obra religiosa de Julián Calvo ocupa un lugar destacado en su catálogo de obras (de las 34 partituras localizadas físicamente, 18 son obras religiosas). Según Benavente, una de sus primeras obras fueron tres versos de un Miserere para la procesión del Entierro de Cristo que fue estrenada, aunque incompleta, en 1854. Doce años después Calvo terminó los ocho números restantes, reestrenándose en la Catedral de Murcia en

\footnotetext{
${ }^{70}$ Véase Figura 9.7.

${ }^{71}$ Lacal, Diccionario, p. 97.
} 
febrero de $1866^{72}$. Según Benavente, Calvo compuso "18 misas [...], multitud de motetes, letanías, Santo Dios, trisagios, gozos, [e] himnos" "73. Por el momento he localizado tres de las misas: dos para cuatro voces y otra para tres, con acompañamiento de orquesta $\mathrm{y} / \mathrm{u}$ órgano (véase Apéndice 9.1). Las fuentes periodísticas dan noticia de algunas otras. La Misa a Santa Cecilia, compuesta por el autor hacia 1860, se interpretó en la festividad del año 1880 en el Convento de las Agustinas y según El Diario de Murcia "Tiene riquezas de melodías, de frases, de motivos, de cantos" "\%4. El Cabildo de la Catedral de Granada encargó una misa a Calvo tras la epidemia de cólera del año $1885^{75}$; este hecho, y la existencia de partituras de Calvo en archivos de varias ciudades de Andalucía, como Granada y Cádiz, muestran que el compositor era conocido e interpretado allí (ver Apéndice 9.1).

La producción sinfónica para orquesta y/o banda de Julián Calvo fue abundante. Benavente menciona trece oberturas ${ }^{76}$. En el concierto celebrado por la Sociedad Filarmónica de Murcia en el Teatro de los Infantes (05-07-1868) para recaudar fondos para erigir un Monumento a los Artistas Célebres de Murcia se interpretó una "Sinfonía a orquesta, banda, piano y armonio" de Julián Calvo que, aunque gustó al público, fue criticada por la prensa por su escasa elaboración:

[...] la sinfonía del señor Calvo es una concepción en alto grado sencilla y ligera. La idea dominante de la obra escrita en el segundo periodo es de un carácter apasionado y tierno.

Al percibirla, nos trasladó el espíritu en busca del crescendo de la sinfonía de JUANA DE ARCO, diciéndonos: "aquí he nacido yo". Esta frase es demasiadamente repetida, desamparada siempre y siempre desnuda. La primera idea del allegro empieza exactamente como el de la sinfonía de STIFFELLIO. Su corte, su ritmo y hasta su color.

Diferenciándose únicamente en que la de STIFFELLIO está escrita en el modo mayor y que la del señor Calvo está escrita en el modo menor. El giro dado a la preparación para volver a la idea dominante con notas sueltas y sonidos agudos en ascenso cromático hasta llegar a la tercera del modo y raíz de la melodía, es muy parecido al que emplea Mercadante en su magnífica sinfonía de EL REGENTE y casi, casi, exacto al mismo procedimiento de Verdi, en su dicha sinfonía de STIFFELLIO.

Como edificio de tan poco peso no tiene otros cimientos armónicos que cuatro acordes. Los perfectos mayor menor, la séptima de primera especie o de dominante, y la séptima disminuida. La instrumentación, como la repartición de las melodías efectuada por el camino ordinario, carece de represas, de combinaciones, y de algún nuevo efecto, circunstancias tan indispensables en la buena instrumentación, que las concepciones más ricas, vírgenes y bien desarrolladas vienen a quedar sumamente pobres.

Sospechamos que el señor Calvo ha confeccionado la obra en muy corto tiempo, por lo cual no extrañamos haya hecho una sinfonía bonita pero sencillísima. El público dio a manifestar su agrado llamando al autor a la escena y colmándole de aplausos. $[\ldots]^{77}$.

${ }^{72}$ Benavente, "Don Julián Calvo", p. 1.

73 Benavente, "Don Julián Calvo", p. 1. Véase también el catálogo que presenta Sobrino, "Calvo García, Julián”, p. 944.

\footnotetext{
${ }^{74}$ El Diario de Murcia, II (1880), no 539, 23 noviembre, p. 2.

${ }^{75}$ La Paz de Murcia, XXVIII (1885), nº 8325, 16 septiembre, p. 1.

${ }^{76}$ Benavente, "Don Julián Calvo", p. 1.

${ }^{77}$ La Paz de Murcia, XI (1868), n 3286, 8 julio, pp. 1-2.
} 
La crítica anterior parece corroborar la opinión de Sobrino, que afirma que más que de un estilo propio en la obra de Calvo, habría que hablar de "la confluencia de elementos de diversos géneros -religioso, pianístico y lírico- propio de los compositores de finales del siglo XIX"78.

La obra de Julián Calvo comprende también un buen número de piezas de salón para piano solo, canto y piano y todo tipo de combinaciones instrumentales (por ejemplo, dos violines, amonio y piano o sexteto de cuerda y piano). Algunas de ellas fueron compuestas para determinadas sociedades de Murcia, como La Locomotora, para la sociedad El Liceo (1858-1859), el Himno para coro y orquesta de la Sociedad Filarmónica y el capricho Los cantos del Segura para La Ilustración ${ }^{79}$.

La pieza Nubes. Seguidillas para canto y piano de Julián Calvo es una pieza que reúne las características del género de salón (ver Apéndice Partituras). Nubes acusa gran influencia de la zarzuela y entronca con la música española de tradición dieciochesca. La parte vocal, denominada genéricamente "canto", podría ser interpretada por una soprano o por un tenor. La partitura, en ritmo ternario, no presenta dificultades ni virtuosismo. La armonía es sencilla, fundamentada en acordes tríadas y funciones tonales claras. La mano izquierda del piano desempeña el acompañamiento con una textura acordal y una figuración rítmica de dos semicorcheas y dos corcheas. El texto, de José Martínez Monroy, está formado por dos seguidillas compuestas, la primera de rima asonante y la segunda consonante, que comparan elementos de la naturaleza (cielo, nubes, rosa) con partes de la anatomía de una dama (ojos, pecho, seno). Su texto se presenta a continuación:

$$
\begin{gathered}
\text { Me gusta ver el cielo } \\
\text { lleno de nubes } \\
\text { de color de la rosa } \\
\text { blancas y azules. } \\
\text { Rosa es tu pecho } \\
\text { azules son tus ojos } \\
\text { blanco tu seno. } \\
\text { Y al no ver tus hechizos } \\
\text { quiero en mi anhelo } \\
\text { ver al menos las nubes } \\
\text { si miro al cielo. } \\
\text { ¡Oh! Suerte dura } \\
\text { me faltan, iay!, las nubes } \\
\text { de tu hermosura. }
\end{gathered}
$$

En el terreno de la música escénica, Julián Calvo compuso tres zarzuelas: Por correo interior, Una broma de estudiantes y Travesuras de Quevedo (las dos últimas de carácter infantil), analizadas en el Capítulo 3.

Algunas de las obras de Julián Calvo fueron publicadas por los editores más importantes del momento, como Martín, Zozaya, Antonio Romero, Manuel Giménez o

\footnotetext{
${ }^{78}$ Sobrino, “Calvo López, Julián”, pp. 942-944 analiza una Salve a voces y órgano obligado, Letanía a tres voces con acompañamiento de órgano, Flor fragante del Carmelo, Panis angelicus, op. 143 en Mi b para bajo y órgano y otras obras de Calvo de repertorio profano y de salón.

${ }^{79}$ Calvo fue nombrado socio honorario de la Sociedad Belluga por sus desinteresadas colaboraciones en ella: La Paz de Murcia, XXX (1887), nº 8105, 29 enero, p. 1.
} 
Saco del Valle (véase Tabla 9.2). Parte de estas publicaciones se conservan en la Biblioteca Nacional de España y en archivos de otras instituciones y particulares.

Tabla 9. 2. Obras publicadas de Julián Calvo.

Fuente: M. C. M., “Notas biográficas. D. Julián Calvo García”. Véase también Apéndice 9.1.

\begin{tabular}{|c|c|c|}
\hline Editor & Género & Título de obra (año de publicación) \\
\hline $\begin{array}{l}\text { Antonio } \\
\text { Romero }\end{array}$ & $\begin{array}{l}\text { Salón } \\
\text { Religioso } \\
\text { Religioso } \\
\text { Salón } \\
\text { Religioso } \\
\text { Sinfónica } \\
\text { Pedagógica } \\
\text { Religioso }\end{array}$ & $\begin{array}{l}\text { Seis pequeños versos sobre motivos del himno Pange } \\
\text { Lingua, para órgano (1871) } \\
\text { Ofertorio sobre motivos del himno Pange Lingua, para } \\
\text { órgano (1872) } \\
\text { Nubes. Seguidilla para canto y piano (1875) } \\
\text { Nocturno para piano en re menor (1875) } \\
\text { Tota pulcra est Maria, a dos y tres voces con } \\
\text { acompañamiento de órgano (1875) } \\
\text { Santa María a tres voces iguales con acompañamiento de } \\
\text { órgano o piano (1876) } \\
\text { Mazurka para piano (1883) } \\
\text { Mazurka para piano en do menor (1884) } \\
\text { Panis Angelicus. Motete para la voz de bajo, con } \\
\text { acompañamiento de órgano (1885) } \\
\text { Salve Regina a cuatro voces y órgano obligado (1885) } \\
\text { La Murciana. Marcha para banda militar (1886) } \\
\text { Facorros y facorras (1886) } \\
\text { Método de Pedalier para el órgano moderno (ca. 1888) } \\
\text { Flor Fragante del Carmelo. Plegaria a Nuestra Señora } \\
\text { del Carmen, para tres voces y órgano (s.a.) } \\
\text { Letanía a tres (s.a.) } \\
\text { Vals para canto y piano (s.a.) }\end{array}$ \\
\hline $\begin{array}{l}\text { Manel } \\
\text { Giménez }\end{array}$ & $\begin{array}{l}\text { Musicológico } \\
\text { Religioso } \\
\text { Religioso } \\
\text { Salón } \\
\text { Religioso } \\
\text { Sinfónico } \\
\text { Religioso }\end{array}$ & $\begin{array}{l}\text { Alegrías y tristezas de Murcia, colección de cantos } \\
\text { populares murcianos } \\
\text { Elevación y Ofertorio para órgano } \\
\text { Gozos al Corazón de Jesús } \\
\text { La mia marusiña. Gran obertura sobre los cantos } \\
\text { populares gallegos para piano (s.a.) } \\
\text { Marcial para órgano } \\
\text { Misa a solo o coro } \\
\text { Misa a tres voces } \\
\text { Motetet a cuatro voces y cuarteto } \\
\text { Padodoble para banda } \\
\text { Stabat Mater, a tres voces } \\
\text { Salve a tres voces }\end{array}$ \\
\hline $\begin{array}{l}\text { Martín } \\
\text { Zozaya }\end{array}$ & $\begin{array}{l}\text { Salón } \\
\text { Sinfónico }\end{array}$ & $\begin{array}{l}\text { Nocturno cuarto } \\
\text { Orfeo. Quinto Nocturno para piano (1876) } \\
\text { Marcha }(1876)\end{array}$ \\
\hline $\begin{array}{l}\text { Carlos Saco } \\
\text { del Valle }\end{array}$ & Pedagógico & $\begin{array}{l}\text { Gran método de solfeo que mereció la probación, } \\
\text { recomendación y elogios de una comisión de la Real } \\
\text { Escuela que lo examinó }\end{array}$ \\
\hline $\begin{array}{l}\text { Andrés Vidal } \\
\text { (hijo) }\end{array}$ & Salón & Gran Vals para canto y piano (¿1874-1875?) \\
\hline
\end{tabular}

Un hecho de gran relevancia en la vida profesional de Julián Calvo fue la construcción del nuevo órgano de la Catedral de Murcia en 1857. La noche del 3 de febrero de 1854, los dos órganos tardobarrocos de Fernando Molero en esa iglesia fueron 
arrasados por un fatal incendio. El Obispo de la Diócesis de Cartagena y Murcia, Mariano Barrio Fernández, aconsejado por Hilarión Eslava, encargó al constructor de origen alemán Joseph Merklin un nuevo órgano que fue entregado e inaugurado en 1857. Fue el primer gran órgano de estética romántica de España ${ }^{80}$. Calvo participó en los actos de inauguración de este magnífico instrumento, junto a otras personalidades del panorama nacional, entre ellas el propio Eslava, que acudieron a Murcia.

En 1870 Calvo escribió una Reseña del gran órgano de la Santa Iglesia Catedral de Cartagena sita en Murcia, fabricado por los señores Merklin, Schütze y compañía, que fue publicada en 1891 (véase Figura 9.8) ${ }^{81}$, en la que presenta los antecedentes que motivaron la construcción del gran órgano y describe la función inaugural y los detalles del instrumento proyectado por Merklin antes de la primera reforma importante del instrumento, emprendida por Aquilino Amézua en 1910. A diferencia de otros órganos de la Península Ibérica, el Merklin- Schütze de la Catedral de Murcia contaba con un teclado de pedales. Sin duda, este hecho y su propia experiencia llevaron a Julián Calvo a escribir el Tratado Práctico del Teclado de Pedales en el Órgano Moderno, publicado al final de la década de los ochenta ${ }^{82}$. Se trata de un método cuya finalidad principal es la de facilitar el domino técnico del pedalero. El Tratado Práctico del Teclado de Pedales de Julián Calvo fue valorado así por Antonio Ramírez:

[...] Hoy, fruto de tan largo estudio, [Julián Calvo] ha podido reunir en un trabajo, en mi concepto notabilísimo, junto a una erudita y completa historia del órgano, desde su invención hasta hoy, una serie de ejercicios y de lecciones progresivas para aprender el órgano de pedales que así se llama. De desear sería que este trabajo del señor Calvo sirviera para la propagación del estudio del órgano, pero creo que es tan desproporcionada la relación que existe entre lo que cuesta aprenderlo y el interés que reporta que dudo que pueda decidir a muchos a su estudio $[\ldots]^{83}$.

Julián Calvo también escribió un Gran método de solfeo, publicado por Carlos Saco del Valle, que "mereció la aprobación, recomendación y elogios de una comisión de la Real Escuela que lo examinó" $" 84$.

${ }^{80}$ Véase la reseña de Fetis, traducida al castellano "Grande órgano destinado a la Catedral de Murcia", Gaceta Musical de Madrid, II (1856), n 29, 20 julio, pp. 221-223 y el anuncio de su construcción en $L a$ Esperanza, X (1854), no 3016, 21 agosto, p. 2. Máximo, El órgano, estudió exhaustivamente el proceso de construcción del órgano Merklin de la Catedral de Murcia; Artigas, "El presupuesto", pp. 13-28, subraya la importancia de este órgano en el contexto de la organería española del siglo XIX y examina la figura de Julián Calvo. Sobre éste y otros órganos levantinos, véase: Melendreras, "El órgano", pp.285-297; Melendreras, “Órganos”, pp. 423-440 y Candel. "Contrato para la construcción”, pp. 251-268.

${ }^{81}$ Sobre esta publicación, véase La Paz de Murcia, XXIV (1881), nº 7082, 8 julio, p. 1.

82 Julián Calvo, Tratado Práctico del Teclado de Pedales en el Órgano Moderno (Madrid: Romero, ca. 1888). El Tratado está dedicado al Obispo de la Diócesis de Cartagena, Tomás Brayan y Livermore y consta de seis secciones, cada una de las cuales ofrece diversos ejercicios y lecciones para ejercitar los pies sobre el teclado. El Tratado concluye con "una pieza para concierto escrita para el gran órgano de la Santa Iglesia Catedral de Murcia con objeto de dar a conocer algunos de sus mejores registros y combinaciones": Calvo, Tratado, p. II El Tratado obtuvo la medalla de bronce de la Exposición Universal de Barcelona. Véase más información en Elizondo, La organería, pp. 71-72 y Artigas, “El presupuesto”, pp. 17-20. pp. 1-2:2.

${ }^{83}$ Antonio Ramírez Pagán, "Revista Musical”, El Diario de Murcia, V (1883), no 1373, 12 septiembre,

${ }^{84}$ Según Loras, Estudio de los métodos, p. 28 este método fue citado por Dionisio Aguado, aunque en la actualidad es ilocalizable. 


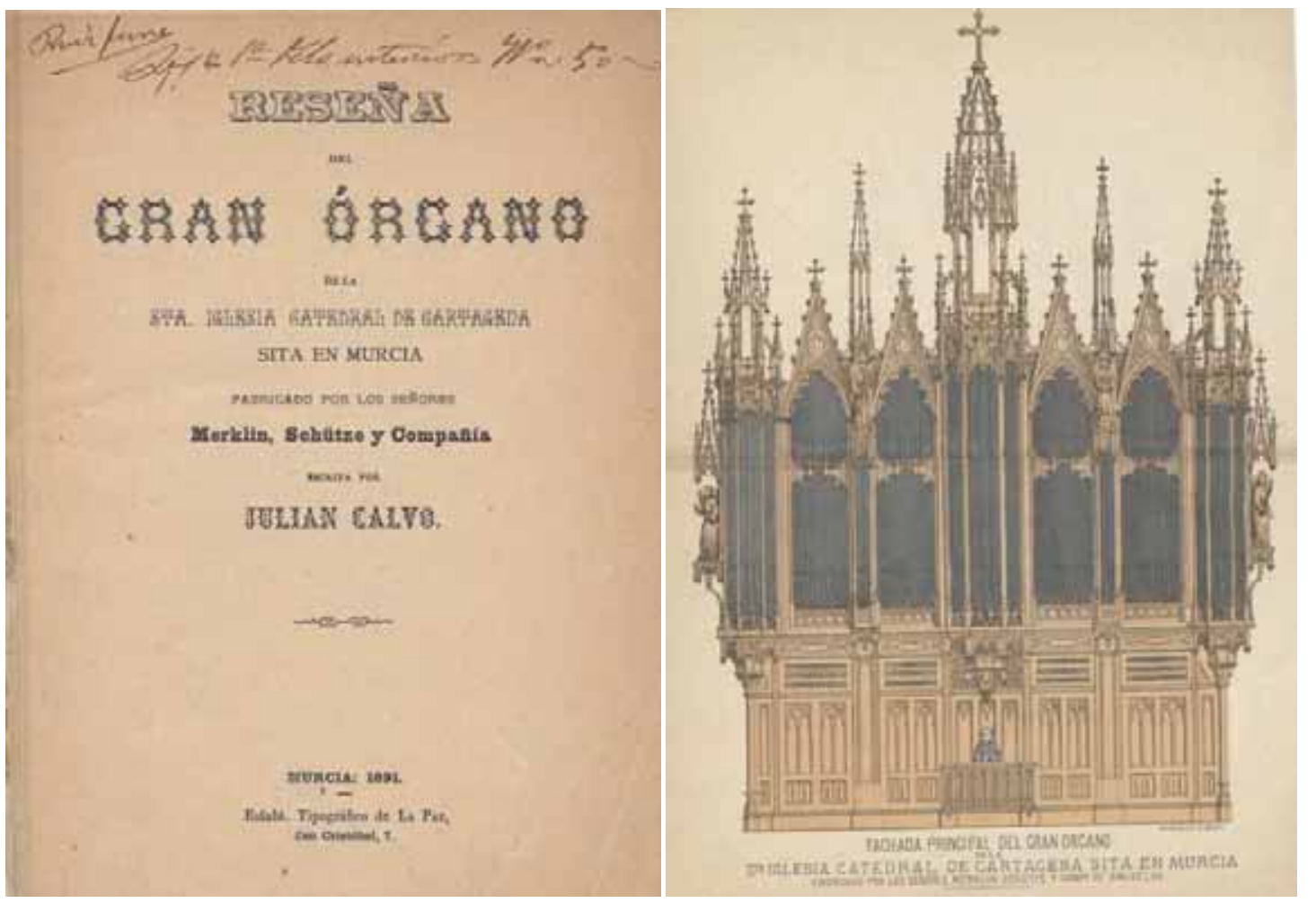

Figura 9. 8. Portada e ilustración del órgano de la Catedral de Murcia de la Reseña del gran órgano de la Reseña del gran órgano de la Santa Iglesia Catedral de Cartagena sita en Murcia, fabricado por los señores Merklin, Schütze y compañía de Julián Calvo.

(Murcia: Establecimiento Tipográfico de La Paz, 1891). E:MUbr.

Accesible en: http://bibliotecadigital.carm.es (acceso el 14-07-2011).

Los intereses de Julián Calvo también incluyeron la investigación musical y la crítica. En 1857 emprendió una labor de recopilación del folclore murciano que le llevó a publicar en 1877 Alegrías y tristezas de Murcia. Colección de cantos populares que canta y baila el pueblo de Murcia en su huerta y campo $^{85}$, la primera colección conocida de cantos y bailes de la Huerta de Murcia. De inspiración romántica y destinada al consumo burgués, casi todas las piezas de Alegrías y tristezas de Murcia están arregladas para canto y piano (salvo la nana inicial, las salves y los cantos de labranza y trilla) y siguen la misma estructura: título, música notada y aclaraciones o explicaciones sobre la naturaleza de la pieza y manera de interpretarse ${ }^{86}$. Según Matía, José Inzenga empleó tres transcripciones de Julián Calvo (Canto que entonan los labradores de la huerta cuando cogen la hoja de las moreras, Canto de la labranza y Parrandas, llamadas de uno) que incluyó en el Cuaderno de Murcia. Cantos y bailes populares de España $(1888)^{87}$.

${ }^{85}$ Julián Calvo García, Alegrías y tristezas de Murcia. Colección de cantos populares que canta y baila el pueblo de Murcia en su huerta y campo (Madrid: Zozaya, 1877).

${ }^{86}$ Véanse más detalles en Encabo, "Las primeras recolecciones", pp. 103-107, quien observa en Alegrías y tristezas de Julián Calvo el anhelo de erudición y cierto rigor cientificista, perceptible en las ricas aclaraciones (estilo, instrumentos originales y datación de la pieza, entre otros) que Calvo incorporó a sus transcripciones musicales con la finalidad de reflejar la mayor cantidad de información posible. Según Encabo, Alegrías y tristezas de Calvo fijó un canon que guió a otros estudiosos posteriores en la recolección de música popular murciana.

87 José Inzenga, Cantos y bailes populares de España (Madrid: Antonio Romero, 1888). Sobre las colaboraciones de Julián Calvo y otros murcianos como Antonio López Almagro y Fernández Caballero en la labor de recopilación de José Inzenga del folclore español, véase Matía, José Inzenga, pp. 287-320. 
En 1859 Julián Calvo dirigió una publicación periódica musical titulada $E l$ Filarmónico. Álbum dedicado a la juventud de la sociedad murciana que gusta de la música y del baile. Cada entrega incluía varias piezas musicales de pequeño formato (polcas, valses, rigodones, romanzas, piezas a cuatro manos, números para canto y piano) compuestas por él mismo con letras de poetas como Francisco Villegas, Ramón Guerrero, Juan Cayuela y José Castell, entre otros ${ }^{88}$.

Julián Calvo colaboró frecuentemente con la prensa. Fue autor de, al menos, una veintena de artículos periodísticos en los que opinó sobre representaciones teatrales (especialmente de ópera), y conciertos (ver Capítulo 4). Sus escritos en la prensa fueron muy valorados en la época, como puso de manifiesto el escritor y también crítico musical Andrés Blanco García en 1891, que se lamentaba además que Calvo no se dedicara por completo a la crítica musical:

[...] A la vez el señor Calvo es conocido ventajosamente en la crítica del arte, y la prensa se ha honrado en diferentes ocasiones con sus artículos y concienzudas revistas, que en determinadas circunstancias han hecho enmudecer las plumas de esos critiquillos que hay ahora en todas partes y que tiznan las columnas de los periódicos, ensartando dislates a diestro y siniestro por el afán que devora a todo el mundo de hablar de aquello que no entiende. Lástima grande que nuestro biografiado no se dedicara por completo a un ramo que, participando igualmente de música y literatura, enalteciera aún más su nombre y viniese a llenar un vació que se deja sentir notablemente en nuestra provincia $[\ldots]^{89}$.

La biblioteca musical de Julián Calvo fue abundante y selecta, e incluía música antigua. En el Catálogo de la Exposición de Bellas Artes y retrospectiva de las Artes Suntuarias de Murcia, celebrada en la capital murciana en septiembre de 1868, Julián Calvo exhibió cinco manuscritos de su propiedad ( ${ }^{\text {os }} 1946-1950$ del catálogo):

1946 Un cuaderno musical conteniendo un rosario a 6 con violines y oboes. (Condomina 1737 autógrafo del autor), al final tiene un aria anticuada a duo.

1947 Ídem. Ídem, de piezas para órgano por don José Elías, profesor de órgano del Real Monasterio de Descalzas Reales de Madrid y que gozó de gran reputación a final del siglo XVII (manuscrito).

1948 Ídem. Ídem, Salmodia, por Francisco Juan Cruceta, (manuscrito), 1749

1949 Ídem. Ídem, encuadernado, Salmodia orgánica por el Padre Francisco Pedro Carrera Lanchares, impreso en 1792. Este célebre compositor fue organista del Real Convento y el señor Eslava en el Museo Orgánico Español celebra y considera de gran mérito esta obra.

1950 Ídem. Ídem, Fandango nuevo para clave, compuesta de setenta variaciones con mucho gusto y manejo ${ }^{90}$.

${ }^{88}$ Según Alemán, Diccionario, p. 71 fue una publicación mensual de la que aparecieron siete entregas. La portada de El Filarmónico fue diseñada por Antonio Soler y la publicación se editaba en Trapería, 73 en la Tipografía de los Hermanos Riera.

${ }^{89}$ Blanco García, "Julián Calvo”, p. 1.

90 Catálogo de la Exposición de Bellas Artes y retrospectiva de las Artes Suntuarias de Murcia (Murcia: Imprenta de Bernabeu, 1868), p. 57. La Exposición se celebró para recaudar fondos para levantar un monumento a los artistas murcianos célebres. En septiembre de 1882, Julián Calvo ofreció subvencionar parte de los gastos para organizar una Exposición Regional: La Paz de Murcia, XXV (1882), n ${ }^{\text {os }} 7390,21$ julio, p. 1 y 7395, 28 julio, p. 1. En uno de los actos de la misma, Calvo ofreció un concierto de piano y armonio junto a otros músicos: La Paz de Murcia, XXV (1882), nº 7416, 23 agosto, p. 1. Según M. C. M., 


\subsection{El maestro de capilla Mariano García López (1836-1906) ${ }^{91}$}

Mariano García López (Murcia, 14/12/1836-Murcia, 3/01/1906) nació en Murcia el 14 de diciembre de 1832 en la Plaza de Santo Domingo, número 2 (después número 76 de la calle del Príncipe Alfonso). Era hijo de Antonio García Guirao, fabricante de tejidos de lana y Juana López Moliner. En 1843 ingresó como infantillo de coro en la Capilla de Música de la Catedral de Murcia, donde estudió con Agustín Monreal, que se ocupó de su formación incluso después de su traslado a la Universidad de Sevilla, primero, y a Madrid, después ${ }^{92}$. Mariano García estudió canto llano con Celestino Mondéjar y recibió lecciones de canto del algezareño Mariano Meseguer Illán (Algezares, Murcia, 1791Murcia, ca. 1860), ex contralto de la Capilla Real de Madrid. En 1859, Mariano García obtuvo por oposición el magisterio de Capilla de la Catedral de Murcia, cargo que mantuvo hasta su muerte el 3 de enero de $1906^{93}$. La Figura 9.9 muestra la Catedral de Murcia, principal centro en el que desarrolló la labor profesional de Mariano García.

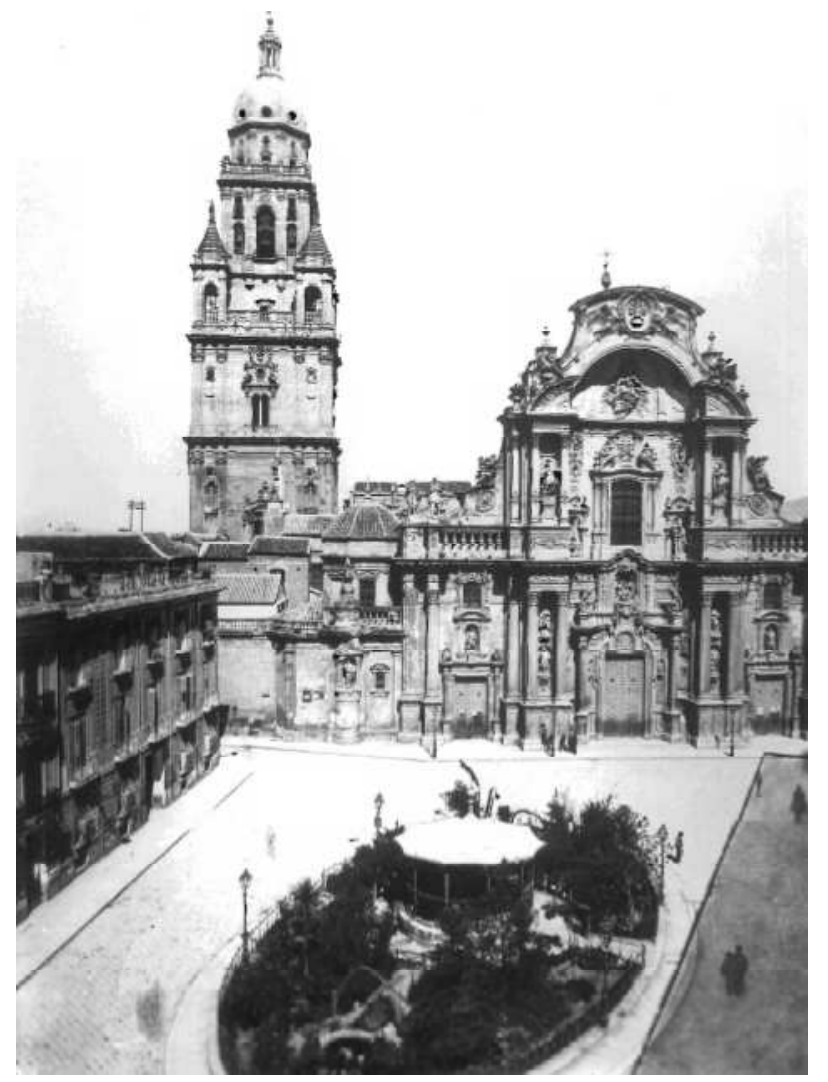

Figura 9. 9. Plaza de Belluga y fachada de la Catedral de Murcia. Principios del siglo XX. $E: M U m$. Accesible en: http://www.archivodemurcia.es (acceso el 26-07-2011).

"Notas biográficas. D. Julián Calvo García", programa de mano del Concierto-Homenaje a Julián Calvo García celebrado el 28-02-1969 en el Conservatorio de Murcia (Murcia: Imprenta San Miguel, 1969) la biblioteca de Julián Calvo fue vendida tras su muerte por quince mil pesetas. Desconozco quién la compró.

${ }^{91}$ No debe confundirse al murciano Mariano García López con el compositor navarro Mariano García Zalba (1809-1869). Sobre este último, véase Sagaseta, "Mariano García”, pp. 231-224 y Sagaseta, "García Zalba”, pp. 502-503.

92 Enrique Martí, “Notas biográficas y bibliográficas”, El Liberal, X (1906), nº 1251, 2 enero, p. 1.

${ }^{93}$ Véanse El Liberal, V (1906), $\mathrm{n}^{\text {os }} 1250,4$ enero, p. 2 y 1251, 5 enero, p. 1. 
Mariano García enseñó música a numerosos jóvenes, burgueses y aficionados de Murcia $^{94}$. Entre sus discípulos estuvieron el director de bandas de música Vicente Espada $^{95}$, Acisclo Díaz, Adolfo Gascón, Fernando Verdú (con el que compartió academia de música desde 1894) y su hijo José Verdú. Mariano García fue uno de los promotores del proyecto para crear un Conservatorio en Murcia. Un cronista resumía así su personalidad: "Amigo entrañable de los músicos murcianos, los ha alentado con sus consejos paternales, ha proporcionado a algunos buenas colocaciones, ha enseñado a otros gratuitamente y ha sido durante largos años el maestro reverenciado y admirable por su sabiduría y su modestia"96. De la documentación consultada se desprende que Mariano García fue muy estimado socialmente y gozó, frente a sus coetáneos, de un estatus social de mayor rango, probablemente por su vinculación con el Cabildo catedralicio ${ }^{97}$.

Mariano García López fue muy admirado también como compositor y, al parecer, siguió fielmente el magisterio de Hilarión Eslava:

[...] Se admiran en las obras de este notable maestro exuberancia de frases melódicas de exquisito corte, dominio completo de la instrumentación y profundos conocimientos de armonía. Merece citarse una circunstancia especialísima en sus empresas artísticas: conocía tan a fondo los secretos del arte de la composición que aún en sus trabajos más notables y de mayor empeño, rara vez consultaba en el piano lo que escribía. Aunque no esclavizaba por completo su fantasía a los moldes clásicos y a la manera escolástica, fue un admirador entusiasta del célebre maestro Eslava, a quien estudió concienzudamente, por lo que sus obras son correctísimas $[\ldots]^{98}$.

Para Enrique Martí, Mariano García tenía un estilo particular que Martí identificó con un "característico movimiento modulante" 99 y según García Seco, fue un compositor de "inspiración brillante" y "de tendencia italianizante"100. $\left.9.3^{101}\right)$ :

José Luis López García localizó las siguientes obras de García López (ver Tabla

${ }^{94}$ En El Diario de Murcia, III (1881), no 651, 21 abril, p. 2 se mencionan entre sus pupilos "a las señoritas de Fernandez Rotenflué, Mazon, Meseguer, Malvastre, Tomas y Serrano. Las niñas Conchita Rodriguez, Angeles Plaza, Blanca Marin Baldo, Guillerma y Remedios Rael, Isabel Navarro, Rosario Valdes, Maria Meseguer, Angustias Cañadas, Teresa Gomez, Angeles Lopez y Elisa Perea. Los jóvenes José Maria Pastor, Antonio Miñano, Antonio Lisson, José Palazon, Luis Gueran y Vicente Espada, con los niños Enrique Visedo, Vicente Pastor, Miguel Quetglas y Pepito Verdú”.

${ }^{95}$ La Paz de Murcia, XXVI (1883), nº 7668, 5 julio, p. 1.

${ }^{96}$ Enrique Martí, “Notas biográficas y bibliográficas”, El Liberal, X (1906), n 1251, 2 enero, p. 1.

${ }^{97}$ Ver, Alén, "Música y músicos".

${ }^{98}$ Martí, "Notas biográficas", p. 1.

${ }^{99}$ Martí, Ibid., p. 1.

${ }^{100}$ García Seco, "Maestro de capilla", p. 23.

${ }^{101}$ López García, Fondos musicales, [pp. 37-40]. 
Tabla 9. 3. Obras de Mariano García en el Archivo Musical de la Catedral de Murcia. Fuente: López García, Fondos musicales, [pp. 37-40].

\begin{tabular}{|c|c|c|}
\hline Obras & Título (fecha composición) & Plantilla \\
\hline \multirow{24}{*}{$\begin{array}{l}\text { Voces } \\
\text { orquesta }\end{array}$} & Tres Lamentaciones para el Jueves (1904) & Tres voces y orquesta \\
\hline & Cuatro Letanías & Tres voces y orquesta \\
\hline & Credidi & Cuatro voces y orquesta \\
\hline & Credidi & Coro y orquesta \\
\hline & Salmo prima (1860) & Coro y orquesta \\
\hline & Miserere $(1900)$ & Tres voces y orquesta \\
\hline & Miserere de Viernes Santo & Cuatro voces y orquesta \\
\hline & Te Deum & Tres voces y orquesta \\
\hline & Te Deum (1902) & Coro a tres voces y orquesta \\
\hline & Salve & Tres voces y orquesta \\
\hline & $\begin{array}{l}\text { Responso Ne recorderis. Escrito para la } \\
\text { conmemoración del III Centenario de } \\
\text { Diego Saavedra Fajardo (6-05-1884) }\end{array}$ & Tres voces y orquesta \\
\hline & Responso Libera me Domine. & Coro y orquesta \\
\hline & Salve & A solo de tiples y orquesta \\
\hline & Feria V in coena Domini (1854) & Tres voces y orquesta \\
\hline & Acceptit Jesus. Motete (24-9-1885) & Cuatro voces y orquesta \\
\hline & Ego Sum Panis Vitae a & Tres voces y orquesta \\
\hline & $\begin{array}{l}\text { Lamentaciones del Miércoles Santo } \\
\text { (1854) }\end{array}$ & Tres voces y orquesta \\
\hline & Lamentaciones (1881) & Tres voces y orquesta \\
\hline & Laudis Te ma specialis & Solo de contralto y orquesta \\
\hline & Adoro Te & A solo de tiple y orquesta \\
\hline & 17 Misas (1897) & A dos y tres voces con órgano \\
\hline & Misa de aguinaldo (1901) & Tres voces y orquesta \\
\hline & Dos misas & Tres voces y orquesta \\
\hline & Misa & Tres voces, orquesta y órgano \\
\hline $\begin{array}{l}\text { Voces } \quad y \\
\text { órgano }\end{array}$ & Visperas funerales (1890) & Tres voces y órgano \\
\hline \multirow[t]{2}{*}{ Voces solas } & Motete para la Bendición de Candelas & Cuatro voces \\
\hline & Homo Quidam a tres voces & Tres voces \\
\hline \multirow[t]{4}{*}{ Otras obras } & Novena a los Dolores & No consta \\
\hline & $\begin{array}{l}\text { Preludio para la toma de posesión del } \\
\text { señor Obispo y Capitulares }\end{array}$ & No consta \\
\hline & Meditaciones & Violines, oboes y contrabajo \\
\hline & Pequeña sinfonía a la señora de Marín & No consta \\
\hline
\end{tabular}

Además de las obras localizadas hasta ahora, hay testimonios de que la producción de Mariano García fue más amplia. Según Martí, Mariano García compuso más de treinta misas, entre ellas la Misa del Maestro, la Misa para sexteto, la Misa para la inauguración de la Iglesia de San Bartolomé y la Misa a Solo y coro de bajos con orquesta y otras para órgano, cuatro lamentaciones, cinco salves, cinco juegos de Novenas de Dolores, varias antífonas de difuntos, sinfonías, ofertorios y motetes ${ }^{102}$.

${ }^{102}$ Martí, "Notas biográficas", p. 1 agrupó las obras de Mariano García en dos grandes apartados: "De orquesta" y "De órgano". Entre las misas para órgano destacó tres compuestas sobre tres himnos del Corpus. Otras misas con acompañamiento de órgano fueron la de la Virgen, la de San Pascual y la de la Arrixaca. Martí también mencionó siete juegos completos de Vísperas, dos Sequentia del Corpus y "un sinnúmero de composiciones de menor importancia, entre las que destaca una Salve a solo de bajo y otra Salve a solo de tenor". 


\subsection{Acisclo Díaz Rocher (1837-1887)}

La biografía de Acisclo Díaz (Alhama de Murcia, 20/06/1837- Murcia, 5/12/1887), cuyo retrato aparece en la Figura 9.10, presenta un perfil muy distinto al de Julián Calvo. Su vida estuvo ligada fundamentalmente a la actividad de las bandas de música y a la docencia. Su prestigio dentro y fuera de la ciudad fue notorio, como muestra la abundante información que sobre él publicó la prensa de la época. Acisclo Díaz formó y educó de forma altruista a cientos de jóvenes huérfanos que vieron en la música una posibilidad de ganarse un sustento.

Los inicios musicales de Acisclo Díaz estuvieron ligados a la banda de música de su pueblo natal, Alhama de Murcia. Trasladado a Murcia, estudió con José Gil varios instrumentos (no constan cuáles) y piano con Mariano García, maestro de capilla de la Catedral $^{103}$. Formó parte de las bandas de Julián Gil y Mariano Córdoba, y de la orquesta del Teatro Romea que entonces dirigía Mariano Esbrí ${ }^{104}$. Tras una estancia en Madrid, donde llegó a ser Músico Mayor de la Banda de Música de la Guardia Real, Acisclo Díaz volvió a Murcia antes de $1879^{105}$.

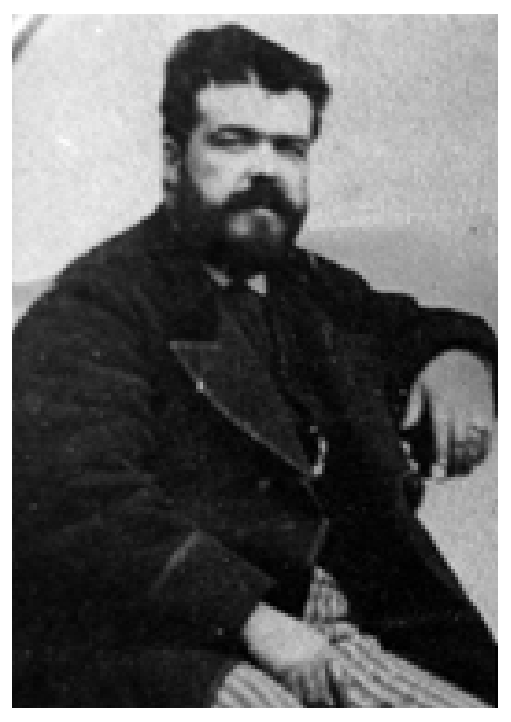

Figura 9. 10. Retrato de Acisclo Díaz.

Accesible en: http://cofradiamisericordia.net/inicio.htm (acceso el 15-07-2011)

La actividad de Acisclo Díaz en varias bandas de música se enmarca en el contexto de las numerosas intervenciones que estas formaciones tenían en la Murcia de la

103 [Anónimo], "Murciano ilustre. Don Acisclo Díaz Rocher". El Diario de Murcia, XVIII (1896), nº 6949, 22 abril, p. 2. Apuntes tomados de la biografía que su hijo Francisco Díaz publicó en La Ilustración Musical.

${ }^{104}$ En la banda de música que dirigió Julián Gil coincidieron Julián Calvo, Fernández Caballero y Acisclo Díaz. En [Anónimo], "Murciano ilustre", p. 2 se menciona que Díaz también formó parte de las bandas de música de Mariano Esbrí y Mariano Córdoba.

${ }^{105}$ Sánchez Pérez, "Don Acisclo Díaz”, p. 31. 
segunda mitad del siglo XIX. La ciudad contaba al menos con seis bandas (ver Tabla $9.4)^{106}$ :

Tabla 9. 4. Bandas de música murcianas durante la segunda mitad del siglo XIX

Fuente: Clares, "Murcia y su música".

\begin{tabular}{|l|l|}
\hline Nombre & Director/es (años de dirección) \\
\hline Banda Municipal & $\begin{array}{l}\text { Ángel Mirete }(1858-+1888) \\
\text { José Ángel Mirete }(1888-?)\end{array}$ \\
\hline Banda de Mariano Esbrí & Mariano Esbrí $(1849-+1890)$ \\
\hline Banda de Emilio Raya & Emilio Raya $(1869-+1882)$ \\
& Antonio Raya $(1882-1883)$ \\
& Lorenzo Llinares $(1883-1885)$ \\
\hline Banda de Antonio Raya & Antonio Raya (1883-1890) \\
\hline Banda de Vicente Espada & Vicente Espada (1887-?) \\
\hline Banda de la Casa de Misericordia & Acisclo Díaz (1879- +1887) \\
& Francisco Fresneda (1887-1891) \\
\hline
\end{tabular}

Acisclo Díaz fue el fundador y primer director de la Banda de la Casa de Misericordia (también llamada "del Hospicio", "de la Diputación" o "Provincial"). El músico había entrado en contacto con la Casa de la Misericordia a través de su hermano, capellán de esta institución. La Real Casa de Misericordia (también llamada Casa del Niño y Hospicio, entre otras denominaciones) acogía, socorría y formaba a niños y jóvenes desprotegidos por la sociedad, fueran o no huérfanos (véase su localización en la Figura 9.11) ${ }^{107}$.

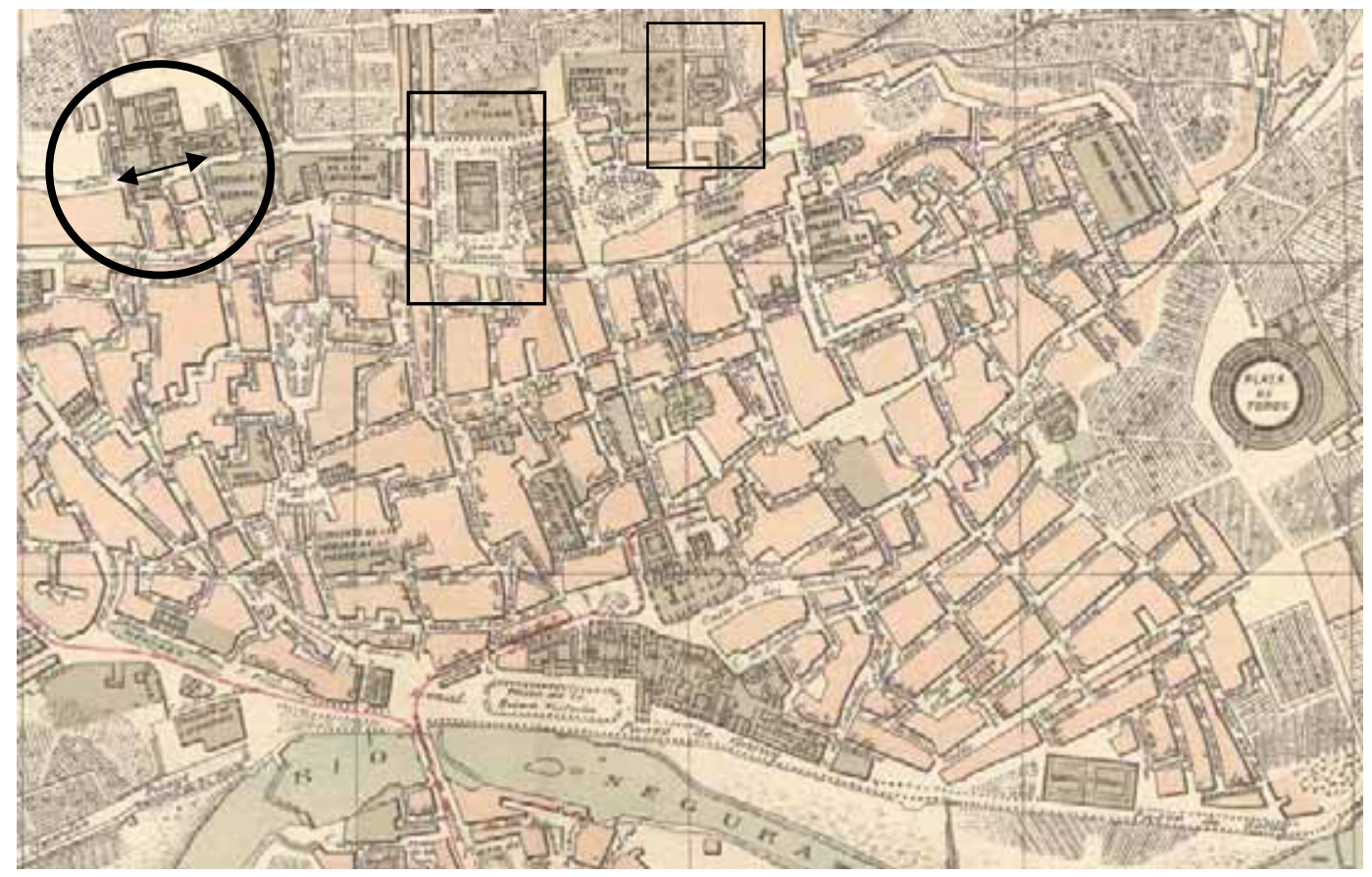

Figura 9. 11. Localización de la Casa de la Misericordia de Murcia (círculo) y calle Acisclo Díaz (flechas). A la derecha, el Teatro Romea y el Teatro Circo Villar . Pedro García Faria, Plano de Murcia (Barcelona: Alberto Martín, s.a.). E:Mpb. Accesible en: http://bibliotecadigital.carm.es (acceso el 16-07-2011).

${ }^{106}$ Véanse más detalles en: Clares, "Murcia y su música”, pp. 124-133.

${ }^{107}$ Véase el interesante artículo de Enseñat y Montojo, “Orden público”, pp. 327-346 en el que, entre otras cosas, se esclarecen las competencias en materia de beneficencia en Murcia durante el siglo XIX. 
La Banda de Música de la Casa de Misericordia se creó en enero de 1879, mediante escritura pública firmada entre la Diputación Provincial de Murcia y el músico Acisclo Díaz Rocher, ante el notario Juan de la Cierva ${ }^{108}$. La formación progresó rápidamente y en septiembre de 1879 hizo su primera actuación pública ${ }^{109}$. La banda perfeccionó y amplió su repertorio, y la prensa elogió constantemente su "acierto y precisión", así como la labor pedagógica del director. El 15 de junio de 1884 se creó la Sociedad Belluga para proteger y financiar la banda (véase Capítulo 6). Se subvencionaron sus actuaciones al aire libre y la organización de eventos, como el "Certamen Belluga" celebrado en noviembre de $1884^{110}$.

Las actuaciones de la Banda de la Misericordia fueron realmente numerosas y traspasaron, incluso, las fronteras de Murcia ${ }^{111}$. Una de las más significativas tuvo lugar en Madrid, en el certamen organizado en junio de 1887 por la sociedad madrileña $E l$ Gran Pensamiento, celebrado en los Jardines del Buen Retiro. En ese momento, la banda contaba con setenta y seis niños de edades comprendidas entre los cinco y los dieciocho años $^{112}$. En el evento competían diversas formaciones instrumentales y vocales como orquestas, bandas (civiles y militares) y orfeones. La Banda de la Casa de Misericordia de Murcia obtuvo el primer premio en la categoría de bandas civiles, que consistió en 2000 pesetas, tras haber interpretado una Fantasía potpurri de zarzuelas modernas y la Gran Marcha de las Antorchas ${ }^{113}$. Además de su dedicación a la banda de música de la Misericordia, Acisclo Díaz mantuvo otras ocupaciones. Desde 1872 tuvo una comisión para la venta de pianos Boisselot ${ }^{114}$. En 1883 se hizo cargo de la dirección de la orquesta del Teatro Romea hasta la oposición pública de 1884 que proveyó a la agrupación de un director titular. Al menos desde 1885, Acisclo Díaz regentó una academia de música (ver Capítulo 6) y fue socio corresponsal en Murcia de la Asociación de Escritores y Artistas, fundada en Madrid en $1871^{115}$. En 1884, Acisclo Díaz recibió la Cruz de Isabel la Católica en 1884 como premio a su incansable labor pedagógica ${ }^{116}$.

108 Acisclo Díaz había intentado ya antes (en mayo de 1878) crear la banda, según Sánchez Pérez, “Don Acisclo Díaz", p. 31. La prensa se hizo eco de la creación de la banda en junio de 1879: El Semanario Murciano, II (1879), $\mathrm{n}^{\circ}$ 68, 1 junio, p. 8 antes de 1879. El redactor aplaudió la pertinencia de crear esta agrupación "pero sobre todas las conveniencias está la de que aprendan tan bello arte los asilados y en el que alguno puede distinguirse y descubrir raras facultades". Otros elogios por la iniciativa de Díaz Rocher se publicaron, por ejemplo, en El Semanario Murciano, IV (1881), ${ }^{\text {os }}{ }^{132,16}$ enero, p. 6; La Paz de Murcia, XXIV (1881), $\mathrm{n}^{\text {os }} 6987,26$ febrero, p. 1 y 7208, 5 diciembre, p. 1.

${ }^{109}$ El Semanario Murciano, II (1879), nº 82, 7 septiembre, p. 8.

${ }^{110}$ Véase Reglamento de la Sociedad Belluga.

${ }^{111}$ Una de sus primeras actuaciones fue en el Casino de Murcia, durante el mes de diciembre de 1879: El Noticiero Murciano, VIII (1879), n ${ }^{\circ}$ 1852, 2 diciembre, p. 3. Fuera de Murcia, el primer concierto que he podido documentar tuvo lugar en Orihuela en noviembre de 1881, en la tradicional fiesta que los vecinos de Roig organizaban anualmente en honor a Nuestra Señora de Montserrat: La Paz de Murcia, XXIV (1881), $\mathrm{n}^{\mathrm{o}} 7181,3$ noviembre, p. 1. Diversos pueblos de Valencia y Alicante fueron puntos frecuentes en las salidas interprovinciales de la Banda del Hospicio.

${ }^{112}$ La Correspondencia de España, XXXVIII (1887), nº 10678, 17 junio, p. 3.

${ }^{113}$ Véanse más detalles en: El Día, (1887), n 2728, 7 diciembre, p. 2; La Correspondencia de España, XXXVIII (1887), n 10678, 7 junio, p. 3; Madrid Cómico, VII (1887), n 226, 18 junio, p. 2; La República, IV (1887), no 1052, 12 de junio, p. 3 y La España, II (1887), n 26, 14 junio, p. 2.

${ }^{114}$ El Semanario Murciano, I (1878), nº 28, 25 agosto, p. 2.

115 [Anónimo], "Murciano ilustre", p. 2.

${ }^{116}$ [Anónimo], "Murciano ilustre”, p. 2. Cutillas, "Díaz Rocher", p. 45 afirma que fue Caballero de la Real Orden de Isabel la Católica en 1886. 
Acisclo Díaz falleció el 5 de diciembre de 1887 en la calle Acequia $\mathrm{n}^{\circ} 16$ de Murcia, a la que se le dio el nombre del director, que mantiene hasta hoy ${ }^{17}$. A su muerte, le sucedió en la dirección de la Banda de la Misericordia su hijo Francisco Díaz Romero ${ }^{118}$.

\subsection{Músicos murcianos afincados en Madrid}

Desde mediados de la década de los cuarenta, el Real Conservatorio María Cristina de Madrid reunió a varios músicos murcianos, desplazados allí para estudiar en el centro. Ese fue el caso de Fernández Caballero (que llegó en 1845), Gaspar Espinosa de los Monteros (en 1852), Luis Mondéjar Brocal (en 1854) y Mariano Padilla (en 1855). El compositor murciano Antonio López Almagro también se marchó a la capital española en 1875 aunque por motivos diferentes. Todos ellos, salvo el caso de Padilla, fijaron su residencia en Madrid.

\subsubsection{Gaspar Espinosa de los Monteros (1836-1898)}

Gaspar Espinosa de los Monteros Jiménez (Murcia, 1836-Madrid, 11/06/1898) era hijo de notario y comenzó la carrera notarial, aunque la abandonó para dedicarse a la música $^{119}$. Su iniciación musical corrió a cargo de José Gil y el organista de la Catedral de Murcia, Agustín Giménez. Espinosa fue pianista y violinista y llegó a formar parte como flautista de la orquesta del Teatro del Toro, probablemente la misma que dirigía Julián Gil en la década de $1840^{120}$. En 1854 fue nombrado músico mayor de la Banda de Artillería, dirigida entonces por Mariano Córdoba, y dos años más tarde se trasladó a Madrid para estudiar armonía con Hilarión Eslava en el Conservatorio de la capital.

Concluidos sus estudios, Espinosa marchó a Cartagena, donde fue nombrado director de orquesta y maestro de capilla de la Antigua Catedral de Santa María. Espinosa fundó y dirigió en esa población la Sociedad de Conciertos El Orfeo ${ }^{121}$. Desconozco cuántos años permaneció en Cartagena. En los primeros años de la década de los setenta debió de volver a Madrid, donde fue director de la Banda y Escuela de Música del Hospicio desde ca.1872, y donde en 1875 era también director de la orquesta y coro de las Escuelas Pías de San Fernando de Madrid ${ }^{122}$. La plaza de director de la Banda del Hospicio la obtuvo por oposición y en ese cargo estuvo durante veintiséis años:

${ }^{117} \mathrm{Su}$ muerte fue anunciada, incluso, en la prensa nacional: La Correspondencia de España, XXXVIII (1887), $\mathrm{n}^{\mathrm{o}} 10852,8$ diciembre, p. 1.

${ }^{118}$ Algunos datos sobre la trayectoria de Francisco Díaz Romero aparecieron en La Verdad, XXVI (1929), no 10107, 31 octubre, p. 2.

${ }^{119}$ Sobrino, "Espinosa de los Monteros”, pp. 783-784. García Seco, “Espinosa de los Monteros”, pp. 158-159; García Segura, Músicos, pp. 162-163.

120 "Un aficionado", “Apuntes para historia de la música (X)”, El Semanario Murciano, I (1878), nº 44, 15 diciembre, p. 5.

${ }^{121}$ García Segura, Músicos, p. 162.

${ }^{122}$ Diario Oficial de Avisos de Madrid, CXVII (1875), n 150, 30 mayo, p. 4. Deduzco la fecha inicial al frente de la Banda del Hospicio del texto citado en nota siguiente. 
[...] Después de brillantísimas campañas y de recorrer triunfalmente toda España ocupado en la creación y dirección de orquestas, bandas y orfeones, obtuvo por oposición rigurosa el puesto de director de la banda y escuela de música del Hospicio de esta Corte, puesto que desempeñó durante veintiséis años $[\ldots]^{123}$.

En la Escuela del Hospicio de Madrid, Espinosa enseñó solfeo, armonía, composición y práctica instrumental y formó a numerosos músicos que después se integraban en bandas, orquestas y sociedades de conciertos de muchas ciudades españolas. Según Sobrino, Espinosa también fue violinista en la Unión Artístico-Musical $\mathrm{y}$ en orquestas de varios teatros madrileños y formó parte de varias sociedades españolas y extranjeras (por ejemplo, la Sociedad de Autores y Compositores de París), en algunas de las cuales ocupó cargos directivos (por ejemplo, fue vocal de la Sociedad de Compositores Españoles y Editores Propietarios de Obras Musicales en 1893) ${ }^{124}$.

Gaspar Espinosa de los Monteros fue un prolífico compositor al que editaron obras Romero y Andía, Carrafa y Sanz Hermanos y Zozaya, entre otros. Al menos veinticinco de sus obras eran de grandes dimensiones y para concierto ${ }^{125}$.

En el campo de la música escénica, Espinosa compuso la ópera en un acto y dos cuadros La muerte de Garcilaso (con libreto del murciano Antonio Arnao Espinosa de los Monteros), que fue estrenada en el Teatro de la Zarzuela de Madrid el 20 de enero de 1877 con notable éxito ${ }^{126}$. Espinosa también compuso al menos nueve zarzuelas, casi todas en un acto y con libretistas como Jackson Veyán, Taboada y De las Heras, entre otros. Algunas de ellas, como Otro monaguillo, obtuvieron mucho éxito en los teatros madrileños por horas de la década de los noventa ${ }^{127}$.

Gaspar Espinosa compuso varias sinfonías y otras obras orquestales como el Baile gitano, varias oberturas (Ecos del Miño, Recuerdo, La muerte de Garcilaso), fantasías (como la Fantasía Gallega), marchas, caprichos (Matilde, Florinda y el más famoso, Moraima) y diferentes piezas para banda. Fue autor del pasodoble $J_{o}$ y Ja, inspirado en la célebre parranda del mismo título y estrenado en Murcia por la Banda de Música de Vicente España en la feria de $1895^{128}$. La pieza fue un encargo del periodista taurino

${ }^{123}$ Ramiro de Adalgisa, "Espinosa de los Monteros", Boletín Musical y de Artes Plásticas, VI (1898), $\mathrm{n}^{\mathrm{o}} 115,10$ julio, p. 354-356:355. Véase también La Correspondencia de España, XXIX (1878), $\mathrm{n}^{\mathrm{o}} 7364,19$ febrero, p. 2 y sobre las actuaciones de esta banda: La Correspondencia de España, XXXVI (1885), $\mathrm{n}^{\circ}$ 9981, 20 julio, p. 3 y La Correspondencia de España, XXXVIII (1887), n 10661, 31 de mayo, p. 2; El País, IV (1890), no 1071, 5 junio, p. 3; Diario de Avisos de Madrid, CXXXIII (1890), nº 19110 julio, p. 2; Diario de Avisos de Madrid, CXXXIV (1891), nº 80, 21 marzo, p. 3; El País, VII (1893), nº 2188, 30 mayo, p. 4.

${ }^{124}$ Sobrino, "Espinosa de los Monteros”, p. 783.

${ }^{125}$ Adalgisa, "Espinosa de los Monteros", p. 355.

${ }^{126}$ La Correspondencia de España, XXVIII (1877), nº 6989, 21 enero, p. 3 y La Época, XXIX (1877), $n^{\circ} 8837,19$ enero, p. pp. 3, 4 .

${ }^{127}$ Sobrino, "Espinosa de los Monteros", p. 717. Otras zarzuelas de Espinosa son: Dar la hora, juguete lírico en un acto con libreto de Eduardo Navarro Gonsalvo: El Día, (1883), n 1118, 25 de junio, p. 6; La perla cubana, Carabanchel de arriba, Vis a vis y La compañia de Jesús.

${ }^{128}$ La Correspondencia de España, XLVI (1895), n 13725, 4 septiembre, p. 1. El Diario de Murcia, XVII (1895), no 6725, 31 agosto, p. 2 y 6741, 16 septiembre, p. 1. El compositor cedió los derechos de estreno a la mencionada banda, aunque permitió que el resto de agrupaciones de la ciudad copiaran la partitura y la interpretaran. 
Antonio Ibáñez González y fue dedicado al famoso matador de toros murcianos, Juan Ruiz Vargas "Lagartija"129. Una de sus obras más célebres fue Moraima, un "capricho característico" compuesto en 1882 que fue estrenado en los jardines del Retiro de Madrid a cargo de Fernández Caballero como director. Su asombroso éxito se constata en la gran cantidad de arreglos para diversos instrumentos que se realizaron en la época ${ }^{130}$.

Buena parte de la música de Gaspar Espinosa de los Monteros está compuesta por pequeñas piezas de salón para piano, canto y piano y bandas de música. Destacan en número las formas bailables como contradanzas (Dulce memoria, La gachona, La ilusión, entre otras), valses (Emilio, Clara luna, Lola, Luis), habaneras (El amor es la vida, Americano amor, La ingratitud), marchas (once), gavotas (Matilde, Otello), polcas (Angelita, La patrona, Lucía, Sultana, Triniada y la citada Ondalina), así como pasodobles. Además, también compuso diversas obras religiosas (tres misas, un miserere y varios motetes, letanías, salves y palabras). Muchas de sus obras fueron estrenadas por la Unión Artístico-Musical e interpretadas por la Sociedad de Conciertos de Madrid ${ }^{131}$.

Gaspar Espinosa poseyó también una importante biblioteca musical, según Ramiro de Adalgisa. Su hermano Mateo Espinosa de los Monteros fue un notorio violonchelista, integrante de la Orquesta del Teatro Real, al menos en 1901. Perteneció al sexteto Arche, dirigido por Pascual Vicente Arche, con cuya formación recorrió diversos puntos de la geografía peninsular, incluida Murcia (ver Capítulo 5) ${ }^{132}$.

\subsubsection{Luis Mondéjar Brocal (1837-?)}

Desconozco cuál fue la formación musical de Luis Mondéjar (Murcia, 21/06/1837-?). Cabe imaginar que se educara en el entorno de profesores del Colegio de San Leandro y probablemente también con su padre, Celestino Mondéjar. En 1853, el pianista José Miró (que se encontraba de gira en Murcia) escuchó tocar el piano a Luis Mondéjar y aconsejó su traslado al Conservatorio de Madrid. En efecto, Mondéjar comenzó a recibir clases de José Miró en el conservatorio madrileño en septiembre de $1854^{133}$.

En Madrid, Mondéjar actuó en veladas musicales. Por ejemplo, en noviembre 1856 tocó un "Gran vals de Schulof [¿Schulhoff?]" en un concierto en el concierto del famoso guitarrista Francisco Trinidad Huerta ${ }^{134}$.

En 1858 obtuvo el primer premio de piano del Conservatorio, compartido con Antonio Sos y Rafael Acebes (éstos, alumnos de Mendizábal). Mondéjar y Acebes

\footnotetext{
${ }^{129}$ Pérez Crespo, El Lagartija.

${ }^{130}$ Julián Calvo, "Los conciertos segundo y tercero por el sexteto del maestro Arche", La Paz de Murcia, XXVI (1883), n 7626, 2 mayo, p. 1. La E:Mn conserva algunos, entre otras piezas de Espinosa de los Monteros.

${ }^{131}$ Véanse más detalles en Sobrino, "Espinosa de los Monteros”, pp. 783-784.

${ }^{132}$ García Segura, Músicos, p. 163.

133 Julián Calvo, "Remitido", La Paz de Murcia, XXI (1878), nº 6313, 22 septiembre, p. 1 y E:Mc, Leg. 9/69, fol. 5 .

${ }^{134}$ El Clamor Público, (1856), nº 3773, 7 noviembre, p. 3.
} 
interpretaron conjuntamente una "Fantasía sobre motivos de la ópera Norma" de Thalberg en el tradicional concierto de premiados ${ }^{135}$.

Durante los años sesenta Mondéjar ofreció conciertos en diversas ciudades de España, como Córdoba y Madrid ${ }^{136}$. También proyectó un periódico musical, titulado Álbum Musical "con el patriótico fin de acrecer el fondo de suscripción nacional para los inútiles y huérfanos a consecuencia de la pasada guerra [carlista]"137.

Luis Mondéjar dirigió la orquesta en las ceremonias religiosas que la Juventud Católica de Madrid organizó en Semana Santa y la Inmaculada Concepción de los años 1879-82 ${ }^{138}$. Estuvo casado con María de los Dolores Amorós y Caperino. La pista biográfica del músico se pierde en $1892^{139}$.

Como compositor, Luis Mondéjar escribió muchas piezas de salón para piano, algunas publicadas por Romero. Destacaron los álbumes El colegia interno, Flores escogidas y Cuatro composiciones para piano ${ }^{140}$. En la Biblioteca Nacional de España se conservan diecisiete de estas piezas (ver Tabla 9.5):

Tabla 9. 5. Obras de Luis Mondéjar Brocal en la $E: M n$.

\begin{tabular}{|c|c|l|l|}
\hline Título (publicación) & Colección & $\begin{array}{l}\text { Signatura } \\
\text { E:Mn }\end{array}$ & pp. \\
\hline $\begin{array}{c}\text { Barcarola para piano en Re b Mayor para } \\
\text { piano (Madrid: Nicolás Toledo, 1877) }\end{array}$ & - & $\mathrm{MC} / 15 / 3$ & 5 \\
\hline $\begin{array}{c}\text { Barcarola para piano en fa menor para piano } \\
\text { (Madrid: Romero y Marzo, 1878) }\end{array}$ & - & $\mathrm{MC} / 507 / 59$ & 4 \\
\hline $\begin{array}{c}\text { Barcarola para piano, n 2 (Madrid: Nicolás } \\
\text { Toledo, 1878) }\end{array}$ & - & $\mathrm{MC} / 20 / 17$ & 6 \\
\hline $\begin{array}{c}\text { La Primavera, mazurca de salón para piano } \\
\text { (Madrid: Antonio Romero, 1877). }\end{array}$ & $\begin{array}{l}\text { Suplemento a } \\
\text { Crónica de la } \\
\text { Música, I (1878), } \\
\mathrm{n}^{\mathbf{0}} 9, \\
\text { noviembre 21 }\end{array}$ & $\mathrm{MC} / 522 / 51$ & 8 \\
\hline
\end{tabular}

${ }^{135}$ La España Artística, II (1858), no 37, 5 julio, p. 285; El Mundo Pintoresco, ilustración española, (1858), no 14, 11 julio, p. 106 y Calendario Musical para el año 1859 (Madrid: Establecimiento de música de Mariano Martín, 1858), p. 32; La Época, XI (1859), n 3000, 17 enero, p. 3; La España, XII (1859), nº 3815, 18 enero, p. 4; El Clamor Público, (1859), n 4454, 19 enero, p. 3

${ }^{136}$ La España Musical, I (1866), no 21, 31 mayo, p. 2.

${ }^{137}$ El Solfeo. Bromazo diario para músicos y danzantes, II (1876), $\mathrm{n}^{\mathrm{o}} 245,4$ mayo, p. 2. No tengo constancia de que el periódico llegara a ser una realidad.

${ }^{138}$ Véase: El Siglo Futuro, IV (1879), nº 1229, 5 diciembre, p. 2; El Siglo Futuro, V (1880), nº 1316, 23 marzo, p. 1 y El Siglo Futuro, VIII (1882), no 1912, 31 marzo, p. 3 y La Discusión. Diario democrático de la mañana. XXIV (1879), nº 155, 13 diciembre, p. 3.

${ }^{139}$ La última noticia que he hallado sobre él fue publicada en Diario Oficial de Avisos de Madrid, CXXXV (1892), no 130, 9 mayo, p. 1: Su esposa solicitaba "que se declare ausente su esposo don Luis Mondéjar Brocal y en su virtud que aquélla tiene facultad para disponer libremente de los bienes propios de la misma y los demás derechos que a la declaración de ausencia sean anejos". El músico había sido requerido a presentarse en el Juzgado antes de dos meses pero desconozco por qué causas, y si finalmente se presentó.

${ }^{140}$ La Correspondencia de España: XXVIII (1870), $\mathrm{n}^{\text {os }} 7040,13$ marzo, p. 4 y XXVIII (1877), $\mathrm{n}^{\mathrm{o}}$ 7136, 16 junio, p. 4; Diario Oficial de Avisos de Madrid, CXIX (1877), $\mathrm{n}^{\text {os }}$ 73, 14 marzo, p. 3 y 168,17 junio, pp. 2, 3; y, La Ilustración Española y Americana, XXI (1877), nº 24, 30 junio, p. 16. 


\begin{tabular}{|c|c|c|c|}
\hline $\begin{array}{l}\text { Azahar, mazurca de salón para piano (Madrid: } \\
\text { Antonio Romero, 1877) }\end{array}$ & Flores escogidas & $\mathrm{MC} / 293 / 53$ & 7 \\
\hline $\begin{array}{l}\text { Anémona, mazurca de salón para piano } \\
\text { (Madrid: Antonio Romero, 1877) }\end{array}$ & & $\mathrm{MP} / 1801 / 31$ & 5 \\
\hline $\begin{array}{l}\text { Camelia, mazurca de salón para piano } \\
\text { (Madrid: Antonio Romero, 1877) }\end{array}$ & & MP/1801/29 & 5 \\
\hline $\begin{array}{l}\text { Felicia, mazurca de salón para piano } \\
\text { (Madrid: Antonio Romero, 1877) }\end{array}$ & & $\mathrm{MC} / 293 / 54$ & 5 \\
\hline $\begin{array}{l}\text { Zinia, mazurca de salón para piano (Madrid: } \\
\text { Antonio Romero, 1877) }\end{array}$ & & $\mathrm{MC} / 293 / 52$ & 4 \\
\hline $\begin{array}{c}\text { El oratorio, plegaria para piano (Madrid: } \\
\text { Antonio Romero, 1877) }\end{array}$ & $\begin{array}{ll}\text { El } & \text { colegial } \\
\text { interno } & \end{array}$ & $\mathrm{MP} / 1801 / 34$ & 4 \\
\hline $\begin{array}{l}\text { Patio de juego, galop para piano (Madrid: } \\
\text { Antonio Romero, 1877) }\end{array}$ & & $\mathrm{MP} / 1801 / 33$ & 4 \\
\hline $\begin{array}{c}\text { La sala de visitas, mazurca para piano } \\
\text { (Madrid: Antonio Romero, 1877) }\end{array}$ & & MP/1801/32 & 3 \\
\hline $\begin{array}{l}\text { Vacaciones, barcarola para piano (Madrid: } \\
\text { Antonio Romero, 1877) }\end{array}$ & & $\mathrm{MP} / 1801 / 36$ & 3 \\
\hline $\begin{array}{l}\text { Lamento para piano (Madrid: Romero y } \\
\text { Marzo, 1878) }\end{array}$ & $\begin{array}{l}\text { Cuatro } \\
\text { composiciones }\end{array}$ & $\mathrm{MC} / 507 / 57$ & 5 \\
\hline $\begin{array}{l}\text { Polonesa para piano en la menor (Madrid: } \\
\text { Romero y Marzo, 1878) }\end{array}$ & para piano & $\mathrm{MC} / 507 / 60$ & 5 \\
\hline $\begin{array}{c}\text { Romanzas sin palabras para piano en fa } \\
\text { menor (Madrid: Romero, 1877) }\end{array}$ & & $\mathrm{MC} / 507 / 58$ & 4 \\
\hline $\begin{array}{l}\text { Romanzas sin palabras (Madrid: Romero y } \\
\text { Marzo, 1878) }\end{array}$ & & $\mathrm{MC} / 15 / 10$ & 5 \\
\hline
\end{tabular}

\subsubsection{Antonio López Almagro (1839-1904)}

Sobre este importante compositor existen varios estudios, entre los que destaca el todavía inédito de José López Rico y Víctor Pliego ${ }^{141}$. La aproximación al músico que presento a continuación se basa en ellos y aporta además datos complementarios obtenidos en mi propia investigación.

Antonio López Almagro (Murcia, 17/09/1839-Villarejo del Valle, Ávila, 9/08/1904) ${ }^{142}$ comenzó sus estudios de música en 1849 con Julián Gil y estudió piano con

${ }^{141}$ López Rico (estudio biográfico) y Pliego de Andrés (estudio musical), Antonio López. Agradezco profundamente a José López Rico, descendiente de Antonio López Almagro, los datos que me ha facilitado y su inestimable y desinteresada ayuda. Su estudio biográfico sobre el músico, todavía inédito, me ha resultado imprescindible para profundizar en la trayectoria del murciano. Otros datos sobre la vida y obra de López Almagro aparecieron en: Alonso, La canción lírica, pp. 475-476; González Cutillas, "Calvo López", pp. 263-264; Gosálvez, La edición musical, pp. 134-135; Felipe Pedrell, "Celebridades contemporáneas. Antonio López Almagro”, La Última Moda, III (1890), n 124, 18 mayo, p. 7; Felipe Pedrell, "Antonio López Almagro", Ilustración Musical Hispano-Americana, II (1880), n 45, 22 noviembre, pp. 169-170; Pliego, Antonio López y "López Almagro”, pp. 1002-1003; Saldoni, Diccionario, vol. III, pp. 197-199 y Vicente Cuenca, “Antonio López Almagro”, El Correo de la Moda, XIX (1869), nº 33, 2 septiembre, p. 264. En este último el autor comenta la Sinfonía Thader de López Almagro.

${ }^{142}$ El Diario de Murcia, VII (1885), nº 1770, 10 enero, p. 3. Fue hijo de Antonio López Marín y Catalina Almagro Molina, agricultores de Javalí Nuevo y encargados de la administración de los bienes y rentas de algunos terratenientes de la zona. Antonio López Almagro fue el más pequeño (y único varón) de los ocho hijos del matrimonio. Sus hermanas fueron: Ginesa, Antonia, María Josefa, Isabel, Estefanía, Concepción y María de la Cruz. Antonio López Almagro fue bautizado en la Parroquia de San Antolín de Murcia. Véanse más detalles sobre su entorno familiar en López Rico y Pliego de Andrés, Antonio López, 
Juan Diego Manresa ${ }^{143}$. El 20 de octubre 1861 contrajo matrimonio con la violinista aficionada María de la O Lacárcel Caballero en la Iglesia de San Lorenzo de Murcia. Vivieron en la calle San Cristóbal 5, y en su casa se celebraron continuas veladas de profesionales y aficionados a la música (ver Capítulo 8).

Según Julián Calvo, López Almagro y él mismo se iniciaron de forma autodidacta en el armonio en $1854^{144}$, cuando ese instrumento apenas se conocía en España:

[...] En 1854 apenas se conocía en España el armonio pero la causalidad hizo que don José Ramírez (constructor de pianos), en un viaje que efectuó a Madrid y Barcelona, conociera estos instrumentos y habiéndole agradado en extremo, trajo uno de dos juegos de la fábrica de Alexandre. En este instrumento fue donde el señor López y el que suscribe [Julián Calvo] aprendieron los primeros secretos que guardaba el armonio.

En 1857, el mismo señor Ramírez, tuvo la representación de la fábrica de Mr. Merklin-Schutze (constructores del gran órgano de la Catedral de Murcia) para la venta de armonios y con este motivo trajo un buen surtido de éstos y, entre ellos, uno de cuatro juegos muy buenos. Este lo compró mi estimado amigo señor López y en él aprendió por sí sólo a darle vida propia y a sacarlo del estado secundario en que se le conocía.

Sus adelantos e inspiraciones artísticas se propagaron con la mayor rapidez hasta que, habiéndole oído los señores Barbieri, Soriano Fuertes, Mariátegui y otras eminencias, observaron que el señor ALMAGRO (así le nombran los profesores de Madrid) tocaba el armonio de distinta manera que los buenos artistas de la corte, y a tanto llegó que, sabedor el gran artista y célebre editor señor don Antonio Romero del mérito singular de mi buen / [p. 114] amigo, le comprometió para que trabajara un gran método para dicho instrumento $[\ldots]^{145}$.

El armonio tuvo una rápida difusión en España como instrumento de salón durante la segunda mitad del siglo XIX y como instrumento auxiliar en el templo a principios del siglo XX, según Pliego ${ }^{146}$. En Murcia gozó de una gran expansión en todos los círculos musicales de la ciudad, a partir de la introducción del instrumento a mitades del siglo XIX por el comerciante José Ramírez. El Casino de Murcia vendió oficialmente armonios de

pp. 19-23; en pp. 21-23 se detallan exhaustivamente las propiedades que heredó de sus padres y que más tarde vendió para adquirir otras.

${ }^{143}$ La Paz de Murcia, IX (1866), nº 2496, 4 abril, p. 1.

144 El armonio se desarrolló a partir del orgue expresiff de Gabril-Joseph Grenié (1810) y fue patentado en 1842 por Debain. Pliego, “Armonio", pp. 693-695 menciona como factores de esta expansión el perfeccionamiento técnico del instrumento, su abaratamiento económico por la construcción industrial, la expresividad, versatilidad y resistencia y sus características técnicas (expresión, autonomía y variedad tímbrica), que encajaban con la estética romántica.

145 [Nota al pie de página original]: "Poco tiempo antes trajeron un armonio a una casa de importancia de esta capital [la de los señores de Stoup] y por no entenderlo se devolvió": Julián Calvo, "Un libro excelente", El Semanario Murciano, IV (1881), n 165, 10 abril, p. 113. Véanse más detalles en Calvo, Reseña, p. 24.

${ }^{146}$ Pliego, "Armonio", p. 695. En Murcia, sin embargo, el armonio se tocaba en algunas iglesias de la ciudad desde la década de los ochenta del siglo XIX. En 1886, por ejemplo, se estrenó para la festividad de la Purísima Concepción celebrada en la Iglesia de Santo Domingo de Murcia una Misa de Mariano Moreno Pretel, entonces profesor de música del Colegio de los Sagrados Corazones de Jesús y María, que fue interpretada por un coro de treinta y cinco niños, acompañados al piano y armonio. Véase, La Paz de Murcia, XXIX (1886), nº 9065, 11 diciembre, p. 1. 
la fábrica de Alexandre al menos desde $1865^{147}$. En los años siguientes, llegaron a la ciudad otros armonios, parte de ellos adquiridos a la Casa Romero de Madrid y elegidos por López Almagro. En noviembre de 1887, por ejemplo, el Casino adquirió un armonio a Casa Romero que costó 5000 reales (1250 pesetas $)^{148}$; y al año siguiente, se compró en el mismo establecimiento madrileño un órgano Mediofon para la capilla de la fábrica de harinas del empresario Antonio Miñano ${ }^{149}$. El auge del armonio en Murcia debe vincularse, sin lugar a dudas, a tres nombres, además del citado Ramírez: Julián Calvo, Antonio López Almagro y Juan Diego Manresa, todos ellos habituales en las veladas musicales de teatros, sociedades, cafés y salones particulares.

Hasta 1872, López Almagro compaginó la música con la administración de sus rentables fincas y negocios familiares ${ }^{150}$, pero varios hechos cambiaron su vida ese año. A finales del mes de marzo, se desplazaron a Murcia Mariano Soriano Fuertes, Francisco Asenjo Barbieri (véanse Figura 9.12 y 9.13), el militar Eduardo Mariátegui y el diplomático Luis del Castillo, probablemente porque el maestro de capilla de la Catedral de Murcia había invitado a Barbieri y a Soriano Fuertes a tomar parte en la interpretación del Miserere de Indalecio Soriano Fuertes en las noches del Miércoles y Jueves Santo ${ }^{151}$. A raíz de esta visita se inició una sólida amistad entre Antonio López Almagro, Barbieri, Mariano Soriano Fuertes, el escritor Javier Fuentes y Ponte, el pianista murciano José María Avilés y el pintor madrileño Eduardo Rosales (que entonces se encontraba en Murcia ${ }^{152}$. Entre López Almagro y Barbieri hubo una fluida correspondencia desde el 5 de abril de 1872, fecha de la primera misiva, hasta 1875, cuando el murciano se trasladó a Madrid $^{153}$. No he podido documentar veladas privadas de estos artistas en Murcia, pero es muy probable que Soriano y Barbieri pudieran escuchar a López Almagro y le animaran a

${ }^{147}$ La Paz de Murcia, VIII (1865), nº 2213, 23 junio, p. 1.

${ }^{148}$ El Diario de Murcia, IX (1887), no 3151, 12 noviembre, p. 3.

${ }^{149}$ Para estrenar ese órgano se celebró una función a San José en la que se cantó una Misa de Mariano García. El instrumento tenía " 21 registros, tres rodilleras, techado transpositor y entre su combinaciones da el resultado de cuatro teclados", según El Diario de Murcia, X (1887), n 3294, 24 abril, p. 1.

${ }^{150}$ Según López Rico y Pliego de Andrés, Antonio López, p. 21, López Almagro heredó una buena cantidad de tierras aunque pareció inclinarse por el negocio de venta de tejidos al por mayor que regentaba su suegro.

${ }^{151}$ La Paz de Murcia, XV (1872), n 4525, 24 marzo, p. 1. Mariano Soriano Fuertes ya había visitado con anterioridad la ciudad. Llegó a Murcia el 2 de febrero de 1872 y se hospedó en la casa del barítono Mariano Padilla: La Paz de Murcia, XV (1872), n ${ }^{\text {os }} 4484,4$ febrero, p. 1 y 4489, 10 febrero, p. 1. Según La Paz de Murcia, XV (1872), n 4490, 11 febrero, p. 1, era la primera vez que volvía a esta ciudad desde su traslado a Madrid treinta años atrás. La crónica sobre la interpretación del Miserere de Indalecio Soriano Fuertes a cargo de la Capilla de Música de la Catedral, algunos músicos de la orquesta de Ángel Mirete y las direcciones de Mariano García, Mariano Soriano Fuertes y Barbieri pueden consultarse en La Paz de Murcia, XV (1872), no 4529, 30 marzo, p. 1 y La Paz de Murcia, XV (1872), n 4531, 2 abril, p. 1, esta última transcrita en el Documentario.

${ }^{152}$ Javier Fuentes y Ponte fue una figura esencial en la vida cultural de Murcia durante el siglo XIX. A él se debió la recuperación de los Juegos Florales de esta ciudad. Escribió Murcia que se fue, obra de referencia de la literatura murciana a la que cariñosamente se referían Barbieri, López Almagro y Soriano Fuertes como El duro que se fue, por su elevado coste de venta que consideraban un "atentado pecuniario", según consta en una carta de López Almagro a Barbieri, fechada el 17-06-1872. Francisco Asenjo, vol. II, p. 700. Todos estos artistas tenían apodos: Mariano Soriano Fuertes era "Soriano Flojo"; Barbieri "Guandalini" (uno de sus apellidos); Mariátegui por "el soldao"; Avilés, "el 6/4” y López Almagro "el murcianico". Según López Rico, Rosales hizo un retrato de López Almagro. Véanse más detalles en López Rico y Pliego de Andrés, Antonio López, pp. 44-45.

${ }^{153}$ Francisco Asenjo, vol. II, pp. 699-702. 
continuar con el estudio del armonio, tal y como confirman las biografías de Saldoni y Pedrell ${ }^{154}$.

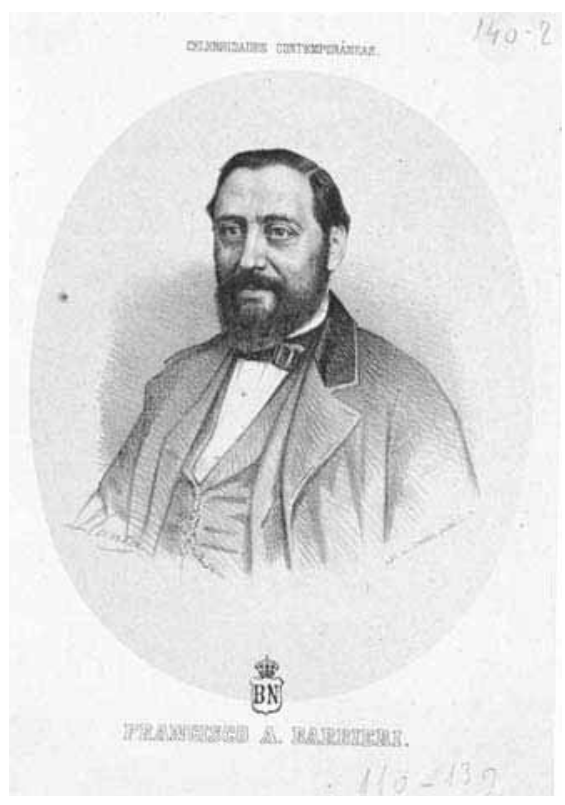

Figura 9. 12 Retrato de Francisco Asenjo Barbieri.

Santiago Llanta y Guerin. Madrid: Litografía de J. Donon, [entre 1866 y 1872], E:Mn.

Accesible en: http://bibliotecadigitalhispanica.bne.es (acceso el 18-07-2011).

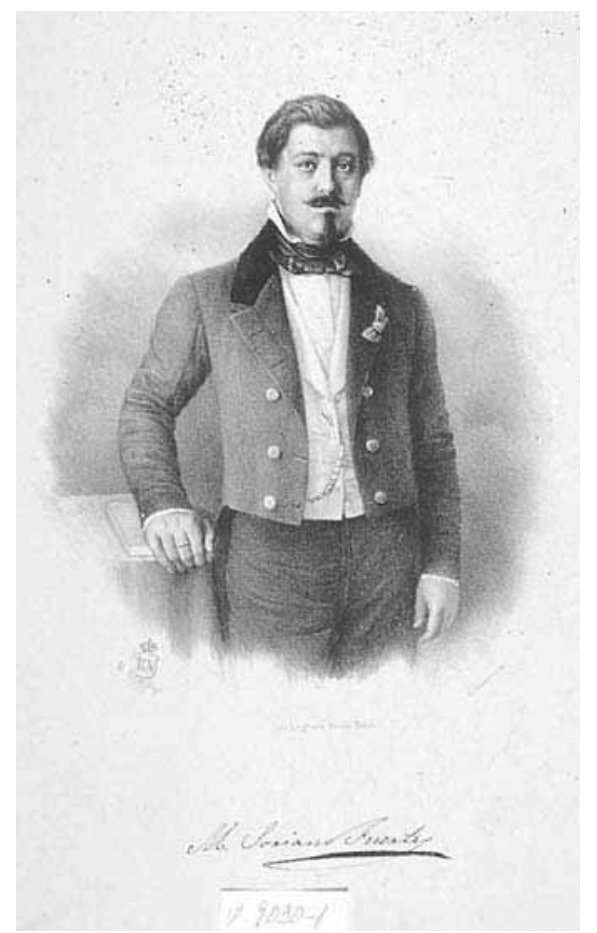

Figura 9. 13 Retrato de Mariano Soriano Fuertes. E:Mn.

Accesible en: http://bibliotecadigitalhispanica.bne.es (acceso el 16-07-2011).

${ }^{154}$ Pedrell, “Celebridades contemporáneas”, p. 7; Pedrell, “Antonio López”, pp. 169-170 y Saldoni, Diccionario, vol. III, pp. 197-199 
El epistolario entre Antonio López Almagro y Barbieri ofrece interesantes datos sobre la vinculación entre ambos artistas. Barbieri envió a López Almagro el tratado de instrumentación de Gevaert (Traité général d'instrumentation), el de Berlioz (Traité général d'instrumentation), varias sonatinas de Lefebure-Wély y sus composiciones Motets, Tirana y Mancha para que López Almagro pudiera estudiarlos a fondo. Además, por mediación de López Almagro, Barbieri envió a Murcia las partituras de algunas de sus zarzuelas como El tributo de las cien doncellas (para su interpretación a cargo de los alumnos de la "Escuela de Canto y Declamación Padilla", creada en 1873) y Sueño de oro (por la compañía de Tomás Brotons) ${ }^{155}$.

Por su parte, López Almagro enviaba regularmente a Barbieri dulces y otros productos murcianos y trataba de complacerle en los favores que el madrileño le pedía, a veces recopilando datos en Murcia para las obras musicológicas de Barbieri ${ }^{156}$. Por ejemplo, en una carta fechada el 15 de mayo de 1875, López Almagro contestaba a Barbieri:

Veré al deán y archivero del cabildo de esta catedral, iré al archivo, tomaré nota de todos los maestros de capilla y organistas habidos hasta la fecha con todos los detalles que pueda servir a sus apuntes históricos $[\ldots]^{157}$.

En mayo de 1872, López Almagro ya había liquidado sus negocios comerciales: "ya no soy comerciante y me tiene usted entregado exclusivamente a los estudios y trabajos musicales", le escribía a Barbieri ${ }^{158}$. Los deseos de López Almagro por salir de Murcia se reiteran en su correspondencia: "todos los que viven rodeados de las glorias de esa corte son unos bribonazos que no se acuerdan de los pobres pipiolos que vegetan por

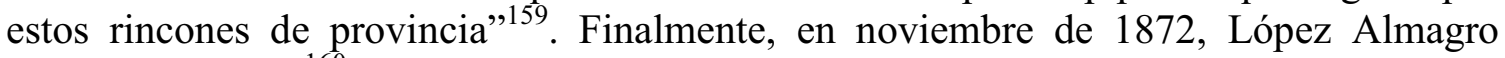
marchó a Madrid ${ }^{160}$, aunque en enero del año siguiente ya se encontraba de vuelta en Murcia. Es probable que esa visita estuviera destinada a preparar su traslado definitivo a la capital española. En 1872, publicó el Método completo teórico-práctico de harmónium (órgano expresivo), posteriormente ampliado con El órgano de doble expresión ${ }^{161}$. Estos métodos sobre el armonio fueron traducidos al francés, reeditados y reimpresos posteriormente (véanse Figuras 9. 14, 9.15 y 9.16) y fueron premiados en las exposiciones universales de Viena (1873), París (1878) y Barcelona (1888) ${ }^{162}$.

\footnotetext{
${ }^{155}$ Francisco Asenjo, vol. II, pp. 700-701.

${ }^{156}$ Francisco Asenjo, vol. II, pp. 699.

${ }^{157}$ Francisco Asenjo, vol. II, pp. 702.

${ }^{158}$ Carta de López Almagro a Barbieri, fechada el 17 de mayo de 1872. Francisco Asenjo, op. cit, p. 700 .

${ }^{159}$ Carta de López Almagro a Barbieri, fechada el 15 de enero de 1872. Francisco Asenjo, op. cit, p. 701.

${ }^{160}$ La Paz de Murcia, XV (1872), no 4639, 12 noviembre, p. 1.

${ }^{161}$ López Rico y Pliego de Andrés, Antonio López, p. 109. En la bibliografía que he consultado, las fechas de publicación de los métodos de armonio son realmente confusas. Indico en cada cado dónde he tomado la referencia.

${ }^{162}$ Vázquez y Garbayo, "López Almagro”, p. 1002.
} 

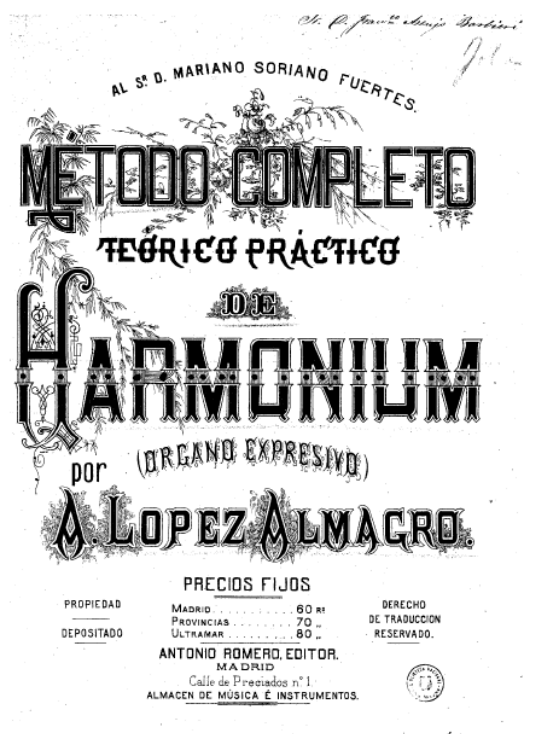

Figura 9. 14. Portada del Método completo teórico-práctico de harmonium de Antonio López Almagro. Madrid: Antonio Romero, $1872^{163}, 148$ pp. Prólogo de Mariano Soriano Fuertes. E: Mn. Accesible en: http://bibliotecadigitalhispanica.bne.es (acceso el 17-07-2011).

Figura 9. 15. Portada de El harmonium de doble expresión. Complemento al método de harmonium del mismo autor de Antonio López Almagro. (Madrid: Antonio Romero/Faustino Echevarría, 1880 ${ }^{164}$ ).

Edición en castellano y francés, traducción de Óscar Comettant, $E: M n$. Accesible en: http://bibliotecadigitalhispanica.bne.es (acceso el 16-07-2011).

${ }^{163}$ Fecha tomada de López Rico y Pliego de Andrés, Antonio López, p. 109. Sobre este método, véase: La Paz de Murcia, XVI (1873), nº 4684, 30 enero, p. 1.

${ }^{164}$ Fecha tomada de: López Rico y Pliego de Andrés, Antonio López, p. 113. Véase la crítica de Julián Calvo, "Un libro excelente", El Semanario Murciano, IV (1881), no 165, 10 abril, p. 113-115, transcrita en el Documentario. Sobre el armonium de doble expresión véase el artículo de José Inzenga, "El armonium de doble expresión", Crónica de la Música, IV (1881), n 133, 6 abril, pp. 1-2. 
CANTO DEL BARDO

(LR ERATT DE BABDE.)

Eupleo del Registro de Baryton. $\quad$ Enploi des Registre de Baryton
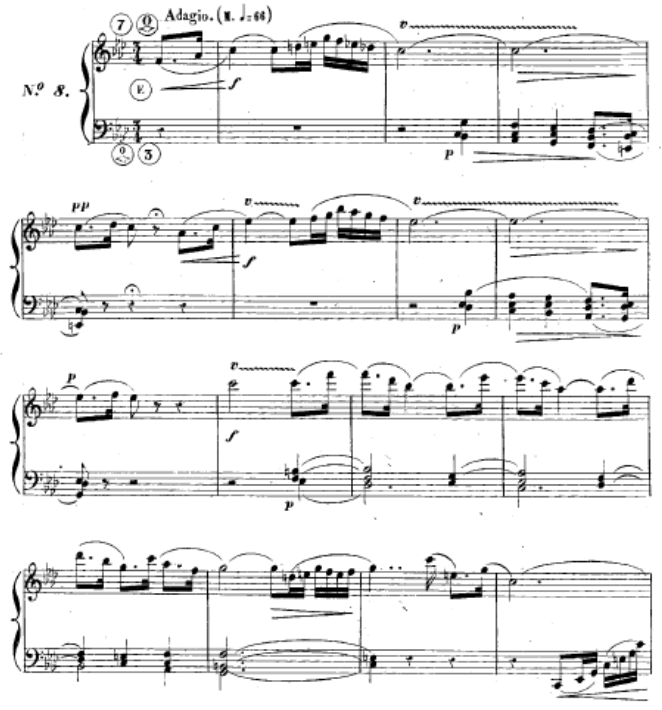

. 3. 359

Figura 9. 16. Inicio del Canto del bardo de López Almagro, dedicada a Julián Calvo e incluida en $E l$ harmonium de doble expresión de Antonio López Almagro. E: Mn. Accesible en: http://bibliotecadigitalhispanica.bne.es (acceso el 16-07-2011).

Ri

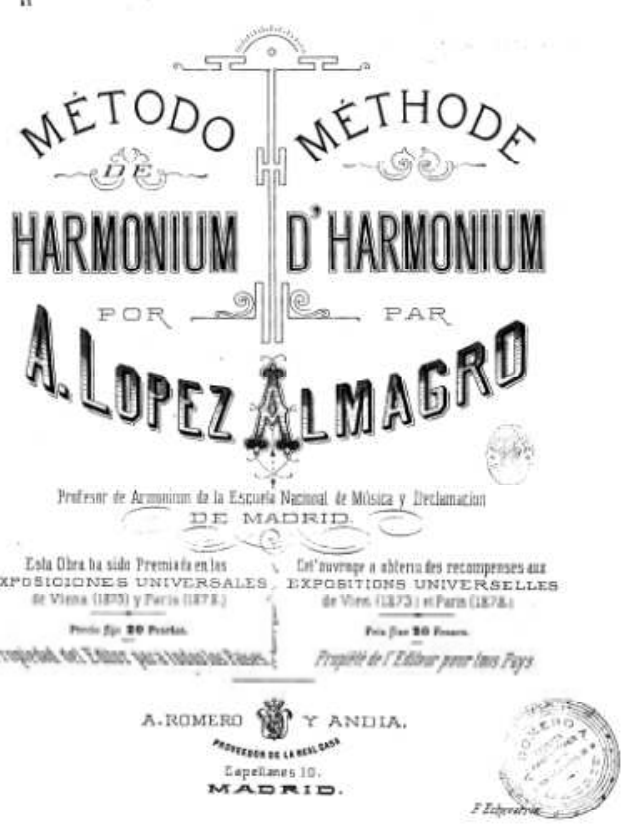

Figura 9. 17. Método de harmonium de Antonio López Almagro en castellano y francés.

(Madrid: Antonio Romero/Faustino Echevarría, ca. 1884) ${ }^{165}, 150$ pp.

Edición en castellano y francés, traducción de Óscar Comettant, $E: M n$

Accesible en: http://bibliotecadigitalhispanica.bne.es (acceso el 16-07-2011)

${ }^{165}$ Fecha tomada de: Iglesias, La música, p. 196. 
A principios de 1875, López Almagro regresó a Madrid, donde en esa ocasión permaneció seis meses: dio clases de armonio, participó en algunas veladas musicales celebradas en la capital ${ }^{166}$, e inició las gestiones necesarias para la creación de la plaza de armonio en el Conservatorio, solicitada formalmente al Ministro de Fomento a mediados del mes de marzo. Para entonces López Almagro ya había entretejido una sólida red de amistades, entre las que se encontraban importantes personalidades del mundo de la música. Barbieri, Soriano Fuertes, Antonio Romero y José Inzenga (quien incluso le propuso como socio corresponsal de la Academia de San Fernando), le apoyaron para defender la implantación del armonio en el Conservatorio, aunque también tuvo detractores. En una carta de Hilarión Eslava a Barbieri, fechada a finales de marzo de 1875, el navarro expresaba claramente que no tenía nada en contra de López Almagro pero consideraba más importante y útil implantar en el conservatorio la enseñanza del órgano:

[...] Correspondo a su carta de ayer diciendo: $1^{\circ}$, que en el Conservatorio, en el Consejo de I[nstrucción] P[ública] y en todas partes he sostenido siempre sus opiniones en pro de la oposición pública para la provisión de plazas de profesores de enseñanza musical; $2^{\circ}$, que por esfuerzos míos se estableció en el Conservatorio la enseñanza de órgano, que hoy ni existe y que considero mucho más importante y útil que la de harmónium, sin que por esto se entienda que niego la importancia que éste tiene; y $3^{\circ}$, que yo faltaría a mi conciencia de hombre y de artista si, en el expediente promovido por los señores López y Amigo, no manifestase mi opinión acerca de las dos materias indicadas. Cumplido este deber, elogiaré cuanto se merece al señor López Almagro $[\ldots]^{167}$.

No es de extrañar que Eslava, precursor del Cecilianismo en España, maestro de la Capilla Real de Madrid, profesor de composición del Conservatorio e intermitentemente su director, se opusiera férreamente a incluir el armonio por delante del órgano. Sus esfuerzos desde 1852 se habían encaminado a constituir "el verdadero género orgánicoreligioso [...] y proponer todos los medios más conducentes para mejorar este ramo, que es uno de los más importantes del arte musical" "168. Emilio Arrieta, director del Conservatorio desde 1868 hasta 1874 con brillantes resultados, apoyó la solicitud de López Almagro ${ }^{169}$, pero el Consejo de Instrucción Pública dictaminó a finales de abril de 1875 que, antes de implantar la enseñanza del armonio en el conservatorio, debía restituirse la de órgano (creada por iniciativa de Eslava y extinguida en el revolucionario año 1868). A pesar de todo, López Almagro fue nombrado Profesor Honorario, sin sueldo, a finales de junio de $1875^{170}$. No se sabe con exactitud cuándo se instaló el músico definitivamente en Madrid. Cabe suponer que después de pasar los seis primeros

${ }^{166}$ El Imparcial, (1875), 5 febrero, p. 3. López Almagro participó, por ejemplo, en un concierto el 29 de marzo de 1875 en la Escuela de Música y Declamación de Madrid: El Imparcial, (1875), 23 marzo, p. 3. Véanse otros conciertos en los que participó en López Rico y Pliego de Andrés, Antonio López, pp. 49-50. 563.

${ }^{167}$ Carta de Hilarión Eslava a Barbieri, fechada el 29 de marzo de 1875. Francisco Asenjo, vol. II, p.

${ }^{168}$ Cita tomada de López Calo, "Hilarión Eslava”, p. 597.

${ }^{169}$ Véanse más detalles sobre la trayectoria de Arrieta en el Conservatorio en Cortizo, Emilio Arrieta, pp. 438-462.

${ }^{170}$ Antonio López Almagro figura en el listado de profesores de la Escuela Nacional de Música al año siguiente: Guía Oficial de España (Madrid: Imprenta Nacional, 1876), p. 712. Véase López Rico y Pliego de Andrés, Antonio López, pp. 50-52. 
meses de 1875 en Madrid, López Almagro pasara el verano en Murcia y retornara a la capital en el mes de septiembre, ya que en esa fecha comenzaron los ensayos en Madrid de su segunda zarzuela, El hidalguillo de Ronda, con la que debutó en el Teatro de la Zarzuela en octubre 1875.

Desde su traslado a la capital hasta 1878, López Almagro preparó reducciones pianísticas de zarzuelas como La marsellesa, Los sobrinos del Capitán Grant (ambos de Fernández Caballero), Canto de Ángeles (de José Rogel), Un estudiante de Salamanca (Oudrid) y Pan y toros (Barbieri) ${ }^{171}$, así como otras obras originales. De los años 1876 y 1877 son la "Fantasía brillante, para piano, sobre motivos de la zarzuela Las nueve de la noche" (1876); la música para la zarzuela en tres actos Ruede la bola (sobre libreto adaptado del francés por Péres Echevarría y Santibáñez); un método de acordeón; la "Fantasía brillante para piano sobre motivos de la zarzuela La Marsellesa" (1877) y un gran número de piezas para piano y para canto y piano, como veremos después.

López Almagro daba también clases particulares de armonio, como se anunciaba en El Imparcial:

Hemos sabido con mucho gusto que el distinguido maestro don Antonio López Almagro, venciendo su modestia y cediendo a las repetidas instancias de sus admiradores, se ha decidido a dar algunas lecciones de armonio y a trasmitir todos los secretos que ha sabido arrancar a este delicioso instrumento ${ }^{172}$.

En junio de 1877, López Almagro fue nombrado "profesor auxiliar de piano de la Escuela Nacional de música", y de forma complementaria a las clases de armonio debía dar lecciones de piano ${ }^{173}$. Desde ese puesto desarrolló una intensa promoción del armonio hasta conseguir crear la Cátedra de Armonio en el conservatorio madrileño diez años más tarde.

En 1881, Antonio López Almagro se asoció con el clarinetista Antonio Romero y Andía (1815-1886) ${ }^{174}$, convirtiéndose en gerente de su negocio de venta de música e instrumentos. Romero defendía una identidad propia de la música española y creía necesario que hubiera obras didácticas específicas para cada materia e instrumento musical, escritas por los mejores músicos españoles ${ }^{175}$. Es probable que esas ideas

${ }^{171}$ Iglesias, La música, p. 121, 124, 130, 135-137 y 139-140; López Rico y Pliego de Andrés, Antonio López, p. 62.

${ }^{172}$ El Imparcial, (1875), [sin $\left.\mathrm{n}^{\mathrm{o}}\right], 5$ febrero, p. 3

${ }^{173}$ Saldoni, Diccionario Biográfico, vol. III, p. 199.

${ }^{174}$ Antonio Romero fue un célebre clarinetista, editor y comerciante de música, que desde 1844 hasta 1867 ocupó la plaza de clarinetista supernumerario de la Real Capilla. Fue también primer oboe de la orquesta del Teatro Circo. En 1849 opositó a la plaza de profesor de clarinete en el Conservatorio de Madrid, donde ejerció la docencia hasta su jubilación en 1876 y, desde 1857 ocupó también la cátedra de oboe. Inventó el llamado "Sistema Romero" (1853) que perfeccionó el clarinete y fue galardonado en diversas exposiciones universales. En 1854 fundó un establecimiento de venta de instrumentos al que añadió posteriormente la edición de impresos musicales. En 1877 la producción editorial había conseguido sacar al mercado 7000 obras editadas. Sobre Antonio Romero y Andía, véase la Tesis Doctoral de Ventimilla, El clarinetista, dirigida por Ramón Sobrino y defendida en la Universidad de Oviedo en 2002.

${ }^{175}$ Sobre las iniciativas de Romero para incentivar la música y la cultura española, véase: Veintimilla, El clarinetista, pp. 21-26 y 630-664. 
animaran a López Almagro a publicar su método de armonio (progresivamente ampliado) y su Método completo teórico-práctico de acordeón (Madrid: Antonio Romero, 1876) (ver Figura 9.18).

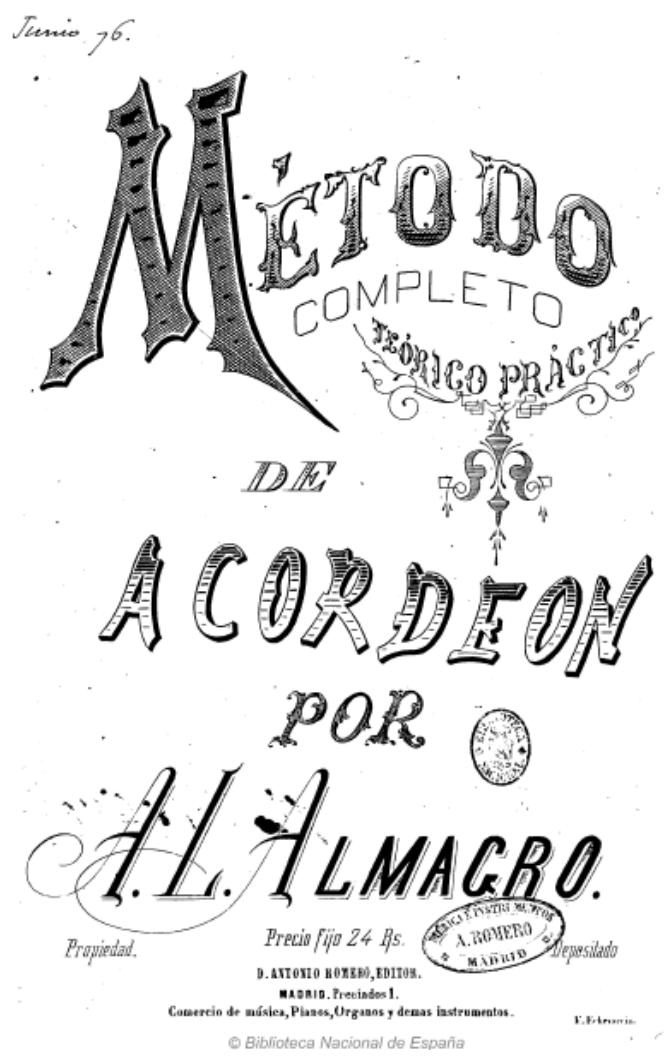

Figura 9. 18. Portada del Método completo teórico-práctico de acordeón de López Almagro. (Madrid: Antonio Romero, 1876). E:Mn. Accesible en: http://bibliotecadigitalhispanica.bne.es (acceso el 16-07-2011)

El Almacén de música de Antonio Romero (fundado en Madrid en 1854) era una de las mejores editoriales musicales del país y el más grande proveedor de música de España. Vendía las marcas más exclusivas de instrumentos y contaba, además, con taller de reparación y fabricación de instrumentos de metal. En la gestión de su negocio, Romero contó con la colaboración de sus cuñados Manuel Giménez, Federico y José Conde Arnal y los socios y amigos Enrique Marzo (oboísta del Teatro Real) y Antonio López Almagro. En 1884, crearon el Salón Romero un espacio adyacente al establecimiento por el que desfilaron los mejores músicos españoles del momento. Según Veintimilla, el Salón Romero permitió a Antonio Romero culminar sus proyectos comerciales y canalizar su idea de que la cultura y la música española tuvieran su lugar en el contexto internacional. El Salón Romero fue sede de la Sociedad de Cuartetos desde enero de 1885 y acogió numerosas veladas benéficas, conciertos, ensayos y debates científico-culturales de sociedades tan relevantes como la Sociedad de Cuartetos $^{176}$, la Sociedad Artístico-Musical de Socorros Mutuos (creada en 1860 y de la

${ }^{176}$ La Sociedad de Cuartetos, creada en 1863, fue fundamental en la difusión del repertorio de cámara europeo en la España de la segunda mitad del siglo XIX. Sobre el Salón Romero y la Sociedad de 
que López Almagro llegó a ser su secretario adjunto ${ }^{177}$ ) y la Asociación de Profesores y Aficionados a la Música, presidida por Antonio López Almagro ${ }^{178}$.

Cuando en 1886 murió Antonio Romero, la propiedad del comercio recayó en su viuda, Fernanda Conde $(+1891)$, pero López Almagro llevó la dirección efectiva del negocio bajo la nueva denominación de Casa Romero. Desde el 6 de septiembre de 1887, López Almagro compaginó sus tareas en Casa Romero con su recién nombrado cargo de Profesor Interino del Conservatorio madrileño ${ }^{179}$. Al año siguiente, López Almagro (único candidato) aprobó la oposición a la recién creada Cátedra de armonio ${ }^{180}$.

Durante los años ochenta y noventa del siglo XIX, la vida de López Almagro transcurrió en los principales núcleos de actividad musical de Madrid y ligada a los músicos e intelectuales más importantes del momento. En la capital vivían entonces una pléyade de artistas murcianos: compositores e instrumentistas como Fernández Caballero, Espinosa de los Monteros y Mondéjar ${ }^{181}$, escritores como Antonio Arnao, colaborador de los más prestigiosos músicos españoles del momento (Monasterio, Inzenga, Arrieta, Bretón, Chapí, Espinosa de los Monteros, López Almagro, Fernández Caballero, entre otros ${ }^{182}$ ), Ricardo Sánchez Madrigal, Pedro Díaz Cassou y Ricardo Gil García, uno de los introductores del Modernismo en España ${ }^{183}$.

López Almagro participó activamente en las frecuentes veladas organizadas en el Conservatorio, en el Salón Romero y en otras muchas salas y locales madrileños, tanto

Cuartetos, véase: Veintimilla, El clarinetista, pp. 630-664, así como García, "La Sociedad de Cuartetos", pp. 149-193.

177 Salón Romero. Almanaque Musical para el año 1885 (Madrid: Antonio Romero, 1885), p. 51 y Crónica de la Música, II (1879), nº 33, 8 mayo, p. 2. Sobre la relación de Antonio Romero con la Sociedad Artístico-Musical de Socorros Mutuos, véase, Veintimilla, El clarinetista, pp. 323.

${ }^{178}$ López Rico y Pliego de Andrés, Antonio López, p. 69-70.

${ }^{179}$ El Día, (1887), no 2645, 15 septiembre, p. 3: El Siglo Futuro, XIII (1887), nº 3755, 16 septiembre, p. 3 y La Época, XXXIX (1887), no 12622, 15 septiembre, p. 3.

${ }^{180}$ El examen tuvo lugar el 3 de abril de 1888 y el tribunal estuvo formado por Emilio Arrieta, presidente; Fernández Grajal, secretario; y Mendizábal, Hernando, Martin, Ovejero y Aguado, como vocales: La Correspondencia de España, XXXIX (1888), no 10965, 30 marzo, p. 3 y El Siglo Futuro, XIV (1888), no 3919, 31 marzo, p. 3. Los exámenes fueron minuciosamente descritos por Julián Calvo, El Diario de Murcia, X (1888), $\mathrm{n}^{\mathrm{o}}$ 3309, 12 mayo, p. 2,

181 A ellos se unieron jóvenes artistas murcianos como el compositor Pedro Muñoz Pedrera y el pianista Antonio Puig, desplazados en esos años a Madrid para estudiar en el Conservatorio.

${ }^{182}$ La personalidad de Antonio Arnao (1828-1889), "romántico rezagado" en palabras de Díez de Reventa y De Paco, Historia, p. 255 estuvo íntimamente vinculada al mundo de la música. Fue funcionario público con cargos de responsabilidad. Su importante labor como escritor fue reconocida al ser elegido Académico de la Real Academia Española y de las de Bellas Artes de San Fernando de Madrid. Escribió los libretos de las óperas Guzmán el Bueno de Tomás Bretón, Las naves de Cortés de Ruperto Chapí y La muerte de Garcilaso, de Gaspar Espinosa de los Monteros. Colaboró con Emilio Arrieta en la balada dramática La sombra; con Jesús de Monasterio en Acuérdate de mí y El cautivo; con José Inzenga en Noche de estio (barcarola), Bajo los sauces y La vuelta del proscrito, por ejemplo; con López Almagro en Amor inmortal, Amor y misterio y La ingratitud de López Almagro; con Valentín Zubiaurre en Melancolía; en el oratorio de Ruperto Chapí, Los ángeles; y en la Plegaria a la Virgen de Mariano Vázquez, entre otras obras. Arnao escribió además poesías para ser cantadas con música de los lieder de Schubert y tradujo al castellano Otello de Verdi y Norma de Bellini. Véanse más detalles sobre su vida en López Gómez, Antonio Arnao.

${ }^{183}$ Díez de Reventa y De Paco, Historia, p. 317. 
como intérprete como compositor. Las fuentes periodísticas dan innumerables testimonios de ello. En el Círculo Nacional de la Juventud de Madrid, por ejemplo, ofreció un concierto junto al violonchelista murciano Agustín Rubio, entre otros músicos, en marzo de 1881. López Almagro interpretó al armonio su Canto de amor y Fiesta de la aldea ${ }^{184}$. Para el Festival de Santa Cecilia organizado por la Sociedad Artístico-Musical de Socorros Mutuos en noviembre de 1880, López Almagro arregló para armonio la Romanza sin palabras, op. 109 de Mendelssohn ${ }^{185}$.

En 1882, en pleno apogeo de su carrera, Antonio López Almagro fue nombrado Caballero de la Real Orden de Isabel la Católica ${ }^{186}$.

En 1898 se extinguió Casa Romero y el murciano fundó Almagro y Cía., empresa con la que produjo alrededor de un millar de impresos musicales, y editó obras de compositores como Fernández Caballero, Tomás Bretón, Luis Foglietti, Gomis, Santoja y José Tragó, entre otros muchos ${ }^{187}$. Almagro y Cía. se mantuvo abierta hasta el 24 de abril de 1901, fecha en que fue absorbida por Casa Dotesio ${ }^{188}$.

El final en 1901 de la empresa editorial de Antonio López Almagro coincidió con otros acontecimientos importantes en la vida del músico. En enero de ese año López Almagro dirigió un escrito al Ministerio de Instrucción Pública y Bellas Artes solicitando una excedencia de tres años y ser sustituido en la Cátedra de armonio por el pianista murciano Antonio Puig ${ }^{189}$. Su solicitud fue aprobada a principios del mes de febrero de 1891 y Puig fue nombrado profesor ${ }^{190}$. Desde octubre de 1901 la especialidad de armonio fue unida a la de órgano en el Conservatorio de Madrid, lo que conllevó que López Almagro quedara en excedencia de su puesto en el centro: "Por haber sido suprimida como especialidad la enseñanza del armonio en el Conservatorio, ha quedado excedente el profesor don Antonio López Almagro"191. El declive en la carrera pedagógica de López Almagro fue paralelo al paulatino y generalizado olvido del armonio con el cambio de siglo ${ }^{192}$.

En sus últimos años, López Almagro se retiró a Villarejo del Valle (Ávila), una pequeña población enclavada en la Falda del Puerto del Pico, en la Sierra de Gredos,

${ }^{184}$ La Paz de Murcia, XXIV (1881), no 7009, 24 marzo, p. 1.

${ }^{185}$ La Correspondencia de España, XXXI (1880), nº 8272, 14 noviembre, p. 3. Anunciado también en El Globo, VI (1880), nº 1859, 19 noviembre, p. 3.

${ }^{186}$ El Día, (1882), no 61022 enero, p. 2 y El Diario de Murcia, IV (1882), nº 885, 27 enero, p. 3.

${ }^{187}$ Gosálvez, La edición, pp.134-136: 134.

${ }^{188}$ Dotesio continuó la serie numérica de las planchas de López Almagro, reimprimiendo muchas de ellas: Gosálvez, La edición, p. 134.

${ }^{189}$ Según López Rico y Pliego de Andrés, Antonio López, pp. 95-96 alegó que pretendía desplazarse al extranjero por un periodo de tres años. Sobre la relación entre Antonio López Almagro y Antonio Puig, véase Julián Calvo, "Dos artistas murcianos y el estreno de un armonio", El Diario de Murcia, XIV (1892), $\mathrm{n}^{\mathrm{o}} 5087,2$ septiembre, p. 2.

${ }^{190}$ El Diario de Murcia, XXIII (18901), nº 8544, 9 febrero, p. 3.

${ }^{191}$ El Día, XXIII (1902), nº 7473, 24 enero, p. 2.

${ }^{192}$ Según Pliego de Andrés, "Armonio", p. 694 el armonio perdió popularidad por la electrificación de sus fuelles, que le restaron expresividad y por la creciente fabricación de pianos y órganos eléctricos. No obstante, en las primeras décadas del siglo XX el armonio era todavía empleado en cafés, en salas de cine mudo y en iglesias. 
donde murió el 9 de agosto de 1904, sin descendencia ${ }^{193}$. Cabría pensar que su retiro pudo estimular su producción musical. Sin embargo, entre 1901 y 1903 el murciano sólo compuso (que se sepa) el oratorio para Semana Santa Los Siete Dolores de la Santísima Virgen con texto de Ricardo Sánchez Madrigal. El aislamiento del compositor en esta etapa parece haber buscado el sosiego y la calma (opinión que comparto con López Rico), tras tantos años de intensa actividad. En su testamento, López Almagro dejó su piano, el armonio y su archivo de música a la Congregación de Religiosas Adoratrices de Ávila. Su esposa, María de la O Lacárcel, se trasladó a Madrid con derecho a una pensión de 875 pesetas anuales del Montepío de Oficinas, y murió en octubre de $1910^{194}$.

Como compositor, Antonio López Almagro dejó un nutrido catálogo de obras de géneros muy diversos en los que predomina la música de salón. Al catálogo confeccionado por Pliego de Andrés y López Rico ${ }^{195}$ he podido añadir alguna obra más localizada en el curso de mi investigación (ver Apéndice 9.3, con obras anteriores a la etapa madrileña del compositor mencionado en la prensa murciana).

Según García Seco, Antonio López Almagro dio a conocer sus primeras composiciones en $1854^{196}$. Mariano Padilla hablaba así del armonista a mediados de los sesenta: "os recomiendo a mi amigo y aventajadísimo joven don Antonio López Marín, cuya constante aplicación y continuos desvelos, le han hecho crear composiciones que, por su originalidad y buen gusto, dan una muestra evidente de su claro y fecundo genio" $" 197$.

En 1866, el periódico El Artista entregó como suplemento la mazurca para piano Adela de López Almagro, poniendo por primera vez en contacto al compositor con el editor de Madrid. En salones de las sociedades recreativas murcianas López Almagro dio a conocer su Trío para armonio, piano y violín (1867), diferentes piezas de salón (Nocturno, 1866; Colección de polcas, 1866; Il Lamento, melodía para violín y piano, 1867; Dos danzas, 1867 ${ }^{198}$; Melodía para armonio, 1868, varias canciones (Il sospetto, melodía para canto y piano sobre poesía de Carlo Angiolini Clericetti, 1867; Adiós a Murcia, nocturno para canto y piano, 1868; Piu che mai, romanza para barítono, y el coro Himno a la libertad, estrenado por los alumnos del Orfeón en el Teatro de la Soberanía Nacional de Murcia en $1868^{199}$. Adiós a Murcia, escrito expresamente por López Almagro para la Sociedad Filarmónica de Murcia, fue estrenada por el cantante Mariano Padilla y se consideró una obra original y con algunas influencias germánicas:

${ }^{193}$ El Liberal, III (1904), no 743, 13 agosto, p. 1, edición de Murcia. En él se incluye un extenso artículo necrológico de Martínez Tornel.

${ }^{194}$ Gaceta de Instrucción Pública, XVII (1905), nº 708, 6 febrero, 1240; La Educación, IX (1905), $\mathrm{n}^{\mathrm{o}}$ 67, 20 febrero, p. 2.

${ }^{195}$ López Rico y Pliego de Andrés, Antonio López, pp. 107-117.

${ }^{196}$ Las primeras obras eran mazurcas, nocturnos y fantasías sobre óperas, según García Seco, "López Almagro", p. 263.

2.

${ }^{197}$ Mariano Padilla, “A mis queridos paisanos”, La Paz de Murcia, VIII (1865), no 2123, 7 marzo, p.

198 Obra no incluida en el catálogo de Víctor Pliego y José Salas.

${ }^{199}$ Véanse los Apéndices a los Capítulos 6 y 8. 
[...] Esta pieza, como todas las que hemos visto de este joven y estudioso compositor, tiene un tinte alemán de buen estilo, que se hace muy recomendable. La introducción excesivamente original, prepara al oyente para beber con avidez las sentidas notas de la inspirada melodía que le sigue. Las sucesivas ideas, melancólicas en alto grado, están bien concebidas y bien conducidas, hasta llegar al verdadero Adiós, enunciando en un canto genuino, tierno y apasionado y de un corte enteramente nuevo $[\ldots]^{200}$.

El Himno a las artes de López Almagro era una cantata para coro, pequeña orquesta, piano y armonio, escrita para la Sociedad Filarmónica de Cartagena y estrenada en junio de 1869 bajo la dirección de Gaspar Espinosa de los Monteros ${ }^{201}$. También en este año estrenó el compositor la sinfonía Tháder (21-08-1869) en los jardines del Buen Retiro de Madrid por la Sociedad de Conciertos, con la orquesta dirigida por Skozdopole $^{202}$. La crítica que Vicente Cuenca publicó en el Correo de la moda contenía comentarios favorables como éstos:

[...] La Sinfonía [en Fa Mayor] da principio con un allegro moderato en compás de cuatro parte, bien entendido y cuyo primer periodo que repite después en su relativo re, está perfectamente desarrollado, siendo de un efecto excelente la peroración que lo une al andante, en el mismo tono y compás.

El motivo de este modulado sabiamente lo inician los violines primeros y el oboe al unísono y cuya melodía se desarrolla en un animato para terminar en un tutti volviendo al primer intento, pero en un lindo pizzicato para conluir en $f a$ dominante del tono, al que siguen después una frase de cuatro compases, pero en allegro moderado, que es notable por varios conceptos.

A estos compases sigue otro Allegro spiritoso cuya modulación se fija en una melodía en mi $b$ mayor que se resuelve en obra menos movida, en fa natural mayor, y la cual en un crescendo bien comprendido termina en un tutti. En este tono principia un piú animato en que se repite el motivo primero por los violines, y después por estos acompañados con algunos instrumentos de viento, pasando la instrumentación por varios tonos.

La peroración final está escrita con mucha maestría y termina de una manera feliz el trabajo del señor López Almagro, de un modo digno $[\ldots]^{203}$.

Es posible que la buena acogida de obras de López Almagro en Madrid animara al compositor a plantearse su traslado a la capital.

Las décadas ochenta y noventa del siglo XIX fueron las más prolíficas para López Almagro en el campo de la música profana. Además de los ya citados métodos y obras pedagógicas para armonio y acordeón, compuso cuatro zarzuelas, varias reducciones de zarzuelas y fantasías inspiradas en óperas y zarzuelas, así como un gran número de piezas de salón. La primera producción escénica de López Almagro fue la zarzuela Dar posada al peregrino (libreto de Ricardo Gil), estrenada en el Teatro Romea de Murcia en febrero de 1874; sus restantes obras de este género fueron estrenadas en los escenarios madrileños (ver Capítulo 3, punto 4).

${ }^{200}$ La Paz de Murcia, XI (1868), nº 3293, 15 julio, p. 2.

${ }^{201}$ La parte de piano fue interpretada por Tamayo y ¿Leandro? Morata. La de piano, por Julián Bas Rodríguez de Calleja: La Paz de Murcia, XII (1869), nº 3597, 13 junio, p. 1.

${ }^{202}$ La Paz de Murcia, XII (1869), n 3660, 27 agosto, p. 1. Vázquez y Garbayo, "López Almagro”, p. 1003 menciona una sinfonía titulada El atardecer de 1869. En la prensa murciana no he hallado referencias a esta composición. Pliego de Andrés y Salas, op. cit. p. 17 afirman que no es del compositor.

${ }^{203}$ Vicente Cuenta, "Revista quincenal”, Correo de la Moda, XIX (1869), n 33, 2 septiembre, p. 264. 
Estrenada en el Teatro de la Zarzuela de Madrid el 2 de octubre de 1875, El hidalguillo de Ronda fue la segunda zarzuela de López Almagro, apenas unos meses después de la anterior. El libreto en tres actos era de Francisco Luis Retes y Francisco Pérez Echevarría. La prensa murciana siguió minuciosamente las noticias que llegaban desde Madrid sobre los ensayos de la zarzuela, realizados en el Teatro Jovellanos de la capital. La Paz de Murcia envió incluso a un corresponsal para cubrir el evento. La empresa había hecho una fuerte inversión en la escenografía y vestuario, según la prensa murciana $^{204}$. Sin embargo, la obra no triunfó. Se afirmó "que el maestro López Almagro, al presentar su primera obra al público de Madrid no sólo ha salvado un libro, sino que lo ha levantado satisfactoriamente" ${ }^{205}$. Peña y Goñi, en La Ilustración Española y Americana, calificó El Hidalguillo de Ronda como "autopsia a un cadáver, que un cadáver y no otra cosa es hoy la producción de los señores Retes y Echevarría, con música de un nuevo compositor, el señor don Antonio López Almagro" ${ }^{206}$. Peña y Goñi propinó duras críticas también a la música, en la que según él había instrumentación "inocente, negativa", "orquesta hueca", "giros melódicos manoseados y vulgares" y "armonía tísica en cuarto grado"207.

Un año después y en el mismo escenario del Teatro de la Zarzuela, se representó Ruede la bola (5-12-1876), una zarzuela en tres actos cuyo libreto, traducido del francés, fue obra de Echevarría y Santibáñez. Duró poco en cartel y tampoco obtuvo críticas elogiosas $^{208}$. El mayor éxito de López Almagro en los escenarios madrileños, aunque muy relativo, tuvo lugar con El capitán Centellas, zarzuela en tres actos compuesta en colaboración con Fernández Caballero, libreto de Juan José Herranz y estrenada en el Teatro Apolo el 15 de diciembre de 1883. Según La Época el "libreto, como escrito hace bastante años, no tiene el movimiento y la animación que ahora se pide a estas obras" aunque se elogió la maestría del compositor ${ }^{209}$.

Las obras más destacadas de López Almagro eran de salón. El famoso Canto de amor, que alcanzó numerosas ediciones y versiones fue, quizá, su obra más conocida en este campo. Algunas de las obras de López Almagro fueron difundidas por Europa (Mariano Padilla, por ejemplo, cantó Piu che mai en París en septiembre de $1868^{210}$ ) y varias se entregaron con los suplementos de algunas revistas. La citada Canto de amor se regaló en un número dominical de la revista "Última Moda" en mayo de 1890 en el que se incluyó, además, un artículo biográfico sobre el compositor escrito por Felipe Pedrell $^{211}$ y la Crónica de la Música entregó Romanza sin palabras de López Almagro

${ }^{204}$ La Paz de Murcia, XVIII (1875), n ${ }^{\text {os }} 5452,23$ septiembre, p. 1; 5459, 1 octubre, p. 1 y 5463, 6 octubre, p. 1.

${ }^{205}$ D. L., "El hidalguillo de Ronda", La Paz de Murcia, XVIII (1875), nº 5463, 6 octubre, p. 1.

${ }^{206}$ Antonio Peña y Goñi, “Crónica musical”, La Ilustración Española y Americana, XIX (1875), n 38, 15 octubre, pp. 235-236: 235

${ }^{207}$ Peña y Goñi, “Crónica musical”, p. 236.

${ }^{208}$ López Rico y Pliego de Andrés, Antonio López, p. 59.

${ }^{209}$ La Época, XXXV (1883), nº 11189, 16 diciembre, p. 3.

${ }^{210}$ Mariano Soriano Fuertes, "Revista musical de París”, La Correspondencia de España, XIX (1868), no 3945, 6 septiembre, pp. 3-4 e igual artículo en La Época, XX (1868), nº 6362, 7 septiembre, p. 1.

${ }^{211}$ Pedrell, "Celebridades contemporáneas", p. 7. 
escrita para armonio o piano ${ }^{212}$. Otras difundidas canciones para canto con acompañamiento del músico murciano fueron Il ruscellino (1872); Il pensiero de la patria lontana, La rondinella (de 1874); Amor inmortal, Amor y misterio, Pena y alegría (de 1875); Canto de la noche (1877); ;Non ti destare!, ;Mio padre!, Ingratitud (de 1884) y La azucena roja $(1889)^{213}$.

Las obras para armonio, piano y órgano ocuparon también un lugar destacado en la producción de López Almagro. A las doce piezas para armonio incluidas en su Método completo teórico-práctico de harmonium (órgano expresivo), hay que añadir los Diez estudios de velocidad para el harmonium (1875), Arabesco (1878) y Romanza sin palabras (1879), entre otras; las fantasías y arreglos para piano ya citados, los caprichos (como Ecos perdidos, 1877), nocturnos (La alborada, 1877), marchas (El abacá. Marcha filipina albayana), mazurcas (la colección Memorias de tres flores, 1876) y polcas (Cintra, 1881). Para órgano y armonio es el Andante expresivo (1884) y para dos armonios son sus dos transcripciones sobre melodías de Mercadante y Meyerbeer (1885).

Menos numerosas son las obras corales de López Almagro. En 1875 puso música a un "Himno a S.M. D. Alfonso XII de Borbón", que se cantó en el Teatro Romea de Murcia el 23 de enero de ese año (ver Figura 9.19). Casi diez años más tarde compuso una Barcarola que interpretaron la banda y coros de la Casa de la Misericordia en el jardín de Floridablanca de Murcia en la feria de septiembre de 1894.

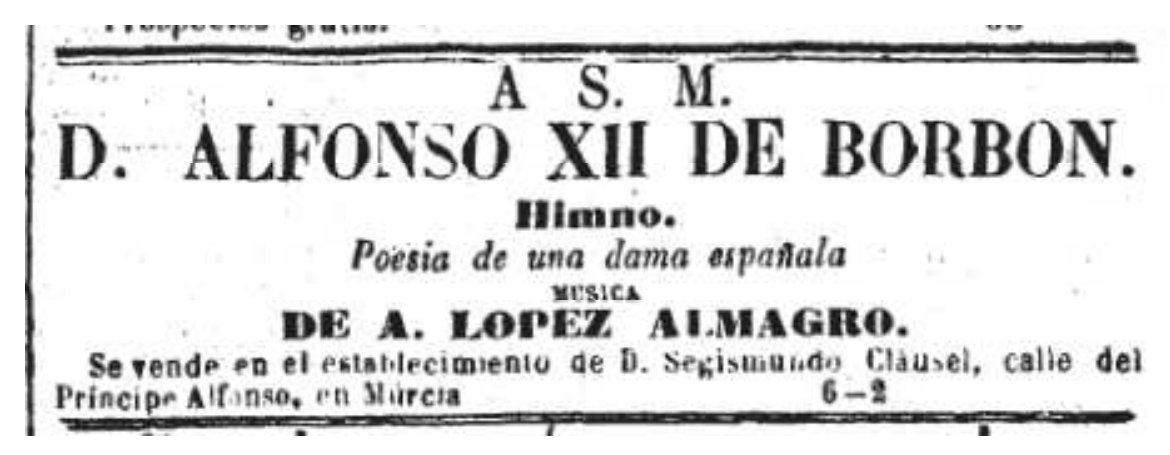

Figura 9. 19. Anuncio de la partitura del Himno a S. M. D. Alfonso XII de Borbón de Antonio López Almagro. E: MUm. La Paz de Murcia, XVIII (1875), nº 5265, 17 enero, p. 4.

Las primeras composiciones religiosas documentadas de López Almagro se remontan a 1866. Para las habituales novenas de Dolores, celebradas en la Iglesia Parroquial de San Nicolás de Murcia, estrenó el 15 de marzo de ese año el Cuarto y Quinto Dolor, con la participación del coro y orquesta de la Capilla de Música de la Catedral $^{214}$.

${ }^{212}$ La Iberia, XXVI (1879), nº 6834, 22 febrero, p. 3. Anuncio publicado también en La Unión, II (1879), no 144,25 febrero, p. 3.

${ }^{213}$ Alonso, La canción, pp. 475-47 destaca desde el punto de vista armónico La azucena roja y la romanza Ingratitud, a las que encuentra gran influencia italiana. Véanse más detalles sobre los autores de los poemas en López Rico y Pliego de Andrés, Antonio López, pp. 107-117.

214 Todas las obras musicales de esa función fueron escritas por murcianos aficionados y profesionales: el Primer Dolor era de Casadó, el segundo de Esteban Capdepón, el tercero de Quercop, el 
En 1868 estrenó López Almagro un Sanctus, un Agnus y un Benedictus, que fueron interpretados junto a un Kyrie, Gloria y Credo de Mercadante en una misa celebrada por la Real Archicofradía de la Santísima Trinidad en el día de su festividad (7 de junio) en la parroquia de San Juan Bautista de Murcia. La recepción de las piezas de López Almagro fue muy favorable:

[...] Fluidez en sus melodías, severidad en sus modulaciones, variedad en las inversiones de sus acordes, oportunidad y gusto en el uso del contrapunto florido, ved aquí los caracteres que distinguen al Sanctus del señor Lopez Almagro. El Benedictus puede decirse que está más bien escrito para ser cantado por ángeles que por hombres, pues es de un carácter apasionado y sublime que hubiera arrancado multiplicados aplausos a no haberse ejecutado en el templo. El Agnus que puede decirse figura como epílogo de la obra, es un conjunto de bellezas artísticas ya por la originalidad en sus cantos como por lo relacionado con la idea genuina. $[\ldots]^{215}$.

De 1881 es la Salve Regina de López Almagro a tres voces con acompañamiento de órgano o piano, publicada por Romero. En los últimos años de su vida, López Almagro produjo muchas obras religiosas como los villancicos En el portal de Belén, El establo, Gloria a Dios, El viaje de los Reyes Magos, de 1898 y el oratorio para Semana Santa Los Siete Dolores de la Santísima Virgen sobre texto de Ricardo Sánchez Madrigal (1903).

\section{Músicos murcianos nacidos en los años cuarenta y cincuenta}

\subsection{Fernando Verdú Sánchez (1845-1919)}

Fernando Verdú (Murcia, 1845- Murcia, 26/12/1919 216 ) fue violinista, compositor, director, funcionario y empresario. Estudió armonía, composición y piano con Mariano García y Celestino Mondéjar, y violín con Ángel Mirete ${ }^{217}$, aunque no se dedicó en exclusiva a la música. Verdú comenzó a trabajar en la Secretaría del Gobierno de Murcia como "escribiente meritorio" en marzo de 1866 y cuatro meses más tarde como "escribiente", ya con sueldo. Desde 1867 hasta 1870 ocupó un cargo similar en la Sección Central de Vigilancia. El 1 de octubre de 1874 fue nombrado Archivero del Gobierno Civil de Murcia, con una gratificación mensual de treinta pesetas $^{218}$. Fernando Verdú

cuarto y quinto de López Almagro, el Sexto de Mariano García y el séptimo de Agustín Rubio: La Paz de Murcia, IX (1866), n 2478, 16 marzo, p. 1.

${ }^{215}$ La Paz de Murcia, XI (1868), nº 3261, 10 junio, p. 1.

${ }^{216}$ Su esquela apareció en El Liberal, XVII (1919), nº 6312, 27 diciembre, p. 1.

${ }^{217}$ La Paz de Murcia, XXI (1878), nº 6313, 22 septiembre, p. 1 y Julián Calvo, "Remitido”, La Paz de Murcia, XXI (1878), nº 6313, 22 septiembre, p. 1.

${ }^{218}$ Véanse más detalles sobre los diversos cargos administrativos de Verdú hasta 1874 en: Enseñat y Montojo, “Orden público", p. 330; Montojo, "La administración provincial”, pp. 65-73; La Paz de Murcia, XI (1868), no 3379, 10 octubre, p. 2 y La Paz de Murcia, XXII (1879), nº 6553, 20 marzo, p. 1. La prensa describió a Fernando Verdú como "un empleado inteligente y laborioso, como lo tiene probado en más de veinte años que cuenta de servicio en dicha dependencia, siendo apreciado por todos los gobernadores": $L a$ Paz de Murcia, XXIX (1886), n 8963, 9 julio, p. 1. El 1 de julio de 1886 la Diputación Provincial de Murcia lo ascendió a "oficial segundo de la Sección de Examen de cuentas del Gobierno Civil", aunque a finales de ese mes le cesó, provocando un gran revuelo en la prensa murciana, que consideró el cese como una injusticia: El Diario de Murcia, VIII (1886), n ${ }^{\text {os }} 2221,1$ agosto, p. 3 y 2222, 3 agosto, p. 1. 
compatibilizó su labor en puestos administrativos con la actividad musical. En 1884, opositó sin éxito a la plaza de director de la orquesta del Teatro Romea. Aunque no la ganó, quedó como vicedirector pero sin sueldo por ese cargo.

Para esa oposición presentó dos sinfonías (1866 y 1867); una "Salve Regina a cinco voces, coro y grande orquesta" (1871); la obertura Tula (1876); una "Gran Marcha Triunfal para orquesta dedicada a Julián Romea" (1880); un "Magníficat para orquesta y tres voces" (1881); la obertura "Un ramillete dedicado a D. Julián Romea" (no consta el año) y un "Miserere a cuatro voces y coro con acompañamiento de orquesta dedicado a don Mariano García, Maestro de Capilla" (1883) (véase Capítulo 2). La prensa reclamó en varias ocasiones que Verdú quedara liberado de sus obligaciones como funcionario para que pudiera dedicarse por completo a la composición:

[...] Una persona de los méritos del señor Verdú, decía anteanoche otra que no le trata, debían tener a gala todas las diputaciones en darle un buen sueldo, no para que asistiera a la oficina, sino para que cada mes presentara algunos trabajos de esos que tanto nombre le dan en la música y a los que solo puede dedicar hoy los pocos ratos de ocio que tiene el señor Verdú. Dedicado exclusivamente a la música, no teniendo que buscar por otros medios el sustento de su honrada y apreciable familia, podía dar obras buenas con que enriqueces el arte y el nombre de Murcia $[\ldots]^{219}$.

Cuando en 1888 falleció Ángel Mirete, Fernando Verdú asumió la dirección de la orquesta del Teatro Romea hasta su supresión en mayo de 1890. Al frente de esta formación Verdú redactó el "Reglamento para el régimen de la Orquesta del Teatro Romea", que fue aprobado en noviembre de 1889. En los años siguientes, Fernando Verdú estuvo al frente de una formación orquestal (en parte formada por los miembros de la antigua orquesta del Teatro Romea) que actuó a veces al completo y a veces en pequeñas formaciones ${ }^{220}$. Con esta orquesta, Verdú participó en muchas veladas organizadas por las sociedades recreativas de la ciudad, ofreció serenatas a personajes ilustres (como la de Chapí en $1894^{221}$ ), acompañó a cantantes e instrumentistas en conciertos (como el de la condesa Vittoria Domenici ${ }^{22}$ ), y actuó con diversas compañías teatrales. Con el elenco de Wenceslao Bueno (Teatro Romea, $2^{\mathrm{a}}$ temporada de 18911892), por ejemplo, la orquesta de Verdú amenizó los intermedios:

${ }^{219}$ La Paz de Murcia, XXIX (1886), nº 8984, 3 agosto, p. 1.

${ }^{220}$ En la prensa se destacó el buen funcionamiento de esta orquesta. Véase por ejemplo, el comunicado escrito por algunos integrantes de la orquesta (Antonio Puche, Mariano Sanz, José Puche, Vicente Espada, Antonio Canales, J. Fresneda, Juan Pérez, Antonio Mendoza) en La Paz de Murcia, XXXIV (1891), nº 11279, 11 marzo, p. 1 (transcrito en el Documentario).

221 Chapí visitó Murcia en enero de 1894 para el estreno de su zarzuela Los Mostenses (libreto de Cantó, Arniches y Lucio): La Paz de Murcia, XXXVI (1894), nº 12603, 24 enero, p. 3. En 1891 se dio otra serenata a Ezequiel Díez Sanz de Revenga, diputado de la Provincia de Murcia en las Cortes durante la Regencia de María Cristina, con "repertorio nuevo en gran parte": La Paz de Murcia, XXXIV (1891), nº 11260, 15 febrero, p. 1.

${ }^{222}$ En esa ocasión, Verdú dirigió un sexteto (no ha quedado constancia con qué instrumentos) e interpretó cuatro sinfonías, además de acompañar a la citada cantante: La Paz de Murcia, XXXVI (1894), $\mathrm{n}^{\mathrm{o}} 12759,19$ agosto, p. 1. 
[...] Todas las noches, en los intermedios, la orquesta del señor Verdú viene ejecutando con gran acierto y precisión una serie de piezas selectas, y completamente nuevas muchas de ellas que agradan extraordinariamente al público, no sólo por el mérito de dichas obras sino también por la perfección y buen gusto con que las ejecuta la orquesta, bajo la competente y acertada dirección de su reputado maestro director don Fernando Verdú.

Anteanoche en uno de los intermedios tocó la referida orquesta una preciosa mazurca que el público aplaudió espontáneamente con gran entusiasmo, haciéndola repetir, cosa poco frecuente en las temporadas de obras dramáticas en las que se ejecuta la música durante los entreactos, cuando generalmente el público no fija en ella toda su atención $[\ldots]^{223}$.

En líneas generales, la crítica siempre fue favorable a Verdú, que fue un músico reconocido y querido en Murcia. Como violinista, participó regularmente en las veladas organizadas por las sociedades murcianas y en los conciertos privados en casas de músicos. Formó parte de la comisión de creación de un Conservatorio para la ciudad ${ }^{224}$ y también se interesó por la investigación de la música en Murcia, aunque no he hallado ninguno de sus escritos ${ }^{225}$. Al menos en 1884, Fernando Verdú tuvo una academia de música junto al maestro de capilla Mariano García (ver Capítulo 6) y, desde 1894 regentó un almacén de música (ver Figuras 9.20 y 9.21):

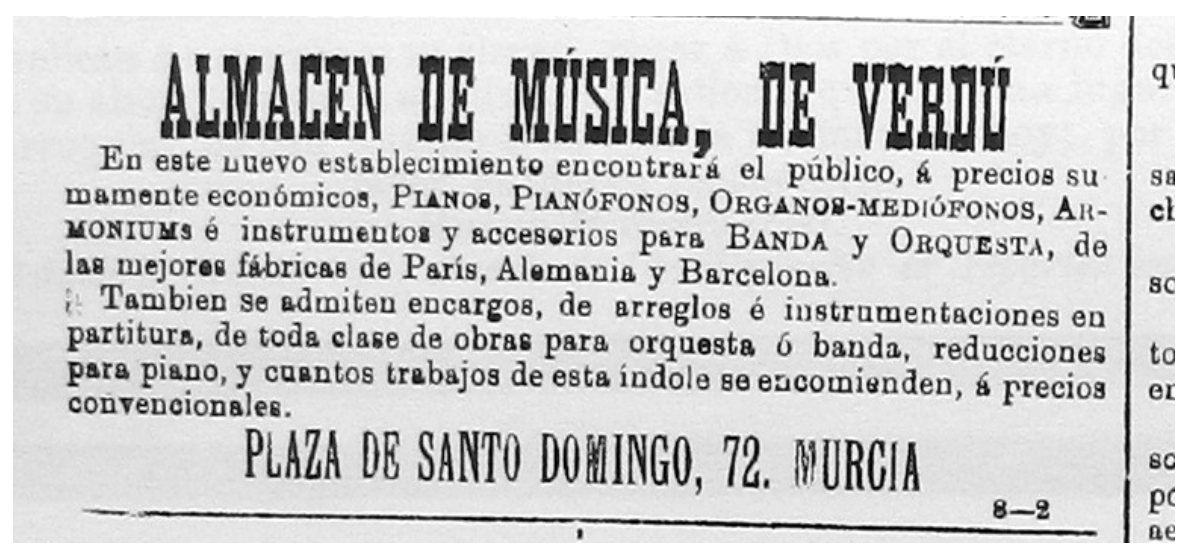

Figura 9. 20. Anuncio del Almacén de Música de Fernando Verdú en Murcia. El Diario de Murcia, XVI (1894), nº 6475, 5 diciembre, p. 1, E: MUm.

${ }^{223}$ El Diario de Murcia, XIV (1892), nº 4593, 24 marzo, p. 3. Otra actuación de la orquesta de Verdú fue con la compañía del primer actor y director Lino Ruiloa, según La Paz de Murcia, XXXVI (1894), n 12839, 21 noviembre, p. 1.

${ }^{224}$ La Paz de Murcia, XXIV (1881), no 7079, 22 junio, p. 1.

${ }^{225}$ El interés de Verdú por la investigación musical fue mencionado por Julián Calvo en una carta remitida a El Semanario Murciano, I (1878), nº 25, 4 agosto, p. 7. 


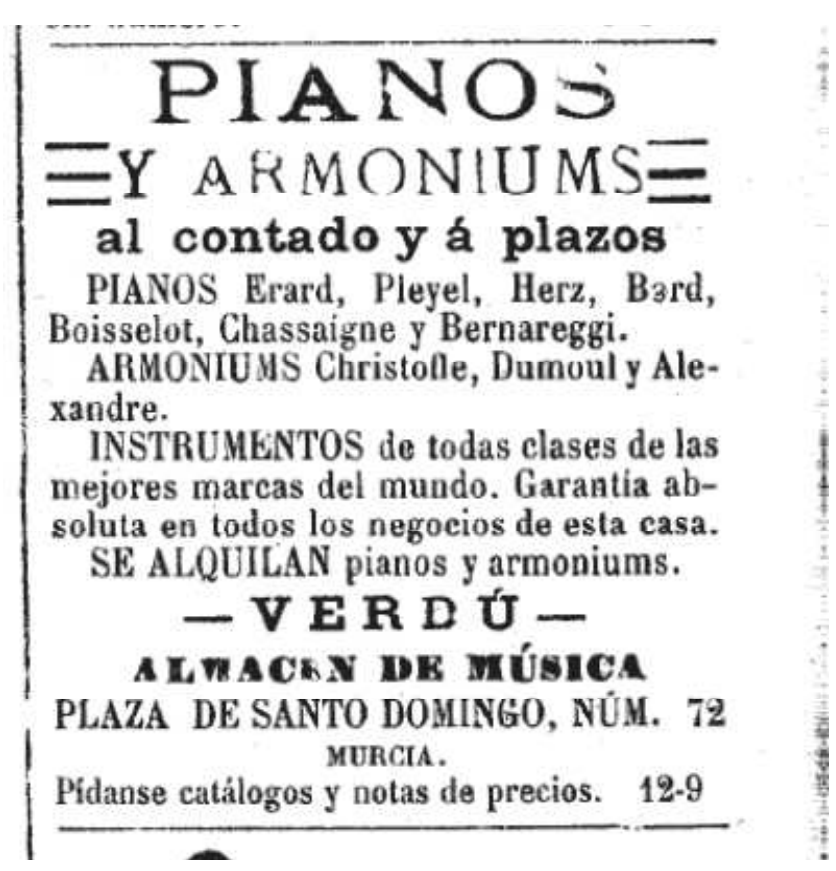

Figura 9. 21. Anuncio de instrumentos musicales disponibles en el Almacén de Música de Fernando Verdú en Murcia. E: MUm. El Diario de Murcia, XXII (1900), nº 8502, 20 diciembre, p. 4.

La vinculación de Fernando Verdú con los centros religiosos de Murcia (especialmente con la Catedral) y su buena relación con el maestro de capilla Mariano García sugieren que éste último pudo verle como su sucesor en el magisterio de capilla. De hecho, en 1906 Verdú fue mencionado en la prensa como maestro honorario de la catedral murciana ${ }^{226}$ y fue también presidente honorario de la Asociación Ceciliana o Capilla de Música de las Madres Agustinas, cargo con el que se le menciona en la prensa en $1919^{227}$.

Fernando Verdú tuvo al menos tres hijos de su matrimonio con Josefa Landívar Oroumendía (?-1902): Fernando, Bibiana y José2 28 . Fernando Verdú hijo murió el 24 de septiembre de 1891 , cuando contaba con diecisiete años de edad ${ }^{229}$. Bibiana Verdú fue esposa del periodista de La Verdad José Tolosa Hernández (fallecido en enero de $1913^{230}$ ) y tuvo dos hijas (Dolores y Matilde Tolosa Verdú). José Verdú Landívar (casado con Estrella Carreras) fue discípulo del maestro de capilla Mariano García, reputado compositor, violonchelista y autor de autor de un interesante Cancionero popular de la Región de Murcia (1906), reeditado por la Academia de Bellas Artes de Murcia en

${ }^{226}$ El Liberal, V (1906), n ${ }^{\text {o }}$ 1349, 12 abril, p. 1, edición de Murcia. Además, formó parte del tribunal al magisterio de capilla de la Catedral de Murcia en marzo de 1906, cuando el cargo quedó vacante por fallecimiento de Mariano García. A las pruebas concurrieron opositores de Orihuela, Teruel y Badajoz. El tribunal estuvo conformado por José Jubés, Fernando Verdú, Vicente Espada, Juan Ortega y José Jover: El Liberal, V (1906), n' 1318, 13 marzo, p. 3.

${ }^{227}$ El Liberal, XVIII (1919), nº 5985, 23 enero, p. 2.

${ }^{228}$ Véase La Paz de Murcia, XXXIV (1891), n 11437, 25 septiembre, p. 3, El Diario de Murcia, XI (1889), n 3819, 3 septiembre, p. 1 y El Liberal, XVII (1919), nº 6312, 27 diciembre, p. 1.

${ }^{229}$ La Paz de Murcia, XXXIV (1891), nº 11437, 25 septiembre, p. 3.

${ }^{230}$ El Tiempo, VII (1913), no 1384, 7 enero, p. 1. 
$2001^{231}$. Como compositor, José Verdú se dio a conocer con la sinfonía Murcia, que dedicó a la Diputación de Murcia en septiembre de $1889^{232}$. José Verdú Landívar murió el 29 de agosto de $1913^{233}$.

Hasta el momento no he localizado ninguna de las composiciones de Fernando Verdú. El Apéndice 9.4 muestra un listado de obras localizadas en fuentes periodísticas. Parece que Verdú se dio a conocer como compositor en una velada teatral de la sociedad del Círculo Industrial, en la que estrenó también una sinfonía $(1870)^{234}$. Para esta sociedad escribió y estrenó, más tarde, el capricho para coro y orquesta i Qué guasón!! (1871) y una Danza Bufa, con letra de Ignacio Basterrechea, que fue interpretada por el coro del Círculo Industrial $(1872)^{235}$.

Una parte importante de la música de Verdú era sinfónica, bien para orquesta sola (cinco sinfonías, una Marcha Triunfal y la obertura titulada Tula) o bien para coro y orquesta. Algunas de estas obras fueron premiadas dentro y fuera de la región de Murcia. La sinfonía Un ramillete, inspirada en cantes murcianos, obtuvo un galardón en el certamen literario-musical de la sociedad dramática Julián Romea de Barcelona en $1880^{236}$; y la Marcha Triunfal, dedicada a José Zorrilla, fue premiada por el Liceo de Granada en $1886^{237}$. Según el periódico granadino La Lealtad esta Marcha Triunfal de Verdú "pertenece al estilo instrumental del gran Meyerbeer. Está hábilmente trazada, tiene gran combinación armónica y está instrumentada con conocimiento de la orquesta" $^{, 238}$.

${ }^{231}$ El Diario de Murcia, XII (1890), n 4000, 12 abril, p. 3. José Verdú, Cancionero popular de la Región de Murcia (Murcia: Academia de Bellas Artes de Murcia, 2001).

${ }^{232}$ Esta sinfonía fue varias veces interpretadas en diferentes eventos de la ciudad. Véanse: La Paz de Murcia: XXXII (1889), no 9915, 5 septiembre, p. 4 y XXXIII (1890), n ${ }^{\text {os }} 10030,22$ enero, p. 4; 10095, 3 abril, p. 4; 11003, 13 abril, p. 1; 11008, 19 abril, p. 4 y 11009, 20 abril, p. 1.

${ }^{233}$ José Verdú Landívar, cuya esquela del primer aniversario de su muerte apareció en apareció en $E l$ Tiempo, VII (1914), nº 1966, 28 agosto, p. 2, tuvo un hijo llamado Fernando Verdú Carreras.

${ }^{234}$ La Paz de Murcia, XIII (1870), nº 3772, 12 enero, p. 1. La sinfonía volvió a ser interpretada en otras veladas de la sociedad Círculo Industrial (véanse los Apéndices del Capítulo 6). Según La Paz de Murcia, XIII (1870), n 3826, 16 marzo, p. 1, la obra causó “un prolongado y merecido aplauso". Fernando Verdú colaboró con el Círculo Industrial en otras ocasiones, incluso como actor. En junio de 1870 representó la zarzuela en un acto ;En las astas del toro!: La Paz de Murcia, XIII (1870), nº 3913, 29 junio, pp. 1, 4. En otras veladas, intervino leyendo poesías: La Paz de Murcia, XIV (1871), nº 4079, 28 enero, p. 1 .

${ }^{235}$ La Paz de Murcia: XIV (1871), n 4084, 4 febrero, p. 1 y XV (1872), nº 4542, 14 abril, p. 1.

${ }^{236}$ La Época, XXXII (1880), n ${ }^{\circ} 10154,7$ octubre, p. 4. La sinfonía fue interpretada en Murcia en la festividad de Santa Cecilia del año 1880; en la reinauguración del Teatro Romea (diciembre de 1880) a petición de El Semanario Murciano, III (1880), n ${ }^{\circ}$ 143, 7 noviembre, p. 359; y, un mes más tarde, en una función a beneficio de la orquesta en el Teatro Circo de la Rambla (enero de 1881): El Diario de Murcia, II (1880), $\mathrm{n}^{\text {os }} 539,23$ noviembre, p. 2 y 555, 12 diciembre, p. 3; El Semanario Murciano: III (1880), $\mathrm{n}^{\circ}$ 146, 28 noviembre, p. 384 y IV (1881), n 153, 16 enero, pp. 22-23; y La Paz de Murcia, XXIV (1881), nº 6948, 11 enero, p. 1.

${ }^{237}$ La Paz de Murcia, XXIX (1886), nº 8963, 9 julio, p. 1 y El Diario de Murcia, VIII (1886), nº 2203, 11 julio, p. 4. La obra fue interpretada en el acto de entrega de premios, celebrado el 28 de junio de 1886 en el Teatro de Isabel la Católica de Granada. Véase también, La Paz de Murcia, XXXII (1889), nº 9914, 4 septiembre, p. 4.

${ }^{238}$ Comentarios publicados en La Lealtad y reproducidos en El Diario de Murcia, VIII (1886), $\mathrm{n}^{\circ}$ 2203, 11 julio, p. 4. 
Entre las composiciones de Verdú para conjuntos de cámara estuvieron el Quinteto doble, la Prima Vellatta [sic], la Tanda de valses, y un arreglo de una Polca de Constant para instrumentos de madera y cuerda con piano ${ }^{239}$. El Quinteto doble, estrenado en 1878 en uno de los primeros conciertos de la recién inaugurada sociedad El Liceo tuvo éxito por las "muchas dificultades felizmente vencidas y delicado gusto"240.

En 1883 estrenó la gavota Aixarah con éxito de crítica: "Original e inspirada, reúne toda la gracia y sentimiento que se requiere para esta clase de obras, resultando un conjunto melódico y sumamente agradable, revestido con una instrumentación tan rica como sencilla y bien armonizada" 241 .

Fernando Verdú compuso también pequeñas piezas para canto y piano (entre ellas, la barcarola Amparo y la romanza A Catalina) y al menos dos obras escénicas, la zarzuela Un hallazgo a tiempo y la revista ;Murcia de mi corazón!.

La zarzuela de costumbres murcianas Un hallazgo a tiempo (junio de 1872), con libreto de Basterrechea fue representada por los alumnos de la Escuela de Canto y Declamación Padilla (ver Capítulos 3 y 6) ${ }^{242}$. En 1881, Verdú estrenó en el Teatro Circo de la Rambla la revista de costumbres y tipos populares en dos actos y verso ; Murcia de mi corazón! cuya música creó en colaboración con Salvador Grajales sobre libreto de José Martínez Tornel (ver Capítulo 3).

Verdú compuso numerosas obras religiosas, parte de ellas estrenadas en interpretadas con frecuencia en la Catedral de Murcia ${ }^{243}$. Algunas de esas obras fueron la Salve Regina a cinco voces, coro y grandes orquesta de 1871, Santa Madre de Dios, premiada en los Juegos Florales de 1878 y el magníficat i;Madre!!, premiado en los Juegos Florales celebrados en 1881 y un Ave María cuyo estreno tuvo lugar en la festividad de Santa Cecilia ( 22 de noviembre) de 1881. Sobre esta última pieza se dijo: "es mucho más religiosa que la de Gounod, [pues] está llena de primores de delicada instrumentación, matizada de notas al piano y es sentida como una plegaria fervorosa" ${ }^{244}$.

${ }^{239}$ La Paz de Murcia, XXVI (1883), nº 7622, 24 abril, p. 1.

${ }^{240}$ La Paz de Murcia, XXI (1878), nº 6231, 2 junio, p. 1. La obra fue interpretada por trece músicos, dirigidos por Fernando Verdú: La Paz de Murcia, XXI (1878), nº 6228, 29 mayo, p. 1. Fernando Verdú asumió la dirección de la Sociedad Santa Cecilia en 1882 y algunas de sus obras fueron interpretadas en las veladas de esta institución. El Quinteto Doble volvió a interpretarse en un concierto de la Sociedad Santa Cecilia en noviembre de 1881 (ver Capítulo 6).

${ }^{241}$ La Paz de Murcia, XXVI (1883), no 7779, 24 noviembre, p. 1. La gavota Aixarah fue posteriormente interpretada en una función teatral a beneficio del tenor Mariano Blaya en el Teatro Romea (30-11-1883): La Paz de Murcia, XXVI (1883), n 7780, 25 noviembre, p. 1. Véase también, El Diario de Murcia, V (1883), $\mathrm{n}^{\text {os }} 1433,21$ noviembre, p. 3 y 1437, 25 noviembre, p. 3.

${ }^{242}$ La Paz de Murcia, XV (1872), n 4502, 23 junio, p. 1; 4725, 30 marzo, p. 1; 4726, 1 abril, p. 1 y El Obrero, (1873), no 16, 3 abril, p. 4.

${ }^{243}$ En 1890, parte de los integrantes de la orquesta de Verdú lo eran también de la Capilla musical catedralicia: La Paz de Murcia, XXXIII (1890), no 11215, 25 diciembre, p. 1. El 5 de junio de 1891 la orquesta de Verdú participó en una ceremonia religiosa en la iglesia de Santo Domingo (por la festividad del Sagrado Corazón de Jesús o Corpus Christi), en esa ocasión, bajo dirección del maestro de capilla de la Catedral, Mariano García. Véase el programa de la ceremonia en: La Paz de Murcia, XXXIV (1891), $\mathrm{n}^{\circ}$ 11343, 2 junio, p. 4.

${ }^{244}$ El Diario de Murcia, III (1881), n 832, 23 noviembre, p. 2. Véase también El Semanario Murciano, IV (1881), n 194, 27 noviembre, p. 352. 
Una de las composiciones religiosas más celebres de Fernando Verdú fue un Miserere para solistas, coro y orquesta en once números, estrenado el Miércoles Santo de 1883 e interpretado frecuentemente en la Catedral de Murcia en los años siguientes ${ }^{245}$. Las críticas sobre esta obra fueron muy positivas. En 1883 se publicó:

[...] El Miserere es la mejor de sus obras conocidas [de Fernando Verdú] y como tal, la que más bellezas y menos defectos tiene. Oída con atención y tratando de apreciarla en toda su magnitud, la composición lleva al alma la elevación y el sentimiento. Sus faltas armónicas pasan desapercibidas en el conjunto grandioso de una orquestación valiente y nutrida y hasta la mucha variedad, que en algún pasaje casi se acerca a romper la unidad, queda velada ante la magnificencia de detalles y giros que adornan sentidas y originales melodías, presentadas con gusto y con perfecto conocimiento del arte $[\ldots]^{246}$.

En 1884, se comentó lo siguiente sobre el Miserere de Verdú: “Composición de género puramente filosófico, su joven autor ha rayado una altura eminente. Su orquestación es majestuosa y brillante. Sus giros armónico-melódicos caracterizan e interpretan concienzudamente aquellos versículos escritos por David en horas de amargura y toda la obra, en conjunto y en detalles, es digna de figurar entre las religiosas de más valor, por más que el nombre de modesto artista no haya traspuesto las fronteras de la provincia" 247 .

Según parece, algunos músicos vieron en el Miserere una gran influencia de la música teatral, lo que se consideraba poco adecuado para el entorno religioso. Antonio Ramírez Pagán, crítico de El Diario de Murcia pensaba, sin embargo, que "no hay incompatibilidad ninguna entre el desarrollo a que ha llegado a la música dramática y la música religiosa. Para cantar a Dios, todos los medios artísticos serán escasos"248. Ramírez valoró muy positivamente el Miserere de Verdú y su estilo ecléctico:

[...] Para expresar en sonidos esa lamentación tiernísima, ese grito inmenso de dolor que expresa el Miserere Mei secundum magnam misericordiam tuam, todos los adelantos de la música del porvenir serán insuficientes y pálidos. El autor ha estado en la composición de este número verdaderamente inspirado. Miserere, dicen las voces con acentos verdaderamente desgarradores, Miserere parece que repite la orquesta con acordes que llena el metal de sonoridad imponente, fundiéndose todos en un magnífico conjunto lleno de verdadera expresión religiosa y elevada.

Sigue el Amplius, que es un solo para voz de barítono, cantado por el señor Conde con delicadísima maestría. Tiene este número un preludio de violín muy bello y que yo no puedo considerar de ninguna manera como profano desde el momento en que admito compatible con el sentido de la plegaria religiosa que el texto expresa

${ }^{245}$ La Paz de Murcia, XXVI (1883), no 7566, 20 febrero, p. 1. El Miserere de Verdú también fue ejecutado el Jueves Santo de 1883.

${ }^{246}$ La Paz de Murcia, XXVI (1883), n ${ }^{\circ}$ 7595, 27 marzo, p. 1, transcrita íntegramente en el Documentario. Véanse también los comentarios de Antonio Ramírez Pagán, "El Miserere del Sr. Verdú", El Diario de Murcia, V (1883), n 1233, 25 marzo, pp. 1-2.

${ }^{247}$ La Paz de Murcia, XXVII (1884), no 7893, 13 abril, p. 1. En 1884 el Miserere de Verdú fue interpretado por el barítono Ramiro Conde y en 1885, por Faustino Millán: La Paz de Murcia, XXVIII (1885), $\mathrm{n}^{\mathrm{o}} 8184,31$ marzo, p. 1. El Miserere se repitió en la Semana Santa de 1888: La Paz de Murcia, XXXI (1888), no 9527, 12 junio, p. 1.

${ }^{248}$ Ramírez Pagán, “El Miserere”, p. 2. 
todas las filigranas, todas las delicadezas de forma que el estilo moderno ha perfeccionado de tan extraordinaria manera. La melodía es tierna y sentida y tiende en sus formas y en sus modulaciones a alejarse del estilo italiano para acercarse al estilo alemán, al estilo de Meyerber y del autor de "Aida". Ecce enim veritatem dilexiti: incerta et oeculta sapientae tue manifestati mihi. He aquí un número de música que yo no vacilaría en calificar de primer orden. [...] Es un coro de bajos, al unis, de corte majestuosísimo al que prestan extraordinario colorido aquellos acordes sueltos del metal que van acompañando $[\ldots]^{249}$.

Las composiciones religiosas de Verdú fueron muy valoradas por su instrumentación y varias de ellas sustituyeron a obras que tradicionalmente se habían interpretado en determinados eventos religiosos. Por ejemplo, el ya citado Miserere desplazó al de Indalecio Soriano Fuertes. En la festividad de la Patrona de Murcia, la Virgen de la Fuensanta se impusieron una Salve Regina, un Trisagio y un Santo Dios, compuestos por Fernando Verdú en 1883:

[...] El señor Verdú, innovador y artista de genio, ha querido romper con la monotonía de ciertos cantos que largos años venimos oyendo y al escribir expresamente el Santo Dios y el Trisagio para las magníficas voces de don Mariano Blaya y don Ramiro Conde, haciendo los melodías de un carácter eminentemente religioso, con una perfecta aplicación de letra y con una hermosura de frases originales y sentidas, que dejaron muy satisfecho el ánimo del auditorio.

Su obra más saliente es la Salve a grande orquesta, composición tan original como inspirada y vestida con el ropaje de una instrumentación rica, variada, amena y llena de detalles a cual más agradable. De entre todas las partes de que se compone, el terceto de tenor, barítono y bajo, fue el que produjo mayor efecto, por la hermosura y filosofía de sus frases. $[\ldots]^{250}$.

También durante las fiestas de la Virgen de la Fuensanta pero en 1887, Verdú estrenó en la Catedral e Murcia un Kyrie y un Gloria ${ }^{251}$, que eran parte de una Misa para voces solistas, coro y orquesta interpretada íntegramente por primera vez en septiembre de $1891^{252}$. Para las mismas fiestas patronales Verdú escribió una segunda Misa en 1894, que se consideró más lograda y religiosa que la primera:

Fernando Verdú es modernista, pero lo es a toda conciencia. La Misa estrenada ayer en la Catedral, en la función a la Virgen de la Fuensanta revela dos importantes adelantos en la música del distinguido maestro. Su factura es más cuidada, más acabada y más perfecta que en anteriores composiciones y como obra religiosa está más impregnada del espíritu místico que su otra Misa grande que, si tiene efectos más brillantes, es en cambio de carácter algún tanto profano. Esta, la de ahora, es más adecuada, es verdaderamente música sagrada $[\ldots]^{253}$.

${ }^{249}$ Ramírez Pagán, “El Miserere”, p. 2.

${ }^{250}$ La Paz de Murcia, XXVI (1883), no 7723, 13 septiembre, p. 1.

${ }^{251}$ La Paz de Murcia, XXX (1887), nº 8298, 13 septiembre, p. 1.

${ }^{252}$ La Paz de Murcia, XXXIV (1891), no 11424, 10 septiembre, p. 3. La Misa fue interpretada junto a su Trisagio y Santo Dios. En la ceremonia participaron los bajos Rafael Rex Torrano y Antonio Noguera.

253 [Anónimo], "La nueva Misa del señor Verdú”, El Diario de Murcia, XVI (1894), nº 6391, 12 septiembre, p. 2. La Misa era para solistas, coro y orquesta: La Paz de Murcia, XXXVI (1894), $\mathrm{n}^{\text {os }} 12776,8$ septiembre, p. 1 y 12778, 11 septiembre, p. 1. 
Otras composiciones religiosas de Fernando Verdú fueron un Te Deum a tres voces y coro, dedicado al Ayuntamiento de Murcia y escrito tras la epidemia de cólera de $1885^{254}$; así como una "fermata" (cadencia) para uno de los responsorios del maestro de capilla Agustín Giménez ${ }^{255}$.

\subsection{Adolfo Gascón Leante (1852-?)}

Adolfo Gascón Leante (Murcia, 1852-?) era hijo del platero y comerciante de diamantes turolense José Gascón y Galindo (1822-1892) y de María Leante García (1824?). De familia acomodada, su padre regentó una de las joyerías más prestigiosas y selectas de Murcia. El matrimonio tuvo seis hijos, aunque tres de ellos murieron a temprana edad $^{256}$. Adolfo Gascón era ciego de nacimiento, lo que no fue un impedimento para su notable carrera musical. Fue discípulo de Mariano García, que le valoraba muy positivamente:

[...] El señor Gascón es un artista de excelentes dotes musicales. A su profesor, don Mariano García, se lo hemos oído elogiar muchas veces y debe caberles a entrambos la satisfacción de ser esto un hecho innegable, puesto que el señor Gascón ha visto sus aspiraciones artísticas premiadas en varios certámenes públicos.

Como pianista debe figurar uno de los primeros, pues tiene acreditado que posee el piano perfectamente tanto en ejecución como en conocimientos. En cuanto a lo primero se ha hecho oír con gran éxito en música de concierto y premiadas varias obras para el mencionado instrumento, teniendo algunas publicadas en Madrid. Añádese a esto lo que le enaltecen sus buenos discípulos, en particular, doña Mariana Ramírez, tanto en el piano cuanto en el canto y el señor García (también ciego) $[\ldots]^{257}$.

Gascón tuvo una variada actividad musical como empresario, comerciante, compositor, pianista, armonista y profesor ${ }^{258}$. Fue promotor y dueño del Café Oriental y de un almacén de música, centros que contribuyeron a dinamizar la vida musical murciana. Según Antonio Ramírez Pagán, el almacén de Gascón era "un establecimiento que honra a esta capital. Hay en él, no solo un vario y abundante surtido de cuanto constituye el comercio musical, sino que a la vez su elegante salón sirve de centro artístico entre profesores y aficionados, organizándose por tal motivo deliciosos

${ }^{254}$ La epidemia de cólera se inició el 4 de junio de 1885, causando miles de muertos: La Paz de Murcia, XXVIII (1885), $\mathrm{n}^{\circ} 8270,14$ julio, p. 1. Como fue habitual en este tipo de catástrofes, las autoridades civiles y el cabildo eclesiástico dispusieron un Te Deum "en el día que se declare Murcia libre del cólera": El Diario de Murcia, VII (1885), n 1913, 19 julio, p. 3. El Te Deum se estrenó el 9 de octubre de 1885: La Paz de Murcia, XXVIII (1885), nº 8339, 9 octubre, p. 1.

${ }^{255}$ La Paz de Murcia, XXXIII (1890), nº 11215, 25 diciembre, p. 1.

${ }^{256}$ Sus hermanos fueron Julio Gascón Leante y José Gascón Leante. Candel, "Plateros murcianos”, pp. $113-134$

${ }^{257}$ Julián Calvo, "Remitido", La Paz de Murcia, XXI (1878), n 6313, 22 septiembre, p. 1. Transcrito íntegro en el Documentario.

${ }^{258}$ Fue propietario del periódico La Tarde de Murcia, editado desde agosto de 1895 . Véase Apéndice 1.3 . 
conciertos o veladas musicales" 259 . Las Figuras 9.22 y 9.23 muestran un anuncio en prensa de este almacén y su ubicación en el plano urbano de Murcia ${ }^{260}$.

Adolfo Gascón tocaba habitualmente el piano y el armonio en los salones de las sociedades recreativas de la ciudad, en su Café Oriental y en los conciertos de su almacén de música.

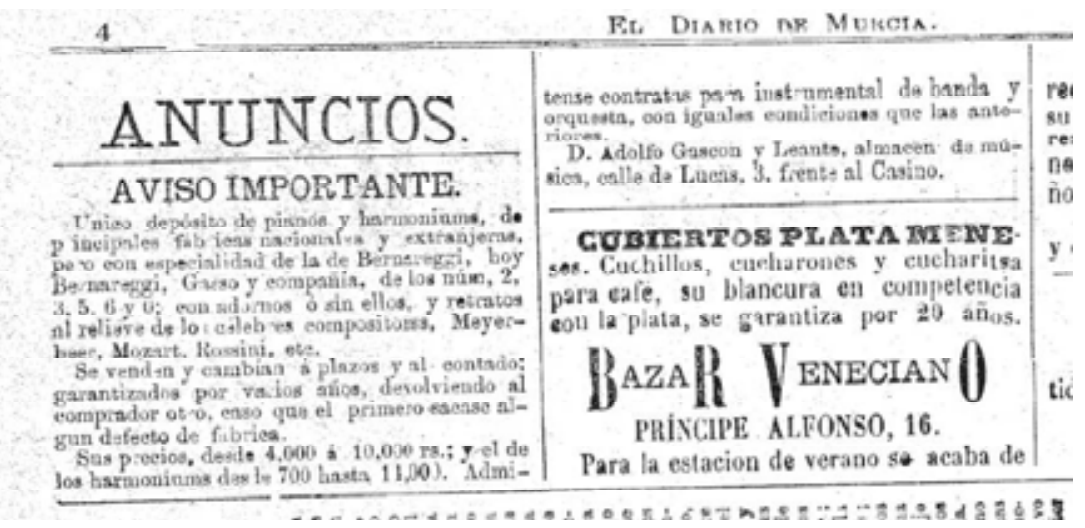

Figura 9. 22. Anuncio del almacén de música de Adolfo Gascón en Murcia.

E: MUm. El Diario de Murcia, II (1880), nº 373, 5 mayo, p. 4.

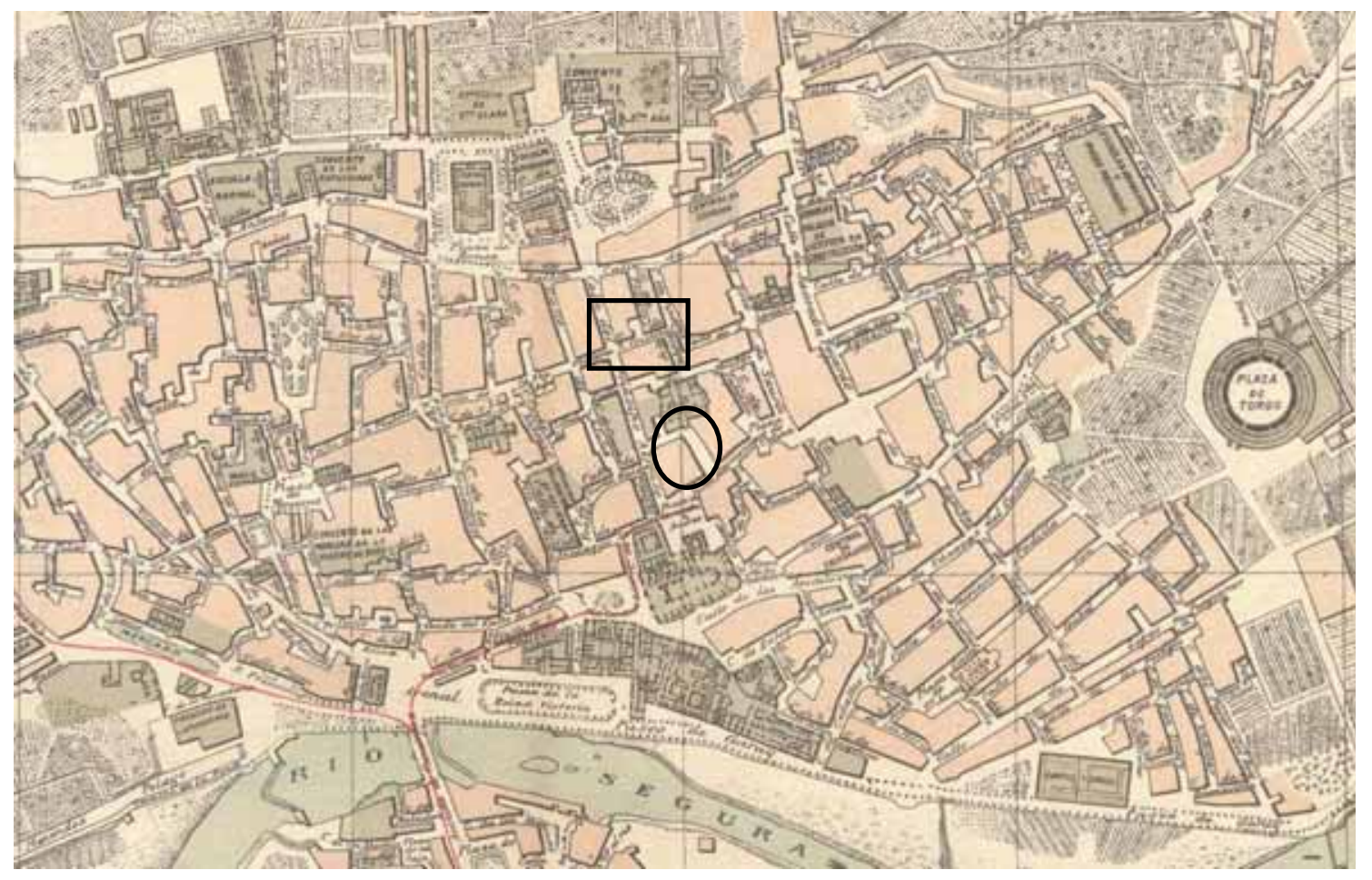

Figura 9. 23. Localizaciones del almacén de música de Adolfo Gascón en 1880, calle Lucas (círculo) y 1904, San Cristóbal, 4 (rectángulo). Pedro García Faria, Plano de Murcia (Barcelona: Alberto Martín, s.a.). $E: M p b$. Accesible en: http://bibliotecadigital.carm.es (acceso el 16-07-2011).

259 Antonio Ramírez Pagán, "Velada musical", El Diario de Murcia, VII (1885), n 2037, 24 diciembre, p. 2.

260 Al menos desde 1892, la ubicación de este almacén cambió a la calle San Cristóbal: Camilo Botella, Guía consultiva de la ciudad de Murcia para el año 1891 (Murcia: Tipografía de Rafael Albaladejo, 1891), p. 265. En 1904, Gascón fue corresponsal de la compañía francesa de Gramophone y vendió estos aparatos en la calle San Cristóbal, 4: Heraldo de Madrid, XV (1904), n 4918, 10 mayo, p. 6. 
Adolfo Gascón compuso cuatro zarzuelas: Los riffeños, en un acto, con libreto de Joaquín Arques, estrenada en octubre de 1893 en el Teatro Romea ${ }^{261}$, El mono sabio, también en un acto con libreto de Joaquín Arques y estrenada en el Teatro Romea en marzo de 1894, El trío Tragaderas o El Alcalde de mi pueblo (en colaboración con el compositor Julián Calvo), con libreto de Juan Martínez Espinosa y, estrenada en el Teatro Circo de Villar en enero de $1895^{262}$ y la zarzuela en un acto titulada El asistente de Zaragata (libreto de Enrique Gallego) y cuyo estreno tuvo lugar en enero de 1896 en el Teatro Romea (ver Capítulo 3).

Gascón compuso un gran número de piezas de salón, algunas de ellas premiadas en los Juegos Florales de Murcia. Entre sus obras para piano destacan la "Fantasía para piano sobre motivos de la ópera Anna Bolena de Donizetti"; la "Fantasía para piano sobre motivos de Lucia di Lammermoor, premiada en los Juegos Florales de 1877; las marzurcas La perla murciana, Mazurca de salón, La floresta, Una sonrisa; el nocturno Plácidas noches; la polca La caprichosa y los valses titulados A orillas del Tháder, El nocturno, El capricho y Un recuerdo. Para canto y acompañamiento eran, entre otras, la melodía para canto y piano Amor sin esperanza (premiada con la Flor Natural de los Juegos Florales de 1874); la barcarola para tiple y piano El amor merced de las olas (premiada en los Juegos Florales de 1876); el himno para coro A la patria, con letra de Ricardo Sánchez Madrigal, estrenado en el Teatro del Liceo de Murcia en 1878 y la romanza Don Rodrigo (premiada en los Juegos Florales de $1877^{263}$ ). El "Andante de cuarteto" El estudio conduce a la inmortalidad de Gascón fue premiado en los Juegos Florales de 1875 (ver Capítulo 11).

Adolfo Gascón experimentó también con la producción religiosa, a la que pertenecen sus obras El Ángel que anunció a María, un Ave maría para tiple o tenor con acompañamiento de órgano, armonio o piano ${ }^{264}$ y el Laudate Veni Creator, una coral para coro, cuarteto y gran orquesta, premiado en los Juegos Florales de 1877.

Según Julián Calvo, Adolfo Gascón también se interesó por la investigación de la música en Murcia, aunque no he hallado más datos sobre esta actividad suya ${ }^{265}$.

${ }^{261}$ El diario de Murcia, XV (1893), $\mathrm{n}^{\circ}$ 6076, 28 octubre, p. 3.

${ }^{262}$ La Paz de Murcia, XXXVII (1895), nº 12886, 19 enero, p. 3.

${ }^{263}$ En E:Mn se conserva una partitura manuscrita de De audaces es la fortuna: romanza de tenor con acompañamiento de piano y armonio sobre el drama lírico D. Rodrigo por D. Antonio Arnao de Adolfo Gascón Leante (signatura MP/3177/2).

${ }^{264}$ El Ángel que anunció a María. Ave María de tiple o tenor para órgano, harmonium o piano se imprimió en Murcia, aunque no hay constancia del impresor ni del año de publicación. Esta obra se conserva actualmente en $E: B b c$.

${ }^{265}$ Julián Calvo, "Remitido", El Semanario Murciano, I (1878), nº 25, 4 agosto, p. 7. 



\section{Capítulo 10. Mariano Padilla (1843-1906): un barítono murciano de proyección internacional}

Mariano Padilla Ramos (Murcia, 18/07/1843- Biarritz, Francia, ¿30?/11/1906) fue uno de los cantantes murcianos con más proyección internacional. En la actualidad, no existe ningún estudio publicado que aborde la carrera de este barítono, y sólo se publicaron algunos datos dispersos sobre él en la prensa murciana de su época y, más recientemente, en algunos diccionarios sobre música y músicos ${ }^{1}$.

A través de diversas colecciones de prensa españolas e italianas, he podido reconstruir gran parte de la carrera artística nacional e internacional de Padilla ${ }^{2}$, aunque existen todavía interrogantes, especialmente en la epata final de su vida. Provisionalmente, he dividido trayectoria de Mariano Padilla, cuyo retrato se muestra en la Figura 10.1, en tres grandes etapas: infancia y juventud, estudios en Italia y trayectoria profesional posterior.

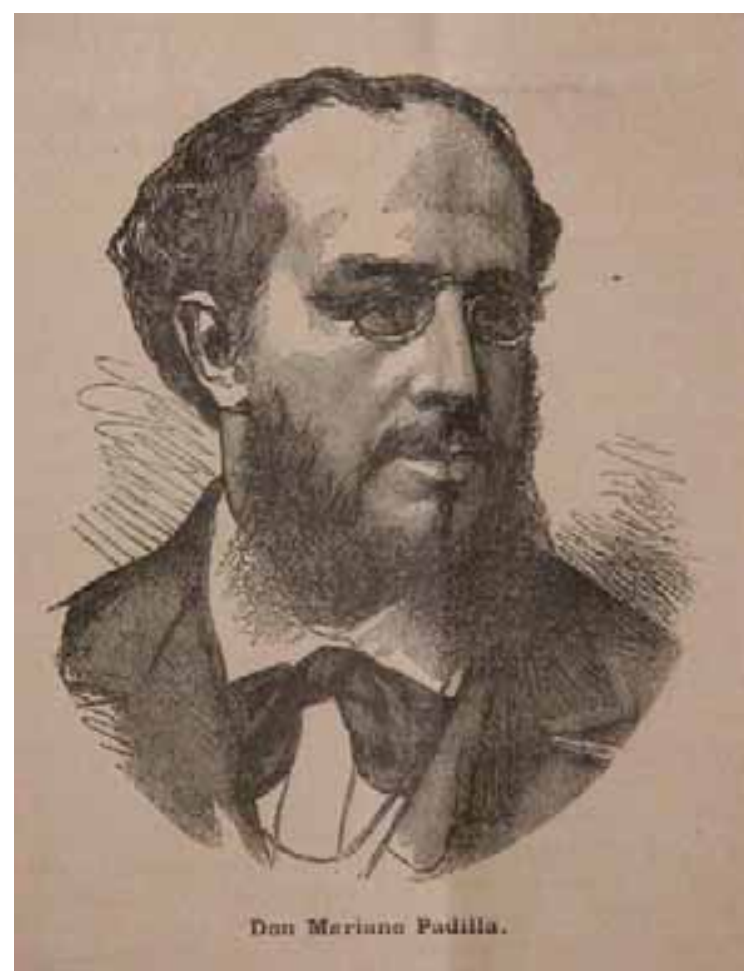

Figura 10.1. Retrato de Mariano Padilla Ramos (1843-1906). Cartagena Artística, I (1890), nº 23, 20 noviembre, p. 94, E: MUm.

1 Eduardo Santos Cánovas, "Don Mariano Padilla", Cartagena Artística, I (1890), no 23, 20 noviembre, p. 1; José Martínez Tornel, "Mariano Padilla", El Liberal, V (1906), no 1663, 2 diciembre, p. 1; García Seco, "Padilla y Ramos", p. 42; Saldoni, Diccionario, vol. II, pp. 112-115; Cano Benavente, Murcianos, pp. 257-261; [Anónimo], "Padilla y Ramos", Dizionario, vol. V, p. 497; Morales Villar, Los tratados, t. 2, p. 139 y la breve información de [Anónimo], "Padilla y Ramos", The New Grove, vol. 18, p. 875 .

2 Para realizar este estudio, he ampliado mis fuentes de consulta con diversas colecciones periódicas españolas e italianas (ver Introducción). Las colecciones periódicas italianas han sido estudiadas durante un periodo de tres meses de estancia en Roma becada por las universidades de Granada y Murcia bajo la tutela del profesor Franco Piperno de la Universidad La Sapienza de Roma en 2007. 


\section{Infancia y juventud: la formación musical de Mariano Padilla en España (1843- 1855)}

Francisco de Asís Mariano del Carmen Marco Padilla Ramos nació en Murcia el 18 de julio de $1843^{3}$ y fue el cuarto de los seis hijos que tuvo el matrimonio formado por Antonio Marco Padilla, Procurador del Número y Notario de la ciudad de Murcia, natural de Orihuela (Alicante) y Manuela Ramos de Alba, de Beniel (Murcia) ${ }^{4}$. Mariano Padilla es en realidad un apodo artístico. El cantante no utilizó su primer nombre (Francisco) ya que su hermana menor también se llamaba Francisca ${ }^{5}$ y además, Mariano Padilla solía utilizar el primer apellido compuesto (Marco Padilla) al menos durante su periodo como estudiante en el Conservatorio Superior de Música de Madrid (ver Figura 10.2). Posteriormente y durante su estancia por estudios en Italia, debió desprenderse de Marco (que allí es un nombre), conociéndosele desde entonces como Mariano Padilla ${ }^{6}$.

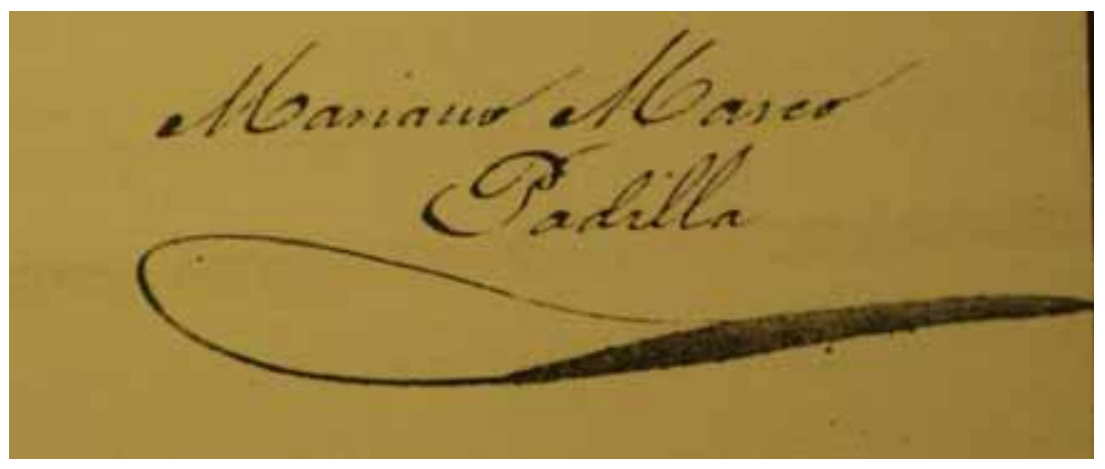

Figura 10.2. Firma de Mariano Padilla en 1855. E:Mc, Leg. 10, Exp. 74.

${ }^{3} E: M U p j$, Libro de Bautismos no 18 , fol. $100 \mathrm{v}$. La transcripción de su partida de bautismo puede consultarse en el Apéndice 10.1. Ninguna de las fechas que hasta el momento se han publicado sobre el nacimiento de Mariano Padilla son correctas y existe, además, cierta confusión sobre sus verdaderos apellidos (ver Nota 5). García Seco, "Padilla y Ramos", p. 42 sitúa su nacimiento el 31 de mayo de 1836, fecha en la nació su hermano Antonio Marco Ramos, según consta en el Libro de Bautismos $\mathrm{n}^{\circ} 17$ de E:MUpj, fol. 180. Las entradas correspondientes a Padilla en The New Grove Dictionary of Music and Musicians y en el Dizionario Enciclopedico Universale della Musica e dei Musicisti indican 1842 como el año de nacimiento de Padilla. En El Diario de Murcia, VII (1885), nº 1770, 10 enero, p. 3 se afirmó que la fecha de nacimiento del barítono murciano era el 16 de marzo de 1834, información tomada de Salón Romero. Almanaque Musical para el año 1885 (Madrid: Antonio Romero, 1885), p. 11.

${ }^{4}$ Información que también constata Cano Benavente, Murcianos, p. 258 tras la consulta del testamento del padre de Mariano Padilla. El Apéndice 10.2 contiene una reconstrucción del árbol genealógico de Mariano Padilla.

${ }^{5}$ Francisca Marco-Padilla Ramos es la única de los hijos del matrimonio en cuya partida de bautismo figuran los dos apellidos del padre y el primero de la madre. Los apellidos del cantante se han escrito de muy diversas maneras en las fuentes consultadas. García Seco titula su voz "Padilla y Ramos, Mariano", de la misma forma que en The New Grove Dictionary y en Dizionario Enciclopedico Universale della Musica e dei Musicisti. En la sesión que el Ayuntamiento de Murcia trató la inscripción del nombre de Mariano Padilla en el monumento de artistas célebres de la plaza Santa Isabel de Murcia se menciona como Mariano Marco Ramos de Padilla (E: MUm, A.C. 25-01-1907, fol. 225 r.) y en la que se acordó dar su nombre a la antigua calle de la Corredera aparece como Mariano Padilla (E: MUm, A.C. 13-09-1886, fol. 328 v.).

${ }^{6}$ Así lo corroboran las primeras noticias encontradas en la prensa italiana, que mencionan al cantante simplemente como Padilla: L'Arte, VII (1857), $\mathrm{n}^{\mathrm{os}}$ 64, 12 agosto, p. 4 y 50, 15 diciembre, p. 4; o Mariano Padilla: Eptacordo VII (1862), n 22, 28 febrero, p. 92. 
Son escasísimos los datos que aporta la prensa murciana sobre los primeros contactos de Mariano Padilla con la música en Murcia. Sólo ha quedado constancia de su participación en conciertos privados organizados por destacadas personalidades, como el Vizconde de Huerta, en los que se animó al joven a dedicarse al canto ${ }^{7}$.

Al margen de estos contactos iniciales, la música no pareció ser el camino elegido por sus padres para el futuro profesional de Padilla. Saldoni afirmó que estudió filosofía y que sus padres le instaron, más tarde, a estudiar Derecho en Madrid, una carrera muy arraigada en su familia ${ }^{8}$. Sin embargo, sus "inclinaciones musicales" le llevaron a ingresar, en mayo de 1855, en las clases de canto de Baltasar Saldoni, Catedrático de Canto en el Conservatorio de Música y Declamación de Madrid 9 .

Al menos durante ese año Padilla tomó lecciones de canto y participó en los diversos eventos organizados por el Conservatorio madrileño, a veces junto a otras instituciones de la ciudad, como el Teatro Real y la Capilla Real de Madrid. El 1 de julio de 1855, Padilla cantó la Romanza del Furioso [sic] de Donizetti en uno de los habituales "ejercicios" que el Conservatorio organizaba con la finalidad de observar los adelantos de los alumnos y ante la presencia la reina Isabel $\mathrm{II}^{10}$. Mariano Padilla coincidió con otros músicos murcianos desplazados a la capital para estudiar en el Conservatorio de Música y Declamación de la capital, como el compositor Manuel Fernández Caballero ${ }^{11}$, el pianista Luis Mondéjar y los cantantes Carlos Beltrán, Rafael Mancha y Miguel Albelda ${ }^{12}$.

En noviembre de 1855 Mariano Padilla escribió una carta al Viceprotector del Conservatorio, que marca el final de su etapa de aprendizaje en la capital española ${ }^{13}$. En la carta, Padilla explicaba que había tenido una entrevista con el cantante Federico Beneventano (sin informar de ello a su profesor Saldoni), ya que el prestigioso barítono

\footnotetext{
${ }^{7}$ Por ejemplo en La Paz de Murcia, XXX (1887), no 9307, 14 diciembre, p. 1. Es probable que, al igual que otros músicos murcianos del momento, Mariano Padilla tuviera sus primeros contactos con la música en alguna de las capillas musicales de Murcia (como la del convento de las Agustinas o la Catedral de Murcia) o en el Colegio de San Leandro.

${ }^{8}$ Además del citado cargo de Notario de su padre, Antonio Marco, su tío y padrino, Francisco Marco Padilla ejerció de abogado.

9 García Seco, "Padilla y Ramos", p. 42 afirma que Saldoni "aprecia[ba] la calidad de voz y condiciones naturales del joven discípulo”. Véase también Morales Villar, Los tratados, t. 1, p. 343.

${ }^{10}$ E:Mc, Leg. 10, Exp. 57. Saldoni refiere las palabras que el crítico de El Correo Universal (4 de julio de 1855) le dedicó a Padilla en el mencionado concierto: "Terminaremos esta ligera reseña (la del concierto) mencionando la extensa voz del señor Padilla, joven barítono que sólo lleva un mes de escuela y que nos inspira grandes esperanzas si continúa aprovechándose así de las lecciones del señor Saldoni, Diccionario, p. 113. La Iberia, II (1855), n 323, 6 julio, p. 4, aunque no mencionó a Padilla, informó del éxito de la velada: "Conservatorio de música y declamación. [...]. Los alumnos del conservatorio que tomaron parte en la orquesta y en el canto y coros, estuvieron felicísimos”.

${ }^{11}$ Manuel Fernández Caballero inició sus estudios en el Conservatorio de Música y Declamación de Madrid el 8 de septiembre de 1850. Estudió piano con Pedro Albéniz, acompañamiento con Antonio Aguado, violín con José Vega y armonía con Mariano Soriano Fuertes e Hilarión Eslava. Obtuvo el Premio de Composición en 1856, a cuyo acto de entrega acudió la reina Isabel II, según González Cutillas, "Manuel Fernández”, p. 245. Véanse más detalles en Iberni, "Fernández Caballero”, pp. 745-755.

12 E:Mc, Leg. 9, Exp. 69: “Admisión de alumnos del Conservatorio de Música y Declamación de Madrid" (03-09-1854), fol. 5. Véanse los datos que aporto sobre Luis Mondéjar en el Capítulo 11.

${ }^{13}$ E:Mc, Leg. 10, Exp. 74: "Don Mariano Marco Padilla al señor Vice-Protector, disculpando su entrevista con el artista italiano señor Beneventano" (12-11-1855).
} 
italiano se había interesado por sus aptitudes como cantante. El asunto debió molestar a Saldoni y Padilla se vio en la obligación de justificarse ante el Viceprotector del Conservatorio (ver Apéndice 10.3). Es muy probable que Beneventano animara a Padilla y le proporcionara los contactos necesarios para marcharse a Florencia a continuar su formación musical e incluso tomara algunas clases particulares en Madrid ${ }^{14}$.

No hay constancia documental de su partida hacia Italia aunque debió de tener lugar en los primeros meses de 1856.

\section{Etapa italiana: conclusión de sus estudios musicales y despegue profesional (1856-1861)}

En Florencia, Mariano Padilla tuvo como maestros a dos grandes músicos del momento: el compositor y director Teodulo Mabellini ${ }^{15}$ y el barítono Sebastiano Ronconi, hermano del también barítono Giorgio Ronconi ${ }^{16}$.

A pesar de que la etapa florentina de Padilla aún no ha sido exhaustivamente investigada, cabe suponer que el elevado ambiente musical de la ciudad repercutiera muy positivamente en el cantante. La ciudad contaba con numerosas asociaciones y sociedades musicales, así como con varios teatros en los que se hicieron importantes premières de ópera italiana ${ }^{17}$. En agosto de 1857, Padilla figuró, entre otros cantantes, en los preparativos de un concierto que tendría lugar en el Palacio Vecchio de Florencia ${ }^{18}$ y en

${ }^{14}$ Morales Villar, Los tratados, t. 2, p. 139.

${ }^{15}$ Teodulo Mabellini (Pistoia, 2/04/1817-Florencia, 10/03/1897) fue director y compositor. En 1833 se trasladó a Florencia y estudió en el Instituto Musical de Florencia hasta 1836, año en que hizo su debut como compositor con la ópera Matilde de Toledo. Posteriormente, se trasladó a Novara donde estudió con Mercadante y, en 1840, produjo en Turín Rolla, su ópera más exitosa. Véanse más detalles en Bussi, "Mabellini", pp. 540-541.

${ }^{16}$ Según Saldoni, Diccionario, vol. II, p. 113, Padilla estudió declamación con Sebastiano Ronconi. El barítono Sebastiano Ronconi (1814-1900) hizo su debut en Lucca en 1836 y continuó su carrera en Europa y Estados Unidos. Su hermano, el también barítono Giorgio Ronconi (1810-1890) debutó en 1831 en Pavía con el personaje Valdeburgo de la ópera La straniera de Vincenzo Bellini. Cantó en teatros de Roma con $I l$ furioso all'isola di San Domingo y el papel principal de Torcuato Tasso en primeras interpretaciones; en cinco premiéres de Donizetti por varias ciudades de Italia y Viena: Il campanello di notte (Nápoles, 1836), Pia de' Tolomei (Venecia, 1837), Maria de Rudenz (Venecia, 1838), Maria Padilla (Milán, 1841) y Maria di Rohan (Viena, 1843); y en París, Londres y diversos teatros de España. Ronconi fue el prototipo de barítono "moderno" y llegó a ser modelo para generaciones posteriores de barítonos. Giorgio Ronconi pasó los últimos años de su vida en España, entre Granada y Madrid, donde murió. Véanse más detalles en Forbes y Parker. "Ronconi, Giorgio", pp. 643-644; Morales Villar, Los tratados, vol. 1, p. 291-309; así como Manuel del Palacio, "Jorge Ronconi y la cuerda granadina. Recuerdos íntimos". En: La Ilustración Española y Americana, XXXIV (1890), nº 4, 30 enero, pp. 62-63.

${ }^{17}$ La Pergola, designada como "teatro Imperial" desde 1810 a 1814 , fue dirigida intermitentemente por Alessandro Lanari entre 1823 y 1862 . En él se hicieron importantes premiéres de óperas como Parisina, de Donizetti (1833), Macbeth de Verdi (1847) y I Rantzau de Mascagni (1892), así como las primeras interpretaciones italianas de Robert le diable (1840), Der Freischütz (1843) y el Dinorah de Meyerbeer (1867). Además de La Pergola, otros teatros contribuyeron a la rica vida musical florentina: el Teatro Alfieri (llamado así desde 1828); el Cocotero (desde 1859 designado con el nombre del poeta florentino Niccolini) y el Teatro Comunale. Sobre el ambiente musical de Florencia, véase: De Angelis, La musica.

18 L'Arte, VII (1857), no 64, 12 agosto, p. 4 informó de los preparativos de este concierto. En la primera parte intervendrían los cantantes Alberini, Scheggi, Bucardè, Bignardi, Tofanari, Storti, Sacconi, 
diciembre de ese año, participó en un concierto un concierto promovido por Martino Pampaloni en Prato, al que también asistió Teodulo Mabellini ${ }^{19}$. La prensa italiana destacó algunas cualidades de Padilla como barítono, que se repetirían en otras críticas a lo largo de su carrera artística: "Il Padilla spagnolo, baritono, quatunque la sua sillabazione ed accentatura resti alquanto dura per il canto italiano, possiede del resto bello e buon metodo di canto e splendidamente si avvia nella carriera musicale da coglierne presto la palma dei bravi",20.

Otras actuaciones de Padilla en tierras italianas fueron su debut oficial en el teatro de Messina en mayo de 1859, y sus actuaciones en Torino, Florencia y, finalmente, en otoño de 1861, en el teatro La Scala de Milán, donde Padilla tuvo ocasión de trabajar bajo la dirección escénica de Francesco Maria Piave en una función de Don Pasquale de Donizetti y en varias de La Traviata de Verdi ${ }^{21}$.

Italia supuso para el cantante murciano no sólo la culminación de sus estudios musicales sino también su despegue profesional. Su paso por importantes teatros, entre ellos La Scala de Milán, debieron de reportarle buenas referencias y una experiencia fundamental para afrontar su carrera artística en los años siguientes.

\section{La carrera profesional de Padilla (1861-1906)}

\subsection{Actuaciones de Padilla en el Teatro Real de Madrid (1861-62 y 1862-62) y en Río de Janeiro (1864)}

Mariano Padilla regresó a España en 1861 y se afincó en Madrid, donde permaneció al menos durante dos años.

Baccabadati y el propio Padilla; así como los directores de orquesta Baiegi y Vannuccini. En la segunda, estaba previsto la actuación de un coro formado por setecientos hombres y mujeres. Desconozco si finalmente tuvo lugar este acontecimiento, ya que no he hallado noticias que lo confirmen.

${ }^{19}$ La Lente, II (1857), $\mathrm{n}^{\circ}$ 50, 15 diciembre, p. 4. El concierto se celebró el 3 de diciembre de 1857 e intervinieron Ausuta e Carlo Baucardè, Brizzi, Giovacchini, Jandelli, Gherardi y Teodulo Mabellini. Aunque no ha quedado constancia precisa de todas las obras interpretadas, la fuente menciona que el repertorio estuvo formado por piezas de canto acompañadas por una orquesta dirigida por Teodulo Mabellini. Junto a las interpretaciones musicales, se recitaron dos sonetos de Giovanni Tacconi y el Doctor Bertini, así como una "Ode all'armonia" de Gaetano Guasti.

${ }^{20}$ La Lente, II (1857), $\mathrm{n}^{\mathrm{o}}$ 50, 15 diciembre, p. 4.

${ }^{21}$ Cambiasi, La Scala, pp. 150-151, 342-343 especifica que se representó nueve veces La Traviata aunque Padilla fue sustituido por Crivelli, sin que se especificasen las causas del cambio. La compañía estuvo integrada por los cantantes Paolina Colson, Carlotta Carozzi-Zucchi, Stefanina Casimir-Ney, Precede Dompieri, Virginia Nebuloni, Luigia Silvio, Linda Fiorio, Rosina Martinengo, Ruggero Sirchia, Albino Bianchi, Melchiorre Vida, Giuseppe Marra, Mariano Padilla, Giorgio Atry, Ferdinando Tasti, Napoleone Rossi, Giovanni Baldinelli, Giacomo Redaelli, Camillo Ferrara, Luigi Bianchi, Vincenzo Paraboschi, Luigi Alessandrini, Francesco Lodetti. Los maestros concertadores fueron Alberto Mazzucato e Francesco Pollini; el maestro de coros, Emanuele Zarini; el director de orquesta y primer violín, Eugenio Cavallini y el director de escena, Francesco Maria Piave. 
Padilla trabajó para el Teatro Real de Madrid en las temporadas 1861-62 y 1862$63^{22}$, interviniendo en las óperas Maria di Rohan y Linda de Chamounix, de Donizetti, y en Rigoletto de Verdi, donde actuó junto a Anna de Langrange, ante la presencia de los reyes, la Infanta Amalia y el propio Verdi ${ }^{23}$. La prensa murciana seguía con entusiasmo la trayectoria de Padilla y publicaba las críticas favorables que el murciano obtenía:

Nos alegramos. Sus Majestades y su Alteza Real la Infanta doña Amalia, honraron anoche con su presencia la función del teatro Real. Cantóse Rigoletto y pocas veces han estado tan felices los artistas encargados de la ejecución. Al terminar el tercer acto, el público aplaudió calurosamente a la señora Lagrange y al señor Padilla, que cantaron el dúo con brío y acento dramático, llamando a la escena al maestro Verdi, quien se presentó dos veces en ella. El triunfo mayor y más merecido para los artistas y para el compositor fue, sin embargo, el célebre cuarteto del cuarto acto, la mejor pieza de música sin duda de cuantas debe el arte a la inspiración de Verdi. Seguros estamos que nunca se ha oído el cuarteto en el regio coliseo como lo oyó anoche el público. La señora Lagrange estuvo sublime. Fraschini admirable y la señora Demeriz [Emilia De Meric Lablache] y el señor Padilla armonizaron perfectamente el cuadro. Los bravos que salían de todos los extremos de la sala interrumpían a cada momento a los artistas. El público entusiasmado hizo repetir la pieza y llamó por dos veces al maestro tributándole una ovación tan grande como merecida ${ }^{24}$.

Durante ese periodo de tiempo, Padilla tuvo ocasión de conocer personalmente a Verdi, ya que el compositor se había trasladado a Madrid en enero de 1863 para dirigir los ensayos y asistir al estreno en Madrid de su ópera La forza del destino ${ }^{25}$, tres meses después de su première mundial en San Petersburgo ${ }^{26}$. Los ensayos en la capital española fueron seguidos por la prensa nacional, y se publicaron numerosas noticias relacionadas sobre el éxito de esa ópera en Rusia, la llegada de las partituras y los cantantes a España,

${ }^{22}$ Sin embargo, el periódico Eptacordo VII (1862), nº 22, 28 febrero, p. 92 publicó su "Disponibilità" como "primo barítono absoluto, in Madrid" en febrero de 1862.

${ }^{23}$ El Apéndice 10.4 recoge las valoraciones de Carmena y Millán sobre las actuaciones de Mariano Padilla en el Teatro Real de Madrid. Durante la temporada 1861-1862, Padilla intervino en Rigoletto, interpretada hasta en seis ocasiones y en Maria de Rohan, llevada a escena el 29 de marzo de 1862. En la temporada siguiente (1862-1863) Padilla sustituyó desde el 18 de noviembre de 1862 al barítono Giraldoni en la ópera Linda de Chamounix, representada hasta en seis ocasiones durante esta temporada. La Iberia, IX (1862), no 2554, 19 noviembre, p. 4, publicó "Anoche fue muy bien recibido en la ópera La Linda el barítono Padilla, particularmente en la escena de la maldición”. También durante la temporada 1862-1863, Padilla caracterizó "bastante bien" el papel principal en Rigoletto, ópera que lideró cartel hasta doce veces, según Carmena y Millán, Crónica, pp. 248-249, 252.

${ }^{24}$ El Segura, I (1863), no 15, 17 enero, p. 1.

${ }^{25}$ La forza del destino se estrenó el 21 de febrero de 1863 en el Teatro Real de Madrid, con los cantantes Anna de Langrange, De Meric, Fraschini, Giraldoni, Cotogni, Bouchè y Padovani. Para Turina, Historia, pp. 104-105, el éxito fue grande por los numerosos ensayos que se hicieron, elogió las decoraciones de Ferri y destacó las once veces que Verdi subió al escenario, aclamado por el público. Véase también, Carmena y Millán, Crónica, p. 254-255.

${ }^{26}$ Desde 1855 hasta 1867 , el compositor estuvo inmenso en extensas giras internacionales con motivo de los estrenos de Les vêpres siciliennes, Don Carlos (estrenadas ambas en el teatro de la Opéra de París el 13 de junio de 1855 y el 11 de marzo de 1867, respectivamente) y La forza del destino, cuyo estreno mundial tuvo lugar en el Teatro Imperial de San Petersburgo (29 de octubre y 10 de noviembre de 1862), con la asistencia del propio Verdi. 
el comienzo de los ensayos, así como algunos datos biográficos del compositor ${ }^{27}$. Padilla y el barítono Giraldoni asistieron conjuntamente a los ensayos previos en la casa donde se alojaba Verdi en Madrid, "pues estos dos barítonos estudian ambos una parte misma para sustituirse en caso de enfermedad" ${ }^{, 2}$, aunque fue Giraldoni quien finalmente estrenó $L a$ forza del destino.

A pesar de ello, el estreno español de La forza del destino supuso un nuevo logro para la carrera artística de Mariano Padilla y el hecho de que la estudiara con Verdi pasó a ser un dato muy significativo y valorado por las biografías publicadas sobre el murciano, incluso por la prensa italiana del momento ${ }^{29}$.

En abril de 1863, Padilla también participó en el Conservatorio de Madrid en un concierto a beneficio de la Sociedad Artístico-Musical de Socorros Mutuos. El programa incluyó piezas vocales e instrumentales y participaron varios cantantes de la compañía que había actuado en el Teatro Real durante la temporada 1862-63, como Anna de Langrange, Demeric Lablanche, Giraldoni y Cotogni, y músicos como Monasterio, Pérez Pló, Castellano, Inzenga y Peña (los dos últimos acompañando al piano a los cantantes). Mariano Padilla cantó la romanza L'addio de su maestro Mabellini ${ }^{30}$.

Aunque las breves críticas sobre estas primeras actuaciones de Padilla en Madrid no fueron generalmente favorables, sí que destacaron lo acertado de algunas interpretaciones, sobre todo en personajes como Rigoletto, papel que interpretaría en muchas ocasiones a lo largo de su vida. Las actuaciones de Padilla en Madrid fueron menos numerosas en comparación con las de Berlín, Londres, San Petersburgo o Moscú. Sin embargo, supusieron un impulso fundamental para su carrera artística. La etapa madrileña permitió además que Padilla ampliara sus contactos con los músicos españoles más relevantes del momento, como Monasterio, Inzenga y el propio Barbieri ${ }^{31}$.

A finales del año 1864, Padilla actuó en Río de Janeiro, aunque las noticias halladas hasta la fecha son escasas. Una breve referencia de La Libertad indicaba que Padilla obtuvo un gran éxito en la ciudad brasileña:

Ha llegado a Madrid de regreso de Río de Janeiro, donde ha estado contratado, nuestro compatriota el distinguido artista don Mariano Padilla.

${ }^{27}$ La Iberia: IX (1862), $\mathrm{n}^{\text {os }} 2540,2$ noviembre, p. 4; 2550, 14 noviembre, p. 4; 2554, 19 noviembre, p. 4; 2561, 27 noviembre, p. 4; X (1863), $\mathrm{n}^{\text {os }} 2595,6$ enero, p. 4; 2604, 14 enero, p. 4; 2605, 15 enero, p. 4; 2606, 16 enero, p. $2 ; 2624,3$ febrero, p. $4 ; 2625,4$ febrero, p. 4 y 2640, 20 febrero, p. 3.

${ }^{28}$ La Iberia, X (1863), nº 2611, 21 enero, p. 4.

${ }^{29}$ Por ejemplo, Euterpe II (1870), no 17, 28 abril, p. 7, en la que también se afirma que Padilla estudió con Verdi la ópera Un ballo in maschera.

${ }^{30}$ El programa completo, que incluyó obras de Haydn, Bériot y diversos fragmentos de ópera, puede consultarse en La Iberia, X (1863), n ${ }^{\text {os }} 2695,17$ abril, p. 4 y 2696, 18 abril, p. 4.

${ }^{31}$ La carta que Amadèe Verger dirigió a Barbieri desde París el 22 de abril de 1864 confirma que Padilla y Barbieri eran amigos: "Días pasados por el conducto de nuestro común amigo Padilla he sabido que estaba usted en ésa y que estaba encargado de formar una compañía de ópera italiana para un nuevo teatro que se ha construido y cuya apertura será para el próximo mes de junio". Francisco Asenjo, vol. II, p. 1086. 
Los periódicos de Brasil nos dieron a conocer los triunfos obtenidos en aquellos países por el joven barítono y hoy leemos en los mismos el profundo sentimiento que ha causado su despedida y el deseo de volver a escucharlo ${ }^{32}$.

\subsection{La gira americana: Actuaciones de Mariano Padilla en el Teatro Principal de México (1865)}

En 1865, Mariano Padilla emprendió una gira por México, motivada por "su gran deseo de conocer la Nueva España"33. El dominio absoluto del repertorio italiano (con contadas interpretaciones del repertorio francés como Meyerbeer, Bizet y Gounod) y de las compañías con cantantes italianos fue la tónica en los diversos teatros mexicanos durante todo el siglo XIX $^{34}$. La temporada otoñal de 1865 en el Teatro Principal de la ciudad de México fue inaugurada por la compañía de Annibale Biacchi, entre cuyos artistas figuró Padilla. Para Olavarría y Ferrari, el elenco de cantantes no "se señalaba por el número o cuantía de sus celebridades, pero sí por su homogeneidad y por la juventud de los cantantes, que alcanzaron muchas simpatías en México y dejaron en él muy buena memoria"35. En el cartel de presentación de la compañía de Biacchi se describía a Mariano Padilla en los siguientes términos:

[...] Primer baritono absoluto, señor Mariano Padilla. Llamado con justicia una gloria de la España artística, aunque joven, ha recorrido con sumo aplauso todos los teatros. El público de México le hará sin duda la misma acogida cuando conozca sus envidiables facultades vocales y raro talento artístico $[\ldots]^{36}$.

Las representaciones de la compañía de Biacchi comenzaron en octubre de 1865, con un abono inicial de doce funciones "lo menos seis óperas diversas y escogidas, y en la temporada tres o cuatro nuevas, tomadas de entre las que han agradado más en el

${ }^{32}$ La Libertad (1865), n 376, 31 enero, p. 4.

${ }^{33}$ Padilla, además, reconocía: “cuando ya me hallaba en vías de suscribir el contrato, mis amigos me instigaban a no hacerlo, diciéndome que era tentar a Dios el exponerme a tantos y tan pavorosos riesgos, como me aguardaban en mi viaje de Veracruz a México": Mariano Padilla, "Recuerdos de un viaje", Crónica de la Música, V (1882), n 199, 12 julio, pp. 4-5, originariamente publicado en el periódico La Revista Germánica. En la crónica, Padilla afirmó que esta gira la había realizado en 1868.

${ }^{34}$ Miranda, "El espejo idealizado", p. 153 afirma que "Este gusto por la ópera italiana raya en lo increíble". Sobre el ambiente musical de México durante el siglo XIX, además del mencionado, véase: Miranda, “A tocar señoritas”, pp. 131-171; Olavarría, Reseña y Stevenson, "México city”, pp. 557-558.

35 La compañía estuvo formada por Isabel Alba, Ángela Peralta y Matilde Plodowka (primeras sopranos), Matilde Saverthal y Adela Halves (primeras tiples), Enriqueta Sulzer (contralto), César Limberti, José Tombesi y Silvestre De Biaggi (primeros tenores), Mariano Padilla y Sabatino Capella (primeros barítonos), Juan B. Taste y Juan B. Cornago (primeros bajos), Marieta Pagliari, Tomás Rubio, Juan Zanini y Jacinto Villanueva (comprimarios), Carlo Bosoni y Carlos Fattori (maestros directores) y Agustín Balderas (maestro de coros). Olavarría, Reseña, vol. I, p. 694. El cartel anunciador de la compañía de de Anníbale Biacchi puede consultarse íntegro en también fue publicado por Reyes de la Maza, El teatro, pp. 137-140.

${ }^{36}$ Véase, Reyes de la Maza, El teatro, p. 139, quien reproduce íntegro el cartel anunciador de la compañía de Annibale Biacchi. En su monumental Reseña histórica del teatro en México, vol. I, p. 694, Olavarría y Ferrari afirmó: "el barítono Padilla, que posteriormente a esa época brilló en grandes teatros europeos, merece el calificativo de insigne artista". 
mundo musical" y con un lujoso vestuario que había sido comprado en Europa ${ }^{37}$. Se llevaron a escena óperas de Verdi, Meyerbeer, Donizetti, Flotow, Bellini y Petrella. El 6 de febrero de 1866 tuvo lugar la función a beneficio del cantante Padilla con la ópera Rigoletto y con gran éxito ${ }^{38}$. Tras regresar de México, el cantante visitó por unos días Murcia $^{39}$.

\subsection{Las temporadas invernales de 1867 y 1868: de Berlín a Rusia}

Tras la gira mexicana, la carrera profesional de Padilla se proyectó claramente hacia el panorama internacional. A finales del año 1866, Padilla era integrante de la compañía de Gatti-Lorini que actuó en el teatro Victoria de Berlín (Alemania) durante la temporada de invierno de 1867 (desde enero hasta marzo) ${ }^{40}$. Representaron Il barbiere di Siviglia, Il Trovatore, La Traviata, La Favorita y Don Pasquale ${ }^{41}$. La prensa murciana, que prestó especial interés en reproducir las noticias publicadas sobre Padilla en la prensa nacional e internacional, ensalzó su éxito en Berlín con la romanza $A$ tanto amor de $L a$ Favorite de Donizetti, un aria muy celebrada por la crítica a lo largo de su carrera artística $^{42}$. En mayo de 1867, Padilla participó en Un ballo in maschera en el Casino Theatre de Copenhague con el personaje Renato y junto a Sarolta de Bujanovis como Amelia (ver Figura 10.3) ${ }^{43}$. El reconocimiento a su trayectoria artística le mereció la concesión de Caballero de la Real Orden de Isabel la Católica también en ese año de $1867^{44}$.

${ }^{37}$ Reyes de la Maza, El teatro, p.140.

${ }^{38}$ Olavarría y Ferrari, Reseña, vol. I, p. 698. La prensa española también se hizo eco de los éxitos de la compañía de Biacchi en México, véase: La escena, II (1866), nº 12, 28 enero, p. 3.

${ }^{39}$ La Paz de Murcia, VIII (1865), no 2104, 11 febrero, p. 2. Según Saldoni, Diccionario, vol. II, p. 113 y también García Seco, "Padilla y Ramos", p. 42, Padilla también actuó en Nueva York aunque ambos autores no especificaron fechas.

${ }^{40}$ Además de Padilla, los miembros de la compañía fueron N. Sarolta, primera soprano que también había actuado en las temporadas 1859-1860 y 1860-1861 del Teatro Real de Madrid, la contralto Norina Grossi, los tenores Pardini y Rubí, el bajo Próspero Derivis, el bajo cómico Frizzi y el maestro y director de orquesta Faccio. Véase, La escena, II (1866), $\mathrm{n}^{\circ}$ 8, 1 diciembre, p. 66 y El Artista, I (1866), $\mathrm{n}^{\mathrm{o}} 27,7$ diciembre, p. 7.

${ }^{41}$ La escena, II (1867), $\mathrm{n}^{\mathrm{o}}$ 7, 17 febrero, p. 51.

${ }^{42}$ La Paz de Murcia, X (1867), no 3104, 29 diciembre, p. 2.

${ }^{43}$ Jürgensen, "Verdi meets Scandinavia", pp. 80-109.

${ }^{44}$ La concesión fue otorgada el 1 de octubre de 1867, según La Paz de Murcia, X (1867), nº 3028, 12 octubre, p. 2. 


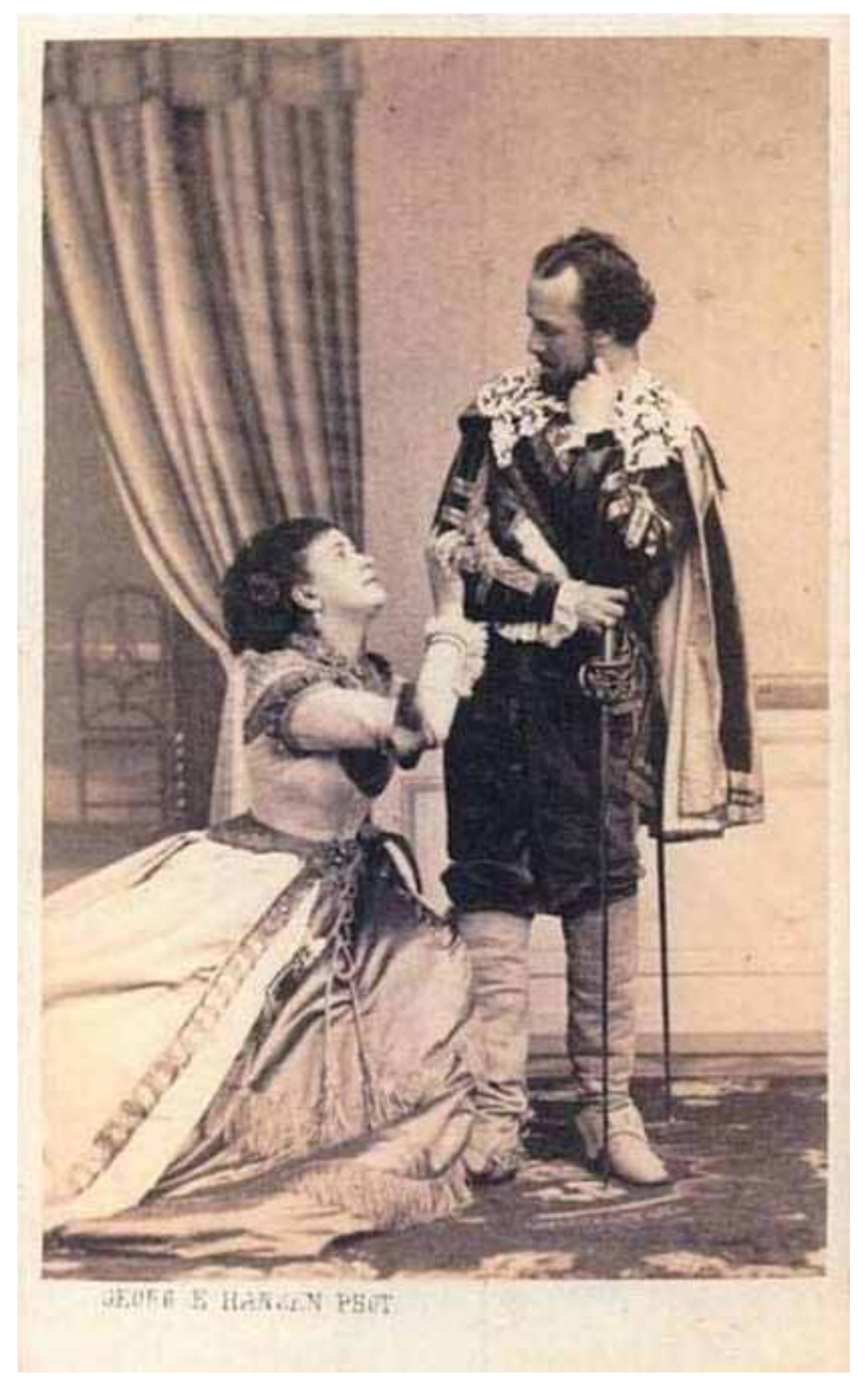

Figura 10.3. Mariano Padilla en el personaje de Renato, junto a la cantante Sarolta de Bujanovis (Amelia), en la ópera de Verdi Un ballo in maschera, representada en el Casino Theatre de Copenhagen (18-051867). Colección Particular.

En junio de 1868, Padilla regresó a Murcia para tomar unos días de descaso, algo que hizo habitualmente después de sus largas giras invernales. Las visitas del cantante a su tierra natal siempre fueron muy celebradas y suponían un gran acontecimiento para la ciudad. Las sociedades e instituciones murcianas solían prepararle calurosos recibimientos, conciertos y veladas culturales. Ese año, por ejemplo, recibieron al cantante el Orfeón de la Sociedad Filarmónica y Coral y "varios de sus infinitos amigos y entusiastas admiradores" $"$. También en esa estancia de junio de 1868, Padilla tuvo ocasión de intervenir en el concierto a beneficio del "Monumento a los artistas murcianos de las Bellas Artes" que se estaba organizando (ver Capítulo 6).

\footnotetext{
${ }^{45}$ La Paz de Murcia, XI (1868), nº 3263, 13 junio, p. 2.
} 
En julio de 1868 y desde Murcia, Mariano Padilla se dirigió a Madrid, donde tomó parte en un concierto privado en casa de Baltasar Saldoni, en el que también actuaron algunos discípulos del Catedrático (Joaquina Alonso, Elena Sans, Soledad Arroyo y el bajo José Sala) ${ }^{46}$.

$\mathrm{Su}$ primer viaje a Moscú (Rusia) tuvo lugar durante el otoño de 1868, donde participó en Il barbiere di Siviglia, Guillermo Tell, Rigoletto, Fausto y Don Juan de Mozart "ópera que cantó para su beneficio". Según La Correspondencia de España el barítono causó sensación entre el público moscovita ${ }^{47}$.

Desde octubre de 1868 se encontraba también en Rusia su futura esposa, Desirèe Artôt, a quien Padilla probablemente conoció en el transcurso de esa gira ${ }^{48}$.

\subsection{Matrimonio con Desirèe Artôt y traslado a Berlín (1869-1883)}

La mezzosoprano de origen belga Desirée Marguerite Artôt (París, 21/07/1835Berlín, 3/04/1907), cuyo retrato se muestra en la Figura 10.4, era hija de Jean Désiré Montagney Artôt (1803-1887), instrumentista de trompa y profesor en el Conservatorio de Bruselas. Désirée Artôt había estudiado canto con la célebre Pauline Viardot-Garcia y con Francesco Lamperti en Londres y París ${ }^{49}$. Por recomendación de Meyerbeer fue contratada para actuar en el Teatro de la Ópera en 1858, donde debutó con el personaje Fidès de Le prophète de Meyerbeer. Más tarde se especializó en repertorio italiano, realizando giras por Francia, Bélgica y, en 1859 por Italia con la compañía de Lorini. Según, Rosenthal su tesitura se amplió de mezzosoprano a soprano, permitiéndole agregar a su repertorio personajes para este último registro. En 1868, Artôt viajó a Rusia donde se prometió con Tchaikovsky ${ }^{50}$. Artôt, sin embargo, se casó con Mariano Padilla a mediados

${ }^{46}$ La crónica del evento apareció en El Artista, III (1868), nº 7, 22 julio, pp. 53-54 a su vez transcrita por La Esperanza, XXIV (1868), no 7299, 28 julio, p. 3 y por Saldoni, Diccionario, vol. II, pp. 114-115: "En cuanto al señor Padilla, verdadero héroe de la fiesta, cantó, además del duetto de la Favorita y aria de esta misma ópera, la romanza de Un ballo in maschera, acompañada al piano de memoria por la señorita [Joaquina] Alonso".

${ }^{47}$ La Correspondencia de España, XX (1869), n 4069, 10 enero, p. 3 recoge un listado de valiosos regalos entregados a Padilla por sus admiradores rusos. En La Paz de Murcia, XI (1868), n 3256, 5 junio, p. 3 se anunció que el cantante murciano actuaría también en San Petersburgo, aunque no se precisan fechas. No he hallado, por el momento, constatación de sus actuaciones en esta ciudad.

${ }^{48}$ Según El Artista, III (1868), n 16, 30 septiembre, p. 127, Desirée Artôt se dirigía hacia Moscú con su familia cuando el tren en que viajaban se descarriló, aunque la cantante no sufrió heridas de gravedad.

${ }^{49}$ Marguerite-Joséphin-Désirée Montagney Artôt también era conocida como Désirée Artôt, Désirée Artôt de Padilla o Désirée Artôt-Padilla. Véase Rosenthal, "Artôt", The New Grove, p. 93; Ménetrat, "Artôt. (Margerite-Joséohine) Désirée", Die Musik, pp. 1050-1051. La Paz de Murcia, $\mathrm{n}^{\text {os }}$ 4525, 24 de marzo, p. 1 y 4526, 26 marzo, p. 1 publicó su biografía en dos extensos artículos trascritos del periódico El Heraldo de las Artes (ver Documentario).

${ }^{50}$ Rosenthal, "Artôt”, The New Grove, p. 93. La relación entre Désirée Artôt y Tchaikovsky también ha sido comentada por Wiley, "Tchaikovsky", pp. 143-183:147. Tchaikovsky dedicó a la cantante su Romance op. 5 (1868) y Six French Songs, op. 65 (1888). En la actualidad se conservan cinco cartas de Tchaikovsky a Artôt fechadas entre 1888 y 1890: Poznasky, The Tchaikovsky, vol. 2, p. 306. 
de septiembre de 1869 en una pequeña población francesa cercana a Sèvres, Ville d'Avray, que fue lugar de residencia de la pareja hasta su traslado a Berlín en $1883^{51}$.

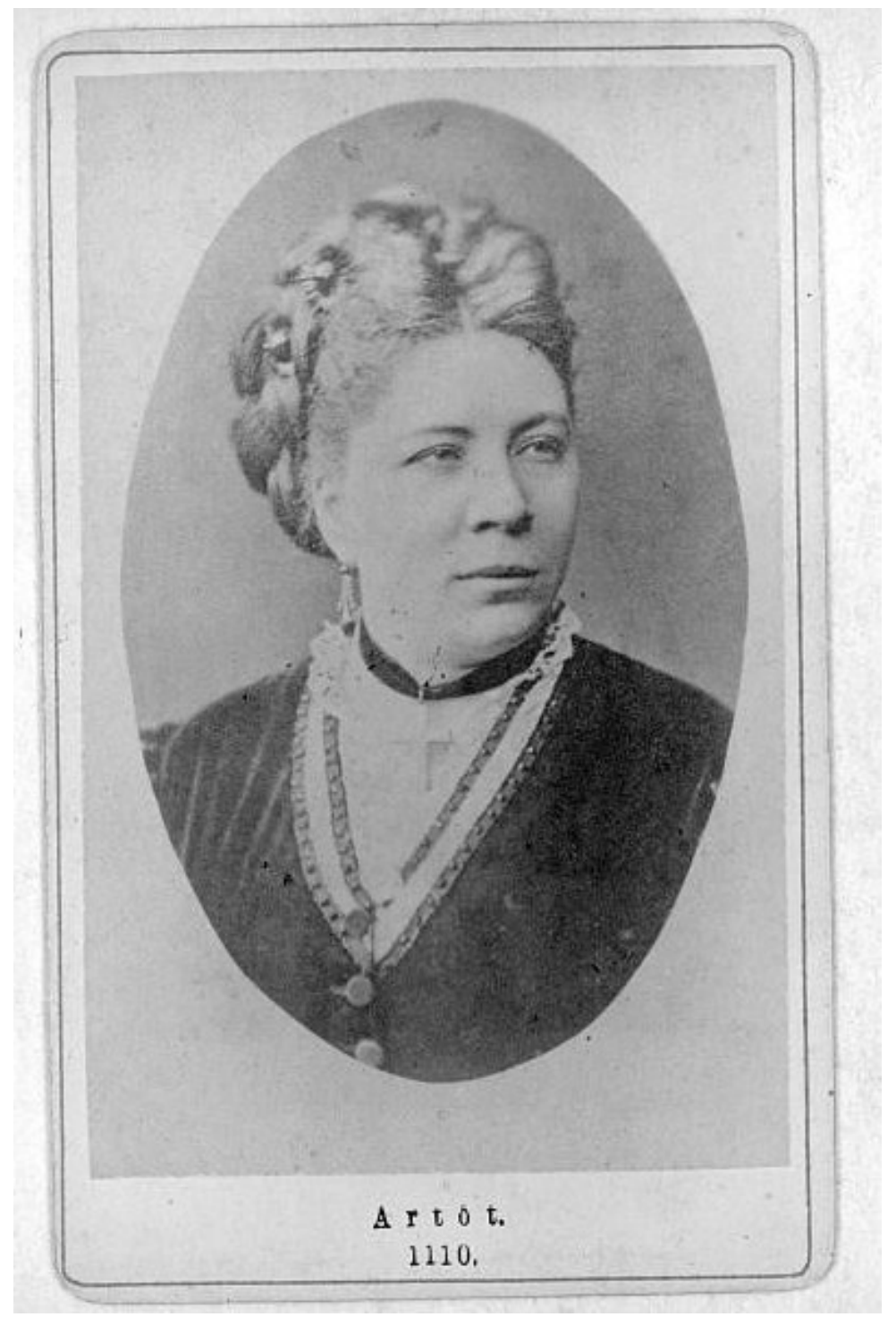

Figura 10.4. Retrato de Marguerite-Joséphin-Désirée Montagney Artôt (París, 1841-Viena, 1907). US: Wc. Accesible en: http://lccn.loc.gov/2005696330 (acceso el 10-10-2011).

Tras el matrimonio, la trayectoria artística de la pareja corrió en paralelo, y actuaron conjuntamente en numerosas ocasiones. Fueron unos años de intensos de viajes y numerosas actuaciones que se reflejaron en la cantidad de páginas que la prensa española e italiana les dedicó. Se publicaron los recorridos teatrales, las críticas de sus representaciones, los teatros con los que habían firmado contratos y las noticias que la prensa extranjera recogía en sus diarios.

${ }^{51}$ Ville-d'Avray es una commune francés situado en el département de Hauts-de-Seine en la región de Ïle-de-France, cercana a Sèvres y Versalles. El enlace fue anunciado en La Correspondencia de España y de él se hizo eco La Paz de Murcia, XII (1869), n 3575, 18 mayo, p. 1. En [Anónimo], "Padilla y Ramos, Mariano", Dizionario, vol. V, p. 497 apuntó que en el mismo año de su matrimonio con Désirèe Artot, ésta fue contratada para actuar en el Teatro de la Ópera de París. 
En marzo de 1870 los Padilla-Artôt participaron en Faust de Gounod en Varsovia, causando un "fanatismo completo" junto a los cantantes Carrion y Bassi". Allí permanecieron hasta abril del mismo año. El periódico milanés Euterpe valoró así los triunfos del matrimonio y, en especial, el de Padilla:

[...] I rinomati conjugi Desiderata Artôt e Mariano, cavalière Padilla, dopo i clamorosi successi ottenuti a Varsavia nella decorsa quaresima, si son recati alla lor villa presso Sèvres, onde riposarsi dalle fatiche sostenute. Sappiamo ch'essi han rifiutato parecchie vantaggiose proposte per la Germania e l'Italia, trovandosi in stato interessante la sposa, e non ritorneranno sulle scene che a Baden il 15 venturo agosto dove rimarranno sino al 22 settembre, per poscia passare a Mosca ove furono per la quarta volta riconfermati. A Baden il Padilla prenderá parte all'esecuzione della Forza del destino, nueva per quel pubblico, e che egli ha studiato collo stesso Verdi a Madrid nell $1862^{53}$.

[Los renombrados cónyuges Desiderata Artôt y Mariano Padilla, después de los clamorosos éxitos obtenidos en Varsovia en la pasada Cuaresma, se han ido a su villa de Sèvres, donde descansan de las fatigas sostenidas. Sabemos que han rechazado ventajosas propuestas para Alemania e Italia, encontrándose en estado de buena esperanza la esposa, y no volverán a la escena hasta el 15 del próximo agosto en Baden, donde permanecerán hasta el 22 de septiembre. Después pueden pasar a Moscú, donde han sido reconfirmados por cuarta vez. En Baden, Padilla tomará parte en la ejecución de La forza del destino, nueva para aquel público, quien lo estudió con el mismo Verdi en Madrid en 1862.]

Tal y como se desprende de la cita anterior, después de Varsovia el matrimonio descansó unos días en su villa de Sèvres. Artôt estaba embarazada y por este motivo rechazaron varias ofertas en teatros alemanes e italianos ${ }^{54}$. Según esta información, Padilla volvió a escena desde el 15 de agosto hasta el 22 de septiembre de 1870 en el Teatro de la Ópera Italiana de Baden con La forza del destino de Verdi, ópera nueva para aquel público ${ }^{55}$.

Varias noticias publicadas en la prensa española e italiana informan del itinerario de las actuaciones de Padilla durante los meses siguientes: Teatro Circo de Barcelona durante la temporada teatral de otoño-carnaval y Pascua ${ }^{56}$; y Frankfurt, donde cantó Traviata "per la prima volta in italiano" junto a Artôt en diciembre de $1870^{57}$. Además, el

${ }^{52}$ Euterpe, II (1870), n’ 13, 31 marzo, p. 5: "Varsavia. Fanatismo completo il Faust. L'Artot, Carrion, Padilla e Bassi, acclamati furono dal principio alla fine dell'opera e ripetutamente evocati alla scena". Véase también Euterpe II (1870), n ${ }^{\text {os }} 12,24$ marzo, p. 8 y 14, 6 abril, p. 3.

${ }^{53}$ Euterpe, II (1870), $\mathrm{n}^{\circ} 17,28$ abril, p. 7.

${ }^{54}$ Es probable que Désirée Artôt estuviera embaraza de Carmen Padilla Artôt, una de las dos hijas del matrimonio. The Library of Congress conserva una fotografía de Désirée, Carmen, Lola (¿segunda? hija del matrimonio) y la soprano Belle Brown. Sobre Lola Artôt de Padilla volveré más adelante.

${ }^{55}$ Euterpe II (1870), n $\mathrm{n}^{\mathrm{O}}$ 18, 5 mayo, p. 7. Además de Padilla, otros cantantes que actuaron en Baden fueron Stolz, Harris, Materna, Cari, el tenor Nicolini y Guadagnini.

${ }^{56}$ Euterpe, II (1870), no 30, 29 julio, p. 6 publicó el elenco de la compañía (tomándolo del periódico barcelonés Correo de teatros) y constaba de: "prime donne assolute, signore Peralta, Artot, Scalchi, Trebelli; tenori assoluti, signori Graziani, Palermi, Bettini; baritoni assoluti, signori Fagotti, Padilla; bassi assoluti, signori Gassier, Juan; bassi comici, signori Zucchini, Ronconi”. 
barítono murciano fue nombrado Caballero de la Orden de Calos III en noviembre del mismo año, una prueba más de la fama que había llegado a alcanzar ${ }^{58}$.

Durante el año 1871 el matrimonio emprendió nuevas giras por Rusia y Europa con distintas compañías y con un abundante repertorio de óperas italianas:

- Teatro Imperial de Moscú, Rusia (enero a marzo) ${ }^{59}$.

- Distintas ciudades de Polonia, Holanda, Alemania, Hungría y Viena (1 de marzo a 10 de junio $)^{60}$.

- Baden-Baden, Alemania (21 de junio a 31 de agosto) ${ }^{61}$, salvo unos días de descanso en Murcia (26 de julio a 3 de agosto) ${ }^{62}$.

- Estocolmo y Copenhague (septiembre de 1871) ${ }^{63}$.

${ }^{57}$ Euterpe, II (1870), n 49, 9 diciembre, p. 3 dio cuenta de la aclamación del matrimonio Padilla-Artot y del éxito del tenor Cassio.

${ }^{58}$ La noticia fue publicada por La Paz de Murcia, XIII (1870), no 4027, 24 noviembre, p. 1 y dos meses más tarde por el periódico italiano Euterpe, II (1871), nº 3, 20 enero, p. 7.

${ }^{59}$ Euterpe, II (1870), $\mathrm{n}^{\mathrm{o}}$ 12, 24 marzo, p. 8. En Euterpe, II (1871), n 6,9 febrero, p. 7 se publicó una interesante carta de un corresponsal italiano del diario veneciano La Scena en Moscú que describía la rapidez con la que se sucedían las representaciones de ópera italiana en los teatros rusos como respuesta a la fuerte demanda de este género por parte del público. El corresponsal (cuyo nombre no consta) hizo extensas críticas de La figlia del reggimento, Il barbiere di Sivilia, Gli Ugonotti y Faust. Sobre Padilla se escribió que fue "onorato di applausi e chiamata" en las dos últimas óperas mencionadas y sobre Artôt, que llegó a entusiasmar tanto al público que en su homenaje le pusieron su nombre a un "batello a vapore della marineria rusa": Euterpe II (1871), n 7,15 febrero, p. 8.

${ }^{60}$ La gira fue anunciada en Euterpe, II (1871), $\mathrm{n}^{\text {os }} 7,15$ febrero, p. 8 y 12, 24 marzo, p. 8. Durante el mes de marzo de 1871 actuaron en Breslavia, Amberes y Ámsterdam. En Breslavia, según Euterpe, II (1871), $\mathrm{n}^{\mathrm{o}}$ 13, 30 marzo, p. 6, ofrecieron diez representaciones de Il barbiere di Sivilia, Figlia del reggimento, Don Pasquale, Rigoletto, Il Trovatore, Don Giovanni y Faust. El 21 de marzo de 1871 cantaron en Ámsterdam Il Barbiere di Siviglia, donde obtuvieron grandes éxitos, especialmente la cantante Artôt. Según Euterpe II (1871), n 14, 7 abril, p. 5, el numeroso público colmó de ovaciones a Marín, Padilla, Bossi y Agnesi en por su interpretación en Il Barbiere di Siviglia. Durante el mes de abril de 1871 actuaron en Weimar, Bruncwich, Cassel, Wiesbaden y Frankfurt: Euterpe II (1871), n 18,5 mayo, p. 4; y, finalmente, desde el 5 de mayo del mismo año, la compañía ofreció una serie de seis recitales de ópera italiana en Wieden (Viena) a cargo de los cantantes Artôt, Padilla, Marin y Bossi: Euterpe II (1871), n 13, 30 marzo, p. 7. Sobre el ambiente musical de Viena, véanse los artículos: C., "La música en Viena", publicados en El Artista, III (1868), $\mathrm{n}^{\text {os }}$ 3, 22 junio, pp. 17-18 y 4, 30 junio, pp. 25-26.

${ }^{61}$ Euterpe II (1871), no 24, 1 junio, p. 6. Los miembros de la compañía fueron: "Gabriella Krauss e Desiderata Artôt, prime donne assolute. Steger Francesco e Perotti Giulio, tenori; Mariano Padilla, baritono; Miller, basso; Bottesini, maestro direttore d'orchestra; Pettenghi Angelo, maestro concertatore".

${ }^{62}$ La Paz de Murcia, XIV (1871), n 4230, 29 julio, p. 1. La llegada del matrimonio supuso un acontecimiento para la ciudad. La noche del miércoles 26 de julio de 1871 fueron obsequiados con una serenata por la banda de Mirete; la del jueves 27, con una "orquesta al estilo de la huerta" dirigida por Ángel Miguelillo y compuesta por dieciséis guitarras, dos bandurrias, dos cítaras, dos violines, una pandereta y dos pares de castañuelas. En comitiva, entraron por la calle de los Dolores y tocaron, bajo el balcón del matrimonio, la marcha de Pan y toros y malagueñas de Murcia cuyas coplas, escritas para la ocasión, fueron interpretadas por el cantaor Torres. En la descripción periodística se añade que Desirée pidió a López Almagro las coplas y música para poder cantarlas en Moscú. El matrimonio partió para Madrid el 3 de agosto de 1871 y la prensa afirmó que se dirigían, tras esta ciudad, a París, Baden-Baden y San Petersburgo. Véase, La Paz de Murcia, XIV (1871), nº 4234, 4 agosto, p. 1.

${ }^{63}$ Euterpe II (1871), n 12,24 marzo, p. 8. 
- Teatro Imperial de la Ópera de San Petersburgo, (1 de noviembre de 1871 a 10 de marzo de 1872) ${ }^{64}$.

Además de estas actuaciones, los Padilla-Artôt fueron frecuentemente reclamados para dar conciertos privados a diversos monarcas europeos. En abril de 1871 actuaron para los reyes de Bélgica en Bruselas ${ }^{65} \mathrm{y}$, unos días más tarde, para los emperadores alemanes en Berlín. En ellos, tuvo cabida otro tipo de repertorio más afín a la música de salón. En el mencionado concierto berlinés, por ejemplo, Padilla interpretó la canción "Déjate querer", con poesía y música del también murciano Mariano Soriano Fuertes ${ }^{66}$.

La fama de ambos ocupó varias páginas de la prensa española del momento. En 1872, El Heraldo de las Artes publicó una extensa biografía sobre Desirèe Artôt que fue, a su vez, transcrita en diferentes medios periodísticos nacionales, entre ellos $\mathrm{La} \mathrm{Paz} \mathrm{de}$ Murcia (ver Documentario).

Las numerosas representaciones de ópera llevadas a cabo por los cantantes prueban la difusión del género en Europa durante el último tercio del siglo XIX y la fama que el barítono había adquirido ${ }^{67}$. Padilla frecuentó en mayor número escenarios de Centroeuropa (especialmente Alemania e Inglaterra) y Rusia, países que visitó regularmente durante su carrera artística. En diciembre de 1873, Mariano Padilla triunfó en el teatro Italiano de París con Il Trovatore y Rigoletto y, más tarde, con Don Giovanni. Un largo artículo firmado por Villegas y publicado por el madrileño periódico El Arte, evaluaba lo que supondría para el cantante actuar, por primera vez, en París:

[...] Mariano Padilla era ya un gran artista, era ya un gran cantante. Tenía la sanción y el aplauso de todos los públicos de Italia y de Rusia, pero le faltaba la gran sanción del público especial de Paris y la está obteniendo de la manera más brillante y ruidosa.

${ }^{64}$ La compañía estuvo integrada por las sopranos Adelina Patti, Volpini, Lucca, Benza, Artôt y Cínico, las contraltos Trebelli-Bettini y Schalchi, los tenores Nicolini, Achile Corsi y Marin (incluso se anunció que también podría ser Enrico Tamberlick, los barítonos Faure, Graziani, Rota, Padilla y Moriami, los bajos Bagagiolo y Bosi y el maestro director de la orquesta, Arditi: Euterpe II (1871), n ${ }^{\circ}$ 25, 26 junio, p. 7. El repertorio de la compañía estuvo compuesto por Il Trovatore, La Traviata, Un ballo in maschera y Rigoletto de Verdi; La Sonnambula e I Puritani de Bellini; Poliuto, Lucia, Don pasquale, Figlia del Reggimento y Elisir de Donizetti; Barbiere, Otello, Gazza ladra, Zora y Carlo Il Temerario de Rossini, Don Giovanni de Mozart, Africana, Dinorah y Ugonotti de Meyerbeer, Faust y Romeo e Giulietta de Gounod, Muta di portici y Fra Diavolo di Auber, Ebrea de Halèvy, Freuschütz y Oberon di Weber y Mignon de Thomas. Los éxitos de los esposos Padilla-Artôt en Rusia fueron seguidos por La Paz de Murcia, que transcribió críticas teatrales y noticias breves procedentes de diversos medios periodísticos nacionales, como El Heraldo. Véase: La Paz de Murcia: XIV (1871), nº 4299, 21 octubre, p. 1 y XV (1872), no 4359, 3 enero, p. 1.

${ }^{65}$ La Paz de Murcia, XV (1872), n 4532, 3 abril, p. 1.

${ }^{66}$ La Paz de Murcia, XV (1872), nº 4555, 27 abril, p. 1. El concierto tuvo lugar en el Palacio Imperial de Berlín el 17 de abril de 1872. La canción fue interpretada al final de la primera parte del concierto y "Mr. de Eismark manifestó después a nuestro paisano Padilla que le gustaba mucho el género de la música española": La Paz de Murcia, XV (1872), n 4555, 27 abril, p. 1. El Emperador regaló a Padilla una sortija de brillantes y a su esposa un aderezo de zafiros valorado en 15000 reales, según la fuente.

${ }^{67}$ Euterpe II (1871), no 12, 24 marzo, p. 8 publicaba "Questi contratti sono la più bella prova del merito degli artisti e valgono meglio di qualsiasi elogio". En Murcia, estos hechos se tradujeron en la inauguración, en marzo de 1872, de una "Escuela de Canto y Declamación titulada Padilla", en el seno de la de la sociedad murciana del Círculo Industrial (ver Capítulo 6). 
También le falta la sanción de sus compatriotas, los aplausos del público madrileño, pues aunque ya se le ha oído en época lejana, todavía no era Padilla el cantante eminente que sus grandes facultades, su amor al arte y su afición al estudio han llegado a crear pura gloria de su nombre y honra de su patria. Pero esa falta, única que le echamos de menos -su contrata en el teatro de la ópera de Madrid, que el señor Padilla ha podido aceptar en varias ocasiones- no tardará en ser un hecho, porque sea cualquiera el empresario que haya en los próximos años, no puede dispensarse de hacer los sacrificios que sean necesarios para devolver al eminente barítono a sus compatriotas que le esperan hace tiempo para tributarle una gran ovación, a más grata, la más hermosa para el artista español $[\ldots]^{68}$.

De la cita se desprende, además, la insistencia de la prensa española para que el barítono volviera a cantar en el Teatro Real de Madrid, algo que no ocurrió, como veremos, hasta la temporada teatral de 1877-1878.

Hasta 1877, el cantante emprendió nuevas giras que le llevaron una vez más a Rusia $^{69}$. Desde septiembre de 1875 Padilla participó en las representaciones de L'Africana e Il Trovatore en Moscú, junto a los tenores españoles Marín y Aramburu ${ }^{70}$. En L'Africana se dijo que el "barítono Padilla en el difícil papel de Nelusko fue igualmente aclamado en diferentes situaciones de esta ópera que [cantó] con un gusto y una expresión dramática admirable" y en la representación de Il Trovatore (1-10-1875) se hicieron comentarios tan elogiosos como los siguientes:

[...] En el terceto final rivalizaron nuestros compatriotas Aramburu y Padilla, hasta el punto de fanatizar al público, que les hizo salir a la escena acompañados de la prima donna señora Vizjaz. [...]

Padilla en la preciosa aria de barítono [del acto segundo] estuvo verdaderamente inspirado cantando el andante con una pasión y un gusto dignos del bel canto. El público le recompensó con muchos bravos, lo mismo que al final de la cabaleta [sic], que dijo con mucha valentía. A la conclusión del acto fueron, como en el anterior, llamados a la escena dos veces. [...]

El acto cuarto ha sido el colmo del entusiasmo [...] Padilla, en su dúo con la Vizjak, inmejorable y llamados a escena.

Con decir que al final de la ópera fueron llamados los artistas nueve veces al palco escénico, se pondrán ustedes forman una idea del éxito que, como he dicho anteriormente, califico de acontecimiento teatral $[\ldots]^{71}$.

${ }^{68}$ Artículo transcrito en La Paz de Murcia, XVI (1873), n 4958, 24 diciembre, p. 1.

${ }^{69}$ A finales de junio de 1875, Padilla visitó Murcia junto a su familia y, desde allí, marcharon a Francia y Rusia. Los detalles sobre su estancia en la ciudad fueron publicados por: La Paz de Murcia, XVIII (1875), $\mathrm{n}^{\text {os }} 5382,9$ junio, p. 1; 5387, 15 junio, p. 1 y 5400, 1 julio, p. 1.

${ }^{70}$ Sus actuaciones fueron seguidas por el corresponsal de La Ópera Española en la ciudad rusa. Véase, La Ópera Española, I (1875), $\mathrm{n}^{\text {os }}$ 4, 22 octubre de, pp. 1-2 y 7, 16 noviembre, p. 4 en los que se recogen los éxitos de Cary, Aramburu y Padilla en La Favorita; de Aramburu y Padilla en La Traviata; y de Artôt y Padilla, entre otrOs, en Gli Ugonotti. Algunos fragmentos de estas críticas fueron también recogidas por La Paz de Murcia: XVIII (1875), 5 noviembre, $\mathrm{n}^{\text {os }}$ 5590, p. 1; 5604, 23 noviembre, p. 1 y XIX (1876), 11 febrero, $\mathrm{n}^{\mathrm{o}} 5588$, p. 1.

${ }^{71}$ La Ópera Española, I (1875), no 4, 22 octubre, pp. 1-2. 
La prensa murciana no ha dejado constancia de ninguna noticia que informe de las actuaciones de Mariano Padilla tras su paso por Moscú ${ }^{72}$ y es en esta misma ciudad donde la información hallada vuelve a comentar los trabajos del cantante a partir de noviembre de $1876^{73}$, un mes después del nacimiento en Sèvres de Lola Padilla Artôt (ver Figura $10.5)^{74}$. En Moscú, Padilla participó en la representación de óperas como Hamlet, Don Carlos, Aida, Il Trovatore y Linda de Chamounix junto a Adelina Patti y Marín: "El crédito de los artistas españoles es cada día mayor en esta importante ciudad, no decayendo un solo punto el entusiasmo con que el público los acoge"75. Mariano Padilla permaneció en Moscú hasta el 8 de diciembre de $1876^{76}$ y todo parece indicar que en los primeros meses del año 1877, el barítono regresó a España. Entre el 1 de abril y el 23 de mayo de 1877, actuó con la compañía de Giovanni Goula en Sevilla ${ }^{77}$ y después se dirigió a Murcia donde permaneció algunos días a principios de junio de $1877^{78}$.

${ }^{72}$ Salvo la siguiente información de La Ópera Española, I (1876), no 24, 12 abril, p. 3: "Está en embrión la idea de formar para la próxima temporada de invierno, una gran compañía de ópera italiana con artistas exclusivamente españoles. Por supuesto que no es para el Teatro Real, donde no caben por lo visto medianías como la Patti, la Volpini, Marín, Abruñedo, Padilla y otros de esta categoría”.

${ }^{73}$ La Paz de Murcia, XIX (1876), 15 noviembre, no 5906, p. 1.

${ }^{74}$ Lola Artôt de Padilla (Sèvres, 5/10/1876-Berlín, 12/04/1933), probablemente la segunda hija del matrimonio Artôt-Padilla, fue una célebre soprano cuya voz fue educada por su madre, Desirèe Artôt. Lola Artôt debutó en 1904 en la Opèra-Comique de París y cantó más tarde en Berlín, Escandinava y Polonia, entre otros países. Entre 1905 y 1908 cantó en el Komische Oper de Berlín y entre 1909 y 1927 en el Hofoper (Teatro de la Ópera Imperial) de la misma ciudad. En 1913 fue nombrada Kammersängerin en Berlín. Cantó con éxito roles como Octavian de Rosenkavalier de Strauss (1911), Zerlina de Don Giovanni (Mozart), Condesa de Almaviva de Le Nozze di Figaro (Mozart), Oscar de Un ballo in maschera (Verdi) y Micaëla de Carmen (Bizet), entre otros. Véanse más detalles en: [Anónimo], "Artôt”, Dizionario, vol. I, p. 153; Ménetrat, "Artôt. Lola Artôt", Die Musik, p. 1051; Rosenthal, "Artôt", The New Grove, p. 93.

${ }^{75}$ Véase, La Ópera Española, I (1876), n 43, 7 diciembre, p. 4. La crítica resaltó el papel de "Don Rodrigo" interpretado por Padilla en Don Carlo de Verdi, en cuya "aria y muerte del cuarto acto recibió frenéticos aplausos, porque su desempeño tuvo momento inspiradísimos."

${ }^{76}$ La Ópera Española, I (1876), nº 45, 23 diciembre, p. 4.

${ }^{77}$ Moreno Mengíbar, La ópera, pp. 263-264. El conjunto de artistas alcanzó el aplauso y los elogios de la prensa y el prestigio alcanzado por Goula convenció al empresario del Teatro de San Fernando de Servilla para actuar en la temporada siguiente.

${ }^{78}$ La Paz de Murcia, XX (1877), nº 6071, 8 junio, p. 1. 


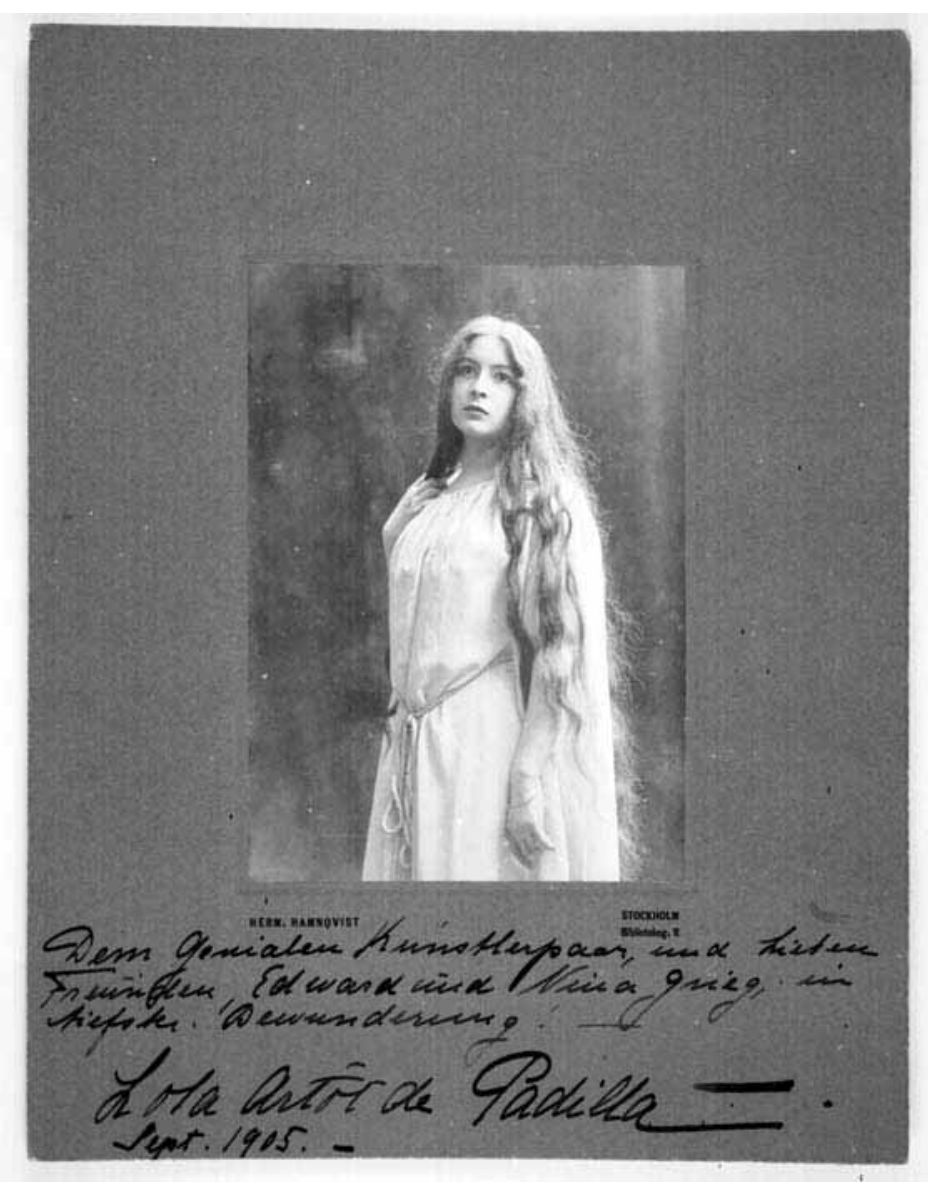

Figura 10. 5. Retrato de Lola Artôt de Padilla, dedicada a Edvard y Nina Grieg (septiembre de 1905). Fotografía realizada por Herm. Hamnqvist. N:Bo, The Edvard Grieg Archives. Accesible en: http://bergenbibliotek.no (acceso el 15-10-2011).

Tras el verano de 1877, Padilla fue contratado en el Teatro Real de Madrid para la temporada teatral de 1877-78. La compañía, que llevaba a cantantes de la talla de la soprano Erminia Borghi-Mamo, contraltos como Anna Belocca y Elena Sanz y tenores como Iginio Corsi, Julián Gayarre y Enrico Tamberlick, era dirigida por Joaquín Espín y Colbrand, Carlo Scalisi y Mariano Vázquez (ver Apéndice 10.4) ${ }^{79}$. Padilla intervino en Linda di Chamounix, L'Africana, Martha, I Puritani, Fausto y Otello con éxitos variables $\mathrm{y}$, según Carmena y Millán, el barítono murciano "cumplió generalmente con mucho acierto", .

Una de las óperas más significativa de la temporada 1877-1878 en el Teatro Real fue Roger de flor de Chapí estrenada en una función regia como parte de las celebraciones de la boda de Alfonso XII y Mercedes de Orleans ${ }^{81}$. Las críticas de Peña y

${ }^{79}$ Durante la temporada teatral de 1877-1878 se dieron en el Teatro Real 152 funciones según datos de Carmen y Millán, Crónica, pp. 364-371.

${ }^{80}$ Carmena y Millán, Crónica, p. 371.

${ }^{81}$ Información que apareció anunciada en La Paz de Murcia, XX (1877), nº 6150, 30 diciembre, p. 1. La ópera Roger de flor, en tres actos, está basada en el poema del mismo título del libretista Mariano Capdepón, publicado originalmente en el segundo libro de los Dramas Líricos. Se estrenó incompleta (sólo dos actos) el 23 de enero de 1878. Las causas de este estreno parcial fueron expuestas por Iberni, Ruperto Chapí, pp. 81-119. Iberni alude a la premura de los ensayos para coincidir con el evento matrimonial, entre 
Goñi y de Gómez coincidieron en destacar a la soprano Borghi Mamo, al tenor Tamberlick y al barítono Mariano Padilla como los artistas más destacables del evento "por sacar partido de la naturaleza extraña de sus respectivos papeles, que parecen refractarios al aplauso" ${ }^{\prime 2}$. Comentarios similares escribió Esteban Gómez en su crítica a Roger de flor, ya que observó que Borghi-Mamo y Padilla eran

\begin{abstract}
los dos personajes en quienes descansa toda la importancia dramática de la obra, y los que tienen sin duda mayor interés bajo el punto de vista musical. Es posible también que sea ésta la causa de que, tanto la señorita Borghi como el señor Padilla, aparezcan para el público con mayor interés y efecto y sean por lo mismo recompensados con más aplausos en las diferentes escenas en que toman parte" ${ }^{" 83}$.
\end{abstract}

Padilla continuó en Madrid hasta febrero de 1878, "en Berlín desde primero de marzo, y después en Viena" "84. Tras sus actuaciones en Austria, el cantante descansó en Murcia durante el mes de junio antes de emprender nuevas representaciones en Bucarest, en agosto de $1878^{85}$. Allí tuvo ocasión de cantar para el Príncipe Carlos de Rumanía, que condecoró a Padilla con la Estrella de Rumanía y a su esposa Artôt con la Orden del Mérito $^{86}$.

A principios de 1879, Padilla actuó con la compañía del director José Lago en el Teatro Imperial de Varsovia, junto a otros cantantes españoles ${ }^{87}$ y es probable que en febrero de 1880 actuara en la corte del emperador alemán Guillermo I junto al violinista Pablo Sarasate ${ }^{88}$. En 1881, el barítono murciano interpretó el personaje Hoel de Dinorah de Meyerbeer ${ }^{89}$ y un año después en el Covent Garden de Londres $^{90}$ y en Leipzig ${ }^{91}$.

otros problemas. La ópera había sido encomendada a los cantantes Borghi Mamo, Gayarre, Padilla y Nannetti. Sin embargo, días antes de la representación, Gayarre se negó a participar (por el escaso tiempo para preparar su personaje) y Tamberlick le sustituyó. Roger de flor volvió a representarse el 11 de febrero de 1878 bajo la dirección de Chapí. El reparto fue: Borghi Mamo (María); Flores (Irene); Tamberlick (Roger de Flor); Padilla (Basila); Nannetti (Miguel Paleólogo); Ugalde (Andrónico); Santos (Nicéforo). 85.

${ }^{82}$ Véase Peña y Goñi, “Teatro Real”, El Tiempo (21-II-1878) transcrito por Iberni, Ruperto Chapí, p.

${ }^{83}$ Esteban Gómez, “Crónica Musical”, Revista Contemporánea, III (1878), enero-febrero, pp. 376$384: 383$

${ }^{84}$ La Paz de Murcia, XX (1877), nº 6242, 20 diciembre, p. 1.

${ }^{85}$ La Paz de Murcia, XX (177), nº 6071, 8 junio, p. 1.

${ }^{86}$ El Comercio transcrita por La Paz de Murcia, XXI (1878), nº 6291, 17 agosto, p. 1.

${ }^{87}$ Saldoni, vol. IV, p, 157.

${ }^{88}$ Altadill, Memorias, p. 69 y Del Campo, "La visita", p. 85

${ }^{89}$ El autor subrayó el éxito de este personaje aunque no se precisa el lugar de la representación. [Anónimo], "Padilla y Ramos, Mariano", Dizionario, vol. V, p. 497.

${ }^{90}$ La Paz de Murcia, XXIV (1881), n ${ }^{\circ} 7158,6$ octubre, p. 1. No tengo constancia de la compañía ni del repertorio interpretado.

${ }^{91}$ La Paz de Murcia, XXV (1882), nº 7345, 16 mayo, p. 1. 


\subsection{La plenitud de su carrera artística: décadas ochenta y noventa}

En 1883 los Padilla-Artôt se instalaron en Berlín ${ }^{92}$. Como ya he comentado, Padilla tuvo un vínculo especial con esta ciudad germana no sólo por el número de veces que actuó en sus teatros sino también por los frecuentes conciertos privados que dio para los soberanos alemanes (ver Gráfico 10.1). En abril de 1884, el matrimonio tomó parte en un concierto en el Palacio Imperial de Berlín ante el Emperador de Alemania y Rey de Prusia, Guillermo I por su 87 cumpleaños: "Después de las primeras piezas, los esposos Padilla cantaron otra arreglada por ellos para dicha noche, en la cual habían introducido varios trozos de diferentes óperas y entre ellos el aria del Barbero" $"$. La relación del barítono con el soberano alemán llegó a proporcionarle el nombramiento de cantante de Cámara del Emperador ${ }^{94}$.

Gráfico 10. 1. Actuaciones de Mariano Padilla (1882-1889)
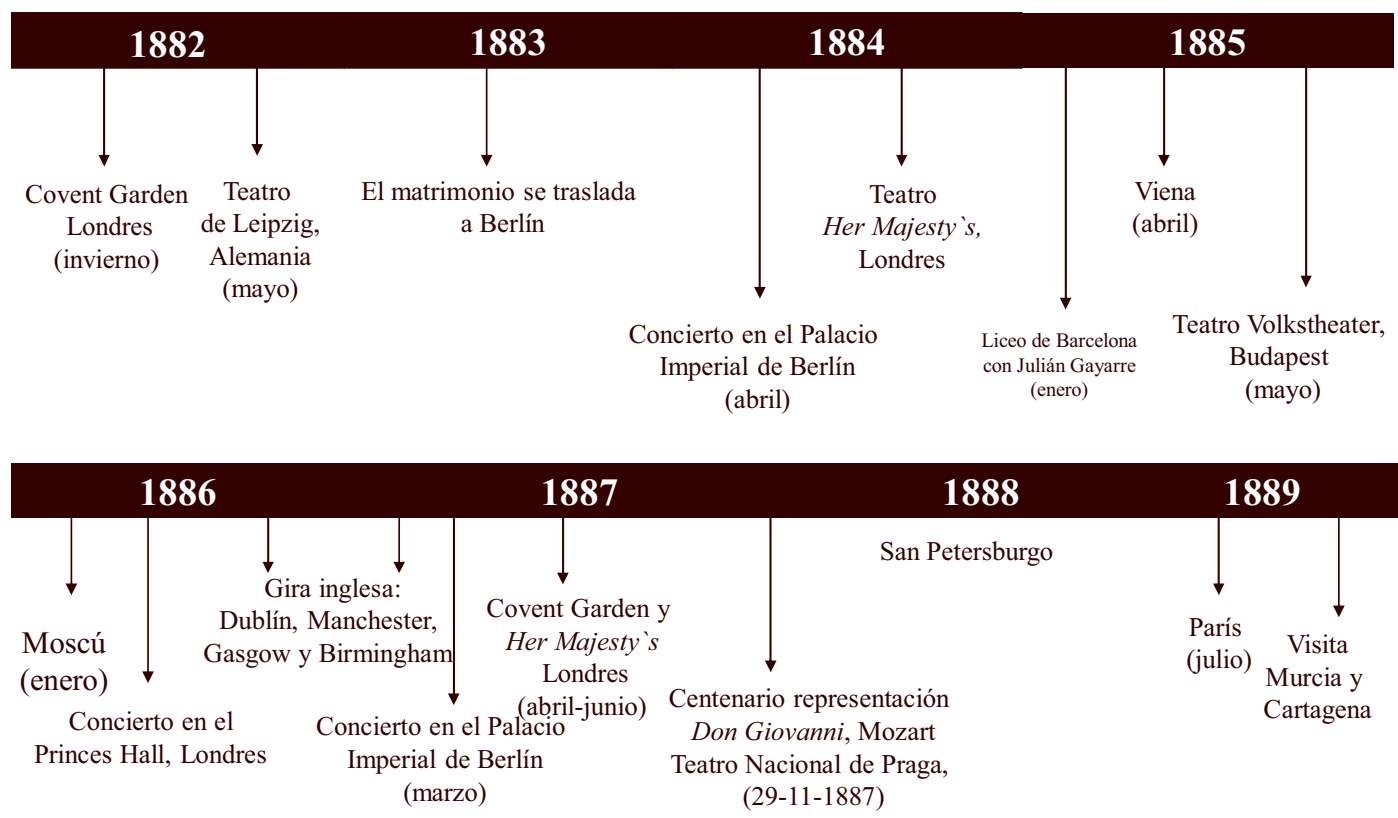

92 La Paz de Murcia, XXVI (1883), n $\mathrm{n}^{\mathrm{o}}$ 7781, 27 noviembre, p. 1 especifica claramente que en noviembre de 1883 el cantante ya había tomado una nueva casa en Berlín. Sin embargo, en la voz [Anónimo] "Padilla y Ramos, Mariano", Dizionario, vol. V, p. 497 aparece el año 1884 como la fecha del traslado. Al menos desde 1895, los Padilla-Artôt vivieron entre Baden-Baden y Biarritz, como después veremos.

${ }^{93}$ La Paz de Murcia, XXVII (1884), no 7885, 3 abril, p. 1.

${ }^{94}$ Así se apunta en la biografía publicada por el periódico Cartagena Artística, I (1890), nº 23, 20 noviembre, p. 1. Hasta la fecha, no he hallado más documentación que confirme este cargo. 
En noviembre de 1884, Mariano Padilla firmó un contrato con la empresa Hayes para actuar en el teatro Her Majesty`s de Londres. Se representaron, entre otras óperas, Il Trovatore, Il Barbiere di Siviglia y Don Giovanni, junto a artistas de renombre internacional como Biró de Marion, Desvignes, Rose Hersee, Sanderini, Castelmary y Frapolli, entre otros ${ }^{95}$.

Durante el mes de enero de 1885, la soprano Emma Albani, el tenor Gayarre, Padilla y el bajo Vidal debutaron en el Liceo de Barcelona con I Puritani de Bellini y del cantante murciano se dijo: "In quest'opera cantò con bellissimo successo il baritono Padilla, che è molto integgillente e buon esecutore" ["En esta ópera cantó con muchísimo éxito el barítono Padilla, que es muy inteligente y buen intérprete"] ${ }^{96}$. Aprovechando su estancia en España, Mariano Padilla visitó Murcia e intervino en el concierto a benefício de las víctimas por el terremoto de Andalucía (diciembre de 1884) el 26 de febrero de $1885^{97}$. Tras el concierto, partió para Berlín y más tarde, Viena, donde había sido contratado para la primavera en el teatro austriaco Carltheater con el empresario Merelli. La compañía estuvo integrada por las cantantes Teodorini, Fohström, Bellocca, Arnoldson, Almati y Corsi, los tenores De Negri, Ravelli y Paroli, los barítonos Padilla y Pantaleoni, los bajos Pinto y Scolara, el maestro concertador y director de orquesta Cleofonte Campanini y el maestro de coros Carlo Corsi. La temporada vienesa fue inaugurada con Lucia di Lammermoor (7-04-1885), a la que siguieron La traviata (con el debut de la soprano Teodorini), Lucrezia Borgia y Rigoletto. El empresario había anunciado un mayor número de óperas que no pudieron representarse por problemas económicos ${ }^{98}$. Il Mondo Artistico lo relató así:

Dopo quattro rappresentazioni, il Merelli dovette abbandonare l'impresa, che fu assunta dallo stesso direttore del teatro, il quale era prima cointeressato semplicemente. Il direttore del teatro, avendo ottenuto qualche facilitazione dagli artisti, ora è sperabile che la stagione proceda regolarmente ed al successo degli spettacoli corrisponda l'esto finanziario $[\ldots]^{99}$.

[Después de cuatro representaciones, Merelli abandonó la empresa, que fue asumida por el mismo director del teatro, el cual era en principio solamente cointeresado. El director del teatro, habiendo obtenido felicitaciones de los artistas,

${ }^{95}$ Il Mondo Artistico, XVIII (1884), nos 44-45, 14 noviembre, p. 10 y 46-47, 24 noviembre, pp. 3-4.

${ }^{96}$ Il Mondo Artistico, XIX (1885), no 4-5, 31 enero, p. 7. El acontecimiento fue seguido por las corresponsalías de La Paz de Murcia y el italiano Il Mondo Artistico. Este último publicó íntegra la carta de su corresponsal, fechado en 23 de enero de 1885. La Paz de Murcia, en cambio, recibió la información de su periodista Ibáñez telegráficamente. Véase, La Paz de Murcia, XXVIII (1885), nº 8118, 14 enero, p. 1.

${ }^{97}$ En el concierto, que produjo un gran beneficio, intervinieron otras instituciones musicales de la ciudad, como la Sociedad Santa Cecilia, la orquesta del Romea y otros músicos. Padilla interpretó dos arias de Il Trovatore y de Il Barbiere di Siviglia. El programa y su crítica se publicaron en La Paz de Murcia, XXVIII (1885), $\mathrm{n}^{\text {os }} 8156,26$ febrero, p. 1 y 8157, 27 febrero, p. 1. Los detalles sobre su llegada, preparativos, recaudaciones y otras informaciones sobre su despedida fueron recogidos en La Paz de Murcia, XXVIII (1885), ${ }^{\text {os }} 8142,10$ febrero, p. 1; 8149, 18 febrero, p. 1; 8152, 21 febrero, p. 1; 8160, 3 marzo, p. 1; 8159, 1 marzo, p. 1; 8160, 3 marzo, p. 1; 8170, 14 marzo, p. 1 y 8201, 21 marzo, p. 1.

${ }^{98}$ Il Mondo Artistico, XIX (1885), $\mathrm{n}^{\text {os }}$ 13, 24 marzo, p. 4; 16-17, 15 abril, p. 10 y 18, 26 abril, p. 4. Se anunciaron óperas no representadas como Il Barbiere di Siviglia, I Puritani, La Sonnabula, Un ballo in maschera, Il Trovatore y Ruy-Blas (esta última ópera era nueva para los vieneses).

99 Il Mondo Artistico, XIX (1885), $\mathrm{n}^{\circ}$ 18, 26 abril, p. 4. No se publicaron más noticias sobre la compañía en el citado diario. 
ahora espera que la temporada continúe regularmente y el éxito de los espectáculos se corresponda con las ganancias].

Es muy probable que en abril de 1885 Padilla actuara también en el Teatro Imperial de Viena con Il Trovatore, ante la presencia del Emperador de Austria y el Rey de Suecia, que felicitaron al barítono por su excelente interpretación ${ }^{100}$.

Después de la estancia en Viena, Padilla actuó a mediados del mes de mayo de 1885 en el Volkstheater de Budapest con Guglielmo Tell, Il Trovatore y Gli Ugonotti, con artistas como Ella Russel, Almati, Merzwinsky, Pintom y el mismo director de orquesta de la compañía de Viena, Cleofonte Campanini ${ }^{101}$. De Padilla se dijo: "Il Padilla pure ebbe un successo magnifico, diviso cogli altri artisti, Pinto e Paroli (Pescatore) [...] Ed un trionfo anche il Padilla, che dovette ripetere l'adagio della sua aria fra grandi applausi" ["Padilla tuvo un éxito magnífico, compartido con los otros artistas, Pinto y Paroli (Pescatore) [...] Y un triunfo también Padilla, che tuvo que repetir el adagio de su aria entre grandes aplausos"' ${ }^{102}$.

En 1885, Padilla figuró en el elenco de artistas del Teatro Kroll de Berlín ${ }^{103}$, junto a la soprano Ella Russel, que comenzaba a ser muy aclamada por el público alemán (ver Figura 10.6), la soprano Donadio, el tenor Frapolli, el bajo Monti y director Pomé. Sobre Il Barbiere di Siviglia, se escribió: "Il Padilla è un protagonista di molto valore; artista provetto, sicuro e continuamente festeggiato dal pubblico. Gli fu anche data una corona d'alloro" ["Padilla es un protagonista de gran valía, artista experto, seguro y continuamente aclamado por el público. Se le dio también una corona de laurel" $]^{104}$. Tras Il Barbiere, se representaron La Sonnambula y Dinorah, en la que la intervención de Padilla "fu eguale alla fama che gode il eccelso artista" ["fue igual a la fama que goza el excelso artista"] ${ }^{105}$.

${ }^{100}$ La Paz de Murcia, XXVIII (1885), no 8218, 10 mayo, p. 1. Según esta misma fuente, Padilla recibió por estas fechas una carta del Ministro de Rumanía concediéndole el diploma de "Caballero de la Estrella", "condecoración igual a la que ya poseía de la Rusia". Es probable que al recibir esta noticia, Padilla se marchara desde Viena a Budapest.

${ }^{101}$ Il Mondo Artistico, XIX (1885), nº 20-21, 19 mayo, p. 10.

${ }^{102}$ Il Mondo Artistico, XIX (1885), no 22-23, 30 mayo, p. 8.

${ }^{103}$ Il Mondo Artistico, XIX (1885), no 39, 12 octubre, p. 7.

${ }^{104}$ Il Mondo Artistico, XIX (1885), n 39, 12 octubre, p. 8.

${ }^{105}$ Il Mondo Artistico, XIX (1885), no 42-42, 1 noviembre, p. 8. 


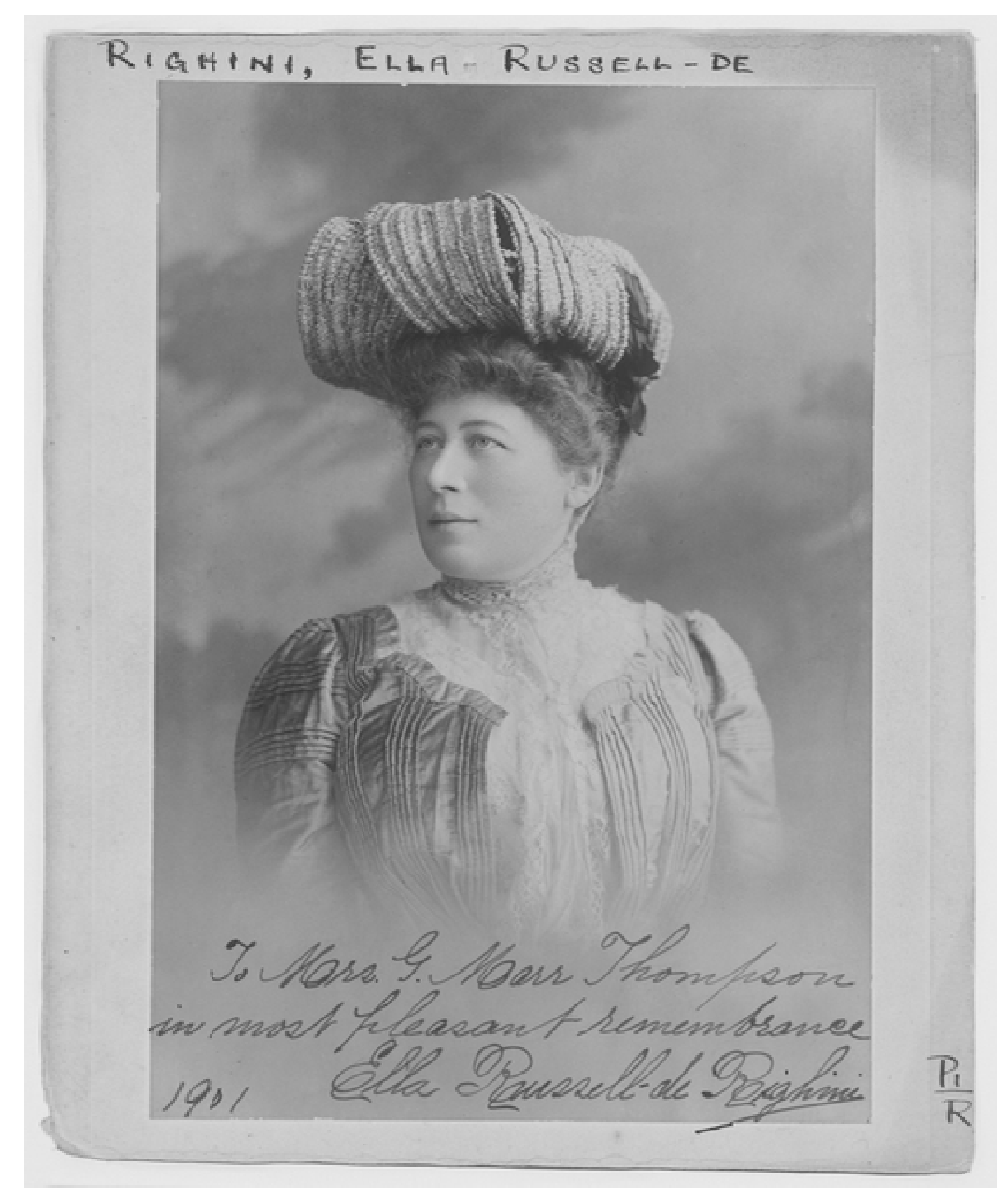

Figura 10.6. Retrato de la cantante Ella Russel-de Righini (1901). AUS:CAnl. Accesible en: http://www.nla.gov.au/ (acceso el 15-10-2011).

Después de Berlín, Padilla participó con gran éxito en Un ballo in maschera y Don Giovanni, en esta última como Don Giovanni y junto a otros cantantes como VanZandt (Zerlina), Drog (Donna Anna), Carbone (Leporello) y Lazzarini (Don Ottavio), en el Teatro Real de Stuttgart y bajo la dirección de Bevignani ${ }^{106}$.

La trayectoria artística de Padilla continuó en Moscú durante el mes de enero de $1886^{107}$ y en marzo de ese año participó en el concierto anual organizado por Luigi Danza en el Princes Hall de Londres (22-05-1886), en el que el cantante murciano destacó por encima del resto de participantes: "Le due colonne della serata erano Padilla e Capi" [Los pilares de la velada fueron Padilla y Capi ${ }^{108}$. A partir de octubre, el barítono inició una extensa gira por Inglaterra con la compañía del prestigio empresario Mapleson que incluyó ciudades como Dublín, Manchester (Thèatre Royal), Glasgow (Teatro Real),

${ }^{106}$ Il Mondo Artistico, XIX (1885), no 47-48, 2 diciembre, p. 6.

${ }^{107}$ Il Mondo Artistico, XX (1886), n ${ }^{\text {os }}$ 3, 17 enero, p. 10 y 4-5, 27 enero, p. 5. Según La Paz de Murcia, XXIX (1886), nº 8442, 9 febrero, p. 1 el matrimonio Padilla-Artôt ofreció un concierto privado a la Gran Duquesa Catalina de Rusia en el Castillo de Remplin, Gran Ducado de Maklenburgo.

${ }^{108}$ Il Mondo Artistico, XX (1886), no 23-24, 5 junio, p. 3. En el concierto intervinieron también el concertista de mandolina De Cristoforo y la violinista Anna Lang. 
Edimburgo, Glasgow (de nuevo), Birmingham ${ }^{109}$ y Londres. El Apéndice 10.5 recoge el itinerario, las óperas representadas y los cantantes de la gira inglesa de la compañía Mapleson. En la capital inglesa, la compañía de Mapleson ofreció representaciones durante el mes de diciembre de 1886 en el Covent Garden y volvió a la ciudad para la temporada estival del Teatro Her Majesty's desde junio de $1887^{110}$, con los siguientes componentes:

[...] prime donne Sinico, Lheman, Isidor, Olma, Oselio, Fohström, Hastreiter, Lablanche, Bauermeister, De Vigne, Dotti, Alameda e Broch.; tenori, Oxilia, Caylus, Bieletto, Rinaldini e Valero (che è chi e non si sogna neppure d'andare a Londra), baritoni: De Anna, Padilla, Lherie (che è a Nizzae poci andrà a Brecia), e Del Puente (che è scritturato al Drury-Lanel); bassi Abramoff, Vitta (?), Vaschetti e Vidal. Maestri Logheder e Rasori ${ }^{111}$.

Sin embargo, después de las primeras representaciones en el Teatro Her Majesty's de Londres el empresario disolvió la compañía" ${ }^{12}$ debido "senza dubbio all'inorportunità dei prezzi ridotti, in questa season" ["sin duda a lo inoportuno de los precios reducidos de esta temporada"] ${ }^{113}$. Entre las razones argumentadas, se aludió al hecho de que la aristocracia londinense prefiriera gozar de conciertos al aire libre durante los meses de verano, más que asistir a representaciones de ópera. A pesar del fracaso económico, Padilla había tenido ocasión de intervenir durante toda la gira inglesa de Mapleson en óperas de compositores como Verdi (Rigoletto, La Traviata, Il Trovatore), Donizetti (La Favorita, Lucia di Lammermoor), Gounod (Faust) y Mozart (Don Giovanni) aunque el repertorio de la compañía incluyó otros títulos de Wagner (Lohengrin), Bizet (Carmen) y Auber (Fra Diavolo), entre otros. Durante sus actuaciones con el elenco de Mapleson, la prensa italiana le reportó sus más halagadoras críticas, llegando a situarlo entre los mejores del arte y uno de los más predilectos del público: "L'ottimo attore-cantante, che sta fra i migliori dell'arte, é uno dei prediletti dal pubblico""114. "Il celebre baritono Mariano Padilla nella tournèe Mapleson" fue el titular con el que Il Mondo Artistico encabezó la serie de noticias y reseñas sobre la compañía, algunas de las cuales fueron transcritas de periódicos ingleses ${ }^{115}$. La fama del barítono murciano se había consolidado en toda Europa. En octubre de 1887, Mariano Padilla protagonizó Don Giovanni de

${ }^{109}$ Il Mondo Artistico, XX (1886), n 52, 24 diciembre, p. 6. En Birmingham, la compañía ofreció Faust, Lohengrin, Marta, Il Trovatore, Carmen, Le Nozze di Figaro, cuyo Figaro fue Padilla, así como un concierto.

${ }^{110}$ No he hallado información en la prensa italiana de los meses enero a marzo de 1887. La Paz de Murcia, XXX (1887), n 9153, 27 marzo, p. 1, sin embargo, informó de la actuación de Mariano Padilla durante el mes de marzo en un concierto ofrecido al Emperador Guillermo en el Palacio Imperial de Berlín.

${ }^{111}$ Il Trovatore, XXXIV (1887), $\mathrm{n}^{\mathrm{o}} 24,17$ junio, p. 2.

${ }^{112}$ En el Teatro Her Majesty's de Londres representaron, al menos Lucia di Lamermoor y Faust: Il Trovatore, XXXIV (1887), $\mathrm{n}^{\mathrm{o}}$ 24, 17 junio, p. 7.

${ }^{113}$ Il Trovatore, XXXIV (1887), $\mathrm{n}^{\circ}$ 25, 24 junio, p. 6. Veáse también, Il Trovatore, XXXIV (1887), $\mathrm{n}^{\circ}$ 29, 22 julio, p. 7.

${ }^{114}$ Il Mondo Artistico, XX (1886), nº 41, 19 octubre, p. 9.

${ }^{115}$ Il Mondo Artistico, XX (1886), no 41, 19 octubre, p. 9 transcribió fragmentos de los diarios ingleses Gaiety Irish Times, Daily Express y Evening Mail. Las reseñas de abril y junio de 1887 fueron escritas por un desconocido H. G. H. y publicadas en Il Trovatore, XXXIV (1887), nº 13, 1 abril, p. 8; 16, 22 abril, p. 7 y 17,29 abril, p. 8. 
Mozart, con motivo del centenario de su primera representación en el Teatro Nacional de Praga el 29 de octubre de 1787:

[...] A Praga abbiamo avuto veramente due rappresentazioni solenni del Don Giovanni: una al teatro Provinciale tedesco (Deustches Landestheater), ed una al teatro Nazionale czeco. Neppure per la musica le due razze, in lotta politica e sociale continua, possono andar d'accordo. Al primo teatro la rappresentazione ebbe luogo nel testo originale italiano; il baritono Padilla, chiamato da Berlino per assumere la parte del protagonista, non solo diresse le ultime prove, ma aiutò anche a far imparare il testo a'suoi compagni d'occasione. Non dirò che sia stata una esecuzione monstre, ma lodevole devesi chiamarla di certo.

Il Padilla, per quanto non abbia più i mezzi vocali di un giavonotto, si mantenne all'altezza della fama, che gode di cantante accuratissimo, della vecchi scuola, e di attore eccellente $[\ldots]^{116}$.

[En Praga hemos tenido dos representaciones verdaderamente solemnes del Don Giovanni: una en el Teatro Provincial alemán (Deustches Landestheater) y otra en el Teatro Nacional checo. [...] En el primer teatro la representación tuvo lugar con el texto original en italiano; el barítono Padilla, llamado de Berlín para asumir la parte del protagonista, no solo dirigió las últimas pruebas sino que ayudó a sus compañeros de reparto a aprender el texto. No diré que fue una ejecución monstruo, pero recomendable debería llamarse en verdad.

Padilla, que no tiene los medios vocales de un joven, se mantiene en lo alto de la fama, que goza de ser un cantante esmerado, de la vieja escuela y de actor excelente].

Las actuaciones de Mariano Padilla durante el año 1888 vuelven a ser, mayoritariamente, sobre escenarios rusos. El cantante trabajó en la compañía del empresario Lago durante la temporada invernal (enero a mayo) de ópera italiana del Teatro Panaïeff de San Petersburgo. Las noticias de la prensa, en cambio, son muy escasas y sólo dan cuenta de alguna función de comienzos de abril (Gli Ugonotti) y mayo (La Favorite) ${ }^{117}$. A partir de noviembre, figura entre los cantantes contratados por Antonio Ughetti, de nuevo, para el Teatro Panaïeff ${ }^{18}$. La compañía estuvo formada por

${ }^{116}$ Venceslao Herditzka,. "Il centenario del Don Giovanni de Mozart". En: Il Teatro Illustrato, VII (1887), $\mathrm{n}^{\circ}$ 83, noviembre, pp. 172-173. Herditzka menciona como notables las representaciones ofrecidas en Praga en los teatros "Nacional Checo" y Deustches Landestheater, cuyo protagonista fue Padilla. El crítico sólo se ocupó de la segunda. El reparto, tal y como lo detalla fue: Donna Anna, Moser; Leporello, Thomacetz; Ottavio, Wallnofer; Donna Elvira, Rosen; y Zerlina, Rettich. Como prólogo a la representación, se coronó un busto de Mozart. La noticia sobre el centenario de Mozart también llegó a Murcia a través de La Paz de Murcia, XXX (1887), nº 9243, 30 septiembre, p. 1.

${ }^{117}$ Gli Ugonotti tuvo lugar el 5 de abril de 1887, a beneficio del director de orquesta Enrico Benignani. Los cantantes fueron: Sandra, Pettigiani, Leonardi, Masini, Mirabella, Padilla, Povoleri: Il Mondo Artistico, XXII (1888), n 16, 7 abril, p. 10. En La Favorite, a beneficio del tenor Massini, Padilla y éste compartieron cartel con la soprano Leonardi: Il Trovatore, XXXV (1888), $\mathrm{n}^{\circ}$ 19, 11 mayo, p. 7. Durante el mes de mayo de 1887, Padilla, Massini y el director Benignani dieron un concierto privado en casa del archimillonario ruso Malinsoff. Interpretaron, entre otras, arias de $\mathrm{Il}$ barbiere di Siviglia recibiendo, a cambio, costosos regalos. Il Trovatore, XXXV (1888), $\mathrm{n}^{\mathrm{o}}$ 19, 11 mayo, p. 7 transcribió la noticia del periódico Journal de Saint Petersbourg.

${ }^{118}$ La temporada se inauguró con Il Barbiere di Siviglia el 26 de noviembre, a la que siguieron Aida, Lucrezia Borgia y Faust. Entre los cantantes que la prensa anunció figuraron: Masini, la Arnoldson, Sofica Scalchi-Lolli, Padilla, Mirabella y Alessandro Pomé como director de la orquesta. Il Trovatore, XXXV (1888), n 48, 30 noviembre, p. 9. Los éxitos de la compañía, en especial los del cantante Masini, fueron 
las cantantes Arnoldson, Pettigiani, Sembrich y Masini, Padilla, Mirabella y Devoyod y permanecieron en San Petersburgo al menos hasta diciembre de 1888, fecha en la que la empresa, en crisis, suspendió su cuarto abono ${ }^{119}$.

A partir de 1889, la trayectoria artística de Padilla comprendió varias giras por España. En ese año, Padilla fue reclamado por el Hospital de la Caridad de Cartagena para cantar en una función benéfica con la compañía de ópera que en ese momento actuaba en la ciudad. Se interpretó Rigoletto, con gran éxito de crítica ${ }^{120}$ y desde allí, el barítono partió para Murcia a visitar a su familia ${ }^{121}$. En 1890, Padilla formó parte de la Gran Compañía de Ópera Italiana, junto a la diva Emma Nevada (ver Figura 10.7) ${ }^{122}$, con la que recorrió entre los meses de mayo a julio varias poblaciones andaluzas, entre las que destacaron: Málaga, donde Padilla tuvo ocasión de reunirse con Camille SaintSaëns ${ }^{123}$, Granada (desde el 31 de mayo de $1890^{124}$ ), Córdoba (desde el 12 de junio ${ }^{125}$ ) y, finalmente, Gibraltar, donde actuó en la inauguración de su Gran Teatro en julio de $1890^{126}$.

Las críticas sobre Mariano Padilla con la Gran Compañía de Ópera Italiana fueron excelentes: "el eminente Padilla [es] uno de los barítonos que más gloria y

reflejados por los periódicos: Il Mondo Artistico: XXII (1888), $\mathrm{n}^{\text {os }} 49-50,5$ diciembre, p. 12; 51, 16 diciembre, p. 12; 51, 21 decembre, p. 6; 52, 30 diciembre, p. 10; XXIII (1889), no 1-2, 9 enero, p. 4 y $L a$ Paz de Murcia, XXXI (1888), nº 9662, 24 noviembre, p. 1.

${ }^{119}$ El periódico Il Trovatore anticipó en junio que la temporada otoñal de 1888 contaría con la nueva dirección artística del ex barítono Antonio Ughetti. La razón del cambio, asumido hasta el momento por el gallego José Lago, fue que éste había ofrecido al público algunos artistas muy mediocres, a pesar de la cantidad de dinero que se embolsó: Il Trovatore, XXXV (1888), $\mathrm{n}^{\circ}$ 22, 1 junio, p. 7. La cuestión, sin embargo, empeoró bajo la dirección de Ughetti, llegándose a hablar de "crisis" en el Teatro Panaïeff. Su mala gestión ("Un po' per incapacità, un po' per impotenza”) acabó con la suspensión de las representaciones del cuarto abono. La policía tuvo que intervenir incautando el dinero del cuarto abono para que no permaneciera en poder de la empresa y la dirección artística fue confiada a una comisión de la que formó parte Masini y L. A. Lolli. Véase, Il Mondo Artistico, XXIII (1889), nº 1-2, 9 enero, p. 4. 4.

${ }^{120}$ La Paz de Murcia, XXXII (1889), nos 9885, 28 julio, p. 1; 9889, 2 agosto, p. 1 y 9890, 3 agosto, p.

${ }^{121}$ La Paz de Murcia, XXXII (1889), nº 9908, 28 agosto, p. 4.

122 Durante 1890, la compañía fue dirigida por el barítono José Tolosa. Además de los mencionados Emma Nevada y Mariano Padilla, figuraron Traves, Vichon, Dante, Suañez, Bachs y Sierra: La Paz de Murcia, XXXIII (1890), nº 11035, 23 mayo, p. 4.

${ }^{123}$ Padilla llegó a Málaga antes del día 13 de mayo de 1890, según La Paz de Murcia, XXXII (1890), $\mathrm{n}^{\circ}$ 11027, 13 mayo, p. 4. Según La Paz de Murcia, XXXIII (1890), n 11041, 20 mayo, p. 4, Saint-Saëns se encontraba de paso en Málaga, camino de Orán y Marsella. El periodista, testigo del encuentro entre ambos, lo describió así: "habiendo sabido [Saint-Saëns] que se encontraba en esta capital el barítono señor Padilla, amigo íntimo suyo, pasó al Hotel de Roma a saludarle, saliendo ambos a visitar la población [y] habiendo tenido nosotros la fortuna de saludarle durante este paseo".

${ }^{124}$ La Gran Compañía de Ópera Italiana actuó en el Teatro de Isabel la Católica de Granada: La Paz de Murcia, XXXIII (1890), $\mathrm{n}^{\text {os }} 11035,23$ mayo, p. 4; 11036, 24 mayo, p. 4; 11048, 8 junio, p. 1 y 11053 , 14 junio, p. 1.

${ }^{125}$ El Diario de Murcia, XII (1890), no 4047, 10 junio, p. 3. Según La Paz de Murcia, XXXIII (1890), $\mathrm{n}^{\mathrm{o}}$ 11066, 29 junio, p. 4, entre Córdoba y Gibraltar, visitaron las siguientes poblaciones: Écija (Lucia di Lammermoor), Jerez de la Frontera (La Sonnambula, Lucia di Lamermoor y Lakmé de Delibes) y San Lúcar de Barrameda (La Sonnambula y Lucia di Lamermoor).

\footnotetext{
${ }^{126}$ La Paz de Murcia, XXXIII (1890), nº 11074, 9 julio, p. 4.
} 
mayores triunfos han conseguido en una larga y brillante carrera artística"127 y se elogió especialmente su papel de Fígaro en Il Barbiere di Siviglia: “

[...] El héroe de la noche fue, sin duda, el barítono señor Padilla, que ha demostrado una vez más que artistas de fuste hay muy pocos. No se puede pedir más elegancia y delicadeza en el decir, sacando efectos sorprendentes de messa voce, haciendo, en una palabra, un Fígaro inimitable $[\mathrm{y}]$ consiguiendo ovaciones en toda la obra $[\ldots]^{128}$.

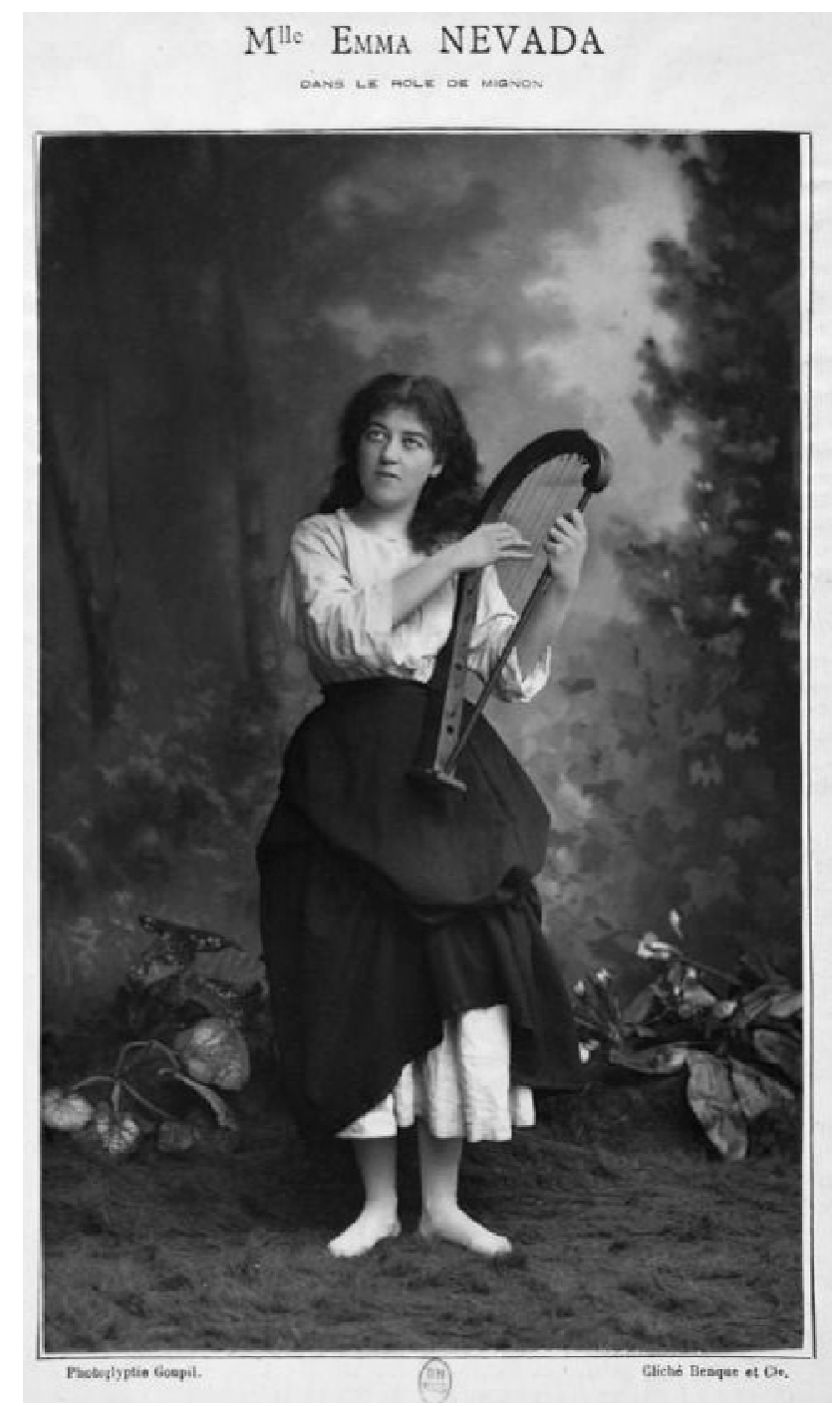

Figura 10.7. Retrato de Emma Nevada (1883).

Benque \& C.o, 33 rue Boissy d'Anglas, Paris. F:Bn, Catálogo Gallica. Acesible en: http://gallica.bnf.fr (acceso el 15-10-2011)

${ }^{127}$ La Paz de Murcia, XXXIII (1890), nº 11041, 20 mayo, p. 4

${ }^{128}$ Información de La Izquierda Liberal de Málaga, transcrita por La Paz de Murcia, XXXIII (1890), $\mathrm{n}^{\mathrm{o}}$ 11038, 27 mayo, p. 1. Véanse también las críticas de Il Mondo Artistico, XXIV (1890), $\mathrm{n}^{\mathrm{os}}$ 24, 29 mayo, p. 9 y 26-27, 16 junio, p. 12. 
Durante el otoño de 1890, Padilla fue contratado para actuar en el Covent Garden de Londres con la compañía del empresario Lago, los directores de orquesta Bevignani y Arditi y artistas como Ella Russel, los tenores Giannini y Perotti y los bajos Meroles, Fiegna y Novara, entre otros. El repertorio de la compañía comprendía óperas de Verdi (Aida, Il Trovatore, Rigoletto, Un ballo in maschera); Meyerbeer (Gli Ugonotti, Roberto Il Davolo, Stella del Nord); Ponchielli (La Gioconda); Wagner (Lohengrin, Tannhäuser); Gounod (Faust); Auber (La Muta di Portici); Bellini (Norma); Donizetti (La Favorita, Lucia di Lammermoor); Arrigo Boito (Mefistofele) y Cimarosa (Il matrimonio segreto), entre otras ${ }^{129}$. Un año más tarde, la Gran Compañía Italiana del director José Loriente actuaba en Murcia y Cartagena con los artistas Emma Nevada y Mariano Padilla (ver Capítulo 4) y también en 1891, Padilla fue contratado por el empresario Lago para actuar en el teatro Shaftesbury de Londres desde mediados de octubre ${ }^{130}$ y en el Acquarium (Sala Alexandroff) de San Petersburgo desde finales de diciembre ${ }^{131}$. En 1892, el barítono actuó de nuevo en el Covent Garden de Londres con las óperas Il Barbiere di Siviglia y Don Giovanni, sus papeles más usuales ${ }^{132}$ y en 1893 fue miembro del jurado en un Certamen Internacional de Música en la localidad francesa de Viráis ${ }^{133}$.

129 "Verity", "Lettere londinesi”, Il Mondo Artistico, XXIV (1890), no 43-44, 18 octubre, pp. 3-4. Además, se anunció que, si llegaban a superarse ciertos obstáculos, se llevaría a escena Otello de Verdi con los cantantes Albani, Giannini y Maurel. Según Il Mondo Artistico, XXIV (1890), n 45-46, 28 octubre, p. 8 el calendario de representaciones en el Covent Garden de Londres comenzaría con Aida, Gli Ugonotti con el siguiente reparto: señora Peri (Valentina), señora Stromfeld (Regina), Giulia Ravogli (Urbano), Perotti (Raoul), Padilla (Nevers), Meroles (Marcello), Faentini-Galassi (S. Bris); director de orquesta, maestro Arditi. El 21 del mismo mes, Faust con la señora Moody (Margherita), señora Costanzi (Siebel), Suanez (Faust), Padilla (Valentino), Novara (Mefistofele), de nuevo Aida y posteriormente Lucia di Lammermoor e Il Trovatore.

130 “L'opera italiana a Londra", Il Mondo Artistico, XXV (1891), no 42-43, 15 octubre, pp. 4-5. Los miembros de la compañía fueron: Giuseppina Gargano, Adelaide Musiani, Giulia Valda, Caintyre, y Elandi (sopranos), Guerrina Fabbri, Grace Damian, Brena (mezzosopranos), Francisco Vignas, T. Bertini, A. Chinelli, E. Dorini, I. Corsi (tenores), R. Blanchart, Padilla, Bronbara y Buti (barítonos), Giulio Rossi, Novara y Manners, entre otros (bajos), Ciampi y Caracciolo (bajos cómicos), Arditi y Bimboni (directores de orquesta). El atractivo de la temporada era Cavalleria rusticana de Pietro Mascagni, nueva para los teatros de Inglaterra. La compañía, además, llevaba en repertorio óperas de Domenico Cimarosa (Il matrimonio segreto), Donizetti (L'Elisir d'amore, Don Pasquale, La Fille du régiment), Gluck (Armide), Gounod (Faust), Halévy (L'Ebrea), Mozart (Don Giovanni, Le Nozze di Figaro), Luigi y Federico Ricci (Crispino e la comare), Rossini (La Cenerentola, Il Barbiere di Siviglia), Verdi (Ernani, Rigoletto, Un Ballo in maschera, Il Trovatore), Wagner (Il Vascello Fantasma, Logengrin) y Weber (Der Freischütz).

${ }^{131}$ Il Mondo Artistico, XXV (1891), no 51, 19 diciembre, p. 10. El periódico anunció como artistas principales de la compañía a la soprano Marcella Sembrich, al tenor Masini y al barítono Padilla. Las óperas representadas pueden consultarse en: Il Mondo Artistico, XXVI (1892), $\mathrm{n}^{\text {os }} 3,20$ enero, p. 12; 8, 20 febrero, p. 12; 9-10, 29 febrero, p. 10 y 11, 10 marzo, p. 4.

${ }^{132}$ Entre el elenco de artistas que actuó en el Covent Garden de Londres también se encontraba Emma Nevada, la soprano ¿Giulia? Valda, ¿Guglielmina? Tremelli, los tenores Piercy y Pandolfini, los barítonos Dufriche, Aramis (además de Padilla), los bajos Castelmary, Abramoff, Novara y Caraciolo y el director de la orquesta Enrico Bevignani: "La "season" d'autunno a Londra", Il Mondo Artistico, XXVI (1892), n' 4142, 8 octubre, p. 4. La crítica teatral de Il Barbiere di Siviglia, con Emma Nevada en el papel de Rosina y Padilla en el de Figaro obtuvo un rotundo éxito de crítica. Véase, Il Mondo Artistico, XXVI (1892), $\mathrm{n}^{\circ}$ 4849, 18 noviembre, pp. 3-4. Sobre Don Giovanni se escribió: "Don giovanni ha ancora fatto risuonare la sala di calorosi applausi, e dei leggendari bis del duetto Là ci darem, e del terzetto delle maschere" ["Don Giovanni ha hecho resonar la sala de calurosos aplausos y unos legendarios bises del dúo Là ci darem y el terceto de las máscaras"]: .Il Mondo Artistico, XXVI (1892), nº 48-49, 18 noviembre, pp. 3-4.

\footnotetext{
${ }^{133}$ El Diario de Murcia, XV (1893), nº 6006, 1 agosto, p. 3.
} 


\subsection{Sus últimos años: los escritos periodísticos de Mariano Padilla en la prensa murciana}

Desde los primeros años de la década de los noventa, los datos que se conocen sobre la vida de Padilla son realmente escasos. Al menos desde 1897, los esposos PadillaArtôt se instalaron en la localidad francesa de Biarritz, una ciudad balneario cercana a la frontera con España, donde la nobleza europea pasaba sus vacaciones desde que en 1854 el emperador Napoleón III y su esposa, la española Eugenia de Montijo, lo escogieron como lugar de descanso estival (ver Figura 10.8).

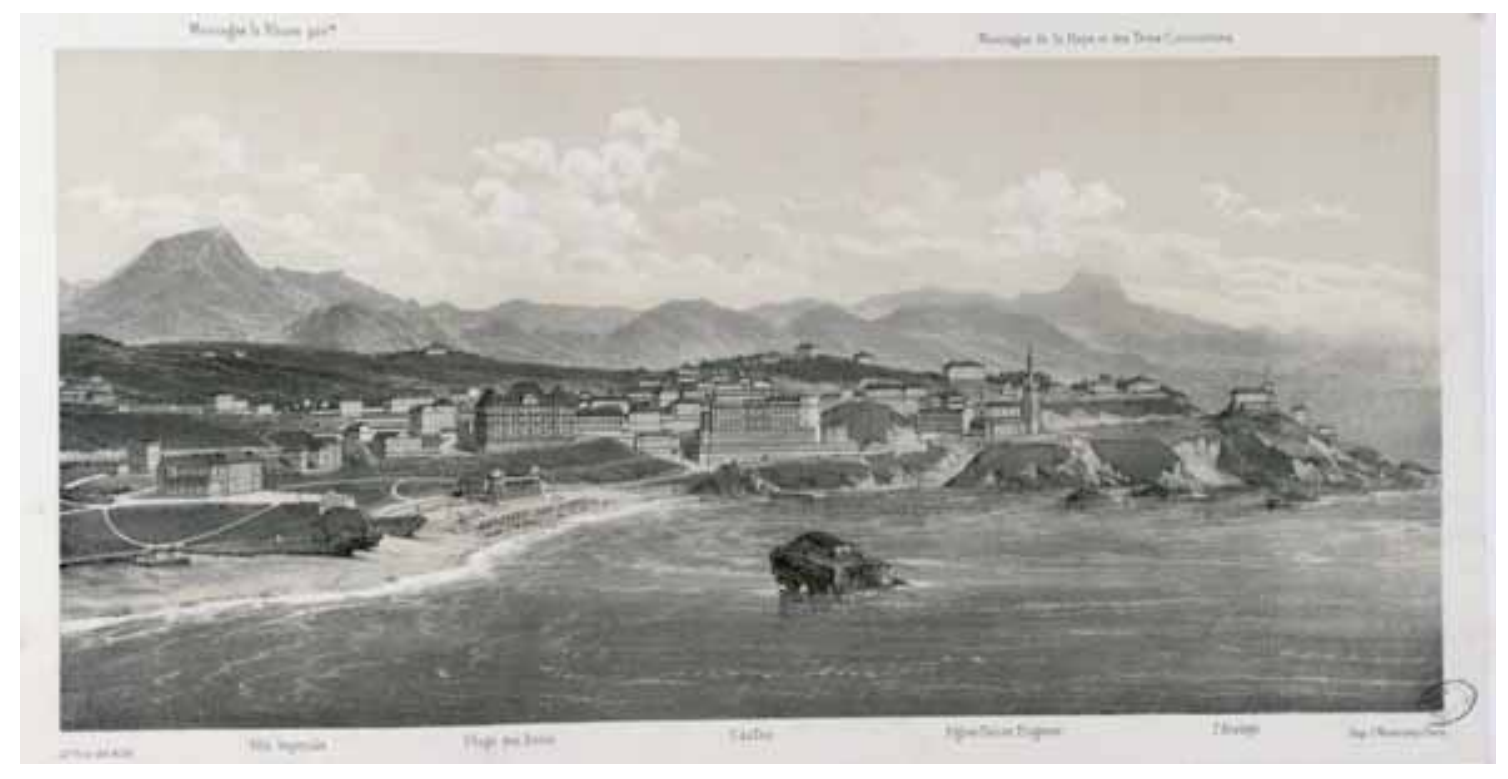

Figura 10.8. Vista general de Biarritz en el siglo XIX. Victor Jean-Baptiste, Vue générale de Biarritz.

(Bagnères de Luchon, Saintes: Dunlon, 18??). F:TLm. Accesible en: http://numerique.bibliotheque.toulouse.fr (acceso el 15-10-2011).

Durante estos años, los Padilla-Artôt impartieron clases de canto, actividad que él alternó con la escritura de interesantes artículos de opinión, publicados en la prensa murciana.

Padilla siempre estuvo vinculado a Murcia, bien a través de sus estancias en la ciudad, por lo general veraniegas; bien a través de las cartas que escribía tras sus visitas y que, en muchas ocasiones, publicó la prensa murciana. Además, colaboró en numerosas funciones y veladas benéficas celebradas en los distintos teatros, sociedades y otras instituciones tanto de Murcia como de Cartagena. En muchas ocasiones era invitado a participar y en otras era Padilla quien las proyectaba:

[...] Mi pensamiento es dar, con motivo de mi próxima llegada a Murcia, una función en el Teatro de Romea, donde cantaré lo que guste la Comisión (siempre en italiano), que se nombrará y cuyos productos que se depositarán, según ella disponga, sirvan para la fundación de tres pensiones:

Primera. Para estudiar el canto durante un año en Italia, al joven o a la joven que presente las facultades más brillantes e indispensables. 
Segunda. Para el compositor de música que, empezando su carrera, pueda ilustrarse en los centros artísticos de París, Alemania, etcétera y

Tercero. Para el pintor que reúna, previo un certamen, las mejores condiciones para perfeccionarse, bien sea en Roma, París o Mónaco.

No faltarán otros que vendrán para auxiliar, amparar y cimentar esa obra de progreso, bien con donativos o con los productos de representaciones teatrales por las sociedades artísticas constituidas.

Desde este momento me pongo a disposición para la realización de mi proyecto, esperando que lo tome con el mismo interés que me inspira, por ser digno de la atención pública $[\ldots]^{134}$.

Mariano Padilla ocupó en varias ocasiones las primeras páginas de la prensa murciana y cartagenera, lo que prueba el afecto y admiración que gozó durante su vida en su tierra natal (véanse Figura 10.9).

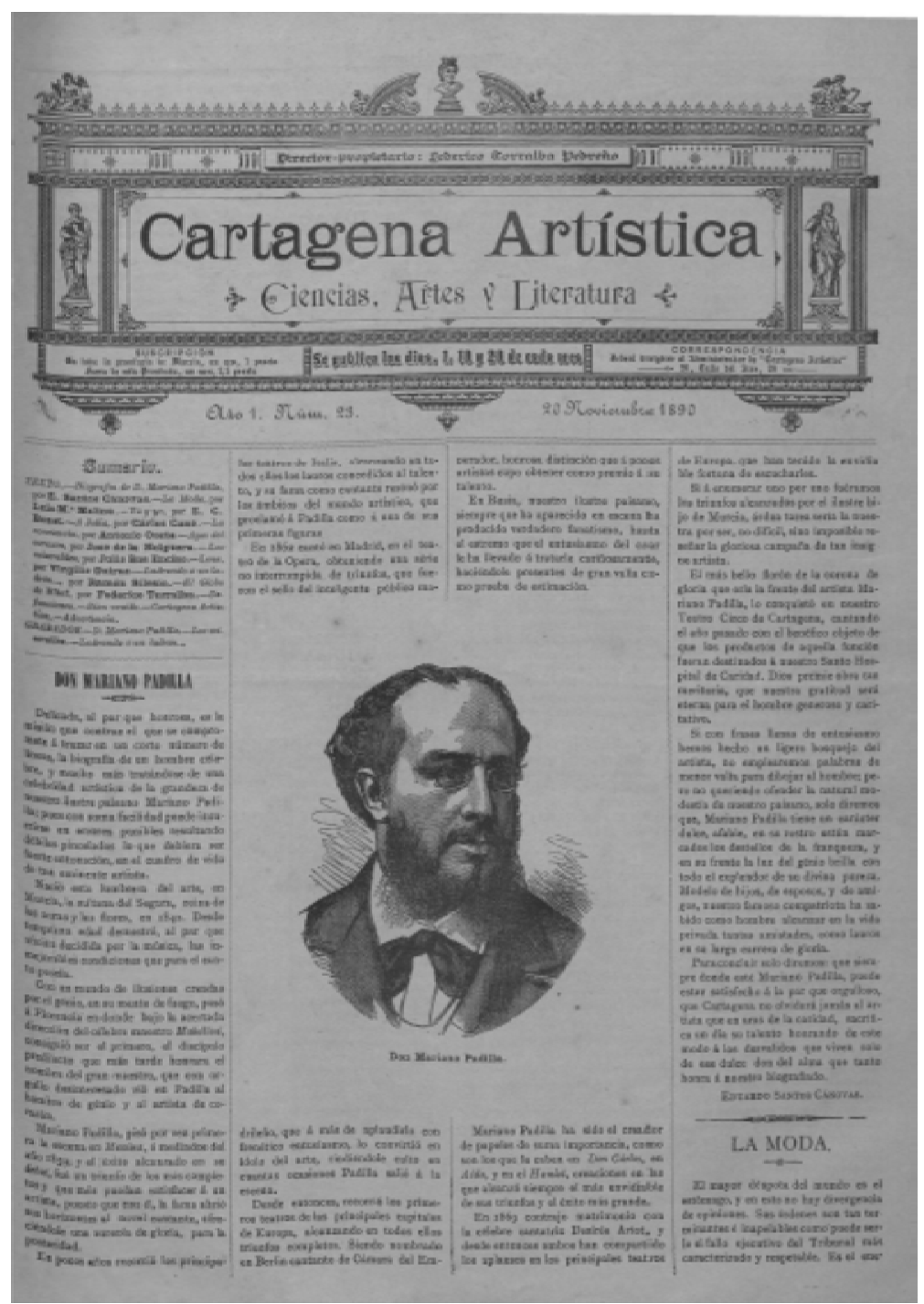

Figura 10.9. Portada de Cartagena Artística dedicada a Mariano Padilla. Cartagena Artística, I (1890), nº 23, 20 noviembre, p. 1, E: MUm.

${ }^{134}$ El Diario de Murcia, X (1889), n 3386, 9 agosto, p. 1. Desconozco si la función se llevó finalmente a cabo. 
La correspondencia y artículos escritos por Padilla y publicados en la prensa ofrece un aspecto de la vida del barítono difícilmente rastreable en otros ámbitos: el de su pensamiento. En esos escritos, Padilla opinó sobre el desarrollo de la música en su ciudad natal, aportó otros datos sobre su carrera artística y la de otros cantantes murcianos. La primera carta publicada que he localizado apareció La Paz de Murcia a principios de marzo de 1865. La carta contestaba un artículo de Casado titulado "Bellas Artes", donde se reivindicaba la enseñanza de la música en las escuelas públicas ${ }^{135}$. Padilla, en su contestación epistolar, observaba que en España la música se iba desarrollando, "sin más base que la espontaneidad". Según su propia visión de la música como "arte divino", por su "excelencia, su sentida belleza, su infinita y benéfica influencia, tanto en la educación de las familias como en la cultura de los pueblos, 1[a] hacen acreedor[a] [de] la más interesada y enérgica recomendación" y sin embargo, en Murcia, la falta de interés de las autoridades murcianas, encargadas de apoyar y proteger la enseñanza musical eran evidentes:

[...] ¿no es triste su lastimosa situación [la enseñanza musical en Murcia], víctima del abandono y apatía por parte de a quienes pudieran muy bien prestarse apoyo y protección?. ¿No se ven en gran número de poblaciones de inferior categoría a la nuestra, sociedades orfeónicas y otras muchas que siempre con el mismo objeto se declaran protectoras y bajo cuyos auspicios se crean establecimientos de enseñanza que reciben multitud de jóvenes ávidos de saber?. ¿Y esto mismo no pudiera tener lugar en esta capital, dando al mundo filarmónico aventajados artistas que, con el apoyo de la filantrópica diputación provincial y con su gloria, honrasen el noble país que les vio nacer? $[\ldots]^{136}$.

En el conjunto más importante de cartas y artículos que el cantante escribió, publicadas en El Diario de Murcia entre los meses de julio a septiembre de 1895 y 1899 , las ideas de Padilla sobre el retraso musical de España y también de Murcia se reiteran continuamente. Se trata de una importante colección de treinta dos escritos en los que el barítono colaboró periodísticamente con la prensa de su ciudad natal. Los temas tratados son muy diversos y no se refieren exclusivamente al ámbito musical, ya que abordan aspectos de la actualidad política, cultural y social del panorama nacional e internacional. Todos los artículos fueron escritos durante los periodos vacacionales de Padilla, bien desde Baden-Baden o bien desde Biarritz, lugares de residencia del cantante. La mayoría de los escritos aparecen encabezados con los títulos de los temas que a continuación trata, con la indicación del lugar donde fueron escritos. Los artículos y los temas se muestran en la Tabla 10.1:

${ }^{135}$ M.M. Casado, "Bellas Artes", La Paz de Murcia, VIII (1865), nº 2120, 3 marzo, p. 2 reivindica la enseñanza de la música en las escuelas públicas, dado "el gran desarrollo que ofrece en la civilización el noble arte de la música". Para argumentar los beneficios de la enseñanza musical en la educación general básica, Casado se apoya en escritores y filósofos como Alfonso Chard ("Los músicos son los hijos mimados del cielo"), Quintiliano, Platón, Aristóteles, Temístocles y Polibio y concluye sus referencias históricas citando al padre Feijóo: "La música acompañada de la virtud es la antesala del cielo". En su artículo, Casado además llegó a plantearse: “¿Por qué la noble ciudad de Murcia, cuna donde se han mecido tantos genios, no había de dedicar en su Academia de Bellas Artes una cátedra que enseñara al que lo deseare este bello lenguaje?" y termina: "La música en nuestra nación espera una mano benéfica que le arranque del lecho del desprecio donde se halla sumergida".

${ }^{136}$ Mariano Padilla, “A mis queridos paisanos”, La Paz de Murcia, VIII (1865), no 2123, 7 marzo, p. 
Tabla 10. 1. Colaboraciones periodísticas de Mariano Padilla con El Diario de Murcia (1895-1899)

\begin{tabular}{|c|c|c|}
\hline & Título del artículo & $\begin{array}{l}\text { Fuente } \\
\text { El Diario de Murcia: }\end{array}$ \\
\hline \multirow{12}{*}{ 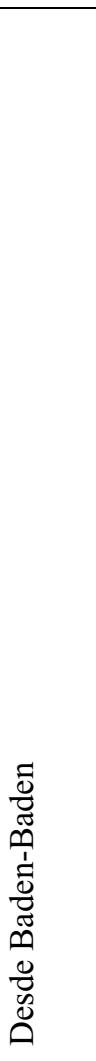 } & $\begin{array}{l}\text { "Chigaco. Sus progresos. } \\
\text { Alemania. Juicio crítico. Todos músicos. } \\
\text { Protéjaseles" }\end{array}$ & XVII (1895), $\mathrm{n}^{\circ}$ 6697, 2 agosto, p. 1 \\
\hline & $\begin{array}{l}\text { "De música. El Conservatorio de París. Nuestro } \\
\text { progreso musical. Lo que debe hacerse en } \\
\text { Murcia para fomentar el arte. Alemania. } \\
\text { Berlín progresa. Una anécdota" }\end{array}$ & XVII (1895), $\mathrm{n}^{\circ} 6705,10$ agosto, p. 2 \\
\hline & $\begin{array}{l}\text { "¡Viva nuestro ejército! Sépase quien es España. } \\
\text { Nuestra marina. La guerra de Cuba. La paz } \\
\text { de Baden-Baden. Bañistas ilustres. Una } \\
\text { fiesta. Los autores de himnos" }\end{array}$ & XVII (1895), $\mathrm{n}^{\circ} 6712,18$ agosto, p. 1 \\
\hline & "Los adelantos del siglo" & XVII (1895), nº 6726, 1 septiembre, p. 1 \\
\hline & "El gran Wagner" & $\begin{array}{l}\text { XVII (1895), } \mathrm{n}^{\mathrm{o}} 6735,10 \text { septiembre, } \mathrm{p} . \\
\end{array}$ \\
\hline & "Gounod" & $\begin{array}{l}\text { XVII (1895), } \mathrm{n}^{\circ} 6742,17 \text { septiembre, pp. } \\
1-2\end{array}$ \\
\hline & $\begin{array}{l}\text { "Toreros y toros. Maniobras militares. Una } \\
\text { gloria musical. El testamento de Verdi". }\end{array}$ & $\begin{array}{l}\text { XVII (1895), no 6743, } 18 \text { septiembre, pp. } \\
1-2 .\end{array}$ \\
\hline & "El maestro Palestrina. La música religiosa [I]". & $\begin{array}{l}\text { XVII (1895), } \mathrm{n}^{\circ} 6750,24 \text { septiembre, } \mathrm{p} \text {. } \\
1 .\end{array}$ \\
\hline & "El maestro Palestrina. La música religiosa [II]". & $\begin{array}{l}\text { XVII (1895), } \mathrm{n}^{\circ} 6749,25 \text { septiembre, } \mathrm{p} . \\
\end{array}$ \\
\hline & "Benedetto Marcello. Músico y poeta" & $\begin{array}{l}\text { XVII (1895), } \mathrm{n}^{\mathrm{o}} 6754,28 \text { septiembre, pp. } \\
1-2\end{array}$ \\
\hline & "Paulina García [I]" & XVIII (1896), $\mathrm{n}^{\circ} 7031,12$ julio, p. 1 \\
\hline & "Paulina García [II]" & $\begin{array}{l}\text { XVIII (1896), } \mathrm{n}^{0} 7032,13 \text { julio, pp. } \\
1-2\end{array}$ \\
\hline \multirow{3}{*}{ 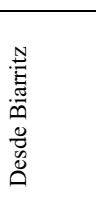 } & "Cartas de Biarritz" [Sobre Wagner] & $\begin{array}{l}\text { XVIII (1896), } \mathrm{n}^{\circ} 7107,27 \text { septiembre, } \mathrm{p} . \\
\quad 4\end{array}$ \\
\hline & "Carta de Biarritz" [Sobre política] & XIX (1897), $\mathrm{n}^{\circ}$ 7391, 1 agosto, p. 1 \\
\hline & "De cosas murcianas" & $\begin{array}{l}\text { XIX (1897), } n^{0} 7426,5 \text { septiembre, } \\
\text { p. } 1\end{array}$ \\
\hline \multirow{7}{*}{ 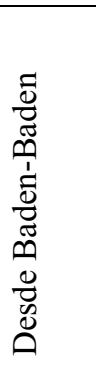 } & "Desde Baden-Baden" & XX (1898), $n^{\circ} 7737,26$ julio, p. 1 \\
\hline & "La protección a los teatros de Alemania" & XX (1898), no 7740,29 julio, p. 1 \\
\hline & "Desde Baden-Baden" & XX (1898), $\mathrm{n}^{\circ} 7745,3$ agosto, p. 1 \\
\hline & "Los teatros de Alemania. I" & XX (1898), $\mathrm{n}^{\mathrm{o}} 7748,6$ agosto, p. 1 \\
\hline & "Los teatros de Alemania. II" & XX (1898), $\mathrm{n}^{\circ} 7755,13$ agosto, p. 1 \\
\hline & "Los teatros de Alemania. III" & $\begin{array}{l}\text { XX (1898), } \mathrm{n}^{\circ} 7774,1 \text { septiembre, } \mathrm{p} \text {. } \\
\quad 1\end{array}$ \\
\hline & $\begin{array}{l}\text { "El sport en Europa. Toros, ciclismo, hipódromo. } \\
\text { Vaya una apuesta" }\end{array}$ & $\begin{array}{l}\text { XX (1898), } \mathrm{n}^{\circ} 7780,7 \text { septiembre, } \mathrm{p} \text {. } \\
\quad 1\end{array}$ \\
\hline \multirow{4}{*}{ 乙 } & "La música en las universidades de Alemania [I]" & XX (1898), $\mathrm{n}^{0} 7787,14$ septiembre, p. 1 \\
\hline & "La música en las universidades de Alemania [II]" & XX (1898), $\mathrm{n}^{\circ} 7791,18$ septiembre, p. 1 \\
\hline & "El maestro de la sinfonía. Beethoven [I]" & XX (1898), $\mathrm{n}^{\circ} 7798,25$ septiembre, p. 1 \\
\hline & "El maestro de la sinfonía. Beethoven. II" & XX (1898), $\mathrm{n}^{0} 7800,27$ septiembre, p. 1 \\
\hline \multirow{4}{*}{$\frac{\dot{1}}{\frac{1}{\tilde{E}}}$} & $\begin{array}{l}\text { "Desde Baden-Baden" [Representaciones de óperas de } \\
\text { Donizetti en Madrid y Francia] }\end{array}$ & $\begin{array}{l}\text { XXI (1899), } \mathrm{n}^{\circ} 8086,16 \text { agosto, pp. } \\
1-2\end{array}$ \\
\hline & "Desde Baden-Baden" [Sobre política europea] & XXI (1899), no 8088, 18 agosto, p. 1 \\
\hline & "Desde Baden-Baden" [Varios temas] & XXI (1899), $\mathrm{n}^{\circ} 8095,26$ agosto, p. 1 \\
\hline & "Desde Baden-Baden" [Sobre política europea] & XXI (1899), nº 8112, 16 septiembre, p. 1 \\
\hline \multirow{2}{*}{ 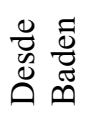 } & "Desde Baden-Baden" [Sobre política europea] & XXI (1899), no 8114, 19 septiembre, p. 1 \\
\hline & "Desde Baden-Baden" [Varios temas] & $\begin{array}{l}\text { XXI (1899), no } 8115,20 \text { septiembre, pp. } \\
1-2\end{array}$ \\
\hline
\end{tabular}


Entre el conjunto de artículos se distinguen tres tipos: los escritos que Padilla dedica a un compositor o cantante como Wagner, Gounod (al que conoció personalmente), Palestrina, Beethoven, Benedetto Marcello o Paulina García, maestra de canto de Desirée Artôt; un segundo tipo que comprenden temas muy diversos (política, deporte, cultura) y un tercer grupo de escritos que dedica a un tema monográfico. Entre los monográficos destaca la serie de artículos sobre los teatros de Alemania y la música en las universidades de este país, temas que trata "para que tengan una idea, mis apreciables paisanos, del interés y rango que tienen en Alemania el desarrollo de la música" $" 137$.

Para Padilla el éxito de los teatros alemanes se basaba, por una parte, en el buen funcionamiento y efectiva organización $\mathrm{y}$, por otra, en el apoyo que los gobiernos alemanes daban a los teatros a través de subvenciones públicas; y para corroborar sus argumentos, Padilla aporta cifras concretas sobre las ayudas estatales a teatros como el Kroll Theatre, el Teatro de la Ópera y el Teatro de la Comedia, los tres en Berlín, o el Teatro Imperial y el de la Comedia, ambos en Viena. Padilla observaba que entre el personal que formaba los coros de los teatros alemanes, por ejemplo, reinaba "ese espíritu de disciplina que les une entre sí y les acostumbra a saber obedecer" ${ }^{138}$. Para Padilla, cada "corista" era debidamente educado y percibía un sueldo digno durante su trayectoria laboral e incluso en su retiro. En Alemania, los músicos contaban con la "caja de pensiones", que aseguraban a los cantantes si perdían la voz, sufrían alguna enfermedad o cualquier otra causa que impidiera el cumplimiento de sus contratos ${ }^{139}$. Además de la protección económica, Padilla afirmaba que los músicos alemanes eran "queridos y respetados, tributándoles unas consideraciones mucho más grandes que a los generales en nuestra patria" ${ }^{140}$. Además, las familias alemanas no se oponían a las inclinaciones artísticas de sus hijos ya que "la consideran una existencia tranquila, feliz y gloriosa". En cambio, Padilla pensaba que en España la carrera artística no tenía porvenir y estaba "desprovista y apartada del respeto de las gentes sensatas" "141. Aunque el barítono admitía que los cantantes alemanes no eran contratados para los papeles principales tan frecuentemente como los franceses o italianos en los teatros europeos, los sueldos de los artistas en Alemania y Viena eran muy superiores. Las orquestas teatrales de España distaban mucho de las formaciones orquestales de teatros como Karlsruhe, Wiesbaden, Darmstadt, Stuttgart y Frankfurt, integradas por sesenta músicos o más, según el barítono. Además, en Alemania los empresarios invertían mucho más en vestuario y enseres escenográficos y éstos eran construidos por el personal técnico de cada teatro. Para el cantante murciano, el Gobierno español debía tomar ejemplo de todo ello y "dar vida a nuestros moribundos teatros" ${ }^{142}$ :

[...] Cuando se piensa en el estado empobrecido y la falta de protección que se le dispensa en nuestra bendita tierra española a la música y se compara la que reciben en los otros países, podemos asegurar que refleja los desacuerdos y desentonaciones de

\footnotetext{
${ }^{137}$ Padilla, "Desde Baden-Baden”, El Diario de Murcia, XX (1898), nº 7737, 26 julio, p. 1.

${ }^{138}$ Padilla, “Desde Baden-Baden”, El Diario de Murcia, XX (1898), nº 7745, 3 agosto, p. 1.

${ }^{139}$ Padilla, "Los teatros de Alemania. I", El Diario de Murcia, XX (1898), no 7748, 6 agosto, p. 1.

${ }^{140}$ Padilla, "Los teatros de Alemania. I", p. 1.

${ }^{141}$ Padilla, "Los teatros de Alemania. I", p. 1.

${ }^{142}$ Padilla, “Desde Baden-Baden”, El Diario de Murcia, XX (1898), n 7745, 3 agosto, p. 1.
} 
nuestra política que es la que se introduce por todas partes consumiendo nuestra existencia. Confiemos, sin embargo, en que las decisiones gubernativas, en tiempos más dichosos, sacudirán el polvo de muchas viejas pelucas, para hacer revivir nuestros músicos con pensiones al extranjero, proporcionándoles la ocasión de ponerse al contacto con los otros países, y saquen destellos de nuestras pasadas glorias artísticas. Foméntense las fiestas musicales, las sociedades corales y concurriremos al galardón de colocarnos al nivel de los progresos en nuestra época ${ }^{143}$.

Padilla lamentaba que estuviesen "encerrados nuestros ilustres maestros en esas mojigangas de pacotilla $\mathrm{u}$ operetas, cuando poseemos ese ardor meridional de nuestra raza y que tantos envidian, y no sepamos darle el valor que merece para producir obras musicales y alternar con ellas en el concierto europeo. Desechemos nuestra proverbial indolencia y preparemos a la lucha para recoger los laureles que merecemos" ${ }^{\text {. }}$.

"La música en las universidades de Alemania" es el título de dos artículos en los Padilla aporta numerosos detalles sobre el número de universidades, planes de estudios y profesores, entre otros aspectos, y en los que se vierten nuevamente ideas sobre el lamentable estado de la enseñanza musical en España, especialmente al compararla con Alemania. Padilla creía que los alemanes "atribuyen una expresión grande y expansiva al par de la vida social e intelectual. La música, en fin, desarrolla en la juventud todas las facultades y disposiciones individuales, dirigiéndoles al cumplimiento exacto de su profesión" y concluye este "conocimiento único de la instrucción musical en las universidades alemanas es un precedente digno de imitarse por algunos célebres conservatorios del extranjero. Estableciendo la ciencia musical en las escuelas públicas, completan las exigencias del arte contemporáneo"145.

Otra de las denuncias de Padilla sobre la situación musical en España era la escasa importancia que se le daba a la conservación de partituras musicales originales en las bibliotecas españolas "y no es de esperar que este desamparo o abandono remueva la conciencia al ministro encargado de vigilar y honrar las Bellas Artes, proponiendo medidas encaminadas a enriquecer nuestras pobres bibliotecas" $" 146$.

Al margen de la actividad periodística de Padilla, los escasos datos sobre su trayectoria entre 1899 y 1906 parecen indicar que el cantante se retiró de los escenarios y se centró en la educación musical de jóvenes artistas. Según González Vidal, Padilla padeció alguna enfermedad mental durante sus años finales y murió en Biarritz a finales de noviembre de $1906^{147}$.

En los años posteriores a su muerte, la ciudad de Murcia emprendió varias acciones que contribuyeron a perpetuar su nombre. En 1907, a petición del concejal

${ }^{143}$ Padilla, "Los teatros de Alemania. III", El Diario de Murcia, XX (1898), nº 7774, 1 septiembre, p. 1.

${ }^{144}$ Padilla, "Desde Baden-Baden”, El Diario de Murcia, XX (1898), no 7745, 3 agosto, p. 1.

${ }^{145}$ Padilla, "La música en las universidades de Alemania [II]", El Diario de Murcia, XX (1898), nº 7791, 18 septiembre, p. 1.

1.

${ }^{146}$ Padilla, "Los teatros de Alemania. III", El Diario de Murcia, XX (1898), nº 7774, 1 septiembre, p.

${ }^{147}$ González Vidal, Papeles murcianos, p. 78. El autor dedica el capítulo "Mariano Padilla versus Chaikovski", pp. 69-78 a relatar la vida de Padilla con un lenguaje más novelesco que científico. 
Antonio García, y previo informe de la Comisión de Policía Urbana, se acordó inscribir en el monumento de artistas célebres de Murcia, de la plaza Chacón (actual plaza de Santa Isabel), al laureado barítono ${ }^{148}$. Dos años más tarde, Serrano Alcázar pidió al Concejo que el nombre del cantante murciano figurara en el Teatro Romea, donde debía ponerse su retrato $^{149}$.

Por acuerdo municipal de 13 de septiembre de 1886, la Calle de la Corredera pasó a llamarse de Mariano Padilla ${ }^{150}$. En 1920, el Concejo cambió la dedicación de la calle, que pasó a homenajear al Catedrático Simón García. A Padilla se le dedicó entonces la antigua calle de los Dolores, donde el músico había nacido ${ }^{151}$.

\section{La personalidad de Mariano Padilla y sus características como cantante a través de la prensa}

La prensa murciana ha dejado varios testimonios que nos permiten conocer con más profundidad la personalidad de Mariano Padilla. Eduardo Bermúdez y Eduardo Santos Cánovas, periodistas de El Diario de Murcia resumieron así sus cualidades humanas:

Es mi querido paisano uno de los buenos murcianos, que jamás se olvidan de su país ni de sus paisanos, y cuantos le han tratado, cuantos nos honramos con su amistad vemos siempre en él al amigo solícito y cariñoso, al que no ha enfatuado el ruido ensordecedor del aplauso, ni endiosado la gloria, ni envanecido los laureles.

Modesto a pesar de su mérito artístico, sencillo, afable en su trato, demostrando también en este su talento, una de las cosas para él más gratas es saber de Murcia [...].

Padilla no envejece. Su fisonomía es la misma, su aspecto, el de hace veinte años. Su rizada barba y su arreglada melena, dan a su cabeza los tonos inequívocos del talento que bulle en su cerebro. [...]

Eduardo Bermúdez ${ }^{152}$.

[...] Mariano Padilla tiene un carácter dulce, afable, en su rostro están marcados los destellos de la franqueza y en su frente la luz del genio brilla con todo el esplendor de su divina pureza. Modelo de hijos, de esposos y de amigos, nuestro famoso compatriota ha sabido como hombre alcanzar en la vida privada tantas amistades como lauros en su larga carrera de gloria ${ }^{153}$.

\footnotetext{
${ }^{148}$ Ortega Pagán, Callejero, pp. 206-207. La decisión también fue publicada por El liberal, VI (1907), $\mathrm{n}^{\mathrm{o}} 1618,26$ enero, p. 2.

${ }^{149}$ El Liberal de Murcia VIII (1909), nº 2425, 17 abril, p. 2.

${ }^{150}$ Ortega Pagán, Callejero, p. 206.

151 Ortega Pagán, Callejero, pp. 407-408. Para recaudar los fondos necesarios para el pago de las lápidas de las nuevas calles una comisión encargada fijó una cuota máxima de 2 pesetas. La recaudación ascendió a 399,50 pesetas y con el sobrante, tras el pago de las mismas, se encargó una nueva lápida destinada a colocarse sobre la fachada de la casa natal de Mariano Padilla. La placa recordaba la fecha de fallecimiento del cantante y la de su colocación el 9 de mayo de 1920.

${ }^{152}$ Eduardo Bermúdez, "Mariano Padilla”, El Diario de Murcia, XVII (1895), nº 6511, 13 enero, p. 1.

${ }^{153}$ Santos Cánovas, “Don Mariano”, p. 1
} 
Desde que Mariano Padilla comenzara su actividad profesional en tierras italianas después de su formación con Beneventano y Ronconi, la prensa vio en él cualidades que le llevaría a situarse con "la palma dei bravi". Hacia la década de 1870, Padilla ya estaba plenamente consagrado como cantante y sus éxitos son mucho más numerosos que sus fracasos o funciones donde pasó indiferente. Las críticas hasta esa época coinciden en observar grandes adelantos en el cantante murciano:

[...] Con respecto al señor Padilla, diremos que ha adelantado mucho desde la última vez que tuvimos el placer de oírle. El estilo purísimo y bello con que cantó, el buen gusto con que interpretó el aria y la romanza ya citados [de La Favorite y Un ballo in maschera, respectivamente], y su modo de frasear, nos dieron a conocer la justicia de los triunfos y aplausos que ha alcanzado en su carrera en los primeros teatros de Europa, y que le han colocado entre los primeros artistas en su clase ${ }^{154}$.

Durante los años posteriores, el barítono murciano llegó a interpretar al menos veinticinco roles diferentes, como se muestran en la siguiente Tabla 10.2:

Tabla 10.2. Óperas y personajes representados por Mariano Padilla a lo largo de su vida.

\begin{tabular}{|c|c|c|}
\hline Ópera (compositor) & Personaje & Fuente \\
\hline Aida (Verdi) & Amonastro & $\begin{array}{l}\text { Eduardo Santos Cánovas, Cartagena Artística, I } \\
\text { (1890), } \mathrm{n}^{\mathrm{o}} 23,20 \text { noviembre, p. } 1 \text {; La Paz de Murcia, } \\
\text { XIX (1876), } 11 \text { febrero, }{ }^{\mathrm{o}} 5588, \text { p. } 1 \text {; La Ópera } \\
\text { Española, I (1876), } \mathrm{n}^{\circ} 43,7 \text { diciembre, p. } 4\end{array}$ \\
\hline Dinorah (Meyerbeer) & Hoel & $\begin{array}{l}\text { "Padilla y Ramos", Dizionario, vol. V, p. } 497 \text {; Il } \\
\text { Mondo Artistico, XIX (1885), no 42-42, } 1 \text { noviembre, } \\
\text { p. } 8\end{array}$ \\
\hline Don Carlo (Verdi) & $\begin{array}{l}\text { Rodrigo, } \\
\text { marqués de } \\
\text { Posa }\end{array}$ & $\begin{array}{l}\text { Eduardo Santos Cánovas, Cartagena Artística, I } \\
(1890), \mathrm{n}^{\mathrm{o}} 23,20 \text { noviembre, p. 1; La Ópera } \\
\text { Española, I (1876), } \mathrm{n}^{\mathrm{o}} 43,7 \text { diciembre, p. } 4\end{array}$ \\
\hline $\begin{array}{l}\text { Don } \\
\text { (Mozart) }\end{array}$ & $\begin{array}{l}\text { Don } \\
\text { Giovanni }\end{array}$ & 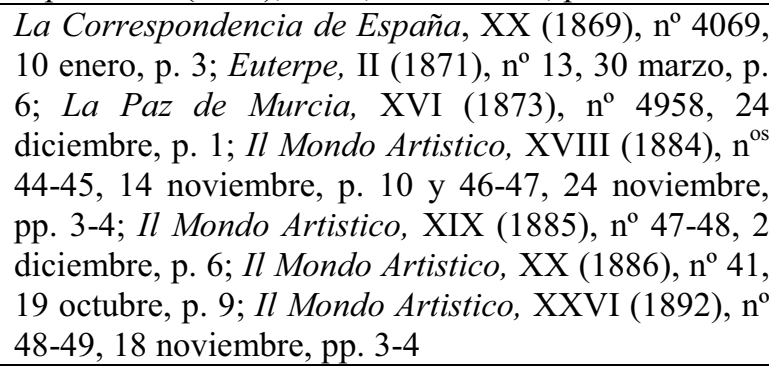 \\
\hline $\begin{array}{ll}\text { Don } & \text { Pasquale } \\
\text { (Donizetti) } & \\
\end{array}$ & $\begin{array}{l}\text { Doctor } \\
\text { Malatesta }\end{array}$ & $\begin{array}{l}\text { Cambiasi, La Scala, pp. 150-151, 342-343; Euterpe, } \\
\text { II (1871), no 13, } 30 \text { marzo, p. } 6\end{array}$ \\
\hline Faust (Gounod) & Valentin & $\begin{array}{l}\text { Euterpe: II }(1870), \mathrm{n}^{\mathrm{o}} 13,31 \text { marzo, p. } 5 ;(1871), \mathrm{n}^{\mathrm{os}} \\
\text { 6, } 9 \text { febrero, p. 7; } 7,15 \text { febrero, p. 6; 13, } 30 \text { marzo, p. } \\
\text { 6; Carmena y Millán, Crónica, p. 371; Il Trovatore, } \\
\text { XXXIV (1887), } \mathrm{n}^{\mathrm{o}} 24,17 \text { junio, p. } 7 \text {; Il Mondo } \\
\text { Artistico, XX }(1886), \mathrm{n}^{\circ} 41,19 \text { octubre, p. } 9\end{array}$ \\
\hline $\begin{array}{ll}\text { Gli Ugonotti } \\
\text { (Meyerbeer) }\end{array}$ & $\begin{array}{l}\text { Conde de } \\
\text { Nevers }\end{array}$ & $\begin{array}{l}\text { Euterpe II (1871), } \mathrm{n}^{\text {os }} 6,9 \text { febrero, p. } 7 \text { y } 7,15 \\
\text { febrero, p. 6; La Opera Española, I (1875), } \mathrm{n}^{\text {os }} 4,22 \\
\text { octubre de, pp. 1-2 y 7, } 16 \text { noviembre, p. 4; Il Mondo } \\
\text { Artistico, XXII }(1888), \mathrm{n}^{\circ} 16,7 \text { abril, p. } 10\end{array}$ \\
\hline $\begin{array}{l}\text { Guillaume } \\
\text { (Rossini) }\end{array}$ & $\begin{array}{l}\text { ¿Guillaume } \\
\text { Tell? }\end{array}$ & $\begin{array}{l}\text { La Correspondencia de España, XX (1869), n }{ }^{\circ} 4069 \text {, } \\
10 \text { enero, p. } 3\end{array}$ \\
\hline
\end{tabular}

${ }^{154}$ El Artista, III (1868), no 7, 22 julio, p. 54. 


\begin{tabular}{|c|c|c|}
\hline Hamlet (Thomas) & $\begin{array}{l}\text { Hamlet, } \\
\text { Príncipe de } \\
\text { Dinamarca }\end{array}$ & $\begin{array}{l}\text { Eduardo Santos Cánovas, Cartagena Artística, I } \\
(1890), \mathrm{n}^{\mathrm{o}} 23,20 \text { noviembre, p. 1; La Ópera } \\
\text { Española, I (1876), } \mathrm{n}^{\mathrm{o}} 43,7 \text { diciembre, p. } 4\end{array}$ \\
\hline I Puritani (Bellini) & $\begin{array}{l}\text { Sir } \\
\text { Riccador } \\
\text { Forth }\end{array}$ & Il Mondo Artistico, XIX (1885), $\mathrm{n}^{\circ} 4-5,31$ enero, p. 7 \\
\hline $\begin{array}{l}\text { Il Barbiere di Siviglia } \\
\text { (Rossini) }\end{array}$ & Figaro & $\begin{array}{l}\text { Euterpe, II (1871), } \mathrm{n}^{\circ} 13,30 \text { marzo, p. 6; Il Mondo } \\
\text { Artistico, XVIII }(1884), \mathrm{n}^{\text {os }} 44-45,14 \text { noviembre, } \mathrm{p} \text {. } \\
10 \text { y 46-47, 24 noviembre, pp. 3-4; Il Mondo } \\
\text { Artistico, XIX (1885), } \mathrm{n}^{\circ} 39,12 \text { octubre, p. 8; La Paz } \\
\text { de Murcia, XXXIII (1890), } \mathrm{n}^{\circ} 11038,27 \text { mayo, p. } 1 \text {; } \\
\text { Il Mondo Artistico, XXVI (1892), } \mathrm{n}^{\circ} 48-49,18 \\
\text { noviembre, pp. 3-4 }\end{array}$ \\
\hline Il Trovatore (Verdi) & $\begin{array}{l}\text { Conde de } \\
\text { Luna }\end{array}$ & $\begin{array}{l}\text { Euterpe, II (1871), } \mathrm{n}^{\circ} 13,30 \text { marzo, p. 6; La Paz de } \\
\text { Murcia, XVI (1873), } \mathrm{n}^{\circ} 4958,24 \text { diciembre, p. } 1 ; \text { La } \\
\text { Ópera Española, I }(1876), \mathrm{n}^{\circ} 43,7 \text { diciembre, p. } 4 \text {; } \\
\text { Mondo Artistico, XVIII (1884), n }{ }^{o s} 44-45,14 \\
\text { noviembre, p. } 10 \text { y 46-47, } 24 \text { noviembre, pp. 3-4; La } \\
\text { Paz de Murcia, XXVIII }(1885), \mathrm{n}^{\circ} 8218,10 \text { mayo, p. } \\
1 \text {; Il Mondo Artistico, XX (1886), } \mathrm{n}^{\circ} 41,19 \text { octubre, } \\
\text { p. } 9\end{array}$ \\
\hline $\begin{array}{l}\text { L'Africana } \\
\text { (Meyerbeer) }\end{array}$ & Nelusko & $\begin{array}{l}\text { La Ópera Española, I }(1875), \mathrm{n}^{\mathrm{os}} 4,22 \text { octubre de, pp. } \\
1-2 \text { y } 7,16 \text { noviembre, p. } 4 \text {; Carmena y Millán, } \\
\text { Crónica, p. } 371\end{array}$ \\
\hline $\begin{array}{ll}\text { La } & \text { Favorite } \\
\text { (Donizetti) } & \end{array}$ & Alfonso XI & $\begin{array}{l}\text { La Ópera Española, I (1875), } \mathrm{n}^{\mathrm{os}} 4,22 \text { octubre de, pp. } \\
1-2 \text { y } 7,16 \text { noviembre, p. 4; La Paz de Murcia XVIII } \\
(1875), 23 \text { noviembre, p. 1; Il Mondo Artistico, XX } \\
(1886), \mathrm{n}^{\circ} 41,19 \text { octubre, p. 9; Il Trovatore, XXXV } \\
(1888), \mathrm{n}^{\mathrm{o}} 19,11 \text { mayo, p. } 7\end{array}$ \\
\hline $\begin{array}{l}\text { La forza del destino } \\
\text { (Verdi) }\end{array}$ & $\begin{array}{l}\text { ¿Don Carlo } \\
\text { di Vargas? }\end{array}$ & Euterpe, II (1870), $\mathrm{n}^{\circ} 18,5$ mayo, p. 7 \\
\hline La Traviata (Verdi) & $\begin{array}{l}\text { ¿Barón } \\
\text { Douphol? }\end{array}$ & $\begin{array}{l}\text { Cambiasi, La Scala, pp. 150-151, 342-343; Euterpe II } \\
(1870), \mathrm{n}^{\mathrm{o}} 49,9 \text { diciembre, p. 3; La Ópera Española, I } \\
(1875), \mathrm{n}^{\text {os }} 4,22 \text { octubre de, pp. 1-2 y 7, } 16 \\
\text { noviembre, p. 4; Il Mondo Artistico, XX (1886), } \mathrm{n}^{\circ} \\
41,19 \text { octubre, p. } 9\end{array}$ \\
\hline $\begin{array}{l}\text { Le Nozze di Figaro } \\
\text { (Mozart) }\end{array}$ & ¿Figaro? & Il Mondo Artistico, XX (1886), n $\mathrm{n}^{\circ}$ 41, 19 octubre, p. 9 \\
\hline $\begin{array}{l}\text { Linda de Chamounix } \\
\text { (Donizetti) }\end{array}$ & $\begin{array}{l}\text { ¿Antonio o } \\
\text { Marqués } \\
\text { de } \\
\text { Boisfleury? }\end{array}$ & $\begin{array}{l}\text { Carmena y Millán, Crónica, pp. 248-249, 252; La } \\
\text { Opera Española, I (1876), } \mathrm{n}^{\circ} 43,7 \text { diciembre, p. 4; La } \\
\text { Paz de Murcia, XX (1877), } \mathrm{n}^{\circ} 6140,18 \text { diciembre, p. } \\
1\end{array}$ \\
\hline $\begin{array}{l}\text { Lucia di Lamermoor } \\
\text { (Donizetti) }\end{array}$ & $\begin{array}{l}\text { Enrico } \\
\text { Ashton }\end{array}$ & Il Mondo Artistico, XX (1886), no 41, 19 octubre, p. 9 \\
\hline $\begin{array}{l}\text { Maria di Rohan } \\
\text { (Donizetti) }\end{array}$ & Enrico & Carmena y Millán, Crónica, pp. 248-249, 252 \\
\hline Martha (Flotow) & Plumbell & $\begin{array}{l}\text { Carmena y Millán, Crónica, p. 371; La Paz de } \\
\text { Murcia, XX (1877), } \mathrm{n}^{\circ} \text { 6144, } 22 \text { diciembre, p. } 1\end{array}$ \\
\hline Otello (Verdi) & Yago & Carmena y Millán, Crónica, p. 371 \\
\hline Rigoletto (Verdi) & Rigoletto & $\begin{array}{l}\text { Olavarría y Ferrari, Reseña, vol. I, p. 698; La escena, } \\
\text { II (1866), } \mathrm{n}^{\circ} 12,28 \text { enero, p. } 3 \text {; Euterpe, II (1871), } \mathrm{n}^{\circ} \\
13,30 \text { marzo, p. 6; La Paz de Murcia, XVI (1873), } \mathrm{n}^{\circ} \\
4958,24 \text { diciembre, p. 1; Il Mondo Artistico, XX } \\
(1886), \mathrm{n}^{\mathrm{o}} 41,19 \text { octubre, p. 9; La Paz de Murcia, } \\
\text { XXXII }(1889), \mathrm{n}^{\text {os }} 9885,28 \text { julio, p. } 1 ; 9889,2 \\
\text { agosto, p. } 1 \text { y 9890, } 3 \text { agosto, p. } 4\end{array}$ \\
\hline
\end{tabular}




\begin{tabular}{|l|l|l|}
\hline $\begin{array}{l}\text { Roger de flor } \\
\text { (Ruperto Chapí) }\end{array}$ & Basila & $\begin{array}{l}\text { La Paz de Murcia, XX (1877), } \mathrm{n}^{\circ} \text { 6150, 30 diciembre, } \\
\text { p. 1; Esteban Gómez, "Crónica Musical", Revista } \\
\text { Contemporánea, III (1878), enero-febrero, pp. 376- } \\
384\end{array}$ \\
\hline $\begin{array}{l}\text { Un ballo in maschera } \\
\text { (Verdi) }\end{array}$ & Renato & $\begin{array}{l}\text { Jürgensen, "Verdi meets Scandinavia", pp. 80-109; Il } \\
\text { Mondo Artistico, XIX (1885), nº 47-48, 2 diciembre, } \\
\text { p. 6 }\end{array}$ \\
\hline
\end{tabular}

El repertorio más numeroso de óperas interpretadas por Mariano Padilla es el constituido por obras de Verdi y, descendiendo en número, Donizetti, Meyerbeer, Rossini y Mozart, entre otros; un repertorio lógico si tenemos en cuenta las compañías para las que trabajó el cantante. Entre los títulos operísticos en los que intervino Padilla destaca por su protagonismo el personaje de Rigoletto, de Rigoletto de Verdi, papel exigente tanto desde el punto de vista vocal (por su gran extensión) como del dramático, por la importante capacidad interpretativa que de ese rol se espera ${ }^{155}$ :

Il celebre baritono Mariano Padilla nella tournèe Mapleson. L'ottimo attorecantante, che sta fra i migliori dell'arte, é uno dei prediletti dal pubblico. A Dublino il suo successo nel Rigoletto è stato immenso. Ecco cosa scrive di lui il Gaiety Irish Times: "Il baritono Padilla diede la piú interessante e squisita interpretazione della parte di Rigoletto. Raramente questo abile e compitissimo artista si fece udire in condizioni più favorevoli. L'esecuzione, da parte sua, fu commendevole da cima a fondo per accuratezza e vigore, per energia e possanza, al tempo stesso che il suo canto fu altrettanto efficace quanto la sua abilità drammatica. Cosicchè gli astanti riconobbero unanimamente la sua superiorità. Disse il Deh, non parlare, con sentimento finissimo, e nel duetto Veglia o donna, cantò con gusto profondo. Il suo maggior trionfo, come era da aspettarsi, lo ottenne nell'appassionato duetto colla figlia, alla fine dell'atto secondo, allorchè volgendosi in un parossismo di furore verso il ritratto dell'ingrato Duca, scoppia nel: Si vendetta, tremenda vendetta. Questo veramente splendido sfogo diodio appassionato venne clamorosamente applaudito e bissato.

Il Daily Express: "Bisogna confessare che l'insieme della rappresentazione del Rigoletto, non fu proprio perfetto, e per la prima volta, a nostra ricordanza, il quartetto mancò di evocare il solito bis. La parte di Rigoletto, resa celebre fra noi da Ronconi, ebbe un eccellente interprete nel signor Padilla, il quale seppe felicemente evitare quell'eccesso di comicità, col quale parecchi resero il personaggio ridicolo più che altro. Ottimo nella scena, cantò ammirabilmente e meritó davvero gli applausi tributatigli lungo la serata".

Il Evening Mail: "Il Rigoletto, colla sua nobile musica ed il suo interessante intreccio, fu allestito superbamente ed eseguito stupendamente. $\mathrm{Ci}$ arrischiamo a sentenziare che la musica del Rigoletto non fu mai cantata meglio nei teatri di Dublino, ed il signor Padilla, oltre che col suo canto, colla esecuzione scenica della parte dello sventurato giullare, raggiunse il più alto grado dell'arte drammatica"156.

[El célebre barítono Mariano Padilla en la tournée Mapleson. El óptimo actorcantante, que está entre los mejores del arte, es uno de los predilectos del público. En Dublín, su éxito en Rigoletto fue inmenso. Así escribió sobre él el Gaiety Irish Times: "El barítono Padilla dio la más interesante y exquisita interpretación de la parte de Rigoletto. Rara vez este hábil y competente artista se deja oír en condiciones más favorables. La interpretación, por su parte, fue digna de alabanza de arriba abajo por su meticulosidad y vigor, por su energía y autoridad, al mismo tiempo que su canto fue tan eficaz como su habilidad dramática. Así, los presentes reconocieron unánimemente

\footnotetext{
${ }^{155}$ Jander, Steane, Forbes et al., "Baritone”, pp. 730-733: 732

${ }^{156}$ Il mondo artsitico, XX (1886), no 41, 19 octubre, p. 9.
} 
su superioridad. Interpretó el Deh, non parlare con delicado sentimiento y en el dúo Veglia o donna cantó con un profundo gusto. Su mayor triunfo, como era de esperar, lo obtuvo en el apasionado dúo con la hija, al final del segundo acto, cuando se dirigió en un arrebato de furor hacia el retrato del ingrato Duca, estalla en Si vendetta, tremenda vendetta. Este espléndido desahogo de odio apasionado fue clamorosamente aplaudido y bissato.

El Daily Express: “[...]. La parte de Rigoletto, que se hizo célebre entre nostros por Ronconi, tuvo un excelente intérprete en el señor Padilla, el cual supo felizmente evitar el exceso de comicidad con el que muchos hicieron el personaje ridículo más que otra cosa. Óptimo en la escena, cantó admirablemente y fue merecedor de los aplausos tributados durante la velada".

El Evening Mail: "El Rigoletto, con su noble música y su interesante trama, fue preparado magníficamente y ejecutado estupendamente. Nos arriesgamos a sentenciar que la música de Rigoletto no fue nunca cantada mejor en los teatros de Dublín, y el señor Padilla, además de con su canto con su ejecución escénica de la parte del desventurado bufón, alcanzó el más alto grado del arte dramático"].

Mariano Padilla debía poseer una amplia tesitura de barítono, lo suficientemente ágil como para resolver los pasajes de coloratura de óperas como Il Barbiere di Siviglia (Figaro), uno de sus roles más interpretados ("Padilla poi ci diede un Figaro unico" ["Padilla nos dio un Fígaro único"] ${ }^{157}$ ). Las críticas consultadas subrayan de él su depurada técnica vocal ligada a la escuela belcantista de canto italiana, cuyas bases técnicas según Morales eran "la impostación y proyección de la voz, el empleo de los resonadores, la unión y homogeneización de los registros, la flexibilidad y brillantez en la ejecución de las agilidades, las fioriture y demás adornos del canto, sin olvidar el gusto y la facilidad musical para improvisar" además de la emisión de sonidos claros y abiertos en todas las vocales ${ }^{158}$.

Las cualidades de la voz de Padilla aparecen descritas en algunas críticas. En Linda de Chamounix (Teatro Real, 1877-1878) se escribió que Padilla tenía "una voz de poco volumen pero extensa y que emite admirablemente y reúne a esta circunstancia brillantes condiciones escénicas" 159 . Su capacidad interpretativa fue, precisamente, una de las características más sobresalientes de Padilla y una de sus facultades más admiradas por la prensa. Sus dotes escénicas fueron definidas con adjetivos como distinción y nobleza:

"Padilla [...] è applaudito nella scena della spada per i suoi superbi mezzi vocali, per la distinzione e la nobiltá con cui interpreta la sua parte; il pubblico l'accoglie con entusiasmo, ridomandandolo alla scena da solo e co'compagni"160.

["Padilla [...] fue aplaudido en la escena de la espada por su magníficos medios vocales, por la distinción y nobleza con las que interpreta su parte. El público le acoge con entusiasmo, reclamándolo en la escena solo o con sus compañeros”.]

${ }^{157}$ Euterpe II (1871), n 6, 9 febrero, p. 7. Alguna biografía de la época le destacó como "creador" de papeles tan relevantes de Verdi como Amonasro de Aida y Rodrigo del Don Carlos, así como Príncipe Hamlet de Hamlet de Thomas. Sin embargo, en la documentación manejada no he hallado constancia de la representación de estas óperas. Cartagena Artística, I (1890), nº 23, 20 noviembre, p. 1.

${ }^{158}$ Morales, Los tratados, p. 860.

${ }^{159}$ La Correspondencia de España citada por La Paz de Murcia XX (1877), $\mathrm{n}^{\circ}$ 6140, 18 diciembre, $\mathrm{p}$. 1.

${ }^{160}$ Crítica a Gli Ugonotti en Moscú: Euterpe II (1871), nº 7, 15 febrero, p. 6. 
La prensa reconoció que "en sus cadencias ha[bía] tomado la escuela del célebre Ronconi, de tal manera que en momentos dados nos parece escuchar a este renombrado artista" aunque un tanto velada lo que, sin embargo, lejos de perjudicarle, resulta de buen efecto" "162. En la ópera Martha de Flotow, Mariano Padilla (junto a Gayarre), obtuvo rotundos comentarios en periódicos como Los Debates: "consumado maestro, a juzgar por el exacto colorido y verdad de que revistió a aquel personaje [Plumbell]. La manera desenvuelta con que jugó la escena, la intención en las frases y su excelente método de canto"; El Globo: "Hagamos, sin embargo, una excepción del señor Padilla, que dio vida y animación a todas las escenas en que intervino"; y, La Mañana, que afirmó de él: "es un verdadero artista" $" 163$.

A Padilla se le consideró como parte del conjunto de glorias nacionales, capaces de contribuir a la ansiada ópera española, y su nombre apareció en más de una ocasión en los artículos que sobre el tema publicó el periódico La Ópera Española, como se muestra en el siguiente párrafo:

\section{LA ÓPERA ESPAÑOLA}

[...] ¿Dirán nuestros enemigos que no tenemos compositores, que no tenemos cantantes? No podrán hacerlo si les recordamos los nombres de Abruñedo, Aramburu, Carrion, Marin, Puente, Azula, Vidal, Calayatud, Moragas, Padilla, la Cortés y la célebre Volpini y otros muchos cantantes que son una constante prueba de lo contrario; y maestros tan notables como Barbieri, Arrieta, Zubiaurre, Chapí, Caballero, Fernandez, Marqués, Giner, Zabala, Diaz de la Peña, Pujol, Barrera, Eduardo Ocon, Blas, Colomer, etcétera, etcétera, etcétera, y otros muchos que pudiéramos enumerar. $[\ldots]$

Los cantantes españoles que nombramos, en unión de otros muchos que no recordamos en este momento, son elogiados, admirados lejos de su querida patria, buscados y pagados con la esplendidez de los que saben apreciar el talento donde quiera que lo hallan. ¿Creen por ventura los que nos combaten por sistema y espíritu de extranjerismo, que esos artistas valen menos que esa tuba de detestables nulidades que aplaudís tan frecuentemente con mengua y escarnio el arte?. Pues se equivocan lastimosamente: una prueba de lo contrario es que, como hemos dicho anteriormente, son premiados y admirados en donde de seguro arrojarían como escoria del arte a los que vosotros aplaudís tan sólo por venir envueltos en deslumbrante oropeles y pomposos bombos pagados en las columnas de los que cobran a tanto por línea. [...]

Guzman $[\ldots]^{164}$.

${ }^{161}$ Comentarios publicados en El globo y recogidos por La Paz de Murcia, XX (1877), nº 6140, 18 diciembre, p. 1.

162 Originariamente publicada en La Mañana y transcrita por La Paz de Murcia, XX (1877), nº 6140, 18 diciembre, p. 1.

${ }^{163}$ Todos los comentarios se publicaron en La Paz de Murcia, XX (1877), nº 6144, 22 diciembre, p. 1.

${ }^{164}$ La Ópera Española, I (1875), no 1, 27 septiembre, pp. 1-2. En abril de 1876, un anónimo artículo titulado "Fiat Lux", La Ópera Española, II (1876), n 36, 10 octubre, p. 1 reiteraba: "Intérpretes para las producciones escénicas los hay: díganlo si no los principales teatros de Europa, donde constantemente y con indecible entusiasmo son aplaudidos las señoras Patti, Villar de Volpini, De-Baillou, Mantilla, Sanz, Ocampo, Cepeda, Mocorrea, Chini, Bonafí de Lucas, Cortés y los señores Marin, Gayarre, Aramburu, Vidal, Azula, Abruñedo, Carrion (hijo), Zabater, Mijá, Padilla, Siegle, Mendioroz, Ulloa, Ordinas, Cruz, etcétera, etcétera". 


\section{Capítulo 11. Creación e investigación musical en Murcia durante la segunda mitad del siglo XIX}

\section{Los Juegos Florales de Murcia y el fomento de la creación musical (1873-1883)}

Los Juegos Florales fueron originariamente certámenes literarios para promover y difundir una lengua. En ellos se premiaban obras literarias en prosa y en verso y, en muchas ocasiones, también se otorgaban distinciones a creaciones de otras artes como la pintura, escultura, arquitectura y música. La denominación "Juegos Florales" aludía al premio de honor o máximo galardón, la "Flor Natural". Este tipo de certámenes tuvo mucha difusión en España y otros países, especialmente durante la segunda mitad del siglo XIX ${ }^{1}$. En Murcia, los Juegos Florales se instauraron en 1873 por iniciativa de Javier Fuentes y Ponte, aunque la sección de música no se incluyó hasta el año siguiente ${ }^{2}$.

Los Juegos Florales de Murcia eran anuales y se celebraban en mayo. Desde 1875, se celebraron además otros Juegos Florales Extraordinarios durante la primera quincena de septiembre, coincidiendo con los días de feria (véase Figura 11.1) ${ }^{3}$. No se organizaron Juegos Florales en mayo de 1880 y 1882.

\footnotetext{
${ }^{1}$ El origen de los Juegos Florales se remonta a la Edad Media y su restauración moderna en España tuvo lugar en Barcelona, cuando en 1859, Manuel Milá y Fontanals, Antoni de Bofarull y Víctor Balaguer, entre otros intelectuales, organizaron un certamen literario cuyo primer premio se denominó "Flor Natural". Véase, Díez de Revenga, "De los juegos florales”, pp. 455-461:456. En Valencia se organizaron Juegos Florales a partir del año 1879 por la institución "Lo Rat Penat". En la actualidad siguen celebrándose estos certámenes en algunas localidades españolas. Sobre la historia de estos certámenes, véase Víctor Balaguer, "Noticia histórica de los Juegos Florales", Revista de España, XI (1878), no 242, marzo y abril, pp. 194206; y Primo López, “Juegos Florales”, La Paz de Murcia, XVIII (1875), no 5330, 7 abril, p. 1, noticia transcrita del periódico La Conciliación. No hay estudios de estos certámenes desde el punto de vista musical.

${ }^{2}$ El Semanario Murciano, I (1878), n 44, 15 diciembre, pp. 1-2: 1. Javier Fuentes y Ponte (Madrid, 1830-Murcia, 1904) fue un hombre polifacético y de gran relevancia en la vida cultura murciana del siglo XIX. Fue el Mantenedor de los Juegos Florales de mayo desde 1873 hasta 1879 y el principal impulsor de las exposiciones de flores (o concursos de "floricultura") que se celebraban en paralelo a los certámenes literarios y artísticos. Véase: El Semanario Murciano, I (1878), nº 3, 3 marzo, pp. 7-8. El programa de los Juegos Florales de Murcia de 1873 se publicó en La Correspondencia de Murcia, I (1873), $\mathrm{n}^{\circ} 10,4$ de febrero, p. 3. Se establecieron las siguientes modalidades y premios: "Mirto de Oro" ("Al autor del mejor boceto al óleo representando cualquier episodio de la Historia religiosa, militar o civil de Murcia, cuya composición original ocupará una superficie útil de 0.50 de largo y 0.35 de altura); "Englantina de Oro" ("Al autor de la mejor composición poética original sobre cualquier asunto de la Historia religiosa, militar o civil de Murcia, con libertad absoluta"); "Jazmín de Plata" ("Al autor del boceto que entre los presentados sea declarado accésit en mérito al del primer premio"); "Pensamiento de Plata" ("Al autor de la composición entre las presentadas sea declarada accésit en mérito a la del segundo premio"); "Flor Natural" de Pintura ("Al autor del mejor cuadro original de género que represente costumbres populares o tradicionales de este reino u otro cualquier asegundo análogo con libertad de tamaño") y "Flor Natural" de Poesía ("Al autor de la mejor composición poética original sobre cualquier asunto de costumbres populares o tradicionales de este reino, en el lenguaje aljabiado con notas aclaratorias pero con libertad absoluta en el metro"). Véanse más detalles en: La Paz de Murcia, XVI (1873), $\mathrm{n}^{\text {os }} 4740,18$ abril, p. 1; 4747, 26 abril, p. 1; 4750, 30 abril, p. 1 y 4753, 3 mayo, p. 1. Las categorías y nombres de los premios pueden consultarse en el Apéndice 11.1.

${ }^{3}$ En este apartado he estudiado los certámenes de mayo correspondientes a los años 1874 a 1879 , 1881 y los de septiembre de 1878 y 1883 , ya que en ellos se incluyó una sección musical.
} 


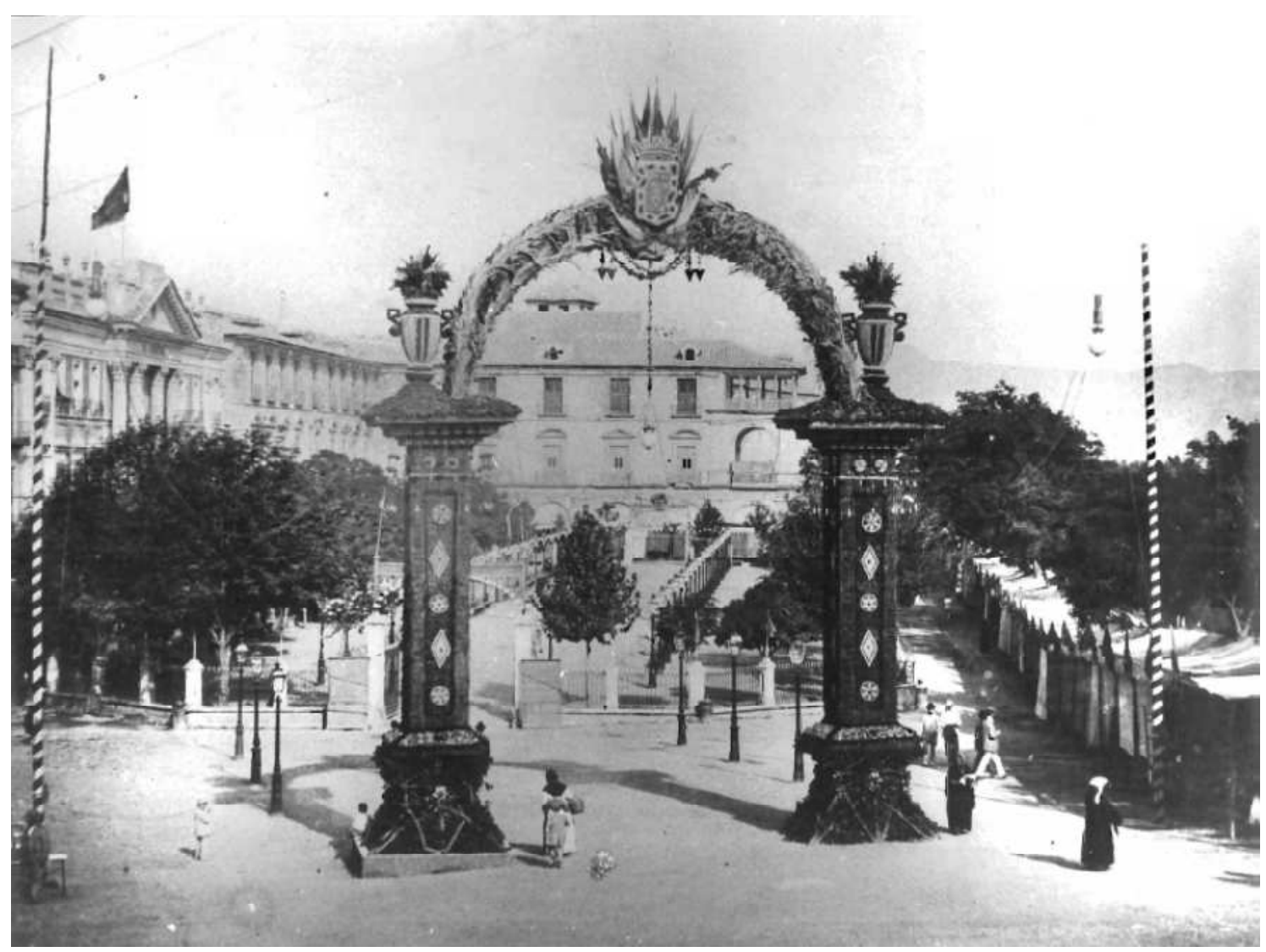

Figura 11.1. Arco de la feria de septiembre en la Plaza del Arenal y Glorieta de Murcia. Principios del siglo XX. E:MUm. Accesible en: http://www.archivodemurcia.es/ (acceso el 12-08-2011).

Los Juegos Florales de Murcia gozaron de una gran difusión fuera de la ciudad. Algunos de los miembros de los jurados tenían prestigio nacional, se concedieron varios premios a compositores no murcianos y la prensa nacional se hizo eco de ellos ${ }^{4}$.

La convocatoria de los Juegos Florales murcianos podía partir de cualquier institución (Ayuntamiento, Ateneo o Casino, por ejemplo) y su organización dependía de un "Consistorio". El funcionamiento de los Juegos Florales es similar en los años estudiados, salvo algunas variaciones. En el mes de enero o febrero de cada año, el director del certamen o Mantenedor hacía públicas las modalidades, premios y bases del concurso, que se publicaban en la prensa regional y, en algunos casos, también en la

\footnotetext{
${ }^{4}$ Véase, por ejemplo: Julián Calvo, Carta remitida, Crónica de la Música, III (1880), nº 67, 1 enero, p. 2.

${ }^{5}$ El "Consistorio" estaba formado por un Mantenedor o director del certamen; un greffier o secretario y una representación de premiados en otros certámenes, entre otros. Véanse más detalles sobre la organización de los Juegos Florales murcianos en "Los Juegos Florales", serie de artículos publicados bajo el pseudónimo "Un Consistorio Honorario" en El Semanario Murciano, I (1878), n ${ }^{\text {os }} 44,15$ diciembre, pp. 1-2; 45, 22 diciembre, pp. 1-2; no 46, 29 diciembre, pp. 1-3 y en los publicados en La Paz de Murcia, XXI (1878), $\mathrm{n}^{\text {os }} 6378,18$ diciembre, p. 1; 6382, 22 diciembre, p. 1 y 6387, 29 diciembre, p. 1. En 1879 se planteó una reforma del reglamento y la sustitución del Mantenedor, Javier Fuentes y Ponte por Gonzalo Baños. Se nombró a Vice-Mantenedor a Martínez Tornel: La Paz de Murcia, XXII (1879), nº 6393, 8 enero, p. 1 y El Diario de Murcia, I (1879), n 65, 6 mayo, pp. 1-2. En 1881, el Mantenedor de los Juegos Florales de mayo fue Zacarías Acosta: El Diario de Murcia, III (1881), nº 579, 11 enero, p. 2.
} 
nacional. Las obras presentadas a concurso se entregaban al Mantenedor de forma anónima, con un lema que las identificaba, en un sobre cerrado que contenía el nombre del autor. Los sobres se depositaban ante notario (en todos los casos estudiados, Juan de la Cierva) y se abrían públicamente en la ceremonia de entrega de premios, de la que se levantaba acta (Véase Figura 11.2).

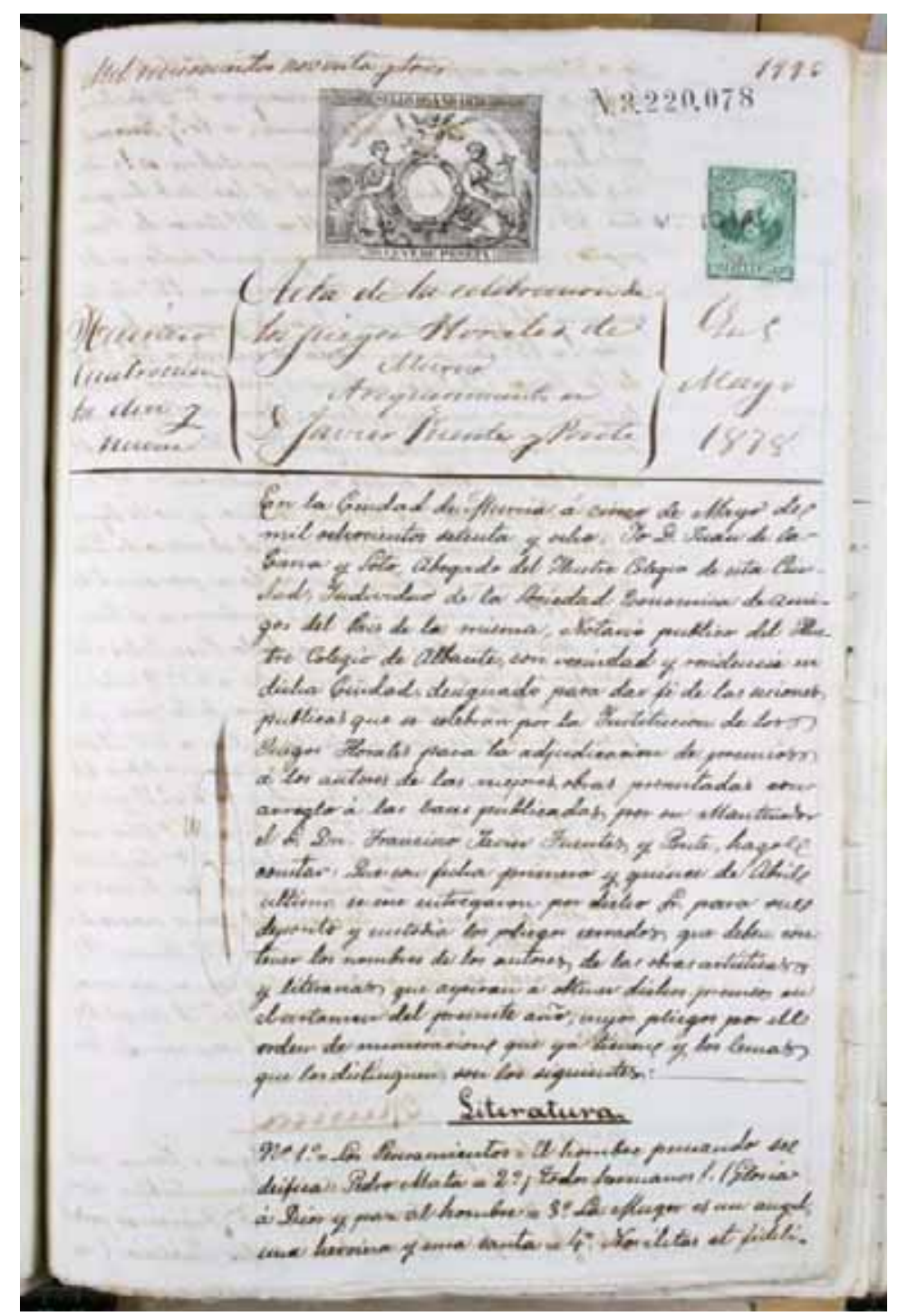

Figura 11.2. Acta de celebración de los Juegos Florales de Murcia (1878) E:MUhp, Protocolo Notarial 10958, fol. 1993.

Los concursantes podían elegir a tres miembros del Tribunal de un listado de nueve candidatos propuesto por la organización. Los lemas de las obras presentadas y los tribunales definitivos se publicaban en la prensa. La Tabla 11.1 muestra los miembros del Tribunal por la organización de los Juegos Florales para la sección de música y los jurados que finalmente fueron escogidos por los aspirantes entre 1874 y 1881: 
Tabla 11. 1. Jurados de música de los Juegos Florales de Murcia (1874-1881)

\begin{tabular}{|c|c|c|c|}
\hline Año & $\begin{array}{l}\text { Miembros propuestos por la } \\
\text { organización }(9)\end{array}$ & $\begin{array}{l}\text { Jurados seleccionados por } \\
\text { los concursantes }(3)\end{array}$ & Fuentes \\
\hline 1874 & $\begin{array}{l}\text { Emilio Arrieta, Francisco } \\
\text { Asenjo Barbieri, José Inzenga, } \\
\text { Hilarión Eslava, Manuel } \\
\text { Fernández Caballero, Baltasar } \\
\text { Saldoni, Mariano Soriano } \\
\text { Fuertes, Mariano García y } \\
\text { Antonio López Almagro }\end{array}$ & $\begin{array}{l}\text { Manuel Fernández } \\
\text { Caballero, Mariano García } \\
\text { y Antonio López Almagro }\end{array}$ & $\begin{array}{l}\text { El Arte, II (1874), } \mathrm{n}^{\mathrm{os}} 25, \\
22 \text { marzo, p. } 3 \text { y } 27,5 \\
\text { abril, p. } 2\end{array}$ \\
\hline 1875 & $\begin{array}{l}\text { Emilio Arrieta, Francisco } \\
\text { Asenjo Barbieri, José Inzenga, } \\
\text { Hilarión Eslava, Manuel } \\
\text { Fernández Caballero, Baltasar } \\
\text { Saldoni, Mariano Soriano } \\
\text { Fuertes, Mariano García y } \\
\text { Antonio López Almagro }\end{array}$ & $\begin{array}{lr}\text { Antonio López } & \text { Almagro, } \\
\text { Manuel } & \text { Fernández } \\
\text { Caballero y Antonio López } \\
\text { Almagro }\end{array}$ & $\begin{array}{l}\text { La Paz de Murcia, XVIII } \\
(1875), n^{\circ} 5327,3 \text { abril, } \\
\text { p. } 1\end{array}$ \\
\hline 1876 & $\begin{array}{l}\text { Emilio Arrieta, Francisco } \\
\text { Asenjo Barbieri, Jesús } \\
\text { Monasterio, Mariano Soriano } \\
\text { Fuertes, José Inzenga, Manuel } \\
\text { Fernández Caballero, Baltasar } \\
\text { Saldoni, Rafael Hernando y } \\
\text { Mariano García }\end{array}$ & $\begin{array}{lrr}\text { Francisco A. } & \text { Barbieri, } \\
\text { Mariano García y } & \text { y Rafael } \\
\text { Hernando } & & \end{array}$ & $\begin{array}{l}\text { La Paz de Murcia, XIX } \\
(1876), \mathrm{n}^{\text {os }} 5645,15 \\
\text { enero, p. } 1 \text { y } 5628,1 \\
\text { abril, p. } 1\end{array}$ \\
\hline 1877 & $\begin{array}{l}\text { Emilio Arrieta, Francisco } \\
\text { Asenjo Barbieri, Jesús } \\
\text { Monasterio, Mariano Soriano } \\
\text { Fuertes, José Inzenga, Manuel } \\
\text { Fernández Caballero, Baltasar } \\
\text { Saldoni, Rafael Hernando y } \\
\text { Mariano García }\end{array}$ & $\begin{array}{lcr}\text { Emilio } & \text { Arrieta, } & \text { José } \\
\text { Inzenga } & \text { y } & \text { Manuel } \\
\text { Fernández } & \text { Caballero }\end{array}$ & $\begin{array}{l}\text { La Paz de Murcia, XX } \\
(1877), n^{\circ} 5946,4 \text { enero, } \\
\text { p. } 1\end{array}$ \\
\hline 1878 & $\begin{array}{l}\text { Emilio Arrieta, Francisco } \\
\text { Asenjo Barbieri, Jesús } \\
\text { Monasterio, Mariano Soriano } \\
\text { Fuertes, José Inzenga, Manuel } \\
\text { Fernández Caballero, Baltasar } \\
\text { Saldoni, Rafael Hernando y } \\
\text { Mariano García }\end{array}$ & $\begin{array}{l}\text { Manuel Fernández } \\
\text { Caballero, Emilio Arrieta y } \\
\text { Mariano García }\end{array}$ & $\begin{array}{l}\text { El Semanario Murciano, } \\
\text { I (1878), } \mathrm{n}^{\circ} 8,7 \text { abril, p. } \\
6 \text {; La Paz de Murcia, } \\
\text { XXI (1878), n } \mathrm{n}^{\mathrm{o}} 6226,3 \\
\text { abril, p. } 1\end{array}$ \\
\hline 1879 & $\begin{array}{l}\text { Emilio Arrieta, } \text { Francisco } \\
\text { Asenjo Barbieri, Valentín } \\
\text { Zubiaurre, Mariano Soriano } \\
\text { Fuertes, Rafael Hernando, } \\
\text { Miguel Marqués, Manuel } \\
\text { Fernández Caballero, Antonio } \\
\text { López Almagro y Mariano } \\
\text { García }\end{array}$ & $\begin{array}{l}\text { Rafael Hernando, Manuel } \\
\text { Fernández Caballero y } \\
\text { Antonio López Almagro }\end{array}$ & $\begin{array}{l}\text { La Paz de Murcia, XXII } \\
(1879), \mathrm{n}^{\text {os }} 6500,16 \\
\text { enero, p. } 1 \text { y } 6565,4 \\
\text { abril, p. } 1 \\
\text { El Diario de Murcia, I } \\
\text { (1879), } \mathrm{n}^{\circ} 43,6 \text { abril, p. } 2\end{array}$ \\
\hline 1880 & - & - & - \\
\hline 1881 & - & $\begin{array}{l}\text { Emilio Arrieta, Manuel } \\
\text { Fernández Caballero y } \\
\text { Antonio López Almagro }\end{array}$ & $\begin{array}{l}\text { La Paz de Murcia, XXIV } \\
\begin{array}{ll}(1881), \quad \mathrm{n}^{\mathrm{o}} & 6978, \\
\text { febrero, p. } 1\end{array}\end{array}$ \\
\hline
\end{tabular}

Entre los miembros de los jurados de los Juegos Florales de Murcia hubo varios destacados compositores del panorama nacional, como Barbieri (1876), Emilio Arrieta (1877, 1878 y 1881) y Rafael Hernando (1876 y 1879). Otros, en cambio, fueron propuestos varios años para el tribunal, aunque nunca llegaron a formar parte de él, como 
les ocurrió a Monasterio, Saldoni, Soriano Fuertes o Zubiaurre. Los murcianos Fernández Caballero, López Almagro y Mariano García fueron asiduos miembros del jurado.

En la sección de música, los premios de los Juegos Florales eran costeados por diferentes instituciones, sociedades o incluso particulares ${ }^{6}$. El Apéndice 11.2 muestra los premios establecidos en la modalidad "Música" de los Juegos Florales de Murcia y las composiciones musicales exigidas en cada caso. En el primer certamen con música (1874) se concedió un único premio ("Flor Natural") al autor de la mejor melodía escrita para canto y piano sobre el poema "Sensitiva pudorosa", Durante los años siguientes, sin embargo, los premios de música fueron más numerosos y variados. El jurado podía dejar premios desiertos y destacar aquellas obras que se consideraban dignas de ser publicadas:

[...] Al tener las premiadas algunas circunstancias que las hagan dignas de publicación, y señalándolas el jurado, se publicarán como premio de honor: las de Pintura y Arquitectura en La Ilustración Española y Americana en consonancia con lo ofrecido por su digno director. Las de música por la institución y las de Poesía en un cuaderno a cargo de LA PAZ DE MURCIA, cuyo digno señor Director lo ha ofrecido al efecto $[\ldots]^{8}$.

En 1880 no se organizaron Juegos Florales en Murcia "por consecuencias de la catástrofe del 15 de octubre del año último". Los Juegos Florales se reanudaron en 1881 con algunos cambios. En enero se nombró a Zacarías Acosta como Mantenedor o

\footnotetext{
${ }^{6}$ Pondré varios ejemplos. Los premios de los Juegos Florales de 1875 fueron costeados por Enrique Clavijo ("Amapola de Oro") y Julio Gascón ("Rosa de plata"): La Paz de Murcia, XVIII (1875), n 5302, 4 marzo, p. 1. Los del año 1877 fueron subvencionados por el Conde de Roche (Flor Natural), Luis Pascual de Riquelme (Amapola Áurea), individuo no mencionado (Medalla de Plata), Juan López Somalo (Rosa de Plata) y los accésits por la organización. El compositor Julián Calvo costeó dos premios en los Juegos Florales del año 1881: una colección de sinfonías de Beethoven a la mejor polonesa para orquesta y otra recopilación de conciertos para piano y orquesta de varios autores al mejor nocturno para piano: La Paz de Murcia, XXIV (1881), nº 6978, 17 febrero, p. 1.
}

${ }^{7}$ La Paz de Murcia, XVII (1874), nº 4987, 30 enero, p. 1. La letra para la melodía fue: [1 ${ }^{\mathrm{a}}$ estrofa]: "Sensitiva pudorosa/ Siempre esquiva, siempre hermosa/ no te pliegues con desvío,/ Al rocío del amor. [2a estrofa]: Blanca estrella deslumbrante,/ Siempre bella, siempre errante,/ No me niegues con desmayo,/ Dulce rayo temblador. [ $3^{a}$ estrofa]: Luz que encanta, luz de aurora, / Hoy te canta quien te llora,/ Como cisne lastimero,/ Canto y muero por amor. [4 $4^{\mathrm{a}}$ estrofa]: Al mirarte fui cautivo,/ Para amarte sólo vivo,/ Pero en vano el alma mía/ Te confía su dolor".

${ }^{8}$ La Paz de Murcia, XIX (1876), n ${ }^{\circ}$ 5645, 15 enero, p. 1. Desde 1877, las bases pedían que las obras presentadas fueran originales e inéditas: La Paz de Murcia, XX (1877), n 5946, 4 enero, p. 1. Los editores Abelardo de Carlos (director de La Ilustración Española) y Enrique Villegas (director de El Arte) se comprometieron a publicar las obras ganadoras de pintura y música en los Juegos Florales de 1874, aunque el Jurado estimó que ninguna de ellas merecía este galardón: El Arte, II (1874), nº 31, 3 mayo, p. 2. Adolfo Gascón obtuvo el único premio de música ese año con una distinción de "mérito relativo".

${ }^{9}$ El Semanario Murciano, III (1880), no 146, 28 noviembre, p. 383. La catástrofe mencionada fue la "Riada de Santa Teresa", que provocó enormes destrozos en el Valle del Guadalentín, en la Huerta de Murcia y en la Vega Baja. La ausencia de Juegos Florales en Murcia se anunció en la prensa nacional: Diario Oficial de Avisos, CCXXII (1880), n 24, 24 enero, p. 4. En agosto de 1880, El Semanario Murciano anunció un Certamen literario organizado por su redacción en sustitución de los Juegos Florales. Se concedió un único premio al mejor "artículo sobre costumbres murcianas": El Semanario Murciano, III (1880), $\mathrm{n}^{\mathrm{o}}$ 132, 22 agosto, p. 271. Formaron el jurado Zacarías Acosta, Francisco Holgado y Antonio Hernández Amores. 
Presidente, y se renovaron otros cargos ${ }^{10}$. Una diferencia relevante respecto a los años anteriores fue que los concursantes no pudieron elegir a los miembros del tribunal, sino que éste fue nombrado directamente por los organizadores del certamen. Para el jurado de la sección de Música, fueron designados Emilio Arrieta, Manuel Fernández Caballero y Antonio López Almagro ${ }^{11}$. Se convocaron cinco premios musicales, dos de ellos costeados por el compositor y organista Julián Calvo ${ }^{12}$.

Los tipos de composiciones que se exigían en los Juegos Florales son un buen indicativo de los gustos musicales imperantes. Las diecisiete obras analizadas en los certámenes de 1874-1877, 1879, 1881 (no he hallado datos de 1878) aparecen agrupadas por géneros en la siguiente Tabla 11.2:

Tabla 11.2. Composiciones musicales exigidas en los Juegos Florales de Murcia (1874-1877, 1879, 1881)

Vls.: violines; vc.: violonchelo; pn.: piano

Fuentes: Ver: Apéndice 11.2.

\begin{tabular}{|c|c|c|}
\hline \multirow[t]{6}{*}{ Profanas } & Tipo de composición & $\mathrm{N}^{\mathrm{o}}$ obras \\
\hline & $\begin{array}{l}\text { Instrumentales para orquesta y/o banda } \\
\text { (sinfonía, capricho, fantasía, polonesa y } \\
\text { marcha) }\end{array}$ & 4 \\
\hline & $\begin{array}{l}\text { Canto con acompañamiento de piano y/o } \\
\text { armonio }\end{array}$ & 3 \\
\hline & Piano solo (barcarola, fantasía y estudio) & 3 \\
\hline & Cuarteto (dos vls., vc. y pn.) & 1 \\
\hline & Totales & 11 \\
\hline \multirow[t]{5}{*}{ Religiosas } & Tipo de composición & $\mathrm{N}^{\circ}$ obras \\
\hline & $\begin{array}{lccc}\text { Voces solistas } \begin{array}{c}\text { y/o } \\
\text { acompañamiento de orquesta }\end{array} & & \\
\text { acon } & \end{array}$ & 2 \\
\hline & Voces solas & 2 \\
\hline & Canto y piano (Ave Maria) & 1 \\
\hline & Totales & 5 \\
\hline \multirow[t]{3}{*}{ De libre elección } & Tipo de composición & $\mathrm{N}^{\mathrm{o}}$ obras \\
\hline & $\begin{array}{l}\text { Libre elección del tipo y género de } \\
\text { composición }\end{array}$ & 1 \\
\hline & $\begin{array}{ll} & \text { Totales } \\
\end{array}$ & 1 \\
\hline
\end{tabular}

Las composiciones musicales que se pedían eran tanto profanas como religiosas, aunque predominaban las primeras. Las obras instrumentales eran las más demandadas, seguidas de las de canto con acompañamiento de piano y/o armonio y composiciones para piano solo. La petición mayoritaria de obras instrumentales para los Juegos Florales fue clara sobre todo a partir de $1879^{13}$. Los años de mayor concurrencia en la sección de

${ }^{10}$ El organigrama de los Juegos Florales se completó así: Vicepresidentes: Olayo Díaz, Javier Fuentes y Gonzalo Baños; Vocales: José María Tornel y Rafael Almazán; Grefier-Secretario: Ricardo Sánchez Madrigal: El Semanario Murciano, IV (1881), n 153, 16 enero, pp. 22-23: 22.

${ }^{11}$ La Paz de Murcia, XXIV (1881), n 6978, 17 febrero, p. 1. Arrieta no participó finalmente en el dictamen, recayendo la calificación de las obras presentadas en los dos compositores murcianos del tribunal. El informe del jurado se publicó en: La Paz de Murcia, XXIV (1881), nº 7065, 3 junio, p. 1.

${ }^{12}$ Véase, El Semanario Murciano, IV (1881), n ${ }^{\text {s }}$ 153, 16 enero, pp. 22-23: 22 y 158, 20 febrero, p. 61.

${ }^{13}$ Para El Eco de Murcia, (1881), nº 30, 31 mayo, p. 3: "Estos certámenes tan honrosos para Murcia han desmerecido mucho de su antiguo esplendor". Opiniones similares se vertieron en El Semanario Murciano en 1882, achacando el declive de este tipo de certámenes a la falta de afición hacia lo literario y 
música fueron 1875 y 1876 ( 29 y 30 concursantes, respectivamente). En el otro extremo, el año de menor concurrencia fue 1879 (6 concurrentes). En 1880 no se celebró ningún certamen y es probable que este sea el motivo de la elevada concurrencia al año siguiente (19 candidatos). El certamen de 1881, sin embargo, había perdido el esplendor de años anteriores, según algunos periódicos de la ciudad.

La entrega de los premios otorgados en los Juegos Florales solía celebrarse el primer domingo de mayo en el Casino de Murcia, en un acto solemne al que acudían los personajes más relevantes de la vida cultural de la ciudad. Durante la ceremonia se exhibían los cuadros, esculturas y proyectos arquitectónicos ganadores y los autores de los premios más importantes daban lectura a sus obras y, en el caso de la música, se interpretaban. Dado que el nombre de los ganadores no se conocía hasta el último momento, la prensa publicaba con anterioridad los lemas de las composiciones ganadoras con el fin de que sus autores (o sus delegados) pudieran ensayarlas. El aviso de 1875 fue el siguiente:

[...] Así mismo se ruega a los incógnitos autores de las dos obras de música se sirvan comisionar personas que, reservando el nombre de aquellos, pueda representarlos y convenir lo oportuno con el que suscribe respecto a la ejecución y prueba de las obras premiadas que, según el programa, queda al cargo de sus autores $[\ldots]^{14}$.

Los compositores y obras premiadas en la sección de música pueden verse en el Apéndice 11.3. La mayor parte de los compositores galardonados fueron murcianos. El pianista y compositor ciego Adolfo Gascón Leante destacó por los nueve premios que recibió: Flor Natural (1874), Amapola de Oro (1874), Amapola Áurea (1877), Rosa de Plata (1877) y cinco accésits. Fernando Verdú, obtuvo siete galardones: Flor Natural (1878), Amapola Áurea (1876), la Colección de sinfonías de Beethoven (1881) y cuatro accésits. Otros compositores murcianos como Ángel Mirete (Flor Natural, 1881) y Julián Calvo (Azucena de Plata, 1879) sólo obtuvieron premios en alguna ocasión. De los músicos premiados que vivían fuera de Murcia destacaron el madrileño Salvador Bustamante (Flor Natural y Rosa de Plata en 1876, Flor Natural en 1877 y Batuta de Plata en 1878) y Pedro Caravantes Enguera, de Pamplona, que recibió una colección de conciertos para piano en 1881 y tres accésits. Entre los premiados estuvieron compositores importantes como José Inzenga (Flora Natural, 1879), el pianista, compositor y pedagogo Claudio Martínez Imbert (Rosa de Plata, 1874) y el primer organista de la Catedral de Zamora, José Luis de Muguerza (Rosa de Plata, 1881) ${ }^{15}$.

artístico: "La nueva generación ha despuntado con aficiones más belicosas o más positivas. No es el gusto literario y artístico el predominante en ella. Los Juegos Florales han muerto por falta de nueva savia": $E l$ Semanario Murciano, V (1882), n ${ }^{\circ}$ 199, 1 enero, p. 386.

${ }^{14}$ La Paz de Murcia, XVIII (1875), nº 5350, 30 abril, p. 1.

15 Claudio Martínez Imbert (Barcelona, 1845- Barcelona, 1919) era compositor y pianista. Sus compositores fueron premiadas en certámenes de diversas ciudades españolas, como Valencia, Zaragoza, Barcelona y A Coruña, según Alonso Fernández, "Martínez Imbert". José Luis Muguerza era socio de la Sociedad Coral de Bilbao. Véase, Nagore, La revolución, p. 218. 
Los dictámenes de los jurados eran publicados en la prensa ${ }^{16}$. En 1875 el jurado formado por López Almagro, Fernández Caballero y Mariano García valoró las cualidades técnicas y estéticas de las obras, sin tener en cuenta su género (vocal, instrumental) o el ámbito (religioso o profano). Se premió un cuarteto de Gascón por su "Originalidad y belleza en los pensamientos melódicos, corrección en la armonía, acierto y oportunidad en la instrumentación y forma elegante". También fue premiada un Ave María de Claudio Martínez Imbert, descrita así:

[...] Su melodía es sencilla y espontánea, su armonía correcta, la aplicación de las palabras natural y fácil. Su forma es un poco larga a causa de la excesiva repetición de la letra pero su estructura agradable y la riqueza y variedad de sus movimientos armónicos no dan lugar a la monotonía. Creemos que el movimiento del compás debe marcarse más despacio de los que indica la palabra moderato escrita en su encabezamiento, lo que atribuimos a error de pluma pues, dados los conocimientos, práctica y buen gusto que el autor demuestra en el discurso de la obra, no cabe la idea de descuido ni ignorancia $[\ldots]^{17}$.

Muy diferentes fueron los planteamientos del dictamen en los Juegos Florales de 1877. Los miembros del jurado (Emilio Arrieta, José Inzenga y Fernández Caballero) establecieron distinciones entre los géneros propuestos por la organización:

[...] Los que suscriben no creen que la importancia de los géneros de música designados ésta en razón directa del orden seguido en el programa. Por el contrario, este jurado considera de escaso interés el primero de los que allí se consignan o sea la "Fantasía para piano sobre motivos de Lucia di Lamermoor" y sin dejar de estimar en lo que merece el género religioso en todo aquello que tiene de grande y dramático, como por ejemplo un oficio y misa de difuntos, un Stabat Mater, unas siete palabras, etcétera, opinan que el "Gran Coral religioso a toda orquesta, cuarteto y coro Veni Creator" tampoco tiene tanto como la "Romanza dramática para tenor" y el "Estudio para piano sobre cantos populares" $[\ldots]^{18}$.

De los cuatro tipos de composición establecidos por la organización (fantasía para piano sobre motivos de la ópera Lucia di Lammermoor, romanza para tenor con acompañamiento de piano y armonio sobre el libreto del drama Don Rodrigo de Antonio Arnao, coral religioso a orquesta, cuarteto y coro sobre el texto "Veni Creator" y un estudio para piano sobre cantos populares murcianos), el jurado consideró que los más importantes eran la romanza para tenor y la pieza para piano sobre cantos populares de Murcia, y aprovechó para subrayar la importancia de estudiar los cantos populares en el contexto de la búsqueda de una ópera genuinamente española:

[...] El primero de estos dos últimos [la "Romanza para tenor sobre motivos de la ópera Lucia di Lamermoor] es el que más preferentemente ha fijado nuestra

${ }^{16}$ La Paz de Murcia, XVIII (1875), no 5360, 13 mayo, p. 1; La Paz de Murcia, XX (1877), no 6050, 13 mayo, p. 1; La Paz de Murcia, XXII (1879), nº 6592, 7 mayo, p. 1 y La Paz de Murcia, XXIV (1881), ${ }^{\circ}$ 7065,3 junio, p. 1. En el Documentario incluyo la transcripción completa de los dictámenes del jurado $1875,1877,1879$ y 1881 .

\footnotetext{
${ }^{17}$ La Paz de Murcia, XVIII (1875), no 5360, 13 mayo, p. 1.

${ }^{18}$ La Paz de Murcia, XX (1877), nº 6050, 13 mayo, p. 1.
} 
atención porque en él es donde con más claridad se revelan todas las condiciones necesarias para los compositores. En él puede demostrarse, mejor que en algún otro, el genio del artista y sus conocimientos en la ciencia y en el arte; y siendo el dramático el más difícil de todos, claro es que el que más circunstancias reúne para escribirle con acierto nunca ha de verse desprovisto de las necesarias para brillar en los demás.

Señalamos el segundo lugar a los "Cantos populares" [el "Estudio para piano sobre cantos populares de Murcia"] porque en el actual estado del arte en España cuando nuestros compositores se ocupan en poner los cimientos de la ópera nacional, nada más importante, a nuestro entender, para la construcción de este edificio que el estudio de los cantos populares, manantial inagotable de riqueza, por desgracia aún no bastante explotado. La notable diferencia que existe entre sus giros melódicos y la estructura especial de su armonía y las mismas circunstancias de la música de otros países hace indispensable un profundo conocimiento al compositor que, al escribir una ópera española, no quiera exponerse a que su obra resulte alemana, francesa o italiana con palabras en español. [... $]^{19}$.

En 1879 y 1881 los galardones de música se otorgaron según los méritos de las obras presentadas, sin establecer distinciones entre géneros. En 1879 quedó desierto el premio en la modalidad de "Salve a tres voces, coro y acompañamiento de orquesta" 20. No he localizado convocatorias de Juegos Florales de mayo después de $1881^{21}$. En cambio, en 1875-1879 y 1883 se organizaron certámenes extraordinarios durante el mes de septiembre ${ }^{22}$, aunque sólo incluyeron premios de música los de 1878 y 1883. El programa de los Juegos Florales Extraordinarios de 1878 se publicó en enero, con la novedad de que el premio musical se aplicó no a la composición, sino a la investigación musical:

[... "Las obras correspondientes al estudio sobre la Historia de la literatura en Murcia y las poesías A la Virgen como los folletos literario-musicales del Estudio histórico-crítico-general sobre la música en Murcia se recibirán por el Mantenedor hasta las seis de la tarde DEL 15 DE JULIO, y la adjudicación del respectivo premio tendrá lugar en uno de los primeros días de septiembre en sesión especial" $[\ldots]^{23}$.

\section{${ }^{19}$ Ibídem.}

${ }^{20}$ La única obra presentada en esta modalidad "adolece de incorrecciones y defectos de detalle y de forma que la imposibilitan para recibir el premio ofrecido a este género y opinando unánimemente que no ha lugar a su adjudicación, declaramos desierta esta parte del certamen": La Paz de Murcia, XXII (1879), n 6592, 7 mayo, p. 1.

${ }^{21}$ En El Diario de Murcia, III (1881), n ${ }^{\circ} 685,1$ junio, p. 2 se indican las causas: "Probablemente ya no se volverá a hablar de Juegos Florales ni de certámenes en esta ciudad hasta el 2 de marzo de 1883 en que hará cien años que murió el gran artista murciano Salzillo. Por iniciativa de don Javier Fuentes se ha lanzado la idea de una gran fiesta en honor de este gran escultor [...]". Es probable, por tanto, que el mayor promotor de los Juegos Florales, Fuentes y Ponte, se dedicara en 1881-1883 a preparar ese gran evento.

${ }^{22}$ Véase: La Paz de Murcia: XVIII (1875), $\mathrm{n}^{\text {os }}$ 5393, 22 junio, p. 1; 5418, 3 agosto, p. 1; 5439, 26 agosto, p. 1 y 5601, 18 noviembre, p. 1; XIX (1876), $\mathrm{n}^{\text {os }} 5717,19$ julio, p. 1; 5745, 23 agosto, p. 1; 5755, 3 septiembre, p. 1; 5757, 6 septiembre, p. 1 y 5762, 13 septiembre, p. 1; XX (1877), n ${ }^{\text {os }} 6133$, 23 agosto, p. 1; 6139, 30 agosto, p. 1; 6142, 2 septiembre, p. 1; 6144, 5 septiembre, p. 1 y 6146, 7 septiembre, p. 1.

${ }^{23}$ La Paz de Murcia, XXI (1878), no 6231, 2 junio, p. 1. En mayo, el Mantenedor, Javier Fuentes y Ponte, anunció la suspensión de estos Juegos Florales: La Paz de Murcia, XXI (1878), nº 6225, 25 mayo, p. 1, aunque finalmente el certamen se llevó a cabo según el programa publicado a comienzos de año: $L a$ Paz de Murcia, XXI (1878), $\mathrm{n}^{\circ}$ 6229, 30 mayo, p. 1. Sobre la concesión de los premios de Literatura y la ceremonia de entrega de premios, véase: La Paz de Murcia, XXI (1878), $\mathrm{n}^{\text {os }}$ 6280, 2 agosto, p. 1; 6304, 1 septiembre, p. 1 y 6305, 13 septiembre, p. 1. 
El premio de investigación musical quedó desierto porque no se presentó ningún candidato, aunque varios testimonios periodísticos revelan que al menos tres personas habían iniciado por separado diferentes investigaciones: Adolfo Gascón, Fernando Verdú y el autor de los "Apuntes de la historia de la música en Murcia", publicados con posterioridad en El Semanario Murciano bajo el pseudónimo Un aficionado ${ }^{24}$.

Los Juegos Florales de septiembre de 1883 se celebraron en los salones de la Sociedad Económica de Amigos del País de Murcia y su Mantenedor fue Javier Fuentes y Ponte. Hubo secciones de literatura, pintura, escultura, música y agricultura ${ }^{25}$. Se establecieron dos premios de Música (Rama de Laurel y Objeto de arte) y dos modalidades de composición: "Vals para piano, de mediana ejecución, con introducción y coda" y "Melodía para barítono con acompañamiento de piano con libertad de letra, género, estilo y dimensiones" 26 . Participaron doce compositores, que fueron valorados por Mariano García, Adolfo Gascón y Fernando Verdú ${ }^{27}$. Los ganadores y los premios concedidos pueden verse en la Tabla 11.3:

Tabla 11.3. Ganadores de la sección de Música en los Juegos Florales de Murcia, septiembre de 1883. Fuentes: La Paz de Murcia, XXVI (1883), $\mathrm{n}^{\text {os }} 7715,2$ septiembre, p. 1 y 7725, 15 septiembre, p. 1.

\begin{tabular}{|l|l|l|l|}
\hline Premio & Ganador & Lema de la obra & Modalidad \\
\hline Rama de Laurel & $\begin{array}{l}\text { Teresa Giménez } \\
\text { Lafuente }\end{array}$ & "Seré premiado!" & Vals \\
\hline Accésit & Concha Rodríguez & "El revoltoso" & Vals \\
\hline Mención honorífica & Manuel Benavente & "Al borde del arroyo" & Vals \\
\hline Objeto de arte & \multicolumn{1}{|c|}{-} & Desierto & Canto y piano \\
\hline Primer accésit & José Miguel Pastor & $\begin{array}{l}\text { "Nada espero porque } \\
\text { valgo poco" }\end{array}$ & Canto y piano \\
\hline Segundo accésit & $\begin{array}{l}\text { Celestino Sadurdi } \\
\text { Gurgui (Barcelona) }\end{array}$ & $\begin{array}{l}\text { "De lejos vengo. } \\
\text { ¿Venceré?" }\end{array}$ & Canto y piano \\
\hline Mención honorífica & Manuel Benavente & "Labor omnia vincit" & Canto y piano \\
\hline
\end{tabular}

Los premios más importantes de 1883 recayeron en dos compositoras, la primera vez que esto ocurría en los Juegos Florales murcianos ${ }^{28}$.

${ }^{24}$ Un revistero, "Revista local", La Paz de Murcia, XXI (1878), nº 6282, 4 agosto, p. 1; Julián Calvo, "Remitido", El Semanario Murciano, I (1878), nos 23, 21 julio, p. 3 y 25, 4 agosto, p. 7. Según El Diario de Murcia, XX (1898), $\mathrm{n}^{\mathbf{0}}$ 7596, 6 marzo, p. 2, entre las partituras y papeles de Julián Calvo tras su fallecimiento se encontraba una Historia de la Música en Murcia que no he localizado, ni tampoco conservan sus familiares.

${ }^{25}$ Se premió en agricultura al mejor "Método de Agricultura o Cartilla Agraria escrita con la concisión posible en lenguaje vulgar y sencillo, para uso directo de los colonos de la huerta de Murcia": La Paz de Murcia, XXVI (1883), $\mathrm{n}^{\circ}$ 7684, 24 julio, p. 1. Véase también: La Paz de Murcia, XXI (1878), n 6231, 2 junio, p. 1.

${ }^{26}$ La Paz de Murcia, XXVI (1883), n ${ }^{\mathrm{o}} 7684,24$ julio, p. 1.

${ }^{27}$ La Paz de Murcia, XXVI (1883), no 7711, 29 agosto, p. 1.

${ }^{28}$ Sobre la creación musical femenina en España véase Álvarez Cañibano, et al. (eds.). Compositoras españolas y, en especial, Sánchez de Andrés, "Compositoras españolas del siglo XIX”, pp. 55-74. Sobre la situación de las mujeres artistas en España durante los siguientes XIX y XX, véase: Muñoz López, "Mujeres", pp. 165-176. 
Además de los Juegos Florales propiamente dichos, también hubo en Murcia otros certámenes programados por diversas instituciones y organismos de la ciudad, similares a los que proliferaron en otras ciudades europeas en el siglo XIX ${ }^{29}$. En Murcia, solían organizarse en los días de feria (primera quincena de septiembre), estimulando la rica actividad cultural de la ciudad durante estas fiestas (Véase Figura 11.3) ${ }^{30}$.

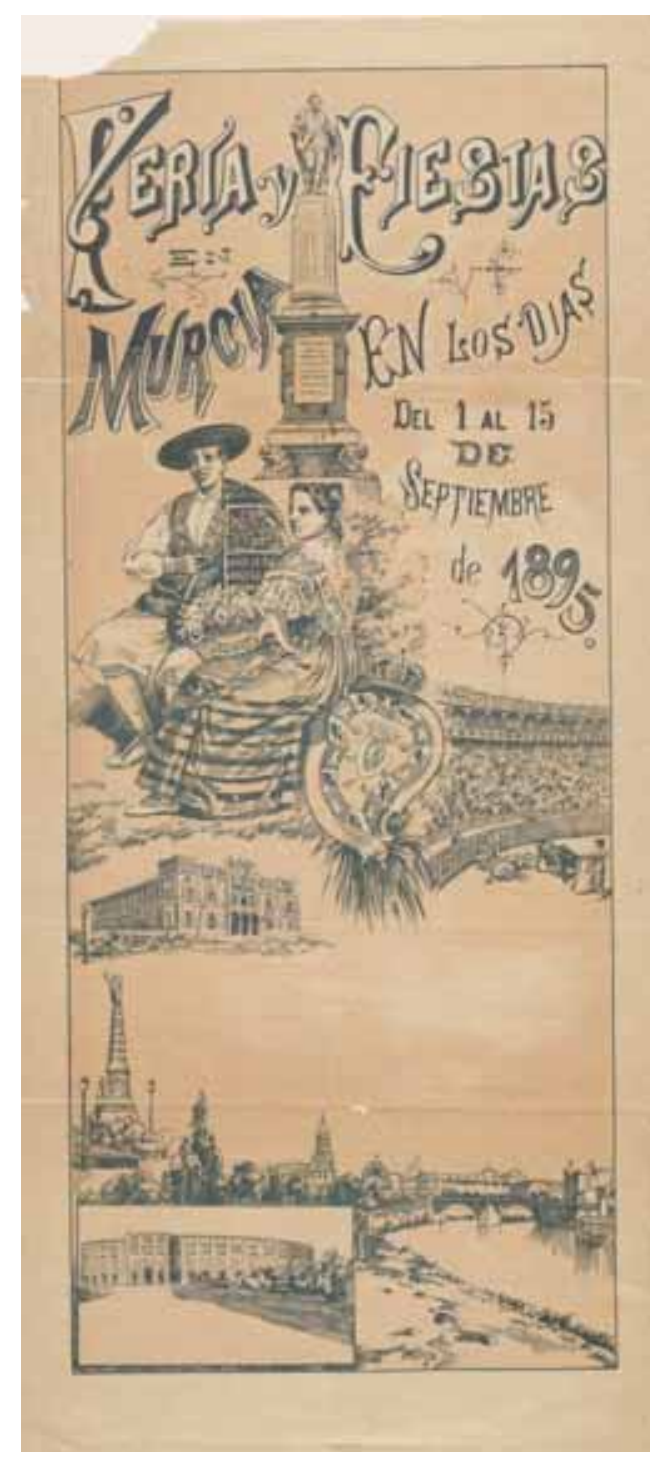

Figura 11.3. Cartel de la feria y fiestas de Murcia (1-15 de septiembre de 1895).

Biblioteca Regional de Murcia. Accesible en: http://bibliotecadigital.carm.es (acceso el 16-07-5011).

\footnotetext{
${ }^{29}$ En Inglaterra, por ejemplo, este tipo de certámenes se difundió en centros industriales en expansión como Leeds, Birmingham, Norwich y Newcastle, auspiciados por la clase media, aficionada a la música. Véase Dale, "The Provincial", pp. 325-347.

${ }^{30}$ La feria de septiembre de Murcia gozó de mucha popularidad en el siglo XIX y coincidía con representaciones teatrales y conciertos públicos al aire libre en las calles y plazas más concurridas de la ciudad. La Glorieta, el Paseo del Malecón y el jardín de Floridablanca fueron los marcos urbanos más habituales de estos espectáculos. En 1886, escuchar un concierto en una de las sillas del Jardín Floridablanca costaba 10 céntimos, un precio económico si tenemos en cuenta que la entrada a una función benéfica en el Teatro Romea, durante el mismo año, costaba 50 céntimos; asistir a un concierto en uno de los céntricos cafés de Murcia, con la consumición incluida, 25 céntimos y, finalmente, el presupuesto diario de una familia de cuatro miembros que viviera en San Antolín, San Juan o en calles periféricas como San Miguel, San Andrés y Santa Eulalia, 1.49 pesetas. Véase, Clares, "Murcia y su música”: pp. 130-131.
} 
En septiembre de 1887, por ejemplo se organizaron en Murcia tres certámenes: uno a cargo de El Diario de Murcia, de carácter literario, uno de bandas civiles y otro artístico. Estos dos últimos fueron programados por la Comisión de Festejos de la Alcaldía de Murcia y tuvieron ámbito provincial ${ }^{31}$. En el certamen de bandas civiles se establecieron tres categorías y seis premios (dos primeros, dos segundos y dos terceros) ${ }^{32}$. Cada banda podía concursar a cualquier categoría, siempre y cuando interpretaran las obras establecidas por la comisión, que eran: Obertura de Der Freischütz de Carl Maria von Weber y pieza de libre elección, para los primeros premios; "Entreacto y danza de Bacantes" de Philémon et Baucis, de Charles Gounod y pieza de libre elección, para los segundos y la gavota Regente del alemán Hermann Fliege y pieza de libre elección, para los terceros. El primer premio fue concedido a la Banda de Mula, dirigida por Julián Santos $^{33}$. El certamen artístico de 1887 tuvo tres modalidades (Literatura, Pintura y Música). En la modalidad de Música se establecieron tres premios y otros tantos accésits para las mejores composiciones para piano solo, todas con temática libre. El funcionamiento de este certamen fue muy similar al de los Juegos Florales. Cada participante identificaba su obra con un lema, acompañado de un sobre cerrado con su nombre y apellidos. Las obras se depositaban en la secretaría del Ayuntamiento ${ }^{34}$. Los lemas ganadores se publicaron en la prensa antes de la ceremonia de entrega de premios, a fin de que los vencedores pudieran interpretar sus obras durante el acto ${ }^{35}$. Las obras premiadas y sus ganadores pueden verse en la Tabla 11.4. Aparte de los premiados, obtuvieron menciones especiales otros compositores, como Vicente Tormo, de Corvera $(\text { Murcia) })^{36}$ :

Tabla 11.4. Obras premiadas en el Certamen Artístico del Ayuntamiento de Murcia (1887). La Paz de Murcia, XXX (1887), ${ }^{\text {os }} 8296,10$ septiembre, p. 4; 8297, 11 septiembre, p. 1 y 8298, 13 septiembre, p. 1 .

\begin{tabular}{|l|l|l|l|}
\hline Premios & Composición & Lema & Ganador \\
\hline $1^{\circ}$ & Nocturno & $\begin{array}{l}\text { "La música y la poesía } \\
\text { tuvieron su origen en los } \\
\text { sentimientos del alma" }\end{array}$ & Pedro Muñoz Pedrera \\
\hline $2^{\mathrm{o}}$ & Impromptu & $\begin{array}{l}\text { "Es la música el idioma de } \\
\text { los ángeles" }\end{array}$ & Manuel Benavente \\
\hline
\end{tabular}

${ }^{31}$ Es decir, a ellos sólo podían concurrir murcianos. Sobre el certamen literario de El Diario de Murcia, véase: El Diario de Murcia, IX (1887), $\mathrm{n}^{\mathrm{o}}$ 3072, 11 agosto, p. 1. Sobre los programas de los certámenes provinciales véase: La Paz de Murcia, XXX (1887), $\mathrm{n}^{\mathrm{os}} 8265,2$ agosto, p. 1 y 8283, 24 agosto, p. 1.

${ }^{32}$ La Paz de Murcia, XXX (1887), nº 8266, 3 agosto, p. 1.

${ }^{33}$ El Diario de Murcia, IX (1887), $\mathrm{n}^{\text {os }} 3099,13$ septiembre, p. 2 y 3100, 14 septiembre, p. 1.

${ }^{34}$ La Paz de Murcia, XXX (1887), n ${ }^{\text {os }} 8266,3$ agosto, p. 1.

${ }^{35}$ La entrega de premios tuvo lugar en el Teatro Romea el 12 de septiembre de 1887 . Véase, El Diario de Murcia, IX (1887), $\mathrm{n}^{\mathrm{o}}$ 3100, 14 septiembre, p. 1 y La Paz de Murcia, XXX (1887), $\mathrm{n}^{\circ}$ 8298, 13 septiembre, p. 1.

${ }^{36}$ Las fuentes periodísticas son contradictorias respecto a las menciones otorgadas. Según La Paz de Murcia, XXX (1887), $\mathrm{n}^{\mathrm{o}} 8297,11$ septiembre, p. 1, un Capricho característico, una barcarola y un galop, obtuvieron las menciones primera, segunda y tercera. Sin embargo, las crónicas sobre la ceremonia de entrega (poco específicas en lo que a música se refiere) citan a Tormo, Muñoz Pedrera, Benavente y Gascón como compositores que obtuvieron accésits, aparte de los tres primeros premios. En La Paz de Murcia, XXX (1887), $\mathrm{n}^{\circ} 8297,11$ septiembre, p. 1 se afirma que las mazurcas bajo los lemas "La Primavera", "La Naveta del Puerto" y "Antonia" obtuvieron un reconocimiento por parte del jurado, ya que reunían "buen gusto y conocimiento en el arte". No ha quedado constancia de quiénes formaron el jurado. 


\begin{tabular}{|l|lr|l|l|}
\hline $3^{\circ}$ & $\begin{array}{l}\text { "Fantasía } \\
\text { concierto de } \\
\text { motivos de la ópera } \\
\text { Ana Bolena" }\end{array}$ & "Gloria al arte musical" & Adolfo Gascón \\
\hline
\end{tabular}

En 1889, el periódico El Diario de Murcia convocó el tradicional certamen de septiembre aunque, a diferencia de los años anteriores, estableció entonces un galardón musical $^{37}$. Las bases del certamen se publicaron a mediados de junio de 1889 y se establecieron seis modalidades: "Instrucción primaria", "Literatura", "Bellas Artes" (música, pintura y dibujo), "Artes y oficios", "Premios al trabajo" y "Premios a la caridad $^{38}$. Sin el amparo de una subvención económica institucional, Martínez Tornel, director de El Diario de Murcia, consiguió involucrar a un buen número de donantes de dentro y fuera de la ciudad (entre ellos la Infanta María Isabel), con los que logró dotar los premios a las diferentes categorías ${ }^{39}$. Para la sección musical se estableció un único premio a la mejor sinfonía para orquesta sobre motivos de aires populares murcianos "combinados con los nacionales que más conocidos son esta ciudad" 40 . El jurado de música estuvo compuesto por tres grandes figuras del panorama musical nacional: Antonio López Almagro, José Inzenga y Mariano Martín Salazar ${ }^{41}$. La única obra presentada, Murcia, era obra de José Verdú, hijo del director de la orquesta del Teatro Romea y discípulo de Mariano García, y fue premiada y valorada elogiosamente:

El tribunal $[\ldots]$ ha examinado detenidamente la única que se la ha remitido titulada "Murcia. Sinfonía para grande orquesta sobre aires populares" y la considera digna de premio por cumplir con las condiciones propuestas.

${ }^{37}$ El Diario de Murcia, XI (1889), no 3795, 4 agosto, p. 1. La promoción de certámenes culturales no fue exclusiva de El Diario de Murcia. En esta misma fuente, se informa del concurso de bandas que $E l$ Criterio proyectó para el mismo mes de septiembre. Sobre él, véanse: La Paz de Murcia, XXXII (1889), $\mathrm{n}^{\text {os }}$ 9889, 2 agosto, p. 1 y 9893, 7 agosto, p. 1; El Diario de Murcia, XI (1889), nº 3793, 2 agosto, p. 1.

38 El Diario de Murcia, XI (1889), sin número, 23 junio, p. 1. Las modalidades de "Instrucción Primaria" y "Enseñanza Superior" premiaban a los estudiantes más destacados mediante exámenes convocados ex profeso. En líneas generales, los galardones a las artes y oficios, al trabajo y a la caridad tenían como finalidad incentivar los trabajos artesanales y ayudar a las familias murcianas más necesitadas. Sobre los exámenes, véanse: El Diario de Murcia, XI (1889), $\mathrm{n}^{\text {os }} 3815,29$ agosto, p. 3 y 3816,30 agosto, p. 1. Los premiados en estas categorías pueden consultarse en: El Diario de Murcia, XI (1889), n ${ }^{\circ} 3818,1$ septiembre, p. 1.

${ }^{39}$ El mismo Martínez Tornel reconocía: "Como han de ser pobres la mayor parte de los premiados, todo lo útil es aceptable. De modo que, como en los años anteriores, distribuiremos premios en dinero, en libros, en objetos de arte y hasta en prendas de verter": El Diario de Murcia, XI (1889), n 3760, 23 junio, p. 1. La Infanta María Isabel donó dos jarrones tibores "de porcelana decorada con dorados y figuras de mucho gusto y mérito artístico": El Diario de Murcia, XI (1889), no 3798, 8 agosto, p. 3. El listado de donativos puede consultarse en: El Diario de Murcia, XI (1889), nº 3814, 28 agosto, p. 3.

${ }^{40}$ El Diario de Murcia, XI (1889), nº 3768, 3 julio, p. 1. El término sinfonía se entenderá “en el sentido general y corriente, no precisándola con otros calificativos para dejar en libertad a los maestros de hacer la pieza musical como creyesen conveniente, dentro de la adaptación de los aires que como motivos se les imponen". El maestro de capilla de la Catedral, Mariano García, escribió a El Diario de Murcia proponiendo que se concretasen más las características de la pieza. Véase su interesante carta en: Mariano García, "Remitido", El Diario de Murcia, XI (1889), no 3768, 3 julio, p. 2. El programa oficial ofrecía un segundo premio a los músicos más destacados de cada una de las bandas de música de la ciudad, menores de 14 años.

${ }^{41}$ El Diario de Murcia, XI (1889), $\mathrm{n}^{\mathrm{o}}$ 3812, 25 agosto, p. 1 
El segundo tiempo "Adagio" y el tercero "Minuetto", que son los dos mejores de la composición, tienen carácter muy adecuado, forma conveniente y apropiada, desarrollo bien comprendido y buen gusto, así en la estructura como en la orquestación; cualidades todas muy estimables en obras de este género $[\ldots]^{42}$.

\section{Orígenes de la historiografía musical murciana: los "Apuntes para la historia de la música en Murcia” de El Semanario Murciano (1878-1879)}

El primer esbozo de una historia de la música de Murcia del que tengo constancia son los trece artículos publicados bajo el título "Apuntes para la historia de la música en Murcia", firmados bajo el pseudónimo "Un aficionado", que aparecieron en el periódico El Semanario Murciano entre julio de 1878 y septiembre de $1879^{43}$. Parte de estos "Apuntes" fueron escritos para concursar en los Juegos Florales celebrados en septiembre de 1878 en Murcia, como reconoció su autor ${ }^{44}$.

\subsection{Andrés Blanco García, posible autor de los "Apuntes para la historia de la música en Murcia"}

El nombre del autor de los "Apuntes para la historia de la música en Murcia” no figura en ninguno de los trece artículos de que constó la obra, aunque hay muchos indicios que permiten pensar que fueron escritos por el abogado, periodista, poeta, escritor y concejal Andrés Blanco García (1849-1916), sobrino además del maestro de capilla de la Catedral de Murcia, Mariano García ${ }^{45}$. Aunque no se dedicó profesionalmente a la música, Blanco tenía conocimientos musicales ${ }^{46}$ y demostró conocer los debates musicales más candentes del siglo XIX español, como prueban sus críticas a diversas representaciones de teatro musical en Murcia y los artículos que publicó en diversos periódicos murcianos sobre ópera española y sobre música wagneriana (ver punto 5 del Capítulo 4$)^{47}$. El lenguaje técnico empleado en los "Apuntes"

${ }^{42}$ El Diario de Murcia, XI (1889), no 3816, 30 agosto, p. 1. Véase también, El Diario de Murcia, XI (1889), n n $^{\circ} 313,27$ agosto, p. 2 y 3819,3 septiembre, p. 1.

${ }^{43}$ En el último artículo de los "Apuntes" aparece la indicación “continuará” aunque, a juzgar por los ejemplares examinados en el $E: M U m$ no se publicaron más.

${ }^{44}$ El Semanario Murciano, I (1878), nº 23, 21 julio, pp. 3-4: 3.

${ }^{45}$ El Liberal, V (1906), n 1251,5 enero, p. 1. Sobre Andrés Blanco García, véase: Crespo, Andrés Blanco; Jiménez Madrid, Narradores, pp. 169-170; Díez de Revenga y De Paco, Historia, pp. 282-283.

${ }^{46}$ Blanco García ingresó en el Seminario de San Fulgencio de Murcia en 1859, donde permaneció hasta la desaparición del centro en 1868 y es probable que estudiara en el Colegio de San Leandro de la Catedral de Murcia. Blanco puso letra al Himno de la libertad, con música de Antonio López Almagro, estrenado por los alumnos del Orfeón de la Sociedad Filarmónica y Coral de Murcia en el Teatro de la Soberanía Nacional en 1868. Según Crespo, Andrés Blanco, p. 26, Blanco tradujo al castellano la canción Vorrei morire de Francesco Paolo Tosti, que fue interpretada en varias ocasiones en el Café Oriental de Murcia.

${ }^{47}$ Recordemos que los artículos de Andrés Blanco García, “Consideraciones sobre la ópera española (I y II)", El Semanario Murciano, III (1880), n ${ }^{\text {os }} 114,18$ abril, pp. 124-125 y 116, 2 mayo, pp. 138-139 son un duro alegato en contra de la zarzuela ("La zarzuela, dominando por todas partes, no solo consiguió bastardear la música e inutilizar hombres eminentes que hubieran podido lucir sus dotes y sus conocimientos en otras composiciones más dignas, sino que en época determinada extendió su perversión a 
sugiere que su redactor fue un aficionado cualificado, capaz de realizar incluso algunos análisis musicales. De entre los periodistas murcianos de la época, Blanco fue el único que escribió sobre temas musicales especializados. Sus habituales colaboraciones con $E l$ Semanario Murciano habrían facilitado probablemente la publicación de los "Apuntes" en ese periódico. Aunque en El Semanario Murciano Blanco solía firmar sus colaboraciones con sus iniciales o con su nombre completo, es posible que no lo hiciera en el caso de los "Apuntes" para no desvelar su nombre, quizás porque pensaba presentar ese trabajo a los Juegos Florales de 1878 en Murcia (que contemplaron por primera vez un premio a trabajos de investigación musical) o a algún otro certamen similar. De hecho, Blanco concursó y obtuvo premios en numerosos juegos florales y certámenes literarios dentro y fuera de Murcia $^{48}$.

Una razón más que apoya que Andres Blanco García pudo haber sido el autor de los "Apuntes" es que fue autor de una obra narrativa, poética y ensayística muy variada en la que domina el interés por recuperar la conciencia regional murciana, un ideal también presente en el intento de narrar una primera historia de la música en Murcia ${ }^{49}$. Por ejemplo, su obra Escenas murcianas, subtitulada "Apuntes para cuadros, costumbres y tipos de Murcia y de su huerta y campo", es una colección de diecisiete estampas localistas con abundantes alusiones musicales ${ }^{50}$. Las romerías, reuniones domésticas y fiestas típicamente murcianas, que fueron objeto de recreación literaria en las Escenas murcianas de Andrés Blanco, fueron también específicamente mencionadas en el Capítulo XII de los anónimos "Apuntes":

[...] Las romerías al poético santuario de Nuestra Señora de la Fuensanta, las reuniones de familia, las fiestas públicas y las diversiones particulares hacen aparecer siempre nuevas cantinelas [populares] que entran a formar parte en la gran colección, que ayudan al hombre a dulcificar y embellecer las penosas tareas de su trabajo, al par que contribuyen a su instrucción, elevando su espíritu e inspirándole sentimientos nobles y generosos $[\ldots]^{51}$.

la poesía") y la falta de protección por parte de las autoridades ("Concretándonos únicamente a la música, los gobiernos, en vez de proteger la nacional, la han despreciado altamente, facilitando toda clase de recursos a la extranjera"). Según Blanco, el camino para conseguir una ópera genuinamente española "es el estudio de los cantos populares". Véase también la conferencia leída por Blanco en el Círculo de Bellas Artes de Murcia en 1905, publicado con el título "Decadencia literaria” en Grandezas del pasado, pp. 77114.

48 Blanco obtuvo galardones literarios en certámenes y juegos florales de ciudades como Murcia, Madrid, Lérida, Reus o Alicante, entre otras. Algunos de sus trabajos premiados se publicaron en su recopilación Composiciones literarias de Andrés Blanco y García premiadas en los juegos florales de Murcia en septiembre de 1883, en el gran certamen literario de la Real Academia de Buenas Letras de Sevilla en abril de 1884 y en el científico-literario promovido por el centro de lectura de Reus en igual fecha.(Murcia: Establecimiento Tipográfico de "La Paz", 1884).

49 Véanse más detalles sobre las obras de Blanco y sobre sus ideales regionalistas murcianos en Jiménez Madrid, Narradores, pp. 169-184 y Crespo, Andrés Blanco, p. 31.

${ }^{50}$ Andrés Blanco García. Escenas murcianas: apuntes para cuadros costumbres y tipos de Murcia y de su huerta y campo. (Murcia: Tipografía de Rafael Albaladejo Brugarolas, 1894), 2a ed.

51 "Un aficionado", "Apuntes para la historia de la música en Murcia” (XII), El Semanario Murciano II (1879), nº 83, 14 septiembre, pp. 2-3: 2. 


\subsection{Estructura y fuentes de los "Apuntes"}

Los "Apuntes para la historia de la música en Murcia" se centraron en cuatro grandes temas: historia del piano, historia de la flauta, historia de la guitarra y cantos populares de Murcia, repartidos en las sucesivas entregas publicadas como sigue:

$\begin{array}{cl}\text { Artículos } & \text { Temática } \\ \text { I-V } & \text { Historia del piano en Murcia } \\ \text { VI-X } & \text { Historia de la flauta en España y en Murcia } \\ \text { XI-XIII } & \text { Historia de la guitarra en Murcia } \\ \text { XII-XIII } & \text { Los cantos populares de Murcia }\end{array}$

La elección y disposición temática de los artículos es significativa y muestra los intereses del autor (ver Apéndice 11.4). Los "Apuntes" no narran una historia general ordenada por acontecimientos históricos ni siguen un orden cronológico, sino que abordan "la historia particular de cada instrumento",52.

Las fuentes empleadas para realizar la obra fueron tanto orales como escritas: "ya copiadas de algunos libros, ya recogid[a]s de diferentes amigos, ya conservadas en nuestra memoria como recuerdos de sabios maestros o como productos de nuestro estudio",53. El autor de los "Apuntes" reconoce la carencia de fuentes fidedignas para reconstruir la historia musical de Murcia en la Antigüedad, aunque especula sobre los orígenes musicales de Murcia:

[...] Murcia, tanto en la época en que perteneció a los pueblos bastitanos, como cuando sus hijos le dieron esplendor e importancia abriendo un venero de grande y perpetua riqueza en la hermosa vega que fertiliza el Segura, parece ser el país más descuidado del mundo con respecto a conservar noticias locales. En sus archivos nada se encuentra referente a la música de la época antigua. Su historia nada nos dice sobre el mismo asunto $\mathrm{y}$, si de algún anticuario pretendemos entresacar datos, sus testimonios a más de carecer de verdadera importancia, están tan embrollados y merecen tan poco crédito que los desechamos como inútiles para nuestro propósito.

Sin embargo, en Murcia debió conocerse la música desde la época más remota. Los diferentes pueblos que invadieron nuestra península, como los fenicios, hebreos, griegos, cartaginenses y romanos, hollaron también con su planta las riberas del Tháder. [...] Queriendo estos pueblos deslumbrar el país que conquistaban y al mismo tiempo introducir de una manera más o menos directa sus usos y costumbres para arraigar mejor su dominio, fueron brindándole con todo género de diversiones, para que los habitantes, entretenidos de este modo, no fijaran su atención en el mucho provecho y riqueza que de nuestro suelo sacaban.

Por eso no faltaban en Murcia diferentes clases de fiestas, sacrificios a sus dioses y funerales de hombres célebres donde la música tomaba siempre una parte muy principal $[\ldots]^{54}$.

52 "Un aficionado", “Apuntes para la Historia de la Música en Murcia”, El Semanario Murciano, I (1878), n 23, 21 julio, pp. 3-4:3.

${ }^{53}$ El Semanario Murciano, I (1878), nº 25, 4 agosto, p. 7.

54 "Un aficionado”, “Apuntes para la Historia de la Música en Murcia (VI), El Semanario Murciano I (1878), n 32, 22 septiembre, pp. 1-2: 1. 
En los “Apuntes" se citan fuentes escritas como la Historia de la música española de Mariano Soriano Fuertes ${ }^{55}$; las Cartas familiares de Bartolomé Cabello, cura de la Iglesia Parroquial de Santa María de la Blanca de Sevilla ${ }^{56}$; Antiguallas musicales, "un cuaderno manuscrito" de Pedro Peceño, organista de la Catedral de Murcia, que "trata de muchas cosas de música antigua especialmente de la música de iglesia" "57; los Discursos históricos de Murcia y su reino, de Francisco Cascales ${ }^{58}$ y "unos apuntes que conservamos del libro de la Capilla de Madres Agustinas" de Murcia ${ }^{59}$. El autor de los "Apuntes" accedió, sin duda, al Archivo de la Catedral de Murcia, donde encontró el mencionado manuscrito de Pedro Peceño y consultó composiciones musicales originales de varios maestros de capilla de esa institución. Los datos de los "Apuntes" referidos a la actividad musical de Murcia son en gran parte fiables.

Los "Apuntes para la historia de la música en Murcia" reflejan una exaltada visión nacionalista de la música española tomada de Soriano Fuertes:

[...] Don Mariano Soriano Fuertes, en su Historia de la música española, tomo primero, página 44, atribuye los conocimientos armónicos de los españoles a la enseñanza de los fenicios y judíos, asegurando que los hebreos, en tiempos de David y Salomón, fueron los mejores músicos del universo. Como prueba de la destreza especial de los españoles en el arte musical, dice: "Los romanos, desde que pisaron el suelo de España y oyeron los suaves acentos de la música española, quedaron tan prendados de ella que el cónsul Metello discurrió hacer un presente a los romanos, enviando a la capital un coro de músicos españoles [...].

Lo que acabamos de transcribir manifiesta lo desarrollada que debía estar la afición en los pueblos del Mediodía de España para producir músicos que llamaran la atención en una ciudad como Roma y de los inmensos pueblos que formaron su imperio. La importancia de los músicos españoles no se redujo solo a su manera de cantar ni al carácter especial de su música, sino también a su disposición universal para la ejecución de todos los instrumentos hasta por las mujeres. [...]. ¿Qué número tan considerable de hombres no supone dedicado en España en la época a que nos referimos a la música, cuando nuestros artistas sobresalían y eran apreciados por todo el mundo? $[\ldots]^{60}$.

${ }^{55}$ Mariano Soriano Fuertes, Historia de la música española desde la venida de los fenicios hasta el año de 1850. (Madrid: Instituto Complutense de Ciencias Musicales, 2007), ed. Facsímil. Sobre la Historia de la música de Soriano Fuertes, véase la Tesis Doctoral aún inédita de Boïls Ibiza, La Historia, a quien agradezco su consulta.

${ }^{56}$ Cabello, Bartolomé. Cartas familiares que D. Bartolomé Cabello, cura de la Iglesia Parroquial de nuestra señora Santa María de la Blanca de Sevilla, ha remitido a un amigo suyo, quien las publica porque juzgar que pueden conducir a la instrucción de muchos. (Murcia: Imprenta de la Viuda de Felipe Teruel, 1787). Sobre esta obra, véase Rodríguez Maraver, "Don Bartolomé”, pp. 19-136.

57 "Un aficionado”, “Apuntes para la Historia de la Música en Murcia (VII)”, El Semanario Murciano I (1878), no 35, 13 octubre, pp. 4-6:5.

${ }^{58}$ Cascales, Francisco, Discursos históricos de la muy noble y muy leal ciudad de Murcia y su Reino (original de 1621; $3^{\mathrm{a}}$ ed., Murcia: Librería de Miguel Tornel y Olmos, 1874). La información que Blanco García toma de Cascales es la referida a la batalla de Sangonera del año 714 (Cascales, Discursos, p. 10). Francisco Cascales (1564-1642) fue un erudito y humanista que enseñó en el Colegio de San Fulgencio y escribió también Discurso de la ciudad de Cartagena (1598). Véase García Soriano, El humanista.

59 "Un aficionado”, “Apuntes para la Historia de la Música en Murcia (VIII), El Semanario Murciano I (1878), $\mathrm{n}^{\mathrm{o}} 42,1$ diciembre, pp. 5-6: 6.

60 "Un aficionado", “Apuntes para la Historia de la Música en Murcia (VII)”, El Semanario Murciano I (1878), n 35, 13 octubre, pp. 4-6. Sobre la visión nacionalista de Soriano Fuertes, véase la Introducción a 
En los “Apuntes" es perceptible también la tradición romántica que atribuye a la música una gran capacidad de influencia en las personas, aún más si va unida a la poesía:

[...] Es la música la expresión más natural del sentimiento humano. La manifestación más espontánea de la belleza por medio de los sonidos combinados con el tiempo, según las impresiones del alma.

La música, obrando directamente en nuestro ser de una manera poderosa, es el agente que trasmite al corazón los efectos más desconocidos e inexplicables como el dolor, la tristeza, la alegría, el valor, etcétera, al par que dulcifica y templa nuestras pasiones y nuestros deseos.

El imperio, la influencia, todos los efectos musicales se aumentan doblemente cuando se unen a las palabras, y tanto la música como la poesía, nacidas al mismo tiempo y caminando siempre juntas, modificaron el carácter de los pueblos primitivos e hicieron más eficaz en ellos el sentimiento de sociabilidad. Por medio de las canciones empezaron a formar su historia, conserván/[p. 2]dola y trasmitiéndola de época en época y echando los cimientos de la elocuencia. Esta misión de la música y la poesía no ha cesado ni cesará jamás $[\ldots]^{61}$.

El texto completo de los "Apuntes" puede verse en el Documentario. En los apartados que siguen comentaré brevemente los principales contenidos de la obra.

\subsection{Historia del piano en Murcia}

En las cinco primeras entregas de los "Apuntes" hay interesante información sobre constructores de pianos murcianos desde el siglo XVI hasta el XIX y autores murcianos de métodos para piano, así como un catálogo de pianos de cola, verticales y de mesa existentes en la ciudad con nombres de sus dueños y de pianistas y afinadores de pianos ${ }^{62}$. Según los "Apuntes", la fabricación de instrumentos de tecla en Murcia se remonta al año 1592, fecha de construcción del primero de los tres órganos que hubo en la Catedral de Murcia, fabricado en la ciudad ante las dificultades para importar instrumentos foráneos ${ }^{63}$. El organero Antón Ramírez ayudó en su colocación y fue el primero en construir espinetas y claves en Murcia ${ }^{64}$. Otros constructores de instrumentos de teclado

cargo de Juan José Carreras a Soriano Fuertes, Historia, así como Carreras, "Hijos de Pedrell” y sobre el desarrollo de la historiografía musical en España, Lolo, "El sentido".

61 "Un aficionado", “Apuntes para la Historia de la Música en Murcia (VI), El Semanario Murciano I (1878), no 32, 22 septiembre, pp. 1-2.

${ }^{62}$ No existe todavía un estudio sistemático sobre la historia del piano en Murcia. Acerca de este tema hay información, además de en los "Apuntes", en [Anónimo], “Apuntes acerca del piano", El Diario de Murcia, I (1879), n' 193, 7 octubre, p. 1.

${ }^{63}$ Prats, "Murcia", p. 892, también menciona que en 1592 se instaló el primer gran órgano de la Catedral de Murcia. Julián Calvo, "[Carta remitida]”, Crónica de la Música, III (1880), nº 67, 1 enero, p. 2 afirmó que desde mediados del siglo XVIII hubo en Murcia hábiles constructores de salterios, cítaras, guitarras, bandurrias, violines, fagotes, bajones, clarinetes, oboes, flautas, arpas, armonios, órganos y contrabajos. Según Calvo, "Las grandes fábricas extranjeras han matado estas industrias artísticas en pequeño". Sobre construcción de contrabajos en Murcia véase también, La Paz de Murcia, XXII (1879), n ${ }^{\text {os }}$ 6720, 10 octubre, p. 1 y 6723, 14 octubre, p. 1.

${ }^{64}$ Se añade además: "Desde esta época hasta nuestros días puede decirse que no han faltado en nuestra ciudad buenos constructores de instrumentos de teclado y cuerdas"; véase "Un aficionado", "Apuntes para 
murcianos mencionados en los "Apuntes" son Manuel de los Reyes, de finales del siglo XVII, y Tadeo Tornel y Fray Juan Cruceta, del siglo XVIII ${ }^{65}$.

La nómina de constructores de pianos murcianos del siglo XIX citada en los "Apuntes" es numerosa. De la primera mitad de la centuria son mencionados José Agüera, Indalecio Soriano Fuertes, José Zamora (discípulo del anterior), Juan de la Paz, Francisco López, José Ramírez (discípulo de Zamora), José Rogel (padre del compositor Manuel Rogel), Domingo Martínez y, de la segunda mitad del siglo XIX, José Herades. Estos artesanos aprendieron a construir instrumentos de tecla de manera amateur o partiendo de otras profesiones, como la carpintería (Agüera, Zamora) ${ }^{66}$. Francisco López (?-1854), según los “Apuntes", construyó más de diecisiete pianos y fue el primer murciano en fabricar pianos verticales en su taller cercano a la Iglesia de la Merced. Juan de la Paz construyó en 1830 un instrumento experimental: "un piano en el que, en vez de cuerdas, herían sus mazos planchas de cristal. [...] Su sonido era muy semejante al de esos juguetes llamados liras que tanto molestan nuestros oídos en tiempo de feria"67. El ebanista, tallista y escultor José Herades comenzó a construir pianos en $1856 \mathrm{y}$, tras construir tres pianos de mesa y uno vertical, abandonó este oficio. Según los "Apuntes", la mayoría de estos instrumentos de tecla se quedaban en Murcia, probablemente para abastecer la progresiva demanda de los aficionados locales. También se importaban pianos extranjeros (franceses e ingleses), algunos de los cuales sirvieron de modelo a los hechos en Murcia.

Según los “Apuntes", el Colegio de San Leandro de Murcia instauró clases de pianoforte y clave en 1761, impartidas por los segundos organistas de la Catedral. El método empleado inicialmente fue el del francés Dandrieu, y paulatinamente se emplearon también otros métodos de autores murcianos, como el de Pedro Peceño y el de Agustín Giménez, maestros del Colegio de San Leandro y segundos organistas de la Catedral a finales del siglo XVIII y principios del XIX, que se combinaban con sonatas de Pleyel o Haydn, entre otros ejercicios ${ }^{68}$. En 1827, el maestro de capilla Agustín Giménez

la historia de la Música en Murcia (II)”, El Semanario Murciano, I (1878), no 24, 28 julio, pp. 3-4: 3. Prats, "Murcia", p. 892, menciona también al murciano Antón Ramírez como constructor de espinetas.

65 Sobre el piano-clave-órgano construido por Tadeo Tornel, conservado actualmente en el Museo Arqueológico de Murcia, véase, Latcham, "The instrument" y Máximo, "Tadeo". Para Latcham la importancia de este instrumento es innegable y su calidad comparable a instrumentos europeos de similares características como los clave-pianos de Giovanni Ferrini (1746), Johann Ludwig Hellen (1763), Johann Andreas Stein (1777 y 1783) y los de John Joseph Merlin (1780). Sobre los órganos de Murcia, véase Artigas, "El presupuesto"; Candel, "Contrato para la construcción"; Máximo, El órgano; Melendreras, "Órganos"; Melendreras, "El órgano" y Pina, "Órganos y organeros".

${ }^{66}$ Bordas, "Tradición”, pp. 203-204 menciona que los organeros españoles del siglo XVIII estaban sujetos al gremio general de carpinteros y fueron éstos los que realizaban otros tipos de instrumentos de tecla como clavicordios, espinetas y claves.

67 "Un aficionado", “Apuntes para la historia de la Música en Murcia (II)”, El Semanario Murciano, I (1878), $\mathrm{n}^{\mathrm{o}}$ 24, 28 julio, pp. 3-4: 3.

${ }^{68}$ Según los “Apuntes para la historia de la Música en Murcia (II)”, El Semanario Murciano I (1878), $\mathrm{n}^{\mathrm{o}}$ 25, 4 agosto, pp. 3-4: 4, "tomando por base los ejercicios de Peceño, formó un verdadero método progresivo, compuesto de ejercicios, sonatas y minués y poniendo por primera vez las escalas por todos los tonos". Con el método de piano de Peceño se formaron pianistas como Joaquín Cascales (organista de la Orihuela), el murciano Antonio Navarro, Alejo Sandoval, Máximo Giménez, Bartolomé Martínez (Maestro de Capilla de Villena), Matías Aliaga y el murciano Antonio García Valladolid (Maestro de Capilla de Valladolid). Véanse más detalles sobre Antonio García Valladolid en Cavia, Antonio García y Cavia, La vida musical. 
introdujo en el Colegio de San Leandro de Murcia el método El Adán Español, de José Sobejano Ayala ${ }^{69}$.

Agustín Giménez comenzó a dar clases de piano a domicilio en 1808, "siendo su primer discípulo [...] la señora del entonces primera autoridad de Murcia, señor Marqués de los Vélez" "70. En los años siguientes el piano se introdujo con fuerza en los hogares murcianos, sustituyendo paulatinamente a la guitarra, entonces muy en boga. La Tabla 11.5 muestra los profesores de piano activos en la ciudad de Murcia tras la Guerra de la Independencia (1808-1814):

Tabla 11.5. Profesores de piano en la ciudad de Murcia (1814-1864)

"Un aficionado", "Apuntes para la historia de la música en Murcia (III)", El Semanario Murciano I (1878), $\mathrm{n}^{\mathrm{o}}$ 25, 4 agosto, pp. 3-4 ${ }^{71}$.

\begin{tabular}{|l|l|}
\hline $\begin{array}{l}\text { Año } \\
\text { (desde) }\end{array}$ & Nombres \\
\hline 1814 & Victoriano de Dios, José Falguera y José Gil Huertos \\
\hline 1818 & Agustín Arenas, Indalecio Soriano Fuertes \\
\hline 1828 & José Gil Prieto, Julián Gil Yuncas y Francisco López \\
\hline 1834 & Celestino Mondéjar y Carlos Gil \\
\hline 1836 & José Calvo y Juan Diego Manresa \\
\hline 1840 & Matías Aliaga y Joaquín González \\
\hline 1854 & Antonio Rospide, Segismundo Clausel y Francisco Gil \\
\hline 1864 & José Quercop \\
\hline
\end{tabular}

En el cuarto artículo de los "Apuntes" se incluye un catálogo de los pianos de cola, verticales y de mesa que entonces se conservaban en la región de Murcia, con comentarios puntuales sobre la fabricación, estado de conservación y dueños de los mismos (ver Apéndice 11.5) ${ }^{72}$. Existían en Murcia capital al menos 253 pianos: cuatro de cola, 169 verticales y 80 de mesa $^{73}$. De ellos, 228 (más del 90\%) eran nacionales y sólo 25 extranjeros. Los pianos nacionales más numerosos eran los de la casa Boisselot y Boisselot-Bernareggi, de Barcelona (110 pianos verticales); seguidos de los murcianos

69 "El método de Sobejano está formado por el mismo plan que el de Giménez, a excepción de "los magníficos estudios que forman la última parte", según "Un aficionado", "Apuntes para la historia de la Música en Murcia (II)", El Semanario Murciano I (1878), n n 25, 4 agosto, pp. 3-4: 4. Otros métodos de piano llegados a Murcia después del de Sobejano fueron los de Albéniz, Le Carpentier, Aranguren y el de la Unión Artístico-Musical. Sobre estos métodos, véase: Vega, "Métodos españoles”, pp. 93-130 y Vega, "La escuela española", pp. 129-146.

70 "Un aficionado", “Apuntes para la historia de la Música en Murcia (II)”, El Semanario Murciano I (1878), n 25, 4 agosto, pp. 3-4: 4.

71 Sobre profesores de piano en otras ciudades murcianas, como Cartagena y Lorca, véase "Un aficionado", “Apuntes para la historia de la música en Murcia (III)”,El Semanario Murciano I (1878), n 25, 4 agosto, pp. 3-4.

${ }^{72}$ El artículo incluye también los pianos de otras localidades de Murcia, como Cartagena.

73 Bordas, "Dos constructores", p. 808, que estudia la figura del constructor murciano Francisco Flórez, entre otras cuestiones, afirma que la expansión del piano en todos los ámbitos musicales europeos se inició en la década 1760-1770. A finales del siglo XVIII se consolidaron dos tipos de mecanismos, el inglés y el vienés o alemán, y tres modelos de muebles para ambos mecanismos: el de mesa que adoptó el modelo de un gran monacordio y solía emplearse en el ámbito doméstico, el de cola, que adoptó la forma de clave y el vertical que sustituyó en el siglo XIX al piano de mesa aunque más decorativo y de menores dimensiones e idóneo para entornos caseros. 
(71 pianos, de los que siete eran verticales y 59 de mesa) y, en menor medida, de los de fabricación alicantina (14), madrileña (11), valenciana (1) y sevillana (1) ${ }^{74}$. Cabe destacar el alto número de pianos construidos en Murcia, que evidencian la alta productividad de los artesanos locales y la popularidad que adquirió el instrumento. Destacaban en número los de Francisco López (ver Tabla 11.6). Entre los pianos de construcción extranjera existentes en Murcia destacan los 26 franceses (19 de París y 7 de la Casa Boisselot de Marsella $\left.{ }^{75}\right)$, seguidos por los de construcción londinense (7 pianos) y alemana (1, de Dresde) $)^{76}$.

Tabla 11.6. Pianos de fabricación murciana existentes en la ciudad de Murcia (1878).

"Un aficionado", “Apuntes para la historia de la música en Murcia (IV)", El Semanario Murciano I (1878), $n^{\circ} 27,18$ agosto, pp. 3-5.

\begin{tabular}{|l|c|l|}
\hline Tipos & $\mathbf{N}^{\mathbf{0}}$ en Murcia & Constructor \\
\hline Verticales & 6 & [Francisco] López \\
\cline { 2 - 3 } & 1 & [José] Ramírez \\
\hline \multirow{4}{*}{ De mesa } & 1 & Soriano Fuertes \\
\cline { 2 - 3 } & 7 & {$[$ José] Zamora } \\
\cline { 2 - 3 } & 13 & [José] Agüera \\
\cline { 2 - 3 } & 2 & [José] Valera \\
\cline { 2 - 3 } & 27 & [Francisco] López \\
\cline { 2 - 3 } & 9 & [José] Ramírez \\
\hline & 5 & $\begin{array}{l}\text { Sin nombre y atribuidos a Indalecio } \\
\text { Soriano Fuertes, según el autor }\end{array}$ \\
\hline
\end{tabular}

En el Capítulo V de los "Apuntes" se describe la vida concertística murciana en torno al piano. Entre los reconocidos pianistas españoles que actuaron en la ciudad estuvieron Emilio Anchorena y José Miró, y pianistas murcianos de prestigio nacional (Luis Mondéjar Zamora) y regional (José Avilés, Mariano García, Segismundo Clausel, Julián Calvo y los pianistas ciegos Adolfo Gascón y Juan Diego Manresa, entre otros) ${ }^{78}$. Los "Apuntes" ofrecen también datos sobre almacenes y ventas de pianos en Murcia (ver Tabla 11.7) y sobre varios afinadores de pianos, como Fernando Pérez, organista del

${ }^{74}$ Sobre construcción de pianos en distintas ciudades de España entre los siglos XVIII a XX, además de los citados, véanse los trabajos de Bordas, "Otros pianos"; Bordas, Hazen, los tres centrados en Madrid; Fukushima, "Fabricantes", sobre construcción de pianos en Barcelona en 1900; Alemany, "La construcción", centrado en Valencia; y Kenyon, "Christopher”, en Sevilla.

${ }^{75}$ Véase Bordas, "Les relations”, pp. 90-91 sobre las relaciones de instrumentos de cuerda entre París y Madrid durante el periodo 1800-1850.

${ }^{76}$ Julián Calvo, "Remitido", La Paz de Murcia, XXI (1878), n 6313, 22 septiembre, p. 1, detectó algunos errores en la cantidad de instrumentos y el nombre de algunos de los dueños facilitados en los "Apuntes", aunque según él sin que los fallos dañaran "al asunto primordial". Calvo aportó además, datos sobre los pianistas murcianos de ese momento (ver el escrito de Calvo en el Documentario).

${ }^{77}$ Julián Calvo, "Remitido", La Paz de Murcia, XXI (1878), n 6313, 22 septiembre, p. 1, afirma que no existió ningún Valera constructor de pianos y considera que el dato era un error de imprenta.

78 "Un aficionado", “Apuntes para la historia de la música en Murcia (V)”, El Semanario Murciano I (1878), $\mathrm{n}^{\circ}$ 28, 25 agosto, pp. 2-3: 2. También se mencionaron otros pianistas (algunos en periodo de formación), como José Antonio Ramírez, José Solano, Juan Ayala, Mariano Redonde, Luis Garan, Francisco Leante, Francisco Soler, Andrés Díaz, los hermanos Luis y Antonio Lisón Albaladejo y el ciego José García, y las reputadas pianistas Dolores González de Oliveros y Rosario Albaladejo de Meseguer, entre otras. 
Carmen Calzado y afinador desde 1837, Juan Diego Manresa, Leonardo Agüera y Francisco Balanza.

Tabla 11.7. Almacenes y venta de pianos en Murcia durante la segunda mitad del siglo XIX ${ }^{79}$

"Un aficionado", “Apuntes para la historia de la música en Murcia (V)", El Semanario Murciano I (1878), no 28, 25 agosto, pp. 2-3:2; Julián Calvo, "Remitido", La Paz de Murcia, XXI (1878), nº 6313, 22 septiembre, p. 1.

\begin{tabular}{|l|l|c|l|}
\hline Almacén de & $\begin{array}{l}\text { Años de } \\
\text { existencia }\end{array}$ & $\begin{array}{l}\mathbf{N}^{0} \text { de pianos } \\
\text { vendidos }\end{array}$ & Fabricación \\
\hline José Ramírez & $\begin{array}{l}{[1853} \\
\text { consta] }\end{array}$ & 50 & [No consta] \\
\hline Celestino Mondéjar & $1860-1871$ & 117 & $\begin{array}{l}13 \text { Boisselot, Marsella; 31 de } \\
\text { Boisselot de Barcelona; 47, } \\
\text { Boisselot-Bernareggi; } \\
\text { Bernareggi, Barcelona }\end{array}$ \\
\hline Remigio Arcusa & $1871-1878$ & 41 & Bernareggi \\
\hline $\begin{array}{l}\text { Acisclo Diaz } \\
\text { Rocher }\end{array}$ & $1872-1874$ & 19 & Bernareggi \\
\hline Francisco Gil & & {$[$ [No consta] } & [No consta] \\
\hline $\begin{array}{l}\text { Segismundo } \\
\text { Clausel }\end{array}$ & {$[$ No consta] } & $\begin{array}{l}\text { [No consta, } \\
\text { diferentes fábricas }]\end{array}$ & [No consta] \\
\hline
\end{tabular}

Los cinco primeros artículos de los "Apuntes" sobre historia del piano en Murcia fueron comentados por el organista y compositor Julián Calvo mediante dos cartas publicadas por La Paz de Murcia. En la primera carta, Julián Calvo califica los "Apuntes" de "excelentes" y "bien escritos" y parece confirmar que fueron la primera investigación publicada sobre la historia de la música en Murcia:

[...] Siendo el objeto de esto el dar la enhorabuena al que ha sido el primero en demostrar que en Murcia se ha cultivado la música desde muy antiguo y a usted por haber sido el primero que ha cobijado en las columnas de su digno periódico un trabajo que debe ser recibido por todos los amantes de los buenos progresos, con el respeto y consideración que merecen el estudio y toda investigación provechosa al hombre ${ }^{82}$.

La segunda carta de Calvo, aunque también en términos elogiosos para el autor de los "Apuntes", corrigió algunas fechas que supuestamente eran erróneas en ellos, matizó las trayectorias de algunos pianistas murcianos, añadió más pianistas de Murcia a la lista

79 "Esta relación, que sólo se refiere a los pianos nuevos, es de los que se han vendido tanto en esta capital como en otras ciudades y pueblos de dentro y de fuera de la provincia", "Un aficionado", "Apuntes para la historia de la música en Murcia (V)”, pp. 2-3:2.

${ }^{80}$ Este comerciante "vendió el primero de la fábrica de Boisselot de Barcelona en el año 1856, marcado con el número 7134 en 4800 reales a don Mariano García": "Un aficionado", "Apuntes para la historia de la música en Murcia (V)”, pp. 2-3:2.

${ }^{81}$ Introdujo los pianos de Pedro Gómez de Valencia. Según Julián Calvo, "Remitido", La Paz de Murcia, XXI (1878), nº 6313, 22 septiembre, p. 1,

82 Julián Calvo, "[Carta remitida]", El Semanario Murciano, I (1878), nº 25, 4 agosto, p. 7 (ver Documentario). 
publicada en los "Apuntes" y señaló que éstos no habían tratado "las ventajas producidas por él [el piano] en este país o en la provincia, ya en arte cuanto en la sociedad y, por último, su influencia en la educación moral" ${ }^{\prime 83}$.

\subsection{Historia de la flauta en Murcia}

Los artículos VI al X de los "Apuntes" versan sobre la historia de la flauta en España y en Murcia. En el primero de esos artículos, el autor supone que la flauta se conocía y tocaba en las civilizaciones remotas que poblaban Murcia y, ante el vacío documental referido a la música de Murcia en la Antigüedad, describe los modelos de flautas y sus usos en las civilizaciones antiguas de la Península Ibérica ${ }^{84}$. En los Capítulos VII y parte del VIII, se describe la evolución de la flauta en la civilización árabe, en la música de juglares, trovadores y troveros, y en la música cristiana desde la Edad Media hasta el siglo XIX, citando fuentes como la Historia de la Música de Mariano Soriano Fuertes y al historiador Francisco Cascales ${ }^{85}$. Partiendo del estudio de la flauta, los "Apuntes" aportan una particular visión del origen de los villancicos e incluso de la zarzuela:

[...] La Iglesia patrocina en las puertas de sus templos los diálogos con música y canto inventados por los trovadores, preparándose con esto los villancicos y bien pronto penetran bajo sus bóvedas estas representaciones sacro-profanas. Y no sólo en las procesiones del Corpus se exhiben [cantos de coros] representando ángeles, sino grupos de baile donde las guitarras y las flautas guían y acompañan y, por último, se organizan los autos sacramentales, cuyas representaciones dan origen indudablemente a la invención de la zarzuela.

Constan en los libros capitulares de nuestra Iglesia Catedral las comunicaciones a los maestros de capilla para que se pongan de acuerdo con los directores de estos entremeses y maestros de baile y les favorezcan con el número de músicos que sean necesarios para que estas fiestas tengan el mayor esplendor y lucimiento. También en los mismos libros y con fecha de 1481 se dice que, siendo tanta la gente que se agolpaba a las representaciones y a las danzas, se mandó quitarse para que el pueblo no las rompiera en su aglomeración, las capas pluviales de seda que en la referida solemnidad llevan los señores canónigos. Los sitios donde tenían lugar estos espectáculos eran la plaza de Pilares, el cobertizo de la Trapería, el cantón de San Cristóbal, Santa Catalina y San Pedro $[\ldots]^{86}$.

Los Capítulos VIII a X de los "Apuntes" son los que más información aportan sobre la historia de la flauta en Murcia, y ofrecen datos sobre la composición e instrumentos de la Capilla de Música de la Catedral de Murcia desde el siglo XV hasta el

${ }^{83}$ Julián Calvo, "Remitido", La Paz de Murcia, XXI (1878), nº 6313, 22 septiembre, p. 1 (ver Documentario). Calvo reiteraba su felicitación al autor de los "Apuntes" porque "ha hecho un bien y ha alcanzado un lauro con ser el que ha iniciado una cuestión tan delicada".

84 "Un aficionado", “Apuntes para la historia de la música en Murcia, (VI)”, El Semanario Murciano I (1878), $n^{\circ} 32,22$ septiembre, pp. 1-2: 1.

85 “Un aficionado”, “Apuntes para la Historia de la Música en Murcia (VII)”, El Semanario Murciano I (1878), no 35, 13 octubre, pp. 4-6: 5.

86 "Un aficionado", “Apuntes para la historia de la música en Murcia, (VIII)”, El Semanario Murciano I (1878), no 42, 1 diciembre, pp. 5-6: 6. 
$\mathrm{XIX}^{87}$. Según los "Apuntes", la flauta dejó de emplearse en la Capilla catedralicia murciana en 1478, y fue sustituida por las chirimías. El maestro de capilla Bruno de Molina, en sus Misereres de 1802 y 1803, fue el que de nuevo "emplea las flautas por primera vez en la Catedral después de más de tres siglos de completo olvido" ${ }^{88}$, aunque diversos músicos habían continuado tañendo el instrumento en otros contextos ${ }^{89}$. La flauta se empleó en Murcia, por ejemplo, en la "Loa" teatral representada en el Seminario de San Fulgencio en 1771, con motivo de la canonización de Santo Tomás de Aquino, en las fiestas reales por los nacimientos de los infantes Carlos y Felipe (hijos de los Príncipe de Asturias) en 1784, y en los rosarios públicos del siglo XVIII ${ }^{90}$. Las flautas también estuvieron presentes en unas rogativas celebradas en 1811, en las que se cantaron unas coplas compuestas por el maestro de capilla Bruno Molina:

[...] Murcia no ha tenido que quejarse de sus maestros ni de sus músicos porque los compositores han tenido el tino de la coordinación, arreglándose a los elementos de que han podido disponer. Popularizando la música todo lo posible, no solo en las fiestas y en los templos sino hasta para implorar la misericordia divina en las calamidades públicas, como sucedió en 1811 con las tan célebres y populares como oportunas coplas de Bruno Molina que, con motivo de la epidemia, entonaba continuamente el pueblo en son de rogativa y cuya letra, escrita con acompañamiento de flautas y bajón empieza: Aplaca, Señor tu ira; coplas que, aunque cantadas con muy poca expresión, aún repite este mismo pueblo en sus grandes aflicciones. $[\ldots]^{91}$.

Los "Apuntes" aportan información sobre los maestros de capilla de la Catedral de Murcia en los siglos XVIII y XIX ${ }^{92}$, citando composiciones musicales en las que incluyeron flauta y/o su instrumento alternativo, el clarinete. De la "Lamentación de Jueves Santo" de Indalecio Soriano Fuertes (maestro de capilla de la Catedral de Murcia entre 1827 y 1830) se comentó que incluía un "sentido solo de flauta, pero aún son los clarinetistas los encargados de tocar los pasajes de flauta, dejando sus respectivos

\footnotetext{
${ }^{87}$ Los datos de los "Apuntes" sobre instrumentistas y sobre la composición de la Capilla de Música de la Catedral de Murcia desde el siglo XV coinciden con la información aportada por Prats, "Murcia”, p. 890.

88 "Un aficionado", “Apuntes para la historia de la música en Murcia (IX), El Semanario Murciano I (1878), no 38, 3 noviembre, pp. 4-5: 4. Bruno Molina fue maestro de Capilla de la Catedral de Murcia desde 1792 hasta su fallecimiento en 1811 y, también según García Seco, "Maestro de capilla", p. 22, fue el que introdujo el uso de la flauta en dicha institución.

89 "Un aficionado”, “Apuntes para la historia de la música en Murcia (IX), El Semanario Murciano I (1878), n 38, 3 noviembre, pp. 4-5: 4. Pedro Ximénez en 1595 era tenor y tocaba la flauta, Francisco de Mesa era en 1613 contralto y flautista, Agustín Carrión tocaba en 1613 la chirimía y la flauta, y Angelo Vela, violín y violon en la Capilla de Música de la Catedral de Murcia desde 1751, fue el primero que tocó la flauta travesera (con seis agujeros y una llave) en una formación orquestal de Murcia diferente a la catedralicia. Véase, "Un aficionado", "Apuntes para la historia de la música en Murcia, (VIII)", El Semanario Murciano I (1878), no 42, 1 diciembre, pp. 5-6: 6.

${ }^{90}$ Los "Apuntes" mencionan la polémica mantenida en Sevilla en 1788 por Bartolomé Cabello a propósito de la utilización de ciertos instrumentos en los rosarios, fruto de la cual fue la publicación de Cabello, Cartas familiares.Véase, "Un aficionado", "Apuntes para la historia de la música en Murcia (IX), El Semanario Murciano I (1878), nº 38, 3 noviembre, pp. 4-5.

91 "Un aficionado", “Apuntes para la historia de la música en Murcia (IX), El Semanario Murciano I (1878), n 38, 3 noviembre, pp. 4-5: 4.

92 Los maestros de capilla de la Catedral de Murcia citados en los "Apuntes" coinciden con los reseñados por Prats, "Murcia”, p. 893.
} 
instrumentos colgados del atril, cuando tenían que ejecutar con las flautas, cosa muy perjudicial, pues no podían cumplir bien ni con uno ni con otro instrumento",93.

En el Capítulo X de los "Apuntes" son mencionados diversos instrumentistas de flauta del siglo XIX en Murcia, como José Calvo, Julián Gil Yuncas, Máximo Giménez, Mariano Esbrí y José Gil Huertos, entre otros muchos, todos ellos vinculados a iglesias o al Colegio de San Leandro de la Catedral. Entre los maestros murcianos dedicados a la enseñanza de la flauta se citan José Gil Huertos, José Gil Prieto, Julián Gil Yuncas, Carlos Gil Yuncas, Francisco López, Daniel Ortiz, José Calvo, Mariano Esbrí, José Jubés y José García Pujol. Entre los métodos empleados por éstos para enseñar la flauta los había murcianos (dos de José Calvo, uno fácil y otro "completo y difícil"), españoles (el Gran método de flauta de Andrés Parera y el Método de flauta de José Beltrán) y extranjeros (Nouvelle méthode théorique et pratique pour la flûte de Fraçois Devienne, Méthode de flûte Jean Louis Tulou, Méthode élémentaire de Jean-Georges Kastner, y el de Antoine Tranquille Berbiguier).

Los "Apuntes" describen también los tipos de flautas que se empleaban en las orquestas murcianas durante el siglo XIX: de boj, de ébano, de marfil, de granadillo y de cristal y plata, y mencionan constructores como Louis-Auguste Buffet, Gautrot, Theobald Boehm, Jean Louis Tulou, Clair Godfroy y el murciano Pascual Arques, entre otros ${ }^{94}$. No se describe la flauta moderna "por ser materia que se encuentra en todos los tratados de instrumentación". En cambio, se menciona que hasta el siglo XVIII se usaba en Murcia "el bajo de flauta", que el flautín u octavín comenzó a emplearse en bandas y orquestas murcianas "ya bien entrado el presente siglo" y que en 1854 se conoció en Murcia la primera "flauta tercerola", que era tocada por el músico Mariano Esbrí ${ }^{95}$.

\subsection{Historia de la guitarra en Murcia}

El Capítulo XI de los "Apuntes" está dedicado a la historia de la guitarra en Murcia, y se publicó seis meses después que el Capítulo X. Se consideraba que la guitarra, "por razón de ser del instrumento más popular de España, aunque por desgracia muy abandonado al presente, merece una particular atención porque en él se encarnan, digámoslo así, nuestros cantos nacionales, acaso la colección más rica, más sentida y más variada del mundo"96. Tras esbozar el origen de la guitarra en la Antigüedad y argumentar las razones por las que la guitarra no forma parte de la orquesta, el autor de los "Apuntes" destaca que la guitarra "por sí sola [forma] una pequeña orquesta que el pueblo ha adoptado como muy suficiente para satisfacer sus necesidades musicales y acompañar los preciosos cantos que forman el bien ponderado género popular español"97. Esta idea

93 "Un aficionado”, “Apuntes para la historia de la música en Murcia (IX), El Semanario Murciano I (1878), n 38, 3 noviembre, pp. 4-5: 5.

${ }^{94}$ Sobre la flauta en España en el siglo XIX, véase Gericó y López Rodríguez, La flauta.

95 "Un aficionado”, “Apuntes para la historia de la música en Murcia (X), El Semanario Murciano II (1879), $\mathrm{n}^{\circ}$ 80, 24 agosto, pp. 2-3: 3.

96 "Un aficionado", “Apuntes para la historia de la música en Murcia (X), El Semanario Murciano II (1879), $\mathrm{n}^{\circ}$ 80, 24 agosto, pp. 2-3: 2.

97 Se sitúa como precedente más remoto de la guitarra a la lira, con ideas muy similares a las de Soriano Fuertes, Historia, vol. IV, pp. 205-217. 
entronca con el discurso de Soriano, quien sostenía que la música española se caracterizaba por la sencillez melódica de los cantos populares, cuya insignia fue la guitarra española ${ }^{98}$. En contraste con los artículos dedicados al piano y a la flauta, el referente a la guitarra no aporta datos sobre instrumentistas, conciertos y construcción de guitarras en Murcia.

\subsection{Los cantos populares de Murcia}

Los Capítulos XII y XIII de los "Apuntes" fueron los últimos publicados de la serie, y tratan sobre la música tradicional murciana. El interés por la música de carácter popular, fruto del impulso nacionalista y regionalista detectado en España y en toda Europa, se plasmó en la edición de numerosos cancioneros y recopilaciones publicados desde el último cuarto del siglo XIX. En Murcia, en 1877 aparecieron las Alegrías y tristezas de Murcia de Julián Calvo, primera recopilación impresa de los cantos de la huerta murciana ${ }^{99}$, que surge en un contexto de creciente interés por la literatura y la música populares de la región ${ }^{100}$. Las artes plásticas y los trajes regionales eran también exponentes de las peculiaridades del folklore popular murciano (ver Figura 11.4) y la prensa local dio cabida a numerosos artículos sobre cantos populares de la región ${ }^{101}$. Los Juegos Florales de Murcia fomentaron la creación de música de inspiración popular, exigiendo en los concursos composiciones basadas en materiales folklóricos. Por ejemplo, en los Juegos Florales de 1877 se pidió un "Estudio para piano sobre cantos populares de Murcia") y en los de 1879 una "Composición instrumental sobre aires populares, murcianos o nacionales".

${ }^{98}$ Carreras, “Introducción”. En: Soriano Fuertes, Historia, pp. XV-XVI.

${ }^{99}$ Calvo, Alegrías y tristezas.

${ }^{100}$ Entre las recopilaciones de música y poesía populares posteriores a la de Julián Calvo, destacan: Pasionaria Murciana (Madrid, 1897) y el Cancionero panocho (Madrid, 1900), cancioneros poéticos recolectados por Pedro Díaz Cassou, con una sección breve de cantos populares transcritos por los músicos murcianos Antonio López Almagro y Mariano García. Sobre la literatura popular de Murcia en el siglo XIX y comienzos del XX, véase Díez de Revenga y De Paco, Historia; y Ma Josefa Díez de Revenga, estudio preliminar al Cancionero popular murciano antiguo, pp. 9-64. Sobre música popular murciana, véase Encabo, "Las primeras recolecciones", pp. 95-115; Encabo, "Los 'Cuadros murcianos",, pp. 117-127; Ortega, "Cantos de labranza", pp. 387-409; Gil, Panorama; Pico, "La recopilación de canciones”, pp. 3-13; Pico, "Cancioneros españoles”, pp. 83-85; Rey y Pliego, "La recopilación de la música popular", pp. 355374.

${ }^{101}$ Por ejemplo: Javier Fuentes y Ponte, "El canto de la aurora (I)”, El Chocolate, I (1872), jícara 3, 3 noviembre, pp.17-18 y "El canto de la aurora (II)", El Chocolate, I (1872), jícara 4, 10 noviembre, pp. 2527; "Der Lehrling”, "La parrandas (I)", El Chocolate, III (1873), n 28, agosto, pp. 225-226; Miguel Moya, "Las playeras", El Diario de Murcia, I (1879), no 32, 23 marzo, p. 1; [Anónimo], "Los himnos populares", El Diario de Murcia, I (1879), n 46, 13 abril, p. 1; [Anónimo], "Cantos populares”, El Diario de Murcia, I (1879), no 120, 11 julio, p. 1 y [Anónimo], “Cantos populares”, El Diario de Murcia, V (1883), n 1303, 17 junio, pp. 1-2 y Francisco Luis Hidalgo, “Aguinaldos”, La Paz de Murcia, XXXIII (1890), nº 11215, 25 diciembre, p. 1. 


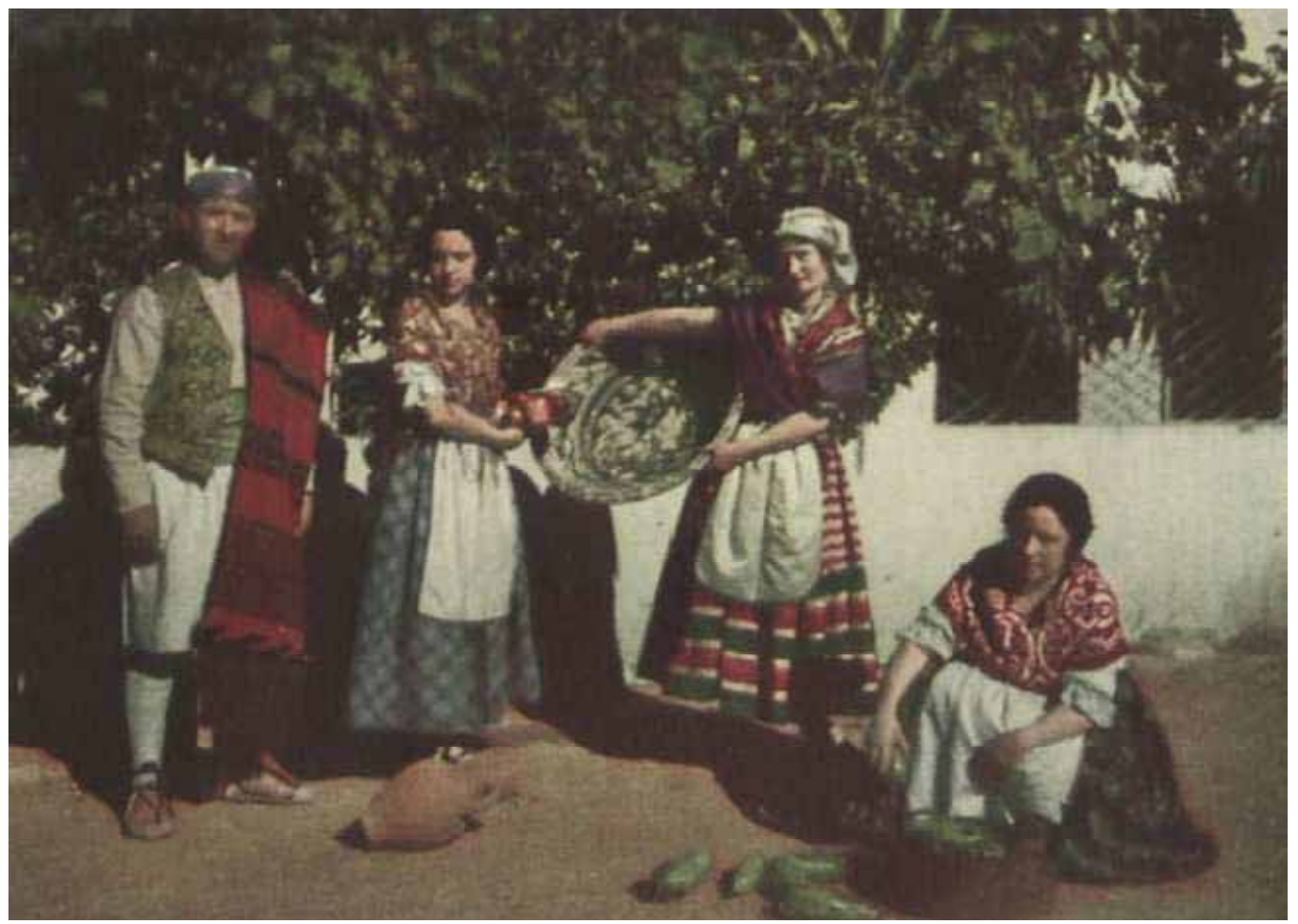

Figura 11.4. Indumentaria típica de los huertanos y huertanas de Murcia.

Fotografía realizada por Vicente Medina y reproducida en Medina, Aires Murcianos, p. 232.

El Capítulo XII de los "Apuntes" comienza subrayando la riqueza de cantos del pueblo murciano, la constante creación de música popular, la necesidad de plasmarla por escrito para evitar su desaparición y la conveniencia de utilizarla como base para crear una ópera nacional:

[...] La invención o aparición de los cantos populares en nuestro país brota sin saber de dónde, extendiéndose con una rapidez prodigiosa hasta que los repiten toda clase de personas sin distinción de sexos ni condiciones. El pueblo murciano sabe inventar estos cantos con una fecundidad admirable. Las romerías al poético Santuario de Nuestra Señora de la Fuensanta, las reuniones de familia, las fiestas públicas y las diversiones particulares hacen aparecer siempre nuevas cantinelas que entran a formar parte en la gran colección, que ayudan al hombre a dulcificar y embellecer las penosas tareas de su trabajo, al par que contribuyen a su instrucción, elevando su espíritu e inspirándole sentimientos nobles y generosos. Muchas de estas cantinelas suelen desaparecer porque no hay un músico que las escriba y perfeccione, descuido imperdonable hoy que tanto se aprecia el género popular y que sólo se espera un compositor de genio para que, apoyándose en estos cantos, haga nacer la ópera española y dé a nuestra música una escuela y un carácter nacional $[\ldots]^{102}$.

El autor de los "Apuntes" reconoció elogiosamente la labor recopiladora de la música popular murciana llevada a cabo por Julián Calvo y describió los siete primeros

${ }^{102}$ El Semanario Murciano II (1879), nº 83, 14 septiembre, pp. 2-3: 2. Las cursivas son editoriales. 
cantos de las Alegrías y tristezas de dicho autor, cuyo listado de cantos reproduzco en la Tabla $11.8^{103}$.

Tabla 11.8. Cantos recogidos en Alegrías y tristezas de Murcia de Julián Calvo (1877). Calvo, Alegrías y tristezas.

\begin{tabular}{|c|c|c|}
\hline $\mathrm{N}^{\mathrm{o}}$ & Título & Dedicatoria \\
\hline 1 & $\begin{array}{l}\text { Cantinela usada por las madres para } \\
\text { dormir a sus niños }\end{array}$ & A su madre \\
\hline 2 & $\begin{array}{l}\text { Pasión que se canta por los ciegos en } \\
\text { la Semana de Pasión }\end{array}$ & \\
\hline 3 & $\begin{array}{l}\text { Pasión que se canta durante la } \\
\text { Cuaresma por dos ciegos o por el } \\
\text { pueblo }\end{array}$ & \\
\hline 4 & $\begin{array}{l}\text { Décimas } \quad \text { glosadas llamadas } \\
\text { vulgarmente El Paño }\end{array}$ & \\
\hline 5 & $\begin{array}{l}\text { Aguinaldos que canta el pueblo y los } \\
\text { ciegos }\end{array}$ & $\begin{array}{l}\text { A su padre, José } \\
\text { Calvo }\end{array}$ \\
\hline 6 & $\begin{array}{l}\text { Aguinaldo que se canta en la huerta y } \\
\text { campo de Murcia }\end{array}$ & \\
\hline 7 & $\begin{array}{l}\text { Malagueña que los mozos de la huerta } \\
\text { y el pueblo cantan en las músicas con } \\
\text { que obsequian a sus novias }\end{array}$ & \\
\hline 8 & $\begin{array}{l}\text { Malagueña que bailan y cantan en la } \\
\text { huerta }\end{array}$ & \\
\hline 9 & Malagueña glosada por la bandurria & \\
\hline 10 & $\begin{array}{l}\text { Parrandas del campo y huerta, } \\
\text { llamadas del Uno }\end{array}$ & $\begin{array}{l}\text { Jesusa y Manuel } \\
\text { Azcárate }\end{array}$ \\
\hline 11 & $\begin{array}{l}\text { Parrandas del campo llamadas del } \\
\text { Tres, o "Las pesadas" }\end{array}$ & $\begin{array}{l}\text { Luis Navarro, su } \\
\text { primo, }\end{array}$ \\
\hline 12 & $\begin{array}{l}\text { Parrandas que se cantan y bailan en la } \\
\text { huerta de Murcia }\end{array}$ & $\begin{array}{l}\text { Desirée Artot y } \\
\text { Mariano Padilla } \\
\text { (Murcia, } 1 \text { de agosto } \\
\text { de 1871) }\end{array}$ \\
\hline$[13-15]$ & $\begin{array}{l}\text { Salve a dos coros, llamada } \\
\text { vulgarmente "La aurora", por ser } \\
\text { costumbre inmemorial el cantarla } \\
\text { desde la una de la noche hasta la Misa } \\
\text { de la aurora }\end{array}$ & $\begin{array}{l}\text { Manuel Fernández } \\
\text { Caballero }\end{array}$ \\
\hline 13 & Salve llamada "La Carnal" & \\
\hline $14-15$ & $\begin{array}{l}\text { Salve llamada "La Ordinaria" y copla } \\
\text { que cantan usualmente }\end{array}$ & \\
\hline [16-19] & $\begin{array}{l}\text { Cantares de los huertanos para cuando } \\
\text { cogen la hoja de las moreras para los } \\
\text { gusanos de la seda, para la labranza } \\
\text { con mulas y con vacas y para la trilla }\end{array}$ & \\
\hline 16 & Canto de la hoja & Antonia, su hija \\
\hline 17 & Canto de la trilla & Pilar, su hija \\
\hline 18 & Canto para labrar con mulas & Pepe, su hijo \\
\hline 19 & $\begin{array}{l}\text { Canto para labrar con vacas o con } \\
\text { bueyes }\end{array}$ & Julián, su hijo \\
\hline 20 & Seguidillas antiguas del Jo y Ja & "Pepiquia" \\
\hline
\end{tabular}

103 "Un aficionado", “Apuntes para la historia de la música en Murcia (XII y XIII), El Semanario Murciano II (1879), $\mathrm{n}^{\text {os }} 83,14$ septiembre, pp. 2-3 y 85, 28 septiembre, pp. 6-7 (véase Documentario). 
Apoyándose en Julián Calvo, el autor de los "Apuntes" subrayó la procedencia árabe de la Cantinela usada por las madres para dormir a sus niños (cuya letra comenzaba con "A la mar tengo de ir") y afirmó que, a pesar de las alteraciones melódicas sufridas por el paso del tiempo, su estructura y modo de cantarse conservaban el carácter original. Para localizar el origen de otros dos cantos (Pasión que se canta por los ciegos en la Semana de Pasión y Pasión que se canta durante la Cuaresma por dos ciegos o por el pueblo), el autor de los "Apuntes" estudió en el Archivo de la Catedral de Murcia algunas composiciones de antiguos maestros de capilla que se habían inspirado en ellos. Según él, la Pasión que se canta por los ciegos en la Semana de Pasión era anterior a 1600, ya que en esa fecha el maestro de la Capilla de Música de la Catedral de Murcia Manuel Tabares compuso, basándose en ella, su célebre Benedictus Dominus Deus Israel, cantado en ese templo desde entonces hasta los años setenta del siglo XIX.

La última entrega de los "Apuntes" (Capítulo XIII) se dedicó en exclusiva a comentar dos recopilaciones de música popular realizadas por Julián Calvo, los Aguinaldos que canta el pueblo y los ciegos y el Aguinaldo que se canta en la huerta y campo de Murcia. Calvo opinaba que las melodías de los populares aguinaldos eran "puramente originales de Murcia"104, y esta idea es repetida por el autor de los "Apuntes". En éstos se establece una distinción entre dos tipos de aguinaldos: "uno que podemos llamar de los músicos y de los más ilustrados del pueblo y otro el de nuestros labradores". Entre las composiciones cultas inspiradas en los aguinaldos, en los "Apuntes" se citan dos villancicos del maestro de capilla de la Catedral de Murcia Bruno Molina (1797) y del organista Agustín Giménez (Siga la fiesta, muchachos, vaya, de 1834) y una Fantasía sobre el aguinaldo de José Calvo (sin fecha).

Las cadencias de los aguinaldos fueron un punto de discrepancia entre Julián Calvo y el autor de los "Apuntes". Calvo las creía basadas en el segundo tono del canto llano, pero el autor de los "Apuntes" opinaba que las cadencias finales de los aguinaldos transcritos por Calvo no eran originales, sino añadidas por los músicos modernos:

[...] Sin que sea nuestro ánimo contradecir el parecer de quien, como organista de nuestra Catedral, es competente en la materia, estamos convencidos de que don Julián Calvo ha sido sorprendido por una novedad introducida en este canto popular que consiste en la variación de su final, terminándolo hoy por algunos en tono menor, quitándole con esto el sello de autenticidad y antigüedad y haciéndole perder el mejor golpe de efecto que su anterior terminación le daba.

Adoptado este nuevo final por el señor Calvo, como se ve en los aguinaldos que en su obrita presenta, tiene su opinión algún fundamento, porque efectivamente se advierte cierta analogía con la entonación regular del segundo tono del canto-llano, pero desechando dicha terminación que, [aunque] no es general sino cosa seguida por algunos de pocos años a esta parte, está bien distante de guardar relación con el referido segundo tono.

Nosotros, que no admitimos como precepto musical la obra de unos cuantos y que verdaderamente es perjudicial porque está contra la belleza de esta cantinela, no nos avenimos con la idea anotada por el señor Calvo. En apoyo de nuestra opinión y siguiendo el espíritu de estos escritos de allegar cuantas noticias nos sea posible, aún cuando parezca que momentáneamente nos apartamos de la exposición de los cantos populares y de la historia de la guitarra, vamos a dar una ligera idea de la formación y

${ }^{104}$ Calvo, Alegrías y Tristezas, p. 6. 
principios esenciales del canto llano, deduciendo que su segundo tono no tiene relación alguna con el aguinaldo murciano. $[\ldots]^{105}$.

Para justificar por qué los aguinaldos murcianos no se basaban en el segundo modo gregoriano, el autor de los "Apuntes" incluyó una explicación sobre el origen del canto llano, basada en la Historia de la Música de Soriano Fuertes ${ }^{106}$. Muy posiblemente estaba previsto que las argumentaciones sobre música popular murciana continuaran en entregas posteriores de los "Apuntes", aunque no he localizado ningún nuevo capítulo de los mismos después del ya comentado Capítulo XIII (1879).

105 "Un aficionado", “Apuntes para la historia de la música en Murcia (XIII), El Semanario Murciano II (1879), $n^{\circ} 85,28$ septiembre, pp. 6-7. Sobre los aguinaldos murcianos, véase Clares, Sonidos antiguos.

${ }^{106}$ Soriano Fuertes, Historia, vol. II, pp. 15 y siguientes. 


\section{Conclusiones generales}

Durante la segunda mitad del siglo XIX, la vida cultural murciana experimentó un florecimiento visible, entre otras manifestaciones, en la proliferación de actividades musicales y publicaciones periodísticas. Mientras que en la primera mitad del siglo XIX se publicaron en Murcia medio centenar de periódicos, durante la segunda mitad de la centuria vieron la luz más de ciento treinta, entre los que destacaron La Paz de Murcia (1858-1896) y El Diario de Murcia (1879-1903), dos de las publicaciones más influyentes de la época que resultan imprescindibles para reconstruir el panorama musical murciano de la época. La prensa fue esencial para canalizar y transmitir las ideas, reivindicaciones, denuncias y creaciones de los dirigentes e intelectuales murcianos, incluidos los músicos. Hubo en Murcia varios periódicos específicamente musicales (hoy ilocalizables), como El Iris, La Lira del Segura, El Filarmónico, La Lira Murciana y otro de título desconocido, dirigido por Mariano García, maestro de capilla de la Catedral de Murcia. La prensa de carácter general proporciona, sin embargo, numerosísimas noticias de interés musical que fueron incrementándose paulatinamente a lo largo del siglo XIX. En el Diario de Murcia se publicó la única partitura publicada en prensa que he localizado en mi investigación, la Romanza Nel la vita io son peregrino, con texto en italiano, pensada para el consumo de los aficionados.

El teatro fue en Murcia, como en tantas otras ciudades españolas de la época, uno de los núcleos fundamentales de la vida musical. Durante la segunda mitad del siglo XIX he podido documentar en Murcia veintiséis teatros y locales en los que se celebraban representaciones teatrales. Hasta 1857, el teatro principal de la ciudad fue la Casa-Teatro (Corral de las Comedias o Teatro del Toro), construido a principios del siglo XVII y varias veces reformado en las centurias siguientes. Aunque las autoridades locales se plantearon construir un nuevo teatro desde 1842, éste no llegó a ser una realidad hasta la inauguración en 1862 del Teatro de los Infantes, considerado un símbolo de adelanto y modernidad en la Murcia de la época. Fue edificado por iniciativa municipal (a diferencia de otros teatros españoles erigidos con capital privado), aunque la burguesía murciana aportó grandes sumas de dinero tanto en la fase de construcción como en remodelaciones posteriores. El Teatro de los Infantes siguió los cánones del "teatro a la italiana", con localidades que marcaban la separación de las clases sociales y su poder económico. A causa de las circunstancias políticas, el 6 de octubre de 1868, el teatro pasó a tener la impopular denominación de Teatro de la Soberanía Nacional, y desde el 6 de mayo de 1872 se le dio su denominación definitiva, Teatro Romea. El Teatro Infantes-Romea sufrió diversas reformas y dos grandes incendios (1877 y 1899) que modificaron considerablemente su aspecto exterior e interior y condicionaron su actividad. El cierre de este teatro en 1877-1880 favoreció la actividad teatral en otros teatros y locales teatrales de la ciudad, muchos de ellos dependientes de sociedades recreativas y en general (y salvo el Teatro del Circo Villar), peor acondicionados, sin temporadas estables, de actividad irregular y a veces limitada a géneros no musicales, y con una gran presencia de actores aficionados (ocasionalmente combinados con profesionales de la escena).

El Teatro Infantes-Romea y todos los asuntos relacionados con él dependían del Ayuntamiento de Murcia, aunque se recurría a accionistas privados que aportaban capital cuando era necesario. Los problemas en el funcionamiento del teatro fueron frecuentes. La escasa rentabilidad económica del teatro provocaba dificultades para encontrar empresas que quisieran alquilarlo, interrupción de los contratos de arrendamiento antes de 
su finalización, y retrasos o menor duración de las temporadas teatrales, entre otros problemas. Con frecuencia se denunciaban además las pobres escenografías, la falta de ensayos de las compañías y la escasa calidad de los artistas. Arrendatarios y empresarios de las compañías trataron constantemente de paliar estos problemas estableciendo medidas como abonos y funciones por turnos o precios más baratos de las localidades. La implantación del sistema de teatro por horas en 1888 dinamizó la actividad del Teatro Infantes-Romea y contribuyó a elevar la asistencia de público, que en algunos casos fue muy alta, pero hubo frecuentes alborotos en la sala que llevaron a cuestionar la pertinencia del sistema por horas y, de paso, la idoneidad moral de algunas de las obras que se representaban. Las funciones por horas fueron prohibidas en $1890 \mathrm{y}$ posteriormente sólo consentidas en determinados días de la semana.

A pesar de las dificultades, el Teatro de los Infantes-Romea mantuvo una impresionante actividad musical, ya que acogió entre 1862 y 1895 más de tres mil setecientas representaciones de zarzuela grande, chica, bufa, sainete lírico, revista y opereta (en castellano - arreglada o adaptada-, y en italiano); y más de doscientas representaciones de ópera, entre 1862 y 1899. Entre los compositores más interpretados estuvieron Barbieri, Joaquín Gaztambide, Emilio Arrieta, Cristóbal Oudrid, Manuel Fernández Caballero y, a partir de la década de los setenta, Ruperto Chapí, Federico Chueca, José Rogel Soriano, Manuel Nieto, Ángel Rubio y Apolinar Brull. En el repertorio del Infantes-Romea hubo una notable presencia de zarzuelas de compositores murcianos (más de una veintena de zarzuelas entre 1860 y 1895), gran parte de las cuales fueron estrenadas en ese mismo teatro. Un ejemplo elocuente de la versatilidad y difusión de la zarzuela en Murcia es la zarzuela en dos actos Una broma de estudiantes, del compositor murciano Julián Calvo sobre libreto de Ramón Guerrero, estrenada en el Teatro Provisional de Murcia por alumnos del Instituto Provincial en 1860, que estudio por primera vez en esta Tesis a partir de los materiales conservados en el archivo particular de la familia Calvo en Murcia.

Hasta la década de los ochenta, la ópera italiana se identificaba con la ópera en general. La introducción de óperas no italianas fue lenta y tardía y tuvo lugar, sobre todo, en las últimas dos décadas del siglo, coincidiendo con el periodo de mayor actividad operística y esplendor cultural de Murcia. El repertorio siguió una tendencia similar a otros teatros españoles, aunque con un notable retraso en las primeras representaciones en Murcia si se compara con las grandes ciudades españolas (Barcelona y Madrid). El compositor de ópera más interpretado en Murcia fue Verdi, seguido por otros compositores como Donizetti, Gounod y Meyerbeer y, a mayor distancia, Bellini, Rossini, Bizet, Ponchielli y Wagner.

El Teatro Infantes-Romea contó con una orquesta titular fundada en 1884, que constaba de 38 músicos (que accedían por oposición), y fue dirigida por Ángel Mirete hasta su fallecimiento en 1888 y posteriormente por Fernando Verdú (autor del Reglamento de la orquesta, aprobado en 1889). A la creación de esta orquesta precedió un largo debate periodístico (denominado "cuestión orquesta") que comenzó en 1881 y se prolongó hasta 1898 y generó más de un centenar de interesantes escritos en los diarios de la ciudad. La orquesta fue suprimida en mayo de 1890 por presión de los accionistas del Teatro Romea y se escindió en dos partes: una parte de sus músicos permaneció reunida bajo la dirección de Fernando Verdú, y otra formó una nueva orquesta dirigida por José Mirete. Ambas formaciones orquestales trabajaron de forma independiente en diferentes teatros de la ciudad, hasta su unificación de nuevo en una sola orquesta en 1898. 
Aun contando con varias formaciones orquestales, entre ellas la citada Orquesta del Teatro Romea (1884-1890), el sinfonismo en Murcia fue, en líneas generales, escaso. El repertorio orquestal se nutrió, casi exclusivamente, de "sinfonías" u oberturas de las óperas de moda y sinfonías potpurrí o de aires españoles, que se insertaban al principio de las funciones teatrales o en distintos momentos de las mismas, dependiendo del carácter y fines del espectáculo. También se interpretaron algunas sinfonías para orquesta y banda de compositores murcianos. En 1884 tuvo lugar la primera interpretación documentada en Murcia de la Sinfonía $n^{\circ} 1$ en Do Mayor, Op. 21 de Beethoven (interpretada para celebrar la recién creada Orquesta titular del Teatro Romea) y un año después la obertura de Rienzi de Wagner, ambas con una acogida favorable en la ciudad.

En el Teatro Romea, como coliseo más importante de la ciudad, tuvieron lugar los conciertos solísticos más relevantes, a cargo de reputados intérpretes de fama nacional o internacional. Entre los grandes intérpretes que llegaron a la ciudad estuvieron los españoles Pablo Sarasate, Isaac Albéniz, Enrique Granados y Julián Arcas, y los extranjeros Catalina Lebouys, Julia Blechschmidt, Clara Schwartz y Agostino Robbio. Granados llegó a Murcia además con el propósito de recopilar música de la región que le sirviera de inspiración para su ópera María del Carmen, algunos de cuyos números fueron interpretados a modo de preestreno en Murcia, sin escenificación, en el almacén de música del pianista ciego Adolfo Gascón. El Sexteto Arche, una de las formaciones instrumentales más relevantes de las que actuaron en Murcia, constituyó un modelo para la formación de sextetos en diversas sociedades recreativas de la ciudad. Una iniciativa singular en el campo de los conciertos pianísticos de Murcia fue el proyecto de estrenar en 1886 un arreglo del murciano Julián Calvo de una Rhapsodie Hongroise de Liszt para diez pianos, cuya partitura manuscrita se conserva en el archivo de la familia Calvo.

La actividad teatral de Murcia se vio enriquecida por la programación musical que hacían otros teatros y salones teatrales más modestos que el Teatro Infantes-Romea. El Teatro del Circo Villar, segundo teatro más importante de la ciudad e inaugurado primero como circo (1892) y después como teatro propiamente dicho (1893), programó actividad músico-teatral de todos los géneros (ópera, zarzuela -también de autores murcianos-, opereta y conciertos esporádicos de solistas). Las actividades teatrales desarrolladas en centros de enseñanza empleaban como actores, mayoritariamente, a los alumnos.

Las sociedades culturales proliferaron en Murcia durante la segunda mitad del siglo XIX, periodo en el que he documentado casi una treintena de este tipo de instituciones (que contaban con el precedente del Liceo Artístico y Literario de Murcia, creado en 1839). Estas asociaciones no tenían carácter exclusivamente musical (salvo importantes excepciones, como la Sociedad Filarmónica y Coral y la Sociedad Santa Cecilia) y su finalidad era casi siempre a la vez educativa y de recreo. Todas contaron con una sección musical que organizaba clases de música, conciertos e interpretación de música en eventos cívicos y religiosos de la ciudad. Muchas tuvieron una corta existencia y se unían a otras de similares intereses cuando el número de socios descendía o aumentaban sus deudas. La composición social de los socios de estas instituciones no era homogénea. El Casino de Murcia, por ejemplo, solía reunir a las clases más pudientes, mientras que La Juventud atraía a grupos sociales menos favorecidos y reunió tanto a obreros y artesanos como a burgueses, aristócratas y personajes ilustrados de la ciudad.

En las sociedades culturales murcianas, además de una intensa actividad teatral, tenía cabida un tipo de repertorio musical que difícilmente se admitía en los teatros de la ciudad (Las siete últimas palabras de Joseph Haydn y el Stabat Mater de Gioacchino 
Rossini, por ejemplo) y en ellas se dio a conocer la labor creativa de compositores locales que a veces componían piezas expresamente para estas asociaciones. Las seguidillas para canto y piano Nubes, de Julián Calvo sobre letra del poeta romántico murciano José Martínez Monroy, reúnen las características habituales de este género, con gran influencia de la zarzuela en la parte vocal, sin dificultades virtuosísticas y con armonía sencilla.

Los salones de las sociedades fueron también el espacio adecuado para la actuación de formaciones instrumentales poco usuales en los teatros (cuartetos, quintetos y octetos) y para la difusión del repertorio de cámara de grandes compositores extranjeros (Haydn, Mozart, Beethoven, Mendelssohn).

Entre las sociedades culturales murcianas no exclusivamente musicales, destacó el Casino de Murcia, que mantuvo una orquesta estable desde 1849 (creada por Mariano Esbrí a partir de un cuarteto de flauta, violín, viola y violonchelo). La sociedad Círculo Industrial (1862-1878) después llamada El Liceo (1878-1883) fue una de las sociedades recreativas e instructivas más relevantes y estables del panorama murciano de la segunda mitad del siglo XIX, y contó con secciones especializadas en música, una "Escuela de Canto y Declamación intitulada Padilla" (1873) y un teatro propio. El Teatro Círculo Industrial-Liceo fue el más importante de los teatros dependientes de sociedades murcianas y el que más música programó, y llegó a rivalizar en captación de público con los teatros murcianos más relevantes.

De las sociedades especializadas en música destacaron la sociedad Filarmónica y Coral y la sociedad Santa Cecilia de Murcia. La Sociedad Filarmónica y Coral (activa en 1867-1868) se creó por iniciativa del instrumentista de armonio Antonio López Almagro. Ofrecía clases de música, contaba con un "Orfeón" y organizaba conciertos regulares a cargo de músicos profesionales y alumnos de la sociedad. La Sociedad Filarmónica y Coral acabó fusionándose con La Juventud, con la que se programaron "sesiones de cuartetos" con músicos profesionales desde noviembre de 1868 hasta febrero del año siguiente. En 1881 se proyectó crear un Conservatorio de música, que terminó formalizándose en la sociedad Santa Cecilia de Murcia, fundada en 1881 para impartir clases de música y programar conciertos tanto de músicos profesionales como de alumnos, colaboró frecuentemente con otras instituciones murcianas. En abril de $1884 \mathrm{se}$ creó en el seno de la Santa Cecilia una sociedad por acciones para arrendar el Teatro Infantes-Romea por un periodo de tres años (1884-1887) que, aunque hizo que la gestión del teatro recayera en músicos entendidos, provocó el descenso de los conciertos de alumnos. La sociedad acabó dividiéndose en dos entidades diferentes (la Sociedad Artística Santa Cecilia, por un lado, y la sociedad arrendataria del teatro, por otro) que desaparecieron a finales de 1887.

Las sociedades culturales más importantes de Murcia organizaron destacados conciertos de solistas, como los de los guitarristas Francisco Tárrega, Manuel y Julián Arcas, Pedro Paredes, José Martínez Toboso y Enrique Romans, los pianistas Óscar Camps e Isaac Albéniz, los violonchelistas Cesare Augusto Casella y las violinistas Julia Bleschsmidt y Carolina Ferni, la soprano Josefina Huguet y la contralto Elisa Rosenthal, entre otros.

En Murcia, como en muchas otras ciudades españolas, buena parte de la educación musical estaba a cargo de las sociedades culturales. Además de la sociedad Santa Cecilia, la Escuela de Canto y Declamación para la carrera artística teatral italiana y española, fundada en Murcia en 1881 Francisco de Lucas y Rodríguez, y activa hasta 1892, fue una 
de las escuelas de música más sobresalientes de Murcia y asumió, al menos en parte, funciones similares a las de un conservatorio. La Escuela de Canto formaba a jóvenes con talento para la música escénica, impartía clases de primeras letras (lectura y escritura), ejercía como agencia teatral (única en la ciudad de Murcia durante la segunda mitad del siglo XIX), y ofertaba becas de estudio. Durante sus cinco primeros años de su existencia, la Escuela de Canto formó a más de cien artistas de Murcia, Valencia, Madrid, Barcelona y País Vasco, entre otros lugares, que trabajaron posteriormente en la escena española y extranjera. Desde 1882 la Escuela de Canto de Murcia contó con el patrocinio de la familia real y pasó a tener el título de Real Escuela de Canto y Declamación gratuita. A principios de 1885 la Real Escuela de Canto se trasladó desde Murcia a Madrid (calle de la Villa, 2) donde prosiguió su trayectoria hasta la muerte de su fundador, Francisco de Lucas Rodríguez, en 1892.

Los cafés murcianos acogían a un público muy variado, incrementado en épocas festivas con la llegada de turistas y vecinos de otras poblaciones. Los cafés más concurridos se situaban en la actual calle Trapería (Café del Comercio, Café Oriental, Café del Casino y Café del Siglo) y en la gran explanada del Arenal, actual Glorieta (Café de la Puerta del Sol y Café del Arenal). Las veladas de estos cafés murcianos incluían un gran abanico de actividades, entre ellas conciertos musicales, funciones teatrales, sesiones de magia y prestidigitación, baile y juego. En el repertorio musical de los cafés murcianos predominaban los arreglos de piezas operísticas (más numerosas que las basadas en zarzuelas). También abundaban piezas para piano y/o armonio, canciones para voz y acompañamiento, música de cámara (local, nacional o extranjera) y música popular (malagueñas, rondeñas, polos, soleás, seguidillas, serranas, jotas, parrandas y aguinaldos). En los cafés tenían notable presencia las composiciones de autores murcianos como Adolfo Gascón, José Solano, Gaspar Espinosa y Julián Calvo, entre otros.

El instrumento más generalizado en los cafés era el piano (tocado sólo o a cuatro manos), aunque en Murcia el armonio, potenciado por músicos como Antonio López Almagro y Julián Calvo, se introdujo también con fuerza desde mediados del siglo y se impuso solo o junto al piano. Las formaciones de conjunto podían ser muy variadas. El piano o el armonio se asociaban a dúo con otros instrumentos como el violín o la flauta. Eran frecuentes los tríos con guitarra, bandurria y piano, así como diversas formaciones de cuartetos, quintetos y sextetos. Más excepcionales fueron las actuaciones en los cafés de coros, orquestas, orquestinas y bandas de música. En su mayor parte, los intérpretes de estas veladas eran músicos locales que obtenían en los cafés ingresos adicionales a sus sueldos habituales, incluso cuando eran músicos de iglesia. A veces los cafés murcianos acogieron actuaciones de músicos con prestigio nacional, como el compositor Federico Chueca o el guitarrista Julián Arcas.

Durante la segunda mitad del siglo XIX, adquirió gran importancia la música de salón como parte del ocio doméstico en Murcia. La proliferación de soirées y conciertos privados tuvo directa relación con el auge de instituciones privadas de enseñanza musical y sociedades recreativas, sobre todo a partir de los años setenta del siglo XIX. Las veladas tenían lugar en salones ricamente decorados de los domicilios de aristócratas o burgueses murcianos (como los de Manuel Fontes y Álvarez de Toledo, conde de Saucedilla o las familias Clavijo y Fernández Albaladejo), en casas de músicos (como Antonio López Almagro, el guitarrista Joaquín Codorniu y los pianistas Juan Diego Manresa y Adolfo Gascón), o en las trastiendas de los almacenes de música de la ciudad (como el de Adolfo 
Gascón). También había conciertos, bailes y representaciones teatrales en casas particulares de aficionados que contaba con salas adecuadas.

Las veladas domésticas eran reuniones de familiares y amigos, a medio camino entre los espectáculos propiamente dichos y las reuniones sociales, cuya finalidad principal era el entretenimiento. El piano, el armonio, o ambos a la vez, eran los instrumentos predominantes y con frecuencia participaban músicos profesionales. La mujer tuvo una gran presencia en estas veladas como intérprete y, en ocasiones, también como compositora. El repertorio de estas veladas estuvo constituido predominantemente por arreglos de ópera y zarzuela y otras piezas de salón, cuyos rasgos esenciales he podido describir a partir de piezas como la romanza Nella vita io son peregrino, para canto y piano, con texto en italiano, de autor anónimo y publicada en el periódico Diario de Murcia en 1851, o el $5^{\circ}$ Nocturno para piano, titulado Orfeo, de Julián Calvo. Estos ejemplos muestran el gusto por la sencillez armónica y de fraseo propia de gran parte de la música de salón interpretada en Murcia, pensada para aficionados, con un tratamiento vocal efectista (aunque no demasiado virtuosístico) y pasajes instrumentales de dificultad media o baja.

Las veladas que tenían lugar en casas de músicos solían contar con discípulos aventajados o intérpretes profesionales. Los programas interpretados en ellas eran más variados que los de las casas de aficionados, incluían obras de mayores dificultades técnicas y acogían cuando había ocasión a músicos profesionales que estaban de paso en Murcia (como Enrique Granados o el saxofonista Juan Marcos y Mas). En las veladas domésticas de casas de músicos se interpretaron, por ejemplo, arreglos para piano y amonio del Stabat Mater de Rossini, obras para piano de Liszt, Krüger, Ketterer y Louis Lefébure-Wély, para piano a cuatro manos de Lefébure-Wély o Steinberg, o incluso para piano a seis manos, como el Capricho Húngaro de Reteres. Menos frecuentes fueron combinaciones de violín y piano (el Adiós a la Alhambra de Jesús de Monasterio es una de las pocas excepciones) y música de cámara. El Grand Trio de Charles-Auguste de Bériot y un Trío de Hummel se interpretaron con violín, piano y armonio en los domicilios murcianos de los músicos Joaquín Codorniu y Antonio López Almagro en la década de los sesenta; y el Cuarteto en Si Bemol [quizás el op. 18, $\mathrm{n}^{\circ}$ 6] de Beethoven fue interpretado en el almacén de música de Gascón por músicos ciegos procedentes del Colegio de Ciegos de Barcelona, ya en los ochenta. Las obras de compositores murcianos estuvieron presentes a veces con plantillas singulares, como el arreglo para dos armonios y cuatro pianos del famoso capricho Moraima, de Gaspar Espinosa de los Monteros.

La rica actividad musical que vivió Murcia en la segunda mitad del siglo XIX era protagonizada sobre todo por músicos locales, en los que he distinguido varias generaciones: la que he denominado "de los maestros", nacidos a finales del siglo XVIII o principios del XIX; la generación de los músicos nacidos en la década de 1830, con destacadas personalidades como Ángel Mirete Sanz (1832-1888), Julián Calvo García (1835-1898), Mariano García López (1836-1906), Acisclo Díaz Rocher (1837-1887), Gaspar Espinosa de los Monteros (1836-1898), Luis Mondéjar Brocal (1837-?) y Antonio López Almagro (1839-1907), entre otros; y, finalmente, la generación de los músicos nacidos desde los años cuarenta del siglo XIX en adelante.

Los músicos murcianos con mayor estabilidad profesional eran los adscritos a un centro o formación instrumental de la ciudad, como la Capilla de Música de la Catedral, la Capilla de Música de las Madres Agustinas, la Banda Municipal o la orquesta del Teatro. Pertenecían normalmente a la clase media (o media baja) y gozaban de prestigio 
en la ciudad. Muchos músicos profesionales de Murcia de la generación de los treinta tuvieron vínculos con la Catedral de Murcia y/o su Colegio de San Leandro y con el convento de las Madres Agustinas, estuvieron estrechamente vinculados a varias sociedades culturales de la ciudad (como fundadores o socios) y educaron a músicos profesionales de generaciones posteriores, así como a un gran número de aficionados. La producción religiosa fue un capítulo importante en la obra de estos compositores murcianos, que casi siempre compaginaban estrenos de obras sacras en iglesias de la ciudad con sus actividades y producción en el terreno profano. Julián Calvo, por ejemplo, compuso 18 obras religiosas (sobre un total de 34 partituras que he localizado físicamente) y Fernando Verdú escribió diez (de las 29 obras que he hallado citadas en la prensa).

Los músicos que ejercían su profesión en la capital murciana establecieron a veces auténticos monopolios, que trascendían los márgenes de instituciones concretas. Ángel Mirete, por ejemplo, contaba con un amplio grupo de músicos a su disposición a los que organizaba según la ocasión, ejerciendo de director de varias formaciones: la Banda Municipal desde 1858, la Capilla de Música de las Madres Agustinas, varias orquestas teatrales desde 1868 y la Orquesta del Teatro Romea, desde 1884. Mirete prohibía a sus músicos formar otras orquestas o separarse de la suya por contrato y so pena de cuantiosa multa (cien duros, o sea, 500 pesetas).

Otro grupo de músicos de la generación de los 30 (Antonio López Almagro, Gaspar Espinosa de los Monteros y el célebre pianista Luis Mondéjar), salió pronto de Murcia para asentarse principalmente en Madrid. Hubo también músicos murcianos como el violinista Fernando Verdú (1845-1919) y el pianista ciego Adolfo Gascón (1852-?) que se ganaron su sustento económico a través de un negocio propio o de un cargo administrativo, compaginando estas ocupaciones laborales con su actividad musical. A partir de la década de los sesenta surgieron notables músicos en Murcia, como Pedro Muñoz Pedrera, José Verdú (hijo de Fernando Verdú), Emilio Ramírez y Manuel Benavente Montalvo, todos compositores, así como el célebre pianista Antonio Puig Ruiz-Funes, cuyas carreras comenzaron a despuntar en los últimos años del siglo XIX, prolongándose en las décadas siguientes. Estos músicos comenzaron a formarse con los maestros murcianos de la generación de los 30, aunque muchos concluyeron después su formación musical en el Conservatorio de Madrid, como fue el caso de Muñoz Pedrera y Antonio Puig.

De todos los músicos murcianos analizados en esta Tesis Doctoral, la trayectoria de mayor proyección internacional (aunque muy poco conocida hasta ahora) fue la del cantante Mariano Padilla (1843-1906). Su brillante carrera se desarrolló en los escenarios más importantes de Europa (Madrid, París, Londres, Berlín, Leipzig, Milán, Florencia, Moscú, San Petersburgo, Bruselas, Viena y Budapest, entre otros) y América (México y Río de Janeiro). Padilla mantuvo un contacto regular con Murcia (a través de frecuentes visitas a la ciudad y, desde los años noventa del siglo XIX, como colaborador de $E l$ Diario de Murcia), y sirvió de ejemplo y estímulo a los músicos murcianos.

Murcia mantuvo durante el periodo estudiado amplias conexiones musicales con otras ciudades españolas, y en especial con Madrid, como muestran los constantes intercambios de compañías teatrales y concertistas, la visita de destacadas personalidades del panorama nacional a Murcia, los vínculos de amistad entre los músicos que residían en Murcia y los que vivían en Madrid, y los debates periodísticos de los músicos locales en la prensa murciana sobre temas tan candentes del panorama musical español del siglo 
XIX como la ópera española y la influencia de Wagner. Una iniciativa que reforzó las conexiones de la música murciana con el exterior a partir de 1874 fueron los Juegos Florales de Murcia, certámenes artístico-literarios con notable difusión fuera de la región. Sus convocatorias eran anunciadas en la prensa nacional, y entre los miembros de los jurados hubo destacados compositores del panorama musical español, como Francisco Barbieri, Emilio Arrieta, Rafael Hernando, Manuel Fernández Caballero y Antonio López Almagro. Algunos premios de estos certámenes fueron concedidos a compositores no murcianos de renombre (por ejemplo, el compositor José Inzenga, el pianista, compositor y pedagogo Claudio Martínez Imbert y el organista José Luis de Muguerza). Los Juegos Florales de Murcia premiaron también a compositores y compositoras locales, y muchas de las obras galardonadas tuvieron una amplia difusión en los salones de la ciudad. Las composiciones musicales que se pedían en estos concursos eran tanto profanas como religiosas y reflejan los gustos imperantes en la época. Se exigían sobre todo obras instrumentales (sinfonías, caprichos, fantasías, polonesas y marchas para orquesta y/o banda, barcarolas, fantasías, cuartetos para dos violines, violonchelo y piano, estudios para piano solo), y en menor medida obras para canto con acompañamiento de piano y/o armonio.

Los inicios de la investigación musical en Murcia estuvieron muy ligados a los Juegos Florales Extraordinarios de 1878, en los que por primera vez se estableció una modalidad teórica que concedía un premio a la investigación de la música murciana. Aunque el galardón quedó desierto por falta de candidatos, algunos músicos (entre ellos Adolfo Gascón y Fernando Verdú) emprendieron entonces investigaciones sobre la música en Murcia. Además, con motivo de ese concurso se escribieron los anónimos "Apuntes para la Historia de la Música en Murcia", que finalmente no se presentaron a los Juegos Florales y fueron publicados en trece entregas en El Semanario Murciano durante los años 1878-1879, firmados con el seudónimo "Un aficionado". Se trata del primer esbozo de una historia de la música murciana del que tengo constancia y es muy probable que su autor fuera el poeta y periodista Andrés Blanco García (1849-1916), sobrino de Mariano García (maestro de Capilla de la Catedral de Murcia), colaborador de El Semanario Murciano y autor de otros interesantes artículos sobre la ópera española (también publicados en la citada publicación en 1880) y sobre música wagneriana (publicados en Cartagena Artística en 1890). Los "Apuntes" no son una historia ordenada cronológicamente, sino un estudio centrado en cuatro grandes temas: el piano, la flauta, la guitarra y los cantos populares murcianos. La obra, influenciada por la Historia de la música española de Mariano Soriano Fuertes, presenta información desigual (con datos abundantes sobre el piano, escasos sobre la flauta y muy pobres sobre la guitarra). Los artículos sobre los cantos populares murcianos son, en parte, una reseña crítica de la recopilación de melodías tradicionales murcianas de Julián Calvo titulada Alegrías y tristezas de Murcia (Madrid, 1877). Las informaciones sobre Murcia de los "Apuntes" se basan en fondos documentales de la Catedral de Murcia, en el manuscrito Antiguallas musicales de Pedro Peceño (organista de la Catedral de Murcia a finales del siglo XVIII) $\mathrm{y}$ en datos facilitados por intelectuales murcianos contemporáneos al autor de la obra, lo que convierte a la obra en una interesante fuente documental en sí misma.

El panorama musical descrito revela una pujante y variada actividad musical en la Murcia de la segunda mitad del siglo XIX que invita a revisar la visión que hasta ahora teníamos de la música española del periodo. El dinamismo y creatividad de la vida musical murciana, sus contactos con el exterior y los importantes artistas y obras que generó muestran que no resulta convincente mantener una visión de la música 
decimonónica española basada sólo en las grandes ciudades como Madrid o Barcelona, ni sólo en determinados géneros de la música culta. Posiblemente futuros estudios sobre la vida musical de otras ciudades de provincias españolas permitirán completar el complejo entramado de redes musicales interurbanas que en esta Tesis se han documentado desde Murcia. Soy muy consciente de que la ingente documentación que aporto en este trabajo puede y debe ser objeto de nuevos y más profundos análisis en el futuro, y pienso que una de las aportaciones que hago es precisamente abrir diversas vías de investigación que pueden ser continuadas en el futuro. Confío en que el estudio realizado sirva para reubicar a Murcia en el mapa musical español del siglo XIX y para contribuir a que la música se entienda como un elemento imprescindible de la historia, la sociedad y la cultura murcianas. 



\section{Principales fuentes consultadas}

1. Fuentes hemerográficas

1.1.Prensa publicada en Murcia y Cartagena (años consultados)

Aguijón, El (1871-1872)

Álbum, El (1876-1877)

Anunciador Mercantil (1890)

Aura Murciana, El (1871)

Avisador Murciano, El (1872)

Avisador, El (1869)

Boletín Oficial de la Junta Provincial Revolucionaria de Murcia (1868)

Boletín Oficial de la Provincia de Murcia $(1884,1887,1891)$

Buen Deseo, El (1869)

Cartagena Artística (1891)

Chocolate, El (1872-1873)

Clamor Murciano, El (1879)

Comercio, El (1878-1879)

Correo Murciano, El (1889)

Correspondencia de Murcia, La (1873)

Criterio Murciano, El (1886, 1888-1890)

Diario de Murcia (1851)

Diario de Murcia, El (1879-1899)

Eco de Murcia, El (1881-1882)

Ideal Politico, El (1873)

Ilustración Murciana, La (1871)

Industrial de Murcia, El (1854)

Juventud Literaria, La (1896-1898)

Liberal Murciano, El (1855)

Murciano, El (1867)

Noticias, Las (1875)

Noticiero de Murcia, El (1872-1898)

Obrero, El (1870-1873)

Paz de Murcia, La (1858-1895)

Perico el de los Palotes (1868)

Provincia, La (1873)

Provincia, La (1882)

Provincias de Levante, Las (1887-1893)

Revista Murciana, La (1886-1887)

Sacamuelas, El (1863-64, 1871)

Segura, El (1863)

Semanario Murciano, El (1878-1882)

Vega, La (1853)

Violeta, La (1872)

Zorongo, El (1871) 
1.2. Otros periódicos españoles (años consultados)

Artista, El (1866-1868)

Boletín Musical y de las Artes Plásticas (1898)

Clamor Público, El (1856)

Correo de la Moda (1869)

Correo Universal, El (1855)

Correspondencia de España, La (1869-1870)

Correspondencia Musical, La (1881)

Crónica de la Música, La (1878-1879)

Día, El (1882, 1902)

Diario de Avisos de Madrid $(1877,1892)$

Discusión, La (1879)

Época, La (1859)

Escena, La (1865-1867)

España Artística, La (1858)

Gaceta Musical de Madrid (1855-1856)

Iberia, La (1855, 1862-1863, 1869)

Ilustración Española y Americana, La (1877)

Liberal, El (1887)

Ópera Española, La (1875-1876)

Siglo Futuro, El (1879-1880)

Solfeo (1876)

Última Moda, La (1890)

1.3. Prensa italiana (años consultados)

Euterpe (1868-1871)

Gazzetta Musicale di Napoli (1852-1857)

L'Arte. Gionale letterario, artistico, teatrale (1857-1858)

L'Eptacordo: giornale poligrafico di teatri, belle arti e varietà (1860-1867)

L'Italia Musicale: giornale dei teatri, di letteratura, belle arti e varietà (1850)

L'Italia Teatrale. Artsitica, musicale e illustrata (1890, 1892); Lo scaramuccia.

Giornale teatrale (1853-1854, 1867-1857)

Mondo Artistico: giornale di musica dei teatri e delle belle arti, Il (1880-1892)

Musica e musicisti: rivista illustrata bimestrale (1902-1905)

Teatro Illustrato e la Musica Popolare: ritratti di maestri ed artisti celebri, vedute e bozzetti di scene, disegni di teatri monumentali, costumi teatrali ornamentazioni, Il (1887-1892)

Teatro Illustrato: ritratti di maestri ed artisti celebri, vedute e bozzetti di scene, disegni di teatri monumentali, costumi teatrali, ornamentazioni, Il (1881-1886) 
2. Fuentes manuscritas

2.1. Archivo Municipal de Murcia

Actas Capitulares de los años 1851, 1859, 1862-1864, 1884, 1888-1892 y 1894

Legajo 2 (1826, 1833, 1834, 1854, 1862-1876)

Legajo 4 (1867)

Legajo 7 (1858, 1860-1861, 1873)

Legajo 595 (1858, 1860, 1873, 1880, 1883-1889)

Legajo 1129 (1857-1858, 1899-1900)

Legajo 1194 (1882, 1884)

Legajo 1327 (1833)

Legajo 1491 (1832-33)

Legajo 1540 (1822)

Legajo 2828 (1836-1844)

Legajo 3194 (1864)

Legajo $3449(1832,1837)$

Legajo 3451 (1836)

Legajo 4159 (1829-1852)

Legajo 3460 (1850-1856)

Legajo 3194 (1864)

Legajo 4166 (1846, 1858)

Legajo 4188 (1843)

2.2. Archivo Histórico Provincial de Murcia

Protocolos Notariales (1878).

2.3. Archivo del Conservatorio Superior de Música de Murcia

Partituras manuscritas de Julián Calvo (en Caja “Julián Calvo”).

2.4. Archivo del Conservatorio Superior de Música de Madrid

Actas de exámenes, Leg. 9 (1856) y Leg. 10 (1857).

2.5. Archivo parroquial de la Iglesia de San Juan Bautista de Murcia

Libros de Bautismos del periodo 1800-1850.

2.6. Archivo Particular de la familia Martínez Calvo, Murcia

Partituras manuscritas e impresas de Julián Calvo (1860-1882), sin signatura.

2.7. Archivo Particular de Mabel Breis, Murcia

Fotocopias de partituras manuscritas de Julián Calvo (años), sin signatura, procedentes del Archivo de la Catedral de Murcia. 



\section{Bibliografía}

AA.VV. Sociedades musicales en España. Siglos XIX-XX, Actas del Curso de Musicología celebrado en la Escuela Asturiana de Estudios Hispánicos, dirigido por M $^{a}$ Encina Cortizo y Ramón Sobrino en La Granda (Asturias), agosto de 1997, volumen monográfico de Cuadernos de Música Iberoamericana, 8-9 (2001).

"Sociedades". En: Diccionario de la Música Española e Hispanoamericana, dir. Emilio Casares. Madrid: Sociedad General de Autores y Editores, 1999-2002, vol. 9 (2002), pp. 1065-1102.

Agostini, Desirée. "Las mujeres en la música del siglo XIX venezolano". En: Revista de la Sociedad Venezolana de Musicología, VI (2006), n 11, pp. 67-98.

Aguilar Gómez, Juan de Dios. Historia de la música en la Provincia de Alicante. Alicante: Instituto de Estudios Alicantinos, 1983.

Agulló y Cobo, Mercedes. "Los Cafés-Teatros madrileños del siglo XIX". En: Villa de Madrid, $\mathrm{n}^{\text {os }}$ 35-36 (1972), pp. 27-32.

Albert, Pierre; Sánchez Aranda, José; Guash, Juan María. Historia de la prensa. Madrid: Ralp, 1990.

Alemán Sainz, Francisco. Diccionario incompleto de la Región de Murcia. Murcia: Editora Regional de Murcia, 1984.

Alemany Ferrer, Victoria. "La construcción de pianos en Valencia hasta inicios del siglo XX”. En: Anuario Musical, 62 (2007), pp. 335-364.

Alén Garabato, Pilar. "Reflexiones sobre un siglo de música gallega (ca. 1808-1916)", Revista de Musicología, 30/1 (2007), pp. 49-102.

. "La música en Galicia: del piano de salón a las masas corales". En: Galicia e América: música, cultura e sociedade arredor do 98, coord. Cristina Iglesias Feijoo, Carmen Rodríguez Mayán y Mercedes Villar Taboada. Santiago de Compostela: Universidade de Santiago de Compostela, 1999, pp. 73-101.

. "Teatro lírico en la ciudad de A Coruña (1872-1879)". En: Delantera de paraíso. Estudios en homenaje a Luis G. Iberni. Madrid: Instituto Complutense de Ciencias Musicales, 2008, pp. 49-73.

. "Música y músicos al servicio del culto (siglos XVI-XIX)": normas de conducta y estima social". En: Congreso Internacional Imagen Apariencia celebrado en murcia entre el 19 y el 21 de noviembre de 2008. Murcia: Universidad de Murcia. Servicio de Publicaciones, 2009. Accesible en: https://alejandria.um.es/cgibin/abnetcl/O7054/IDc11 cfa03/NT5 (acceso el 17-10-2011).

Alier y Aixalá, Roger y Mata, Francesc X. El Gran Teatro del Liceo. Historia artística. Barcelona: Edicions Francesc X. Mata, 1991. 
Alonso de Quintanilla, Manuel. El Teatro Romea desde 1900 a 1987. Murcia: Banco de Murcia, 1987.

Alonso Fernández, Ma Ángeles. "El órgano en la prensa musical del siglo XIX". En: La música española en el siglo XIX, eds. Emilio Casares y Celsa Alonso. Oviedo: Universidad de Oviedo, 1995, pp. 407-423.

. "Martínez Imbert, Claudio". Suárez Pajares, Javier. "Martínez Toboso, José". En: Diccionario de la Música Española e Hispanoamericana, dir. Emilio Casares. Madrid: Sociedad General de Autores y Editores, 1999-2002, vol. 7 (2000), p. 292.

Alonso González, Celsa. "Los salones: un espacio musical para la España del siglo XIX". En: Anuario Musical, 48 (1993), pp. 165-205.

La canción lírica española en el siglo XIX. Madrid: Instituto Complutense de Ciencias Musicales, 1998.

. “Canción”. En: Diccionario de la Música Española e Hispanoamericana, dir. Emilio Casares. Madrid: Sociedad General de Autores y Editores, 1999-2002, vol. 3 (1999), pp. 1-11.

- "La canción lírica española en el siglo XIX: la cotidianidad del género lírico de salón en España”. En: Música Iberoamericana de Salón, coord. José Peñín. Caracas: Fundación Vicente Emilio Sojo, 2000, vol. I, pp. 41-66.

. "Un espacio de sociabilidad musical en España romántica: las sociedades instructo-recreativas". En: Cuadernos de Música Iberoamericana, 8-9 (2001), pp. $17-40$.

Alonso González, Celsa; Gutiérrez, Carmen Julia; Suárez-Pajares, Javier (eds.). Delantera de paraíso. Estudios en homenaje a Luis G. Iberni. Madrid: Instituto Complutense de Ciencias Musicales, 2008.

Alonso Navarro, Serafín. Prensa murciana del siglo XIX: El Semanario Murciano, El Diario de Murcia, Heraldo de Murcia. Murcia: Asociación de la Prensa de Murcia, 1987.

"La Hemeroteca, fuente de investigación histórica". Marín, Javier; Lara, Francisco; Armario, Fernando; y Fresneda Corrado, Rafael (coords.). Hemerotecas: aportaciones al estudio y tratamiento de publicaciones periódicas. Murcia: Editora Regional de Murcia, Confederación de Asociaciones de Archiveros, Bibliotecarios, Museólogos y Documentalistas, ANABAD, 1996, 2ª reimpresión, pp. 36-62.

Altadill, Julio. Memorias de Sarasate. Pamplona: Imprenta de Aramendía y Onsalo, 1909. Accesible en: http://www.archive.org/details/memoriasdesarasa00alta (2-09-2011).

Álvarez Cañibano, Antonio. "Academias, sociedades musicales y filarmónicas en la Sevilla del siglo XIX” (1800-1875). En: Revista de Musicología, XIV/1-2 (1991), pp. 63-69. 
. “Teatros y música escénica. Del Antiguo Régimen al Estado Burgués". La música española en el siglo XIX, eds. Emilio Casares y Celsa Alonso. Oviedo: Universidad de Oviedo, 1995, pp. 123-160.

. "La zarzuela en Andalucía". En: La zarzuela en España e Hispanoamérica. Centro y periferia, 1800-1950, Actas del Congreso Internacional celebrado en Madrid en 1995. Cuadernos de Música Iberoamericana, vol. 2-3 (1996-1997) pp. 351-362.

Álvarez Cañibano, Antonio; González Ribot, $\mathrm{M}^{\mathrm{a}}$ José; Guitérrez Dorado, Pilar y Marcos Patiño, Cristina (eds.). Compositoras españolas: La creación musical femenina desde la Edad Media hasta la actualidad. Madrid: Instituto Nacional de Artes Escénicas y Música, Centro de Documentación de Música y Danza, 2008.

Álvarez Junco, José. Mater dolorosa. La idea de España en el siglo XIX. Madrid, Taurus, 2001.

Álvarez Martínez, Rosario. "L’opera italiana alle Canarie (1860-1914). En: Il teatro dei due mondi. L'opera italiana nei paesi di lingua iberica, ed. Anna Laura Bellina. Treviso: Associazione musicale Ensemble '900, 2000, pp. 141-163.

Anónimo. "Artôt". En: Dizionario Enciclopedico Universale della Musica e dei Musicisti, 20 vols, ed. Alberto Basso. Torino: Unione tipografico-editrice torinese, 1983-1989, vol. I, p. 153.

."Padilla y Ramos, Mariano". En: Dizionario Enciclopedico Universale della Musica e dei Musicisti, 20 vols, ed. Alberto Basso. Torino: Unione tipograficoeditrice torinese, 1983-1989, vol. V, p. 497.

. "Padilla y Ramos, Mariano". En: "Padilla y Ramos, Mariano". En: The New Grove Dictionary of Music and Musicians, ed. Stanley Sadie, 29 vols., $2^{\mathrm{a}}$ edición. London: Macmillan, 2001, 2001, vol. 18, p. 875.

Antolini, Bianca Maria. Editori e librai musicali a Roma nella prima metà dell'Ottocento. Roma: Torre d'Orfeo, 1988.

Arias de Cossío, Ana Ma " "La escenografía operística en el Madrid del siglo XIX". En: La ópera en España e Hispanoamérica, eds. Emilio Casares y Álvaro. Madrid: Instituto Complutense de Ciencias Musicales, 2002, vol. II, pp. 283-292.

Arimón, Santiago. El código del teatro: compilación metódica anotada y comentada de todas las disposiciones legales relacionadas con el teatro y demás espectáculos públicos. Pamplona: Analecta, 2006. Reproducción facsímil de Madrid: Centro de Publicaciones Jurídicas, 1912.

Arroyo Cabello, M ${ }^{\text {a }}$ Socorro. "La prensa murciana en el Sexenio Revolucionario (18681874)". Actas de las Jornadas sobre el Sexenio Revolucionario y el Cantón Murciano. En: Anales de Historia Contemporánea, 9 (1993-1994), pp. 69-79.

. "La prensa murciana en el desastre del 98". En: Historia y Comunicación Social, 3 (1998), pp. 15-25. 
Artigas Pina, Javier. "El presupuesto $\mathrm{n}^{\circ} 2$ de Aquilino Amézua: un documento inédito e indispensable para completar la historia y posterior restauración del gran órgano Merklin-Schütze de la Santa Iglesia Catedral de Cartagena, sita en Murcia". En: Nassarre: Revista Aragonesa de musicología, 22/1 (2006), pp. 13-28.

Aviñoa, Xosé. "Les constans ideològiques en la crítica musical de 'L'Avenç'” (18811884 i 1889-1893). En: D’art, 8-9 (1983), pp. 81-98. . La música i el modernisme. Barcelona: Curial, 1985.

. "Barcelona, del wagnerismo a la generación de la República". En: España en la música de occidente: actas del congreso internacional celebrado en Salamanca, 29 de octubre-5 de noviembre de 1985, coord. José López-Calo, Ismael Fernández de la Cuesta y Emilio Casares, 2 vols. Madrid: Instituto Nacional de las Artes Escénicas y de la Música, 1987, vol. 2, pp. 323-340.

Bagües i Erriondo, Jon. "El coralismo en España en el siglo XIX". En: España en la música de occidente: actas del congreso internacional celebrado en Salamanca, 29 de octubre-5 de noviembre de 1985, coord. José López-Calo, Ismael Fernández de la Cuesta y Emilio Casares, 2 vols. Madrid: Instituto Nacional de las Artes Escénicas y de la Música, 1987, vol. 2, pp. 173-198.

Bahamonde, Ángel y Martínez, Jesús. Historia de España. Siglo XIX. Madrid: Cátedra, 1994.

Ballester Nicolás, José. Amanecer de la prensa periódica en Murcia: panorama de una pequeña ciudad. Murcia: Academia Alfonso X El Sabio, 1971.

Bando General de Buen gobierno. Murcia: Imprenta de los Hijos de P. Nogués, reimpresión de 1884 .

Barberá Soler, José Miguel. "La música en Granada en el siglo XIX”. En: Revista del Centro de Estudios Históricos de Granada y su Reino, 7 (1993), pp. 227-250.

Barce, Ramón. "El sainete lírico (1880-1915)". En: La música española en el siglo XIX, eds. Emilio Casares y Celsa Alonso. Oviedo: Universidad de Oviedo, 1995, pp. 195-244.

Barce, Ramón (coord.). Actualidad y futuro de la zarzuela. Actas de las jornadas celebradas en Madrid del 7 al 9 de noviembre de 1991. Madrid: Alpuerto, Fundación Caja de Madrid, 1994.

Barceló Jiménez, Juan. El Teatro Romea y otros teatros de Murcia. Murcia: Sucesores de Nogués, 1962.

. "El Teatro Romea y otros teatros de Murcia”. En: Murgetana, 19 (1962), pp. 5-58. . Historia del teatro en Murcia. Murcia: Academia Alfonso X el Sabio, 1980.

- "El periodismo taurino en Murcia". Actas de las Jornadas sobre prensa y sociedad en la Murcia contemporánea. En: Anales de Historia Contemporánea, 12 (1995-1996), pp. 579-585. 
Barrère, Bernard, et al. Metodología de la prensa española. Madrid: Siglo Veintiuno de España, 1982.

Belando Meléndez, Juan y Perelló, José María. Guía de Murcia. Murcia: José María Perelló, 1899.

Benito Argáiz, Inmaculada. La vida escénica en Logroño (1850-1900). Tesis Doctoral. Logroño: Universidad de La Rioja, 2003. Accesible en: http://dialnet.unirioja.es/servlet/tesis? codigo=93 (acceso el 12-04-2011).

Berguices Jausoro, Ángel. “Arriola Jauregui, Juan Ambrosio". En: Diccionario de la Música Española e Hispanoamericana, dir. Emilio Casares. Madrid: Sociedad General de Autores y Editores, 1999-2002, vol. 1 (1999), pp. 757-758.

Blanco García, Andrés. Composiciones literarias de Andrés Blanco y García premiadas en los juegos florales de Murcia en septiembre de 1883, en el gran certamen literario de la Real Academia de Buenas Letras de Sevilla en abril de 1884 y en el científico-literario promovido por el centro de lectura de Reus en igual fecha. Murcia: Establecimiento Tipográfico de "La Paz", 1884. Accesible en: http://bibliotecadigital.carm.es/opac/ficha.php?informatico $=00000121 \mathrm{MO \& idpag}=$ 1171298112\&codopac=OP041 (acceso el 29-09-2011)

Escenas murcianas: apuntes para cuadros costumbres y tipos de Murcia y de su huerta y campo. Murcia: Tipografía de Rafael Albaladejo Brugarolas, 1894, $2^{\text {a }}$ edición.

Accesible

en: http://bibliotecadigital.carm.es/opac/ficha.php?informatico=00000189MO\&idpag= 2053742624\&codopac=OP041 (acceso el 29-09-2011).

. Grandezas del pasado. Murcia: Tipografía de "La Verdad2, 1905. Accesible en: http://bibliotecadigital.carm.es/opac/ficha.php?informatico=00001401MO\&idpag= 978663061\&codopac=OP041 (acceso el 19-09-2011).

Blanco Martín, Miguel Ángel. “Opinión pública y libertad de prensa (1808-1868)”. En: La prensa española durante el siglo XIX. I Jornadas de especialistas en prensa regional y local, coord. José Simón Díaz. Almería: Instituto de Estudios Almerienses, 1988, pp. 27-51.

Blas Vega, José. Los cafés cantantes de Madrid (1846-1936). Madrid: Guillermo Blázquez, 2006.

Bobes Naves, María del Carmen. Semiótica de la escena: análisis comparativo de los espacios dramáticos en el teatro. Madrid: Arco Libros, 2001.

Bödeker, Hans Erich, Veit, Patrice y Werner, Michael (ed.). Espaces et lieux de concert en Europe 1700-1920. Architecture, musique, société. Berlin: Berliner Wissenschafts-Verlag, 2008.

. Organisateurs et formes d'organisation du concert en Europe $1700-1920$. Institutionnalisation et pratiques. Berlin: Berliner Wissenschafts-Verlag, 2008. 
Bödeker, Hans Erich y Veit, Patrice (ed.). Les sociétés de musique en Europe. 17001920. Structures, pratiques musicales, sociabilités. Berlin: Berliner WissenschaftsVerlag, 2007.

Boïls Ibiza, Juan Bautista. La "Historia de la Música Española" de Mariano Soriano Fuertes (1817-1880). Edición crítica de una fuente esencial en la historiografía de la música española del siglo XIX. Valladolid: Universidad de Valladolid, 2010. Tesis Doctoral inédita.

Bongiovanni, Carmela. "Almanachi, guide e annuari commerciali italiani come fonti per la storia musicale tra Otto e Novecento". En: Canoni bibliografici. Atti del convegno internazionale IAML-IASA (Perugia, 1-6 settembre 1996), ed. Licia Sirch (ed.). Lucca: Libreria Musicale Italiana, 2001, pp. 229-246.

Bordas Ibáñez, Cristina. "Dos constructores de piano en Madrid: Francisco Flórez y Francisco Fernández”. En: Revista de Musicología, 11/3 (1988), pp. 807-854. . Hazen y el piano en España. Las Rozas (Madrid): Hazen, 1989.

. “Otros pianos de F. Flórez y F. Fernández”. En: Revista de Musicología, 13/1 (1990), pp. 227-230.

. Les relations entre Paris et Madrid dans le domaine des instruments á cordes 1800-1850”. En: Musique, Images, Instruments, 1 (1995), pp. 85-97.

. "Tradición e innovación en los instrumentos musicales". En: La música en España en el siglo XVIII, eds. Malclom Boyd y Juan José Carreras. Madrid: Cambridge University Press, 2000, pp. 201-217.

Botella, Camilo. Guía consultiva de Murcia e indicador general de la Provincia. Murcia: Tipografía de Rafael Albaladejo, 1891.

Botías, Antonio. El Correo de Murcia: un periódico del XVIII. Murcia: Universidad Católica San Antonio, Caja de Ahorros del Mediterráneo, 2001.

Botrel, Jean-François. Libros, prensa y lectura en la España del siglo XIX. Madrid: Fundación Germán Sánchez Ruipérez, 1993.

Burgos Bordonau, Esther. "La enseñanza musical en el Colegio Nacional de Sordomudos y Ciegos de España desde su fundación hasta la primera república: una aproximación documental". En: Revista General de Información y Documentación, 14/1 (2004), pp. 67-78. Accesible en http://dialnet.unirioja.es/servlet/articulo?codigo=1075393 (acceso el 2-10-2011).

. "La educación musical del colectivo invidente en la España del siglo XIX". En: Música y Educación, no 62 (2005), pp. 65-82.

Bussi, Francesco. "Mabellini, Teodulo". En: Dizionario Enciclopedico Universale della Musica e dei Musicisti, ed. Alberto Basso. Torino: Unione tipografico-editrice torinese, 1983-1989, vol. IV, pp. 540-541. 
Cabello, Bartolomé. Cartas familiares que D. Bartolomé Cabello, cura de la Iglesia Parroquial de nuestra señora Santa María de la Blanca de Sevilla, ha remitido a un amigo suyo, quien las publica porque juzgar que pueden conducir a la instrucción de muchos. Murcia: Imprenta de la Viuda de Felipe Teruel, 1787. Accesible en http://bvpb.mcu.es (acceso el 31-08-2011).

Calvo García, Julián. Alegrías y tristezas de Murcia. Colección de cantos populares que canta y baila el pueblo de Murcia en su huerta y campo. Madrid: Zozaya, 1877.

- Tratado Práctico del Teclado de Pedales en el Órgano Moderno. Madrid: Romero, 1888.

- Reseña del gran órgano de la Santa Iglesia Catedral de Cartagena sita en Murcia, fabricado por los señores Merklin, Schütze y compañía. Murcia: Establecimiento Tipográfico de "La Paz", 1891. Accesible en http://bibliotecadigital.carm.es (acceso el 15-10-2011).

Método de solfeo. Murcia: Litografía de Ibáñez, [s.a.]. Accesible en http://bibliotecadigital.carm.es/opac/ficha.php?informatico=00000340MO\&idpag= 1009909156\&codopac $=$ OP041 (acceso el 13-07-2011).

Cambiasi, Lompeo. La Scala 1778-1906: Nota storiche e statistiche, $5^{a}$ edición. Milán: Ricordi, 1906.

Cancionero popular murciano antiguo. Edición, estudio preliminar y notas de María Josefa Díez de Revenga Torres. Murcia: Academia Alfonso X El Sabio, 1984.

Candel Crespo, Francisco. "Plateros murcianos del siglo XIX". En: Imafronte, $\mathrm{n}^{\mathrm{o}}$ 12-13 (1996-1997), pp. 113-134.

- "Contrato para la construcción del órgano de la iglesia parroquial de San Bartolomé, en Murcia, por Miguel Alcarria. 1817”. En: Nassarre: Revista Aragonesa de musicología, 14/1 (1998), pp. 251-268.

Cano Benavente, José. Alcaldes de Murcia 1820-1885. Murcia: Imprenta Belmar, 1977. . Murcianos de otro tiempo. Murcia: Academia Alfonso X El Sabio, 1986.

Capmani, Aurelio. El Café del Liceo, 1837-1939. El Teatro y sus bailes de máscaras. Barcelona: Dalmau, 1943.

. Un siglo de baile en Barcelona. Qué y dónde bailaban los barceloneses el siglo XIX. Barcelona: Millá, 1947.

Capra, Marco. "Alla ricerca dei periodici musicali: in margine alla publicazione del Catalogo dei periodici musicali delle biblioteche della Campania". En: Rivista itlaiana di Musicologia, vol. 32, nº 2 (1997), p. 367-382.

Carbonell i Guberna, Jaume. "Aportaciones al estudio de la sociabilidad coral en la España contemporánea", Hispania. Revista española de historia, vol. 63, n 214 (2003), pp. 485-504. 
Carew, Derek. "The consumption of music". En: The Cambridge history of nineteenthcentury music, ed. Jim Samson. Cambridge: Cambrigde University Press, 2002, pp. 237-258.

Carmena y Millán, Luis. Crónica de la ópera italiana en Madrid. Edición facsímil. Madrid: Instituto Complutense de Ciencias Musicales, 2002.

Carredano, Consuelo y Eli, Victoria (eds.). La música en Hispanoamérica en el siglo XIX, vol. 6. Historia de la música en España e Hispanoamérica, dir. y coord. ed. Juan Ángel Vela del Campo. Madrid: Fondo de Cultura Económica de España, 2010.

Carreras, Juan José. "Hijos de Pedrell. La historiografía musical española y sus orígenes nacionalistas (1780-1980). En: Il Saggiatore musicale, VIII/1 (2001), pp. 121-169.

. "Música y ciudad: de la historia local a la historia cultural". En: Música y cultura urbana en la Edad Moderna, eds. Andrea Bombi, Juan José Carreras y Miguel Ángel Marín. Valencia: Universitat de València, 2005, pp. 17-52.

Casares Rodicio, Emilio. "El teatro de los bufos o una crisis en el teatro lírico del XIX español”. En: Anuario Musical, no 48 (1993), pp. 217-228.

. "El café concierto en España". En: Tiempo y espacio en el arte: homenaje al profesor Antonio Bonet Correa. Madrid: Universidad Complutense, 1994, vol. 2, pp. 1285-1293.

. "La crítica musical en el XIX español. Panorama general". En: La música española en el siglo XIX, eds. Emilio Casares y Celsa Alonso. Oviedo: Universidad de Oviedo, 1995, pp. 463-491.

. "La música del siglo XIX español. Conceptos fundamentales". En: La música española en el siglo XIX, eds. Emilio Casares y Celsa Alonso. Oviedo: Universidad de Oviedo, 1995, pp. 13-122.

. "Historia del teatro de los Bufos, 1866-1881. Crónica y dramaturgia". En: La zarzuela en España e Hispanoamérica. Centro y periferia, 1800-1950, Actas del Congreso Internacional celebrado en Madrid en 1995. Cuadernos de Música Iberoamericana, vol. 2-3 (1996-1997) pp. 73-118.

. "L'opera in Spagna dal 1730 ai nostri giorni”. En: Musica in scena. Storia dello spettacolo musicale. Torino: Utet, 1997, vol. III, pp. 469-528.

. "Café". En: Diccionario de la Música Española e Hispanoamericana, dir. Emilio Casares. Madrid: Sociedad General de Autores y Editores, 1999-2002, vol. 2 (1999), pp. 871-876.

. “Camps y Soler, Óscar". En: Diccionario de la Música Española e Hispanoamericana, dir. Emilio Casares. Madrid: Sociedad General de Autores y Editores, 1999-2002, vol. 2 (1999), pp. 1003-1004.

. "Muñoz Pedrera, Pedro". En: Diccionario de la Música Española e Hispanoamericana, dir. Emilio Casares. Madrid: Sociedad General de Autores y Editores, 1999-2002, vol. 7 (2000), p. 885. 
. "Un espacio alternativo de la música de salón: El café y su música”. En: Música Iberoamericana de Salón, coord. José Peñín. Caracas: Fundación Vicente Emilio Sojo, 2000, vol. I, pp. 67-92.

. "La creación operística en el siglo XIX. Premisas para la interpretación de un patrimonio". En: La ópera en España e Hispanoamérica, eds. Emilio Casares y Álvaro. Madrid: Instituto Complutense de Ciencias Musicales, 2001, vol. I, pp. 2157.

. "Soriano (I)". En: Diccionario de la Música Española e Hispanoamericana, dir. Emilio Casares. Madrid: Sociedad General de Autores y Editores, 1999-2002, vol. 10 (2002), pp. 11-16.

. “Asenjo Barbieri, Francisco de Asís Esteban". En: Diccionario de la Zarzuela. España e Hispanoamérica, dir. Emilio Casares, 2 vols. Madrid: Instituto Complutense de Ciencias Musicales, Ayuntamiento de Madrid, 2006, $2^{\circ}$ edición aumentada y corregida, vol. I, pp. 165-173.

- "Compañías de zarzuela". En: Diccionario de la Zarzuela. España e Hispanoamérica, dir. Emilio Casares, 2 vols. Madrid: Instituto Complutense de Ciencias Musicales, Ayuntamiento de Madrid, 2006, 2 ${ }^{\text {a }}$ edición aumentada y corregida, vol. I, pp. 525-539.

. "Diamantes de la corona, Los". En: Diccionario de la Zarzuela. España e Hispanoamérica, dir. Emilio Casares, 2 vols. Madrid: Instituto Complutense de Ciencias Musicales, Ayuntamiento de Madrid, 2006, $2^{\mathrm{a}}$ edición aumentada y corregida, vol. I, pp. 632-635.

. "Rogel Serrano, José". En: Diccionario de la Zarzuela. España e Hispanoamérica, dir. Emilio Casares, 2 vols. Madrid: Instituto Complutense de Ciencias Musicales, Ayuntamiento de Madrid, 2006, 2 ${ }^{\mathrm{a}}$ edición aumentada y corregida, vol. II, p. 641.

. "Sainete". En: Diccionario de la Zarzuela. España e Hispanoamérica, dir. Emilio Casares, 2 vols. Madrid: Instituto Complutense de Ciencias Musicales, Ayuntamiento de Madrid, 2006, 2ª edición aumentada y corregida, vol. II, p. 641.

. “Opereta”. En: Diccionario de la Zarzuela. España e Hispanoamérica, dir. Emilio Casares, 2 vols. Madrid: Instituto Complutense de Ciencias Musicales, Ayuntamiento de Madrid, 2006, $2^{\mathrm{a}}$ edición aumentada y corregida, vol. II, pp. 369377.

"Zarzuela". En: Diccionario de la Zarzuela. España e Hispanoamérica, dir. Emilio Casares, 2 vols. Madrid: Instituto Complutense de Ciencias Musicales, Ayuntamiento de Madrid, 2006, $2^{\text {a }}$ edición aumentada y corregida, vol. II, pp. 963983.

Casares Rodicio, Emilio (dir.). Diccionario de la Música Española e Hispanoamericana. Madrid: Sociedad General de Autores y Editores, 1999-2002, 10 vols. 
- Diccionario de la Zarzuela. España e Hispanoamérica. Madrid: Instituto Complutense de Ciencias Musicales, Ayuntamiento de Madrid, 2006, $2^{\circ}$ edición aumentada y corregida, 2 vols.

Casares, Emilio y Torrente, Álvaro (eds.). La ópera en España e Hispanoamérica. Madrid: Instituto Complutense de Ciencias Musicales, 2001-2002, 2 vols.

Casares Rodicio, Emilio y Alonso, Celsa (eds.). La música española en el siglo XIX. Oviedo: Universidad de Oviedo, 1995.

Cascales, Francisco, Discursos históricos de la muy noble y muy leal ciudad de Murcia y su Reino. (Murcia: Librería de Miguel Tornel y Olmos, 1874), tercera edición. Accesible en: http://bibliotecadigital.carm.es (acceso el 15-09-2011).

Catálogo de la Exposición de Bellas Artes y retrospectiva de las Artes Suntuarias de Murcia. Murcia: Imprenta de Bernabeu, 1868.

Cavia Naya, Victoria. Antonio García Valladolid (1805-1876). Lamentación Primera para el Miércoles Santo. Valladolid: Edades del Hombre, 1998.

. La vida musical de la Catedral de Valladolid en el siglo XIX. Valladolid: Diputación Provincial de Valladolid, 2004.

Clares Clares, $\mathrm{M}^{\mathrm{a}}$ Esperanza. Sonidos antiguos, significaciones modernas: el aguinaldo murciano. Granada: Universidad de Granada, 1997. Trabajo inédito de Licenciatura para la asignatura "Patrimonio Musical Andaluz".

. La vida musical murciana en la primera mitad del siglo XIX a través de la prensa: estudio y documentario. Granada: Universidad de Granada, 2003, 449 pp., Trabajo de Investigación Tutelada para la obtención del D.E.A., inédito.

. "Bandas y música en la calle: una visión a través de la prensa en las ciudades de Murcia y Cartagena (1800-1875)". En: Revista de Musicología, 28/1(2005), pp. 543-562.

. "La colección de El Dispertador, Gazeta Patriótica de Murcia (1810-1811) de la Hemeroteca Municipal de Valencia”. En: Murgetana, 115 (2006), pp. 87-107.

. "La música teatral en Murcia a través de la prensa local (1820-1851)". En: Revista de Musicología, 30/2 (2007), pp. 451-478.

. "Murcia y su música al aire libre en el siglo XIX". En: Diálogos "Las noches de las tres culturas 2010", coord. Soren Peñalver. Murcia: Ayuntamiento de Murcia, 2011, pp. 124-133.

Climent, José. "Giménez, Agustín”. En: Diccionario de la Música Española e Hispanoamericana, dir. Emilio Casares. Madrid: Sociedad General de Autores y Editores, 1999-2002, vol. 5 (1999), pp. 616.

- "Gil Yuncar [sic], José”. En: Diccionario de la Música Española e Hispanoamericana, dir. Emilio Casares. Madrid: Sociedad General de Autores y Editores, 1999-2002, vol. 6 (2000), pp. 609-610. 
Comellas Barri, Monserrat. "Pianistas de paso en Barcelona (1850-1875)". En: Nassarre. Revista Aragonesa de Musicología, 16/2 (2000), pp. 59-76.

Conati, Marcello. "I periodici teatrali e musicali italiani a metá Ottocento". En: Periodica Musica, 7 (1989), pp. 13-28.

Cooper, Jeffrey. The rise of instrumental music and concert series in Paris, 1828-1871. Ann Arbor, Michigan: UMI Research Press, 1983.

Cortès i Mir, Francesc, "Consideracions sobre els models operístics entre 1875 i 1936". En: Recerca Musicologica, 14-15 (2004-2005), pp. 77-85.

Cortizo Rodríguez, $\mathrm{M}^{\mathrm{a}}$ Encina. "La zarzuela del siglo XIX. Estado de la cuestión (18321856)". En: La música española en el siglo XIX, eds. Emilio Casares y Celsa Alonso. Oviedo: Universidad de Oviedo, 1995, pp. 161-194.

. Emilio Arrieta. De la ópera a la zarzuela. Madrid: Instituto Complutense de Ciencias Musicales, 1998.

. "Zarzuela". En: Diccionario de la Música Española e Hispanoamericana, dir. Emilio Casares. Madrid: Sociedad General de Autores y Editores, 1999-2002, vol. 10 (2002), pp. 1145-1154.

. "La ópera romántica española hasta la apertura del Teatro Real (1800-1850)". En: La ópera en España e Hispanoamérica, eds. Emilio Casares y Álvaro. Madrid: Instituto Complutense de Ciencias Musicales, 2002, vol. II, pp. 7-62.

. "Zarzuela y ópera bufa. Modelos estilísticos del teatro lírico español a finales del siglo XIX". En: La musique entre France et Espagne. Interactions stylistiques, I (1870-1939), coord. Luis Jambou. París: Université de Paris-Sorbone, 2003, pp. 5980.

. "Jeroma la castañera". En: Diccionario de la Zarzuela. España e Hispanoamérica, dir. Emilio Casares, 2 vols. Madrid: Instituto Complutense de Ciencias Musicales, 2006, $2^{\text {a }}$ edición, vol. II, pp. 5-7.

. "Tío Caniyitas, El”. En: Diccionario de la Zarzuela. España e Hispanoamérica, dir. Emilio Casares, 2 vols. Madrid: Instituto Complutense de Ciencias Musicales, 2006, 2ª edición, vol. II, pp. 803-804.

Cortizo Rodríguez, $\mathrm{M}^{\mathrm{a}}$ Encina y Sobrino, Ramón. “Asociacionismo musical en España”. En: Sociedades musicales en España. Siglos XIX-XX, Actas del Curso de Musicología celebrado en la Escuela Asturiana de Estudios Hispánicos, dirigido por $\mathrm{M}^{\mathrm{a}}$ Encina Cortizo y Ramón Sobrino en La Granda (Asturias), agosto de 1997, volumen monográfico de Cuadernos de Música Iberoamericana, 8-9 (2001), pp. 11-16.

Cotarelo y Mori, Emilio. La Historia de la zarzuela o sea el Drama Lírico en España, desde su origen a fines del siglo XIX. Madrid: Instituto Complutense de Ciencias Musicales, 2000. Edición facsímil. 
Cowgill, Rachel y Holman, Peter (eds.). Music in the British Provinces, 1690-1914. Aldershot, Hampshire Burlington, VT: Ashgate, 2007.

Crespí, Joana. "Publicaciones periódicas musicales del siglo XIX en Catalunya". En: Actas. Ponencias españolas e hispanoamericanas. $18^{\circ}$ Congreso de la Asociación Internacional de Bibliotecas Musicales, Archivos y Centros de Documentación (San Sebastián, 21-26 junio 1998). Madrid: Asociación Española de Documentación Musical, 1999, pp. 213-234.

Crespo, Antonio. Un viejo teatro cuenta su historia. Recuerdos anecdóticos del Romea, Murcia. Murcia: Imprenta Belmar, 1969.

. Historia del Teatro de los Infantes de Murcia. Murcia: Real Academia Alfonso X el Sabio, 1993.

. "Los dos incendios del Teatro Romea de Murcia”. En: Murgetana, no 89 (1994), pp. 85-96.

. "Algunos autores teatrales en la Murcia del siglo XIX". En: Murgetana, $\mathrm{n}^{\circ} 91$ (1995), pp. 69-88.

. Antiguos teatros de la ciudad de Murcia. Murcia: Real Academia Alfonso X el Sabio, 1997.

- "Apuntes sobre compositores murcianos del siglo XIX". En: Murgetana, 94 (1997), pp. 107-117.

. Historia de la prensa en la ciudad de Murcia. Murcia: Academia Alfonso X el Sabio, 2000.

- "El Teatro de los Crímenes, un coliseo murciano que nunca existió". En: Murgetana, 102 (2000), pp. 65-69.

. El Teatro Romea de Murcia en el siglo XIX. Murcia: Real Academia Alfonso X el Sabio, 2001.

. “Un sindicato de prensa en la Murcia de 1889”. En: Murgetana, n 110 (2004), pp. 105-109.

. Andrés Blanco García, escritor y concejal murciano (1849-1916). Murcia: Antonio Crespo, 2005.

. “Las 'guías’ más antiguas de Murcia”. En: Murgetana, 116 (2007), pp. 139-150.

Cuadrado Caparrós, María Dolores. Bartolomé Pérez Casas y la Orquesta Filarmónica de Madrid (1915-1936). Alzira, Valencia: Germania, 2007.

Cymbron, Luísa. “L'Egemonia dell'opera italiana nel Portogallo del XIX secolo". En: Il teatro dei due mondi. L'opera italiana nei paesi di lingua iberica, ed. Anna Laura Bellina. Treviso: Associazione musicale Ensemble '900, 2000, pp. 125-140. 
. "A produção e recepção das óperas de Verdi em Portugal no século XIX (com algumas notas sobre a relação do compositor com o nosso país)". En: Verdi em Portugal 1843-2001 (Catálogo da Exposição Comemorativa do Centenário da Morte do Compositor). Lisboa: Biblioteca Nacional de Lisboa, 2001, pp. 21-40.

Chivelet, Mercedes. Historia de la prensa cotidiana en España. Madrid: Acento, 2001.

Dale, Catherine. "The Provincial Musical Festival in Nineteenth-century England: A case Study of Bridlington". En: Music in the British Provinces, 1690-1914, eds. Rachel Cowgill y Peter Holman. Aldershot, Hampshire Burlington, VT: Ashgate, 2007, pp. 325-347.

De Angelis, Marcello. La musica del Granduca. Vita musicale e corrente critiche a Firenze 1800-1855. Firenze: Vallecchi, 1978.

De Brito, Manuel Carlos y Cranmer, David. Crónicas da vida musical na primeira metado do século XIX. Lisboa: Impresa Nacional, Casa da Moeda, 1990.

De Eguizábal, José Eugenio. Apuntes para una historia de la legislación española sobre imprenta desde el año 1480 al presente. Madrid: Imprenta de la Revista de Legislación, 1879.

De Jaime Lorén, José y De Jaime Gómez, José. "Índice de las obras clásicas de la literatura española del siglo XIX, en cuyos títulos figuran refranes y frases hechas". En: Paremia, 13 (2004), pp. 43-51. Accesible en: www.paremia.org (acceso el 1506-2011).

De los Reyes, Antonio. "La prensa murciana del siglo XIX: una aproximación". Actas de las Jornadas sobre prensa y sociedad en la Murcia contemporánea. En: Anales de Historia Contemporánea, 12 (1995-1996), pp. 343-370.

De los Reyes, Antonio. "El asociacionismo en la prensa murciana". En: Murgetana, $\mathrm{n}^{\circ} 70$ (1986), pp. 85-91.

. "Publicaciones periódicas en el siglo XVIII en Murcia. Nuevas aportaciones". En: Murgetana, 81 (1990), pp. 69-89.

Del Campo, Manuel. "La visita de Sarasate a Málaga”. En: Jábega no 1 (1973), pp. 84-85. Accesible en http://www.cedma.com/archivo/jabega_pdf/jabega1_84-85.pdf (acceso el 15 de junio de 2011).

Del Valle Collado, Ana María. "El violonchelista y compositor murciano Agustín Rubio Sánchez (1856-1940)". OpusMusica, $\mathrm{n}^{\mathrm{0}} 22$ (2008). Accesible en: http://www.opusmusica.com/022/rubio.html (acceso el 8-10-2011).

Delgado, Cristóbal. "Regino Martínez". En: Almoraima, Revista de estudios campogibraltareños (1990), $\mathrm{n}^{\circ} 3$, pp. 87-90.

Díaz Cassou, Pedro; López Almagro, Antonio y García, Mariano. Pasionaria murciana: la Cuaresma y la Semana Santa en Murcia. Madrid: Imprenta de Fortanet, 1897. 
. Cancionero panocho: colas, cantares, romances de la huerta de Murcia. Madrid: Imprenta de Fortanet, 1900.

Diccionario de la Lengua Española, 22ª edición. Madrid: Real Academia Española, 2001.

Díez de Revenga, Francisco Javier. "De los juegos florales a la poesía recitada en la España contemporánea". Historia de los espectáculos en España, coords. Andrés Amorós y José Díez Borque. Madrid: Castaglia, 1999, pp. 455-461. . "La prensa murciana en su historia". En: Monteagudo, nº 7 (2002), pp.- 169-172.

Díez de Revenga, Francisco Javier y De Paco, Mariano. Historia de la literatura murciana. Murcia: Universidad de Murcia, Academia Alfonso X El Sabio, Editora Regional de Murcia, 1989.

Díez Huerga, $\mathrm{M}^{\mathrm{a}}$ Aurelia. "Las sociedades musicales en el Madrid de Isabel II (18331868)". En: Anuario Musical, 58 (2003), pp. 253-277. Accesible en: http://anuariomusical.revistas.csic.es/index.php/anuariomusical/article/view/76 (acceso el 3-08-2011).

- "Salones, bailes y cafés: costumbres socio-musicales en el Madrid de la reina castiza (1833-1868). En: Anuario Musical, no 61 (2006), pp. 189-210. Accesible en: http://anuariomusical.revistas.csic.es/index.php/anuariomusical/article/view/10 (acceso el 2-09-2011).

Drage, Sally. "The Larks of Dean: Amateur Musicians in Northern England”. En: Music in the British Provinces, 1690-1914, eds. Rachel Cowgill y Peter Holman. Aldershot, Hampshire Burlington, VT: Ashgate, 2007, pp. 195-221.

Duque, Ellie Anne. La música en las publicaciones periódicas colombianas (1848-1860). Santa Fé de Bogotá: Fundación de Música, 1998.

Elizondo Iriarte, Esteban. La organería romántica en el País Vasco y Navarra (18561940). Barcelona: Universidad de Barcelona, 2001. Accesible en http://tdx.cat/bitstream/handle/10803/1274/TOL6501.pdf?sequence=2 (acceso el 14-07-2011).

Ellis, Katharine. "The structures of musical life". En: The Cambridge history of nineteenth-century music, ed. Jim Samson. Cambridge: Cambrigde University Press, 2002, pp. 343-370.

Encabo Fernández, Enrique. "Las primeras recolecciones de cantos populares en Murcia; entre el Volkgeist y el esteticismo". En: III Jornadas Nacionales Folclore y Sociedad. Madrid: CIOFF-España, 2006, pp. 95-115.

. 'Los 'Cuadros murcianos' de Emilio Ramírez: estudio analítico del folklore al escenario”. En: Revista de Musicología, 32/2 (2009), pp. 117-127.

Enseñat Calderón, Luis Ramón y Montojo Montojo, Vicente. "Orden público y beneficencia en la Murcia contemporánea. Su incidencia sobre mujeres y niños”. En: Anales de Historia Contemporánea, 19 (2003), pp. 327-346. 
Espadas Burgos, Manuel y De Urquijo Goitia, José Ramón. Guerra de la Independencia y época constitucional (1808-1898). En: Historia de España, coord. Ángel Montenegro Duque, 17 vols. Madrid: Gredos, 1986-1994, vol. 11 (1990).

Espín Templado, $\mathrm{M}^{\mathrm{a}}$ Pilar. "El sainete del último tercio del siglo XIX: culminación de un género dramático histórico en el teatro español”. En: Epos, Revista de filología, n 3 (1987), pp. 97-122. Accesible en: http:/espacio.uned.es/fez/view.php?pid=bibliuned:Epos-0B3E730E-B65C-A098-8CAC76A5BBEE6DE7 (acceso el 5-05-2011).

- "Panorama literario de la Zarzuela Grande en el siglo XIX: lo autóctono y lo extranjero, 1996-1997". En: La zarzuela en España e Hispanoamérica. Centro y periferia, 1800-1950, Actas del Congreso Internacional celebrado en Madrid en 1995. Cuadernos de Música Iberoamericana, vol. 2-3 (1996-1997) pp. 57-72.

. "Las ideas literarias en la prensa de la época romántica: el debate 'Sobre la influencia del teatro en las costumbres' (a propósito de varios artículos de Miguel Agustín Príncipe)". Anales de Literatura Española, no 18 (2005), pp. 129-142. Accesible en: http://dialnet.unirioja.es/servlet/articulo?codigo=2724544 (acceso el 12-04-2011).

Esposito, Francesco. "O sucesso de Verdi na música pianística as edições musicais lisboetas do século XIX". En: Verdi em Portugal 1843-2001 (Catálogo da Exposição Comemorativa do Centenário da Morte do Compositor). Lisboa: Biblioteca Nacional de Lisboa, 2001, pp. 41-58.

Ester-Sala, María y Vilar, Josep Ma " "La presencia de Rossini en la vida cotidiana en la Catalunya del ochocientos". En: Nassare, vol. 8, n 2 (1992), pp. 69-82.

Estatutos de reglamento interior del Liceo Artístico y Literario de Murcia. Murcia: Oficina de Hernández, 1839.

Fernández de la Cuesta, Ismael. "La Iglesia Católica frente a la música secular del siglo XIX. Música eclesiástica en teatros y salas de concierto". En: Música Iberoamericana de Salón, coord. José Peñín. Caracas: Fundación Vicente Emilio Sojo, 2000, vol. II, pp. 755-768.

Fernández de Latorre, Ricardo. Historia de la música militar de España. Madrid: Ministerio de Defensa, 2000.

Fernández Vargas, Valentina. Sangre o dinero: el mito del ejército nacional. Madrid: Alianza Editorial, 2004.

Flores Arroyuelo, Francisco. "Los auroros de la huerta de Murcia". En: Narria: Estudios de artes y costumbres populares, $\mathrm{n}^{\text {os }} 49-50$ (1988), pp. 46-51.

Fonseca, Ana Maria Liberal da. A vida musical no Porto na segunda medate do século XIX: o pianista e compositor Miguel Angelo Pereira (1834-1901). Santiago de Compostela: Universidade de Santiago de Compostela, 2006.

Fontestad Piles, Ana. El conservatorio de música de Valencia. Antecedentes, fundación y primer etapa (1879-1910). Valencia: Universitat de Valencia, 2006. Tesis doctoral. 
Accesible en: http://dialnet.unirioja.es/servlet/tesis?codigo=7273 (acceso el 30-082011).

Forbes, Elizabeth y Parker, Roger. "Ronconi, Giorgio". En: The New Grove Dictionary of Music and Musicians, ed. Stanley Sadie, 29 vols., $2^{\text {a }}$ edición. London: Macmillan, 2001, vol. 21, pp. 643-644.

Fornaro Bordolli, Marina. "Género, belleza y salud: la representación del cuerpo en los medios artísticos uruguayos durante la primera mitad del siglo XIX". En: El cuerpo: objeto y sujeto de las ciencias humanas y sociales. Ponencias del Congreso Internacional celebrado en Barcelona en 2009, Yolanda Aixelá, María Gembero, Josep Martí, José Pardo-Tomás, Roser Salicrú, Assumpció Vilar (eds.). Barcelona: Institució Milà i Fontanals, 2009. pp. 1-23.

Francisco Asenjo Barbieri. Documentos sobre música española y epistolario (Legado Barbieri). Edición, transcripción e introducción a cargo de Emilio Casares Rodicio. Madrid: Fundación Banco Exterior, 1986-1988, 2 vols.

Freire López, Ana. Literatura y sociedad: los teatros en casas particulares en el siglo XIX. Madrid: Artes Gráficas Municipales, 1996.

Fresneda, Rafael (coord.). Hemerotecas. Aportaciones al estudio y tratamiento de publicaciones periódicas. Murcia: Editora Regional de Murcia, Anabad, 1996.

Fuentes y Ponte, Javier. Murcia que se fue. Madrid: Imprenta de la Biblioteca de Instrucción y Recreo, 1872.

Fukushima, Mutsumi. "Fabricantes de piano en la Barcelona de 1900". En: Recerca Musicologica, XVII-XVIII (2007-2008), pp. 279-297.

Galbis López, Vicente. "La zarzuela en el área mediterránea". En: La zarzuela en España $e$ Hispanoamérica. Centro y periferia, 1800-1950, Actas del Congreso Internacional celebrado en Madrid en 1995. Cuadernos de Música Iberoamericana, vol. 2-3 (1996-1997), pp. 327-349.

. “Ópera. De 1800 a 1939”. En: Diccionario de la música valenciana, dir. Emilio Casares. Madrid: Instituto Complutense de Ciencias Musicales, 2006, vol. II, pp. 531-538.

. "Crítica musical”. En: Diccionario de la Música Valenciana, dir. Emilio Casares. Madrid: Instituto Complutense de Ciencias Musicales, 2006, vol. I, pp. 269-270.

García Caballero, María. La vida musical en Santiago a finales del siglo XIX. Santiago de Compostela: Alvarellos, 2008.

García Fraile, Dámaso. "Reivindicación del idioma castellano en la ópera española de finales del siglo XVIII". En: La ópera en España e Hispanoamérica, eds. Emilio Casares y Álvaro. Madrid: Instituto Complutense de Ciencias Musicales, 2001, vol. I, pp. 455-475.

García Hourcade, José Jesús. "Panorama de la prensa murciana de la Ilustración al Liberalismo". Actas de las Jornadas sobre prensa y sociedad en la Murcia 
contemporánea. En: Anales de Historia Contemporánea, 12 (1995-1996), pp. 373383.

García Laborda, José Ma " "Benavente Montalvo, Manuel”. En: Diccionario de la Música Española e Hispanoamericana, dir. Emilio Casares. Madrid: Sociedad General de Autores y Editores, 1999-2002, vol. 2 (1999), pp. 354-355.

García Melero, José Enrique. Arte español de la Ilustración y del siglo XIX. En torno a la imagen del pasado. Madrid: Encuentro Ediciones, 1998.

García Seco, José Andrés. "Mariano Soriano-Fuertes y Piqueras: músico murciano del siglo XIX: estudio biográfico-crítico". En: Primera Semana de Estudios Murcianos. Murcia: Sucesores de Nogués, 1961, vol. I, p. 85-97.

- "Calvo García, Julián". En: Gran Enciclopedia de la Región de Murcia, dir. Serafín Alonso Navarro. Murcia: Ayalga, 1991-1995, vol. 2 (1992), p. 288.

. “Calvo López, José”. En: Gran Enciclopedia de la Región de Murcia, dir. Serafín Alonso Navarro. Murcia: Ayalga, 1991-1995, vol. 2 (1992), pp. 288-289.

. “Calvo, José". En: Gran Enciclopedia de la Región de Murcia, dir. Serafín Alonso Navarro. Murcia: Ayalga, 1991-1995, vol. 2 (1992), pp. 287-288.

- "Conservatorio Superior de Música”. En: Gran Enciclopedia de la Región de Murcia, dir. Serafín Alonso Navarro. Murcia: Ayalga, 1991-1995, vol. 3 (1993), pp. 255-256.

- "Espinosa de los Monteros Jiménez, Gaspar". En: Gran Enciclopedia de la Región de Murcia, dir. Serafín Alonso Navarro. Murcia: Ayalga, 1991-1995, vol. 4 (1994), pp. 158-159.

. "Fernández Caballero, Manuel". En: Gran Enciclopedia de la Región de Murcia, dir. Serafín Alonso Navarro. Murcia: Ayalga, 1991-1995, vol. 4 (1994), pp. 210211.

. "Maestro de capilla". En: Gran Enciclopedia de la Región de Murcia, dir. Serafín Alonso Navarro. Murcia: Ayalga, 1991-1995, vol. 6 (1995), pp. 21-23.

. "Mirete Ramírez, Ángel”. En: Gran Enciclopedia de la Región de Murcia, dir. Serafín Alonso Navarro. Murcia: Ayalga, 1991-1995, vol. 6 (1995), p. 146.

. "Muñoz Pedrera, Pedro". En: Gran Enciclopedia de la Región de Murcia, dir. Serafín Alonso Navarro. Murcia: Ayalga, 1991-1995, vol. 6 (1995), p. 224.

. "Padilla y Ramos, Mariano". En: Gran Enciclopedia de la Región de Murcia, dir. Serafín Alonso Navarro. Murcia: Ayalga, 1991-1995, vol. 7 (1995), pp. 42-43.

. "Prensa musical". En: Gran Enciclopedia de la Región de Murcia, dir. Serafín Alonso Navarro. Murcia: Ayalga, 1991-1995, vol. 7 (1995), p. 164.

. "Puig Ruiz-Funes, Antonio". En: Gran Enciclopedia de la Región de Murcia, dir. Serafín Alonso Navarro. Murcia: Ayalga, 1991-1995, vol. 7 (1995), p. 190. 
. "Raya, Familia". En: Gran Enciclopedia de la Región de Murcia, dir. Serafín Alonso Navarro. Murcia: Ayalga, 1991-1995, vol. 7 (1995), p. 227.

. "Soriano Fuertes, Indalecio". En: Gran Enciclopedia de la Región de Murcia, dir. Serafín Alonso Navarro. Murcia: Ayalga, 1991-1995, vol. 8 (1995), pp. 143144.García Segura, Alfredo. Músicos en Cartagena. Cartagena: Ayuntamiento de Cartagena, 1995.

García Soriano, Justo. El humanista Francisco Cascales. Su vida y sus obras. Estudio biográfico, bibliográfico y crítico. Murcia: Real Academia Española, 1924. Accesible en: http://bvpb.mcu.es/es/consulta/registro.cmd?id=442001 (acceso el 2-09-2011).

. Anales de la imprenta en Murcia y noticia de sus impresores. Madrid: García Enciso, 1941.

García, Mónica. "La Sociedad de Cuartetos de Madrid (1863-1894)". En: Cuadernos de Música Iberoamericana, vol. 8-9 (2001), pp. 149-193.

Gauthier, Laure y Traversier, Mélanie (dir.). Mélodies urbaines. La musique dans les villes d'Europe (XVI ${ }^{e}$-XIX $X^{e}$ siécles). París: Presses Universitaires de la Sorbonne, 2008.

Gelardo Navarro, José. El flamenco, otra cultura, otra estética: testimonios de la prensa murciana del siglo XIX. Sevilla: Portada Editorial, Consejería de Educación y Cultura de Murcia, 2003.

. Las claras del día. El flamenco en la ciudad de Murcia a finales del siglo XIX. Historia y crónicas. Murcia: Nausícaä, 2003.

. El flamenco en Lorca, Lorca en el flamenco: viaje a través de la prensa de los siglos XIX y XX. Murcia: Azarbe, 2004.

. Con el flamenco llegó el escándalo. Sierra Minera de Cartagena y La Unión. Prensa, historia escrita, historia oral. Siglo XIX, Murcia, Editorial Azarbe, 2006.

- "Los cafés cantantes en tierras murcianas (1870-1900). En: Guía secreta de Murcia en el siglo XIX, dir. Ricardo Montes. Murcia: Azarbe, 2008, pp. 129-168.

Gembero Ustárroz, María y Ros-Fábregas, Emilio (coords. y eds.). La Música y el Atlántico. Relaciones musicales entre España y Latinoamérica. Granada: Universidad de Granada, 2007.

Gericó Trilla, Joaquín y López Rodríguez, Francisco Javier. La flauta en España en el siglo XIX. Madrid: Real Musical, 2001.

Giglio, Consuelo. "La musica nei periodici dell'Ottocento e del primo Novecento pubblicati a Palermo". En: Fonti musicali italiana: Periodico di ricerca musicologica, vol. 2 (1997), pp. 95-153.

Gil, Bonifacio. Panorama de la música popular murciana. Murcia: Sucesores de Nogués, 1961. 
Gimeno Arlanzón, Begoña. "Sociedad, cultura y actualidad artística en la España de fines del siglo XIX a través de las publicaciones periódicas musicales: Zaragoza y la revista El Correo Musical, 1888”. En: Anuario Musical, 61 (2006), pp. 211-262. Accesible en: http://anuariomusical.revistas.csic.es/index.php/anuariomusical/article/viewArticle/ 11 (acceso el 02-06-2011).

Gimeno Arlanzón, Begoña. Las publicaciones periódicas musicales zaragozanas en la España de la Restauración (1883-1924) un estudio de la sociedad, cultura y actualidad artística locales. Zaragoza: Universidad de Zaragoza, 2010. Tesis doctoral. Accesible en: http://dialnet.unirioja.es/servlet/tesis?codigo=21920 (acceso en 11-04-2011).

Girardi, Maria. "La musica nei periodici veneziani della seconda metà del Settecento e dell'Ottocento". Canoni bibliografici. Atti del convegno internazionale IAML-IASA (Perugia, 1-6 settembre 1996), ed. Licia Sirch. Lucca: Libreria Musicale Italiana, 2001, pp. 211-228.

Gómez Amat, Carlos. Historia de la música española. 5. Siglo XIX. Madrid: Alianza Editorial, 1984.

. "Sinfonismo y música de cámara en la España del siglo XIX". En: España en la música de occidente: actas del congreso internacional celebrado en Salamanca, 29 de octubre-5 de noviembre de 1985, coord. José López-Calo, Ismael Fernández de la Cuesta y Emilio Casares, 2 vols. Madrid: Instituto Nacional de las Artes Escénicas y de la Música, 1987, vol. 2, pp. 211-223.

Gómez Pintor, Ma Asunción. "Música y sociedad en la ciudad de Vigo en los siglos XIX y XX". Delantera de paraíso. Estudios en homenaje a Luis G. Iberni, coords. Celsa Alonso, Carmen Julia Gutiérrez y Javier Suárez Pajares. Madrid: Instituto Complutense de Ciencias Musicales, 2008, pp. 273-279.

González Cutillas, Juan. "Díaz Rocher, Acisclo”. En: Gran Enciclopedia de la Región de Murcia, dir. Serafín Alonso Navarro. Murcia: Ayalga, 1991-1995, vol. 4 (1994), p. 45 .

. "García López, Mariano". En: Gran Enciclopedia de la Región de Murcia, dir. Serafín Alonso Navarro. Murcia: Ayalga, 1991-1995, vol. 4 (1994), p. 305.

. "Gasque Llopis, José María". En: Gran Enciclopedia de la Región de Murcia, dir. Serafín Alonso Navarro. Murcia: Ayalga, 1991-1995, vol. 4 (1994), p. 317.

. "Gil Yuncas, Julián". En: Gran Enciclopedia de la Región de Murcia, dir. Serafín Alonso Navarro. Murcia: Ayalga, 1991-1995, vol. 6 (1994), pp. 24-25.

. "López Almagro, Antonio". En: Gran Enciclopedia de la Región de Murcia, dir. Serafín Alonso Navarro. Murcia: Ayalga, 1991-1995, vol. 5 (1994), pp. 263-264.

. "López Villanueva, Antonio". En: Gran Enciclopedia de la Región de Murcia, dir. Serafín Alonso Navarro. Murcia: Ayalga, 1991-1995, vol. 5 (1994), pp. 272273. 
. "Manuel Fernández Caballero: de la zarzuela al género chico". En: Actualidad y futuro de la zarzuela: actas de las jornadas celebradas en Madrid del 6 al 9 de noviembre de 1991, coord. Ramón Barce. Madrid: Alpuerto, 1994, pp. 243-250.

. "Gil Yuncas, Julián”. En: Diccionario de la Música Española e Hispanoamericana, dir. Emilio Casares. Madrid: Sociedad General de Autores y Editores, 1999-2002, vol. 6 (2000), p. 610.González Vidal, José Mariano. Papeles murcianos, op. 7. Murcia: Universidad de Murcia, 1992.

Gosálvez Lara, Carlos José. La edición musical española hasta 1936. Madrid: Asociación Española de Documentación Musical, 1995.

Gris Martínez, Joaquín (coord.). Los Auroros de la Región de Murcia. Manifestación religiosa popular ritual y cantos. Murcia: Editora Regional, 1993.

Guereña, Jean-Louis. "Espacios y formas de la sociabilidad en la España contemporánea". En: Hispania: Revista española de historia, 63/214 (2003), pp. 409-413. Accesible en: http://dialnet.unirioja.es/servlet/articulo? codigo $=867023$ (acceso el 3-09-2011).

Guía Oficial de España. Madrid: Imprenta Nacional, 1876.

Guirao López de Navas, José. El casino de Murcia, 1847-1994. Murcia: Grafimar, 1994.

Haynes, Bruce. "Pitch. Western pitch standards". En: The New Grove Dictionary of Music and Musicians, ed. Stanley Sadie, 29 vols., $2^{\text {a }}$ edición. London: Macmillan, 2001, vol. 19, pp. 793-802.

Hernández Franco, Juan. "Prensa y propaganda contrarrevolucionaria. El "Correo Literario de Murcia" (1792- 1795). En: Poder ilustrado y revolución, coords. Carmen Cremades y Antonio Díaz Bautista. Murcia: Universidad de Murcia, 1991, pp. 109-128.

Hernández Pina, Ma Fuensanta. "La enseñanza media en Murcia en el siglo XIX: el Instituto 'Alfonso X el Sabio"”. En: Murgetana, 53 (1978), pp. 15-58.

Herrero Pascual, Cristina. "Tratamiento de publicaciones periódicas". En: Hemerotecas. Aportaciones al estudio y tratamiento de publicaciones periódicas, coord. Rafael Fresneda. Murcia: Editora Regional de Murcia, Confederación de Asociaciones de Archiveros, Bibliotecarios, Museólogos y Documentalistas, ANABAD, 1996, $2^{\text {a }}$ impresión, pp. 63-76.

Hess, Carol A. "Enric Granados y el contexto pedrelliano". En: Recerca Musicològica, XIV-XV (2004-2005), pp. 47-56.

Huertas Vázquez, Eduardo. El teatro de los bufos madrileños. Madrid: Instituto de Estudios Madrileños, 1993.

. "La zarzuela paródica y sus incursiones políticas". En: En: La zarzuela en España e Hispanoamérica. Centro y periferia, 1800-1950, Actas del Congreso Internacional celebrado en Madrid en 1995. Cuadernos de Música Iberoamericana, vol. 2-3 (1996-1997), pp. 165-181. 
Ibáñez García, José María. Serie cronológica de la prensa periódica en Murcia: fichas para una futura hemeroteca. Murcia: Tipografía San Francisco, 1931.

Iberni, Luis G. Pablo Sasarate. Madrid: Instituto Complutense de Ciencias Musicales, 1994.

. Ruperto Chapí. Madrid: Instituto Complutense de Ciencias Musicales, 1995.

. "Controversias entre ópera y zarzuela en la España de la Restauración". En: La zarzuela en España e Hispanoamérica. Centro y periferia, 1800-1950, Actas del Congreso Internacional celebrado en Madrid en 1995. Cuadernos de Música Iberoamericana, vol. 2-3 (1996-1997) pp. 157-164.

- "Fernández Caballero, Manuel". En: Diccionario de la Música Española e Hispanoamericana, dir. Emilio Casares. Madrid: Sociedad General de Autores y Editores, 1999-2002, vol. 5 (1999), 1999, pp. 28-35.

- “Chapí y Llorente, Ruperto". En: Diccionario de la Zarzuela. España e Hispanoamérica, dir. Emilio Casares, 2 vols. Madrid: Instituto Complutense de Ciencias Musicales, 2006, 2a edición, vol. I, p. 453-460.

- "Fernández Caballero, Manuel”. En: Diccionario de la Zarzuela. España e Hispanoamérica, $2^{\mathrm{a}}$ edición, Madrid: Instituto Complutense de Ciencias Musicales, 2006, vol. I, pp. 745-755.

. "Pablo Sarasate (1844-1908), regreso al compositor". En: Príncipe de Viana, 238 (2006), pp. 655-674. Ejemplar dedicado a "Conmemoración del VIII Centenario de la Chantía de la Catedral de Pamplona como dignidad eclesiástica (1206-2006)", coord. María Gembero Ustárroz. Accesible en: http://dialnet.unirioja.es/servlet/articulo? codigo=2070767 (acceso el 10-08-2011).

Iglesias Martínez, Nieves (dir.). La música en el Boletín de la Propiedad Intelectual. Madrid: Biblioteca Nacional, 1997.

Inzenga, José. Cantos y bailes populares de España. Madrid: Antonio Romero, 1888.

Jander, Owen; Steane, John Barry; Forbes, Elizabeth et al. "Baritone". En: The New Grove Dictionary of Music and Musicians, ed. Stanley Sadie, 29 vols., $2^{\text {a }}$ edición. London: Macmillan, 2001, vol. 2, pp. 730-733.

Jiménez de Gregorio, Fernando. "El Colegio-Seminario Conciliar de San Fulgencio. (Aportación documental inédita al estudio de los precedentes de la Universidad murciana)". En: Anales de la Universidad de Murcia (1949-1950), pp. 139-218.

Jiménez Madrid, Ramón. Narradores murcianos de antaño (1595-1936). Murcia: Universidad de Murcia, Academia Alfonso X El Sabio, Editora Regional, 1990

Jover, $\mathrm{M}^{\mathrm{a}}$ Ángeles. "Archivos y documentación local de la Región de Murcia". En: Documentación de las Ciencias de la Información, no 13 (1990), pp. 113-131.

- "Fondos hemerográficos del Archivo Municipal de Murcia". Hemerotecas. Aportaciones al estudio y tratamiento de publicaciones periódicas, coord. Rafael 
Fresneda. Murcia: Editora Regional de Murcia, Confederación de Asociaciones de Archiveros, Bibliotecarios, Museólogos y Documentalistas, ANABAD, 1996, $2^{\mathrm{a}}$ impresión, pp. 143-158.

Jürgensen, Knud Arne. "Verdi meets Scandinavia. The early Danish Verdiperformances". En: Studi verdiani, 15 (Parma: Istituto Nazionale di Studi Verdiani, (2000-2001), pp. 80-109.

Kalfa, Jacqueline e Iglesias, Antonio. “Albéniz Pascual, Isaac Manuel”. En: Diccionario de la Música Española e Hispanoamericana, dir. Emilio Casares. Madrid: Sociedad General de Autores y Editores, 1999-2002, vol. 1 (1999), pp. 188-201.

Kauffmann, Jacobo. Jacques Offenbach en España, Italia y Portugal. Zaragoza: Libros Certeza, 2007.

Kenyon de Pascual, Beryl. "Christopher Nobbs. Sevilla: un importante centro español de construcción de claves y pianos de mediados del siglo XVIII". En: Revista de Musicología, 20/2 (1997), pp. 849-856.

Koury, Daniel. Orchestral performance practices in the nineteenth century. Ann Arbor, Michigan: UMI Research Press, 1986.

Lacal de Bracho, Luisa. Diccionario de la música. Madrid: Establecimiento Tipográfico de San Francisco de Sales, 1900.

Lafourcade Señoret, Octavio. Ramón Carnicer en Madrid, su actividad como músico, gestor y pedagogo en el Madrid de la primera del siglo XIX. Alicante: Biblioteca Virtual Miguel de Cervantes, 2009. Accesible en http://www.cervantesvirtual.com/obra/ramon-carnicer-en-madrid-su-actividadcomo-musico-gestor-y-pedagogo-en-el-madrid-de-la-primera-mitad-del-siglo-xix-0/ (acceso el 13-07-2011).

Lanza, Andrea. "Generali, Pietro". En: The New Grove Dictionary of Music and Musicians, ed. Stanley Sadie, 29 vols., $2^{\text {a }}$ edición. London: Macmillan, 2001, vol. 21, pp. 320-321.

Lanzón Meléndez, Juan. La música en Murcia a partir de la Guerra Civil Española (1939-1975). Cartagena, Murcia: Juan Lanzón/Áglaya, 2001.

Latcham, Michael. "The instrument of many colours made by Tadeo Tornel in Murcia, 1777”. En: Verdolay: Revista del Museo Arqueológico de Murcia, no 10 (2007), pp. 299-342.

Leza Cruz, José Máximo. "Las orquestas de ópera en Madrid entre los siglos XVIII y XIX". En: Campos Interdisciplinares de la Musicología. V Congreso de la Sociedad Española de Musicología (Barcelona, 25-28 de octubre de 2000), ed. Begoña Lolo. Madrid: Sociedad Española de Musicología, 2001, vol. 1, pp. 115139.

Liberal, Ana María. “Antonio Reparaz, un músico español en Oporto: nuevos datos para su biografía”. En: Cuadernos de Música Iberoamericana, vol. 19 (2010, pp. 91-115. 
Lloret i Esquerdo, Jaume. El teatre a Alacant, 1833-1936. Valencia, Consell Valenciá de Cultura, 1998.

. Personatges de l'escena alacantina. Alicante: Patronat Municipal de Cultura, Ajuntament d'Alacant, 2002.

Lolo, Begoña. "El sentido de la historicidad en música. España versus Europa". En: Anuario del Departamento de Historia y Teoría del Arte, no 4 (1992), pp. 359-365. Accesible en: http://dialnet.unirioja.es/servlet/articulo?codigo=152772 (acceso el 13-10-2011).

Lolo, Begoña (ed.). Campos Interdisciplinares de la Musicología. Madrid, Sociedad Española de Musicología, 2 vols., 2001.

López Almagro, Antonio. Método completo teórico-práctico de harmonium. Madrid: Antonio Romero, $1872 . \quad$ Accesible en: http://bibliotecadigitalhispanica.bne.es/view/action/singleViewer.do?dvs=13207761 44105 978\&locale=es_ES\&VIEWER_URL=/view/action/singleViewer.do?\&DEL IVERY_RULE_ID=10\&frameId=1\&usePid1=true\&usePid2=true (acceso el 17-072011).

. Método completo teórico-práctico de acordeón. Madrid: Antonio Romero, 1876. Accesible http://bibliotecadigitalhispanica.bne.es/view/action/singleViewer.do?dvs=13207768 18412 488\&locale=es_ES\&VIEWER_URL=/view/action/singleViewer.do?\&DEL IVERY_RULE_ID=10\&frameId=1\&usePid1=true\&usePid2=true (acceso el 17-092011).

. El harmonium de doble expresión. Complemento al método de harmonium del mismo autor. Madrid: Antonio Romero/Faustino Echevarría, 1880. Accesible en: http://bibliotecadigitalhispanica.bne.es/view/action/singleViewer.do?dvs=13207760 99572 141\&locale=es_ES\&VIEWER_URL=/view/action/singleViewer.do?\&DEL IVERY_RULE_ID $=10 \&$ frameId=1\&usePid1=true\&usePid2=true (acceso el 17-072011).

. Método de harmonium. Madrid: Antonio Romero/Faustino Echevarría, ca. 1884. Edición en castellano y francés, traducción de Óscar Comettant. Accesible en: http://bibliotecadigitalhispanica.bne.es/view/action/singleViewer.do?dvs=13207762 58304 317\&locale=es_ES\&VIEWER_URL=/view/action/singleViewer.do?\&DEL IVERY_RULE_ID=10\&frameId=1\&usePid1=true\&usePid2=true (acceso el 17-072011).

López Cabrera, María del Mar. "Sobre la crítica teatral en la prensa grancanaria (18531900). En: Signa: Revista de la Asociación Española de Semiótica, no 14 (2005), pp. 255-276.Accesible

en: http://dialnet.unirioja.es/servlet/articulo? codigo=1456695 (acceso el 14-04-2011).

López Calo, José. "Hilarión Eslava (1807-1878), precursor del Cecilianismo en España". En: Príncipe de Viana, $\mathrm{n}^{\mathrm{o}} 238$ (2006), pp. 577-608. Ejemplar dedicado a "Conmemoración del VIII Centenario de la Chantía de la Catedral de Pamplona como dignidad eclesiástica (1206-2006)”, coord. María Gembero Ustárroz. 
Accesible

en:

http://dialnet.unirioja.es/servlet/busquedadoc?t=hilari\%C3\%B3n+eslava+precursor $\& \mathrm{db}=1 \& \mathrm{td}=$ todo $($ acceso el 10-08-2011).

López García, José Luis. “Obras de Indalecio Soriano Fuertes (1788-1851) en los archivos musicales de las catedrales de Murcia y de Orihuela (Alicante)". En: Nassarre, 3/2 (1987), pp. 61-93.

. Los fondos musicales existentes en el archivo musical de la Santa Iglesia Catedral de Murcia ubicado en la Capilla de los Junterones de dicha Iglesia Catedral. Murcia: Universidad de Murcia, 1981. Estudio inédito.

López Gómez, Santiago. Antonio Arnao: vida y obra de un poeta murciano del siglo XIX. Murcia: Academia Alfonso X El sabio, 1987.

López Rico, José y Pliego de Andrés, Víctor. Antonio López Almagro, compositor, editor y maestro de harmonium. Murcia, 2010. Estudio inédito.

López, Begoña. "L'activitat concertística d'Isaac Albéniz a Barcelona (1874-1895). Aportació documental i estudi”. En: Recerca Musicològica, 17-18 (2007-2008), pp. 251-277. Accesible en: http://dialnet.unirioja.es/servlet/articulo?codigo $=3128146$ (acceso el 2-09-2011).

Loras Villalonga, Roberto. Estudio de los métodos de solfeo españoles en el siglo XIX y principios del XX. Valencia: Universidad de Valencia, 2008. Tesis Doctoral. Accesible en http://riunet.upv.es/handle/10251/3341 (acceso el 15-07-2011).

Los lombardos: ópera seria en cuatro actos. Murcia: Imprenta de José Carles Palacios, 1847.

Los dos foscaris: tragedia lírica en tres actos. Murcia: Imprenta de José Carlos Palacios, 1846.

M. C. M., "Notas biográficas. D. Julián Calvo García”, programa de mano del ConciertoHomenaje a Julián Calvo García celebrado el 28-02-1969 en el Conservatorio de Murcia. Murcia: Imprenta San Miguel, 1969.

Macchione, Daniela. "Attivitá concertistica e musical strumentale da camera a Roma (1856-1870). En: Rivista Italiana di Musicologia, 37/2 (2002), pp. 265-320.

Majolo Molinari, Olga. La stampa periodica romana dell'Ottocento. Roma: Istituto di studi romani, 1963, 2 vols.

Manresa, Juan Diego. Memoria de la cuestión fermata. Promovida con motivo de haber usado una cantante, de la facultad que este signo le concede, en una obra representada en el teatro Romea de esta capital. Murcia: Establecimiento Tipográfico de La Paz de Murcia, 1877.

Martín Tenllado, Gonzalo. La música en Málaga durante el siglo XIX. Ocón: músico nacionalista en la Catedral de Málaga. Granada: Universidad de Granada: 1991. Tesis Doctoral. Accesible en: http://digibug.ugr.es/handle/10481/14057 (acceso el 11-10-2011). 
Martínez Anguita, $\mathrm{M}^{\mathrm{a}}$ Rosa. La música y los músicos en el Jaén del siglo XIX. Jaén: Ayuntamiento de Jaén, 2000.

Martínez Carrión, José Miguel. Historia económica de la Región de Murcia: siglos XIX y XX. Murcia: Editora Regional de Murcia, 2002.

Martínez García, Salvador y Narejos Bernabeu, Antonio. Pasionaria murciana según los auroros. Murcia: Dirección General de Promoción Cultura, 2008.

Martínez López, Maribel. "El teatro y las gentes de Murcia (1936-1939)". En: Murgetana, $\mathrm{n}^{\mathrm{o}} 109$ (2003), pp. 115-128.

. El Romea y otros teatros de Murcia durante la Guerra Civil. Murcia: Universidad de Murcia, 2003.

Martínez Martínez, Francisco. Fuentes del periodismo, la hemerografía y los medios audiovisuales de la región murciana. Murcia: Instituto de la Comunicación, 1996.

Martínez Tornel, José. Guía de Murcia. Murcia: Imprenta de "El Diario de Murcia", 1887.

Mas y Vives, Joan. El teatre a Mallorca a l'època romántica. Barcelona: Abadía de Monserrat, 1986.

Matía Polo, Inmaculada. "La música popular como base para la construcción de una ópera española: los cancioneros de José Inzenga (1828-1891). En: Musiker: cuadernos de música, $\mathrm{n}^{\mathrm{o}} 17$ (2010), pp. 421-446. Accesible en http://dialnet.unirioja.es/servlet/articulo?codigo=3627490 (acceso el 60-06-2011).

. José Inzenga. La diversidad de acción de un músico español en el siglo XIX (1828-1891). Madrid: Sociedad Española de Musicología, 2010.

Marín, Miguel Ángel. "Familia colegas y amigos. Los músicos catedralicios de la ciudad de Jaca durante el siglo XVIII". Música y cultura urbana en la Edad Moderna, eds. Andrea Bombi, Juan José Carreras y Miguel Ángel Marín. Valencia: Universitat de València, 2005, pp. 115-156.

Máximo, Enrique. "Tadeo Tornel, «ymbentor de ynstrumentos de música»". En: Imafronte, $\mathrm{n}^{\mathrm{o}} 15$ (2000-2001), pp. 167-182. Accesible en http://dialnet.unirioja.es/servlet/articulo?codigo=306095 (acceso el 28-06-2011). . El órgano Merklin Schütze de la Catedral de Murcia. Murcia: Caja Murcia, 1994.

Medina, Vicente. Aires murcianos. Rosario de Santa Fe (Argentina): Vicente Medina, 1923, ilustraciones $y$ fotografías de Vicente Medina. Accesible en http://bvpb.mcu.es/es/consulta/registro.cmd?id=442163 (acceso el 30-06-2011)

Meierovich, Clara. "Enseñanza, crítica y publicaciones periódicas". En: La música en Hispanoamérica en el siglo XIX, eds. Consuelo Carredano y Victoria Eli, vol. 6. Historia de la música en España e Hispanoamérica, dir. y coord. ed. Juan Ángel Vela del Campo. Madrid: Fondo de Cultura Económica de España, 2010, pp. 323364. 
Melendreras Gimeno, José Luis. "El órgano de la Catedral de Murcia". En: El órgano español: actas del II Congreso Español de Órgano, coord. Antonio Bonet Correa. Madrid: Instituto Nacional de las Artes Escénicas y de la Música, 1987, pp.285297.

. "Monumentos murcianos del siglo XIX”. En: Estudios románticos, vol. 6 (19871989), pp. 1697-1712. Accesible en: http://dialnet.unirioja.es/servlet/articulo? codigo=231922 (acceso el 11-08-2011).

. "Escultura decorativa del Casino de Murcia". En: Boletín de la Real Academia de Bellas Artes de San Fernando, $\mathrm{n}^{\mathrm{o}} 80$ (1995), pp.325-341. Accesible en: http://213.0.4.19/FichaObra.html?Ref=22944\&portal=186 (acceso 1-10-2011).

. "Órganos barrocos y neoclásicos levantinos". En: Boletín de la Sociedad Castellonense de Cultura, LXXI/ III (1995), pp. 423-440.

Ménetrat, Andrè. "Artôt". En: Die Musik in Geschichte und Gegenwart, ed. Ludwig Finscher. Kassel: Bärenreiter, 1994, vol. 1, pp. 1050-1051.

Merino Álvarez, Abelardo. Geografía histórica de la Provincia de Murcia. Madrid: Imprenta del Patronato de Huérfanos de Intendencia e Intervención Militares, 1915. Reimpresa en Murcia: Academia Alfonso X El Sabio, 1981.

Miranda, Ricardo. "A tocar, señoritas: una mirada al repertorio mexicano para piano durante el siglo XIX”. En: Música Iberoamericana de Salón, Actas del Congreso Iberoamericano de Musicología, coord. José Peñín. Caracas: Fundación Vicente Emilio Sojo, 2000, vol. I, pp. 131-171.

. "El espejo idealizado: un siglo de ópera en México (1810-1910)". En: La ópera en España e Hispanoamérica, eds. Emilio Casares y Álvaro Torrente. Madrid: Instituto Complutense de Ciencias Musicales, 2001, vol. I, pp. 143-185.

Montalbán Martínez, Nicolás. "Análisis teatral: veinte años de manifestaciones shakesperianas en la Murcia del siglo XIX. Una didáctica finisecular". En: Murgetana, $\mathrm{n}^{\mathrm{o}} 115$ (2006), pp. 109-146.

Montes Bernárdez, Ricardo. "Las murallas de Murcia en el siglo XIX. Reconstrucción y destrucción”. En: Murgetana, no 106 (2002), pp. 95-101. Accesible en: http://dialnet.unirioja.es/servlet/articulo? codigo=2654921 (acceso el 11-08-2011).

. "Los tranvías de Murcia y Cartagena" (1892-1959). En: Estudios sobre Murcia contemporánea. Murcia: Real Academia Alfonso X El Sabio, 2003, pp. 191-213.

. "La iluminación en la Región de Murcia. Orígenes e historia (1797-1935). En: Estudios sobre Murcia contemporánea. Murcia: Real Academia Alfonso X El Sabio, 2003, pp. 173-190.

Montojo Montojo, Vicente. "La administración provincial de Fomento de Murcia, contexto histórico y fuentes documentales. Su remodelación tras el 98”. En: Anales de Historia Contemporánea, 14 (1998), pp. 65-73. 
Morales Villar, María del Coral. Los tratados de canto en España durante el siglo XIX: técnica vocal e interpretación de la música lírica. Granada: Universidad de Granada, Facultad de Filosofía y Letras, 2008. Tesis Doctoral. Accesible en: http://hdl.handle.net/10481/2044 (acceso el 15-09-2011).

Moreno Mengíbar, Andrés. La ópera en Sevilla en el siglo XIX. Sevilla: Universidad de Sevilla, 1998.

Moreno, Juan y Vera Botí, Alfredo. "El edificio-calle y el Casino de Murcia". En: Anales de la Universidad de Murcia. Filosofia y Letras, vol. XXXV, no 1-4 (1978), pp. 227-248.

Muñoz López, Pilar. "Mujeres artistas en España durante el siglo XX: análisis y evolución de las prácticas artísticas femeninas". En: Periphery and Centre III, coords. Rubén Jarazo y Lidia María Montero. La Coruña: Asociación de Estudiantes de Filoloxía Inglesa, 2008, pp. 165-176.

Muñoz Zielinski, Manuel. "Lugares 'selectos' de ocio: casinos, círculos y sociedades". En: Guía secreta de Murcia en el siglo XIX, dir. Ricardo Montes. Murcia: Azarbe, 2008, pp. 241-270.

Muñoz, Adelaida y Cabeza, Antonio. "Algunos aspectos de la vida musical de Palencia en el siglo XIX: Las bandas de música". En: Revista de Musicología, vol. XIV, 1-2 (1991), pp. 277-295.

Nagore Ferrer, María. "La vida zarzuelística en Bilbao (1850-1936). En: La zarzuela en España e Hispanoamérica. Centro y periferia, 1800-1950, Actas del Congreso Internacional celebrado en Madrid en 1995. Cuadernos de Música Iberoamericana, vol. 2-3 (1996-1997), pp. 399-408.

. "Aportaciones al estudio del movimiento coral en España”. En: Miscel-lània Oriol Martorell, ed. Xosé Aviñoa. Barcelona: Universidad de Barcelona, 1998, pp. 345358.

. La revolución coral. Estudio sobre la Sociedad Coral de Bilbao y el movimiento coral europeo (1800-1836). Madrid: Instituto Complutense de Ciencias Musicales, 2002.

. "La Escuela Municipal de Música de Pamplona: una institución pionera en el siglo XIX". En: Príncipe de Viana, $\mathrm{n}^{\circ} 238$ (2006), ejemplar dedicado a "Conmemoración del VIII Centenario de la Chantría de la Catedral de Pamplona como dignidad eclesiástica (1206-2006)”, coord. María Gembero Ustárroz, pp. 537-560.

Navarro Sales, José Manuel. Diccionario de la Lírica en Alicante: casi dos siglos de zarzuela y ópera. Alicante: Instituto Alicantino de Cultura Juan Gil-Albert, 2007.

Nicolás Gómez, Dora. Arquitectura y arquitectos del siglo XIX en Murcia. Murcia: Ayuntamiento de Murcia, Colegio de Arquitectos de Murcia, 1993.

Olavarría y Ferrari, Enrique. Reseña histórica del teatro en México, 1538-1911. México: Porrúa, 1961, $3^{\mathrm{a}}$ ed. 
Oliver Belmás, Antonio. Medio siglo de artistas murcianos (1900-1950). Madrid: Nueva Imprenta Radio, 1952.

Ortega Castejón, José Francisco. "Cantos de labranza, de trilla y de recogida de la hoja en cancioneros murcianos del siglo XIX y principios del XX". En: Revista Murciana de Antropología (2008), no 15, pp. 387-409.

Ortega Pagán, Nicolás; Ortega Lorca, Nicolás y Ortega Lorca, José. Callejero murciano. Murcia: Ayuntamiento de Murcia, 1973.

Ortiz de Urbina Sobrino, Paloma. "La recepción de la obra de Richard Wagner en Madrid entre 1900 y 1914”. En: Cuadernos de Música Iberoamericana, vol. 12 (2006), pp. 89-108.

Palacios Sanz, José Ignacio. “Aproximación histórica a la capilla de música en la Catedral de Burgo de Osma durante el siglo XIX: de Bernardo Pérez al "Motu Proprio". En: Revista de Musicología, 14/1-2 (1991), pp. 549-559.

Pannain Bertone, Alberta (ed.). Catalogo dei giornali/ Biblioteca Nazionale e Centrale Vittorio Emanuele II. Roma: Istituto poligrafico e Zecca dello Stato, 1992.

Parker, Roger. "The opera industry". En: The Cambridge history of nineteenth-century music, ed. Jim Samson. Cambridge: Cambrigde University Press, 2002, pp. 87-117.

Pedrell, Felipe. Diccionario Técnico de la Música, 2a edición. Barcelona: Isidro Torres Oriol, 1894.

Peña y Goñi, Antonio. La música dramática en España en el siglo XIX. Madrid: Imprenta de El Liberal, 1881.

. La ópera española y la música dramática en España en el siglo XIX. Apuntes históricos. Madrid: Instituto Complutense de Ciencias Musicales, 2004. Edición facsímil.

Peñín, José (coord.). Música Iberoamericana de Salón, Actas del Congreso Iberoamericano de Musicología celebrado en Caracas en 1998. Caracas, Fundación Vicente Emilio Sojo, 2000.

Perandones Lozano, Miriam. "María del Carmen de Enrique Granados y el ideal predelliano de ópera española". Delantera de paraíso. Estudios en homenaje a Luis G. Iberni, coords. Celsa Alonso, Carmen Julia Guitérrez y Javier Suárez Pajares. Madrid: Instituto Complutense de Ciencias Musicales, 2008, pp. 201-220.

Pérez Crespo, Antonio. El Entierro de la Sardina y el Bando de la Huerta en el siglo XIX. Murcia: Amigos de Mursiya, 2000-2003, 3 vols.

Pérez Crespo, Antonio. El Lagartija y su época. Murcia: Ayuntamiento de Murcia, 1988. . El Cantón Murciano. Murcia: Academia Alfonso X El Sabio, 1990. 
. "La censura en la prensa murciana: 1870-1880". Actas de las Jornadas sobre prensa y sociedad en la Murcia contemporánea. En: Anales de Historia Contemporánea, 12 (1995-1996), pp. 417-434.

Pérez Picazo, Ma Teresa. "Historia". Oligarquía urbana y campesinado en Murcia (18751902). Murcia: Academia Alfonso X el Sabio, 1979, $2^{a}$ edición.

. "1805-1930: Un tiempo de estancamiento y de transformaciones". En: Historia de la Región murciana, dir. histórica Francisco Chacón Jiménez et al. Murcia: Mediterráneo, 1980-1989, vol. 8, pp. 1-179.

Pérez Picazo, Ma Teresa y Guy Lemeunier. El proceso de modernización de la Región murciana (siglos XVI-XIX). Murcia: Editora Regional Murciana, 1984.

Pérez Rojas, Javier. Casino de la Región Murciana: un estudio preliminar (1850-1920). Valencia: Colegio Oficial de Arquitectos, 1980.

Pérez Samper, María de los Ángeles. "Espacios y prácticas de sociabilidad en el siglo XVIII: tertulias, refrescos y cafés de Barcelona”. En: Cuadernos de Historia Moderna, $\mathrm{n}^{\mathrm{o}} 26$ (2001), pp. 11-55. Accesible en: http://dialnet.unirioja.es/servlet/articulo?codigo=208696 (acceso el 2-09-2011).

Peruarena Arregui, Juan. "Alrededor de la idea del Teatro y su figuración arquitectónica en España”. En: Pensamiento español y música: Siglos XIX y XX, eds. Margarita Vega y Carlos Villar-Taboada. Valladolid: SIMTEM-Glares, 2002, pp. 13-35.

. "Imaginario burgués y arquitectura teatral en la España del siglo XIX". En: Cuadernos de Música, Artes Visuales y Artes Escénicas, 2/1 (2005-2006), pp. 97142. Accesible en http://cuadernosmusicayartes.javeriana.edu.co/ (acceso el 08-082011).

Pico Pascual, Miguel Ángel. "La recopilación de canciones y bailes populares efectuada a finales del siglo XIX por José Inzenga Castellanos en tierras valencianas y murcianas (I)". En: Revista de Folklore, no 187 (1996), pp. 3-13. Accesible en http://www.funjdiaz.net/folklore/07ficha.cfm?id=1534 (acceso el 6-06-2011).

- "Cancioneros españoles del siglo XIX editados en Europa. La obra de A. Fouquier". En: Revista de Folklore, no 279 (2004), pp. 83-85. Accesible en http://www.funjdiaz.net/folklore/07ficha.cfm?id=2139 (acceso el 60-06-2011).

Pidal Fernández, María de los Ángeles. "Breve reflexión sobre la Gaceta musical de Madrid, un modelo de crítica musical en el siglo XIX". En: Miscel-lània Oriol Martorell, ed. Xosé Aviñoa. Barcelona: Universidad de Barcelona, 1998, pp. 359378.

Pina Caballero, Cristina Isabel. "La música civil en la Murcia del siglo XVIII: de Felipe V a Carlos III". En: Revista de Musicología, vol. XXVIII/2 (2005), pp. 1579-1596.

. La música civil en Murcia de Felipe V a Carlos III: del barroco cambio dinástico al esplendor de la Ilustración. Valladolid: Universidad de Valladolid, 2006. Tesis Doctoral inédita. 
. "Órganos y organeros en Murcia entre los reinados de Felipe V y Carlos III: algunas fuentes”. En: Nassarre, 22/1 (2006), pp. 507-528.

- "La Capilla de Música de Santa Cecilia: un ejemplo de asociacionismo en la Murcia del siglo XVIII”. En: Revista de Musicología, 30/1 (2007), pp. 379-393.

Piperno, Franco y Niels Martin Jensen (eds.). The Opera Orchestra in the 18th-and 19thCentury Europe. Berlin: Berliner Wissenschafts-Verlag, 2008, 2 vols.

Piperno, Franco y Rostagno, Franco. "The Orchestra in Nineteenth-Century Italian Opera Houses", eds. Piperno, Franco y Niels Martin Jensen. The Opera Orchestra in the 18th- and 19th-Century Europe. Berlin: Berliner Wissenschafts-Verlag, 2008, vol. I, pp. 15-62.

Pizarroso Quintero, Alejandro. Historia de la prensa. Madrid: Editorial Centro de Estudios Ramón Areces, 1994.

Plantinga, Leo. "The piano and the Nineteenth Century". En: Nineteenth-Century Piano Music, ed. Larry Todd. London: Routledge, 2004, 2a edición, pp. 1-15.

Pliego de Andrés, Víctor. Antonio López Almagro. Catedrático de Harmonium u Órgano Expresivo en la Escuela Nacional de Música y Declamación (1877-1901). Madrid: Real Conservatorio de Música de Madrid, 1986-1987, 2 vols.. Estudio inédito. Accesible en: http://www.profesdemusica.es/curriculo.html (acceso el 18-07-2011).

. “Armonio". En: Diccionario de la Música Española e Hispanoamericana, dir. Emilio Casares. Madrid: Sociedad General de Autores y Editores, 1999-2002, vol. 1 (1999), pp. 693-695.

Polanco Olmos, Rafael. La crítica musical en la prensa diaria valenciana: 1912-1923. Valencia: Universidad de Valencia, 2008. Tesis doctoral. Accesible en: http://www.tesisenxarxa.net/TDX-1111109-090621/index.html (acceso en 12-042011).

Poznasky, Alexander. The Tchaikovsky handbook: a guida to the man and his music, 2 vols. Indianapolis: Indiana University Press, 2002.

Prats Redondo, Consuelo. "Murcia". En: Diccionario de la Música Española e Hispanoamericana, dir. Emilio Casares. Madrid: Sociedad General de Autores y Editores, 1999-2002, vol. 7 (1999), pp. 889-896.

. Educación Musical en la Catedral de Murcia: Los infantes de coro y el Colegio de San Leandro, 1600-1760. Murcia: Universidad de Murcia, Facultad de Letras, 2004, trabajo de investigación inédito para la obtención del D.E.A.

- Música y músicos en la Catedral de Murcia entre 1600-1750. Murcia: Universidad de Murcia, 2010. Tesis doctoral inédita.

Quintana, Hugo. "El movimiento musical de la Caracas de fines del siglo XIX y principios del XX, visto a través de las páginas de El cojo ilustrado". En: Música Iberoamericana de Salón, coord. José Peñín. Caracas: Fundación Vicente Emilio Sojo, 2000, vol. II, pp. 445-491. 
. "La música de salón en Colombia y Venezuela, vista a través de las publicaciones periódicas de la segunda mitad del siglo XIX y las primeras décadas del siglo XX. A propósito de un ejercicio de historia musical comparada". A tres bandas: mestizaje, sincretismo e hibridación en el espacio sonoro iberoamericano, dir. Albert Recasens Barberá. Madrid: Akal, 2010, pp. pp. 91-99.

Ramos, Vicente. El Teatro Principal en la historia de Alicante (1847-1947). Alicante: Sucesor de Duch, Serra y Compañía, 1965.

Reglamento de La Juventud, sociedad de enseñanza. Murcia: Imprenta de J. Sellés, 1868.

Reglamento de la Sociedad Belluga aprobado por el señor Gobernador Civil de la Provincia en 2 de mayo de 1885. Murcia: Establecimiento Tipográfico de "El Noticiero", 1885.

Reglamento del Círculo Industrial de Murcia. Murcia: Establecimiento Tipográfico de "El Obrero", 1873.

Reglamento del Círculo Industrial de Murcia. Murcia: Imprenta de Francisco Bernabeu, 1863.

Reglamento orgánico de la sociedad de enseñanza La Juventud. Murcia: Imprenta de Pedro Belda, 1867.

Reglamento para el buen régimen y orden interior del Círculo Industrial de Murcia. Murcia: Imprenta de Francisco Bernabeu, 1865.

Reglamentos orgánico e interior del Círculo Industrial de Murcia. Murcia: Establecimiento Tipográfico de "La Paz", 1870.

Rey García, Emilio y Pliego de Andrés, Víctor. "La recopilación de la música popular española en el siglo XIX: cien cancioneros en cien años". En: Revista de Musicología, 14/1-2 (1991), pp. 355-374.

Reyes de la Maza, Luis. El teatro en México durante el Segundo Imperio (1862-1867). México: Imprenta Universitaria, 1959.

Rigolli, Alessandro. La divulgazione musicale in Italia oggi. Atti del Convegno Parma, 5 e 6 novembre 2004. Parma: Istituzione Casa della Musica, 2005.

Rink, John, “The profession of music". En: The Cambridge history of nineteenth-century music, ed. Jim Samson. Cambridge: Cambrigde University Press, 2002, pp. 55-86.

Rioja, Eusebio. "El guitarrista Julián Arcas. Sus relaciones con Málaga”, Jábega, no 84 (2000), pp. 73-87, http://www.cedma.com/archivo/jabega_pdf/jabega84_73-87.pdf (acceso en 12-06-2011).

. "Julián Arcas Lacal (1832-1882), concertista internacional, compositor y maestro de guitarra". En: Revista velezana, $\mathrm{n}^{\circ} 12$ (1993), pp. 43-54.

RIPM. Retrospective Index to Music Periodicals. (http://www.nisc.org, acceso en 3 de abril de 2010). 
Rocamora Rivera, Bartolomé. Los auroros de Murcia: origen, ritual y canto. Murcia: Dirección General de Cultura, 2006.

Rodríguez Legendre, Fidel. "Los compositores venezolanos y la música de salón en las publicaciones Lira Venezolana y El Zancudo 1880-1883". En: Música Iberoamericana de salón. Actas del Congreso Iberoamericano de Musicología, coord. José Peñín. Caracas: Fundación Vicente Emilio Sojo, 2000, vol. I, pp. 279319.

Rodríguez Llopis, Miguel. Historia de la Región de Murcia. Murcia: Editora Regional de Murcia, 1998.

Rodríguez Llopis, Miguel (dir.) y Martínez Carrión, José Miguel (coord.). Atlas histórico ilustrado de la región de Murcia y su antiguo reino. Murcia: Fundación Séneca, Agencia de Ciencia y Tecnología de la Región de Murcia, 2006.

Rodríguez Maraver, Francisco Javier. "Don Bartolomé Cabello Barroso, un pileño ilustrado". En: Sobre historia de Pilas. VI Jornada sobre Historia de Pilas celebrada el 16 de febrero de 2008. Pilas (Sevilla): Ayuntamiento de Pilas, 2008, vol. VI, pp. 19-136.

Roselló i Verguer, Vicente María. Evolución urbana de Murcia (831-1973). Murcia: Ayuntamiento de Murcia, 1975.

Rosenthal, Harold. "Artôt Marguerite-Joséphine Désirée Montagney". En: The New Grove Dictionary of Music and Musicians, ed. Stanley Sadie, 29 vols., $2^{\mathrm{a}}$ edición. London: Macmillan, 2001, vol. 2, p. 93.

Rubio Arróniz, Miguel. El Carnaval de Murcia en el año 1854. Poema Joco-Serio. Murcia: Imprenta R. Vivancos, 1858.

. Crónica Oficial de los festejos celebrados en la ciudad de Murcia en los días 24, 25, 26 y 27 de octubre de 1862, con motivo de la visita de SS. MM. y AA. a dicha población. Murcia: Imprenta de Anselmo Arques, 1862. Biblioteca Digital de la Región de Murcia. Accesible en: http://bibliotecadigital.carm.es/opac/ficha.php?informatico=00000133MO\&idpag= $516357897 \&$ codopac $=$ OP040 $($ acceso el 4-08-2011).

Rubio García, Luis. "Documentos para la historia del teatro en Murcia". Murgetana, 94 (1997), pp. 73-87.

Ruiz Tarazona, Andrés. "Puig, Antonio". En: Diccionario de la Música Española e Hispanoamericana, dir. Emilio Casares. Madrid: Sociedad General de Autores y Editores, 1999-2002, vol. 8 (2001), p. 998.

Saavedra Robaina, Isabel y Siemens, Lothar. "El asociacionismo musical en España: el camino hacia un marco legal", Revista de Musicología, XXVIII/1 (2005), pp. 269279.

Sadie, Stanley (ed.). The New Grove Dictionary of Music and Musicians, $2^{\mathrm{a}}$ edición. London: Macmillan, 2001, 2001, 29 vols., $2^{a}$ edición. 
Sáez Gómez, José Miguel; Marset Campos, Pedro y Crespo León, Fernando. "El cólera de 1885 y las polémicas doctrinales en la presa". En: Llull: Revista de la Sociedad Española de Historia de las Ciencias y de las Técnicas, 20/38 (1997), pp. 273-292.

Sagaseta Aríztegui, Aurelio. "García Zalba, Mariano". En: Diccionario de la Música Española e Hispanoamericana, dir. Emilio Casares. Madrid: Sociedad General de Autores y Editores, 1999-2002, vol. 5 (1999), pp. 502-503.

. "Mariano García Zalba (1809-1869): nuevas aportaciones sobre su biografía y producción musical". En: De Musica hispana et aliis, miscelánea en honor al Prof. Dr. D. José López-Calvo, 2 vols, ed. Emilio Casares y Carlos Villanueva. Santiago de Compostela: Universidad de Santiago de Compostela, 1990, vol. II, pp. 231-224.

Salaün, Serge. "La zarzuela, híbrida y castiza". En: La zarzuela en España e Hispanoamérica. Centro y periferia, 1800-1950, Actas del Congreso Internacional celebrado en Madrid en 1995. Cuadernos de Música Iberoamericana, vol. 2-3 (1996-1997), pp. 235-256.

Saldoni, Baltasar. Diccionario Biográfico-Bibliográfico de efemérides de músicos españoles. Madrid: Ministerio de Cultura, 1986, 4 vols. Edición facsímil de Madrid, Imprenta de Antonio Pérez Dubrull, 1887.

Salón Romero. Almanaque Musical para el año 1885. Madrid: Antonio Romero, 1885.

Samson, Jim (ed.). The Cambridge history of nineteenth-century music. Cambridge: Cambrigde University Press, 2002.

Sánchez Alcolea, Diego. Proyecto de automatización de los fondos musicales del Casino de Murcia. Murcia: Universidad de Murcia, Escuela de Biblioteconomía, 1994. Trabajo Fin de Carrera.

Sánchez de Andrés, Leticia. "Compositoras españolas del siglo XIX: la lucha por espacios de libertad creativa desde el modelo de feminidad decimonónico". En: Compositoras españolas: la creación musical femenina desde la Edad Media hasta la actualidad, ed. Álvarez Cañibano et al. Madrid: Instituto Nacional de Artes Escénicas y Música, Centro de Documentación de Música y Danza, pp. 55-74.

Sánchez Huedo, Olga. La actividad artístico-musical de Albacete en la segunda mitad del siglo XIX. Albacete: Instituto de Estudios Albacetenses "Don Juan Manuel" de la Excelentísima Diputación de Alicante, 2004.

Sánchez Pérez, Ramón. "Don Acisclo Díaz Rochel y la Casa de la Misericordia". 50 Aniversario de la Cofradía del Santísimo Cristo de la Misericordia. Murcia, 1999. Accesible en http://cofradiamisericordia.net/inicio.htm (acceso el 16-07-2011), p. 31 .

Sánchez Sánchez, Víctor. Tomás Bretón. Un músico de la restauración. Madrid: ICMMU, 2002.

. "Es California una tierra ideal... Sonidos españoles en la California del Gold Rush". En: Cuadernos de Música Iberoamericana, vol. 17 (2009), pp. 131-154 
. "Es California una tierra ideal... (2). Zarzuelas en los teatros de San Francisco durante el siglo XIX”. En: Cuadernos de Música Iberoamericana, vol. 19 (2010), pp. 117-144.

Sancho García, Manuel. El sinfonismo en Valencia durante la Restauración (1876-1916). Valencia: Universidad de Valencia, 2003.

. Romanticismo y música instrumental en Valencia (1832-1916). Valencia: Institució Alfons el Magnánim, Diputació de Valencia, 2007.

Sanz Romero de Castellón, Ma Elisa. "Escenografía del Teatro Romea de Murcia de 1862 a 1877’. En: Imafronte, 8-9 (1992-93), pp. 379-387.

Scott, Derek B. "Music and social class". En: The Cambridge history of nineteenthcentury music, ed. Jim Samson. Cambridge: Cambrigde University Press, 2002, pp. 544-567.

Selgas Ruiz, José. Partida disuelta. Madrid: Velasco, 1909.

Seoane Couceiro, Ma Cruz. Historia del periodismo en España, II. El siglo XIX. En: Historia del periodismo en España, dirs. $\mathrm{M}^{\mathrm{a}}$ Dolores Sáiz y $\mathrm{M}^{\mathrm{a}}$ Cruz Seoane. Madrid: Alianza Editorial, 1983-1996, 3 vols.

Sirera, Josep Lluís. El Teatre Principal de València: aproximació a la seua história. Valencia: Institució Alfons el Magnànim, 1986.

Sobrino, Ramón. "Un estudio de la prensa musical española en el siglo XIX: vaciado científico e índices informáticos de la prensa musical española”. En: Revista de Musicología, vol. XVI, 6 (1993), pp. 52-60.

"Calvo García, Julián”. En: Diccionario de la Música Española e Hispanoamericana, dir. Emilio Casares. Madrid: Sociedad General de Autores y Editores, 1999-2002, vol. 2 (1999), pp. 942-944.

. “Espinosa de los Monteros, Gaspar”. En: Diccionario de la Música Española e Hispanoamericana, dir. Emilio Casares. Madrid: Sociedad General de Autores y Editores, 1999-2002, vol. 4 (1999), pp. 783-784.

. "La Sociedad de Conciertos de Madrid, un modelo de sociedad profesional". En: Cuadernos de Música Iberoamericana, 8-9 (2001), pp. 125-148.

. "La ópera española entre 1850 y 1874: Bases para una revisión crítica". En: $L a$ ópera en España e Hispanoamérica, eds. Emilio Casares y Álvaro. Madrid: Instituto Complutense de Ciencias Musicales, 2002, vol. I, pp. 77-142.

. "Vicente Bermejo [Arche], José". En: Diccionario de la Música Española e Hispanoamericana, dir. Emilio Casares. Madrid: Sociedad General de Autores y Editores, 1999-2002, vol. 10 (2002), pp. 847-848.

. "Canción de la Lola, La o Celos engendran desdichas". En: Diccionario de la Zarzuela. España e Hispanoamérica, dir. Emilio Casares, 2 vols. Madrid: Instituto Complutense de Ciencias Musicales, 2006, 2a edición, vol. I, pp. 374-378. 
. "Espinosa de los Monteros y Jiménez, Gaspar". En: Diccionario de la Zarzuela. España e Hispanoamérica, dir. Emilio Casares, 2 vols. Madrid: Instituto Complutense de Ciencias Musicales, 2006, 2ª edición, vol. I, p. 717.

. "Orquesta". En: Diccionario de la Zarzuela. España e Hispanoamérica, dir. Emilio Casares, 2 vols. Madrid: Instituto Complutense de Ciencias Musicales, 2006, $2^{\mathrm{a}}$ edición, vol. II, pp. 381-385.

Soler Gómez, Pedro. Manuel Fernández Caballero. Un músico murciano para la historia. Murcia: Real Academia de Bellas Artes de Santa María de la Arrixaca, 2006.

Soriano Fuertes, Mariano. Historia de la música española desde la venida de los fenicios hasta el año de 1850. Madrid: Instituto Complutense de Ciencias Musicales, 2007. Edición facsímil. Introducción a cargo de Juan José Carreras.

Stevenson, Robert. "México city". En: The New Grove Dictionary of Music and Musicians, ed. Stanley Sadie, 29 vols., 2a edición. London: Macmillan, 2001, vol. 16 , pp. 557-558.

Suárez Pajares, Javier. "Julián Arcas: figura clave en la historia de la guitarra española". En: Revista de Musicología, 16/6 (1993), pp. 3344-3368.

. “Guitarra. España. El siglo XIX”. En: Diccionario de la Música Española e Hispanoamericana, dir. Emilio Casares. Madrid: Sociedad General de Autores y Editores, 1999-2002, vol. 5 (1999), pp. 104-108.

- "Martínez Toboso, José". En: Diccionario de la Música Española e Hispanoamericana, dir. Emilio Casares. Madrid: Sociedad General de Autores y Editores, 1999-2002, vol. 7 (2000), pp. 306-307.

. “Mas, Benito". En: Diccionario de la Música Española e Hispanoamericana, dir. Emilio Casares. Madrid: Sociedad General de Autores y Editores, 1999-2002, vol. 7 (2000), p. 321.

Suárez Pajares, Javier y Rioja, Eusebio. El guitarrista almeriense Julián Arcas (18321882): una biografia documental. Almería: Instituto de Estudios Almerienses, 2003.

Suárez, José Ignacio. "La recepción de la obra de Richard Wagner en Madrid entre 1861 y 1876”. En: Cuadernos de Música Iberoamericana, vol. 10 (2005), pp. 71-96.

. "La recepción de la obra de Richard Wagner en Madrid entre 1877 y 1893". En: Cuadernos de Música Iberoamericana, vol. 14 (2007), pp. 73-141.

Subirá, José. Historia de la música teatral en España. Barcelona: Editorial Labor, 1945. . La ópera en los teatros de Barcelona. Estudio histórico-cronológico desde el siglo XVIII al XX. Barcelona: Librería Millá, 1946.

. Historia y anecdotario del Teatro Real. Madrid: Editorial Plus Ultra, 1949. 
Historia de la música. Barcelona: Salvat, 1958, $3^{\text {a }}$ edición.

Tejera y Ramón de Moncada, José Pío. Biblioteca del murciano o Ensayo de un diccionario biográfico y bibliográfico de la literatura en Murcia. Madrid: Tipografía de la Revista de Archivos Bibliotecas y Museos, 1922, 3 tomos.

Torres Mulas, Jacinto. "La prensa musical madrileña. Bases para un estudio". En: Actas de las II Jornadas de Estudios sobre la Provincia de Madrid. Madrid: Diputación Provincial, 1981, pp. 385-389;

. Las publicaciones periódicas musicales en España (1812-1990). Estudio críticobibliográfico. Repertorio general. Madrid: Instituto de Bibliografía Musical, 1991, $2^{\mathrm{a}}$ edición ampliada.

- "Fuentes documentales para el estudio del romanticismo musical español. Un centenar y medio de revistas musicales". En: Revista de Musicología, 14 (1991), pp. $31-44$.

. "El trasfondo social de la prensa musical española en el siglo XIX". En: Revista de Musicología, 16/3 (1993), pp. 1679-1700.

. "El 'Repertorio de Periódicos Musicales en Bibliotecas Españolas' en Internet”. En: AEDOM: Boletín de la Asociación Española de Documentación Musical, $\mathrm{n}^{\mathrm{o}} 1$ (1995), pp. 145-146.

. "Filarmonía y prensa musical". En: Hemeroteca Municipal de Madrid. 75 Aniversario. Madrid: Ayuntamiento de Madrid, Cultura y Medio Ambiente, Departamento de Archivos y Bibliotecas, 1995, pp.165-167.

. "La prensa musical española en RIMP". En: AEDOM: Boletín de la Asociación Española de Documentación Musical, 4, 2, VII-XII (1997), pp. 97-100.

. "Music periodicals in Spain. Beginnings and Historical Development". En: Fontes Artis Musicae, 44/4 (1997), pp. 331-342;

- "Economía y poder en las publicaciones periódicas musicales. Una revisión tipológica", Nassarre, 14/1 (1998), pp. 9-38.

. "El Anfión Matritense, periódico filarmónico-poético". En: Trabajos de la Asociación Española de Bibliografía, II. Madrid: Nuevo Siglo, 1998, pp. 421-458.

- "El valor historiográfico de las publicaciones periódicas: Bilbao y la prensa musical". En: Bidebarrieta III Simposio "Bilbao, 700 años de memoria. Una ciudad musical”, (1998), pp. 195-219.

. "Estrategias y criterios para los volúmenes españoles del Repertorio Internacional de la Prensa Musical (RIPM)". $18^{\circ}$ Congreso de la Asociación Internacional de Bibliotecas Musicales, Archivos y Centros de Documentación. Madrid: Asociación Española de Documentación Musical, 1999, pp. 327-330.

- "Periódicos musicales. España". En: Diccionario de la Música Española e Hispanoamericana, dir. Emilio Casares. Madrid: Sociedad General de Autores y 
Editores, 1999-2002, vol. 8 (2001), pp. 692-703.Tuñón de Lara, Manuel (dir.). La prensa de los siglos XIX y XX. Bilbao: Universidad del País Vasco, 1986.

Tuñón de Lara, Manuel; Elorza, Antonio y Pérez Ledesma, Manuel (eds.). Prensa y sociedad en España (1820-1936). Madrid: Edicusa, 1975.

Turina Gómez, Joaquín. Historia del teatro Real. Madrid: Alianza Editorial, 1997.

Tusa, Michael C. "Carl Maria (Friedich Ernst) von Weber". En: The New Grove Dictionary of Music and Musicians, ed. Stanley Sadie, 29 vols., $2^{\mathrm{a}}$ edición. New London: Macmillan, 2001, vol. 27, pp. 135-172.

Uría, Jorge. "La taberna. Un espacio multifuncional de sociabilidad popular en la Restauración española". En: Hispania. Revista española de historia, 63/214 (2003), $\mathrm{n}^{\mathrm{o}} 214$, pp. 571-604.

Valero Abril, Pilar. La música en los cafés-concierto y en los cines murcianos a principios del siglo XX. Logroño: Universidad de La Rioja, 2009, 102 pp., Trabajo de Investigación Tutelada para la obtención del D.E.A., inédito.

Valls, Josep-Francesc. Prensa y burguesía en el XIX español. Barcelona: Anthropos, 1988.

Vargas Liñán, Belén. "La música en el Álbum Granadino: un periódico intelectual de mediados del siglo XIX”. En: Revista de Musicología, 28/1 (2005), pp. 426-442.

- "La música en la prensa femenina de México: 'La Semana de las Señoritas Mexicanas' (1850-1852)”. En: La música y el Atlántico. Relaciones musicales entre España y Latinoamérica, coords. y eds. María Gembero y Emilio Ros-Fábregas. Granada: Universidad de Granada, 2007, pp. 455-486.

- "La música en la prensa femenina andaluza del siglo XIX a través de 'La Moda' de Cádiz". El patrimonio musical de Andalucía y sus relaciones con el contexto ibérico, eds. Francisco Giménez, Joaquín López y Consuelo Pérez. Granada: Universidad de Granada, 2008, pp. 345-364.

Vázquez Tur, Mariano. "Piano de salón y piano de concierto en la España del siglo XIX". En: Revista de Musicología, 14/1-2 (1991), pp. 225-248.

Vázquez Tur, Mariano y Garbayo, Javier. “López Almagro, Antonio”. En: Diccionario de la Música Española e Hispanoamericana, dir. Emilio Casares. Madrid: Sociedad General de Autores y Editores, 1999-2002, vol. 6 (2000), pp. 1002-1003.

Vega Toscano, Ana. "Métodos españoles de piano en el siglo XIX". En: Cuadernos de Música Iberoamericana, vol. 5 (1998), pp. 129-146.

. "La escuela española de piano en el siglo XIX: Métodos, estudios y literatura pedagógica”. Música Iberoamericana de Salón, ed. José Peñín. Caracas: Fundación Vicente Emilio Sojo, 2000, vol. I, pp. 93-130.

Veintimilla Bonet, Alberto. El clarinetista Antonio Romero y Andía (1815-1886). Oviedo: Universidad de Oviedo, 2002, 2 vols. Tesis Doctoral. Accesible en 
http://www.consmupa.com/web/files/ta/tesis/TESIS-AVB-optimizada.pdf (acceso el 16-07-2011).

Vera Botí, Alfredo. El casino de Murcia: notas para la historia de la arquitectura ecléctica. Murcia: Colegio Oficial de Arquitectos, 1991.

. "El Casino". En: Cuadernos de patrimonio histórico-artístico de Murcia. Asociación Patrimonio Siglo XXI, no 33 (1998), pp. 1-32.

Verdú Landívar, José. Cancionero popular de la Región de Murcia. Murcia: Academia de Bellas Artes de Murcia, 2001.

Verti, Roberto. "La presenza della musica nei periodici bolognesi dal 1800 al 1830". En: Periodica Músicagau, 1 (1983), pp. 21-26.

Vicente Jara, Francisco. Política educativa, escuela y sociedad en Murcia del siglo XIX (1800-1857). Murcia: Diego Marín Editor, 1997.

Vilanova Rivas, Mercedes y Moreno Juliá, Xavier. Atlas de la evolución del analfabetismo en España de 1887 a 1981. Madrid: Centro de Publicaciones del Ministerio de Educación y Ciencia, 1992.

Vilar García, $\mathrm{M}^{\mathrm{a}}$ José Territorio y ordenación y administrativa en la España Contemporánea. Los orígenes de la actual Región uniprovincial de Murcia. Murcia: Asamblea Regional de Murcia y Real Academia Alfonso X El Sabio, 2004.

- "Entre la Ilustración y la Revolución: 'El Correo Literario de Murcia' en los orígenes de la prensa murciana (1792-1795)". En: Historia, politica y cultura: homenaje a Javier Tusell. Madrid: Universidad Nacional de Educación a Distancia, 2009, pp. 353-375.

Vilar Ramírez, Juan Bautista. Murcia: de la emigración a la inmigración. Murcia: Fundación Centro Estudios Históricos e Investigaciones Locales, 2002.

Viñao Frago, Antonio. Historia y educación en Murcia. Murcia: Universidad de Murcia, 1983.

. "El proceso de alfabetización en el municipio de Murcia (1759-1860)". En: La Ilustración española. Alicante: Instituto Juan Gil- Albert, Diputación Provincial de Alicante, 1985, pp. 235-250.

. "Historia de un largo proceso". En: Cuadernos de Pedagogía, no 179 (1990), pp. 45-50.

Virella i Cassañes, Francisco. La ópera en Barcelona. Estudio histórico-crítico. Barcelona: Establecimiento tipográfico de Redondo y Xumetra, 1888.

Virgili Blanquet, María Antonia. "Música y teatro en Valladolid en el siglo XIX". En: Revista de Musicología, 10/ 2 (1987), pp. 653-659. 
. "La música religiosa en el siglo XIX español”. La música española en el siglo $X I X$, eds. Emilio Casares y Celsa Alonso. Oviedo: Universidad de Oviedo, 1995, pp. 375-405.

. "La zarzuela en Castilla". En: La zarzuela en España e Hispanoamérica. Centro y periferia, 1800-1950, Actas del Congreso Internacional celebrado en Madrid en 1995. Cuadernos de Música Iberoamericana, vol. 2-3 (1996-1997), pp. 363-397.

. "El pensamiento musical y la estética de salón en la España del siglo XIX". En: Música Iberoamericana de Salón, Actas del Congreso Iberoamericano de Musicología 1998, coord. José Peñín. Caracas: Fundación Vicente Emilio Sojo, 2000, vol. I, pp. 11-3.

"Asociaciones musicales decimonónicas: el Liceo Artístico y Literario vallisoletano (1842) y su contexto en Castilla y León”. En: Delantera de paraíso: estudios en homenaje a Luis G. Iberni, coord. Celsa Alonso González, Carmen Julia Guitérrez, Javier Suárez Pajares. Madrid: Instituto Complutense de Ciencias Musicales 2008, pp. 369-380.

Weber, William. Music and the Middle Class. The Social Structure of Concert Life in London, Paris and Vienna. London: Croom Held, 1975.

Wiley, Roland John. "Tchaikovsky [Chaykovsky], Modest Il'ych [Il'ich]”. En: The New Grove Dictionary of Music and Musicians, ed. Stanley Sadie, 29 vols., $2^{\mathrm{a}}$ edición. London: Macmillan, 2001, vol. 25, pp. 143-183.

Yanes Mesa, Julio Antonio. Metodología de la historia de la comunicación social en Canarias. La prensa y las fuentes hemerográficas. Tenerife: Baile del Sol, 2005.

Zamacois, Eduardo. Tipos de café. Siluetas contemporáneas. Madrid: Resurrección, 1936. 



\section{Tablas}

1.1 Evolución demográfica de Murcia en el contexto español (1787-1910)

1.2 Evolución de la población del municipio de Murcia (1860-1901)

1.3 Población rural y urbana del municipio de Murcia (1860-1899)

1.4 Evolución porcentual de la alfabetización en la Región de Murcia, por sexos (1860-1910)

1.5 Niños escolarizados en la ciudad de Murcia (1830-1855)

1.6 Cuotas de suscripción y cantidades generadas al periódico La Paz de Murcia en 1867

1.7 Evolución porcentual de las noticias de interés musical en periódicos de Murcia (1800-1851)

1.8 Porcentajes de ejemplares con noticias de interés musical de La Paz de Murcia (1858-1895)

2.1 Financiación del nuevo Teatro de los Infantes de Murcia

2.2 Precios de las localidades en el Teatro de los Infantes y posterior Teatro Romea (1858-1887)

2.3 Precios diarios de las localidades del Teatro Romea de la compañía de zarzuela de Ventura de la Vega (Romea, segunda temporada de 1885-1886)

2.4 Precios de las localidades del Teatro Romea

con la compañía de zarzuela de Enrique Lloret (Romea, primera temporada de 1889-1890)

2.5 Plazas vacantes en las orquestas dirigidas por Fernando Verdú y José Mirete (1891)

2.6 Compañías teatrales que actuaron en Murcia con orquestas de menos de cuarenta componentes

3.1 Zarzuelas más interpretadas en el Teatro Provisional de Murcia (1858-1860)

3.2 Compañías teatrales del Teatro Romea (1895-1899)

3.3 Circuito de actuaciones de la compañía de Manuel Taberner (1892-1893)

3.4 Compositores y zarzuelas más representadas en el Teatro de los Infantes de Murcia (1862-1871).

3.5 Compositores y zarzuelas más representadas en el Teatro Romea (1871-1888)

3.6 Comparativa de años de estreno de algunas zarzuelas bufas en Madrid y Murcia

3.7 Compositores de zarzuelas más representadas en el Teatro Romea (1888-1895)

3.8 Evolución de la extensión de las zarzuelas representadas en el Teatro InfantesRomea de Murcia (1862-1895)

3.9 Zarzuelas representadas por la compañía de Rafael Villalonga en el Teatro Circo de la Rambla de Murcia (1880)

3.10 Representaciones de zarzuela y ópera de la compañía de Eugenio Fernández en el Teatro Circo de la Rambla (1880-1881)

3.11 Compositores y obras más representadas en el Teatro Circo de la Rambla de Murcia (1880-1885)

3.12 Representaciones de zarzuela de la compañía de Eduardo Ortiz en el Teatro Circo Villar de Murcia (1893-1894)

3.13 Géneros teatrales en los teatros Romea y Circo Villar de Murcia (1893-1895)

3.14 Zarzuelas representadas por la compañía de Ventura de la Vega en el Teatro Circo Villar de Murcia (1894)

3.15 Representaciones de zarzuela de la compañía de Lino Ruiloa en el Teatro Circo Villar de Murcia (1894-1895) 
3.16 Compositores y obras más representadas en el Teatro Circo de Villar entre 1893 y 1895

3.17 Zarzuelas de autores murcianos estrenadas en los teatros Provisional, Romea y Circo Villar de Murcia (1860-1895)

3.18 Números musicales de la zarzuela infantil en dos actos, Una broma de estudiantes, de Julián Calvo (1860).

3.19 Malasangre (1892) de Pedro Muñoz Pedrera (música) y Joaquín Arques (libreto), zarzuela en un acto: estructura musical

3.20 Representaciones de zarzuela de la Compañía Romana de Opereta y Baile de Gaetano Tani en el Teatro Romea de Murcia (1894)

4.1 Representaciones de las compañías de ópera del Teatro Romea (1881-1899)

4.2 Representaciones completas de ópera en los teatros del Toro y Provisional de Murcia (1851-1880)

4.3 Repertorio de títulos anunciados por las compañías de ópera que actuaron en el Teatro Romea (1881-1899)

4.4 Óperas representadas de forma íntegra en el Teatro Romea de Murcia (18811899)

4.5 Primeras representaciones documentadas de ópera en Murcia

4.6 Compositores y títulos más representados en el Teatro Romea de Murcia por las diferentes compañías de ópera (1881-1899)

5.1 Conciertos en los teatros murcianos (1859-1899)

5.2 Obras interpretadas por Julián Arcas en los teatros murcianos (1859-1881)

5.3 Obras interpretadas por el Sexteto Arche en el Teatro Romea de Murcia (1883)

6.1 Funciones teatrales organizadas por la sociedad Liceo de Murcia (1858-1859)

6.2 Autores y obras más interpretadas en los conciertos de la Sociedad Filarmónica $y$ Coral de Murcia (1867-1868)

6.3 Enseñanzas y profesorado según el proyecto de creación de un conservatorio murciano (1881)

6.4 Músicos documentados que participaron en los conciertos de la Sociedad Santa Cecilia (1882-1883)

6.5 Repertorio interpretado en los conciertos de la sociedad Santa Cecilia (18821883)

6.6 Eventos celebrados por la festividad de Santa Cecilia en los años 1880-1884, 1886,1889 y 1891

6.7 Programa musical y discurso de la ceremonia de entrega de premios a los alumnos de la Casa de Misericordia de Murcia el 12 de diciembre de 1886 en el Instituto Provincial de Segunda Enseñanza

6.8 Programa musical del acto de inauguración de la Sociedad Filarmónica Fernández Caballero (4-12-1892)

6.9 Programa musical de la velada en los salones de la Juventud Católica (26-011872)

6.10 Alumnos de Antonio Ramírez, Julián Calvo y Mariano García que tomaron parte en las veladas musicales de la Real Sociedad Económica de Amigos del País de Murcia (1881)

6.11 Zarzuelas representadas por la compañía de Galinier en el Teatro del Porvenir entre julio de 1887 y enero de 1888

6.12 Programa musical de la velada en el Círculo Católico Obrero de Murcia (1406-1892)

7.1 Veladas musicales del Café del Sol 
7.2 Conjuntos instrumentales e intérpretes habituales del Café Oriental (18861894)

7.3 Compositores de ópera interpretados en las veladas del Café Oriental (18761879, 1886-1888, 1890-1892)

9.1 Premios recibidos por Julián Calvo en certámenes de ámbito nacional (18791892)

9.2 Obras publicadas de Julián Calvo

9.3 Obras de Mariano García en el Archivo Musical de la Catedral de Murcia

9.4 Bandas de música murcianas durante la segunda mitad del siglo XIX

9.5 Obras de Luis Mondéjar Brocal en la $E: M n$

10.1 Colaboraciones periodísticas de Mariano Padilla con El Diario de Murcia (1895-1899)

10.2 Óperas y personajes representados por Mariano Padilla a lo largo de su vida

11.1 Jurados de música de los Juegos Florales de Murcia (1874-1881)

11.2 Composiciones musicales exigidas en los Juegos Florales de Murcia (1874$1877,1879,1881$ )

11.3 Ganadores de la sección de Música en los Juegos Florales de Murcia, septiembre de 1883

11.4 Obras premiadas en el Certamen Artístico del Ayuntamiento de Murcia (1887)

11.5 Profesores de piano en la ciudad de Murcia (1814-1864)

11.6 Pianos de fabricación murciana existentes en la ciudad de Murcia (1878)

11.7 Almacenes y venta de pianos en Murcia durante la segunda mitad del siglo XIX

11.8 Cantos recogidos en Alegrías y tristezas de Murcia de Julián Calvo (1877) 



\section{Figuras}

I. La Paz de Murcia, I (1858), no 13, 2 marzo, p. 1

1.1 Vista de la ciudad de Murcia (1879)

1.2 Paisaje de la huerta murciana. Primera mitad del siglo XIX

1.3 Plaza de toros de Murcia. Primera mitad del siglo XIX

1.4 Retrato de José Martínez Tornel, director de El Diario de Murcia

1.5 Cabecera de El Diario de Murcia, I (1879), no 3, 18 febrero, p. 1

1.6 Cabecera del primer ejemplar conservado del periódico La Paz de Murcia, I (1858), $\mathrm{n}^{\mathrm{o}} 13,2$ marzo, p. 1

1.7 Cabecera del último ejemplar conservado de La Paz de Murcia, XXXVII (1895), no 12940, 31 marzo, p. 1

1.8 Edición especial de La Paz de Murcia, II (1859), no 497, 29 septiembre, p. 1

1.9 En primer plano, cabecera del suplemento a La Paz de Murcia, IX (1866), ${ }^{\circ}$ 2546, 27 de mayo, p. 1. Detrás, La Paz de Murcia, IX (1866), nº 2547, 28 mayo, p. 1

1.10 Cabecera especial de La Paz de Murcia, XVIII (1875), $\mathrm{n}^{\mathrm{o}}$ 5253, 1 enero, p. 1 dedicada a Alfonso XII de Borbón

II. Teatro Romea de Murcia

2.1 Ubicación del Teatro Romea, originariamente denominado Teatro de los Infantes

2.2 Retrato de Julián Romea (1813-1868)

2.3 Patio de butacas, palcos y plateas del Teatro Romea, antes de su cierre en 2007

2.4 Vestíbulo de entrada al Teatro Romea de Murcia, antes de su cierre en 2007

2.5 Fachada del Teatro Romea de Murcia en 1890

2.6 Cartelera teatral de la función a beneficio del director de orquesta Serafín Costa en el Teatro del Toro de Murcia, ca. 1830

2.7 Bocaporte, bambalinón y telón de boca del Teatro Romea (1901)

2.8 Ubicación del Teatro Provisional sobre el callejero de la ciudad de Murcia

2.9 Ubicación del Teatro Circo Villar sobre el callejero de la ciudad de Murcia

2.10 Interior del Teatro Circo Villar, ¿principios del siglo XX?

2.11 Cartel de la "Gran Compañía de Ópera del Teatro Real de Madrid" con el tenor Miguel Fleta en el Teatro Circo Villar (junio de 1925)

2.12 Aspecto actual del Teatro Circo Villar de Murcia

3.1 Anuncio de arreglos de números de La Tempestad

3.2 Gira de la compañía de Manuel Taberner por el sur de España (1892-1893)

3.3 Portada e introducción de la zarzuela infantil Una broma de estudiantes de Julián Calvo (1860)

3.4 Puente Viejo y explanada del Arenal de Murcia. Principios del siglo XX.

3.5 Santuario de la Fuensanta, enclavado en el paraje natural del Valle en la Sierra de Carrascoy, Algezares (Murcia)

3.6 Paisaje de la huerta murciana

3.7 Viñeta alusiva a la zarzuela Villar y Compañía, música de Antonio Puig y Muñoz Pedrera y libreto de Mariano Perní

4.1 Caricatura de Tomás Bretón

4.2 Emma Nevada

4.3 Portada de la Memoria sobre la cuestión fermata, de Juan Diego Manresa

5.1 Sala de descanso y de celebración de conciertos del Teatro Romea, antes de su cierre en 2007

5.2 Manuel Rodríguez y Sáez (1826-1885), célebre violinista cartagenero 
5.3 Retrato del violinista cubano Claudio José Domingo Brindis de Salas y Garrido

5.4 Retrato del pianista Capitán Voyer

III. Fachada del Casino de Murcia a principios del siglo XX.

6.1 Fachada del Casino de Murcia después de su última restauración

6.2 Galería central del Casino de Murcia en la actualidad

6.3 Configuración actual del Casino de Murcia

6.4 Fases de construcción del Casino de Murcia

6.5 Salón del Té del Casino de Murcia en la actualidad

6.6 La cantante de Cartagena Ana López Peñafiel (1866-?)

6.7 Viñeta sobre los bailes del Casino de Murcia (1893)

6.8 Salón de baile del Casino de Murcia en la actualidad

6.9 Himno "Venid del Táder hijos", música de Julián Calvo y letra de autor desconocido, escrita para la inauguración de la Sociedad Filarmónica y Coral de Murcia (marzo de 1867)

6.10 Recibo mensual de la sociedad La Juventud

6.11 Anuncio de la Academia de música Santa Cecilia

6.12 Anuncio del Colegio de Primera Enseñanza Santa Cecilia

6.13 Anuncio de la Escuela de Canto y Declamación para la carrera artística italiana y española (1881)

6.14 Calle Cartagena (izquierda) y calle de Floridablanca (derecha), en el barrio del Carmen de Murcia

6.15 Anuncio de la Academia de música de Mariano García y Fernando Verdú

6.16 Anuncio de la Academia de música de Acisclo Díaz Rocher

6.17 Anuncio de la academia de música de Francisco Gil López

6.18 Anuncio de las clases particulares de Cayetano Belda

6.19 Anuncio de las clases particulares de José Palazón Pérez

7.1 En un café murciano

7.2 Explanada del Arenal (círculo) y calle del Príncipe Alfonso (rectángulo), núcleos de concentración de cafés murcianos

7.3 Vista de los cafés Moderno (en primer plano) y Arenal (al fondo), ambos situados en la explanada del Arenal de Murcia

7.4 Calle Trapería con la torre de la Catedral de Murcia al fondo. Principios del siglo XX

7.5 Hotel Patrón de Murcia y su café en la calle del Príncipe Alfonso (frente al Casino de Murcia) a principios del siglo XX

7.6 Reconstrucción ideal del exterior del Café Oriental de Murcia, realizada por el pintor Adrián Liza Clares

7.7 Reconstrucción ideal del interior del Café Oriental de Murcia, realizada por el pintor Adrián Liza Clares

7.8 Ubicación de la Repostería de Levante de Murcia, en la plaza Fernández Caballero (círculo negro)

8.1 Salón oriental de la casa particular del cartagenero Tomás Valarino Gattorno, conde de Santa Lucía

8.2 Ubicación del Teatro de Elías Lahorra, en la plaza Jofré de Murcia

8.3 Ubicación de los teatros particulares de la plaza de Santa Eulalia de Murcia, de la calle de Victorio y del Val de San Juan

8.4 Traje femenino "de visita"

8.5 Ubicación del almacén de música de Adolfo Gascón, en la calle San Cristóbal número 4 de Murcia 
8.6 Teatro del Balneario de Archena, Murcia, ca. 1910

8.7 Escena típica de canto y baile murciano

IV. Portada de El Álbum Murciano dedicada a Mariano Padilla

9.1 Colegio de San Leandro en la Plaza de los Apóstoles de Murcia

9.2 Portada y página tres del Método de solfeo de José Calvo (Murcia: Litografía de Ibáñez, [s.a.])

9.3 Partida de bautismo de Ángel Mirete Sanz (1832-1888)

9.4 Retrato de Julián Calvo y su esposa

9.5 Dedicatoria manuscrita de Julián Calvo a su discípulo, el pianista murciano Antonio Puig, sobre el reverso de la portada del Tratado Práctico del Teclado de Pedales en el Órgano Moderno

9.6 Artículo de Andrés Blanco García sobre Julián Calvo en Cartagena Artística, II (1891), $\mathrm{n}^{\mathrm{o}}$ 47, 20 julio, p. 1

9.7 Batuta de Julián Calvo

9.8 Portada e ilustración del órgano de la Catedral de Murcia de la Reseña del gran órgano de la Reseña del gran órgano de la Santa Iglesia Catedral de Cartagena sita en Murcia, fabricado por los señores Merklin, Schütze y compañía de Julián Calvo (Murcia: Establecimiento Tipográfico de La Paz, 1891)

9.9 Plaza de Belluga y fachada de la Catedral de Murcia

9.10 Retrato de Acisclo Díaz

9.11 Localización de la Casa de la Misericordia de Murcia y calle Acisclo Díaz

9.12 Retrato de Francisco Asenjo Barbieri

9.13 Retrato de Mariano Soriano Fuertes

9.14 Portada del Método completo teórico-práctico de harmonium de Antonio López Almagro

9.15 Portada de El harmonium de doble expresión. Complemento al método de harmonium del mismo autor de Antonio López Almagro

9.16 Inicio del Canto del bardo de López Almagro, dedicada a Julián Calvo e incluida en El harmonium de doble expresión de Antonio López Almagro

9.17 Método de harmonium de Antonio López Almagro en castellano y francés

9.18 Portada del Método completo teórico-práctico de acordeón de López Almagro

9.19 Anuncio de la partitura del Himno a S. M. D. Alfonso XII de Borbón de Antonio López Almagro

9.20 Anuncio del Almacén de Música de Fernando Verdú en Murcia

9.21 Anuncio de instrumentos musicales disponibles en el Almacén de Música de Fernando Verdú en Murcia

9.22 Anuncio del almacén de música de Adolfo Gascón en Murcia

9.23 Localizaciones del almacén de música de Adolfo Gascón en 1880, calle Lucas y 1904, San Cristóbal, 4

10.1 Retrato de Mariano Padilla Ramos (1843-1906)

10.2 Firma de Mariano Padilla en 1855

10.3 Mariano Padilla en el personaje de Renato, junto a la cantante Sarolta de Bujanovis (Amelia), en la ópera de Verdi Un ballo in maschera, representada en el Casino Theatre de Copenhagen (18-05-1867)

10.4 Retrato de Marguerite-Joséphin-Désirée Montagney Artôt (París, 1841-Viena, 1907)

10.5 Retrato de Lola Artôt de Padilla, dedicada a Edvard y Nina Grieg (septiembre de 1905)

10.6 Retrato de la cantante Ella Russel-de Righini (1901) 
10.7 Retrato de Emma Nevada (1883)

10.8 Vista general de Biarritz en el siglo XIX

10.10 Portada de Cartagena Artística dedicada a Mariano Padilla

11.1 Arco de la feria de septiembre en la Plaza del Arenal y Glorieta de Murcia

11.2 Acta de celebración de los Juegos Florales de Murcia (1878)

11.3 Cartel de la feria y fiestas de Murcia (1-15 de septiembre de 1895)

11.4 Indumentaria típica de los huertanos y huertanas de Murcia 


\section{Gráficos}

1.1 Presencia de noticias musicales en periódicos de Murcia (1800-1851)

1.2 Evolución porcentual de las noticias de interés musical en periódicos de Murcia, por décadas (1800-1851)

1.3 Evolución porcentual de las noticias de interés musical de La Paz de Murcia, por décadas (1858-1895)

1.4 Ejemplares con noticias de interés musical en La Paz de Murcia (1858-1895)

1.5 Evolución de las noticias de interés musical de La Paz de Murcia, por años (1858-1895)

4.1 Representaciones de obras de Verdi y Donizetti en los teatros del Toro y Provisional de Murcia (1851, 1858-1859)

7.1 Géneros interpretados en las veladas musicales del Café Oriental (1876-1879, 1886-1888, 1890-1892)

7.2 Géneros interpretados en las veladas musicales del Café del Comercio (1878)

7.3 Géneros interpretados en las veladas musicales del Café del Siglo y porcentajes ente los mismos (1891)

7.4 Compositores de zarzuela más interpretados en las veladas de los cafés murcianos de la segunda mitad del siglo XIX

8.1 Géneros musicales interpretados en las veladas de ámbito doméstico en Murcia (1865-1894)

10.1 Actuaciones de Mariano Padilla (1882-1889) 
